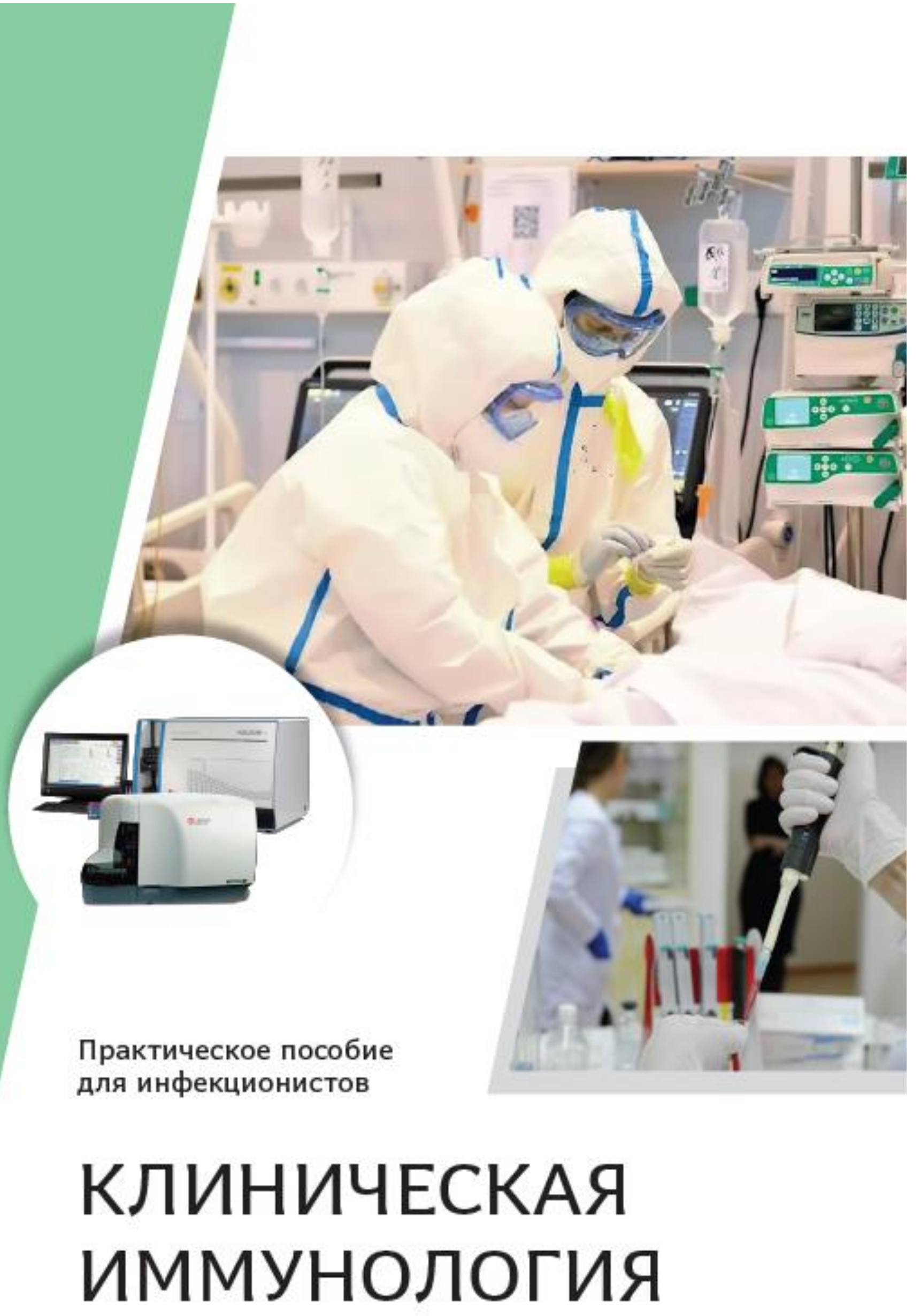


Красноярский государственный медицинский университет имени профессора

В.Ф. Войно-Ясенецкого Минздрава России

Научно-исследовательский институт медицинских проблем Севера ФИЦ КНЦ СО РАН

НМИЦ им. В. А. Алмазова Минздрава России

Институт экспериментальной медицины

Институт клинической иммунологии

В.А.Козлов, Е.П.Тихонова, А.А.Савченко, И.В. Кудрявцев, Н.В. Андронова, Е.Н.Анисимова, А.С.Головкин, Д.В. Демина, Д.Э. Здзитовецкий, Ю.С.Калинина, Э.В. Каспаров, И.Г. Козлов, И.А. Корсунский, Д.А. Кудлай, Т.Ю. Кузьмина, Н.С. Миноранская, А.П.Продеус, Э.А. Старикова, Д.В.Черданцев, А.Б. Чесноков, П.А. Шестерня, А.Г. Борисов

\section{КЛИНИЧЕСКАЯ ИММУНОЛОГИЯ}

ПРАКТИЧЕСКОЕ ПОСОБИЕ ДЛЯ ИНФЕКЦИОНИСТОВ 
ББК 52.7

K 49

Клиническая иммунология. Практическое пособие для инфекционистов/ В.А.Козлов, Е.П.Тихонова, А.А.Савченко, И.В. Кудрявцев, Н.В. Андронова, Е.Н.Анисимова, А.С.Головкин, Д.В. Демина, Д.Э. Здзитовецкий, Ю.С. Калинина, Э.В. Каспаров, И.Г. Козлов, И.А. Корсунский, Д.А. Кудлай, Т.Ю. Кузьмина, Н.С. Миноранская, А.П.Продеус, Э.А. Старикова, Д.В. Черданцев, А.Б. Чесноков, П.А. Шестерня, А.Г. Борисов

- Красноярск: Поликор, 2021. - 550 с.

ISBN 978-5-94285-235-1

В монографии обобщены современные данные о диагностике и лечении нарушений функции иммунной системы при инфекционных болезнях. Освещены основные вопросы этиологии, иммунопатогенеза по основным нозологиям. Описаны методы клинической и лабораторной диагностики иммунных нарушений. Особое внимание уделено разделу иммунотерапии в клинике инфекционных болезней и современным методам коррекции иммунных нарушений.

Книга может представлять интерес для инфекционистов, но может представлять интерес для широкого круга практикующих врачей различных специальностей, работающих в лечебных учреждениях амбулаторно-поликлинического звена

Табл. $123 . \quad$ Ил. $185 . \quad$ Библиография.: 97 назв.

Р е ц е н 3 е н т ы

доктор медицинских наук, академик Лобзин Ю.В.

доктор медицинских наук, академик Румянцев А.Г.

Утверждено к печати Ученым советом

Научно-исследовательского института медицинских проблем

Севера ФИЦ КНЦ СО РАН

Без объявления

ISBN 978-5-94285-235-1
(C) В.А.Козлов, Е.П.Тихонова, А.А.Савченко, И.В. Кудрявцев, Н.В. Андронова, Е.Н.Анисимова, А.С.Головкин, Д.В. Демина, Д.Э. Здзитовецкий, Ю.С. Калинина, Э.В. Каспаров, И.Г. Козлов, И.А. Корсунский, Д.А. Кудлай, Т.Ю. Кузьмина, Н.С. Миноранская, А.П.Продеус, Э.А. Старикова, Д.В. Черданцев, А.Б. Чесноков, П.А. Шестерня, А.Г. Борисов, 2021

(C) Красноярский государственный медицинский университет имени профессора В.Ф. Войно-

Ясенецкого, Минздрава России 2021

(C) НИИ медицинских проблем Севера ФИЦ КНЦ CO РAH, 2021

(C) НМИЦ им. В. А. Алмазова» Минздрава России, 2021

(C) Институт экспериментальной медицины», 2021

(C) Институт клинической иммунологии, 2021 


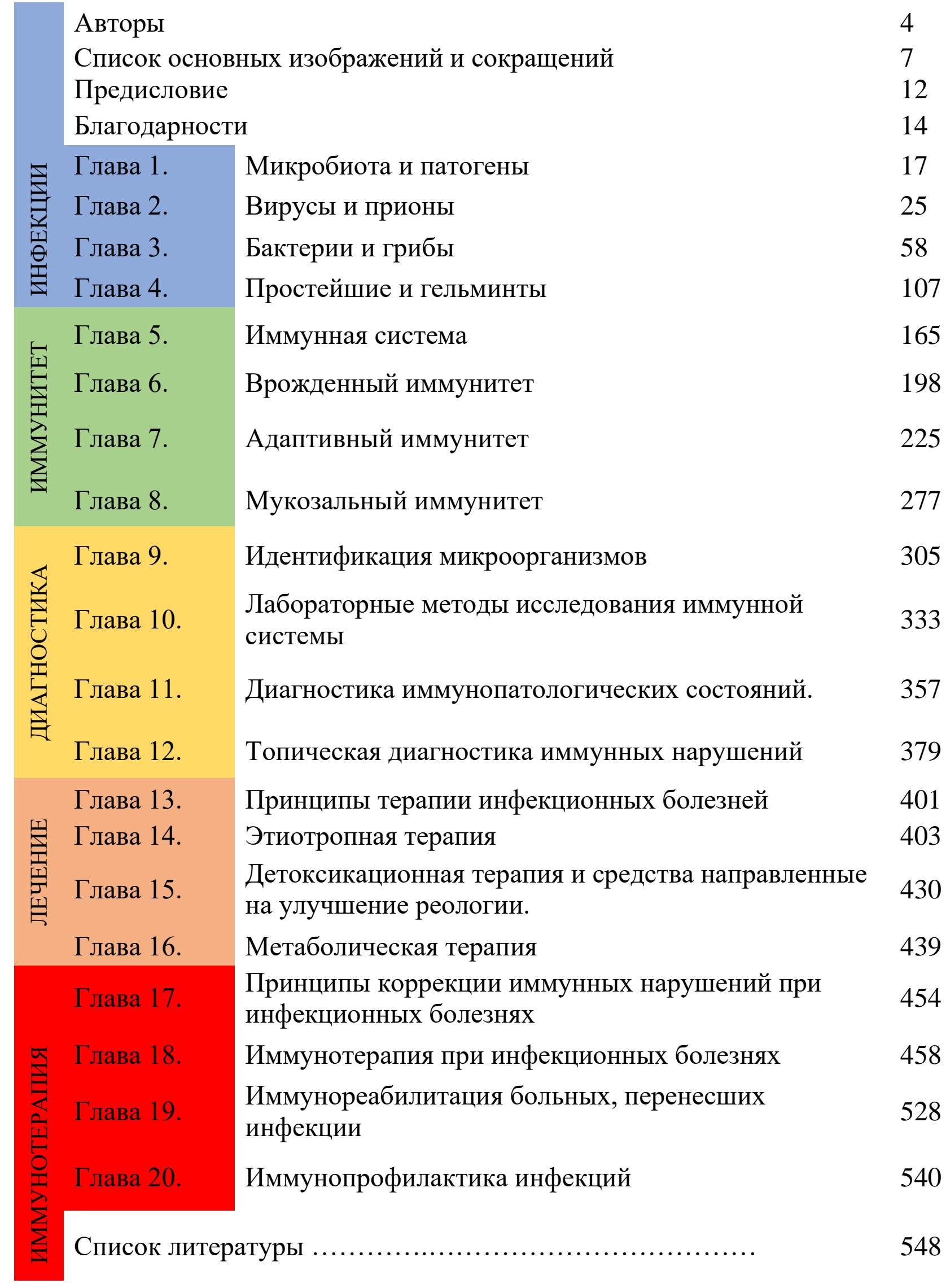




\section{АВТОРЫ}

Андронова Наталья Владимировна, врач высшей категории, к.м.н., доцент кафедры инфекционных болезней и эпидемиологии Красноярского государственного медицинского университета им. проф. В.Ф. ВойноЯсенецкого.

Анисимова Елена Николаевна, врач высшей категории, к.м.н., доцент кафедры кардиологии, функциональной и клинико-лабораторной диагностики Института последипломного образования Красноярского государственного медицинского университета им. проф. В.Ф. Войно-Ясенецкого.

Борисов Александр Геннадьевич, врач высшей категории, к.м.н.. Главный врач Института клинической иммунологии. Ведущий научный сотрудник НИИ медицинских проблем Севера ФИЦ КНЦ СО РАН. Ассистент кафедры инфекционных болезней и эпидемиологии Красноярского государственного медицинского университета им. проф. В.Ф. ВойноЯсенецкого.

Головкин Алексей Сергеевич, Д.м.н., руководитель группы генноклеточной инженерии Института молекулярной биологии и генетики, НМИЦ им. В. А. Алмазова.

Демина Дарья Владимировна, врач высшей категории, к.м.н., НИИ фундаментальной и клинической иммунологии, заведующая отделением аллергологии, главный аллерголог-иммунолог Новосибирской области.

Здзитовецкий Дмитрий Эдуардович, врач высшей категории, д.м.н., заведующий кафедрой факультетской хирургии имени профессора Ю.М.Лубенского Красноярского государственного медицинского университета им. проф. В.Ф. Войно-Ясенецкого.

Калинина Юлия Сергеевна, врач высшей категории, к.м.н., ассистент кафедры инфекционных болезней и эпидемиологии Красноярского государственного медицинского университета им. проф. В.Ф. ВойноЯсенецкого.

Каспаров Эдуард Вильямович, заслуженный врач Российской Федерации, д.м.н., профессор, директор НИИ медицинских проблем Севера ФИЦ КНЦ СО РАН.

Козлов Владимир Александрович, академик $\mathrm{PAH}$, научный руководитель НИИ фундаментальной и клинической иммунологии. Заслуженный деятель науки РФ. Почетный вице-президент РНОИ. Вицепрезидент Education Instruction Committee of World Federation of Chinese 
Medicine Societies, почетный член The World Immunopathology Organization (WIPO).

Козлов Иван Генрихович, д.м.н., профессор, профессор кафедры организации и управления в сфере обращения лекарственных средств ИПО ФГАОУ ВО Первый Московский государственный медицинский университет им. И.М. Сеченова Министерства здравоохранения Российской Федерации (Сеченовский университет), Вице-президент Российского научного общества иммунологов.

Корсунский Илья Анатольевич врач высшей категории, д.м.Н., заведующий центром аллергологии и иммунологии ДГКБ № 9 им. Г.Н.Сперанского, профессор кафедры педиатрии и детских инфекционных болезней ФГАОУ ВО Первый Московский государственный медицинский университет им. И.М. Сеченова Министерства здравоохранения Российской Федерации (Сеченовский университет).

Кудлай Дмитрий Анатольевич д.м.н., профессор кафедры фармакологии Института Фармации ФГАОУ ВО Первый МГМУ им. И.М. Сеченова Минздрава России (Сеченовский университет). Ведущий научный сотрудник лаборатории персонализированной медицины и молекулярной иммунологии “ГНЦ Институт иммунологии” ФМБА России.

Кудрявцев Игорь Владимирович, к.б.н., заведующий лабораторией иммунорегуляции ФГБНУ "Институт экспериментальной медицины", СанктПетербург; доцент кафедры иммунологии, Первый Санкт-Петербургский государственный медицинский университет им. И.П. Павлова, СанктПетербург.

Кузьмина Татьяна Юрьевна, врач высшей категории, к.м.н., доцент кафедры инфекционных болезней и эпидемиологии Красноярского государственного медицинского университета им. проф. В.Ф. ВойноЯсенецкого.

Миноранская Наталья Сергеевна, врач высшей категории, д.м.н., профессор кафедры инфекционных болезней и эпидемиологии Красноярского государственного медицинского университета им. проф. В.Ф. ВойноЯсенецкого.

Продеус Андрей Петрович, врач высшей категории, д.м.н., профессор, заведующий кафедрой иммунологии и аллергологии Высшей медицинской школы, главный внештатный специалист-иммунолог МЗ Московской области, главный педиатр ГДКБ №9 им. Г.Н. Сперанского Департамента здравоохранения г. Москвы. 
Савченко Андрей Анатольевич, д.м.н., профессор заведующий лабораторией клеточно-молекулярной физиологии и патологии ФГБНУ Федеральный исследовательский центр «Красноярский научный центр Сибирского отделения Российской академии наук», обособленное подразделение «НИИ медицинских проблем Севера».

Старикова Элеонора Александровна, к.б.н., с.н.с. лаборатории клеточной иммунологии, ФГБНУ "Институт экспериментальной медицины", Санкт-Петербург.

Тихонова Елена Петровна, врач высшей категории, д.м.н., профессор заведующая кафедрой инфекционных болезней и эпидемиологии Красноярского государственного медицинского университета им. проф. В.Ф. Войно-Ясенецкого. Главный внештатный инфекционист министерства здравоохранения Красноярского края.

Черданцев Дмитрий Владимирович, врач высшей категории, д.м.н., профессор, проректор по лечебной работе и развитию регионального здравоохранения, заведующий кафедрой госпитальной хирургии имени профессора А.М. Дыхно с курсом ПО Красноярского государственного медицинского университета им. проф. В.Ф. Войно-Ясенецкого.

Чесноков Андрей Борисович, врач высшей категории, к.м.н., врач дерматовенеролог стационарного отделения Красноярского краевого кожновенерологического диспансера, заместитель главного врача Института клинической иммунологии.

Шестерня Павел Анатольевич, врач высшей категории, д.м.н., профессор, проректор по научной работе, заведующий кафедры пропедевтики внутренних болезней и терапии Красноярского государственного медицинского университета им. проф. В.Ф. Войно-Ясенецкого. 


\section{Список основных изображений и сокращений}

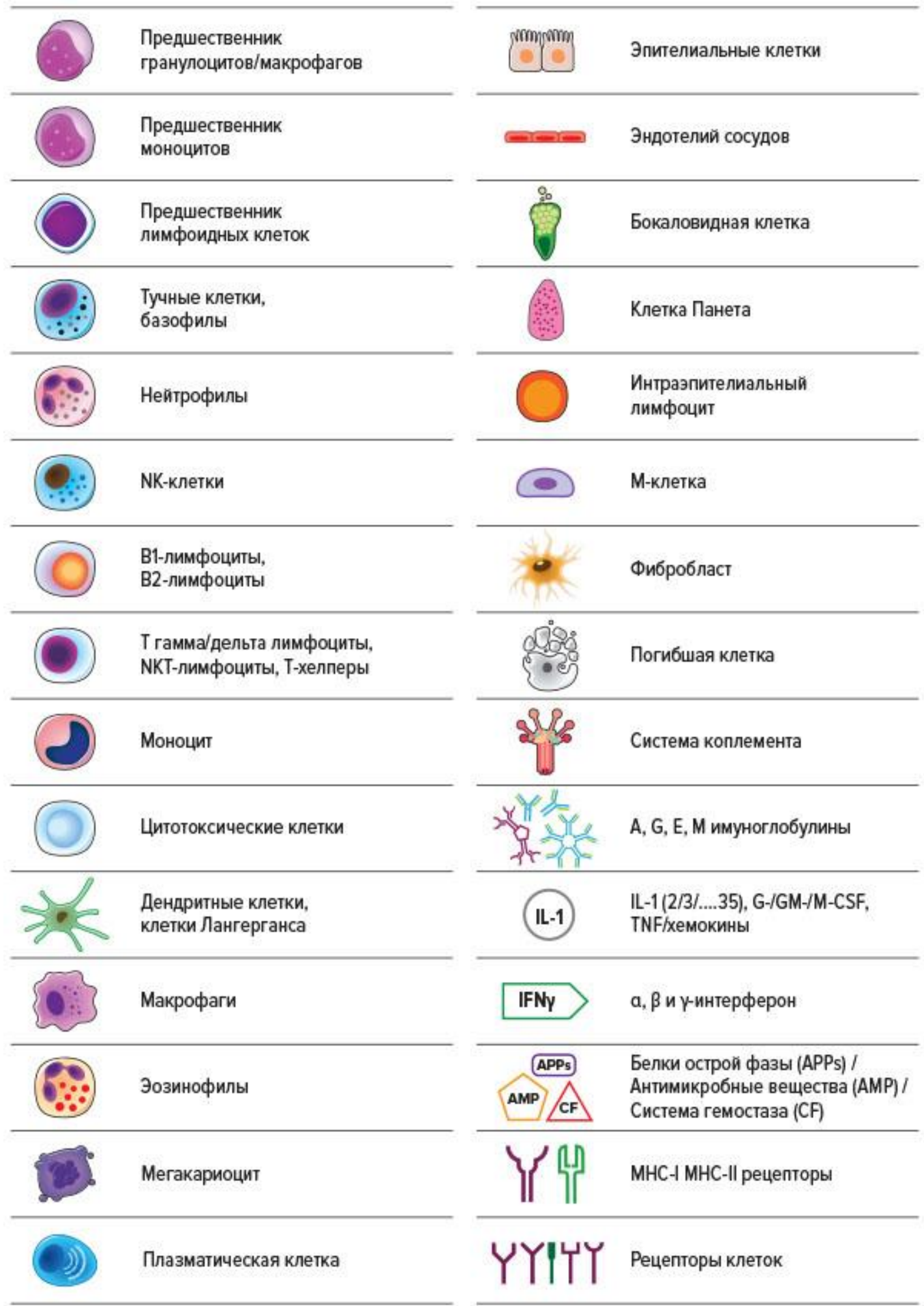




\begin{tabular}{|c|c|c|}
\hline $\mathrm{Ab}, \mathrm{AT}$ & - & antibody, антитело \\
\hline $\mathrm{Ag}, \mathrm{A \Gamma}$ & - & antigen, антиген \\
\hline AIDS, СПИД & - & $\begin{array}{l}\text { acquired immunodeficiency syndrome, синдром } \\
\text { приобретенного иммунодефицита }\end{array}$ \\
\hline AMPs & - & antimicrobial peptides, антимикробные пептиды \\
\hline АРС, АПК & - & antigen-presenting cell, антигенпрезентирующие клетки \\
\hline APPs & - & acute-phase proteins, белки острой фазы \\
\hline ARDS & - & острый респираторный дистресс-синдром \\
\hline B-cell & - & В-лимфоцит \\
\hline BAFF & - & фактор В-клеточной активации \\
\hline BCR & - & B-cell receptor, В-клеточный рецептор \\
\hline BCG & - & Bacillus Calmette Guerin vaccine. БЦЖ-вакцина \\
\hline Bph & - & basophil, базофил \\
\hline CARS & - & compensatory anti-inflammatory response syndrome, синдром \\
\hline $\mathrm{CD}$ & - & $\begin{array}{l}\text { компенсаторного противовоспалительного ответа } \\
\text { cluster of differentiation, кластер дифференцирования }\end{array}$ \\
\hline $\mathrm{CF}$ & - & coagulation factors, факторы свертывания крови \\
\hline CMV, ЦМВ & - & cytomegalovirus, цитомегаловирус \\
\hline $\mathrm{CR}$ & - & complement receptor, рецептор к комплементу \\
\hline CRP, СРБ & - & C-reactive protein, C-реактивный белок \\
\hline CТL, ЦТЛ & - & Cytotoxic T-lymphocyte, цитотоксический Т-лимфоцит \\
\hline CTLA-4 & - & Cytotoxic T-lymphocyte-associated antigen 4 \\
\hline DAMP & - & $\begin{array}{l}\text { цитотоксический Т-лимфоцитассоциированный антиген } \\
\text { danger-associated molecular pattern, связанный с опасностью } \\
\text { молекулярный паттерн }\end{array}$ \\
\hline DC, ДК & - & dendritic cells, дендритная клетка \\
\hline DII & - & диетический воспалительный индекс \\
\hline ЕВV, ВЭБ & - & Epstein-Barr virus, вирус Эпштейна-Барр \\
\hline ELISA, ИФA & - & $\begin{array}{l}\text { enzyme-linked immunosorbent assay, иммуноферментный } \\
\text { анализ }\end{array}$ \\
\hline Eo, & - & eosinophil, эозинофил \\
\hline ELISPOT & - & $\begin{array}{l}\text { enzyme-linked immunospod, связанные с ферментной } \\
\text { иммунной активностью пятна (секретирующие клетки) }\end{array}$ \\
\hline EPO & - & erythropoietin, эритропоэтин \\
\hline Fab & - & $\begin{array}{l}\text { monovalent Ig antigen-binding fragment after papain digestion } \\
\text { моновалентный антигенсвязывающий фрагмент } \\
\text { иммуноглобулина }\end{array}$ \\
\hline FDC, ДКф & - & follicular dendritic cell, фолликулярная дендритная клетка \\
\hline G-/GM-/M - & - & granulocyte/ granulocyte-macrophage/ macrophage colony - \\
\hline CSF & & $\begin{array}{l}\text { stimulating factor, гранулоцитарный/ гранулоцитарно- } \\
\text { макрофагальный/ макрофагальный } \\
\text { колониестимулирующий фактор }\end{array}$ \\
\hline GALT & - & $\begin{array}{l}\text { gut-associated lymphoid tissue, лимфоидная ткань, } \\
\text { ассоциированная с кишечником }\end{array}$ \\
\hline $\mathrm{GC}$ & - & зародышевые центры \\
\hline HBV ВГВ & - & вирус гепатита В \\
\hline $\mathrm{HCV}$ ВГC & - & вирус гепатита C \\
\hline HDV & - & дельта-вирус человека \\
\hline $\mathrm{HBsAg}$ & - & $\begin{array}{l}\text { hepatitis B surface antigen, поверхностный антиген вируса } \\
\text { гепатита В }\end{array}$ \\
\hline HIV, ВИЧ & - & $\begin{array}{l}\text { human immunodeficiency virus, вирус иммунодефицита } \\
\text { человека }\end{array}$ \\
\hline
\end{tabular}




\begin{tabular}{|c|c|c|}
\hline HLA & - & $\begin{array}{l}\text { human leukocyte antigens, лейкоцитарные антигены } \\
\text { человека }\end{array}$ \\
\hline HLH & & $\begin{array}{l}\text { синдром вторичного гематофагоцитарного } \\
\text { лимфогистиоцитоза }\end{array}$ \\
\hline HMGB-1 & - & high-mobility group protein B1, амфотерин \\
\hline HРV, ВПЧ & - & human papillomavirus, вирус папилломы человека \\
\hline HSC & & hematopoietic stem cell, гемопоэтические стволовые клетки \\
\hline ISV, ВПГ & - & herpes simplex virus, возбудитель простого герпеса \\
\hline ITLV & - & $\begin{array}{l}\text { human T-cell leukemia virus, вирус Т-клеточного лейкоза } \\
\text { человека }\end{array}$ \\
\hline CAM & - & $\begin{array}{l}\text { intercellular adhesion molecule, молекула межклеточной } \\
\text { адгезии }\end{array}$ \\
\hline $\mathrm{IFN} \alpha / \beta / \gamma$ & - & $\alpha$-interferon (also IFN $\beta$, IFN $\gamma$ ), интерферон- $\alpha / \beta / \gamma$ \\
\hline $\operatorname{IgA} / \mathrm{D} / \mathrm{E} / \mathrm{M} / \mathrm{G}$ & - & $\begin{array}{l}\text { immunoglobulin A D E M G, иммуноглобулины класса A D } \\
\text { E M G }\end{array}$ \\
\hline IL-1 (2/3/ и т.д) & - & interleukin-1 (also IL-2, IL-3, etc.), интерлейкины \\
\hline $\mathrm{C}$ & - & врожденные лимфоидные клетки \\
\hline AK & - & Janus kinases, Янус киназы \\
\hline IR & - & $\begin{array}{l}\text { кe receptors, киллерные } \\
\text { ные рецепторы }\end{array}$ \\
\hline KREC & - & $\begin{array}{l}\text { kappa-deleting recombination excision circle (кольцевые } \\
\text { участки, вырезанные при созревании в-клеток, из локуса, } \\
\text { кодирующего каппа-цепь) }\end{array}$ \\
\hline LPS & - & $\begin{array}{l}\text { lipopolysaccharide (endotoxin), липополисахарид } \\
\text { (эндотоксин) }\end{array}$ \\
\hline mAb, мAT & - & Intibody, моноклональное антитело \\
\hline IAC & - & membrane attack complex, мембранно-атакующий комплек \\
\hline 1ALDI (TOF) & - & $\begin{array}{l}\text { матрично-активированная лазерная десорбция/ионизация } \\
\text { (time of flight - времяпролетный) }\end{array}$ \\
\hline MAIT & - & $\begin{array}{l}\text { mucosal associated invariant T cell, инвариантные Т-клетки, } \\
\text { связанные со слизистой оболочкой }\end{array}$ \\
\hline MALT & - & $\begin{array}{l}\text { mucosa-associated lymphoid tissue, лимфоидная ткань, } \\
\text { ассоциированная с слизистыми }\end{array}$ \\
\hline MARS & - & $\begin{array}{l}\text { mixed antagonist response syndrome, синдром смешанного } \\
\text { антагониста ответа }\end{array}$ \\
\hline & - & mast cell, туг \\
\hline MHC & - & $\begin{array}{l}\text { atibility complex, главный комплекс } \\
\text { ости }\end{array}$ \\
\hline $\mathrm{Iph}, \mathrm{M}$ & - & 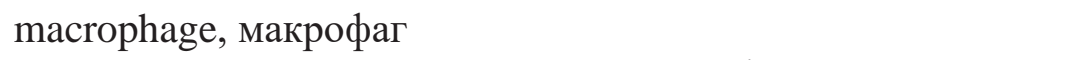 \\
\hline $\begin{array}{l}\text { IODS, MOF } \\
\Pi \mathrm{OH}\end{array}$ & - & $\begin{array}{l}\text { синдром полиорганной недостаточности/полиорганной } \\
\text { дисфункции }\end{array}$ \\
\hline IRSA & - & $\begin{array}{l}\text { methicillin-resistant Staphylococcus aureus, Метициллин- } \\
\text { резистентный золотистый стафилококк }\end{array}$ \\
\hline AD НАД & - & окисленный никотинамидадениндинуклеотид \\
\hline $\mathrm{ADH}$ & - & тенный никотинамидадениндинуклеотид \\
\hline ADP НАДФ & - & окисленный никотинамидадениндинуклеотидфосфат \\
\hline NADPH & - & восстановленный никотинамидадениндинуклеотидфосфа \\
\hline NET & 一 & внеклеточные ловуши нейтрофилов \\
\hline NGS & - & $\begin{array}{l}\text { next generation sequencung, секвенирование нового } \\
\text { поколения }\end{array}$ \\
\hline مו & - & подобный рецептор \\
\hline & - & natural killer cell, натуральный киллер \\
\hline ell & - & natural killer T cell, естественные киллерные Т лимфоциты \\
\hline
\end{tabular}




\begin{tabular}{|c|c|c|}
\hline NLR & - & NOD-Like Receptors, NOD-подобные рецепторы \\
\hline $\mathrm{Nph}$ & - & neutrophil, нейтрофил \\
\hline PAMP & - & $\begin{array}{l}\text { pathogen-associated molecular pattern, патоген- } \\
\text { ассоциированный молекулярный паттерн }\end{array}$ \\
\hline $\mathrm{PG}(\mathrm{E})$ & - & prostaglandin (E etc.), простагландин \\
\hline PICS & - & $\begin{array}{l}\text { Persistent Inflammation/Immunosuppression and Catabolism } \\
\text { Syndrome. синдром стойкого воспаления / } \\
\text { иммуносупрессии и катаболизма }\end{array}$ \\
\hline PRR & - & патоген распознающий рецептор \\
\hline SARS, & - & $\begin{array}{l}\text { severe acute respiratory syndrome, тяжёлый острый } \\
\text { респираторный синдром }\end{array}$ \\
\hline $\operatorname{sIg}$ & - & secretor IgA, секреторный иммуноглобулин А \\
\hline ROS AФК & - & активные формы кислорода \\
\hline RSV & - & респираторно-синцитиальный вирус \\
\hline SIRS & - & $\begin{array}{l}\text { system inflammatory responsive syndrome, синдром } \\
\text { системного воспалительного ответа }\end{array}$ \\
\hline STAT & - & $\begin{array}{l}\text { signal transducer and activator of transcription, } \\
\text { преобразователь сигналов и активатор транскрипции }\end{array}$ \\
\hline TB & - & tubercle bacillus, возбудитель туберкулеза \\
\hline T-cell & - & thymus-derived lymphocyte, Т-лимфоцит \\
\hline $\mathrm{T} \gamma \delta$-cells & - & gamma delta T cells, гамма-дельта Т-клетки \\
\hline TcR & - & Т-клеточный рецептор \\
\hline $\operatorname{Th}(1 / 2 / 3 / 9 / 17)$ & - & $\begin{array}{l}\text { T-helper cell (subset 1, 2, 3, } 9 \text { or 17), Т-хелпер (1/2/3/9/17) } \\
\text { типа }\end{array}$ \\
\hline Treg & - & Regulatory T cells, Т-регуляторные лимфоциты \\
\hline THF & - & thymic humoral factor, гуморальный фактор тимуса \\
\hline TIL & - & $\begin{array}{l}\text { tumor infiltrating lymphocytes, лимфоциты, } \\
\text { инфильтрирующие опухоль }\end{array}$ \\
\hline TLR & - & Toll-Like Receptors, Toll-подобные рецепторы \\
\hline $\mathrm{TGFb}$ & - & трансформирующий фактор роста бетта \\
\hline TNF & - & tumor necrosis factor, фактор некроза опухоли \\
\hline ТPO & - & thrombopoietin, тромбопоэтин \\
\hline TREC & - & $\begin{array}{l}\text { T-cell receptor excision circles, кольцевые участки, } \\
\text { вырезанные из ДНК в Т-лимфоците при его созревании }\end{array}$ \\
\hline VCAM & - & $\begin{array}{l}\text { vascular cell adhesion molecule, молекула адгезии клеток } \\
\text { сосудов }\end{array}$ \\
\hline АД & - & артериальное давление \\
\hline АДС & - & вакцина против дифтерии и столбняка \\
\hline АДФ & - & аденозиндифосфат \\
\hline АКДС & - & вакцина против коклюша, дифтерии и столбняка \\
\hline АКТГ & - & адренокортикотропный гормон \\
\hline АЛТ & - & аланинаминотрансфераза \\
\hline АМФ & - & аденозинмонофосфат \\
\hline АРВП & - & антиретровирусная терапия \\
\hline ACT & - & аспартатаминотрансфераза \\
\hline АТФ & - & аденозинтрифосфат \\
\hline БАВ & - & биологически активные вещества \\
\hline ВВИГ & - & внутривенные иммуноглобулины \\
\hline $\mathrm{B} Г А / B / C$ & - & вирусный гепатит A/B/C \\
\hline ВИД & - & вторичные иммунодефициты \\
\hline ГАМК & - & g-аминомасляная кислота \\
\hline ГЭБ & - & гематоэнцефалический барьер \\
\hline
\end{tabular}




\begin{tabular}{|c|c|c|}
\hline ДВС & - & $\begin{array}{l}\text { синдром диссеминированного внутрисосудистого } \\
\text { свертывания крови }\end{array}$ \\
\hline ДНК & - & дезоксирибонуклеиновая кислота \\
\hline ЖКТ & - & желудочно-кищечный тракт \\
\hline ЛДГ & - & лактатдегидрогеназа \\
\hline KT & - & компьютерная томография \\
\hline ЛПВП & - & липопротеиды высокой плотности \\
\hline ЛПНП & - & липопротеиды низкой плотности \\
\hline ЛПОНП & - & липопротеиды очень низкой плотности \\
\hline ЛПС & - & липополисахарид \\
\hline MPT & - & магнитно-резонансная томография \\
\hline ПИД & - & первичный иммунодефицит \\
\hline ПОЛ & - & перекисное окисление липидов \\
\hline ПППД & - & препараты прямого противовирусные действия \\
\hline ПЦР & - & полимеразная цепная реакция \\
\hline $\begin{array}{l}\text { РНК, ТРНК, } \\
\text { мРНК }\end{array}$ & - & $\begin{array}{l}\text { рибонуклеиновая кислота, транспортная рибонуклеиновая } \\
\text { кислота, матричная рибонуклеиновая кислота }\end{array}$ \\
\hline СДГ & - & сукцинатдегидрогеназа \\
\hline СОД & - & супероксиддисмутаза \\
\hline ТКИД & - & тяжелый комбинированный иммунодефицит \\
\hline УЗИ & - & ультразвуковое исследование \\
\hline цАМФ & - & циклический аденозинмонофосфат \\
\hline ЦИК & - & циркулирующие иммунные комплексы \\
\hline ЦНС & - & центральная нервная система \\
\hline ЦОГ & - & циклооксигеназа \\
\hline ЧСС & - & частота сердечных сокращений \\
\hline
\end{tabular}




\section{Предисловие}

С чем/с кем встречается человечек, иммунная система этого человечка, когда он покидает свое стерильное обиталище и приходит в иной “жестокий” мир. Конечно же с инфекциями, вирусно-бактериальными и другими биологическими врагами. Еще далеко до аллергенов, еще не видно опухолей, еще за горами, за долами атеросклероз, а вирусы с бактериями уже расположились на коже, в верхних дыхательных путях, в кишечнике. Все, кончились безалаберные 9 месяцев, начались трудовые будни иммунной системы организма на формирование “дружеских” отношений с нужными микроорганизмами, и строительство оборонительных рубежей против не нежных микроорганизмов. От результатов этих суровых взаимоотношений во многом будет зависеть формирование в организме любых патологических состояний, включая аллерго-и аутоиммунную патологию, опухолевый рост, атеросклероз. Не без основательно существует мнение, что вся органная патология базируется на механизмах влияния на них тех или иных микроорганизмов.

Високосный 2020-й год запомнится, без сомнений, человечеству на долгие лета, ибо оно было “короновано" вирусом. Хотя, в принципе, не прошло еще 100 лет с прошлого, всечеловеческого мора, когда более 20 млн жизней захватила с собой в никуда "Испанка" гриппозная.

Уже много очень сказано о вирусной “короне”. Мы многое узнали о непосредственных причинах гибели человека от вируса. Нам стали известны мельчайшие подробности иммунопатогенеза данного инфекционного заболевания, хотя еще множество мелочей мы еще не знаем. Мы возлагаем большие надежды на вакцину, о которой уже очень много сказано. Уже кто-то кого-то обвиняет в воровстве “самой лучшей” вакцины. Думают не об охране жизней человеческих, а о престижности своего “Я”. Ну, да Бог с ними.

Теперь о не менее главном! Что такое вирусное заболевание (любое)? Это заболевание, исход которого зависит от состояния иммунной системы организма. Справится иммунная система, жить человек будет “долго и счастливо”, да ещё и с хорошим иммунитетом. Не справится иммунная система, плохо будет тогда человеку... Что такое вакцина против вируса (любого)? По-существу, это профилактика вирусного заболевания за счет создания хорошего иммунитета, когда иммунная система справится с проникшим вирусом, встретив его во всеоружии. Что такое терапия вирусного заболевания (любого)? Здесь два фронта борьбы. Один будет бороться напрямую с вирусом, препятствуя его размножению в организме. Второй будет связан с борьбой за нормализацию функций иммунной системы, 
которые были нарушены интервенцией вируса. И все же в большей степени положительный исход будет зависеть от иммунной системы.

Смотрим, заболевание, лечение, профилактика - все три состояния завязаны на иммунную систему! Это самое главное, о чем нельзя никогда забывать!

Но есть ещё одно условие, условие основательное для успешной борьбы с “коронованным" вирусом. Оно заключается в необходимости готовить высоко-иммунную почву для встречи с вирусом, которая ляжет в основу будущей успешной борьбы с вирусом. Речь идет о неспецифической иммунопрофилактике.

Вакцина - это специфическая, но то же иммунопрофилактика. Неспецифическая иммунопрофилактика включает в себя использование всех тех лекарственных и не лекарственных (растительного и животного происхождения) препаратов, которые мягко или сильно (все зависит от конкретной ситуации) стимулируют функции иммунной системы. Тут цель одна: не дать вирусу встретиться с ослабленной иммунной системой. Все время быть, как бы, наготове.

Нам просто необходимы знания о тончайших механизмах взаимодействия нашего макроорганизма и его иммунной системы с царством микроорганизмов, чтобы очень постараться не допустить победы над нами любой инфекции, какой бы она смертоносной не была

Научный руководитель

НИИ фундаментальной и клинической иммунологии

Почетный вице-президент

Российского научного общества иммунологов

Академик РАН

В.А. Козлов 


\section{Благодарности}

Авторы выражают благодарность всем лицам, оказавшим помощь в подготовке данной книги, прежде всего рецензентам чьи практические, критические и редакционные замечания были очень полезны.

Особая благодарность д.м.н., профессору О.В. Первовой, д.м.н., профессору С.А. Догадину, к.м.н. Р.Н. Борисову, к.б.н. Е.В. Слепову, к.м.н. Ю.Л. Тонких, врачуревматологу А.А. Мастеровой, врачам-инфекционистам С.В. Левицкому и А.А. Упировой, научным сотрудникам В.Д. Беленюку, И.И. Гвоздеву, совместные работы с которыми послужили основанием для написания этой книги.

На создание данной книги большое влияние оказали наши друзья-коллеги академик А.А. Тотолян, академик В.В. Зверев, член-корреспондент А.С. Симбирцев, член-корреспондент В.Т. Манчук, д.м.н., профессор С.В. Смирнова, д.м.н., профессор, Н.М. Калинина, д.м.н., профессор А.В. Зурочка, д.м.н., профессор Т.Г. Федоскова, д.м.н., профессор Е.И. Прахин, д.м.н. И.А. Балдуева, д.б.н. С.В. Хайдуков, д.б.н. Т.Н. Заботина, д.б.н. И.А. Пашнина, к.м.н. А.В. Новик, к.б.н. Е.Г. Костоломова, к.б.н. Т.Л. Нехаева, к.б.н. К.Б. Остроумов, к.б.н. А.Е. Кондаков с которыми в течении длительного времени мы обсуждали многие аспекты данной книги. Мы благодарны им за это.

За административное сопровождения данной книги благодарим сотрудников НИИ медицинских проблем Севера к.б.н. Е.П. Бронникову, к.м.н. А.Н. Латышеву, к.б.н. А.Ю. Холомееву.

Мы благодарим компании: «Бекман Культер», «БиоХимМак», «Си Эс Эл Беринг Биотэрапис», «Биотех», «ГЕНЕРИУМ», «Гилеад Сайенсиз Раша», «ЛабТЭК», «Люминекс», «Завод Медсинтез», «Пептек», «Полисорб», «Р-фарм» их руководителей и сотрудников за поддержку в издании данной книги. Отдельное спасибо нашему другу С.С.Лайкевичу.

Приносим благодарности за предоставленный фотоматериал врачам С.A. Борисову, А.О. Бабушкину, автору иллюстраций художнику-дизайнеру О.Цаю.

Должны сказать большое спасибо директору ООО «Поликор» А.Н. Щелканову и всему коллективу, участвующему в создании настоящей книге.

Можно с уверенностью сказать, что без этой искренней помощи всех этих замечательных людей мы не смогли бы никогда выпустить в свет данную книгуучебник, которая крайне необходима врачу-клиницисту каждому из многочисленных врачебных специальностей. Мы очень уверены и хотели бы, чтобы наша уверенность передалась врачам, что без иммунологических знаний у современной медицины нет перспектив для успешного развития. А это в первую очередь аукнется здоровьем Человека.

Еще много и много раз спасибо всем тем, кто своим прекрасным отношением к иммунологии способствовал изданию этого печатного труда. 


\section{Шеф}

Да именно такому негласному отношению, со стороны близких ему сослуживцев, был удостоен Юрий Викторович Скавинский, заведующий кафедрой инфекционных болезней КГМИ. Стоит признать, что и мы сотрудники БСМП, работающие бок обок с коллегами кафедры, невольно восприняли это уважительное к нему обращение.

«A теперь, дорогие коллеги, могу с удовлетворением признать что, если до настоящего дня вы были врачами De facto!», то сегодня вы ими стали De jure!». Примерно так в июне 1974 года в своем приветствии провозгласил нам, выпускникам Красноярского медицинского института, Юрий Викторович, будучи председателем государственной экзаменационной комиссии.

Стоит признать, что все мы работники трех инфекционных отделений наитеснейшим образом были связаны с кафедрой инфекционных болезней, базой которой была БСМП. Это утренние отчеты дежурной бригады, на которых мы получали, мягко говоря, запоминающиеся ЦУ от шефа. А регулярные профессорские обходы! Они представляли собой, в некотором роде, театрализованный ритуал! И если для пациентов, они становились ярким жизнеутверждающим действом, то для «свиты», стоит признать, таковым был не всегда... Пишу эти строки и, невольно поймал себя на мысли, что воспринял от Юрия Викторовича этакую, доброжелательно - ироничную форму отношений.

Беспредельно благодарен ему тем, что именно он определил мой «путь в профессию!». Его артистически неповторимая форма подачи, превращала порой суховатый теоретический материал, в живые, запоминающиеся и увлекательные истории. И, должен сказать, что это впечатление сохранили многие студенты, даже не посвятившие себя профессии инфекциониста.

Именно тогда, на пятом курсе, я стал участником студенческого научного общества (CHO), возглавляемой им кафедры. Там мы приобщались к «научным изысканиям», представляя их результаты даже на обществе инфекционистов и эпидемиологов! Не раз приходилось получать от шефа одобрительно - ироничную оценку «нашим изысканиям». И, могу признать, что это воспринималось с пониманием... Так мы учились работать, думать, сомневаться и принимать самостоятельные решения.

Тогда, в начале 70-х, кафедра располагалась в одноэтажных деревянных корпусах, в районе нынешней Предмостной площади.. Они то и навели меня на воспоминание одного любопытного факта моей жизни. 
В начале прошлого века здесь была развернута, так называемая «переселенка», а позже базировалась городская больница Красноярска. В далеком 1951 году в одном из корпусов располагался роддом, откуда я и получил свою жизненную «прописку»...

В 1974 году в качестве врача - интерна я был принят в БСМП. Думаю, можно назвать удачей начало пути в профессию под непосредственным началом двух авторитетных руководителей, - Н.С. Карповича и Ю.В. Скавинского. Безусловно, Юрий Викторович был первым моим учителем. Однако я просто обязан упомянуть и о других старших коллегах, сотрудниках кафедры инфекционных болезней, делившихся со мной своим практическим опытом. Это Н.И. Захаров и В.Г. Кузнецов, А.И. Бычкова и Е.А. Малькова, А.П. Миноранская и М. М. Чигодаева.

С удовлетворением могу признать, что с Юрием Викторовичем у меня сложились достаточно искренние и даже, можно сказать, доверительные отношения. Вспомнилось, как уже на второй год работы в БСМП, мне случилось зайти в его просторный кабинет. К моему удивлению тогда я был удостоен чести ознакомиться с объемистым машинописным экземпляром его докторской диссертации по теме «Токсоплазмоз». Тогда он сопроводил это представление в своей торжественно - ироничной манере. «Вот, смотрите, это четыре килограмма моего труда, по теме я посвяти памяти своего отцуа». На первой странице значилось примерно следующее: «Отиу своему В.А. Скавинскому посвящаю свой труд». Рад и тому, что Юрий Викторович доверил мне сделать этот фотопортрет. К тому же, в моем фото - архиве еще несколько удачных фрагментов.

1977 г. Ю.В. Скавинский и А.Н. Юрьев.

1979 г. Н.И. Захаров, Ю.В. Скавинский и В.Г. Кузнецов
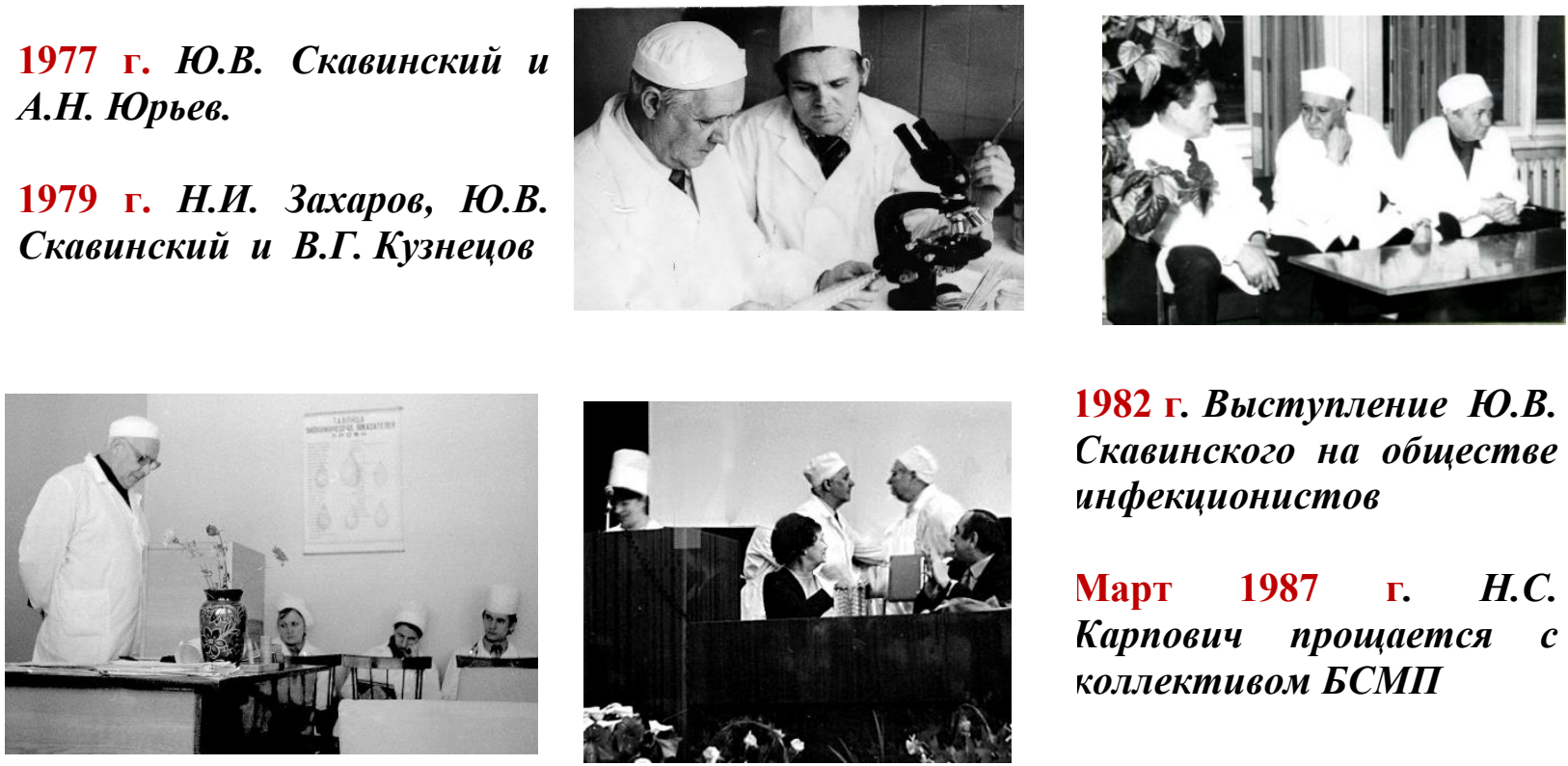

1982 г. Выступление Ю.В. Скавинского на обществе инфекционистов

$\begin{array}{llll}\text { Март } 1987 & \text { г. } & \text { H.C. }\end{array}$ Карпович прощается $c$ коллективом БСМП

Бабушкин А.О. Июнь 20212. 


\section{Глава 1. Микробиота и патогены}

Инфекционные болезни известны с давних времен. От чумы, оспы, холеры, брюшного и сыпного тифа, гриппа и других инфекций погибло больше людей чем от войн и стихийных бедствий. Только от чумы в XIV веке погибло примерно 150 миллионов человек. В пандемию гриппа, вызванной вирусом $\mathrm{H}_{1} \mathrm{~N}_{1}$ гриппа А, с февраля 1918 года по апрель 1920 года заразилось более 500 миллионов человек (в то время треть населения мира), максимальное число погибших достигло 100 миллионов человек. Не меньшие потери и от других инфекционных заболеваний. Только острые респираторные инфекции в мире ежегодно регистрируют у половины населения, у $30 \%$ жителей в мире бывают кишечные инфекции. Малярия в течении года определяется у 350-500 млн. человек. Практически все население мира заражено вирусами герпеса. Практически у $80 \%$ сексуально активных молодых женщин до 30 лет выявляется вирус папилломы человека, два типа которого в 70\% всех случаев вызывают рак шейки матки. Гепатитом в мире переболели около двух миллиардов человек. По оценки ВО3, 5\% человек во всем мире живут с хроническим гепатитом В, $1 \%$ с хроническим гепатитом С. Распространенность ВИЧ среди взрослых в мире составляет $0,8 \%$, в некоторых странах она превышает $10 \%$. Четверть населения мира инфицированы туберкулезом. Паразитарные инвазии во всем мире имеют более 2 миллиардов человек. Опасность для здоровья человека представляют инфекции с высоким уровнем смертности такие как брюшной и сыпной тиф, полиомиелит, менингококковая инфекция, дифтерия, ботулизм, различные виды геморрагических лихорадок и пр. Все эти и многие другие заболевания связанны с проникновением микроорганизмов во внутреннюю среду организма человека, которые приводят к нарушению гомеостаза организма с развитием физиологических и патологических реакций, определенные как инфекция или инфекционный процесс.

Согласно определению И.И. Мечникова, «...инфекция есть борьба между двумя организмами». Подразумевается, что в инфекционном процессе участвуют защитная система организма, его иммунная система и микроорганизм (патогенный микроорганизм). В связи с этим прежде всего необходимо определить, кто это такой патогенный микроорганизм т.к. мы живем и с нами 
живет большое количество других непатогенных микроорганизмов, которые очень важны для нормальной жизни человека в том числе и его защиты.

Микробиота (нормальная микрофлора, нормофлора, комменсалы, биотоп) - сообщество, состоящее из более 1000 видов симбиотических и комменсальных бактерий, архей, простейших, грибов и вирусов, населяющих организм человека в пределах тканей и жидкостей. Объем микробиоты оценивается в $10^{14}$ клеток, составляя до 1\% массы человека (около 1 кг). По количеству клеток микробиота сопоставима с общим количеством клеток человека, однако общий ее геном (микробиом) больше в 100 раз. Стоит обратить внимание, что при оценке микробиома в расчет не принимают вирусы и фаги, присутствующие в различных средах организма, которые по численности превосходят количество бактерий на порядок.

Популяция микробов, их количество и состав в различных тканях существенно отличаются (рис. 1). Если количество микробов увеличивается за пределы своих типичных диапазонов (чаще всего из-за нарушения функции иммунной системы) или микробы заселяют (например, из-за травмы) участки организма, где они обычно не присутствуют или стерильные зоны (кровь, брюшная полость и др.), возникают заболевания.

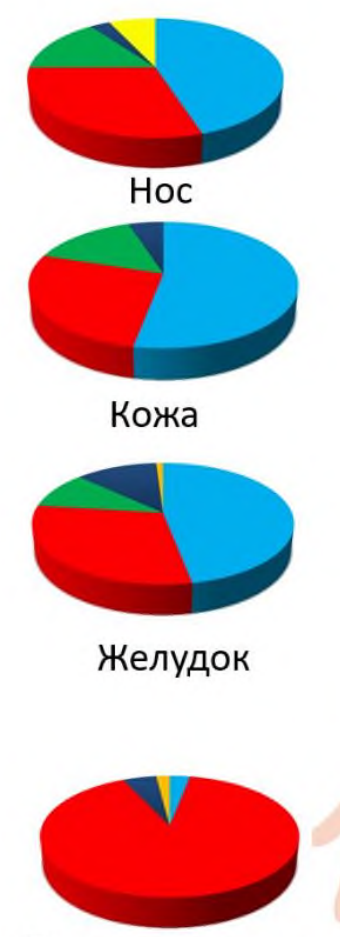

Половые органы
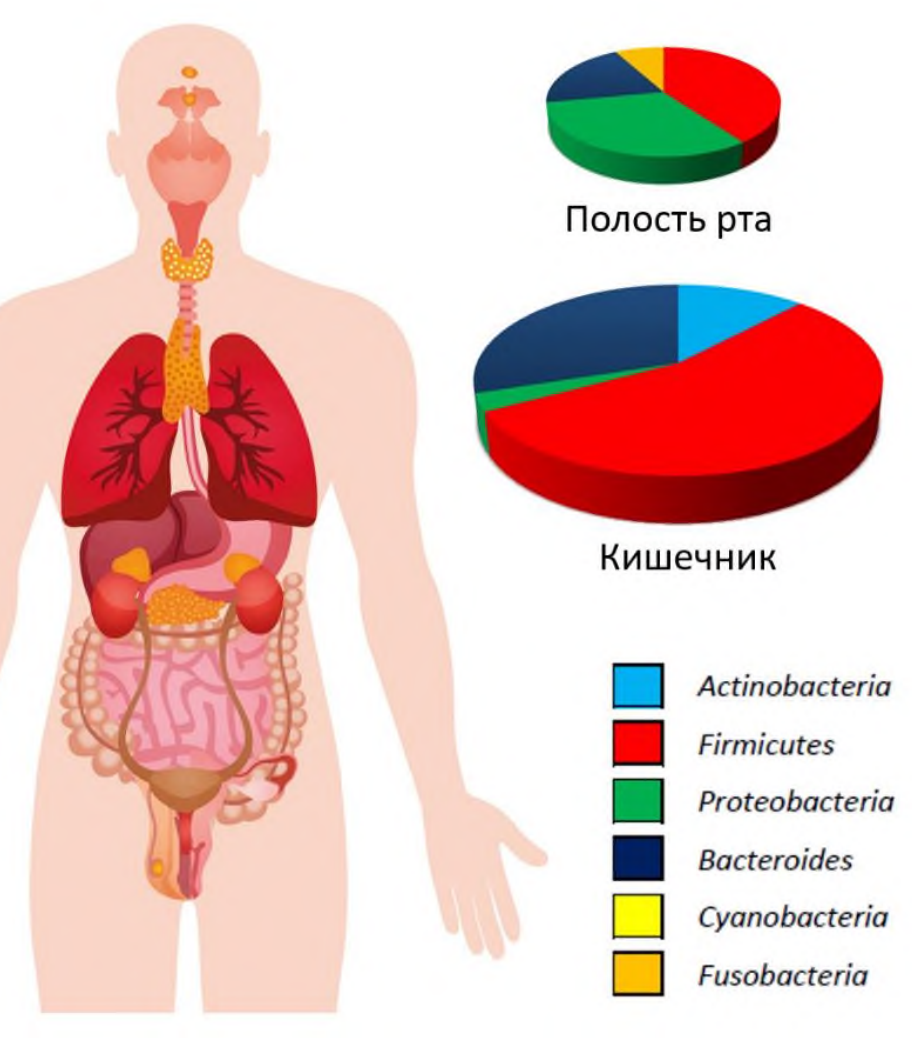

Рис. 1. Состав микробиоты человека.

(В рисунке использованы элементы изображение сайта https://clinimm.ru) 
С клинической точки зрения необходимо выделить микроорганизмы, постоянно живущие основные (резидентная микробиота - около 90\%), постоянно живущие сопутствующие (факультативная микробиота - менее 9,5\%) и случайно попавшие (транзиторная микробиота - до $0,5 \%$ ). К транзиторной микробиоте относятся патогенные микроорганизмы.

Состав микробиоты человека со временем может меняться. Чаще всего такое изменение связано с изменением диеты и общего состояния здоровья.

Наиболее исследованной и самой большой по объему является микробиота желудочно-кишечного тракта (более 75\%). Она представлена в основном анаэробами (табл. 1). Состав кишечных бактерий каждого человека индивидуален и формируется в зависимости от возраста, местоположения, характера питания, образа жизни и состояния здоровья. На основе микробного состава по преобладанию тех или иных ключевых родов бактерий Bacteriodes, Prevotella и Ruminococcaceae выделяют три основных энтеротипа (как группа крови). При 1-м энтеротипе доминируют представители рода Bacteroides, при 2-м - Prevotella, при 3-м - Ruminococcus.

Таблица 1

Микробиота интестинального тракта

\begin{tabular}{|l|l|l|}
\hline \multicolumn{1}{|c|}{ Тип } & \multicolumn{1}{|c|}{ Класс } & \multicolumn{1}{c|}{ Семейство, вид } \\
\hline \multirow{2}{*}{ Firmicutes (50\%) } & Clostridia & $\begin{array}{l}\text { Lachnospiraceae (20-25\%) - Faecalicatena contorta } \\
\text { Clostridiaceae (1-3\%), Heliobacteriaceae }\end{array}$ \\
\cline { 2 - 3 } & & $\begin{array}{l}\text { Ruminococcaceae (10-15\%) - Faecalibacterium } \\
\text { prausnitzii }\end{array}$ \\
\cline { 2 - 3 } & Bacilli & $\begin{array}{l}\text { Bacilliales - Bacillaceae, Staphylococcaceae } \\
\text { Lactobacillus - Lactobacillaceae, Enterococcaceae, } \\
\text { Streptococcaceae }\end{array}$ \\
\cline { 2 - 3 } & Mollicutes & Clostridium, Mycoplasma и Ureaplasma \\
\cline { 2 - 3 } & Negativicutes & Veilonellaceae \\
\hline Bacteroidetes (30\%) & Bacteroides & $\begin{array}{l}\text { Bacteroidaceae (10-15\%), Porphyromonadaceae (4- } \\
\text { 8\%), Rickenellaceae (3-5\%) }\end{array}$ \\
\cline { 2 - 4 } & Prevotella & Prevotellaceae (4-8\%) \\
\hline Proteobacteria (3\%) & Enterobacteriaceae & Escherichia, Klebsiella \\
\hline Actinobacteria (1\%) & Bifidobacterium & Bifidobacterium, Propionebacterium, Atopobium \\
\hline Fusobacteria & Fusobacteriia & Fusobacterium \\
\hline Verrucomicrobia & Verrucomicrobiae & Verrucomicrobium spinosum \\
\hline Archaea (до 20\%) & Methanobacteria & Methanobrevibacter smithii \\
\hline
\end{tabular}


Основная масса микрофлоры (пристеночная микрофлора) фиксирована и тесно связана с энтероцитами, образуя биопленку (микробно-тканевой комплекс, включающий в себя микроколонии бактерий и их метаболитов,

Основная масса микрофлоры (пристеночная микрофлора) фиксирована и тесно связана с энтероцитами, образуя биопленку (микробно-тканевой комплекс, включающий в себя микроколонии бактерий и их метаболитов, секреты бокаловидных клеток, клеток Панета, эндокриноцитов и пр.), незначительная часть находится в просвете кишки (просветная микрофлора).

Микробиота активно участвует в пищеварении, расщепляя основные пищевые субстанции и синтезируя новые. Многие виды белков, жиров и углеводов, из рациона человека, могут быть расщеплены только определенными кишечными микроорганизмами (табл. 2).

Таблица 2

\section{Участие микробиоты в обмене веществ человека}

\begin{tabular}{|c|c|c|}
\hline $\begin{array}{c}\text { Тип } \\
\text { бактерий }\end{array}$ & Участие в метаболизме & Диета \\
\hline Bacteroides & $\begin{array}{l}\text { Расщепляют клетчатку, гидролиз белков, } \\
\text { переработка сложных углеводов. }\end{array}$ & Мясные и сладкие блюда \\
\hline Prevotella & $\begin{array}{l}\text { Переработка сложных и простых } \\
\text { углеводов. }\end{array}$ & $\begin{array}{l}\text { Растительная диета, вегетарианцы, } \\
\text { сладкоежки }\end{array}$ \\
\hline $\begin{array}{l}\text { Firmicutes } \\
\text { faecalibacterium }\end{array}$ & $\begin{array}{l}\text { Производят масляную кислоту за счет } \\
\text { расщепления сложных углеводов. }\end{array}$ & $\begin{array}{l}\text { Большое потребление овощей, } \\
\text { фруктов и злаков }\end{array}$ \\
\hline $\begin{array}{l}\text { Firmicutes } \\
\text { ruminococcus }\end{array}$ & $\begin{array}{l}\text { Способны перерабатывать целлюлозу, } \\
\text { крахмала. }\end{array}$ & $\begin{array}{l}\text { Макароны, картофель, зеленые } \\
\text { бананы, чечевица, зеленый } \\
\text { горошек, белая фасоль }\end{array}$ \\
\hline $\begin{array}{l}\text { Firmicutes } \\
\text { eubacterium }\end{array}$ & $\begin{array}{l}\text { Превращают лактат в кишечнике в } \\
\text { масляную кислоту. }\end{array}$ & Цельные злаки, бурый рис \\
\hline $\begin{array}{l}\text { Firmicutes } \\
\text { blautia }\end{array}$ & $\begin{array}{l}\text { Расщепляет сложных углеводы с } \\
\text { образованием ацетата. }\end{array}$ & $\begin{array}{l}\text { При большом употреблении } \\
\text { клетчатки }\end{array}$ \\
\hline $\begin{array}{l}\text { Firmicutes } \\
\text { roseburia }\end{array}$ & $\begin{array}{l}\text { Расщепляют растительные маннаны. } \\
\text { Контролируют воспалительных } \\
\text { процессов в кишечнике, атеросклероз. }\end{array}$ & $\begin{array}{l}\text { В орехах, бобовых, кокосах, } \\
\text { томатах, кофейных зернах }\end{array}$ \\
\hline $\begin{array}{l}\text { Firmicutes } \\
\text { coprococcus }\end{array}$ & $\begin{array}{l}\text { Расщепляют разные виды волокон и } \\
\text { производят масляную кислоту. }\end{array}$ & $\begin{array}{l}\text { При большом употреблении } \\
\text { клетчатки }\end{array}$ \\
\hline $\begin{array}{l}\text { Firmicutes } \\
\text { erysipelotrichia }\end{array}$ & Метаболизируют жиры & Жирная пища \\
\hline Bifidobacterium & $\begin{array}{l}\text { Синтезируют молочную, уксусную, } \\
\text { муравьиную, янтарную и гамма- } \\
\text { аминомасляную кислоты. Подавляют } \\
\text { рост патогенных бактерий. }\end{array}$ & $\begin{array}{l}\text { Ферментированные продукты } \\
\text { (кефир, хлеб на закваске, } \\
\text { квашеная капуста), соя, чеснок, } \\
\text { томаты, лук, банан, яблоко, } \\
\text { спаржа, мед }\end{array}$ \\
\hline Lactobacillus & $\begin{array}{l}\text { Образуют антибиотические вещества - } \\
\text { лактолин, лактоцидин, ацидофилин. }\end{array}$ & Молочные продукты \\
\hline Akkermansia & $\begin{array}{l}\text { Участвуют в обмене муцина, синтезирует } \\
\text { жирные кислоты. } \\
\text { Противовоспалительное действие. }\end{array}$ & Голодание \\
\hline
\end{tabular}


Помимо этого, нормальная микрофлора участвует в синтезе короткоцепочечных жирных кислот (ацетат, бутират, пропионат и пр.), аминокислот (аргинин, глутамин), витаминов (К, В1, В2, В3, В5, В6, В12, С, Д, биотина, пантотеновой кислоты), гормонов. Она способствует всасыванию ионов железа, кальция, обеспечивая полностью питательными и энергетическими веществами эпителий кишечника, определяя его созревание и регенерацию. Также микробиота, участвуя в обмене солей желчных кислот и холестерина, обеспечивает гиполипидемический эффект.

Микробные метаболиты способствуют укреплению эпителиального барьера, например, индол, за счет связывания белков цитоскелета формирует плотные контакты между эпителиоцитами.

Детоксикационная функция микробиоты осуществляется путем нейтрализации экзогенных и эндогенных токсических продуктов, в т.ч. канцерогенов (амины, тиолы, фенолы, ксенобиотики и др.), которые в дальнейшем утилизируются в реакциях метаболизма и/или выводятся из организма с кишечным содержимым.

Одной из основных функций нормальной микрофлоры является предотвращение развития патогенных макроорганизмов, в основе которого лежит принцип микробного антагонизма. Помимо этого, в качестве защиты бактерии микробиоты кишечника вырабатывают антимикробные пептиды и другие метаболиты с антимикробными свойствами, изменяют $\mathrm{pH}$, а также физически противодействуют колонизации патогенами.

Аналогичные функции выполняет нормальная микрофлора и на других участках. Кожа, дыхательные пути, урогенитальный тракт и пр. имеют свой состав микрофлоры, который активно участвуют в формировании мукозального иммунитета.

Любой инфекционный процесс можно считать дисбиозом, т.к. когда начинает превалировать патогенный микроорганизм, снижается количество и разнообразие числа других бактерий. Как защитную функцию можно рассматривать процессы взаимодействия иммунной системы и нормальной микробиоты с формированием толерантности микробиоты и организма человека.

В отличии от нормальной микробиоты, организм человека постоянно соприкасается с микроорганизмами, способными вызывать заболевания (патогены, возбудители) при естественных, для данного микроба условий, заражения (рис. 2). Они имеют структуры, ферментативные системы и другие факторы, способные преодолевать защитные факторы организма и прежде всего мукозальный иммунитет. Развитие заболевания, вызванное микроорганизмами, происходит за счет прямого воздействия на клетки организма человека, и/или 
производством эндотоксинов, которые повреждают клетки организма, и/или за счет сильной стимуляции иммунного ответа, приводящего к повреждению клеток и тканей организма человека.

Большинство инфекционных заболеваний вызывает определенный возбудитель и/или его болезнетворные компоненты т.е. патоген является специфичным для определенной инфекции.

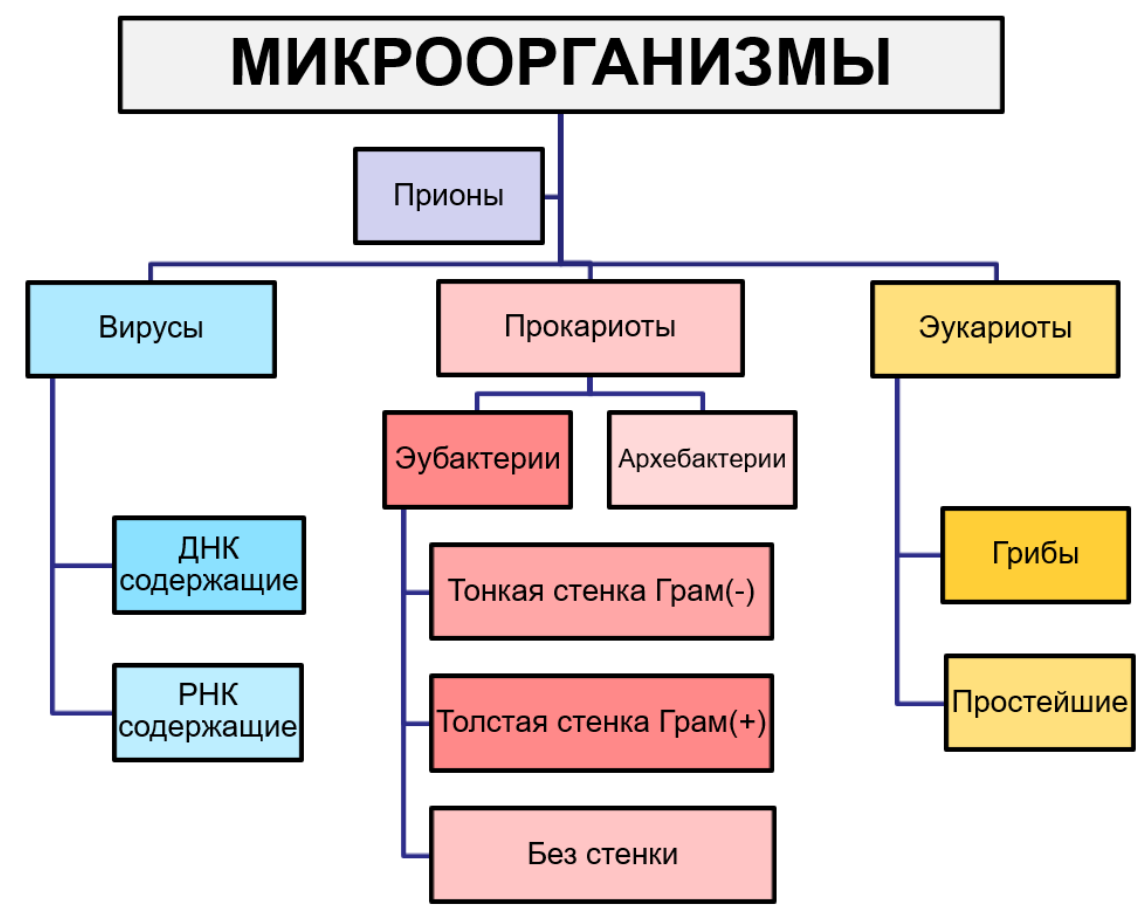

Рис. 2. Патогены.

Они наделены механизмами для преодоления нормальных защитных сил организма. Эти свойства определены как мера патогенности или вирулентность, которая зависит от способности микроорганизма к колонизации в организме человека, в том числе к способности прикреплению к клеткам, входа и выхода патогена из клетки, поглощению питательных веществ, уклоняться от иммунной системы путем ускользания и/или иммуносупрессии, наличием элементов, способствующим распространению инфекционных агентов по тканям. Так же одним из основных факторов вирулентности являются эндо- и экзотоксины, в основном вырабатываемые бактериями и грибами.

Bce патогенные микроорганизмы имеют молекулярные структуры, отсутствующие в организме человека. PAMP (Pathogen-associated molecular patterns (образы патогенности) чужеродные структуры патогенов). Это пептидогликаны, ЛПС (липополисахариды), липопротеины, липотейхоевая и тейхоевая кислоты, флагеллин, нуклеиновые кислоты вирусов и бактерий, 
вирусные белки и др., являющиеся составными частями микроорганизма. Часть молекул или молекулярные структуры, которые организм рассматривает как чужеродное и к которым формирует иммунный ответ, направленный на инактивацию и удаление его из организма определены как антигены (англ. от antibody generator - «производитель антител»).

Антигенами являются белки, пептиды (не менее 7-10 аминокислот) и полисахариды. Липиды и нуклеиновые кислоты становятся антигенами только в сочетании с белками и полисахаридами.

Антигены - это белки, пептиды (аминокислотные цепи) и полисахариды (цепи моносахаридов / простых сахаров), но липиды и нуклеиновые кислоты становятся антигенами только в сочетании с белками и полисахаридами.

В области иммунологии, антиген (АГ), может присутствовать на наружной стороне патогена, которые могут быть связаны с помощью антигенспецифических антител или антигенов В-клеточного рецептора. Присутствие антигенов в организме обычно вызывает иммунный ответ.

Процесс взаимодействия между патогенными молекулами и иммунной системой происходит по рецепторному типу.

В качестве лиганда выступает АГ, который образует комплекс с клеточным рецептором, отвечающим за обнаружение такого лиганда. После чего в клетке происходят серии биохимических реакций, инициируемых стимулом (первый мессенджер), передаваемым внутрь клетки через вторичные мессенджеры, которые усиливают сигнал и направляют его эффекторным молекулам, заставляя клетку реагировать на первоначальный стимул в виде биохимических, физиологических или фармакологических эффектов (рис. 3).

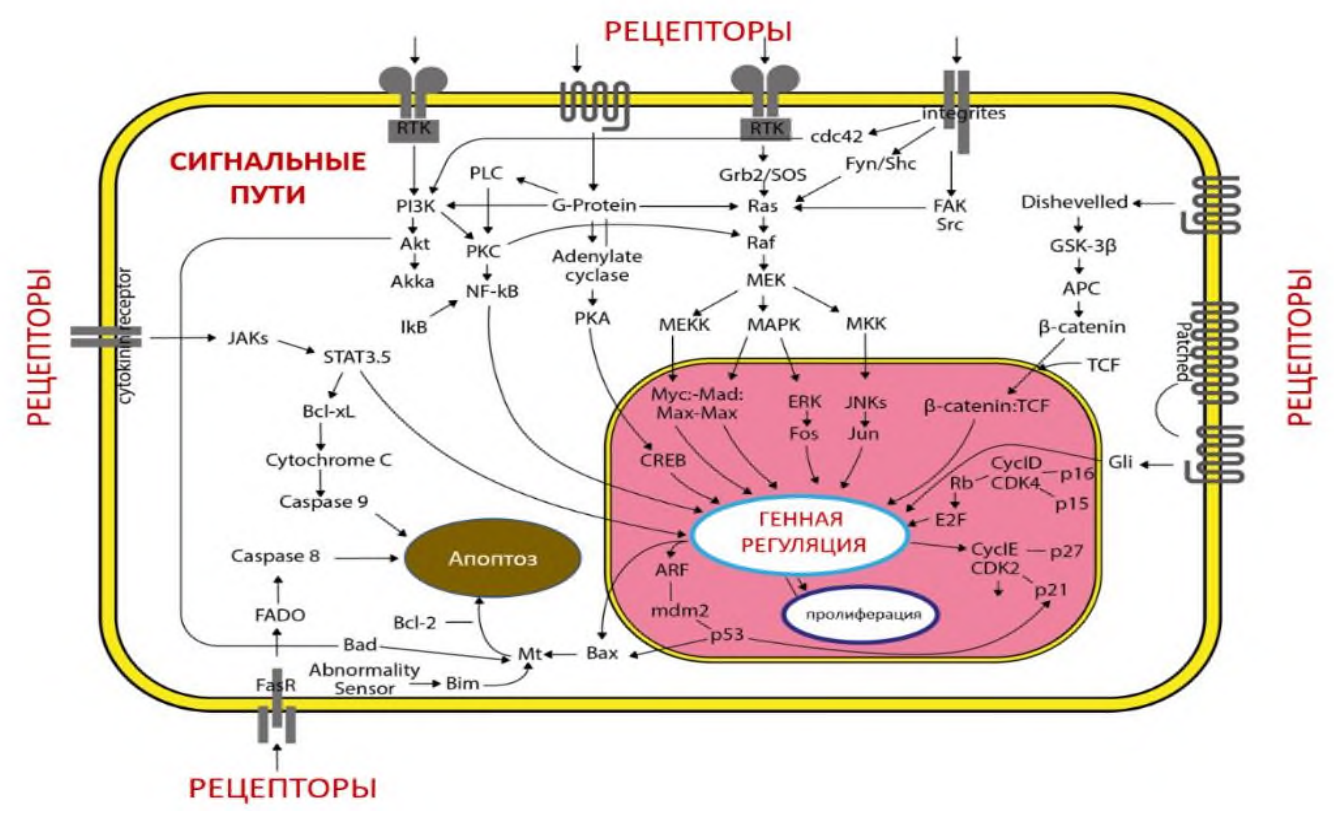

Рис. 3. Передача сигнала. 
Выделяют рецепторы врожденной иммунной системы (табл. 3) и рецепторы адаптивного иммунитета (табл. 4). Рецепторы врожденного иммунитета одинаковы у разных людей, ограничены по количеству и разнообразию, напротив, рецепторы адаптивного иммунитета, генерируемые при сборке, имеют большое количество рецепторов используя случайные комбинации генов.

Таблица 3

\section{Рецепторы врожденной иммунной системы}

\begin{tabular}{|c|c|c|}
\hline Рецептор & Лиганд & Функция \\
\hline $\begin{array}{l}\text { Рецепторы } \\
\text { распознавания } \\
\text { образов (PRR) }\end{array}$ & $\begin{array}{l}\text { Патоген - ассоциированные } \\
\text { молекулярные паттерны } \\
\text { (РАМР) }\end{array}$ & $\begin{array}{l}\text { Посредством производства цитокинов } \\
\text { инициируют воспаление }\end{array}$ \\
\hline $\begin{array}{l}\text { Киллер- } \\
\text { активируемые и } \\
\text { киллер- } \\
\text { ингибируемые } \\
\text { рецепторы (KAR и } \\
\text { KIR) }\end{array}$ & $\begin{array}{l}\text { МНС I + молекулы стресса } \\
\text { (МІСА и МІСВ). Лектины С- } \\
\text { типа и пр. }\end{array}$ & $\begin{array}{l}\text { Позволяет NK-клеткам идентифицировать } \\
\text { аномальные клетки-хозяева (KAR) или } \\
\text { подавлять несоответствующее разрушение } \\
\text { клеток-хозяев (KIR) }\end{array}$ \\
\hline $\begin{array}{l}\text { Рецепторы } \\
\text { комплемента }\end{array}$ & $\begin{array}{l}\text { Белки комплемента, } \\
\text { например, микробов }\end{array}$ & $\begin{array}{l}\text { Позволяют фагоцитам и В-клеткам } \\
\text { распознавать микробы и иммунные } \\
\text { комплексы }\end{array}$ \\
\hline Рецепторы Fc & $\begin{array}{l}\text { Комплексы эпитоп- } \\
\text { антитело }\end{array}$ & Стимулируют фагоцитоз \\
\hline $\begin{array}{l}\text { Цитокиновые } \\
\text { рецепторы }\end{array}$ & Цитокины & Регуляция и координация иммунных ответов \\
\hline
\end{tabular}

Таблица 4

Рецепторы адаптивной иммунной системы

\begin{tabular}{|l|l|l|}
\hline \multicolumn{1}{|c|}{ Рецептор } & \multicolumn{1}{|c|}{ Лиганд } & \multicolumn{1}{|c|}{ Функция } \\
\hline $\begin{array}{l}\text { Антиген - } \\
\text { распознающие } \\
\text { рецепторы }\end{array}$ & $\begin{array}{l}\text { Эпитопы (антигенные } \\
\text { детерминанты) }\end{array}$ & $\begin{array}{l}\text { Дифференцировка В-клеток в плазматические } \\
\text { клетки и пролиферация }\end{array}$ \\
\hline $\begin{array}{l}\text { Рецепторы Т- } \\
\text { клеток }\end{array}$ & $\begin{array}{l}\text { Линейные эпитопы, } \\
\text { связанные с МНС }\end{array}$ & Активация Т-клетки \\
\hline
\end{tabular}




\section{Глава 2. Вирусы и прионы}

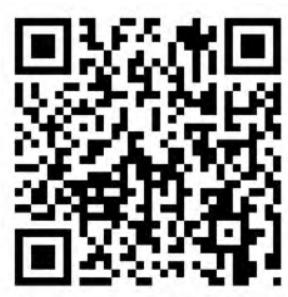

Прионы - представляют собой неправильно свернутые белки, обладающие способностью передавать свою неправильно свернутую форму нормальным вариантам того же белка. За счет этого формируются амилоиды белковые агрегаты, включающие плотно упакованные слои, амилоидные бляшки, которые разрушают нормальные ткани за счет внеклеточной агрегации в центральной нервной системе, вызывая её повреждение. Разрушение ткани характеризуется появлением губчатых «дырок», в сочетании с другими гистологическими изменениями, такими как звездчатая болезнь и отсутствие воспалительной реакции, все это создает «губчатую» структуру нервной ткани. Это дало основание определить эту группу заболеваний как трансмиссивная губчатая энцефалопатия.

У человека прионы вызывают болезнь Крейтцфельдта - Якоба, синдром Герстмана - Штраусслера - Шейнкера, фатальную семейную бессонницу, куру и вилюйский энцефалит. Инкубационный период заболевания приона, как правило, очень долгий, и как только появляются симптомы, болезнь быстро прогрессирует, что приводит к повреждению мозга и смерти.

В настоящее время прионная болезнь классифицируется как разновидность инфекционного заболевания. Однако патогенетический механизм прионной болезни ближе к метаболическим нарушениям, чем к инфекции.

Вирусы (от лат. virus - «яд») - неклеточные инфекционные агенты, которые могут воспроизводиться только внутри клеток. В среднем размеры вируса составляют около одной сотой размера бактерии. У них полностью отсутствует системы основного и энергетического обмена и структуры синтеза белка. Вне клетки вирусы существуют в виде биополимеров или вирионов, состоящих из генетического материала (ДНК или РНК) и капсида, белковой оболочки, которая окружает и защищает генетический материал, в некоторых случаях имеется дополнительная липидная оболочка. Наличие капсида отличает вирусы от вирусоподобных инфекционных нуклеиновых кислот - вироидов. Строение капсида имеет спиральный, кубический (икосаэдрический) и смешанный тип симметрии.

Процесс репродукции вируса происходит в несколько стадий (рис.5). 


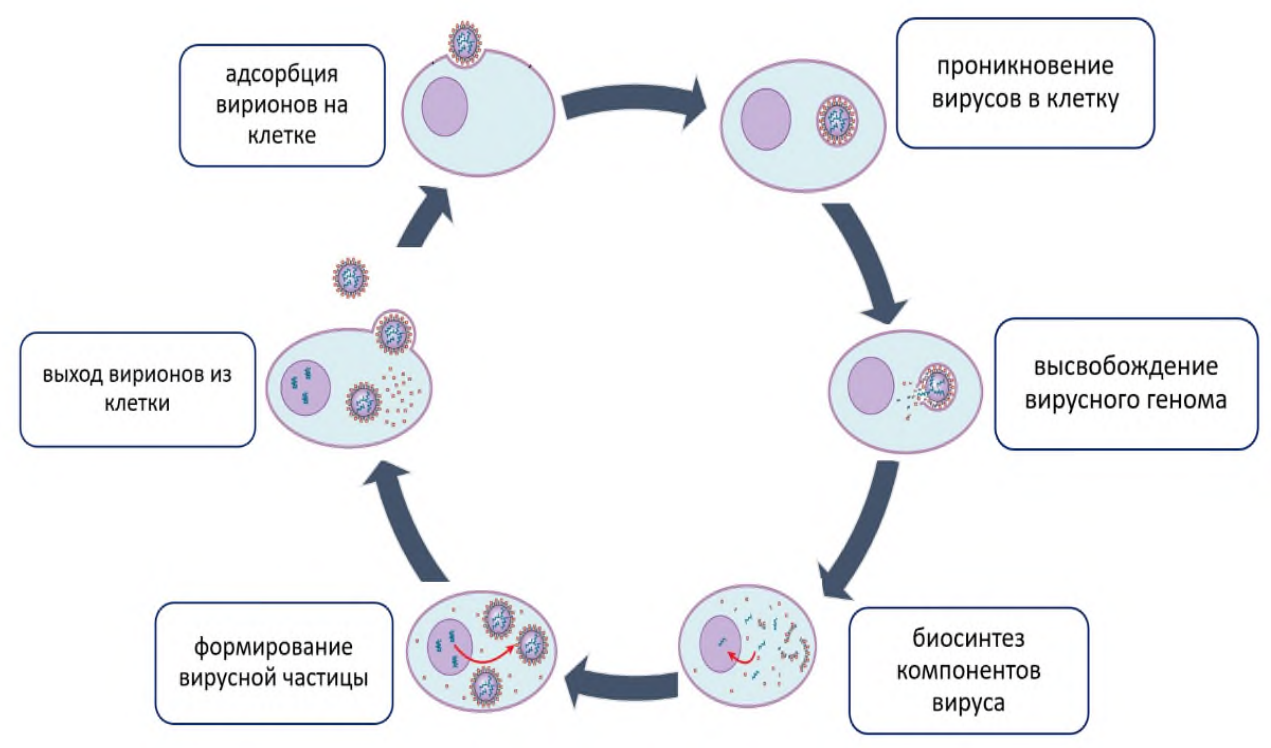

Рис. 5. Цикл репродукции вирусов.

(В рисунке использованы элементы изображение сайта https://clinimm.ru)

Вирусы не способны размножаться вне клетки, поэтому они находятся на границе живого. С одной стороны, они имеют свой набор генов, способны размножаться, создавая собственные копии путём самосборки и эволюционируют путём естественного отбора, за счет чего их можно отнести к «живым» микроорганизмам, с другой стороны это комплекс органических молекул без собственного обмена веществ, и синтеза собственных молекул. В отличии от риккетсий и хламидий, которые размножаются в пораженных клетках, используя свои собственные структуры, вирусы собираются в инфицированной клетке, используя системы клетки, которая вынуждена производить копии исходного вируса.

По переносу генетической информации на матричную РНК все вирусы можно отнести к одной из семи групп (табл.5.)

Вирусы поражают все типы организмов, от растений и животных до бактерий и архей. Не всегда взаимодействие вируса и клетки продуктивной фазы или, возможно, поражение клетки вирусами может ограничиваться прерыванием инфекционного процесса в клетке, когда новые вирионы не образуются (абортивный тип инфекции) или встраиванием вирусной ДНК в геном клетки и их совместном сосуществовании (интегративный тип инфекции).

Еще одной особенностью вирусных инфекций является тропизм вирусов. Вирусы поражают только те клетки, которые экспрессируют рецепторы, используемые вирусами для проникновения в клетку, поэтому вирусные инфекции чаще всего имеют типичную клиническую картину характерную для определенных органов и систем (рис.6). 


\section{Таблица 5}

\section{Классификация вирусов по типа нуклеиновой кислоты, типу транскрипции и репликации (классификации вирусов по Балтимору)}

\begin{tabular}{|c|c|c|}
\hline Группа & $\begin{array}{c}\text { Тип транскрипции и } \\
\text { репликации }\end{array}$ & $\begin{array}{c}\text { Основные } \\
\text { представители }\end{array}$ \\
\hline \multicolumn{3}{|c|}{ ДНК вирусы } \\
\hline $\begin{array}{l}\text { Двуцепочечные ДНК- } \\
\text { вирусы }\end{array}$ & $\begin{array}{l}\text { Матричная РНК образуется на самом } \\
\text { геноме. }\end{array}$ & $\begin{array}{l}\text { Герпесвирусы, аденовирусы, } \\
\text { папилломавирусы, } \\
\text { поксвирусы }\end{array}$ \\
\hline $\begin{array}{l}\text { Вирусы с } \\
\text { одноцепочечной ДНК }\end{array}$ & $\begin{array}{l}\text { На одноцепочечной ДНК образуется } \\
\text { комплементарная цепь, которая } \\
\text { станет матрицей образования РНК. }\end{array}$ & Парвовирусы \\
\hline \multicolumn{3}{|c|}{ РНК-вирусы } \\
\hline $\begin{array}{l}\text { Двуцепочечные РНК } \\
\text { вирусы }\end{array}$ & $\begin{array}{l}\text { Напрямую образуется матричная РНК } \\
\text { вируса. }\end{array}$ & Ротавирусы \\
\hline $\begin{array}{l}\text { Вирусы, содержащие } \\
\text { одноцепочечную (+) } \\
\text { РНК }\end{array}$ & $\begin{array}{l}\text { Для образования матричной РНК } \\
\text { образуется промежуточная } \\
\text { репликативная форма - } \\
\text { антигеномная минус РНК. }\end{array}$ & $\begin{array}{l}\text { Коронавирусы, норовирусы, } \\
\text { пикорнавирусы, гепевирусы, } \\
\text { астровирусы, гепатовирусы, } \\
\text { флавивирусы, альфавирусы }\end{array}$ \\
\hline $\begin{array}{l}\text { Вирусы, содержащие } \\
\text { одноцепочечную (-) } \\
\text { РНК }\end{array}$ & $\begin{array}{l}\text { По принципу комплементарного } \\
\text { синтеза образуется матричная } \\
\text { вирусная РНК. }\end{array}$ & $\begin{array}{l}\text { Парамиксовирусы, пневмо-и } \\
\text { рабдовирусы, буньявирусы, } \\
\text { ортомиксовирусы, } \\
\text { филовирусы, дельтавирус }\end{array}$ \\
\hline \multicolumn{3}{|c|}{ Вирусы обратной транскрипции } \\
\hline $\begin{array}{l}\text { Одноцепочечный РНК } \\
\text { вирус с промежуточной } \\
\text { ДНК }\end{array}$ & $\begin{array}{l}\text { На РНК образуется одноцепочечная } \\
\text { ДНК, далее двуцепочечная ДНК, и с } \\
\text { нее матричная вирусная РНК. }\end{array}$ & Ретровирусы \\
\hline $\begin{array}{l}\text { Двухцепочечные ДНК - } \\
\text { вирусы }\end{array}$ & $\begin{array}{l}\text { С двуцепочечная ДНК образуется } \\
\text { одноцепочечную (-) РНК, которая } \\
\text { является матрицей для образования } \\
\text { матричной РНК. }\end{array}$ & Гепаднавирусы \\
\hline
\end{tabular}

Исходя из этого, вирусные инфекции клинико-эпидемиологически можно разделить на респираторные инфекции, инфекции, поражающие желудочнокишечный тракт, ЦНС, печень, арбовирусные инфекции (переносчиками которых являются членистоногие), онковирусы и т.д. Однако тропность вирусов может распространятся на несколько органов и систем, поэтому традиционно вирусные инфекции связывают с определенным возбудителем. 


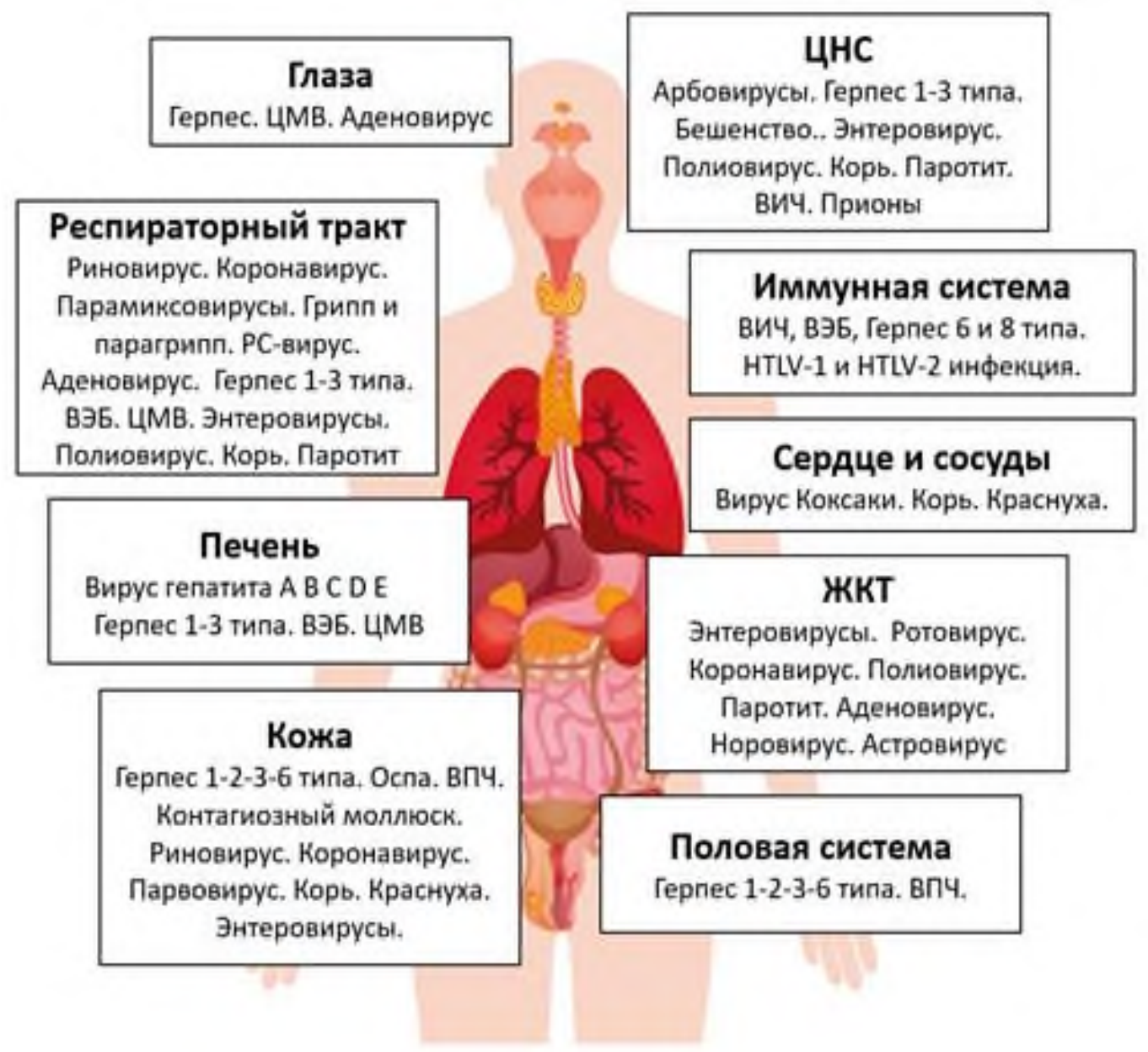

Рис. 6. Основные вирусные инфекции.

(В рисунке использованы элементы изображение сайта https://clinimm.ru)

ДНК вирусы представлены семействами вирусов, содержащие двуцепочную и одноцепочную ДНК. Основные патогенные для человека двуцепочные ДНК вирусы - герпесвирусы, поксвирусы, аденовирусы, папилломавирусы; одноцепочные - парвовирус.

Герпесвирусы чрезвычайно широко распространены среди людей. Инфицирование происходит воздушно-капельным путем. Мишенями для вируса являются клетки мукозального иммунитета (эпителиальные клетки, макрофаги, В-лимфоциты) с дальнейшей локализацией вируса в длительно живущих клетках (клетки нервной системы, клетки иммунной памяти). Более $90 \%$ взрослых инфицированы хотя бы одним из 9 разновидностей вирусов. Латентная форма вируса остается почти у всех инфицированных людей. Вирус, находясь в клетках, персистирует бесконечно длительное время, без клинических проявлений. Реактивация латентных вирусов происходит за счет системных чаще транзиторных иммунных нарушений и проявляется различной клиникой (табл.6). 
Таблица 6

\section{Вирусы герпеса человека}

\begin{tabular}{|c|c|c|}
\hline $\begin{array}{c}\text { Тип } \\
\text { герпесвируса }\end{array}$ & $\begin{array}{l}\text { Клетки } \\
\text { мишени }\end{array}$ & Синдромы \\
\hline \multicolumn{3}{|c|}{ Группа $\alpha$ (Альфа) - герпесвирусов } \\
\hline $\begin{array}{l}\text { Вирус простого } \\
\text { герпеса -1 (HSV- } \\
\text { 1) HHV - } 1\end{array}$ & \multirow{3}{*}{$\begin{array}{l}\text { Эпителиальные } \\
\text { клетки с } \\
\text { последующим } \\
\text { поражением } \\
\text { нейронов. }\end{array}$} & $\begin{array}{l}\text { Чаще оральный (герпетический стоматит, } \\
\text { везикулярное высыпания на губах, кератит фарингит) и } \\
\text { генитальный, многоформная эритема, энцефалит. }\end{array}$ \\
\hline $\begin{array}{l}\text { Вирус простого } \\
\text { герпеса } 2 \text { (HSV-2) } \\
\text { HHV-2 }\end{array}$ & & $\begin{array}{l}\text { Чаще генитальный (в т.ч. вагинальный) и оральная } \\
\text { герпетиформноя экзема, герпетический панариций, } \\
\text { кератит, эритема, менингит Молларета. }\end{array}$ \\
\hline $\begin{array}{l}\text { Вирус ветряной } \\
\text { оспы (VZV) HHV-3 }\end{array}$ & & $\begin{array}{l}\text { Ветряная оспа, опоясывающий лишай различной } \\
\text { локализации. }\end{array}$ \\
\hline \multicolumn{3}{|c|}{ Группа $\beta$ (бета) - герпесвирусов } \\
\hline $\begin{array}{l}\text { Цитомегаловирус } \\
\text { (ЦМВ, CMV, HSV- } \\
\text { 5) HHV-5 }\end{array}$ & $\begin{array}{l}\text { Моноциты и } \\
\text { эпителиальные } \\
\text { клетки, клетки } \\
\text { железистых } \\
\text { органов. }\end{array}$ & $\begin{array}{l}\text { Инфекционный мононуклеоз, ретинит, гепатит, } \\
\text { увеличение органов брюшной полости, воспаление } \\
\text { слюнных желез (так называемое слюнотечение). }\end{array}$ \\
\hline $\begin{array}{l}\text { Вирус простого } \\
\text { герпеса - } 6 \text { (HSV- } \\
\text { 6) HHV-6A }\end{array}$ & \multirow[t]{3}{*}{ Т-клетки } & \multirow{2}{*}{$\begin{array}{l}\text { Шестая болезнь - детская розеола или внезапная } \\
\text { экзантема. Гепатит, злокачественные лимфомы, } \\
\text { интерстициальная пневмония, миалгический } \\
\text { энцефаломиелит, гистиоцитарный некротический } \\
\text { лимфаденит, розовый лишай. }\end{array}$} \\
\hline HHV-6B & & \\
\hline HHV-7 & & $\begin{array}{l}\text { Экзантема новорожденных, вероятная причина } \\
\text { синдрома хронической усталости, розовый лишай. }\end{array}$ \\
\hline \multicolumn{3}{|c|}{ Группа ү (Гамма) - герпесвирусов } \\
\hline $\begin{array}{l}\text { Вирус Эпштейна } \\
\text { - Барра (EBV) } \\
\text { HНV-4 }\end{array}$ & $\begin{array}{l}\text { В-клетки и } \\
\text { эпителиальные } \\
\text { клетки }\end{array}$ & $\begin{array}{l}\text { Инфекционный мононуклеоз. Лимфопролиферативный } \\
\text { синдром лимфома Беркитта, лимфома ЦНС, } \\
\text { назофарингеальная карцинома. }\end{array}$ \\
\hline $\begin{array}{l}\text { Радиновирус } \\
\text { HHV-8 (KSHV) }\end{array}$ & $\begin{array}{l}\text { Лимфоциты и } \\
\text { другие клетки }\end{array}$ & $\begin{array}{l}\text { Саркома Капоши, первичная лимфома серозных } \\
\text { полостей, некоторые разновидности болезни } \\
\text { Кастельмана. }\end{array}$ \\
\hline
\end{tabular}

Особое внимание из этой группы вирусов необходимо уделить вирусу Эпштейна-Барр (EBV), который непосредственно поражает клетки иммунной системы. Два типа вирус Эпштейна-Барра (EBV-1 и EBV-2) представители семейства Herpesviridae (Gammaherpesvirinae, герпесвирус человека 4 типа (HHV4) являются одними из наиболее распространенных вирусов в мире. До 5 лет заражается более $50 \%$ детей, взрослые заражены практически все, несмотря на то, что вирус не является очень контагиозным и не выявляется в окружающей среде.

Вирус, проникая в верхние отделы дыхательных путей поражает эпителий и лимфоидную ткань (кольцо Пирогова-Вальдейера), заражает наивные В- 
клетки, активируя их в пролиферирующие латентно инфицированные бласты. Эти клетки затем перемещаются в зародышевые центры (GC) лимфатических узлов, селезенки и другие лимфоидные образования. Репликация вируса в Влимфоцитах стимулирует их активную пролиферацию и дифференцировку в плазмоциты. Последние секретируют иммуноглобулины низкой специфичности. Одновременно нарастает количество и активность Т-лимфоцитов. Цитотоксические Т-лимфоциты (Tc) уничтожают инфицированные вирусом клетки, распознавая мембранные вирус-индуцированные антигены. Однако латентно инфицированные В-клетки памяти не повреждаются Тс.

После первичной инфекции вирус Эпштейна-Барр остается в организме, прежде всего в В - (EBV-1) и Т-лимфоцитах (EBV-2), пожизненно. В любое время небольшое подмножество латентно инфицированных В-клеток памяти инициирует литическую реактивацию в сочетании с сигналами терминальной дифференцировки. Этот процесс приводит к высвобождению вируса, который может попасть в слюну для распространения инфекции или инфицировать новые наивные В-клетки. Возможно развитие лимфопролиферативных (лимфома Ходжкина, лимфома Беркитта, первичная церебральная лимфома, диффузная Вклеточная лимфома, лимфогистиоцитоз) и нелимфоидных злокачественных опухолей (рак желудка, рак легких, рак носоглотки, саркомы мягких тканей, лейомиосаркома), нелимфопролиферативных заболеваний (рассеянный склероз, системная красная волчанка, хроническая активная инфекция EBV, волосатая лейкоплакия, болезнь Кикучи (некротический лимфаденит), синдром Алисы в стране чудес (AIWS), гепатит, ангина, посттрансплантационные лимфопролиферативные заболевания).

Поксвирусы или вирусы оспы представлены тремя вирусами, имеющими клиническое значение: вирус натуральной оспы, вирус осповакцины и вирус контагиозного моллюска.

Натуральная оспа высокозаразная особо опасная вирусная инфекция, вызывается одним из двух вариантов вируса Variola major и Variola minor. Характеризуется тяжёлым течением. Первоначально начинается с высокой лихорадки, после этого образуются язвы во рту и кожная сыпь. Через несколько дней кожная сыпь превратилась в характерные пузыри, заполненные жидкостью, с вмятиной в центре. Затем пузырьки покрываются корками и отпадают, оставляя шрамы. Летальность в среднем 20 - 40 \%, в некоторых случаях до 90 \%.

Вирус осповакцины эпидемиологически не опасная инфекция, развитие заболевания связано с применением вакцины и может провяляться в виде: генерализованной реакции на осповакцину (генерализованное высыпание по типу оспы), прогрессирующей реакцией на осповакцину (безболезненный 
прогрессирующий некроз и изъязвлением на месте введения вакцины), вакцинальной экземе, эритемы, окружающей место инъекции осповакцины.

Контагиозный моллюск (водяные бородавки) - инфекция кожи, вызывается одним из четырех существующих типов вируса контагиозного моллюска (MCV1, MCV-2, MCV-3, MCV-4). Из них наиболее распространён MCV-1, a MCV-2 обычно проявляется у взрослых и часто передается половым путём. Также может передаваться через воду (например, бассейн). Приводит к появлению небольших приподнятых розовых поражений с ямочкой в центре. Они могут вызывать зуд или болезненность и возникать по отдельности или группами. Может быть поражен любой участок кожи, чаще всего - живот, ноги, руки, шея, область гениталий и лицо. Поражения появляются примерно через семь недель после заражения, обычно проходят в течение года без рубцов.

Аденовирусы - двухцепочечные ДНК вирусы без оболочки (без внешнего липидного бислоя). У людей выделено более 50 различных серотипов аденовирусов, вызывающих широкий спектр заболеваний, чаще всего с поражением верхних дыхательных путей. Одна из основных причин вирусного конъюнктивита, тонзиллита, отита. Наиболее опасным является аденовирус серотипа 14, в отличие от других аденовирусов, вызывающий смертельные инфекции. Аденовирусы 40 и 41 серотипа могут вызывать гастроэнтерит. Наиболее тяжелое течение инфекции характерно у людей с недостаточностью функции иммунной системы. Основными осложнениями аденовирусной инфекции являются: вирусная пневмония, энцефалит, отиты, синуситы, поражение почек. У детей раннего возраста нередко бывает ларингоспазм.

Парвовирус В19 - единственный известный одноцепочный ДНК-вирус, поражающий человека из семейства парвовирусов. Заболевание может возникнуть в любом возрасте, хотя чаще всего встречается у детей в возрасте от шести до десяти лет. Заболевание начинается с высокой температуры, недомогания, головной боли, тошноты, диареи. Когда лихорадка спадает, на щеках образуется красная сыпь с относительной бледностью вокруг рта («сыпь пощечины»), сохраняющейся около носогубных складок, лба и рта. Красная сыпь на туловище или конечностях, напоминающая кружево (сетчатая), затем следует за сыпью на лице. Инфекция у взрослых обычно включает только сетчатую сыпь с преобладанием множественных болей в суставах. Обострение сыпи может возникнуть от солнечного света, тепла, стресса. У подростков или молодых людей может развиться так называемый «синдром папулезнопурпурных перчаток и носков». У взрослых до 15\% всех новых случаев артрита связано с инфекцией парвовируса В19. Обычно симптомы со стороны суставов 
длятся 1 - 3 недели, но у 10-20\% пострадавших они могут длиться от нескольких недель до месяцев.

Папилломавирусы или вирусы папилломы человека (ВПЧ, HPV). В мире является наиболее распространённым заболеванием. Почти каждый человек в какой-то момент своей жизни инфицирован ВПЧ. Заражение вирусом возможно через общие предметы и кожу других людей, половым путём. Однако само по себе инфицирование ВПЧ не означает доказательство сексуального контакта, поскольку стандартный жизненный цикл вируса рассчитан на заражение через микротрещины в коже и на слизистых эпителиальных клетках базального слоя. Инфицирование обычно происходит при нарушении эпителиального барьера.

После инфицирования в большинстве случаев нет каких-либо явных клинических проявлений и человек просто является носителем вируса, но может заражать других людей.

В настоящее время известно более 170 типов вируса папилломы человека. По фактору онкогенности их можно разделенные на три группы (табл. 7).

Вирусы папилломы человека

\begin{tabular}{|c|c|c|}
\hline Группа & Тип ВПЧ & Проявление \\
\hline \multirow{3}{*}{$\begin{array}{l}\text { Неонкогенные } \\
\text { папилломавирусы }\end{array}$} & $2,7,22$ & Обычные бородаквки \\
\hline & $1,2,4,63$ & Подошвенные бородавки \\
\hline & $3,10,28,41,49$ & Плоские бородавки \\
\hline \multirow{6}{*}{$\begin{array}{l}\text { Онкогенные } \\
\text { папилломавирусы } \\
\text { низкого риска }\end{array}$} & $6,11,42,44$ & Аногенитальные бородавки \\
\hline & $5,8,12,14,15,17$ & Бородавчатая эпидермоплазия \\
\hline & 13,32 & Очаговая гиперплазия эпителия \\
\hline & 60 & Веррукозная киста \\
\hline & 6,11 & Папилломатоз гортани \\
\hline & $6,7,11,16,32$ & Папилломы во рту \\
\hline \multirow{3}{*}{$\begin{array}{l}\text { Онкогенные } \\
\text { папилломавирусы } \\
\text { высокого риска }\end{array}$} & $\begin{array}{l}\text { Самый высокий риск: 16, 18, } \\
31,45\end{array}$ & \multirow{3}{*}{$\begin{array}{l}\text { Анальная дисплазия } \\
\text { Бовеноидный папуллез } \\
\text { интраэпителиальной неоплазии } \\
\text { шейки матки. Рак шейки матки, } \\
\text { гортани, вульвы, влагалища, пениса, } \\
\text { ануса } \\
\text { Рак ротоглотки }\end{array}$} \\
\hline & $\begin{array}{l}\text { Высокий риск: 33, 35, 39, 51, } \\
52,56,58,59\end{array}$ & \\
\hline & $\begin{array}{l}\text { Вероятно, высокий риск: } 26 \text {, } \\
53,66,68,73,82\end{array}$ & \\
\hline
\end{tabular}


РНК-вирусы. Генетическая информация в РНК-вирусах представлена рибонуклеиновой кислотой. В зависимости от полярности РНК, количества цепей эти вирусы классифицированы на одноцепочечные РНК-вирусы с отрицательной цепью, одноцепочечные РНК-вирусы с положительной цепью и двухцепочечные РНК-вирусы. Вирусы, содержащие одноцепочечную (+) РНК похожую на мРНК и способные осуществлять транслирование непосредственно в зараженной клетки. (-) РНК вирусы перед трансляцией формируют мРНК под действием РНК-зависимой РНК-полимеразы. Двухцепочечные РНК вирусы напоминают (-) РНК-содержащие вирусы тем, что они также транслируют гены с отрицательной (некодирующей) цепи РНК.

Наиболее важными патогенами человека в семействе двуцепочечные РНК реовирусов являются ротавирусы. Имеются шесть серотипов ротавируса поражающих человека. Инфекция распространена по всему миру, и к 6 годам большинство детей имеют антитела по крайней мере к одному серотипу. Для ротавирусной инфекции характерны тошнота, рвота и частый обильный водянистый стул, не содержащий крови. Наиболее тяжело гастроэнтерит протекает у детей за счет дегидратации и электролитных нарушений, может возникнуть гиповолемический шок. Симптоматика у взрослых обычно минимальна.

К группе одноцепочечных (+) РНК вирусов относятся три вида и большая группа неклассифицированных вирусов. Патогенными для человека являются семейство коронавирусов, пикорнавирусов, норовирусов, гепатовируса, астровируы, флавивирусы, альфавирусы.

Коронавирусы - семейство оболочечных вирусов, вызывают болезни у млекопитающих и птиц. У людей вирусы вызывают респираторные инфекции, которые обычно протекают в легкой форме, хотя более редкие формы, такие как SARS (в т.ч. и COVID-19) и MERS, могут быть смертельными. Особого внимание заслуживает SARS-CoV-2 вирус, который после того, как в декабре 2019 был выявлен в Ухане (Китай), распространился по всему миру, что привело к продолжающейся до настоящего времени пандемии.

Вирус SARS-CoV-2 использует в качестве инфицирования рецепторы ангиотензин-превращающего фермента 2-го типа (ACE2) и мембрано-связанную сериновую протеиназу (TMPRSS2), которые находятся на многих типах клеток (поэтому COVID-19 нужно рассматривать как системную инфекцию). Изначально в основном поражаются эпителиальные клетки, альвеолярные эпителиальные клетки, эндотелиальные клетки кровеносных сосудов и макрофаги. После инфицирования клеток вирус SARS-CoV-2 предотвращает или 
замедляет запуск синтеза интерферонов I и III типа. Без этих ответов вирус способен поражать другие клетки верхних дыхательных путей и легкие. Пораженные клетки запускают программируемую клеточную смерть в виде пироптоза. Это воспалительный тип гибели клеток (по типу некроза) с повреждением клеточных мембран и выходом в межклеточное пространство большого количества аларминов или молекулярных паттернов, ассоциированных с повреждением (DAMP - damage-associated molecular pattern). Сама вирусная РНК выявляется патоген-распознающими рецепторами (TLR 3, 7 , 8, RIG-I, MDA-5) и через систему адаптивных белков запускает синтез провоспалительных цитокинов (ИЛ-1, ИЛ-18, ФНО).

Распознавание DAMP за счет цитоплазматического комплекса инфламмасомы приводит также к продукции других провоспалительных цитокинов и хемокинов (ИЛ-6, ИФН- $\gamma$, IP-10, Г-КСФ, макрофагальный воспалительный белок $1 \alpha$ и $1 \beta, \mathrm{MCP} 1)$. Вообще воспаление - необходимая часть иммунного ответа, без которой успешное разрешение инфекционного процесса и прекращение повреждения клеток невозможны, однако, в некоторых случаях, обычно на 7-10-е сутки болезни, наблюдается ухудшение состояния пациентов. Нарастает лихорадка, одышка, повышаются острофазовые маркеры воспаления (СОЭ, С-реактивный белок, ферритин), коагулопатии (повышение концентрации D-димера) и цитолиз (повышение активности АЛТ, АCT, КФК, ЛДГ). Это все проявления синдрома системной воспалительной реакции - гиперцитокинемии или «цитокинового шторма». Развивающийся «цитокиновый шторм» приводит к поражению органов и систем к формированию острой полиорганной недостаточности. Более того, нейтрализующие антитела, продуцируемые B-лимфоцитами, могут усилить инфекцию SARS-CoV-2 через феномен антителозависимого усиления инфекции, что приводит к дальнейшему органному повреждению.

При нормальном иммунном ответе интерферон блокирует развитие инфекции в зараженных клетках, вирус-специфические Т-лимфоциты поступают в очаг воспаления в самом начале воспалительного процесса и элиминируют пораженные клетки до распространения вируса. Нейтрализующие антитела блокируют вирусную инфекцию, альвеолярные макрофаги распознают комплексы антитело-вирус, а также клетки, подвергшиеся апоптозу, и уничтожают их путем фагоцитоза. Таким образом происходит клиренс вирусов при минимальном повреждении ткани. При этом синтез и секреция цитокинов происходят непродолжительное время (матричная РНК цитокинов короткоживущая) т.к. «запрос» на их синтез, из-за блокирования вируса, прекращается. Клетки, синтезирующие цитокины, переключаются на синтез супрессорных цитокинов и/или экспрессируют ингибиторные рецепторы или 
рецепторы для сигналов к апоптозу. При несостоятельности местных защитных реакций синтез цитокинов возрастает в разы. Прежде всего, это синтез провоспалительных цитокинов врожденного иммунитета, в меньшей степени цитокинов продукта активированных Т-лимфоцитов (рис. 7).

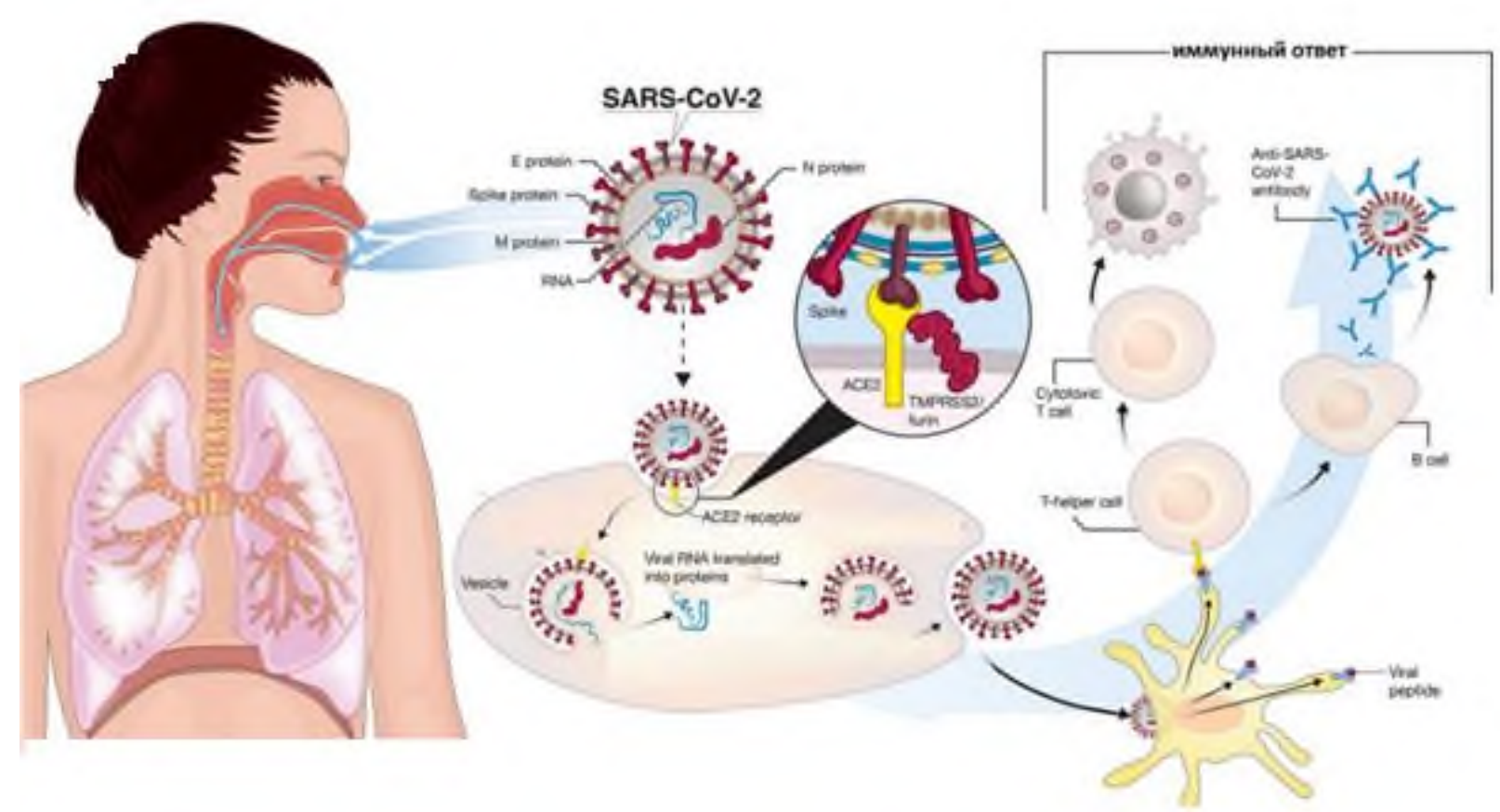

Рис. 7. Иммунопатогенез COVID-19.

(В рисунке использованы элементы изображение Центра по контролю и профилактике заболеваний Министерства здравоохранения и социальных служб США DPD CDC)

Большинство людей, заболевших COVID-19, полностью выздоравливают в течение нескольких недель. Но некоторые люди - даже те, у кого была легкая форма болезни - продолжают испытывать симптомы более четырех недель после выздоровления. Признаки и симптомы, которые сохраняются с течением времени, включают: усталость, потеря трудоспособности, лихорадка, одышка или затрудненное дыхание, кашель, боли в суставах мышцах или головная боль, учащенное сердцебиение, когнитивные нарушения в т.ч. потеря запаха или вкуса, проблемы с памятью, концентрацией или сном, депрессия или тревога. Многие из этих симптомов связаны с дисфункцией иммунной системы.

Прежде всего это синдромы, связанные с «цитокиновым штормом» и системным воспалением (SIRS), CARS - синдром компенсаторного противовоспалительного ответа, MARS - синдром смешанного ответа антагониста, PICS - стойкое воспаление, иммуносупрессия и синдром катаболизма. Все они формируются за счет дисрегуляции про- и противовоспалительных реакций и нарушения работы адаптивного иммунитета. 
Как отдаленные последствия следует ожидать всплеск онкологических заболеваний.

Пикорнавирусы, большая группа безоболочечных РНК-вирусов способных инфицировать человека. Из них наибольшее значение имеют энтеровирусные (включая полиовирусы и риновирусы), афтовирусы, кардиовирусы и гепатовирус.

Энтеровирусные инфекции - группа острых инфекционных болезней, вызываемых полиомиелитными (возбудитель полиомиелита) и неполиомиелитными (22 вируса Коксаки А, 6 вирусов Коксаки В, 28 эховирусов и 25 других вирусов) энтеровирусами и риновирусами. В большинстве случаев заболевание протекает бессимптомно или в легкой форме. Тяжелое течение наблюдается в менее 5\% случае. Могут поражаться практически все органы и системы организма.

Основные проявления инфекции:

Острая респираторная инфекция энтеровирусной этиологии, характеризуется субфебрильной температурой тела, с насморком, кашлем, дискомфортом в горле. В течении 7-10 дней полностью проходит.

Малая болезнь (энтеровирусная лихорадка, или "летний грипп") непродолжительная (1-3 дня) лихорадка, не сопровождающаяся явными органными поражениями. Может проявляться также дискомфортом в животе, головной болью, слабостью, умеренной гиперемией слизистой оболочки ротоглотки, увеличением шейных лимфоузлов. Редко бывают рецидивы и вторая волна лихорадки. Проходит в течение недели.

Энтеровирусная пузырчатка начинается с умеренной лихорадки, слабости, озноба. На этом фоне на ладонях и подошвах (характерно для энтеровируса) иногда на теле появляются папулёзные высыпания различных размеров (до 5 мм), которые переходят в везикулы и вскрываются. Высыпания сопровождаются слабым зудом.

Герпангина, или везикулярный афтозный фарингит. Так же сопровождается высокой температурой, болью в горле, недомоганием и часто дисфагией, потерей аппетита, болями в спине и головной болью.

Перикардит и/или миокардит. Обычно симптомы включают лихорадку с одышкой и болью в груди, также сопровождается аритмией, сердечной недостаточностью, инфарктом миокарда.

Энтеровирусная экзантема - лихорадочная реакция, сопровождающаяся слабостью, тошнотой, иногда рвотой, миалгиями (мышечными болями), головной болью с одномоментным (на 1-2 суток) появлением полиморфной сыпи 
(макуло-папулёзной или пятнистой) на различных участках тела, иногда с геморрагическим компонентом.

Эпидемическая миалгия (болезнь Борнхольма, или плевродиния) вызывается вирусом Коксаки группы В. Это лихорадочное заболевание с ярко выраженным болевым синдромом в мышцах грудной клетки, верхнего и среднего отдела живота. Очень болезненные ощущения при глубоком вдохе (полимиозит - острое воспаление мышц). Как правило, доброкачественное течение, редко возможен запуск аутоиммунных реакций, сопровождающихся длительным поражением мышц.

Острый геморрагический конъюнктивит.

Риновирусы являются основной причиной респираторных инфекций. Симптомы включают боль в горле, насморк, заложенность носа, чихание и кашель; иногда сопровождаются мышечными болями, усталостью, недомоганием, головной болью, мышечной слабостью или потерей аппетита. У детей, может быть, от шести до двенадцати простудных заболеваний в год.

Ящур - инфекция, вызываемая афтовирусом, передающегося человеку только от больных ящуром животных и сопровождающегося интоксикацией и везикулезно-эрозийным (пузырьково-язвенным) поражением слизистой оболочки ротовой и носовой полости, а также поражением межпальцевых складок и околоногтевого ложа.

Кардиовирусы - из шести видов вирусов этой группы человека могут поражать вирус вилюйского энцефаломиелита человека (VHEV) и вирус Саффолда (SAFV). Последний широко распространен среди людей (>90\%) при некоторых условиях способен вызывать рассеянный склероз.

Кобувирус - имеется шесть видов этого вируса, патогенным для человека является Aichivirus A, который вызывает гастроэнтерит. Впервые идентифицирован в 1989 году и связан с сырой устрицей.

Саливирус - это род вирусов поражает человека, вызывая гастроэнтерит.

Парэховирусы. 18 типов этого вируса могут вызывать желудочнокишечные и/или респираторные заболевания у новорожденных, а также могут быть причиной миокардита и энцефалита. Более 95 \% людей инфицируются парэховирусом от двух до пяти лет.

Сенекавирус - онколитический пикорнавирус, способный к репликации. Он обладает избирательным тропизмом в отношении рака с нейроэндокринными особенностями, включая мелкоклеточный рак легкого (SCLC) и несколько детских солидных опухолей, включая ретинобластому, нейробластому и медуллобластому. В некоторых случаях рассматривается как онколитический вирус. 
Норовирус относится к семейству калицивирусов, является наиболее частой причиной гастроэнтерита, особенно в зимнее время («зимняя рвота»). Инфекция характеризуется диареей без крови, рвотой и болями в животе. Может быть, лихорадка и/или головные боли.

Относительно новое семейства вирусов, астровирусы человека (8 типов), могут быть причиной гастроэнтерита у детей, и у пожилых людей с нарушениями функции иммунной системы.

Большое клиническое значение имеют флавивирусы. 53 определенных вида патогенных вирусов этой группы передаются при укусах инфицированных членистоногих (комаров или клещей) их еще классифицируются как арбовирусы. Это большая группа вирусов распространена по всему миру (рис.8).

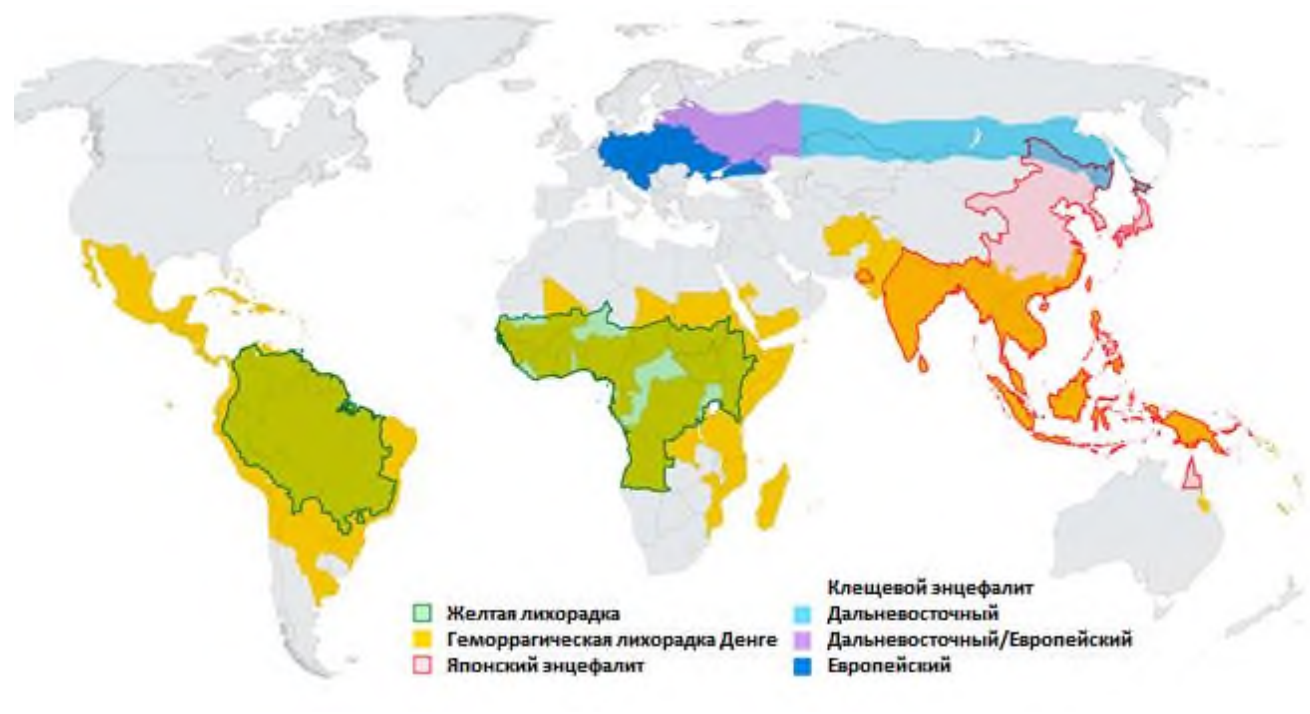

Рис. 8 Ареал распространения флавивирусов.

C клинико-эпидемиологической точки зрения выделяют вирусы, передающиеся клещами (клещевой энцефалит и др.) и вирусы, передающиеся комарами, которые делятся на вирусы, вызывающие энцефалит (японский энцефалит, лихорадка западного Нила и др.), и вирусы, вызывающие геморрагическую лихорадку (лихорадка денге, Омская геморрагическая лихорадка, желтая лихорадка, лихорадка Зика и др.). Возможна передача этих инфекций при разделки инфицированных животных, потребление непастеризованных молочных продуктов, переливание крови, половых контактах и от матери ребенку. От человека человеку эти инфекции не передаются.

В России наибольшее значение принадлежит клещевому энщефалиту. Основным резервуаром, вируса являются иксодовые клещи - Ixodes persulcatus (в азиатской части России) и Ixodes ricinus (в европейском регионе). Возбудитель 
длительно сохраняется при низких температурах. Традиционный ореол распространения - Сибирь, Урал, Дальний Восток, но также встречается в средней полосе России, Северо-Западном регионе (рис.12). При присасывании клеща поражаются различные дикие и домашние животные и птицы.

Человек так же заражается при укусе инфицированными клещами и/или раздавлении клеща руками, возможен алиментарный путь заражения при употреблении в пищу сырого молока коз и коров.

Первичная репродукция вируса происходит в макрофагах, где вирус продуцируется без повреждения клетки. Вторичная репродукция происходит в регионарных лимфоузлах, в клетках печени, селезёнки и эндотелия сосудов, затем вирус попадает в двигательные нейроны передних рогов шейного отдела спинного мозга, клетки мозжечка и мягкой мозговой оболочки, приводя к менингоэнцефалиту.

К флавивирусам относится и вирус гепатита С (род Hepacivirus), поражающий прежде всего печень. Существует семь основных генотипов ВГС и 67 его подтипов, которые известны как генотипы с первого по седьмой. По оценкам ВО3, 1\% человечества во всем мире живут с хроническим гепатитом С. Около 3 миллиона человек ежегодно заражаются, и около 400000 человек ежегодно умирают от болезней, связанных с гепатитом С.

Вирион гепатита С небольшой сферической формы, имеет белковолипидную оболочку, сформированную липидами инфицированных клеток и поверхностными белками вируса. Под оболочкой располагается нуклеокапсид икосаэдрической формы, который сформирован сердцевинным (core) белком и содержит вирусную РНК (рис.9). Существует семь основных генотипов и 67 их подтипов. Наиболее распространен в мире генотип 1 (около половины всех инфекций) и генотип 3 (треть инфекций). Около 10\% ВГС составляют генотипы 2 и 4, которые широко распространены в Азии, Африке и на Ближнем Востоке. 5, 6 и 7 генотипы чаще встречаются в Южной и Центральной Африке, ЮгоВосточной Азии.

В геноме содержится всего один ген, который кодирует различные белки, воздействием на которых возможно полностью блокировать репликацию вируса:

NS3 / 4A блокирует телапревир, боцепревир, фалдапревир, симепревир, асунапревир, паритапревир, данопревир, гразопревир, ванипревир, воксилапревир.

NS5A - даклатасвир, ледипасвир, омбитасвир, эльбасвир, велпатасвир.

NS5B - софосбувир, дасабувир, мерицитабин, ломибувир, сетробувир. 


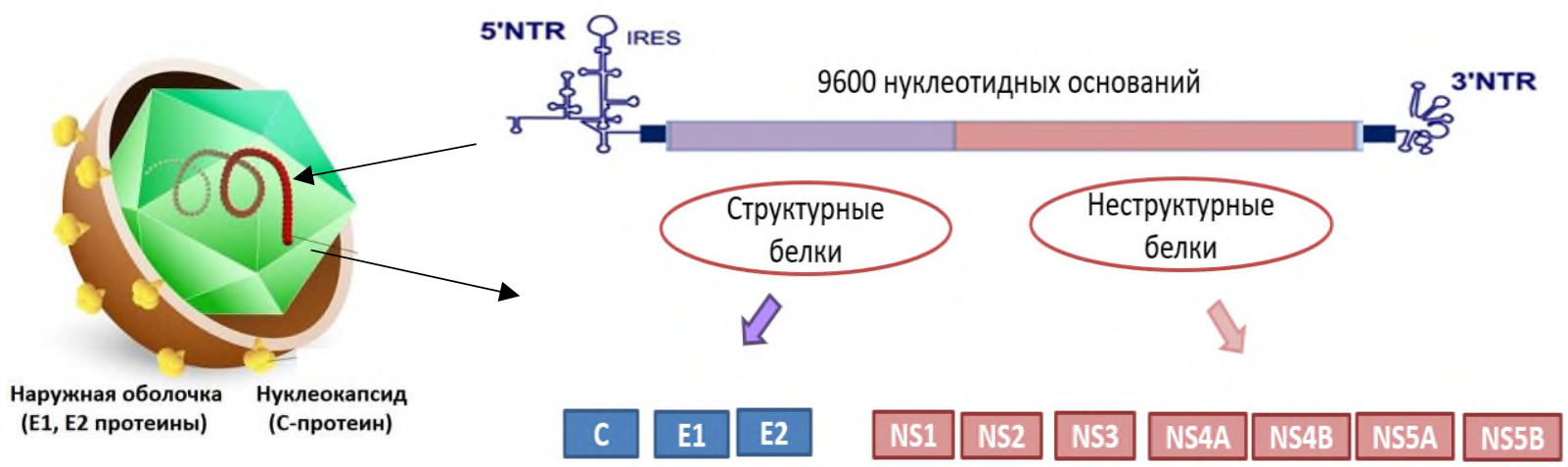

Рис. 9. Структурно-функциональная организация генома вируса гепатита C.

(В рисунке использованы элементы изображение с сайта https://commons.wikimedia.org)

C - Core нуклеокапсидный белок

NS1 NS2 - трансмембранные белки

NS4A - кофактор протеазы

NS5A - активатор транскрипции
E1 E2 - оболочечные белки

NS3 - РНК протеаза

NS4B - модуляция РНК-полимеразы

NS5B - РНК-полимераза

Первоначальное заражение вирусом гепатита $\mathrm{C}$ сопровождается усталостью, тошнотой и рвотой, лихорадкой, болью в мышцах и/или суставах, животе, снижение аппетита, желтухой (примерно у 25\% инфицированных). В дальнейшем у 75-85\% инфицированных вирус сохраняется много лет с формированием хронического гепатита, цирроза печени и гепатоцеллюлярной карциномы, при этом большинство больных не испытывают никаких симптомов в течение первых нескольких десятилетий инфекции. Иногда хронический гепатит $\mathrm{C}$ может быть связан с усталостью и легкими когнитивными нарушениями. Примерно у половины инфицированных до того, как разовьется цирроз присутствуют жировой гепатоз. Примерно у 20\% инфицированных в течение 20-30 лет развивается циррозом печени. Цирроз чаще встречается у мужчин, больных, дополнительно инфицированных гепатитом В и/или ВИЧ, у лиц, злоупотребляющих алкоголем (риск развития цирроза увеличивается в 5 раз). Цирроз печени может привести к портальной гипертензии, асциту, нарушению гемостаза (синяки и/или кровотечению), варикозному расширению вен (в желудке, пищеводе и прямой кишке), желтухе и синдрому когнитивных нарушений, в виде печеночной энцефалопатии.

Совместно с хроническим гепатитом В вирус гепатита С является основной причиной гепатоцеллюлярной карциномы третьей по значимости причиной смерти от рака во всем мире.

Помимо поражения печени хроническая инфекция может быть причиной других проблем. Чаще всего встречаются васкулиты с поражением мелких и средних кровеносных сосудов (смешанная криоглобулинемия, некролитическая 
акральная эритема), поражение кожи (плоский лишай, поздняя кожная порфирия, узловатая почесуха Хайда), аутоиммунная патология (артриты, синдром Шегрена, тромбоцитопения, аутоиммунный тиреоидит, увеличение ревматоидного фактора) возможно развитие резистентности к инсулину, сахарного диабета, диабетической нефропатии, В-клеточных лимфпролиферативные нарушениях. Сообщается о связи хронической инфекции с развитием кардиомиопатии, нарушениями сердечного ритма, заболеваниями центральной нервной системы. Помимо гепатоцеллюлярной карциномы инфекция гепатита С связана с повышенным риском рака поджелудочной железы.

Гепатовирус - единственный патогенный вирус из группы энтеровирусов, поражающий печень вирус гепатита А. Вирусный гепатит А - острая циклическая болезнь с преимущественно фекально-оральным механизмом передачи, характеризующаяся поражением печени и проявляющаяся синдромом интоксикации, увеличением печени и нередко желтухой.

Гепатит А характеризуется полиморфизмом клинических проявлений. Выделяют периоды: инкубационный (от 7 до 50 дней); преджелтушный (продромальный) период, продолжительностью в среднем 5-7 дней, характеризуется гриппоподобным и/или диспепсическим и/или астеновегетативным синдромами; желтушный, продолжающийся в среднем 2-3 недели за счет поражения печени и увеличения билирубина, происходит желтушное окрашивание слизистых и кожи, отмечаются изменения окраски мочи, приобретающей цвет пива или чая, обесцвечивание фекалий. В этот период отмечается гепатомегалия, иногда спленомегалия. Возникновение желтухи сопровождается улучшением общего самочувствия, что служит важным дифференциально-диагностическим признаком гепатита. В развитии желтухи различают фазы нарастания, максимального развития и угасания. С исчезновением желтухи наступает период реконвалесценции, продолжительностью от 1 до 12 мес. Исход гепатита А обычно благоприятный.

Печень поражает и вирус гепатита $\mathbf{E}$, относящийся к семейству Hepeviridae. Вирус встречается повсеместно, но чаще всего в странах ЮгоВосточной и Центральной Азии, в Средней Азии, в Северной и Центральной Африке, в Центральной Америке. Эпидемические вспышки, как правило, всегда связаны с нарушением гигиенических мероприятий. Механизм передачи фекально-оральный, основной путь передачи - водный. Заболевание протекает подобно гепатиту А. Наибольшую опасность это заболевание представляет для беременных женщин, среди которых смертность составляет 10 - $20 \%$. Хронических форм у гепатита Е нет. 
Альфавирусы. Поражают человека при укусе комаров, вызывая тяжелые инфекции (лихорадка чикунгунья, лихорадка Синдбис, конские энцефалиты (западный, восточный, венесуэльский), лихорадка реки Росс), однако наиболее распространенным альфавирусом является рубивирус, вызывающий краснуху.

Краснуха, распространенная во всех регионах мира инфекция, проявляющаяся через 2-3 недели после заражения в виде умеренной температуры с головной болью, фарингитом, заднешейной и затылочной лимфаденопатией (патогномоничный признак данного заболевания), конъюнктивитом. Высыпания появляются через 48 часов, сыпь пятнистая не зудящая, вначале на лице, потом спускается на всё тело в течение нескольких часов; вначале сыпь напоминает коревую, затем скарлатину. Она преобладает на лице, в области поясницы и ягодиц, разгибательных поверхностях рук, ног. Сыпь держится от 2 до 7 дней, затем исчезает без пигментации и шелушения. Довольно часто регистрируются легкие формы этого заболевания.

Группа вирусов, содержащие одноцепочечную (-) РНК - это многочисленное число вирусов, поражающих человека. Они разделены на два подтипа, которые имеют несегментированные геномы (патогенные для человека группа парамиксовирусов, филовирусов, пневмо- и рабдовирусов) и сегментированные геномы (буньявирусы, ортомиксовирусы).

Парамиксовирусы - многочисленная группа вирусов, вызывающая разнообразные заболевания у человека.

Корь - очень заразное инфекционное заболевание, вызываемое вирусом кори. Классические симптомы обычно появляются через 10-14 дней после заражения и включают в себя резкий подъём температуры до $38-40{ }^{\circ} \mathrm{C}$, сухой кашель, насморк, чихание, светобоязнь и конъюнктивит, гиперемия зёва с коревой энантемой (красные пятна на твёрдом и мягком нёбе). Патогномоничный симптом кори развивается на 2-й день болезни: на слизистой щёк в области напротив нижних 1-го и 2-го моляров появляются мелкие белёсые пятнышки, окружённые узкой красной каймой (как «крупинки соли на красноватом фоне») это пятна Бельского - Филатова - Коплика. Они представляют собой изъязвленные поражения слизистой оболочки с некрозом, нейтрофильным экссудатом и неоваскуляризацией. Через три - пять дней после появления симптомов появляется коревая сыпь (экзантема). Сначала на лице, шее, за ушами, на следующий день на туловище и на 3-й день высыпания покрывают разгибательные поверхности рук и ног, включая пальцы. Сыпь состоит из мелких папул, окружённых пятном и склонных к слиянию (в этом её 
характерное отличие от краснухи, сыпь при которой не сливается). Из-за иммуносупрессии, вызванной корью развиваются осложнения с поражением дыхательной системы (ларингит, круп, бронхит, трахеит, отит, синусит, первичная коревая пневмония, вторичная бактериальная пневмония), центральной нервной системы (коревой энцефалит, подострый склерозирующий панэнцефалит и изъязвление роговицы) и желудочно-кишечного тракта (диарея, гепатит, мезентериальный лимфаденит).

Обратное развитие сыпи начинается с 4-го дня высыпаний: сыпь темнеет, буреет, пигментируется, шелушится (в той же последовательности, что и высыпания). Пигментация сохраняется на протяжении от одной до 1,5 недели.

У вакцинированных людей наблюдается длительный инкубационный период, симптомы не выражены, сыпь редкая и непродолжительная.

Вирусы парагриппа человека (HPIV) имеет четыре разновидности. HPIV-1 и HPIV-2 являются основными возбудителями крупа. HPIV-3 связан с бронхиолитом и пневмонией у детей в возрасте до 1 года. HPIV-4 протекает в легкой форме или бессимптомно. Это типичные респираторные инфекции, передающиеся воздушно-капельным путем.

Типичными вирусами, поражающими респираторный тракт, так же являются пневмовирусы: респираторно-синцитиальный вирус (RSV) и метапневмовирус человека (HMPV).

Инфекция, вызванная двумя видами респираторно-синцитиального вируса человека, в большинстве случаев вызывает слабые симптомы, часто неотличимые от других респираторных заболеваний. В течение первых двух лет жизни дети обычно переносят одну из двух инфекций. Повторное инфицирование является обычным явлением на протяжении всей жизни. Однако у трети детей обычно с дисфункциями иммунитета развиваются более серьезные инфекции такие как бронхиолит (70\% случаев всех бронхиолитов), вирусная пневмония или круп. Особенно восприимчивы пациенты, получающие иммуносупрессивную терапию после трансплантации гемопоэтических стволовых клеток, трансплантации легких, интенсивной химиотерапии. В этой группе инфекций, риск пневмонии и смерти, вызываемой RSV, составляет почти $80 \%$.

Клиническая картина инфекции, вызванной метапневмовирусом человека мало отличается от клиники RSV-инфекции. За исключением того, что чаще пик заболеваний у этой инфекции приходится на 6-12 месяцев (при RSVинфекции 2-3 месяца) и то, что эта инфекция часто встречается у лиц пожилого возраста.

Эпидемический паротит (свинка) - это инфекционное заболевание вызывает одноименный вирус, вирус эпидемического паротита. Обычно через 
16-18 дней после контакта с вирусом возникают начальные симптомы. Они неспецифичны и включают лихорадку, головную боль, недомогание, мышечную боль и потерю аппетита. На этом фоне возникает поражение железистых органов (слюнные железы, поджелудочная железа, яички у мужчин, молочные железы и яичники у женщин). Обычно это одностороннее поражение. Около трети инфекций протекают бессимптомно, однако в результате инфицирования вирусом могут возникать другие поражения (менингит, менингоэнцефалит, панкреатит, орхит, эпидидимит, мастит, миокардит, артриты, нефрит).

К парамиксовирусам относится группа хенипавирусов вирус Непах и Хендра, которые вызывают тяжелые энцефалиты. Резервуаром вируса Нипах являются летучие лисы в Камбодже и летучие мыши в Таиланде, Малайзии, Мадагаскаре и Гане. Вирус Хендра выявлен у летучих лисиц Австралии, Бангладеша, Индии, Индонезии, Камбоджи, Китая, Мадагаскара, Малайзии, Папуа-Новой Гвинеи, Таиланда. Передача инфекции происходила воздушнокапельным и/или контактным путем. Через 4-45 дней развиваются гриппоподобные симптомы, затем следует головокружение, сонливость, изменённое сознание и неврологические признаки, которые указывают на острый энцефалит. У некоторых людей может развиться атипичная пневмония с дыхательной недостаточностью.

Болезнь Ньюкасла (NDV) также относится к инфекциям, вызываемыми парамиксовирусами подсемейством авулавирусом. Она является смертельной инфекцией для домашних и диких птиц. У человека в большинстве случаев она протекает бессимптомно; в редких случаях может вызывать легкую лихорадку и гриппоподобные симптомы и/или конъюнктивит. Этот вирус интересен тем, что он может заражать и убивать раковые клетки, поэтому он пока в экспериментах используют для лечения рака. Штаммы вируса болезни Ньюкасла также использовались для создания вирусных векторных вакцин.

В семействе рабдовирусов патогенным для человека является рабивирус и везикуловирусы.

Рибавирус - вирус, вызывающий бешенство. Заболевание встречается редко, но после появления симптомов практически всегда наступает летальный исход. В 90\% случаев заражение у людей происходят от укуса больных домашних собак. Другие источники бешенства - летучие мыши, обезьяны, еноты, лисы, скунсы, крупный рогатый скот, волки, койоты, кошки и мангусты. Вирус является нейротропным и распространяется по нервным путям в центральную нервную систему. При укусе сначала заражаются мышечные клетки. После того, как реплицируется достаточное количество вирусов, они начинают связываться с рецепторами ацетилхолина в нервно-мышечных 
соединениях. Затем вирус проходит через аксон нервной клетки реплицируется в двигательных нейронах и достигает мозга. После заражения мозга вирус перемещается к периферической и вегетативной нервной системе, в конечном итоге мигрируя в слюнные железы, где он готов к передаче следующему хозяину. Бешенство - это вирусное заболевание, вызывающее воспаление мозга. Ранние симптомы включают лихорадку и покалывание в месте укуса. В дальнейшем по мере развития поражения мозга возникает: тошнота, рвота, резкие движения, неконтролируемое возбуждение, боязнь воды, неспособность двигать частями тела, спутанность сознания и потеря сознания. Период между заражением и появлением симптомов обычно составляет от одного до трех месяцев, но может варьироваться от менее одной недели до более одного года. Это зависит от расстояния, которое вирус должен пройти по периферическим нервам, чтобы достичь центральной нервной системы.

Опасны для человека везикуловирусы. Вирус везикулярного стоматита (VSIV) - Индиана, Кокал, Алагбас и Мараба. Вирус является зоонозным и вызывает у инфицированных людей острое поражение слизистой оболочки рта, дёсен и глотки, проявляющееся везикулярными высыпаниями. Аттенуированный VSIV c мутацией в М-белке обладает онколитическими свойствами. Он уменьшает размер опухоли и способствует ее распространению при меланоме, раке легких, раке толстой кишки и некоторых опухолях мозга на лабораторных моделях рака.

Филовирусы, вызывающие у людей тяжелую геморрагическую лихорадку вирус Эбола (4 из 5 видов) и вирус Марбург.

Геморрагические лихорадки - это группа вирусных инфекций, в патогенезе которых возбудитель поражает эндотелий сосудов, что приводит к развитию геморрагического васкулита и полиорганной недостаточности. В зависимости от нозологической формы на первый план выходит поражение того или иного органа - почек, печени, желудочно-кишечного тракта, ЦНС в сочетании с системным воспалительным ответом и геморрагическим синдромом.

Геморрагическая лихорадка Эбола - редкая высококонтагиозная инфекция зафиксированая в Центральной и Западной Африке с летальностью от 25 до 90 \% (в среднем 50 \%). Начинается внезапно, через 2-21 дня после контакта с кровью и/или выделениями из организма больного. Начальный период болезни, продолжительностью 2-7 дней, характеризуется общетоксическими явлениями - лихорадкой, головной болью, миалгией и артралгией, признаками капилляротоксикоза - гиперемией лица, шеи, инъекцией сосудов склер и гиперемией конъюнктивы («кроличьи глаза»), геморрагической энантемой на 
мягком небе, положительными эндотелиальными симптомами, нередко брадикардией и гипотонией, изменениями в периферической крови (лейкопения до 3-4-го дня болезни, нарастающий нейтрофильный сдвиг влево, тромбоцитопения). Период разгара болезни (7-14 дней), развивается часто после кратковременного понижения температуры тела и сопровождается резким нарастанием интоксикации, гемодинамических нарушений, геморрагического синдрома и полиорганными поражениями. В этом периоде часто возникают осложнения: инфекционно-токсический шок, острая почечная недостаточность, мозговая кома и др. Период реконвалесценции продолжается несколько недель и характеризуется длительно сохраняющимся астено - вегетативным синдромом и медленным восстановлением нарушенных функций различных органов. Клинически неотличима от геморрагической лихорадки Эбола, инфекции, вызванной вирусом Марбург.

Буньявирусы и ортомиксовирусы имеют одноцепочечную сегментированную (-) РНК.

Вирион буньявирусов имеет сферическую форму с липидной оболочкой и типоспецифическими гликопротеинами (рис.10), за счет сегментированного генома, они способны к быстрой рекомбинации, что увеличивает риск вспышек заболеваемости. Насчитывается более 477 видов этих вирусов. Обычно обнаруживаются у членистоногих и/или у грызунов, некоторые вирусы заражают людей.

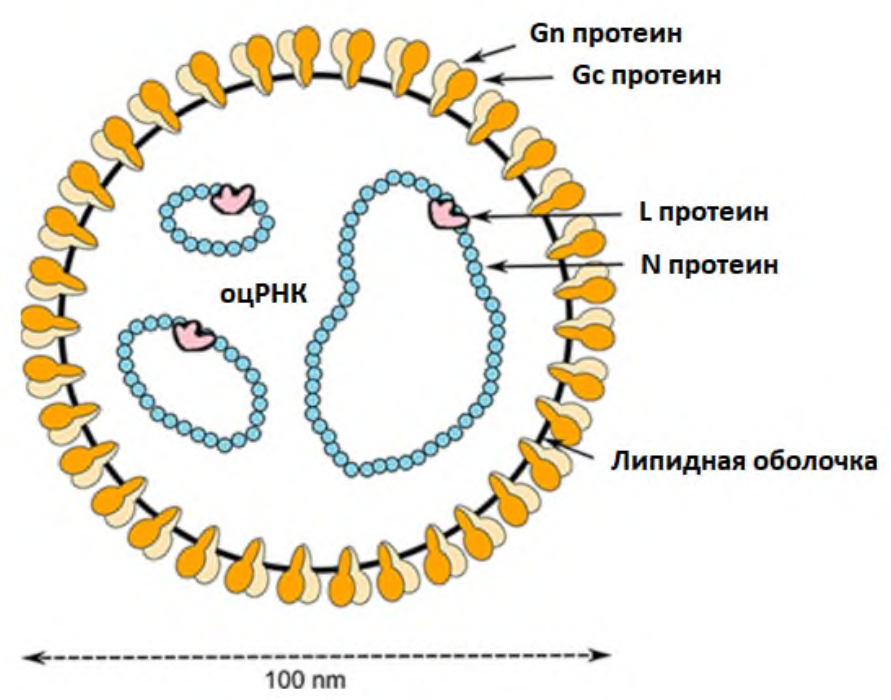

Рис.10. Строение буньявируса.

(В рисунке использованы элементы изображение с сайта https://commons.wikimedia.org)

Клинико-эпидемиологические параметры заболеваний, вызываемые буньявирусами представлены в таблице (табл.8). 


\section{Клинико-эпидемиологические характеристики заболеваний, вызванных буньявирусами}

\begin{tabular}{|c|c|c|}
\hline $\begin{array}{c}\text { Заболевание, вызванное } \\
\text { буньявирусом }\end{array}$ & $\begin{array}{c}\text { Области } \\
\text { распространения }\end{array}$ & $\begin{array}{c}\text { Резервуар вируса. } \\
\text { Переносчик }\end{array}$ \\
\hline $\begin{array}{l}\text { Конго-Крымская } \\
\text { (среднеазиатская) } \\
\text { геморрагическая лихорадка }\end{array}$ & $\begin{array}{l}\text { Африка, юг и восток Европы, } \\
\text { Индия, Пакистан, Китай, } \\
\text { Турция, Средний Восток, } \\
\text { территория бывшего СССР }\end{array}$ & $\begin{array}{l}\text { Мелкие млекопитающие или } \\
\text { грызуны. } \\
\text { Клещи }\end{array}$ \\
\hline Лихорадка Рифт-Валли & $\begin{array}{l}\text { Африка, Аравийский } \\
\text { полуостров }\end{array}$ & $\begin{array}{l}\text { Летучие мыши, мелкие } \\
\text { млекопитающие. Комары }\end{array}$ \\
\hline Лихорадка Бвамба & Африка & Обезьяны, ослы. Комары \\
\hline Калифорнийский энцефалит & США & Млекопитающие. Комары \\
\hline $\begin{array}{l}\text { Энцефалит Джеймстаунского } \\
\text { каньона }\end{array}$ & США & $\begin{array}{l}\text { Млекопитающие (белохвостый } \\
\text { олень). Комары }\end{array}$ \\
\hline Лихорадка Ласса & Западная Африка & \multirow{3}{*}{$\begin{array}{l}\text { Грызуны. } \\
\text { Аэрозольные экскременты }\end{array}$} \\
\hline $\begin{array}{l}\text { Аргентинская } \\
\text { геморрагическая лихорадка }\end{array}$ & Аргентина, Парагвай & \\
\hline $\begin{array}{l}\text { Боливийская } \\
\text { геморрагическая лихорадка }\end{array}$ & Боливия & \\
\hline $\begin{array}{l}\text { Тяжелая лихорадка } \quad \text { c } \\
\text { тромбоцитопенией }\end{array}$ & Китай, Лаос, Корея & Животные. Членистоногие \\
\hline $\begin{array}{l}\text { Хантавирусная } \\
\text { геморрагическая лихорадка }\end{array}$ & $\begin{array}{l}\text { Азия (впервые в Корее) и } \\
\text { Европа }\end{array}$ & $\begin{array}{l}\text { Рыжая полевка. Аэрозольные } \\
\text { экскременты }\end{array}$ \\
\hline
\end{tabular}

Патогенез многих буньявирусных инфекций человека изучен слабо. Клиническая картина не имеет характерных симптомов. В основном преобладают скрытые формы в виде гриппоподобного состояния. В некоторых случаях уже в начале заболевания формируется тяжелый системный воспалительный ответ с полиорганной недостаточностью, приводя к инфекционно-токсическому шоку с клинически выраженным синдромом диссеминированного внутрисосудистого свертывания по типу геморрагической лихорадки (см. выше) с тромбоцитопенией. Может поражаться ЦНС в виде энцефалитов и менингитов, развиваться острая почечная недостаточность.

Семейство ортомиксовирусов включает семь родов, патогенными для человека являются три: Alphainfluenzavirus (вирус гриппа A), Betainfluenzavirus (вирус гриппа В) и Gammainfluenzavirus (вирус гриппа C). Это оболочечные вирусы: внешний слой - липидная мембрана, в которую вставлены «шипы»: гликопротеины и матриксный белок М2, формирующий ионные каналы. Под липидной мембраной расположен матричный (матриксный) белок M1, он формирует внутренний слой оболочки вируса, придает устойчивость и жесткость внешней липидной оболочке (рис.11). 


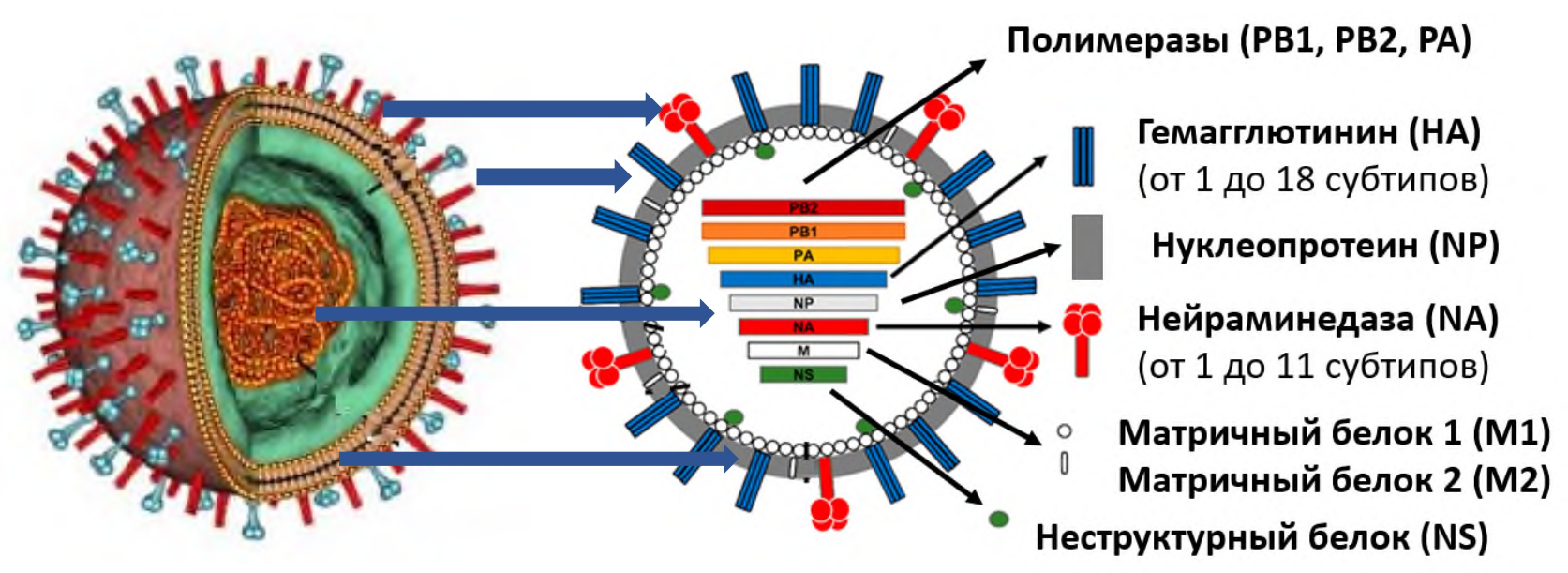

Рис.11. Строение вируса гриппа.

(В рисунке использованы элементы изображение с сайта https://commons.wikimedia.org)

На основе восемнадцати субтипов вирусных поверхностных белков гемагглютинина (HA или Н) и одиннадцати субтипов нейраминидазы (NA или N) вирусы гриппа А дополнительно классифицируются. В настоящее время определено более 2000 вариантов вируса гриппа А и 5 подтипов вирусов гриппа $\mathrm{B}$, которые различаются своим антигенным составом. Изоляты конкретных штаммов гриппа идентифицируются по стандартной номенклатуре, определяющей тип вируса, географическое положение где был выделен вирус, порядковый номер изоляции, год изоляции и подтипы по НА и NA. Например, $\mathrm{A} / \mathrm{CCCP} / 90 / 77(\mathrm{H} 1 \mathrm{~N} 1)$ или A/Тайвань/1/70(H3N2) или А/Гонконг/1/68 (H3N2) или А/Новая Каледония/20/99(H1N1). Антигенный состав вирусов гриппа меняется случайно за счет мутаций, возникающих в процессе репликации вируса (дрейф антигенов) или за счет антигенной изменчивости (антигенный сдвиг), возникающей при заражении двумя различными штаммами вируса гриппа, с обменом генетического материала. Это возникает, при сборке вируса, когда из 8 отдельных сегментов РНК от каждого из штамма вирусов в состав частицы включается одна копия каждого сегмента по типу мини-хромосомы. Новый штамм будет состоять из сегментов смешанного происхождения с образованием нового подтипа. Все эти изменения способствуют ускользанию от иммунитета с развитием заболевания.

Вирусы гриппа А и В - одна из основных причин острых инфекций дыхательных путей и причиной сезонных эпидемий.

За счет антигенной изменчивости новые вирусы гриппа А, могут приводить к пандемическим вспышкам, связанных со значительной заболеваемостью и смертностью.

Источником инфекции является больной человек в т.ч. со стёртой формой заболевания, с первого часа до 5-7 дня болезни. К гриппу восприимчивы все 
возрастные категории людей. Путь передачи воздушно-капельный или контактный. Наиболее высокий риск эпидемий возникает при температуре от -5 до $+5{ }^{\circ} \mathrm{C}$ (уменьшается влажность воздуха, создаются благоприятные условия для проникновения вирусов в дыхательные пути).

В патогенезе гриппа условно можно выделить несколько фаз: внедрение и репродукция вируса в клетках органов дыхательной системы; вирусемия; заболевание; обратное развитие патологического процесса.

Сильный тропизм к верхним дыхательным путям, трахее и бронхам имеют сезонные вирусы гриппа человека. Эти вирусы обильно прикрепляются к мерцательным эпителиальным клеткам этих тканей и/или к нересничным клеткам. Это соответствует наиболее распространенному фенотипу заболевания (ринит, синусит, фарингит, ларингит и трахео-бронхит). Сопутствующие патологические изменения носят поверхностный характер и характеризуются некрозом респираторного эпителия и инфильтрацией собственной пластинки преимущественно лимфоцитами и гистиоцитами (табл. 9).

Таблица 9

\section{Клиническая картина гриппа}

\begin{tabular}{|c|c|}
\hline $\begin{array}{l}\text { Симптомы и } \\
\text { синдромы }\end{array}$ & Клиническая характеристика \\
\hline \multicolumn{2}{|r|}{ Основные синдромы } \\
\hline $\begin{array}{l}\text { Интоксикационный } \\
\text { синдром }\end{array}$ & $\begin{array}{l}\text { Озноб, головная боль, ломота в мышцах, суставах, боль при движении } \\
\text { глазных яблок, светобоязнь, слезотечение, резкая слабость и утомляемость, } \\
\text { вялостью. Интоксикационный синдром в первый день болезни доминирует } \\
\text { над катаральным синдромом. }\end{array}$ \\
\hline $\begin{array}{l}\text { Синдром поражения } \\
\text { респираторного } \\
\text { тракта (катаральный } \\
\text { синдром) }\end{array}$ & $\begin{array}{l}\text { Выражен не резко, характеризуется затруднением носового дыхания, } \\
\text { скудным слизисто-серозным ринитом, сухостью слизистых, першением в } \\
\text { горле, саднением или сухим нечастым, а иногда грубым «трахеитным», с } \\
\text { болью за грудиной, кашлем. Характерна умеренная гиперемия, зернистость и } \\
\text { инъекция сосудов на мягком небе, задней стенке глотки. }\end{array}$ \\
\hline $\begin{array}{l}\text { Геморрагический } \\
\text { синдром }\end{array}$ & $\begin{array}{l}\text { Носовые кровотечения, возможна мелкоточечная или петехиальная сыпь на } \\
\text { коже, геморрагии на слизистых, конъюнктив, гематурия. Развитие синдрома } \\
\text { диссеминированного внутрисосудистого свертывания (ДВС). }\end{array}$ \\
\hline \multicolumn{2}{|r|}{ Локальные поражения } \\
\hline $\begin{array}{l}\text { Острый } \\
\text { стенозирующий } \\
\text { ларинготрахеит }\end{array}$ & $\begin{array}{l}\text { Осиплость голоса, обструкция дыхательных путей, лающий кашель и } \\
\text { инспираторная одышка), развиваются в первые часы заболевания на фоне } \\
\text { гипертермии и выраженной интоксикации. }\end{array}$ \\
\hline Острый бронхит & $\begin{array}{l}\text { Поражение бронхов крупного и среднего калибров, обструктивный синдром, } \\
\text { с преобладанием спастического характера обструкции. }\end{array}$ \\
\hline $\begin{array}{l}\text { Внебольничная } \\
\text { пневмония }\end{array}$ & $\begin{array}{l}\text { Может развиваться в начале заболевания, и в периоде реконвалесценции } \\
\text { обычно в конце первой- начале второй недели от начала заболевания после } \\
\text { короткого светлого промежутка наблюдается новый подъем температуры } \\
\text { тела с усилением интоксикации и появлением локальных изменений в легких, } \\
\text { подтверждаемых рентгенологически. }\end{array}$ \\
\hline $\begin{array}{l}\text { Поражения ЛОР- } \\
\text { органов }\end{array}$ & $\begin{array}{l}\text { Отиты, евстахииты, синуситы, тонзиллит развивающиеся с участием } \\
\text { бактериальной микрофлоры, на любом этапе заболевания. }\end{array}$ \\
\hline
\end{tabular}


H5N1 обширно поражает обонятельные аксоны слизистой оболочки носа далее распространяется непосредственно от обонятельной слизистой оболочки к обонятельной луковице и остальной части центральной нервной системы, вызывая тяжелый энцефалит, менингит, эпендимит и хориоидит, кроме того, Н5N1 индуцировал значительно более высокую продукцию провоспалительных цитокинов, что может объяснять разнообразные системные поражения (табл.10).

Таблица 10

\section{Системные осложнения при гриппе}

\begin{tabular}{|c|c|}
\hline Синдромы & Клиническая характеристика \\
\hline $\begin{array}{l}\text { Инфекционно- } \\
\text { токсический шок }\end{array}$ & $\begin{array}{l}\text { Септикоподобный синдром с системной воспалительной реакцией и } \\
\text { полиорганными поражениями. }\end{array}$ \\
\hline $\begin{array}{l}\text { Инфекционно- } \\
\text { токсическая } \\
\text { (гипоксическая) } \\
\text { энцефалопатия } \\
\text { (нейротоксикоз) }\end{array}$ & $\begin{array}{l}\text { Острая внутричерепная гипертензии с нарушением сознания, } \\
\text { менингеальными симптомами. Отек мозга приводит к коме и судорогам, } \\
\text { параллельно нарастает декомпенсация гемодинамики, при остром } \\
\text { отеке/набухании головного мозга брадикардия, повышение } \\
\text { артериального давления и расстройство дыхания центрального генеза. }\end{array}$ \\
\hline $\begin{array}{l}\text { Острый } \\
\text { респираторный } \\
\text { дистресс-синдром }\end{array}$ & $\begin{array}{l}\text { Признаки нарастающей легочной гипертензии и синдрома острого } \\
\text { легочного сердца, за счет поражением вирусами альвеоло-капиллярных } \\
\text { мембран, увеличение капиллярной проницаемости }\end{array}$ \\
\hline $\begin{array}{l}\text { Синдром Гассера } \\
\text { (гемолитико- } \\
\text { уремический с } \\
\text { развитием) }\end{array}$ & $\begin{array}{l}\text { Острая почечная недостаточность, нарастающая сердечная и } \\
\text { дыхательная недостаточность в результате микротромбоза и } \\
\text { микроангиопатии почечных клубочков, повреждения эритроцитов и } \\
\text { тромбоцитов, формируется гемолитическая анемия (Нb 50-80 г/л) и } \\
\text { тромбоцитопения (до } 20000-50000 \text { в } 1 \text { мкл). }\end{array}$ \\
\hline Рабдомиолиз & $\begin{array}{l}\text { В связи с массивным поражением поперечно-полосатых мышц } \\
\text { возникает миалгией и типичным миозитом с отеком тканей } \\
\text { конечностей, появлением в кровотоке свободного миоглобина, } \\
\text { миоглобинурия (>70-90 мг/л), высокий уровень креатининфосфокиназы. } \\
\text { Острая почечная недостаточность. }\end{array}$ \\
\hline Синдром Рея & $\begin{array}{l}\text { Токсическая энцефалопатия с жировой дегенерацией печени, острая } \\
\text { печеночная недостаточность. }\end{array}$ \\
\hline Синдром Кишша & Острая коронарная недостаточность. Неврологические расстройства. \\
\hline $\begin{array}{l}\text { Синдром Уотерхауза- } \\
\text { Фридериксена (острая } \\
\text { надпочечниковая } \\
\text { недостаточность) }\end{array}$ & $\begin{array}{l}\text { Развивается молниеносная пурпура вследствие кровоизлияния в кору } \\
\text { надпочечников с последующим возникновением кровоизлияний в } \\
\text { различные органы с последующим развитием сосудистого коллапса (АД } \\
\text { снижается, тахикардия до } 240 \text { в } 1 \text { мин), гипертермия сменяется } \\
\text { гиптермией, быстро наступает кома. }\end{array}$ \\
\hline $\begin{array}{l}\text { Синдром } \\
\text { диссеминированного } \\
\text { внутрисосудистого } \\
\text { свертывания (ДВС } \\
\text { синдром) }\end{array}$ & $\begin{array}{l}\text { Поражение системы микроциркуляции, выделяют } 3 \text { стадии: } \\
\text { І стадия - гиперкоагуляция и гипертромбообразование: } \\
\text { ІІ стадия - переход от гиперкоагуляции к гипокоагуляции (коагулопатия } \\
\text { потребления). } \\
\text { III стадия - глубокая гипокоагуляция (активация фибринолиза) вплоть до } \\
\text { полной несвертываемости крови и выраженной тромбоцитопении. }\end{array}$ \\
\hline
\end{tabular}


Иммунная система хозяина функционирует сразу после обнаружения вируса. Иммунная система задействует множественные механизмы защиты от инфекции. С другой стороны, чтобы успешно репродуцировать вирус, также используют множество стратегий, чтобы избежать обнаружения или удаления иммунным ответом хозяина. Известные стратегии включают регуляцию передачи сигналов IFN, ингибирование экспрессии цитокинов, модуляцию апоптоза, вмешательство в аутофагию и влияние на продукцию антител. Все это влияет на исход заболевания и его осложнения.

Особой формой вируса является дельта-вирус гепатита (HDV), это кольцевая одноцепочечная РНК, инкапсулированная белком оболочки вирусапомощника. HDV считается сателлитом вируса гепатита В. Передача HDV может происходить либо при одновременном инфицировании $\mathrm{HBV}$ (коинфекция), либо при наличии хронического гепатита В или носительства гепатита В (суперинфекция). Одновременное инфицирование человека HDV и HBV считается наиболее серьезным типом вирусного гепатита из-за тяжести его осложнений. Эти осложнения включают большую вероятность развития печеночной недостаточности при острых инфекциях и быстрое прогрессирование цирроза печени с повышенным риском развития рака печени при хронических инфекциях. В сочетании с вирусом гепатита В, гепатит D имеет самый высокий уровень смертности среди всех инфекций гепатита - $20 \%$. Недавняя оценка за 2020 год предполагает, что в настоящее время этим вирусом инфицировано 48 миллионов человек.

Группа вирусов с обратной транскрипцией имеют геномы, состоящие из ДНК или РНК, и реплицируются посредством обратной транскрипции. Существуют две группы вирусов с обратной транскрипцией: вирусы с одноцепочечной РНК и обратной транскриптазой (оцРНК-ОТ) и вирусы с двухцепочечной ДНК и обратной транскриптазой (дцДНК-ОТ). К первому относится ретровирусы в т.ч. вирус иммунодефицита человека, ко вторым вирус гепатита B.

Ретровирусы. Из 68 ретровирусов для человека патогенными являются Тлимфотропный вирус человека и вирус иммунодефицита человека 1 и 2. Это семейство РНК вирусов после того, как генетический материал вируса попадает в клетку, за счет фермента обратной транскриптазы синтезирует нить ДНК на матрице вирусной РНК, затем на ней достраивается комплементарную спираль ДНК. Двунитевая вирусная ДНК встраивается в хромосому и начинает синтез вирусной РНК, которая выходит в цитоплазму, где уже происходит сборка вирусных частиц, способных инфицировать другие клетки. 
Наибольшее распространение из ретровирусов получил вирус иммунодефицита человека (ВИЧ). Вирусы ВИЧ-1 в свою очередь делятся на 4 группы (М, O, N, P), ВИЧ-2 на 8 групп (от А до Н). Ответственная за пандемию СПИДа является группы М ВИЧ-1, которая на основе данных генетической последовательности подразделена на подтипы (табл.11).

ВИЧ-2 не получил широкого распространения за пределами Африки.

С 1984 г. по настоящее время зарегистрировано более 79 млн человек заразившихся ВИЧ (по разным данным от 55,9 млн-110 млн) из них 36,3 млн (27,2 млн-47,8 млн) человек умерло от связанных со СПИДом болезней. Число новых случаев инфицирования ВИЧ составляет около 1,5 млн (1,0 млн-2.0 млн) в год. В 2020 году общемировое число умерших от связанных со СПИДом болезней составило 680000 человек. В 2004 году этот показатель составлял 1,9 млн. человек, в 2010 году и 1,3 млн человек.

Таблица 11

\section{Распространенность групп и подтипов ВИЧ-1}

\begin{tabular}{|c|c|c|c|}
\hline Подтип & Распространение & Подтип & Распространение \\
\hline \multicolumn{4}{|c|}{ Вирусы группы М (англ. main - основная) } \\
\hline $\begin{array}{l}\text { A } \\
E\end{array}$ & $\begin{array}{l}\text { Восточная Африка и России } \\
\text { совместно с подтипом А в Юго- } \\
\text { Восточной Азии }\end{array}$ & B & $\begin{array}{l}\text { Европа, Северная и Южная Америка, } \\
\text { Япония, Таиланд, Австралия }\end{array}$ \\
\hline $\mathrm{C}$ & $\begin{array}{l}\text { Южная и Восточная Африка, Индия, } \\
\text { Непал, Китай }\end{array}$ & $\mathrm{D}$ & Восточная и Центральная Африка \\
\hline $\mathrm{F}$ & $\begin{array}{lcc}\text { Центральная Африка, } & \text { Южная } \\
\text { Америка, Восточная Европа } & \end{array}$ & G & Африка и Центральная Европа \\
\hline $\mathrm{H}$ & Центральная Африка & J & $\begin{array}{l}\text { Северная, Центральная и Западная } \\
\text { Африка, страны } \\
\text { бассейна }\end{array}$ \\
\hline K & Конго и Камерун & $\mathrm{L}$ & Конго \\
\hline \multicolumn{2}{|c|}{ Группа О (англ. outlier - непохожий) } & \multicolumn{2}{|c|}{ Центральная и Западная Африка (Камерун)е. } \\
\hline \multicolumn{2}{|c|}{ Группа N (англ. non-M, non-O - ни М, ни O) } & \multicolumn{2}{|l|}{ Камерун } \\
\hline \multicolumn{2}{|l|}{ Группа Р } & \multicolumn{2}{|c|}{$\begin{array}{l}\text { Камерунские женщины, проживающие во } \\
\text { Франции }\end{array}$} \\
\hline
\end{tabular}

ВИЧ поражает Т-хелперы, моноциты, макрофаги, дендритные клетки (CD4+ клетки), за счет чего ослабевает иммунитет, увеличивая риск развития различных в том числе оппортунистических инфекций и раковых заболеваний (табл. 12).

Заражение может произойти при попадании вируса в биожидкостях (кровь, сперма, влагалищный секрет) непосредственно в крово- или лимфоток человека, а также на повреждённые слизистые оболочки (рис. 16). 


\section{СПИД-индикаторные заболевания}

Таблица 12

Бактериальные инфекции, множественные или рецидивирующие

Пневмония, рецидивирующая

Диссеминированная и/или легочная и/или внелегочная инфекция Mycobacterium avium (MAC) или инфекция, вызванная Mуcobacterium kansasii, туберкулез, вызванный Mycobacterium tuberculosis, Mycobacterium, другими видами или неидентифицированными видами Септицемия, вызванная Salmonella (нетифоидной), рецидивирующая

Кандидоз бронхов, трахей или легких, пищевода

Кокцидиоидомикоз, диссеминированный или внелёгочный

Внелёгочный криптококкоз

Гистоплазмоз, диссеминированный или внелёгочный

Криптоспоридиоз хронический кишечный (продолжительностью > 1 месяца)

Токсоплазмоз головного мозга, развивающийся в возрасте старше 1 месяца

Пневмония, вызванная Pneumocystis jirovecii (ранее известная как Pneumocystis carinii)

Изоспориаз (цистоизоспориаз), хронический кишечный (продолжительностью > 1 месяца)

Цитомегаловирусная болезнь (кроме печени, селезёнки или лимфоузлов) начинается в возрасте старше 1 месяца

Цитомегаловирусный ретинит (с потерей зрения)

Простой герпес: хронические язвы (длительность > 1 месяца) или бронхит, пневмонит или эзофагит (начало болезни происходит в возрасте старше 1 месяца)

Рак шейки матки, инвазивный

Саркома Капоши

Лимфома Бёркитта (или эквивалентный термин)

Лимфома иммунобластная (или эквивалентный термин)

Первичная церебральная лимфома

Прогрессивная многоочаговая лейкодистрофия

Кахексия, ассоциируемая с Вич

Энцефалопатия, связанная с Вич

При риске инфицирования не позднее чем через 72 часа после вероятного проникновения вируса обязательна химиопрофилактика (четырёхнедельный курс высокоактивной антиретровирусной терапии). Период от момента заражения до появления реакции организма обычно составляет от 3 нед. до 3 мес (в единичных случаях может затягиваться и до года), поэтому для исключения диагноза ВИЧ с 3 месяца, раз в 3 месяца в течение года обязательные лабораторные исследования на выявления ВИЧ-инфекции (определение АТ и вирусной нагрузки).

В стадии первичных проявлений (стадия 2) происходит резкое снижение Т-хелперов, прежде всего Т-лимфоцитов центральной памяти, и дендритных клеток. Частыми клиническими проявлениями этой стадии являются субфебрильная температура, крапивница, стоматит, лимфаденопатия (по типу инфекционного мононуклеоза). 


\begin{tabular}{|c|c|c|c|c|}
\hline $\begin{array}{l}\text { 1. Стадия } \\
\text { инкубации }\end{array}$ & \multicolumn{3}{|c|}{ ВИЧ-ИНФЕКЦИИ } & $\begin{array}{c}\text { 5. Терминальная } \\
\text { стадия }\end{array}$ \\
\hline \multicolumn{5}{|l|}{ 1-12 мес } \\
\hline $\begin{array}{l}\text { 2. Стадия первич- } \\
\text { ных проявлений }\end{array}$ & $\begin{array}{c}\text { 3. Субклиническая } \\
\text { стадия }\end{array}$ & до 8 лет & $\begin{array}{c}\text { 4. Стадия вторичных } \\
\text { заболеваний }\end{array}$ & \\
\hline \multirow[t]{2}{*}{$\begin{array}{l}\text { А. Бессимптомное } \\
\text { Б. Острая инфек- } \\
\text { ция без вторичных } \\
\text { заболеваний } \\
\text { в. Острая инфек- } \\
\text { ция с вторичными } \\
\text { заболеваниями }\end{array}$} & & $\begin{array}{l}\text { 4А. Потеря массы } \\
\text { тела менее 10\%, } \\
\text { грибковые, вирус- } \\
\text { ные, бактериаль- } \\
\text { ные поражения } \\
\text { кожи и слизистых, } \\
\text { повторные фарин- } \\
\text { гиты, синуситы, } \\
\text { опоясывающий ли- } \\
\text { шай. }\end{array}$ & $\begin{array}{l}\text { 4Б. Потеря массы тела } \\
\text { более } 10 \% \text {, необъяс- } \\
\text { нимая диарея или ли- } \\
\text { хорадка более ме- } \\
\text { сяца, повторные стой- } \\
\text { кие вирусные, бакте- } \\
\text { риальные, грибковые, } \\
\text { протозойные пораже- } \\
\text { ния внутренних орга- } \\
\text { нов, локализованная } \\
\text { саркома Капоши, по- } \\
\text { вторный или диссеми- } \\
\text { нированный опоясы- } \\
\text { вающий лишай. }\end{array}$ & $\begin{array}{l}\text { 4В. Кахексия. Генерали- } \\
\text { зованные вирусные, } \\
\text { бактериальные, мико- } \\
\text { бактериальные, гриб- } \\
\text { ковые, протозойные, } \\
\text { паразитарные заболе- } \\
\text { вания, в том числе: кан- } \\
\text { дидоз пищевода, брон- } \\
\text { хов, трахеи, легких; } \\
\text { пневмоцистная пнев- } \\
\text { мония; злокачествен- } \\
\text { ные опухоли; пораже- } \\
\text { ния центральной нерв- } \\
\text { ной системы. }\end{array}$ \\
\hline & & $\begin{array}{l}\text { Фаза: } \\
\text { прогрессирование в } \\
\text { отсутствие антиретро- } \\
\text { вирусной терапии, на } \\
\text { фоне антиретровирус- } \\
\text { ной терапии. }\end{array}$ & & $\begin{array}{l}\text { Фаза: } \\
\text { ремиссия (спонтанная, по- } \\
\text { сле антиретровирусной те- } \\
\text { рапии, на фоне антиретро- } \\
\text { вирусной терапии). }\end{array}$ \\
\hline
\end{tabular}

\section{Рис.12. Клиническая классификация ВИЧ-инфекции.}

Гибель CD4+ клеток происходит в результате прямого цитопатического действия ВИЧ, апоптоза зараженных клеток, действием NK-клеток и ЦТЛ $(\mathrm{CD} 8+)$. Затем происходит активная продукция антител (определяются АТ к ВИЧ). Стадия первичных проявлений обычно продолжается 7 - 14 дней и диагностируется чаще всего как ОРВИ или инфекционный мононуклеоз (стадия 2Б). Если развиваются вторичные заболевания (стадия 2В) различной этиологии (ангина, бактериальная и пневмоцистная пневмония, кандидозы, герпетическия инфекция и др.) стадия первичных проявлений может затянуться на несколько месяцев.

После чего отмечается стабилизация процесса с увеличением числа CD4 клеток, что инициирует субклиническую стадию. На этой стадии происходит активное размножение вируса со снижением CD4 клеток $\left(0,05-0,07 * 10^{9} /\right.$ л в год). Основным местом, где происходит репликация ВИЧ, является вторичная лимфоидная ткань, и прежде всего лимфоидную ткань кишечника (GALT). Основной резервуар ВИЧ в организме моноциты, макрофаги и дендритные клетки. Непрерывная репликация ВИЧ вызывает состояние генерализованной иммунной активации, сохраняющейся на протяжении всей субклинической стадии. 
Длительность субклинической стадии продолжается от 2 до 20 и более лет (в среднем - 6-7 лет). Клиническим характерным симптомом этой стадии является лимфаденопатия (увеличение двух и более лимфатических узлов не менее чем в двух не связанных между собой группах (не считая паховые). Продолжающаяся репликация ВИЧ, приводящая к гибели и/или истощению Тхелперов, с развитием стадии вторичных заболеваний - СПИД (стадия 4).

СПИД определяется при наличии СПИД-индикаторных заболеваний (табл.14) и/или количеству Т-хелперов (CD4+ Т-лимфоцитов периферической крови) $<200 /$ мкл и/или $\leq 14 \%$. В зависимости от тяжести вторичных заболеваний выделяют стадии 4А, 4Б, 4В и фазы прогрессирования (на фоне отсутствия противоретровирусной терапии или на фоне противоретровирусной терапии) и ремиссии (спонтанной или на фоне противоретровирусной терапии) заболевания.

Менее известная инфекции, которая вызывается Т-лимфотропными вирусами человека и так же поражает иммунную систему человека. Это HTLV1 и HTLV-2 инфекция. Т-лимфотропный вирус человека вызывает у людей злокачественные новообразования лимфоидной и кроветворной тканей (Тклеточный лейкоз и Т-клеточную лимфому).

HTLV-1-инфекция, вызываемая одним из шести подтипов человеческого Т-клеточного лимфотропного вируса 1 типа, относящегося к дельта ретровирусам. По оценкам экспертов, около 20 миллионов человек во всем мире инфицированы HTLV-1. Считается, что инфекция обычно протекает бессимптомно, 90\% зараженных людей остаются носителями в течение своей жизни, однако иммунопатогенез этого ретровируса связан с постоянной

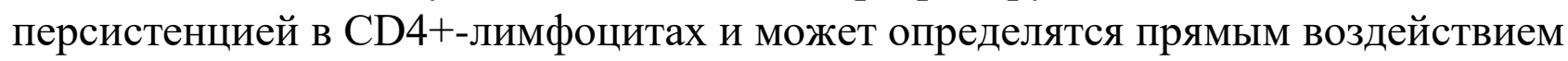
вируса на иммунную систему и/или следствием реакции иммунной системы на вирус, вызывая субклиническую иммуносупрессию. C HTLV-1 связана с повышенной частотой инфекций, таких как туберкулез и стронгилоидоз, увеит, повреждения кожи, миозит и полимиозит, полинейропатия, миелопатия (тропический спастический парапарез), психические расстройства. Около 1-5\% инфицированных людей заболевают раком в виде Т-клеточная лейкемия/лимфома взрослых и Т-клеточной лимфомы кожи.

Патогенез HTLV-2 инфекции связан так же с повреждением Tлимфоцитов (чаще всего CD8+ - лимфоцитов). Он связан с увеличением числа случаев пневмонии, острого бронхита, сенсорные невропатии, аномалии походки, дисфункция мочевого пузыря, легкое когнитивное нарушение, нарушения моторики, миелопатии. В отличие от HTLV-1 инфекции, HTLV-2ассоциированной миелопатии обычно также включает в периферической невропатии и атаксии, однако неврологические заболевания у пациентов с HTLV-2-инфекцией встречаются значительно реже, чем у пациентов, инфицированных HTLV-1 или ВИЧ. 
Вирус с двухцепочечной ДНК и обратной транскриптазой (дцДНК-ОТ) патогенным для человека является вирус гепатита В

Вирус гепатита В (HBV), единственный представитель гепаднавирусов человека, частично двухцепочечный ДНК вирус. В структуре вириона (частица Дэйна) выделяют ряд маркеров, которые характеризуют вирусную инфекцию (рис.13).

Выделяют 10 генотипов вируса: от А до J. Генотипы A и D распространены повсеместно; генотипы С и В характерны для Юго-Восточной Азии и Японии. Е - распространен преимущественно в Африке. F - найден среди коренного населения Южной Америки и на Аляске. G - спорадически встречается в различных частях света. Генотипы вируса гепатита В могут обладать различными биологическими свойствами. В последнее время все большое значение придаётся генотипу вируса в клинических аспектах течения вирусной инфекции, а также чувствительности к антивирусным препаратам.

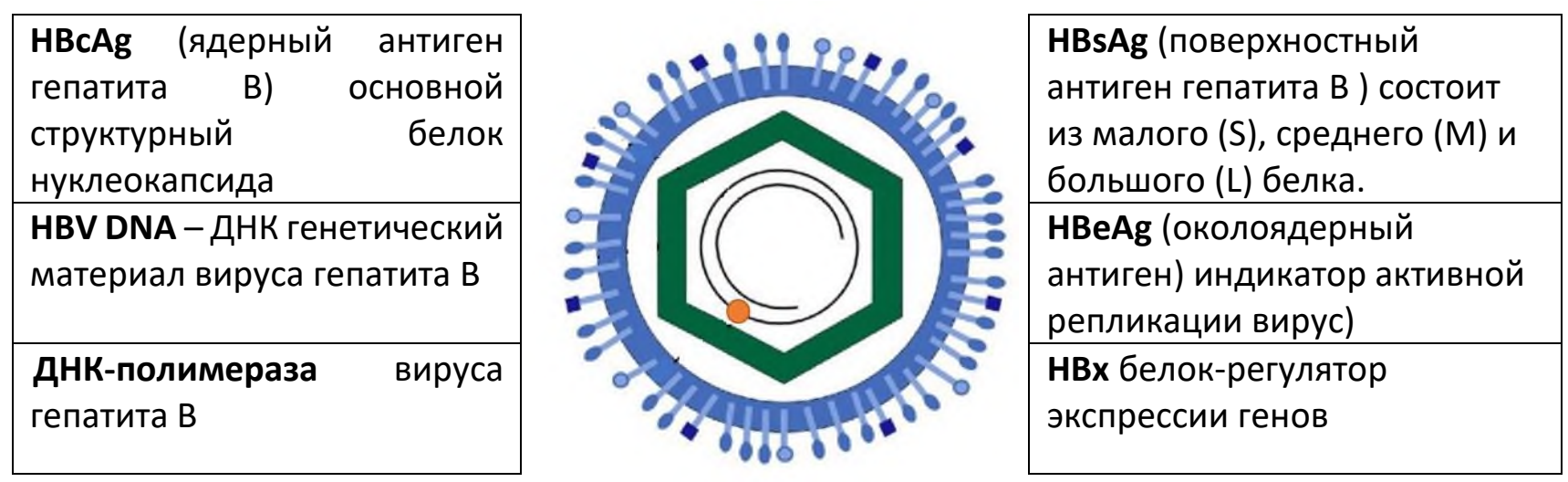

Рис. 13. Структура и маркеры вируса гепатита В.

(В рисунке использованы элементы изображение с сайта https://commons.wikimedia.org)

Заражение вирусным гепатитом В происходит при контакте с инфицированной кровью и/или биологическими жидкостями через поврежденные барьерные органы (кожа, слизистые). Источник инфекции больной человек или вирусоноситель. Вирус гепатита В - один из наиболее заразных вирусов, его инфекционная доза составляет всего 10-7 миллилитра инфицированной крови (в 1 капле 1 млн. доз). Вирус отличается высокой устойчивостью к температурам, химическим и физическим воздействиям.

Инкубационный период вирусного гепатита В в среднем составляет 3-6 месяцев. Преджелтушный период длится 7-12 дней. Однако часто острый период протекает в безжелтушных форме (у 65\%).

Желтушный период характеризуется наибольшей выраженностью проявлений болезни. Общая продолжительность этого периода в зависимости от тяжести болезни составляет 1-3 недели. В этот период возможно развитие 
тяжелых форм с холестатическим компонентом (10\%), фульминантных форм (25\%) с последующим развитием осложнения в виде острой печеночной энцефалопатии.

Период выздоровления более длителен, и составляет 1,5-3 месяцев. Полное выздоровление наступает в 70\%. Затяжное течение составляет 20-25\%, в 5-10\% случаев формируется хроническая инфекция. В мире по различным оценкам от 3 до $6 \%$ людей инфицировано вирусом гепатита В. Носительство вируса не обязательно сопровождается гепатитом, однако носитель вируса может заражать других людей.

Хроническая инфекция гепатита В - это динамический процесс, взаимодействия между репликацией вируса гепатита В и иммунной системой человека. Не все пациенты, зараженные вирусом гепатита В, имеют хронический гепатит. Течение хронической инфекции вирусного гепатита В было разделено на пять этапов, принимая во внимание наличие $\mathrm{HBsAg}, \mathrm{HBeAg}$, уровень ДНК $\mathrm{HBV}$, уровень активности аланинаминотрансферазы (АЛТ) и неинвазивные маркеры фиброза (эластография или биомаркеры), или биопсия печени (табл.13).

Таблица 13

\section{Течение и оценка состояния больных с хронической инфекцией вирусного гепатита B}

\begin{tabular}{|c|c|c|c|c|c|}
\hline Показатель & 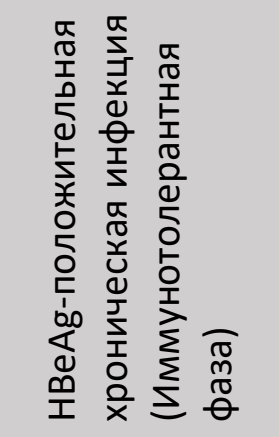 & 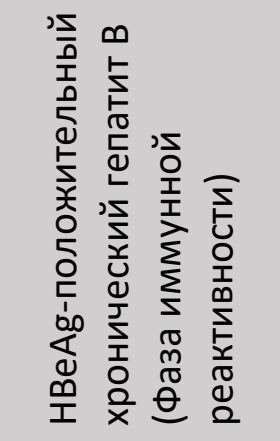 & 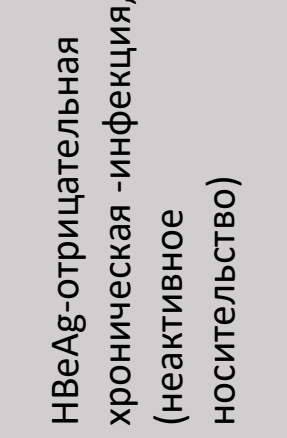 & 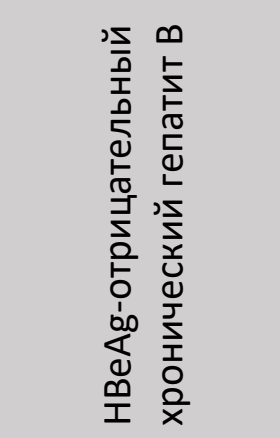 & 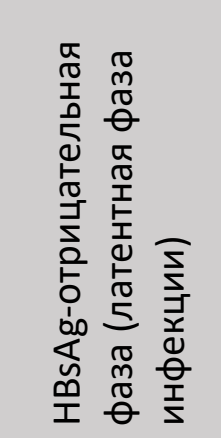 \\
\hline $\mathrm{HBsAg}$ & $\begin{array}{l}\text { Высокий } \\
\text { уровень }\end{array}$ & $\begin{array}{l}\text { Высокий/ } \\
\text { средний }\end{array}$ & $\begin{array}{l}\text { низкий < } 1000 \\
\text { МЕ / мл }\end{array}$ & $\begin{array}{l}\text { Средний } \\
\text { уровень }\end{array}$ & Нет \\
\hline ДНК НВV & $>10^{7} \mathrm{ME} / \mathrm{м} л$ & $10^{4}-10^{7} \mathrm{ME} / \mathrm{M} \pi$ & $<2000$ МЕ/мл & $\begin{array}{l}>2000 \mathrm{ME} / \\
\text { мл }\end{array}$ & $\begin{array}{l}\text { выявление } \\
\text { не всегда }\end{array}$ \\
\hline $\mathrm{HBeAg} / \mathrm{anti}-\mathrm{HBe}$ & $\mathrm{HBeAg}+$ & $\mathrm{HBeAg}+$ & $\begin{array}{l}\text { HBeAg- anti- } \\
\mathrm{HBe}+\end{array}$ & $\begin{array}{l}\mathrm{HBeAg} \text { - anti- } \\
\mathrm{HBe}+\end{array}$ & $\begin{array}{l}\mathrm{HBeAg}- \\
\text { anti-HBe + }\end{array}$ \\
\hline АЛТ & Норма & Повышены & Норма & $\begin{array}{l}\text { Повышено } \\
\text { длительно/ } \\
\text { периодически } \\
\end{array}$ & Норма \\
\hline $\begin{array}{l}\text { Воспалительно- } \\
\text { некротические } \\
\text { изменения }\end{array}$ & \multirow{2}{*}{$\begin{array}{l}\text { Отсутствует/ } \\
\text { минимальные } \\
\text { признаки } \\
\text { болезни }\end{array}$} & $\begin{array}{l}\text { Умеренные } \\
\text { или } \\
\text { выраженные }\end{array}$ & Минимальные & Выражены & \multirow[t]{2}{*}{$\begin{array}{l}\text { Прогрессии } \\
\text { нет }\end{array}$} \\
\hline Фиброз & & $\begin{array}{l}\text { Быстро } \\
\text { прогрессирует }\end{array}$ & Минимальный & Прогресс & \\
\hline
\end{tabular}




\section{Глава 3. Бактерии и грибы}

Клеточные патогены - это микроорганизмы, имеющие свой обмен веществ и возможность автономного самовоспроизведения. Они бывают безъядерные (прокариоты: бактерии, археи), и с наличием ядра (эукариоты: некоторые грибы, простейшие). В большинстве случаев они полезны или безвредны для человека. Однако относительно небольшой перечень болезнетворных возбудителей (около 100) может вызывать инфекционные заболевания.

Бактерии классифицируются на основании различных показателей: строение клеточной стенки, особенности окрашивания, способность расти в присутствии или отсутствии кислорода и способность образовывать споры (рис.14).

Патогенные бактерии - группа заболеваний, вызываемых прокариотами эубактериями (бактериями). Археи не рассматриваются как возбудители заболеваний. Только бактерии и то небольшое их количество являются возбудителями заболеваний. Некоторые бактерии вызывают заболевание при определенных условиях, таких как нарушения мукозального иммунитета, возникающие при повреждении кожи и/или слизистых и/или системного иммунитета. Последние возникающие при иммунодепрессии называются условно-патогенными микроорганизмами (Acinetobacter baumanni, Burkholderia cenocepacia, Clostridium difficile, Mycobacterium avium, Pseudomonas aeruginosa, Staphylococcus aureus, Streptococcus pyogenes и пр.).

Грамположительные бактерии. Характерным свойством для этой группы бактерий является наличие в стенке многослойного муреина и отсутствие чаще всего внешней мембраны. Бактерии высокоустойчивы к неблагоприятным условиям, поэтому для их уничтожения требуется высокоэффективные средства дезинфекции. Наибольшее клиническое значение имеют: Streptococcus, Staphylococcus, Bacillus, Clostridium, Corynebacterium u Listeria. 


\begin{tabular}{|c|c|c|c|c|c|}
\hline & & & СВОЙСТВА & БАКТЕРИИ & ЗАБОЛЕВАНИЯ \\
\hline & & & Кокки & $\begin{array}{l}\text { Streptococcus } \\
\text { Enterococcus }\end{array}$ & $\begin{array}{l}\text { Пневмония, фарингит, инфекции кожи, } \\
\text { Инфекции мочевыводящих путей и жКТ }\end{array}$ \\
\hline & & $\stackrel{\Perp}{\underline{0}}$ & & Staphylococcus & $\begin{array}{l}\text { Абсцессы кожи и других органов, раневые } \\
\text { инфекции, пневмония, сепсис }\end{array}$ \\
\hline & & $\stackrel{\frac{1}{2}}{\stackrel{2}{E}}$ & $\begin{array}{l}\text { Спорообразующие } \\
\text { палочки Аэро6ные }\end{array}$ & Bacillus & Сибирская язва \\
\hline & & 产 & $\begin{array}{l}\text { Спорообразующие } \\
\text { палочки Анаэробные }\end{array}$ & Clostridium & Столбняк, газовая гангрена, ботулизм \\
\hline & & 亮 & Неспорообразующие & Corynebacterium & Дифтерия \\
\hline & & 贾 & палочки Безжгутиковые & Listeria & Менингит \\
\hline & & & Неспорообразующие & Actinomyces & Актиномикоз \\
\hline & & & палочки Жгутиковые & Nocardia & $\begin{array}{l}\text { Пневмония, инфекции кожи и } \\
\text { центральной нервной системы }\end{array}$ \\
\hline & 窎 & & Кокки & \begin{tabular}{|l|} 
Neisseria \\
Moraxella \\
\end{tabular} & $\begin{array}{l}\text { Гонорея, менингит } \\
\text { Инфекции верхних дыхательных путей }\end{array}$ \\
\hline & 要 & & Факультативные анаэро6 & ы Прямые Палочк & \\
\hline$\sqrt{2}$ & $\frac{d}{n}$ & & Респираторные & Haemophilus & Менингит \\
\hline$\underline{E}$ & $\frac{1}{6}$ & & & Bordatella & Коклюш \\
\hline ঙ & $\stackrel{5}{\underline{G}}$ & & & Klebsiella & Пневмония \\
\hline$\frac{4}{10}$ & $\frac{5}{4}$ & & & Legionella & Пневмония \\
\hline$\frac{\vec{T}}{\omega}$ & 产 & & Энтеральные & Salmonella & Брюшной тиф и паратиф, сальмонеллез \\
\hline উ & $\frac{1}{5}$ & & & Shigella & Энтероколит, дизентерия \\
\hline 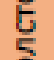 & $\vec{\exists}$ & $\stackrel{\Perp}{\underline{\underline{n}}}$ & & Escherichia & Инфекции мочевыводящих путей, диарея \\
\hline 음 & $\underset{\frac{m}{2}}{\frac{m}{2}}$ & $\frac{\vec{T}}{5}$ & & Proteus & Госпитальные инфекции \\
\hline$\underset{x}{\stackrel{\Psi}{x}}$ & 응 & ఏ & & Enterobacter & \\
\hline है & 究 & 罗 & Полиорганные & Brucella & Бруцеллез \\
\hline$\ddot{x}$ & 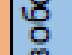 & $\vec{a}$ & & Francisella & Туляремия \\
\hline & 8 & 學 & & Yersinia & $\begin{array}{l}\text { Чума } \\
\text { Иерсиниоз }\end{array}$ \\
\hline & & & Факультативные анаэроб & ы Изогнутые & \\
\hline & & & & Vibrio & Холера \\
\hline & & & & Helicobacter & Гастрит, пептическая язва \\
\hline & & & & Campylobacter & Энтероколит \\
\hline & & & Аэробные Палочки & & \\
\hline & & & & Pseudomonas & $\begin{array}{l}\text { Пневмония, инфекции мочевыводящих } \\
\text { путей }\end{array}$ \\
\hline & & & Анаэро6ные Палочки & & \\
\hline & & & & Bacteroides & Перитонит \\
\hline & & Кис & ото- и спиртоустойчивые & & \\
\hline & & & & Mycobacterium & Туберкулез, проказа \\
\hline & & лигат & ные внутриклеточные & Rickettsia & $\begin{array}{l}\text { Пятнистая лихорадка Скалистых гор, тиф, } \\
\text { Ку-лихорадка }\end{array}$ \\
\hline & & & & Chlamidia & Уретрит, трахома, пситтакоз \\
\hline & & & & Treponema & Сифилис \\
\hline & & rethil & генные бактерии & Borrelia & Болезнь Лайма \\
\hline & & & & Leptospira & Лептоспироз \\
\hline & ктер & ии 6 e & 3 клеточной стенки & Mycoplasma & Пневмония \\
\hline
\end{tabular}

Рис. 14. Классификация основных патогенных бактерий. 
Стрептококки - это сферические грамположительные кокки, организованные в цепочки или пары. Обитают в верхних дыхательных путях и желудочно-кишечном тракте (полость рта, носа, толстый кишечник). На основе их гемолитических свойств при культивировании на кровяном агаре выделяют $\alpha$-гемолитические стрептококки (не полностью окисляют гемоглобин, среда вокруг колоний становится зеленоватой), $\beta$-гемолитические стрептококки (разрушают эритроцит полностью, среда становится полностью прозрачной) и $\gamma$ гемолитические стрептококки (не вызывают гемолиза). По углеводным антигенам клеточной стенки выделяют 21 серотип стрептококков (от А до W). Они вызывают широкий спектр заболеваний (табл.16), однако в большинстве случаев являются условно-патогенными. Патогенность и вирулентность стрептококков определяется способностью их продуцировать токсины и ферменты и/или «ускользать» от иммунной системы. Так стрептококки группы А продуцируют ферменты: гиалуронидазу (разрушает гиалуроновую кислоту способствует быстрому распространению бактерий), стрептокиназу (фибринолизин растворяет фибрин препятствует ограничению очага инфекции), ДНКазу (стрептодорназа разрушает ДНК в экссудате или некротических тканях). Кроме того, стрептококки продуцируют токсины такие как стрептолизин О и стрептолизин $\mathrm{S}$ (гемолизины, которые вызывают $\beta$-гемолиз), пиогенный экзотоксин А (токсин вызывающий токсический шок), экзотоксин В (протеаза, разрушающая ткани), эритрогенный токсин (поражающий сосуды вызывает сыпь).

Ряд стрептококков имеют полисахаридную капсулу, которая защищает их от фагоцитоза и антикапсулярных антител. Зеленящие стрептококки, продуцируют гликокаликс, предназначенный для прикрепления микроорганизма к клапанам сердца.

Типичным острым инфекционным заболеванием, вызываемым $\beta$ гемолитический стрептококк группы А, является рожа.

Микробы попадают на кожу от людей, являющихся источником гноеродных микробов, или же проникают из очагов собственного организма. При нарушении мукозального иммунитета происходит инфицирование с развитием местных и общих реакций. Местный процесс проявляется воспалением кожи, сопровождается покраснением и отеком пораженных участков кожи и подкожной клетчатки. В патологический процесс также вовлекаются лимфатические (лимфангит), артериальные (артериит) и венозные (флебит) сосуды. Общее действие стрептококковой инфекции при роже проявляется лихорадкой, интоксикацией, токсическим поражением внутренних органов. Распространяющиеся по лимфатическим и кровеносным сосудам стрептококки при определенных условиях могут вызывать вторичные гнойные осложнения. 
Таблица 14

\section{Патогенными для человека стрептококки}

\begin{tabular}{|c|c|c|}
\hline Вид стрептококка & Характеристика & Заболевания \\
\hline S.pyogenes & $\begin{array}{l}\beta \text {-гемолитические } \\
\text { стрептококк группы A }\end{array}$ & $\begin{array}{l}\text { Фарингит, тонзиллит, инфекции ран и } \\
\text { кожи, рожа, септицемия, скарлатина, } \\
\text { пневмония, некротизирующий фасциит, } \\
\text { стрептококковый шок. Провоцирует } \\
\text { развитие гломерулонефрита и } \\
\text { ревматической лихорадки. }\end{array}$ \\
\hline S.agalactiae & $\begin{array}{l}\beta \text {-гемолитические } \\
\text { стрептококк группы В }\end{array}$ & $\begin{array}{l}\text { Сепсис, послеродовой или неонатальный } \\
\text { сепсис, менингит, инфекции кожи, } \\
\text { эндокардит, септический артрит, } \\
\text { инфекции мочевых путей. }\end{array}$ \\
\hline $\begin{array}{l}\text { S.equi, S.canis } \\
\text { S.equisimilis, } \\
\text { S.zooepidemicus, } \\
\text { S.dysgalactiae }\end{array}$ & $\begin{array}{l}\beta \text {-гемолитические } \\
\text { стрептококк группы C }\end{array}$ & $\begin{array}{l}\text { Фарингит, пневмония, инфекции кожи, } \\
\text { пиодермия, рожистое воспаление, } \\
\text { импетиго, инфекции раны, послеродовой } \\
\text { сепсис, неонатальный сепсис, } \\
\text { эндокардит, септический артрит. }\end{array}$ \\
\hline $\begin{array}{l}\text { S.gallolyticus, S.bovis } \\
\text { (или S.equinus). }\end{array}$ & $\begin{array}{l}\alpha \text {-гемолитические } \\
\text { стрептококк группы D }\end{array}$ & $\begin{array}{l}\text { Эндокардита, инфекций мочевыводящих } \\
\text { путей, реже сепсис, перитонит, } \\
\text { неонатальный менингит. Имеется связь с } \\
\text { раком кишечника. }\end{array}$ \\
\hline $\begin{array}{l}\text { S.mutans, S.sanguis, } \\
\text { S.salivarius, S.mitior, } \\
\text { S.anginosus, } \\
\text { S.constellatus, } \\
\text { S.intermedius }\end{array}$ & \multirow[t]{3}{*}{$\begin{array}{l}\text { а-гемолитические } \\
\text { стрептококки Viridans } \\
\text { (вне группы) }\end{array}$} & $\begin{array}{l}\text { Эндокардит, бактериемия, менингит, } \\
\text { локализованная инфекция, абсцессы } \\
\text { (особенно S. anginosus). }\end{array}$ \\
\hline S. suis & & $\begin{array}{l}\text { Менингит, иногда синдром токсического } \\
\text { шока. }\end{array}$ \\
\hline S. iniae & & Целлюлит, инвазивные инфекции. \\
\hline $\begin{array}{l}\text { Enterococcus faecalis, } \\
\text { faecium, durans }\end{array}$ & $\begin{array}{l}\text { a-гемолитические } \\
\text { стрептококк группы D }\end{array}$ & $\begin{array}{l}\text { Нозокомиальная инфекция } \\
\text { мочевыводящих путей, эндокардит. }\end{array}$ \\
\hline S. pneumoniae & $\begin{array}{l}\alpha \text {-гемолитические (в } \\
\text { аэробных условиях) или } \\
\beta \text {-гемолитические (в } \\
\text { анаэробных условиях) }\end{array}$ & $\begin{array}{l}\text { Основная причина внебольничной } \\
\text { пневмонии и менингита. Так же может } \\
\text { быть причиной бронхита, ринита, острого } \\
\text { синусита, среднего отита, сепсиса, } \\
\text { конъюнктивита, остеомиелита, } \\
\text { септического артрита, эндокардита, } \\
\text { перитонита, перикардита, абсцесса } \\
\text { головного мозга. }\end{array}$ \\
\hline
\end{tabular}

Инкубационный период длится от нескольких часов до 2-3 суток. Различают эритематозную, эритематозно-буллезную, буллезногеморрагическую и некротическую рожу. По частоте клинических проявлений выделяют впервые возникшую рожу, повторную и рецидивирующую. 
Длительность лихорадочного периода колеблется от 2 до 10 дней и зависит от начала лечения и тяжести болезни. Поражение кожи сохраняется в течение 515 суток.

Рецидивы рожи могут возникнуть в период от нескольких дней до 2 лет после предыдущего заболевания. При частых рецидивах рожи лихорадка небольшая в течение 1-2 дней, самочувствие больного остается удовлетворительным, поражение кожи в виде отдельных неярких пятен без отека.

Осложнения: возможно появление гнойных осложнений: абсцессов, флегмон, отитов, тромбофлебитов. При нарушении лимфооттока (при повторных заболеваниях рожей) развивается слоновость, особенно на нижних конечностях.

Стафилококки - это сферические грамположительные кокки, за счет деления по нескольким осям, образуют гроздевидные скопления. Bсе стафилококки продуцируют каталазу, которая разлагает перекись водорода и таким образом снижает способность нейтрофилов убивать бактерии. Патогенными для человека являются три вида стафилококка: St. aureus, St. epidermidis u St. saprophyticus. Они вызывают гнойные инфекции (табл.17). St. aureus помимо продукции каталазы выделяют несколько других токсинов и ферментов. Ферменты включают коагулазу (нарушает гемостаз ограничивает зону воспаления, препятствуя миграции в эту зону нейтрофилов), стафилокиназа (является фибринолизином), гиалуронидазу, протеазы. Клинически важными токсинами является энтеротоксин (вызывает пищевые токсикоинфекции), токсин синдрома токсического шока (вызывает токсический шок, при этом в посевах крови роста St. aureus нет), эксфолиатин (вызывает синдром «ошпаренной кожи» у маленьких детей), альфа-токсин (вызывает некроз кожи и гемолиз эритроцитов), лейкоцидин Пантона-Валентайна (повреждает клетки, особенно лейкоциты, разрушая их мембрану вызывают тяжелую некротическую пневмонию). Коагулазоотрицательных Staphylococcus epidermidis и Staphylococcus saprophyticus не продуцируют экзотоксины, не вызывают пищевых отравлений или синдрома токсического шока, тем не менее являются причиной пиогенных инфекции особенно при недостаточности гуморального иммунитета, включая снижение уровня антител, комплемента и гранулематозных заболеваниях, для которых характерно нарушение способности нейтрофилов фагоцитировать бактерии.

Некоторые штаммы St. aureus не подавляются пенициллинами, благодаря изменениям пенициллинсвязывающего белка на мембранах их клеток. Эти штаммы обычно известны как метициллин-резистентные (MRSA) и/или 
оксациллин-резистентные St. aureus (ORSA). Выявлены так же штаммы St. aureus с промежуточной (VISA) и полной (VRSA) резистентностью к ванкомицину.

Таблица 15

\section{Патогенными для человека стафилококки}

\begin{tabular}{|c|c|c|}
\hline Вид стафилококка & Резервуар инфекции & Заболевания \\
\hline St. aureus & $\begin{array}{l}\text { Верхние дыхательные } \\
\text { пути, кожа человека }\end{array}$ & $\begin{array}{l}\text { Инфекции кожи, мягких тканей, костей, } \\
\text { суставов, легких, сердца и почек, } \\
\text { пищевые токсикоинфекции, } \\
\text { инфекционно-токсический шок. }\end{array}$ \\
\hline St. epidermidis & $\begin{array}{l}\text { Кожа человека, } \\
\text { почти всегда } \\
\text { госпитальная инфекция }\end{array}$ & $\begin{array}{l}\text { Представитель нормальной микрофлоры } \\
\text { кожи. Инфекция протезов суставов и } \\
\text { клапанов сердца. }\end{array}$ \\
\hline St. saprophyticus & $\begin{array}{l}\text { Слизистые половых } \\
\text { путей человека }\end{array}$ & Инфекции мочевыводящих путей \\
\hline
\end{tabular}

Большое клиническое значение имеют грамположительные палочки. Это семейство Bacillus, Clostridium, Corynebacterium, Listeria, Actinomyces и Nocardia. Спорообразующие аэробы Bacillus и анаэробы Clostridium. Не спорообразующие без жгутиковые Corynebacterium и Listeria и жгутиковые Actinomyces и Nocardia.

Представителем Bacillus является сибирская язва (синонимы: злокачественный карбункул; anthrax - англ.; Milzbrand - нем.; charbon, anthrax carbon - франц.) - острая инфекционная болезнь, протекающая преимущественно в виде кожной формы, реже наблюдается легочная и кишечная формы. Относится к зоонозам. Вирулентность возбудителя обусловлена наличием капсулы и экзотоксина.

Источник инфекции - домашние животные (крупный рогатый скот, овцы, козы, верблюды, свиньи). Пути передачи: контактный, алиментарный, воздушно-пылевой и трансмиссивный. Заражение может наступать при уходе за больными животными, убое скота, обработке мяса, а также при контакте с продуктами животноводства (шкуры, кожи, меховые изделия, шерсть, щетина), обсемененными спорами сибиреязвенного микроба. Инкубационный период продолжается от 2 до 14 дней, чаще 2-4 дня.

Заболевание сопровождается эндотоксинемией, для которой характерна лихорадка, слабость, головная боль и появлением кожных поражений возникновение карбункула, который представляет собой конусовидный фокус серозно-геморрагического воспаления с некрозом поверхностных слоев кожи и образованием буро-черной корки (струп). Струп, который закрывает язву, безболезненный за счет местной анестезии, которой обладает сибиреязвенный 
токсин. Одновременно процесс сопровождается регионарным лимфаическим отеком (симптом Стефанского).

Род Clostridium включает несколько важных патогенов человека, в том числе возбудителей ботулизма и столбняка.

Столбняк (тетанус, tetanus, генерализованный, острый, распространенный столбняк) - острое инфекционное заболевание, обусловленное воздействием на организм экзотоксина столбнячной палочки с преимущественным поражением нервной системы, характеризующееся тоническими и судорожными сокращениями поперечно-полосатых мышц. Заболевание известно со времен Гиппократа, сын которого стал жертвой столбняка. Клинические проявления столбняка обусловлены действием столбнячного токсина, который выделяется при размножении бактерий Clostridium tetani (Bacillus tetani).

Эпидемиология. Заболевание распространено во всех регионах земного шара. В обычных условиях входными воротами инфекции являются мелкие бытовые травмы (проколы, ссадины и т. п.). Больные эпидемиологической опасности не представляют.

Инкубационный период - от трех дней до трех недель; чем он длиннее, тем благоприятнее исход. Первым симптомом болезни у людей является тризм напряжение и судорожное сокращение жевательных мышц, препятствующее открыванию рта. Необычное беспокойство, раздражительность, тугоподвижность мышц шеи, болезненность жевательной мускулатуры и других мышц, изменение походки могут быть предвестниками болезни. Позже развивается ригидность (напряженность) мышц шеи и спины, усиливаются затруднения при открывании рта, появляется обильный пот, возрастают напряженность мышц конечностей и ограничение подвижности суставов. В тяжелых случаях зубы крепко сжаты, открыть рот невозможно. Судорожные сокращения мимических мышц лица придают больному своеобразное выражение - одновременно улыбки и плача; на лице больного сохраняется застывшая сардоническая улыбка. Мучительные судороги охватывают большие группы мышц и тяжелых случаях повторяются почти непрерывно. Из-за преобладающего напряжения отдельных групп мышц тело больного может принимать причудливые позы: иногда из-за сильного спазма мышц шеи и спины голова больного запрокидывается, и он выгибается дугой. Сознание остается ясным. Летальный исход может наступить на высоте судорог от асфиксии вследствие спазма мышц гортани в сочетании с уменьшением легочной вентиляции из-за напряжения межреберных мышц и диафрагмы.

Ботулизм (синонимы: ихтиизм, аллантиизм; botulism, allantiasis, sausagepoisoning - англ.; botulisme, allantiasis - франц.; Botulismus Wurst-Vergiftung, 
Fleischvergtftung - нем.) - острая инфекционная болезнь, обусловленная поражением токсинами бактерий ботулизма нервной системы, характеризующаяся парезами и параличами поперечнополосатой и гладкой мускулатуры, иногда в сочетании с синдромом гастроэнтерита в начальном периоде.

Возбудители ботулизма - Clostridium botulinum представляют собою анаэробные подвижные грамотрицательные палочки. По антигенным свойствам продуцируемых токсинов они подразделяются на 7 серологических типов - A, B, $\mathrm{C}, \mathrm{D}, \mathrm{E}, \mathrm{F}$ и G. Оптимальные условия роста вегетативных форм - крайне низкое остаточное давление кислорода $(0,40-1,33$ кПа) и температурный режим в пределах $28-35^{\circ} \mathrm{C}$. В то же время, прогревание при температуре $80^{\circ} \mathrm{C}$ в течение 30 мин вызывает их гибель. Возбудители ботулизма широко распространены в природе. Вегетативные формы и споры обнаруживаются в кишечнике различных домашних и в особенности диких животных, водоплавающих птиц, рыб. Попадая во внешнюю среду (почву, ил озер и рек), они в спорообразном состоянии длительно сохраняются и накапливаются. Практически все пищевые продукты, загрязненные почвой или содержимым кишечника животных, птиц, рыб могут содержать споры или вегетативные формы возбудителей ботулизма. Однако заболевание может возникнуть только при употреблении тех из них, которые хранились при анаэробных или близких к ним условиях без предварительной достаточной термической обработки. Это могут быть консервы, особенно домашнего приготовления, копченые, вяленые мясные и рыбные изделия, а также другие продукты, в которых имеются условия для развития вегетативных форм микробов и токсинообразования. В России чаще регистрируются заболевания, связанные преимущественно с употреблением грибов домашнего консервирования, копченой или вяленой рыбы. Эти продукты чаще вызывают групповые, "семейные" вспышки заболеваний. Если инфицированный продукт твердофазный (колбаса, копченое мясо, рыба), то в нем возможны "гнездная" инфицированность возбудителями ботулизма и образование токсинов. Поэтому встречаются вспышки, при которых не все лица, употреблявшие один и тот же продукт, болеют. В настоящее время преобладают заболевания, обусловленные отравлениями токсинами А, В или Е.

В патогенезе ботулизма ведущая роль принадлежит токсину. При обычном заражении (пищевой путь) он попадает в организм вместе с пищей, содержащей также и вегетативные формы возбудителей - продуцентов яда. Всасывание ботулотоксина происходит через слизистую оболочку проксимальных отделов желудочно-кишечного тракта, начиная с полости рта. Но наиболее значимо поступление токсина через слизистую оболочку желудка и тонкой кишки, откуда он попадает в лимфу и в последующем в кровь, которой разносится по всему организму. Установлено, что ботулинический токсин прочно связывается 
нервными клетками. При этом поражаются и нервные окончания и мотонейроны передних рогов спинного мозга. Ботулотоксин избирательно воздействует на холинэргические отделы нервной системы, вследствие чего прекращается выделение ацетилхолина в синаптическую щель, а, следовательно, нарушается нервно-мышечная передача возбуждений (парезы, параличи). Холинэстеразная активность в синапсах практически не изменяется. В первую очередь нарушается иннервация мышц, находящихся в состоянии постоянной и высокодифференцированной функциональной активности (глазодвигательный аппарат, мышцы глотки и гортани). Результатом поражения мотонейронов является также и угнетение функции основных дыхательных мышц, вплоть до паралича. Воздействие ботулинических токсинов обратимо и со временем двигательная функция полностью восстанавливается. Угнетению холинэргических процессов предшествует повышение содержания катехоламинов. Вследствие нарушения вегетативной иннервации снижается секреция пищеварительных желез (выделение слюны, желудочного сока), развивается стойкий парез желудочно-кишечного тракта. Парезы или параличи межреберных мышц, диафрагмы приводят $\mathrm{\kappa}$ острой вентиляционной дыхательной недостаточности с развитием гипоксии и респираторного ацидоза. Нарушению вентиляции легких способствует угнетение функции мышц глотки и гортани, скопление густой слизи в над- и подсвязочном пространстве, аспирация рвотных масс, пищи, воды. При ботулизме вследствие опосредованного или прямого действия токсина развиваются все разновидности гипоксии - гипоксическая, гистотоксическая, гемическая и циркуляторная.

Инкубационный период при ботулизме продолжается до суток, реже до 23 дней и очень редко (в единичных описаниях) до 9 и даже 12 дней. Не исключено, что более длительный инкубационный период соответствует манифестации скрытых проявлений болезни из-за дополнительного поступления ботулотоксина из желудочно-кишечного тракта. При более коротком инкубационном периоде наблюдается, хотя и не всегда, более тяжелое течение болезни. Прием алкоголя, как правило, не сказывается на течении болезни, а опьянение может затушевывать первые проявления ботулизма, препятствуя его своевременной диагностике.

Ключевыми клиническими признаками ботулизма являются различные неврологические симптомы, совокупность которых может варьировать в широком диапазоне и различной степени выраженности. Однако примерно у каждого второго больного первыми проявлениями ботулизма могут быть кратковременные симптомы острого гастроэнтерита и общей инфекционной интоксикации. В таких случаях больные обычно жалуются на острые боли в животе, преимущественно в эпигастральной области, после чего наступают повторная рвота и жидкий, без патологических примесей стул, не больше 10 раз 
в сутки, чаще 3-5 раз. К концу суток гипермоторика желудочно-кишечного тракта сменяется стойкой атонией, температура тела становится нормальной.

Наиболее типичными ранними признаками ботулизма являются нарушения остроты зрения, сухость во рту и мышечная слабость. Появляется двоение в глазах. Развивается птоз различной степени выраженности. Изменяются высота и тембр голоса, иногда отмечается гнусавость. При прогрессировании болезни голос становится сиплым, охриплость может перейти в афонию. Довольно типичным признаком ботулизма является нарушение глотания. Появляются ощущение инородного тела в глотке ("непроглоченная таблетка"), поперхивание, затруднение глотания вначале твердой, а затем и жидкой пищи, воды. В тяжелых случаях наступает полная афагия. Птоз, мышечная слабость могут в легких случаях болезни протекать в недостаточно манифестированной форме. Мышечная слабость нарастает соответственно тяжести болезни.

Clostridium perfringens - возбудитель пищевых отравлений человека, один из возбудителей газовой гангрены. Бактерии обитают в почве и уличной пыли. Раны, загрязненные землей, имеющие раневые карманы, участки омертвевшей либо плохо снабжаемой кровью ткани, не подвергшиеся первичной хирургической обработке, предрасположены к газовой гангрене. Бактерии вызывают мионекроз специфическими экзотоксинами с характерным черным поражения на коже появляются в форме пузырьков, что позволяет визуализировать газообразующие бактерии. Патогномоничными симптомами так же являются:

1. Симптом лигатуры (симптом Мельникова) - при наложении лигатуры на участок конечности через 15-20 минут нить начинает впиваться в кожу;

2. Симптом шпателя - при постукивании металлическим шпателем по поражённой области слышен характерный хрустящий, с тимпаническим оттенком звук. Такой же звук может быть слышен при бритье кожных покровов вокруг раны (симптом бритвы);

3. Симптом пробки шампанского - при извлечении тампона (салфетки) из раневого хода слышен хлопок;

4. Симптом Краузе - межмышечные скопления газа на рентгеновском снимке визуализируются в виде «ёлочек».

Corynebacterium широко распространены в природе, чаще всего существующие в симбиотических отношениях с хозяевами, составляя нормальную микробиоту. Однако C.diphtheriae является высокопатогенным микроорганизмом вызывая дифтерию. 
Дифтерия - острое инфекционное заболевание, характеризующаяся местным фибринозным воспалением преимущественно слизистых рото- и носоглотки, а также явлениями общей интоксикации и поражением внутренних органов. Основным источником дифтерийной инфекции является человек больной дифтерией или бактерионоситель токсигенных дифтерийных микробов. В организме больного дифтерией возбудитель обнаруживается уже в инкубационном периоде, находится в течение всей острой стадии болезни и у большинства лиц продолжает выделяться спустя некоторое время после нее. Эпидемиологически наиболее опасны лица, находящиеся в инкубационном периоде болезни, больные со стертыми, атипичными формами дифтерии, особенно редких локализаций (например, дифтерия кожи в виде экземы, опрелостей, гнойничков и др.), которые отличаются более длительным течением по сравнению с дифтерией обычной локализации и типичного течения, поздно диагностируются. Бактерионосительство развивается после перенесенной дифтерии и у здоровых лиц, при этом может быть носительство токсигенных, атоксигенных и одновременно обоих типов коринебактерий. Восприимчивость к дифтерии невысокая, индекс контагиозности колеблется в пределах 10-20\%. Наиболее восприимчивы к дифтерии дети в возрасте от 1 года до 5-6 лет. К 1820 годам и старше невосприимчивость достигает $85 \%$, что обусловливается приобретением активного иммунитета.

Передача инфекции происходит главным образом воздушно-капельным путем при разговоре, кашле и чихании. В зависимости от удельного веса капельки бактерии могут оставаться в воздухе в течение нескольких часов (аэрозольный механизм).

Инкубационный период при дифтерии составляет от 2 до 10 дней. В зависимости от ворот проникновения инфекции и реакции макроорганизма развиваются различные клинические формы дифтерии по локализации и тяжести.

Клинические формы: в связи с различной локализацией местного процесса и выраженностью общетоксических явлений дифтерия отличается многообразием клинических форм. Наиболее часто дифтерийный процесс локализуется в ротоглотке. На долю дифтерии зева приходится 90\% всех случаев. Различают локализованную, распространенную и токсическую формы дифтерии зева. Локализованная дифтерия ротоглотки - наиболее частая форма.

При локализованной форме налеты располагаются только на миндалинах и не выходят за их пределы. Заболевание начинается остро, обычно с повышения температуры тела до $38-39^{\circ} \mathrm{C}$ и появления слабо выраженных симптомов интоксикации. Больные жалуются на общее недомогание, головную боль, незначительные боли при глотании, при осмотре общее состояние мало нарушено, отмечается небольшое увеличение регионарных лимфатических 
узлов с обеих сторон, реже с одной стороны. Лимфатические узлы слабо болезненны, подвижны.

В зависимости от характера поражения зева различают пленчатую, островчатую и катаральную формы локализованной дифтерии зева. Наиболее типична пленчатая (сплошная) форма, при которой пленка сероватого цвета, гладкая с перламутровым блеском, с довольно четко очерченными краями, покрывает всю миндалину. Пленка располагается на поверхности миндалин, трудно снимается. При насильственном еe отторжении ткань миндалин кровоточит, а сам пленчатый налет не растирается между двумя предметными стеклами.

Распространенная дифтерия зева встречается реже, чем локализованная. Налет при этом распространяется за пределы миндалин на слизистую оболочку небных дужек, язычка. Симптомы интоксикации выражены умеренно.

Токсическая форма - это наиболее тяжелая форма дифтерии зева.

Бактериальная инфекция, которая, в основном, вызывается бактерией Listeria monocytogene - листериоз. В некоторых случаях листериоз вызывали и другие листерии (L. ivanovii и L. grayi). Листерия распространена повсеместно и в основном передается оральным путем после приема зараженных пищевых продуктов, после чего бактерии проникают в кишечник, вызывая системные инфекции. Листериоз может вызвать тяжелое заболевание, включая тяжелый сепсис, менингит или энцефалит, иногда приводя к пожизненному вреду и даже смерти. Однако чаще это легкий, самоограничивающийся гастроэнтерит и лихорадка. Риску тяжелого заболевания подвержены люди с нарушениями функции иммунной системы. У беременных женщин это может вызвать мертворождение или самопроизвольный аборт, а преждевременные роды обычное явление.

Actinomyces, «лучевой гриб» (от греч. Actis, луч или луч, и mykes, гриб) назван так ошибочно, так как внешний вид этих колоний похож на колонию грибов. Однако это грамположительные бактерий распространены повсеместно, встречаются в почве и микробиоте животных, включая микробиоту человека. Могут вызывать заболевание актиномикоз - хроническая очаговая или гематогенная анаэробная инфекция, вызванная Actinomyces israelii и другими видами Actinomyces. Характерное поражение при актиномикозе представляет собой отвердевшую область множественных небольших сообщающихся абсцессов, окруженных грануляционной тканью. Поражения имеют тенденцию формировать свищи, которые сообщаются с кожей. Выделяют несколько форм заболевания. Шейно-лицевая форма обычно начинается как маленькая, плоская, твердая опухоль, с болью или без, под слизистой оболочкой ротовой полости или кожей шеи или как опухоль челюсти. Впоследствии появляются области размягчения, которые опорожняются через пазухи и свищи с выделением 
характерных серых гранул. Могут быть затронуты щека, язык, глотка, слюнные железы, кости черепа, мягкие мозговые оболочки или головной мозг, обычно контактным путем.

При абдоминальной форме поражаются кишечник (обычно слепая кишка и аппендикс) и брюшина. Характерны боль, лихорадка, рвота, диарея или запор и истощение организма. Происходит развитие одного или более образований в области брюшины, что вызывает признаки частичной кишечной непроходимости. Может развиться опорожнение кишечных свищей с распространением процесса на внешнюю брюшную стенку.

При очаговой тазовой форме у пациенток, которые используют внутриматочную спираль, наблюдаются выделения из влагалища и боль в области таза или нижней брюшной части.

При торакальной форме поражение легких напоминает туберкулез. Обширная инвазия может произойти до того, как появятся боль в области грудной клетки, лихорадка и продуктивный кашель. Заболевание может вызвать перфорацию стенки грудной клетки с хроническими дренажными свищами.

При генерализованной форме инфекция распространяется гематогенно во многие области, включая кожу, позвоночную костную ткань, головной мозг, печень, почки, мочеточники, а у женщин - и органы таза. В связи с локализацией могут проявляться разные симптомы (например, боль в пояснице, головная боль, боль в животе).

Аналогичными с актиномицетами характеристиками обладают бактерии нокардия. Эти бактерии встречаются в почве, время от времени вызывают спорадические заболевания людей и животных во всем мире. Из 85 их видов патогенные для человека Nocardia asteroides и Nocardia brasiliensis, которые могут вызывать нокардиоз. Это инфекционное заболевание, чаще всего встречается у мужчин, с нарушениями функции иммунной системы, особенно ее клеточного звена. В виде инфекционного осложнения она может быть у пациентов, принимающих иммунодепрессанты (после трансплантации органов, и гемопоэтических стволовых клеток, при системных заболеваниях или лечении рака). Это гранулематозная и гнойная инфекция может протекать в виде:

- легочной инфекции, вызывающей прогрессирующую форму пневмонии, с ночной потливостью, жаром, кашлем, болью в груди, не поддается лечению стандартными антибиотиками. Рентгенологическое исследование выявляет множественные легочные инфильтраты со склонностью к центральному некрозу (церебральные абсцессы).

- неврологическая инфекция в виде менингита и/или церебрального абсцесса, который достаточно сложно диагностировать. Проявляется внезапно с головной болью, вялостью, спутанностью сознания, судорогами, не начало неврологического дефицита. 
- эндокардитом, как основным проявлением. В зарегистрированных случаях это приводило к повреждению сердечных клапанов, как естественных, так и протезных.

- инфекции кожи, которые могут ошибочно рассматриваться как стафилококковая инфекция, особенно поверхностные кожные инфекции, которые похожи на рожу, но протекает менее остро.

Диссеминированный нокардиоз возникает у пациентов с тяжелым иммунодефицитом. У пациентов с инфекцией нокардии с поражением головного мозга смертность превышает 80\%; при других формах летальность составляет $50 \%$ даже при соответствующей терапии.

Грамотрицательные бактерии, не сохраняют окраску кристаллическим фиолетовым, при окрашивании их методом Грама т.к. имеют две мембраны (рис.15), чем и обусловлено такое окрашивание.
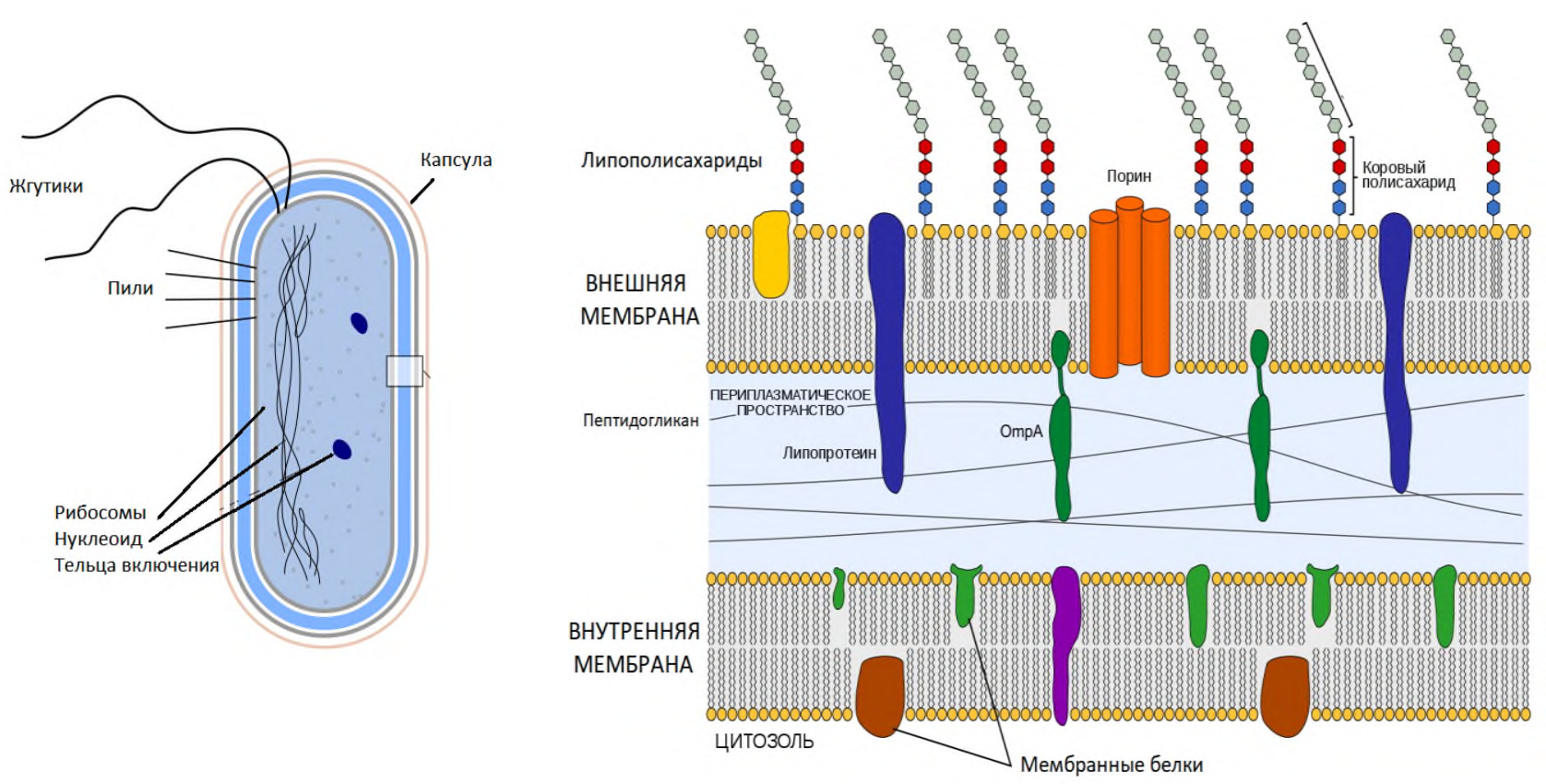

Рис.15. Строение грамотрицательной бактерии.

(В рисунке использованы элементы изображение с сайта https://commons.wikimedia.org)

Внутренняя клеточная (цитоплазматическая) мембрана состоит из пептидогликана, который намного тоньше чем у грамположительных бактерий. Наружная мембрана содержит липополисахариды (липид $\mathrm{A}$, основного полисахарида, О-антигена, фосфолипидов). Между этими мембранами имеется периплазматическое пространство, заполненное концентрированным гелеобразным веществом, где находятся транспортные белки и гидролитические ферменты. С липополисахаридом во многом связана патогенность грамотрицательных бактерий. ЛПС вызывает токсическую реакцию и 
воспаление, которое характеризуется синтезом цитокинов и активацией иммунной системы.

К грамотрицательным бактериям относятся многие патогенные бактерии. К числу важных с медицинской точки зрения это грамотрицательные кокки (Neisseria gonorrhoeae, Neisseria meningitidis, Moraxella catarrhalis) и палочки, вызывающие респираторные инфекции (Haemophilus, Bordatella, Legionella и пр.), инфекции ЖКТ (Salmonella, Shigella, Pseudomonas и другие Enterobacteriaceae), мочеполовые инфекции (Escherichia, Enterobacter), зоонозные инфекции (Brucella, Francisella, Yersinia и др.). Особую проблему создают грамотрицательные бактерии, связанные с внутрибольничными инфекциями (Acinetobacter baumannii, Pseudomonas, Serratia), которые вызывают бактериемию, вторичный менингит и пневмонию, связанную с искусственной вентиляцией легких, в отделениях интенсивной терапии больниц.

Гонорея - это инфекция, передающаяся половым путем во время орального, анального и вагинального секса, вызываемая бактерией Neisseria gonorrhoeae. Он также может передаваться от матери к ребенку во время родов. Гонореей страдают около $1 \%$ жителей всего мира. Ежегодно в год регистрируется от 33 до 110 миллионов новых случаев. Риск заражения у мужчин $20 \%$ от одного вагинального полового акта с инфицированной женщиной, у женщин 60-80\% от однократного вагинального полового акта с инфицированным мужчиной.

Инкубационный период составляет как правило, от двух до 14 дней, при этом большинство симптомов появляются от четырех до шести дней после заражения.

У большинства мужчин наблюдается воспаление уретры полового члена, за счет сужения и уплотнения просвета уретры ощущается жжения и боли при мочеиспускании, гнойные выделениями из полового члена. Наиболее частым осложнением гонореи у мужчин является воспаление придатка яичка. С гонореей связан повышенный риск развития рака простаты.

Более чем у половины женщин гонорея протекает бессимптомно. Симптомы гонореи связаны с воспалением шейки матки, в виде выделения из влагалища, боли внизу живота или боль во время полового акта. Общие медицинские осложнения нелеченной гонореи у женщин включают воспалительные заболевания органов малого таза, которые могут вызвать рубцы на фаллопиевых трубах и привести к более поздней внематочной беременности у беременных женщин.

И мужчины, и женщины с инфекциями горла могут испытывать боль в горле, увеличение лимфатических узлов на шее. Если не лечить, гонококковая инфекция может распространиться из первоначального очага инфекции, 
инфицировать и повредить суставы, кожу и другие органы. В очень редких случаях может развиваться перитонит, эндокардит или менингит.

Менингококковая инфекция - антропонозное острое инфекционное заболевание, протекающее в виде нозофарингита, менингококкцемии, и гнойного менингита и реже с поражением других органов и систем, возбудитель которого является Neisseria meningitides. ОН отличается высокой морфологической изменчивостью, в типичных случаях в препаратах выглядит как диплококк, располагающийся попарно в виде кофейных зерен. На основе группоспецифических антигенов менингококки подразделяются на ряд серологических групп (A, B, C, D, N, X, Y, Z и др.). Основным фактором агрессии возбудителей служит липополисахаридный комплекс (эндотоксин). Возбудитель малоустойчив к воздействию факторов внешней среды. Резервуар и источник инфекции - человек с генерализованной формой, острым назофарингитом, а также здоровые носители. Механизм передачи - аэрозольный. Возбудитель передается с капельками слизи при кашле, чиханье, разговоре.

Наиболее распространенной манифестной формой менингококковой инфекции является назофарингит, его этиологическая расшифровка клинически затруднительна. Инкубационный период не превышает 2-3 дней. Больные отмечают повышение температуры тела, чаще в виде субфебрилитета, головную боль, катаральные проявления: кашель, першение и боли в горле, заложенность носа и насморк со слизисто-гнойным отделяемым. В некоторых случаях больные жалуются на боли в суставах. Лицо пациента бледное. Наблюдается гиперемия миндалин, мягкого нёба, дужек. Обращают на себя внимание яркая гиперемия и зернистость задней стенки глотки, покрытой слизисто-гнойным налетом. Подчелюстные железы могут быть увеличенными и болезненными при пальпации. Заболевание длится 3-5 дней и заканчивается выздоровлением.

При генерализации процесса может развиться менингококкцемия (менингококковый сепсис). Заболевание начинается остро, с повышения температуры за несколько часов до $40-41^{\circ} \mathrm{C}$, что сопровождается головной болью, неукротимой рвотой, болями в мышцах спины и конечностей. Наиболее демонстративным симптомом является экзантема. Типичны звездчатые геморрагические элементы, плотные на ощупь. Сыпь имеет тенденцию к слиянию, располагается на ягодицах, нижних конечностях, в подмышечных впадинах, на верхнем веке. При массивной бактериемии и интоксикации сыпь может располагаться на любой поверхности тела и становится некротической. При обратном развитии сыпи могут образовываться язвенно-некротические поверхности на ушных раковинах, кончике носа, дистальных отделах конечностей. В редких случаях менингококкцемия может приобретать хроническое течение, сопровождающееся длительной интермиттирующей лихорадкой, полиморфными высыпаниями на коже, артритами и полиартритами, 
развитием гепатолиенального синдрома. При сверхострых (молниеносных) формах менингококкцемии в короткий срок развивается инфекционнотоксический шок, определяющий неотложное состояние и часто приводящий к смерти.

При менингококковом менингите заболевание начинается остро с подъема температуры до высоких цифр, резкой, мучительной головной боли, часто неукротимой рвоты без тошноты, не связанной с приемом пищи. Больные возбуждены, эйфоричны, у части из них уже в первые часы заболевания наступает расстройство сознания. Лицо гиперемировано, нередки герпетические высыпания на губах, возникает тактильная, слуховая и зрительная гиперестезия. Возможен судорожный синдром. Выражена тахикардия, артериальное давление имеет склонность к падению. Мочеотделение задержано. Менингеальная симптоматика проявляется уже в первые сутки заболевания в виде ригидности затылочных мышц, симптомов Кернига, Брудзинского и др. Понятие «менингококковый менингит» весьма условно, поскольку между оболочками и веществом мозга существует тесная анатомическая связь. При переходе воспалительного процесса на вещество мозга и развитии менингоэнцефалита обычно быстро нарастают психические нарушения, сонливость, стойкие параличи и парезы.

C Moraxella catarrhalis также известен как Neisseria catarrhalis или Branhamella catarrhalis колонизирует верхние дыхательные пути у детей на первом году жизни практически в 100\%. Колонизация, по-видимому, представляет собой непрерывный процесс с чередованием элиминацииколонизации различных штаммов. При этом он вместе со Streptococcus pneumoniae и Haemophilus influenzae является основной причиной среднего отита и синусита, у детей и взрослых с хроническим заболеванием легких может вызывает бронхит и пневмонию и иногда является причиной бактериемии и менингита, особенно у лиц с нарушением функции иммунной системы.

Грамотрицательные бактерии в виде палочек с клинической точки зрения удобнее описывать с позиций локализации их поражения. Выделяют бактерии, поражающие в основном респираторный тракт, ЖКТ, мочеполовую систему. Отдельную группу составляют зоонозные инфекции.

\section{Грамотрицательные бактерии респираторного тракта.}

Haemophilus influenzae первоначально описан как возбудитель гриппа. После установления вирусной природы гриппа определено, что этот микроб является одним из возбудителей пневмонии, менингита, эпиглоттита. У людей с нарушениями функции иммунной системы он может быть причиной перикардита, инфекций кожи, остеомиелитом и септическим артритом. Поражает только людей. 
Некоторые штаммы $H$. influenzae обладают полисахаридной капсулой и, на основе биохимических различий капсулы, их еще подразделяются на 6 различных типов (a-f). Штаммы, не имеющие капсулы не типируются. Самый вирулентный штамм - H. influenzae типа b (Hib) может вызывать менингит, пневмонию, перикардит, эпиглоттит, инфекции кожи и подкожной клетчатки. Неинкапсулированныме Н. influenzae обычно вызывают различные инфекции слизистых оболочек, включая средний отит и конъюнктивит.

Коклюш (от фр. coqueluche; лат. Pertussis, также известный как 100дневный кашель) - острая антропонозная воздушно-капельная бактериальная инфекция, наиболее характерным признаком которой является приступообразный спазматический кашель. Заражение происходит воздушнокапельным путём при прямом контакте с заражённым человеком или бактерионосителем.

Инкубационный период длится от 7 до 14 дней. Больной заразен с 1-го до 25-го дня заболевания. Заражение происходит воздушно-капельным путём. Заболевание обычно начинается с легких респираторных симптомов, включая легкий кашель, чихание или насморк (известная как катаральная стадия). По прошествии одной или двух недель кашель, как правило, переходит в неконтролируемые приступы. Кашель может длиться долго до 10 и более недель (100-дневный кашель). Затем происходит постепенный переход к стадии выздоровления, которая обычно длится от одной до четырех недель. Эта стадия отмечена уменьшением пароксизмов кашля, хотя возможны рецидивы кашля при других респираторных инфекциях в течение многих месяцев после начала коклюша. Симптомы коклюша могут быть разными, особенно у иммунизированных и неиммунизированных людей. Иммунизированные и взрослые имеют более легкую форму инфекции (приступообразный кашель недлительный или вообще отсутствует) однако, несмотря на это, они могут передавать болезнь другим людям.

Легионеллёз (болезнь легионеров) - сапронозное острое инфекционное заболевание, обусловленное различными видами микроорганизмов, относящихся к роду Legionella (более 42 видов, составляющих 64 серогруппы). Наиболее распространенным видом является L. pneumophila, вызывающим до $90 \%$ случаев легионеллеза (серогруппы 1, 4 и 6 основные причины заболеваний человека), так же патогенными являются L. micdadei (также известный как возбудитель пневмонии Питтсбурга), L. bozemanii, L. dumoffii и L. longbeachae. В естественной среде бактерии встречаются в пресной воде. Они могут загрязнять резервуары с горячей водой, гидромассажные ванны и кондиционеры. Заражение происходит при вдыхании капель воды из загрязненного источника, однако не все заболевают. Инфекция, возникает чаще и протекает более тяжело у пациентов с нарушением функции иммунной системы (престарелые, пациенты с 
диабетом или хронической обструктивной болезнью легких, курильщики больные с ВИЧ).

Заболевание протекает, как правило, с выраженной лихорадкой, общей интоксикацией, поражением лёгких, центральной нервной системы, органов пищеварения, возможно развитие синдрома полиорганной недостаточности. Как вариант легионеллеза выделяют лихорадку Понтиака инфекцию без поражения легких.

Микроорганизмы Klebsiella обычно обнаруживаются в носу, рту и желудочно-кишечном тракте человека как нормальная флора, однако они также могут вести себя как условно-патогенные микроорганизмы человека. Они могут вызывать широкий спектр заболеваний (пневмонию, инфекции мочевыводящих путей, сепсис, менингит, диарею, перитонит и инфекции мягких тканей). Большинство инфекций, вызываемых клебсиеллами человека, вызываются K.pneumoniae и $K$. oxytoca. Клебсиелы также вовлечены в патогенез анкилозирующего спондилита и других спондилоартропатий. Инфекции чаще встречаются у пациентов с нарушением функции иммунной системы.

\section{Инфекции желудочно-кишечного тракта.}

Одним из основных патогенных для человека бактерий, поражающий ЖКТ, являются различные типы Salmonella enterica. Salmonella typhi возбудитель брюшного тифа, Salmonella paratyphi A, paratyphi B, Salmonella hirschfeldii - возбудители паратифов А, В и С. Разнообразные серотипы Salmonella enterica (более 2200 серотипов, один вид, 7 подвидов, каждый подвид разделяется на серовары в соответствии с О- и Н-антигенной специфичностью штаммов) - возбудители сальмонеллеза. Все они встречается во всех регионах мира. Механизм передачи возбудителя фекально-оральный. Путь передачи преимущественно водный и/или пищевой, но возможны и бытовые пути передачи.

Брюшной тиф - острая циклически протекающая кишечная антропонозная инфекция, вызываемая Salmonella typhi. Сальмонеллы брюшного тифа имеют сложную антигенную структуру. Различные серовары содержат характерный набор антигенных факторов, которые складываются из сочетания О- и Н-антигенов. Резервуар и источники возбудителя: человек, больной или носитель (транзиторный, острый или хронический). Период заразительности источника. Наибольшее выделение возбудителя с фекалиями наблюдается в течение 1-5 недель заболевания с максимумом на 3-й недели, с мочой - в течение 2-4 недели. Реконвалесценты нередко выделяют возбудителя во внешнюю среду в течение 14 дней (транзиторное носительство), у $10 \%$ переболевших этот процесс продолжается до 3 месяцев (острое носительство), а 3-5 \% становятся хроническими носителями, выделяя брюшнотифозную палочку в течение ряда 
лет. Перемежающийся характер выделения возбудителя брюшного тифа у хронических носителей затрудняет выделение и повышает их эпидемиологическую опасность. Путь передачи - преимущественно водный, но возможны пищевой и бытовой пути передачи.

Естественная восприимчивость людей высокая, хотя клинические проявления заболевания могут варьировать от стертых до тяжело протекающих форм. Перенесенное заболевание оставляет стойкий иммунитет.

Инкубационный период - от 7 до 23 дней, в среднем 2 недели. Схема распространения микроорганизма: возбудитель - рот - кишечник - пейеровы бляшки и солитарные фолликулы (лимфаденит и лимфангит) - кровяное русло бактериемия - первые клинические проявления. Циркулирующие в крови микроорганизмы частично погибают - высвобождается эндотоксин, обусловливающий интоксикационный синдром, а при массивной эндотоксемии - инфекционно-токсический шок.

Начальный период (время от момента появления лихорадки до установления ее постоянного типа) - продолжается 4-7 дней и характеризуется нарастающими симптомами интоксикации. Бледность кожи, слабость, головная боль, снижение аппетита, брадикардия. Обложенность языка белым налетом, запоры, метеоризм.

Период разгара - 9-10 дней. Температура тела держится постоянно на высоком уровне. Симптомы интоксикации резко выражены. Больные заторможены, негативны к окружающему. При осмотре на бледном фоне кожи можно обнаружить бледно-розовые единичные элементы сыпи - розеолы, слегка выступающие над поверхностью кожи, исчезающие при надавливании, располагающиеся на коже верхних отделов живота, нижних отделов грудной клетки, боковых поверхностях туловища, сгибательных поверхностях верхних конечностей. Отмечаются глухость тонов сердца, брадикардия, гипотония. Язык обложен коричневатым налетом, с отпечатками зубов по краям. Живот вздут, имеется склонность к запорам. Увеличивается печень и селезенка. Осложнением этого периода является инфекционно-токсический шок, на 3-й недели болезни перитонит, кишечное кровотечение, могут развиться миокардит, вторичная пневмония, гнойный менингит и менингоэнцефалит, септикопиемия.

В период реконвалесценции у 3-10\% больных может наступить рецидив болезни. Предвестниками рецидива являются субфебрилитет, отсутствие нормализации размеров печени и селезенки, сниженный аппетит, продолжающаяся слабость, недомогание. Рецидив сопровождается теми же клиническими проявлениями, что и основная болезнь, но протекает менее продолжительно.

В настоящее время в клинической картине брюшного тифа произошли большие изменения. Это связано с повсеместным применением антибиотиков, а 
также с иммунопрофилактикой. Вследствие этого стали преобладать стертые и абортивные формы заболевания. Лихорадка может длиться до 5-7 дней (иногда 2-3 дня). Чаще встречается острое начало (без продромального периода - в 60$80 \%$ случаев). Что касается картины крови, то в 50\% случаев сохраняется нормоцитоз, эозинофилы в норме. Серологические реакции на брюшной тиф могут быть отрицательными в течение всей болезни.

Паратифы А и В - Возбудителем паратифа А является бактерия Salmonella paratyphi A, паратифа В - Salmonella paratyphi B. Резервуаром в случае паратифа А является человек, больной или носитель, а для возбудителя паратифа В - домашний скот, птица. Паратифы передаются с помощью фекальноорального механизма пищевым, водным или бытовым путем. Для паратифа А более характерен водный путь заражения, для В - пищевой. Люди и животные выделяют микроорганизм в окружающую среду на протяжении всего периода клинических проявлений и около 2-3 недель после (реконвалесценция). Бессимптомное бактерионосительство при паратифах развивается чаще, чем при брюшном тифе.

Заболеваемость паратифом А преимущественно отмечается в ЮгоВосточной Азии, Африке, паратиф В не имеет региональной очаговости. Отмечают как единичные случаи, так и эпидемические вспышки.

Инкубационный период при паратифе А составляет обычно от 6 до 10 дней, начало острое, отмечается быстрое повышение температуры тела, насморк. Кашель. При осмотре выявляется гиперемия лица, инъекции склер, иногда высыпания наподобие герпеса на губах и крыльях носа. В отличие от брюшного тифа лихорадка не настолько постоянная, менее продолжительна, часто приобретает неправильный характер. В разгар заболевания могут отмечаться озноб и потливость. На 4-7 день болезни появляется сыпь, чаще всего розеолезного характера, но может быть и петехиальной или кореподобной. Сыпь обильно покрывает кожу живота, груди, конечностей, отличается полиморфизмом элементов, с течением заболевания экстенсивно распространяется. Обычно течение паратифа А среднетяжелое, с умеренной, более кратковременной, чем брюшнотифозная, интоксикацией. Иногда паратиф может приобретать рецидивирующий характер.

Паратиф В характеризуется инкубационным периодом около 5-10 дней, отличается преимущественно кишечными проявлениями в начальном периоде. На фоне повышения температуры отмечается боль в животе, тошнота, рвота, диарея. Нередко первоначальная клиническая картина напоминает симптоматику пищевой токсикоинфекции. Вскоре присоединяется сыпь, подобная таковой при паратифе А. В остальном виды паратифов сходны по своему течению. Паратиф В в редких случаях может протекать тяжело с развитием осложнений, таких как септицемия, воспаления мозговых оболочек. 
Паратиф C в отличие от паратифа А или В протекает в виде пищевой токсикоинфекции (дисфункция ЖКТ с частым развитием обезвоживания, формирование катарально-геморрагического, язвенно-некротического колита, длительность 4-5 суток). В других формах (тифоподобной и септической) встречается редко, в основном у лиц с нарушением функции иммунной системы.

Сальмонеллез - это инфекционная болезнь, вызываемая большой группой сальмонелл наиболее значимы для человека S. typhimurium, S. enteridis, S. panama, S. infantis, S. newport, S. agona, S. derby, S. london (85-91\% сальмонеллезов). Основными факторами патогенности сальмонелл являются холероподобный энтеротоксин и эндотоксин липополисахаридной природы.

Источники инфекции - домашние животные и птицы - основные, человек (больной, носитель) - дополнительный источник. Мясо животных может обсеменяться гематогенным путем при жизни (если заболевание у них текло остро), или посмертно содержимым кишечника при неправильном забое и разделке туш животных - бактерионосителей. Сальмонеллы длительно сохраняются во внешней среде, в некоторых продуктах могут размножаться, не изменяя внешнего вида и вкуса продуктов. Наибольшую опасность человек как источник инфекции представляет для детей первого года жизни, которые высокочувствительны ко всем кишечным инфекциям. Бактериовыделитель может представлять опасность и для взрослых в том случае, если он имеет отношение к приготовлению пищи, раздаче ее или продаже пищевых продуктов. В стационарах сальмонеллез приобрел черты госпитальной инфекции.

Основной путь заражения - алиментарный, обусловленный употреблением в пищу продуктов, в которых содержится большое количество сальмонелл. Сальмонеллезы могут встречаться в виде групповых вспышек (обычно алиментарного происхождения), так и в виде спорадических заболеваний.

Инкубационный период при пищевом пути заражения сальмонеллезом колеблется от 6 часов до 3 суток (чаще 12-24 часа). При внутрибольничных вспышках, когда преобладает контактно-бытовой путь передачи инфекции, инкубация удлиняется до 3-8 дней. Воротами инфекции является тонкая кишка, где происходит колонизация возбудителя. Далее сальмонеллы захватываются макрофагами, но это не приводит к их фагоцитозу. Они обладают способностью не только сохраняться, но и размножаться в макрофагах, преодолевать внутри них барьер кишечного эпителия, проникать в лимфатические узлы и кровь. Бактериемия у больных сальмонеллезом встречается часто, но обычно бывает кратковременной.

В собственном слое слизистой оболочки тонкой кишки наблюдается интенсивное разрушение бактерий с высвобождением энтеротоксина и эндотоксина. Эндотоксин приводит к развитию лихорадки и нарушению микроциркуляции вплоть до развития инфекционно-токсического шока. 
Энтеротоксин, активируя аденилатциклазу энтероцитов, приводит к нарастанию внутриклеточной концентрации цАМФ, фосфолипидов, Pg и др БАВ. Это приводит к нарушению транспорта ионов $\mathrm{Na}$ и $\mathrm{Cl}$ через мембрану клеток кишечного эпителия с накоплением их в просвете кишки. По возникающему осмотическому градиенту вода выходит из энтероцитов, развивается водянистая диарея. В тяжелых случаях заболевания вследствие потери жидкости и электролитов наблюдаются значительное нарушение водно-солевого обмена, уменьшение ОЦК, снижение артериального давления и развитие гиповолемического шока.

Одновременно развивается ДВС синдром, который является как следствием воздействия эндотоксина на свертывающую систему крови, так и гиповолемии. Страдает и сосудисто-нервный аппарат, что проявляется в понижении тонуса сосудов, нарушении терморегуляции.

Иммунные реакции представляются в виде сочетания местного (кишечного) иммунитета (секреция IgA и слабовыраженная клеточная реакция) и общего (продукция различных классов Ig и повышение фагоцитарной активности макрофагов). Возможно развитие сенсибилизации организма с формированием реакций гиперчувствительности.

Выделяют следующие клинические формы сальмонеллеза:

гастроинтестинальная (локализованная), протекающая в гастритическом, гастроэнтеритическом, гастроэнтероколитическом и энтероколитическом вариантах;

генерализованная форма в виде тифоподобного и септического вариантов;

бактерионосительство: острое, хроническое и транзиторное; субклиническая форма.

Манифестные формы сальмонеллеза различаются и по тяжести течения.

Гастроинтестинальная форма (острый гастрит, острый гастроэнтерит или гастроэнтероколит) - одна из самых распространенных форм сальмонеллеза (9698\% случаев). Начинается остро, повышается температура тела (при тяжелых формах до $39^{\circ} \mathrm{C}$ и выше), появляются общая слабость, головная боль, озноб, тошнота, рвота, боли в эпигастральной и пупочной областях, позднее присоединяется расстройство стула. У некоторых больных вначале отмечаются лишь лихорадка и признаки общей интоксикации, а изменения со стороны желудочно-кишечного тракта присоединяются несколько позднее. Наиболее выражены они к концу первых и на вторые и третьи сутки от начала заболевания. Выраженность и длительность проявлений болезни зависят от тяжести.

Тифоподобный вариант генерализованной формы. Заболевание чаще начинается остро. У некоторых больных первыми симптомами болезни могут быть кишечные расстройства в сочетании с лихорадкой и общей интоксикацией, но через 1-2 дня кишечные дисфункции проходят, а температура тела остается 
высокой, нарастают симптомы общей интоксикации. Лихорадка может быть постоянного типа, но чаще волнообразная или ремитирующая. Больные заторможены, апатичны. Лицо бледное. У некоторых больных на 2-3-й день появляется герпетическая сыпь, а с 6-7-го дня - розеолезная сыпь с преимущественной локализацией на коже живота. Наблюдается относительная брадикардия, понижение АД, приглушение тонов сердца. Над легкими выслушиваются рассеянные сухие хрипы. Живот вздут. К концу 1-й недели болезни появляется увеличение печени и селезенки. Длительность лихорадки 13 недель.

Септическая форма - наиболее тяжелый вариант генерализованной формы сальмонеллеза. Заболевание начинается остро, в первые дни оно имеет тифоподобное течение. В дальнейшем состояние больных ухудшается. Температура тела становится неправильной - с большими суточными размахами, повторным ознобом и обильным потоотделением. Заболевание протекает, как правило, тяжело, плохо поддается антибиотикотерапии. Вторичные септические очаги могут образоваться в различных органах, вследствие чего клинические проявления этого варианта сальмонеллеза весьма разнообразны, а диагностика его трудна.

Бактерионосительство. При этой форме отсутствуют клинические симптомы, и она выявляется при бактериологических и серологических исследованиях.

Развитие тифоподобной, септической, субклинической и хронических форм сальмонеллеза объясняется возникновением иммунологической толерантности к антигенам сальмонелл (причины: мимикрия антигенов, временное снижения функциональной активности фагоцитов и лимфоцитов).

Одно ведущее место в группе кишечных инфекций занимают бактерии рода Shigella вызывающие дизентерию.

Дизентерия (шигеллезы) - инфекционное заболевание, одно из основных бактериальных причин диареи во всем мире. В настоящее время выделяют четыре вида возбудителей дизентерии $S$. dysenteriae (15 серотипов), S. flexneri (9 серотипов), S. boydii (19 серотипов), S. sonnei (один серотип, но имеются различия по способности продуцировать различные ферменты). Серотип $S$. dysenteriae Григорьева-Шиги продуцируют токсин Stx1 и stx2, который действуют на эндотелий сосудов приводя к поражению сосудов и формированием гемолитико-уремического синдрома.

Дизентерия относится к антропонозам с фекально-оральным механизмом передачи возбудителя, реализующимся пищевым, водным и контактно-бытовым путями, удельный вес среди кишечных инфекций составляет от 50 до 75\%, чаще в развивающихся странах (превалируют S. flexneri, в развитых странах чаще встречается S. sonnei). 
Источником возбудителя инфекции при дизентерии являются больные острой и хронической формой, a также бактерионосители, лица с субклинической формой инфекции, которые выделяют шигеллы во внешнюю среду с фекалиями. Вследствие того, что Shigella относительно устойчивы к желудочному соку, проглатывание всего лишь 10-100 микроорганизмов может привести к болезни. Вспышки болезни происходят наиболее часто в условиях избыточной плотности населения при несоответствующих мерах гигиены. Бактериальная дизентерия особенно распространена среди маленьких детей, проживающих в эндемичных областях. У взрослых обычно менее тяжелая форма заболевания.

Инкубационный период составляет 1-7 (в среднем 2-3) дней, но может сокращаться до 2-12 ч. Выделяют следующие формы и варианты течения инфекции:

Острая дизентерия: колитический и гастроэнтероколитический варианты. По тяжести течения подразделяются на легкие, среднетяжелые, тяжелые и очень тяжелые; по особенностям течения выделяют стертые, субклинические и затяжные.

Хроническая дизентерия: рецидивирующая и непрерывная.

Бактерионосительство шигелл: реконвалесцентное и транзиторное.

При колитическом варианте заболевание начинается остро. В начале развивается синдром общей интоксикации, характеризующийся повышением температуры тела, ознобом, чувством жара, разбитости, снижением аппетита, адинамией, головной болью, брадикардией, снижением артериального давления. Поражение желудочно-кишечного тракта проявляется болями в животе, вначале тупыми, разлитыми по всему животу, имеющими постоянный характер. Затем они становятся более острыми, схваткообразными, локализуются в нижних отделах живота, чаще слева. Боли обычно усиливаются перед дефекацией, появляются тенезмы и ложные позывы. При ректороманоскопии в слизистой оболочке кишки на всем протяжении фибринозное воспаление, множественные очаги кровоизлияний и некроза. После отторжения фибринозных налетов и некротических масс образуются медленно заживающие язвы. Период разгара болезни продолжается 5-10 дней. Выздоровление происходит медленно, инфильтрация и болезненность толстой кишки сохраняются до 3-4 нед., полная нормализация слизистой оболочки происходит через 2 мес. и более.

Для гастроэнтеритического варианта характерно одновременное развитие синдромов общего токсикоза, гастроэнтерита и обезвоживания, в то время как симптомы в первые сутки выражены слабо или отсутствуют.

Диагноз хронической дизентерии устанавливается в случае, если заболевание продолжается более 3 мес. Бактерионосительство шигелл, продолжающееся выделение шигелл у лиц, перенесших острую дизентерию, 
сроком до 3 месяцев при отсутствии клинических симптомов болезни и нормальных данных ректороманоскопии является реконвалесцентным бактерионоснтельством.

Холера - карантинная инфекция, поражающая желудочно-кишечный тракт, возбудителем является Vibrio cholerae. В настоящее время дифференцируется холера, вызываемая истинным, или классическим биотипом Vibrio cholerae classica и холера Эль-Тор, вызываемая биотипом Vibrio cholerae El Tor. Холерные вибрионы Эль-Тор, в отличие от классических биологических вариантов, способны гемолизировать эритроциты барана. Вибрионы содержат термостабильные О-антигены (соматические) и термолабильные Н-антигены (жгутиковые).

Источником холерных вибрионов является только человек. Наиболее интенсивное рассеивание инфекции отмечается вокруг больных с тяжелой формой холеры, страдающих сильной диареей и многократной рвотой. В острую стадию болезни в 1 мл жидких испражнений больной холерой выделяет до $10^{5}$ $10^{7}$ вибрионов. Определенную эпидемиологическую опасность представляют вибрио носители, больные с легкой (стертой) формой, составляющие основную группу инфицированных людей, нередко не обращающихся за медицинской помощью, но тесно общающихся со здоровыми людьми.

Воротами инфекции является пищеварительный тракт. Холерные вибрионы часто погибают в желудке вследствие наличия там соляной кислоты. Заболевание развивается лишь тогда, когда они преодолевают желудочный барьер и достигают тонкой кишки, где начинают интенсивно размножаться и выделять экзотоксин. Возникновение холерного синдрома связано с наличием у вибриона белкового энтеротоксина — холерогена (экзотоксина) и нейраминидазы.

Холероген связывается со специфическим рецептором энтероцитов C1M1 ганглиозидом. Нейраминидаза, расщепляя кислотные остатки ацетилнейраминовой кислоты, образует из ганглиозидов специфический рецептор, усиливая тем действие холерогена. Комплекс холерогенспецифический рецептор активирует аденилатциклазу, которая, при участии и посредством стимулирующего действия простагландинов, увеличивает образование циклического аденозинмонофосфата (АМФ). АМФ регулирует посредством ионного насоса секрецию воды и электролитов из клетки в просвет кишечника. В результате активации этого механизма слизистая оболочка тонкой кишки начинает секретировать огромное количество изотонической жидкости, которую не успевает всасывать толстая кишка. Начинается профузный понос изотонической жидкостью.

Инкубационный период колеблется от нескольких часов до 5 суток (чаще 2-3 дня). 
Первыми клиническими признаками являются внезапный позыв на дефекацию и отхождение кашицеобразных или, с самого начала, водянистых испражнений. В последующем эти императивные позывы повторяются, они не сопровождаются болевыми ощущениями. Испражнения выделяются легко, интервалы между дефекациями сокращаются, а объем испражнений с каждым разом увеличивается. Испражнения имеют вид «рисовой воды»: полупрозрачные, мутновато-белой окраски, иногда с плавающими хлопьями серого цвета, без запаха или с запахом пресной воды. Больной отмечает урчание и неприятные ощущения в пупочной области. При прогрессировании болезни к поносу присоединяется рвота, нарастающая по частоте. Рвотные массы имеют такой же вид «рисового отвара», как и испражнения. Характерно, что рвота не сопровождается каким-либо напряжением и тошнотой. С присоединением рвоты обезвоживание - эксикоз - быстро прогрессирует. Жажда становится мучительной, язык сухим с «меловым налетом», кожа и слизистые оболочки глаз и ротоглотки бледнеют, тургор кожи снижается, количество мочи уменьшается вплоть до анурии. Возникают судороги икроножных мышц, кистей, стоп, жевательных мышц, нестойкий цианоз губ и пальцев рук, охриплость голоса.

Тяжелая форма холеры характеризуется резко выраженными признаками эксикоза вследствие очень обильного (до 1-1,5 л за одну дефекацию) стула, который становится таковым уже с первых часов болезни, и такой же обильной и многократной рвоты. Больных беспокоят болезненные судороги мышц конечностей и мышц живота, которые по мере развития болезни переходят от редких клонических в частые и даже сменяются тоническими судорогами. Голос слабый, тонкий, часто чуть слышный. Тургор кожи снижается, собранная в складку кожа долго не расправляется. Кожа кистей и стоп становится морщинистой - «рука прачки». Лицо принимает характерный для холеры вид: заострившиеся черты лица, запавшие глаза, цианоз губ, ушных раковин, мочек ушей, носа. Появляется тахипноэ, нарастает тахикардия до 110-120 уд/мин. Пульс слабого наполнения («нитевидный»), тоны сердца глухие, АД прогрессивно падает ниже 90 мм рт. ст. сначала максимальное, затем минимальное и пульсовое. Температура тела нормальная, мочеотделение уменьшается и вскоре прекращается. Понос и рвота возникают вновь на фоне или после окончания регидратации.

Основные причины смерти при неадекватном лечении больных - это гиповолемический шок, метаболический ацидоз и уремия в результате острого некроза канальцев.

Кампилобактериоз у человека вызывается бактериями Campylobacter обычно $C$. јејuni и/или $C$. coli (не являются патогенными у крупного рогатого скота, свиней и птиц), но болезнь также может быть вызвана, C. upsaliensis 
(обнаружен у кошек и собак) и $C$. lari (присутствует у морских птиц). Это одна из наиболее частых причин бактериального гастроэнтерита человека.

Животные и птица, выращиваемые на мясо, являются основным источником кампилобактериоза (в 97\% случаев). Обычными путями передачи бактерий являются фекально-оральный при употребление зараженной пищи (обычно непастеризованное (сырое) молоко и недоваренная или плохо обработанная птица, и мясо), а также через воду (питьевая вода). Контакт с зараженной домашней птицей, домашним скотом или домашними животными, особенно щенками, также может вызвать заболевание. Это одна из причин так называемой диареи путешественников.

Инфекционная доза составляет 1000-10 000 бактерий (хотя от десяти до пятисот бактерий может быть достаточно, чтобы заразить человека). Продолжительность инкубационного периода 1-2 дня, после которого начинается продромальный период продолжительностью 24-48 часов сопровождается лихорадкой, головной болью, миалгией, недомоганием, повышается температура тела до $40^{\circ} \mathrm{C}$. Картина очень схожа с гриппом. Обычно через 1-5 дня за ними начинается диарея (до 10 водянистых, часто кровянистых испражнений в день), спазмы и боли в животе лихорадка снижается до $38^{\circ} \mathrm{C} . \mathrm{У}$ большинства людей болезнь длится 2-10 дней. У больных с нарушением функции иммунной системы возможны осложнения в виде токсического мегаколона, гиповолемического шока и сепсиса. Возможно хроническое течение болезни который развиваться без отчетливой острой фазы с длительным периодом субфебрильной температуры и астении. Могут развиться так же повреждение глаз, артрит, эндокардит. У некоторых людей инфецированных C.jejuni и C.upsaliensis (1-2 случая из 100 000) развивается острая идиопатическая демиелинизирующая полинейропатия (синдром Гийена - Барре), при которой наблюдаются симптомы восходящего паралича, дизестезии, и, на более поздних стадиях, дыхательная недостаточность. В небольшом количестве случаев инфекция может быть связана с гемолитико-уремическим синдромом и тромбоцитопенической пурпурой.

С кампилобактериями тесно связан Helicobacter Pylori, ранее известный как Campylobacter Pylori. От 30 до 80\% населения мира инфицирована этой бактерией. Наиболее вероятный путь передачи от человека к человеку оральнооральный или фекально-оральный. Чтобы избежать кислой среды внутри просвета желудка, H. pylori использует свои жгутики, чтобы достичь и прикрепляется к липидам и углеводам мембраны эпителиальным клеткам, с помощью адгезинов. В дополнение к использованию хемотаксиса, H. pylori нейтрализует кислоту желудка, производя большое количество уреазы, которая расщепляет мочевину, присутствующую в желудке, на диоксид углерода и аммиак. Экспрессия уреазы необходима не только для установления начальной 
колонизации, но и для поддержания хронической инфекции. Бактериий так же продуцируют во внешнюю среду литические ферменты (муциназа, протеаза, липаза) вызывающие растворение защитной слизи (состоящей в основном из муцина) и повреждение слизистой желудка. Все эти факторы вирулентности $H$. pylori определяются цитотоксин-ассоциированным геном A (CagA).

Способность H. pylori колонизировать слизистую желудка и вызывать поражения желудка зависит не только от индивидуальных особенностей конкретного штамма бактерии, но и от состояния иммунитета организма человека. Считается, что в отсутствие лечения H. pylori, однажды колонизовав слизистую желудка, может существовать в течение всей жизни человека, несмотря на иммунный ответ хозяина. Последствия инфекции были связаны с развитием различных желудочно-кишечных заболеваний, такие как гастрит, язвенная болезнь желудка, рак желудка, лимфома, связанная со слизистой оболочкой (MALT), и рак желчных путей. В последнее время было высказано предположение, что $H$. pylori и его метаболизм в микробиоме желудка и кишечника могут играть положительную роль в здоровье человека. Так недавние исследования показывают, что снижение заболеваемости $H$. pylori в развивающихся странах происходит параллельно с увеличением заболеваемости аллергиями и аутоиммунными заболеваниями. Кроме того, отсутствие H. pylori связывают с повышенным уровнем заболеваемости, например, рассеянным склерозом и целиакией.

\section{Группа инфекции поражающих желудочно-кишечный тракт и мочевыводящие пути. \\ Эшерихиоз (коли-инфекция, колибактериоз, колиэнтерит,} колидиспепсия). Хотя многие Escherichia являются комменсальными членами кишечной микробиоты, определенные штаммы некоторых видов, в первую очередь серотипы E. coli , являются патогенами человека и являются наиболее частой причиной инфекций мочевыводящих путей и желудочно-кишечные заболевания, от простой диареи до состояний, подобных дизентерии. Патогенные кишечные палочки по антигенным свойствам условно разделяют на 5 групп (табл. 17).

Источниками патогенных кишечных палочек являются больной колиинфекцией, бактерионоситель, а также инфицированные домашние животные. Пути заражения - пищевой, водный, контактно-бытовой (возбудитель инфекции передается через загрязнённые руки матерей, через предметы ухода за ребёнком и др.). Кишечные палочки устойчивы в окружающей среде, могут месяцами сохраняться в воде, почве. До 30 дней сохраняют жизнеспособность в молоке, до 100 дней -в детских питательных смесях, до 3-5 месяцев - на игрушках. 


\section{Патогенными для человека эшерихии}

\begin{tabular}{|c|c|c|c|}
\hline Вид эшерихий & Серогруппы & $\begin{array}{c}\text { Факторы } \\
\text { патогенности }\end{array}$ & Заболевания \\
\hline Энтеропатогенные & $\begin{array}{l}\text { Класс 1: 055, 086, } \\
0111,0119,0125, \\
0126,0127,0128 \mathrm{ab}, \\
0142 \\
\text { Класс 2: 018, 044, } \\
0112,0114\end{array}$ & $\begin{array}{l}\text { Имеют плазмиду, } \\
\text { кодирующую } \\
\text { синтез фактора } \\
\text { адгезивности }\end{array}$ & $\begin{array}{l}\text { Эпидемические вспышки } \\
\text { энтеритов и } \\
\text { гастроэнтеритов у детей } \\
\text { раннего возраста, в т. ч. у } \\
\text { новорождённых } \\
\text { (особенно часто у } \\
\text { недоношенных и } \\
\text { ослабленных детей) }\end{array}$ \\
\hline Энтероинвазивные & $\begin{array}{l}\text { 028ac, 029, 0124, } \\
\text { 0136, 0143, 0144, } \\
0152,0164,0167\end{array}$ & $\begin{array}{l}\text { Способны } \\
\text { проникать и } \\
\text { размножаться в } \\
\text { клетках эпителия } \\
\text { кишечника } \\
\end{array}$ & $\begin{array}{l}\text { Заболевание, сходное по } \\
\text { клинике с дизентерией, у } \\
\text { детей всех возрастных } \\
\text { групп (особенно у детей } \\
\text { старше } 1 \text { года) и взрослых }\end{array}$ \\
\hline Энтеротоксигенные & $\begin{array}{l}06,08,015,020, \\
025,027,063,078, \\
080,085.0115, \\
0128 a c, 0139, \\
0148,0153,0159, \\
0167\end{array}$ & $\begin{array}{l}\text { Выделяют } \\
\text { термолабильный и } \\
\text { термостабильный } \\
\text { энтеротоксины, } \\
\text { напоминающие } \\
\text { токсин холерного } \\
\text { вибриона }\end{array}$ & $\begin{array}{l}\text { Гастроэнтериты, энтериты } \\
\text { реже энтероколита у } \\
\text { детей всех возрастов } \\
\text { (чаще у детей в возрасте } \\
\text { от } 6 \text { мес. до } 2 \text { лет) и } \\
\text { взрослых }\end{array}$ \\
\hline $\begin{array}{l}\text { Энтеро- } \\
\text { геморрагические }\end{array}$ & $\begin{array}{l}0157,0126,0111, \\
0145\end{array}$ & $\begin{array}{l}\text { Образуют } \\
\text { шигаподобный } \\
\text { токсин } 1 \text { и } 2\end{array}$ & $\begin{array}{l}\text { Эпидемические вспышки } \\
\text { геморрагических колитов, } \\
\text { у взрослых может } \\
\text { вызывать гемолитическо- } \\
\text { уремический синдром }\end{array}$ \\
\hline Энтероадгезивные & & $\begin{array}{l}\text { Не образуют } \\
\text { цитотоксины }\end{array}$ & Диарея у детей \\
\hline
\end{tabular}

Уропатогенные эшерихии (связаны с филогенетической группой В2, в меньшей степени с D) обычно происходят из микрофлоры кишечника, вызывают около $80 \%$ обычных и более $30 \%$ госпитальных поражений (цистит, уретрит, пиелонефрит, воспаление тазовых органов). Бактерии проникают в мочеиспускательный канал, затем в мочевой пузырь, прикрепляются к переходному эпителию и активно размножаются. Определённую роль играют анатомические и физиологические аномалии, затрудняющие нормальную эвакуацию мочи (например, стеноз мочеиспускательного канала или пузырномочеточниковый рефлюкс).

У лиц с нарушением функции иммунной системы кишечная палочка может вызвать пневмонию, пиелонефрит, менингит, сепсис. По данным ВОЗ, в 2011 г. в 16 странах Европы (Германии, Швеции, Франции) и Северной Америки было 
зарегистрировано более 4000 случаев заболевания эшерихиозом вызванным энтерогеморрагической кишечной палочкой E. coli 0104-H4, высокоустойчивой к антибиотикам. В 52 случаях наблюдался смертельный исход. Причина и условия возникновения очагов так и не были установлены.

Близким по строению к кишечной палочке являются энтеробактерии. Представители рода Enterobacter встречаются практически во всех местообитаниях, включая кишечник человека. Там они относятся к нормальной кишечной флоре. Однако есть виды, которые, несмотря на то что они является членом нормальной кишечной флоры многих людей, могут вызывать заболевания у человека это прежде всего Enterobacter cloacae которыйе связаны с инфекциями мочевыводящих и дыхательных путей у пациентов с нарушением функции иммунной системы.

Широко распространенным сапрофитом, обитающим в сточных водах, почве, кишечнике млекопитающих и человека является Proteus. Эти бактерии являются частью нормальной кишечной флоры человека, однако некоторые представители могут оказывать патогенное действие у пациентов с нарушением функции иммунной системы. Три вида - P.vulgaris, P.mirabilis и P.penneri являются условно- патогенными микроорганизмами человека. Они вызывают многие инфекции мочевыводящих путей человека, при этом поражают почки гораздо чаще, чем E. coli. Могут быть причиной энтероколитов, вызывать инфекции ран. Активно образуя биопленки, многие протеи нечувствительны к антибиотикам.

За счет образования уреазы вырабатываемой бактерий Proteus и ощелачиванием мочи в почках могут формироваться струвитные камни.

Для ряда бактериальных инфекций характерны полиорганные поражения.

Чума - острое инфекционное заболевание человека из группы карантинных инфекций, вызывается Yersinia pestis. Возбудитель чумы имеет сложный набор ферментов, из которых наиболее изучены пероксидаза, гемолизин, коагулаза, фибринолизин. Антигенная структура чумного микроба также сложна. Большую известность получили основной соматический антиген, липополисахарид, мышиный токсин и фракция I - видовой специфический, капсульный антиген, играющий важную диагностическую роль.

Чумной микроб патогенен для многих видов дико живущих грызунов, зайцеобразных, верблюдов и хищных млекопитающих - ласок, хорьков, кошек, лисиц, некоторых видов обезьян, лабораторных животных - морских свинок, белых мышей.

Эпидемиология: чума у домашних и диких животных может проявляться в двух формах: энзоотий и эпизоотий. Эпизоотии относительно стабильный цикл циркуляции инфекции (грызун $\rightarrow$ блоха $\rightarrow$ грызун) среди сравнительно устойчивой к этому заболеванию популяции. 
Человек заболевает чумой после укуса блохой, ранее сосавшей кровь больного грызуна. Инкубационный период при чуме колеблется от 3 до 6 суток, чаще не превышает 3 суток. При отдельных формах заболевания бывает и короче. Выделяют локальную форму (кожная, бубонная и кожно-бубонная) - в такой форме чумный микроб во внешнюю среду практически не попадает (хотя инфекция может передаваться укусившим больного блохам и даже клопам) и генерализованную форму (первично и вторично-септическая) с повышенным рассеиванием микроба во внешнюю среду (первично-лёгочная, вторичнолёгочная и кишечная) с обильным выбросом микроба. В нелеченных случаях сепсис и токсинемия являются основными причинами гибели больных. Заболевание протекает бурно с высокой контагиозностью с летальным исходом до $100 \%$. Наряду с общими симптомами болезни у больных чумой развиваются также признаки местных поражений, которые и определяют клиничекую форму заболевания. В настоящее время наиболее часто регистрируются случаи бубонной и септической форм чумы, реже легочной.

Yersinia вызывают еще одну группу заболеваний иерсиниоз инфекционная болезнь, характеризующаяся поражением желудочно-кишечного тракта, суставов, кожи и других органов и систем, нередко волнообразным течением с обострениями и рецидивами. Возбудитель Yersinia enterocolitica и pseudotuberculosis.

Источником возбудителя инфекции являются различные дикие и домашние животные (свиньи, коровы, собаки, кошки), птицы, грызуны (мыши, крысы и др.), а также человек - больной и бактерионоситель. Выделяя возбудителя с фекалиями и мочой, больные животные загрязняют различные объекты окружающей среды, в т. ч. пищевые продукты. Большое значение имеют также овощи и фрукты. Возбудитель попадает на овощи на полях, при удобрении почвы навозом, поливе водой, содержащей стоки ферм и сбросы городской канализации, кроме того, грызуны, больные иерсиниозом могут загрязнять овощи и фрукты в овощехранилищах и на полях. Групповые заболевания чаще связаны с употреблением овощей и различных овощных салатов (особенно из капусты). Кроме пищевого, возможен и водный путь передачи.

Инкубационный период от 15 часов до 15 суток. Различают следующие клинические формы иерсиниоза: гастроинтестинальную, абдоминальную (аппендикулярная, псевдоаппендикулярная), генерализованную и вторичноочаговую. Всем формам иерсиниоза присущи некоторые общие клинические признаки: острое начало, лихорадка, интоксикация, боли в животе, расстройство стула, высыпания на коже, боли в суставах и мышцах, увеличение периферических лимфатических узлов и печени, склонность к волнообразному течению с обострениями и рецидивами. Течение болезни может быть острым (до 3 месяцев), затяжным (до 6 месяцев), хроническим (6 месяцев - 1/2-2 года). 
Одним из наиболее частых симптомов при генерализованной форме иерсиниоза является сыпь и поражение суставов. Высыпания на коже появляются на 2-3-й день от начала болезни, но возможны в сроки от нескольких часов до конца 2-й недели. Они располагаются на груди, животе, спине, руках и ногах; характерна локализация сыпи на ладонях и подошвах, при этом больные ощущают жжение (иногда независимо от наличия сыпи), возникают отечность и гиперемия кожи. По характеру сыпь чаще всего бывает мелкоточечной, реже мелко- и крупнопятнистой, иногда папулезной, петехиальной, уртикарной, типа узловатой эритемы, полиморфной. Длительность периода высыпания чаще всего составляет 1-4 дня, но сыпь может сохраняться в течение 1-2 недель. Возможны подсыпания в различные сроки болезни, причем характер и локализация сыпи каждый раз могут быть различными. С 12-15-го дня болезни обычно начинается крупно- и мелкопластинчатое шелушение кожи пальцев рук и ног или отрубевидное шелушение кожи лица, бедер, плеч.

Артралгии обычно развиваются на 3-4-й день от начала заболевания, иногда через 2-4 недели. Поражаются коленные, плечевые, голеностопные, лучезапястные, межфаланговые суставы. Возможны артриты, особенно мелких суставов, появляются различной интенсивности боли в мышцах спины, ног, шеи, в пятках и подошвах при ходьбе.

Вторично-очаговая форма не является самостоятельной, а может развиться после любой из форм заболеваний. При этом заболевание может протекать субклинически, либо первые проявления иерсиниоза (например, гастроэнтерит) и возникшие затем очаговые поражения бывают отделены друг от друга длительным периодом, в течение которого самочувствие остается хорошим. В этих случаях первым выраженным клиническим проявлением болезни служит поражение какого-либо органа (сердца, печени, сустава, мозговых оболочек).

Наиболее частый вариант этой формы - полиартрит с поражением 2-3 суставов или моноартрит; артралгиям в 50-80\% случаев предшествуют диспептические явления (боли в животе, тошнота, рвота, диарея) и симптомы интоксикации. Особенно характерно асимметричное поражение суставов ног. Обычно последовательно поражаются 2-3 сустава с интервалом от нескольких дней до 2-3 недели. Иерсиниозный гепатит может быть не только проявлением генерализованной формы, но и вариантом вторично-очаговой формы. Желтуха, как правило, непродолжительная и неинтенсивная, а лихорадка и интоксикация, с которых начинается заболевание, могут быть выраженными и длительными.

Менингит также может быть вариантом вторично-очаговой формы, он обычно бывает серозным, течение, как правило, нетяжелое, встречается редко. К редким вариантам вторично-очаговой формы иерсиниоза относятся синдром Рейтера, шейный лимфаденит, офтальмит, уретрит, остеит. Иерсиния может быть связана с болезнью Крона. 
Бруцеллез (синонимы: мальтийская лихорадка, болезнь Банги) заболевание, обусловленное различными видами бруцелл, склонное к хроническому течению, характеризуется поражением опорно-двигательного аппарата, нервной, половой и других систем. Бруцеллез человека может быть обусловлен 4 видами бруцелл: Brucella melitensis (3 биотипа), Br. Abortus (9 биотипов), Br. Suis (4 биотипа), Br. ovis it Br. neotomae для человека непатогенны. Бруцеллез является зоонозом. Резервуаром и источником инфекции являются домашние животные (овцы, козы, коровы, свиньи, реже собаки). Пути передачи: контактный, алиментарный и аэрогенный. В большинстве случаев это профессиональные заболевания. Инкубационный период при бруцеллезе от 3 недель до нескольких месяцев. Первично-латентная форма бруцеллеза характеризуется состоянием практического здоровья. При тщательном обследовании лиц с этой формой бруцеллезной инфекции иногда можно обнаружить микросимптомы в виде небольшого увеличения периферических лимфатических узлов, нередко повышается температура тела до субфебрильной, отмечается повышенная потливость при физическом напряжении. При ослаблении защитных сил организма она может перейти или в остросептическую, или в первично-хроническую метастатическую форму. Остросептическая форма характеризуется высокой лихорадкой $\left(39-40^{\circ} \mathrm{C}\right.$ и выше), с большими суточными размахами, повторными ознобами и потами. Несмотря на высокую температуру тела, самочувствие больного остается хорошим. Эта форма не угрожает жизни больного, даже без этиотропного лечения она заканчивается выздоровлением. Все группы лимфатических узлов умеренно увеличены, некоторые из них чувствительны при пальпации. К концу первой недели болезни отмечается увеличение печени и селезенки. При исследовании периферической крови отмечается лейкопения, СОЭ не повышена.).

Хронические формы бруцеллеза в одних случаях развиваются сразу, минуя острую фазу, в других случаях признаки хронического бруцеллеза появляются спустя какое-то время после остросептической формы бруцеллеза. К общим симптомам можно отнести длительную субфебрильную температуру, слабость, повышенную раздражительность, плохой сон, нарушение аппетита, снижение работоспособности. Почти у всех больных отмечается генерализованная лимфаденопатия, выявляется увеличение печени и селезенки. На этом фоне выявляются органные поражения, наиболее часто со стороны опорнодвигательного аппарата, нервной и половой системы.

Туляремия - зооантропонозная инфекция, имеющая природную очаговость. Возбудитель заболевания - бактерия Francisella tularensis. Носители бактерии туляремии - зайцы, кролики, водяные крысы, полёвки. Инфекция передается человеку или непосредственно при контакте с животными (охота), 
или через заражённые пищевые продукты и воду, реже аспирационным путём (при обработке зерновых и фуражных продуктов, обмолоте хлеба), кровососущими членистоногими (слепень, клещ, комар и др.).

Инкубационный период в среднем 3 - 7 дней (может быть от 1 до 21 дня). Выделяют бубонную, язвенно-бубонную, конъюнктивально-бубонную, ангинозно-бубонную, абдоминальную (кишечную), бронхо-пневмоническую с бронхитическим и пневмоническим вариантом течения, генерализованную (первично-септическая) формы. Болезнь начинается остро с внезапного подъёма температуры до 38,5-40 ㄷ․ Появляется резкая головная боль, головокружение, боли в мышцах ног, спины и поясничной области, потеря аппетита. В тяжелых случаях может быть рвота, носовые кровотечения. Часто наблюдается эйфория и повышение активности на фоне высокой температуры, выраженная потливость, нарушение сна в виде бессонницы или наоборот сонливости. Характерный признак - увеличение различных лимфатических узлов, размеры которых могут быть от горошины до грецкого ореха. Бубоны мало болезненны и имеют чёткие контуры величиной до 5 см. В дальнейшем происходит либо размягчение бубона (1-4 мес.), либо его самопроизвольное вскрытие с выделением густого сливкообразного гноя и образованием туляремийного свища. Чаще поражаются подмышечные, паховые и бедренные лимфатические узлы.

Большое значение среди внутрибольничных инфекций (госпитальные, нозокомиальные) имеют инфекции, вызванные синегнойной палочкой (Pseudomonas aeruginosa). Бактерий Pseudomonas, широко распространены в почве, воде и растениях. У здоровых людей его штаммы могут встречаться на коже во влажных частях тела, например, в подмышках или в области гениталий, горле. У пациентов с нарушением функции иммунной системы они могут быть причиной различных заболеваний (инфекции среднего и наружного уха, раневые инфекции, особенно ожоги, инфекции дыхательных путей (особенно у пациентов с муковисцидозом и пациентов с хронической механической вентиляцией легких), ограниченный и распространенный перитонит и сепсис, инфекции мочевыводящих путей, инфекции костей и суставов, эндокардит, менингит и абсцесс головного мозга, бактериальный кератит). Патогенность синегнойной палочки обусловлена наличием подвижности, токсинообразования, продукция гидролитических ферментов. В связи с относительной непроницаемостью клеточной стенки и мембраны бактерии обладают естественной устойчивостью ко многим антибиотикам.

Наиболее тяжелые инфекции возникают в больницах т.к. синегнойная палочка нечувствительна к стандартным дезинфицирующим средствам и может легко расти на медицинском оборудовании (например, катетерах), которые не очищены должным образом. Возможна передача бактерии от инфицированного пациента при плохой обработке рук. 
К грамотрицательным бактериям относятся и спирохеты. Это бактерии имеют длинную спирально скрученную форму в виде штопора или спирали за счет имеющейся в периплазматическом пространстве жгутиков (эндофлагеллы). Многие спирохеты являются сапрофитами, которые встречаются в почве, воде и других средах, однако некоторые вызывают тяжелые заболевания.

Лептоспироз - острое инфекционное заболевание, вызывающее более десяти генетических типов Leptospirae, семейству Spirochaetales. Различают природные и антропоургические очаги лептоспироза. Источниками возбудителя инфекции в природных очагах являются грызуны, насекомоядные, парнокопытные, хищные животные многих видов, реже птицы. Наибольшее значение имеют мыши, полевки, ондатры. В антропоургических очагах источники инфекции - крупный и мелкий рогатый скот, лошади, свиньи, собаки, а также домовые мыши и крысы. Животные - хозяева возбудителей - выделяют лептоспир с мочой в течение нескольких месяцев.

Люди в большинстве случаев заражаются при купании и использовании для хозяйственных и бытовых нужд воды из открытых водоемов, инфицированной животными-лептоспиро-носителями, и реже в период сельскохозяйственных работ на сырых угодьях, на охоте, рыбной ловле, при уходе за домашними животными, разделке туш и обработке животного сырья, при употреблении продуктов питания, зараженных грызунами, а также сырого молока от больных коров. Больные лептоспирозом не заразны.

Инкубационный период - от 2 до 20 дней, чаще 7-10 дней. Возбудитель, внедрившийся в организм через слизистые оболочки и поврежденную кожу, током крови заносится главным образом в печень, селезенку, почки, проникает через гематоэнцефалический барьер. В тканях этих органов возбудитель размножается, после чего вновь поступает в кровь, обусловливая генерализацию инфекции, клинически проявляющуюся лихорадкой и интоксикацией. При распаде лептоспир выделяется эндотоксин, вызывающий повреждение эндотелия капилляров различных органов и тканей с возникновением диапедезных кровоизлияний. Геморрагический синдром усугубляется нарушением функционального состояния тромбоцитов и поражением печени, в которой наблюдаются дистрофические и некротические изменения гепатоцитов. Возникающая в части случаев желтуха имеет смешанную природу, так как кроме поражения гепатоцитов происходит и гемолиз эритроцитов. Наибольшее накопление лептоспир и их метаболитов отмечается в почках, что вызывает повреждение эпителия почечных канальцев с развитием в ряде случаев острой почечной недостаточности. На 3-й неделе болезни наблюдаются максимальная выработка антител и очищение органов и тканей от возбудителя. 
Сифилис (люэс) - системное венерическое инфекционное заболевание, вызываемое спирохетами вида Treponema pallidum (бледная трепонема). Признаки и симптомы сифилиса различаются в зависимости от того, на какой из четырех стадий он находится (табл.18).

\section{Классификация сифилиса}

\begin{tabular}{|c|c|c|}
\hline Стадия & Базовые значения & Клинические проявления \\
\hline \multicolumn{3}{|c|}{ Приобретенный } \\
\hline Первичный & Контагиозный & $\begin{array}{l}\text { Твердый шанкр (маленькая, безболезненная } \\
\text { ранка на коже), местное увеличение } \\
\text { лимфатических узлов }\end{array}$ \\
\hline Вторичный & $\begin{array}{l}\text { Контагиозный. } \\
\text { Появляется через } \\
\text { недели или месяцы } \\
\text { после первой стадии }\end{array}$ & $\begin{array}{l}\text { Сыпь (которую можно перепутать с другими } \\
\text { заболеваниями), эрозии на слизистых, потеря } \\
\text { волос, лихорадка, много других неспецифических } \\
\text { симптомов }\end{array}$ \\
\hline \multirow[t]{2}{*}{ Латентный } & $\begin{array}{l}\text { Обычно } \\
\text { неконтагиозный } \\
\text { Ранний латентный } \\
\text { сифилис (<2 года от } \\
\text { заражения) }\end{array}$ & $\begin{array}{l}\text { Бессимптомный. Может быть невыраженным иногда } \\
\text { с рецидивами инфекционных поражений или } \\
\text { сменяться заболеванием поздней стадии }\end{array}$ \\
\hline & $\begin{array}{l}\text { Поздний скрытый } \\
\text { сифилис ( } \geq 2 \text { лет от } \\
\text { заражения) }\end{array}$ & $\begin{array}{l}\text { В редких случаях с рецидивами; положительный } \\
\text { результат серологических тестов }\end{array}$ \\
\hline $\begin{array}{l}\text { Поздний или } \\
\text { третичный }\end{array}$ & $\begin{array}{l}\text { Симптоматичный; } \\
\text { неконтагиозный }\end{array}$ & $\begin{array}{l}\text { Доброкачественный третичный сифилис } \\
\text { (бессимптомный), формирование гумм, } \\
\text { сердечно-сосудистый сифилис, нейросифилис }\end{array}$ \\
\hline \multicolumn{3}{|r|}{ Врожденный } \\
\hline Ранняя стадия & Симптоматическое & Наблюдается до возраста 2 лет \\
\hline Поздняя стадия & Симптоматическое & $\begin{array}{l}\text { Проявляется позже в течение жизни. Зубы } \\
\text { Гетчинсона, патологии глаз или костей }\end{array}$ \\
\hline $\begin{array}{l}\text { Перманентно- } \\
\text { латентном }\end{array}$ & $\begin{array}{l}\text { Бессимптомном } \\
\text { состоянии }\end{array}$ & Проявлений нет \\
\hline
\end{tabular}

Сифилис чаще всего передается половым путем. Он также может передаваться от матери к ребенку во время беременности или при родах, что приводит к врожденному сифилису.

После инкубационного периода в 3-4 недели (диапазон 1-13 недель), на месте проникновения развивается твердый шанкр (начальная красная папула с последующей безболезненной язвочкой с твердой основой) увеличиваются периферические лимфоузлы, они твердые и безболезненные.

Около половины инфицированных женщин и треть инфицированных мужчин не знают о наличии шанкра, потому что он почти не вызывает 
симптомов. Шанкр обычно заживает через 3-12 недель. После этого люди выглядят полностью здоровыми.

Примерно через 2 месяца после заражения начинается вторая стадия заболевания (вторичный сифилис). Она характеризуется наличием сыпи (которая периодически то появляется, то исчезает) на коже туловища, ладоней, подошв, слизистой оболочке половых органов и ротовой полости. Помимо сыпи, наблюдается лихорадка, усталость, боль в суставах, реже - выпадение волос. На шее могут появиться участки более светлой кожи округлых очертаний, что образно окрестили "ожерельем Венеры". Если заболевание не лечить, то через 45 и более лет после заражения наступает третья стадия сифилиса, которая приводит к поражению спинного и головного мозга, психическим заболеваниям, параличу, обезображиванию больного.

Самым распространённым среди заболеваний, передаваемых при присасывании клещей, встречающийся на территории России повсеместно клещевой боррелиоз (Болезнь Лайма, иксодовый клещевой боррелиоз). Возбудителями клещевого боррелиоза являются спирохеты рода боррелий. В Европе и Азии Borrelia afzelii, garinii, spielmanii, bavariensis, в Северной Америке, бактерии Borrelia burgdorferi, bissettiae u mayonii. Зараженность возбудителями болезни Лайма клещей - переносчиков в разных природных очагах может варьировать в широком диапазоне (от 5-10 до 70-90\%). Больной клещевым боррелиозом (болезнью Лайма) для окружающих не заразен.

Заражение клещевым боррелиозом происходит при присасывании инфицированного клеща. Боррелии со слюной клеща попадают в кожу и в течение нескольких дней размножаются, после чего они распространяются на другие участки кожи и внутренние органы (сердце, головной мозг, суставы и др.). Боррелии в течение длительного времени (годами) могут сохраняться в организме человека, обусловливая хроническое и рецидивирующее течение заболевания. Хроническое течение болезни может развиться после длительного периода времени. Процесс развития болезни при боррелиозе сходен с процессом развития сифилиса.

Инкубационный период клещевого боррелиоза составляет - от 2 до 30 дней, в среднем - 2 недели. Характерным признаком начала заболевания в 70\% случаев является появление на месте укуса клещом покраснения кожи. Красное пятно постепенно увеличивается по периферии, достигая 1-10 см в диаметре, иногда до 60 см и более. Форма пятна округлая или овальная, реже неправильная. Наружный край воспаленной кожи более интенсивно красный, несколько возвышается над уровнем кожи. Со временем центральная часть пятна бледнеет или приобретает синюшный оттенок, создается форма кольца. В месте укуса клеща, в центре пятна, определяется корочка, затем рубец. Пятно без лечения сохраняется 2-3 недели, затем исчезает (раннее локализованный период). Если 
не проводится лечение, через 1-1,5 месяца развиваются признаки поражения нервной системы (лимфоцитарный менингит, краниальный неврит, радикулопатии и/или множественные мононевриты), сердца (кардит Лайма), суставов, что в ряде случаев приводит к инвалидности (ранняя диссеминированная инфекция).

У нелеченых или недостаточно пролеченных людей через от 6 месяцев до 2 лет после острого периода могут развиться поздняя диссеминированная инфекция с поражением суставов, нервов, ЦНС, глаз и сердца. Эту фазу, как и спорный диагноз хронического боррелиоза, можно рассматривать, как форму патоген-индуцированного аутоиммунного заболевания за счет молекулярной мимикрии, когда боррелии избегают уничтожения иммунной системой и формируется длительный воспалительный процесс.

Лайм-артрит встречается почти у 60\% нелеченных больных. Обычно поражается только один сустав, часто колено или другие крупные суставы. Патогномоничным является поражение височно-нижнечелюстного сустава. Обычно наблюдается большой выпот и отек суставов с легкой или умеренной болью.

Хронические неврологические симптомы возникают примерно у 5\% людей, не получающих лечения. Периферическая невропатия или полиневропатия может развиваться, вызывая неприятные ощущения, такие как онемение, покалывание или жжение, начиная с ног и/или рук с последующим ограничением движения конечностей.

Энцефалопатия Лайма, связана с когнитивными нарушениями, бессонницей, общим плохим самочувствием. В некоторых случаях может развиваться хронический энцефаломиелит напоминающий рассеянный склероз. Психоз, который ошибочно принимают за шизофрению или биполярное расстройство может быть так же проявлением энцефалопатия Лайма.

Хронический атрофический акродерматит - это прогрессирующий кожный процесс обусловлен продолжающимся активным заражением спирохетами Borrelia afzelii. Начинается с красновато-синего пятна обесцвеченной кожи, часто на тыльной стороне рук или ног. Поражение медленно атрофируется в течение нескольких недель или месяцев, при этом кожа сначала становится тонкой и морщинистой, а затем, при отсутствии лечения, полностью сухой и безволосой. Течение длительное, до нескольких лет, и приводит к обширной атрофии кожи, а у некоторых пациентов к ограничению подвижности суставов верхних и нижних конечностей.

Очень сложно дифференцировать по Грамму микобактерии. Они не являются грамотрицательными или грамположительными. Отличительной чертой этих микроорганизмов является то, что клеточная стенка у них толстая состоит из гидрофобного слоя миколята и слоя пептидогликана, удерживаемых 
вместе полисахаридом арабиногалактаном. За счет этого они обладают естественной устойчивостью к различным антибиотикам и могут выдерживать длительное воздействие антисептиков.

С клинической точки зрения микобактерии можно разделить на несколько основных групп: M. tuberculosis complex, который может вызывать туберкулез (M. tuberculosis, M. bovis, M. africanum, M. microti, M.canettii, M.pinnipedii, M.caprae), M. leprae, вызывающая проказу или лепру или болезнь Хансена, и нетуберкулезные микобактерии, которые могут вызывать заболевание легких, напоминающее туберкулез, лимфаденит, кожное заболевание или диссеминированное заболевание.

Туберкулез (чахотка) - антропозоонозная инфекция, ведущая причина заболеваемости и смертности среди взрослых во всем мире. Около четверти населения всего мира инфицированы. Из всех инфицированных, более 15 миллионов человек имеют активную форму заболевания. Ежегодно от туберкулеза умирает приблизительно 1,5-2 миллиона человек.

Контагиозность пациентов с нелеченой активной формой туберкулеза легких широко варьируется. Считается, что только 1 из 3 пациентов инфицирует при тесном контакте с больным с невылеченным туберкулезом легких. По оценкам ВОЗ каждый невылеченный пациент может заразить от 10 до 15 человек в год. Считается, что пациенты с нарушением функции иммунной системы болеют чаще. Туберкулез может протекать в трех стадиях: первичное инфицирование; латентная инфекция; активная инфекция. Инфекция обычно не передается в начальной стадии и никогда не является контагиозной в латентном периоде.Болезнь, как правило, локализуется в органах дыхания, однако в процесс могут вовлекаться и другие органы. Любой орган, первоначально инфицированный возбудителем, может стать источником реактивации инфекции, но чаще всего она начинается в верхушках легких.

Исходя из степени распространённости и локализации выделяют различные клинические формы туберкулеза (рис.16).

Помимо этого, характеристика туберкулезного процесса включает данные по локализации и фазе процесса (инфильтрации, распада, обсеменения или рассасывания, уплотнения, рубцевания, обызвествления) а также наличию или отсутствию микобактерий туберкулеза в диагностическом материале (МБТ+ или МБТ-) полученном от больного. Осложнения туберкулеза: кровохарканье и легочное кровотечение, спонтанный пневмоторакс, легочно-сердечная недостаточность, ателектаз, амилоидоз, свищи и др. Остаточные изменения после излеченного туберкулеза органов дыхания: фиброзные, фиброзноочаговые, буллезно-дистрофические, кальцинаты в легких и лимфатических узлах, плевропневмосклероз, цирроз. 


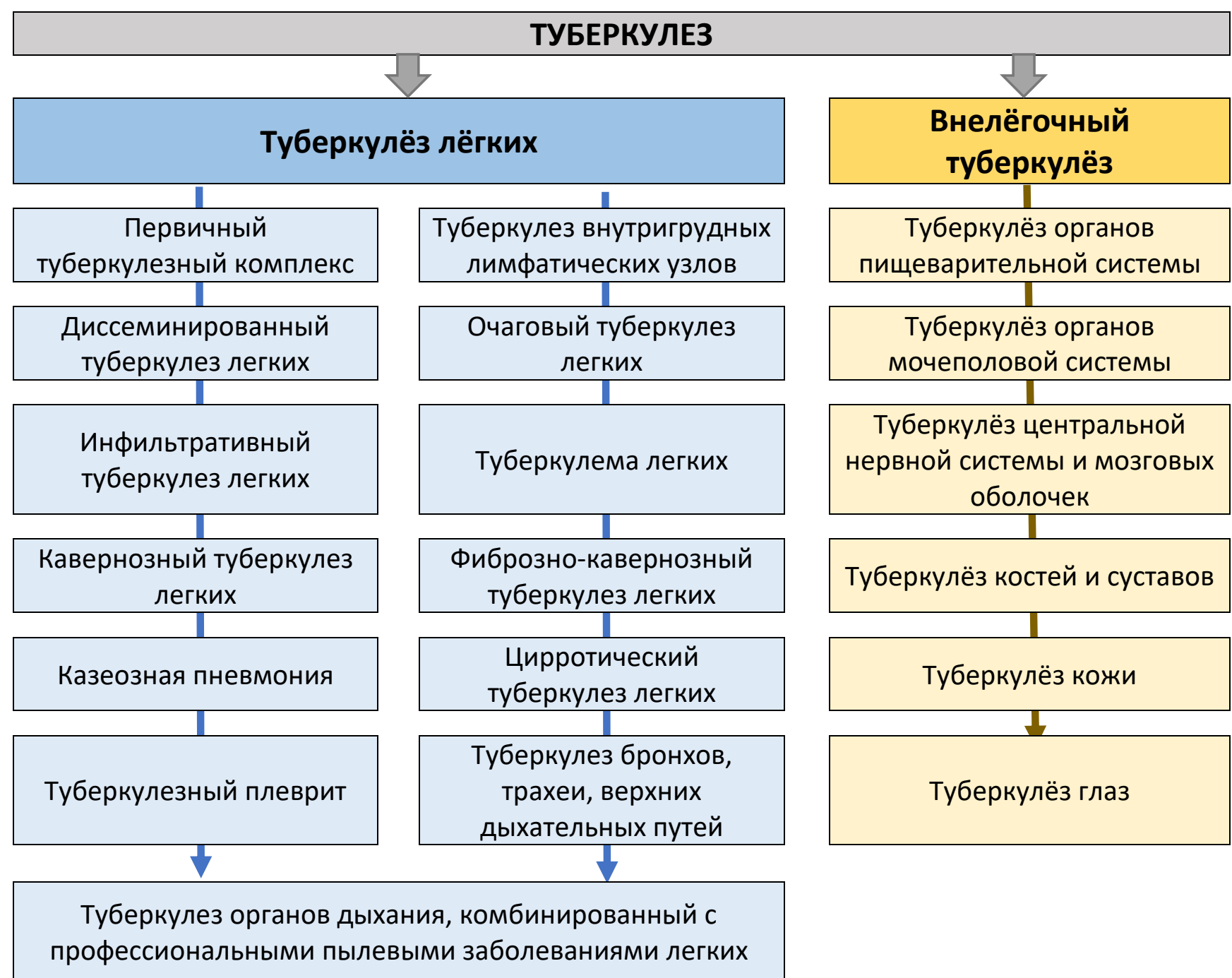

\section{Рис.16 Клинические формы туберкулеза.}

Несколько видов микобактерий отличаются от группы M. tuberculosis и составляют группу нетуберкулезных микобактерий. Они широко распространены в окружающей среде и менее патогенные при сравнении с прототипом. По скорости роста и способности продуцировать пигмент выделяют 4 группы атипичных микобактерий:

Группа I (фотохромогены) - медленно рустующие, образуют желтооранжевые пигментированные колонии под действием света. Они обитают в воде. M. kansasii, вызывают легочное заболевание, клинически похожее на туберкулез. М. marinum вызывает «гранулему плавательных бассейнов», также известную как гранулема рыбного садка. Эти гранулематозно-язвенные поражения возникают на местах ссадин, полученных в бассейнах или аквариумах.

Группа II (скотохромогены) - медленно рустующие, продуцируют пигмент в темноте. Обитают в воде, но могут быть в составе сапрофитной микрофлоры 
дыхательных путей человека. M. scrofululaceum вызывает золотуху, гранулематозный шейный аденит.

Группы III (нонхромогены) растут медленно, пигмента продуцируют мало или не продуцируют совсем. Представлены M. avium и M. intracellulare. Микроорганизмы широко распространены в окружающей среде, включая воду и почву. Причина заболевания легких, клинически сходного с туберкулезом у больных СПИДом. Высоко резистентны к противотуберкулезным препаратам.

Группы IV (быстро растущие микобактерии) растут быстро, образуя колонии менее чем за 7 дней, пигмент не продуцируют. M. fortium и M. chelonei. являются сапрофитами, распространенными в почве и воде, заболевание у человека вызывают редко. Инфекция развивается у пациентов с нарушениями функции иммунной системы как госпитальная инфекция, при искусственных протезах, длительно стоящих катетерах, инфекциях кожи и мягких тканей. Они часто резистентны к противотуберкулезным препаратам. Mycobacterium abscessus - так же широко распространены в окружающей среде. Является причиной хронической инфекции легких, кожи, костей и суставов. Высоко резистентна к антибиотикам. Mycobacterium smegmatis не вызывает заболеваний у человека, но входит в состав нормальной флоры смегмы.

Проказа (лепра, болезнь Хансена) - разновидность гранулематоза, вызываемая микобактериями Mycobacterium leprae и Mycobacterium lepromatosis. Протекает с преимущественными поражениями периферической нервной системы, кожи, иногда передней камеры глаза, верхних дыхательных путей выше гортани, яичек, а также кистей и стоп.

Считается, что лепра распространяется от человека к человеку воздушнокапельным путем, через близкий, длительный контакт с зараженным человеком. Она имеет низкую патогенность, и у 95\% людей, инфицированных M. leprae, болезнь не развивается. Инкубационный период обычно составляет 5 лет, но может колебаться от 6 месяцев до нескольких десятилетий (описан инкубационный период продолжительностью в 40 лет).

Первым заметным признаком проказы часто является появление бледных или розовых пятен на коже, которые могут быть нечувствительны к температуре и/или боли. Участки обесцвечивания кожи иногда сопровождаются или предшествуют нервным расстройствам, включая онемение или болезненность в руках или ногах. Вторичные инфекции могут привести к некрозу ткани. При отсутствии лечения из-за инфильтрации кожи и деструкция нервов развиваются выраженные деформации облика и уродства.

Хламидии и риккетсии относятся к облигатным внутриклеточным паразитам, способным расти и делится только внутри другой клетки. 
Хламидиоз - инфекция, вызываемая Chlamydia (C. trachomatis, $C$. pneumoniae $u$ C. psittaci). Клеточная стенка хламидии похожа на клеточные стенки грамотрицательных бактерий, но у них отсутствует типичный слой пептидогликана. Хламидии инфицируют в первую очередь эпителиальные клетки слизистых оболочек или легких. Жизненный цикл начинается, когда внеклеточное, «спороподобное» (метаболически инертное) элементарное тело проникает в клетку и превращается в большие, метаболически активные сетчатые тела. Они размножаются бинарным делением (окрасив можно идентифицировать под микроскопом) и выделяются из клетки разрушая ее (рис.17).

Инвазивную, диссеминированную инфекцию хламидии вызывают редко. Инфекция может протекать бессимптомно или типичными заболеваниями.

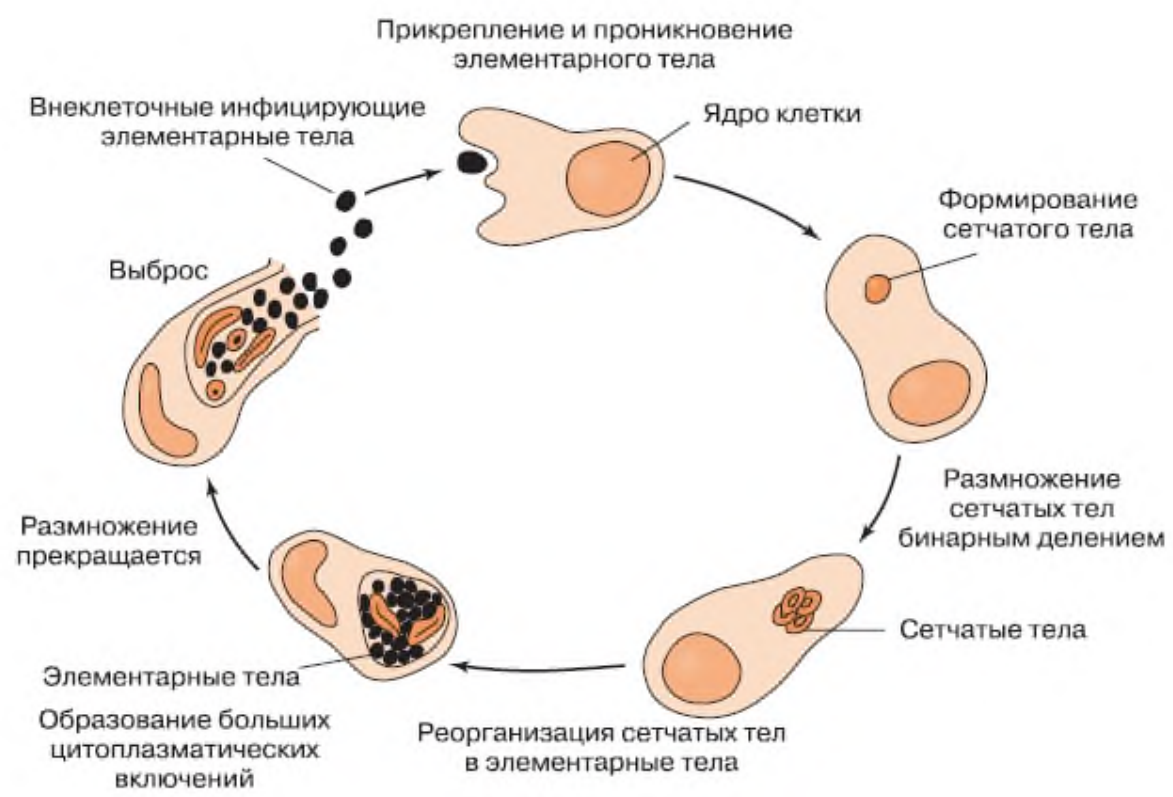

Рис. 17. Жизненный цикл хламидий.

(В рисунке использованы элементы изображение с сайта https://commons.wikimedia.org)

Типы A, В и C C. trachomatis вызывают трахому, хронический конъюнктивит эндемичен для Африки и Азии. Трахома может рецидивировать в течение многих лет и приводить к слепоте. Типы D-K вызывают инфекции половых путей. У мужчин обычно в виде негонорейного уретрита с осложнениями такими как эпидидимит, простатит или проктит. У женщин развивается цервицит, который может осложняться сальпингитом и воспалительными заболеваниями малого таза, рецидивы которых могут быть причиной бесплодия или внематочной беременности. Пациенты с инфекциями C. trachomatis приблизительно в 10-30\% случаев одновременно инфицируются и Neisseria gonorrhoeae. 
У детей, рожденных инфицированными матерями, через 7-12 дней после родов часто развивается слизисто-гнойный конъюнктивит. Конъюнктивит, вызванный хламидиями, может возникать и у взрослых. У пациентов с инфекцией половых путей, вызванной C. trachomatis, высок риск развития синдрома Рейтера, для которого характерны уретрит, артрит и увеит. Это аутоиммунная реакция, связанная перекрестно-реагирующими антигенами клеток уретры, суставов и увеального тракта с антител к C. trachomatis. Иммунотипы L1-L3 C. trachomatis являются возбудителями венерического лимфогранулематоза, заболевания передающегося половым путем с поражением половых органов и лимфатических узлов.

C. pneumoniae является возбудителем инфекций верхних и нижних дыхательных путей, в частности бронхита и пневмонии. Пситтакоз человека обычно не контагиозен. Инфекция может протекать бессимптомно или вызывать высокую лихорадку и пневмонию.

Риккетсиозы - группа заболеваний, вызываемых облигатным внутриклеточным бактериям роду Rickettsia. Особенность жизненного цикла риккетсий заключается в том, что в природе они персистируют на определенных членистоногих, таких как клещи, вши и блохи, и передаются человеку при укусе членистоногих. Исключение составляет C. burnetii, вызывающая Ку-лихорадку, которая передается не членистоногими, а воздушно-капельным путем. Практически все риккетсиозы относятся к зоонозам, лишь эпидемический тиф является антропонозом. Он встречается только у людей потому, что его возбудителя, $R$. prowazekii, переносят вши на теле человека. Основные виды риккетсиозных заболеваний приведены в таблице (табл. 19).

Таблица 19

\section{Виды риккетсиозов}

\begin{tabular}{|l|l|l|l|}
\hline \multicolumn{1}{|c|}{ Вид } & \multicolumn{1}{|c|}{ Хозяин } & \multicolumn{1}{c|}{ Переносчик } & \multicolumn{1}{c|}{ Вид заболевания } \\
\hline R. prowazekii & Человек & Вши & Эпидемический сыпной тиф \\
\hline R. typhi & Грызуны & Блохи & Эпидемический тиф \\
\hline R. tsutsugamushi & Грызуны & Клещи & Клещевой сыпной тифа \\
\hline R. sibirica & Грызуны & Клещи & Клещевой сыпной тифа \\
\hline R. ricketsii & $\begin{array}{l}\text { Собаки, } \\
\text { грызуны }\end{array}$ & Клещи & $\begin{array}{l}\text { Пятнистая лихорадка Скалистых } \\
\text { гор }\end{array}$ \\
\hline R. akari & Мыши & Клещи & Везикулярный риккетсиоз \\
\hline C. burnetii & $\begin{array}{l}\text { Крупный } \\
\text { рогатый скот, } \\
\text { овцы, козы }\end{array}$ & $\begin{array}{l}\text { Воздушно- } \\
\text { капельно }\end{array}$ & Ку-лихорадка \\
\hline $\begin{array}{l}\text { Orientia } \\
\text { tsutsugamushi }\end{array}$ & Клещ & Клещ & Лихорадка Цуцугамуши \\
\hline
\end{tabular}


Типичное поражение, вызываемое риккетсиями - васкулит, возникает в эндотелиальном слое сосудистой стенки, где микроорганизм находят чаще всего.

Повреждение сосудов кожи приводит к появлению характерной сыпи, отеку и кровоизлияниями, связанными с повышением капиллярной проницаемости. Патогенез этих инфекций остается неясным. Имеются данные по участию в этом процессе эндотоксина, что согласуется с природой некоторых проявлений, таких как лихорадка и петехиальные кровоизлияния, однако экзотоксинов или цитолитических ферментов у риккетсий не найдено.

Инкубационный период после укуса у риккетсиозов продолжается 3-7 дней. Заболевание начинается остро. Появляются озноб, головная боль, слабость, боль в суставах и мышцах, уже в первые сутки температура тела повышается до 38-39 ${ }^{\circ} \mathrm{C}$ и выше, длительность лихорадки (без антибиотикотерапии) -до 15 дней. С первых дней на месте укуса можно обнаружить первичный эффект в виде небольшого участка некроза кожи, покрытого темно-коричневой корочкой и окруженного участком гиперемированной и инфильтрированной кожи. Диаметр первичного эффекта 3-4 см. Сыпь обильная макуло-папулезного характера, появляется на 4-5-й день болезни. Элементы сыпи состоят из папул и пятен диаметром до 1 см. Иногда сыпь сгущается в области крупных суставов. Отмечается гиперемия лица и шеи, инъецирование сосудов склер, гиперемия слизистой оболочки зева. Может наблюдаться бронхит, реже пневмония.

Микоплазмы уникальные очень мелкие, не имеющие клеточной стенки, микроорганизмы. Их наружная поверхность представляет гибкую клеточную мембрану из холестерол - стерола которая может принимать разнообразную форму. Из-за этого микоплазмы плохо окрашиваются по Грамму, против них не эффективно большинство антибиотиков, подавляющих синтез клеточной стенки. Основным патогеном является Мусорlasma pneumoniae которая встречается во всем мире, преимущественно в зимнее время, патогенна только для человека, передается воздушно-капельным путем. Этот микроорганизм чаще вызывает пневмонию у лиц молодого возраста и бывает причиной вспышек при близком контакте: в семьях, воинских и студенческих коллективах. Установлено, что микоплазменная пневмония составляет около 5-10\% всех внегоспитальных пневмоний.

Микоплазменная пневмония развивается постепенно, обычно начинается с непродуктивного кашля, боли в горле. Кашель с небольшим количеством светлая мокрота без примеси крови. Основу симптоматики составляют выраженные лихорадка, головная боль, общее недомогание и миалгия. Скудные данные клинического обследования грудной клетки отчетливо контрастируют с выраженным инфильтратами, обнаруживаемыми на рентгенограммах грудной клетки пациента. Заболевание проходит самостоятельно через 10-14 дней. Кроме пневмонии М. pneumoniae вызывает бронхит. Внелегочные проявления 
включают синдром Стивенса-Джонсона, мультиформную эритему, феномен Рейно, сердечные аритмии, артралгии, гемолитическую анемию и неврологические проявления, такие как синдром Гийена-Барре.

Mycoplasma hominis в редких случаях становится причиной воспалительных заболеваний малого таза. Ureaplasma urealyticum может быть причиной приблизительно $20 \%$ случаев негонококкового уретрита.

Микозы, или грибковые инфекции, заболевания человека, вызываемые патогенными и условно-патогенными грибами.

Грибы распространены в природе повсеместно и существуют как свободноживущие микроорганизмы. Так как они широко распространены в природе и являются частью местной микробной флоры человека трудно оценить, является ли гриб, обнаруженный во время болезни, патогеном или не имеет к заболеванию никакого отношения. Из более 120 тысяч различных грибов в настоящее время известно около 300 грибов патогенных для человека. Ежегодно во всем мире грибковые инфекции поражают более одного миллиарда человек. В 2020 г. выявлено 1,7 миллиона случаев смерти от грибковых инфекций.

Существуют два вида грибов: дрожжевые и плесневые. В отличии от бактерий они крупнее, имеют ядро, митохондрии и эндоплазматический ретикулум, компоненты клеточной стенки содержат хитин, для размножения используют половые и бесполые споры.

Патогенные для человека четыре класса грибов: аскомицеты, зигомицеты, базидиомицеты и дейтеромицеты. Основную роль в этиологии грибковых заболеваний играют три группы возбудителей: дерматофиты, дрожжеподобные грибы и плесени. Среди дерматофитов наиболее распространенными являются грибы рода Trichophyton (виды T.rubrum, T.mentagrophytes, T.schonleinii, T.verrucosum, T.tonsurans, T.violaceum); Microsporum (M. cams, M. audouinii, M. ferrugineum) u Epidermophyton (E.floccosum). Основными условно-патогенными возбудителями заболеваний кожи и слизистых оболочек являются грибы рода Candida, преимущественно C. albicans, реже другие виды (C. tropicalis, C. pseudotropicalis, C. krusei, C. parapsilosis и др.); меньшее значение имеют виды Pityrosporum и Torulopsis. Из огромного количества плесневых грибов только несколько видов могут быть причиной микозов: Exophialiawerneckii, вызывающая черный лишай (Tineanigra), и Piedraiahorta, являющаяся причиной черной пьедры. Все они вызывают болезни кожи и/или слизистых. В особую группу выделяются глубокие и системные микозы, которые, однако, не являются патологией кожи.

Большое количество патогенных грибов попадает из внешней среды воздушно-пылевым и/или контактным путем, однако возможно заражение от больного человека или животного. В развитии грибковой инфекции необходимо 
выделить две фазы. Инкубационный период, когда гриб растет, не выделяя метаболиты (трофофаза). И период, соответствующий клиническим проявлениям (идиофаза), когда снижается скорость роста грибов, но возрастает продукция метаболитов. Входными воротами чаще всего служит кожа. У патогенных грибов имеются адгезины (полисахариды) и ряд ферментов обеспечивающие агрессию грибов. Так у возбудителей поверхностных микозов это кератолитические ферменты, щелочная фосфотаза, коллагеназа и эластаза которые катализируют кератин ногтей и коллагена волос. У возбудителей подкожных микозов, помимо этого, имеются кислые протеиназы, которые лизируют мембраны клеток кожи и иммуноглобулины. У возбудителей системных микозов имеется гиалуронидаза, нейраминидаза и токсины, которые оказывают цитопатическое действие и усиливают повреждение.

Можно выделить три патогенетических механизма действия грибов: токсическое (микотоксикоз), сенсибилизирующее (микогенная аллергия) и инфекционное (развитие микозов кожи и других органов).

Наиболее известны микотоксикозы в результате поедания бледной поганки и мухомора (грибы Amanita), имеющие токсины аманитин и фаллоидин. При употреблении зерна, арахиса, подсолнечника, и других бобовых и зерновых культур (рис, кукуруза, горох, нут, кунжут) зараженных грибами Fusarium culmorum, Fusarium graminearum (основной токсин дезоксиниваленол или вомитоксин поражающий ЖКТ), Aspergillus flavus и Aspergillus parasiticus (афлатоксин В1 обладает гепатотоксичным и канцерогенным действием), Penicillum citrinum (цитринин - нефротоксичен), Aspergillus ochraceus, Aspergillus carbonarius, Penicillium verrucosum (охратоксин А - нейротоксин, канцероген, мутаген, тератоген оладает нефро- и гепатотоксичностью, иммунодепресант), Fusarium moniliforme, Fusarium verticillioides (Фумонизин В1 канцероген), Aspergillus fumigatus Trichoderma veride, T.lignorum u Penicillium obscurum (глиотоксин - иммунодепресант за счет активации апоптоз клеток иммунной системы). Споры Aspergillus fumigatus может вызывать аллергическую реакцию гиперчувствительности немедленного типа. Однако основная масса патогенных грибов вызывает грибковые инфекции - микозы (табл.20).

Единой классификации микозов нет. Традиционное деление на поверхностные, подкожные и системные не всегда соответствует этому определению.

Кандидозы и ряд других микозов, так называемые условно патогенные грибы, которые развиваются на фоне нарушения функции иммунной системы, составляют отдельную группу иммунодефицит опосредованных или оппортунистических микозов. Они могут проявляться поражением кожи в слизистых оболочек, но могут вызывать и генерализованным поражением 
Таблица 20

Основных инфекционные заболевания, вызванные грибами

\begin{tabular}{|c|c|}
\hline Заболевание & Основной возбудитель \\
\hline \multicolumn{2}{|c|}{ ПОВЕРХНОСТНЫЕ МИКОЗЫ (КератомикозЫ) } \\
\hline $\begin{array}{l}\text { Разноцветный (отрубевидный) лишай, } \\
\text { себорейный дерматит }\end{array}$ & $\begin{array}{l}\text { Дрожжеподобный гриб, существующий в трех } \\
\text { формах: округлой (Pityrosporum orbiculare), овальной } \\
\text { (Pityrosporum ovale) и мицелиальной (Malassezia } \\
\text { furfur). Способны изменяться друг в друга. }\end{array}$ \\
\hline Узловатый трихоспороз (Пъедра) & $\begin{array}{l}\text { Белая педра Trichosporon Beigelii, Trichosporon hoitai } \\
\text { Brumpt. Черная педра Piedraia hortae }\end{array}$ \\
\hline Черный лишай & Phaeoannellomyces werneckii \\
\hline \multicolumn{2}{|c|}{ КОЖНЫЕ МИКОЗЫ (дерматомикозы) } \\
\hline $\begin{array}{l}\text { Стригущий лишай рук, ног и туловища, } \\
\text { стопа спортсмена, грибковая инфекция в } \\
\text { области паха, грибковая инфекция кожи } \\
\text { головы и волос. }\end{array}$ & Microsporum, Trichophyton, Epidermophyton \\
\hline \multicolumn{2}{|c|}{ Преимущественно волосистой части головы } \\
\hline \multirow[t]{5}{*}{$\begin{array}{l}\text { Трихомикозы (микроспория и } \\
\text { трихофития) }\end{array}$} & $\begin{array}{l}\text { Зоофильные грибы (Microsporum canis, Microsporum } \\
\text { nanum, Trichophyton verrucosum, Trichophyton } \\
\text { mentagrophytes) }\end{array}$ \\
\hline & $\begin{array}{l}\text { Антропофильные (Microsporum audouinii, } \\
\text { Microsporumferrugineum, Trichophyton tonsurans, } \\
\text { Trichophyton violaceum, Trichophyton schonleinii, } \\
\text { Trichophyton rubrum, Trichophyton mentagrophytes) }\end{array}$ \\
\hline & $\begin{array}{l}\text { Геофильные (Microsporum gypseum, Microsporum } \\
\text { fulvum). }\end{array}$ \\
\hline & Trichophyton mentagrophytes и T. verrucosum \\
\hline & Trichophyton schoenleinii \\
\hline \multicolumn{2}{|c|}{ Преимущественно конечностей } \\
\hline Дистальный подногтевой онихомикоз & $\begin{array}{l}\text { Trichophyton rubrum, а так же T. interdigitale, } \\
\text { Epidermophyton floccosum, T. violaceum, Microsporum } \\
\text { gypseum, T.tonsurans, T.soudanense }\end{array}$ \\
\hline $\begin{array}{l}\text { Стопа атлета (межпальцевая, } \\
\text { подошвенная («мокасиновая стопа»), } \\
\text { острая язвенная, пузырчатая }\end{array}$ & \multirow[t]{3}{*}{$\begin{array}{l}\text { Trichophyton rubrum, T. mentagrophytes, } \\
\text { Epidermophyton floccosum }\end{array}$} \\
\hline Грибковая инфекция в паховой области & \\
\hline Грибковое поражение кистей и ладоней & \\
\hline
\end{tabular}


Таблица 20 (продолжение)

Основных инфекционные заболевания, вызванные грибами

\begin{tabular}{|c|c|}
\hline Заболевание & Основной возбудитель \\
\hline \multicolumn{2}{|c|}{ ПОДКОЖНЫЕ МИКОЗЫ } \\
\hline $\begin{array}{l}\text { Споротрихоз (кожный, легочный, } \\
\text { диссеменированный) }\end{array}$ & Sporothrix schenckii \\
\hline $\begin{array}{l}\text { Хромобластомикоз (папилломатозные } \\
\text { опухоли, склонные к образованию язв) }\end{array}$ & $\begin{array}{l}\text { Плесневые грибы: Cladophialophora carrionii, } \\
\text { Fonsecaea compacta, Fonsecaea pedrosoi, } \\
\text { Phialophora verrucosa и Rhinocladiella aquaspersa }\end{array}$ \\
\hline $\begin{array}{l}\text { Мицетома (длительное время } \\
\text { подкожные узелки, с развитием язв с } \\
\text { зернистым выделением) }\end{array}$ & $\begin{array}{l}\text { Madurella mycetomatis, Madurella grisea, } \\
\text { Leptosphaeria senegalensis, Curvularia lunata, } \\
\text { Scedosporium apiospermum, Neotestudina rosatii, } \\
\text { Acremonium spp. } \text { и Fusarium spp. }\end{array}$ \\
\hline \multicolumn{2}{|c|}{ СИСТЕМНЫЕ (ГЛУБОКИЕ) МИКОЗЫ } \\
\hline Гистоплазмоз & Histoplasma capsulatum, Histoplasma capsulatum \\
\hline Бластомикоз & Blastomyces dermatitidis \\
\hline $\begin{array}{l}\text { Паракокцидиоидомикоз или } \\
\text { бластомикоз Южной Америки }\end{array}$ & Paracoccidioides brasiliensis \\
\hline Феогифомикоз & Alternaria, Cladosporium, Curvularia, Exophiala \\
\hline Мадуромикоз & Pseudallescheria boydii \\
\hline Кокцидиоидомикоз & Coccidioides immitis, Coccidioides posadasii \\
\hline \multicolumn{2}{|c|}{ ИММУНОДЕФИЦИТ ОПОСРЕДОВАННЫЕ (ОППОРТУНИСТИЧЕСКИЕ) МИКОЗЫ } \\
\hline $\begin{array}{l}\text { Кандидоз (молочница или кандидозный } \\
\text { стоматитом до диссеминированных } \\
\text { поражений) }\end{array}$ & $\begin{array}{l}\text { Candida albicans и родственные виды (C. tropicalis, } \\
\text { C.parapsilosis) }\end{array}$ \\
\hline Криптококкоз (пневмония, менингит) & Cryptococcus neoformans \\
\hline Аспергиллез & Aspergillus fumigatus, другие виды \\
\hline Острый и хронический токсикоз & Aspergillus flavus \\
\hline Пневмоцистная пневмония & Pneumocystis ijeroveci \\
\hline $\begin{array}{l}\text { Мукоромикозы (инвазивные } \\
\text { некротические поражения в носу и на } \\
\text { нёбе) }\end{array}$ & Грибы Mucor, Rhizopus и Absidia \\
\hline Туберкулезоподобное заболевание & Penicillium marneffei \\
\hline
\end{tabular}




\section{Глава 4. Простейшие и гельминты}

Простейшие и гельминты традиционно объединены в группу паразитов. По определению медицинской паразитологии термин «паразит» означает патогенные простейшие и многоклеточные возбудители, способные инфицировать людей и вызывать паразитарные заболевания. Отличительная особенность всех их связана с тем, что их размеры не сопоставимы с размерами клеток иммунной системы.

Паразитарные заболевания занимают важное место в структуре заболеваемости человека особенно для стран с теплым и жарким климатом. По данным ВО3 85\% населения мира заражены хотя бы одним паразитом. Ежегодно от паразитарных заболеваний умирает более одного миллиона человек.

Протозойные инфекции - это паразитарные заболевания, вызываемые одноклеточными одноядерными организмами (простейшими). По строению патогенные простейшие делятся на 4 группы (рис.18). Однако с клинической точки зрения удобнее распределить заболевания, вызываемые простейшими в соответствии с местом их локализации: в кишечнике (амебы Entamoeba

\begin{tabular}{|c|c|c|c|}
\hline \multicolumn{2}{|c|}{ Амебы } & \multicolumn{2}{|c|}{ Споровики } \\
\hline $\begin{array}{l}\text { Entamoeba histolytica, } \\
\text { E.dispar }\end{array}$ & $\begin{array}{l}\text { Амебиаз или амебная } \\
\text { дизентерии }\end{array}$ & $\begin{array}{l}\text { Plasmodium falciparum. } \\
\text { P.malariae. } \\
\text { P.vivax u P.ovale }\end{array}$ & Малярия \\
\hline Naegleria fowleri & $\begin{array}{l}\text { Неглериоз (первичный } \\
\text { менингоэнцефалит) }\end{array}$ & Toxoplasma gondii & Токсоплазмоз \\
\hline Acanthamoeba & $\begin{array}{l}\text { Акантамебиаз (кератит, } \\
\text { гранулематозный энцефалит) }\end{array}$ & Cryptosporidium parvum & Криптоспоридиоз \\
\hline Balamuthia mandrillaris & Гранулематозный энцефалит & Cyclospora cayetanensis & Циклоспориаз \\
\hline & & Cystoisospora belli & Цистоизоспориаз \\
\hline \multicolumn{2}{|c|}{ Жгутиковые } & Babesia microti & Бабезиоз \\
\hline Trichomonas vaginalis & Трихомониаз & $\begin{array}{l}\text { Sarcocystis hominis, } \\
\text { S.suihominis, S.bovihominis }\end{array}$ & Саркоцистоз \\
\hline Giardia intestinalis & Лямблиоз & & \\
\hline Leishmania spp. & Лейшманиоз & \multicolumn{2}{|c|}{ Инфузории } \\
\hline Trypanosoma brucei & $\begin{array}{l}\text { Африканский трипаносомоз } \\
\text { (сонная болезнь) }\end{array}$ & Balantidium coli & Балантидиаз \\
\hline Trypanosoma cruzi & $\begin{array}{l}\text { Американский трипаносомоз } \\
\text { (Болезнь Шагаса) }\end{array}$ & & \\
\hline
\end{tabular}

Рис. 18. Паразитарные болезни, вызываемые простейшими. 
histolytica, жгутиковые лямблии Giardia lamblia и споровики Cryptosporidium, инфузория Balantidium coli); в мочеполовой системе (жгутиковое Trichomonas vaginalis) и в крови и тканях (жгутиковые Trypanosoma u Leishmania, споровики Plasmodium u Toxoplasma).

Основные механизмы передачи паразита: фекально-оральный (водный, алиментарный (или пищевой), контактно-бытовой), трансмиссивный (при укусе насекомых), контактный (при контакте с источником инфекции напрямую или опосредовано в т.ч. посредством полового контакта). В жизненном цикле простейших стоит выделить стадию трофозоит (стадия активной жизнедеятельности и бинарного деления) и стадия цисты (неподвижная, неметаболизирующие, неразмножающиеся формы, окруженные толстыми клеточными стенками). В виде цисты простейшие хорошо выживают в неблагоприятной окружающей среде и передаются другому хозяину.

При проникновении паразит вызывает механическое разрушение клеток и повреждение тканей хозяина в месте проникновения и локализации паразита с развитием локальных и системных иммунных реакций. Некоторые паразиты выделяют протеолитические ферменты и иммунодепрессивные факторы. В результате жизнедеятельности паразитов формируется хроническая интоксикация и сенсибилизация хозяина. Однако в большинстве случаев яркая клиническая картина и специфическая симптоматика отсутствует. Часто наблюдается бессимптомное носительство.

\section{Протозойные инвазии кишечника}

Лямблиоз (жиардиаз) - заболевание, вызываемое жгутиковыми простейшими - лямблиями (Giardia lamblia или G. duodenalis или G. intestinalis), паразитирующими в тонкой кишке человека и некоторых животных.

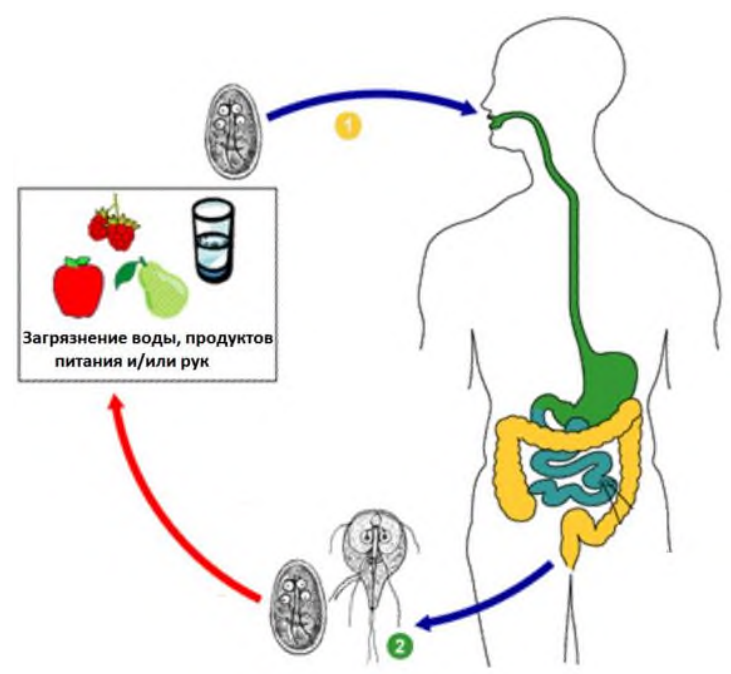

Рис. 19. Жизненный цикл лямблий. (В рисунке использованы элементы изображение DPD CDC)
Они распространены во всем мире, чаще встречается в теплом климате и у детей. Уровень инфицирования людей достигает от $7 \%$ до $30 \%$. Заражение происходит при попадании цист в загрязненную воду, пищу или фекально-оральным путем (рис. 19). В тонком кишечнике из цисты высвобождаются два трофозоида. Трофозоиды размножаются путем продольного бинарного деления, оставаясь в просвете проксимального отдела тонкой кишки, где они могут быть свободными или прикреплены к 
слизистой оболочке с помощью вентрального сосательного диска. При прохождении трофозоида в толстый кишечник формируются цисты. Они устойчивы к факторам внешней среды, например, могут сохранятся несколько месяцев в холодной воде. Именно они ответственны за передачу лямблиоза.

Острый лямблиоз развивается после инкубационного периода от 1 до 14 дней (в среднем 7 дней) и обычно длится от 1 до 3 недель. Симптомы включают диарею, боль в животе, вздутие живота, тошноту и рвоту. При хроническом лямблиозе симптомы варьируется от бессимптомного носительства до периодических рецидивов с нарушением всасывания питательных веществ в кишечнике. Возникают проблемы с усвоением лактозы, витамина А и В12, фолиевой кислоты. Это все приводит к значительной потере веса и утомляемости. Кроме того, развивается кожный зуд, крапивница, реже отеки глаз и суставов, фиксируется субфебрильная температура.

Амебиаз (амебная дизентерия). Entamoeba histolytica хорошо известна как патогенная амеба, связанная с кишечными и внекишечными инфекциями. Другие морфологически идентичные виды E. dispar, E. moshkovskii u E. bangladeshi, как правило, не связаны с заболеванием, хотя могут колонизироваться у людей. Некоторые непатогенные амебы (Endolimax nana) сопровождают Entamoeba histolytica, что имеет важное диагностическое значение.

Патогенные виды Entamoeba встречаются во всем мире и часто извлекаются из пресной воды, загрязненной фекалиями человека. Большинство случаев амебиаза происходит в развивающихся странах. В других странах к группам риска относятся туристы, путешественники, иммигранты.

Цисты Entamoeba могут выжить до месяца в почве или до 45 минут под ногтями. Цисты и трофозоиты передаются с калом, при этом трофозоиты обычно обнаруживаются в стуле при диарее (рис.20). Заражение Entamoeba histolytica $u$ E. dispar происходит при попадании в организм зрелых цист из пищи, воды или рук, зараженных фекалиями. Также может происходить контакт инфекционными цистами $\mathrm{c}$ трофозоитами в фекалиях во время полового контакта. В тонком кишечнике из цисты выделяются

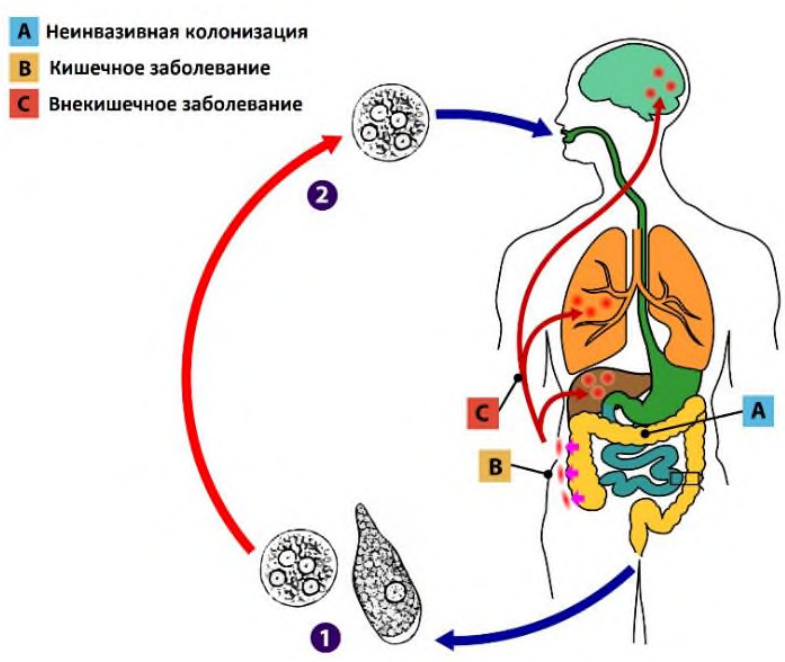

Рис. 20. Жизненный цикл патогенной амебы.

(В рисунке использованы элементы изображение DPD CDC) 
трофозоит, которые мигрируют в толстую кишку. Происходит колонизация трофозоидами которые могут длительное время оставаться в просвете кишечника (неинвазивная инфекция (рис. 20. А), люди выделяют цисты оставаясь здоровыми (бессимптомные носители). Трофозоиты так же могут проникать в слизистую оболочку кишечника (кишечная инфекция (рис. 20. В) или кровеносные сосуды, достигая внекишечных участков, таких как печень, мозг и легкие (внекишечное заболевание (рис. 20. С).

Трофозоиты размножаются путем бинарного деления и образуют цисты, которые выделяются с фекалиями. Цисты могут выживать от нескольких дней до недель во внешней среде и оставаться заразными в окружающей среде из-за защиты, обеспечиваемой их стенками. Трофозоиты, попавшие со стулом, быстро разрушаются после выхода из организма, и в случае попадания внутрь не выдерживают воздействия желудочной среды.

Криптоспоридоз является паразитарным заболеванием, вызванным Cryptosporidium относящийся к споровикам. Cryptosporidium parvum (генотип II C. parvum) и C. hominis (генотип I C. parvum) являются основными причинами криптоспоридиоза человека. C. meleagridis, C. felis, C. canis, C. ubiquitum, C. cuniculus, C. viatorum, генотип I бурундука, Cryptosporidium генотип норки и С. muris также могут инфицировать людей. Они поражают дистальный отдел тонкой кишки, а у лиц с нарушениями функций иммунной системы может распространяться на другие органы, включая органы респираторного тракта, гепатобилиарную систему (бескаменный холецистит, склерозирующий холангит, панкреатит) верхние отделы желудочно-кишечного тракта и мочевой пузырь.

Передача криптоспорий происходит в основном при проглатывании воды, загрязненной фекалиями или пищи, или при прямом контакте с инфицированными животными или людьми (рис.21).

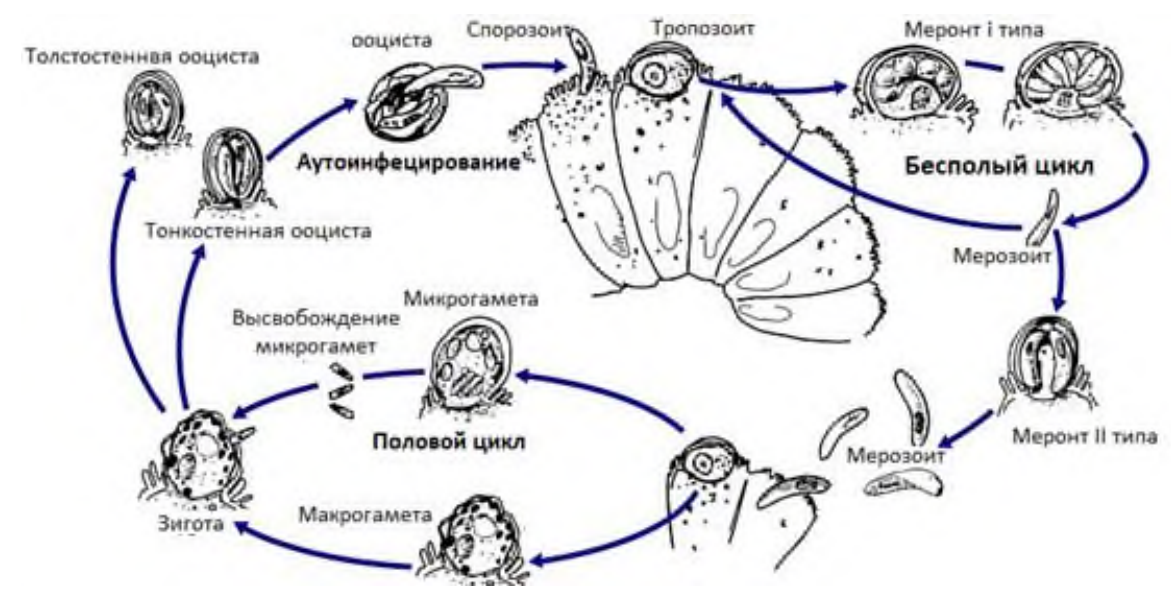

Рис. 21. Жизненный цикл криптоспоридий.

(В рисунке использованы элементы изображение DPD CDC) 
После проглатывания спорозоиты высвобождаются и паразитируют на эпителиальных клетках желудочно-кишечного тракта и, возможно, дыхательных путей. В этих клетках, обычно в пределах щеточной каймы, паразиты подвергаются бесполому размножению, а затем половому с формированием макрогамет и микрогамет. При оплодотворении макрогамонтов микрогаметами формируется зиготы, которые дают начало двум различным типам ооцист (толстостенным и тонкостенным). Толстостенные ооцисты (80\%) выводятся из организма хозяина в окружающую среду, а тонкостенные ооцисты (20\%) участвуют во внутреннем аутоинфекционном цикле и не выделяются с калом.

Заражение и развитие криптоспорид приводят к широкому спектру признаков и симптомов. Инкубационный период составляет в среднем 7 дней (диапазон: 2-10 дней). У пациентов с нормальной функционирующей иммунной системой может развиться самоизлечивающееся диарейное заболевание, которое обычно проходит в течение 2-3 недель. Возможны варианты без клинических проявлений. Пациенты с нарушениями функции иммунной системы могут иметь более серьезные осложнения. Так у больных пациентов со СПИДом, криптоспоридиоз проходит медленно или не разрешается совсем и часто вызывает особенно тяжелую и стойкую форму водянистой диареи в сочетании с обезвоживанием, истощением и, возможно неблагоприятным исходом. В целом прогноз смертности инфицированных больных СПИДом основан на определении количества CD4+ лимфоцитов. Пациенты с числом CD4 + более 200

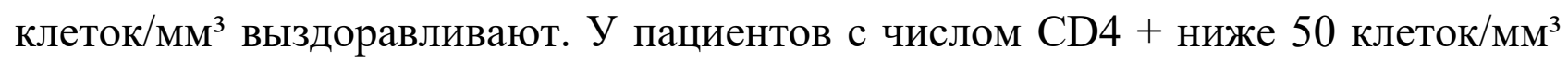
последствия обычно заканчиваются летальным исходом в течение 3-6 месяцев.

Балантидиаз - инфекция, вызываемая Balantidium coli. Это единственная простейшая инфузория, которая может заражать людей. Встречается во всем мире, но наиболее распространена в тропических и субтропических регионах. Поскольку свиньи являются резервуаром, заражения людей чаще возникают в районах их выращивания, особенно если не соблюдаются правила гигиены. Заражение происходит при приеме внутрь зараженной пищи или воды. После проглатывания трофозоиты колонизируют толстый кишечник. Трофозоиты находятся в просвете толстой кишки и аппендикса человека и животных, где они реплицируются путем бинарного деления. Из трофозоит образуются инфекционные цисты. Некоторые трофозоиты проникают в стенку толстой кишки и размножаются, вызывая язвенную патологию в стенке толстой кишки. Некоторые возвращаются в просвет и распадаются. Зрелые цисты передаются с калом являясь стадией передачи балантидиаза.

Большинство случаев протекает бессимптомно. Клинические проявления могут быть острыми или хроническими с абдоминальными симптомами. Осложнения сопутствующей диареи или дизентерии могут возникать при 
затяжных инфекциях. Симптомы могут быть тяжелыми или смертельными у с ослабленным иммунитетом. Внекишечная инфекция встречается редко, но потенциально опасна и обычно возникает вторично по отношению к кишечной инфекции. Перитонит и абсцессы печени наблюдались после перфорации кишечника или разрыва молниеносных язв толстой кишки. Поражение урогенитального тракта может быть вызвано заражением из анальной области или через свищи, вызванные тяжелой инфекцией.

\section{Протозойные инвазии мочеполовой системы}

Трихомониаз - инфекционное заболевание вызываемое анаэробным, жгутиковым протозойным паразитом Trichomonas vaginalis. Он находится в

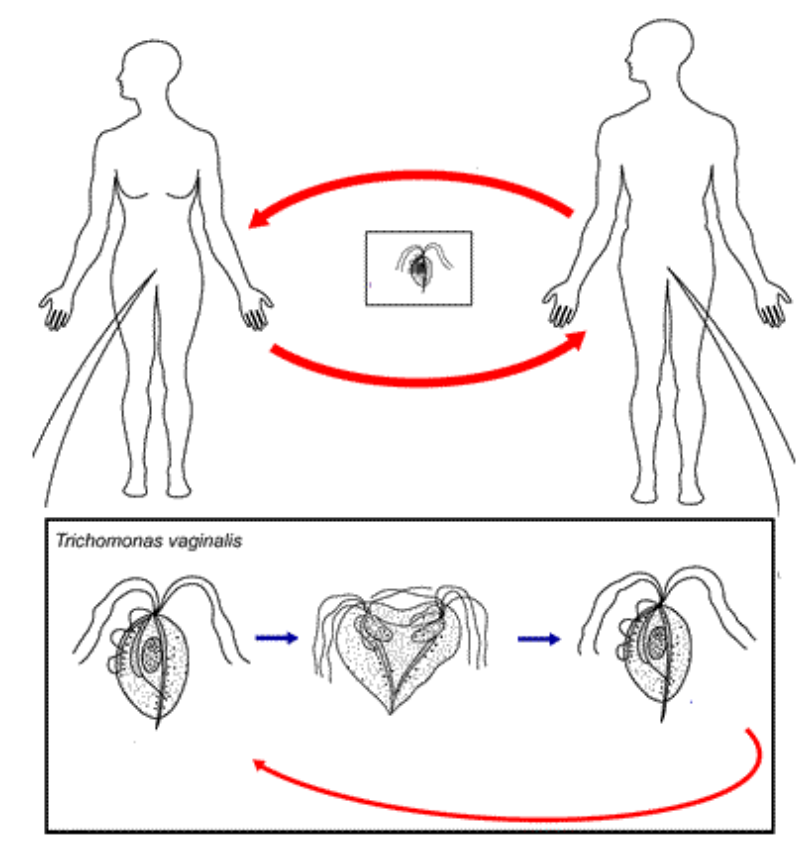

Рис. 22. Жизненный цикл

трихомонад.

(В рисунке использованы элементы изображение DPD CDC)

нижних отделах женских половых путей, а также в уретре и простате у мужчин, где воспроизводится путем бинарного деления. Паразит, не имеет формы цисты и плохо выживает во внешней среде.

Человек его единственный известный хозяин. Количество заражённых по миру составляет около $2 \%$ земного населения. Инфекция, передается от человека чаще всего половым путем, но известны случае передачи через прикосновение к гениталиям (рис.22). Трихомониаз поражает как женщин, так и мужчин, однако большинство, инфицированных

Trichomonas vaginalis не имеют никаких симптомов и могут оставаться незамеченными в течение многих лет (около 70\% женщин и мужчин не имеют симптомов заражения). Симптомы обычно появляются в течение 5-28 дней после заражения. Клинические проявления чаще возникают у женщин. Симптомы включают боль, жжение или зуд в половом члене, уретре (уретрит) или влагалище (вагинит). Дискомфорт может усиливаться во время полового акта и мочеиспускания. У женщин также могут быть желто-зеленые, зудящие, пенистые выделения из влагалища с неприятным запахом («рыбный» запах). У мужчин бессимптомный простатит, вызванный T. vaginalis может в конечном итоге, привести к раку простаты. 


\section{Протозойные инвазии, локализованные в крови и тканях.}

Малярия (mala aria - «плохой воздух», «болотная лихорадка») - группа трансмиссивных инфекционных заболеваний, передаваемых человеку при укусах самками комаров рода Anopheles («малярийных комаров»), вызывается споровиками рода Plasmodium.

На сегодняшний день малярия - одна из самых массовых трансмиссивных инфекций, которая регистрируется во многих странах, в том числе Российской Федерации и странах СНГ в виде спорадических случаев, вспышек и эпидемий. В последние годы возрос завоз малярии на территории России за счет развивающихся международных связей, туризма.

Возбудитель малярии - простейшие, плазмодии пять видов плазмодиев могут инфицировать человека. Большинство смертей вызвано P. Falciparum возбудитель тропической малярии, тогда как $P$. vivax - возбудитель трехдневной малярии, P. ovale - возбудитель овале - малярии и P. malariae - возбудитель четырехдневной малярии, P. knowlesi болезни у людей вызывает редко.

Источником инфекции болезни являются люди, в крови которых циркулируют зрелые гаметоциты. При кровососании вместе с кровью в желудок комара проникают гаметоциты, и комар становится резервуаром инфекции. Ведущий механизм заражения человека - трансмиссивный, через укус самок комаров рода Anopheles. Возможен парентеральный путь заражения при гемотрансфузиях, а также передача плазмодиев от матери к плоду. Заболевание имеет сезонность, связанную с активностью комаров в различных климатических зонах: в умеренно теплых - летом 1,5 - 2 месяца, в субтропиках - 5-6 месяцев, тропиках - круглогодично.

Жизненный цикл плазмодиев осуществляется со сменой хозяев: половое развитие (спорогония) протекает в организме комара рода Anopheles, бесполое развитие (шизогония) - в организме человека (рис.26).

При укусе комара спорозоиты попадают в организм человека, проходят фазы тканевой (внеэритроцитарной) и эритроцитарной шизогонии. Тканевая шизогония протекает в гепатоцитах, где спорозоиты через стадии трофозоитов и шизонтов превращаются в десятки тысяч тканевых мирозоитов. Цикл эритроцитарной шизогонии составляет при тропической малярии 6 суток, трехдневной - 8 суток, овале - малярии - 9 суток, при четырехдневной -15 суток.

В отличие от тропической и четырехдневной малярии, при трехдневной и овале - малярии возможно длительное, в течение нескольких месяцев, пребывание паразитов в печени в дремлющем состоянии с последующим завершением шизогонии и выходом в кровь. Поступившие в кровь тканевые мирозоиты внедряются в эритроциты, и начинается фаза эритроцитарной шизогонии. В эритроцитах паразиты проходят стадии юного и зрелого трофозонта, шизонта, морулы с последующим образованием эритроцитарных мерозоитов, которые разрушают эритроциты и выходят в кровь. 


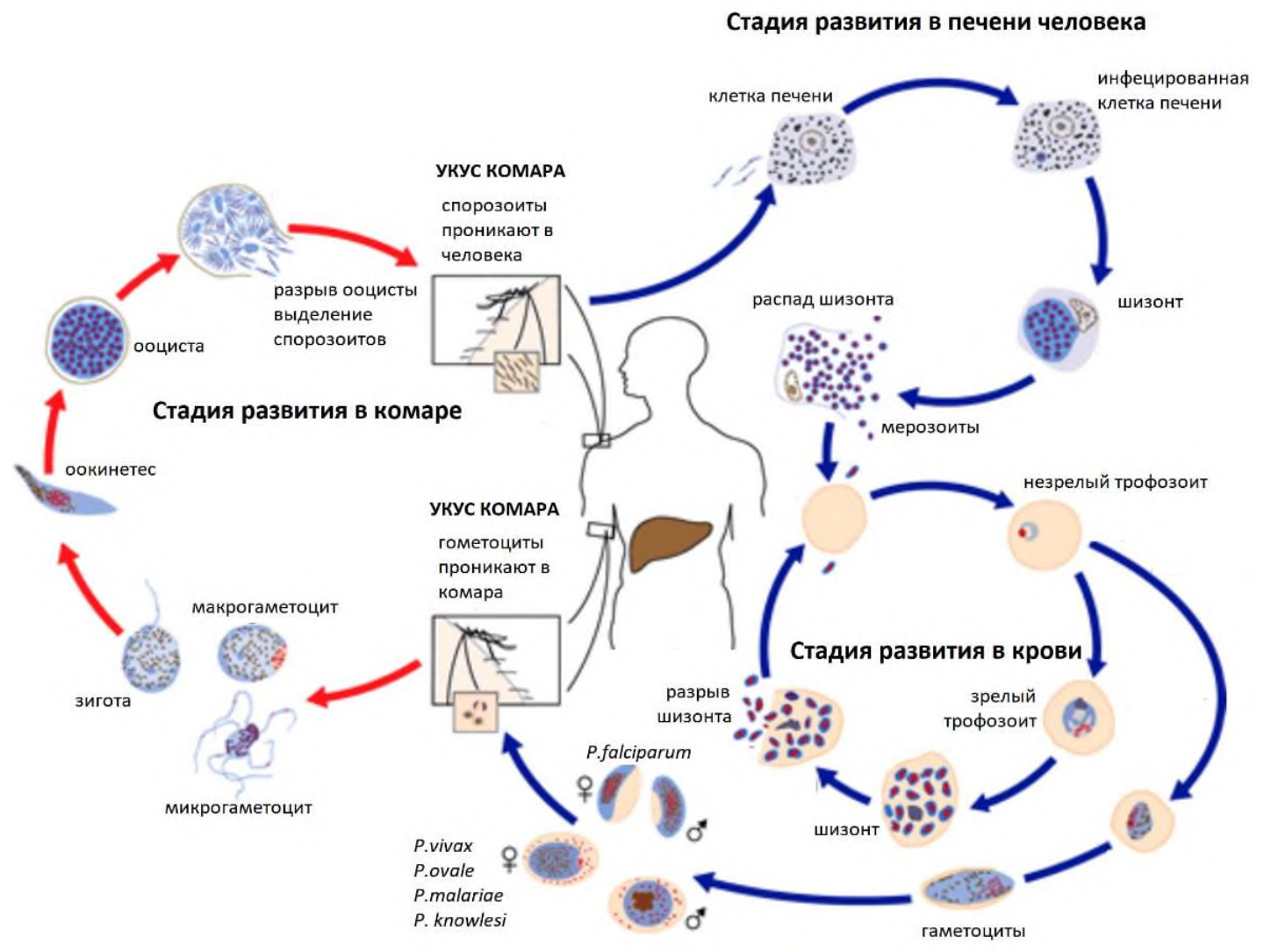

Рис. 26. Жизненный цикл плазмодиев.

(В рисунке использованы элементы изображение DPD CDC)

При тропической, трехдневной и овале-малярии фаза эритроцитарной шизогонии занимает 48 часов, при четырехдневной - 72 часа. Часть мирозоитов после выхода в кровь внедряется в новые эритроциты, и процесс эритроцитарной шизогонии повторяется. Часть мирозоитов превращается в половые клетки гаметоциты, некоторые паразиты погибают.

Основные изменения в организме человека при малярии определяются стадией эритроцитарной шизогонии. Происходит разрушение эритроцитов, накопление в кровяном русле паразитов, их антигенов, продуктов жизнедеятельности, которые действуют на центр терморегуляции, что проявляется, характерной интермиттирующей лихорадкой. Разрушение эритроцитов приводит к развитию анемии. При тропической малярии в капиллярах внутренних органов скапливаются поврежденные эритроциты и паразиты, вследствие чего нарушается микроциркуляция, возникают тяжелые изменения в различных органах - печени, почках, головном мозге. Эти изменения у людей, впервые заболевших малярией, развиваются очень быстро, в течение первых дней болезни, и могут быть причиной смерти.

Клиническая картина малярии. При свежем малярийном заболевании клинические проявления болезни наблюдаются после инкубационного периода, составляющего 10-20 дней при малярии, вызванной Pl. vivax vivax, 6-14 месяцев 
при малярии, вызванной $P l$. vivax hibernans, 8-16 дней при тропической малярии, 7-20 дней при ovale-малярии и 3-6 недель при четырехдневной малярии. К концу его у многих появляются продромальные признаки: недомогание, слабость, разбитость, головная боль, миалгии и артралгии, сухость во рту, болевые ощущения в области печени и селезенки. Продолжительность продромы колеблется от нескольких часов до 2-3 дней; вслед за этим наступает лихорадочный приступ, характер и продолжительность которого зависят от видовой принадлежности возбудителя. Клиническая картина малярийного приступа при всех формах малярии имеет много общего и проходит в три стадии: озноба, жара, пота. Степень выраженности каждой из этих стадий зависит от формы малярийной инвазии.

Первая стадия приступа - озноб. Проявляется чувством познабливания или потрясающего озноба на фоне повышения температуры до субфебрильных цифр, возникает тахикардия, усиливается головная боль, сухость во рту, язык сухой, густо обложен белым налетом. Отмечается цианоз губ, носа, кончиков пальцев. Кожа становится сухой, нередко шероховатой. Беспокоят мышечные и поясничные боли. Характерны боли в области печени и селезенки. Продолжительность этой стадии от 30-40 минут до 1-3 часов.

Вторая стадия - жар - характеризуется значительным ухудшением самочувствия больного. Температура повышается до $39-41^{\circ} \mathrm{C}$. кожа сухая и горячая на ощупь, лицо гиперимировано, нередко появляется herpes labialis. Головная боль резко усиливается. Могут наблюдаться головокружение, рвота, расстройство сознания, бред и судороги. При обследовании больных отмечаются тахикардия, гипотония, глухость сердечных тонов, одышка. Размеры печени и селезенки еще не изменены, но пальпация их болезненна. Уменьшается суточный диурез. Эта стадия при различных формах малярии протекает от 1 до $12-14$ часов и сменяется стадией пота.

В стадии пота температура критически снижается, нередко до субнормального уровня. Падение температуры сопровождается выраженной, часто профузной потливостью, астенизацией, исчезновением болевых ощущений. Больной, обессиленный приступом, часто засыпает. После пробуждения самочувствие - удовлетворительное.

Общая продолжительность малярийного параксизма составляет от 6 до 12 - 14 часов, а при тропической малярии - до суток и более. После окончания приступа наблюдается период апирексии продолжительностью 1 день при трехдневной малярии, 2 дня при четырехдневной и менее суток при тропической малярии.

В клинической картине тропической малярии инкубационный период составляет 8 - 16 дней. У большинства пациентов болезнь начинается внезапно ознобом, высокой лихорадкой, головной болью, миалгиями, возбуждением. В первые $3-8$ дней температура может быть постоянной, а затем принимает характер приступов. Приступы чаще возникают в первой половине дня, длятся 
около 30 часов, после чего наступает короткий (менее суток) период аперескии - нормальной температуры тела.

Тропическая малярия опасна осложнениями, которые встречаются преимущественно у неиммунных людей. В первые - вторые сутки от начала болезни может развиться церебральная кома. У таких больных возникает сильная головная боль, беспокойство или заторможенность, которые затем сменяются нарушением сознания вплоть до комы. Отмечаются менингиальные симптомы, иногда судороги.

Другим осложнением является инфекционно-токсический шок, проявляющийся падением сердечно-сосудистой деятельности.

После према хинина или примахина может возникнуть еще одно осложнение - гемоглобинурийная лихорадка, сопровождающаяся массовым внутрисосудистым гемолизом эритроцитов. Основным симптомом гемоглобинурии является выделение мочи черного цвета за счет содержащегося в ней оксигемоглобина, а в последующей моче - метгемоглобина. У больных появляется лихорадка, ломота в теле, суставах, боли в пояснице. Гемоглобинурийная лихорадка может привести к острой почечной недостаточности и гибели больного. В нетяжелых случаях осложнения купируется через $3-7$ дней.

Трехдневная малярия. Инкубационный период может быть, как коротким - 10-21 день, так и длинным - 6-13 месяцев. Трехдневная малярия протекает доброкачественно, но длительно. У неиммунизированных лиц болезнь начинается с продромальных явлений - слабости, недомогания, головной боли, лихорадки в течение 2 - 3 дней. Затем начинаются приступы, такие же как при тропической малярии, но они четко очерчены, наступают в одно и то же время дня (между 11 и 15 часами), через равные интервалы. Лихорадочные приступы продолжаются 5-8 часов, во время снижения температуры наблюдается повышенное потоотделение. Период нормальной температуры длится $40-43$ часа. Для трехдневной малярии характерны рецидивы: ранние через $6-8$ недель и поздние, наступающие после латентного периода, продолжительностью от 3 месяцев до3 - 4 лет.

Четырехдневная малярия. Инкубационный период - $21-42$ дня, однако при парентеральном заражении шизонтами инкубационный период может удлиняться до нескольких месяцев. Продромальные симптомы встречаются редко. Лихорадочные приступы напоминают трехдневную малярию. Пароксизмы лихорадки продолжаются 13 часов и повторяются каждый 4-й день. Возбудитель четырехдневной малярии может десятки лет сохраняться в организме человека после перенесенного заболевания.

Овале-малярия по клиническим симптомам имеет сходство с трехдневной малярией. Инкубационный период -11 - 16 дней. В отличие от трехдневной малярии пароксизмы лихорадки возникают в вечерние и ночные часы. Течение 
доброкачественное, нередко спонтанное выздоровление. Продолжительность болезни около 2 лет.

Трипасомозы - это группа заболеваний, вызываемых паразитическими жгутиковыми простейшими трипаносомами. У людей это включает африканский трипаносомоз (сонная болезнь) и болезнь Шагаса.

Африканский трипаносомоз вызывается Trypanosoma brucei gambiense, или Trypanosoma brucei rhodesiense. Они передаются между млекопитающимихозяевами с помощью насекомых-переносчиков, принадлежащих к разным видам мухи цеце (Glossina). Передача происходит при укусе насекомого. Паразиты претерпевают сложные морфологические изменения, перемещаясь между насекомыми и млекопитающими в течение своего жизненного цикла.

Люди считаются основным резервуаром Trypanosoma brucei gambiense, но этот вид также встречается у животных, включая приматов и копытных. T.b.gambiense - эндемик в Западной и Центральной Африке. T.b.rhodesiense ограничен Восточной и Юго-Восточной Африкой. Эти ареалы не пересекаются, хотя в Уганде оба подвида являются эндемичными, с T.b.gambiense, обнаруженный у северной границы, и T.b.rhodesiense встречается в центральных и южных регионах этой страны.

Передача инфекции происходит, когда муха кусает инфицированного человека или животное, а затем другого человека. В месте укуса мухи цеце в течение от нескольких дней до 2 недель может возникнуть бугорок. Он приобретает темно-красную окраску и может превращаться в болезненную и припухшую язву. Инфекция распространяется в крови и лимфе в течение недель или месяцев. У человека развивается перемежающаяся лихорадка, озноб, головная боль, а также боли в мышцах и суставах. Может наблюдаться временный отек лица. У некоторых людей развивается сыпь, а также увеличиваются лимфатические узлы. Может развиться анемия. В случае поражения головного мозга и спинномозговой жидкости головная боль становится постоянной. Человек становится заторможенным, не может сосредоточиться, у него развивается шаткость походки. Сонливость усугубляется: человек может заснуть прямо во время работы. При отсутствии лечения поражение мозга прогрессирует, приводя к коме и смерти.

Болезнь Шагаса, также известная как американский трипаносомоз, представляет собой тропическое паразитарное заболевание, вызываемое Trypanosoma cruzi. В основном он распространяется насекомыми, известными как известными как Triatominae (триатомовый клоп). По оценкам, 6,2 миллиона человек, в основном в Мексике, Центральной Америке и Южной Америке, болеют болезнью Шагаса. В отличии от Trypanosoma brucei жизненный цикла Trypanosoma cruzi происходит внутри клетки хозяина (рис.25). 


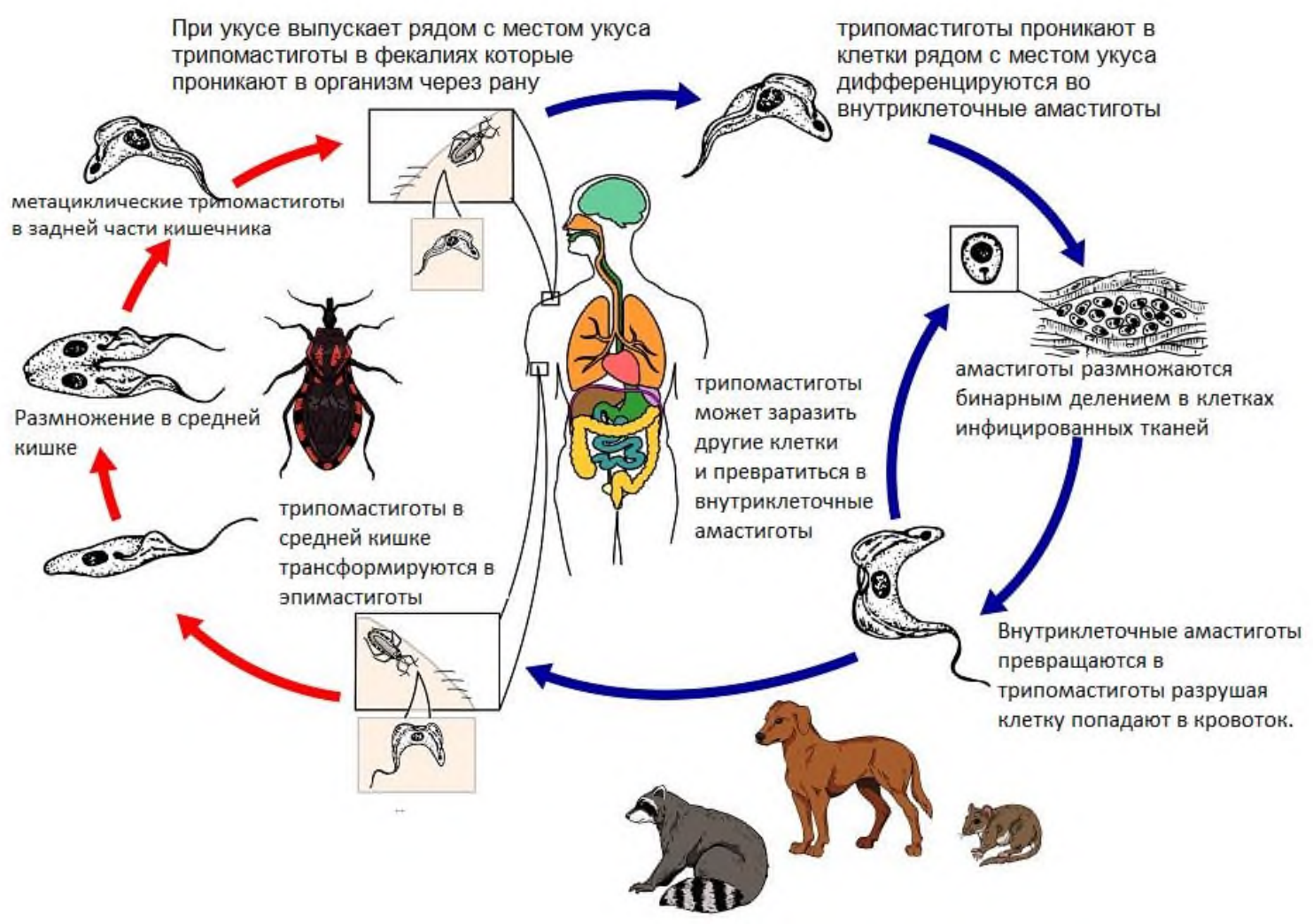

Рис. 25. Жизненный цикл трипаносом при болезни Шагаса.

(В рисунке использованы элементы изображение DPD CDC)

Основными переносчиками инфекции человека являются виды триатомовых клопов, населяющих жилища людей, известные под несколькими местными названиями, в том числе винчука в Аргентине, Боливии, Чили и Парагвае, барбейро (парикмахер) в Бразилии, пито в Колумбии, чинче в Центральной Америке и чипо в Венесуэле. Триатоминовый клоп может заразиться T.cruzi, когда он питается инфицированным хозяином. T.cruzi размножается в кишечном тракте насекомого и выделяется с фекалиями. Когда зараженный триатомин питается, он протыкает кожу и поглощает кровь, в то же время испражняясь, чтобы освободить место для новой еды. Укус обычно безболезненный, но вызывает зуд. Расчесывание укуса приводит к попаданию фекалий T. cruzi в укушенную рану, инициируя инфекцию.

Болезнь Шагаса протекает в две стадии: острая стадия, которая развивается через одну-две недели после укуса насекомого, и хроническая стадия, которая развивается в течение многих лет. Острая стадия часто протекает без симптомов. При наличии симптомы они обычно незначительны и не специфичны для какоголибо конкретного заболевания, включают лихорадку, недомогание, головную боль, увеличение печени, селезенки и лимфатических узлов. В редких случаях у людей появляется опухший узел на месте инфекции, который называется «признаком Романьи», если он находится на веке, или «чагомой», если он 
находится в другом месте на коже. После острой фазы люди остаются хронически инфицированными $T$. cruzi после выздоровления.

Большинство хронических инфекций протекает бессимптомно, что называется неопределенной хронической болезнью Шагаса. Однако за десятилетия хронической болезни Шагаса у 30-40\% людей развивается дисфункция органов (детерминированная хроническая болезнь Шагаса), которая чаще всего поражает сердце и/или пищеварительную систему.

Наиболее частым проявлением является болезни сердца, которые встречается у 14-45\% людей (аритмии, дилатационная кардиомиопатия, сердечная недостаточность, тромбоэмболия). Поражение пищеварительной системы (увеличение пищевода или толстой кишки) страдают 10-21\% людей.

Лейшманиоз - это трансмиссивное заболевание, которое вызывается жгутиковыми внутриклеточными простейшими из рода Leishmania, передается 93 видами москитов, которые могут так же передавать арбовирусы и бартонеллез. Резервуар инфекции грызуны (песчанки, суслики и др.), псовые и человека.

В настоящее время считается, что инфицировано от 4 до 12 миллионов человек в 98 странах. Ежегодно регистрируется около 2 миллионов новых случаев, и от 20 до 50 тысяч случаев смерти. Лейшманиоз встречается в Мексике, Центральной Америке и Южной Америке - от северной Аргентины до Техаса (не в Уругвае, Чили и Канаде), южной Европе (лейшманиоз не встречается у путешественников в южную Европу), Азии (не Юго-Восточная Азия), Ближний Восток и Африка (особенно Восточная и Северная Африка, с некоторыми случаями в других местах). Более 90 процентов случаев висцерального лейшманиоза в мире приходится на Индию, Бангладеш, Непал, Судан и Бразилию.

Лейшманиоз передается при укусе инфицированных самок москитов, которые передают простейших (рис.26). Москиты вводят промастиготы, во время еды крови человека. Промастиготы фагоцитированные макрофагами превращаются амастиготы. Амастиготы (безжгутиковая форма) размножаются в инфицированных клетках и поражают разные ткани человека. В зависимости от места поражения развиваются различные клинические проявления лейшманиоза.

Москиты заражаются при укусах инфицированного человека проглатывая амастиготы. В средней кишке москитов паразиты дифференцируются в промастиготы, которые размножаются, дифференцируются в метациклические промастиготы и мигрируют в хоботок.

Лейшманиоз человека включает множество клинических синдромов, но наиболее распространенными являются кожная, кожно-слизистая и висцеральная формы. Инкубационный период - от 10 дней до 2 лет, в среднем 3-5 месяцев. Первичный аффект - небольшая папула розового цвета в месте укуса москита, возникает через 1-2 недели (обычно остается незамеченным). 




Рис. 26. Жизненный цикл лейшманий.

(В рисунке использованы элементы изображение DPD CDC)

Кожный лейшманиоз - наиболее распространенная форма, при которой в местах укусов образуется открытая язва, которая заживает от нескольких месяцев до полутора лет, оставляя шрам неприятного вида. При массовом поражении может развиваться диффузный кожный лейшманиоз, широко распространенные кожные поражения, напоминающие проказу, которые не заживают самостоятельно.

Кожно-слизистый лейшманиоз характеризуется образованием язвы как кожи, так и слизистых оболочек с поражением, главным образом, носа и рта.

Висцеральный лейшманиоз или кала-азар («черная лихорадка») является наиболее серьезной формой и, как правило, приводит к летальному исходу при отсутствии лечения. Продромальный период сопровождается слабостью, недомоганием, постепенным повышением температуры. Затем развивается разгар заболевания (анемико-спленомегалический период). Характерны большие суточные размахи температуры, двукратные подъемы и снижения в течение суток. В некоторых случаях кожа в связи с поражением надпочечников приобретает темную окраску (кала-азар - черная болезнь). Постепенно увеличивается печень и, особенно, селезенка. При пальпации край органов безболезнен, плотный. Происходит увеличение лимфоузлов. Развивается панцитопения, снижается содержание $\gamma$-глобулинов и альбуминов. При отсутствии лечения происходит истощение, отеки, резкое увеличение размеров живота, развивается геморрагический синдром. Присоединяются различные инфекционные заболевания, которые в 75-95 \% случаев приводят к смерти. 
При выздоровлении у некоторых больных на коже различных частей тела развиваются лейшманоиды - эритематозные пятна, узелки или участки с пониженной пигментацией. Они являются результатом размножения лейшманий в коже, сохраняются длительно и служат источником лейшманий для переносчиков.

Токсоплазмоз - это паразитарное заболевание, вызываемое жгутиковыми простейшими Toxoplasma gondii. Токсоплазмоз является одной из самых распространенных инфекций человека во всем мире. Распространен повсеместно. До половины населения мира инфицировано токсоплазмозом, но не имеет симптомов. Среди беременных женщин он регистрируется в $15 \%$ случаев.

В жизненном цикле токсоплазм выделяют промежуточного и окончательного хозяина. Окончательный хозяин - млекопитающие семейства кошачьих. Промежуточные хозяева - млекопитающие, в том числе человек и животные, разводимые для употребления в пищу, многие виды птиц, могут быть рептилии (рис.27).

Жизненный цикл токсоплазм сложный, со сменой хозяев и чередованием полового и бесполого размножения. Когда животное из семейства кошачьих заражается T.gondii паразит выживает, проходя через желудок, в конечном итоге заражая эпителиальные клетки тонкой кишки кошки.

Кошачьи являются единственным окончательным хозяином, поскольку в их кишечнике отсутствует фермент, расщепляющий линолевую кислоту. Избыток линолевой кислоты необходим для полового размножения T. gondii.

Инфицированные эпителиальные клетки в конечном итоге разрываются и выделяют ооцисты в просвет кишечника, после чего они выделяются с фекалиями кошки. Ооцисты за 1-5 дня спорулируются в окружающей среде и становятся заразными. Обладая высокой устойчивостью, они могут выжить и оставаться заразными в течение многих месяцев в холодном и сухом климате.

Промежуточные хозяева заражаются после проглатывания почвы, воды или растительныйого материала, зараженного ооцистами.

Когда ооциста или тканевая циста попадает в организм человека или другого теплокровного животного, стенка цисты растворяется протеолитическими ферментами в желудке и тонком кишечнике, высвобождая спорозоиты из ооцисты. Паразиты проникают в клетки эпителия кишечника и внутри этих клеток паразиты дифференцируются в тахизоитов (тахизойские мерозоиты), подвижную и быстро размножающуюся клеточную стадию Т. gondii. Тахизоиты реплицируются внутри специализированных вакуолей (называемых паразитофорными вакуолями), созданных из мембраны клеткихозяина во время вторжения в клетку. Тахизоиты размножаются внутри этой вакуоли до тех пор, пока клетка-хозяин не умирает и не разрывается, высвобождая и распространяя тахизоиты через кровоток во все органы и ткани тела, включая мозг. 


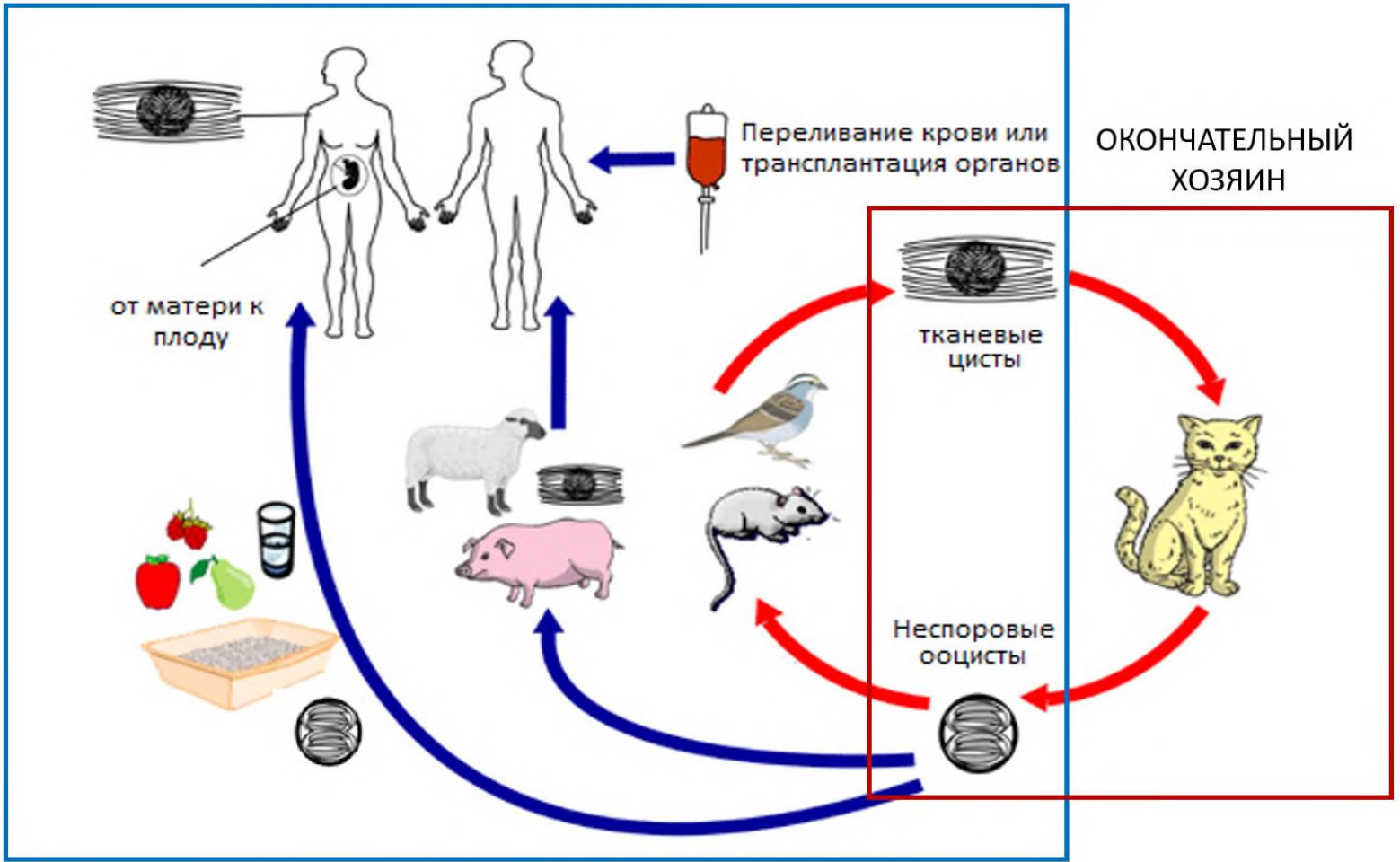

Рис. 27. Жизненный цикл токсоплазм.

(В рисунке использованы элементы изображение DPD CDC)

После начального периода под воздействием иммунной системы в тканях тахизоиты превращаются в брадизоиты (тканевые цисты) медленно делящееся клеточная стадия паразита. Цисты обычно имеют размер от 5 до 50 мкм в диаметре (50 мкм - две трети ширины среднего человеческого волоса). Поедание тканевых цист в мясе является одним из основных способов заражения при токсоплазмозе как для человека (особенно свинина и баранина), так и для животных. Поедание тканевой цисты также является основным средством заражения кошек. Тканевые цисты могут сохраняться в ткани хозяина в течение всей жизни животного. При этом постоянное присутствие цист, происходит изза периодического процесса разрыва кисты и повторного энцистирования.

Теоретически T.gondii может передаваться между промежуточными хозяевами бесконечно через цикл потребления тканевых цист в мясе. Однако жизненный цикл паразита начинается и завершается только тогда, когда паразит передается кошке-хозяину, единственному хозяину, внутри которого паразит может снова подвергаться половому развитию и размножению. В редких случаях болезнь передается от инфицированной матери ребенку во время беременности, при переливании крови, трансплантации органов.

В зависимости от механизма заражения различают приобретенный и врожденный токсоплазмоз. У приобретенного токсоплазмоза выделяют две стадии острую и хроническую. 
Острая стадия приобретенного токсоплазмоз чаще всего у здоровых взрослых людей протекает бессимптомно. У ряда людей симптомы могут проявляться и часто похожи на грипп или как тифоподобное заболевание (с высокой температурой, увеличением печени, селезёнки) очень редко протекает с преимущественным поражением нервной системы (головная боль, судороги, рвота). Лимфаденопатия один из основных синдромов токсоплазмоза. Увеличение лимфоузлов может возникать в разное время после первоначальной инфекции, сохраняться и повторяться разное время независимо от противопаразитарного лечения. Увеличенные лимфатические узлы рассасываются в течение 1-2 месяцев в 60\% случаев. Однако четверти пострадавших требуется 2-4 месяца, а 8\% - 4-6 месяцев. Значительное число (6\%) возвращается к норме гораздо позже. У большинства пациентов с нарушением функции иммунной системы и маленьких детей может развиться тяжелый токсоплазмоз с повреждением головного мозга (энцефалит) или глаз (некротический ретинохориоидит). Наибольший риск наблюдается среди тех, у кого число CD4+ <200/мкл. У этих пациентов, как правило, присутствуют головная боль, нарушения психического состояния, приступы лихорадки иногда фокальный неврологический дефицит (потеря моторного или сенсорного контроля, параличи черепного нерва, отклонения по зрению). При КТ или МРТ сканировании с контрастом выявляется энцефалит и массивные кольцевые внутричерепные поражения.

При хронической стадии токсоплазмоз протекает с периодической субфебрильной температурой, головной болью, увеличением лимфоузлов и печени, понижением работоспособности; может сопровождаться поражением глаз, сердца, нервной и других систем и органов. В редких случаях может происходить поражения кожи включая многоформные высыпания, похожие на розеолу и эритему, узелки, похожие на пруриго, крапивницу и пятнистопапулезные поражения. Однако чаще всего хронический токсоплазмоз протекает в латентной (скрытой) форме, бессимптомно.

Врожденный токсоплазмоз является следствием первичной острой, часто бессимптомной инфекции, приобретенной матерью во время беременности.

\section{Редкие протозойные инвазии, опасные для человека}

Необходимо обратить внимание на ряд протозойных инвазий, которые встречаются достаточно редко, но приводят к тяжелым, часто летальным последствиям.

Naegleria fowleri («амеба, поедающая мозг») — это пресноводный вид амебы, который может быть смертельным для человека при попадании через нос. Симптомы возникают быстро после инфицирования (1-9 дней; в среднем через 5 дней после плавания или другого контакта носа с водой, содержащей Naegleria). 
Симптомы похожи на бактериальный менингит (изменения вкуса и запаха, головная боль, лихорадка, тошнота, рвота, боли в спине, ригидность затылочных мышц, спутанность сознания, галлюцинации, атаксия, судороги), за который часто ошибочно его и принимают, с ухудшением неврологической функции и осложнениями. Летальность чрезвычайно высока (98,5\%).

Acanthamoeba может вызывать амебный кератит и энцефалит у человека. Амебы попадают в организм через открытую рану и затем распространяются в мозг. Гранулематозный амебный энцефалит вызывается амебной инфекцией центральной нервной системы. Он характеризуется неврологическими симптомами, включая головную боль, судороги и нарушения психического статуса. Комбинация иммунных реакций и секретируемых амебных протеаз вызывает массивный отек мозга, приводящий к смерти около 95\% инфицированных. При попадании в глаза штаммы Acanthamoeba могут вызывать акантамебный кератит, который может привести к язвам роговицы или даже к слепоте. Это заболевание чаще всего возникает у тех, кто носит контактные линзы, которые не дезинфицируют линзы должным образом, что усугубляется тем, что они не вымыли руки перед тем, как брать линзы в руки. Растворы для многоцелевых контактных линз в значительной степени неэффективны против Acanthamoeba, тогда как растворы на основе перекиси водорода обладают хорошими дезинфицирующими характеристиками.

Balamuthia mandrillaris является причиной гранулематозного амебного менингоэнцефалита (часто со смертельным исходом). Амеба может заразить организм через открытые раны или при вдыхании. Они больше лейкоцита человека, что делает невозможным фагоцитоз. Вместо этого иммунная система пытается сдержать их у входного портала (обычно открытой раны), вызывая реакцию гиперчувствительности замедленного типа. При введении, амеба может образовывать повреждение кожи, или в некоторых случаях, может мигрировать в мозг, в результате чего развивается гранулематозный амебный энцефалит, как правило, со смертельным исходом. Баламутия также может вызывать множество не неврологических симптомов, включая поражения кожи часто похожем на поражение MRSA, которое плохо поддается лечению антибиотиками.

\section{Cyclospora cayetanensis - простейшее споровик, вызывающее} циклоспориаз. Основные признаки включают водянистую диарею с симптоматикой желудочно-кишечного тракта и системными признаками. Циклоспориаз зарегистрирован во многих странах, но наиболее распространен в тропических и субтропических регионах. Это типичная кишечная инфекция. Вспышки заболевания в мире выявляются почти каждый год.

Cystoisospora (Isospora) belli вызывает протозойную инфекцию цистоизоспороз - внезапная, водянистая диарея без крови, с лихорадкой, коликами в животе, тошнотой, анорексией и недомоганием. Обычно болезнь 
заканчивается спонтанно, но может длиться в течение недель. У пациентов с угнетением клеточно-опосредованного иммунитета, как это происходит при СПИДе, цистоизоспороз может вызвать тяжелую, непрекращающуюся, обильную диарею с потерей веса, подобную таковой при криптоспоридиозе. В отличие от других простейших инфекций при цистоизоспорозе может наблюдатся эозинофилия.

Babesia divergens, Babesia duncani, Babesia microti - простейшие споровики, вызывают бабезиоз. Трансмиссивная инфекция, передающаяся иксодовыми клещами. Резервуар инфекции грызуны. Жизненный цикл Babesia включает двух хозяев грызуна и иксодового клеща. Люди обычно являются тупиковыми хозяевами (рис.28).

Люди могут заразиться в результате укуса инфицированного клеща. Попадая в кровь бабезии размножаются в эритроцитах, где их можно увидеть в виде крестообразных включений (четыре мерозоита, отпочковывающихся бесполым путем, но соединенных вместе, образуя структуру, напоминающую «мальтийский крест») вызывают гемолитическую анемию, очень похожую на малярию.

В отличие от Plasmodium, у Babesia отсутствует экзоэритроцитарная фаза, поэтому печень и селезенка обычно не поражается.

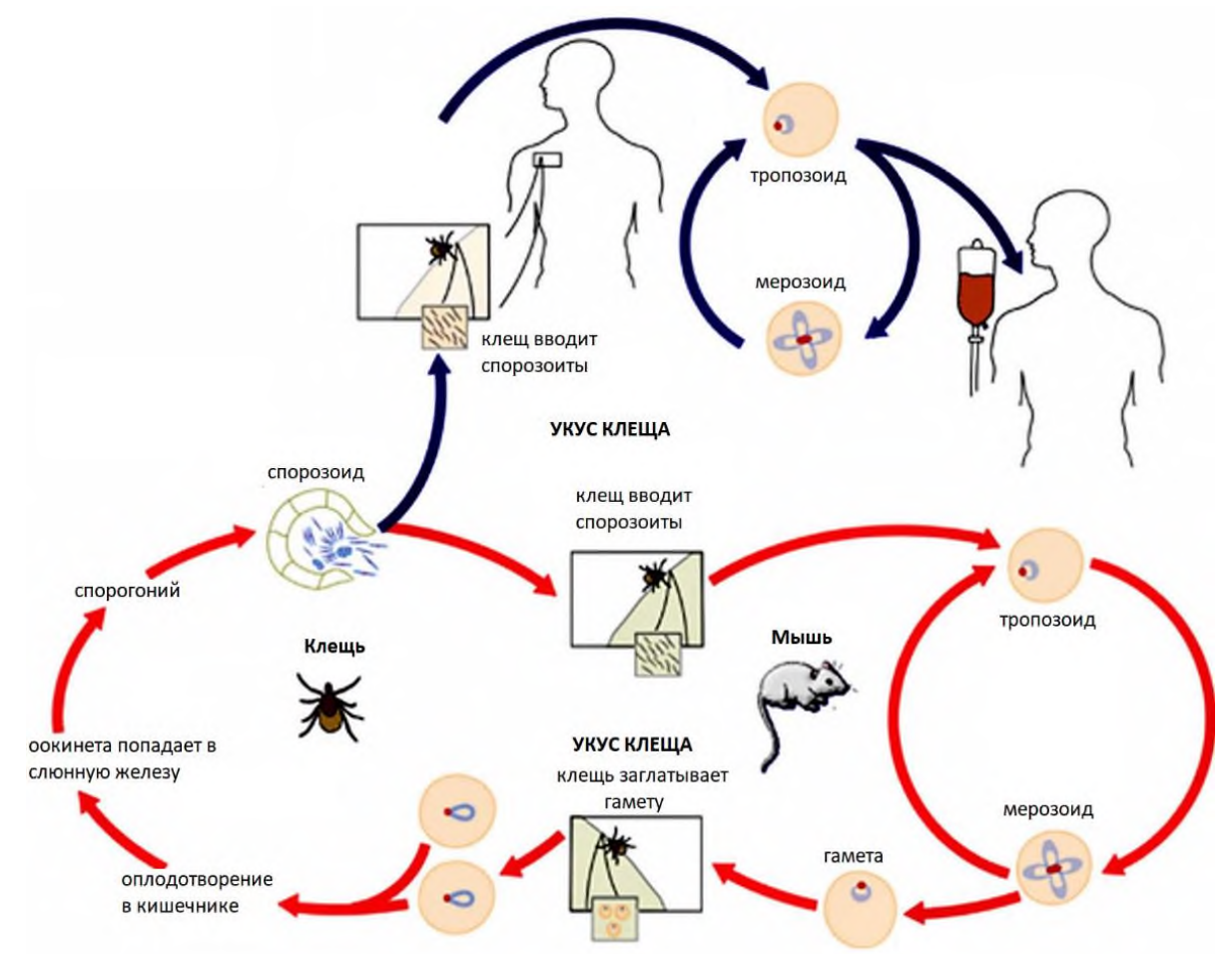

Рис. 28. Жизненный цикл при бабезиозе.

(В рисунке использованы элементы изображение DPD CDC) 
Инкубационный период 1-4 недели, после укуса. Половина всех детей и четверть ранее здоровых взрослых с инфекцией бабезии протекают бессимптомно. Однако у инфицированного может постепенно развиваться недомогание, утомляемость, затем поднимается температура, появляется озноб, ночная потливость. Симптомы могут длиться от нескольких дней до нескольких месяцев. У людей с нарушением функции иммунной системы, перенесших сепсис и спленэктомию могут развиваться тяжелые формы заболевания похожие на малярию, с лихорадкой до $40^{\circ} \mathrm{C}$, дрожащим ознобом и тяжелой анемией (гемолитической анемией). Может последовать органная недостаточность, включая респираторный дистресс-синдром.

\section{Гельминтозы}

Наиболее распространенные и массовые паразитарные болезни человека, возникающие в результате сложных взаимоотношений между наиболее высокоорганизованными многоклеточными паразитами (гельминтами) и организмом хозяина (человеком).

В общей структуре инфекционных и паразитарных заболеваний гельминтозы занимают ведущее место. Они насчитывают более 200 нозоформ, распространены во всех широтах земли, однако совокупность природноклиматических факторов и социально-экономических предпосылок определяет преимущественное распространение многих из них в развивающихся странах тропического и субтропического поясов. Интенсивная передача гельминтозов в этих регионах обусловлена также распространенностью полиинвазий среди пораженного населения. На территории России и в пограничных государствах обнаружено свыше 70 видов, около 30 из них достаточно широко распространены в отдельных регионах или повсеместно.

Во многих случаях гельминтозы протекают со слабо выраженными симптомами или бессимптомно.

Возбудители гельминтозов - низшие черви - гельминты (от греч. helmins - червь). Медицинское значение имеют гельминты, относящиеся к типам плоских (Plathelminthes) и круглых или первичнополостных (Nemathelminthes) червей (рис. 29). Плоские черви, паразитирующие у человека, входят в состав классов Trematoda (сосальщики) и Cestoidea (Cestoda) (ленточные черви). Первичнополостные гельминты человека принадлежат к классу собственно круглых червей (Nematoda).

В соответствии с особенностями жизненных циклов и механизмом заражения человека гельминты подразделяются на три основные группы: геогельминты (яйца, личинки развиваются во внешней среде), биогельминты (яйца и личинки паразитируют в организме промежуточных хозяев) и контагиозные гельминты (яйца и личинки способны к инвазии без предварительного развития во внешней среде). 


\begin{tabular}{|c|c|c|c|c|c|}
\hline \multicolumn{2}{|c|}{ Круглые черви } & \multicolumn{4}{|c|}{ Плоские черви } \\
\hline Аскарида & Аскаридоз & \multicolumn{2}{|c|}{ Ленточные } & \multicolumn{2}{|c|}{ Сосальщики } \\
\hline Острица & Энтеробиоз & $\begin{array}{l}\text { Широкий } \\
\text { лентец }\end{array}$ & Дифиллоботриоз & $\begin{array}{l}\text { Кошачья } \\
\text { двуустка }\end{array}$ & Описторхо́з \\
\hline Анкилостома & Анкилостомоз & Бычий цепень & Тениаринхоз & $\begin{array}{l}\text { Двуустка } \\
\text { китайская }\end{array}$ & Клонорхоз \\
\hline Власоглав & Трихоцефалёз & $\begin{array}{l}\text { Свиной } \\
\text { цепень }\end{array}$ & $\begin{array}{l}\text { Тениоз } \\
\text { Цистицеркоз }\end{array}$ & $\begin{array}{l}\text { Печеночная } \\
\text { двуустка }\end{array}$ & Фасциолёз \\
\hline Трихинелла & Трихинеллез & $\begin{array}{l}\text { Карликовый } \\
\text { цепень }\end{array}$ & Гименолепидоз & Шистосома & Шистосомоз \\
\hline Дирофилярии & Дирофиляриоз & Эхинококк & Эхинококкоз & $\begin{array}{l}\text { Лёгочный } \\
\text { сосальщик }\end{array}$ & Парагонимоз \\
\hline Токсокара & Токсокароз & & & & \\
\hline $\begin{array}{l}\text { Угрица } \\
\text { кишечная }\end{array}$ & Стронгилоидоз & & & & \\
\hline
\end{tabular}

\section{Рис. 29. Гельминтозы.}

К геогельминтам относится большинство видов наиболее распространенных круглых червей (аскарида, власоглав, анкилостомиды и др.) Цикл развития проходит без смены хозяев. Геогельминты выделяют незрелые яйца, которые созревают во внешней среде, чаще в почве. Лишь у кишечных угриц (Strogyloides stercoralis) в некоторых случаях цикл развития может завершаться внутри организма одного хозяина без выхода паразита во внешнюю среду (при упорном запоре, в условиях пребывания рабдитовидных личинок в кишечнике более суток), обуславливая процесс аутосуперинвазии.

Тип механизма передачи возбудителей большинства геогельминтозов фекально-оральный. Человек заражается преимущественно при проглатывании зрелых яиц гельминтов или их личинок с пищей, особенно с овощами и фруктами. Важным фактором передачи служат руки, загрязненные субстратом, содержащим яйца гельминтов. Таким путем происходит заражение яйцами аскарид, власоглава, анкилостомы и других круглых червей, в то же время личинки стронгилид и некатора сами активно внедряются через кожу при соприкосновении с почвой. Поскольку для развития личинок геогельминтов до инвазионной стадии требуется несколько дней или недель, то больные такими гельминтозами опасности для окружающих не представляют.

Возбудители биогельминтозов весь цикл развития проходят только в живых организмах и для его полного завершения им необходима смена двухтрех хозяев (промежуточного и окончательного). Развитие личинок до инвазионной стадии происходит в одном или двух промежуточных хозяевах, а в 
организме окончательного (дефинитивного) хозяина биогельминт достигает половой зрелости. К биогельминтозам относятся практически все трематодозы (шистосомозы, описторхоз, клонорхоз, фасциолез, парагонимоз и др.), цестодозы (тениоз, тениаринхоз, дифиллоботриоз, эхинококкоз и др.), ряд нематодозов (дранкулез, филяриозы, трихинеллез).

Для большинства биогельминтов человек служит окончательным хозяином (цепни бычий и свиной, лентец широкий, описторх, клонорх и др.) и лишь для некоторых - промежуточным (цистный эхинококк, альвеококк). Существуют биогельминты, личинки и зрелые формы которых обитают у одного и того же хозяина и даже у одной и той же особи хозяина, но в разных его тканях или органах (карликовый цепень, трихинеллы).

Заражение человека биогельминтами может происходить разнообразными путями. Многими из биогельминтов человек заражается при употреблении в пищу продуктов, приготовленных без достаточной кулинарной обработки из различных органов промежуточных хозяев, содержащих жизнеспособные личинки гельминтов (описторх, лентец широкий, бычий и свиной цепни, трихинеллы). Заражение некоторыми биогельминтами происходит при проглатывании с водой инвазированного промежуточного хозяина или личинки, покинувшей промежуточного хозяина (ришта, печеночная двуустка). Личинки шистосом (церкарии) могут проникать через неповрежденную кожу человека. Личинки филярий передаются двукрылыми насекомыми при кровососании (трансмиссивный путь передачи). Заражение яйцами эхинококка может происходить по пищевому, водному, контактно-бытовому и воздушно-пылевому путям передачи.

Проникая в организм человека на одной из стадий своего развития, гельминт покидает его на другой стадии, поэтому инвазированный гельминтозами человек, за исключением контагиозных гельминтозов, для окружающих непосредственно не заразен.

Контагиозную группу гельминтов составляют те виды паразитических червей, которые, как и геогельминты, развиваются без промежуточных хозяев, но их яйца не требуют для своего развития пребывания в почве. Созревание яиц происходит в кишечнике хозяина (цепень карликовый, цепень свиной, угрица кишечная) или завершается вскоре после отложения яиц на перианальных складках хозяина (острица). Заражение происходит при непосредственном контакте с больным или через предметы домашнего обихода, игрушки и т.п. (контактно-бытовой путь передачи).

Ниже, в таблице, представлены элементы эпидемиологического анамнеза, способствующие выявлению различных гельминтов (табл. 21). 
Таблица 21

Элементы эпидемиологического анамнеза, способствующие поиску гельминтов

\begin{tabular}{|c|c|}
\hline Элементы анамнеза & Возможный гельминтоз \\
\hline \multicolumn{2}{|c|}{ ПИЩЕВЫЕ ПРИВЫЧКИ } \\
\hline $\begin{array}{l}\text { Употребление в пищу термически } \\
\text { необработанной рыбы, пресноводных } \\
\text { раков, крабов }\end{array}$ & $\begin{array}{l}\text { Дифиллоботриоз, описторхоз, клонорхоз, } \\
\text { парагонимоз, анизакидозы }\end{array}$ \\
\hline $\begin{array}{l}\text { Употребление в пищу термически } \\
\text { необработанной }\end{array}$ & Тениоз, тениаринхоз, трихинеллез \\
\hline \multicolumn{2}{|c|}{ КОНТАКТ С ЖИВОТНЫМИ } \\
\hline Собаками & Токсокароз, эхинококккозы \\
\hline \multicolumn{2}{|c|}{ КОНТАКТ С ВОДОЙ/ПОЧВОЙ } \\
\hline Хождение босиком & Анкилостомидозы, стронгилоидоз \\
\hline Купание в водоемах, стирка белья & Шистосомозы, церкариозы \\
\hline \multicolumn{2}{|c|}{ ПРОФЕССИОНАЛЬНАЯ ДЕЯТЕЛЬНОСТЬ } \\
\hline Огородничество & Аскаридоз \\
\hline $\begin{array}{l}\text { Обработка и утилизация продуктов } \\
\text { животного происхождения (мясо, рыба, } \\
\text { молоко и пр.) }\end{array}$ & $\begin{array}{l}\text { Описторхоз, парагонимоз, клонорхоз, } \\
\text { дифиллоботриозы, тениаринхоз, тениоз, трихинеллез, } \\
\text { токсоплазмоз }\end{array}$ \\
\hline Очистка городов & Эхинококкоз, токсокароз \\
\hline Персонал психиатрических учреждений & Токсокароз, стронгилоидоз \\
\hline $\begin{array}{l}\text { Персонал детских дошкольных } \\
\text { учреждений }\end{array}$ & Энтеробиоз \\
\hline
\end{tabular}

Продолжительность жизни гельминтов различных видов в организме окончательного хозяина составляет от нескольких недель (острицы) до нескольких лет (цепни) и даже десятилетий (описторхи).

Механизмы патогенного действия гельминтов на организм человека чрезвычайно разнообразны. Выделяют следующие синдромы:

Аллергия - важнейший фактор патогенеза при всех гельминтозах. Аллергические реакции возникают вследствие сенсибилизации организма человека продуктами обмена и распада гельминтов, обладающими антигенными свойствами. При дополнительном или повторном (извне) поступлении антигенов гельминтов возникают аллергические реакции немедленного и замедленного типов. Компонентом аллергических реакций характерна эозинофилия. Эозинофилы, связываясь с покрывающими мигрирующих личинок антителами, выделяют на поверхность паразитов лизосомные ферменты, нейтрализующие биологически активные продукты обмена паразитов. Так же они ограничивают тканевую воспалительную реакцию, выделяя многие ферменты, регулирующие выработку гистамина и гистаминоподобных веществ. В комплексе с $\operatorname{IgE}$, уровень 
которого при гельминтозах неизменно повышается, эозинофилы совместно с тканевыми базофилами, Т-лимфоцитами, макрофагами и другими клетками включаются в процессы формирования гранулем, ограничивающих патогенное воздействие личинок на организм хозяина.

Иммунодепрессивное действие гельминтов проявляется ухудшением течения ряда инфекционных болезней (шигеллез, брюшной тиф, туберкулез, хронический вирусный гепатит) при их сочетании с гельминтозами.

Механическое влияние гельминтов на ткани хозяина связано с их фиксацией и миграцией по организму личинок паразитов

Влияние на микрофлору. Паразитирование гельминтов в кишечнике способствует изменению его микрофлоры и активизации находящихся в организме хозяина «дремлющей» или условно-патогенной микрофлоры.

Нарушение обменных процессов при гельминтозах связано с ухудшением питания хозяина вследствие потребления гельминтами части питательных веществ, поступающих в его организм.

Токсическое влияние гельминтов обусловлено действием выделяемых ими продуктов обмена веществ и секретов желез, в результате чего в организме хозяина развиваются различные патологические процессы.

Антиферментное действие гельминтов. Кишечные гельминты выделяют особые вещества, которые нейтрализуют пищеварительные ферменты хозяина и защищают паразита от их действия.

Нервно-рефлекторное влияние гельминтов выражается в раздражении ими нервных окончаний (интероцепторов), что нередко приводит к тяжелым вегетативным расстройствам, сопровождающимся бронхоспазмами, дисфункциями кишечника, зудом кожи

Стимуляция новообразований. Экспериментально установлена способность некоторых гельминтов стимулировать развитие новообразований.

Психогенное воздействие. Внешний вид гельминтов, выходящих из ануса (членики цепней и др.) или через рот (аскариды), может вызвать у лиц с неустойчивой психикой или страдающих первичными психическими заболеваниями сильнейший психоэмоциональный стресс, который оставляет неизгладимый след в их сознании даже после излечения инвазии, заставляя вновь и вновь лечиться от уже несуществующего заболевания.

По характеру патогенного действия можно выделить две стадии течения гельминтозов: острую и хроническую.

Острая стадия продолжается от двух недель до двух месяцев после заражения. Она обусловлена внедрением гельминта и жизнедеятельностью его личинок, антигены которых вызывают аллергические реакции. Эти реакции особенно выражены при миграции личинок гельминтов в тканях. Ведущие клинические синдромы этой стадии: лихорадка, эозинофилия, лимфоаденопатия, зудящие полиморфные высыпания на коже, артралгии и миалгии. При этом могут возникнуть тяжелые поражения органов: отечный легочный синдром, 
диффузно-очаговая эозинофильная пневмония, аллергический миокардит, гепатит (иногда с желтухой), аллергический менингоэнцефалит, энцефаломиелит, изменения белкового состава крови и др.

В начале второй, хронической стадии, происходит созревание молодых гельминтов. Клинические явления в этот период менее выражены. В последующем периоде хронической стадии, когда особенно высока репродуктивная активность гельминтов, в наибольшей степени проявляются специфические для данного гельминтоза синдромы. По мере снижения интенсивности жизнедеятельности паразитов они постепенно стихают.

Степень проявления клинических синдромов при каждом гельминтозе зависит от величины и численности паразитов, особенностей их биологии и места локализации в организме хозяина. Большое значение в развитии клинической картины имеет также возраст и состояние организма хозяина. У детей инвазия гельминтозами вызывает значительно более тяжелые патологические процессы, чем у взрослых, и часто отражается на общем развитии их организма.

Гельминты поражают любые органы и ткани человека. Тем не менее по локализации различают просветные гельминтозы, в том числе кишечные (аскаридоз, трихоцефалез, стронгилоидоз, тениаринхоз и др.), гельминтозы гепатобилиарной системы (описторхоз, клонорхоз, фасциолез), тканевые гельминтозы (трихинеллез, шистосомоз, филяриатозы, токсокарозы), в том числе легочные гельминтозы (парагонимозы, томинксоз), офтальмогельминтозы (дирофиляриоз, онхоцеркоз, токсокароз, цистицеркоз и др.)

\section{Кишечные гельминтозы}

Аскаридоз - антропонозный геогельминтоз, вызываемый паразитическим аскаридами Ascaris lumbricoides и Ascaris suum (аскарида свиньи). Один из наиболее распространенных гельминтозов. По оценкам, одна шестая часть населения инфицирована этими круглыми червями.

Источник инфекции - предметы, зараженные фекальными массами, содержащими яйца. Аскаридоз встречается почти во всех ландшафтноклиматических зонах за исключением зоны вечной мерзлоты, пустынь и полупустынь. Яйца могут выжить во внешней среде до 15 лет, а один червь может производить 200000 яиц в день. Наибольшее количество яиц аскарид выявлено в сточных водах (от 100 до 1050 в литре). Проглатывание инфекционных яиц из почвы, загрязненной фекалиями человека или зараженными овощами и водой, является основным путем заражения.

После проглатывания инфекционных яиц личинки вылупляются, проникают в слизистую кишечника и переносятся через воротную вену, а затем через системный кровоток в легкие (рис.29). 


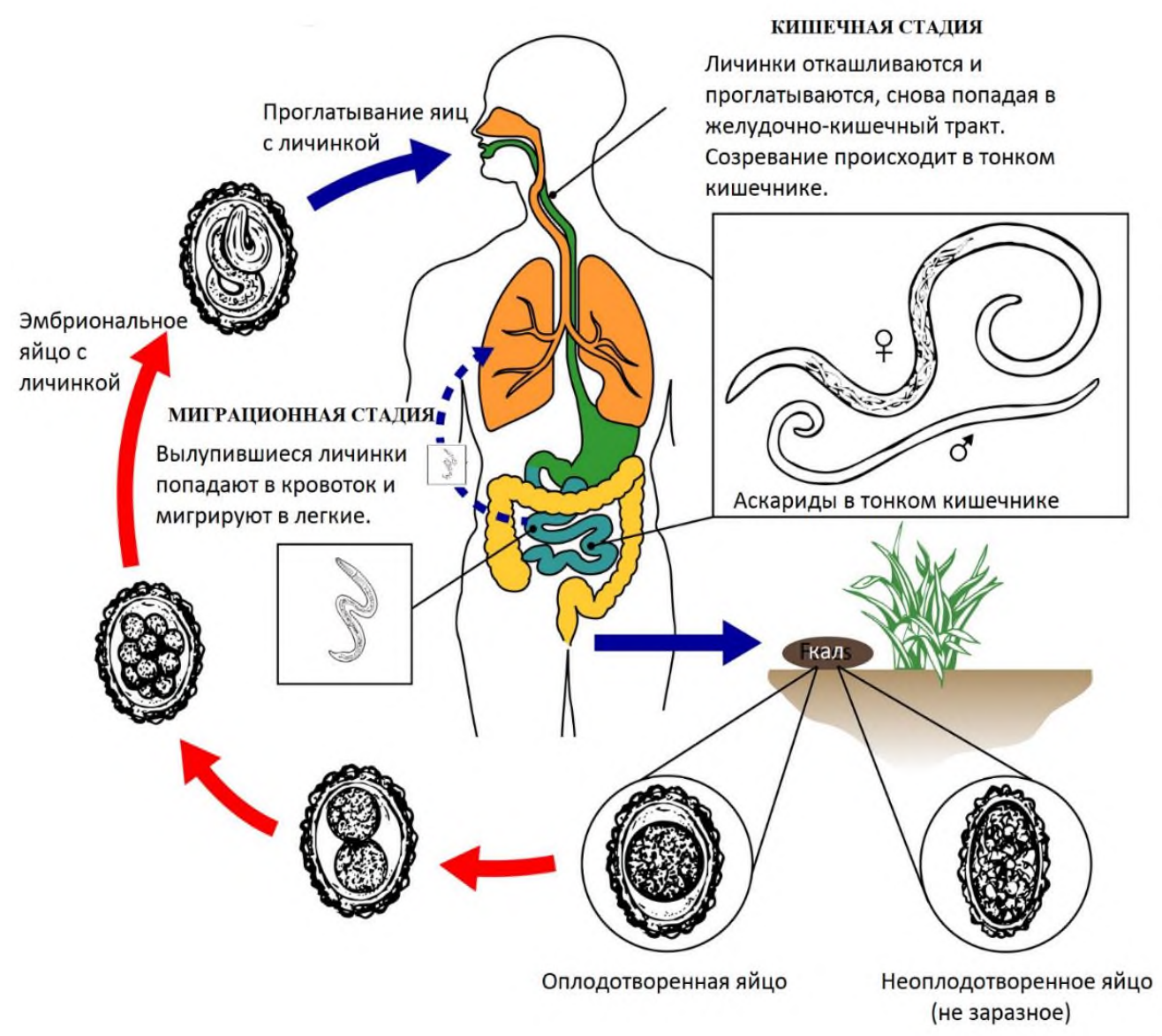

Рис. 29. Жизненный цикл аскарид.

(В рисунке использованы элементы изображение DPD CDC)

Личинки созревают в легких (от 10 до 14 дней), проникают через альвеолярные стенки, поднимаются по бронхиальному дереву к глотке и проглатываются. Достигнув тонкой кишки, они превращаются во взрослых червей. От приема инфекционных яиц до их откладки взрослой самкой требуется от 2 до 3 месяцев. Взрослые черви могут жить от 1 до 2 лет. Длина взрослого гельминта составляет $25-30 \mathrm{~cm}$.

В клиническом течении при аскаридозе выделяют миграционную и кишечную стадию.

Миграционная стадия в раннюю фазу болезни (на 2-3-й день после заражения) больные отмечают недомогание, слабость, потливость, раздражительность, иногда сочетающиеся с субфебрильной (реже более высокой) температурой. Характерны для этой стадии изменения на коже, которые часто проявляются в виде крапивницы и мелких пузырьков с прозрачным содержимым на кистях и стопах. При миграции личинок в дыхательные пути (на 3-7-й день после заражения) возникают кашель (сухой или с отделением слизистой мокроты), одышка, боли в груди, иногда кровохарканье. Выслушиваются сухие (реже влажные) хрипы при менее отчетливых изменениях 
перкуторного звука. Чаще всего эти данные служат основанием для диагноза “банальной пневмонии”; «астматического компонента», иногда картина миграционной стадии может ввести малоопытного клинициста в заблуждение, заставив его заподозрить у пациента респираторный аллергоз.

При рентгенологическом исследовании легких отмечается наличие округлых, овальных, звездчатых, фестончатых, многоугольных инфильтратов. Инфильтраты могут быть как одиночными, так и множественными. Контуры их неровные, расплывчатые. Эозинофильные инфильтраты выявляются в пределах 2-3 недель; у отдельных больных, исчезнув, они появляются вновь спустя некоторое время, сохраняясь месяцами.

Кишечная стадия (через 10-12 дней после заражения) для нее характерны неспецифические клинические проявления - боли в животе, преимущественно в эпигастрии или в правом подреберье, неустойчивость стула (задержка в чередовании с послаблением), сочетающиеся с нарушением аппетита, тошнота; возникают головные боли, головокружение, нарушение сна. Более чем в 85\% случаев инфекции протекают бессимптомно, особенно если количество глистов невелико.

Энтеробиоз - контагиозный антропонозный гельминтоз, вызываемый червями из рода остриц (Enterobius vermicularis). В XXI веке - самый распространённый гельминтоз человека. Энтеробиоз один из наиболее эволюционно адаптированных к существованию в организме человека гельминтозов. Яйца остриц были обнаружены в человеческих копролитах (7800 лет до н.э.), что позволяет считать их древнейшими из обнаруженных паразитов человека.

Жизненный цикл начинается с проглатывания яиц (рис.30). Из яйца в двенадцатиперстной кишке выходят личинки. Личинки остриц быстро вырастают до размеров от 140 до 150 микрометров и мигрируют через тонкий кишечник к толстой кишке. Во время этой миграции они дважды линяют и становятся взрослыми. Самки живут от 5 до 13 недель, а самцы - около 7 недель. Мужские и женские острицы спариваются в подвздошной кишке, после чего мужские острицы обычно умирают.

Беременной самки остриц оседают в подвздошной, слепой кишки, аппендиксе и восходящей ободочной кишки. Почти все тело беременной самки заполнено яйцами (от 11000 до 16 000). Процесс откладывания яиц начинается примерно через пять недель после того, как человек-хозяин впервые проглотил яйца острицы. Острицы мигрируют через толстую кишку к прямой кишке со скоростью от 12 до 14 сантиметров в час, выходят из заднего прохода, и, перемещаясь по коже около заднего прохода, откладывают яйца. После откладывания яиц самка умирает. 


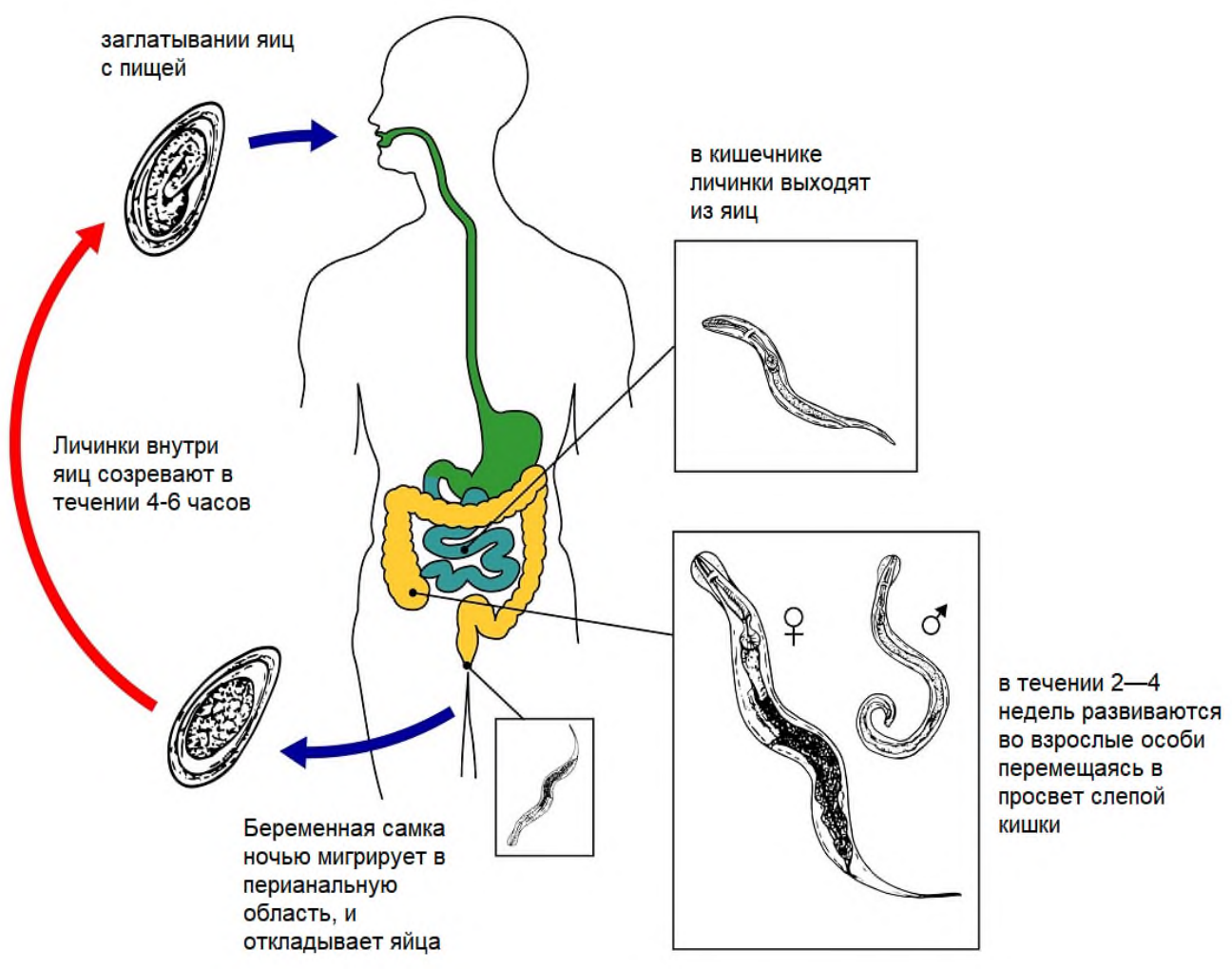

Рис. 30. Жизненный цикл остриц.

(В рисунке использованы элементы изображение DPD CDC)

Выраженность клинических проявлений энтеробиоза зависит от индивидуальной реактивности организма больного и от интенсивности инвазии. В связи с этим у части больных он может протекать субклинически или бессимптомно. Ранняя фаза нередко клинически латентна.

Далее наблюдается прогрессирующие зуд и жжение в перианальной, а иногда и более широкой зоне (промежность, половые органы, бедра, живот), возникающие вечером или ночью в результате выползания остриц из анального отверстия. Зуд обусловлен механическим воздействием самих гельминтов и химического действия их секрета на кожу и держится 3 - 4 дня, затем проходит, через 2 - 3 недели опять появляется и вновь исчезает. Такая периодичность обусловлена созреванием новых поколений самок, попадающих в кишечник в результате экзогенных аутоинвазий. По мере возрастания интенсивности инвазии зуд приобретает постоянный характер и изнуряет больного. В связи с интенсивным зудом происходит нарушение сна, появляется раздражительность.

На зудящих местах, вследствие расчесов, возникают воспалительные процессы, ссадины, трещины и экземы, нередко присоединяется вторичная инфекция, приводящая к развитию пиодермии.

При тяжелом течении могут быть боли в животе, жидкий стул с императивными позывами, ночное недержание мочи. Могут развиться сфинктерит, парапроктит. 
У женщин зуд и заползание остриц в вагину вызывают вульвовагиниты. Иногда острицы проникают в полость матки, фаллопиевы трубы и в брюшную полость, приводя к образованию гранулем и флегмон.

Дифиллоботриоз - зоонозный биогельминтоз с хроническим течением, характеризующийся нарушением функций верхнего отдела пищеварительного тракта, а при тяжелом течении - развитием анемии. Возбудители - более 10 видов лентецов из рода Diphyllobothrium. На территории РФ и в континентальных водоемах Северной Европы род Diphillobothrium представлен 4 видами: D. latum, D. dendriticum (D.minus), D.ditremum, D.vogeli. Наиболее изучен и имеет наибольшее клиническое значение - Diphyllobothrium latum (лентец широкий). Относительно недавно на Дальнем Востоке обнаружен новый вид лентеца - D. klebanovski, который приспособлен к существованию в соленой воде (до $20 \%$ соли), однако случаев паразитирования этого вида гельминтов у человека достоверно не выявлено.

Инвазия регистрируется главным образом в районах с пресноводными водоемами. На территории РФ выделяют 6 речных и озерных зон с относительно высоким риском заражения дифиллоботриозом: Северо-Западная, ВолжскоКамская, Обь-Иртышская, Енисейско-Ленская, Дальневосточная, ЧерноморскоАзовская.

Попадая в желудочно-кишечный тракт окончательного хозяина, плероцеркоид прикрепляется к слизистой оболочке начальной части тонкой кишки (рис.31).

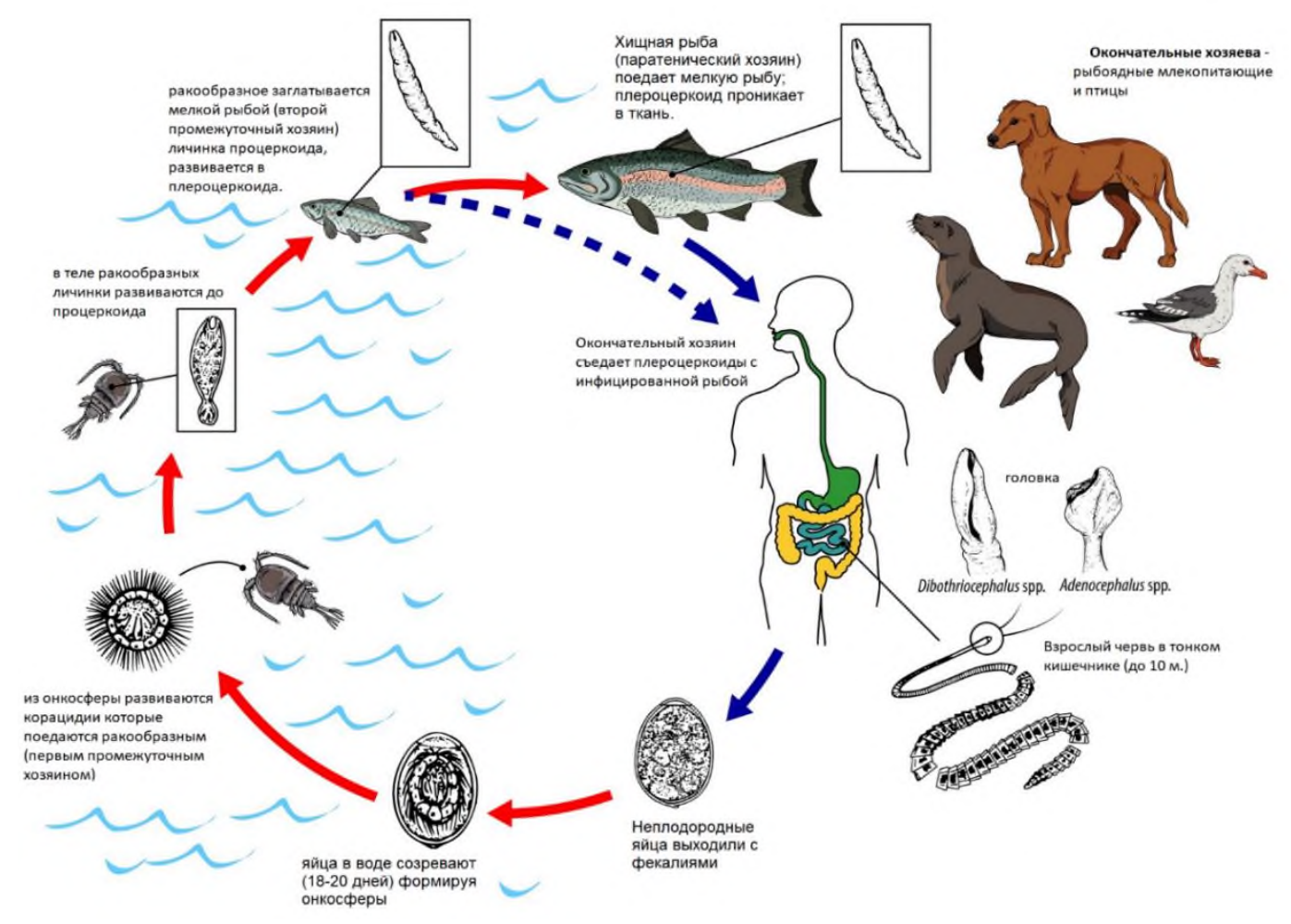

Рис. 31. Жизненный цикл дифиллоботрий.

(В рисунке использованы элементы изображение DPD CDC) 
Через 14 - 30 дней паразит достигает стадии половозрелой особи (мариты) и начинает выделять яйца. Весь цикл развития продолжается 15 - 25 недель. Количество яиц очень велико и может достигать 2 млн в 1 г фекалий. Продукция огромного количества яиц компенсирует гибель большинства личинок на первых стадиях цикла развития. В кишечнике человека обычно обитает одна, иногда несколько особей лентеца широкого, но отмечены случаи паразитирования 100 и более экземпляров. Продолжительность жизни широкого лентеца может достигать 20 и более лет.

Окончательный диагноз устанавливается при обнаружении в кале яиц гельминта или фрагментов стробилы. Поскольку в кале содержится большое количество яиц, они обычно легко обнаруживаются даже методом нативного мазка.

Тениозы - антропонозный биогельминтоз с хроническим течением, характеризующийся преимущественно желудочно-кишечными расстройствами. Вызывают инвазию у людей: Taenia solium (свиной цепень), Taenia saginata или Taeniarhynchus saginata (бычий цепень) и Taenia asiatica (азиатский цепень). Taenia saginata возникает из-за употребления зараженной недоваренной говядины, а Taenia solium и Taenia asiatica - из зараженной недоваренной свинины. При употреблении в пищу яиц $T$. solium, выделенных из организма человека с фекалиями развивается цистицеркоз. Тениозы распространены по всему миру.

Крупный рогатый скот и свиньи заражаются при поедании растений, зараженных яйцами или проглоттидами (рис.32). В кишечнике животного вылупляются онкосферы, они проникают в стенку кишечника и мигрируют в поперечнополосатые мышцы, где развиваются в цистицерки.

Цистицерк может жить у животного несколько лет. Люди заражаются при употреблении в пищу сырого или недоваренного инфицированного мяса. В кишечнике человека цистицерки развиваются в течение 2 месяцев во взрослого ленточного червя, который может жить годами прикрепляясь к тонкой кишке своими сколексами и располагаются в тонкой кишке.

Длина взрослых червей обычно составляет 5 м или меньше для T. saginata (однако она может достигать 25 м) и от 2 до 7 м для T. solium. Длительность инвазии составляет несколько десятков лет (до 25). Taeniarhynchus saginata обычно паразитирует в единственном числе, откуда старое название паразита солитер (от франц. solitare - одинокий), но крайне редко в интенсивных очагах может встречаться и множественная инвазия. Взрослые особи продуцируют проглоттиды, которые созревают, беременеют, отделяются от ленточного червя и мигрируют в задний проход или выводятся с калом. Взрослые особи T. saginata обычно имеют от 1000 до 2000 проглоттид, а взрослые особи Т. solium имеют в среднем 1000 проглоттидов. Яйца, содержащиеся в проглоттидах, высвобождаются. В одном проглоттид содержится у Т. saginata до 100000 яиц, а у Т. solium - 50000 яиц. 


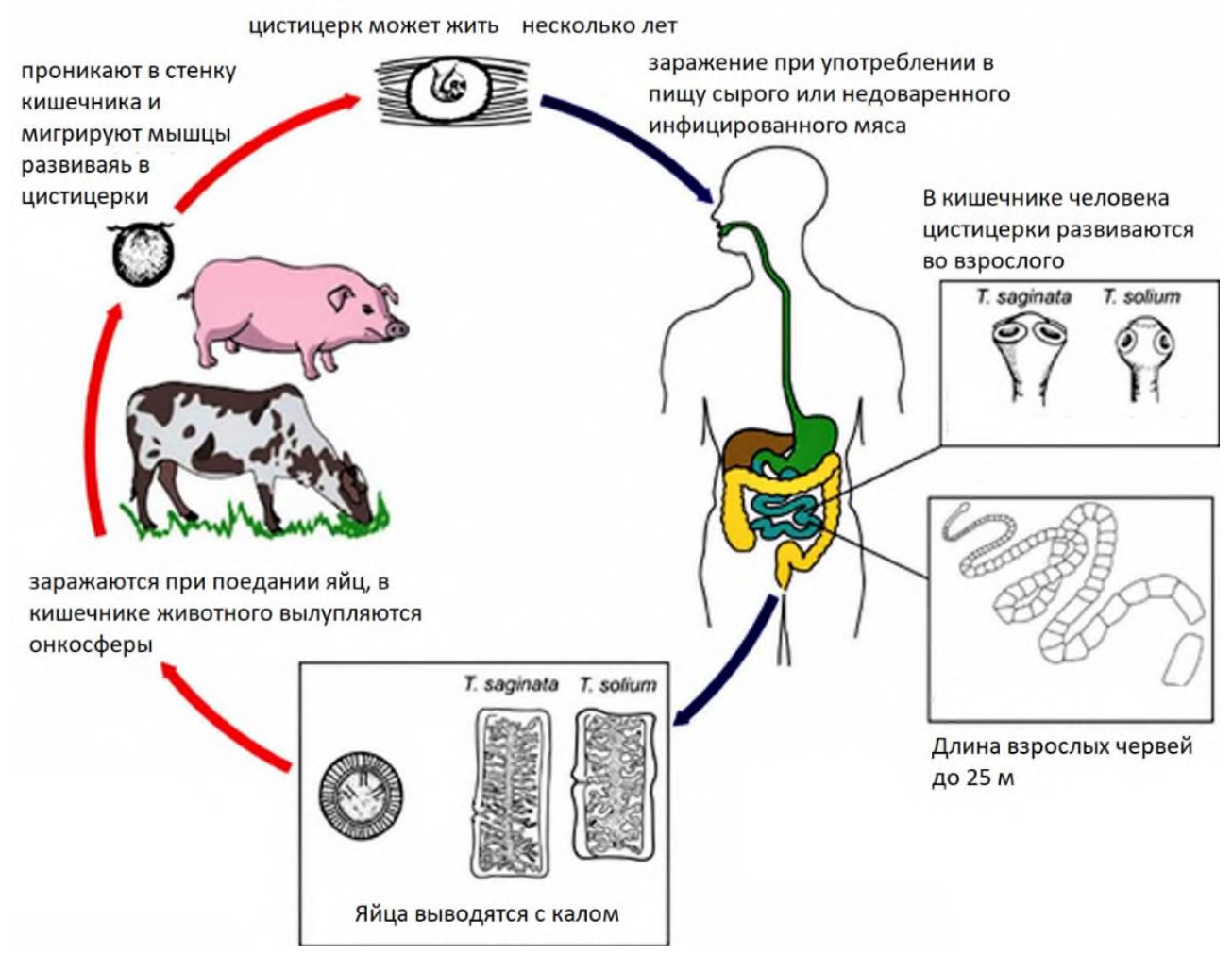

Рис. 32. Жизненный цикл цепней.

(В рисунке использованы элементы изображение DPD CDC)

Человек заражается при употреблении в пищу сырого или полусырого мяса, содержащего финны (финнозное мясо). Финны могут оставаться живыми в шашлыке, недостаточно проваренном мясе, в строганине из слабомороженного мяса, в фарше, который некоторые люди пробуют или едят сырым и т. д. Человек является единственным окончательным хозяином при тениозе.

Гименолепидоз - контактный биогельминтоз человека, вызывается двумя видами цестод (ленточных червей): Hymenolepis nana (карликовый цепень, взрослые особи размером от 15 до 40 мм) и Hymenolepis diminuta (крысиный цепень, взрослые особи размером от 20 до 60 см). Hymenolepis diminuta - цестода грызунов, редко встречающаяся у людей. Половозрелые и личиночные формы гельминтов паразитируют в кишечнике одного хозяина, что сопровождается поражением желудочно-кишечного тракта.

Гименолепидоз является одним из наиболее распространенных гельминтозов в мире, встречается повсеместно, особенно часто в странах с сухим жарким климатом. Дети болеют в 4-5 раз чаще, чем взрослые. Очаги гименолепидоза могут возникать в детских дошкольных учреждениях и в закрытых детских учреждениях (детские дома, интернаты и др). В России наиболее высокая заболеваемость гименолепидозом отмечается на Северном Кавказе, в ближнем зарубежье - в Туркменистане, Узбекистане, Казахстане, 
Кыргызстане и Молдавии. Гименолепидоз часто регистрируют в средиземноморских странах, на полуострове Индостан, в Южной Америке.

Источником заражения гименолепидозом является человек. Механизм передачи - фекально-оральный, пути передачи - контактно-бытовой и пищевой.

Факторами передачи карликового цепня являются загрязненные яйцами гельминта руки, горшки, предметы личной гигиены, дверные ручки, пищевые продукты, а также мухи, тараканы, на которых яйца гельминта Hymenolepis nana сохраняют свою жизнеспособность в течение 24 часов. Яйца Hymenolepis nana чувствительны к высыханию и воздействию высокой температуры. Они способны сохраняться на руках человека в течение 2 х часов; при высушивании на предметных стеклах при комнатной температуре погибают через 60-70 часов; в речной воде в летнее время сохраняют жизнеспособность около 1 месяца. У взрослых больных гименолепизозом имеет место тесный контакт с детьми (обслуживающий персонал в детских учреждениях, матери больных детей), поэтому для заболевания характерны семейные очаги.

Инвазионные яйца заглатываются человеком, попадают в проксимальные отделы тонкой кишки, из яиц освобождаются онкосферы и внедряются в кишечные ворсинки, где происходит их превращение в ларвоцистыцистицеркоиды (5-7 дней). Цистицеркоиды выходят в просвет кишечника, поступают в дистальные отделы тонкой кишки, где в течение 2-2,5 месяцев развиваются в половозрелые особи (рис.33).

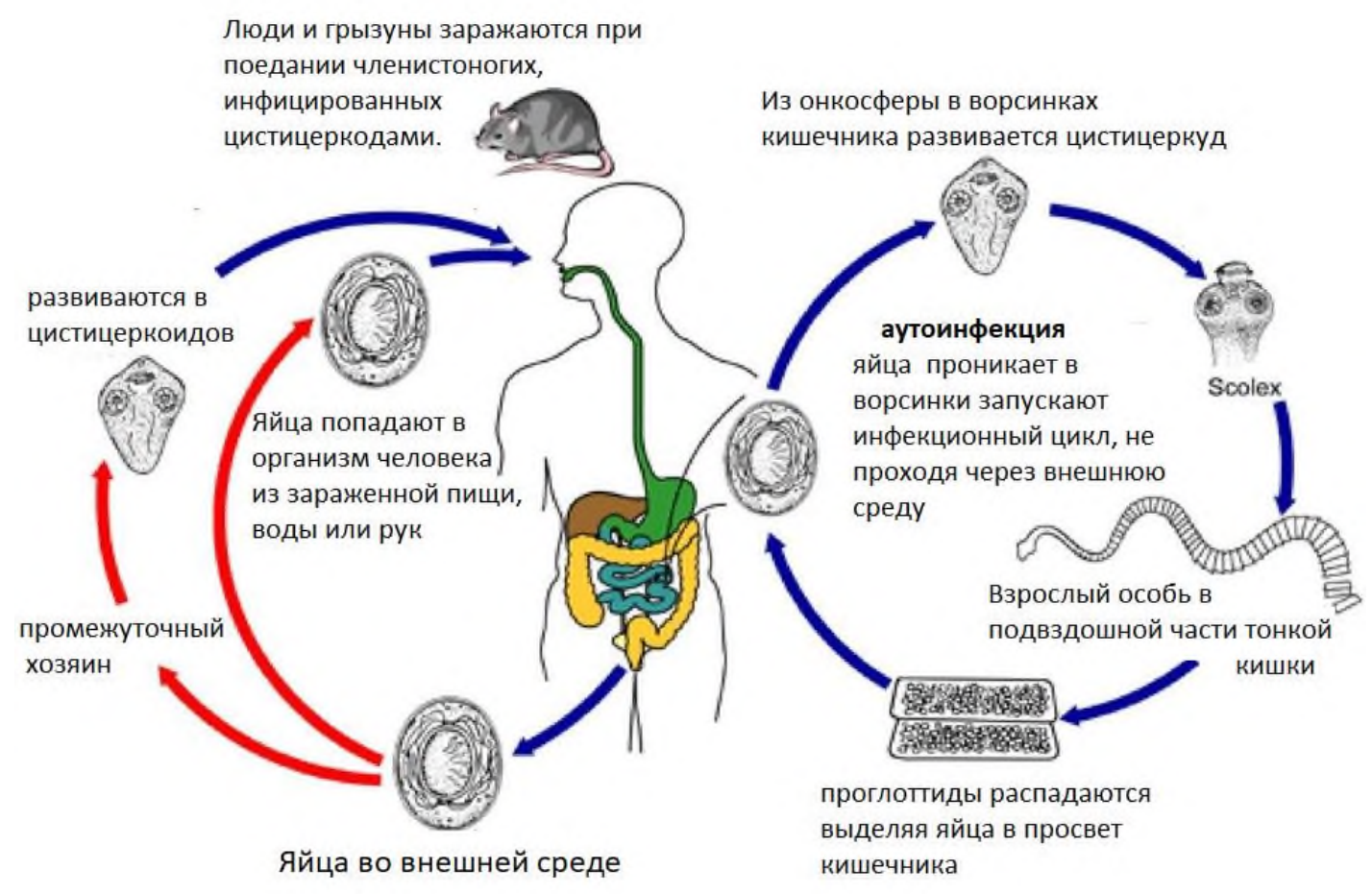

Рис. 33. Жизненный цикл карликового цепня.

(В рисунке использованы элементы изображение DPD CDC) 
В редких случаях цикл развития Hуmenolepis nana происходит со сменой хозяев, когда промежуточным хозяином служат личинки или имаго насекомых (мучной хрущак, блохи). В организме промежуточного хозяина личинки развиваются до стадии цистицеркоида, а человек заражается при случайном заглатывании инвазированных насекомых.

Инкубационный период гименолепидоза составляет около 2 недель. Чаще всего заболевание протекает бессимптомно (в среднем, у 30\% инвазированных). Степень тяжести зависит от реактивности организма и количества глистов. Считается, что более чем 2000 карликовых цепней проявляются симптомами поражения ЖКТ (тошнота, изжога, нарушение аппетита, рвота, неустойчивый стул, метеоризм; боли в эпигастрии, в правом подреберье без четкой связи с приемом пищи (ноющие и/или приступообразные), нередко наблюдается гепатомегалия и нарушения функции печени, аллергические реакции (кожный зуд, крапивница, ринит, эозинофилия в клиническом анализе крови и др.), симптомы интоксикации (субфебрилитет, головная боль, головокружение, слабость, повышенная утомляемость, раздражительность), неврологические нарушения (сонливость, апатия, судорожные мышечные, подергивания, эпилептиформные припадки, обмороки, бессонница).

Трихоцефалез - антропонозный геогельминтоз, проявляющийся диспепсическим синдромом и невротическими явлениями. Характеризуется хроническим течением (до 3 - 5 лет). Нередко протекает бессимптомно или субклинически. Вызывается Trichuris trichiura, также называемая власоглавом человека.

Паразитирует власоглав только у человека, локализуясь преимущественно в слепой кишке, но в случае интенсивной инвазии может заселять всю толстую кишку и конечный отдел тонкой кишки. Заражение происходит через рот при проглатывании инвазионных яиц, развивающихся и сохраняющихся в почве (рис.34).

Попав с пищей или водой в кишечник человека, личинки выходят из яйцевых оболочек и внедряются в ворсинки слизистой оболочки тонкой кишки, где развиваются около $10-12$ суток, а затем выходят в просвет кишечника, спускаются в слепую кишку и своими тонкими передними концами внедряются в слизистую оболочку ее стенки. Они питаются клетками эпителия кишечника и кровью хозяина (факультативный гематофаг).

В течение месяца паразиты достигают половой зрелости. Выделение яиц с фекалиями начинается примерно через 6 недель после заражения. Продолжительность жизни власоглава 5 - 6 лет и более. Интенсивность инвазии может быть различной - от одного, до десятков и сотен, описаны единичные случаи паразитирования до 2500 экземпляров. 


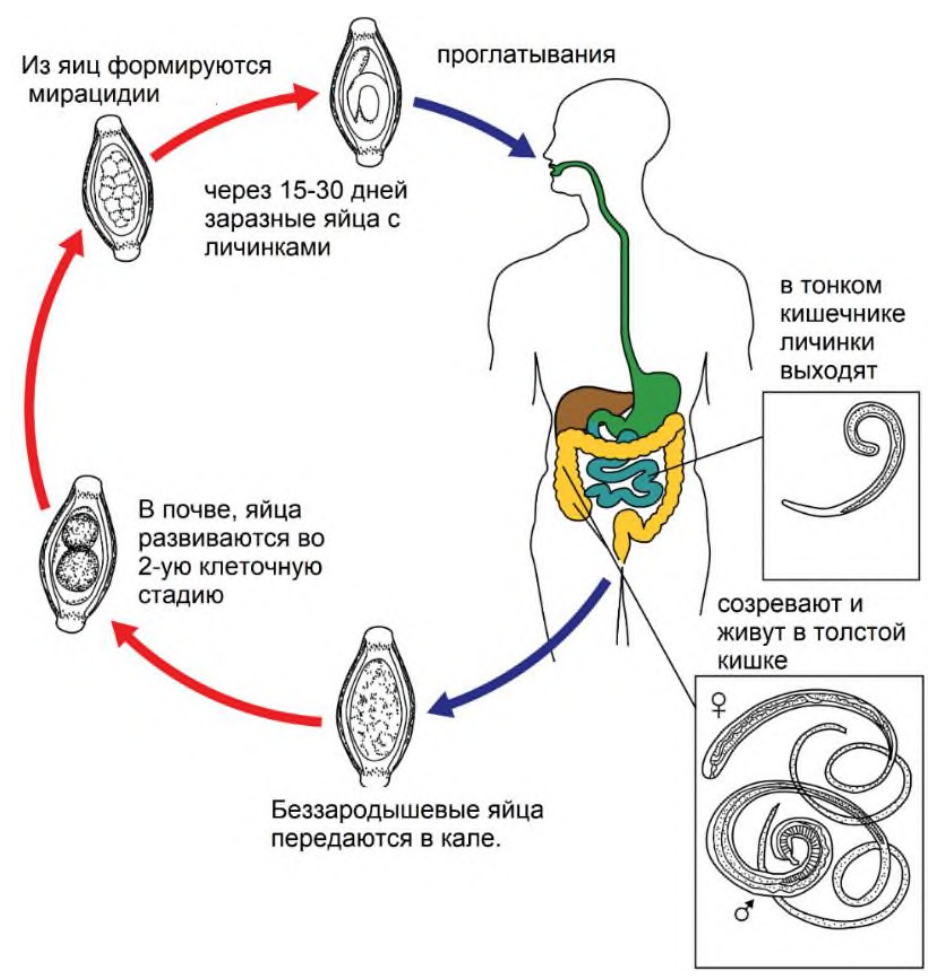

Рис. 34. Жизненный цикл возбудителя при трихоцефалезе.

(В рисунке использованы элементы изображение DPD CDC)

Для клинического проявления инвазии требуется наличие большого количества взрослых паразитов. Инвазия единичными паразитами обычно вызывает незначительные клинические проявления или протекает латентно. Явная клиническая картина болезни развивается при интенсивной инвазии (2001000 экземпляров паразитов и выше, что соответствует наличию 30 тысяч яиц или более в 1 мл фекалий).

Зараженные люди теряют 0,005 мл крови на 1 паразита в день, поэтому при инвазии более чем 800 паразитов развивается гипохромная анемия, невыраженный лейкоцитоз, умеренная эозинофилия.

Тяжелое течение гельминтозов обычно имеет место только у детей. Клиническая картина тяжелой инвазии проявляется в виде гемоколита,

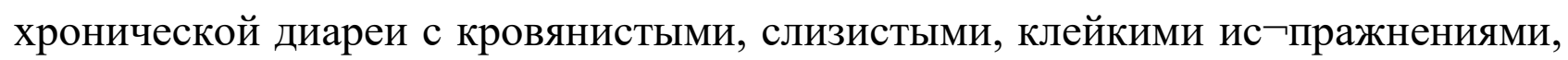
тенезмами, болями в животе, похуданием.

Стронгилоидоз - $а$ антропонозный хронически протекающий геогельминтоз с преимущественным поражением желудочно-кишечного тракта и общими аллергическими проявлениями, вызывается Strongyloides stercoralis, иногда C. Fülleborni (угрица кишечная). Гельминтоз, передается через почву. По самым низким оценкам считается, что он поражает 30-100 миллионов человек во всем мире, главным образом в тропических и субтропических странах, в то время некоторые исследователи считают, что в мире инфицировано до 370 миллионов человек. 
Половозрелые паразиты обитают в двенадцатиперстной и тощей кишках человека. Самцы находятся в просвете кишки, самки зарываются в толщу слизистой оболочки. Длительность жизни гельминта в кишечнике составляет несколько месяцев. Каждая самка выделяет в сутки до 50 яиц с уже сформировавшимися личинками. Личинки покидают яйцевые оболочки, находясь в кишечнике человека. Иногда, хотя и редко, яйца можно обнаружить в жидком стуле больного, при диарее. Личинки, попавшие вместе с фекалиями в условия среды, через 1-2 дня линяют и превращаются в инвазионных нитевидных личинок. При контакте с кожей человека инвазионные личинки внедряются в нее, проникают в капилляры и мигрируют по кровеносным сосудам в легкие. Затем по дыхательным путям поднимаются в глотку, из нее попадают в кишечник, локализуются и развиваются там до половой зрелости. В кале личинки появляются через 17-28 дней после заражения (рис.38).

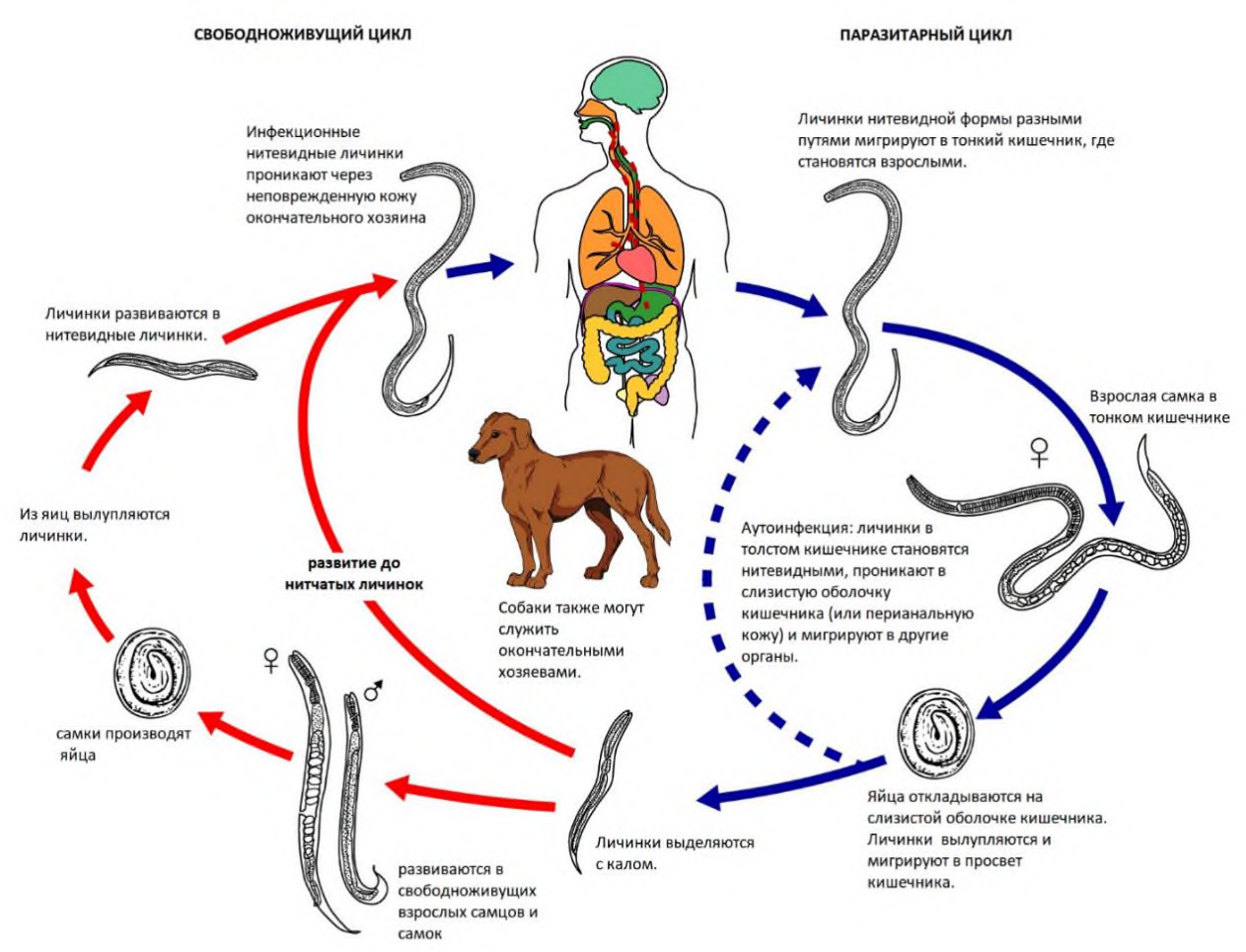

Рис. 35. Жизненный цикл возбудителя при стронгилоидозе.

(В рисунке использованы элементы изображение DPD CDC)

Значительно реже личинки попадают в кишечник человека через рот вместе с пищей или водой. Но и в этом случае они проникают через слизистую оболочку ротовой полости в кровеносные сосуды и проделывают тот же миграционный путь, что и личинки, внедрившиеся в кожу.

В местах внедрения личинок появляются кожный зуд, эритематозные и папулезные высыпания, которые исчезают через 30-40 минут. При повторных 
заражениях местная реакция выражена сильнее и более продолжительна. Локальные аллергические дерматиты возникают преимущественно на коже стоп и пальцев, где наиболее часто происходит внедрение личинок. Через несколько часов в этих местах появляются отеки, распространяющиеся на тыльную поверхность стоп и кистей, возникают боли в суставах пальцев.

Миграционная фаза у большинства инвазированных протекает бессимптомно. В раннюю фазу болезни больные могут отмечать недомогание, слабость, сочетающиеся с субфебрильной (реже более высокой) температурой. Появляются полиморфные высыпания на коже (уртикарные, эритематознопапулезные, мелко - или крупнопятнистые, по типу «вульгарной пузырчатки»), сопровождающиеся кожным зудом, возникает кашель с мокротой, бронхоспазмом и астматическим компонентом. В легких прослушиваются сухие и влажные хрипы. Рентгенологически выявляются «летучие инфильтраты» и пневмонические очаги. Иногда, особенно при пероральном заражении, появляются боли в животе, тошнота, рвота, диарея, увеличиваются печень и селезенка. Характерным признаком ранней стадии стронгилоидоза является гиперэозинофилия до $30-60 \%$. Отмечается также лейкоцитоз и повышение СОЭ.

Кишечная стадия, признаки которой появляются через 4 - 5 недель после заражения, связана с процессами воспаления слизистой оболочки кишечника в местах паразитирования взрослых червей.

Основной симптом кишечной стадии заболевания - диарея. Стул учащается до 20 и более раз в сутки, он обычно водянистый, иногда с примесью слизи и крови. При тяжелом течении болезни диарея становится непрерывной. Испражнения приобретают гнилостный запах и содержат много остатков непереваренной пищи, слизь и кровь. При длительном течении стронгилоидоза поносы нередко чередуются с запорами, способствующими аутоинвазии. Развиваются тяжелая вторичная анемия и кахексия.

Течение заболевания может быть длительным (латентным) с обострениями через 5-8 лет после инфицирования; это подтверждается длительным паразитированием нитевидных личинок (более 30 лет) у лиц, выехавших из эндемичных районов.

У некоторых больных клинические проявления заболевания могут отсутствовать, но при иммунодефиците имеется угроза развития гиперинвазионного синдрома с развитием тяжелой пневмонии, менингита, паралитического илеуса и летального исхода.

Анкилостомоз - это инфекция, вызываемая двумя распространенными кишечными паразитами, известными как Ancylostoma duodenale u Necator americanus. По оценке ВО3, от 576 до 740 миллионов человек инфицированы анкилостомозом. Основной причиной заражения анкилостомами является 
N.americanus, который встречается в Северной и Южной Америке, Африке к югу от Сахары и в Азии. A. duodenale встречается в более рассеянных очаговых средах, а именно в Европе и Средиземноморье.

Человек заражается при контакте со свободноживущими личинками обычно при хождении босиком по зараженной почве. Личинки проникают через кожу и переносятся по кровеносным сосудам в сердце, а затем в легкие. Они проникают в легочные альвеолы, поднимаются по бронхиальному дереву к глотке и проглатываются, достигают тощей кишки тонкой кишки, где живут и созревают во взрослых особей. Взрослые черви живут в просвете тонкой кишки, обычно в дистальном отделе тощей кишки, где прикрепляются к стенке кишечника, что приводит к потере крови хозяином. Большинство взрослых глистов уничтожаются за 1-2 года, но продолжительность жизни может достигать нескольких лет. Самки откладывают до 30000 яиц в день и от 18 до 54 миллионов яиц в течение жизни, которые выходят с фекалиями (рис.36).

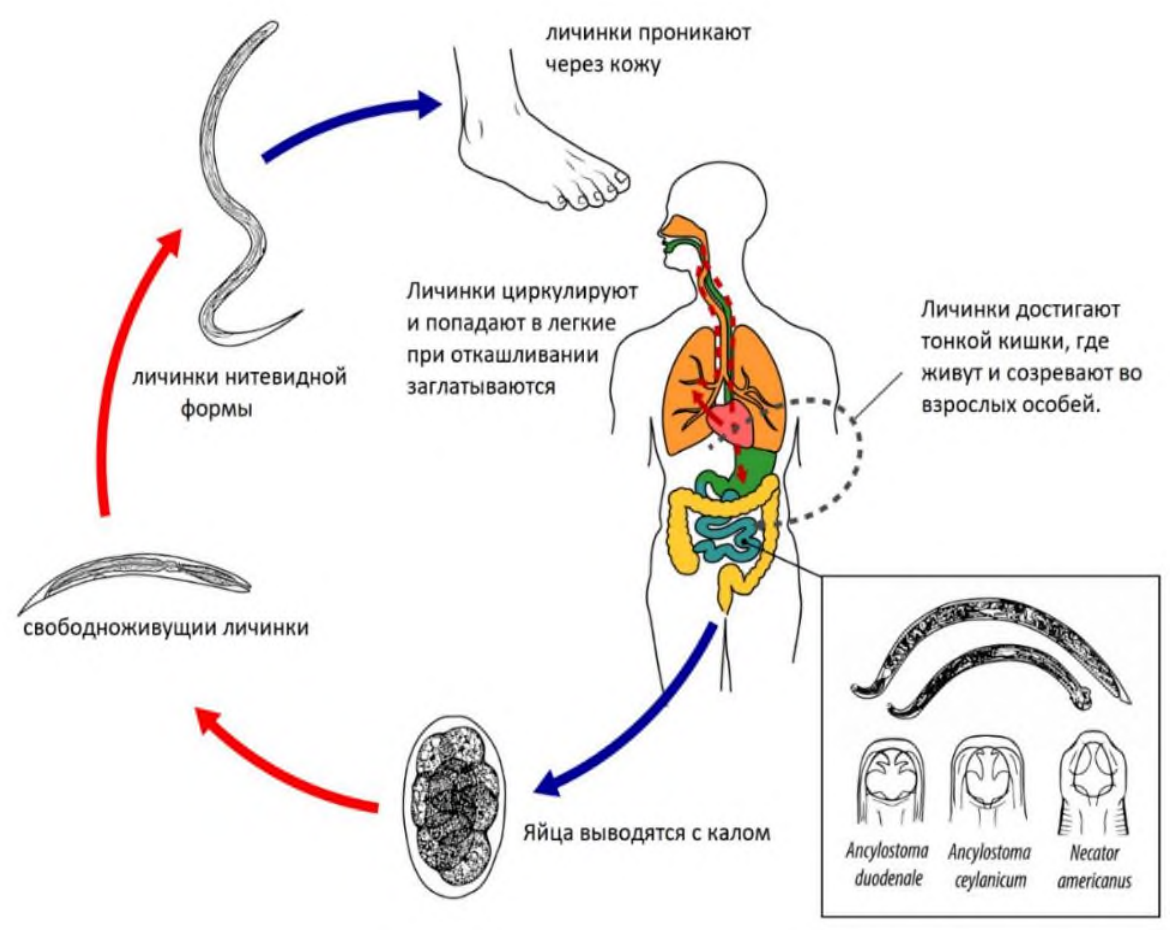

Рис. 36. Жизненный цикл возбудителя при анкилостомозе.

(В рисунке использованы элементы изображение DPD CDC)

Яйца выводятся с калом, и при благоприятных условиях (влажность, тепло, тень) личинки вылупляются через 1-2 дня и становятся свободноживущими в зараженной почве. Эти выпущенные рабдитовидные личинки растут в фекалиях и/или почве, и через 5-10 дней они становятся инфекционными личинками нитевидной формы. Эти инфекционные личинки могут выжить от 3 до 4 недель в благоприятных условиях окружающей среды заражая человека. 


\section{Гельминтозы гепатобилиарной системы}

Описторхоз - природноочаговый биогельминтоз, характеризующийся поражением гепатобилиарной системы и поджелудочной железы. Возбудитель плоский червь, сосальщик Opisthorchisfelineus (кошачья (сибирская) двуустка) и Opisthorchi. viverrini (беличья двуустка).

Крупнейший в мире природный очаг описторхоза, расположен в ОбьИртышском бассейне, до настоящего времени здесь регистрируются наиболее высокие показатели заболеваемости населения (до 500 на 100 тыс.). В бассейнах рек Северной Двины, Камы, Волги, Урала, Дона, Днепра, Десны, Южного Буга и Немана также существуют природные очаги описторхоза, но они менее интенсивны. В Красноярском крае основной очаг описторхоза расположен в бассейне р.Чулым (Балахтинский, Ирбейский, Тюхтецкий, Ширинский и др. районы). Описторхоз выявляется также в ряде стран Европы - во Франции, Болгарии, Голландии, Италии, Швейцарии, Швеции, Польше и Румынии. Инвазии О. viverrini отмечают в Таиланде и некоторых странах Индокитая.

Взрослые двуустки откладывают полностью развитые яйца, которые выводятся с калом (рис.37). После проглатывания улиткой (первым промежуточным хозяином) из яиц выделяются мирацидии, они проходят у улитки несколько стадий развития (спороцисты, редии, церкарии). Церкарии высвобождаются из улитки и проникают в пресноводную рыбу семейства карповых (карп, язь, елец, чебак, плотва, вобла, линь, сазан, лещии др.), инцистируя метацеркарии в мышцах или под чешуей (второй промежуточный хозяин).

Окончательный хозяин-млекопитающее (кошки, собаки и различные рыбоядные млекопитающие, включая человека) заражаются при поедании недоваренной рыбы, содержащей метацеркарии. После проглатывания метацеркарии выделяются в двенадцатиперстной кишке и поднимаются через ампулу Фатера в желчные протоки, где они прикрепляются и развиваются во взрослых особей, которые откладывают яйца через 3-4 недели. Взрослые двуустки (O. viverrini : от 5 до 10 мм на 1 мм до 2 мм; O. felineus : от 7 до 12 мм на 2 мм до 3 мм) проживают в желчных и панкреатических протоках млекопитающего-хозяина, где они прикрепляются к слизистой оболочке.

Источником заражения являются инвазированные описторхисами люди, а также домашние и дикие плотоядные животные, в рацион которых входит рыба. Заражение человека происходит при употреблении в пищу сырой или необеззараженной путем нагревания, замораживания или засолки рыбы, содержащей жизнеспособных метацеркариев. 


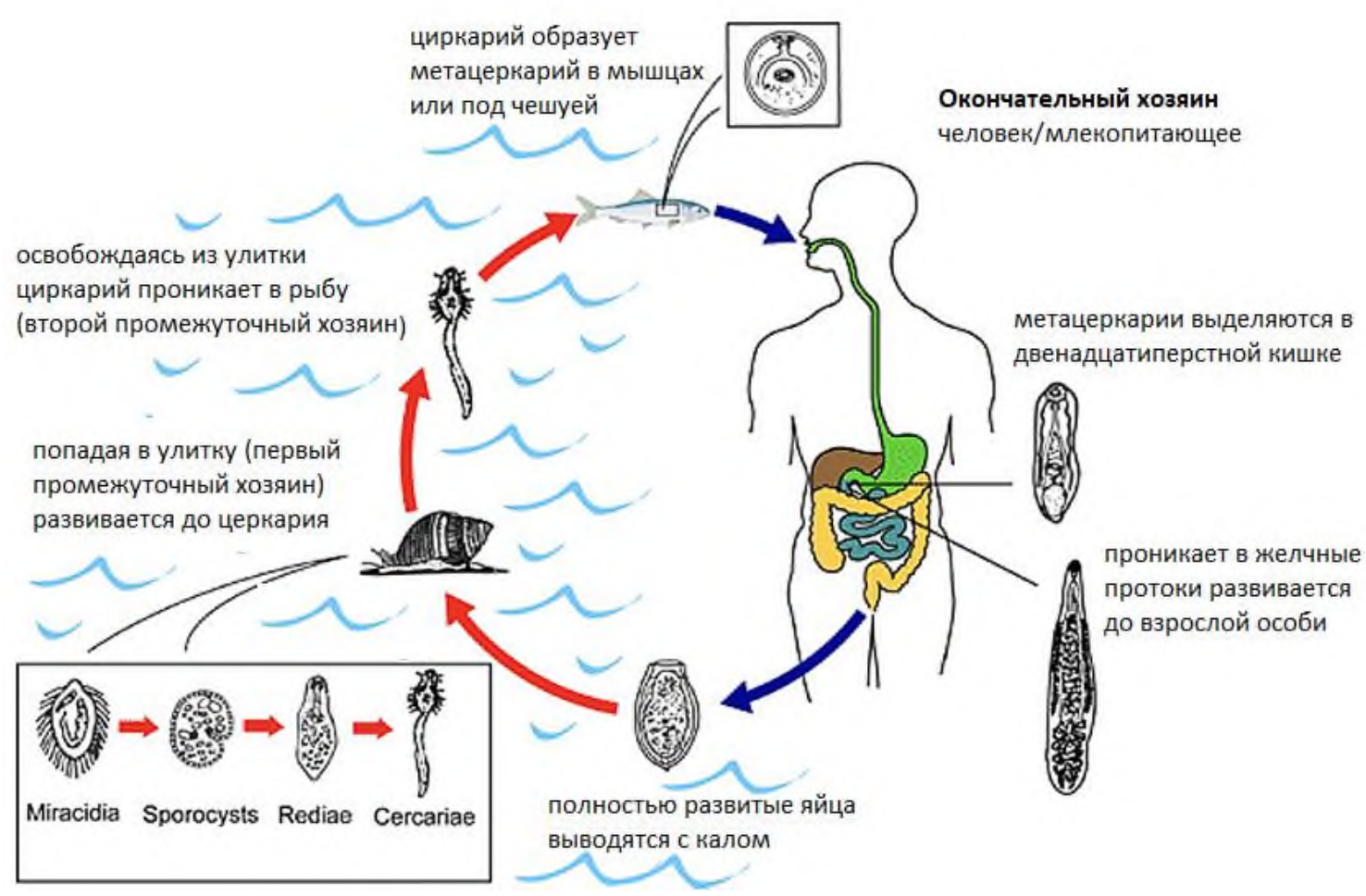

\section{Рис. 37. Жизненный цикл возбудителя при описторхозе.}

(В рисунке использованы элементы изображение DPD CDC)

Основную роль в патогенезе описторхоза играют: аллергические реакции (особенно выраженные в ранней фазе болезни), которые возникают в результате выделения гельминтами продуктов их обмена веществ; механическое воздействие гельминтов, которое состоит в повреждении стенок желчных и панкреатических протоков и желчного пузыря присосками и шипиками, покрывающими поверхность тела гельминта. Скопление паразитов обусловливает замедление тока желчи и секрета поджелудочной железы; нервнорефлекторные влияния посредством раздражения гельминтами нервных элементов протоков, в результате чего возникают патологические нервные импульсы, передающиеся прежде всего на желудок и двенадцатиперстную кишку; возникновение условий (дискинезия желчевыводящих путей, скопление в них паразитов, яиц, клеток слущенного эпителия, временное и полное прекращение тока желчи), благоприятных для присоединения вторичной инфекции желчных путей; железистая пролиферация эпителия желчных и панкреатических протоков, которую следует рассматривать как предраковое состояние.

При хроническом описторхозе возможны тяжелые осложнения - абсцессы печени, разрывы паразитарной кисты, а также формирование холангиокарциномы. 
Клонорхоз - инфекционное заболевание, вызываемое китайской печеночной двуусткой (Clonorchis sinensis). Это плоский червь, сосальщик, длиною от 10 до 25 мм, обитает в желчных протоках печени. Жизненный цикл и клиническая картина не отличается от описторхоза, что дает основание объединит этих три паразитов (Opisthorchis viverrine, O. felineus $u$ C. sinensis) к группе папразитов вызывающих клонорхоз. По оценкам, 45 миллионов человек в Европе и Азии в настоящее время инфицированы этими печеночными сосальщиками. Из них 35 миллионов инфицированы $C$. sinensis в основном в Китае, 10 миллионов - O. viverrini в Юго-Восточной Азии и 1,2 миллиона - $O$. felineus в Восточной Европе и России.

Клонорхоз - известный фактор риска развития холангиокарциномы, новообразований желчевыводящей системы.

Фасциолез - зоонозный биогельминтоз, характеризующийся хроническим течением с преимущественным поражением печени и желчевыводящих путей. Возбудителями фасциолеза являются два вида плоских червей, сосальщиков Fasciola hepatica (печеночный сосальщик, 20-30 на 8-12 мм.) и Fasciola. gigantica (гигинский сосальщик, 33- 76 на 7 - 12 мм).

Фасциолез, вызванный Fasciola hepatica, распространен в большинстве стран мира. Особенно часто он встречается в тех регионах Европы, Среднего Востока, Южной Америки и Австралии, где пастбища для крупного рогатого скота расположены ниже уровня моря. В основном регистрируются спорадические случаи, однако во Франции, на Кубе и в Чили были зарегистрированы вспышки, охватившие сотни людей. Описаны вспышки фасциолеза в Прибалтике, Узбекистане и в Грузии. Наиболее интенсивные очаги, связанные с Fasciola gigantica отмечены во Вьетнаме и в других странах ЮгоВосточной Азии, на Гавайских островах и в некоторых странах тропической Африки.

Основным источником заражения служат инвазированные травоядные сельскохозяйственные животные, главным образом крупный рогатый скот. Человек большой роли в эпидемиологии фасциолеза не играет, так как является лишь случайным хозяином паразита (рис.38). Незрелые яйца выводятся по желчным протокам и выводятся с калом изображение. В пресной воде яйца развиваются в течение 2 недель; яйца с личинками выделяют мирацидии, которые вторгаются в подходящего промежуточного хозяина улитку. У улитки паразиты проходят несколько стадий развития (спороцисты, редии, церкарии).

Церкарии выделяются из улиток и энцистируют в виде метацеркарий на водной растительности или других субстратах. Люди и другие млекопитающие заражаются при употреблении в пищу растений, зараженных метацеркариями. 


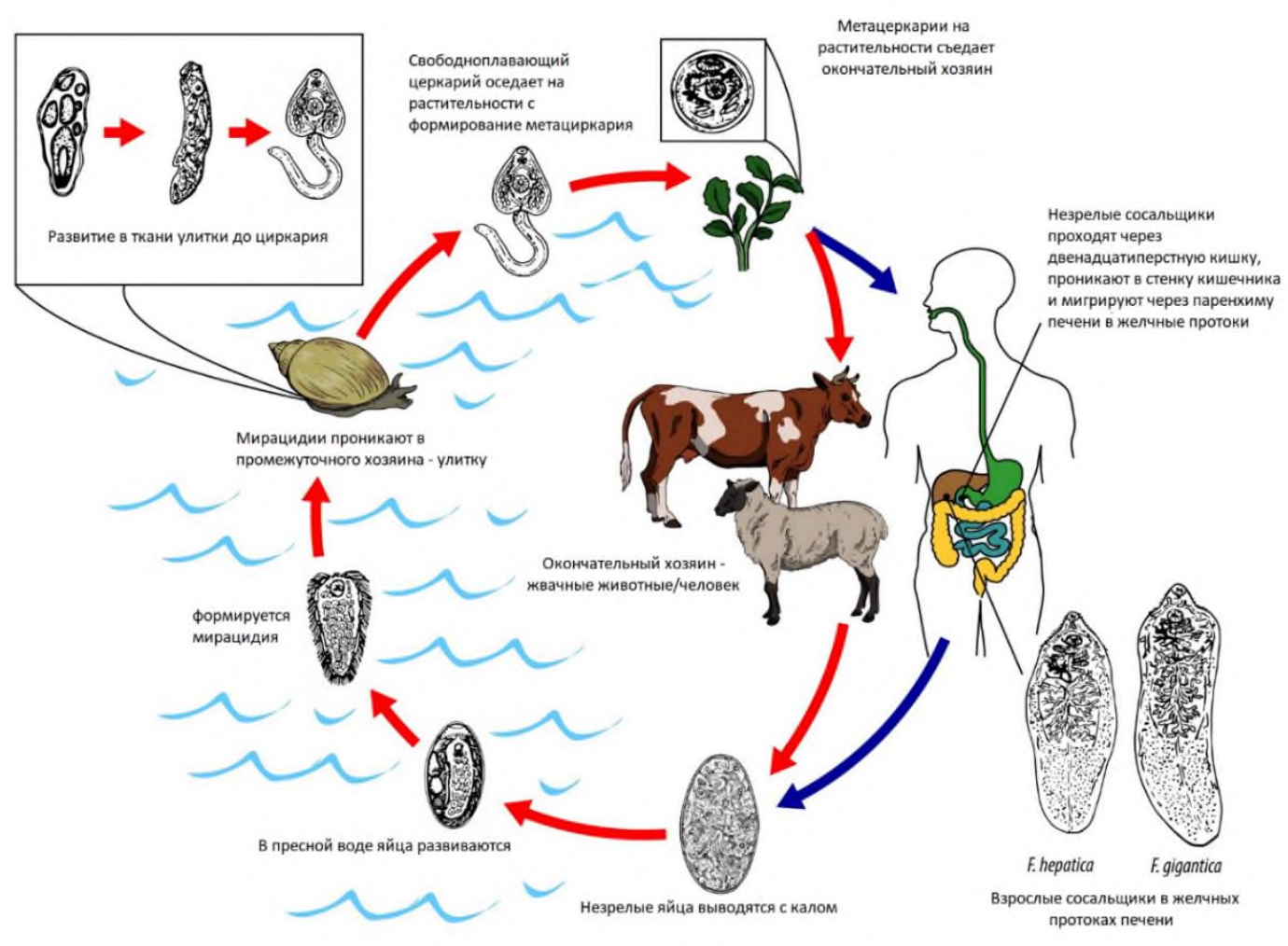

Рис. 38. Жизненный цикл возбудителя при фасциолезе.

(В рисунке использованы элементы изображение DPD CDC)

После проглатывания метацеркарии выделяются в двенадцатиперстной кишке. проникают через стенку кишечника в полость брюшины. Затем незрелые сосальщики мигрируют через паренхиму печени в желчные протоки, где они созревают и превращаются в взрослых сосальщиков и производят яйца. У человека превращение метацеркарий во взрослых сосальщиков обычно занимает около 3-4 месяцев; Развитие F. gigantica может занять несколько больше времени, чем $F$. hepatica.

Клинические проявления опосредованы сенсибилизирующим, токсическим и механическим действием гельминта. Различают острый и хронический периоды (фазы) заболевания.

Поздняя хроническая фаза протекает с выраженными диспептическими расстройствами, поражением печени и желчевыводящих путей, спленомегалией на фоне субфебрильной температуры.

В качестве казуистики отмечается проникновение печеночных двуусток в другие органы, сопровождающееся нарушением их функции.

В ряде случаев фасциолы могут обнаруживаться при ультразвуковом исследовании печени, при нахождении гельминтов в желчном пузыре и крупных желчевыводящих путях. 


\section{Тканевые гельминтозы}

Трихинеллез - зоонозный биогельминтоз, вызываемый личинками трихинелл и характеризующийся острым течением, лихорадкой, выраженными аллергическими проявлениями и поражением поперечнополосатой мускулатуры. Основным возбудителем трихинеллеза человека служит один из видов рода трихинелл - Trichinella spiralis. В меньшей степени человек заражается Trichinella nativa $u$ Trichinella nelsoni, которые циркулируют в основном в природных очагах трихинеллеза среди диких животных.

Половозрелые особи трихинелл (рис.39) обитают в тонком и начальном отделе толстого кишечника у обширного круга млекопитающих животных (боле 100 видов) и у человека.

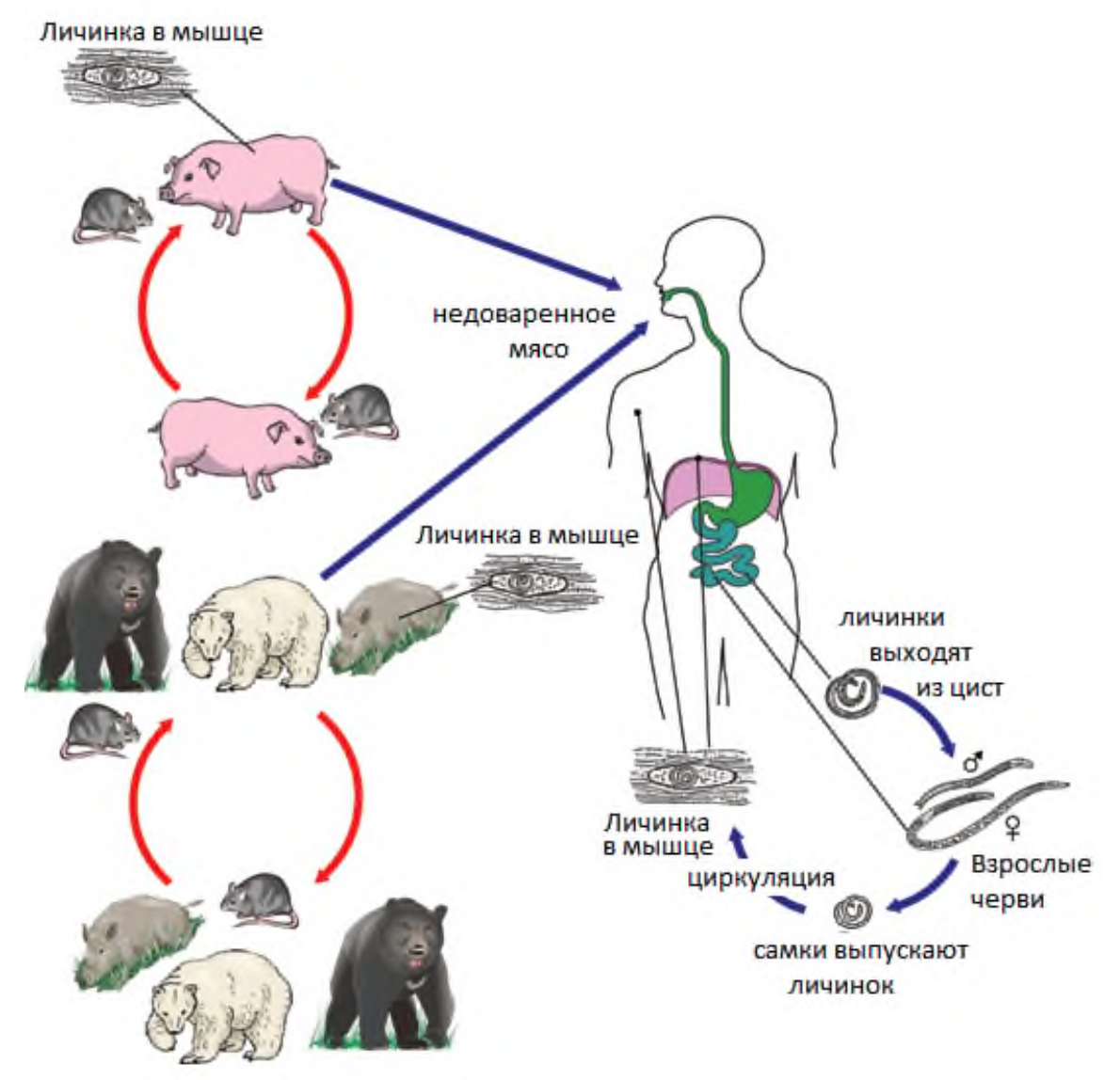

Рис. 39. Жизненный цикл трихинелл.

(В рисунке использованы элементы изображение DPD CDC)

Питаются трихинеллы содержимым кишечника хозяина. В отличие от других кишечных нематод человека они живородящи. Длительность жизни самок трихинелл в кишечнике человека составляет $3-6$ недель. За это время одна самка выделяет от 200 до 2000 личинок, размером около 0,1 мм. Через слизистую оболочку кишечника личинки проникают в лимфатическую, а затем в кровеносную систему и током крови разносятся по всему организму хозяина. Миграция личинок начинается на 6 день после заражения. При помощи 
буравящего стилета и выделяемой ими гиалуронидазы личинки активно проникают из капилляров в мышечные волокна поперечнополосатой скелетной мускулатуры. Там они увеличиваются в размерах до 0,8 - 1 мм, начинают свертываться спиралью.

Трихинеллы чаще всего поражают наиболее активно работающие мышцы, обильно снабжаемые кровью, насыщенной кислородом: ножки диафрагмы, межреберные, жевательные, глазодвигательные, шейные мышцы, мышцы гортани и языка.

При интенсивной инвазии в 1 г этих мышц может находиться от 50 до 100 и более личинок трихинелл. Вследствие продуктивного воспалительного процесса вокруг личинки образуется интенсивная клеточная инфильтрация, а затем формируется капсула, состоящая из сарколеммы мышечного волокна, соединительнотканного и гиалинового слоев.

К 21-30 дню пребывания личинок в мышечном волокне капсула становится заметной. С шестого месяца после инвазирования в капсулах начинается процесс обызвествления, при этом многие личинки погибают, но некоторые могут сохранять жизнеспособность в течение 25 и более лет.

Если мясо с инвазионными личинками будет съедено одним из многочисленных хозяев трихинелл (человек, свинья, крыса и др.), личинки в желудке и двенадцатиперстной кишке освобождаются от капсул и начинают развиваться, проходя четыре линьки (через 12, 19, 26 и 36 часов) и превращаются в половозрелых особей. Самцы копулируют с самками, и спустя 1,5 суток самки начинают отрождать личинок.

Клиническая картина болезни определяется как количеством личинок трихинелл, поступивших в организм, так и степенью его общей резистентности и иммунологической реактивности.

Для установления окончательного паразитологического диагноза проводят исследование мышц с целью обнаружения личинок трихинелл.

Если установлено, что источником групповых заболеваний с указанными симптомами послужило недостаточно термически обработанное мясо диких или домашних животных, то остатки такого мяса исследуются на наличие в нем личинок трихинелл.

Токсокароз - личиночный, хронически протекающий тканевой геогельминтоз. Заболевание характеризуется длительным и рецидивирующим течением, полиморфизмом клинических проявлений, с преимущественным поражением внутренних органов и глаз. Возбудитель токсокароза - нематода семейства Anisakidae, рода Toxocara. Известны два вида токсокар: Tocsocara canis - гельминт, поражающий главным образом представителей семейства псовых, и Toxocara mystax - гельминт семейства кошачих, который иногда в англоязычных странах называют Tocsocara cati. Роль T. canis в патологии 
человека доказана, а роль T.mystax еще обсуждается, поэтому в настоящее время термин «токсокароз» подразумевает только заболевание человека, вызываемое Toxocara canis.

Взрослые паразиты локализуются в тонком кишечнике и желудке облигатных хозяев. Средняя продолжительность жизни половозрелых особей составляет 4 мес., максимальная 6 мес. Самка откладывает более 200 тыс. яиц в сутки. Поскольку интенсивность инвазии у животных достигает сотен особей, они загрязняют окружающую среду миллионами яиц ежедневно Яйца выделяются незрелыми и неинвазионными. Срок созревания яиц зависит от температуры окружающей среды и влажности. (рис.40).

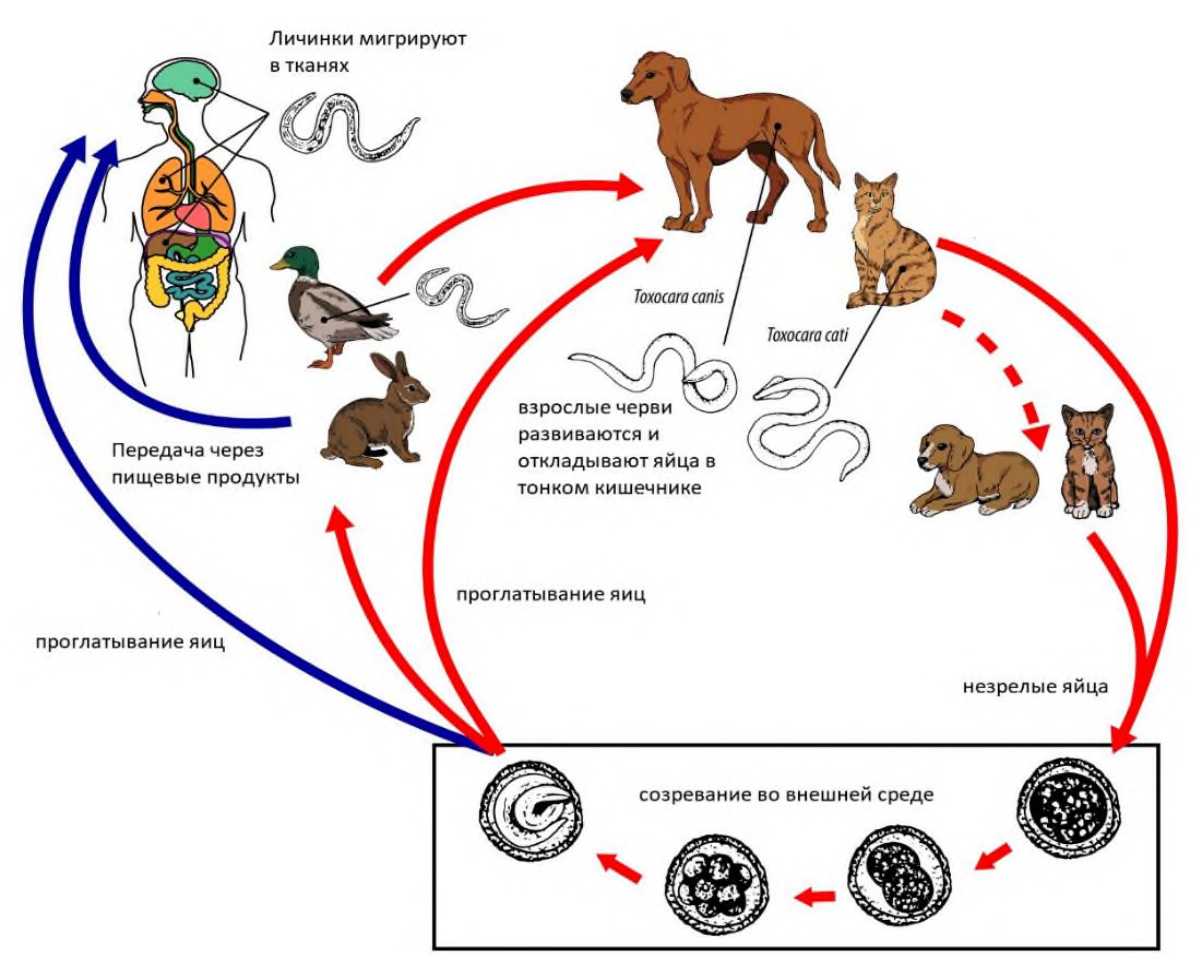

Рис. 40. Жизненный цикл токсокар.

(В рисунке использованы элементы изображение DPD CDC)

Для человека токсокароз - зоонозная инвазия. распространено во всем мире, наиболее высокая распространенность как среди животных, так и среди людей наблюдается в развивающихся странах.

Токсокароз характеризуется тяжелым, длительным и рецидивирующим течением, полиморфизмом клинических проявлений, обусловленных миграцией личинок токсокар по различным органам и тканям.

Заражение человека происходит при проглатывании инвазионных яиц токсокар. В проксимальном отделе тонкого кишечника из яиц выходят личинки, которые через слизистую оболочку проникают в кровоток, затем заносятся в печень и правую половину сердца. Попав в легочную артерию, личинки продолжают миграцию и переходят из капилляров в легочную вену, достигают 
левой половины сердца и затем разносятся кровью по разным органам и тканям. Мигрируя, они достигают пункта, где диаметр сосуда их не пропускает (диаметр личинки 0,02 мм), и здесь они покидают кровяное русло. Личинки токсокар оседают в печени, легких, сердце, почках, поджелудочной железе, головном мозге, глазах и других органах, и тканях. Здесь они сохраняют жизнеспособность в течение длительного времени (месяцы, годы) личинки, осевшие в тканях, пребывают в "дремлющем" состоянии, а затем под влиянием каких-то факторов активизируются и продолжают миграцию.

Личинка в организме человека может выживать до 10 лет. Это как бы противоречащая выраженному иммунному ответу хозяина жизнеспособность личинки связана с выделением ею маскирующей субстанции, способной защитить личинку от агрессии эозинофилов и антител хозяина при помощи сложной реакции, в результате которой предотвращается их контакт с эпикутикулой личинки.

С течением времени часть личинок инкапсулируется и постепенно разрушается внутри капсулы.

Прижизненный паразитологический диагноз токсокароза практически невозможен. При офтальмоскопии могут быть обнаружены личинки токсокар в стекловидном теле, области зрительного нерва, макулярной области или периферии сетчатки.

Цистицеркоз - биогельминтоз, который вызывается личинками T.solium после употребления в пищу яиц, с формированием личиночной стадии цепня вооруженного - цистицерка (Cysticercus cellulosae). В редких случаях T.solium, может вызывать нейроцистицеркоз. Тениидоз и цистицеркоз встречаются во всем мире, однако частота заболевания выше в Южной и Восточной Африке, Южной и Центральной Америке, на территории бывшего Советского Союза.

Тениоз может осложняться цистицеркозом, при котором человек служит промежуточным хозяином свиного цепня. Инвазионная стадия в этом случае яйцо. Попадает в организм человека при случайном заглатывании яиц с грязных рук, с зараженной водой и пищей либо при забросе зрелых члеников в желудок во время рвоты. Освободившиеся под действием ферментов онкосферы проникают в кровь и разносятся по телу, попадая в глаза, головной мозг, сердечную мышцу, где через 2-4 месяца превращаются в цистицерки (рис.41).

В развитии цистицерка различают стадии жизнеспособного (до 5 лет после заражения), отмирающего и погибшего паразита. На первой стадии воспалительная реакция вокруг цистицерков выражена умеренно. В стадии отмирания происходит набухание и расплавление личинки. Образующиеся при этом продукты распада оказывают более выраженное воздействие на организм хозяина, вследствие чего появляется субфебрильная лихорадка, увеличивается число эозинофилов и лейкоцитов в периферической крови, повышается СОЭ. Постепенно капсула уплотняется. Погибший паразит подвергается обызвествлению. 


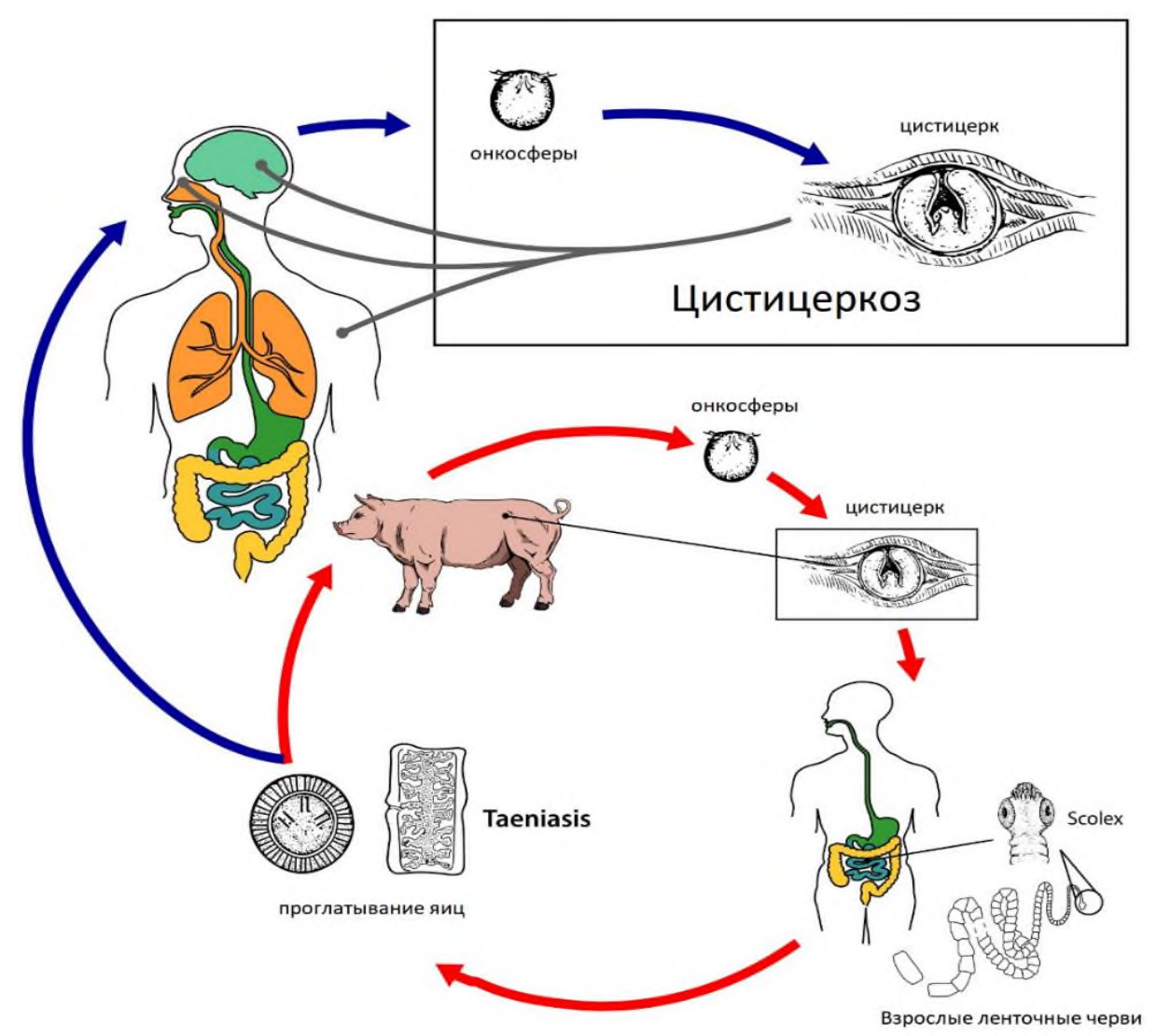

Рис. 41. Жизненный цикл T.solium.

(В рисунке использованы элементы изображение DPD CDC)

Наиболее опасна локализация цистицерков в мозге (41-82\% случаев) которая проявляется эпилептическими припадками (эпилептическая форма), повышением внутричерепного давления (гипертензивно-гидроцефалическая форма), очаговой симптоматикой без выраженных мозговых проявлений (псевдотуморозная форма), признаками нарушения мозгового кровообращения в виде гемипарезов, гемиплегии, преходящей афазией.

У половины больных цистицеркозом поражаются глаза (как правило, один глаз). Наиболее часто, в 73,2\% случаев, цистицерк локализуется в стекловидном теле и под сетчаткой. Вначале, когда паразит попадает под сетчатку, возникает местное кровоизлияние, а затем ее отслойка. Позднее цистицерк проникает в стекловидное тело, в котором может оставаться жизнеспособным в течение месяцев, обычно не вызывая каких-либо серьезных изменений. В некоторых случаях под воздействием продуктов обмена паразита возникает воспалительная реакция, приводящая к помутнению стекловидного тела, развитию ирита и иридоциклита. В случае гибели паразита развиваются тяжелые воспалительные реакции, проявляющиеся эндофтальмитом с последующим фтизисом глазного яблока. 
Иммуноферментный анализ служит чувствительным методом серологической диагностики цистицеркоза, однако у некоторых больных с другими инвазиями возможно перекрестное реагирование.

Эхинококкоз человека является паразитарной болезнью, вызываемой личиночной стадией ленточных червей рода Echinococcus. Echinococcus granulosus (sensu lato) вызывает кистозный эхинококкоз и является наиболее часто встречающейся формой. Другой вид, E. multilocularis, вызывает альвеолярный эхинококкоз. Два вида, обитающих исключительно в Южной Америке E.vogeli (неотропический эхинококкоз) и чрезвычайно редкий E.oligarthrus (моникистозная форма эхинококка). Известно несколько различных генотипов E. granulosus, классический E.granulosus sensu stricto (генотипы G1 G3), E.ortleppi (G5) и группа E.canadensis (обычно рассматриваемую как G6, G7, G8 и G10). Не все генотипы вызывают инфекцию у людей. Генотип, который вызывает подавляющее большинство случаев инфицирования кистозным эхинококкозом у людей, в основном поддерживается в цикле «собака-овцасобака», хотя может затрагивать и других домашних животных, включая коз, свиней, крупный рогатый скот, верблюдов и яков.

Альвеолярный эхинококкоз обычно встречается среди диких животных и поддерживается в циклах между лисицами или другими плотоядными животными и мелкими млекопитающими (в основном грызунами), выступающими в роли промежуточных хозяев. Окончательными хозяевами могут также быть домашние собаки и кошки.

Кистозный эхинококкоз распространен во всем мире и обнаруживается на всех континентах, кроме Антарктиды, но чаще всего в странах с развитым пастбищным скотоводством (Южная Америка, Северная Африка, Австралия, Новая Зеландия).

Возбудителем эхинококкоза человека является личинка (гидатида) эхинококкового цепня - Echinococcus granulosus. Половозрелые особи этого цепня паразитируют в кишечнике собак и диких представителей семейства волчьих. E.granulosus - очень мелкая цестода. Длина ее тела составляет от 2 до 6 мм. Головка грушевидной формы, шириной около 0,3 мм имеет хоботок с двумя венчиками крючьев, среднее количество которых составляет 30-40. На сколексе находятся 4 присоски диаметром около 0,13 мм. Тело состоит из 3-4 члеников. Первый членик незрелый, второй - гермафродитный (половозрелый), а последний, самый крупный, - зрелый; он занят маткой, заполненной яйцами.

Развитие гельминтов до половой зрелости происходит в течение 4-9 недель после заражения. Нередко число их достигает десятков тысяч. Яйца или членики эхинококков выделяются с испражнениями животных (членики могут самостоятельно выползать из анального отверстия) и загрязняют шерсть, а также воду, почву, траву, помещения и предметы, с которыми соприкасается зараженная собака. 
Человек заражается от собак или волков при заглатывании яиц эхинококков с водой, пищей или после заноса их в рот грязными руками. Яйца эхинококков также могут попасть на шерсть скота (если овцы или коровы лежат на загрязненной собаками земле), а с нее - на руки человека при стрижке, уходе за скотом, дойке и т. д. Доказана также возможность трансплацентарной передачи гельминтоза. Люди являются так называемыми случайными промежуточными хозяевами в том смысле, что они инфицируются тем же путем, что и остальные промежуточные хозяева, но не участвуют в передаче инфекции окончательным хозяевам.

Проглоченные промежуточным хозяином онкосферы, достигают двенадцатиперстной кишки, где освобождаются от оболочки, а выделившиеся личинки при помощи крючьев, раздвигая клетки слизистой оболочки, проникают вглубь кишечной стенки и внедряются в мезентериальные кровеносные сосуды.

Далее, попав в кровеносное русло портальной системы, они заносятся в печень, где большинство онкосфер оседает в мелких капиллярах. Меньшая часть их минует печеночный барьер и может попасть в легкие (через малый круг кровообращения). Незначительная часть проходит фильтр легких и попадает в почки, кости, мозг и другие органы (рис.42).

Под воздействием иммунной системы личинки в большом количестве погибают, а выжившие и имплантированные в органах начинают постепенно увеличиваться в объеме, превращаясь в эхинококковый пузырь. В пораженном органе может развиваться одна киста (солитарное поражение) или несколько (множественный эхинококкоз), размеры кист значительно варьируют: от 1 мм до 50 см и более в диаметре. Эхинококковая киста растет экспансивно, отодвигая и сдавливая ткани хозяина, которые атрофируются и некротизируются. К концу 5 месяца вокруг кисты формируется фиброзная капсула.

Эхинококковый пузырь имеет сложное строение. Стенка пузыря состоит из 2-х слоев: Наружного (кутикулярного или гиалинового) - толстая фиброзная оболочка с тонким хитиновым слоем, состоит из множества концентрических пластинок, не содержащих клетки. Внутренний (зародышевый или герминативный) слой формирует выводковые капсулы в начале в виде выпячивания, затем формируется мелкий пузырек, соединенный с зародышевым слоем тонкой ножкой, затем выводковая камера отделяется и свободно плавает в полости пузыря.

Внутри капсулы находятся инвагинированные личиночные головки (протосколексы) - размером 143-160х100-123 мкм. При большом увеличении микроскопа видно, что головка имеет овальную или яйцевидную форму. Сквозь ткани втянутой внутрь головки просвечивают крючья, которые группируются вокруг ее продольной оси, образуя венчик.

Пузырь заполнен бесцветной жидкостью и содержит эхинококковый «песок»- массу таких камер (в одном пузыре их может быть сотни и более). 


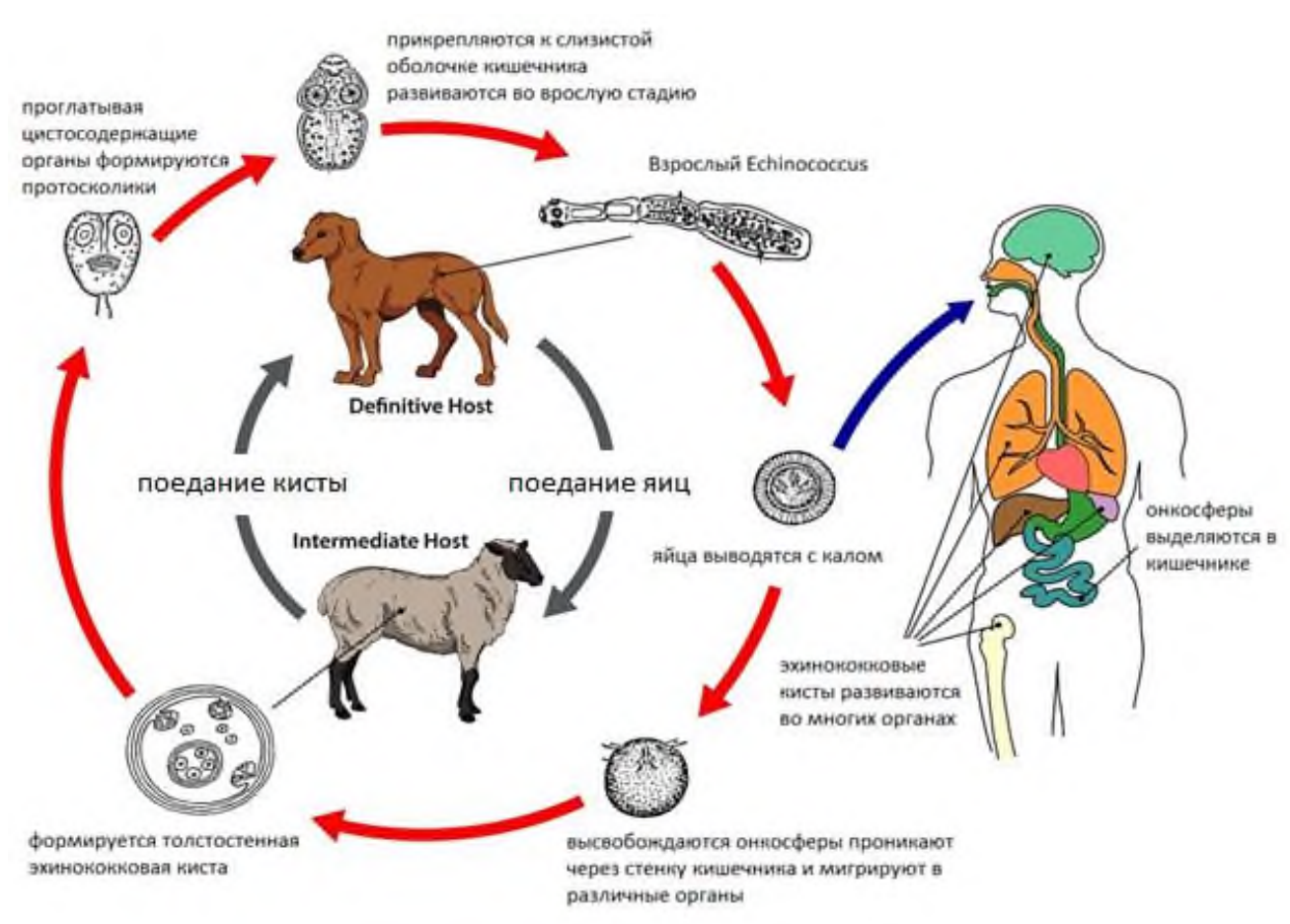

Рис. 42. Жизненный цикл Echinococcus.

(В рисунке использованы элементы изображение DPD CDC)

При разрушении выводковых капсул протосколексы попадают в жидкость пузыря, где из них внутри первичного (материнского) пузыря нередко могут развиваться вторичные (дочерние) пузыри такого же строения, а в них третичные (внучатые). Иногда дочерние пузыри формируются снаружи материнского пузыря.

Инфицирование человека приводит к развитию одной или нескольких гидатидных кист, локализованных чаще всего в печени и легких и реже в костях, почках, селезенке, мышцах и центральной нервной системе.

Бессимптомный инкубационный период болезни может продолжаться многие годы до тех пор, пока гидатидные кисты не разовьются до таких размеров, при которых появляются клинические признаки, при этом примерно половина всех пациентов, получающих медицинское лечение от инфекции, начинают его получать через несколько лет после первоначального инфицирования паразитом.

Если гидатиды локализуются в печени, часто наблюдаются боли в области живота, тошнота и рвота. Если поражены легкие, клинические признаки включают хронический кашель, боли в груди и одышку. Другие признаки зависят от локализации гидатид(ы) и от давления, оказываемого на прилегающие ткани. Неспецифические признаки включают анорексию, потерю веса и слабость. 
Для альвеолярного эхинококкоза характерны бессимптомный инкубационный период длительностью 5-15 лет и медленное развитие первичного опухолевидного поражения, локализованного обычно в печени. Клинические признаки включают потерю веса, боли в области живота, общее недомогание и признаки печеночной недостаточности.

После диссеминации паразита через кровеносную и лимфатическую системы личиночные метастазы могут распространяться либо в органы, прилегающие к печени (например, в селезенку), либо в отдаленные места (например, в легкие или мозг). При отсутствии лечения альвеолярный эхинококкоз прогрессирует и приводит к смертельному исходу.

Предположительный диагноз эхинококкоза может быть установлен при наличии опухолевидного, медленно растущего образования в печени, легких или других органов. При этом принимается во внимание эпидемиологический анамнез: пребывание в эндемичных районах, контакт с собаками. В гемограмме отмечается увеличение количества эозинофилов до 4-6\%, реже до 60-70\%.

Наиболее простым методом выявления эхинококковых пузырей является рентгенография, позволяющая обнаружить характерные округлые образования, окруженные кольцом обызвествления в печени и необызвествляющиеся округлые тени при цистном эхинококкозе легкого. Существенное значение имеют инструментальные методы диагностики (УЗИ, КТ и МРТ).

Эффективна иммунодиагностика, которая дает возможность подтвердить диагноз эхинококкоза не только при клинически выраженных симптомах, но и в раннем периоде болезни. Хотя в начале болезни титры обычно невысокие. В настоящее время широко используется метод ИФА, который дает положительные результаты в 90\% и более случаев при поражении печени и около 60\% - при эхинококкозе легких.

Шистосомоз, (бильгарциоз, лихорадка улиток, лихорадка Катаяма) группа тропических биогельминтов вызывается некоторыми видами трематод крови (кровяные сосальщиками) из рода Schistosoma. (табл.22).

В отличие от других трематод, которые являются гермафродитами, Schistosoma spp. особи раздельного пола.

Люди - главный резервуар инфекции. Во всем мире заражены приблизительно 221 миллионов человек. По оценкам ВО3, ежегодно в мире регистрируется 200000 случаев смерти от шистосомоза. Различные животные, такие как крупный рогатый скот, собаки, кошки, грызуны, свиньи, лошади и козы, служат резервуарами для S.japonicum, а собаки - для S.mekongi. S.mansoni также часто получают от диких приматов в эндемичных районах. Промежуточные хозяева - улитки. 
Таблица 22

\section{Виды паразита и географическое распространение шистосомоза}

\begin{tabular}{|l|l|l|}
\hline \multicolumn{1}{|c|}{ Шистосом03 } & \multicolumn{1}{|c|}{ Виды } & \multicolumn{1}{|c|}{ Географическое распределение } \\
\hline $\begin{array}{l}\text { шишечный } \\
\text { шистомо3 }\end{array}$ & Schistosoma mansoni & $\begin{array}{l}\text { Африка к югу от Сахары и в некоторых странах } \\
\text { Южной Америки (Бразилия, Венесуэла, } \\
\text { Суринам) и Карибском бассейне, Аравийский } \\
\text { полуостров }\end{array}$ \\
\cline { 2 - 3 } & Schistosoma japonicum & Индонезия, Китай, Филиппины \\
\cline { 2 - 3 } & Schistosoma mekongi & $\begin{array}{l}\text { Некоторые районы Камбоджи и Лаосской } \\
\text { Народно-Демократической Республики }\end{array}$ \\
\cline { 2 - 3 } & $\begin{array}{l}\text { Schistosoma guineensis и } \\
\text { связанная с ней S. } \\
\text { intercalatum }\end{array}$ & Влажные лесные районы Центральной Африки \\
\hline $\begin{array}{l}\text { Мочеполовой } \\
\text { шистосомоз }\end{array}$ & $\begin{array}{l}\text { Schistosoma } \\
\text { haematobium }\end{array}$ & $\begin{array}{l}\text { Африки и Азии (Западная Индия, Ангола, } \\
\text { Нигерия, Судан, Египет, Сирия, Ливан, Ирак, } \\
\text { Саудовская Аравия и др.) }\end{array}$ \\
\hline
\end{tabular}

Инфицированные люди выделяют яйца шистосомы в воду с фекалиями или мочой (рис.43). Из яиц «вылупляются» мирацидии, которые плавают и заражают пресноводных улиток (промежуточный хозяин). После выхода из улитки инфекционные церкарии выходят из улитки и попадает в воду, где может жить до 48 часов без млекопитающего-хозяина.

Попадая в кожу человека-хозяина, они мигрируют через кровоток в печень, где созревают до взрослых особей.

Взрослые особи из печени мигрируют в их конечное место пребывания в брыжеечных венулах, расположение которых зависит от вида (за некоторыми исключениями) шистосом. S. japonicum чаще встречается в верхних брыжеечных венах, дренирующих тонкий кишечник, S. mansoni чаще встречается в нижних брыжеечных венах, дренирующих толстую кишку. S.intercalatum u S.guineensis также обитают в нижнем брыжеечном сплетении, но ниже в кишечнике, чем S.mansoni. S.haematobium чаще всего обитает в везикулярном и тазовом венозном сплетении мочевого пузыря, но также может быть обнаружен в венулах прямой кишки.

Самки (размер от 7 до 28 мм в зависимости от вида) откладывают яйца в венулах. Яйца постепенно продвигаются к просвету кишечника (S.mansoni, S.japonicum, S.mekongi, S.intercalatum) и мочевого пузыря и мочеточников (S.haematobium) и выводятся с фекалиями или мочой соответственно. Если яйца не выводятся из организма, они могут закрепиться в тканях тела и вызвать иммунные реакции и повреждение органов. Яйца обнаруживаются в кале или моче через 1-3 месяца после заражения. Продолжительность жизни взрослого червя колеблются от 3 до 7 лет. 


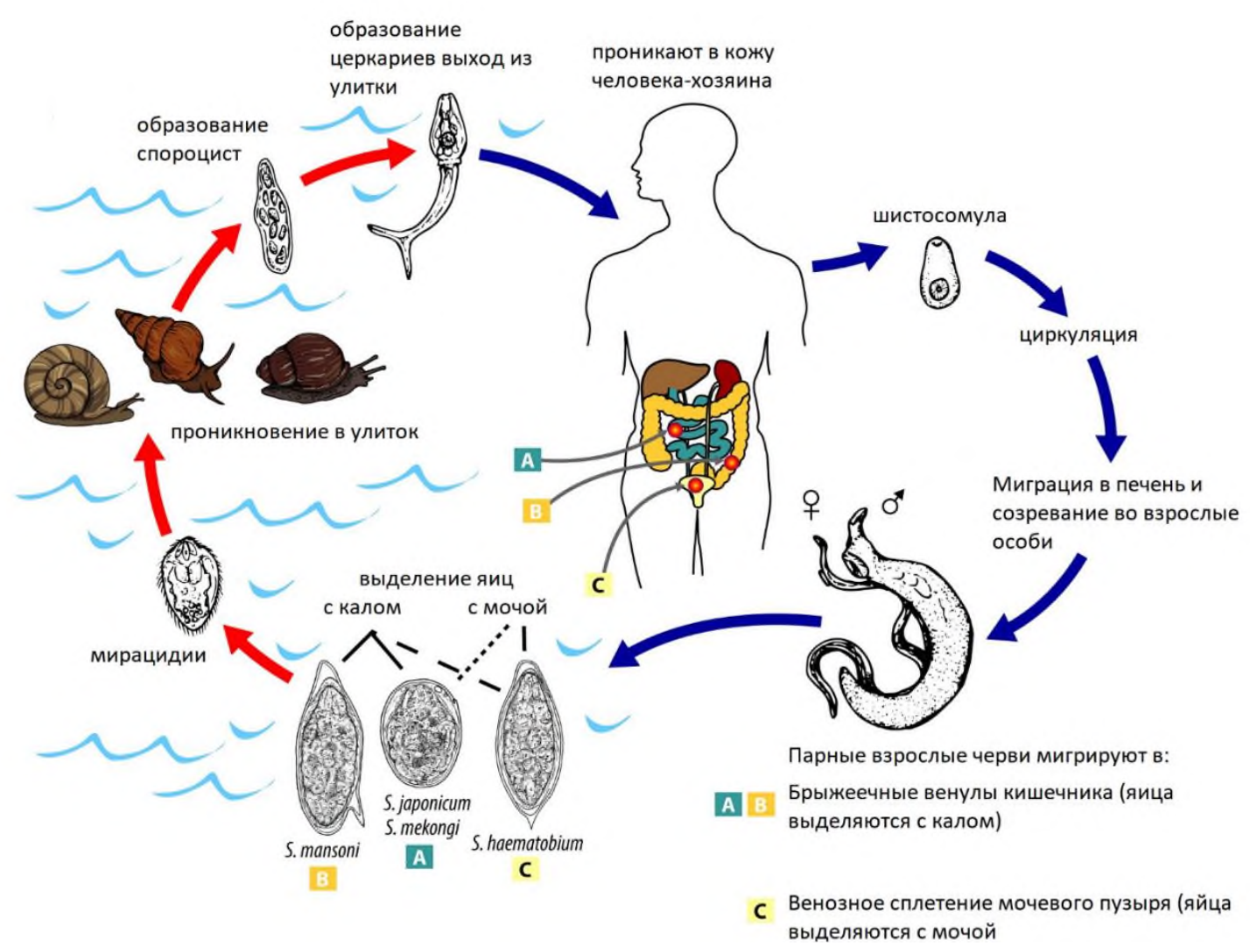

Рис. 43. Жизненный цикл шистосом.

(В рисунке использованы элементы изображение DPD CDC)

Люди сталкиваются с личинками паразита Schistosoma, когда они попадают в загрязненную воду во время купания, игры, плавания, стирки, рыбалки или прогулки по воде. Хотя передача обычно происходит только в странах, где пресноводные улитки являются эндемиками, однако был зарегистрирован случай, когда человек заразился Schistosoma через инфицированную улитку в своем аквариуме.

Инкубационный период составляет 4-6 недель.

Местная кожная реакция гиперчувствительности может возникать на месте проникновения церкарий в кожу, в виде небольших зудящих пятнистопапулезных поражений, которая сохраняется 1-2 дня.

Острый шистосомоз (лихорадка Катаяма) - это системная воспалительная реакция гиперчувствительности, которая может возникать после первоначального заражения, особенно S.mansoni u S.japonicum. Проявления включают системные признаки (лихорадка, кашель, боли в суставах и головная боль, тошнота, рвота, боль в животе, диарея, гепатоспленомегалия, эозинофилия). Продолжительность этой стадии 2-3 недели. В позднейших стадиях болезни клиника зависит от локализации паразита. 
При кишечном шистосомозе характерны боль в животе, чередование запора и поносов, стул с примесью крови и слизи. В этот период возможен гематогенный занос яиц в центральную нервную систему, что вызывает эпилептиформные припадки, параплегии, расстройства зрения и речи, психические нарушения. При мочеполовом шистосомозе - боли и тяжесть в промежности и надлобковой области, дизурические расстройства, терминальная гематурия. Стадия развившейся инвазии продолжается 3-7 лет.

Стадия поздней инвазии и осложнений. Выделение яиц уменьшается или прекращается, на первый план выступают симптомы, связанные с прогрессирующим фиброзом тканей, кальцификацией яиц в стенках органов.

При мочеполовом шистосомозе усиливаются дизурические расстройства из-за сужения мочеточников и шейки мочевого пузыря, присоединяются пиелонефрит, почечнокаменная болезнь, возможен рак мочевого пузыря. Резко нарушаются функции половых желез. При кишечном шистосомозе возникают признаки портальной гипертензии. Характерны гепатоспленомегалия, асцит и отеки нижних конечностей, кровотечения из расширенных вен пищевода, анемия, возможны фиброз и рак печени.

Филяриатозы (филяриозы) - группа заболеваний, вызываемых круглыми червями биогельминтами из семейства Onchocercidae надсемейства Filarioidea (филярии, или нитчатки). Окончательным хозяином для них является позвоночное животное, млекопитающее в т.ч. и человек, птицы, рептилия или земноводное, но не рыба. Промежуточный хозяин - кровососущие насекомые, такие как мошка и комары, за счет которых филярии и распространяются. Эти паразиты существуют в дикой природе в субтропических частях южной Азии, Африки, южной части Тихого океана и некоторых частях Южной Америки. Отсутствуют в Северном полушарии. Однако в связи с развитием туризма и иммиграции могут диагностироваться у приезжих.

У восьми известных нитчатых червей окончательным хозяином является человек. В зависимости от локализации поражения они делятся на три группы:

Лимфатический филяриоз вызывается червями Wuchereria bancrofti, Brugia malayi u Brugia timori. Эти черви поражают лимфатическую систему, включая лимфатические узлы. При хроническом течении приводят к синдрому слоновости.

Подкожный филяриоз вызывается Loa loa (глазным червем), Mansonella streptocerca u Onchocerca volvulus. Эти черви локализуются непосредственно под кожей. L.loa вызывает лоао, O.volvulus вызывает речную слепоту. Дирофиляриоз вызывают паразиты рода Dirofilaria (D. immitis D. repens) проявляется в виде опухолевидного образования, которое может перемещаться по телу до тридцати сантиметров за сутки. 
Серозный филяриоз вызван червями Mansonella perstans и Mansonella ozzardi, которые вызывают филяриоз серозных полостей брыжейке, брюшине и подкожной клетчатке.

Человеческие черви-филярии имеют сложный жизненный цикл, который в основном состоит из пяти стадий (рис.44). Насекомое-переносчик вводит инфекционные личинки в слой дермы кожи.

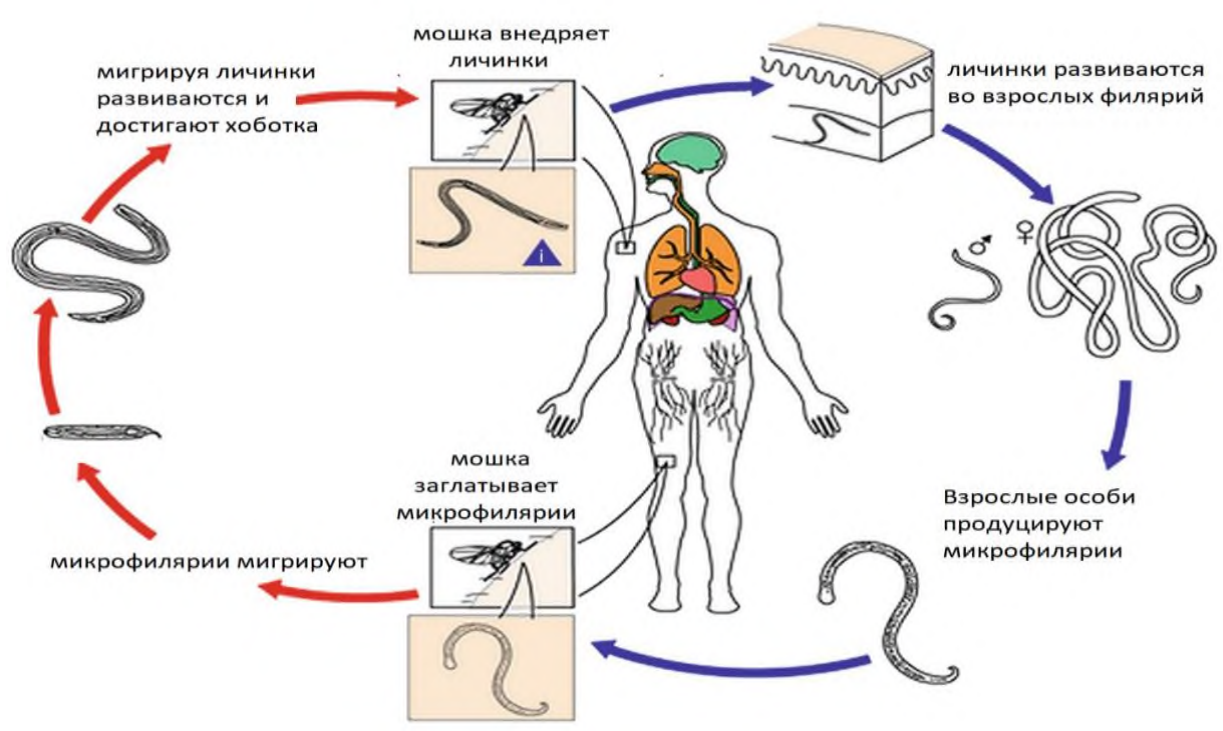

Рис. 44. Жизненный цикл филярий.

(В рисунке использованы элементы изображение DPD CDC)

Примерно через год личинки проходят еще две стадии, превращаясь во взрослых червей. После спаривания самца и самки самка рождает тысячи живых микрофилярий. Микрофилярии захватываются насекомыми- переносчиками (промежуточным хозяином) во время укуса. У промежуточного хозяина микрофилярии линяют и развиваются в личинок третьей стадии (инфекционных). Во время укуса зараженное насекомое вводит инфекционные личинки в слой дермы. Половозрелые черви живут до 15-17 лет.

Для всех филяриатозов характерно поражение лимфатической системы, однако при вухерериозе и бругиозе эти поражения являются ведущими, в то время как при онхоцеркозе и лоаозе одновременно в процесс вовлекаются кожа, подкожная клетчатка, соединительно-тканые оболочки, орган зрения, поражения которых в клинике болезни становятся ведущими. Дипеталонематоз и стрептоцеркоз по клинической картине близки к лоаозу, мансонеллез вухерериозу, однако патогенность возбудителей этих болезней для человека до настоящего времени не общепризнана. Для клиники филяриатозов - болезней, вызываемых филяриями животных, характерны поражения легких, кожи, лимфаденопатия, иногда гепатоспеленомегалия. 
Особое внимание заслуживают дирофиляриозы, которые регистрируются на территории России. Во многих случаях у людей обнаружены единичные, чаще неполовозрелые самки, реже самцы филярий. Последние, как правило, паразитируют в узелковых утолщениях под кожей, подкожной клетчатке различных частей тела, в глазу, реже филярии находят в глубоких лимфатических узлах, кровеносных сосудах легких, в сердце. Дирофилярии часто являются возбудителями тропической эозинофилии ("эозинофильной болезни легких") - хронически рецидивирующих поражений легких, сопровождающихся лихорадкой, высокой эозинофилией крови, гепатоспленомегалией. Синдром тропической эозинофилии у лиц с необычной реакцией иммунологической системы могут вызывать и филярии человека.

Болезнь проявляется мучительным сухим кашлем с астматическим компонентом, иногда тяжелыми, чаще ночными приступами бронхиальной астмы, одышкой, болями за грудиной, умеренной, реже - высокой лихорадкой, гиперэозинофилией крови, гипергаммаглобулинемией. Рентгенологически в легких находят усиленный бронхиально-сосудистый рисунок, пятнистые мелкоочаговые тени, преимущественно в средних и нижних легочных полях с радиальной пятнистостью от корней.

Парагонимоз (paragonimoses) - паразитарное заболевание человека из группы трематодозов, вызываемое лёгочным сосальщиком Paragonimus westermani. Характеризуется преимущественным поражением лёгких, подкожной клетчатки и скелетных мышц, реже - головного мозга. Различают обычный (лёгочный) и ларвальный (личиночный) парагонимозы. Ежегодно заражается около 22 миллионов человек во всем мире.

Виды Paragonimus широко распространены в Азии, Африке, Северной и Южной Америке, встречается в Юго-Восточной Азии и Японии, а Paragonimus kellicotti является эндемиком Северной Америки. Это очень распространенный паразит млекопитающих, питающихся ракообразными.

Яйца, выделяемые через слюну или экскременты, развиваются 2-3 недель в пресной воде до мирацидий (первая личиночная стадия). Мирацидии поражают улиток; там они развиваются, размножаются и в конечном счете превращаются в церкарии (свободно плавающие личинки). Церкарии поражают пресноводных крабов или речных раков и в их организме превращаются в метацеркарии. Люди заражаются при употреблении в пищу сырых, засоленных или плохо приготовленных ракообразных (рис.45).

Метацеркарии выходят из цисты в желудочно-кишечном тракте человека, проникают через стенку кишечника и продвигаются в брюшную полость, затем через диафрагму в плевральную полость; они проникают в ткани легкого, инкапсулируются и развиваются в гермафродитных взрослых червей, которые откладывают яйца. 


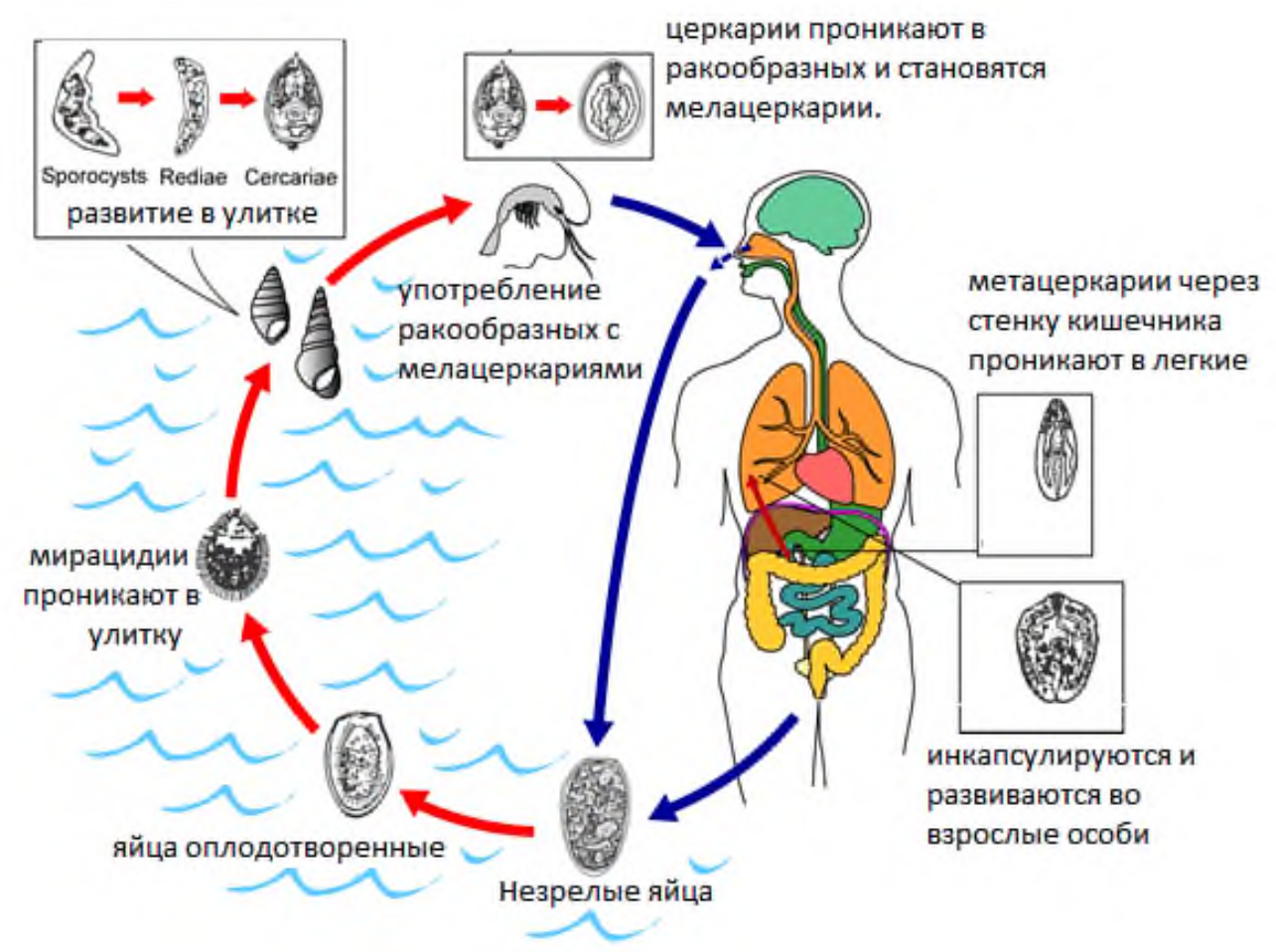

Рис. 45. Жизненный цикл Paragonimus.

(В рисунке использованы элементы изображение DPD CDC)

Взрослые черви вырастают до 7,5-12 мм в длину и 4-6 мм в диаметре. Из легких яйца попадают в окружающую среду вместе с мокротой при ее откашливании и сплевывании или при заглатывании мокроты и выведении из организма с калом. Во время миграции личинки парагонимусов могут попасть в головной мозг, печень, лимфоузлы, кожу и спинной мозг и там развиваться. Однако в этих случаях их жизненный цикл оказывается незавершенным, поскольку яйца не способны покинуть пределы человеческого организма. Взрослые трематоды могут существовать в течение от 20 до 25 лет.

Во время инвазии и миграции трематод могут развиваться диарея, боль в животе, лихорадка, кашель, крапивница, гепатоспленомегалия, легочная патология и эозинофилия.

В хронической фазе наиболее повреждены легкие, но могут быть вовлечены и другие органы. Проявления легочной инфекции развиваются медленно и включают хронический кашель, боль в груди, кровохарканье и одышку; клиническая картина напоминает туберкулез.

Церебральные поражения проявляются, как правило, в течение года после начала легочного заболевания. Случаются приступы судорог, афазия, парез и нарушения зрения. 
Дракункулез (болезнь дракункулеза) или ришта (от тадж. нить) вызывается нематодой (аскаридой) Dracunculus medinensis (гвинейский червь). Заболевание распространено в субтропических и тропических регионах, особенно в Индии, Юго-Западной Азии (Ирак, Иран, Пакистан и т.д.), и сельских районах Африки (Чаде, Эфиопии, Мали, Южном Судане и Анголе).

Паразит попадает в организм человека перорально с водой, в которой находились веслоногие раки, заражённые личинками ришты (рис.46).

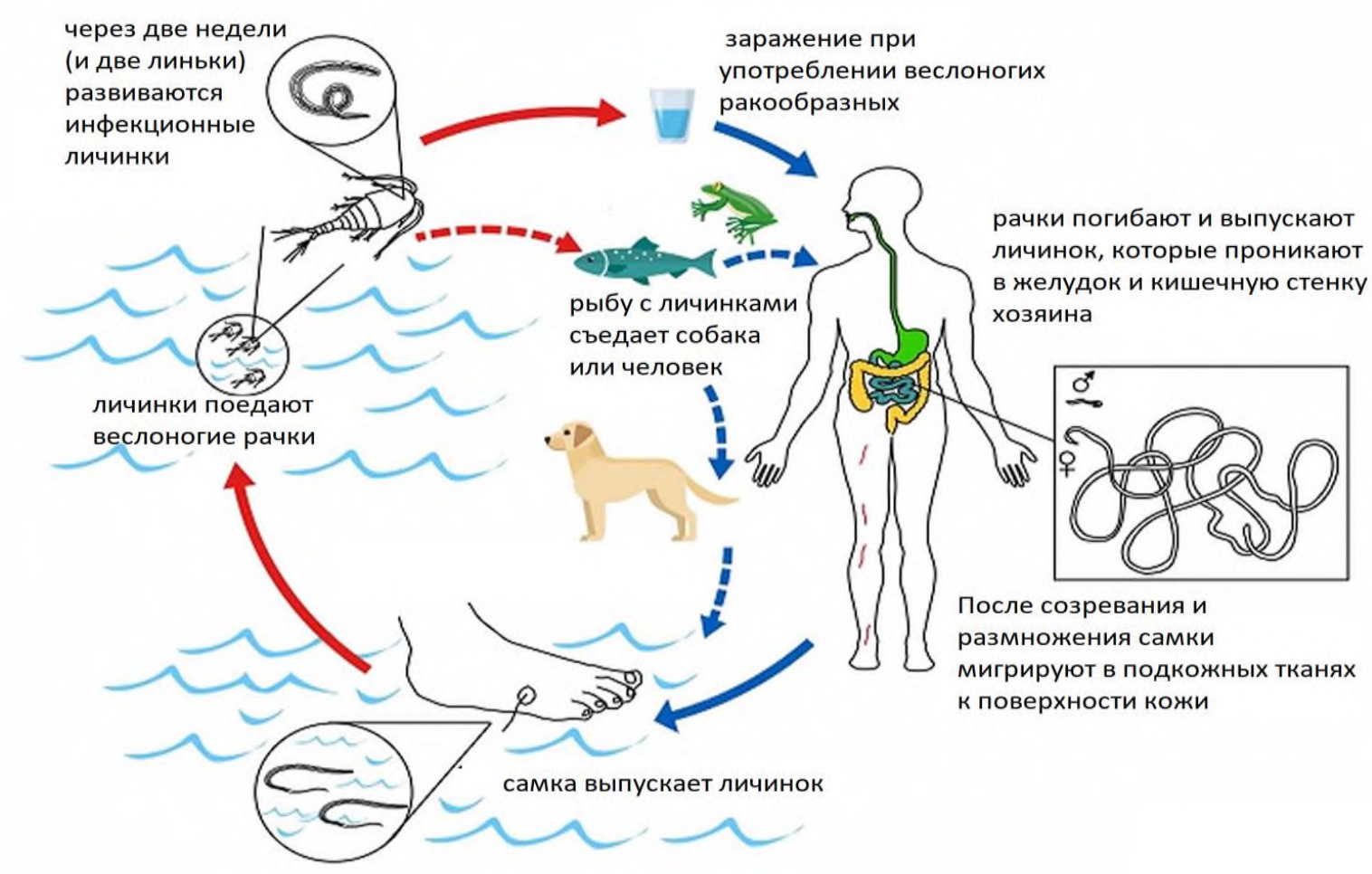

Рис. 46. Жизненный цикл дракункулеза.

(В рисунке использованы элементы изображение DPD CDC)

При попадании в организм человека личинка внедряется в стенки желудка и тонкого кишечника и далее в лимфатические сосуды, а оттуда проникает в брюшную полость и ретроперитонеальное пространство, где претерпевает две последовательные линьки и достигает половой зрелости через несколько месяцев после заражения. После спаривания самцы гибнут, а самки мигрируют в кожу, где локализуются в подкожной клетчатке. Там вокруг стенки тела червя образуется пузырь, напоминающий кисту, который со временем (примерно через год после заражения) лопается, и образуется язва, из которой торчит передний конец тела червя. При контакте тела ришты с водой стенка тела червя лопается в области вульвы, и из выпячивающейся наружу матки выбрасываются в воду многочисленные личинки первой стадии, которые для замыкания цикла должны заразить веслоногого рачка. Вне организма хозяина личинки жизнеспособны в 
течение 3 недель. В организме рачка личинки внедряются через стенку кишечника в гемоцель, где проделывают две линьки и становятся инвазионными через 12 дней.

Дракункулез, как правило, протекает бессимптомно в течение первого года. Симптомы обычно развиваются, когда червь локализуется в коже. Местные признаки включают в себя интенсивный зуд и острую боль на месте поражения кожи. Обитающие в подкожной клетчатке крупные нематоды приводят к возникновению легко вскрывающихся зудящих гнойников. Основную опасность представляет вторичное заражение раненой области. Крапивница, эритема, одышка, рвота и зуд, как полагают, отражают аллергические реакции на антигены червей.

В настоящее время существуют только оперативные методы лечения. Традиционный метод, описанный ещё в древнеегипетском тексте середины второго тысячелетия до н. э., состоит в извлечении паразита через разрез кожи, в ходе которого червя медленно наматывают на стержень. Процедура длится очень долго - до нескольких недель. Это делается из предосторожности, чтобы червь не порвался и в рану не попала токсичная псевдоцельная жидкость. Если целостность червя нарушается во время извлечения, то развивается тяжелая воспалительная реакция, которая вызывает невыносимую боль. Симптомы исчезают, язва заживает, как только взрослый червь удален. Приблизительно в 50\% случаев вторичные бактериальные инфекции наблюдаются вдоль следа, прокладываемого червем. 


\section{Глава 5. Иммунная система}

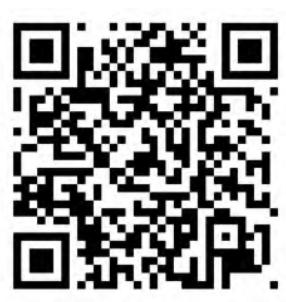

Иммунная система - функционально взаимосвязанный комплекс органов, тканей, клеток, специфических белков и регуляторных компонентов, способная распознавать различные структуры как чужеродные для себя, так и измененные свои с дальнейшей их нейтрализацией и уничтожением с формированием невосприимчивости организма при их повторной встрече. Помимо этого, иммунная система контролирует пролиферацию клеток, процессы регенерации, осуществляет элиминацию и детоксикацию опасных для организма и разрушенных макро- и микромолекул и обеспечивает взаимодействие с нормальной микрофлорой.

Компоненты системы иммунитета входят во все ткани организма, поэтому, с одной стороны изменения в системе иммунитета будут сказываться на функционировании одного или нескольких органов, а с другой - та или иная патология органов и систем будет влиять и на иммунитет. Вот почему иммунная система практически при любой патологии - неотъемлемый участник патологических процессов (рис. 47).
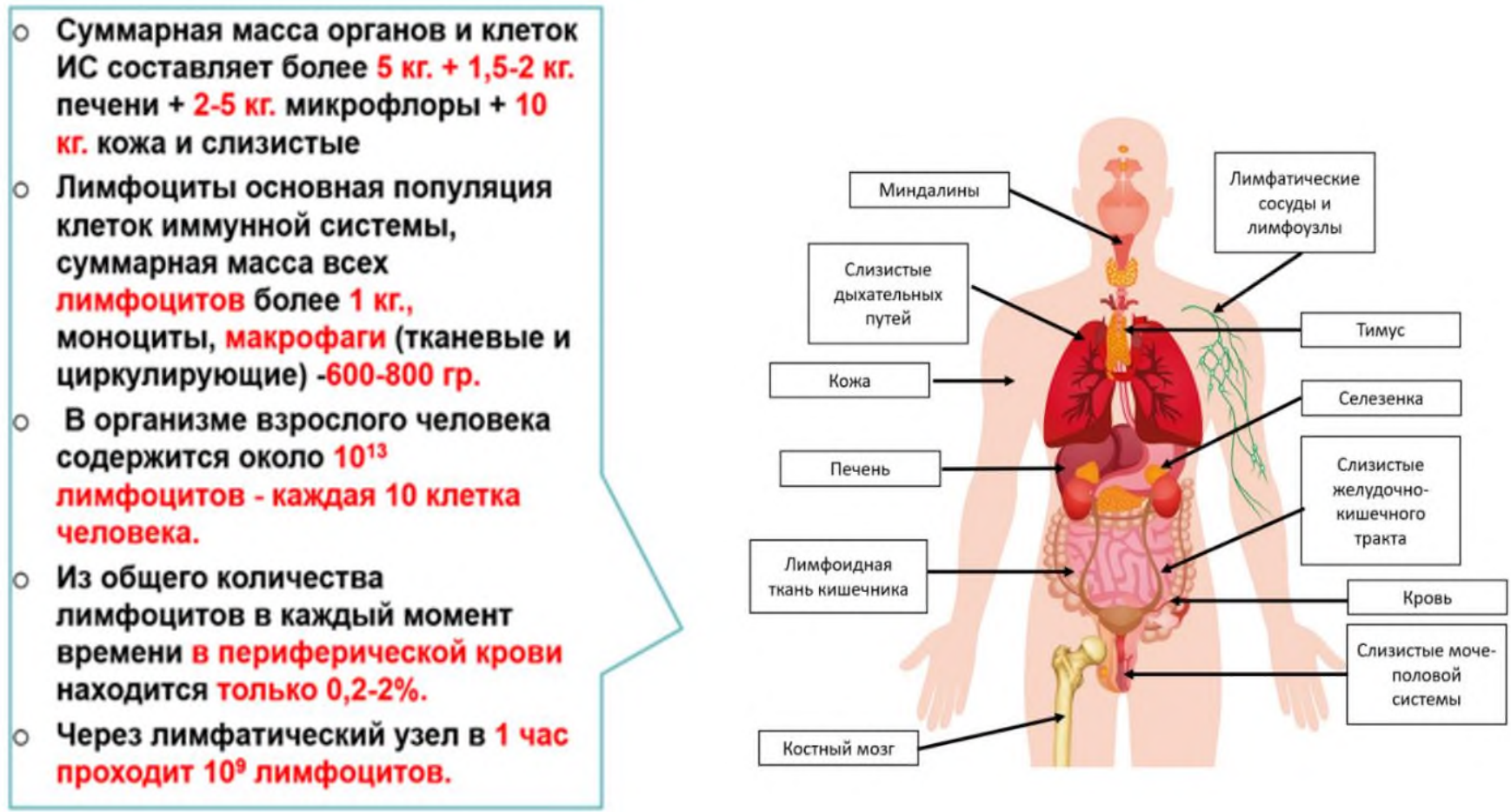

Рис. 47. Иммунная система человека. 
С функциональной точки зрения можно выделить защиту локальную или мукозальный иммунитет, и защиту системную которые тесно переплетены и обеспечиваются реакциями врожденного (неспецифический) и адаптивного (приобретенный или специфический) иммунитета (рис. 48). Помимо этого, большое значение в защитных функциях принадлежит нормальной микрофлоре человека.

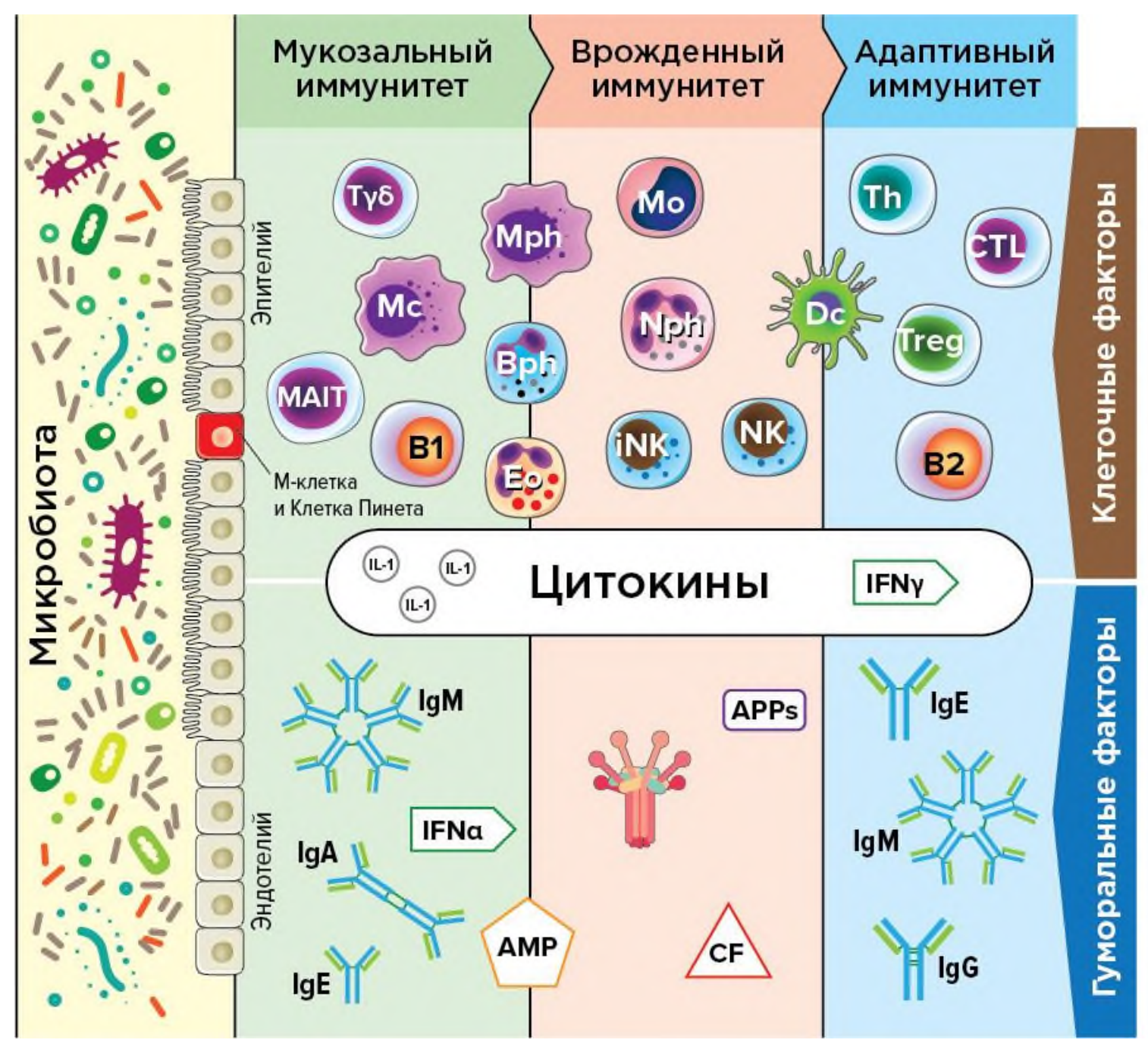

Рис. 48. Функциональная организация иммунной системы человека.

Клетки иммунной системы являются ее основной функциональной единицей и включают в себя различные популяции различного происхождения. В настоящее время имеет смысл все клетки иммунной системы по происхождению разделить на эмбриональные и костномозговые (рис. 49). Некоторые макрофаги, включая клетки Куппфера и Лангерганса, микроглия головного мозга, В1 лимфоциты, гамма/дельта Т-лимфоциты формируются до рождения и поддерживают себя без дальнейшего участия в кроветворении во взрослом состоянии. Это же относится и к эпителиальным клеткам. 


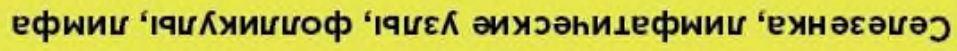
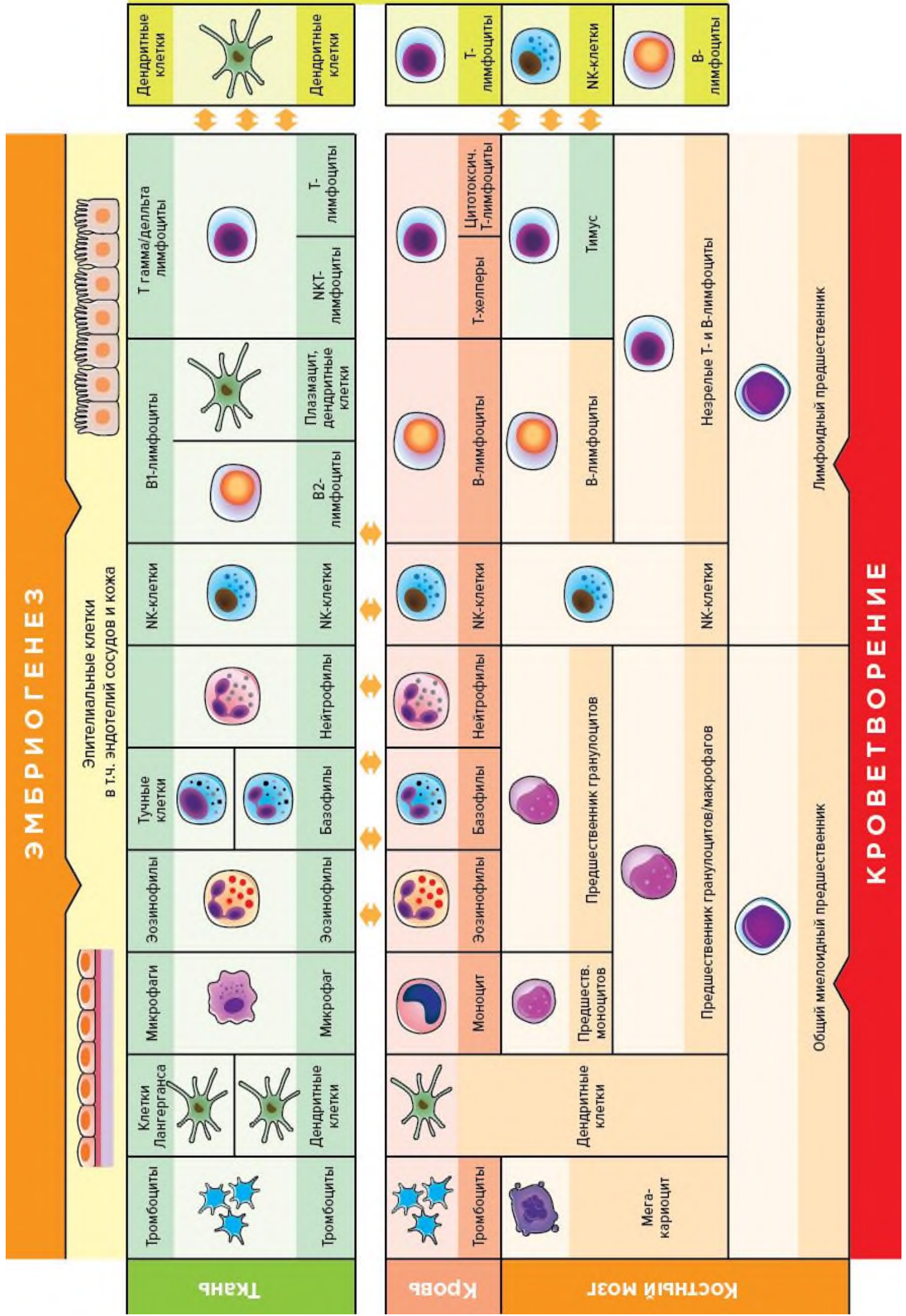

'0 
Первой линией обороны против инфекционных агентов служат эпителиальные клетки (табл.23).

\section{Таблица 23}

\section{Типы эпителиальных клеток}

\begin{tabular}{|c|c|c|}
\hline Клетки & Локализация & Функция \\
\hline \multicolumn{3}{|c|}{ Однослойный } \\
\hline Плоский эпителий & $\begin{array}{l}\text { Слизистая оболочка рта, } \\
\text { пищевода, серозные оболочки, } \\
\text { лимфатические и кровеносные } \\
\text { сосуды (эндотелий), альвеолы } \\
\text { легких }\end{array}$ & $\begin{array}{l}\text { Задействован в обмене веществ } \\
\text { и газов между кровью, лимфой } \\
\text { и другими тканями. Сигнальные } \\
\text { и АГП клетки иммунной системы }\end{array}$ \\
\hline Кубовидный эпителий & $\begin{array}{l}\text { Глаза, щитовидная железа, } \\
\text { почечные трубки, яичники, } \\
\text { слюнные } \\
\text { поджелудочная железа }\end{array}$ & $\begin{array}{l}\text { Могут выполнять секреторную, } \\
\text { абсорбционную или } \\
\text { выделительную функции }\end{array}$ \\
\hline Столбчатый эпителий & $\begin{array}{l}\text { Ресничный: мелкие бронхи, } \\
\text { спинномозговые полости, } \\
\text { желудочки головного мозга, } \\
\text { матка, яйцеводы. } \\
\text { Нересничный ЖкТ, мочевой } \\
\text { пузырь }\end{array}$ & $\begin{array}{l}\text { Могут быть секреторными, } \\
\text { абсорбирующими или } \\
\text { экскреторными }\end{array}$ \\
\hline Псевдостолбчатый эпителий & $\begin{array}{l}\text { Трахея, верхние дыхательные } \\
\text { пути мужская уретра, придатки } \\
\text { яичка. } \\
\text { Разделяют на ресничные, } \\
\text { вставочные, базальные и } \\
\text { бокаловидные клетки }\end{array}$ & $\begin{array}{l}\text { Выделяют слизь, мерцательная } \\
\text { ткань перемещает слизь }\end{array}$ \\
\hline \multicolumn{3}{|c|}{ Многослойный } \\
\hline $\begin{array}{l}\text { Многослойный плоский } \\
\text { эпителий }\end{array}$ & $\begin{array}{l}\text { Внешний слой кожи } \\
\text { (ороговевающий). Внутренняя } \\
\text { оболочку рта, пищевода и } \\
\text { влагалища (ороговевающий) }\end{array}$ & Защита в том числе от истирания \\
\hline 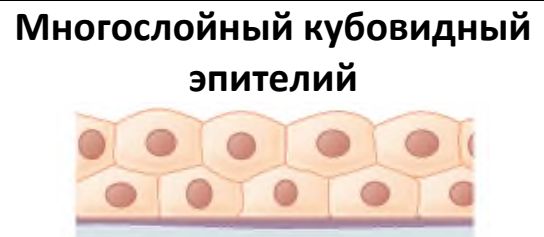 & $\begin{array}{l}\text { Потовые железы, слюнные } \\
\text { железы и молочные железы }\end{array}$ & Защитная ткань \\
\hline $\begin{array}{l}\text { Многослойный столбчатый } \\
\text { эпителий }\end{array}$ & $\begin{array}{l}\text { Мужская уретра и протоки } \\
\text { некоторых желез }\end{array}$ & Секретирует и защищает \\
\hline 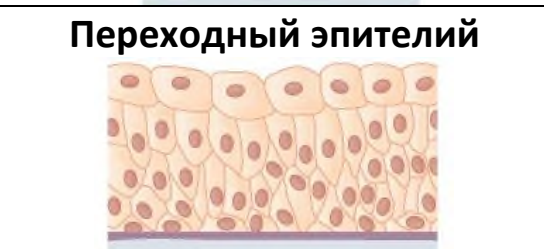 & $\begin{array}{l}\text { Выстилает мочевой пузырь, } \\
\text { уретру и мочеточники }\end{array}$ & $\begin{array}{l}\text { Защита в т.ч. позволяет } \\
\text { мочевым органам расширяться } \\
\text { и растягиваться }\end{array}$ \\
\hline
\end{tabular}


Механическая защита, осуществляемая эпителием, образует границу между внешней и внутренней средой организма (табл. 24). В эпителии отсутствуют межклеточное вещество и кровеносные сосуды, он непроходим для большинства патогенов. Помимо клеток эпителия в эпителиальном пласте находится большое количество резидентных клеток иммунной системы.

Таблица 24

\section{Локализация эпителия и его виды}

\begin{tabular}{|c|c|}
\hline Ткань & Тип (подтип) эпителия \\
\hline \multicolumn{2}{|r|}{ Кожа и серозные оболочки } \\
\hline Поверхностный слой & Многослойный, ороговевающий \\
\hline Плевра, брюшина, перикард & Простой плоскоклеточный (мезотелий) \\
\hline \multicolumn{2}{|r|}{ Дыхательная система } \\
\hline Ротоглотка, голосовые связки & Многослойный, неороговевающий эпителий \\
\hline Гортань трахея бронхи, нос & $\begin{array}{l}\text { Псевдостратифицированный столбчатый, реснитчатый } \\
\text { (дыхательный эпителий) }\end{array}$ \\
\hline $\begin{array}{l}\text { Воздуховоды из придаточных } \\
\text { пазух носа }\end{array}$ & Многослойный столбчатый \\
\hline $\begin{array}{l}\text { Терминальные бронхиолы, } \\
\text { дыхательные бронхиолы }\end{array}$ & Простой кубовидный, реснитчатый \\
\hline Каверны & Простой плоскоклеточный \\
\hline \multicolumn{2}{|r|}{ Желудочно-кишечный тракт } \\
\hline $\begin{array}{l}\text { Десна, твердое небо, задняя часть } \\
\text { языка }\end{array}$ & Многослойный ороговевающий \\
\hline Пищевод & Многослойный неороговевающий \\
\hline Желудок & Простой столбчатый, не ресничный (эпителий желудка) \\
\hline $\begin{array}{l}\text { Тонкая кишка, толстая кишка } \\
\text { прямая кишка, желчный пузырь }\end{array}$ & Простой столбчатый, не ресничный (кишечный эпителий) \\
\hline Анус & $\begin{array}{l}\text { Многослойный плоский неороговевающий и } \\
\text { многослойный чешуйчатыми, ороговевающий }\end{array}$ \\
\hline \multicolumn{2}{|r|}{ Мочеполовая система } \\
\hline Уретра & Псевдостратифицированный столбчатый, не реснитчатый \\
\hline $\begin{array}{l}\text { Почечные лоханки, мочеточник, } \\
\text { мочевой пузырь, }\end{array}$ & Переходный (уротелий) \\
\hline Почки & $\begin{array}{l}\text { Простой кубовидный с микроворсинками и без микроворсинок, } \\
\text { простой плоскоклеточный, простой кубоидальный }\end{array}$ \\
\hline Яичники, яички & Простой кубоидальный (зародышевый эпителий) \\
\hline $\begin{array}{l}\text { Фаллопиевы трубы, эндометрий } \\
\text { (матка) }\end{array}$ & Простой столбчатый, реснитчатый \\
\hline Шейка матки (эндоцервикс) & $\begin{array}{l}\text { Простой столбчатый и } \\
\text { Многослойный, неороговевающий }\end{array}$ \\
\hline Вагина & Многослойный, неороговевающий \\
\hline Половые губы & Многослойный, ороговевающий \\
\hline $\begin{array}{l}\text { Придатки яичка, протоки, } \\
\text { семеные везикулы }\end{array}$ & Псевдостратифицированный столбчатый \\
\hline $\begin{array}{l}\text { Эякуляторный проток, } \\
\text { бульбоуретральные железы }\end{array}$ & Простой столбчатый \\
\hline
\end{tabular}




\section{Клетки иммунной системы}

Мононуклеарные фагоциты по их онтогенезу, расположению, функциям и фенотипу можно разделить на 3 группы: моноциты, макрофаги и дендритные клетки.

Моноциты - самые крупные из лейкоцитов клетки с крупным бобовидным ядром и большим количеством цитоплазмы, в которой находится большое количество лизосом. Число в крови 80-600 клеток в 1 мм $^{3}(2-10 \%$ всех лейкоцитов). Помимо фагоцитоза в нормальных условиях пополняют пул резидентных макрофагов, в ответ на сигналы воспаления мигрируют в ткани с последующей дифференцировкой в макрофаги или дендритные клетки для осуществления иммунного ответа и/или поддерживая общего количества. В стабильном состоянии выполняют фагоцитоз. Фагоцитоз, антигенпрезентация и секреция цитокинов обеспечивают одну из ключевых ролей моноцитов в иммунном ответе, особенно при бактериальной инфекции. Благодаря секреции факторов роста хемокинов и IL-10 (основной противовоспалительный цитокин) моноциты активно участвуют в репаративных процессах, кроветворении, гемостазе и фибринолизе. Выделяют как минимум 3 типа моноцитов (табл.25).

Таблица 25

\section{Моноциты}

\begin{tabular}{|c|c|c|}
\hline Популяция & $\begin{array}{l}\text { Фенотипическая } \\
\text { характеристика }\end{array}$ & Функция \\
\hline $\begin{array}{l}\text { Классические } \\
\text { моноциты }\end{array}$ & CD14 ++ CD16 - & $\begin{array}{l}\text { Высокая фагоцитарная активность апоптотических телец, } \\
\text { опсонизированных патогенов, за счет выраженной экспрессии } \\
\text { рецепторов-мусорщиков, слабая антигенпрезентация }\end{array}$ \\
\hline $\begin{array}{l}\text { Неклассические } \\
\text { моноциты }\end{array}$ & CD14 + CD16 ++ & $\begin{array}{l}\text { Основные функции - презентация антигенов и продукция } \\
\text { провоспалительных цитокинов TNF } \alpha \text {, IL-1 } 1 \beta \text {, IL-12, IL-10. Слабо } \\
\text { выражен фагоцитоз }\end{array}$ \\
\hline $\begin{array}{l}\text { Переходные } \\
\text { моноциты }\end{array}$ & CD14 ++ CD16 + & $\begin{array}{l}\text { Считается, что эти клетки образуются в результате активации и } \\
\text { дифференцировки классических моноцитов. Их основные } \\
\text { функции: IgG опосредованный фагоцитоз, распознавание PAMP } \\
\text { и синтез цитокинов (противовоспалительные цитокины (TNF } \alpha \text {, } \\
\text { IL-1 и пр.) и IL-10), антигенпрезентация. Низкая экспрессия } \\
\text { рецепторов-мусорщиков, участвующих в репаративных } \\
\text { процессах (синтезируют факторы роста, хемокины) }\end{array}$ \\
\hline
\end{tabular}

Макрофаги. Основные клетки барьерных тканей (мукозального иммунитета). Макрофаги представляют собой крупные клетки, которые присутствуют во всех органах и тканях, где может произойти микробное вторжение или накопление инородных частиц. В зависимости от местоположения имеют разные названия: моноциты - костный мозг / кровь, клетки Купфера - печень, гистиоциты - лимфатические узлы и соединительная ткань, микроглия - центральная нервная система, остеокласты - кость, внутриклубочковые мезангиальные клетки - почки, альвеолярные макрофаги легкие, макрофаги красной пульпы - селезенка и т.д. 
По происхождению необходимо выделять популяцию тканевых (или резидентных) макрофагов и макрофаги моноцитарного (костномозгового) происхождения. Тканевые макрофаги заселяют ткани в период эмбриогенеза и поддерживают свою численность за счёт пролиферации. Это долгоживущие клетки имеют выраженную тканеспецифичность и превалируют по численности над моноцитарными макрофагами, однако с возрастом организма их доля уменьшается.

Популяция макрофагов моноцитарного происхождения короткоживущая, однако их количество резко увеличивается при воспалении и нормализуется по его окончании. Это независимые друг от друга популяции выполняют многочисленные функции.

Во-первых, удаление умирающих или мертвых клеток и клеточного мусора. Во-вторых, играют решающую роль в инициации иммунного ответа, представляя антигены. В-третьих, за счет синтеза широкого спектра цитокинов макрофаги регулируют развитие воспаления, мукозальный, врожденный и адаптивный иммунные ответы. Синтезируя протеин $\mathrm{C}$, тромбомодулин, тканевой фактор, фактор VII, фактор XIII и ингибитор активатора плазминогена, регулируют гемостаз.

Под воздействием различных сигнальных молекул макрофаги активируются с формированием различных функциональных фенотипов (рис. 50). Традиционно макрофаги разделяют на «классически активированные» макрофаги (М1 фенотип) и «альтернативно активированные» макрофаги (M2 фенотип), что позволило сформулировать гипотезу об их поляризации (по типу Th1/Th2).

Однако накопившиеся сведения про другие типы макрофагов, которые отличались от фенотипов М1- и М2макрофагов и метаболическое перепрограммирование макрофагов из M1 в М2 и наоборот не позволяют однозначно определять различные типы макрофагов. Тем не менее, на основе их функции и ключевых маркеров можно выделить популяцию M1 и 4 популяции M2 макрофагов.

М1 макрофаги формируются под воздействием PAMP, DAMP и провоспалительных цитокинов (IFN $\gamma$, TNF). Эти клетки обладают высокой фагоцитарной активностью, что позволяет им нейтрализовать любые

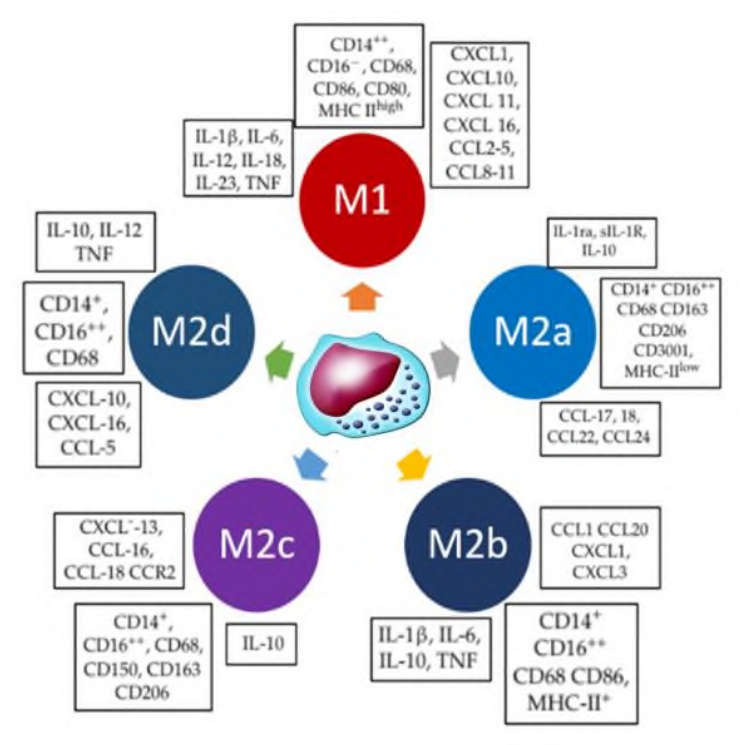

Рис. 50. Фенотипы макрофагов. 
патогены и фагоцитировать апоптозные нейтрофилы и другие клетки, обильно продуцируют цитокины. Альтернативно активированные макрофаги М2 формируются при стимуляции их интерлейкинами, глюкокортикоидами, иммунными комплексами, агонистами TLR и др. Они мигрируют в зоны инвазии гельминтов, скапливаются в очагах фиброза, в заживающих ранах кожи и опухолях. На основе их функции и ключевых маркеров М2 макрофаги разделены на четыре отдельных типа - M2a, M2b, M2c и M2d.

М2а наблюдаются вокруг личинок гельминтов и простейших, аллергены которых индуцируют иммунный Th2 ответ, сопровождающийся продукцией IL4 и IL-13.

M2b функционально близки к M1 макрофагам, продуцируют провоспалительные медиаторы, но и IL-10, усиливают продукцию антител.

М2c макрофаги обладают супрессивными свойствами - тормозят активацию и пролиферацию $\mathrm{CD} 4+$-лимфоцитов, вызванную антигенной стимуляцией и способствуют элиминации активированных Т-клеток.

M2d особая группа макрофагов, формирующиеся в ответ на IL-6 и аденозины. Эти макрофаги также рассматриваются как ассоциированные с опухолью макрофаги (ТАМ). Они стимулируют миграцию раковых клеток, образование метастазов и ангиогенез.

Дендритные клетки - это крупные круглые или овальные клетки с эксцентрически расположенным ядром и многочисленными разветвлёнными отростками. Являются посредниками между врожденным и адаптивным иммунитетом, т.к. представляют Т- и В-лимфоцитам обработанный антигенный материал. Группа достаточно гетерогенная, до сих пор неясно сколько существует подтипов дендритных клеток, тем не менее выделяют нескольких подтипов с уникальными функциями (рис. 51).

Миелоидные дендритные клетки 1 типа (cDC1) обладают высокой способностью презентовать антигены через MHC класса I, активировать Th1 и CD8+ T-клеток за счет секреции IL-12, активировать NK-клетки, продуцировать интерфероны III типа, обеспечивая противовирусную активность.

Миелоидные дендритные клетки 2 типа (cDC2) - основная популяция миелоидных дендритных клеток крови, тканях и лимфоидных органах человека. По экспрессии различных рецепторов выделяют две подгруппы cDC2: «DCподобную» и «моноцитоподобную».

Оснащены широким спектром лектинов, TLR, NOD- и RIG-I-подобных рецепторов, хорошо распознают и презентуют антигены микобактерий и других патогенов. Секретируют IL-23, IL-1, TNF, IL-8 и IL-10, но слабо синтезируют интерфероны III типа. Мощные активаторы Th1, Th2, Th17 и CTL. Неклассические моноциты так же рассматриваются как предшественники cDC2. Они доминируют по составу клеток при перитоните, воспалительных заболеваниях кишечника, синовитах, экземе, псориазе, аллергических реакциях хотя нет полной ясности о грани между моноцитами, макрофагами и DC. 


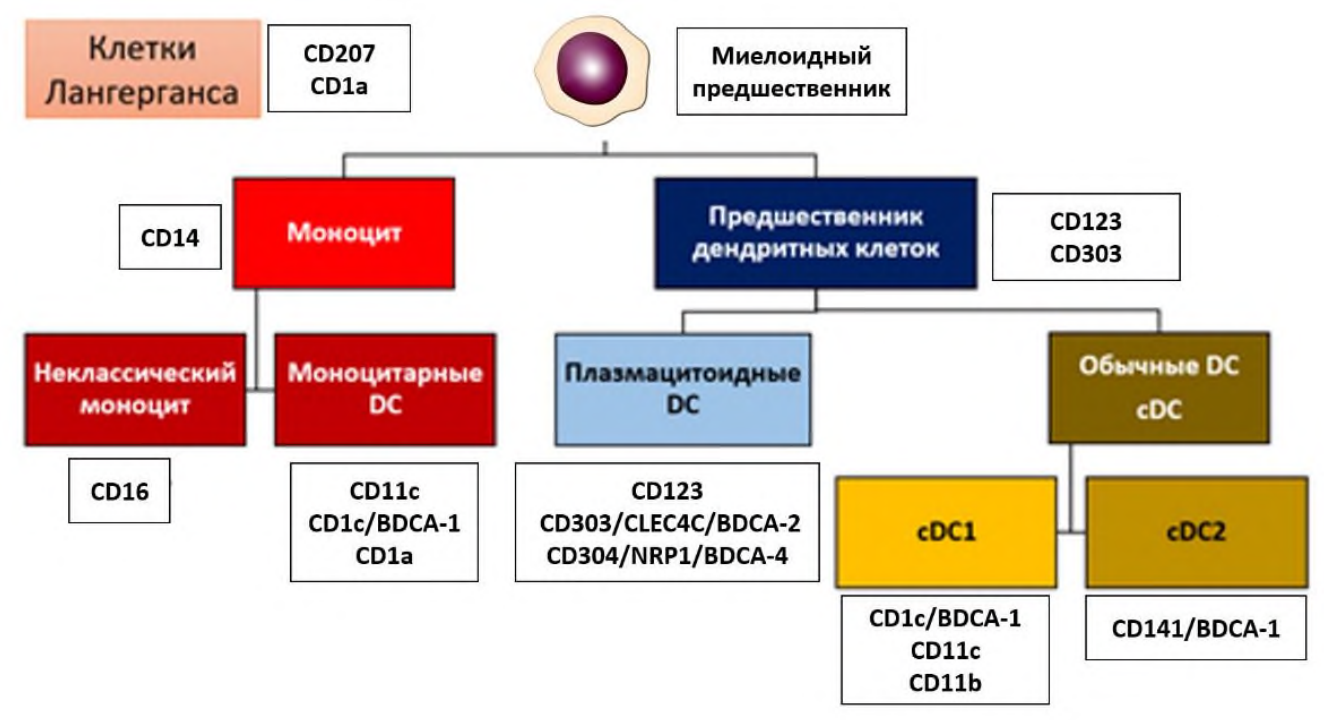

Рис. 51. Подтипы дендритных клеток и их отличительные поверхностные рецепторы.

Плазмацитоидные дендритные клетки (pDC), обычно реагируют на вирусную РНК и ДНК посредством продукции высоких уровней интерферонов I и III типа, воспалительными цитокинами (IL-6 и TNF $\alpha$ ). Однако pDC могут экспрессировать МНСІІ и костимулирующие молекулы и поэтому могут действовать как антиген-презентующие клетки.

Клетки Лангерганса (LC) - это специализированные DC, которые населяют базальный эпидермис и другой многослойный плоский эпителий. В отличии от макрофагов, к которым традиционно их причисляют после захвата антигена, они мигрируют в лимфатические узлы. В отличии от других дендритных клеток LC способны к локальному самообновлению, независимо от костного мозга.

\footnotetext{
Гранулоциты - клетки

с сегментированными ядрами и цитозольными гранулами, происходят из общей полипотентной СК в костном мозге (рис.52). Они осуществляющие защитные функции в основном за счет фагоцитоза (нейтрофилы) и/или за счет секреции токсических субстанций, содержащихся в их гранулах (эозинофилы, базофилы, тучные клетки).
}

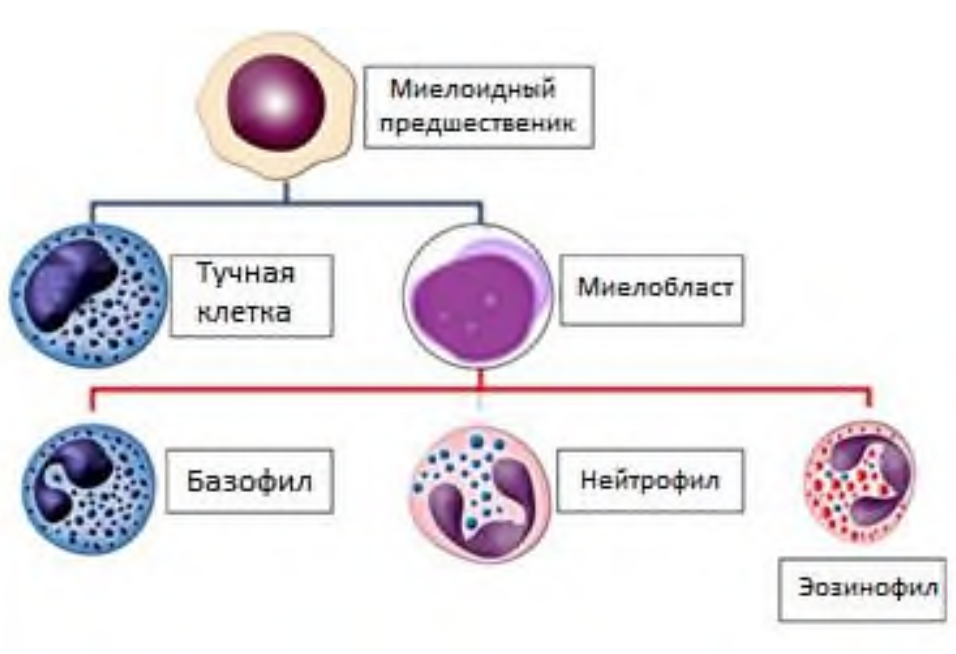

Рис. 52. Гранулоциты. 
Нейтрофилы полиморфно - ядерные лейкоциты с сегментированным ядром и цитозольными гранулами. Классически считаются клетками, определяющими первую линию защиты врожденного иммунитета. Они быстро мигрируют в больших количествах к участкам воспаления, уничтожая патогены в первые дни заражения. Основной состав гноя. Уничтожения патогенов нейтрофилами происходит с помощью:

- $\quad$ фагоцитоза, способны поглощать микроорганизмы или частицы;

- дегрануляции, высвобождение набора белков из гранул (табл. 26), которые обладают антимикробными свойствами;

- NEToза, запрограммированная гибель нейтрофилов с высвобождением внеклеточных ловушек нейтрофилов (NET).

Таблица 26

\section{Состав гранул нейтрофилов}

\begin{tabular}{|l|l|}
\hline \multicolumn{1}{|c|}{ Гранулы нейтрофилов } & \multicolumn{1}{|c|}{ Содержание гранул } \\
\hline Секреторные везикулы & $\begin{array}{l}\text { Молекулы адгезии, которые обеспечивают возможность миграции } \\
\text { нейтрофилов из сосудистой системы к месту повреждения }\end{array}$ \\
\hline Гранулы желатиназы & $\begin{array}{l}\text { Катепсин, желатиназа, коллагеназа, матричная металлопептидаза } \\
- \text { которая обеспечивает миграцию нейтрофилов }\end{array}$ \\
\hline Гранулы азурофилов & $\begin{array}{l}\text { Миелопероксидаза, дефенсины, сериновые протеазы, эластаза } \\
\text { нейтрофилов и катепсин G (убивают патогены) и эластазы, } \\
\text { разрушающие наружные мембраны бактерий }\end{array}$ \\
\hline Особые гранулы & $\begin{array}{l}\text { Щелочные фосфатазы, лизоцим, НАДФН-оксидаза, лактоферрин, } \\
\text { гистаминазы и кателицидин - задерживают вещества, } \\
\text { необходимые для роста бактерий, а также разрушают мембраны }\end{array}$ \\
\hline
\end{tabular}

Нейтрофилы активно секретируют цитокины IL-1 $\beta$, TNF $\alpha$, IL-6, IL-12, IL17A, G-CSF.

Морфологическая характеристика нейтрофилов определяется степенью зрелости клеток: юные, палочкоядерные и сегментоядерные нейтрофилы. Эти популяции можно дополнительно идентифицировать с помощью набора клеточных маркеров (незрелые нейтрофилы экспрессируют CD15 и CD11b, при достижения полной зрелости - CD16).

Сегментоядерные нейтрофилы - терминально дифференцированные клетки, которые во время воспаления могут мигрировать в ткани и выполнять свои эффекторные функции (например, фагоцитоз, производство реактивных форм кислорода (ROS) и уничтожение бактерий). Важно отметить, что нейтрофилы, могут быстро менять свои характеристики и поведение по мере того, как они активируются, стареют или входят в новую среду при остром или хроническом воспалении (реализуют совершенно разные эффекторные механизмы). 
Нейтрофильные гранулоциты обладают рядом свойств, обусловливающих их участие в патогенезе острого воспаления это: богатый набор цитотоксических факторов; высокая чувствительность к всевозможным локальным изменениям гомеостаза; способность накапливаться в очагах поражения и инициировать цепную реакцию с выделением цитотоксических веществ и созданием локального перевеса в балансе эффектор-ингибитор; секреция биологически активных веществ, активирующих предшественников медиаторов воспаления.

Нейтрофилы принимают участие в реализации иммунокомплексных повреждений тканей и в антителозависимых цитотоксических реакциях.

Эозинофилы, базофилы, тучные клетки еще одна группа гранулоцитов. В отличии от нейтрофилов их защитная функция осуществляется не фагоцитозом, а мощной цитотоксической реакцией за счет дегрануляции.

Учитывая их полиморфизм, с клинической точки зрения следует различать клетки относимые к мукозальному иммунитету, которые заложены со времени эмбриогенеза (резидентные эозинофилы, тучные клетки) и традиционные эозинофилы и базофилы (продукты СККМ).

Тучные клетки богатые гранулами, иммунные клетки, которые распределены по всему организму в областях, где обычно возможно соприкосновение с микроорганизмами (барьерные ткани), таких как слизистые оболочки и кожа, а также в большинстве тканей, окружающих кровеносные сосуды и нервы. Традиционно выделяют две подгруппы тучных клеток: клетки соединительной ткани (СТМС) и клетки слизистой оболочки (ММС). По происхождению СТМС делят на самоподдерживающиеся, которые заселены в тканях до рождения, и СТМС, поддерживаемые костным мозгом.

Тучные клетки признаны регуляторными и эффекторными клетками как врожденного, так и адаптивного иммунитета, принимающими активное участие в развитии острых и хронических аллергических, аутоиммунных, воспалительных заболеваний и рака. Эти первичные, сигнальные клетки, связаны со многими иммунными и неиммунными клетками, которые реагируют на патогены и инициируют защитный ответ, высвобождая медиаторы, оказывающие различное действие на окружающие ткани (табл. 27). Они активно участвуют в формировании воспаления, аллергии и анафилаксии. Также тучные клетки играют важную роль в заживлении ран, ангиогенезе, иммунной толерантности, защите от патогенов и формировании гематоэнцефалического барьера.

Активация тучных клеток происходит за счет распознавания DAMP и/или PAMP и/или рецепторов, связанных с G-белком, так же активаторами могут служить белки комплемента. 


\section{Медиаторы тучных клеток и базофилов и их свойства}

\begin{tabular}{|c|c|}
\hline Медиаторы & Биологическое действие \\
\hline \multicolumn{2}{|c|}{ Находящиеся в связанном с гранулярным матриксом состоянии, быстро высвобождаемые } \\
\hline Гистамин & $\begin{array}{l}\text { Повышает сосудистую проницаемость; гиперсекрецию слизи; } \\
\text { вызывает сокращение гладкой мускулатуры; вызывает зуд (H1); } \\
\text { образование простагландинов; повышение уровня цАМФ (Н2) или } \\
\text { цГМФ (Н1) либо торможение (H2) хемотаксиса нейтрофилов и } \\
\text { эозинофилов }\end{array}$ \\
\hline $\begin{array}{l}\text { Эозинофильный } \\
\text { хемотаксический фактор } \\
\text { анафилаксии (ЭХФА) и ЭХФА- } \\
\text { олигопептиды }\end{array}$ & $\begin{array}{l}\text { Вызывают хемоаттракцию и инактивацию эозинофилов и } \\
\text { нейтрофилов }\end{array}$ \\
\hline $\begin{array}{l}\text { Нейтрофильный } \\
\text { хемотаксический фактор }\end{array}$ & Вызывает хемоаттракцию и инактивацию нейтрофилов \\
\hline Арилсульфатаза А & Гидролиз ароматических сульфатных эфиров \\
\hline \multicolumn{2}{|c|}{ Находящиеся в связанном с гранулярным матриксом состоянии, прочно связанные } \\
\hline Гепарин & $\begin{array}{l}\text { Антикоагуляция; торможение активации комплемента; } \\
\text { высвобождение липопротеинлипазы и фосфолипазы }\end{array}$ \\
\hline Химаза & Гидролиз протеогликанов; повышение сосудистой проницаемости \\
\hline $\begin{array}{l}\text { Триптаза (трипсиноподобный } \\
\text { фермент) }\end{array}$ & $\begin{array}{l}\text { Генерация СЗа анафилатоксина; протеолиз; деградация } \\
\text { кининогена }\end{array}$ \\
\hline Пероксидаза & Инактивация лейкотриенов \\
\hline Супероксид дисмутаза & Дисмутация $\mathrm{O}_{2}$ в пероксид водорода \\
\hline \multicolumn{2}{|r|}{ Образуемые в ходе активации клетки } \\
\hline Лейкотриены C4, D4, E4 & $\begin{array}{l}\text { Сокращение гладкой мускулатуры, повышение проницаемости } \\
\text { стенок сосудов; синергизм с гистамином; генерация } \\
\text { простагландинов }\end{array}$ \\
\hline Простагландин D2 & $\begin{array}{l}\text { Сокращение гладкой мускулатуры; повышение артериального } \\
\text { давления; повышение уровня цАМФ }\end{array}$ \\
\hline Тромбоксан А2 & $\begin{array}{l}\text { Сокращение гладкой мускулатуры; стимуляция агрегации } \\
\text { тромбоцитов }\end{array}$ \\
\hline Эндопероксиды (G2, H2) & Сокращение гладкой мускулатуры \\
\hline $\begin{array}{l}\text { Фактор, активации тромбоцитов } \\
\text { (ФАТ) }\end{array}$ & $\begin{array}{l}\text { Агрегация тромбоцитов, высвобождение из них аминов; } \\
\text { повышение проницаемости стенок сосудов; }\end{array}$ \\
\hline $\begin{array}{l}\text { Простагландингенерирующий } \\
\text { фактор }\end{array}$ & Индукция образования простагландинов, тромбоксана В2 \\
\hline $\begin{array}{l}\text { Базофильный калликреин } \\
\text { анафилаксии (в базофилах) }\end{array}$ & $\begin{array}{l}\text { Бронхоспазм; расширение сосудов; повышение сосудистой } \\
\text { проницаемости; боль }\end{array}$ \\
\hline
\end{tabular}

\section{Отдельный механизм связан с рецептором IgE. Тучные клетки} экспрессируют высокоаффинный рецептор (FceRI) для Fc-области IgE. Этот рецептор имеет высокое сродство и необратимо связывается с IgЕ. В результате чего тучные клетки покрываются IgЕ. Как и любое АТ оно специфично к одному конкретному антигену (аллергену). Аллерген связывается с вариабельными участками $\operatorname{IgE}$, находящимся на поверхности тучных клеток, активируют их с 
быстрым высвобождением (анафилактическая дегрануляция) содержимого гранул. Этим и обусловлены аллергические реакции.

Благодаря большому разнообразию других рецепторов, тучные клетки реагируют на различные типы стимулов, включая микробные, нервные, иммунные, гормональные, метаболические и химические триггеры. Именно взаимодействие тучных клеток и нервов способствует возникновению боли и зуда.

Базофилы наименее распространенный в периферической крови тип гранулоцитов, составляющий от 0,5 до $1 \%$ циркулирующих лейкоцитов. Морфологически, в отличии от других гранулоцитов крови, имеют базофильные гранулы, а в отличии от тучных клеток - сегментированное ядро, меньшие

размеры и округлую форму. Базофилы функционально тесно связаны с тучными клетками, хотя совершенно разные по своему происхождению и развиваются из разных гемопоэтических клонов. В отличие от тучных клеток, базофильные гранулы базофилов содержат меньше протеаз, кроме того, этих гранул в базофилах в целом меньше. Базофилы секретируют сравнительно немного активных веществ, однако по количеству выделяемого IL-4 они главный источник в организме, превосходя даже Т-клетки.

На поверхности базофилов представлено большое число хемотаксических рецепторов, однако спектр Toll-подобных рецепторов (PRR) представлен скудно. Подобно тучным клеткам, базофилы имеют два типа рецепторов к иммуноглобулинам Е: высокоаффинные (FceRI) и низкоаффинные (FceRII, или CD23), а также гистаминовые рецепторы H2. За счет этого базофилы быстро рекрутируются в лимфатические узлы, могут функционировать как антигенпрезентирующие клетки и имеют решающее значение для индукции дифференцировки Тh2-клеток, а также связанных с ними воспалительных реакций после контакта с паразитами гельминтов или аллергенами. Все это дает основание предполагать, что базофилы в основном являются регуляторными, а не эффекторными клетками иммунитета.

Эозинофилы - разновидность гранулоцитов с крупными эозинофильными гранулами и сегментированным ядром. Это больше тканевые клетки, чем циркулирующие, поэтому в периферической крови их не более 150 клеток/мкл (1-3\%). Дифференцировка эозинофилов регулируется цитокинами (IL-3, IL-5, GM-CSF). После созревания IL-5 контролирует миграцию эозинофилов из костного мозга в кровь.

Исходно эозинофилы локализуются в вилочковой железе, желудочнокишечном тракте, матке и молочной железе. Эозинофилы способны секретировать на исходном уровне или при стимуляции большое количество разнообразных медиаторов (табл. 28). 
Состав гранул эозинофилов

\begin{tabular}{|c|c|c|}
\hline $\begin{array}{c}\text { Гранулы } \\
\text { эозинофилов }\end{array}$ & Основное содержание & $\begin{array}{l}\text { Назначение } \\
\text { содержимого }\end{array}$ \\
\hline $\begin{array}{l}\text { Специфические } \\
\text { (крупные, } \\
\text { вторичные) }\end{array}$ & $\begin{array}{l}\text { Главный основный белок } 1 \text { (МВР-1); главный } \\
\text { основный белок } 2 \text { (МВР-2); эозинофильный } \\
\text { нейротоксин (EDN); эозинофильный катионный } \\
\text { белок (ЕСР); эозинофильная пероксидаза (ЕРО). }\end{array}$ & Внеклеточный цитолиз \\
\hline Мелкие & Арилсульфатаза В, кислая фосфатаза, пероксидаза & Бактерицидность \\
\hline Первичные & $\begin{array}{l}\text { Лизофосфолипаза (кристаллы Шарко -Лейдена или } \\
\text { галектин-10), митохондриальная ДНК }\end{array}$ & Липидный метаболизм \\
\hline Липидные тельца & $\begin{array}{l}\text { Арахидоновая кислота, липоксигеназа, } \\
\text { циклоксигеназа для синтеза простагландинов, } \\
\text { простациклинов, тромбоксанов, лейкотриенов и др. }\end{array}$ & $\begin{array}{l}\text { Выработка } \\
\text { эйкозаноидов }\end{array}$ \\
\hline $\begin{array}{l}\text { Секреторные } \\
\text { везикулы }\end{array}$ & $\begin{array}{l}\text { Ферменты: эластаза, гистаминаза, коллагеназа. } \\
\text { Цитокины: IL-1, IL-2 , IL-4 , IL-5 , IL-6, IL-8, IL-13, TNFa, } \\
\text { GM-CSF. Факторы роста TGF beta , VEGF и PDGF. } \\
\text { Хемокины CCL3, CCL5, CCL11, CXCL13 }\end{array}$ & Регуляторная роль \\
\hline $\begin{array}{l}\text { Активные формы } \\
\text { кислорода }\end{array}$ & $\begin{array}{l}\mathrm{O}_{2}, \mathrm{H}_{2} \mathrm{O}_{2} \text {, Гидроксильные радикалы. Синглетный } \\
\text { кислород }\end{array}$ & Бактерицидность \\
\hline
\end{tabular}

Исходя из локализации (паренхима/барьерная ткань), морфологии ядра (кольцеобразная/сегментированная), поверхностному фенотипу, ответу на IL-5 различают два типа эозинофилов - резидентный (rEOS) и воспалительный (iEOS).

Характерной особенностью эозинофилов является их защитная антипаразитарная функция. Гельминты и их продукты их жизнедеятельности, медиаторы воспаления (прежде всего, гистамин) и хемокины, макрофагов, тучных и эпителиальных клеток привлекают эозинофилы в ткани. Оказавшись в месте повреждения, эозинофилы прикрепляются к поверхности паразитов за счет своего рецептора к С3b (большинство гельминтов активируют систему комплемента по альтернативному пути с образованием C3b), высвобождают свои цитотоксические гранулярные белки, а также предварительно сформированные цитокины и липидные медиаторы, способствуя уничтожению паразитов, развитию воспаления и повреждению тканей.

Эозинофилы являются эффекторами в метаболизме гистамина, секретируемого тучными клетками. Фермент гистаминаза, выделяемый эозинофилами, катализирует расщепление гистамина, так же эозинофилы фагоцитируют гистаминсодержащие гранулы тучных клеток, адсорбируют гистамин на своей плазмалемме, связывая его своими рецепторами, помимо этого эозинофилы секретируют фактор, тормозящий дегрануляцию и высвобождение гистамина из цитоплазмы тучных клеток. 
Эозинофилы являются предполагаемыми антигенпрезентирующими клетками и играют существенную роль в активации тучных клеток, коммуникации и функции Т-клеток.

Врожденные лимфоидные клетки (ILC) - система клеток врожденного иммунитета (отсутствует антиген-специфические рецепторы), которые происходят от общего лимфоидного предшественника (CLP) и принадлежат к лимфоидной линии. На основании путей развития, фенотипа и продуцируемых сигнальных молекулах, ILC разделены на 5 групп: NK-клетки, ILC1, ILC2, ILC3 и LTi (рис.53). Помимо эффекторной функции ILC участвуют во многих других физиологических функциях, включая гомеостаз ткани, морфогенез, метаболизм, репарацию и регенерацию.

Многие из их функций аналогичны Т-клеткам, поэтому предполагается, что они являются врожденными аналогами Тклеток. Нарушение регуляции ILC может привести к иммунной патологии. ILC1 и NK-клетки имеют много общих маркеров и функций, однако основная отличительная черта то, что в ткани LC1 это нецитотоксические или слабоцитотоксические клетки, реагирующие инфекций, вызываемых вирусами и некоторыми бактериями. Однако основными клетками этой группы лимфоцитов являются NK-клекти.

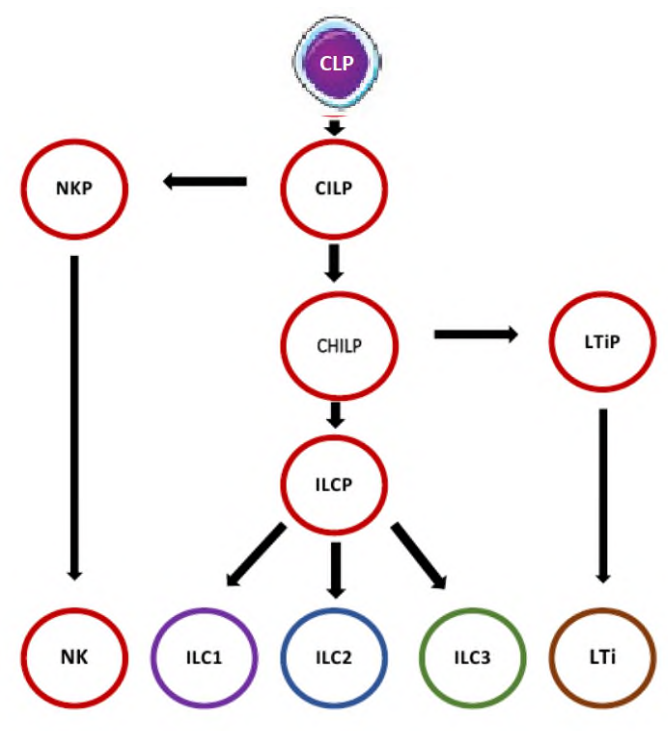

Рис. 53. Развитие врожденных лимфоидных клеток

Естественные или натуральные киллеры (NK). Большие гранулярные лимфоциты («нулевые клетки», «не Т-, не В-клетки»). Число NK в крови - 5$15 \%$; в лимфоузлах и селезенке 2,5-5\% (от всех мононуклеаров). Срок жизни - 710 суток (IL-15). Т- клеточный рецептор отсутствует. В тимусе не «обучаются», созревают в лимфатических узлах. Популяция не клонируется.

Мишени - вирус-трансформированные и опухолевые клетки. Распознают «чужое» по отсутствию «своего» - ключевая роль принадлежит активирующим и ингибирующим сигналам. Основными лигандами активирующих рецепторов являются молекулы, которые появляются на поверхности собственных клеток организма при различных «стрессовых» ситуациях и инфицировании различными патогенами. Ингибиторные рецепторы - KIRs (иммуноглобулиновое суперсемейство) и гетеродимер NKG2A (лектиновый рецептор) - CD94. Их лигандами являются молекулы МНС I класса. В норме, эти 
молекулы представлены постоянно на поверхности нормальных, неизмененных клеток.

Контактный цитолиз происходит в четыре этапа:

Первый этап представляет собой распознавание клеток-мишеней эффекторной клеткой. Ключевую роль в процессах распознавания клетокмишеней играют молекулы главного комплекса гистосовместимости I класса (MHC).

Второй этап контактного цитолиза, сопровождается формированием контакта (или иммунологического синапса) между клеткой-эффектором и клеткой-мишенью, что приводит к поляризации киллерной клетки. Ключевую роль в этих процессах играют интегриновые рецепторы. При этом движение гранул, содержащих перфорин и гранзимы, в зону контакта направляют микротрубочки, ориентированные в сторону клетки-мишени. Сокращение актиновых волокон приводит к выбросу гранул в зону контакта.

Третий этап - это экзоцитоз или выброс гранул клеткой-эффектором. В состав гранул цитотоксических клеток входит несколько компонентов, ключевыми являются перфорин и гранзим В.

И, наконец, последним - четвертым этапом контактного цитолиза является индукция апоптоза клетки-мишени при помощи описанных ниже механизмов.

В настоящее время описано три способа индукции апоптоза цитотоксическими клетками в клетках-мишенях:

- во-первых, это цитолиз, осуществляемый за счет высвобождения перфорина, способного к полимеризации в плоскости мембраны клетки-мишени;

- во-вторых, это запуск апоптоза в клетке-мишени за счет активации на ее поверхности рецепторов, принадлежащих к семейству TNF-подобных белков;

- в-третьих, индукция апоптоза в клетках-мишенях при помощи растворимых молекул семейства TNF, которые способны вызывать кластеризацию рецепторов и активацию каскада каспаз внутри клеток-мишеней.

NK-клетки синтезируют такие цитокины как IFN $\gamma$, TNF $\alpha$, GM-CSF, IL-10 или IL-13. IFN $\gamma$ ингибирует пролиферацию опухолевых клеток in vitro и косвенно рост опухоли in vivo путем индукции антиангиогенных факторов; IFN $\gamma$ усиливает цитотоксичность NK-клеток за счет избыточной экспрессии молекул адгезии и повышения чувствительности опухолевых клеток к цитотоксичности, обусловленной высвобождением гранул или TNF.

Большую роль в формировании иммунитета так же принадлежит Влимфоцитам. Их можно разделить на 3 популяции: В1-, фолликулярные или В2лимфоциты и В-клетки маргинальной зоны. 
В1-лимфоциты - это небольшая популяция В-клеток (около 5 \% от общей популяции В-клеток). Они осуществляют быстрые реакции на проникновение через барьеры широко распространённых бактерий (противобактериальные «пограничники»), поэтому и локализованы в основном в прибарьерных полостях (брюшная и плевральная полости). Там же находятся и клетки-предшественники В1-лимфоцитов, т.к. их пул поддерживается без участия стволовых клеток костного мозга. В1-лимфоциты продуцируют $\operatorname{IgM}$ (определяется как $\operatorname{IgM}$ крови, который в основном и вырабатывается В1лимфоцитами). Помимо этого, В1-лимфоциты продуцируют аутоантитела, структурно похожие на бактериальные антигены, например, белки системы групп крови АВО. Имеется мнение, что В1-клетки можно разделять на подклассы B1a (CD5+) и В1b (CD5-), хотя они сходные по своим свойствам.

В2 (фолликулярные) лимфоциты - обычные «классические» Влимфоциты, созревают в костном мозге, затем мигрируют в селезенку, проходя через две переходные стадии: Т1 и Т2. Т2 дифференцируются в фолликулярные (FO) В-клетки или В-клетки маргинальной зоны (MZ). В2-клетки - наиболее распространенный тип В-клеток, не циркулируют в крови, обнаруживаются в основном в лимфоидных фолликулах (содержащих зародышевые центры), селезенке и лимфатических узлах. В отличии от других В-лимфоцитов, В2клетки экспрессируют высокие уровни $\operatorname{IgD}$ и CD23, низкие уровни CD21 и $\operatorname{IgM}$, при отсутствии CD1 или CD5. Основная их функция: связываться с антигеном, получая помощь от Т-хелперов, дифференцироваться в плазматическую клетку, которая секретирует большое количество антител.

К Т-лимфоцитам относят клетки, основной характеристикой которых является способ распознавания АГ. Они распознают пептидные фрагменты чужеродных белков, встроенные в аутологичные молекулы главного комплекса гистосовместимости (MHC - major histocompatibility complex). Этот молекулярный комплекс им «поставляют» антигенпрезентирующие клетки (АПК). Распознавание осуществляется с помощью клоноспецифического рецептора неиммуноглобулиновой природы, экспрессируемого на поверхности Т-клеток. Таким образом, Т-клетки распознают не «чужое», как, в частности, Вклетки, а «измененное свое», причем антигенный пептид узнается «в контексте» с аутологичной молекулой МНС. В результате акта распознавания Т-клетки активируются и дифференцируются в эффекторные и регуляторные клетки.

К эффекторным клеткам относят Т-лимфоциты, экспрессирующие на своей поверхности рецептор CD8. Такие клетки определяются как цитотоксические Т-лимфоциты. После вовлечения их в иммунный ответ и распознавания специфического АГ в клетках начинается синтез de novo определенных веществ, которые называются цитотоксинами. В виде функционально неактивных молекул-предшественников цитотоксины 
накапливаются в гранулах цитотоксических Т-лимфоцитов и представляют собой как минимум два типа:

1. Перфорины - высвобождаясь из гранул в присутствии Са2+, в течение нескольких секунд полимеризуются в мембране клетки-мишени. В результате образуется пора диаметром 16 нм.

2. Гранзимы - сериновые протеиназы, проникающие в клетку-мишень через перфориновые поры и активирующие процесс апоптоза.

Таким образом, апоптоз является одним из основных механизмов элиминации антигенмодифицированных клеток. Но если в результате какихлибо дефектов в клетке-мишени апоптоз не запускается, то цитотоксические Тлимфоциты все равно разрушат клетку некрозом - осмотическим лизисом за счет сформированных перфориновых пор.

Особыми защитными свойствами в основном без фагоцитоза на слизистых и в ткани обладают резидентные лимфоидные клетки. Эти популяции включают резидентные $\mathrm{T}$ - клетки памяти (T-RM) и «нетрадиционные» Т-клетки (инвариантные NKT (iNKT) -клетки, связанные со слизистой оболочкой инвариантные Т-клетки (MAIT) и $\gamma \delta \mathrm{T}$-клетки, и появляющееся семейство резидентных в ткани $\mathrm{NK}$ ( $\operatorname{tr} \mathrm{NK})$-клетки. Они представляют большую группу лимфоцитов, выстилающие весь желудочнокишечный тракт человека (на десять эпителиальных клеток приходится один лимфоцит). Часть из них представлено интраэпителиально (кишечные интраэпителиальные лимфоциты (iIEL), часть находится в собственной пластинке кишечника, образуя совместно с другими клетками иммунной системы лимфоидные структуры, такие как брыжеечные лимфатические узлы и пейеровы бляшки, а также диффузные лимфоидные фолликулы. Группа iIEL включает разные подмножества CD4+TCR $\alpha \beta+, \quad \mathrm{CD} 4+\mathrm{CD} 8 \alpha \alpha+\mathrm{TCR} \alpha \beta+$, $\mathrm{CD} 8 \alpha \beta+\mathrm{TCR} \alpha \beta+, \mathrm{CD} 8 \alpha \beta+\mathrm{CD} 8 \alpha \alpha+\mathrm{TCR} \alpha \beta+, \mathrm{CD} 8 \alpha \alpha+\mathrm{TCR} \alpha \beta+, \mathrm{iCD} 8 \alpha, \mathrm{iCD} 3+$, однако функция многих из них не определена.

Гамма/дельта Т-лимфоциты, (интраэпителиальные лимфоциты, $\gamma \delta \mathrm{T}$ клетки). «Неклассическая» субпопуляция Т-лимфоцитов, обладают одновременно свойствами эффекторных и регуляторных клеток. Основное место локализации MALT: слизистая оболочка кишечника и респираторного тракта,

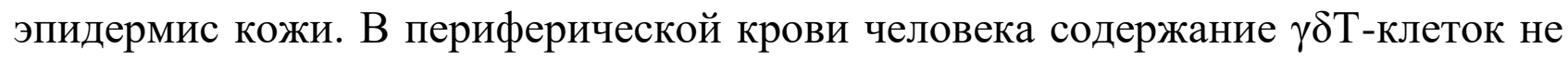
более $5 \%$ от числа лимфоцитов. Они участвуют в формировании 1-й линии иммунной защиты, играя роль цитотоксических клеток; выступая в качестве регуляторных Т-клеток ограничивают интенсивный иммунный ответ и аутоагрессию; способны к фагоцитозу мигрируя в лимфатические узлы, выступают как АПК и способствуют регенерации эпителия при его повреждениях. В основном распознают АГ без представления пептидных 
эпитопов в МНС, играют важную роль в распознавании липидных антигенов, могут запускаться сигналами тревоги, формировать иммунную память.

Клетки iNKT представляют собой липид-чувствительные Т-клетки врожденного иммунитета, напоминающие клетки ILC1 и ILC3, которые мы опишем ниже. Они играют значительную роль в надзоре за опухолью и контроле некоторых вирусных и бактериальных инфекций.

Резидентные в ткани NK $(\operatorname{trNK})$ клетки. Клетки $\operatorname{trNK}$ были выделены из NK-клеток и считаются «врожденными аналогами» T-RM-клеток. Впервые описаны в печени. В дальнейшем дифференцируются в матке, коже, почках, легких и жировой ткани. Подмножество клеток $\operatorname{trNK}$ представляет собой CD56bright-клетки, экспрессируют Ig-подобный рецептор киллерных клеток (KIR), с низким уровнем CD16, CD57 и перфорина. Они продуцируют высокие уровни воспалительных цитокинов, таких как IFN $\gamma$, TNF и GM-CSF, плохо дегранулируют при стимуляции. Этот тип клеток был идентифицирован на границе раздела матери и плода. Их уменьшение ухудшает развитие плода и приводит к задержке роста плода.

Клетки МАIT очень распространены у людей и проявляют функции аналогичные для клеток iNKT. MAIT-клетки помимо слизистых оболочек могут быть в крови, печени и легких. Клетки МАIT реагируют на воспалительные цитокины (IL-7, IL-12, IL-15, IL-18, IFN- $\alpha / \beta)$. Инфицированные клетки слизистых представляют АГ МАIT-клеткам, которые лизируют бактериальноинфицированные клетки, используя гранзим В. МАIT так же вырабатывают провоспалительные цитокины и цитокины, активирующие адаптивный иммунитет, формируют иммунную память. При всех этих процессах необходимо большое количество витамина В2 (рибофлавин).

К клеткам, обладающим защитными свойствами, имеет смысл отнести и многочисленные секреторные клетки вырабатывают вещества различной химической природы. Так, например, в кишечнике функционально схожие с нейтрофилами клетки Панета под воздействием бактерий или бактериальных антигенов секретируют антимикробные пептиды (дефензины, лизоцим и фосфолипазу А2) в просвет кишечной железы, тем самым способствуя поддержанию желудочно-кишечного барьера.

Важное значение в иммунном ответе принадлежит регуляторным клеткам. Описано более 30 разных популяций и субпопуляций клеток, обладающих стимулирующей и супрессорной функцией в отношении активности других клеток. Однако ведущая роль принадлежит Т-лимфоцитам, на поверхности которых выявляется рецептор CD4 (Т-хелперы, Тh-клетки). Среди всех клеток систем врожденного и приобретенного иммунитета Т-хелперы (Th) выделяются особенным разнообразием выполняемых функций, что находит свое отражение в крайне высокой гетерогенности данной популяции. Все они 
дифференцируются из наивной Т-хелперной клетки (Th0) в последующем в зависимости от продукции цитокинов среди CD3+CD4+ лимфоцитов выделяли клетки, способные к синтезу IFN $\gamma$ и получившие название T-хелперов 1 типа (Th1), и клетки, названные T-хелперами 2 типа (Th2) и синтезировавшие IL-4. Далее были описаны Th17 и фолликулярные T-хелперы (Tfh). Мы остановимся несколько позднее только на этих четырех типах клеток, так как их реальное существование не подвергается сомнению (рис.58).

Следует отметить, что с завидной регулярностью появляются работы, свидетельствующие о возможности перехода Тh из одной популяции в другую в зависимости от микроокружения, типа получаемых цитокиновых сигналов метаболизма клеток и широчайшего спектра других факторов.

\section{Молекулы иммунной системы}

Клетки иммунной системы вырабатывают большое количество биологически активных молекул, которые выполняют эффекторные и регуляторные функции (табл. 29). Все эти вещества, играющие важную роль в процессе распознавания и элиминации из организма человека чужеродных веществ, тесно взаимосвязаны между собой и в то же время могут функционировать автономно. Поэтому они оказывают на организм очень разностороннее и, порой, неоднозначное действие.

Таблица 29

\section{Молекулы иммунной системы}

\begin{tabular}{|l|l|l|l|l|}
\hline \multicolumn{2}{|c|}{ Эффекторные } & \multicolumn{3}{|c|}{ Регуляторные } \\
\hline \multicolumn{1}{|c|}{ Специфические } & \multicolumn{1}{|c|}{ Неспецифические } & \multicolumn{1}{|c|}{ Цитокины } & \multicolumn{1}{|c|}{ Медиаторы } & Гормоны \\
\hline Антитела & $\alpha$ и $\beta$-интерфероны, & Интерлейкины & Гистамин & Тимозин \\
(иммуноглобулины & комплемент, СРБ, ПкТ & ү-интерферон & Серотонин & Тимопоэтин \\
А М G E D) & и др. белки острой & ФНО, КСФ, & Простагландины & \\
& фазы, факторы & хемокины, & Лейкотриены & \\
& свертывания крови & факторы роста & & \\
\hline
\end{tabular}

Основными эффекторными продуктами адаптивного иммунитета являются иммуноглобулины (антитела). Это белки, гликопротеины, относящиеся к $\gamma$-глобулиновой фракции белков крови, продуцируемые плазматическими клетками (конечный этап дифференцировки В-лимфоцитов), (рис. 53). Термины «антитело» и «иммуноглобулин» часто используются взаимозаменяемо, хотя термин «антитело» иногда зарезервирован для секретируемой растворимой формы, т.е. исключая рецепторы В-клеток. 
Основой структуры различных классов или изотипов антител (IgA, $\operatorname{IgM}, \operatorname{IgG}, \operatorname{IgE}, \operatorname{IgD})$ является большой, Y-образный белок, состоящий из четырех полипептидных цепей (две идентичные тяжелые цепи и две идентичные легкие цепи) соединенные дисульфидными связями. Функционально антитело можно разделить на два антигенсвязывающих фрагмента (Fab) и константный участок $(\mathrm{Fc})$ участвующий во взаимодействиях с другими компонентами иммунной системы. Fab содержит паратоп, который специфичен для одного конкретного эпитопа, который распознает уникальную молекулу возбудителя, называемую антигеном, взаимодействуя между собой подобно замку и ключу. Используя этот механизм связывания, антитело может помечать микроб или инфицированную клетку для уничтожения другими факторами иммунитета, или может нейтрализовать его непосредственно. Особая группа антител - это секреторные антитела $\operatorname{Ig} \mathrm{A}(\mathrm{sIg}$ ). Данные антитела представляют собой димеры молекул IgA, соединенных Jцепью и секреторным компонентом, который транспортируется через барьер эпителиальных клеток в просвет органа (до 5 г в день). Секреторный компонент $\operatorname{sg}$ А защищает иммуноглобулин от действия протеолитических ферментов. $\operatorname{sgA}$ связывается со слоем слизи желудочно-кишечного тракта, предстательной железы, респираторного эпителия, слезой, слюной, потом, выделением из мочеполовых путей покрывает эпителий, и действует как антигенспецифический барьер для патогенов и токсинов. Наличие его в молозиве обеспечивает иммунитета новорождённых и способствует формированию, а в дальнейшем и регулированию состава
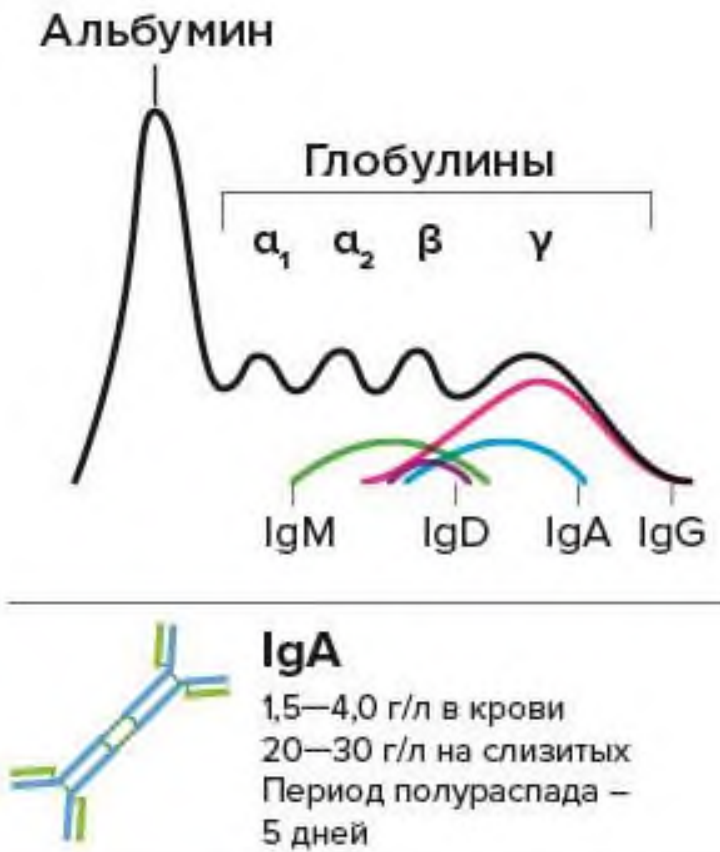

$\lg \mathbf{A}$

$1,5-4,0$ г/л в крови 20-30 r/л на слизитых Период полураспада 5 дней

IgG
$9,0-18,0$ г/n
Период полураспада -
$7-23$ дня

Рис. 53. Иммуноглобулины человека. 
комменсальной микробиоты. Этот эффект достигается тем, что Fc-концы sIgA сшиты и не активируют фагоциты и комплемент.

Антитела разных классов различаются по тому, где они выделяются в организме и на какой стадии иммунного ответа действуют.

К химическим факторам, способствующим защите поверхности эпителия, можно отнести различные растворимые секреты (слизь, слеза, слюна, моча) в большом количестве присутствующие на слизистых и коже (табл.30).

Таблица 30

\section{Растворимые факторы секретов}

\begin{tabular}{|c|c|c|}
\hline Факторы & Локализация & Механизм действия \\
\hline Кислый рH & $\begin{array}{l}\text { Кожа, влагалище, } \\
\text { желудок }\end{array}$ & Подавляет рост бактерий \\
\hline Жирные кислоты & Пот & Подавляет рост бактерий \\
\hline $\begin{array}{l}\text { Муцины и } \\
\text { агглютинины }\end{array}$ & Секреты & Агрегация бактерии \\
\hline Пероксидазы & Секреты & $\begin{array}{l}\text { Катализируют окисление липидных мембран } \\
\text { бактерий }\end{array}$ \\
\hline Ингибиторы протеазы & Секреты & $\begin{array}{l}\text { Подавляют функцию } \\
\text { активность протеаз }\end{array}$ \\
\hline $\begin{array}{l}\text { Лизосомальные } \\
\text { ферменты }\end{array}$ & Пот и секреты & $\begin{array}{lcc}\text { Уничтожают } & \text { бактерии, } & \text { гидролизуя } \\
\text { полисахаридный компонент клеточной стенки. }\end{array}$ \\
\hline Лактоферрин & Секреты & Подавляет рост бактерий, связывая железо \\
\hline Гистатины & Слюна & $\begin{array}{l}\text { Обладают противогрибковыми свойствами, } \\
\text { нарушая функцию митохондрий }\end{array}$ \\
\hline Катионные белки & Пот и секреты & $\begin{array}{lcr}\text { Обладают } & \text { антибактериальной } & \text { активностью, } \\
\text { связываясь } & \text { с } & \text { липидными } \\
\text { мембранами } & & \\
\text { млеточными }\end{array}$ \\
\hline $\begin{array}{l}\text { Дефенсины и другие } \\
\text { антибактериальные } \\
\text { пептиды }\end{array}$ & Секреты & $\begin{array}{l}\text { Секретируются лейкоцитами и активны против } \\
\text { бактерий, грибков и вирусов в оболочке }\end{array}$ \\
\hline
\end{tabular}

Слизь, действует как защитный барьер, препятствующий прикреплению бактерий к эпителиальным клеткам. Микробы и другие чужеродные частицы, захваченные слизью, удаляются механическим путем за счет движения ресничек эпителия, с кашлем и чиханием.

При патологических процессах эти процессы усиливаются, возникает рвота, диарея, ринорея, слущивание (образование перхоти, шелушение). С другой стороны, плотный слой слизи отделяет кишечный эпителий от резидентных микробов, обеспечивая защиту за счет статического экранирования гликокаликсом (пушистое покрытие на внешней поверхности мембран) и ограничивая захват дендритными клетками кишечника микробов, содержит их в противовоспалительном состояние. 
В качестве факторов защиты в ответ на вторжение вируса и некоторых бактериальных агентов зараженные клетки различных тканей вырабатывают интерфероны I и III типа (IFN). Они секретируются сразу после контакта с вирусом и прямо пропорционально заражающей дозе. Под воздействием IFN в клетке происходит выработка сотен белков, вызывающих различные эффекты. Прежде всего РНК-активируемая протеинкиназа и рибонуклеаза L, приводящие к разрушению вирусной РНК, новые вирусные частицы, либо вовсе не формируются, либо их число уменьшается в десятки или сотни раз. Помимо этого, секретируемый IFN защищает соседние клетки от вирусов, активирует клетки иммунной системы, подавляет пролиферацию клеток, усиливает экспрессию MHC I класса. Участвует IFN и в формировании системных реакций (лихорадка, слабость, недомогание, головная боль), регулирует гемопоэз (рис. 54).

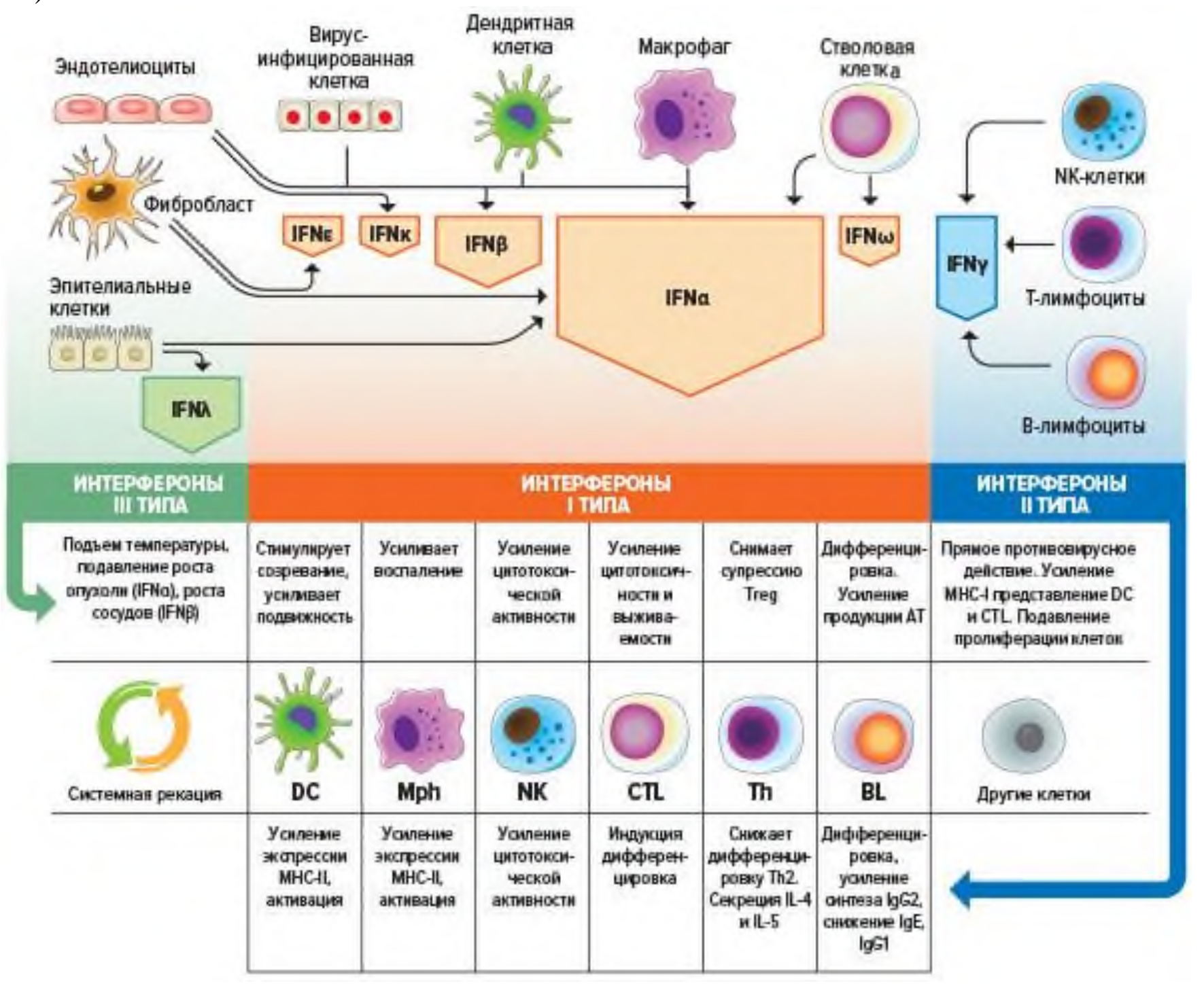

Рис. 54. Интерфероны. 
Среди циркулирующих протеинов крови важнейшим цитолитическим фактором является система белков комплемента. Большая часть компонентов комплемента синтезируется гепатоцитами и мононуклеарными фагоцитами и циркулируют в крови в неактивной форме. В условиях воспалительной реакции первый компонент этой системы (C3) распознает комплекс АГ-АТ. Также возможна активация комплемента по альтернативному и лектиновому пути в результате контакта с АГ на поверхности бактериальных клеток

Последовательная активация всех компонентов системы комплемента имеет ряд последствий.

Во-первых, происходит каскадное усиление реакции, образуется большое количество продуктов реакции, которые обладают, в частности, хемотаксической активностью.

Во-вторых, на поверхности бактерии фиксируются компоненты (С9) комплемента, резко усиливающие фагоцитоз этих клеток.

В-третьих, при ферментативном расщеплении белков системы комплемента образуются фрагменты, обладающие мощной воспалительной активностью. При включении в комплекс АГ-АТ последнего компонента комплемента этот комплекс приобретает способность формировать пору в клеточной мембране и, тем самым, вызывать гибель чужеродных клеток (рис. $55)$.

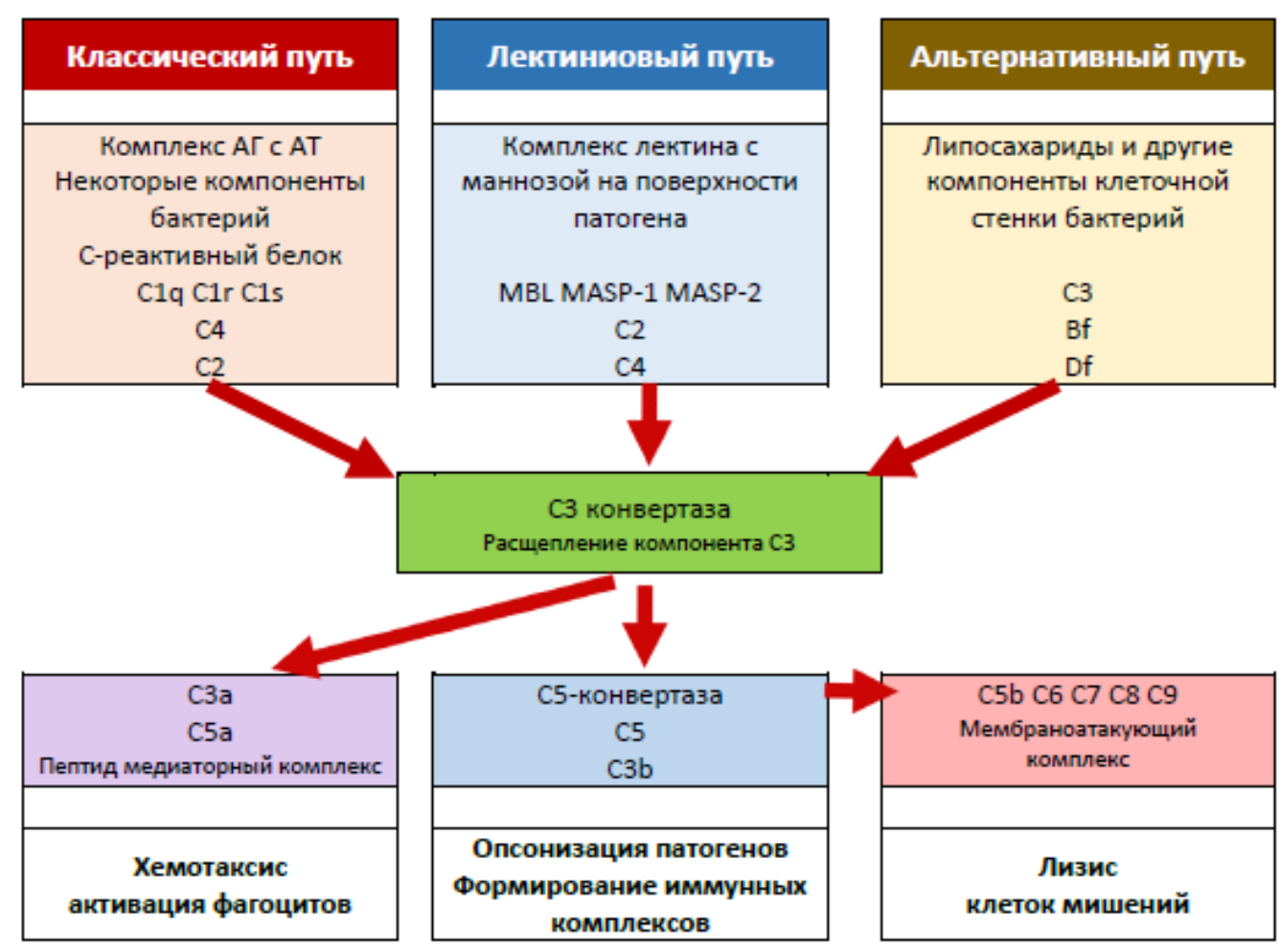

Рис. 55. Система белков комплемента. 
Комплемент активируется любым комплексом АГ-АТ, недостаточность в системе комплемента может приводить к развитию патологических процессов.

Гуморальная регуляция межклеточных взаимодействий в иммунной системе осуществляется цитокинами (более 200).

Цитокины - это низкомолекулярные регуляторные белки или гликопротеины, секретируемые клетками иммунной системы и различными другими клетками в ответ на ряд стимулов. С их помощью осуществляется межклеточная коммуникация: регулируется функция клеток, пролиферация и дифференцировка, хемотаксис, активация специфических мембранных рецепторов, секреция других цитокинов и иммуноглобулинов. Они регулируют развитие иммунных эффекторных клеток, некоторые цитокины обладают собственными эффекторными функциями. Некоторые цитокины могут связываться с рецепторами на мембране той же самой клетки, которая его секретировала, оказывая аутокринное действие; он может связываться с рецепторами на клетке-мишени в непосредственной близости от клеткипродуцента, оказывая паракринное действие; в некоторых случаях он может связываться с клетками-мишенями в отдаленных частях тела, оказывая системное действие. В одних случаях один и тот же цитокин может стимулировать пролиферацию клеток, в других их дифференцировку, в-третьих, - изменять функциональное состояние. Многие цитокины характеризуются целым спектром эффектов, оказываемых на различные ткани тканеспецифичность действия, которая определяется различными типами рецепторов, экспрессирующихся на клетках, и факторами транскрипции, активирующимися при передаче сигнала. При этом биологические эффекты, оказываемые разными цитокинами, могут в значительной степени перекрываться, поскольку многие рецепторы используют общие цепи и/или запускают сходные внутриклеточные каскады. Именно от их баланса зависит исход развития патологического процесса как в ранний, так и в отсроченный период.

Традиционно цитокины подразделяют на несколько групп: интерфероны, интерлейкины, семейство фактора некроза опухолей, хемокины, ростовые и факторы дифференцировки.

У здоровых людей концентрация цитокинов в крови ничтожно мала (пикограммы-10-12/мл), при развитии патологического процесса «по запросу» начинается синтез и секреция цитокинов, но они вырабатываются непродолжительное время (матричная РНК цитокинов короткоживущая). При отсутствии «запроса» клетка, синтезирующая цитокины, переключается на синтез супрессорных цитокинов и/или экспрессирует ингибиторные рецепторы или рецепторы для сигналов к апоптозу. При несостоятельности местных защитных реакций синтез цитокинов возрастает в разы. Прежде всего, это синтез провоспалительных цитокинов врожденного иммунитета, в меньшей степени провоспалительных цитокинов активированных Т-лимфоцитов. (табл. 31). 
Таблица 31

\section{Провоспалительные цитокины}

\begin{tabular}{|c|c|c|c|}
\hline Цитокины & Клетки-продуценты & Мишени & Эффекты \\
\hline \multicolumn{4}{|c|}{ врождённого иммунитета } \\
\hline 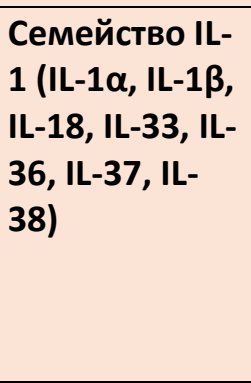 & $\begin{array}{l}\text { Моноциты, } \\
\text { макрофаги, } \\
\text { дендритные клетки, } \\
\text { NK-клетки, B- } \\
\text { лимфоциты, } \\
\text { эпителиальные и } \\
\text { эндотелиальные } \\
\text { клетки }\end{array}$ & $\begin{array}{l}\text { Клетки сосудистой } \\
\text { системы, } \\
\text { гипоталамуса, } \\
\text { печени }\end{array}$ & $\begin{array}{l}\text { Вызывает воспалительные сосудистые } \\
\text { реакции, повышение температуры тела, } \\
\text { индукцию секреции белков острой фазы }\end{array}$ \\
\hline $\begin{array}{l}\text { Семейство IL- } \\
6 \text { (IL-6, IL-27, } \\
\text { IL-31, LIF) }\end{array}$ & $\begin{array}{l}\text { Макрофаги, Т-клетки, } \\
\text { эндотелиальные } \\
\text { клетки, кератиноциты } \\
\text { другие в } \\
\text { т.ч. опухолевые клетки }\end{array}$ & $\begin{array}{l}\text { Гепатоциты, } \\
\text { моноциты, Th, B- } \\
\text { лимфоциты, } \\
\text { плазматические } \\
\text { клетки } \\
\end{array}$ & $\begin{array}{l}\text { Индукция секреции белков острой фазы, } \\
\text { ингибитор TNF и IL-1, стимулирует } \\
\text { дифференцировку B-клеток, активация T- } \\
\text { лимфоцитов и дифференцировка их в } \\
\text { Th17-клетки. Миокины }\end{array}$ \\
\hline TNF $\alpha$ & $\begin{array}{l}\text { В основном } \\
\text { макрофаги, а также } \\
\text { моноциты, NK-, Th1- } \\
\text { клетки }\end{array}$ & $\begin{array}{l}\text { Сосудистая система, } \\
\text { печень, нейтрофилы } \\
\text { и многие другие } \\
\text { типы клеток }\end{array}$ & $\begin{array}{l}\text { Кахексия. Сосудистые реакции, индукция } \\
\text { секреции белков острой фазы, } \\
\text { активирует нейтрофилы, вызывает } \\
\text { апоптоз клеток в т.ч. опухолевых }\end{array}$ \\
\hline \multicolumn{4}{|c|}{ продукт активированных Т-лимфоцитов } \\
\hline ФHOß (LT $\alpha)^{*}$ & Тh1, ЦТЛ & Многие типы клеток & $\begin{array}{l}\text { Активность сходна с TNF } \alpha, \text { сильное } \\
\text { противоопухолевое действие }\end{array}$ \\
\hline $\begin{array}{l}\text { IL-5 (CSF для } \\
\text { эозинофилов) }\end{array}$ & Th2, тучные клетки & $\begin{array}{l}\text { Эозинофилы, } \\
\text { В-лимфоциты }\end{array}$ & $\begin{array}{l}\text { Дифференцировка и активация } \\
\text { эозинофилов. Переключение синтеза на } \\
\text { IgA }\end{array}$ \\
\hline IL-16 & $\begin{array}{l}\text { ЦТЛ, эпителиальные } \\
\text { клетки, эозинофилы }\end{array}$ & $\begin{array}{l}\text { Т-лимфоциты, } \\
\text { дендритные клетки, } \\
\text { макрофаги, } \\
\text { моноциты, } \\
\text { эозинофилы }\end{array}$ & $\begin{array}{l}\text { Хемоатрактант и активатор для клеток, } \\
\text { экспрессирующих CD4 (Th, макрофаги, } \\
\text { дендритные клетки, моноциты, } \\
\text { эозинофилы) }\end{array}$ \\
\hline $\begin{array}{l}\text { Семейство IL- } \\
17 \text { (IL-17A, IL- } \\
\text { 17B, IL-17C, IL- } \\
\text { 17D, IL-17F, IL- } \\
25)\end{array}$ & Т-лимфоциты (Th17) & $\begin{array}{l}\text { Эпителиальные и } \\
\text { эндотелиальные } \\
\text { клетки, фибробласты }\end{array}$ & $\begin{array}{l}\text { Стимулирует секрецию } \\
\text { провоспалительньгх цитокинов, } \\
\text { хемокинов и простагландинов, } \\
\text { стимулирует ангиогенез }\end{array}$ \\
\hline IFNY & $\begin{array}{l}\text { Th1-, NK-, ЦТЛ, } \\
\text { В-лимфоциты }\end{array}$ & $\begin{array}{l}\text { Моноциты, } \\
\text { макрофаги, В- } \\
\text { лимфоциты, Th2- } \\
\text { лимфоциты }\end{array}$ & $\begin{array}{l}\text { Активация макрофагов и нейтрофилов. } \\
\text { усиление МНС І и II, индукция молекул } \\
\text { адгезии на эндотелии }\end{array}$ \\
\hline
\end{tabular}

Действие цитокинов на кроветворную систему связано с существенной активацией гемопоэза за счет цитокинов, влияющих на гемопоэз (табл.32). Увеличение числа лейкоцитов необходимо для наращивания количества клеток, убивающих патогены, и для восполнения потерь нейтрофильных гранулоцитов в очаге гнойного воспаления. Они попадают в циркуляцию и их действие проявляется на системном уровне. 
Таблица 32.

\section{Основные гемопоэтические цитокины}

\begin{tabular}{|c|c|c|c|}
\hline Цитокин & Клетки-продуценты & Мишени & Эффекты \\
\hline Эритропоэтин & $\begin{array}{l}\text { Один из гормонов } \\
\text { почек, также } \\
\text { секретируется в клетках } \\
\text { печени }\end{array}$ & $\begin{array}{l}\text { Стимулятор } \\
\text { эритропоэза }\end{array}$ & $\begin{array}{l}\text { Связываясь с рецептором } \\
\text { эритропоэтина (ЕроR) блокирует } \\
\text { апоптоз эритроид. предшественников }\end{array}$ \\
\hline Тромбопоэтин & $\begin{array}{l}\text { Клетки печени, в } \\
\text { меньшей степени-в } \\
\text { почках и поперечно- } \\
\text { полосатой мускулатуре }\end{array}$ & $\begin{array}{l}\text { Стимулирует } \\
\text { выработку и } \\
\text { дифференцировку } \\
\text { мегакариоцитов }\end{array}$ & $\begin{array}{l}\text { Повышении числа тромбоцитов } \\
\text { уменьшает уровень тромбопоэтина, } \\
\text { воздействие на мегакариоциты }\end{array}$ \\
\hline $\begin{array}{l}\text { IL-1 } \\
\text { (гемопоэтин-1) }\end{array}$ & $\begin{array}{l}\text { Эпителиальные клетки, } \\
\text { моноциты, макрофаги, } \\
\text { ДК, NK-клетки, B- } \\
\text { лимфоциты }\end{array}$ & $\begin{array}{l}\text { Клетки сосудистой } \\
\text { системы, печени } \\
\text { гипоталамуса, }\end{array}$ & $\begin{array}{l}\text { Вызывает воспалительные сосудистые } \\
\text { реакции, повышение температуры } \\
\text { тела, индукцию секреции белков } \\
\text { острой фазы }\end{array}$ \\
\hline M-CSF(CSF1)* & $\begin{array}{l}\text { Моноциты, } \\
\text { гранулоциты, } \\
\text { фибробласты и } \\
\text { эндотелиальные клетки }\end{array}$ & $\begin{array}{l}\text { Стволовые клетки } \\
\text { костного мозга } \\
\text { (СККМ), моноциты }\end{array}$ & $\begin{array}{l}\text { Стимулирует пролиферацию } \\
\text { моноцитов, активирует их и } \\
\text { макрофаги, стимулирует секрецию } \\
\text { провоспалительных цитокинов }\end{array}$ \\
\hline GM-CSF(CSF2)* & $\begin{array}{l}\text { Фибробласты, } \\
\text { эндотелиальные клетки, } \\
\text { макрофаги, Th }\end{array}$ & $\begin{array}{l}\text { СККМ, клетки } \\
\text { миелоидного } \\
\text { ряда, } \\
\text { эндотелиальные } \\
\text { клетки }\end{array}$ & $\begin{array}{l}\text { Стимулирует пролиферацию } \\
\text { гранулоцитов и моноцитов. } \\
\text { Хемотрактант для нейтрофилов, } \\
\text { стимулирует фагоцитоз, вызывает } \\
\text { созревание дендритных клеток }\end{array}$ \\
\hline G-CSF(CSF3)* & $\begin{array}{l}\text { Эндотелиальные клетки } \\
\text { нейтрофилы, моноциты, } \\
\text { макрофаги, } \\
\text { фибробласты }\end{array}$ & $\begin{array}{l}\text { СККМ, } \\
\text { гранулоциты, } \\
\text { клетки плаценты }\end{array}$ & $\begin{array}{l}\text { Стимулирует пролиферацию } \\
\text { предшественников гранулоцитов }\end{array}$ \\
\hline IL-3 (мульти-CSF) & $\begin{array}{l}\text { Кератиноциты, тучные } \\
\text { клетки, эндотелиальные } \\
\text { клетки, Т-лимфоциты, } \\
\text { NК-клетки, моноциты } \\
\end{array}$ & $\begin{array}{l}\text { СККМ, макрофаги, } \\
\text { мегакариоциты, } \\
\text { эозинофилы, } \\
\text { тучные клетки } \\
\end{array}$ & $\begin{array}{l}\text { Направляет дифференцировку СКК в } \\
\text { сторону миелоидного ряда, } \\
\text { стимулирует пролиферацию всех } \\
\text { клеток миелоидного ряда }\end{array}$ \\
\hline $\begin{array}{l}\text { IL-7 (CSF для } \\
\text { лимфоцитов) }\end{array}$ & $\begin{array}{l}\text { Строма тимуса и } \\
\text { костного мозга, } \\
\text { эпителиальные клетки } \\
\text { кишечника }\end{array}$ & $\begin{array}{l}\text { Предшественники } \\
\text { В -лимфоцитов, Т- } \\
\text { лимфоциты, NK- } \\
\text { клетки, моноциты, } \\
\text { мегакариоциты, }\end{array}$ & $\begin{array}{l}\text { Направляет дифференцировку СКК в } \\
\text { сторону лимфоидного ряда, } \\
\text { стимулирует пролиферацию В- и Т- } \\
\text { лимфоцитов, стимулирует синтез } \\
\text { воспалительных цитокинов } \\
\text { моноцитами }\end{array}$ \\
\hline IL-11 & Строма костного мозга & $\begin{array}{l}\text { Мегакариоциты, } \\
\text { остеокласты, } \\
\text { адипоциты, } \\
\text { гепатоциты } \\
\end{array}$ & $\begin{array}{l}\text { Стимулирует пролиферацию } \\
\text { мегакариоцитов и эритроцитов. } \\
\text { Стимулирует секрецию белков острой } \\
\text { фазы. Ингибирует адипоциты }\end{array}$ \\
\hline $\begin{array}{l}\text { SCF (фактор } \\
\text { стволовых } \\
\text { клеток) }\end{array}$ & $\begin{array}{l}\text { Фибробласты, клетки } \\
\text { стромы костного мозга } \\
\text { эндотелиальные клетки }\end{array}$ & $\begin{array}{l}\text { СККM, } \\
\text { меланоциты, } \\
\text { тучные клетки, } \\
\text { врожденные } \\
\text { лимфоидные } \\
\text { клетки (ILC3) }\end{array}$ & $\begin{array}{l}\text { Связывается с рецептором КIT (CD117) } \\
\text { увеличивает выживаемость } \\
\text { гемопоэтических стволовых клеток, } \\
\text { тучных клетках, меланоцитах и } \\
\text { половых клетках }\end{array}$ \\
\hline
\end{tabular}


Формируется системная воспалительная реакция. Она может проявляться множеством симптомов, начиная от легких, похожих на грипп (лихорадка, утомляемость, головная боль, сыпь, артралгии и миалгия), до тяжелых угрожающих жизни проявлений чрезмерной воспалительной реакции.

Одно из первых проявлений, связанно с действием цитокинов на терморегуляторный центр гипоталамуса, с подъемом температуры тела. Увеличение температуры является одной из эффективных защитных реакций, так как при повышенной температуре снижается способность ряда бактерий к размножению, и, напротив, возрастает пролиферация лимфоцитов.

В печени под влиянием цитокинов увеличивается синтез острофазных белков и компонентов системы комплемента, необходимых для борьбы с патогеном, одновременно снижается синтез альбумина. Т.е. на уровне регуляции генов цитокины направляют энергетические потоки, для развития защитных реакций. Действие провоспалительных цитокинов на ЦНС приводит так же к снижению аппетита и изменению всего комплекса поведенческих реакций. Более тяжелые случаи характеризуются гипотонией, а также высокой температурой и могут прогрессировать до неконтролируемой системной воспалительной реакции с цитокиновым штормом, требующим реанимационных мероприятий.

Поэтому важно, чтобы своевременно началась выработка противовоспалительных цитокинов (табл.33).

Таблица 33

Противовоспалительные цитокины

\begin{tabular}{|c|c|c|c|}
\hline Цитокин & $\begin{array}{c}\text { Клетки- } \\
\text { продуценты }\end{array}$ & Мишени & Эффекты \\
\hline $\begin{array}{l}\text { Семейство } \\
\text { IL-10 (IL-10, } \\
\text { IL-19, IL-20, } \\
\text { IL-22, IL-24) }\end{array}$ & $\begin{array}{l}\text { T-(Th1, Th2 и Th22) и } \\
\text { В-лимфоциты, } \\
\text { моноциты, } \\
\text { макрофаги, } \\
\text { кератиноциты }\end{array}$ & $\begin{array}{l}\text { Th1, ЦТЛ, В-лимфоциты, } \\
\text { антигенпрезентирующие } \\
\text { клетки }\end{array}$ & $\begin{array}{l}\text { Ингибирование функции макрофагов } \\
\text { (снижение секреции TNF, IL-1, IL-12, } \\
\text { угнетение экспрессии MHC II), Th1 } \\
\text { (угнетение IL-2, IL-3, IFNY), стимуляция } \\
\text { пролиферации B-лимфоцитов }\end{array}$ \\
\hline IL-4 & Th2, тучные клетки & B- n Th & $\begin{array}{l}\text { Подавляет активность макрофагов, } \\
\text { стимулирует экспрессии МHC-II } \\
\text { переключает синтез антител на IgG1 и IgE }\end{array}$ \\
\hline $\begin{array}{l}\text { IL-8 } \\
\text { (хемокин } \\
\text { CXCL8) }\end{array}$ & $\begin{array}{l}\text { Моноциты, } \\
\text { макрофаги, } \\
\text { эндотелий }\end{array}$ & $\begin{array}{l}\text { Нейтрофилы, наивные Т- } \\
\text { лимфоциты }\end{array}$ & $\begin{array}{l}\text { Мобилизация, активация и дегрануляция } \\
\text { нейтрофилов, хемотаксис лимфоцитов. } \\
\text { Стимулирует ангиогенез }\end{array}$ \\
\hline IL-13 & Th2, тучные клетки & $\begin{array}{l}\text { Макрофаги, } \\
\text { В-лимфоциты, эпителий } \\
\text { кишечника }\end{array}$ & $\begin{array}{l}\text { Подавляет макрофагов, переключение } \\
\text { синтеза антител на IgG1 и IgE, } \\
\text { стимуляция выработки слизи, медиатор } \\
\text { аллергического воспаления }\end{array}$ \\
\hline IL-26 & Т-лимфоциты & Эндотелиальные клетки & $\begin{array}{l}\text { Усиливает секрецию IL-8 и IL-10 } \\
\text { эндотелиальными клетками }\end{array}$ \\
\hline TGF $\beta$ & $\begin{array}{l}\text { Т-лимфоциты, } \\
\text { макрофаги, } \\
\text { эндотелиальные } \\
\text { клетки, многие } \\
\text { опухолевые клетки }\end{array}$ & Многие типы клеток & $\begin{array}{l}\text { Ингибирование роста Т-клеток и } \\
\text { макрофагов, эндотелиальных клеток, } \\
\text { кератиноцитов, фибробластов, } \\
\text { гепатоцитов. Переключение синтеза } \\
\text { антител на IgA. Стимуляция роста } \\
\text { сосудов }\end{array}$ \\
\hline
\end{tabular}


Гуморальная регуляция в системе адаптивного иммунитета так же осуществляется за счет цитокинов. Цитокины, регулирующие адаптивный иммунитет представлены в таблице (табл.34).

Таблица 34

Иммунорегуляторные цитокины

\begin{tabular}{|c|c|c|c|}
\hline Цитокин & Клетки-продуценты & Мишени & Эффекты \\
\hline $\begin{array}{l}\text { Семейство IL-2 } \\
\text { (IL-2, IL-4, IL-7, } \\
\text { IL-9, IL-15, IL-21) }\end{array}$ & Т-лимфоциты & Лимфоциты & $\begin{array}{l}\text { Стимулирует пролиферацию Т- и В- } \\
\text { лимфоцитов, NK-клеток }\end{array}$ \\
\hline $\begin{array}{l}\text { Семейство IL- } \\
12 \text { (IL-12, IL-23, } \\
\text { IL-27, IL-35) }\end{array}$ & $\begin{array}{l}\text { Макрофаги, } \\
\text { дендритные клетки, В- } \\
\text { лимфоциты }\end{array}$ & $\begin{array}{l}\text { NK-клетки, Th1 и } \\
\text { Th2 }\end{array}$ & $\begin{array}{l}\text { Вызывает дифференцировку Th1, } \\
\text { ингибирует Th2, стимулирует секрецию } \\
\text { IFNץ, усиливает активность NK- и ЦТЛ }\end{array}$ \\
\hline IL-14 & $\begin{array}{l}\text { Т-лимфоциты, В- } \\
\text { лимфоцитарные } \\
\text { опухоли }\end{array}$ & В-лимфоциты & $\begin{array}{l}\text { Контролирует рост и пролиферацию В- } \\
\text { клеток, подавляет секрецию Ig }\end{array}$ \\
\hline IL-18 & $\begin{array}{l}\text { Макрофаги, } \\
\text { дендритные клетки, } \\
\text { эпителиальные клетки }\end{array}$ & $\begin{array}{l}\text { Th1, NK-клетки, B- } \\
\text { лимфоциты }\end{array}$ & $\begin{array}{l}\text { Стимулирует выработку IFNy, } \\
\text { увеличивает активность NK-клеток, } \\
\text { усиливает продукцию IgG2a, } \\
\text { стимулирует ангиогенез }\end{array}$ \\
\hline IL-34 & $\begin{array}{l}\text { Клетки селезенки, } \\
\text { печени, тимуса, } \\
\text { кишечника, легких и } \\
\text { пр. }\end{array}$ & $\begin{array}{l}\text { CD14+ макрофаги } \\
\text { и моноциты }\end{array}$ & $\begin{array}{l}\text { Регулирует дифференцировку, } \\
\text { пролиферацию и выживание } \\
\text { моноцитов, макрофагов и остеокластов }\end{array}$ \\
\hline IFNy & $\begin{array}{l}\text { Th1-, NK-, ЦТЛ, } \\
\text { В-лимфоциты }\end{array}$ & $\begin{array}{l}\text { Моноциты, } \\
\text { макрофаги, B- } \\
\text { лимфоциты, Th2- } \\
\text { лимфоциты }\end{array}$ & $\begin{array}{l}\text { Противовирусный и } \\
\text { противоопухолевый эффект } \\
\text { (стимулирует экспрессию МНС I и II). } \\
\text { Активация макрофагов и нейтрофилов. } \\
\text { Индукция молекул адгезии на } \\
\text { эндотелии, подавляет Th2. Подавляет } \\
\text { ангиогенез. }\end{array}$ \\
\hline APRIL & $\begin{array}{l}\text { Дендритные клетки, } \\
\text { макрофаги, моноциты, } \\
\text { нейтрофилы, Т-клетки }\end{array}$ & В-лимфоциты & $\begin{array}{l}\text { Дифференцировка В-лимфоцитов, } \\
\text { выживания долгоживущих } \\
\text { плазматических клеток в костном } \\
\text { мозге }\end{array}$ \\
\hline BAFF & $\begin{array}{l}\text { Т-лимфоциты, } \\
\text { макрофаги, } \\
\text { дендритные клетки, В- } \\
\text { лимфоциты }\end{array}$ & В-лимфоциты & $\begin{array}{l}\text { Фактор активации и дифференцировки } \\
\text { В-лимфоцитов, продуцируется } \\
\text { аутокринно и стимулирует } \\
\text { пролиферацию активированных В- } \\
\text { лимфоцитов }\end{array}$ \\
\hline MIF & $\begin{array}{l}\text { Макрофаги, } \\
\text { лимфоциты, } \\
\text { эпителиальные клетки } \\
\text { (легких, кишечника и } \\
\text { кожи) опухолевые } \\
\text { клетки }\end{array}$ & $\begin{array}{l}\text { Макрофаги, } \\
\text { многие другие } \\
\text { клетки }\end{array}$ & $\begin{array}{l}\text { Связываясь с CD74 на иммунных } \\
\text { клетках, ингибирует их миграции. } \\
\text { Предотвращает апоптоз опухолевых } \\
\text { клеток. Важное значение при развитии } \\
\text { ГЧзт }\end{array}$ \\
\hline $\begin{array}{l}\text { VEGF (A, B, C, D, } \\
\text { E } и F)\end{array}$ & $\begin{array}{l}\text { Макрофаги, клетки } \\
\text { эпителия, гипофиза, } \\
\text { гладких мышц, } \\
\text { опухолевые клетки }\end{array}$ & $\begin{array}{l}\text { Эндотелиальные } \\
\text { клетки, } \\
\text { макрофаги, } \\
\text { гранулоциты }\end{array}$ & $\begin{array}{l}\text { Участвует в формировании сосудов. } \\
\text { Стимулирует миграцию и } \\
\text { пролиферацию эндотелиальных } \\
\text { клеток, хемотаксис макрофагов и } \\
\text { гранулоцитов }\end{array}$ \\
\hline
\end{tabular}


Помимо комплемента и цитокинов к гуморальным факторам врожденного иммунитета относятся и другие белки, и пептиды, относящиеся к системе врожденного иммунитета. Это прежде всего белки острой фазы, концентрация которых в плазме увеличивается или снижается в ответ на воспаление. Действие их многообразно: некоторые действуют, чтобы разрушить или подавить рост микробов, другие влияют на коагуляцию ограничивая инфекцию и улавливая патогены в сгустках крови, так же продукты системы свертывания крови могут вносить вклад в систему врожденного иммунитета благодаря своей способности увеличивать проницаемость сосудов и действовать как хемотаксические агенты для фагоцитарных клеток (табл. 35).

Таблица 35.

\section{Белки острой фазы}

\begin{tabular}{|c|c|c|}
\hline Наименование & Механизм действия & Эффект действия \\
\hline С-реактивный белок & $\begin{array}{l}\text { Связывается с } \\
\text { лизофосфатидилхолином мертвых } \\
\text { или умирающих клеток и некоторых } \\
\text { типов бактерий. Активирует систему } \\
\text { комплемента через С1q }\end{array}$ & $\begin{array}{l}\text { За счет опсонизация патогенных } \\
\text { молекул, микробов, апоптотических } \\
\text { клеток значительно усиливается } \\
\text { фагоцитоз и распознавание NK- } \\
\text { клетками }\end{array}$ \\
\hline $\begin{array}{l}\text { SAA сывороточный } \\
\text { амилоид A }\end{array}$ & $\begin{array}{l}\text { Активирует каскад инфламмасом } \\
\text { индуцируя синтез провоспалительных } \\
\text { цитокинов, является хемотаксиком } \\
\text { для нейтрофилов и тучных клеток }\end{array}$ & $\begin{array}{l}\text { Ключевую роль в развитии амилоидоза } \\
\text { А-типа, участвует в патогенезе } \\
\text { хронических воспалительных } \\
\text { заболеваний, ревматоидном артрите, } \\
\text { атеросклерозе }\end{array}$ \\
\hline $\begin{array}{l}\text { MBL лектин, } \\
\text { связывающий } \\
\text { маннозу }\end{array}$ & $\begin{array}{l}\text { Распознает образцы углеводов, } \\
\text { обнаруженные на поверхности } \\
\text { большого количества патогенных } \\
\text { микроорганизмов, включая бактерии, } \\
\text { вирусы, простейшие и грибы }\end{array}$ & $\begin{array}{l}\text { Активации лектинового пути системы } \\
\text { комплемента. Связывает стареющие, } \\
\text { апоптотические клетки и дебрис } \\
\text { усиливает поглощение фагоцитами }\end{array}$ \\
\hline Ферритин & $\begin{array}{l}\text { Связывает железо, ингибирование } \\
\text { потребление железа микробами }\end{array}$ & $\begin{array}{l}\text { Препятствие развитие } \\
\text { микроорганизмов }\end{array}$ \\
\hline Гепсидин & $\begin{array}{l}\text { Ингибирует перенос железа из } \\
\text { кишечника ограничивает } \\
\text { потребление железа микробами }\end{array}$ & $\begin{array}{l}\text { Препятствие развитие } \\
\text { микроорганизмов }\end{array}$ \\
\hline Церулоплазмин & $\begin{array}{l}\text { Основной белок крови, переносящий } \\
\text { медь, участвует в метаболизме } \\
\text { железа }\end{array}$ & $\begin{array}{l}\text { Подавляет образование свободных } \\
\text { кислородных радикалов }\end{array}$ \\
\hline $\begin{array}{l}\text { Фибриноген, } \\
\text { протромбин, фактор } \\
\text { Виллебранда }\end{array}$ & $\begin{array}{l}\text { Образование локальных тромбов в } \\
\text { области воспаления. Улавливают } \\
\text { вторгшиеся микробы. Вызывают } \\
\text { хемотаксис }\end{array}$ & Ограничение воспаления \\
\hline $\begin{array}{l}\text { Альфа-1- } \\
\text { антитрипсин, альфа- } \\
\text { 1-антихимотрипсин }\end{array}$ & $\begin{array}{l}\text { Противодействуют повышенному } \\
\text { высвобождению протеаз }\end{array}$ & Уменьшение повреждения тканей \\
\hline
\end{tabular}


Хемотаксис - направленная миграция в межклеточном пространстве за счет градиента концентрации хемотаксических веществ в очаге воспаления (продукты протеолиза тканей) и разностью потенциалов между отрицательно заряженным лейкоцитом и положительным зарядом ткани. Хемотаксис имеет значение на всех этапах миграции лейкоцитов, особенно в ткани, в которой отсутствуют сосуды.

Во всех процессах миграции большая роль принадлежит хемокинам и их рецепторам. Семейство этих небольших цитокинов или сигнальных белков, секретируемых практически всеми видами клеток, играют центральную роль в регуляции миграции клеток, особенно лейкоцитов (табл.36).

Таблица 36

\section{Хемокины привлекающие клетки иммунной системы}

\begin{tabular}{|c|c|c|}
\hline Привлекаемые клетки & & Хемокины \\
\hline Моноциты / макрофаги & $\mathrm{CCL} 2, \mathrm{CCL} 3$, & CCL7, CCL8, CCL13, CCL17 и CCL22 \\
\hline \multirow[t]{2}{*}{ Т-лимфоциты } & \multicolumn{2}{|c|}{ CCL2, CCL1, CCL22 и CCL17 CXCR3 } \\
\hline & \multicolumn{2}{|c|}{ Индуцируемые IFNү хемокины - CXCL9, CXCL10 и CXCL11 } \\
\hline Тучные клетки & CCL2 и CCL5 & CXCL8 ингибирует тучные клетки \\
\hline Эозинофилы & \multicolumn{2}{|c|}{$\begin{array}{l}\text { CCL11, CCL24, CCL26, CCL5, CCL7, CCL13 и CCL3 } \\
\text { CCL11 (эотаксин) CCL5 (RANTES) }\end{array}$} \\
\hline Нейтрофилы & \multicolumn{2}{|l|}{ CXCL8 (IL-8) } \\
\hline
\end{tabular}

Однако с активацией хемокинов связано и множество других биологических процессов, включая пролиферацию, выживаемость, дифференцировку, продукцию цитокинов, дегрануляцию и респираторный взрыв (рис.56).

У человека известно около 50 хемокинов (по структуре это четыре группы: СХC, СC, СХ3С, C). Рецепторы хемокинов экспрессируются во всех лейкоцитах (наибольшее их количество и разнообразие на Т-лимфоцитах). Именно от различных комбинаций хемокиновых рецепторов (описано 19 хемокиновых рецепторов четырех семейств) зависят различные пути миграции лейкоцитов. По выполняемым функциям хемокины можно разделить на постоянно вырабатывающиеся (гомеостатические) для миграции лейкоцитов и образующиеся при патологических состояниях (воспалительные).

Воспалительные хемокины продуцируются в высоких концентрациях во время инфекции или травмы и определяют миграцию воспалительных лейкоцитов в поврежденную область (CCL2, CCL3 и CCL5, CCL11, CXCL1, CXCL2, CXCL8, CXCL10). 


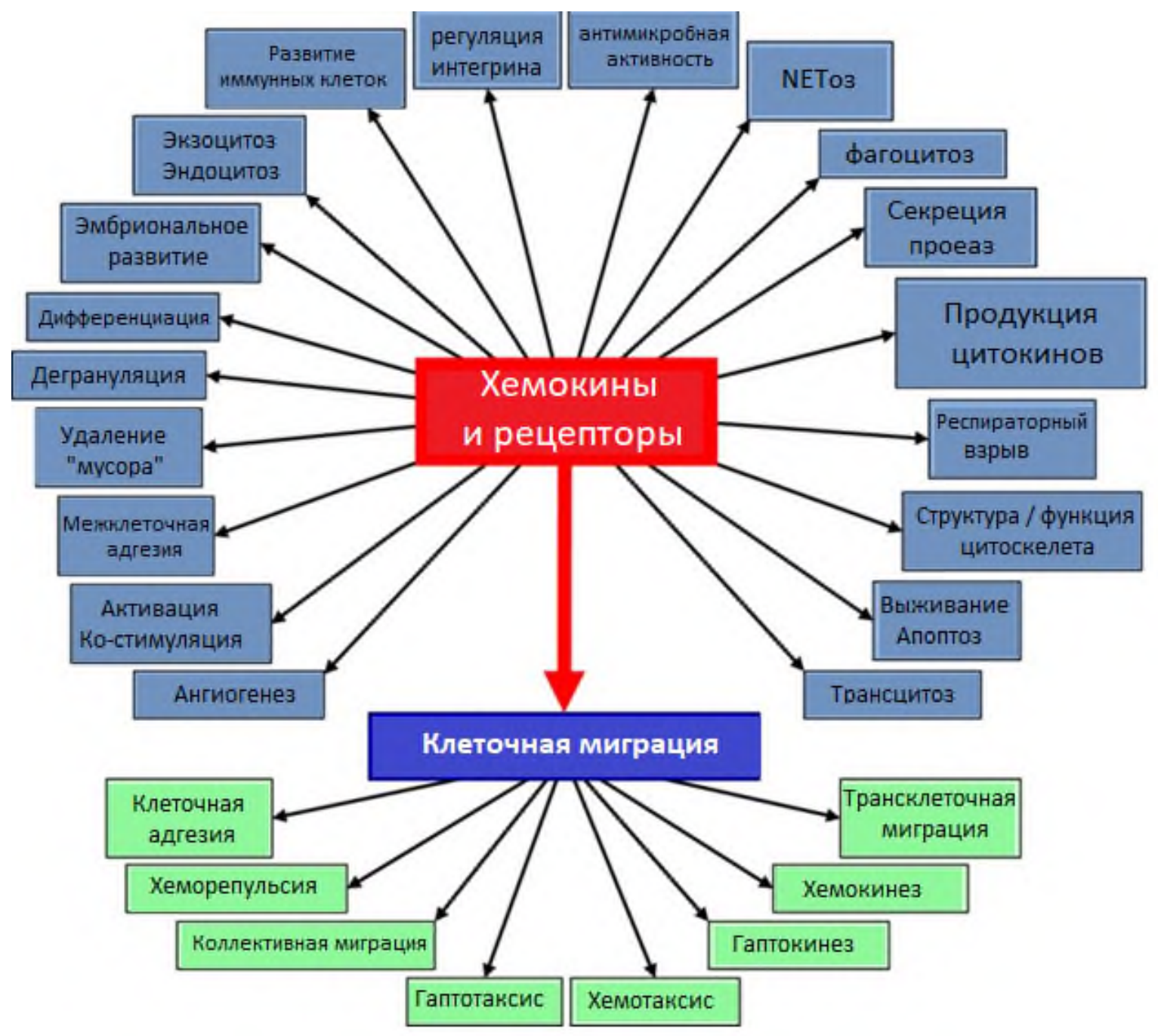

Рис. 56. Функции хемокинов и их рецепторов.

Основной из них CXCL8, действует как хемоаттрактант для нейтрофилов. Поэтому клеточный состав экссудата в значительной степени зависит не только от этиологического фактора, но и от состава хемокинов и их рецепторов. Так, если воспаление вызвано стафилококками и стрептококками, в вышедшей жидкости преобладают нейтрофильные гранулоциты, если оно протекает на иммунной основе (аллергия) или вызвано паразитами (гельминты) - содержится много эозинофилов. При хроническом воспалении (туберкулез, сифилис) в экссудате имеется много мононуклеаров (лимфоциты, моноциты).

Клетки и молекулы, участвующие в формировании иммунного ответа, наиболее эффективно действуют в составе специальных тканей и органов, объединенных в лимфоидную систему. Эта система представляет собой совокупность органов и рассеянных в организме других структурных лимфоидных образований, которые имеют между собой слабые анатомические связи, но объединены в единую систему кровеносными и лимфатическими сосудами и функционируют согласованно за счет иммунной регуляции (рис. 50 ). 
Выделяют первичные (центральные) и вторичные (периферические) лимфоидные органы. Отдельной структурой является мукозо-ассоциированная лимфоидная ткань.

У человека к первичным лимфоидным органам относят тимус (вилочковая железа) и красный костный мозг. В этих органах происходит дифференцировка лимфоцитов, закладываются основные рецепторы, определяющие распознавание всего разнообразия антигенных структур организма. Иммунологические процессы осуществляются в основном в лимфоидной ткани вторичных лимфоидных органов - в лимфоузлах, селезенке, миндалинах, скоплениях лимфоидной ткани под слизистой оболочкой кишечника, гортани, бронхов, мочеполовых органов, а также в почках и коже. Структурированная лимфоидная ткань представлена в виде миндалин, аппендикса, групповых лимфатических фолликул (Пейеровы бляшки), а также организована в виде некапсулированных фолликулов. В этой лимфоидной ткани осуществляются реакции врожденного и адаптивного иммунитета. В Пейеровых бляшках (аналог сумки Фабрициуса птиц), дифференцируются Т- и Влимфоциты. 


\section{Глава 6. Врожденный}

\section{иммунитет}

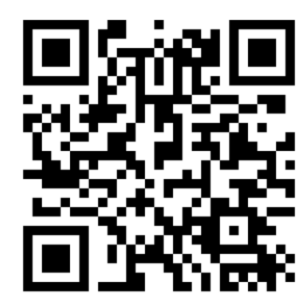

Любой повреждающий агент-фактор, который по силе и длительности превосходит адаптационные возможности ткани, может вызвать ответную защитную реакцию организма. Эти факторы принято делить на внешние (экзогенные - микроорганизмы, химические вещества, физические воздействия) и внутренние (эндогенные - появляющиеся в самом организме в результате патологического процесса). Защитная реакция направлена на то, чтобы не допустить распространения патогена, ограничив и уничтожив его на месте проникновения, привлекая факторы всего организма (в отличии от мукозального иммунитета, где реакции обычно ограничиваются «местными» клетками и молекулами). Это достигается, прежде всего, воспалением, которое формируется в ответ на взаимодействие PRR с PAMP и/или DAMP, описанными выше (см. главу 1). Происходит активация большого количества клеток с формированием воспаления (рис.57).

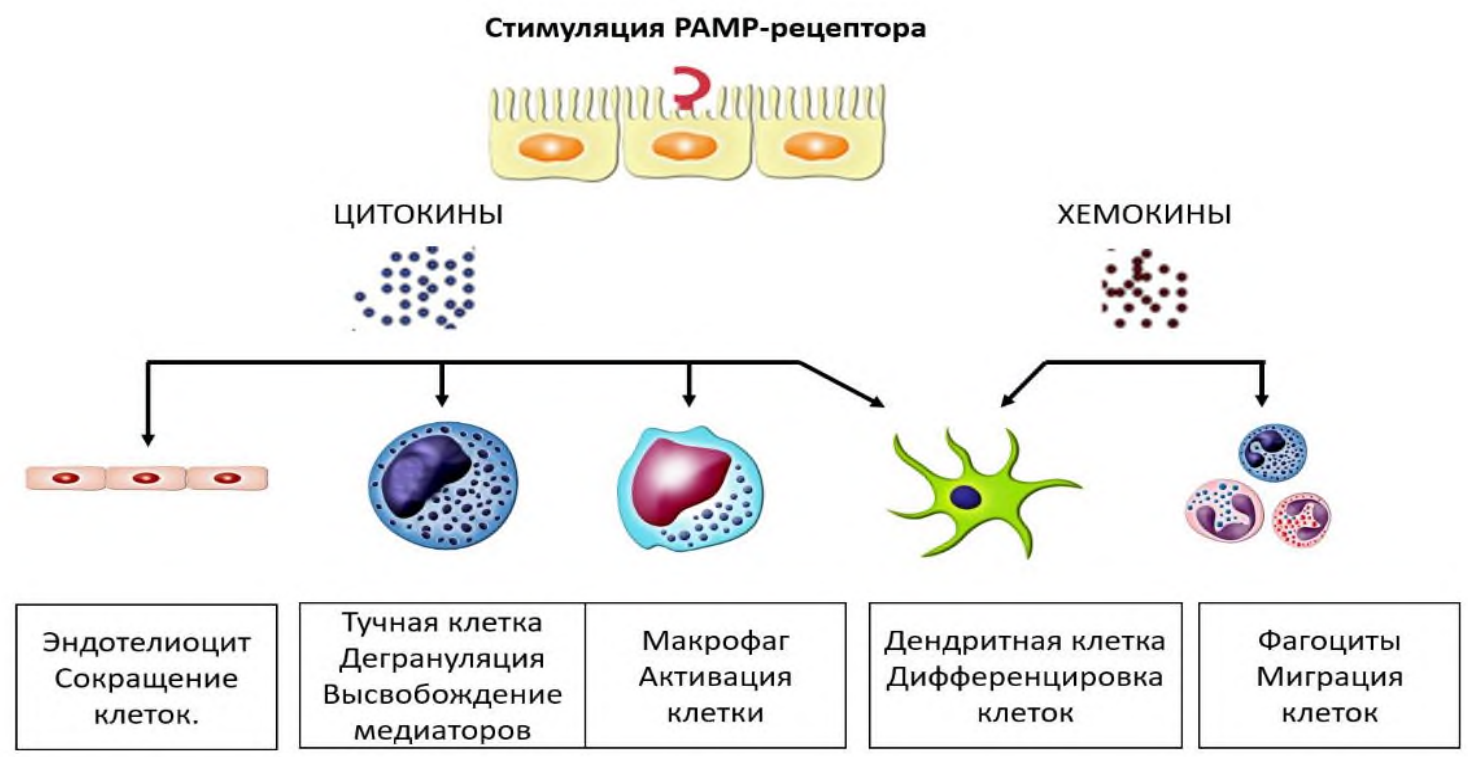

Рис. 57. Системные эффекты стимуляции РАМР

Воспаление представляет собой скоординированный каскад системных иммунных, эндокринных и неврологических реакций, возникающий, в случае, когда повреждающий агент по силе и длительности превосходит барьерные возможности ткани, проявляется в локальных и системных реакциях, направленных на устранение патогена и максимального восстановления зоны повреждения. 
Воспаление всегда начинается с повреждения ткани и распознавания чужеродных веществ. При этом причиной повреждение клеток (некроз) может быть различной этиологии - физической, химической, вирусной и т. д. С первичным повреждениями всегда связано вторичное, которое возникает из-за запрограммированной гибели клеток. Механизмы такой гибели достаточно обширные (табл. 37).

Можно выделить шесть групп молекулярных механизмов, имеющих большое значение в патогенезе повреждения клетки.

- Липидные механизмы повреждения клетки, происходящие за счет перекисного окисление липидов, активации мембранных фосфолипаз и детергентного действия свободных жирных кислот.

- Кальциевые механизмы - повреждение клетки обусловлено повышением концентрации ионов кальция в ее цитоплазме. В основе такого повышения могут лежать два механизма: избыточное поступление Са2+ в цитоплазме и нарушение удаления их из цитоплазмы.

- Электролитно-осмотические механизмы обусловлены сдвигами в содержании главных клеточных катионов $(\mathrm{Na}+$ и $\mathrm{K}+)$.

- Ацидотические механизмы - в основе этой группы механизмов повреждения лежит увеличение концентрации ионов водорода в клетке, т.е. внутриклеточный ацидоз.

- Протеиновые механизмы, включающие в себя ингибирование ферментов, денатурацию и протеолиз, осуществляющийся под действием лизосомальных гидролитических ферментов (катепсинов) и Са2+-активируемых протеаз.

- Основу нуклеиновых механизмов повреждения клеток составляют нарушения трех процессов: репликации ДНК, транскрипции и трансляции.

На субклеточном уровне реализация рассмотренных выше молекулярных механизмов повреждения клетки приводит к нарушению строения и функции отдельных ее органелл. Поскольку большинство из них относится к мембранным образованиям, универсальным механизмом повреждения субклеточных структур является нарушение проницаемости и целостности клеточных мембран.

Повреждение цитоплазматической мембраны может проявляться нарушениями ее барьерной функции, расстройствами систем активного транспорта веществ $\left(\mathrm{Na}^{+}, \mathrm{K}^{+}-\right.$и $\mathrm{Ca}^{2+}$-насосов, $\mathrm{Na}^{+}, \mathrm{Ca}^{2+}-$ и $\mathrm{Na}^{+}, \mathrm{H}^{+}$-обменных механизмов и др.), изменениями белков, образующих специфические каналы ионной проводимости, повреждением рецепторных макромолекул, воспринимающих внешние регуляторные сигналы, нарушениями белковых комплексов, осуществляющих межклеточные взаимодействия, и, наконец, изменениями гликопротеидов, определяющих антигенность клетки. 


\section{Виды клеточной гибели}

\begin{tabular}{|c|c|}
\hline Вид & Механизм \\
\hline Некроз & $\begin{array}{l}\text { Местная гибель ткани за счет экзогенных и/или эндогенных факторов, } \\
\text { приводящих к нарушению целостности клеточной мембраны и } \\
\text { высвобождению продуктов гибели клеток (DAMP) во внеклеточное } \\
\text { пространство с развитием воспаления }\end{array}$ \\
\hline $\begin{array}{l}\text { Некроз, зависимый от } \\
\text { проницаемости } \\
\text { митохондрий (МРТ) }\end{array}$ & $\begin{array}{l}\text { При сильном окислительном стресс и значительном повышении } \\
\text { концентрации ионов кальция в цитозоле происходит исчезновению } \\
\text { электрохимического градиента на мембране митохондрий с их разрушением }\end{array}$ \\
\hline Некроптоз & $\begin{array}{l}\text { Запрограммированная форма некроза, воспалительная гибель клеток, в } \\
\text { результате клеточного повреждения или инфильтрации патогенами }\end{array}$ \\
\hline Пироптоз & $\begin{array}{l}\text { Под воздействием бактериальных липополисахаридов и активаци каспазы- } \\
\text { формируются поры в мембране с последующей гибелью клетки }\end{array}$ \\
\hline Ферроптоз & $\begin{array}{l}\text { Инициированная окислительными нарушениями повреждение клеточных } \\
\text { липидов из-за ионов железа, некроз с повреждением митохондрий }\end{array}$ \\
\hline Партанатос & $\begin{array}{l}\text { Независимая от каспаз гибель клеток за счет активации PARP1 (Поли (АДФ- } \\
\text { рибоза) полимераза) фермента, обнаруживающего повреждение ДНК с } \\
\text { последующей биоэнергетической катастрофой и деградацией ДНК }\end{array}$ \\
\hline $\begin{array}{l}\text { Лизосомальная } \\
\text { гибель клеток (LDCD) }\end{array}$ & $\begin{array}{l}\text { При повреждении лизосом происходит высвобождение в цитоплазму их } \\
\text { содержимого (протеолитические ферменты), за счет чего активируются } \\
\text { внутриклеточные каскады, приводящие к гибели клетки }\end{array}$ \\
\hline $\begin{array}{l}\text { Іая } \\
\text { Ібель }\end{array}$ & $\begin{array}{l}\text { Гибель клетки, которая определяется активацией адаптивного иммунного } \\
\text { ответа }\end{array}$ \\
\hline Немоз & $\begin{array}{l}\text { Процесс активации и гибели фибробластов создает большое количество } \\
\text { медиаторов воспаления (простагландины) }\end{array}$ \\
\hline $\begin{array}{l}\text { Апоптоз: } \\
\text { внешний и } \\
\text { внутренний }\end{array}$ & $\begin{array}{l}\text { За счет внешних сигналов (рецепторный путь) и/или выхода апоптогенных } \\
\text { белков из митохондрий в цитоплазму клетки (митохондриальный путь), клетка } \\
\text { под действием каспазного каскада распадается на отдельные апоптотические } \\
\text { тельца, ограниченные плазматической мембраной. Апоптические тельца } \\
\text { фагоцитируются макрофагами и расщепляются в их лизосомах, без } \\
\text { воспаления }\end{array}$ \\
\hline Аноикис & $\begin{array}{l}\text { Специфический вариант внутреннего апоптоза, инициированного потерей } \\
\text { интегрин-зависимого закрепления }\end{array}$ \\
\hline Митот & Внутренний апоптоз, вызванный митотической катастрофой \\
\hline Эриптоз & $\begin{array}{l}\text { Гибель эритроцитов, которая возникает в поврежденных эритроцитах из-за } \\
\text { различных факторов, включая гиперосмолярность, окислительный стресс, } \\
\text { истощение энергии, воздействие тяжелых металлов или ксенобиотиков }\end{array}$ \\
\hline Аутофагия & $\begin{array}{l}\text { Компоненты клетки захватываются лизосомой (микроаутофагия), окружаются } \\
\text { мембранной и сливаясь с лизосомами } \\
\text { денатурированные белки докроаутофагия) или } \\
\text { (шапероновая аутофагия). Оставляются в } \quad \text { лизосомы шаперонами } \\
\text { макрофагами, без воспаления }\end{array}$ \\
\hline Эффероцитоз & Механизм захвата и удаления мертвых клеток и их фрагментов фагоцитами \\
\hline $\begin{array}{l}\text { Энтотическая гибель } \\
\text { клеток }\end{array}$ & $\begin{array}{l}\text { Возникает в результате актомиозин-зависимой интернализации клетки, в } \\
\text { клетке (энтоза) осуществляется лизосомами }\end{array}$ \\
\hline Корнификация & $\begin{array}{l}\text { Клетки внешнего слоя эпидермиса погибают за счет накопления кератина, } \\
\text { образуя роговой слой (слой мертвых кератиноцитов - ороговевание) }\end{array}$ \\
\hline Параптоз & $\begin{array}{l}\text { Гибель клеток за счет активации митоген-активированной протеинкиназа и N- } \\
\text { концевые киназы с внутриклеточным образованием вакуолей и набуханием } \\
\text { митохондрий }\end{array}$ \\
\hline
\end{tabular}


Наиболее характерными проявлениями повреждения митохондрий являются эффекты разобщения окисления и фосфорилирования и угнетение клеточного дыхания. Основной патогенетический фактор разобщения окисления и фосфорилирования - нарушение барьерной функции внутренней митохондриальной мембраны, в результате чего не может быть реализован механизм сопряжения клеточного дыхания и ресинтеза АТФ.

Повреждение эндоплазматического ретикулума проявляется нарушениями свойственных ему многочисленных функций: синтетической, детоксикационной, депонирующей и др.

Повреждение лизосом сопровождается выходом и активацией многочисленных гидролитических ферментов, в результате чего повреждение клетки становится необратимым, происходит ее аутолиз.

С повреждением микротрубочек и микрофиламентов могут быть связаны изменения формы клетки, нарушение ее подвижности, угнетение процессов клеточного деления.

В процессе разрушения клеток выходит большое количество DAMP, которые совместно с РАМР распознаются макрофагами, эпителиальными клетками и кератоцитами с формированием в них инфламмасом (цитозольный мультибелковый олигомер ответственный за активацию воспалительных реакций) с активным синтезом провоспалительных цитокинов и инициации пироптоза.

На повреждение отвечают все элементы ткани: микроциркуляторные единицы (артериолы, капилляры, венулы), соединительная ткань, тучные и нервные клетки. Формируется воспаление. Несмотря на многообразие факторов, вызывающих воспалительную реакцию, закономерности ответа на повреждение, которые происходят в тканях, однотипны (рис. 58).

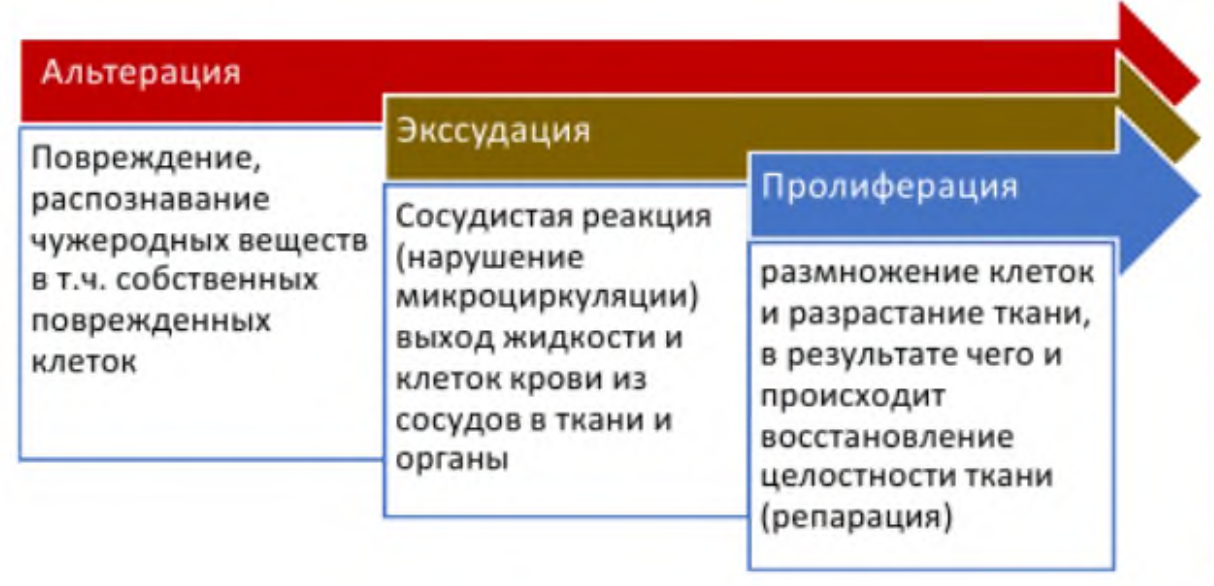

ВОСПАЛЕНИЕ

rubor - местное покраснение

tumor - опухоль (отёк).

calor -

повышение температуры.

dolor - боль.

functio laesa -

нарушение

функции.

Рис. 58. Воспаление. 
Сосудистая реакция начинается со спазма сосудов - кратковременной реакции, которая переходит в фазу артериальной гиперемии (более длительная). Гиперемия - это усиленное кровенаполнение ткани за счет увеличенного притока крови: возрастает скорость кровотока, повышается давление в сосудах и интенсивность обмена веществ в капиллярах. Отсюда внешние признаки воспаления на этой фазе - покраснение, местный жар (повышение температуры), боль, вызванная действием медиаторов. Уже на этой стадии начинается процесс экссудации.

Под действием медиаторов происходит выход жидкой части плазмы за пределы сосуда - экссудация. Экссудат содержит большое количество белка в связи с нарушением проницаемости сосуда. Он сдавливает венулы и происходит смена артериальной гиперемии на венозную. Чем больше экссудата, тем более выражены явления венозного застоя. Венозная гиперемия постепенно переходит в венозный стаз. Именно в этой фазе происходят значительные изменения поврежденной ткани - так называемые явления вторичного повреждения. Любой венозный застой сопровождается гипоксией: переход на анаэробный процесс окисления - гликолиз, возникновение ацидоза за счет недоокисленных продуктов, т.е. те изменения, которые характерны для первичного повреждения. Накопление кислых продуктов в фазу венозного застоя достигает колоссальных количеств. Наблюдается резко выраженный ацидоз (сдвиг рН до 6,0 - 5,8), а такой сдвиг рН уже непереносим клетками, и они погибают. В центре очага воспаления возникает некроз. При незначительном повышении концентрации водородных ионов (на периферии очага воспаления), нелетальных повреждений клеток незначительный сдвиг $\mathrm{pH}$ стимулирует разрастание грануляционной ткани - образуется грануляционный вал на периферии, здоровая ткань отграничивается от поврежденной. Она богата фиксированными макрофагами, способна поглощать поврежденные клетки, токсины, очищая очаг.

Вторичное повреждение также проявляется гиперосмией и гиперонкией. Развитие гиперосмии определяется усиленным катаболизмом и распадом тканей. Распад белковых частиц, жиров, углеводов, выброс калия из клеток с усилением диссоциации солей создают высокую осмотическую концентрацию - гиперосмию. Гиперонкия - увеличение концентрации белков за счет распада ткани, экссудации плазменных белков из сосудов с нарушенной проницаемостью. Эти явления создают порочный круг, усиливая процесс экссудации. Белки как бы притягивают воду, а гиперосмия является повреждающим фактором, который повышает проницаемость стенки сосуда.

При экссудации изменяются биологические свойства крови увеличивается ее вязкость, кровоток замедляется, усиливаются процессы тромбообразования, наблюдается краевое стояние лейкоцитов, которые выстраиваются вдоль сосудистой стенки, а затем наблюдается их миграция в 
очаг воспаления. Изменение спектра плазменных белков (выход альбумина, повышение концентрации $\gamma$-глобулинов, простагландинов и других медиаторов) влияет на состав мембран, повышает ригидность, преобразует поверхностное натяжение мембран эритроцитов, что усиливает их способность к агрегации (причина ускореного СОЭ).

Тромбоциты тоже приобретают способность к агрегации, но в отличие от эритроцитов этот процесс идет на поверхности сосудистой стенки, в месте ее повреждения. При воспалении происходит еe повреждение, количество простациклина, который предотвращает адгезию и агрегацию тромбоцитов, уменьшается, начинаются процессы адгезии и агглютинации тромбоцитов. Из тромбоцитов выделяются тромбоксаны - мощные стимуляторы процессов адгезии и агрегации. В нормальных условиях простациклин-тромбоксановая система уравновешена. При воспалении происходит активация фактора Хагемана, уменьшение содержания гепарина, что ведет к коагуляции и множественным процессам тромбообразования в очаге воспаления.

Экссудация способствует отграничению очага воспаления, препятствует оттоку токсинов, микробов, распавшихся тканей. В составе экссудата в поврежденную ткань выходят биологические активные вещества, медиаторы, которые способны нейтрализовать токсины, защитные белки, АТ, лейкоциты.

За счет увеличения проницаемости сосудистой стенки происходит проникновение не только белков, но и клеток - клеточная миграция. При этом различные популяции мигрирующих клеток появляются в очаге воспаления в определенном порядке. Первыми, как правило, прибывают нейтрофилы (через 1,5-2 часа). В течение первых суток их популяция преобладает среди пула клеток воспалительного экссудата.

На вторые сутки в очаг начинают поступать мононуклеарные фагоциты и лимфоциты. Позже других мигрируют цитотоксические Т-клетки и Влимфоциты. Следует отметить, что, как и многие другие процессы при воспалении, миграцию не всегда удается трактовать однозначно. Она изменчива и зависит от целого ряда факторов как эндотелиального, так и лейкоцитарного происхождения. Миграция зависит и от анатомической области, где протекает воспаление, и от присутствия хемотаксических молекул, и от наличия различных цитокинов в тканях (прежде всего хемокинов), и от характера активации мигрирующих клеток (наличие на их поверхности рецепторов) и т.д. В процессах миграции можно выделить несколько основных этапов (рис. 59):

Адгезия лейкоцитов на эндотелии сосудов, осуществляемая за счет молекул межклеточной адгезии (связанные с плазматической мембраной белки, обеспечивающие механическое взаимодействие клеток друг с другом). Выделяют: интегрины - молекулы, функционирующие как клеточносубстратные, так и межклеточные адгезивные рецепторы; адгезивные 
рецепторы суперсемейства иммуноглобулинов (ICAM), которые участвуют в межклеточной адгезии, заживлении ран и иммунном ответе; селектины (-L, -P и -Е) - обеспечивает адгезию лейкоцитов к эндотелиальным клеткам; адрессины - находятся на мембране эндотелиоцитов - лиганды для селектинов, с которыми обеспечивают

адгезию клеток к стенке сосуда, и дальнейшего проникновения в очаг поражения; кадгерины кальцийзависимые гомофильные межклеточные адгезивные белки; хоминговые рецепторы - молекулы, обеспечивающие попадание лимфоцитов в специфическую лимфоидную ткань.

Трансэндотелиальная миграция лейкоцитов, осуществляемая под действием медиаторов воспаления,

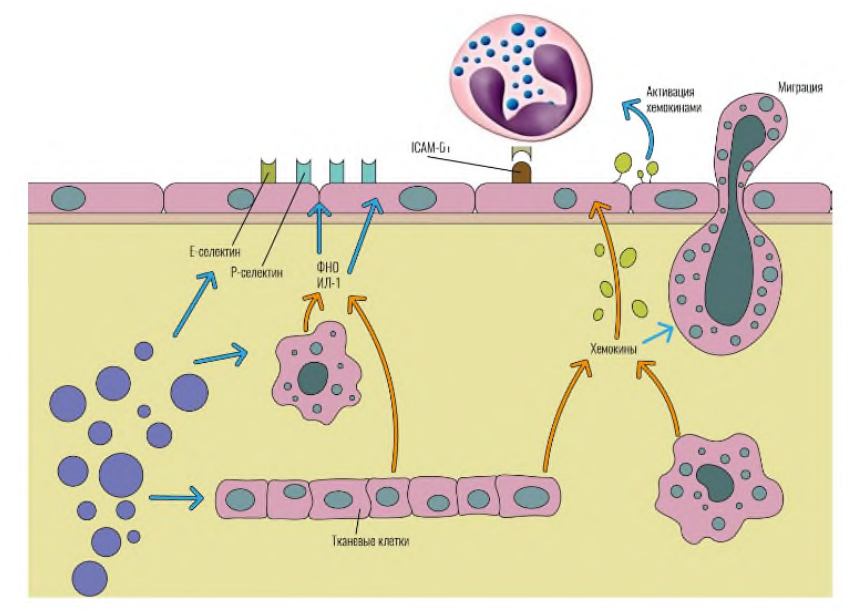

Рис. 59. Клеточная миграция. взаимодействия интегринов и молекул адгезии, клетки преодолевают эндотелиальный слой за счет повышенной сосудистой проницаемости и тока жидкости из сосуда в ткань, а базальные мембраны за счет лизосомальных протеиназ, растворяющие ее, и катионных белков, изменяющие ее коллоидное состояние.

Хемотаксис - направленная миграция в межклеточном пространстве за счет градиента концентрации хемотаксических веществ в очаге воспаления (продукты протеолиза тканей) и разностью потенциалов между отрицательно заряженным лейкоцитом и положительным зарядом ткани.

В процессе развития воспаления клетки участники синтезируют и секретируют большое количество цитокинов, обладающих как про- так и противовоспалительным действием.

Именно от их баланса зависит исход развития патологического процесса как в ранний, так и в отсроченный период (рис 60), и, в конечном итоге, уровень системного воспалительного ответа (СВО).

В последнее десятилетие достигнуты значительные успехи в понимании патофизиологических изменений в организме во время критических состояний. Продолжает формироваться представление о СВО, уточняются и дополняются критерии его оценки, изучаются особенности течения этого процесса при различных состояниях и заболеваниях. 


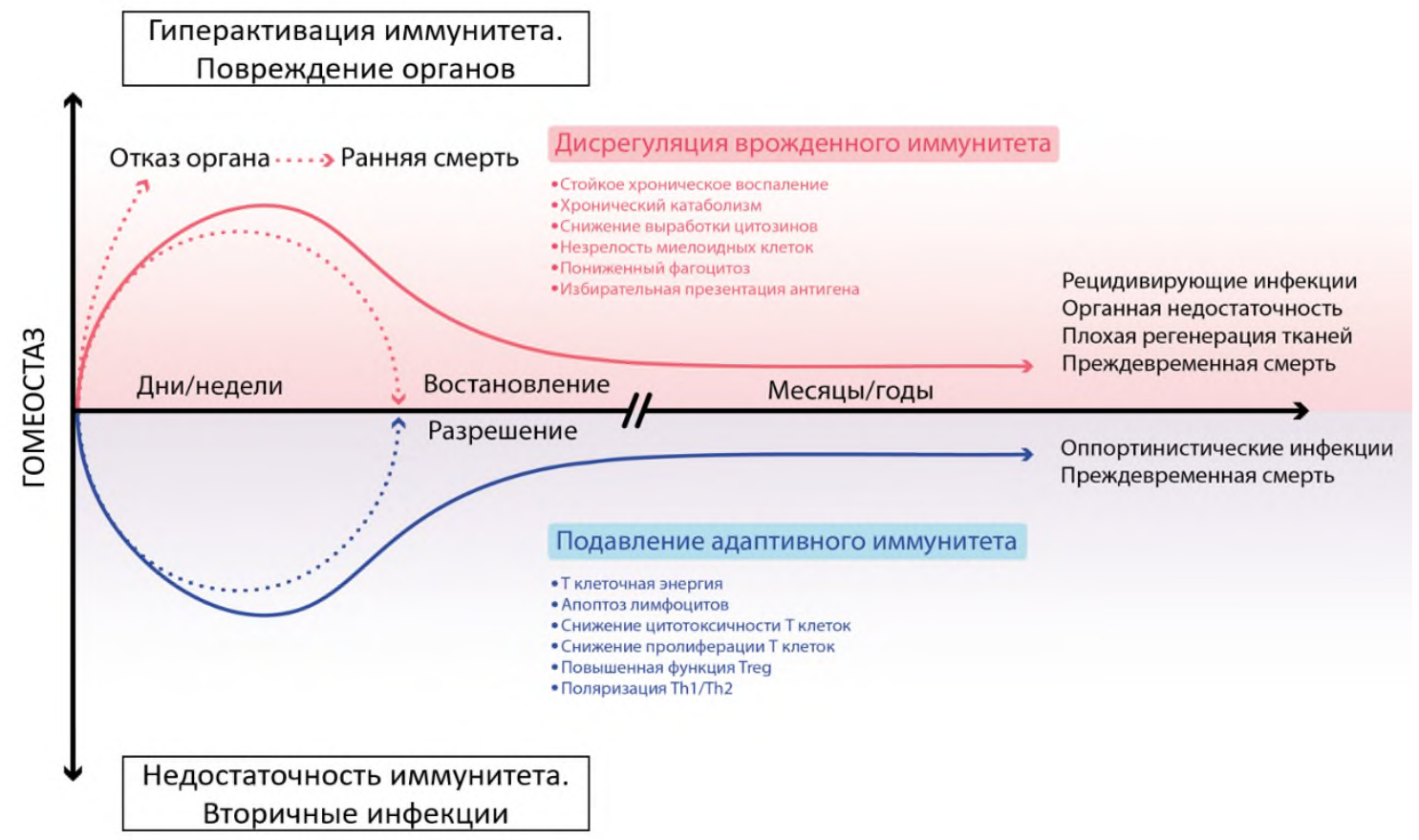

Рис. 60. Биологическое эффекты цитокинов при патологических процессах.

В настоящее время не вызывает большого сомнения сам факт развития системного воспаления неинфекционной природы после множественных травм, больших полостных хирургических операций, в том числе выполненных в условиях искусственного кровообращения, инсультов и т.д. Однако отношение к этому процессу неоднозначное. С одной стороны, системный воспалительный ответ - это реакция организма на воздействие высокой силы (как правило, местное, но с дистантными эффектами) и в таком случае эту реакцию можно считать нормальной, физиологичной. С другой стороны, в ряде случаев СВО рассматривается как патологическая реакция в случаях, когда организм не может локализовать местное повреждение, что приводит к генерализации процесса, повреждении внутренних органов, развитию полиорганной недостаточности.

\section{Определение системного воспаления. Основные звенья патогенеза.}

Системное воспаление - типовой мультисиндромный, фазоспецифичный патологический процесс, развивающийся при системном повреждении и характеризующийся тотальной воспалительной реактивностью эндотелиоцитов, плазменных и клеточных факторов крови, соединительной ткани, а на заключительных этапах и микроциркуляторными расстройствами в жизненно важных органах и тканях.

Патогенез системного воспалительного ответа сложен и еще исследуется и уточняется. Принципиальные аспекты патогенеза и формирование порочного круга представлено на рисунке (рис.61). 
Системный воспалительный ответ неинфекционного генеза может развиваться в ответ на повреждение тканей и реализовываться при участии инфламмасом. Инфламмасомы представляют собой особый белковый комплекс, локализующийся в макрофагах и нейтрофилах, который приводит к запуску воспалительной реакции после контакта с паттернами микроорганизмов либо с эндогенными молекулами, образующимися при повреждении - DAMP (от англ. «danger-associated molecular patterns») или аларминами, способными связываться c TOLL-подобными или с NOD-подобными рецепторами.

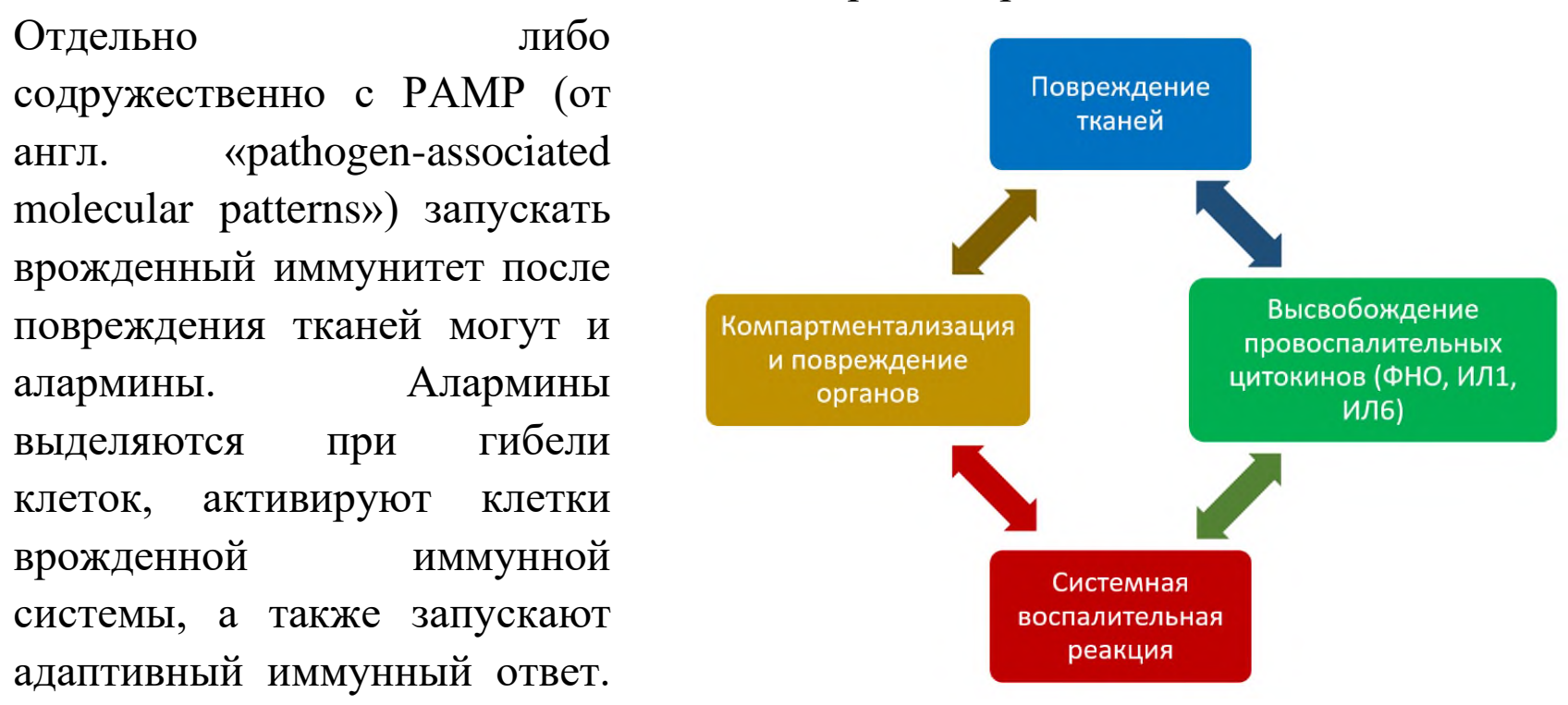

В конечном итоге алармины восстанавливают гомеостаз за счет стимулирования восстановления тканей, поврежденных в результате травмы либо воспаления. В качестве аларминов могут выступать HMGB1, S100s, кристаллы мочевой кислоты, IL-1 и т.д. Алармины, выделяясь из некротизированных или просто поврежденных клеток, запускают реакции местного и системного воспаления. Алармины, входя в состав инфламмасом, стимулируют выход провоспалительных цитокинов, в первую очередь интерлейкина-1 $\beta$. Одним из наиболее значимых аларминов считается HMGB1 (от англ. «high mobility group protein B1»), который может выступать как активный провоспалительный цитокин сам по себе, а также способен стимулировать продукцию провоспалительных цитокинов и хемокинов. В культуре моноцитов человека рекомбинантный HMGB1 вызывает выделение TNF $\alpha$, IL- $1 \alpha,-1 \beta,-6,-8, \mathrm{MIP}-1 \alpha, \mathrm{MIP}-1 \beta$ в количестве, эквивалентном септическим состояния. Таким образом, повреждение клеток любого генеза приводит к выходу во внеклеточное пространство значительного количества аларминов, сигналов опасности, которые могут связываться с соответствующими рецепторами (TLR, NLR, P2RX7 и т.д.), что, в свою очередь, будет приводить к стимуляции продукции и выброса цитокинов (рис.62). 


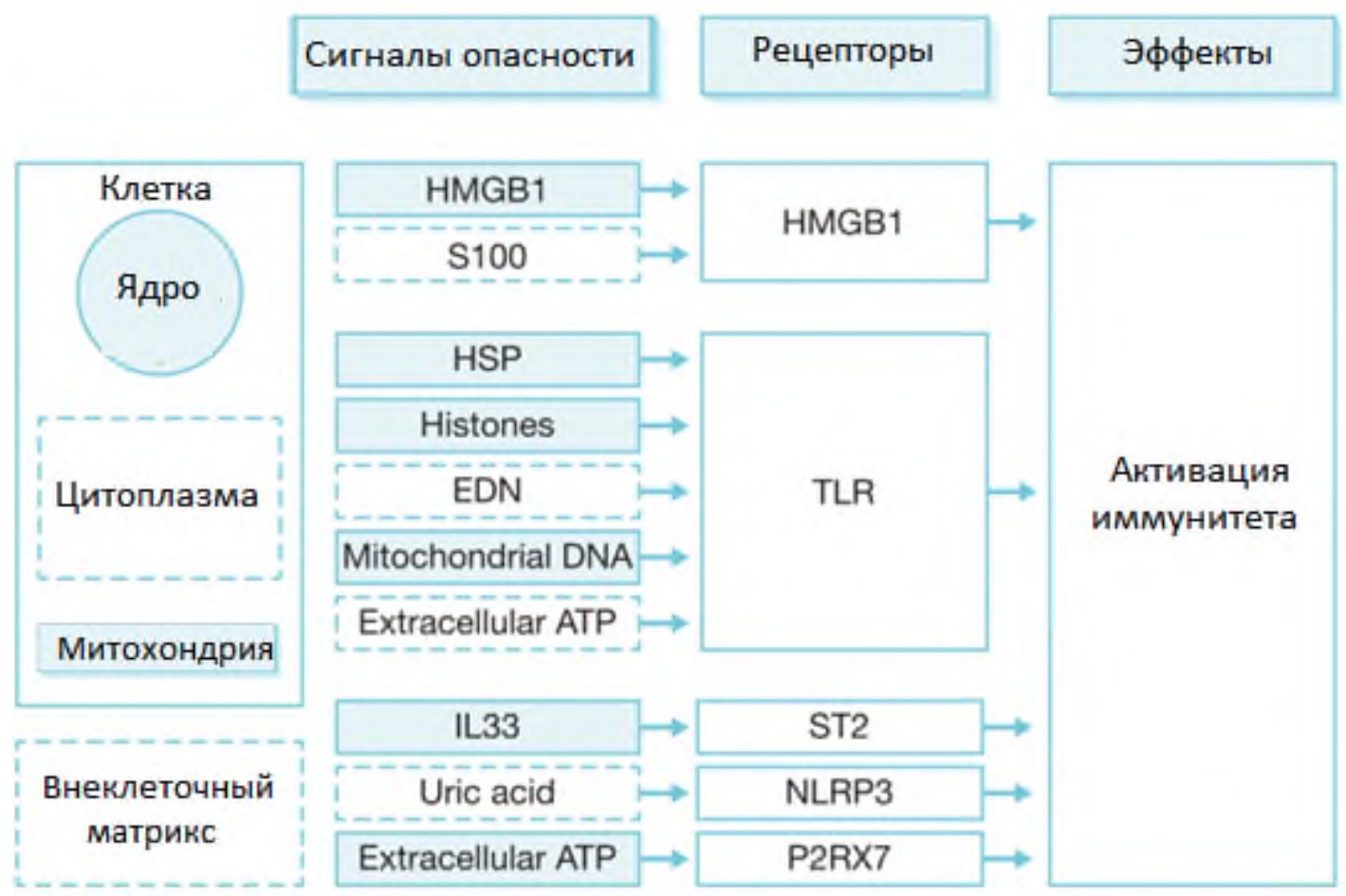

Рис. 62 Выход компонентов клеток при их повреждении и участие в развитии иммунных реакций.

Выброс провоспалительных белков и дисбаланс цитокинов являются наиболее важными компонентами развития системного воспалительного ответа. При этом продуцентами цитокинов являются не только клетки иммунной системы, но и клетки других органов и тканей (эндотелиоциты, кардиомиоциты, макрофаги, гепатоциты и т.д.).

Таким образом, определено ведущее значение иммунной системы в формировании системного воспалительного ответа. Гиперпродукция провоспалительных цитокинов, оксидативный стресс, протеазнный взрыв важные патогенетические составляющие фазы первичного флогогенного удара системного воспаления. В этих процессах ключевую роль играет врожденная иммунная система.

Системой врожденного иммунитета распознаются высококонсервативные чужеродные структуры, называемые PAMPs (от англ. «патогенассоциированные молекулярные паттерны (образы)») через специфические, наследственно закодированные рецепторы PRRs (паттерн-распознающие рецепторы).

Среди сигнальных PRRs центральное место занимают чрезвычайно чувствительные Toll-like рецепторы (TLR), которые управляют целым рядом эффекторных функций (хемотаксис, фагоцитоз, респираторный взрыв, дегрануляция нейтрофилов, синтез эффекторных и регуляторных молекул), а так 
же регулируют адаптивный иммунный ответ. Имеется специфичность TLRs и их лигандов. Например, кроме липополисахарида (LPS), лигандами для TLR4 являются кристаллы мочевой кислоты, HMGB-1, кальций связывающим протеином А8, сывороточным амилоидом А. Белки теплового шока 60 (Hsp 60) и Hsp 70 являются лигандами для TLR2, TLR4 и CD14 и т.д.

Окисленные фосфолипиды, являясь побочным продуктом внутриклеточного окислительного взрыва, ингибируют активацию TLR и блокирует воспалительные реакции. Таким образом, становится все более очевидной высокая значимость рецепторов врожденного иммунитета, а именно TOLL-подобных рецепторов, не только в противоинфекционном иммунитете, но и в реализации воспаления (местного и системного) при состояниях, ассоциированных с ишемией, реперфузией, окислительным стрессом.

Общим конечным итогом в клетке является активации фактора транскрипции NF-кB, его миграция в ядро и стимуляция транскрипции многих провоспалительных генов, кодирующих синтез воспалительных регуляторных субстанций, включая провоспалительные цитокины: IL-1 $\beta$, IL-6, IL-12, IL-18, IL23 , TNF $\alpha$, хемокины и другие компоненты врожденного иммунитета. Моноциты и макрофаги, являясь основными носителями TLR и продуцентами цитокинов, вносят серьезный вклад в формирование гиперцитокинемии - важного патогенетического звена СВО.

Фактически DAMP являются провоспалительными медиаторами в значительной степени активируемыми в условиях клеточного стресса и повреждения, которые в свою очередь в конечном итоге могут приводить к клеточной гибели. Этими стимулами могут являться стерильные агенты продукты метаболизма собственных клеток, например кристаллы холестерина при атеросклерозе, или экзогенные токсины, например при асбестозе.

DAMP имеют решающее значение для инициации «стерильного» воспаления. При этом процесс ассоциируется с повышенной экспрессией эффекторных цитокинов, которая связана с адаптивной реакцией Т-клеток. Быстрая реакция клеток выбросом цитокинов в ответ на воздействие указывает на их высокую значимость в патогенезе неинфекционного воспаления.

Цитокины оказывают не только локальное действие, характеризующееся активацией комплекса сосудистых и тканевых изменений в зоне воспаления, но, попадая в кровоток, обладают дистантным действием и вызывают развитие системных реакций. Системная воспалительная реакция носит, с одной стороны, компенсаторно-приспособительный характер, с другой стороны, при чрезмерной выраженности этих процессов развивается комплекс реакций повреждения и дезадаптации. При этом решающую роль в выраженности эффектов цитокинов и, соответственно, направленности их (протективное или повреждающее), играет степень дисбаланса цитокинов и цитокинового шторма. Так, TNF $\alpha$, IL- 1 , 
IL-6, воздействую на центр терморегуляции вызывают повышение температуры тела с лихорадкой, что является протективной реакцией организма. Те же цитокины могут стимулировать продукцию лейкоцитов в костном мозге. IL-1 и IL-6 являются мощными стимуляторами продукции белков острой фазы (например, С-реактивного белка) печенью. Вместе с тем, чрезмерно высокие уровни провоспалительных цитокинов могут вызывать неблагоприятные эффекты. Например, большие количества TNF приводят к снижению сердечного выброса, повышенной проницаемости сосудов, усилению тромбообразования, метаболическим нарушениям, связанным с развитием резистентности к инсулину, т.е., в конечном счете, к развитию шока.

Следующим значимым фактором патогенеза системного воспаления, определяющим повреждающие эффекты, является окислительный стресс (ОС). Основными повреждающими факторами, определяющими развитие ОC, являются гипоксия (ишемия), воспалительная и стрессорная реакция. Антиоксидантный потенциал больных часто оказывается недостаточным для компенсации развивающихся нарушений.

Антиоксидантная система играет ключевую роль в защите тканей от ишемического повреждения (супероксиддисмутаза, гемоксигеназа, каталаза, глютатионпероксидаза, глютатионредуктаза). Одной из причин оксидативного стресса может быть снижение эффективности этой системы. Например, при ишемии-реперфузии происходит торможение активности антиоксидантной системы, снижение уровня токоферола, запускается перекисное окисление липидов. Таким образом, в тканях отмечается резкий дефицит антиоксидантов, что служит пусковым моментом в запуске ОС. Восстановление перфузии тканей приводит к активному поступлению кислорода и глюкозы в клетки, вызывая резкую интенсификацию процессов свободнорадикального окисления и/или снижение резерва антиоксидантной защиты, результатом чего будет значительное накопление активных форм кислорода (АФК). В свою очередь АФК, в частности $\mathrm{H}_{2} \mathrm{O}_{2}$, индуцируют появление однонитевых разрывов ДНК, которые усиливают экспрессию главного проапоптотического белка р53, приводя к апоптотической гибели клеток. Кроме того, активные формы кислорода обуславливают запуск программы апоптоза по митохондриальному пути с высвобождением растворимых межмембранных белков. Среди них имеется ряд ключевых апоптогенных факторов: цитохром С, прокаспазы-2, -3 и -9, белок AIF и эндонуклеаза G.

Наряду с активными формами кислорода, существенную роль в патологических процессах играют активные формы азота и их метаболиты. Окись азота (NO) - внутренняя регуляторная молекула, включенная в ряд физиологических процессов, как, например, регулирование тонуса сосудов и пролиферацию гладкомышечных клеток. NO синтезируется во всех типах 
клеток, в том числе эндотелиальных и кардиомиоцитах, из L-aргинина с помощью трех изоформ NO-синтаз (NOS). Две изоформы (eNOS и nNOS) постоянно экспрессируются и строго регулируются кальцием-кальмодулином и фосфорилированием, в то время как третья форма (iNOS) индуцируется в процессе воспаления и производит высокие уровни NO в течение более длительного периода.

В патологических условиях происходит перегрузка клеток ионизированным кальцием. Этот процесс опосредован через нарушение проводимости кальциевых каналов, либо через высвобождение ионизированного кальция из эндоплазматического ретикулума в цитозоль. Повышение в цитоплазме ионизированного кальция приводит к пермеабилизации мембраны митохондрий и запуску апоптоза по митохондриальному пути. Ионы кальция участвуют в развитии апоптоза путем прямой активации $\mathrm{Ca}^{2+}, \mathrm{Mg}^{2+}$-зависимой эндонуклеазы и последующей межнуклеосомной деградации ДНК.

Было установлено, что лизосомы наравне с клеточным ядром и митохондрией играют важную роль в апоптотической гибели клеток. Ряд факторов (активные формы кислорода, гипоксия, перегрузка клеток кальцием, цитокины, перерастяжение кардиомиоцитов) прямо или косвенно стимулируют пермеабилизацию лизосомальных мембран и высвобождение в цитозоль катепсинов - цистеиновых лизосомальных протеиназ. В цитозоле катепсины могут запускать клеточную смерть различными путями, включая активацию каспаз, высвобождение проапоптотических факторов из митохондрий, а так же расщепление антиапоптотических белков семейства Bcl-2, и Bid.

Катепсины являются непосредственными исполнителями апоптоза, в основе которого лежит протеолиз, обусловленный цистеиновыми протеазами типа каспаз, катепсинов, гранзима, калпаина. В частности катепсин D является основным посредником между стимулами апоптоза и белком p53, TNF и IFN $\gamma$. Лизосомальная дезинтеграция с выходом катепсина $\mathrm{D}$ в цитозоль и митохондриальная - с выходом цитохрома $\mathrm{C}$ - считаются начальными стадиями апоптоза.

Способность макрофагов выделять эластолитические протеолитические протеазы предполагает, что они могут использовать катепсины для миграции через артериальную стенку. Адгезия и миграция моноцитов, их превращение в макрофаги играют важную роль в патогенезе воспаления, в том числе возникающего в поврежденных тканях. Эти клетки могут использовать внеклеточные цистеиновые протеазы в качестве вспомогательных инструментов миграции.

Известно, что недостаток катепсина S приводит к снижению количества макрофагов, Т-клеток, и понижению уровня IFN $\gamma$. Кроме того, кроме непосредственного участия катепсинов в процессе воспаления, возможно их косвенное участие через снижение экспрессии TGF $\beta$. 
В литературе имеются данные о взаимоотношении матриксных металлопротеиназ и катепсинов. Так, известно, что макрофаги синтезируют MMP-7, MMP-9 и катепсины B, L, S. При этом только катепсины выявляются в межклеточном пространстве. Ингибирование катепсинов L и S (но не MMP) полностью блокировало макрофагальную эластолитическую активность. Таким образом, доказывается роль катепсинов как наиболее мощных макрофагальных эластаз. Матриксные металлопротеиназы вовлечены в процесс иммунного ответа на патоген, но также они могут участвовать в неконтролируемом повреждении тканей. Известно, что при сепсисе достоверно повышается уровень proMМР-1 и ММР-1, при этом повышенный уровень коррелирует со смертностью. В экспериментальных исследованиях установлено, что при сепсисе MМР-1 активно синтезируется эндотелиальными клетками. Блокирование ММР-1 приводит к уменьшению повреждения эндотелиального барьера, дессиминированного внутрисосудистого свертывания, проницаемости сосудов легких и цитокинового шторма при сепсисе.

Воздействие MMP-1 и MMP-3 на макрофаги приводит к быстрому высвобождению TNF $\alpha$, который был заблокирован ингибиторами матриксных металлопротеиназ. Синтез и выброс MMP-9 макрофагами зависит от TNF $\alpha$ и простагландинов. Потенциальная возможность МMP-1 и МMP-3 регулировать секрецию макрофагами простагландинов и ММР-9 указывает на их важную роль в патогенезе воспаления. Кроме того, ММР-9 участвует в слущивании ICAM-1 с поверхности клеток. Интересно участие матриксной металлопротеиназы 9 в развитии воспаления при церебральной ишемии. При этом одним из основных триггеров восплительного процесса считается выход аларминов, в первую очередь HMGB-1, в межклеточное пространство из поврежденных клеток. Установлено, что НMGB-1 вызывает активацию выброса MMP-9, причем происходит это через рецепторы TLR-4. Кроме того, в экспериментах in vitro было установлено, что ММР-9 ответственна за стимуляцию выброса провоспалительных медиаторов, а также за индукцию апоптоза эндотелиальных клеток. Таким образом, ключевую роль в развитии системного воспаления играют такие факторы как протеазный взрыв, оксидативный стресс и дисбаланс цитокинов («цитокиновый шторм»).

Важным участником активации ранних воспалительных реакций и СВО признан триггерный рецептор, экспрессированный на миелоидных клетках-1 (TREM-1). Он впервые описан как активирующий рецептор воспалительного ответа. Отличительная особенность TREM-1, делающая его привлекательным для изучения в аспекте СВО, связана с его способностью к активации всех эффекторных функции врожденного иммунитета и многократному усилению продукции цитокинов при совместной стимуляции с главными рецепторами врожденного иммунитета (Toll-подобные рецепторы и Nod-подобные рецепторы). До недавнего времени TREM-1 считался маркером сепсиса и инфекционного СВО. Умеренное повышение мембранной и растворимой формы 
TREM-1 (sTREM-1) наблюдается во время инфекций, вызванных бактериями, вирусами и грибами, а значительное увеличение - при сепсисе и септическом шоке. Однако за последние несколько лет появились исследования, указывающие на связь TREM-1 с CBO неинфекционного генеза.

Связывание TREM-1 с лигандом вызывает сильную и немедленную активацию всех эффекторных механизмов, приводя к выраженной дегрануляции и респираторному взрыву нейтрофилов, умеренной стимуляции фагоцитоза, повышению продукции провоспалительных цитокинов, хемокинов и ингибированию синтеза IL-10.

Растворимая форма sTREM-1 высвобождается с поверхности клеток путем шеддинга (слущивания) мембранной формы матриксными металлопротеиназами и является естественным рецептором-ловушкой, который, конкурируя за лиганд с мембранной формой TREM-1, снижает его активацию.

В патогенезе системного воспалительного ответа важно участие эндокринной системы, особенно в отношении взаимной регуляции с иммунной системой. Активация гипаталамо-гипофизарно-надпочечниковой и симпатоадреналовой систем с выходом большого количества кортизола и катехоламинов, по-видимому, приводит к нарушению баланса Th1/Th2 клеток. Предполагается, что ключевую роль в регуляции иммунных нарушений играет снижение экспрессии и сигналинга IL-12 и повышение экспрессии Tрегуляторных клеток (Treg). Кроме того, цитокины, продуцируемые Th2 повышают экспрессию аргиназы 1 в миелойдных супрессорных клетках, приводя, тем самым, к дефициту аргинина, что в дальнейшем снижает функциональную активность лимфоцитов.

На ранних этапах развития ССВО большое количество лейкоцитов прикрепляется к активированным эндотелиальным клеткам стенок сосудов, что может нарушать миркроциркуляцию. Отчасти адгезия лейкоцитов связана с повышенной экспрессией молекул адгезии на поверхности эндотелиальных клеток, к которой приводят высокие уровни медиаторов воспаления, таких как $\mathrm{TNF} \alpha$ и IL-1. Помимо механического закупоривания микроциркуляторного русла, активированные лейкоциты могут повреждать окружающие эндотелиальные клетки и периваскулярные ткани. В результате развивается дисфункция эндотелия.

Активированные эндотелиальные клетки экспрессируют несколько факторов (например, тканевой фактор, молекулу адгезии тромбоцитов к эндотелиальным клеткам, тромбоксан), которые преобразуют их локальный коагулянтный статус из нейтрального в прокоагулянтный. Кроме этого, TNF $\alpha$ запускает каскады коагуляции путем активации внешних путей. Фактор XIIa запускает как внутренний путь свертывания крови посредством активации фактора XI, так и побуждает эндотелиальные клетки и макрофаги продуцировать тканевой фактор, который, в свою очередь, активирует внешний путь коагуляции. Возможно повышение уровней тканевого активатора плазминогена 
(tPA) в плазме, которое быстро уравновешивается высвобождением ингибитора активатора плазминогена (PAI) При развитии сепсиса уровни протеина $\mathrm{C}$ и антитромбина III в плазме снижаются, а уровень PAI-1 в плазме повышается. Тромбомодулин плазмы, который образуется в результате деградации тромбомодулина мембран эндотелиальных клеток, также увеличивается при ССВО. Процессу нарушению коагуляционного гемостаза способствует множественное действие тромбина и нарушение естественных ингибиторных механизмов, таких как антитромбин III, протеин $\mathrm{S}$, протеин $\mathrm{C}$ и плазменные ингибиторы фибринолиза. Эта прокоагулянтная среда в сочетании с повреждением эндотелиальных клеток предрасполагает к развитию чрезмерного количества микротромбов, дополнительно затрудняя местный кровоток и усугубляя дисфункцию органов-мишеней. Эти потенциально деструктивные местные и системные реакции при ССВО (повышенная периферическая вазодилатация, чрезмерная проницаемость микрососудов, ускоренное свертывание в микрососудах, активация лейкоцитов/эндотелиальных клеток) способствуют развитию глубоких патологических изменений в различных органах и считаются основными этиологическими факторами при развитии септического шока, диссеминированного внутрисосудистого свертывания крови (ДВС), острого респираторного дистресс-синдрома (ОРДС) и других дисфункций органов-мишеней, приводящих к синдрому полиорганной недостаточности $(\mathrm{CПОН})$.

В развитии и поддержании системного воспалительного ответа значительную роль играет компартментализация. Воспаление является типовым патологическим процессом, однако события, связанные с ним, в различных органах имеют отличия. Дисбаланс цитокинов в системном кровотоке, развивающийся при системном воспалительном ответе, является отражением сложной сети разнонаправленных регулирующих сигналов, модулируемых специфическими клетками микроокружения и различающихся в зависимости от компартмента. Исходя из этого представления ткани могут являться источником биологически активных веществ, инициирующих и поддерживающих системное воспаление за счет дистантного действия и вовлечения в процесс отдаленных органов. При этом триггером местного «стерильного» воспаления является ишемия/реперфузия, окислительный стресс, апоптотическое, некротическое, механическое повреждение тканей (рис.63).

Таким образом, за счет развития микроциркуляторных расстройств, нарушений гемостаза, вовлечения отдаленных органов в патологический процесс, системный воспалительный ответ может иметь неблагоприятное течение с формированием изолированных органных дисфункций или полиорганной недостаточности. При этом сам ССВО в качестве противовеса имеет систему компенсаторную противовоспалительного ответа (КПВО). Считается, что за развитие ССВО отвечает система врожденного иммунитета, а КПВО обеспечивается активностью адаптивной иммунной системы. 


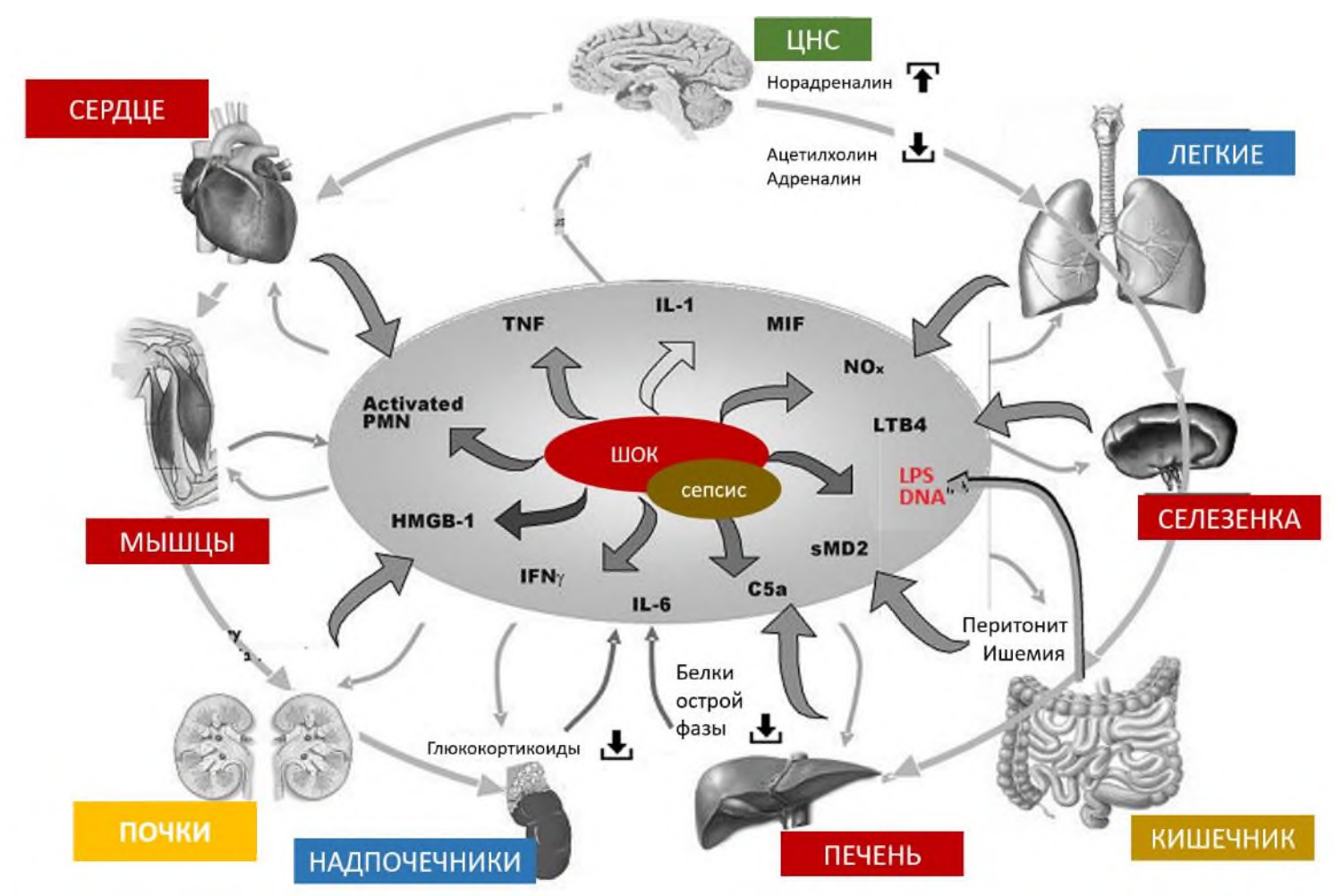

Рис. 63. Порочный круг развития системного воспаления и его распространение из одного компартмента в другой.

(адаптировано из Journal of Endotoxin Research, Vol. 12, No. 3, 2006

DOI 10.1179/096805106X102246).

IL-10 является ключевым цитокином противовоспалительного ответа и продуцируется CD4+ Th2-клетками, моноцитами и В-клетками. Именно этот цитокин является главным в попытке иммунного ответа контролировать гипервоспаление.

Возможные взаимоотношения, а также варианты исходов клинического течения в зависимости от преобладания актвиности той или иной системы представлены на рисунке (Рис.64). Так, при гиперэргическом воспалительном ответе и полной несостоятельности противовоспалительной системы, а также стремительном течении возможно развитие полиорганной недостаточности, приводящей к смерти пациента. При недостаточной эффективности противовоспалительной системы, но при выраженном воспалительном ответе течение заболевания затягивается, что может привести к персистирующему хроническому воспалению с иммуносупрессией и катаболическим синдромом. С другой стороны, при явном преобладании противовоспалительной системы и, соответственно, активности адаптивной иммунной системы, возможно развитие прогрессивной иммуносупрессии, а при умеренном дисбалансе с преобладанием противовоспалительной системы - усиление катаболизма белков, кахексии и, в самых неблагоприятных случаях, смерти в отдаленном периоде. 


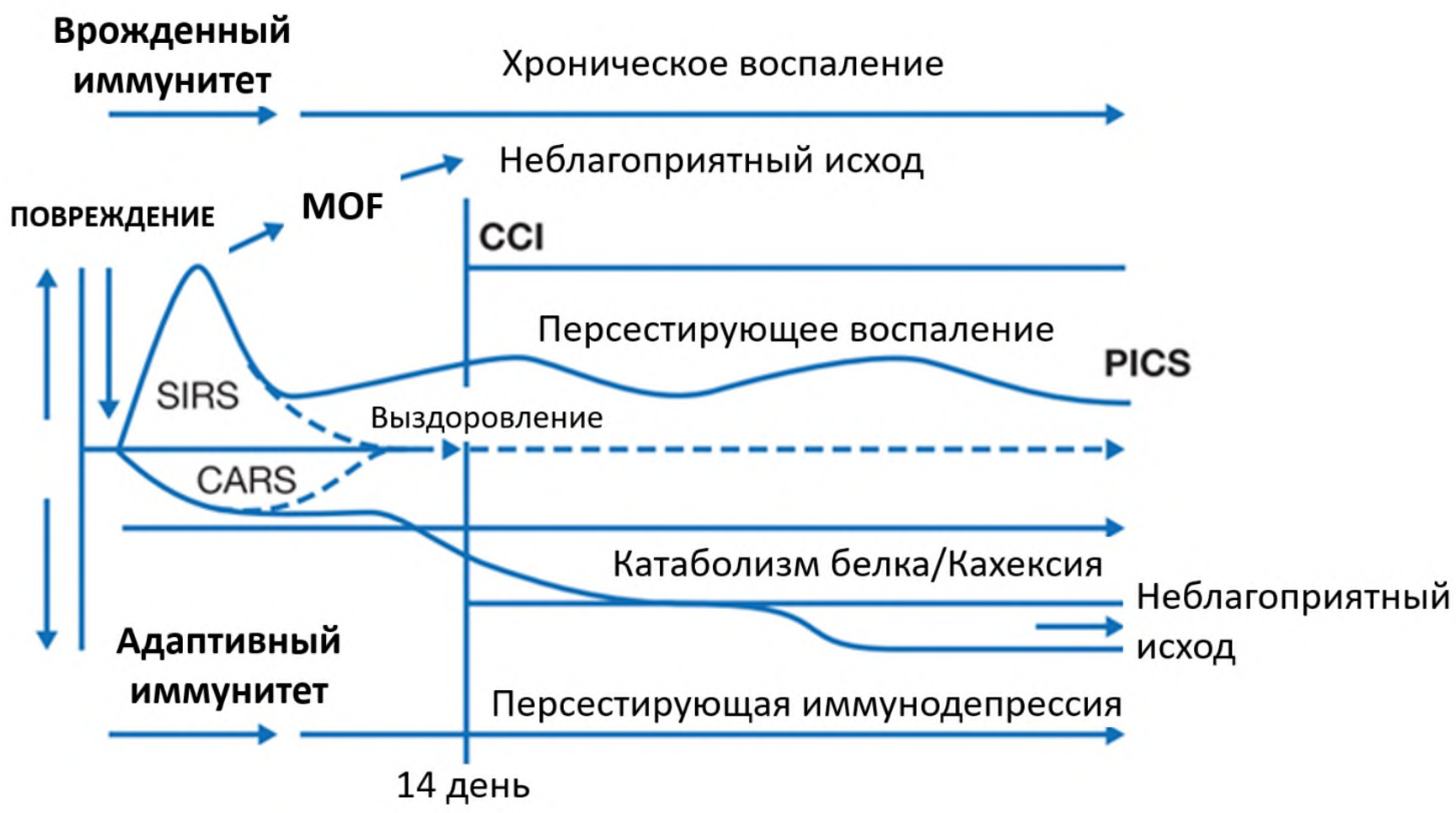

Рис. 64. Модель взаимоотношения систем воспалительного ответа и противовоспалительного ответа, а также варианты клинических исходов CCI - хроническое критическое заболевание, MOF - полиорганная недостаточность, PICS - синдром стойкой иммуносупрессии и катаболизма, SIRS - синдром системного воспалительного ответа, CARS - компенсаторный противовоспалительный ответ

(адаптировано из J Trauma Acute Care Surg. 2014 Jan; 76(1): 21-30.

DOI:10.1097/TA.0b013e3182ab1ab5).

Таким образом, баланс воспалительной (врожденный иммуннитет) и провоспалительной (адаптивный иммуннитет) систем является ключевым для течения ССВО и быстрого выздоровления, либо затяжного течения и развития неблагоприятных исходов в случае дисбаланса этих систем.

Сам термин «синдром системного воспалительного ответа - CСВО» (от англ. «Systemic inflammatory response syndrome» или SIRS) был принят в 1992 году на заседании Согласительной комиссии Американского колледжа пульмонологов и Общества критической медицины. Тогда же было определено, что этот термин предпочтительнее термина сепсис при описании распространенного воспаления (или клинической реакции на это воспаление), которое может возникнуть у пациентов с такими разнообразными заболеваниями, как инфекция, панкреатит, ишемия, множественная травма, геморрагический шок и т.д., а также опосредованными активностью иммунной системы повреждениями органов. Термин «сепсис», подкатегория дисфункции, которая была определена как ССВО, следует использовать только для пациентов 
с подтвержденной инфекцией. То есть, сразу было проведено разделение генерализованных воспалительных реакций, ассоциированных с инфекционными агентами, и без таковых.

Основанием для диагностики ССВО было определено наличие двух или более представленных клинико-диагностических критериев:

- температура тела более $38^{\circ} \mathrm{C}$ или менее $36^{\circ} \mathrm{C}$;

- частота сердечных сокращений более 90 уд/мин;

- частота дыхания более 20 в минуту;

- уровень лейкоцитов крови более $12 * 10^{9} /$ л или менее $4 * 10^{9} /$;

- содержание молодых форм гранулоцитов более $10 \%$.

Критерии диагностики были приняты в 1992 году и до сих пор для многих клинических специалистов являются определяющими. Однако со временем стало очевидно, что постановка диагноза на основании этих критериев представляет трудности. Кроме того, эти критерии были описаны при диагностике сепсиса, а не «асептического» ССВО.

Недостатком предлагаемого способа диагностики ССВО, например, применительно к пациентам после полостных оперативных вмешательств является то, что тахикардия и тахипноэ в большинстве клинических ситуаций не являются диагностически значимыми в виду проводимой противоаритмической терапии и продленной искусственной вентиляции легких. На температуру тела в значительной степени влияет применение анальгетиков, обладающих жаропонижающим эффектом. После проведенной операции со значительным повреждением тканей и органов лейкоцитоз со сдвигом формулы влево является естественной реакцией, а не проявлением осложненного ССВО.

Важно отметить сложные взаимоотношения системного воспаления, инфекции и полиорганной недостаточности. ССВО может быть ассоциирован с большим количеством патологических состояний, таких как травма, ожоги, панкретит, ишемия, геморрагический шок и т.д.

Действительно, системный воспалительный ответ нельзя рассматривать как синоним сепсиса или даже просто инфекционного процесса. Если для генерализованной инфекции, к которой относится и сепсис, системная воспалительная реакция является обязательным и непременным атрибутом, то локализованный процесс может протекать и без явлений системного воспаления. Существует масса примеров запуска ССВО без инфекционного компонента. В частности к таким ситуациям может относиться управляемая ишемия и реперфузия, сопровождающая проведение операции по реваскуляризации миокарда, когда кроме ишемии/реперфузии существует большое количество триггеров, к которым относятся механическое повреждение тканей с выходом большого количества аларминов, повреждение клеток вследствие развившегося окислительного стресса, контакт иммунокомпетентных клеток с большим 
количеством чужеродных материалов (трубок системы ИК, фильтров, оксигенаторов и т.д.), использование большого количества фармацевтических препаратов для проведения наркоза, кардиоплегии, поддержания функции жизненно важных органов.

Кроме того, провоцировать системное воспаление может назначение препаратов, обладающих высокой медиаторной активностью, таких как фактор некроза опухоли и других цитокинов. Возможными осложнениями могут быть острый респираторный дистресс-синдром, шок, почечная недостаточность, полиорганная недостаточность.

Предложенные критерии для диагностики ССВО и сепсиса были применены в клинике и, как результат, расширили знания о патогенезе, а также о прогнозе заболевания. Вместе с тем, стала очевидной необходимость в расширении критериев диагностики, в том числе, за счет биохимических и иммунологических показателей. В результате в 2001 году была проведена международная конференция по сепсису (2001 SCCM/ESICM/ACCP/ATS/SIS International Sepsis Definitions Conference), на которой было определено, что

1) имеющаяся концепция по сепсису, тяжелому сепсису и септическому шоку остается приемлемой как для клиницистов, так и для исследователей;

2) имеющиеся определения этих состояний не позволяют точно определять стадию или прогнозировать реакцию хозяина на инфекцию;

3) хотя CCBO (SIRS) остается полезной концепцией, диагностические критерии, опубликованные в 1992 г., слишком чувствительны и неспецифичны;

4) расширенный список признаков и симптомов сепсиса может лучше отражать клиническую реакцию на инфекцию

Было предложено ввести ряд диагностических критериев системного воспаления в ответ на инфекцию (табл. 38).

В конечном счете, эта схема направлена на систематизацию физических и лабораторных данных, которые побуждают опытного клинициста сделать вывод, что пациент «выглядит септическим». Вместе с тем, ни один из параметров не является специфическим для сепсиса.

Таким образом, ССВО неспецифичен для инфекции, и его полезность в качестве инструмента скрининга на сепсис ограничена высокой распространенностью этих аномалий у госпитализированных пациентов. Приравнивание ССВО к сепсису может способствовать чрезмерному и необоснованному использованию антибиотиков и назначению инфузионной терапии. С патофизиологической точки зрения теперь считается, что сепсис представляет собой дисрегуляцию реакции организма на инфекцию, тогда как ССВО представляет собой нормальный физиологический ответ на инфекцию, который может быть адаптивным. 
Таблица 38

\section{Диагностических критериев системного воспаления в ответ на} инфекцию

\begin{tabular}{|c|c|}
\hline Показатель & Значение \\
\hline \multicolumn{2}{|c|}{ Общие параметры } \\
\hline Лихорадка (температура тела & $>38,3^{\circ} \mathrm{C}$ \\
\hline Гипотермия (температура тела & $<36^{\circ} \mathrm{C}$ \\
\hline Частота сердечных сокращений тахикардия & ЧСС >90 ударов/мин \\
\hline Тахипноэ & $>30$ в минуту \\
\hline \multicolumn{2}{|l|}{ Нарушения в ментальном статуе } \\
\hline Значительные отеки или жидкостный баланс & Более 20 мл/кг за сутки \\
\hline Гипергликемия при отсутствии диабета в анамнезе & Глюкоза плазмы >7,7 ммоль/л \\
\hline \multicolumn{2}{|c|}{ Критерии воспаления } \\
\hline Лейкоцитоз & $>12000$ /мкл \\
\hline Лейкопения & $<4$ 000/мкл \\
\hline Нормоцитоз с молодыми формами в формуле & $>10 \%$ \\
\hline С-реактивный белок (СРБ) плазмы & >2 стандартных отклонений от \\
\hline Прокальцитонин плазмы & нормальных значений \\
\hline \multicolumn{2}{|c|}{ Гемодинамические критерии } \\
\hline Артериальная гипотензия & $\begin{array}{c}\text { Систолическое давление <90 мм } \\
\text { рт.ст., среднее артериальное } \\
\text { давление <70 мм.рт.ст. или } \\
\text { диастолическое давление >40 мм } \\
\text { рт.ст }\end{array}$ \\
\hline Сатурация кислорода смешанной венозной крови & $>70 \%$ \\
\hline Сердечный индекс & $>3,5$ л мин/м \\
\hline \multicolumn{2}{|c|}{ Параметры органных дисфункций } \\
\hline Артериальная гипоксемия & $\mathrm{PaO}_{2} / \mathrm{FIO} 2<300$ \\
\hline Острая олигурия & Моча $<0,5$ мл/кг/час \\
\hline Повышение креатинина & $\geq 0,5 \mathrm{мг/дл}$ \\
\hline Нарушения коагуляции & $\begin{array}{r}\mathrm{MHO}>1,5 \\
\mathrm{~A} 4 \mathrm{~T} \mathrm{~B}>60 \mathrm{c}\end{array}$ \\
\hline Кишечник & Отсутствие шумов перистальтики \\
\hline Тромбоцитопения & $<100$ 000/мкл \\
\hline Гипербилирубинемия & Общий билирубин > 70 ммоль/л \\
\hline Гиперлактатемия & $>3$ ммоль/л \\
\hline Микроциркуляторные расстройства & $\begin{array}{l}\text { Уменьшение наполнение } \\
\text { капилляров, пятнистость }\end{array}$ \\
\hline
\end{tabular}


Все эти измененные представления привели к тому, что в 2016 году была проведен Третий международный Консенсус по определению сепсиса и септического шока (Third International Consensus Definitions for Sepsis and Septic Shock (Sepsis-3)). Было принято решение не уделять внимание CCВО при определении сепсиса и вместо этого сосредоточиться на дисфункции органов. Считалось, что септический шок - это нечто большее, чем просто сепсис с рефрактерной гипотонией или сердечно-сосудистой дисфункцией, требующий также признаков клеточных или метаболических нарушений.

В результате были внесены изменения в определения терминов, определяющих септические и воспалительные состояния. В частности, сепсис определен как «опасная для жизни дисфункция органа, вызванная разрегулированной реакцией организма на инфекцию». Септический шок «подгруппа сепсиса, при которой особенно серьезные нарушений кровообращения, клеточные и метаболические нарушения ассоциированы с более высоким риском смерти, чем только при сепсисе». Принципиальные отличия по изменениям в терминологии и взаимоотношении критических состояний представлены на рисунке (Рис.65).

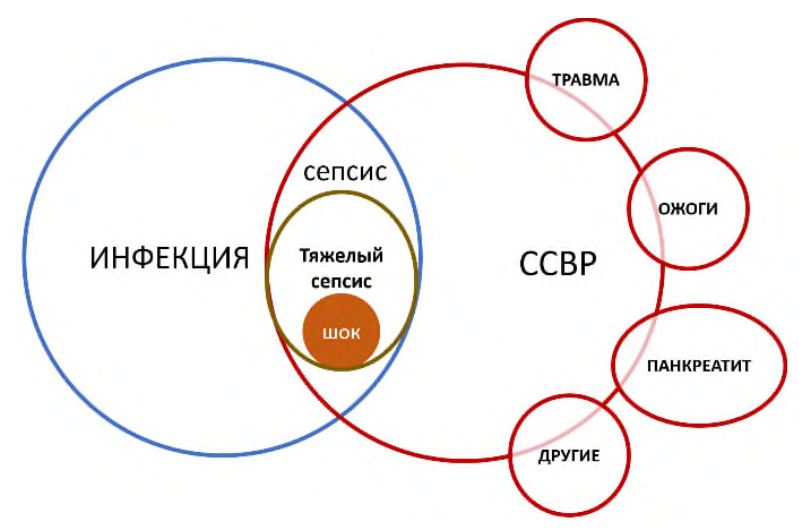

A

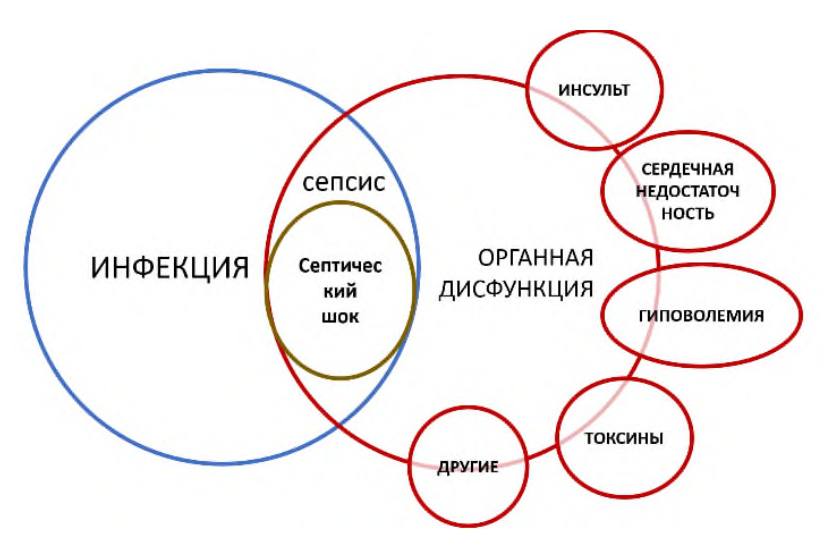

B

Рис. 65. Принципиальное сравнение взаимоотношений состояний при определении сепсиса и ССВО 1992 года (А) и 2016 года (В).

Поскольку новые определения сепсиса смещают акцент с синдрома системного воспалительного ответа на органные дисфункции, было предложено использовать последовательную шкалу оценки органных дисфункций (Sequential Organ Failure Assessment (SOFA)), как простой проверенный метод количественной оценки дисфункции органов, а также потребность в вазопрессорной терапии для поддержания системного давления и повышение уровня лактата в отсутствие гиповолемии, для диагностики септического шока. 
Диагноз сепсиса устаналивается при наличии документированной (предположительной) инфекции и $\geq 2$ баллов по шкале SOFA (Табл.39).

Таблица 39

Шкала полиорганной недостаточности связанная с сепсисом (шкале SOFA)

\begin{tabular}{|c|c|c|c|c|c|}
\hline \multirow{2}{*}{ Показатель } & \multicolumn{5}{|c|}{ Баллы } \\
\hline & 0 & 1 & 2 & 3 & 4 \\
\hline $\begin{array}{l}\text { Неврологический } \\
\text { статус. Шкала комы } \\
\text { Глазго }\end{array}$ & 15 & $13-14$ & $10-12$ & $6-9$ & $<6$ \\
\hline $\begin{array}{l}\text { Артериальная } \\
\text { гипотензия }\end{array}$ & нет & $\begin{array}{c}\text { Среднее } \\
\text { артериальное } \\
\text { давление } \\
\text { <70мм рт.ст. }\end{array}$ & $\begin{array}{c}\text { Низкие } \\
\text { дозы } \\
\text { добутамина } \\
\text { и допамина }\end{array}$ & $\begin{array}{c}\text { Допамин 5- } \\
15 / \\
\text { адреналина / } \\
\text { нормадрена- } \\
\text { лин <0.1 }\end{array}$ & $\begin{array}{c}\text { Допамин } \\
>15 / \\
\text { адреналин/ } \\
\text { норадрена- } \\
\text { лин >0.1 }\end{array}$ \\
\hline $\begin{array}{l}\text { Дыхательная } \\
\text { система. Уровень } \\
\text { PaO2/FiO2 }\end{array}$ & $>400$ & $300-399$ & $200-299$ & $\begin{array}{c}100-199+ \\
\text { механическая } \\
\text { вегтиляция }\end{array}$ & $\begin{array}{c}<100+ \\
\text { механическая } \\
\text { вегтиляция }\end{array}$ \\
\hline $\begin{array}{l}\text { Мочевыделительная } \\
\text { система. Креатинин } \\
\text { мг/дл }\end{array}$ & $<1,9$ & $1,2-1,9$ & $2,0-3,4$ & $\begin{array}{c}3,5-4,9 \text { или } \\
\text { диурез < } 500 \\
\text { мл/сут } \\
\end{array}$ & $\begin{array}{c}\text { 5,0 или } \\
\text { диурез < } 200 \\
\text { мл/сут } \\
\end{array}$ \\
\hline $\begin{array}{l}\text { Печень. } \\
\text { билирубин } \\
\text { (ммоль/л) }\end{array}$ & $<20$ & $20-32$ & 33-101 & $102-204$ & $>204$ \\
\hline $\begin{array}{l}\text { Система гемостаза. } \\
\text { Ттромбоциты } 10^{9} / л\end{array}$ & $>150$ & $100-149$ & $50-99$ & $20-49$ & $<20$ \\
\hline
\end{tabular}

Кроме того, новые критерии определения сепсиса предлагают шкалу быстрая SOFA для эффективного скриннинга у постели больного для выявления потенциальных инфицированных пациентов с риском неблагоприятных исходов вне стационара, отделениях неотложной терапии и общесоматических отделениях. Критерии быстрой SOFA включают ( $\geq 2$ баллов идентифицируют пациентов с высоким риском неблагоприятных исходов):

- Систолическое давление $\geq 100$ мм рт.ст;

- Частота дыхания $\geq 22$ в минуту;

- Изменения психического состояния.

И, наконец, критериями септического шока определено считать:

$\checkmark$ Стойкая артериальная гипотензия после введения жидкостей, а также

$\checkmark$ Потребность в вазопрессорах, а также

$\checkmark$ Лактат $>2$ ммоль/л при отсутствии гиповолемии. 


\section{Лабораторная диагностика ССВО.}

Как следует из всего вышеизложенного, в настоящее время в диагностике ССВО лидирующими аспектами являются диагностика выраженности органных дисфункций, подтверждение наличия (или наоборот, отсутствие) инфекционного агента и идентификация выраженности собственно воспалительного процесса. Для оценки состояния функционирования основных систем организма может быть использован весь спектр возможностей лабораторной диагностики. Эти аспекты рассматриваются в соответствующих разделах и по соответствующим дисциплинам.

Септическое воспаление, в том числе системное является наиболее изученным как в отношении патогенеза, так и в плане лабораторной диагностики. В ряду возможных осложнений септическое состояние, несмотря на постоянно совершенствуемые методы интенсивной терапии и антибиотикотерапии, занимает одно из ведущих мест среди причин смертности пациентов. Причины возникновения сепсиса до конца не до конца изучены, вместе с тем, взаимосвязь данного состояния с эффективностью функционирования иммунной системы пациента не вызывает сомнения. Именно поэтому в клинической практике широко применяются методы и подходы, позволяющие оценить состояние защитных систем пациента в постоперационном периоде. К их числу относятся исследования абсолютного и относительного числа лимфоцитов, их основных субпопуляций и доли апоптотических клеток, изучение функционального состояния фагоцитарного звена - циркулирующих моноцитов и нейтрофилов периферической крови, равно как и определения уровня про- и противовоспалительных цитокинов, Среактивного белка и компонентов каскада комплемента в сыворотке крови.

За последние 20 лет проведены большие исследования по поиску биомаркеров крови для ранней диагностики инфекции или сепсиса. В том числе, были проведены актуальные исследования по поиску маркеров, пригодных для дифференциальной диагностики сепсиса и неинфекционного ССВО. На основании проведенного в 2016 году мета-анализа литературы с оценкой маркеров ССВО и сепсиса суммарно у 10438 пациентов, были выделены 7 параметров, которые обладали диагностической чувствительностью от 0,62 (LBP-lypopolysaccharide binding protein, липополисахарид связывающий белок) до 0,87 (CD64) и специфичностью от 0,67 (СРБ - С-реактивный белок) до 0,93 (CD64).

Прокальцитонин (РСТ) является предшественником гормона кальцитонина. Повышение концентрации РСТ происходит при системном воспалении бактериальной этиологии, при тяжелых бактериальных инфекциях и сепсисе. Синтез РСТ активируется в клетках ретикуло-эндотелиальной системы. Основными индукторами при этом являются липополисахарид 
грамотрицательных бактерий, а также провоспалительные цитокины IL-6 и TNF $\alpha$ Концентрация РСТ в плазме крови повышается пропорционально тяжести инфекционного процесса. Вместе с тем, важно отметить, что умеренные повышения прокальцитонина являются атрибутом неинфекционного ССВО и могут быть связанны с изолированными органными дисфункциями, но не с наличием инфекции. Чувствительность теста определена в 0,79 , специфичность - 0,78. Оценка уровня прокальцитонина является одним из трех маркеров (наравне с уровнем СРБ и IL-6), которые являются основными и наиболее эффективными в диагностике ССВО.

С-реактивный белок относится к белкам острой фазы воспаления, продуцируемым гепатоцитами в ответ на повышенные уровни провоспалительных цитокинов, в частности, IL-6. Имеется большое количество указаний на высокую диагностическую значимость СРБ в диагностике инфекции, а также на высокую неблагоприятную прогностическую значимость длительно повышенного уровня маркера. Вместе с тем, совместная оценка уровня СРБ и прокальцитонина повышает качество диагностики инфекций и позволяет отличать пациентов с системной инфекцией от пациентов с неинфекционным ССВО. Чувствительность СРБ в диагностике инфекции и ССВО составила 0,75 , а специфичность 0,67 .

Интерлейкин-6 - один из самых важных цитокинов при острых воспалительных реакциях, имеющий как местные, так и системные эффекты. Он запускает синтез белков острой фазы в печени, стимулирует выработку нейтрофилов в костном мозге и способствует дифференцировке Т-хелперов в направлении Th17. IL-6 синтезируется мононуклеарными фагоцитами, дендритными клетками, эндотелиальными клетками, фибробластами и др. в ответ на PAMP, а также в ответ на IL-1 и TNF. На примере больных с CCBO и с сепсисом было показано, что наравне с прокальцитонином и СРБ, IL-6 может быть полезен в диагностике этих состояний. Вместе с тем, прокальцитонин, IL-5 и IL-6 обладают отличительными свойствами для определения степени тяжести сепсиса. Чувствительность маркера составила 0,72 , а специфичность - 0,73.

STREM-1 (от англ. «soluble trigger receptor expressed on myeloid cells», растворимая форма триггерного рецептора, эксперссируемого на миелоидных клетках). TREM-1 является активирующим рецептором моноцитов и нейтрофилов, является важным регулятором в системе врожденного иммунитета и индукции адаптивного иммунитета. До недавнего времени TREM-1 считался маркером сепсиса и инфекционного СВО. Умеренное повышение мембранной и растворимой формы TREM-1 (sTREM-1) наблюдается во время инфекций, вызванных бактериями, вирусами и грибами, а значительное увеличение - при сепсисе и септическом шоке. Однако за последние годы появились исследования, указывающие на связь TREM-1 с CCBO неинфекционного генеза. Диагностическая чувствительность маркера оценена в 0,78 , специфичность - 
0,78. Важно отметить, что динамическое исследование уровня sTREM-1 и сравнение с исходными, например, дооперационными значениями у пациентов с полостными хирургическими вмешательствами, может выступать в качестве эффективного прогностического маркера неблагоприятного течения послеоперационного периода.

Presepsin (sCD14). CD14 - поверхностный многофункциональный гликопротеин, который присутствует на мембране различных клеток (моноциты, макрофаги, нейтрофилы, хондроциты, В-клетки и т.д.) или в растворенной форме (sCD14). Специфичный высокоаффинный рецептор для комплексов липополисахарида (ЛПС) и липополисахарид связывающего белка (LBP, от англ. «lipopolysaccharide binding protein»). В кровотоке растворимая форма появляется в результате шеддинга, а также в результате секреции гепатоцитами. В диагностике сепсиса и септических состояний продемонстрировал схожую значимость с прокальцитонином и СРБ. Таким образом, несмотря на достаточно высокую чувствительность $(0,84)$ и специфичность $(0,77)$, вследствие отсутствия преимуществ по сравнению общепринятыми тестами - уровень прокальцитонина и С-реактивного белка - вряд ли может быть признан в качестве дополнительного критерия диагностики ССВО и инфекций.

LBP (lipopolysaccharide binding protein). Представляет собой полипептид массой 50 кДа (в кровотоке - 58-60 кДа в результате гликозилирования). Синтезируется в печени и играет ключевую роль в функционировании иммунной системы как растворимая паттерн-распознающая молекула. LBP осуществляет связывание и рекрутинг эндотоксина и является основным плазменным белком, ответственным за транспорт эндотоксина к эффекторным клеткам иммунной системы, несущим CD14. У пациентов с сепсисомотмечено повышенная секреция LBP в ответ на липополисахарид. В ряде исследований демонстрировал диагностическую эффективность, сопоставимую с прокальцитонином, по идентификации бактериемии, в том числе у пациентов клиническими проявлениями $\mathrm{CCBO}$ и нейтропенией. Вместе с тем, преимуществ не продемонстрировал и из отобранных наиболее перспективных маркеров обладал наименьшей чувствительностью $(0,62)$ и, одной из наименьших, специфичностью $(0,70)$.

CD64 и CD64 Index. CD64 является высокоаффинным Fс-рецептором, который в норме экспрессируется на моноцитах, макрофагах и слабо на покоящихся нейтрофилах. Ранее были опубликованы наблюдения, в которых у пациентов с ССВО неинфекционного генеза уровень экспрессии CD64 оставался неизменным, особенно на нейтрофилах. Оценка уровня экспрессии CD64 на нейтрофилах является наиболее чувствительным $(0,87)$ и специфичным $(0,93)$ тестом ранней диагностики инфекции, в том числе у пациентов с лихорадкой. Кроме того, дополнительное определение уровней прокальцитонина, IL-6 и СРБ, может существенно повысить чувствительность и специфичность ранней диагностики инфекции. 
Таким образом, синдром системного воспалительного ответа является опасным состоянием организма, развивающимся в результате различных воздействий и повреждений, но не только в результате инфекции, и может сам по себе быть причиной более тяжелого течения основного заболевания и неблагоприятного прогноза. Патогенез ССВО сложен и включает в себя повреждение клеток и тканей различного генеза, активацию системы врожденного иммунитета, развитие цитокинового шторма с выбросом, в первую очередь, провоспалительных цитокинов, поражением эндотелия и развитием эндотелиальной дисфункции, компартментализацией воспаления с поражением и вовлечением в процесс отдаленных тканей и органов. Для целей сдерживания в организме имеет место компенсаторная система противовоспалительного ответа, активность которой связана, преимущественно, с адаптивной иммунной системой.

Диагностика ССВО достаточно сложна и диагностические критерии в настоящее время уточняются. Вместе с тем, по современным представлениям диагностика ССВО должна быть направлена на установление факта наличия или отсутствия инфекции, определения выраженности органных дисфункций, для которой может быть использована шкала SOFA. Для лабораторной диагностики ССВО инфекционной и неинфекционной природы наилучшими (с высокой специфичностью и чувствительностью) критериями являются определение уровня прокальцитонина, С-реактивного белка и интерлейкина 6 сыворотки или плазмы крови, а также определение уровня экспрессии CD64 на нейтрофилах периферической крови. 


\section{Глава 7. Адаптивный иммунитет}

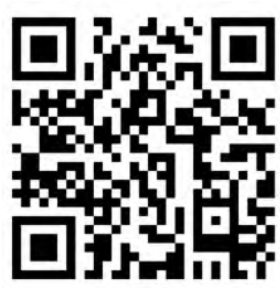

Активачии клеточных и гуморальных реакций адаптивного иммунитета начинается с распознавания антигенных пептидов, представленных на поверхности антигенпрезентирующих клеток Т лимфочитами.

Начиная данный раздел, следует отметить, что ключевую роль в активации клеточных и гуморальных реакций системы адаптивного иммунитета играет процесс, получивший название «презентация» (иногда «представление») антигенов (рис.66).

Захват антигена

А) Активация «наивных» клеток, клональная экспансия, формирование эффекторов

Б) Активация эффекторной клетки - продукция цитокинов, активация макрофагов (клеточный ответ)

В) Активация эффекторной клетки - активация В-пимфоцитов, продукция антител (гуморальный ответ)

Рис. 66. Основные этапы развития специфического иммунного ответа. 
За реализацию всех процессов, связанных с презентацией антигенов, отвечают так называемые антиген-презентирующие клетки (АПК) гетерогенная популяция лейкоцитов с выраженными иммуностимулирующими свойствами, обладающие способностью осуществлять «процессинг» антигена и предоставлять (презентировать) его иммунокомпетентным клеткам (в первую очередь, различным популяциям Т-хелперов и цитотоксическим Т-лимфоцитам).

Процессинг антигенов - это частичный (ограниченный) протеолиз белковых антигенов (расщепление до 5-20 аминокислотных остатков), упаковка полученных фрагментов антигена на молекулы главного комплекса гистосовместимости 1 и 2 классов (MHC I и MHC II), а также последующая экспрессия образующихся комплексов на поверхность АПК - т.е. презентация антигена в иммуногенной форме (той самой форме, которая может вызвать развитие специфического иммунного ответа с последующим формирование иммунологической памяти). Т-лимфоциты, клетки, которые запускают и контролируют реакции адаптивного иммунитета, могут распознавать своими Т клеточными рецепторами только короткие антигенные пептиды в составе молекул МНС I и/или II класса.

Какие клетки отвечают за презентацию антигенов? Обычно выделяют «профессиональные» АПК - дендритные клетки, макрофаги и В-лимфоциты - на поверхности этих клеток молекулы МНС II класса присутствуют постоянно. Наряду с «профессиональными» АПК, некоторые типы соматических клеток (кератиноциты, тироциты, эндотелиоциты) при различных воспалительных процессах в условиях активации цитокинами также приобретают способность участвовать в презентации антигенов. Антигенные пептиды в составе молекул МНC II класса распознают Т хелперы- клетки, которые координируют развитие всех типов иммунного ответа и воспаления, продуцируя цитокины, регулирующие активность клеток врожденного и приобретенного иммунитета. Что же касается молекул МНC I класса, то они постоянно (конститутивно) представлены на поверхности всех ядросодержащих клеток организма, кроме клеток трофобласта. Под действием провоспалительных факторов (цитокины, патоген-ассоциированные молекулярные паттерны, маркеры повреждения собственных клеток и т.д.) уровень экспрессии молекул МНC I класса может существенно повышаться.

В ходе развития специфического иммунного ответа выделяют следующие этапы:

1) Первичное проникновение патогена через барьерные ткани;

2) Распознавание патогена при помощи паттерн-распознающих рецепторов (в первую очередь, TLRs для внеклеточных патогенов, NLR и RLR для внутриклеточных), активация клеток и запуск различных механизмов эндоцитоза (поглощение патогена в различных АПК протекает с использованием 
различных механизмов эндоцитоза); более того, распознавание патогена или его фрагментов при помощи PRR необходимо для индукции экспрессии костимуляционных молекул (см. ниже);

3) Захват и интернализация при помощи эндоцитоза патогена или его фрагментов АПК, которые могут быть локализованы в барьерных тканях (например, дендритные клетки) или в лимфе, собранной из тканей в лимфатическом узле (В-лимфоциты);

4) Процессинг и доставка антигенов в Т-зависимые зоны периферических лимфоидных органов активированными АПК (в этом случае АПК становятся зрелыми и начинает экспрессировать рецепторы «хоуминга» в лимфоидную ткань, в Т-зависимые зоны, где вероятность встречи с «наивными» и клетками центральной памяти максимальна. Периферические лимфоидные органы являются организованными структурами лимфоидной ткани, в которой созданы условия для взаимодействия клеток иммунной системы и развития реакций адаптивного иммунного ответа;

5) Презентация антигенов Т-лимфоцитам в Т-зависимых зонах периферических лимфоидных органов;

6) Выбор направления и развитие адаптивного ответа, связанного с получением Т-клеткой активационных сигналов (распознавание антигена, сигнал от ко-стимулирующих молекул, и сигнал от цитокинов),

7) Клональная экспансия Т-лимфоцитов и формирование пула эффекторных клеток, способных мигрировать в очаг проникновения патогена и долгоживущих клеток памяти.

В том случае, если этапы 1-3 могут протекать как в периферических тканях (в случае дендритных клеток как АПК), так и в лимфоидной ткани (Вклетки как АПК), то последующие этапы (4-6) в норме протекают исключительно в периферических лимфоидных органах. Именно поэтому периферические органы иммунной системы расположены по регионарному принципу, что позволяет контролировать поступление антигенов из определенных частей тела и обеспечивать развитие иммунного ответа. Каждый лимфатический узел контролирует строго определенную часть тела, от которой к нему поступает лимфа. Селезенка является барьером для антигенов, поступивших в кровоток. Кроме того, лимфоидная ткань и диффузные скопления лимфоидных клеток расположены в барьерных тканях - слизистых оболочках и коже.

Презентация эндогенных антигенов в составе MHC I запускает развитие противоопухолевого и противовирусного иммунного ответа.

Презентация антигенов, локализованных в цитоплазме клеток в составе MHC I класса индуцирует развитие противовирусного и противоопухолевого иммунного ответа. Этот процесс протекает постоянно во всех ядросодержащих 
клетках организма (кроме клеток трофобласта); ключевую роль в распознавание клеток, несущих в своей цитоплазме «чужие» (инфицированные вирусами или некоторыми бактериями, живущими в цитоплазме без мембранной упаковки) или собственные «измененные» (переродившиеся опухолевые клетки) антигены играют цитотоксические Т-лимфоциты с фенотипом CD3+CD8+. Именно благодаря молекуле CD8 (которая способна к специфическому взаимодействию с MHC I), эти клетки получают подтверждающие сигналы о том, что они распознали антигены, локализованные в цитозоле, и могут запустить процессы, связанные с индукцией апоптоза в этой клетке. Презентация антигенов через молекулы МНС I класса традиционно разбивается на несколько стадий (рис.67):

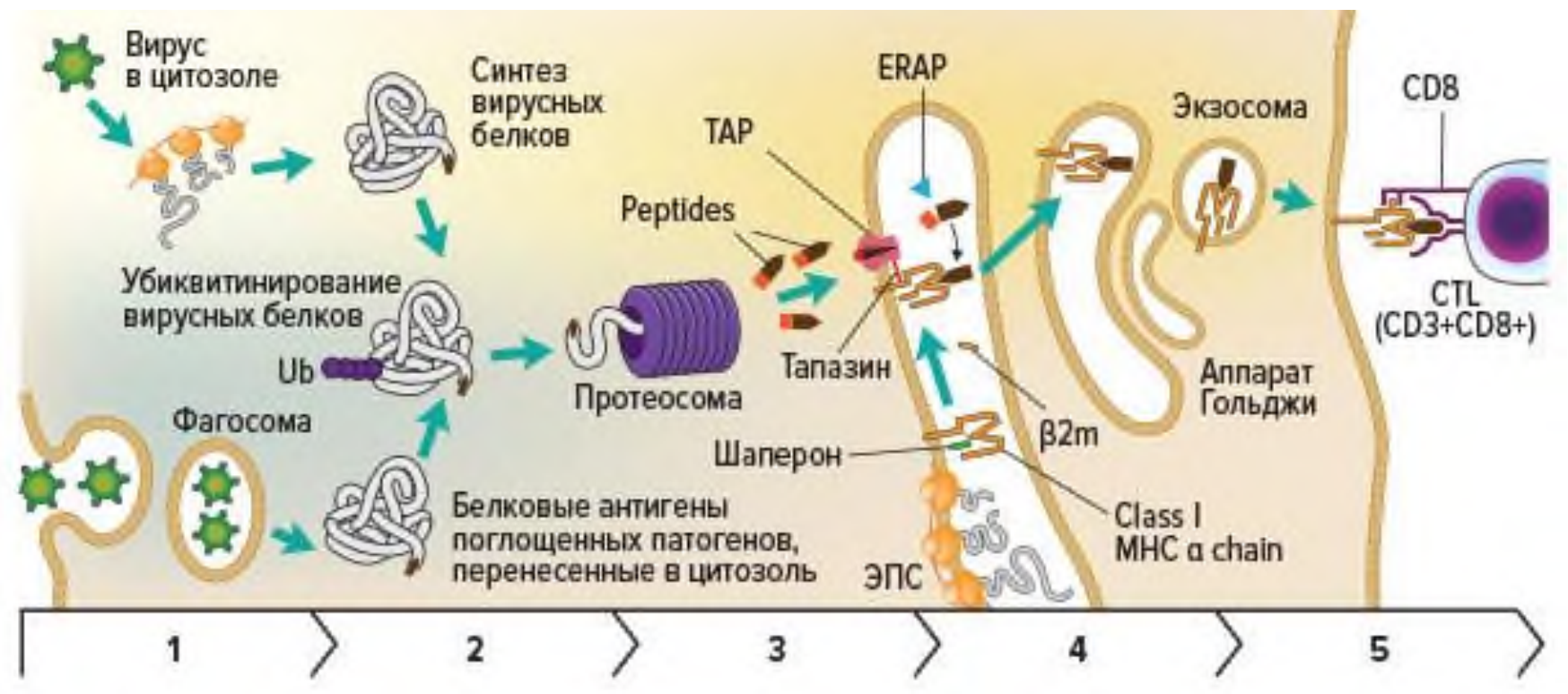

\section{Рис. 67. Презентация антигенов, локализованных в цитоплазме клеток, при помощи МНС I класса - реализация противовирусного и противоопухолевого специфического иммунного ответа.}

1. Синтез белков в цитоплазме клетки на свободных рибосомах;

2. Ограниченный протеолиз белков (обычно около $30 \%$, а при активации клеток - до $70 \%$ от общего объема вновь синтезированных белков) в специальной белковой «мясорубке» - протеасоме (ее активность также зависит от провоспалительных сигналов извне клетки);

3. Все полученные фрагменты белков (их уже можно называть антигенами) специфическим образом маркируются и переносятся при помощи специализированных белков-транспортеров семейства ТАР из цитозоля в полость ЭПС;

4. Загрузка пептида на МHC I

5. Перемещение комплекса «MHC I-пептид» на наружную мембрану клетки для распознавания цитотоксическими Т-клетками.

(адаптировано из Cellular and Molecular Immunology by Drs. Abul K. Abbas, Andrew H. H. Lichtman, and Shiv Pillai 9th edition, 2017).

Многие патогены используют стратегии избегания или снижения эффективности иммунного ответа за счет нарушения презентация антигенов в состтаве МНС I. Так, способностью к снижению ферментативной активности протеосомы обладают белки вирусов EBV и CMV, что снижает эффективность 
процессинга вирусных белков. Некоторые белки HSV способны блокировать работу белков-транспортеров семейства ТАР, что снижает эффективность доставки процессированных антигенов в ЭПС. Аденовирусы и CMV подавляют синтез молекул МНС I в инфицированной клетке и/или нарушают их транспорт в ЭПС. Более того, CMV способствует удалению MHC I из ЭПС, тогда как CMV мыши может вызывать еще и продукцию собственных MHCI-подобных молекул вируса, способных связываться с ингибиторными рецепторами на поверхности НК-клеток и подавлять их активность.

Презентация экзогенных антигенов в составе МНС II класса необходима для запуска всех типов адаптивного иммунного ответа.

Презентация экзогенных антигенов в составе MHC II класса необходимое условие развития специфического иммунного ответа против всех типов патогенов. Презентацию антигена осуществляют профессиональные АПК, а также некоторые другие активированные клетки (эндотелиальные, эпителиальные и др.), поглотившие при помощи различных типов эндоцитоза «чужие» (бактериальные, грибковые, вирусные и т.д.) антигены. Ключевую роль в распознавании антигенов в составе MHC II класса играют Т-хелперы с фенотипом CD3+CD4+. Именно благодаря экспрессии молекулы CD4 (которая способна к специфическому взаимодействию с МНC II), эти клетки получают подтверждающие сигналы о том, что они распознали экзогенные (захваченные из межклеточного пространства) антигены. Распознавание антигенов Тхелперами запускает продукцию этими клетками цитокинов, которые способны активировать различные типы эффекторных клеток, что определяет дальнейшую стратегию борьбы с патогеном или тип адаптивного иммунного ответа.

В процессе презентации антигенов в составе молекул МНC II класса традиционно выделяют несколько стадий (рис.68).

Следует отметить, что подобно вирусам, блокирующим презентацию антигенов в составе MHC I класса, многие внеклеточно-паразитирующие патогены - в первую очередь, бактерии и грибы - используют различные стратегии избегания или снижения эффективности презентации своих антигенов за счет нарушения данного процесса презентации в составе MHC II класса. Например, многие бактерии нарушают процессы созревания фаголизосом, что позволяет им избежать не только собственной гибели, но и процессинга собственных антигенов. Некоторые виды Mycobacterium и Ehrlichia блокируют созревание фагосом в самом начале, тогда как сальмонеллы позволяет фагосомам немного большее созревание, а, например, Coxiella высвобождается в цитоплазму уже из зрелой фаголизосомы. На аналогичной стадии фаголизосомы способны покидать некоторые виды Listeria и Rickettsia. 
Итак, патогены применяют весьма эффективные стратегии избегания презентации собственных антигенов. Именно поэтому были разработаны многочисленные фармакологические подходы, целью которых являлось повышение эффективности распознавания антигенов клетками иммунной системы.

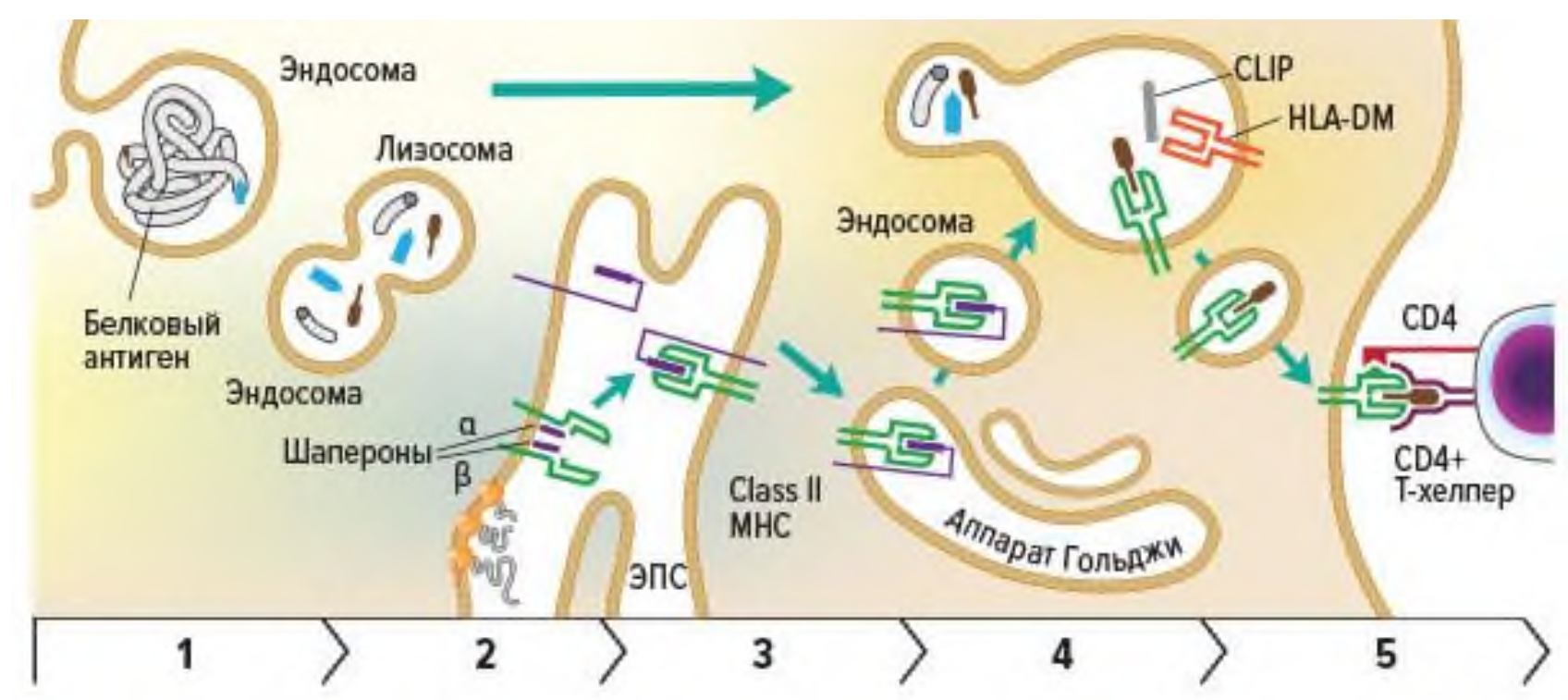

Рис. 68. Презентация внеклеточных антигенов при помощи МНС II класса - реализация специфического иммунного ответа против внеклеточных патогенов.

1. Эндоцитоз внеклеточного антигена АПК;

2. Ограниченный протеолиз поглощенного антигена в фаголизосоме/эндосоме;

3. Синтез молекул МНС II в ЭПС с последующим их транспортом в эндосому, содержащую процессированные антигены (сайт для связывания с антигеном на МНС II закрыт специальным белкомзаглушкой, что позволяет предотвратить загрузку внутриклеточных антигенов, которые находятся в полости ЭПС);

4. Удаление белка-заглушки с МНC II и загрузка антигена на МHC II;

5. Транспорт образовавшегося комплекса «МНC II-антиген» на поверхность клетки для распознавания Т-хелперами.

(адаптирована из Cellular and Molecular Immunology by Drs. Abul K. Abbas, Andrew H. H. Lichtman, and Shiv Pillai 9th edition, 2017).

В онкологии применяются различные химиотерапевтические препараты (например, цисплатин или гемцитабин), одним из эффектов которых является увеличение экспрессии молекул МНС I класса на всех клетках организма, в том числе опухолевых, На разных стадиях клинических испытаний находятся препараты на основе ингибиторов тирозинкиназ, способные усиливать экспрессию молекул МНС I и II классов, а также оказывать влияние на плотность экспрессии ко-стимулирующих молекул CD86 и CD40. Препараты, содержащие интерфероны I и II типов, также оказывают стимулирующее действие как на соматические клетки (за счет усиления экспрессии МНCI и белков семейства TAP), так и (в случае IFN $\gamma$ ) на профессиональные АПК (за счет усиления экспрессии МНС II и ко-стимулирующих молекул). Столь же эффективны 
различные препараты, содержащие в своем составе агонисты TOLL-подобных рецепторов. Например, такой агонист TLR 2/4 как БЦЖ способен повышать на АПК экспрессию MHC-II, ко-стимулирующих CD80/CD86 и адгезионных ICAM молекул.

Молекулярные механизмы активации Т-лимфоцитов при распознавании антигеных пептидов, презентированных на поверхности АПК в составе МНСI и МНC-II класса.

\section{Формирование и структура «иммунного» синапса.}

Когда комплекс TcR распознает MHC-ассоциированные пептиды на АПК, в области физического контакта между Т-клеткой и АПК формируется макромолекулярная структура, образованная поверхностными и внутриклеточными сигнальными молекулами, которая называется «иммунным» синапсом или надмолекулярным активационным кластером (SMAC, от англ. «supramolecular activation cluster»). В самом центре SMAC находятся такие молекулы как Т-клеточный рецептор в ассоциации с CD3 (все цепи, включая 丂), корецепторы CD4 или CD8 (в случае Т-хелпера или цитотоксического Tлимфоцита, соответственно), различного рода внутриклеточные сигнальные молекулы, главной из которых является протеинкиназа $\theta$ (PKC- $\theta$ ), а также адапторные белки, отвечающие за передачу сигнала внутрь клетки. В этой области синапса, называемой также с-SMAC (центральная часть SMAC, от англ. «central SMAC»), расстояние между плазматической мембраной Т-лимфоцита и мембраной АПК составляет около 15 нм. Адгезионные молекулы (LFA-1 со стороны Т-лимфоцита с ICAM-1 на поверхности АПК) формируют периферическую часть «иммунного» синапса и играют ведущую роль в стабилизации сайта взаимодействия между Т-клеткой и АПК. Эта область получила название периферическая часть SMAC или p-SMAC (от англ. «peripheral SMAC»). В этой внешней части синапса мембраны контактирующих клеток разделяет расстояние в пределах 40 нм. Кроме того, по периферии со стороны Т-лимфоцита формируется дополнительное кольцо из молекул CD44 и CD45, получившее название d-SMAC (от англ. «distal SMAC»).

В покоящейся Т-клетке все эти сигнальные и адгезионные молекулы обычно располагаются диффузно в плоскости плазматической мембраны лимфоцита в составе так называемых липидных «рафтов» (от англ. «lipid rafts») или плотов, то есть фрагментов мембраны, обогащенных гликолипидами. Только после активации Т-клеточного рецептора и получения ко-стимулирующих сигналов липидные «рафты» за счет белков т цитоскелета направленно мигрируют в зону контакта с АПК и сливаются, формируя иммунологический синапс. 


\section{Функции иммунного синапса.}

Иммунный синапс выполняет несколько важнейших функций, связанных с активацией Т-лимфоцита (рис. 69). Во-первых, стабилизация взаимодействия Т-клеточного рецептора с комплексом антигенный пептид-МНС (рер-МНС) обеспечивает время, необходимое для активации пролиферации Т-лимфоцита и синтеза ряда поверхностных и растворимых молекул. Более того, сродство или аффинность TcR к антигену может быть весьма низким, но длительное взаимодействие гарантирует эффективное проведение сигнала и активацию лимфоцита.

Во-вторых, формирование синапса позволяет собрать вместе несколько комплексов MHC-антиген, чтобы активировать сразу несколько TcR, что повышает вероятность активации Т-лимфоцита.

\section{Сигнал 1 Сигнал 2 Сигнал 3}
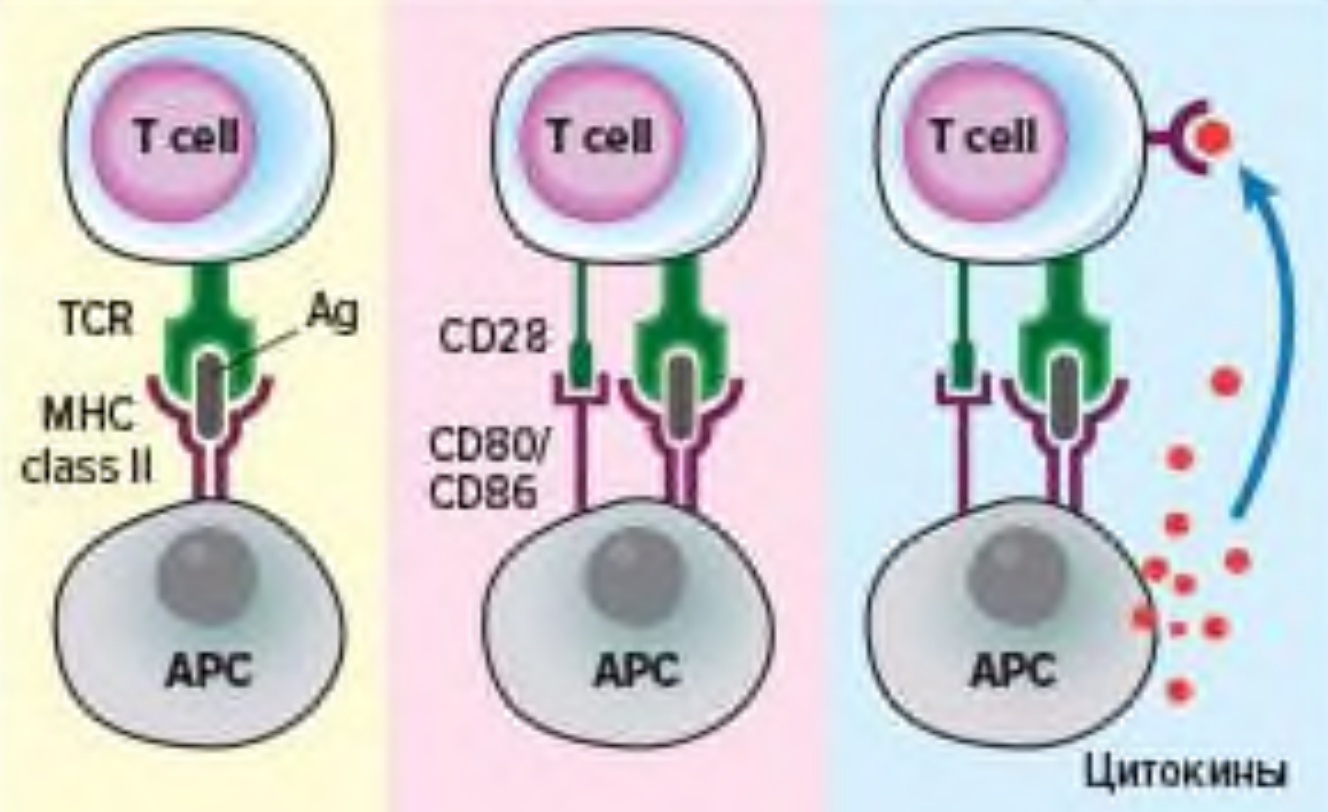

Рис. 69. Схематическое изображение трех основных «сигналов», необходимых для активации Т-лимфоцита и запуска антигензависмой стадии дифференцировки в периферических лимфоидных органах.

(адаптирована из Клиническая иммунология, 2020).

В-третьих, именно в пределах синапса происходит обмен цитокиновыми сигналами между АПК и Т-лимфоцитом. Условная изолированность внутреннего пространства синапса позволяет локально повысить концентрацию этих цитокинов, что также обеспечивает эффективное проведение сигнала и активацию Т-лимфоцита. 
В-четвертых, «иммунный» синапс, особенно в своей центральной части с$\mathrm{SMAC}$, играет важную роль для эффективной передачи сигнала внутрь клетки. Следует помнить о том, что после фосфорилирования и активации сигнальных молекул последние быстро инактивируются. Это способствует прекращению активации Т-клеток. А продолжительный контакт клеток способствует генерации новых активационных молекул.

Для активации Т-лимфоцитов и запуска антигензависимой стадии дифференцировки в периферических лимфоидных органах необходимы три сигнала от АПК.

В процессе презентации антигена Т-лимфоциты получают от АПК три сигнала, которые являются обязательным условием активации этих клеток и запуска реакций адаптивного иммунитета.

Сигнал 1 обеспечивает распознавание Т-клеточным рецептором антигена в ассоциации с молекулами главного комплекса гистосовместимости I (для цитотоксических Т-лимфоцитов) или II (для Т-хелперов) класса. Этот сигнал определяет специфичность реакций адаптивного иммунитета. Другими словами, именно этот сигнал обеспечивает активацию и клональную экспансию только тех лимфоцитов, которые несут рецепторы способные распознавать этот конкретный антиген.

Сигнал 2 является результатом взаимодействия между костимулирующими молекулами АПК и Т-лимфоцита. Ко-стимулирующие молекулы CD80/CD86 появляются на поверхности АПК только в случае активации на ней рецепторов врожденного иммунитета, то есть исключительно в ответ на распознавание «чужого» (PAMPs), а не случайно презентируемого «своего» (рис. 70). Именно патогены являются индукторами экспрессии костимулирующих молекул на АПК (без патогена и/или его компонентов запуск иммунного ответа невозможен - это свойство применяется, например, при создании эффективных вакцин, где лиганды TLR и других паттернраспознающих рецепторов являются одними из важнейших компонентов). Взаимодействие между CD80/CD86 и CD28 происходит только при презентации «чужого», а не «своего» антигена и необходимо для активации и клональной экспансии Т-лимфоцитов.

Сигнал 3 создают цитокины, секретируемые АПК или другими клетками микроокружения. Этот сигнал обеспечивает поляризацию наивных Тлимфоцитов в один из типов Т-хелперов, что в конечном итоге, определяет стратегию развития иммунного ответа и способ элиминации данного конкретного патогена. Механизмы, определяющие продукцию тех или иных комбинаций цитокинов, продуцируемых в момент презентации антигена в 
настоящее время плохо изучены. Предполагают, что это в значительной степени зависит от природы патогена, а именно, набора эволюционно консервативных структур конкретного патогена (PAMPs), которые распознает АПК своими паттерн-распознающими рецепторами. Не исключают также, что разные типы АПК способны рецептировать разные комбинации PAMPs, продуцировать разные наборы цитокинов и способствовать развитию разных типов иммунного ответа.

\section{Роль костимуляторных сигналов в индукции реакий алаптивного} иммунитета (рис.70).

Взаимодействие $\mathrm{CD} 80 / \mathrm{CD} 86$ со стороны АПК и CD28 со стороны Тлимфоцита в момент презентации антигена приводит к:

- сигналам на выживание для Тлимфоцита, а именно усилению экспрессии в $\mathrm{T}$ клетках антиапоптотических белков;

- синтезу и секреции IL-2 и увеличению экспрессии CD25 (а-цепь рецептора IL-2) на поверхности клетки; IL-2 является важнейшим аутокринным ростовым фактором для Т-клеток, без него Т-клетки не могут пролиферировать и формировать клон эффекторных клеток;

- пролиферации или клональной экспансии - наработке пула клеток, обладающих Т-клеточным рецептором заданной специфичности. Если исходно антиген распознает одна наивная Т-клетка с уникальным рецептором, то в ходе развития иммунного ответа формируется целый

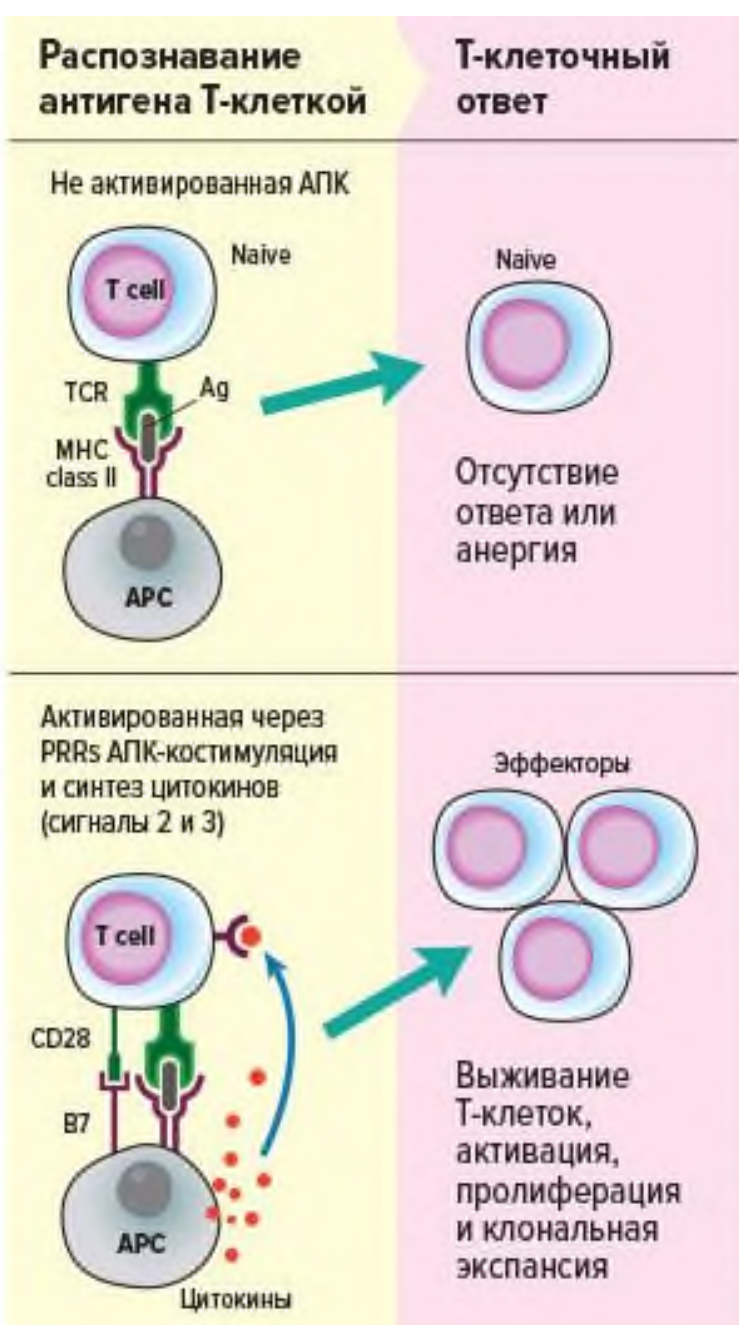

Рис. 70. Ко-стимулирущие молекулы, клон клеток, несущих рецептор такой

же специфичности. Чем больше клон, тем быстрее, эффективнее и с минимальным повреждением организма происходит элиминация патогена;

- увеличению уровня экспрессии белков-циклинов, отвечающих за прохождение активированного Т-лимфоцита по фазам клеточного цикла, выход из фазы покоя и переход к митозу; 
- дифференцировке в эффекторные клетки и клетки памяти. При этом эффекторы должны бороться с патогеном в очаге инфекции, тогда как клетки памяти отвечают на ускоренный ответ на повторное проникновение патогена. Именно формирование пула клеток памяти является важнейшей целью вакцинации.

Необходимо подчеркнуть, что сигнал 2 (сигнал костимуляции) служит важнейшим инструментом контроля и ограничения аутоагрессии. Только лимфоцит, распознающий «чужеродный» антиген получает от АПК разрешение на выживание и клонирование. Потенциально опасные, аутореактивные клоны лимфоцитов при распознавании аутоантигена не получают сигналов костимуляции от АПК, поэтому анти-апоптотические белки в таких клетках не экспрессируются, и они погибают путем апоптоза. Отсутствие сигнала костимуляции позволяет также избежать синтеза аутореактивными лимфоцитами IL-2, формирования высоко-аффинного рецептора для этого цитокина и клональной экспансии. Срыв периферической толерантности лежит в основе аутоиммунных патологических состояний, поэтому ко-стимулирующие молекулы являются перспективными мишенями для терапии этих заболеваний. Ведущая роль костимуляторных молекул CD80/CD86 и CD28 в поддержании периферической толерантности положена в основу разработки и эффективного применения некоторых современных биологических препаратов. За создание таких препаратов Джеймсу Эллисону была присуждена Нобелевская премия по медицине и физиологии в 2018 году.

Что же касается АПК, то они тоже получают сигналы от Т-лимфоцитов обмен сигналами носит взаимный характер! Так, после взаимодействия CD80/CD86 и CD28, на поверхности активированной Т-клетки экспрессируется CD40L. Данная молекула связывается с CD40 на поверхности AПК, что приводит к усилению экспрессии CD80/CD86 и продукции цитокинов, необходимых для выживания и дифференцировки Т-клетки. Таким образом клетки стимулируют друг друга на выживание и проявление эффектов, необходимых для развития иммунного ответа.

В ходе активации и клональной экспансии «наивных» Т-лимфоцитов формируются популяции клеток памяти, которые патрулируют разные компартменты организма и обеспечивают более быстрый и более сильный иммунный ответ при повторной встрече с антигеном.

1. Т-лимфоциты центральной памяти.

- не обладают выраженными эффекторными свойствами;

- способны пролиферировать и быстро дифференцироваться (обычно 3-5 дней) в эффекторные клетки;

- локализуются в периферических лимфоидных органах, а, благодаря способности к «рециркуляции», регулярно посещают («патрулируют») 
периферические лимфоидные органы различной локализации, живут годами отвечают за долговременный иммунитет;

- нуждаются в презентации антигена в периферических лимфоидных органах и ко-стимуляции для проявления своих свойств и клональной экспансии.

\section{2. Т-лимфоциты эффекторной памяти.}

- быстро активируются и увеличивают уровень продукции цитокинов и других эффекторных молекул;

- обладают низкой способностью к пролиферации;

- постоянно находятся в периферических тканях - потенциальных участках повторного проникновения патогена;

- не нуждаются в презентации антигена в периферических лимфоидных органах и ко-стимуляции.

\section{3. Эффекторные Т-лимфоциты:}

- обладают выраженными эффекторными свойствами, играют ведущую роль в продукции цитокинов, необходимых для эффективного функционирования эффекторных клеток (моноцитов и макрофагов в случае Th1; тучных клеток, базофилов и эозинофилов в случае Th2; клеток соединительной ткани, эпителиальных пслатов и нейтрофилов в случае Тh17) врожденного иммунитета.

- не способны к пролиферации.

- короткоживущие, время жизни 10-20 дней;

- локализуются преимущественно в периферических тканях;

Проявление эффекторных свойств клетками приобретенного иммунитета.

Т-хелперы продуцируют разные комбинации цитокинов и руководят функциями других клеток иммунной системы.

Среди всех клеток систем врожденного и приобретенного иммунитета Tхелперы (Th) выделяются особенным разнообразием выполняемых функций, что находит свое отражение в крайне высокой гетерогенности данной популяции (табл.40).

Таблица 40

Основные характеристики «поляризованных» Т-хелперов, используемые для выявления отдельных субпопуляций клеток

\begin{tabular}{|c|c|c|c|c|}
\hline $\begin{array}{c}\text { Популяции } \\
\text { Т-хелперов } \\
\text { человека }\end{array}$ & $\begin{array}{c}\text { Ключевые } \\
\text { цитокины для } \\
\text { дифференцировки }\end{array}$ & $\begin{array}{c}\text { Ключевые } \\
\text { факторы } \\
\text { транскрипции }\end{array}$ & $\begin{array}{c}\text { Ключевые } \\
\text { секретируемые } \\
\text { цитокины }\end{array}$ & $\begin{array}{c}\text { Ключевые } \\
\text { поверхностные } \\
\text { молекулы }\end{array}$ \\
\hline Th1 & IL-12, IFNץ & T-bet & IFNץ & CXCR3, CCR5 \\
\hline Th2 & IL-4, IL-5, IL-13 & GATA3 & IL-4, IL-5, IL-13 & CCR4,CCR8, CD294 \\
\hline Th17 & IL-6, IL-23, IL-21, TGF $\beta$ & ROR-үt & IL-17A, IL-17F, IL-22 & CCR6, CD161 \\
\hline Tfh & IL-21, IL-6, IL-27 & BCL6 & IL-21, IL-10 & CXCR5, PD-1, CD40L \\
\hline
\end{tabular}


Однако все эти клетки объединяет общее свойство - они, продуцируя разные комбинации цитокинов, руководят функциями других клеток иммунной системы, или помогают клеткам иммунной системы выполнять их функции. Поэтому они получили название хелперы (рис.71).

\begin{tabular}{|c|c|c|c|c|c|}
\hline Т-хелперы & Цитокины & $\begin{array}{c}\text { Клетки } \\
\text { мишени } \\
\end{array}$ & Иммунная реакция & Патоген & Роль в болезни \\
\hline & IFNY & & Активация макрофагов & $\begin{array}{c}\text { Внутриклеточные } \\
\text { патогены }\end{array}$ & $\begin{array}{c}\text { Аутоиммунитет, } \\
\text { хроническое } \\
\text { воспаление }\end{array}$ \\
\hline & $\begin{array}{l}\mathrm{IL}-4 \\
\mathrm{IL}-5 \\
\mathrm{IL}-13\end{array}$ & & $\begin{array}{c}\text { Активация эозинофилов и } \\
\text { тучных клеток }\end{array}$ & Гельминты & Аллергия \\
\hline & $\begin{array}{l}\mathrm{IL}-17 \\
\mathrm{IL}-22\end{array}$ & & $\begin{array}{c}\text { Привлечение нейтрофилов } \\
\text { и их активация }\end{array}$ & $\begin{array}{l}\text { Внеклеточные } \\
\text { бактерии и грибы }\end{array}$ & $\begin{array}{c}\text { Аутоиммунитет; } \\
\text { воспаление }\end{array}$ \\
\hline & $\begin{array}{c}\text { IL-22 } \\
\text { (и IFNץ } \\
\text { или IL-4) }\end{array}$ & & Производство антител & $\begin{array}{c}\text { Внеклеточные } \\
\text { патогены }\end{array}$ & $\begin{array}{l}\text { Аутоиммунитет } \\
\text { (аутоантитела) }\end{array}$ \\
\hline
\end{tabular}

\section{Рис. 71. Основные популяции «поляризованных» Т-хелперов и их мишени.}

Исходно на основании продукции цитокинов среди CD3+CD4+ лимфоцитов выделяли клетки, способные к синтезу IFN $\gamma$ и получившие название T-хелперов 1 типа (Th1), и клетки, названные Т-хелперами 2 типа (Th2) и синтезирующие IL-4. Позднее были описаны Th17 и фолликулярные T-хелперы (Tfh).

Каждый из типов Т хелперов за счет продукции цитокинов поддерживает определенный тип воспаления и адаптивного иммунного ответа. Так, поляризация в сторону Th1 регулирует макрофагально-лимфоцитарное воспаление, направленное преимущественно на элиминацию внутриклеточных патогенов. Поляризация в сторону Th2 способствует активации тучных клеток, базофилов и эозинофилов и развивается в ответ инвазию многоклеточными патогенами. Поляризация в сторону Th17 приводит к активации нейтрофилов, которые играют ключевую роль в уничтожении грибов и внеклеточнопаразитирующих бактерий. И, наконец, Тfh регулируют развитие гуморального иммунного ответа, активацию и дифференцировку В-лимфоцитов и продукцию антител. Мы остановимся только на этих четырех типах клеток, так как их реальное существование не подвергается сомнению большинством исследователей. Следует отметить, что с завидной регулярностью появляются работы, свидетельствующие о возможности перехода Тh из одной популяции в другую в зависимости от сигналов микроокружения, цитокиновых сигналов, изменения метаболического профиля и широчайшего спектра других факторов. 


\section{Th1 тип адаптивного иммунного ответа.}

Ключевую роль в «поляризации» Th0 в Th1 играет IL-12, синтезируемый в лимфоидной ткани активированными дендритными клетками, хотя IL-18 и IL33 в присутствии IL-12 также способствуют появлению CD3+CD4+ клеток со свойствами Th1. Поляризация наивного T - хелпера в Th1 происходит под контролем транскрипционного фактора T-bet. Для Th1 характерна продукция провоспалительных цитокинов IFN $\gamma$ и TNF $\alpha$, а также IL-2 и IL-15, и экспрессия на поверхностной мембране CXCR3, CCR5 и рецептора для IL-18 (IL-18R). Основной задачей Th1 является активация тканевых макрофагов и мигрировавших в периферические ткани моноцитов с целью повышения эффективности уничтожения поглощенных этими клетками патогенов. Основным фактором, обеспечивающим реализацию этих функций, является IFN $\gamma$, функции которого будут описаны ниже. При гиперфункции Th1, связанной с продукцией цитокинов (в первую очередь, IFN $\gamma$ и TNF $\alpha$ ), в организме могут формироваться очаги хронического воспаления, вызывающие повреждения окружающих тканей (гранулем). Более того, формирование клонов аутореактивных Th1 связано с развитием органно-специфических и системных аутоиммунных заболеваний.

\section{Th2 тип адаптивного иммунного ответа.}

Дифференцировка Th0 в Th2 клетки происходит под влиянием IL-4, при условии, что в микроокружении отсутствует IL-12. Поляризацию в сторону Th2 регулирует транскрипционный фактор Gata3. Th2 лимфоциты синтезируют IL-4, IL-5, IL-6, IL-9, IL-10 и IL-13, отвечающие за регуляцию клеточного и гуморального иммунного ответа (функции этих цитокинов будут рассмотрены ниже). Для этих клеток характерна экспрессия на поверхностной мембране CD294, CCR3, CCR4, CCR8. Основной функцией Th2 является активация тканевых тучных клеток и мигрировавших в периферические ткани из крови базофилов и эозинофилов с целью повышения эффективности уничтожения крупных многоклеточных патогенов (в первую очередь, гельминтов) и их ядов. Другой важной функцией Th2 является стимуляция «поляризации» тканевых макрофагов (рис.72) в

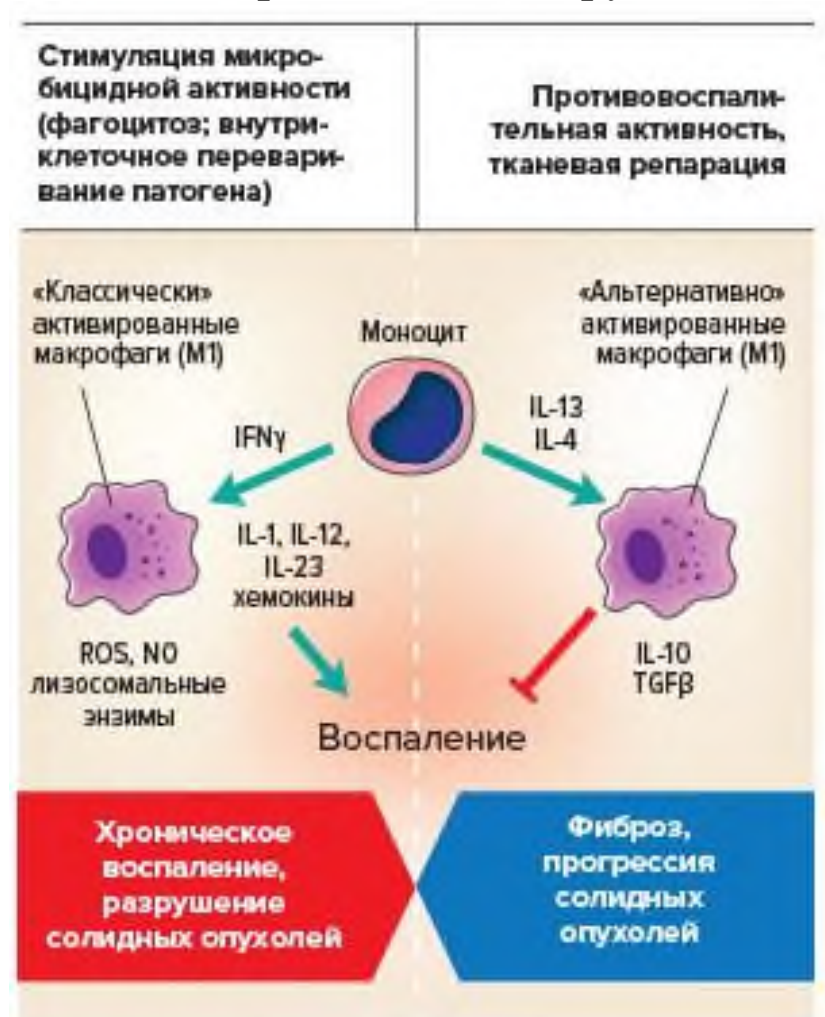

Рис. 72. Роль Тх1 и Тх2 в «поляризации» тканевых макрофагов. 
сторону М2. Это способствует запуску процессов репарации ткани при гельминтозах, а гиперпродукция Th2 цитокинов может сопровождаться формированием очагов фиброза в тканях. Помимо активации лейкоцитов, цитокины, продуцируемые Th2, влияют на функционирование гладкомышечных клеток трубчатых органов, эндотелий сосудов и тканевые макрофаги.

\section{Th17 тип адаптивного иммунного ответа.}

Th17 играют ведущую роль в защите от внеклеточных патогенов бактерий и грибов, являясь ключевыми клетками, которые регулируют развитие воспалительной реакции по 3 типу. Th17 были впервые описаны в 2005 как клетки с фенотипом CD3+CD4+, способные к синтезу и секреции IL-17A, IL-17F, IL-21 и IL-22. Формирование Th17 из «наивных» клеток у мыши и человека происходит под действием таких цитокинов как TGF- $\beta$, IL-1 $\beta$, IL-6, IL-21 и IL-23 и находится пол контролем транскрипционного фактора ROR $\gamma \mathrm{t}$. Ha поверхностной мембране Th17 обнаружена высокая плотность таких антигенов как CXCR4, CCR6 и CD161. Основной задачей Th17 является активация тканевых и мигрировавших в периферические ткани из крови нейтрофилов с целью повышения эффективности уничтожения внеклеточных патогенов за счет фагоцитоза.

Помимо активации лейкоцитов, цитокины, продуцируемые Th17 повышают барьерные функции эпителиев, активируют эндотелий сосудов, тканевые макрофаги и фибробласты (рис.73).

Совместно с Th1, Th17 регулируют функциональную
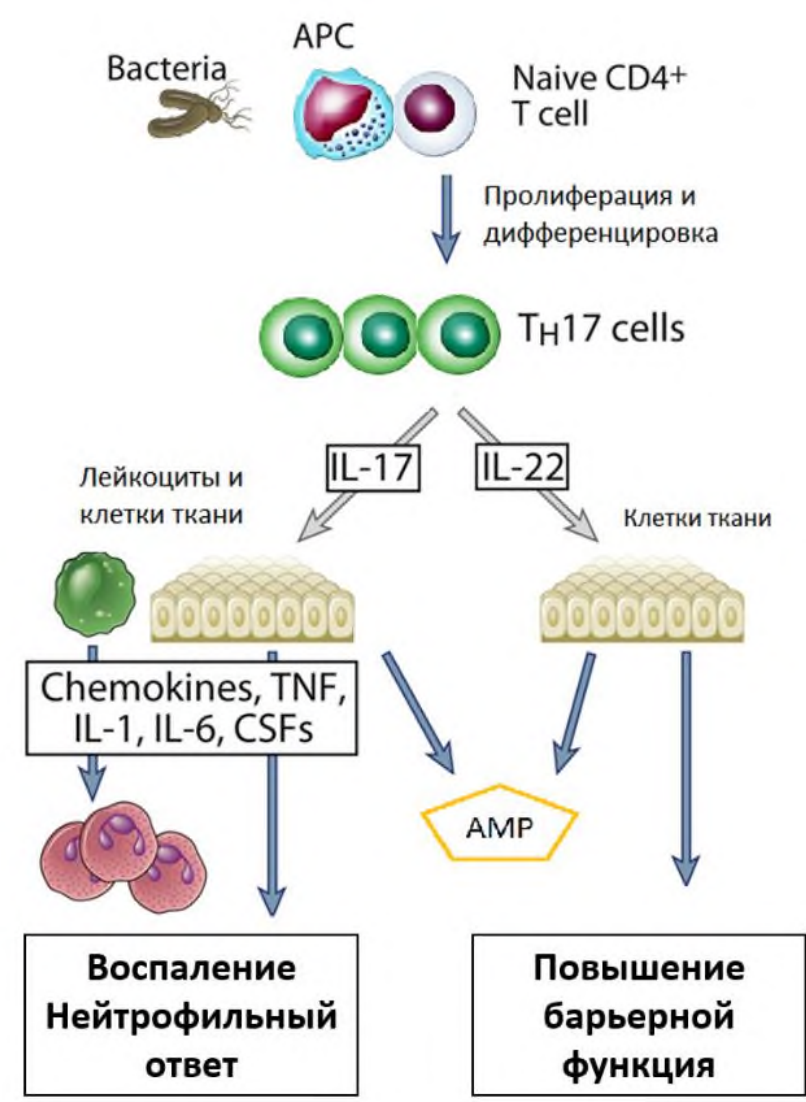

Рис. 73. Т-хелперы 17 - роль в реализации клеточных реакций приобретенного иммунитета.

(адаптирована из Cellular and Molecular Immunology by Drs. Abul K. Abbas, Andrew H. H. Lichtman, and Shiv Pillai 9th edition, 2017). активность фагоцитов (нейтрофилов и моноцитов) при реализации клеточноопосредованных реакций врожденного иммунитета. Гиперактивация Тh17 является причиной развития широкого спектра патологических состояний, в основе которых лежат неконтролируемые воспалительные процессы в различных тканях - псориаз, воспалительное заболевание кишечника, 
ревматоидный артрит и рассеянный склероз. Именно поэтому Th17 являются мишенью для различных биологических препаратов, направленных на нейтрализацию эффекторных цитокинов (IL-6, IL-17, IL-23, TNF $\alpha$ ).

Фолликулярные Т-хелперы. В начале 2000-ых годов впервые в составе миндалин была охарактеризована популяция Т-хелперов, с необычным фенотипом. Эти клетки несли на своей поверхности нехарактерные для $\mathrm{T}$ лимфоцитов хемокиновые рецепторы CXCR5 и CCR7, отвечающие за миграцию в В-клеточные фолликулы. Позже было установлено, что основной их функцией является участие в формировании и развитии специфического гуморального иммунного ответа, поддержании жизнеспособности и пролиферации В-клеток, регуляции переключения класса синтезируемых антител, запуске соматических гипермутаций, а также в дифференцировке В-лимфоцитов в сторону плазматических клеток и долгоживущих В-клеток памяти. Исходя из описанных функций и способности мигрировать в В-клеточные фолликулы, эти Т хелперы получили название Tfh. Экспрессия хемокинового рецептора CXCR5 позволяет Tfh направленно мигрировать в B-зависимые зоны лимфатических узлов по градиенту концентрации хемокина CXCL13, также известного как BCA1 (от англ. «B cell-attracting chemokine 1»). CXCL13 синтезируется клетками стромы В-клеточных фолликулов в периферических лимфоидных органах, что определяет миграцию В-клеток и фолликулярных Т-хелперов, экспрессирующих CXCR5 в эти области. Ключевыми поверхностными маркерами Tfh, помимо CXCR5 (CD185), являются молекулы CD40L (CD152), ICOS (CD278), SAP и PD1 (CD279), которые участвуют во взаимодействии Tfh с В-лимфоцитами.

В настоящее время известно, что «поляризацию» Th0 в сторону Tfh регулирует широкий спектр цитокинов (IL-6, IL-21, IL-12, IL-23, IL-2, IL-7,TGFb) и транскрипционных факторов (Bcl-6, STAT1, STAT3, STAT4, Batf, IRF4, c-Maf, TCF-1, Acl2). Секретируемые Tfh цитокины влияют на следующие процессы:

1) за счет продукции цитокинов (IL-4 и BAFF) и контактных взаимодействий (CD40L со стороны Т-клетки и CD40 со стороны В-клетки) Tfh блокируют запуск апоптоза в активированной В-клетке;

2). при помощи взаимодействия CD40L (со стороны Tfh) и CD40 (со стороны В-клетки) в последней запускается пролиферация;

3). IL-21, синтезируемый Tfh, запускает дифференцировку В-клетки в плазматическую клетку;

4). под действием цитокинов (IL-4 и IL-21) в В-клетке инициируется процесс соматических гипермутаций, приводящий (после селекции полученных клонов) к увеличению аффинности В-клеточного рецептора и секретируемых антител; 
5). цитокины, секретируемые Tfh (IL-4, IL-17, IL-21), стимулируют переключение класса синтезируемых В-клеткой антител с $\operatorname{IgM}$ на $\operatorname{IgG}, \operatorname{Ig}$ А или $\operatorname{IgE}$.

Взаимодействие между активированным антигеном В-лимфоцитом и антиген-специфическим фолликулярных Т-хелпером играет ключевую роль в развитии специфического гуморального ответа.

Считается, что взаимодействие В-лимфоцитов с Tfh клеток происходит на границе Т- и В-зависимых зон лимфоидной ткани в периферических лимфоидных органах различной локализации. Однако, еще до специфического взаимодействия этих клеток, должно произойти два ключевых события, которые тесно связаны с процессами распознавания и презентации антигенов (рис.74).

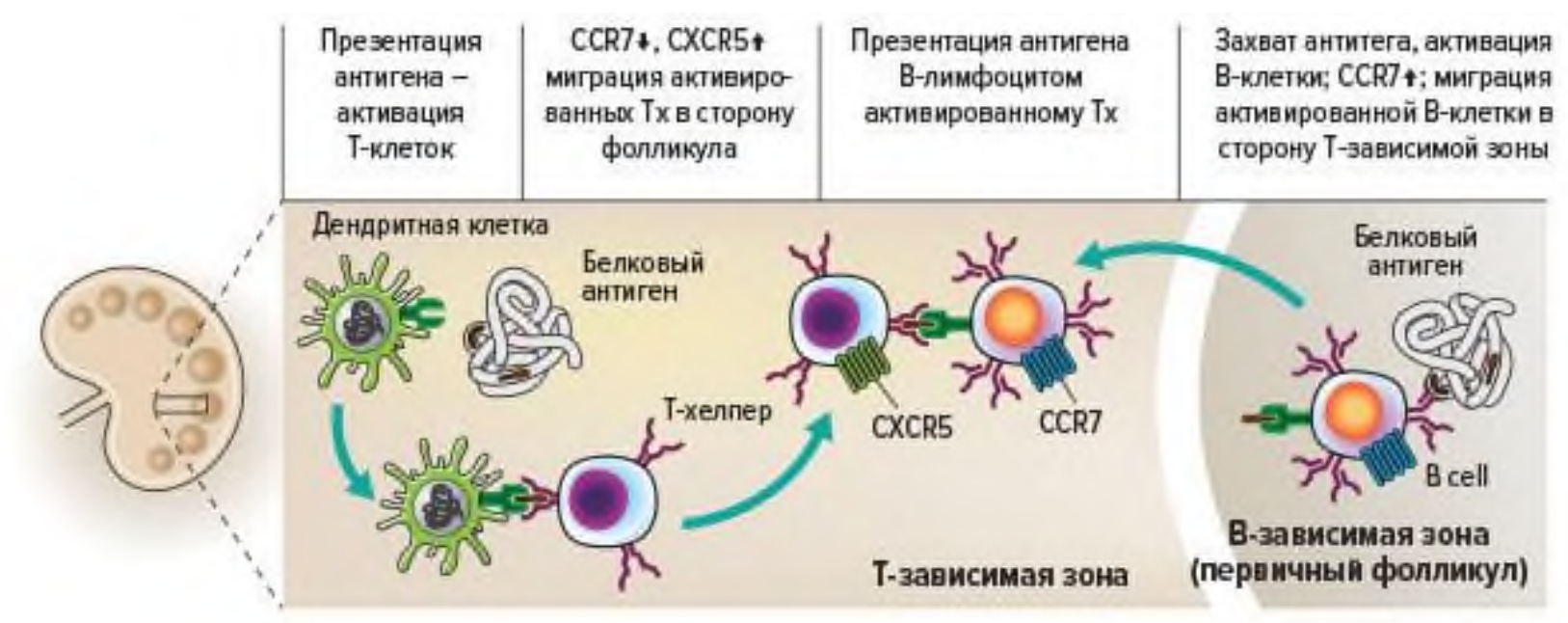

Рис. 74. Фолликулярные Т-хелперы. Формирование фолликулярных Тхелперов и миграция в В-зависимые зоны периферических лимфоидных органов.

(адаптирована из Cellular and Molecular Immunology by Drs. Abul K. Abbas, Andrew H. H. Lichtman, and Shiv Pillai 9th edition, 2017).

Антиген должен быть доставлен в лимфоидную ткань дендритной клеткой из периферических тканей в Т-зависимые зоны для презентации и активации Tfh (при первичном ответе Tfh формируются впервые за счет поляризующих цитокинов, а при вторичном ответе - ключевую роль в повторном распознавании антигена играют Tfh памяти). Одновременно растворимый антиген должен быть доставлен в лимфоидную ткань с током лимфы и распознан В-клеткой в В-зависимой зоне лимфоидной ткани. В дальнейшем антиген должен быть поглощен при помощи рецепторопосредованного эндоцитоза, процессирован и презентирован активированным В-лимфоцитом, который в данном случае выполняет роль АПК. В отличие от 
других профессиональных АПК, В лимфоцит специфически распознает и захватывает антиген с помощью В клеточного рецептора. Следует отметить, что В-клетки распознают своим В-клеточным рецептором «нативные» или не процессированные антигены. Это могут быть части крупных молекул с высокой молекулярной массой или даже части целых вирусов и бактерий (рис.75).

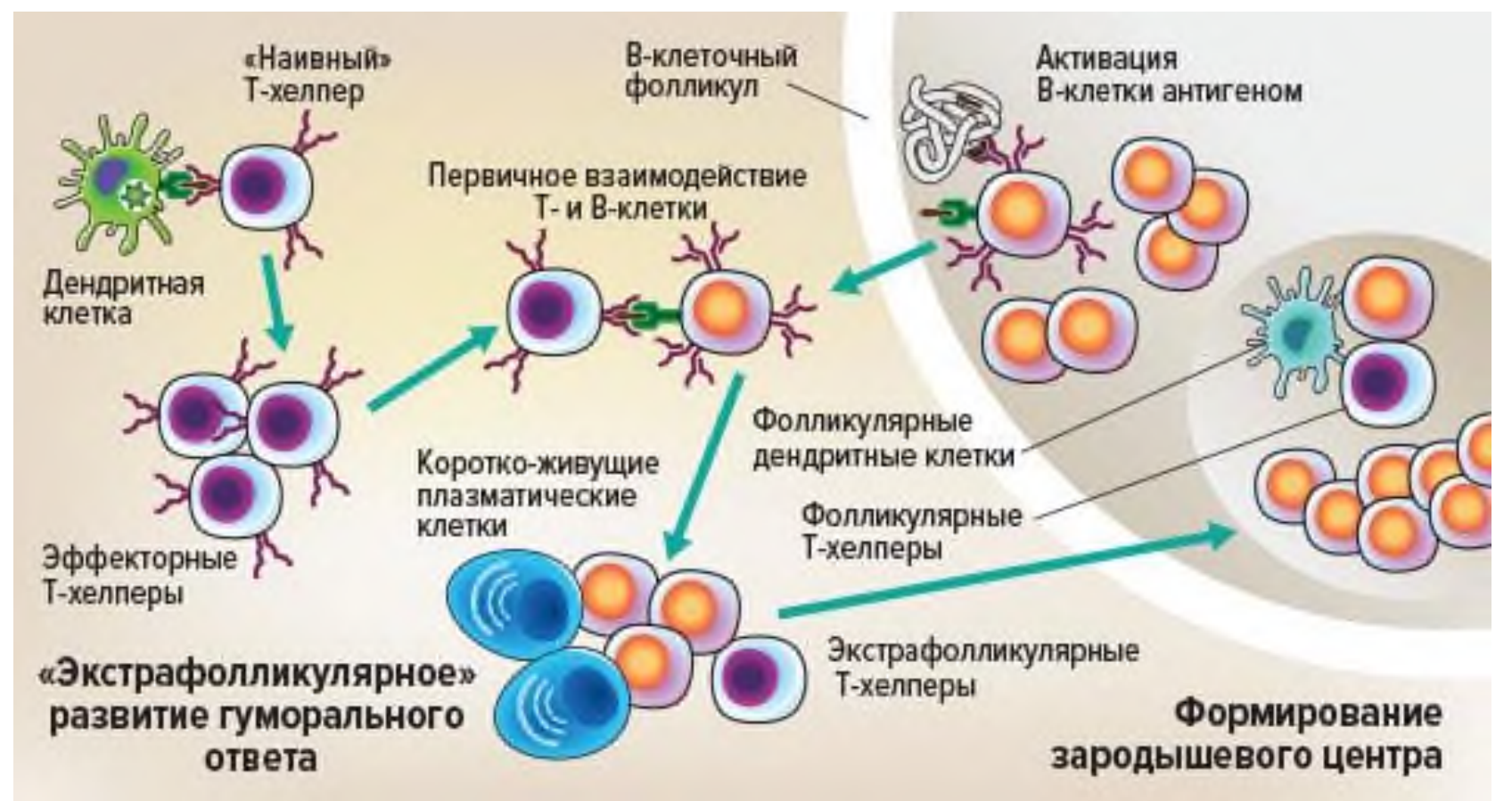

Рис. 75. Взаимодействие фолликулярного Тх и В-лимфоцита на границе Ти В-зависимых зон.

(адаптирована из Cellular and Molecular Immunology by Drs. Abul K. Abbas, Andrew H. H. Lichtman, and Shiv Pillai 9th edition, 2017).

В ходе дальнейшего процессинга эти крупные «конформационные» антигены разделяются на небольшие фрагменты (отдельные эпитопы), которые в фаголизосомах встраиваются в молекулы МНC II класса. Суть этого процесса сводится к тому, что исходно один «антиген», поглощенный и «разрезанный» на отдельные пептидные фрагменты В-клеткой, может быть распознан несколькими Tfh, обладающими различной специфичностью уже к отдельным эпитопам исходно большой молекулы - этот механизм, по-видимому, увеличивает вероятность встречи В- и Т-клеток в пределах лимфоидной ткани. Более того, подобно другим АПК, В-клетка также нуждается в сигнале от паттерн-распознающих рецепторов врожденного иммунитета. Примером такого сигнала может служить взаимодействие CD21 - рецептора на В-лимфоцитах с фрагментами C3 компонента каскада комплемента. Получение этого сигнала подтверждает, что В-клеткой был распознан именно «чужеродный» антиген, и является защитой от потенциальной аутореактивности. Сигналы от рецепторов 
врожденного иммунитета, индуцируют экспрессию В-лимфоцитом молекул миграции в Т-зависимые зоны (в первую очередь, CCR7).

В Т-зависимой зоне лимфатического узла, при распознавании антигенного пептила происходит активация и клональная экспансия антигенспецифических Tfh, которые начинают двигаться в сторону В-зависимых зон, тогда как в из В-зависимых зон им на встречу устремляются активированные антигеном В-лимфоциты. Считается, что встреча этих клеток происходит как раз на границе Т- и В-зависимых зон периферических лимфоидных органов, и Вклетка презентирует антиген Tfh. В случае распознавания антигена в составе с MHC II класса Т-клеточным рецептором, происходит формирование «иммунного» синапса и обмен сигналами между клетками.

После этого В-лимфоцит перестает выполнять функции АПК, и в нем активируются программы, свойственные лимфоцитам, главной из которых является клональная экспансия. Ключевую роль в данном процессе играют взаимодействие CD40L-CD40 и продукция цитокинов фолликулярным Th, про что было рассказано ранее. В ходе клональной экспансии и серии последовательных циклов митозов формирование части В-клеток может происходить вне В-клеточного фолликула. Это касается, в частности, формирования клона короткоживущих плазматических клеток, которые секретируют антитела той же специфичности, что и исходный В-лимфоцит; Однако часть активированных В-клеток возвращается в В-зависимые зоны, пролиферирует и формирует В-клеточные фолликулы сложной морфологической структуры и клеточного состава. Именно с формированием Вклеточного фолликула связана дифференцировка В-клеток памяти и плазматических клеток, способных к синтезу и секреции высоко-аффинных антител классов, отличных от IgM. Ключевую роль в формировании фолликула принимают фолликулярные Th, а также специализированные типы дендритных клеток, получивших название фолликулярных дендритных клеток:

Фолликулярные Тh обеспечивают В-клетки необходимыми цитокинами и контактными сигнальными молекулами, необходимыми для пролиферации, активации процесса соматических гипермутаций, а также переключения класса синтезируемых антител. Фолликулярные дендритные клетки, в отличие от всех остальных типов ДК, имеют негемопоэтическое происхождение. Они способны сорбировать и длительное время экспонировать на своей поверхности антигены в том виде, в котором они поступили в лимфатический узел с током лимфы. То есть, они являются «хранилищем» неизменных или «нативных» «конформационных» антигенов. Это «хранилище» антигенов необходимо для отбора высокоаффинных клонов В-клеток после соматических гипермутаций Вклеточных антиген-распознающих рецепторов.

Итак, в сформированном В-клеточном фолликуле, в темной зоне, под действием цитокинов Tfh происходит клональная экспансия или пролиферация В-клеток. Пролиферация В клеток сопровождается соматическими 
гипермутациями, точечные замены нуклеотидов в участках, кодирующих антигенразпознащие сайты В-клеточного рецептора. При этом, фермент AID (от англ. «activation-induced deaminase») случайным образом замещает $\mathrm{C}$ на $\mathrm{U}$ в пределах CDR участков антигенраспознающих рецепторов. В дальнейшем при репликации ДНК U может заменяться на T, в свою очередь, C тоже может заменяться на Т. Только В-клетки, которые случайным образом сформировали высоко-аффинный В-клеточный рецептор могут «отнять» антиген у фолликулярной дендритной клетки, процессировать его и презентировать Тfh (рис.76).

Активация В-клеток антигеном и Тh.

Точечные мутации носят єслучайых характер, поэтому необходима дополнительная селекция полученных клонов В-лимфоцитов.

1. При соматических гипермутациях изменяется аффинность В-клеточного рецептора.

2. В-клетки с высоко аффинным В-клеточным рецептором способны распознавать антиген на фолликулярных ДК, связывать его и презентировать фолликулярным Th.

3. Только В-клетки с высоко аффинным В-клеточным рецептором способны выживать, благодаря сигналам от фолликулярных Тх; остальные В-клетки - элиминируют

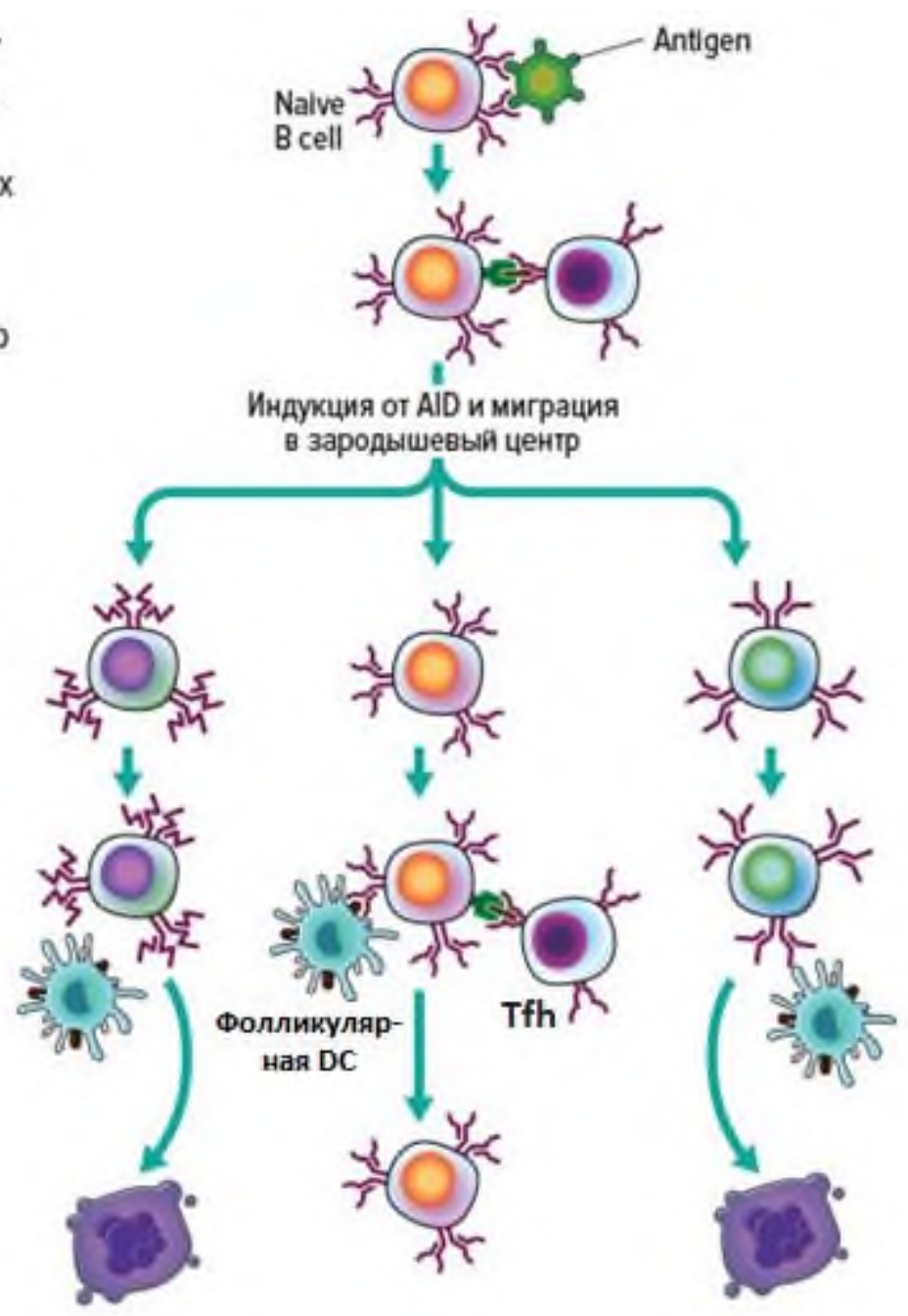

Рис. 76. Что такое «гипермутации», и для чего необходим этот процесс при развитии В-клеточного специфического ответа?

(адаптирована из Cellular and Molecular Immunology by Drs. Abul K. Abbas, Andrew H. H. Lichtman, and Shiv Pillai 9th edition, 2017).

Поэтому только В-клетки, несущие высокоаффинный В клеточный рецептор получают сигнал на выживание от Tfh. Таким образом, фолликулярные ДК и Tfh осуществляют селекцию или отбор из, образовавшихся после 
гипермутаций клонов, несущих высокоаффинный рецептор. Этот процесс напоминает «естественный отбор» в ходе которого сначала формируется разнообразие В лимфоцитов с немного отличающимися рецепторами, а потом из них отбираются «лучшие», с высокоаффинным рецептором. Сигнал на выживание получает В-клетка, способная связать антиген, и так как количество антигена сильно лимитировано, то связывание будет происходить только с самыми высоко-аффинными рецепторами. Остальные В-лимфоциты сигналов на выживание не получат, и будут погибать путем апоптоза. Описанные процессы селекции протекают в светлой зоне фолликула, где содержание клеток снижается на порядки по сравнению с этим в темной зоне (рис.77).

Активация В-лимфоцитов фолликулярными Тh и миграция В-клетокв ткань фолликула

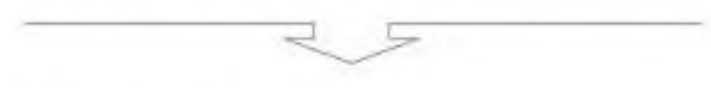

Клональная экспансия В-клеток

Соматические гипермутации и увеличение аффинности В-клеточного рецептора; переключение класса синтезируемых антител

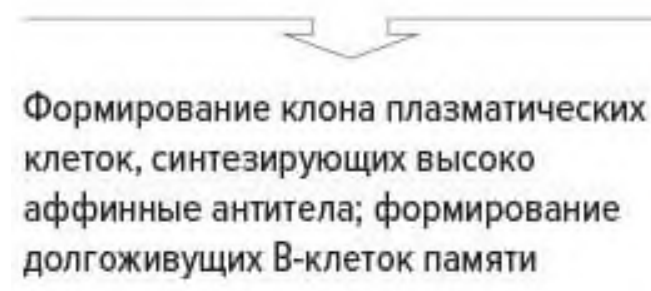

долгоживущих В-клеток памяти

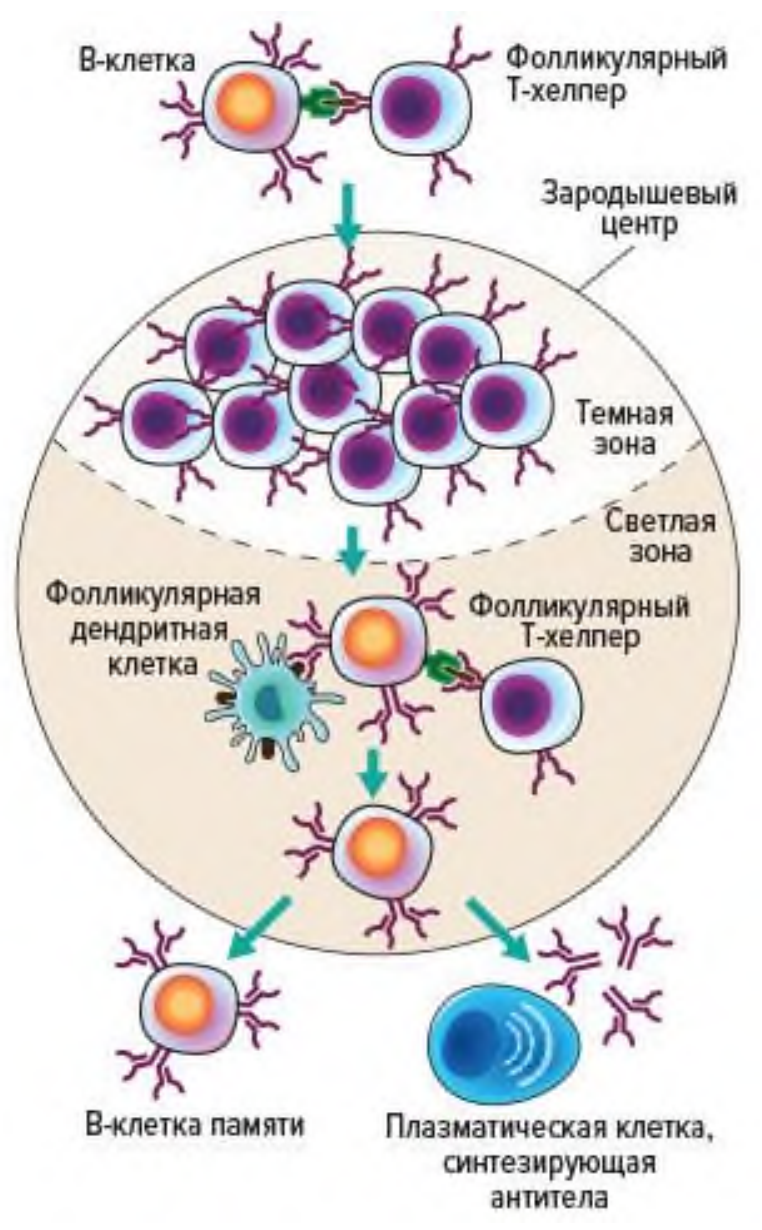

Рис. 77. Что такое «гипермутации», и для чего необходим этот процесс при развитии В-клеточного специфического ответа?

(адаптирована из Cellular and Molecular Immunology by Drs. Abul K. Abbas, Andrew H. H. Lichtman, and Shiv Pillai 9th edition, 2017).

Гуморальный иммунный ответ в большей или менышей степени развивается при любом типе иммунного ответа, в ответ на проникновение любого патогена. Однако разные типы иммунного ответа отличаются продукцией классов, синтезируемых антител. Переключение класса 
синтезируемых антител с $\operatorname{IgM}$ на $\operatorname{IgG}, \operatorname{Ig} \mathrm{A}$ или $\operatorname{IgE}$ в В-лимфоцитах происходит под действием Tfh и цитокинового микроокружения, характерного для каждого типа иммунного ответа. Каждый класс антител обладает своими специфическими свойствами. Так $\operatorname{IgG}$ способны к опсонизации внеклеточных патогенов для повышения эффективности фагоцитоза макрофагами и нейтрофилами. Эти антитела могут активировать каскад комплемента по классическому пути, что способствует борьбе с внеклеточными патогенами. IgG опосредуют антитело-зависимую клеточную цитотоксичность НК-клеток, направленную на элиминацию вирус-инфицированных и опухолевых клеток. Возможность переноса IgG через плаценту способствует формированию гуморальной защиты новорожденных. Антитела класса $\operatorname{IgA}$ обеспечивают мукозальный иммунитет, защиту слизистых оболочек, участвуют в формировании и поддержании состава микрофлоры кишечника. Антитела класса $\mathrm{IgE} \mathrm{регулируют} \mathrm{активность} \mathrm{тучных} \mathrm{клеток,} \mathrm{базофилов} \mathrm{и} \mathrm{эозинофилов} \mathrm{для} \mathrm{борьбы}$ с многоклеточными патогенами и грибами (рис.78).

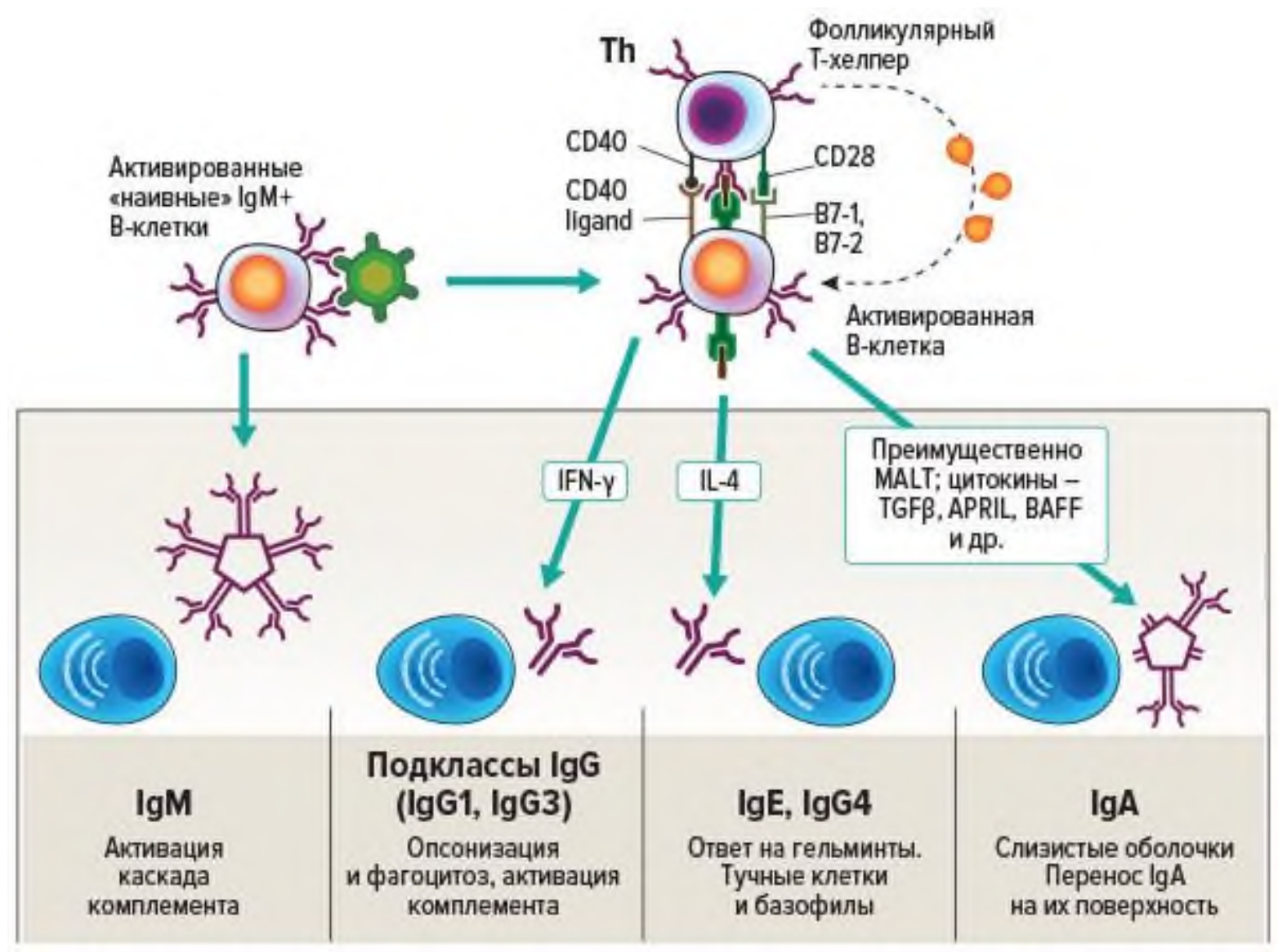

Рис. 78. Что такое «переключение класса синтезируемых антител» Влимфоцитом, и для чего необходим этот процесс при развитии Вклеточного специфического ответа?

(адаптирована из Cellular and Molecular Immunology by Drs. Abul K. Abbas, Andrew H. H. Lichtman, and Shiv Pillai 9th edition, 2017). 
В результате взаимодействия В-лимфоцита и фолликулярного Тh формируется популяции зрелых В-клеток. Выделяют следующие популяции зрелых В-лимфоцитов, различающиеся по свойствам и функциям.

1. В клетки памяти отвечают за формирование долговременной иммунологической памяти. Они способны пролиферировать и быстро, в течение 3-5 дней о дифференцироваться в плазматические клеткии (обычно 3-5 дней); при повторном контакте с антигеном, в результате соматических гипермутаций, способны к увеличению аффинности и переключению класса синтезируемых антител; локализуются в периферических лимфоидных органах, способны к «рециркуляции», живут годами.

2. Долгоживущие плазматические клетки: конститутивно (постоянно) синтезируют антитела только одного класса и только одной специфичности; быстро активируются и увеличивают уровень продукции антигенспецифических антител при повторном контакте с антигеном; преимущественно располагаются в пределах красного костного мозга; не способны к пролиферации и клональной экспансии.

3. Короткоживущие плазматические клетки: время жизни 10-20 дней; продукция антител только одного класса и только одной специфичности; локализуются преимущественно в периферических лимфоидных органах и соединительной ткани, подстилающей барьерные ткани организма; - не способны к пролиферации, переключению класса синтезируемых антител и запуску процесса соматических гипермутаций.

Плазматические клетки (как коротко- так и долгоживущие) продуцируют антитела, выполняющие широкий спектр функций, связанных с «наведением» атаки клеточных и гуморальных факторов на патоген. В целом все многообразие функций антител можно свести к четырем основным (рис.79).

1. Нейтрализация патогенов и их токсинов (например, блокада

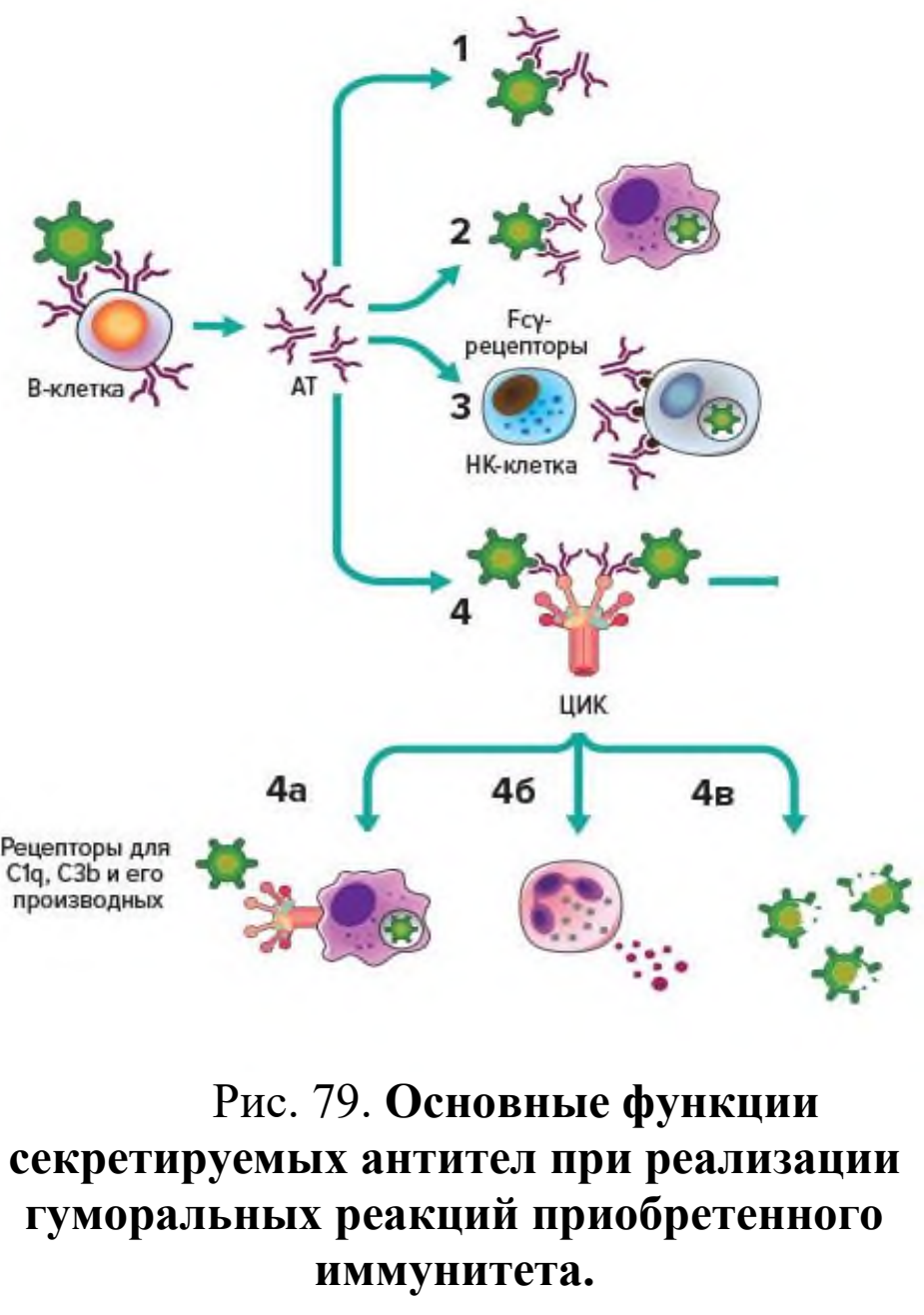


контакта патогенов с клетками эпителиальных пластов слизистых оболочек $\operatorname{IgA;~или~нейтрализация~различных~токсинов~при~помощи~} \operatorname{IgM})$;

2. Опсонизация и усиление фагоцитоза патогенов (взаимодействие комплексов IgG-антиген и Fc $\gamma$-рецепторов на поверхности фагоцитов в очаге воспаления);

3. Антитело-зависимая клеточная цитотоксичность (вирус-специфические или опухоль-специфические IgG, связавшиеся с клеткой-мишенью, и Fc $\gamma$ рецепторы на поверхности НК-клеток);

4. Активация каскада комплемента - данная функция связана, в первую очередь, с сывороточными антителами классов IgM и IgG, которые образовали «иммунные комплексы» со специфическими антигенами, которые могут находиться как в жидкой фазе, так и на поверхности клеток-мишеней. При этом можно выделить три аспекта, связанные с активаций каскада комплемента. Так как данный белковый каскад участвует в:

а) дополнительной опсонизации патогена и усилении его поглощения при помощи фагоцитоза за счет С3 и его производных, к которым на поверхности фагоцитов имеются специфические рецепторы;

б) усилении воспаления за счет формирования анафилатоксинов С3а и С5a, привлекающих и активирующих лейкоциты в очаге проникновения патогена;

в) сборка мембранно-атакующего комплекса и лизис клеток-мишеней.

\section{Три типа воспалительного ответа проти патогенов.}

Иммунный ответ начинается с развития неспецифического воспаления, и далее происходит формирование иммунокомпетентных клеток эффекторов адаптивного иммунитета, усиливающих это воспаление и придающих ему высокую специфичность, т.е. направленность на данный конкретный патоген. Практические любой патологический процесс, инфекционной и неинфекционной природы, сопровождается развитием воспаления и поэтому происходит с вовлечением иммунной системы. В настоящее время выделяют 3 основные типа врожденного и адаптивного клеточно-опосредованного эффекторного иммунитета, которые определяют как 1 тип, 2 тип и 3 тип воспаления. Различные типы иммунных реакций обеспечивают характерную для каждого типа патогена максимально эффективную и минимально затратную защитную реакцию. В тоже время, те же самые три типа воспаления или их комбинации, лежат в основе патогенеза различных иммуноопосредованных расстройств, имеющих неинфекционную природу (рис.80). Считается, что наша иммунная система уже на этапе реакций врожденного иммунитета может грубо различать три типа патогенов. Это внутриклеточно-паразитирующие патогены (бактерии, простейшие, вирусы), многоклеточные паразиты (напр. гельминты) и внеклеточно-паразитирующие патогены (бактерии и грибы). 


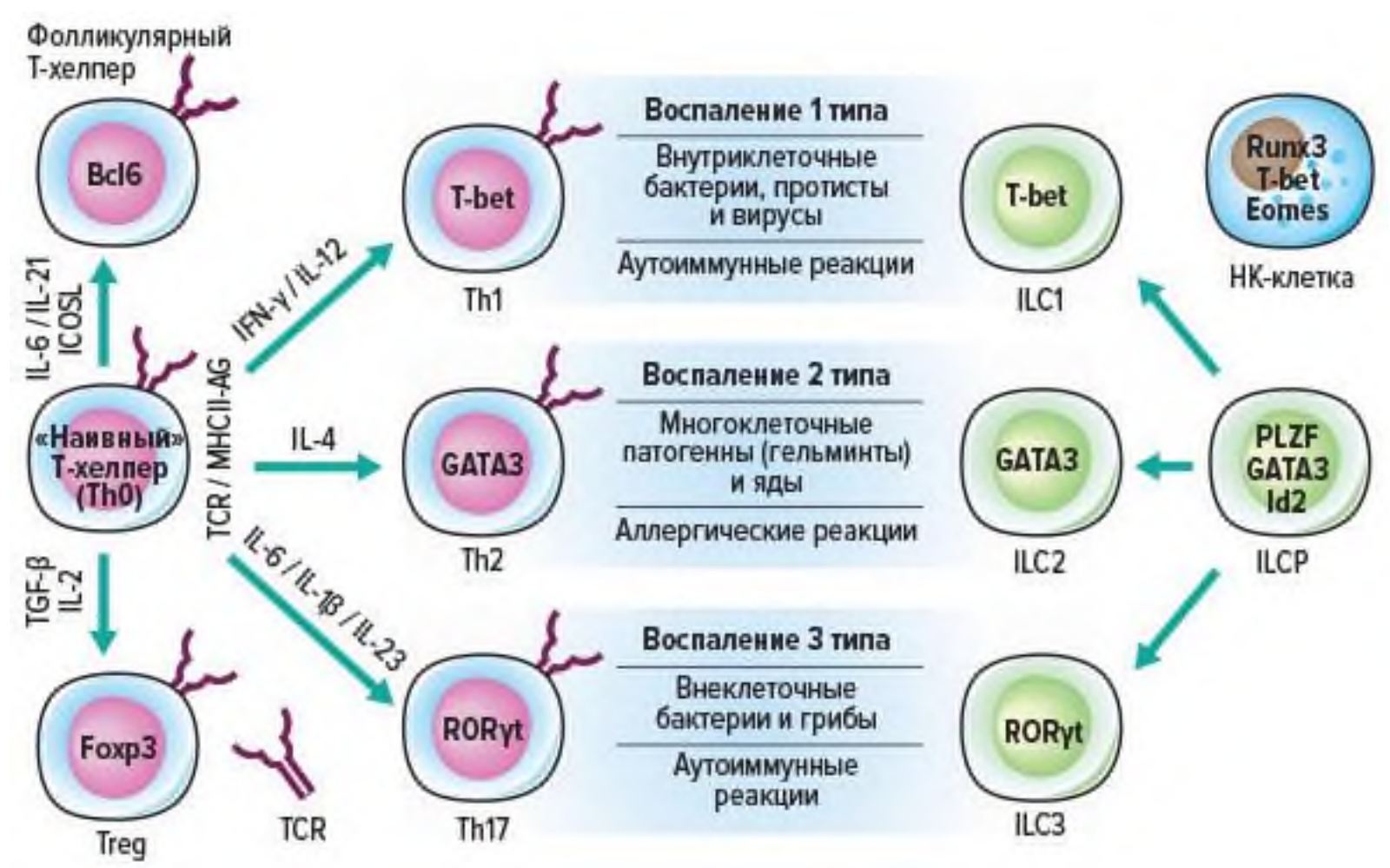

Рис. 80 Основные популяции "поляризованных" T-хелперов и ILCs, принимающих участие в реализации воспалительных реакций 3 основных типов.

(адаптирована из Int. J. Mol. Sci. 2020, 21(21), 8011; https://doi.org/10.3390/ijms21218011).

Предполагают, что выбор стратегии иммунного ответа определяется типом патогена и его локализацией. Эту стратегию определяют цитокины, которые секретируют клетки, входящие в состав барьерных тканей нашего организма, а также специализированные - дендритные клетки (DCs). После распознавания PAMPs и/или DAMPs тканерезидентные клетки получают информацию о природе патогена и, продуцируя соответствующие комбинации цитокинов, «транслируют» эту информацию на ILCs. B дальнейшем именно цитокины, продуцируемые активированными DCs и ILCs, определяют направление "поляризации" "наивных" Т-хелперов при развитии определенного типа ответа в лимфоидной ткани. И, наконец, по завершении клональной экспансии и дифференцировки Т-хелперов в периферические ткани мигрируют зрелые Th клетки, которые при распознавании патогена продуцируют эффекторные цитокины, способные активировать различные эффекторые клетки. Именно клетки-эффекторы врожденного и приобретенного иммунитета играют ведущую роль в уничтожении внедрившегося патогена. В рамках данного раздела при разборе каждого из типов воспалительных реакций мы будем последовательно описывать: 
- - механизмы индукции, свойственные тому или иному типу воспаления, включая клетки (дендритные клетки и ILCs) и цитокины, необходимые для запуска иммунного ответа определенного типа;

- - эффекторные механизмы, направленные на элиминацию патогена, включая типы "поляризованных" Т-хелперов, продуцируемые ими эффекторые цитокины и клетки-эффекторы. Что же касается отдельных популяций эффекторных клеток врожденного иммунитета, а также механизмов, при помощи которых эти клетки уничтожают патогены, то эта информация была представлена в предыдущих разделах данной монографии.

Иммунные реакции, опосредованные клетками 1 типа, наиболее эффективны в отношении внутриклеточно-паразитирующих микроорганизмов, а также опухолевых клеток. Этот тип иммунных реакций также опосредует отторжение трансплантата и лежит в основе развития некоторых аутоиммунных процессов.

Реакций 1 типа регулируют ILC1 и CD4+ Th1, экспрессирующие Tbet+IFN $\gamma$. В инициации реакций адаптивного иммунитета задействованы, главным образом плазмацитоидные дендритные клетки (pDCs) и классические дендритные клетки 1 (cDCs1). Цитокины, регулирующие инициацию и реализацию реакций 1 типа, - это IL-12, -18, -15, IFN I типа, TNF $\alpha$ и др. Ключевые клетки-эффекторы при данном типе иммунного ответа, которые непосредственно уничтожают патоген - лимфоциты с цитотоксическими свойствами, а именно NK- и CD8+T-клетки, а также тканевые макрофаги. Традиционно выделяют 3 главные задачи или функции, которые реализуются при развитии воспаления 1 типа:

- элиминация зараженной (вирусами) клетки (NK).

- элиминация патогена в фаголизосомах (M1-макрофаги).

- придание незараженным клеткам антивирусного статуса (IFN I и III типа).

\section{Клетки, принимающие участие в индукции воспаления по 1 типу.}

Дендритные клетки.

В рамках воспаления по 1 типу pDC, с фенотипом CD123+CD11c-, играют ведущую роль за счет продукции интерферонов I и III типов и IL-12, необходимого для «поляризации» Th1 и активации ILC1 (рис.81). Важно отметить, что pDCs несут на своей поверхности молекулы II класса гистосовместимости (MHC-II) и ко-стимулирующие молекулы CD40, CD80 и CD86, необходимые для представления антигена CD4+ T-лимфоцитам. Однако антиген-презентирующая функция pDCs не так эффективна, как у классических ДК (cDCs). 

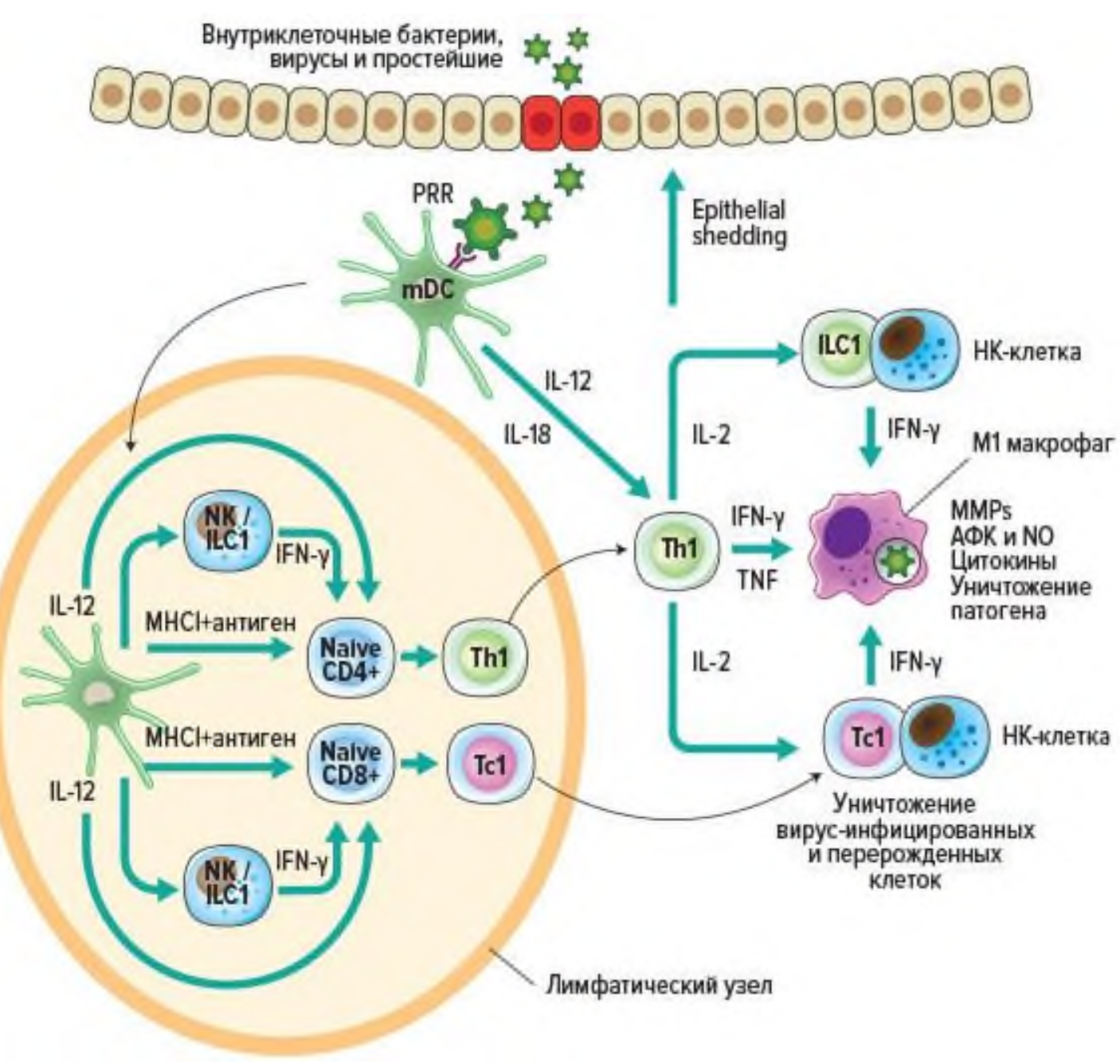

Рис. 81 Схематическое изображение развития воспаления по 1 типу.

Экспрессия молекул главного комплекса гистосовместимости I и II класса (MHC I и MHC II) вместе с ко-стимулирующими молекулами (CD80, CD86 и $\mathrm{CD} 40$ ) позволяют $\mathrm{pDCs}$ осуществлять презентацию антигенов как $\mathrm{CD} 8+\mathrm{T}$ лимфоцитам, так и CD4+ T-хелперам. Тогда как секреция IFN I типа и IL-12 pDCs способна стимулировать пролиферацию, дифференцировку и созревание эффекторных CD8+ T-лимфоцитов, а также дифференцировку и «поляризацию» «наивных» CD4+ T клеток в сторону Th1. Более того, популяция pDCs - это один из основных источников интерферонов I типа $(\alpha, \beta)$ на ранних этапах развития иммунного ответа. Эти клетки за счет экспрессии TLR-7 и TLR-9 в эндосомах способны распознавать вирусные нуклеиновые кислоты - одноцепочечную РНК (ssRNA) и CpG последовательности в составе ДНК. Особого внимания заслуживает тот факт, что активированные через TLRs pDCs вырабатывают в 100-1000 раз больше IFN I типа, чем обычные соматические клетки организма, 
что и определяют важнейшую роль этих клеток в формировании сигналов, необходимых для инициации противовирусного ответа.

ILC 1 типа.

ILC 1 не могут самостоятельно распознавать патогенные паттерны. Эти клетки активируются под влиянием цитокинов микроокружения, которые генерируют DCs и другие тканерезидентные клетки. В ответ на стимуляцию IL12 и IL-18 ILC1 способны продуцировать IFN $\gamma$, TNF, GM-CSF и даже IL-2. Это, a также, экспрессия соответствующих транскрипционного фактора Tbet, позволяет считать эти клетки аналогами Th1 лимфоцитов системы приобретенного иммунитета. Наиболее известными и хорошо изученными представителями ILC 1 являются NK-клетки. В отличие от ILC1 NK-клетки, кроме T-bet+, дополнительно экспрессируют транскрипционный фактор Eomes. Фенотипически ILC1 можно описать как Lin-CD127+ лимфоциты.

\section{Цитокины, принимающие участие в индукции воспаления по 1 типу.}

IL-12 и его биологические эффекты:

Основным источником цитокина являются моноциты/макрофаги и дендритные клетки, которые были активированы патогеном через паттернраспознающие рецепторы различных типов. В некоторых случаях В-клетки, которые в данном случае могут рассматриваться как профессиональные АПК, тоже могут продуцировать IL-12. Основной функцией IL-12 является стимуляция продукции IFN $\gamma$ NK-клетками и Т-лимфоцитами. Индуцированная под влиянием IL-12 продукция IFN $\gamma$ усиливает высвобождение провоспалительного цитокина IL-18 и повышает экспрессию рецептора для IL18, что способствуют амплификации ответа. IL-12 совместно с IL-18 усиливает продукцию IFN $\gamma$ и самого IL-12, а также стимулирует миграцию клеток Лангерганса в периферические лимфоидные органы, что способствует усилению развития воспаления за счет повышения эффективности презентации антигенов в лимфоидной ткани и активации реакций адаптивного иммунитета. Ключевой функцией IL-12 является поляризация наивных Th0 в сторону Th1, а также подавление поляризации в сторону Th2. Это способствует усилению воспаления по 1 типу, потому что цитокины 1 и второго типов воспаления способны реципрокно подавлять активность друг друга. Непосредственно в очаге воспаления IL-12 усиливает цитолитическую активность эффекторных клеток NK-клеток и антиген-специфических CD8+ T-лимфоцитов;

IL-18 и его биологические эффекты:

IL-18 относится к семейству IL-1, и, подобно некоторым членам этой группы провоспалительных цитокинов, синтезируется в виде неактивного предшественника. Для превращения IL-18 в активную форму с молекулярной массой 18 кДа необходим внутриклеточный процессинг, который осуществляет 
каспаза-1. Такой механизм позволяет клеткам накапливать IL-18 в неактивной форме и быстро секретировать для выполнения своих биологических функций только при наличии специфического стимула. Так, проформа IL-18 конститутивно экспрессируется в эндотелиальных клетках, а также клетках барьерных тканей - кератиноцитах и эпителиальных клетках кишечника по всему желудочно-кишечному тракту, тканевых макрофагах и дендритных клетках, то есть в местах, наиболее вероятного проникновения патогена. Более того, в очаге воспаления, предшественник IL-18 высвобождается из умирающих клеток и процессируется внеклеточно под действием протеаз нейтрофилов (например, протеиназы-3), что позволяет за короткое время достигать весьма высоких локальных концентраций данного цитокина. Такой же механизм синтеза и секреции характерен для некоторых других членов цитокинового семейства - IL-1 и IL-33.

IL-18 проявляет основные свойства провоспалительных цитокинов, способствуя увеличению экспрессии молекул клеточной адгезии, синтезу оксида азота и продукции других провоспалительных цитокинов и хемокинов. Синергично c IL-12, IL-18 вызывает поляризацию Th0 в Th1, что способствует амплификации воспаления по 1 типу. Это связано с тем, что IL-18 способен стимулировать продукцию IFN $\gamma$ либо совместно с IL-12, либо с IL-15. Самостоятельным действием на продукцию IFN $\gamma$ IL-18 не обладает. Кроме того, IL-12 и/или IL-15 увеличивают экспрессию $\beta$-цепи рецептора для IL-18 по принципу обратной положительной связи. Еще одной важной особенностью IL18 как иммунорегуляторного цитокина является его способность стимулировать продукцию IFN $\gamma$ NK-клетками. IL-18 также напрямую повышает перфорин- и FasL-зависимую цитотоксичность NK-клеток и CD8+ Т-лимфоцитов, что особенно важно при защите от внутриклеточных патогенов. Макрофаги, активированные или «праймированные» M-CSF, экспрессируют мембранную форму IL-18, которая подвергается ферментативному отщеплению в очаге воспаления. Под действием IL-18 и IL-12 тканевые макрофаги могут усиливать продукцию IFN $\gamma$. Таким образом, IL-18 играет важнейшую роль в активации различных эффекторных клеток, вовлеченных в воспалительные реакции 1 типа.

\section{Эффекторные клетки приобретенного иммунитета воспалительных реакций 1 типа.}

CD4+ Th1 клетки.

В ходе развития адаптивного иммунного ответа, после активации TCR в определенном цитокиновом микроокружении «наивные» CD4+ T-клетки могут дифференцироваться или «поляризоваться» в Th1-клетки. Решающую роль в поляризации Th0 в Th1-клетки играет IL-12, который могут секретировать АПК в ответ на распознавание определенных PAMPs. IL-12 активирует фактор 
транскрипции STAT4. В тоже время IFN $\gamma$, продуцируемый NK-клетками, активирует другой фактор транскрипции, STAT1. Одновременная активация экспрессии в Th0 лимфоцитах транскрипционных факторов STAT1 и STAT4 способна индуцировать экспрессию главного Th1-поляризующего фактора T-bet. T-bet, совместно с другими транскрипционными факторами (Hlx, Runx3, Ets-1 и Bhlhe40), запускает экспрессию гена, кодирующего IFN $\gamma$. T-bet, самостоятельно или в сочетании с Runx3 ингибирует экспрессию транскрипционных факторов GATA3 и ROR $\gamma$, которые контролируют поляризацию Th0 в другие типы Th (Th2 и Th17). Недавно было установлено, что IL-23 и IL-27 также, обладают способность «поляризовать» Th0 в Th1. К поляризации в Th1 способны не только «наивные» CD4+ T-лимфоцитов. Благодаря значительной «пластичности» поляризованных хелперов, Th1 могут брать свое начало от других Т-хелперных субпопуляций, включая Th17, Treg и Tfh-клетки. Th1 экспрессируют характерный набор хемокиновых рецепторов, которые регулируют их миграцию в очаг воспаления. Основными хемокиновыми рецепторами Th1 клеток являются CXCR3 и CCR5, что определяет способность этих клеток мигрировать по градиенту концентрации хемокинов CXCL9, CXCL10 и CXCL11 - лигандов CXCR3 и градиенту концентрации CCL3, CCL4 и CCL5 - лигандов CCR5. Под действием IFN $\gamma$ кератиноциты и эпителиальные клетки продуцируют CXCL9, CXCL10 и CXCL11, что способствует дополнительному привлечению Th1 клеток в очаг проникновения патогена и усилению воспаления по 1 типу.

CD8+ T-лимфоциты.

Основной функцией $\mathrm{CD} 8+$ T-лимфоцитов является уничтожение зараженных или опухолевых клеток-мишеней. Эти клетки реализуют свой эффекторный потенциал при помощи трех основных механизмов. Первый механизм основан на продукции эффекторных цитокинов IFN $\gamma$ и TNF при распознавании клеток-мишеней через Т-клеточный рецептор. Вторым механизмом является «контактный цитолиз», основанный на высвобождении из гранул перфорина и гранзимов, как это было описано ранее для НК-клеток. И, наконец, третий способ уничтожения клеток-мишеней - это запуск апоптоза за счет активации на их поверхности рецепторов, принадлежащих к семейству TNF-подобных белков (классическим примером является взаимодействие Fas/FasL). Подобно дифференцировке CD4+ Th1, IFN $\gamma$ и IL-12 способствуют дифференцировке и созреванию цитотоксических $\mathrm{CD} 8+$ T-лимфоцитов. Транскрипционный фактор T-bet активирует в цитотоксических Т-клетках для продукции IFN $\gamma$, а также является крайне необходимым для проявления их цитолитического потенциала. Более того, CD8+ T-лимфоциты (в первую очередь, Тс1) экспрессируют на своей поверхности хемокиновые рецепторы CCR5 и CXCR3, свойственные и для Th1, что позволяет этим двум популяциям 
Т-клеток направленно мигрировать в один и тот же очаг воспаления, локализованный в периферических тканях.

\section{Ключевые эффекторные цитокины и их функции при реализации воспаления по 1 типу.}

Биологические эффекты IFN $\gamma$ :

IFNy является ключевым цитокином, вызывающим активацию макрофагов. После стимуляции под влиянием IFN $\gamma$, а также при получении сигнала от CD40L происходит активация макрофагов, что выражается в усилении его микробицидных свойств продукции активных форм кислорода и азота, повышении эффективности фагоцитоза, секреции провоспалительных цитокинов и хемокинов, а также поляризация этих клеток в сторону М1. Более того, под действием IFN $\gamma$ повышается эффективность презентации антигенов через MHC II и продукция IL-12, что способствует усилению клеточного ответа как в воспаленной ткани, так и в периферических лимфоидных органах. В лимфоидной ткани IFN $\gamma$ способствует «поляризации» «наивных» Th0 в сторону Th1, подавляя Th2 и Th17 программы дифференцировки. IFN $\gamma$, продуцируемый клетками Th1, важен для разрушения плотных контактов между кератиноцитами, что улучшает условия миграции лейкоцитов в очаг воспаления в коже, где эпителий образуют достаточно прочный барьер на пути мигрирующих лейкоцитов. IFN $\gamma$ по крайней мере у мышей, играет важную роль в развитии гуморального ответа, способствуя переключению класса синтезируемых В-лимфоцитами антител с $\operatorname{IgM}$ на некоторые изотипы $\operatorname{IgG}$, подавляя синтез и секрецию IgE.

Биологические эффекты TNF $\alpha$ :

TNF $\alpha$ синтезируется иммунными клетками, в первую очередь моноцитами и макрофагами, а также некоторыми другими типами клеток. Первоначально он синтезируется как молекула с молекулярной массой 26 кДа, ассоциированная с клеточной поверхностью и заякоренная N-концевым гидрофобным доменом. Эта мембраносвязанная форма TNF $\alpha$ обладает сходными с растворимой молекулой биологической активностью. Специфический белок матричной металлопротеиназы, называемый TNFпревращающим ферментом, расщепляет форму 26 кДа до растворимой формы 17 кДа, которая, благодаря самосборке, формирует гомотример, что является важной особенностью для связывания и активации рецепторов для TNF. Практически все ядерные клетки экспрессируют рецепторы TNF (хотя их распределение зависит от типа клетки).

Защитные функции TNF $\alpha$ связаны с его ключевой ролью в иммунном ответе, а также в уничтожении определенных опухолей. TNF $\alpha$ является важнейшим белком острой фазы воспаления, который инициирует каскад 
цитокинов, увеличивает проницаемость сосудов, и, тем самым, рекрутирует моноциты и нейтрофилы в очаг инфекции из кровотока. Биологические и метаболические эффекты TNF $\alpha$ in vivo зависят от количества и скорости, с которой TNF $\alpha$ продуцируется в ответ на специфический стимул. Высокие уровни TNF $\alpha$ приводят к системным реакциям с повреждением тканей. TNF $\alpha$ способствует развитию лихорадки, высвобождению белков в острой фазы, активации эндотелия, повышению проницаемости сосудов, диссеминированному внутрисосудистому свертыванию. Эти процессы лежат в основе развития респираторного дистресс-синдрома у взрослых, желудочнокишечного некроза, острого некроза почечных канальцев, кровоизлияния в надпочечники. Под действием TNF $\alpha$ развивается гепатоспленомегалия, субэндокардиальное воспаление, увеличивается скорость метастазирования опухолей. TNF $\alpha$ индуцирует выброс катаболических гормонов гипоталамуса, усиливает катаболизм белков, липолиз, развитие инсулинорезистентность и анорексии. Считается, что эти реакции направлены на снижение потребления глюкозы клетками тканей и обеспечение необходимыми нутриентами клеток иммунной системы.

\section{Воспаление по 1 типу - эффекторная фаза ответа.}

Важнейшая физиологическая роль иммунного ответа 1 типа - это защита от внутриклеточных патогенов, к числу которых относится Mycobacterium tuberculosis, Leishmania major, Toxoplasma gondii. Многие внутриклеточные патогены могут выживать и размножаться внутри тканевых макрофагов периферических тканей, а также некоторых других клетках организма хозяина. Тканевые макрофаги являются важными эффекторными клетками врожденного иммунитета, способными поглощать и убивать многие бактериальных патогены. Поэтому многие внутриклеточно-паразитирующие бактерии выработали разнообразные механизмы, которые позволяют им выживать в фаголизосомах и цитоплазме клеток. Активированные в ходе реакций врожденного иммунитета ILC1 и Th1 клетки, а также и CD8+ цитотоксические Т-лимфоциты, секретируют IFN $\gamma$ и TNF. Эти цитокины повышают эффекторные функции НК-клеток врожденного иммунитета, направленные на уничтожение вирусинфицированных и собственных перерожденных клеток. Как показали недавние исследования ILC1, являются основными продуцентами IFN $\gamma$ и других цитокинов во время заражения Toxoplasma gondii, однако вклад отдельных ILC1 защиту от других внутриклеточных патогенных инфекций требует дальнейшего изучения. IFN $\gamma$ и TNF значительно усиливают микробицидную активность макрофагов. Под действием IFN $\gamma$ тканевые макрофаги приобретают «провоспалительный» M1 фенотип, наращивают активностть лизосомальных протеолитических ферментов, продукцию микробицидных субстанций АФК и NO. 
Во время внутриклеточной персистенции патогена некоторая часть микробных белков из фагосом и цитоплазмы процессируются и презентируются в составе молекул MНC I класса. Презентированные антигены могут быть распознаны CD8+ цитотоксическими Т-лимфоцитами и служат сигналом того. CD8+ T-лимфоциты крайне важны для защиты от вирусов, так как за счет продукции IFN $\gamma$ и TNF $\alpha$ и своего цитолитического потенциала они способны эффективно уничтожать вирус-инфицированные и собственные перерожденные клетки.

С другой стороны, чрезмерный воспалительный ответ 1 типа с вовлечением Th1 реакций адаптивного иммунитета может лежать в основе патогена некоторых заболеваний неифекционной природы. К их числу можно отнести аутоиммунные органоспецифические патологии - ревматоидный артрит, рассеянный склероз, тиреоидит Хашимото, инсулинозависимый сахарный диабет, аутоиммунный гастрит и другие хронические воспалительные заболевания.

\section{Эффекторный иммунитет, опосредованный клетками 2 типа}

Иммунный ответ по 2 типу, развитие которого регулируют цитокины Th2 и ILC2, характеризуется вовлечением в воспалительный процесс эозинофилов, тучных клеток, базофилов и альтернативно активированных макрофагов (ААМ). Этот тип воспаления сформировался в ходе эволюции для защиты от гельминтов, а также от яда змей, насекомых и клещей. Развитие воспалительного процесса по 2 типу в ответ на безвредные антигены, поступающие извне - пища и вдыхаемые аллергены лежит в основе аллергических заболеваний. Распознавание эволюционно-консервативных структур этих патогенов паттернов клетками врожденного иммунитета и тканерезидентными клетками инициирует воспаление 2 типа, но «адаптивные» Th2 - усиливают этот тип ответа за счет продукции цитокинов 2 типа - IL-4, $-5,-9$ и -13 и специфичным, направленным на элиминацию конкретных антигенов (рис.82).

\section{Клетки, принимающие участие в индукции воспаления по 2 типу.}

Дендритные клетки. Как уже отмечалось ранее, cDC2 обладают фенотипом CD1c+FceR1+SIRPA+ и играют ведущую роль в инициации Th2 адаптивного ответа. Функции этих клеток пока еще детально не исследованы, но они рассматриваются в качестве одного из источников цитокинов для "поляризации Th0 в сторону Th2, а также обеспечивают необходимые для активации Tхелперов костимуляционные сигналы.

ILC 2 типа. Было показано, что ILC2 присутствуют в очень небольшом количестве в тканях легких, коже и кишечнике, а также в мезентериальном жире. Эти характеризуются высокой экспрессией фактора транскрипции GATA-3, a также IL-7R, CD25, рецепторов IL-33 и IL-25, ILC2 человека, помимо этих маркеров, также экспрессируют CRTH2 (от англ. «Chemoattractant receptorhomologous molecule expressed on TH2 cells» или CD294) и CD161. Активация 


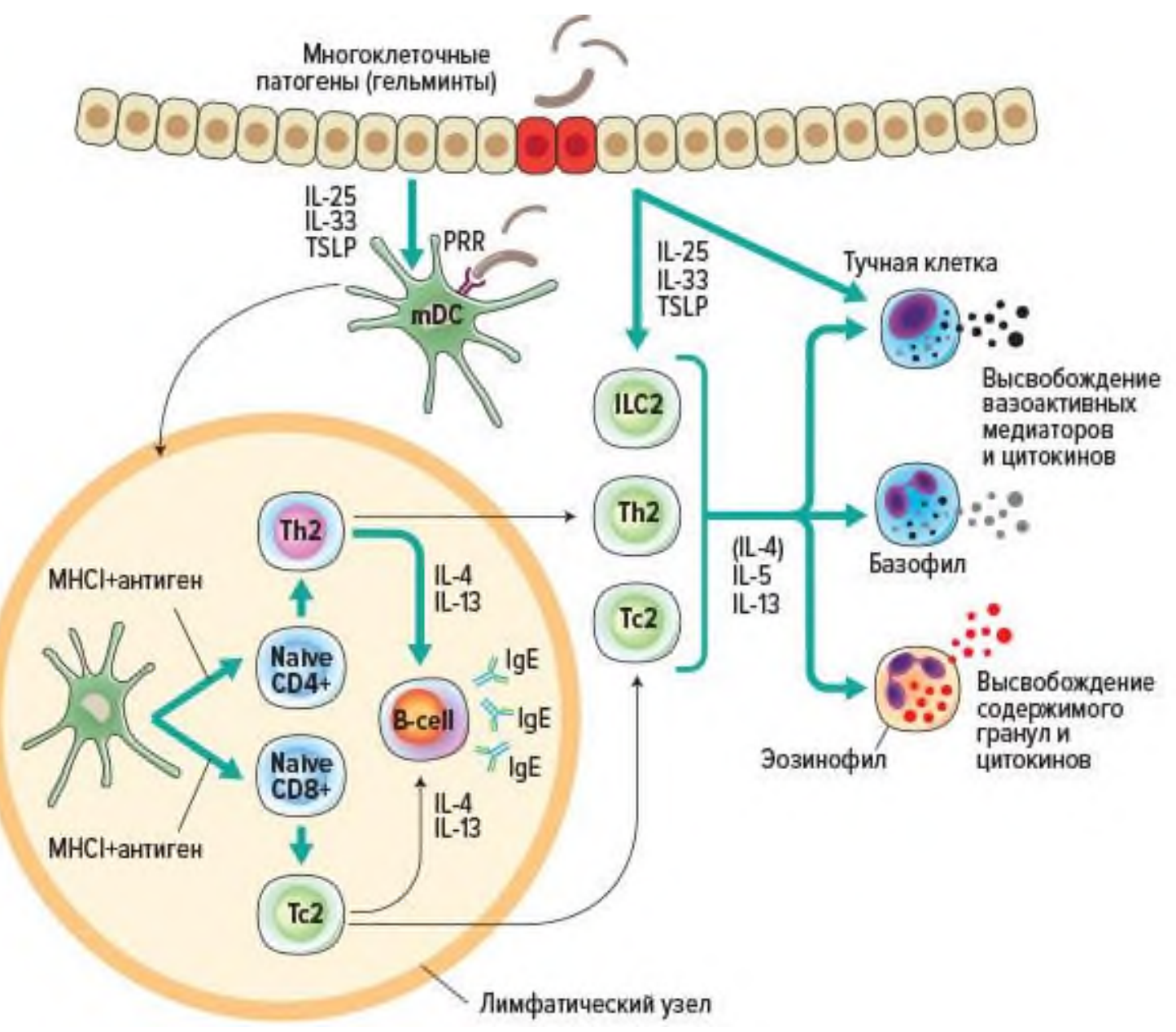

Рис. 82 Схематическое изображение развития воспаления по 2 типу.

ILC2 происходит под действием IL-25, IL-33 и TSLP, которые продуцируются эпителиальными клетками после повреждения ткани при аллергии или гельминтозах. В ответ на активацию ILC2 человека продуцируют полный набор цитокинов, характерных для Th2 - IL-4, IL-5, IL-9 и IL-13, а также некоторое количество провоспалительных IL-6, IL-8 и GM-CSF. ILC2 являются важнейшим источником IL-5, по крайней мере, у мышей. ILC2 кишечника в ответ на поступление пищи, под действием вазоактивного кишечного пептида конститутивно экспрессируют IL-5 и IL-13. Клинические наблюдения указывают на то, что уровень ILC, продуцирующих IL-13, увеличивается у взрослых с филяриозными инфекциями (например, Loa loa, Wuchereria bancrofti или Onchocerca volvulus). У пациентов, инфицированных Schistosoma haematobium, была обнаружена взаимосвязь между площадью фиброзного поражения тканей и уровнем ILC2. Однако было показано, что у детей в возрасте от 6 до 9 лет количество LC2 положительно коррелируют с успешным разрешением шистосомоза. Лучше всего исследована роль ILC2 при аллергических реакциях, у пациентов с хроническим риносинуситом и бронхиальной астмой. Также ILC2 играют важную роль в процессах регенерации кожи. 


\section{Цитокины, принимающие участие в индукции воспаления по 2 типу.}

Ключевую роль в запуске реакций данного типа играют активированные под влиянием PAMPs клетки барьерных тканей, которые в ответ на стимуляцию и/или повреждение секретируют три ключевые сигнальные молекулы тимический стромальный лимфопоэтин (TSLP, от англ. «thymic stromal lymphopoietin»), IL-25 и IL-33.

TSLP был впервые охарактеризован как фактор роста лимфоцитов. Основным источником этого цитокина являются активированные эпителиальные клетки легких и кишечника, кератиноциты и фибробласты. Однако дендритные клетки (ДК), тучные клетки и, предположительно, другие иммунные клетки также могут продуцировать TSLP при стимуляции. К числу клеток-мишеней TSLP относят иммунные клетки (дендриты, ILC2, Т- и Вклетки, NKT и Treg-клетки, эозинофилы, нейтрофилы, базофилы, моноциты, тучные клетки и макрофаги) и неиммунные клетки (тромбоциты и нейроны). TSLP обладает способностью усиливать активацию и функциональную активность $\mathrm{CD} 11 \mathrm{c}+\mathrm{cDC}$, вызывая усиление экспрессии МHC II, костимулирующих молекул CD40 и CD80 и высвобождение хемокинов, привлекающих клетки Th2. В Т-лимфоцитах TSLP активирует транскрипционный фактор STAT5, что в сочетании с сигналом от Т-клеточного рецептора индуцирует пролиферацию клеток. TSLP участвует в патогенезе различных аллергических заболеваниях (например, атопическом дерматите, бронхиальной астме, эозинофильном эзофагите), хотя показана его роль и в развитии хронических воспалительных (например, хроническая обструктивная болезнь легких и целиакия) и аутоиммунных (например, псориаз, ревматоидный артрит) расстройствах и некоторых видах рака.

IL-33 относится к «внутриядерным» цитокинам, которые высвобождаются после гибели клетки при повреждении тканей. Следует отметить, что IL-33 конститутивно обнаруживается в ядрах эндотелиальных клеток человека, эпителиальных клетках, кератиноцитах, фибробластах, гладкомышечных клетках и глиальных клетках. В живых клетках после синтеза белка, цитозольный IL-33 перемещается в ядро, где связывается с хроматином. Nконцевой домен IL-33 содержит последовательность ядерной локализации и хроматин-связывающий домен, что обеспечивает его ядерную транслокацию. Пассивное высвобождение IL-33 из некротических клеток позволяет рассматривать данный цитокин в качества «алармина». Первоначально IL-33 был идентифицирован как индуктор дифференцировки Th2-клеток и продукции цитокинов 2-го типа - IL-4, IL-5 и IL-13. Однако мишенями этого цитокина также являются Th2, ILC2, Treg, NKT-клетки, CD8 + T-клетки, M2 макрофаги, нейтрофилы, эозинофилы, базофилы, тучные клетки и NK-клетки. IL-33 стимулирует ILC2 для экспрессии цитокинов 2 типа - IL-5 и IL-13, а также 
эпидермального фактора роста амфирегулина (AREG), чем обусловлено его регенеративное действие при повреждении тканей.

IL-25 относится к семейству цитокинов IL-17. IL-25 вырабатывается многими типами клеток. Эти клетки включают Т-клетки, дендритные клетки, макрофаги, тучные клетки, базофилы, эозинофилы, эпителиальные клетки и клетки Панета. IL-25 стимулирует эффекторные функции эозинофилов и, повидимому, играет важную роль в Th2-опосредованной активации при глистных инвазиях. Уровень этого цитокина нарастает при обострении аллергических заболеваний дыхательных путей. Основными мишенями IL-25 являются клетки врожденного иммунитета - NKT-клетки, моноциты и ILC2. IL-25 способствует поляризации «наивных» CD4+ T-лимфоцитов в сторону Th2, а усиливает продукцию цитокинов эффекторными Th2 клетками и Th2 клетки памяти. Гиперпродукция IL-25 может способствовать нарушению регуляции Th2-ответа при астме, снижать эффективность защитного иммунитета против гельминтов, а также приводить к развитию некоторых аутоиммунных заболеваний.

\section{Эффекторные клетки приобретенного иммунитета воспалительных} реакций 2 типа.

CD4+ Th2 клетки

IL-2 и IL-4 являются двумя ключевыми цитокинами для «поляризации» $\mathrm{Th} 2$, Эт а комбинация цитокинов индуцирует экспрессию фактора транскрипции GATA3, абсолютно необходимого для дифференцировки клеток Th2 и их функционирования как in vitro, так и in vivo. Более того, GATA3 не только играет важную роль в индукции и поддержании программы Th2 клеток, он также подавляет экспрессию других факторов транскрипции - T-bet и ROR $\gamma \mathrm{t}$. Помимо GATA3, другие факторы транскрипции, включая с-Maf, STAT3 и Notch/CSL, также могут регулировать дифференцировку и функции Th2-клеток. Было обнаружено, что присутствие IL-4 в микроокружении при взаимодействии АПК c «наивными» Th0-клетками критически необходимо для дифференцировки Th2клеток как у мышей, так и у человека, но источник этого цитокина до сих пор не известен. Предполагают, что базофилы могут действовать как Th2индуцирующие АПК, но только для Т клеток памяти. Потому что только зрелые ДК имеют достаточно высокий для активации наивных $\mathrm{T}$ клеток уровень костимуляторных сигналов. Каким бы ни был источник раннего IL-4, этот цитокин имеет решающее значение для поляризации Th0 в Th2. Th2 человека экспрессируют экспрессируют такой же набор хемокиновых рецепторов, что и ILCs2 - CCR3, CCR4 и CCR8 и мигрируют в ответ на общие сними хемоаттрактанты. 


\section{Ключевые эффекторные цитокины и их функции при реализации} воспаления по 2 типу.

$\mathrm{IL}-4$ и и его биологические эффекты.

IL-4 имеет решающее значение для «поляризации» Th0 в сторону Th2 (блокируя другие программы «поляризации» Тh и, в первую очередь, Th1), a также является важнейшим аутокринным фактором для дифференцировки и пролиферации Th2. Вместе с тем, IL-4 может также стимулировать DCs и макрофаги к усилению синтеза ими IL-12, обеспечивая механизм отрицательной обратной связи для регуляции Th2 ответа и воспаления по 2 типу в целом. IL-4 стимулирует рост и дифференцировку В-лимфоцитов, стимулирует повышенную экспрессию MHC II и FcRII (CD23) и самое важное, способствует переключению класса синтезируемых антител В-клеток на IgG4 и IgE, который необходим для эффективного противогельминтного иммунитета.

В очаге воспаления IL-4, совместно c IL-13, отвечает за поляризацию и поддержание функциональной активности M2 макрофагов с выраженными противовоспалительными свойствами и способностью запускать процессы репарации и регенерации поврежденных тканей. IL-4 ингибирует секрецию провоспалительных хемокинов и цитокинов, снижает способность производить активные формы кислорода и азота, а также блокирует IFN $\gamma$-индуцированную экспрессию молекул клеточной адгезии активированными макрофагами.

IL-4 является важнейшим фактором роста тучных клеток и контролирует $\operatorname{IgE-опосредованную~дегрануляцию~тучных~клеток.~Продукция~IgE~позволяет~}$ клеткам, несущим рецепторы для IgE, проявлять свои эффекторные свойства. IL4, IL-5 и IL-13, за счет активации эндотелия сосудов микроциркуляторного русла и секреции хемокинов, отвечают за привлечение лейкоцитов в очаг воспаления. IL-4 стимулирует перистальтику кишечника.

IL-5 и и его биологические эффекты.

IL-5 играет ключевую роль во всех аспектах функционирования эозинофилов, включая их активацию, терминальную дифференцировку, пролиферацию и выживании эозинофилов как на ранних стадиях развития, так и в очаге воспаления. Эозинофилы обладают высокой экспрессией рецептора для данного цитокина, а также являются одним из важнейших его источников. IL-5 также подавляет апоптоз активированных эозинофилов. Уровень IL-5 увеличиваются при астме, аллергии и воспалении. IL-5 является важнейшей терапевтической мишенью для заболеваний, связанных с эозинофилами.

$\mathrm{IL}-13$ и его биологические эффекты.

IL-13 выполняет множество различных функций как на местного, так и на системного характера. К местным эффектам данного цитокина можно отнести усиление продукции фибробластами коллагена, что является неотъемлемой частью как репаративных процессов, так и фиброзирования тканей. IL-13 
стимулирует пролиферацию гладкомышечных клеток и активирует эндотелий сосудов и эпителий слизистых. IL-13 играет важную роль в усилении функциональной активности тучных клеток соединительной ткани и эозинофилов, подавляя провоспалительные свойства тканевых макрофагов, их способствует поляризации в M2. На системном уровне IL-13 усиливает перистальтику кишечника и секрецию слизи способствуя механическому удалению многоклеточных паразитов. IL-13 индуцирует переключение класса синтезируемых В-клеткой антител с IgM на IgE. В целом, функции IL-13 очень тесно схожи с таковыми IL-4, что указывает на синергизм в биологических эффектах этих двух цитокинов.

\section{Воспаление по 2 типу - эффекторная фаза ответа.}

Длительное время развитие реакций воспаления по 2 типу рассматривали, как процессы направленные на исключительно на уничтожение гельминтов. Сейчас же эти представления существенно расширились, т.к. было установлено, что развитие 2 типа воспаления происходит в ответ на ядовитые ксенобиотики, яды различных эктопаразитов (включая клещей и комаров), гематофагиальной жидкости и ряда других факторов, проникающих в организм из окружающей среды, вызывающих развитие аллергических реакций. Ранее аллергический ответ считался неадекватным проявлением реакций иммунитета, т.к. считалось, что аллергия возникает, в ответ на безвредные антигены окружающей среды. Самая последняя свежая и новая точка зрения состоит в том, что аллергены на самом деле не являются безобидными. Эта гипотеза согласуется с недавней демонстрацией того, что фосфолипаза А2, основной аллерген пчелиного яда, вызывает некроз клеток посредством ферментативного расщепления мембранных фосфолипидов и высвобождения IL-33 инициирует развитие воспаления 2 типа.

\section{Эффекторный иммунитет, опосредованный клетками 3-го типа.}

Клеточный иммунный ответ по 3 типу, который регулируют цитокины, продуцируемые Th17 и ILC17, характеризуется притоком из периферической крови в воспаленную ткань нейтрофилов, а также активацией клеток барьерных тканей с увеличением продукции слизи и антимикробных защитных факторов. Иммунитет 3 типа направлен на элиминацию внеклеточных бактерий и грибов, ключевую роль в его индукции играют ROR $\mathrm{t}+$ лимфоциты, продуцирующие только IL-17 или IL-17 в комбинации с IL-22. Ключевую роль в запуске реакций данного типа играют активированные PAMPs клетки эпителиев и иммунные клетки, которые локализованы в барьерных тканях. Распознавание патогенных паттернов внеклеточных бактерии и грибов индуцирует секретируют этими клетками IL-1 $\beta$ и IL-23, а также IL-6. cDC2 тоже специализируются на 
распознавании консервативных структур этих патогенов и продуцируют IL-1 $\beta$ и IL-23. Эти цитокины запускают продукцию эффекторных цитокинов ILC3 в периферических тканях и обеспечивают «поляризацию» Th0 в Th17 во вторичных лимфоидных органах. IL-17A, IL-17F и IL-22 активируют, как иммунные, так и неиммунные клетки, запускают секрецию матриксных металлопептидаз (ММР), оксида азота (NO), цитокинов, антимикробных пептидов, привлекают и активируют нейтрофилы за счет продукции CXCL8 (IL8). Продуцируемый ILC3 IL-22, способствует усилению барьерных функций эпителия слизистых. Этот тип иммунного ответа играет важную роль в патогенезе аутоиммунных заболеваний (рис.83).

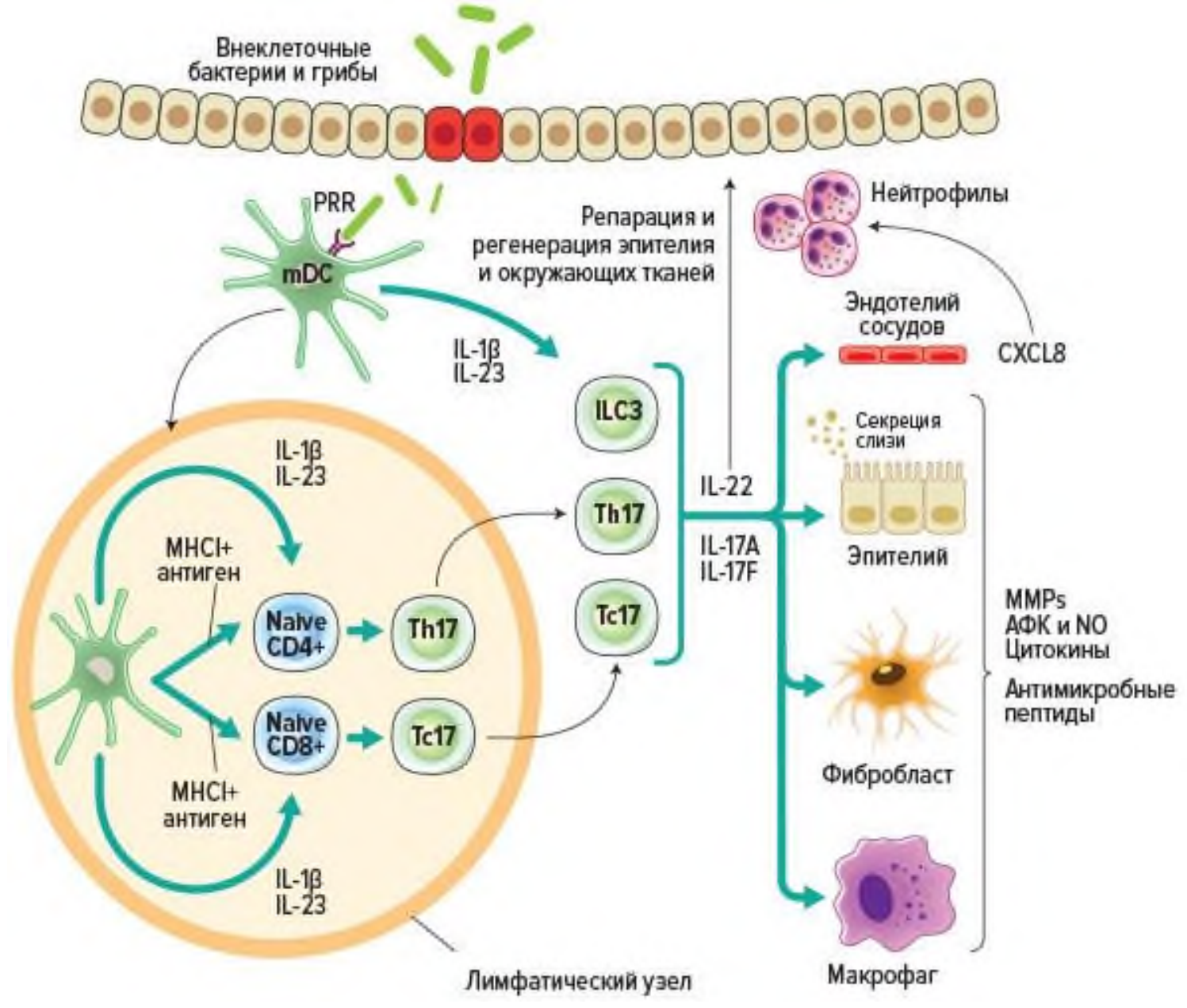

Рис. 83 Схематическое изображение развития воспаления по 3 типу.

\section{Клетки, принимающие участие в индукции воспаления по 3 типу.}

Дендритные клетки. Следует отметить, что наши представления о роли различных типов DCs в развитии ответа по 3 типу весьма фрагментарны и базируются, в основном, на наблюдениях за модельными животными, которые указывают на ведущую роль активированных внеклеточными патогенами cDC2. Так, функции CD103+CD11b+ cDC2 тесно связаны с активацией врожденных лимфоидных клеток группы 3 (ILC3), формированием антиген-специфического 
IgA за счет формирования Tfh и поляризацией «наивных» Th0 в сторону Th17. Хотя механизмы, лежащие в основе повышенной способности сDC2 формировать Th17, до конца не изучены, было показано, что CD11b+CD103+ cDC2 являются основным источником IL-6 и IL-23 после стимуляции паттернраспознающих рецепторов.

ILC 3 типа. ILC 3 группы или ILC3 характеризуются экспрессией фактора транскрипции $\mathrm{ROR} \gamma \mathrm{t}$, который играет ключевую роль в регуляции экспрессии эффекторных молекул этих клеток, а также важен для их развития и эффективного функционирования при активации. Кроме того, они несут на своей поверхности IL-7R, способны к синтезу и секреции IL-17 и IL-22. ROR $\gamma \mathrm{t}+\mathrm{ILC} 3$, появляющиеся во врем эмбриогенеза важны для пренатального формирования периферических лимфоидных органов - лимфатических узлов и Пейеровских бляшек. ROR $\gamma \mathrm{t}+\mathrm{ILC} 3$ присутствуют в небольшом количестве и после рождения у людей и мышей на поверхности слизистых оболочек. ILC3 человека характеризуются экспрессией ROR $\gamma \mathrm{t}$, IL-7R, LT $\alpha 1 \beta 2$ и IL-22 (и в меньшей степени IL-17). Было показано, что в дополнение к упомянутым цитокинам, ILC3 человека, выделенные из миндалин, экспрессируют IL-26, GM-CSF, TNF, CCL20 и IL-2. Продукция цитокинов ILC3 мыши и человека может быть вызвана при стимуляции IL-1 $\beta$ и IL-23.

\section{Цитокины, принимающие участие в индукции воспаления по 3 типу.}

IL-1及 синтезируется в виде проформы (цитоплазме в неактивном состоянии). Для его активации необходима сборка инфламмасомы (мультипротеиновой платформы), ключевым этапом которой является мультимеризация адаптера ASC (или PYCARD), после чего идет рекрутирование каспазы-1, ее димеризация каспазы- 1 = активация и аутопротеолиз. После этого возможен протеолиз pro-IL-1 или pro-IL-18 с последующей секрецией этих цитокинов. Известно, по крайней мере, семь различных рецепторов инфламмасом, а именно NLRP1, NLRP3, NLRC4, NLRP6, NLRP12 и AIM2. Bсе используют ASC для запуска образования каспазы 1. Таким образом, для активации IL-1 $\beta$ необходим сложный процесс сборки инфламмасомы, который запускается под действием различных сигналов, например, появлением высоких концентраций АТФ, выходящих из окружающих поврежденных клеток. Все это необходимо для более точной настройки системы и предотвращения спонтанной активации воспаления по 3 типу.

Биологические эффекты IL-1 $\beta$ связаны с его способностью активировать клетки различного происхождения на продукцию провоспалительных цитокинов и хемокинов. За счет активации клеток эндотелия сосудов происходит привлечение в очаг воспаления из кровотока лейкоцитов с последующей их активацией, усилением фагоцитарной активности. На системном уровне этот цитокин отвечает за регуляцию температуры тела, регуляцию работы желез 
внутренней секреции, а также усиление продукции белков острой фазы воспаления гепатоцитами печени. К системным эффектам также можно отнести и стимуляцию гемопоэза в красном костном мозге.

IL-23 относится к провоспалительным цитокинам, принадлежит к семейству IL-12 вместе с IL-12, IL-27, IL-35 и IL-39. IL-23 преимущественно секретируется активированными макрофагами и дендритными клетками, расположенными в тканях, таких как кожа, слизистая оболочка кишечника, суставы и легкие. IL-23 способствует продукции IL-17, IL-22, GM-CSF и TNF $\alpha$ целевыми популяциями клеток-мишеней. Эти цитокины способствуют привлечению в очаг инфекции нейтрофилов и макрофагов, что сопровождается развитием очагов хронического воспаления и может приводить к повреждению тканей. IL-23 играет ключевую роль в поляризации адаптивного иммунного ответа, индуцируя дифференцировку «наивных» клеток Т-клеток (Th0) в Тхелперы 17 типа (Th17). IL-23 выполняет важнейшую защитную функцию при бактериальных и грибковых инфекциях. Одновременно, гиперпродукция этого цитокина связана с развитием хронического воспаления и аутоиммуннных реакций, включая псориаз, анкилозирующий спондилоартрит, воспалительные заболевания кишечника, ревматоидный артрит, синдрома Шегрена, рассеянный склероз и т.д.

IL-6 является «плейотропным» цитокином, проявление биологической активности которого связано с регуляцией процессов дифференцировки, выживаемости, гибели при помощи апоптоза и пролиферации клеток различного происхождения. IL-6 функционирует как аутокринный, паракринный и «гормоноподобный» регулятор разнообразных локальных и системных процессов. Так, к эффектам IL-6 относятся регуляция острофазового ответа (синтез белков острой фазы воспаления клетками печени), дифференцировка «иммунокомпетентных» клеток, участвующих в воспалительном ответе, «поляризация» Th0 в Th17 и фолликулярных Th, переключение классов синтезируемых антител В-клетками, стимуляция миелопоэза, активация остеокластов и ремоделирование костной ткани.

\footnotetext{
Эффекторные клетки приобретенного иммунитета воспалительных реакций 3 типа.

CD4+ Th17 клетки

Th17 играют ведущую роль в развитии антиген-специфического ответа по 3 типу, направленного на защиту от внеклеточных бактерий и грибов и участвуют в развитии многих аутоиммунных заболеваниях, включая рассеянный склероз. Несколько независимых исследований, посвященных анализу роли IL23 и IL-12 в развитии аутоиммунных патологий и вышедших в 2003 году, послужили основой для выделения Th17 клеток в отдельный тип уже в 2005 году.
} 
Компоненты бактериальной клеточной стенки и клеточной стенки грибов могут активировать АПК для выработки провоспалительных цитокинов IL- $1 \beta$, IL-6 и IL-23, которые, в свою очередь, направляют «наивные» CD4+ T-клетки к дифференцировке в сторону Th17. Интересно, что для дифференцировки и «поляризации» Th0 в Th17 было требуется больше молекул-регуляторов, чем для «поляризации» в другие типы хелперов. Цитокины IL-6 и IL-23 активируют STAT3, который необходим для запуска экспрессии главного транскрипционного фактора Th17- поляризующего ROR $\gamma \mathrm{t}$. Передача сигналов от TCR тоже может индуцировать экспрессию ROR $\gamma \mathrm{t}$ опосредованно, через активацию NFAT/NF-кB/AP-1. В свою очередь, ROR $\gamma \mathrm{t}$ наряду с другими факторами транскрипции (IRF4, BATF и Runx1) способствует активации экспрессии генов, специфичных для Th1 7 клеток. TGF- $\beta$ в сочетании с IL-6 и IL21 участвуют в дифференцировке Th17 клеток в условиях in vitro, хотя в литературе сообщалось о возможности TGF- $\beta$-независимого пути дифференцировки Th17 клеток. Th17 секретируют эффекторные цитокины -IL17A, IL-17F и IL-22, которые индуцируют секрецию матриксных металлопептидаз (ММР), оксида азота (NO), цитокинов и антимикробных пептидов в разных типов иммунных и не иммунных клеток. Действие всех этих факторов направлено на элиминацию внеклеточных патогенов. CXCL8 и G-CSF, продуцируемые Th17 привлекают в участки воспаления нейтрофилы, которые уничтожают патогены при помощи фагоцитоза и продукции широкого спектра микробицидных субстанций. Th17 человека также синтезируют IL-26, который также могут продуцировать и Th1 клетки. Функции этого цитокина изучены слабо, однако известно, что его сывороточная концентрация значительно увеличивается при воспалении кишечника, и в синовиальной жидкости пациентов с ревматоидным артритом.

\section{Ключевые эффекторные цитокины и их функции при реализации воспаления по 3 типу.}

Основная роль T-хелперов 17 и ILC3 состоит в регуляции клеточных реакций за счет продукции IL-17 и IL-22.

IL-17 и его биологические эффекты.

В настоящее время описано шесть членов семейства IL-17 - IL-17A-IL-17F. Однако наиболее хорошо изученными являются IL-17A и IL-17F, так как их гиперпродукция связана с развитием хронических воспалительных заболеваний. IL-17A и IL-17F связываются как дисульфидно-связанные гомо- или гетеродимеры с рецепторным комплексом, образованным субъединицами IL17RA и IL-17RC на поверхности многочисленных клеток-мишеней. Так, IL17RA экспрессируется на многих неиммунных клетках, таких как эндотелиальные клетки, эпителиальные клетки и фибробласты, а также на иммунных клетках, включая нейтрофилы и Т-клетки. 
Под действием IL-17 происходит активация тканевых DCs и макрофагов, что сопровождается продукцией провоспалительных медиаторов широкого профиля действий. Еще одной мишенью данного цитокина являются клетки эндотелия сосудов, которые под действием IL-17 также продуцируют широчайший спектр провоспалительных цитокинов и хемокинов, а также повышают экспрессию молекул клеточной адгезии, обеспечивая приток лейкоцитов в очаг воспаления. IL-17 активирует фибробласты соединительной ткани, индуцируя продукцию этими клетками провоспалительных цитокинов и хемокинов, матриксных металлопротеиназ (MMPs, от англ. «matrix metalloproteinases»), способных разрушать основные типы белков внеклеточного матрикса. Отдельно следует упомянуть о местных эффектах IL-17 на слизистых оболочках. IL-17 усиливает продукцию клетками эпителия, фибробластами соединительной ткани и кератиноцитами антимикробных пептидов, цитокинов и хемокинов, привлекающих тучные клетки, нейтрофилы, воспалительные макрофаги Th17 и ILC3. Опосредованная IL-17 продукция IL-6 и G-CSF дополнительно активирует нейтрофилы и другие миелоидные клетки. Также необходимо подчеркнуть, что важнейшими мишенями IL-17 при формировании очагов аутоиммунного воспаления являются хондроциты, остеобласты и остеокласты, которые активируются и продуцируют цитокины и хемокины, способствующие амплификации воспаления.

IL-22 и его биологические эффекты, системные эффекты.

IL-22 синтезируется и секретируется в разных типах тканей, а его рецептор экспрессируется на стромальных и эпителиальных клетках. IL-22 принадлежит к семейству цитокинов IL-10, и активные мономеры IL-22 связываются с рецепторным комплексом IL-22 (IL-22R), образованным субъединицами IL-22R1 и IL-10R2. Большая часть функций данного цитокина тесно связана с регуляцией активности клеток, которые входят в состав барьерных тканей. Так, IL-22 способствует регенерации эпителиальных тканей при повреждении, индуцируя пролиферацию и ингибируя апоптоз эпителиальных клеток. IL-22 играет важную роль в стимуляции выживания и пролиферации эпителиальных клеток во время острого повреждения ткани, но чрезмерная продукция IL-22 может привести к гиперпролиферации кератиноцитов, выработке провоспалительных сигналов и последующему привлечению активированных эффекторных клеток из кровотока в воспаленные ткани. Известно, что IL-22 имеет решающее значение для иммунитета против Citrobacter rododentium и вызывает экспрессию генов, регулирующих пролиферацию, заживление ран и апоптоз эпителиальных клеток кишечника, а также стимулирует продукцию ими муцинов и антимикробных пептидов. IL-22 усиливает продукцию антимикробных пептидов и TNF $\alpha$ тканевыми макрофагами. 
При воспалительных реакциях, протекающих в кожных покровах, IL-22 оказывает плейотропное действие на кератиноциты, индукцируя пролиферацию, миграцию, ремоделирование тканей, секрецию антимикробных пептидов, цитокинов и хемокинов. Этот цитокин способствует выработке привлекающих нейтрофилы хемокинов и экспрессии металлопротеиназ внеклеточного матрикса, которые необходимы для ремоделирования тканей во время восстановления эпителия.

GM-CSF и его биологические эффекты, нейтрофилы.

Несмотря на то, что GM-CSF первоначально был открыт, как ростовой фактор, (от англ. «granulocyte-macrophage colony stimulating factor») этот цитокин играет второстепенную роль в миелопоэзе и становится основным медиатором воспаления тканей. GM-CSF секретируется в виде мономерного цитокина, который связывается с рецептором GM-CSF - гетеродимером, образованным определенной субъединицей $\alpha$ - и $\beta$-, общей с рецепторами IL-3 и IL-5. Связывание этого цитокина с рецептором способствует активации Jak2 и последующей активацией сигнальных путей STAT5, фосфатидилинозитол-3киназы (PI3K) и митоген-активируемой протеинкиназы (МАРК). Основными клетками-мишенями для GM-CSF являются дендритные клетки, моноциты, макрофаги, гранулоциты, нейтрофилы и, а также микроглия и астроциты. Он опосредует взаимодействие ILC3 и макрофагов, а также усиливает поляризацию ответа по 3 типу. GM-CSF усиливает воспаление, фагоцитоз и хемотаксис лейкоцитов, а также играет важную роль в повреждении тканей и демиелинизации.

CCL20 и его биологические эффекты

Хемокин CCL20 экспрессируется кератиноцитами и некоторыми другими клетками барьерных тканей. Его продукция повышается под действием TNF $\alpha$ и IL-17A, а также IL-22. Синовиальные клетки также экспрессируют CCL20, и его экспрессия на этих клетках увеличивается под действием TNF $\alpha$, IL-17A и IL-1 $\beta$, но подавляется IFN $\gamma$ или IL-4/IL-13. CCL20 играет ведущую роль в привлечении в очаг повреждения тканей Th17 и дендритных клеток, что способствует амплификации ответа.

\section{Воспаление по 3 типу - эффекторная фаза ответа.}

Основная роль реакций иммунитета 3 типа состоит в защите от внеклеточных бактерий и грибов. IL-17, главный цитокин при данном типе воспаления, привлекает нейтрофилы и тканевые макрофаги в ткани и стимулирует продукцию этими клетками антимикробных факторов. Одной из важных функций IL-17 является усиление барьерных функций эпителиев за счет продукции слизи и антимикробных пептидов эпителиальными клетками. В экспериментальных моделях инфекции на животных, IL-17-дефицитные мыши были больше восприимчивы к бактериям и грибам, включая Klebsiella 
pneumoniae, Staphylococcus aureus и Candida albicans. В настоящее время накоплены многочисленные доказательства защитной активности иммунитета типа 17 против внеклеточных бактерий и грибов. Пациенты с мутациями STAT3 (гипер-IgE синдром) очень чувствительны к стафилококковым и грибковым инфекциям, вследствие нарушения развитие клеток Th17. Дефицит рецептора IL17 приводит к частым грибковым инфекциям рода Candida. Аутосомнорецессивная мутация гена, кодирующего адапторную молекулу CARD9, проводящую сигнал от рецептора IL-17 повышает восприимчивость к инфекции грибков рода Candida. У пациентов с хроническим кожно-слизистым кандидозом были описаны различные мутации, стимулирующие функции транскрипционного фактора STAT1, ответственного за развитие IL-17продуцирующих клеток. При хронических кожно-слизистых кандидозах, разной этиологии у пациентов обнаруживаются нейтрализующие антитела к IL-17. Также известно, что пациенты с мутациями в гене RORC, кодирующим ROR $\gamma \mathrm{t}$, страдают хроническим кандидозом, что согласуется с отсутствием у этих пациентов клеток Th17. Реакции адаптивного иммунитета по типу Th17 играют ключевую роль в развитии ряда аутоиммунных заболеваний, среди котрорых ревматодиный артрит, рассеянный склероз, инсулинозависимый сахарный диабет, увеит, псориаз и синдром воспаленного кишечника (болезнь Крона).

Таким образом, при инфекции развивается иммунный ответ к возбудителю, при аллергии развивается иммунный ответ к аллергену, в ходе онкологического процесса формируется иммунный ответ к опухолевым антигенам и, наконец, аутоиммунные заболевания характеризуются развитием иммунного ответа к структурам собственного организма - аутоантигенам. И, как всякая функция, которая может нанести вред организму в случае ее избыточности, иммунные реакции должны находиться под жестким контролем. Этот контроль осуществляется за счет нейроэндокринной регуляции и внутрисистемной регуляции гуморально-клеточными факторами иммунитета.

Интерес к регуляторным Т-лимфоцитам как основной популяции клеток периферической крови, способной подавлять развитие воспалительных реакций по всем трем описанным выше типам, не угасает уже многие годы. Снижение же функциональной активности Treg приводило к нарушению толерантности к собственным антигенам организма и развитию аутоиммунных патологических состояний. Популяция Treg не является однородной. Описаны как минимум две субпопуляции, циркулирующие в периферической крови и принципиально различающиеся по происхождению. «Тимические» или «натуральные» регуляторные Т-лимфоциты (от англ. «thymus derived» или «natural» Treg, nTregs или tTregs) проходят дифференцировку в тимусе в ходе антиген-независимой стадии созревания Т-клеток. nTregs обладают фенотипом 
«наивных» клеток периферической крови - CD45RA+CD45R0-CD62L+CCR7+. Другая популяция «периферические» или «индуцибельные» или «адаптивные» Treg (от англ. «peripherally derived», «induced» или «adaptive» Treg, iTregs) регуляторные Т-клетки формируется в процессе антиген-зависимой дифференцировки в периферических лимфоидных органах. В 2013 году была предпринята попытка стандартизировать номенклатуру Treg, и было предложено Treg, дифференцирующиеся в тимусе, обозначать как nTreg, a Treg, формирующиеся из Th0 на периферии, в лимфатических узлах, как pTreg. Название iTreg (от англ. «in vitro-induced» Treg) было предложено употреблять для обозначения регуляторных Т-клеток, которые были получены в ходе дифференцировки в условиях in vitro, чтобы отличать их от pTreg, формирующихся in vivo. Эффекторные молекулы регуляторных Т-лимфоцитов представлены на рис.84.

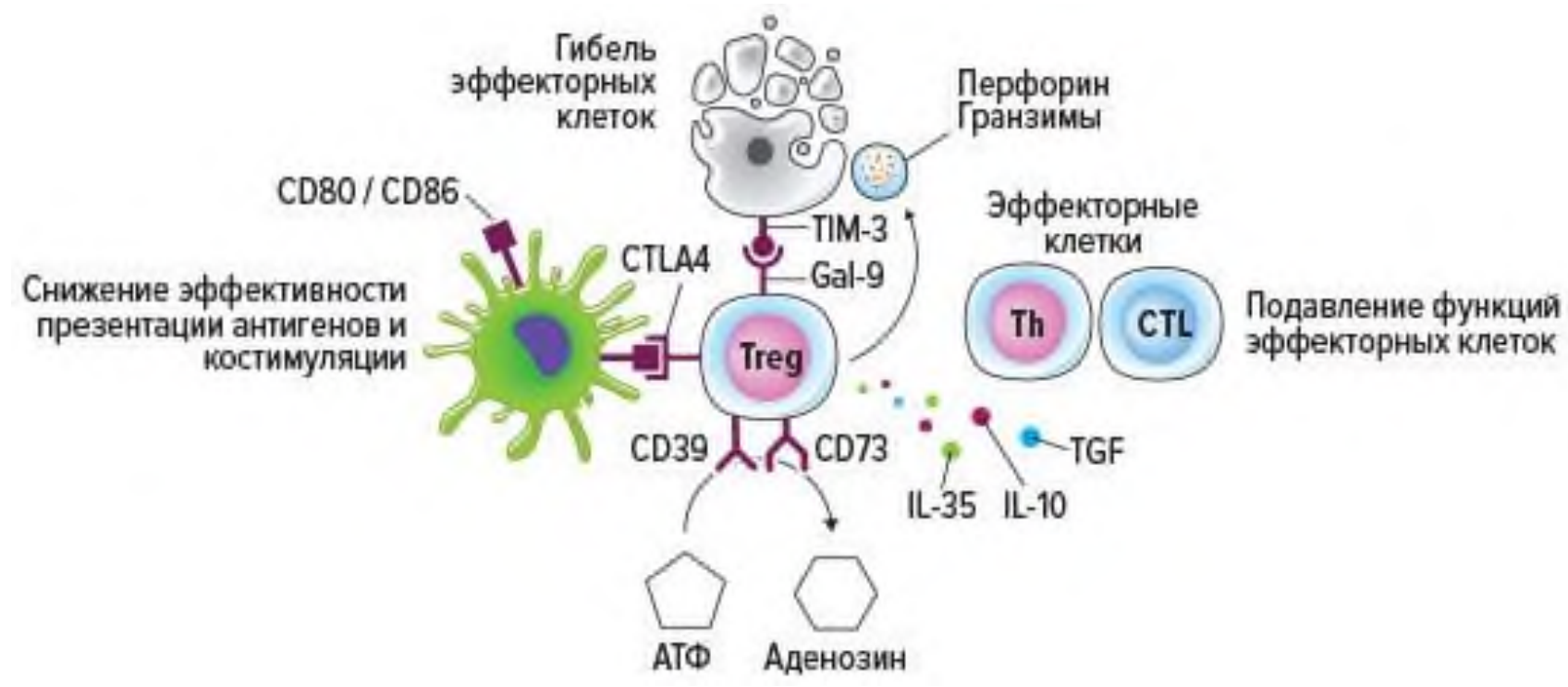

\section{Рис. 84. Эффекторные молекулы регуляторных Т-лимфоцитов.}

Мишенями Treg являются все клетки врожденного (тканевые макрофаги, антиген-презентирующие клетки, натуральные киллеры) и приобретенного иммунитета (эффекторные цитотоксические Т-лимфоциты и Т-хелперы, а также В-лимфоциты). Для реализации функций Treg используют различные механизмы, которые традиционно разделяют на «бесконтактные» (опосредованные действием высвобождаемых регуляторными Т-клетками различных растворимых молекул, диффундирующих в тканевые жидкости) и «контактные» (опосредованные взаимодействием рецепторов Treg и поверхностных структур на клетке-мишени).

«Бесконтактные» механизмы супрессии Treg. 
Ключевыми иммунорегуляторными гуморальными факторами Treg человека являются IL-10, TGFb и IL-35, а также внеклеточный аденозин. Аденозин образуется путем гидролиза внеклеточного АТФ ферментами CD39 и CD73, локализованными на цитоплазматической мембране Treg.

IL-10 является белком с молекулярной массой около 18 кДа, который, помимо Treg, синтезируют моноциты, дендритные клетки, нейтрофилы, различные популяции Th (например, Th17 и Th22, как уже отмечалось ранее) и некоторые популяции В-лимфоцитов (значение этих популяций В-клеток будет рассмотрено в следующей главе данной монографии). Ключевыми функциями данного цитокина являются:

- угнетение продукции провоспалительных цитокинов и, в первую очередь, IL-12, играющего ведущую роль в «поляризации» Th0 в сторону Th1. Это приводит к снижению продукции IFN $\gamma$ и формирования эффекторных Th1;

- за счет блока эффектов IFN $\gamma$, усиление дифференцировки тканевых макрофагов в M2, которые также являются продуцентами противовоспалительных цитокинов - IL-10 и TGFb;

- увеличение эффективности фагоцитоза и элиминации клеточного дебриса в очаге воспаления,

- снижение эффективности взаимодействия между АПК и антигенраспознающими клетками, путем блокировки передачи сигнала от TcR в ядро лимфоцитов. Снижение экспрессии ко-стимулирующих молекул CD80 и CD86 и комплексов антиген-МНС II, что существенно ограничивает пролиферативную активность, созревание и дифференцировку клона антиген-специфических лимфоцитов (как Т-хелперов, так и цитотоксических Т-лимфоцитов);

TGFb является белком с молекулярной массой около 25 кДа, который секретируется в виде неактивного пептида, состоящего из собственно ТGFb и пептида LAP (от англ. «Latency-Associated Peptide»). TGFb снижает пролиферативную активность активированных Т-лимфоцитов за счет подавления синтеза и секреции IL-2 и подавляет их дифференцировку в эффекторные клетки (как Т-хелперов, так и эффекторных цитотоксических Тлимфоцитов). TGFb, стимулируя экспрессию транскрипционного фактора FOXP3, способствует преимущественной поляризации регуляторных Tлимфоцитов. Под действием TGFb снижается уровень активации тканевых макрофагов, дендритных клеток и натуральных киллеров, равно как и пролиферация активированных В-лимфоцитов.

IL-35 принадлежит к семейству IL-12 и является гетеродимерным белком, состоящим из двух субъединиц - p35 и Ebi3. В отличие от остальных членов данного семейства (IL-12, IL-23 и IL-27), обладающих провоспалительными свойствами, IL-35 обладает выраженной иммуносупрессорной активностью. 
Основными функциями данного цитокина являются подавление пролиферативной активности «наивных» Т-лимфоцитов и «поляризация» Тh0 в сторону Treg, продуцирующих большое количество IL-35 и получивших еще название «iTr35». Считается, что именно IL-35 является мощнейшим фактором, ограничивающим провоспалительную функциональную активность Th17, так как он способен подавлять дифференцировку Тh в сторону эффекторных Th17.

Аденозин подавляет адгезию лейкоцитов к эндотелиальным клеткам микроциркуляторного русла, снижает продукцию супероксид анионов нейтрофилами и снижает синтез и секрецию провоспалительных цитокинов клетками различного происхождения. Аденозин способствует продукции противовоспалительного IL-10 моноцитами, а также запускает продукцию VEGF - мощного индуктора ангиогенеза и сосудистой проницаемости. Большинство из этих эффектов аденозина реализуются через различных представителей семейства А2 рецепторов. Аденозин подавляет активность эффекторных Тлимфоцитов, ингибирует дифференцировку Th1 и Th2 за счет снижения уровня пролиферативной активности и продукции IL-2, что выражается еще и в снижении продукции эффекторных цитокинов, свойственных Th1 и Th2 линиям дифференцировки Т-хелперов. Он также угнетает активность (проявление цитолитических свойств или синтез цитокинов), и других популяций Т-клеток. Под действием аденозина снижается экспрессия ко-стимулирующих молекул CD2 и CD28 - активированными Т-лимфоцитами. Для самих Treg аденозин является мощнейшим аутокринным фактором активации. Под его воиянием на поверхности Treg увеличивается плотность супрессорных молекул CTLA-4, CD39 и CD73, а также уровень экспрессии CD25. Также было отмечено ,что после культивирования in vitro в присутствии аденозина происходит повышение доли Treg, что указывает на активацию процессов пролиферации данной популяции клеток.

«Контактные» механизмы иммуносупрессии основаны на взаимодействии рецепторов Treg с их лигандами на клетке-мишени.

CTLA-4 (от англ. «Cytotoxic T-lymphocyte-associated antigen 4», или CD152) экспрессируется Treg. Известно, что CTLA-4 имеет высокую плотность экспрессии на Treg и ингибирует иммунный ответ. Главными лигандами CTLA4 являются ко-стимулирующие молекулы CD80 и CD86. Эти молекулы также являются лигандами активационной костимулирующей молекулы CD28. Но аффинность связывания CTLA-4 с лигандами, значительно выше, чем таковая для CD28. Именно поэтому основной функцией CTLA-4 является «экранирование» CD80 и CD86 от активированных Т-клеток, экспрессирующих CD28. В результате взаимодействия CTLA-4 с лигандами происходит интернализация CD80 и CD86 антиген-презентирующей клеткой, что 
существенно снижает эффективность презентации антигена и угнетает формирование клона антиген-специфических Т-клеток. С другой стороны, Treg через взаимодействие CTLA-4 с CD80/86 регулируют созревание дендритных клеток.

LAG3 (от англ. «Lymphocyte-Activation Gene 3» или CD223). Основным лигандом LAG3 являются молекулы MHC II класса на АПК, причем аффиность взаимодействия LAG3-MHC II существенно выше такового комплекса CD4MHC II, что способствует снижению активации Т-хелперов и блокирует развитие воспаления по всем трем типам.

Treg способны вызывать апоптоз эффекторных клеток при помощи двух основных механизмов. Во-первых, Treg индуцируют апоптоз за счет секреции в окружающее пространство перфорина и гранзимов, как это показано для натуральных киллеров и эффекторных цитотоксических Т-лимфоцитов. Вовторых, индукции апоптоза клеток мишеней реализуется за счет экспрессии на поверхности Treg галектина-9 (Gal-9) - $\beta$-галактозидаза-связывающего белка, способного связываться с ТIM-3 (от англ. «Т cell immunoglobulin and mucin domain 3» или CD366) на поверхности зрелых эффекторных клеток. Результатом такого взаимодействия является активации каспаз в клетке-мишени. Кроме того, за счет Gal-9 осуществляется подавление пролиферации антиген-специфических Т-клеток.

В настоящее время существует множество различных определений понятия «иммунологическая толерантность», некоторые из которым приводятся ниже. Иммунологическая толерантность:

- отсутствие иммунного ответа при наличии в организме антигенов (толерогенов), доступных лимфоцитам;

- специфическая ареактивность к какому-либо антигену, индуцированная предшествующим контактом с этим антигеном (на уровне организма или иммунной системы);

- это отсутствие активации лимфоцитов (и, соответственно, продукции эффекторных молекул) при наличии специфического антигена (на уровне отдельных клонов клеток иммунной системы).

В чем состоит биологический смысл иммунологической толерантности?

1. В ходе развития лимфоцитов в центральных органах иммунной системы, в результате реаранжировки генов возникают уникальные Т- и Вклеточные рецепторы. Поэтому каждая клетка - Т- или В-лимфоцит УНИКАЛЬНА, что является ключевым отличием этих клеток от клеток врожденного иммунитета.

2. Так как реаранжировка генов рецепторов носит «случайный» характер, образующие при этом Т- и В- лимфоциты способны к распознаванию любых 
антигенов, включая антигены собственного организма - то есть «аутоантигены». Именно это может приводить к развитию аутоиммунных заболеваний. Если по каким-то причинам, АПК презентирует аутоантигены при наличии 2 и 3 сигналов (костимуляции и цитокинового) «свое» распознается системой приобретенного иммунитета как «чужое».

3. Именно поэтому при созревании Т- и В-клеток необходимы механизмы «селекции» - индукция «центральной» толерантности, формирование «периферической» толерантности или контроль за потенциальными «беглецами», В-клетками, которые изменяют специфичность своего рецептора в ходе развития иммунного ответа.

Центральная (иногда называет «естественная») толерантность - это совокупность механизмов, направленных на уничтожение аутореактивных клеток в центральных лимфоидных органах (тимус и красный костным мозг) в ходе их (клеток) созревания и дифференцировки. ОДНАКО в ходе этого процесса часть аутореактивных клеток может избегать апоптоза. К механизмам индукции центральной толерантности относятся - негативная селекция клеток; редактирование рецепторов (для В-лимфоцитов), а также формирование «натуральных» или «тимических» Treg, которые способны распознавать собственные антигены и блокировать развитие иммунного ответа на них при помощи механизмов, которые детально описаны нами в разделе, посвященном данной популяции Т-лимфоцитов.

Центральная иммунологическая толерантность обусловлена отрицательной селекцией аутореактивных клонов лимфоцитов. и развивается в процессе онтогенеза за счет уничтожения аутореактивных клонов Т- и Влимфоцитов. Классическим примером формирования толерантности к собственным антигенам организма является процесс «негативной» селекции тимоцитов (будущих Т-лимфоцитов) в тимусе. Так, в ходе позитивной селекции сигнал к выживанию получают клетки, способные распознавать молекулы МНС в ассоциации с собственными антигенами организма и способные, как следствие, проводить сигнал от TcR. Остальные тимоциты не получают необходимый сигнал от TcR и в дальнейшем гибнут путем апоптоза. Клетки, прошедшие положительную селекцию, т.е. сформировавшие функционально-активный Тклеточный рецептор, проходят следующий этап отбора, получившего название «негативной» селекции. В ходе этого процесса происходит оценка интенсивности сигнала от TcR, который формируется при распознавании аутоантигенов, то есть собственных антигенов организма, экспрессирующихся на строме тимуса. Ключевая роль в негативной селекции отводится антигенпрезентирующим и эпителиальным клеткам. Медуллярные тимические эпителиальные клетки экспрессируют ядерный белок, называемый AIRE 
(аутоиммунный регулятор, от англ. «autoimmune regulator»), который, как считается, способен на низком уровне индуцировать в тимусе экспрессию множества генов. Белковые продукты этих генов обычно экспрессируются только в определенных периферических органах и тканях, и называются «тканеспецифичные» антигены. Экспрессия в тимусе «тканеспецифичных» антигенов делает их доступными для презентации и распознавания незрелыми Т-клетками. Возможно, что именно этот механизм обеспечивает негативную селекцию и удаление аутореактивных клонов и формирования пула тимических регуляторных Т-клеток, способных подавлять ответ на собственные антигены организма в периферических лимфоидных органах. Косвенным подтверждением такого механизма селекции и роли AIRE в формировании центральной толерантности является тот факт, что мутации в гене, кодирующем белок AIRE, приводят к развитию аутоиммунного полиэндокринного синдрома.

B ходе негативной селекции высокоаффинное связывание TcR c комплексом аутоантиген-МНC генерирует сильный сигнал, запускающий в тимоцитах процесс апоптоза. Слабый сигнал свидетельствует о низкой аффинности связывания TcR c аутоантигеном, что дает возможность клетке продолжить свое развитие. В то же время «промежуточные» значения этого сигнала способствуют формированию тимических или натуральных регуляторных Т-лимфоцитов. Следует особо подчеркнуть, что тонкие механизмы негативной селекции в настоящее время недостаточно хорошо изучены, и наши представления об этом носят в значительной степени теоретический характер.

Периферическая толерантность - это совокупность механизмов, направленных на уничтожение аутореактивных клеток в периферических лимфоидных органах (лимфатические узлы, Пейеровы бляшки и т.д.) при инициации иммунного ответа.

Периферическая толерантность - элиминация "беглецов" (Т- и В-клеток) и вновь образованных после соматических гипермутаций аутореактивных Вклеток. Ведущую роль в регуляции механизмов поддержания периферической толерантности играют «ауто-реактивные» Treg. При генетических дефектах, затрагивающих развитие Тreg-клеток аутоиммунные реакции проявляются наиболее сильно. Это наблюдается у больных с IPEX-синдромом (врожденные иммунодефицит, X-ассоциированная иммунная дисрегуляция, полиэндокринопатия, энтеропатия), который развивается в результате мутации гена FOXP3/Foxp3 и связан с множественными аутоиммунными реакциями. Как уже нами отмечалось ранее, Foхр3 является ключевым маркером регуляторных Т-клеток, который регулирует формирование в тимусе и поддержание пула Treg 
на периферии, а также крайне важен для реализации супрессорных функций этих клеток.

Периферическая толерантность реализуется за счет следующих механизмов:

- делеция клона. Лимфоциты, связавшие антиген вместо активации, погибают в результате апоптоза;

- анергия клона. Лимфоциты, связавшие антиген вместо активации, входят в состояние «неотвечаемости» из-за отсутствия 2 сигнала (костимулирующих молекул) со стороны АПК;

проявление эффекторных свойств Treg (продукция противовоспалительных цитокинов, образование аденозина и широкий спектр контактных взаимодействий с клетками-мишенями). 


\section{Глава 8. Мукозальный иммунитет}

Первой линией обороны против инфекционных агентов служат слизистые оболочки и кожа, которые совместно с клетками и молекулами иммунной системы образуют мукозо-ассоциированную лимфоидную ткань (mucosaassociated lymphoid tissue - MALT) препятствующую проникновению микроорганизмов. В ней сконцентрирована основная масса иммунной системы (на общей площади $400 \mathrm{~m}^{2}\left(120 \mathrm{M}^{2}\right.$ - дыхательная система, 250-400 $\mathrm{m}^{2}$ желудочно-кишечный тракт, кожа - 1,5-2,0 м², мочеполовая система - 1,5-2,0 м²) располагаются около 50\% клеток иммунной системы). Структуризация MALT зависит от анатомической локализации барьерной ткани (табл. 41).

Таблица 41

Структуры мукозо-ассоциированной лимфоидной ткани (MALT)

\begin{tabular}{|l|l|l|}
\hline Наименование & \multicolumn{1}{|c|}{$\begin{array}{c}\text { Анатомическая } \\
\text { локализация }\end{array}$} & \multicolumn{1}{c|}{$\begin{array}{c}\text { Механизмы } \\
\text { защиты }\end{array}$} \\
\hline SALT & Кожа (дерма) & $\begin{array}{l}\text { Клиренс кератоцитов, кислый рН, кожное } \\
\text { сало, }\end{array}$ \\
\hline NALT & $\begin{array}{l}\text { Носовая полость, рот и } \\
\text { ротоглотка, конъюнктива }\end{array}$ & $\begin{array}{l}\text { Чихание, слюна, слезы, катионный белок, } \\
\text { гистатины, лизоцим }\end{array}$ \\
\hline BALT & Трахея, бронхи, легкие & $\begin{array}{l}\text { Кашель, катионный белок, дефенсины, } \\
\text { гликоконъюгаты, муцин }\end{array}$ \\
\hline VALT & Половые органы & $\begin{array}{l}\text { Кислый рН, катионный белок, спермин, } \\
\text { муцин }\end{array}$ \\
\hline GALT & $\begin{array}{l}\text { Пищевод, желудок, тонкий } \\
\text { кишечник; толстый кишечник; } \\
\text { урогенитальный тракт; }\end{array}$ & $\begin{array}{l}\text { Рвота, перистальтика, слизь, кислый рН, } \\
\text { трипсин, дефензины, лизоцим и пр. } \\
\text { Диарея, мочеиспускание, катионный белок, } \\
\text { дефензины }\end{array}$ \\
\hline
\end{tabular}

Слизистые оболочки представляют собой тонкий слой эпителиальных клеток, которые выстилают кишечник, дыхательные или мочеполовые пути. Слизистые оболочки служат входными воротами для большинства патогенных микроорганизмов. Иммунные реакции слизистых отличаются от системных иммунных реакций, которые чаще всего инициируются после взаимодействия наивных лимфоцитов с АПК в дренирующем лимфатическом узле или селезенке. В отличие от этого, адаптивный иммунитет на слизистых формируется локально, в местах первичного проникновения антигена, то есть для этого нет необходимости транспорта антигена в дренирующий лимфатический узел через афферентные лимфатические сосуды. Формирующиеся при этом эффекторные 
популяции лимфоцитов могут проникать в эфферентную лимфу или кровь, но затем направленно мигрируют в слизистые оболочки и кожу, для реализации эффекторных функций. Однако этим реакциям сопутствует системный иммунный ответ, при котором эффекторные клетки элиминируют тот же антиген и в других компартментах организма, потому что АПК из слизистых мигрируют в дренирующий лимфатический узел, где активируют «наивные» Т- и Влимфоциты.

В настоящее время выделяют несколько типов слизистых оболочек, различающихся по структуре эпителия. Слизистые оболочки I типа, такие как кишечник и легкие, состоят из одного слоя цилиндрического эпителия. Слизистые оболочки II типа обнаруживаются там, где требуется более прочный барьер, например, во рту, носу и влагалище, для этих участков характерно наличие верхнего слоя однослойного плоского эпителия. Оба типа слизистых оболочек получили свое название из-за их способности генерировать слизь вязкий раствор полисахаридов в воде, который покрывает апикальную (обращенную к просвету) мембрану эпителиальной клетки. Слизь содержит различные антитела, преимущественно $\operatorname{sgA}$ в слизистых оболочках I типа и IgG в слизистых оболочках II типа, а также антимикробные молекулы, которые помогают защитить слизистые оболочки от инвазии патогенов. Эти антимикробные молекулы включают лизоцим, который разрушает компоненты клеточной стенки, и лактоферрин, который связывает железо, необходимое для роста бактерий, и пр.

Защита слизистых от атаки со стороны микробов осуществляется с помощью иммунных реакций, которые реализуются в лимфоидной ткани, ассоциированной со слизистыми или MALT (от англ. «mucosa-associated lymphoid tissue»). MALT образована скоплениями АПК и лимфоцитов, которые расположены непосредственно под слизистой оболочкой. Эти клеточные популяции функционируют как независимые структуры иммунной системы, которые отвечают за иммунные реакции слизистой оболочки. MALT включает в себя несколько подсистем, связанных с разными компартментами организма GALT (от англ. «gut-associated lymphoid tissue), NALT (от англ. «nasopharynxassociated lymphoid tissue») и BALT (от англ. «bronchus-associated lymphoid tissue»), в зависимости от их расположения в кишечнике, носоглотке и бронхах, соответственно. В MALT, выделяют индукторные и эффекторные сайты или участки (рис.85).

Индукторный сайт - это компартмент (участок) слизистой оболочки, где происходит распознавание антигена и инициируется первичный адаптивный иммунный ответ. 


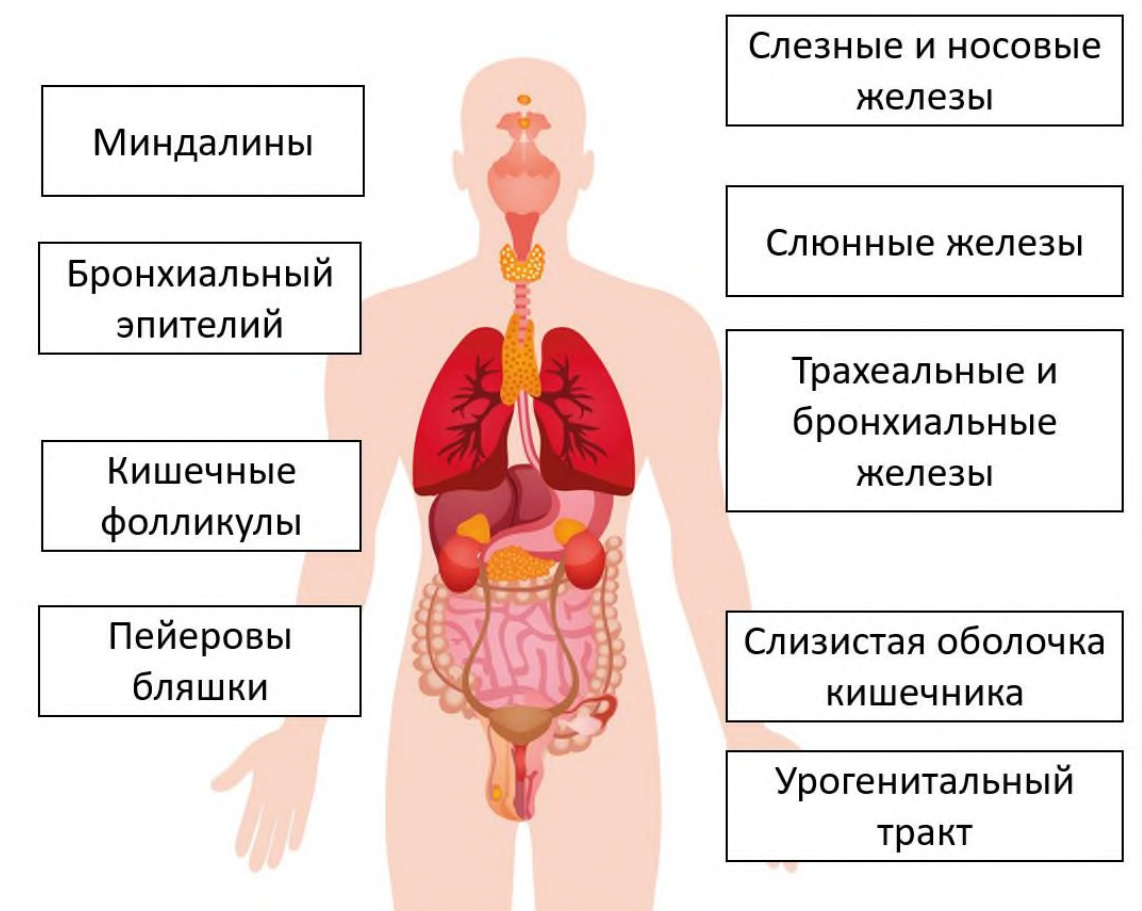

\section{Рис. 85. Индукторные сайты (слева). Эффекторные сайты (справа).}

Индукторные сайты в GALT, в тонкой кишке, образованы такими лимфоидными структурами как Пейеровы бляшки, аппендикс, диффузные скопления лимфоцитов и антигенпрезентирующих клеток, рассеянны внутри и непосредственно под кишечным эпителием. Индукторные сайты имеют строение, принципиально схожее со строением лимфатических узлов, в них также выделяют Т и В клеточные зоны, содержащие все характерные клеточные элементы. B BALT и NALT основными индукторными участками являются бронхиальный эпителий и скопление миндалин в носоглотке соответственно.

Эффекторный сайт - это специфическая область слизистой оболочки, в которую мигрируют эффекторные популяции лимфоцитов для реализации иммунного ответа.

Среди наиболее важных эффекторных участков слизистой оболочки выделяют экзокринные железы, такие как слюнные и слезные. Эти железы вырабатывают защитные внешние секреции (такие как слюна и слезы), которые содержат антимикробные молекулы и секреторные антитела. Области MALT, ассоциированные со слизистыми оболочками I типа, более плотно заселены DCs и лимфоцитами, по сравнению с MALT, ассоциированными со слизистыми оболочками II типа. 
Недавние исследования показали, что в кишечнике и легких в ответ на инфекцию или травму могут возникать провизорные индукторные сайты, которые представляют собой форму третичной лимфоидной ткани, иногда определяемой как iBALT или iGALT. Формирование этих третичных лимфоидных органов регулируют те же цитокины, которые участвуют в формировании вторичных лимфоидных органов в эмбриогенезе. В частности, локальная продукция лимфотоксина (LT) и IL-17 при воспалении приводят к эктопическому развитию лимфоидных фолликулов и лимфатических сосудов. Эти цитокины также способствуют привлечению в iMALT DCs и T- и Bлимфоцитов. Основными источниками LT и IL-17 являются Th17 - лимфоциты и LTi-лимфоциты, называемые клетками-индукторами лимфоидной ткани.

После того, как Т- и В-клетки слизистой оболочки активируются в индукторном участке, они мигрируют через лимфу и кровь к различным эффекторным участкам, где дифференцируются в Тh-эффекторы, цитотоксические $\mathrm{CD} 8+\mathrm{T}$-лимфоциты и плазматические клетки. Таким образом, после активации лимфоцитов в одном индукторном участке, иммунная защита может формироваться во множестве разделенных эффекторных участках слизистой оболочки. Например, когда антиген захватывается в Пейеровых бляшках (индукторный участок), специфические антитела могут быть обнаружены не только в слизистой оболочке кишечника, но и в урогенитальном тракте, и в молочных железах (эффекторные участки). Таким образом, можно говорить об общей иммунной системе слизистых оболочек.

\section{Структура лимфоидной ткани, ассоциированной с кишечником (GALT).}

GALT образована кишечным эпителием, который обращен в просвет кишки и представляет собой слизистую оболочку I типа, а также лежащей под ним собственно пластинкой lamina propria, состоящей из рыхлой соединительной ткани, расположенной между базальной поверхностью эпителия и мышечным слоем. Можно выделить три основных компонента кишечного барьера: микробиота, слой слизи; эпителий с его специализированными клетками (бокаловидные клетки, клетки Панета и энтероциты) и клетки лимфоидной ткани, ассоциированные с кишечником, включая интраэпителиальный лимфоциты (рис.86).

В целом кишечный эпителий формирует криптовые (вогнутые) и ворсинчатые (выпуклые) структуры. Исключение составляют небольшие плоские участки кишечного эпителия, называемые фолликул-ассоциированным эпителием (FAE), которые содержат М - клетки и покрывают кишечные фолликулы, межфолликулярные области и купол (dome). 


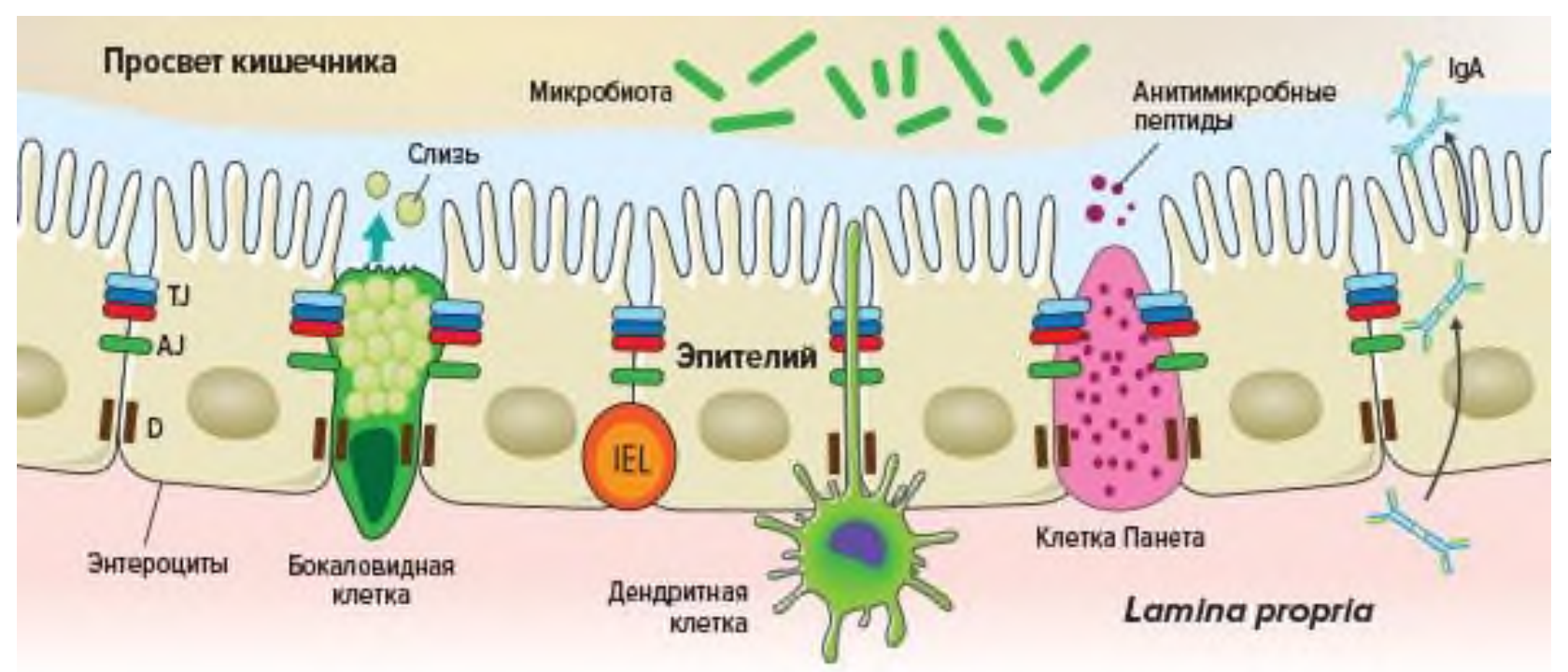

Рис. 86. Схематическое изображение кишечного барьера.

AJ - Адгезивное соединение, D - десмосома, TJ - Узкий стык, IEL- внутриэпителиальный лимфоцит. IgA - секреторный иммуноглобулин А.

Функция кишечного эпителия состоит как в поглощении нутриентов, так и в защите от патогенов и вредных веществ. Реализация этих взаимно противоположных функций зависит от совместной работы разных типов клеток, формирующих кишечный эпителий. Энтероциты составляют большую часть однослойного эпителия, который выстилает кишечник и образует крипты и ворсинки. Основная функция энтероцитов - поглощение питательных веществ, но исследования последних нескольких лет показали их важную роль в интеграции множества экзогенных и эндогенных сигналов и координации иммунных реакций в GALT. B различных участках слизистой оболочки кишечника между энтероцитами встречаются другие типы эпителиальных клеток.

Энтероэндокринные клетки, как правило, локализуются в ворсинках, в то время как клетки Панета и бокаловидные клетки расположены в основании или по бокам кишечных крипт, соответственно. Энтероэндокринные клетки продуцируют слизь и секретируют гормоноподобные молекулы, оказывающие стимулирующее воздействие на окружающие клетки. Клетки Панета продуцируют антимикробные молекулы, а бокаловидные клетки антимикробные молекулы и слизь (рис.87).

Кроме того, в составе эпителия слизистых ЖКТ и ВДП встречаются ресничные клетки (taft cells) (не показаны на рисунке). Эти, редко встречающиеся секреторные клетки, не вызывали сильного интереса иммунологов, пока в 2016 году не было установлено, что они тесно связаны с 
развитием 2 типа воспаления в тонком кишечнике. Ресничные клетки обладают способностью продуцировать широкий спектр участвующих в развитии аллергических реакций биологически активных молекул, таких как IL-25, эйкозаноиды (лейкотриены и простагландин D2) и нейромедиатор ацетилхолин. Внеклеточные сигналы, регулирующие функцию ресничных клеток, плохо изучены.

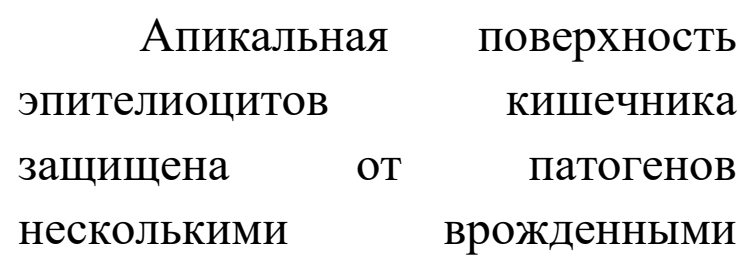
барьерами. Прежде всего, любой патоген должен конкурировать за питательные вещества и жизненное пространство с триллионами комменсальных организмов (также называемых

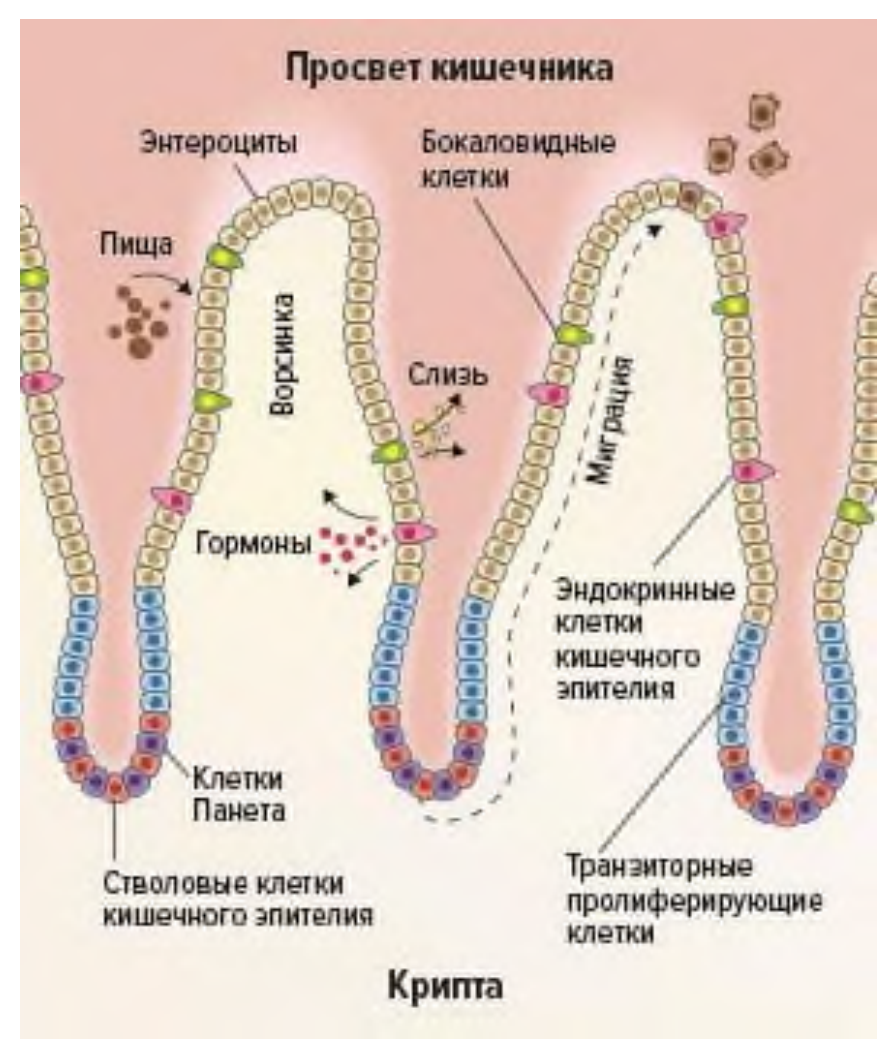

Рис. 87. Клеточные элементы эпителия кишечника.

микробиотой или микрофлорой), которые обычно живут в кишечном тракте. В дополнение, некоторые из этих комменсалов выделяют токсины, которые могут серьезно ограничивать развитие патогенной микрофлоры. Микробиота также способствует формированию подлежащего слоя слизи. Таким образом, чем больше комменсальных бактерий присутствует в данной области кишечника, тем толще слизь в этой области.

Защитный слой слизи играет решающую роль в поддержании гомеостаза между организмом-хозяина и микробиотой, а также противомикробной защите организма-хозяина. Большая часть слоя кишечной слизи состоит из муцина 2 , который образует гидратированный гель толщиной от 300 до 700 мкм.

Слизь продуцируют бокаловидные клетки в нижней части крипты, затем она движется вверх между ворсинками, таким образом, кончики ворсинок не всегда покрыты слизью. В тонком кишечнике слизь образует один прерывистый слой, вероятно, чтобы облегчить всасывание питательных веществ. В желудке и толстой кишке образуются два слоя слизи: наружный "рыхлый" слой, легко смываемый, и внутренний слой слизи, который прочно прикрепляется к эпителию. Большая часть бактерий обнаруживается в наружной части слизи. Таким образом, слой слизи действует как физический барьер, удерживающий 
местную микробиоту на расстоянии от эпителия. Поэтому бактерии редко вступают в прямой контакт с эпителием тонкого кишечника.

Слизь служит не только механическим барьером для кишечных микробов, она также связывает антимикробные пептиды, которые в большом количестве продуцируются на слизистых разными типами клеток. Практически все антимикробные пептиды в кишечнике происходят из четырех различных источников (рис.88).

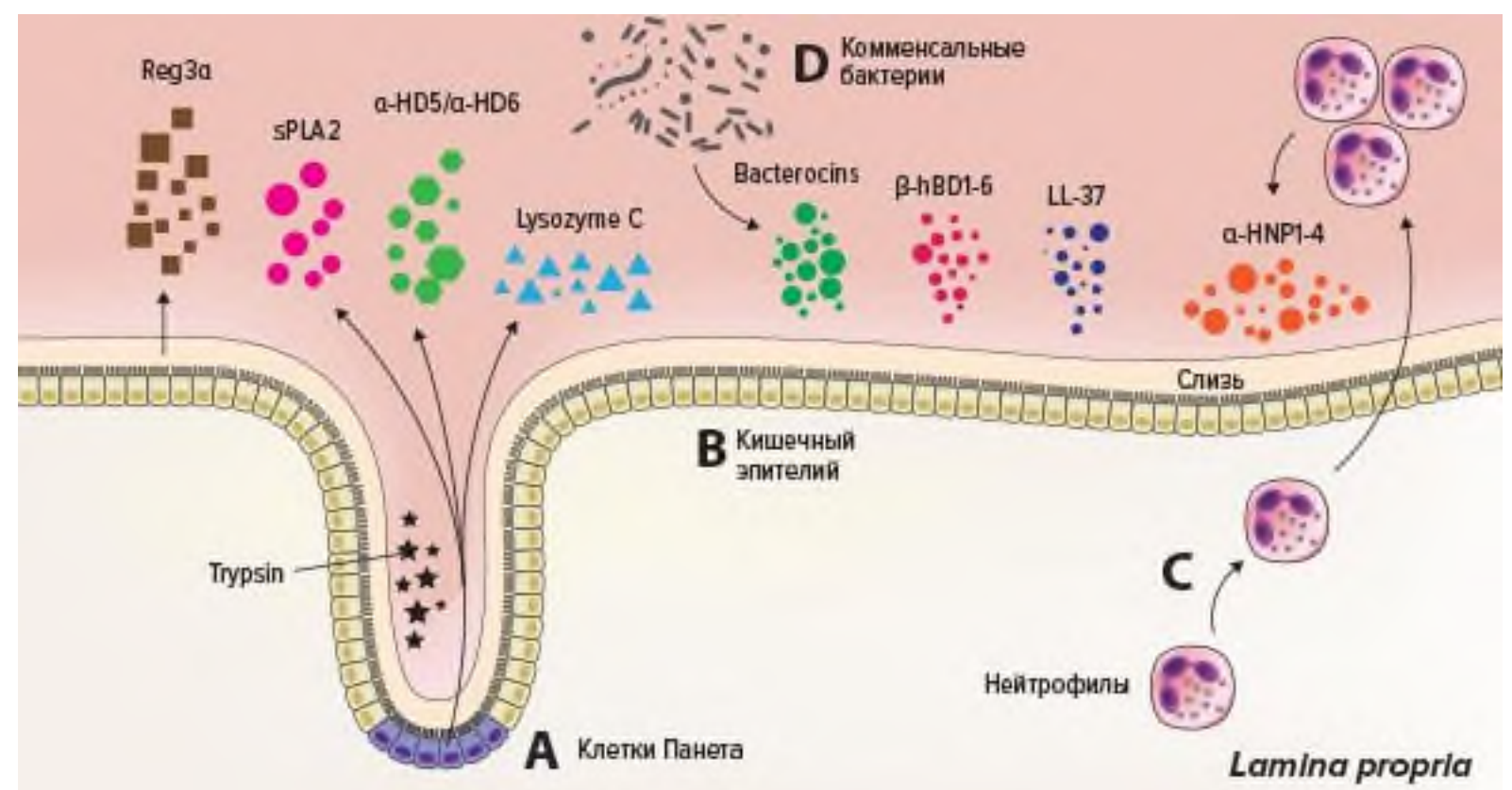

\section{Рис. 88. Источники антимикробных пептидов в слизистой оболочке кишечника.}

А - клетки Панета: лизоцим, кишечные $\alpha$ дефензины (pro-HD5 и pro-HD6) и REG3a $\mathrm{C}$ - нейтрофилы: значительный запас HNPs
В - кишечный эпителий: $\beta$-дефензины 1-6,

LL37, REGa и другие лектины

D - комменсальные бактерии: широкий спектр антимикробных пептидов бактериального происхождения

Антимикробные пептиды не диффундируют в просвет кишечника, а остаются прикрепленными к полианионным сульфатированным и сиалированным гликопротеинам муцина слизи. Концентрация антимикробных пептидов в просвете крипты может достигать 100 мг/мл.

Антимикробные пептиды формируют в слое слизи градиент от апикальной поверхности эпителия к просвету кишечника и от дна крипты (где расположены клетки Панета) к вершине ворсинки. В толстой кишке градиент антимикробного пептида усиливается за счет двух слоев слизи. Нижний слой слизи образует физический барьер для проникновения бактерий благодаря своей плотной сетчатой структуре. Он также ограничивает действие антимикробных пептидов в основном на поверхности эпителия. 
Если патогену удается выжить в окружении микробиоты и проникнуть через слой слизи, он сталкивается со «щеточной каймой». Это структура образована микроворсинками, которые образуют эпителиоциты. Щеточная кайма покрыта толстым слоем гликокаликса, который несет отрицательный заряд, что отталкивает многие патогенны за счет электрических взаимодействий. Кроме того, с гликокаликсом связаны несколько типов гидролитических ферментов, которые разрушают микробы и макромолекулы. Патоген, которому удается проникнуть через физические и химические барьеры, защищающие слизистую оболочку кишечника, сталкивается с клеточными факторами врожденного иммунитета.

На слизистых, также как и в других компартментах организма, эти рецепторы являются сенсорами «чужого» или эволюционно консервативных структур микробов. Однако особенность иммунитета слизистых состоит в том, что здесь эпителиальные клетки постоянно сталкиваются с комменсальными микробами, поэтому подвергаются постоянному воздействию PAMPs. Большинство кишечных микробов не патогенны, но экспрессируют те же эволюционно консервативные молекулы (PAMPs=MAMPs), что и патогены ЛПC, петидогликаны, CpG DNA, флагеллин и т.д. Постоянная активация PRR может привести к развитию воспаления и даже спровоцировать аутоиммунные реакции, поэтому в кишечном эпителии выработались механизмы гипореактивности, чтобы ограничить и ослабить сигналы от PRRs. Предотвратить чрезмерную и нежелательную активацию PRRs на слизистых помогает жесткий контроль пространственной локализации и активации.

Эпителиальные клетки экспрессируют мембраносвязанные TLR в основном на своей базолатеральной поверхности. Это гарантирует, что микроорганизмы получают доступ к PRRs только после преодоления физических и химических барьеров, и обеспечивает активацию PRRs только под влиянием потенциально вирулентных патогенов. В гомеостатических условиях большинство рецепторов - TLR2, TLR4 и TLR5 - локализуются на базолатеральной плазматической мембране эпителия в кишечнике и дыхательных путях, или на базальных клетках в стратифицированном эпителии в полости рта. Только после нарушения целостности эпителиального барьера патогенами, активация TLR на базолатеральных поверхностях эндотелиоцитов будет вызывать развитие воспаление.

В условиях воспаления экспрессия TLR2 и TLR4 на эпителиальных клетках может усиливаться. Их внутриклеточная локализация также может изменяться. Так, в дыхательных путях было обнаружено значительное количество TLR4 в комплексе Гольджи, и транслокация этих рецепторов на поверхность клетки происходила только после контакта с патогеном. Например, в клетках молочной железы крупного рогатого скота при воспалении большое 
количество TLR2 экспрессируется на апикальной стороне эпителиальных клеток молочной железы, тогда как на эпителии здоровой железы наблюдалось низкое количество TLR2. Кроме того, апикальная локализация (транслокация) TLR4 происходит при хроническом воспалении в подвздошной и толстой кишке. Наконец, эндосомальные - локализованные на мембране эндосом клетки - TLR (TLR3, TLR7, TLR8 и TLR9) осуществляют рецепцию лигандов нуклеиновых кислот от вирусов и бактерий, только если патогены проникли в клетку через эндоцитарные или фагоцитарные пути. Кроме того, если патогены или их РАМР попадают в цитоплазму без мембранной упаковки, они могут активировать цитоплазматические рецепторы, такие как NLRs (от англ. «nucleotide-binding and oligomerization domain (NOD)-like receptors») или RIG-I (от англ. «retinoic acidinducible gene I»).

Повышенный порог чувствительности PRR кишечного эпителия снижает вероятность развития воспаления на кишечную микробиоту.

Ограниченная экспрессия или даже полное отсутствие корецепторов, принимающих участие в сигналинге от PRR, является еще одним механизмом снижения чувствительности системы и повышения порога, необходимого для индукции воспаления. Этот механизм используется для подавления сигналов от TLR2 и TLR4 посредством ограничения взаимодействия рецепторов с их кофакторами CD36, MD2 и CD14 в эпителиальных клетках дыхательных путей. Так, последние из них регулируют активность TLR путем ассоциации с их внеклеточным доменом. Большее количество растворимых форм этих кофакторов могут секретировать резидентные макрофаги при активации и, таким образом, усиливать воспалительную реакцию соседних эпителиальных клеток. Регуляция воспаления также может осуществляться за счет изменения экспрессии негативных регуляторов (или ингибиторов) сигнальных путей от PRR. В настоящее время описано более 200 сигнальных белков, способных подавлять воспаление. Предполагается, что регуляция трансдукции сигнала от PRR осуществляется по-разному в разных типах клеток.

Толстый слой слизи создает градиент микробных продуктов, поступающих к эпителию. Если слой слизи хорошо сформирован, бактериальные продукты поступают к бокаловидным клеткам в низкой концентрации. Если слой слизи тонкий или нарушена его барьерная функция, высокие концентрации микробных молекул достигают поверхности бокаловидных клеток. Это приводит к их активации через TLR и Myd88 с продукцией ROS, и активацией Nlrp6 инфламмасом, опосредованной активацией каспаз 1 и 11, что сопровождается быстрым экзоцитозом гранул, высвобождением слизи, гибелью бокаловидной клетки с последующим ее вытеснением из эпителия. 
PRRs играют ключевую роль в поддержании целостности эпителиального барьера и в содействии формированию иммунной системы слизистой оболочки. Комменсальные бактерии через PRRs модулируют экспрессию широкого спектра генов, участвующих в поддержании целостности эпителия, воспалительных реакциях, синтезе и секреции антимикробных пептидов различными клетками. Так, у мышей с дефицитом PRRs может развиться воспаление кишечника. Взаимодействие TLR2 с консервативными структурами микробов в физиологических условиях необходимо для сохранения целостности слизистой оболочки кишечника. Безвредные инкапсулированные бактерии (капсула которых содержит полисахарид A) способны связываться с TLR2. Это индуцирует внутриклеточный сигнал, который усиливает барьерные функции эпителия. В отсутствии устойчивого сигнала от TLR2 межклеточные связи ослабляются, и целостность эпителиального барьера нарушается.

TLR5, TLR9 и NOD2 - три других PRR, важная роль которых для гомеостаза кишечника была недавно раскрыта. Связывание TLR5 с флагеллином комменсальных микробов приводит к усилению экспрессии антиапоптотических генов в энтероцитах, поддерживая их жизнеспособность. TLR9, лигандом которого является $\mathrm{CpG}$ (короткая одноцепоченая последовательность ДНК, которая в изобилии представлена в геноме прокариот), выполняет в слизистых функцию, отличную от его роли в качестве эндосомального PRR лейкоцитов врожденного иммунитета. TLR9 экспрессируется преимущественно на базолатеральных поверхностях энтероцитов и клеток Панета. В стационарных условиях взаимодействие TLR9 с CpG комменсальных микробов подавляет воспаление и снижает высвобождение антимикробных пептидов клетками Панета. Цитозольный белок NOD2 (от англ. «nucleotide-binding oligomerization domain containing 2»), лигандом которого является бактериальный мурамилдипептид, экспрессируется клетками Панета и необходим для продукции этими клетками антимикробных пептидов, нормального развития Пейеровых бляшек и регуляции числа М-клеток.

Большинство интраэпителиальных лимфоцитов проявляют эффекторный фенотип или фенотип клеток-памяти, который определяет их способность быстро реагировать на активирующие сигналы.

Между эпителиальными клетками кишечника на базолатеральной стороне располагаются интраэпителиальные лимфоциты или iIELs (от англ. «intestinal intraepithelial lymphocytes»). Эпителий тонкой кишки содержит $\sim 1$ iIEL на каждые 10 эпителиальных клеток, что делает его одним из крупнейших иммунных компартментов организма. Рекрутирование iIELs в кишечный эпителий частично опосредуется хемокином CCL25, который продуцируется 
кишечным эпителием и распознается рецептором хемокина CCR9 на поверхности iIEL. Проникновение и удержание iIELs в эпителий дополнительно обеспечивается взаимодействием Е-кадгерина на энтероцитах с $\mathrm{aEb7-}$ интегрином (CD103) на iIELs. В отличие от лимфоцитов в других тканях, iIEL слизистых не проникают в периферические лимфоидные органы. Большинство iIELs проявляют эффекторный фенотип или фенотип клеток-памяти, который определяет их способность быстро реагировать на активирующие сигналы в воспаленных тканях. Как и другие факторы иммунитета, iIELs играют двойственную роль - они необходимы для поддержания барьерной функции кишечного эпителия, но также участвуют в развитии воспаления в желудочнокишечном тракте.

Интраэпителиальные лимфоциты преимущественно представлены $\gamma \delta$-Т-лимфоцитами.

В норме среди iELs тонкого кишечника примерно 75\% составляют CD8позитивные $\alpha \beta$-Т-клетки, 10\% составляют CD4-позитивные $\alpha \beta$-Т-клетки и 15\% составляют клетки, которые являются CD4- и либо CD8-, либо CD8+. Таким образом, iIELs преимущественно представлены Т-лимфоцитами и, по сравнению с большинством других тканей, обогащены Т-клетками, экспрессирующими $\gamma \delta$ TCRs.

Следует напомнить, что в отличие от $\alpha \beta$-Т-клеток, механизм распознавания антигена в $\gamma \delta$-Т-клетках не ограничен распознаванием комплекса антиген-МНС. В то время как $\alpha \beta-$-клетки распознают пептидные фрагменты в составе МНС, $\gamma \delta$-Т-клетки могут распознавать молекулы клеточного стресса (MICA и МICB), не пептидные метаболиты биосинтеза изопреноидов, белки теплового шока и так далее. Более того, для $\gamma \delta+$ iIELs характерен сильно ограниченный антиген-распознающий репертуар TcR c самого рождения, в то время как антиген-распознающий репертуар $\alpha \beta+$ iIELs весьма разнообразен у новорожденных мышей и людей. С возрастом репертуар $\alpha \beta+$ iIELs становится в значительной степени ограниченным или «олигоклональным», что, повидимому, связано с колонизацией кишки определённой микробиотой. Поэтому в настоящее время предполагают, что при физиологических условиях эти рецепторы распознают в основном антигены комменсальной микробиоты. Еще одной интересной особенностью ilELs является то, что многие клетки экспрессируют гомодимерный вариант CD8 - CD8 $\alpha \alpha$, причем, в отсутствии экспрессии CD $8 \alpha \beta$. Известно, что $\mathrm{CD} 8 \alpha \beta$ функционирует как ко-рецептор Tклеточного рецептора, усиливая взаимодействие между TcR и комплексом пептид-МНС I. Более того, на невоспаленном эпителии тонкой кишки 
экспрессируются молекулы BTNL2 (от англ. «Butyrophilin-like protein 2»), которые функционируют как негативный регулятор активации Т-клеток, так как мутации в гене, кодирующем этот белок, повышают риск воспалительных заболеваний кишечника (ВЗК).

B lamina propria слизистых находятся индукторные сайты, в которых происходит захват, презентация антигенов и запуск реакций адаптивного иммунитета.

Под базолатеральной поверхностью эпителия кишки находится рыхлая соединительная ткань, содержащая lamina propria (Рис.89).

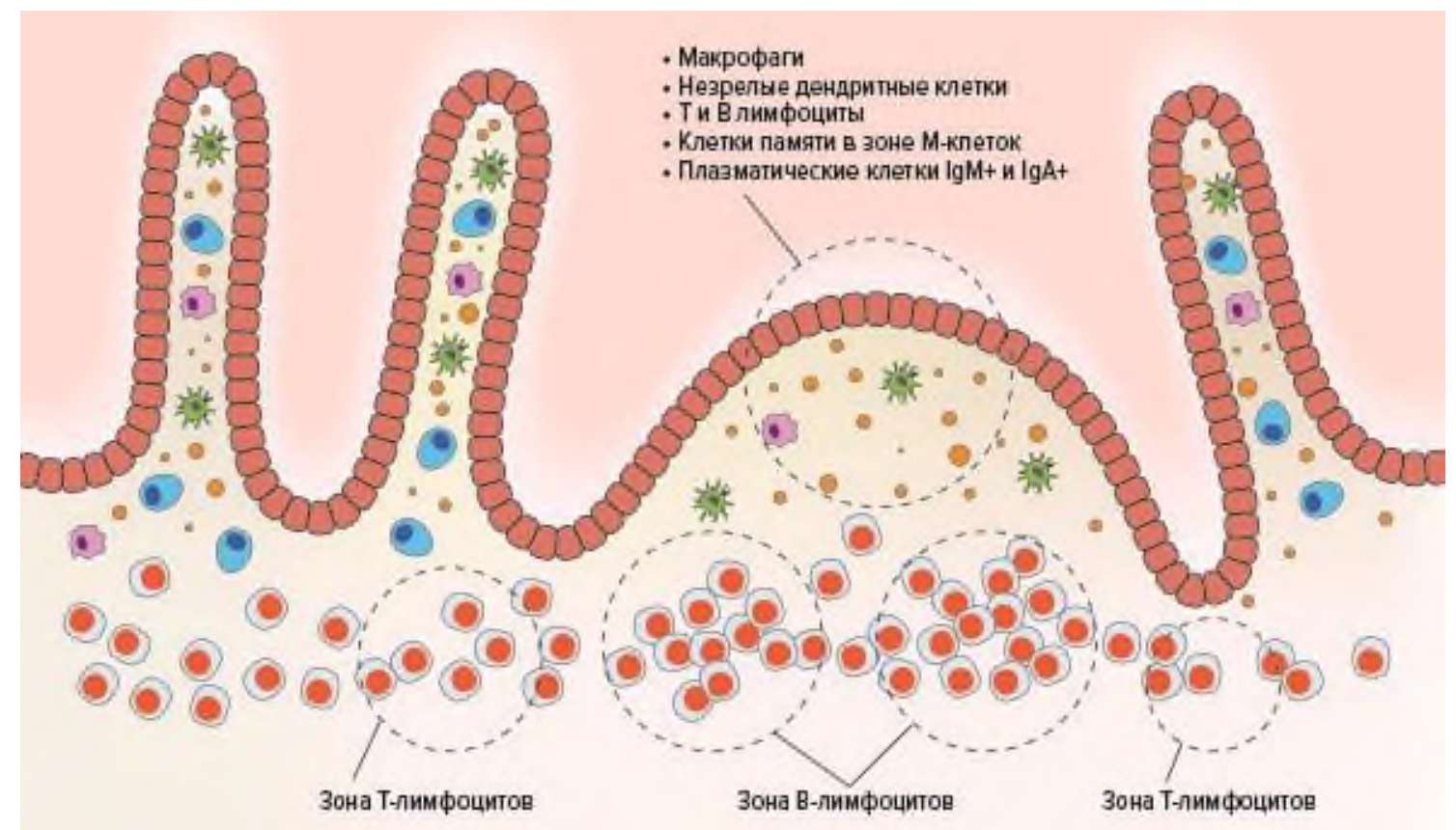

Рис. 89. Состав клеток в lamina propria.

B lamina propria находятся клетки-резиденты, многочисленные макрофаги и нейтрофилы, а также в небольшом количестве NKT-клетки, тучные клетки, незрелые DC, $\gamma \delta$-Т-лимфоциты. B lamina propria в изобилии содержатся $\alpha \beta-\mathrm{T}$ клетки памяти (как $\mathrm{CD} 4+$, так и $\mathrm{CD} 8+$ ) и B-клетки памяти, а также эффекторные Th17 клетки. Многие из этих лимфоцитов распределены диффузно в lamina propria, тогда как другие находятся в составе лимфоидных фолликулов. Кишечные фолликулы могут встречаться поодиночке, которые могут быть рассеяны по всей длине кишечника, или располагаться небольшими или большими группами по 30-40 фолликулов (как, например, в Пейеровых бляшках). Дендритные клетки - резиденты GALT и lamina propria - участвуют как в поддержании толерантности к комменсальной микробиоте и пище, так и в развитии защитных иммунных реакций против внедрившихся патогенов. Эта функциональная пластичность частично обусловлена способностью дендритных 
клеток воспринимать и интегрировать сигналы микроокружения и формировать последующий иммунный ответ. Распознавание антигена дендритными клетками в lamina propria приводит, в частности, к активации В-лимфоцитов и образованию зародышевых центров В-клеточных фолликулов. В результате постоянного контакта слизистой оболочки кишечника с патогенами, в любой момент времени около 10-15\% В-клеток lamina propria дифференцируются в плазматические клетки, подавляющее большинство из которых под действием цитокинов микроокружения синтезируют IgA. Общая секреция IgA антител этими плазматическими клетками значительно превышает выход $\operatorname{IgA}$, синтезируемых плазматическими клетками селезенки, красного костного мозга и лимфатических узлов остальных частей организма.

\section{В пределах фолликул-ассоциированного эпителия М-клетки осуществляют захват антигенов из просвета кишечника и их транспорт в lamina propria}

Фолликулы в кишечнике лежат непосредственно под небольшими участками плоского кишечного эпителия, который называют фолликулассоциированным эпителием или FAE (от англ. «follicle-associated epithelium»). Его основная функция состоит в захвате антигенов из просвета кишечника (Рис.90).

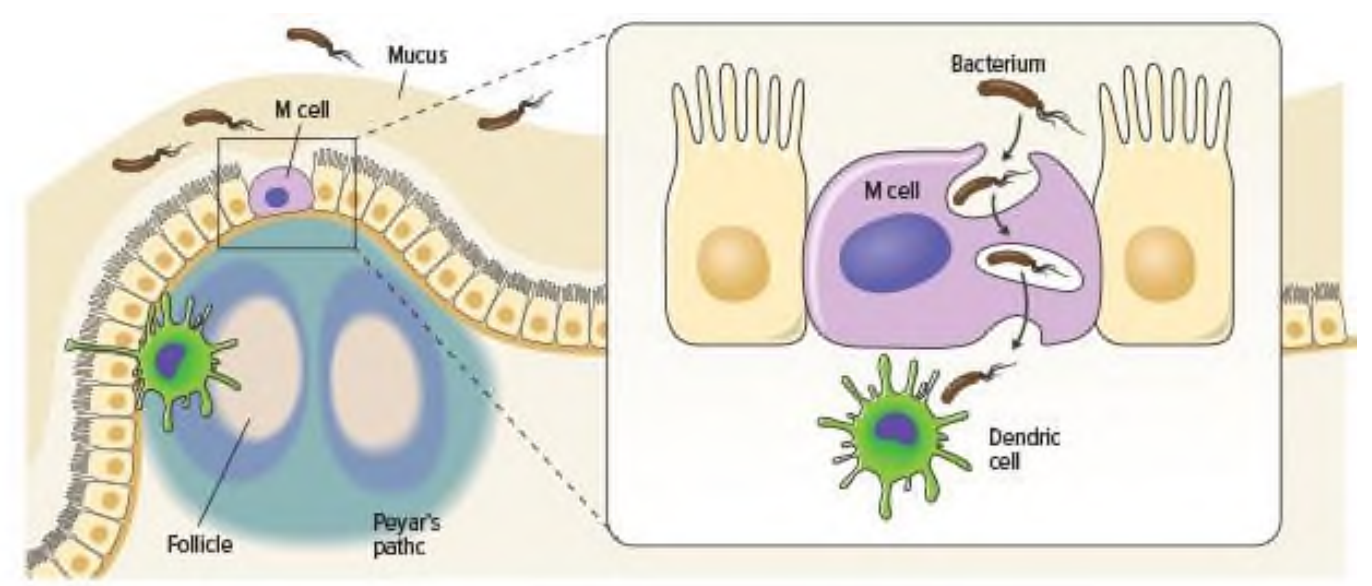

Рис. 90. Фолликул-ассоциированный эпителий.

Подавляющее большинство клеток FAE составляют энтероциты, но 10$20 \%$ клеток - это большие, не имеющие ресничек клетки, называемые Мклетками (от англ. “membranous" или “microfold”), которые осуществляют перенос или «трансцитоз» (в данном случае, транспорт при помощи эндосом с апикальной поверхности клетки на ее базальную или латеральную без протеолаза) антигенов из просвета кишечника в фолликулы, что позволяет доставить антиген в «нативном» или необработанном виде. М-клетки 
располагаются над Пейеровыми бляшками. Между фолликулами и вышележащим эпителием находится купол (или англ. «dome»), содержит В- и Тлимфоциты, DCs и макрофаги. М-клетки участвуют в транспорте интактных микробов или микробных молекул.

Гистологическая структура кишечного фолликула напоминает таковую большинства вторичных лимфоидных органов.

Область между М-клеткой и нижележащими кишечными фолликулами называется куполом (или англ. «dome»). Внутри купола находятся популяции антиген-презентирующих клеток, которые захватывают антигены, транспортируемые М-клеткой. Помимо ДК и макрофагов, купол содержит CD4+ и $\mathrm{CD} 8+\alpha \beta-\mathrm{T}$-клетки, покоящиеся В-клетки и различные субпопуляции регуляторных Т-клеток. Сам кишечный фолликул (В-клеточные области) состоит из зародышевого центра, содержащего активированные В-клетки и фолликулярные дендритные клетки. Фолликулы разделены межфолликулярными областями (Т клеточные области), которые содержат большое количество зрелых $\alpha \beta$-Т-клеток, окружающие венулы с высоким эндотелием HEV.

Таким образом, гистологическая структура фолликула напоминает таковую большинства вторичных лимфоидных органов, но в отличие от фолликулов большинства вторичных лимфоидных органов, фолликулы кишечного эпителия лишены афферентных лимфатических сосудов. По сути, функцию афферентного лимфатического сосуда выполняют М-клетки или дендритные клетки и лимфоциты в кишечных фолликулах получают антигены путем их захвата непосредственно с поверхности слизистой. Поэтому М-клетки эволюционировали так, что они лишены компонентов эпителиального барьера, что облегчает интернализацию антигенов.

B пределах GALT выделяют две популяции дендритных клеток cDC1 и cDC2. Как и в других органах и тканях, в lamina propria кишечника обнаруживают cDC1 и сDC2. Как говорилось выше, морфологически Пейеровы бляшки разделены на три основных домена: фолликулярную область, межфолликулярную область и фолликуло-ассоциированный эпителий. Фолликул окружен субэпителиальным куполом, который содержит В-клетки, Тклетки, макрофаги и DC. cDC1 локализуются в пределах межфолликулярной области, обогащенной Т-клетками, в то время как сDC2 присутствуют под фолликуло-ассоциированным эпителием в субэпителиальном куполе.

Однако презентация захваченных DCs антигенов происходит не только в лимфоидной ткани, ассоциированной с кишечником (или слизистыми оболочками в целом), так как часть этих клеток мигрирует с током лимфы в 
ближайшие лимфатические узлы, ключевыми из которых являются мезентериальные лимфатические узлы. Так, в совокупности мезентериальные лимфатические узлы, которые дренируют тонкую кишку, слепую кишку и восходящую ободочную кишку, являются самыми крупными лимфоидными скоплениями в организме. Здесь обнаруживаются как мигрирующие с периферии cDC, так и резидентные cDC. Мигрирующие cDC - это MHC-IIhi клетки со зрелым фенотипом, в то время как резидентные cDC - это MHC-II+ клетки с незрелым фенотипом. После активации сDC1 и CD103+ cDC2 тонкой кишки транспортируют люминальные антигены в мезентериальные лимфатические узлы и презентируют эти антигены «наивным» Т-клеткам, что приводит к развитию специфического иммунного ответа уже на уровне организма. В условиях воспаления cDC1 и cDC2 презентируют антигены и индуцируют разные типы адаптивного иммунного ответа, Th1 или Th2, Th17, соответственно (Рис. 91).
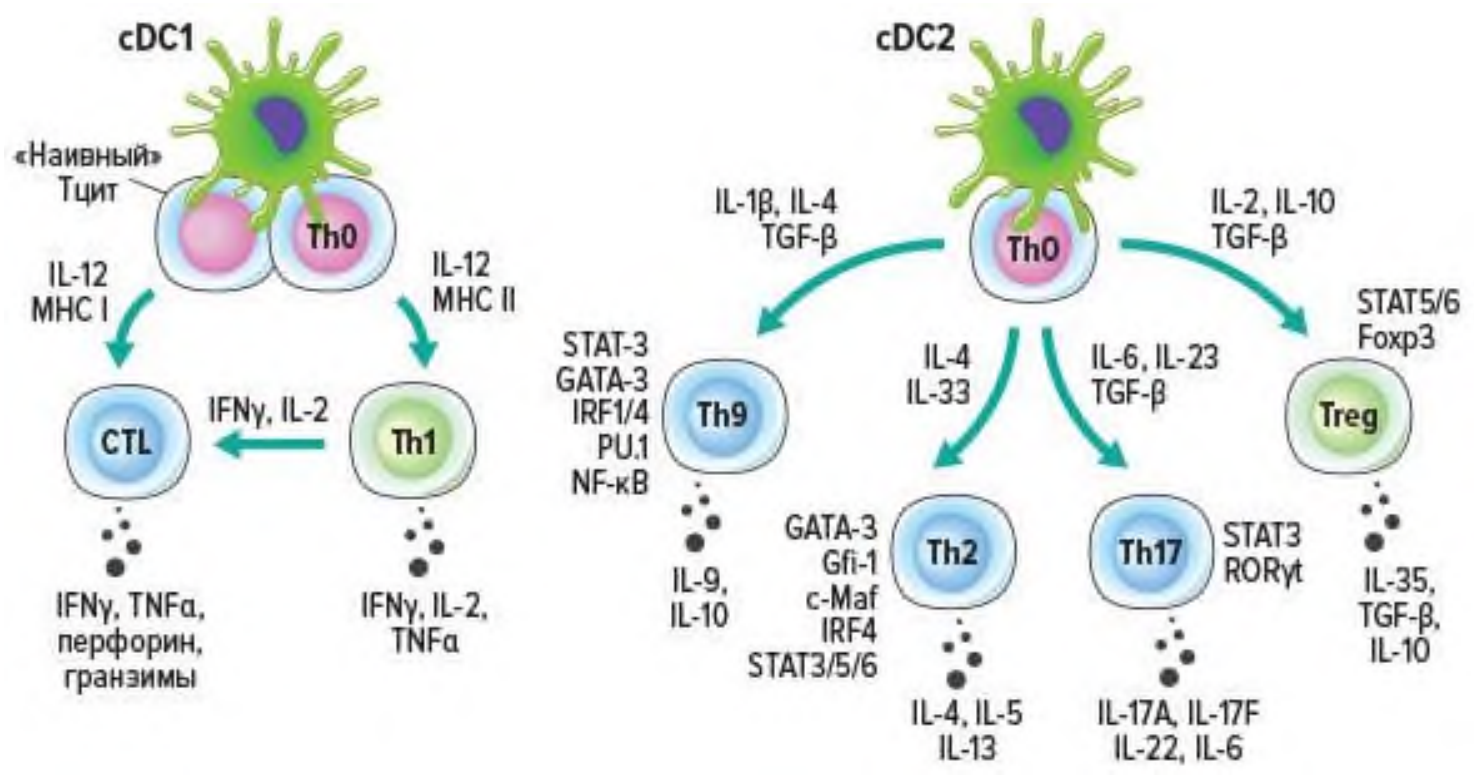

Рис. 91. Участие сDC1 и сDC2 в развитии T - клеток.

В норме при физиологических условиях большинство DCs в GALT индуцируют анергию или гибель «наивных» активированных Т-лимфоцитов, которые способны распознавать антигены комменсальных микробов или пищевые антигены, либо DCs способствуют их поляризации в регуляторные Tклетки. Толерогенные свойства DCs формируются под влиянием микроокружения в слизистых. Например, муцин-2 - основной компонент слизи - подавляет активацию $\mathrm{cDC}$ под влиянием микробных факторов и способствует индукции оральной толерантности. MLN cDC1 и CD103+ cDC2 экспрессируют avb8-интегрин, который преобразует неактивный TGF-b в его активную форму. 
Столь же важна роль микробиоты в подавлении иммунного ответа на слизистых оболочках.

Факторы окружающей среды кишечника и микробиоты способствуют формированию сDC с толерогенными свойствами.

Как уже отмечалось ранее, кишечный эпителий находится на переднем крае взаимодействия организма-хозяина как с комменсальными, так и с патогенными микробами. В физиологических условиях взаимодействие PRR энтероцитов с консервативными структурами микробов индуцирует продукцию молекул, которые подавляют развитие воспаления. Адаптивный иммунный ответ на безвредные микробы также предотвращаются. Взаимодействие TLR2 энтероцитов с микробиотой приводит к синтезу этими клетками TGF $\beta$ и TSLP, которые способствуют формированию толерогенных DCs, продуцирующих противовоспалительный цитокин IL-10 и индуцирующих дифференцировку iTreg. Продукция энтероцитами TSLP необходима для нормального иммунного гомеостаза кишечника, поскольку этот цитокин подавляет выработку IL-12 зрелыми DCs. Таким образом, в кишечнике любая активированная Т-клетка с большей вероятностью поляризуется в сторону Th2, a не Th1 или Th17, что способствует развитию иммунных реакций, при которых вероятность повреждения кишечного эпителия не высока.

Наиболее хорошо изученным диетическим фактором, определяющим толерогенные свойства DCs кишечника, является метаболит витамина А ретиноевая кислота (РА). Стромальные клетки кишечника, эпителиальные клетки и DCs обладают способностью превращать витамин А в РА благодаря экспрессии ретинальдегиддегидрогеназы (RALDH). PA оказывает плейотропное действие на иммунную систему кишечника. PA поддерживает определенную функциональную программу, индуцируя как в $\mathrm{DDC} 1$, так и в $\mathrm{CDC} 2$, экспрессию RALDH и a4b7-интегрина. Продукция PA обеспечивает тропизм лимфоцитов к кишечнику, индуцируя экспрессию интегрина $\alpha 4 \beta 7$ и рецептора хемокина CCR9 на этих клетках. Интегрин a4b7 и хемокиновый рецептор CCR9 служат молекулами хоуминга и обеспечивают миграцию клеток в кишку. Кроме того, PA способствует доминированию в кишке сDC2, а не cDC1 популяции.

В дополнение к PA, стимулировать экспрессию RALDH в DCs и эпителиальных клетках кишечника способны короткоцепочечные жирные кислоты - бутираты и пропионаты, генерируемые из пищевых волокон (Рис.92). Короткоцепочечные жирные кислоты способствуют индукции экспрессии Fохр3 в активированных «наивных» CD4+ T-лимфоцитах, что превращает их в iTregs. Это, в свою очередь, увеличивает в кишке количество Treg, тем самым, 
способствуя развитию оральной толерантности. Индуцированная РА, экспрессия CCR9 на Tregs, наделяет их способностью мигрировать из мезентериальных ЛУ в lamina propria кишечника.

При развитии воспаления из-за травмы или инфекции, в lamina propria привлекаются новые DCs, «не подвергнутые» толерогенным сигналам микроокружения кишечника. Распознавание этими клетками PAMPs/DAMPs приводит к их активации, созреванию и приобретению провоспалительного фенотипа. В этом случае, DCs будут презентировать процессированные антигены и экспрессировать необходимый набор ко-стимуляцонных молекул на своей поверхности для активации Т-клеток слизистой оболочки. Зрелые DCs могут мигрировать из купола Пейровой бляшки в дренирующий мезентериальный лимфатический узел, где будут презентировать антигены, активировать «наивные» Т- лимфоциты с вовлечением в иммунный ответ Вклеток и развитием системных реакций на слизистых.

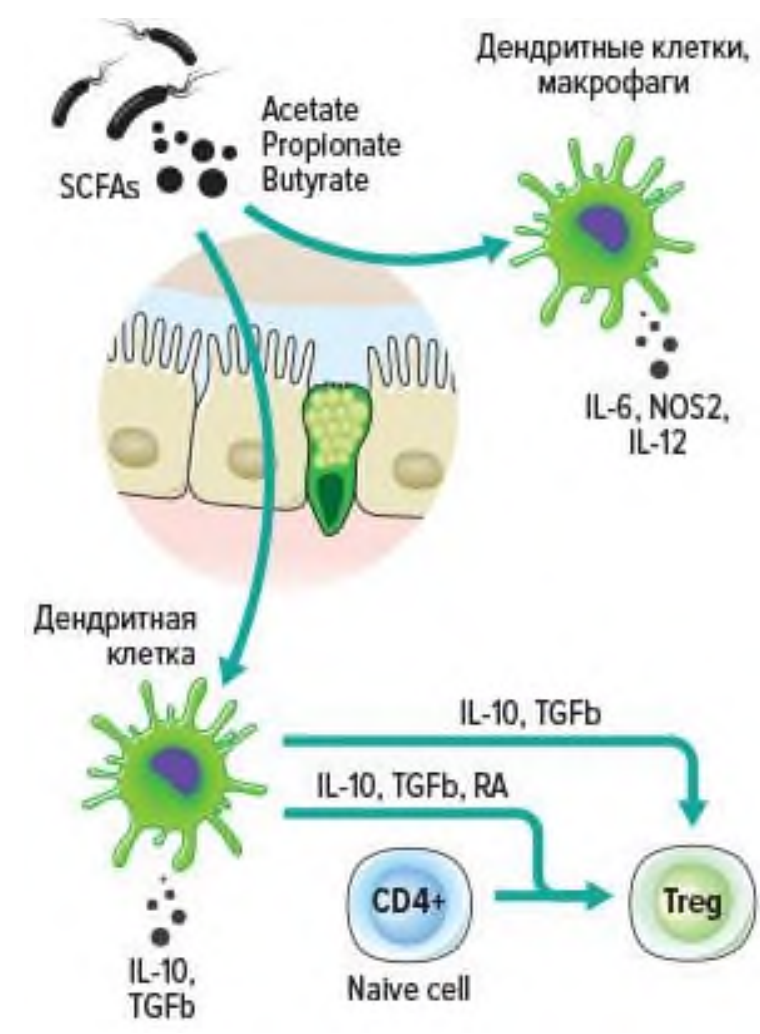

\section{Рис. 92. Участие сDC1 и сDC2 в развитии $\mathrm{T}$ - клеток.}

Метаболиты микробиоты (короткоцепочечные жирные кислоты: ацетаты, пропионат, бутират) подавляют воспаление, индуцируя продукцию TGF- $\beta$.

Под влиянием TGF- $\beta$ который в изобилии продуцирует микроокружение, макрофаги и DCs приобретают уникальный фенотип, который позволяет продуцировать противоспалительные цитокины и индуцировать дифференцировку в Tregs. Дифференцировке в Tregs также способствует локальная продукция ретиноевой кислоты CD103+ дендритными клетками и макрофагами, экспрессирующими ретинолдегидрогеназу. Кроме того, короткоцепочечные жирные кислоты подавляют эеспрессию HDAC (Histone deacetylase) и провоспадителные свойства макрофагов и DCs.

\section{Особенности лимфоидной ткани, связанной с носоглоткой и бронхами (NALT и BALT).}

NALT и BALT обеспечивают иммунную защиту от вредных факторов и патогенов во вдыхаемом воздухе. NALT включает в себя железы в подслизистой оболочке носа (гланды), миндалины и эпителий, выстилающий носоглотку (верхних дыхательных путей). К BALT относятся железы подслизистой 
оболочки бронхов, эпителий, выстилающий трахею, бронхи, легкие, а также фолликулы и диффузные скопления лимфоцитов, лежащие в основании эпителия нижних дыхательных путей. Бронхи и легкие покрыты однослойным цилиндрическим эпителием, типичным для слизистых оболочек I типа. Большую часть носоглотки защищает слизистая оболочка II типа. Волосы в носу представляют собой первый механический барьер на пути крупных вредных факторов, проникающих в NALT. Кроме того, биение ресничек на эпителиальных клетках верхних дыхательных путей и такая сложная поведенческая реакция как кашель также мешают проникающим в верхние дыхательные пути патогенам закрепиться на эпителии.

Эпителий носоглотки покрыт слоем слизи, содержащей $\operatorname{sg} \mathrm{A}$, лактоферрин, лизоцим и другие антимикробные молекулы, и защитные факторы, а также поддерживает развитие симбиотических микробов. В условиях стресса эпителиальные клетки носоглотки сами могут секретировать воспалительные цитокины и хемокины, которые быстро активируют и привлекают клетки врожденного иммунитета в участок проникновения патогена. Аналогичная защитная стратегия присутствует в BALT. Бронхиальные и бронхоальвеолярные эпителиальные клетки являются важными источниками IL-5, IL-6, IL-10 и TGF $\beta$, которые способствуют дифференцировке плазматических клеток и переключению изотипов секретируемых иммуноглобулинов на IgA. Кроме того, бронхиальные и бронхоальвеолярные эпителиальные клетки секретируют коллектины - SP-A и SP-D, которые способны опсонизировать патогенные бактерии и усиливать их фагоцитоз. Связывание SP-A и SP-D с TLR на лейкоцитах также стимулирует продукцию провоспалительных цитокинов. В NALT миндалины являются наиболее важными индукторными участками. Миндалина состоит из сети ретикулярных клеток, которые поддерживают лимфоидные фолликулы и межфолликулярную ткань. Фолликулы содержат зародышевые центры, заселенные фолликулярными DCs и многочисленными Влимфоцитами. В межфолликулярных областях содержится большое количество $\alpha \beta$-Т-клеток и профессиональных АПК. Интересно, что миндалины также, повидимому, служат эффекторными сайтами в NALT, потому что высокие концентрации зрелых плазматических клеток, экспрессирующих IgG, IgM и IgA, обнаруживаются в этих структурах. Многие индукторные сайты в BALT структурно схожи с теми, что находятся в кишечнике. Группы фолликулов слизистой оболочки, напоминающих Пейеровы бляшки и лежащие в их основании М-клетки, можно обнаружить в lamina propria бронхиального эпителия (Рис.93).

\section{Захват антигенов, их презентация и развитие иммунного ответа.}

Считается, что поглощение антигена в дыхательных путях происходит легче, чем в GALT, потому что в дыхательных путях отсутствуют ферменты и низкий уровень $\mathrm{pH}$, характерный для кишечника. В слизистых оболочках дыхательных путей I типа, выстланных однослойным эпителием, забор антигена 


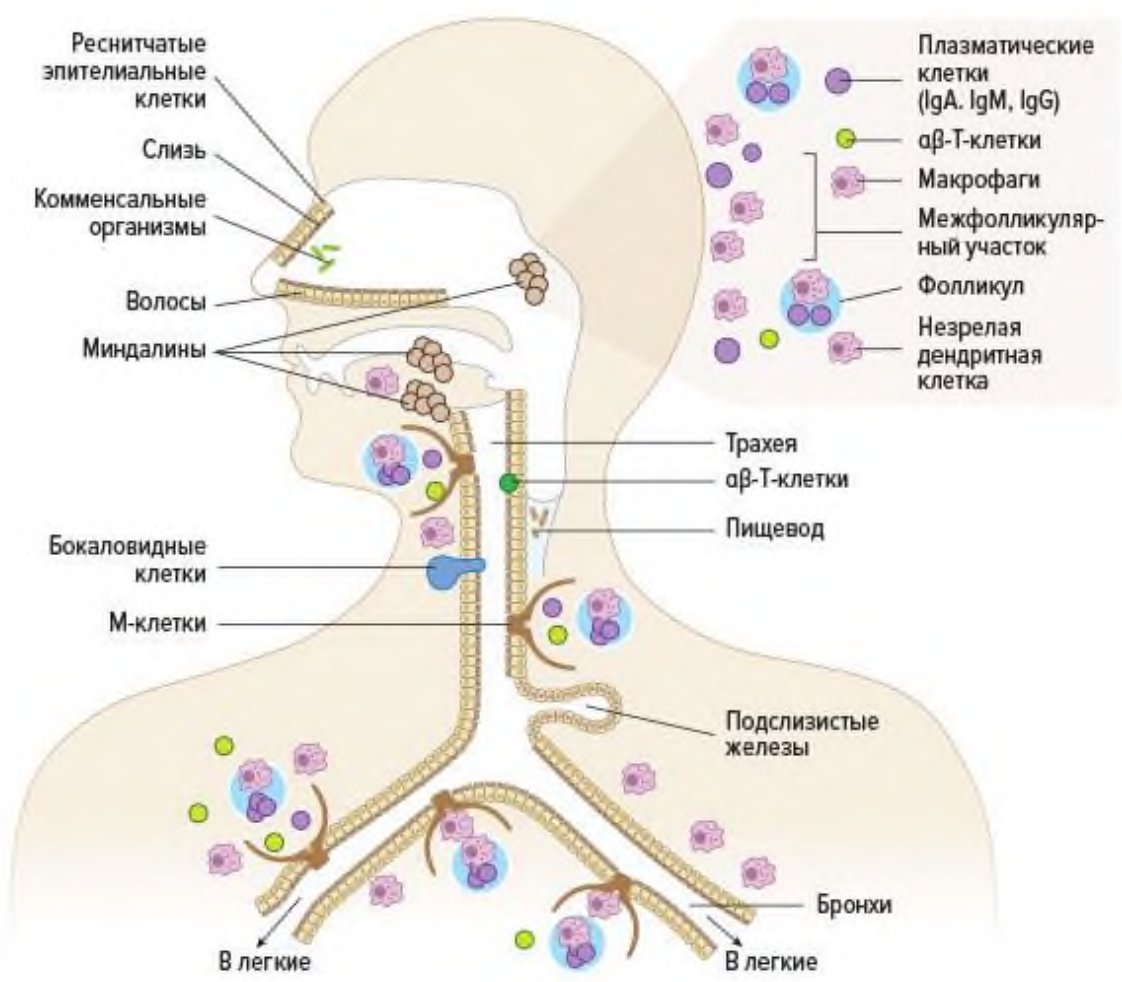

\section{Рис. 93. Компоненты NALT/BALT.}

$\begin{array}{lr}\text { Иммунная } & \text { защита в } \\ \text { лимфоидных } & \text { тканях, } \\ \text { связанных с } & \text { носоглоткой и } \\ \text { бронхами, } & \text { опосредована } \\ \text { различными } & \text { элементами } \\ \text { врожденного } & \text { и } \\ \text { идаптивного } \\ \text { имунитета, } \\ \text { врожденные } & \text { включая } \\ \text { механизмы } & \text { бащерные } \\ \text { защиты, }\end{array}$ комменсальные организмы и клеточные элементы врожденного и адаптивного иммунитета, в фолликулоассоциированом эпителии и в миндалинах.

может осуществляться М-клетками. В миндалинах и областях дыхательных путей, покрытых слизистой оболочкой II типа, антигены транспортируются к индукторным сайтам DCs различных популяций, которые могут образовывать длинные отростки между эпителиальными клетками в просвет дыхательного тракта и захватывать вдыхаемые антигены. После захвата антигена DCs созревают и мигрируют в нижележащие диффузные лимфоидные ткани в lamina propria, чтобы инициировать местный иммунный ответ, или мигрируют в дренирующие лимфатические узлы, чтобы инициировать системный иммунный ответ слизистых.

Большая часть наших знаний об иммунных реакциях слизистой оболочки происходит из исследований GALT. Однако считается, что такие же принципы лежат в основе развития иммунных реакций в NALT и BALT.

\section{Развитие иммунного ответа на патогены в MALT}

Слизистая оболочка кишечника, пожалуй, самая сложная иммунологическая среда в организме человека. Кишечные эпителиальные клетки и клетки-резиденты врожденного и адаптивного иммунитета находятся в постоянном состоянии взаимодействия с триллионами кишечных микробов. Взаимодействия хозяина и микроба способствуют здоровому иммунному гомеостазу кишечника. Хотя микробиота кишечника состоит из сотен видов микробов, имеются данные, указывающие на то, что существуют ключевые штаммы бактерий, необходимые для поддержания баланса между 
воспалительными и противовоспалительными реакциями. Структурные компоненты бактерий (например, ЛПС, флагеллин), молекулы, высвобождаемые некротическими эпителиальными клетками хозяина (например, АТФ), а также PRRs клеток организма-хозяина и секретируемые цитокины влияют на иммунную регуляцию в кишечнике. Общее состояние кишечника определяют очень сложные и динамичные процессы, которые, с одной стороны, должны ограничивать повреждение кишечника и воспаление и, с другой стороны, быть готовым ответить воспалением и адаптивным иммунитетом в случае нападения опасного патогена.

\section{Развитие реакций врожденного иммунитета на патогены.}

Врожденные лимфоциты, находящиеся в эпителиальном слое и подслизистой оболочке, являются ключевыми сенсорами сигналов нарушения эпителиального барьера.

$\gamma \delta$-Т-лимфоциты составляют основной компонент пула лимфоцитов кишечного эпителия. Последние данные указывают на то, что эти клетки очень подвижны и активно «сканируют» эпителий на наличие признаков клеточного стресса. Как уже отмечалось ранее, $\gamma \delta$-Т-клетки распознают на клетках эпителиальных пластов наличие стресс-молекул МICA и MICB, которые функционируют как триггеры цитотоксичности. Так, МICA и МICВ активируют цитотоксические NK-подобные IELs и NK-клетки через NKG2D и CD94/NKG2C рецепторы. Контакт эпителиальных клеток с кишечными бактериями может индуцировать экспрессию $\gamma \delta$-Т-клетками антимикробных пептидов. $\gamma \delta$-Т-клетки могут проявлять широкую цитотоксическую активность в отношении инфицированных клеток, которая обусловлена взаимодействием FasL c FasR на клетках-мишенях и продукцией перфорина/гранзима для дестабилизации клеточной мембраны с индукцией апоптоза. $\gamma \delta$-Т-клетки также секретируют различные цитокины и хемокины, включая провоспалительные Th1 цитокины, такие как IFN- $\gamma$ и TNF- $\alpha$, необходимые для активации DCs и Th1. Благодаря этим цитотоксическим свойствам $\gamma \delta$-Т-клетки, наряду с CD8+ T- и NK-клетками, являются мощным инструментом элиминации зараженных вирусами и внутриклеточными бактериями клеток.

Активация NK- и NKT-клеток также происходит при распознавании микробов с помощью PRR и/или Т-клеточного рецептора. NK-клетки и NKTклетки, расположенные среди энтероцитов, также играют важнейшую роль в защите первой линии, используя разнообразные эффекторные механизмы. Например, IL-15 играет ключевую роль в усилении цитолитической активности IELs за счет увеличения экспрессии на эпителии кишечника MICA и MICB. Продукция IL-15 приводит к цитотоксическому поражению эпителиальных клеток и повышению проницаемости кишечника для различных люминальных макромолекул, включая иммуногенные пептиды глютена.

Если устойчивое состояние организма-хозяина нарушается из-за травмы или атаки агрессивных патогенов или под воздействием токсинов, связывание 
PRRs на энтероцитах, c PAMPs/DAMPs активирует эти клетки для выработки «аларминов» (IL-1 $\beta$ при инфекции Candida sp.., IL-33, IL-25, TSLP - при глистной инвазии или IL-12 - при вирусной инфекции), а также привлекает из циркуляции к месту инфекции DCs и другие, соответствующие каждому типу воспаления (см. в других разделах) клетки врожденного иммунитета (моноциты, нейтрофилы, эозинофилы и т.д.). Нейтрофилы, наряду с дегрануляцией и фагоцитозом, продуцируют IL-18, который в сочетании c IL-12, продуцируемым DCs, стимулирует NK-клетки к высвобождению IFNg. IFNg активирует DCs и макрофаги и усиливает выработку воспалительных цитокинов. Оксид азота, вырабатываемый активированными фагоцитами, особенно эффективен в ингибировании репликации вируса и может изменять $\mathrm{pH}$ микроокружения. Нейтрофилы также захватывают внеклеточные бактерии в нейтрофильные внеклеточные ловушки, которые состоят из хроматинового каркаса, связанного c антимикробными белками азурофильных и специфических гранул. Исследования реакций врожденного иммунитета в BALT показали, что большое количество нейтрофилов, рекрутированных в места бактериальной инфекции в легких, может быть столь же разрушительным, как и действие патогенов, которых они пытаются уничтожить. Хотя эти лейкоциты жизненно важны для защиты от таких видов бактерий, как Klebsiella pneumoniae и Streptococcus pneumoniae, накопление слишком большого количества нейтрофилов может привести к острому повреждению ткани легких или острому респираторному дистресс-синдрому. Избыток IL-18, высвобождаемый активированными нейтрофилами, может стимулировать другие лейкоциты для продукции провоспалительных цитокинов. Повреждению нежной слизистой оболочки легких способствует разрушение внеклеточных бактерий в нейтрофильных ловушках, которое вызывает высвобождение большого количества микробных веществ.

Система приобретенного иммунитета при реакции на патогены.

Специфический гуморальный иммунный ответ слизистых оболочек формируют секреторные антитела класса A (sIgA).

Большинство слизистых оболочек, особенно слизистые оболочки I типа в кишечнике и легких, по своей природе являются «хрупкими», так что они легко могут быть повреждены продуктами патогенов во время развития воспалительных реакций. По этой причине иммунитет слизистой оболочки в значительной степени формируют секреторные антитела и, в первую очередь, секреторный иммуноглобулин класса A (sIgA). Эти антитела являются ключевыми компонентами слизи и других жидкостей организма барьерных тканей, таких как слюна и слезная жидкость, и защищают от патогенных микроорганизмов. Хотя $\operatorname{sgM}$ присутствует в некоторых жидкостях организма, 
подавляющее большинство секреторных антител - это sIgA. Мыши, неспособные продуцировать SIgA из-за нарушения C альфа-экзона или дефектов синтеза Ј-цепи, демонстрируют повышенную восприимчивость к инфекции и неблагоприятным изменениям состава микробиоты. Секреторный IgA имеет несколько особенностей, которые делают его идеальным для защиты слизистой оболочки. Во-первых, sIgA конститутивно локализуются в слизи, для нейтрализации практически любого патогена или токсина, способного вступить в контакт с эпителием. Во-вторых, независимо от антигенной специфичности, углеводные фрагменты С-доменов молекул $\operatorname{sg} A$ могут связываться с молекулами адгезии, экспрессируемыми многими патогенами. В-третьих, по крайней мере, в кишечнике около половины всех антител sIgA обладают способностью перекрестно реагировать с большим количеством эпитопов. Это означает, что более широкому спектру угроз можно противостоять с помощью меньшего количества антител. В-четвертых, sIgA не являются эффективными активаторами комплемента, что снижает вероятность активации этого каскада и инициации повреждающего воспаления при формировании комплексов антигенантитело. В-пятых, sIgA обладает высокой устойчивостью к широкому спектру протеаз хозяина и микробов, в том числе, в кишечнике млекопитающих.

\section{Механизмы выработки SIgA слизистой оболочки}

Энтероциты, взаимодействуя с комменсальными бактериями, продуцируют цитокины, которые индуцируют продукцию В клетками sIgA

Выработка sIgA в организме намного превышает выработку антител любого другого изотипа. В среднем, в кишечнике взрослого человека ежедневно синтезируется около 2-3 граммов sIgA. sIgA-продуцирующие плазматические клетки присутствуют в кишке даже в отсутствие патогенов из-за влияния микробиоты на В-клетки слизистой. Постоянная продукция sIgA держит численность комменсалов под контролем, защищая слизистые оболочки и поддерживая гомеостаз.

В случае Т-зависимых реакций, $\mathrm{cDC}$ способствуют формированию высокоаффинных IgA не только к комменсальной микробиоте, но и к патогенам и их токсинам. cDC в Пейеровых бляшках регулируют процессы переключения класса синтезируемых антител на $\operatorname{IgA}$, а также экспрессию рецепторов «хоуминга» в ткани слизистых на IgA продуцирующих плазматических клетках и их предшественниках.

Энтероциты слизистых оболочек также играют важную роль в продукции sIgA (Рис.94). Когда энтероциты с помощью PRR (особенно TLR2) связываются с комменсальными бактериями, это вызывает продукцию цитокинов BAFF (от англ. «B-cell-activating factor belonging to the TNF family»), APRIL (от англ. «а proliferation inducing ligand») и IL-10, которые индуцируют в 80\% активированных В-клеток lamina propria переключение изотипа иммуноглобулинов именно на $\operatorname{IgA.}$ 

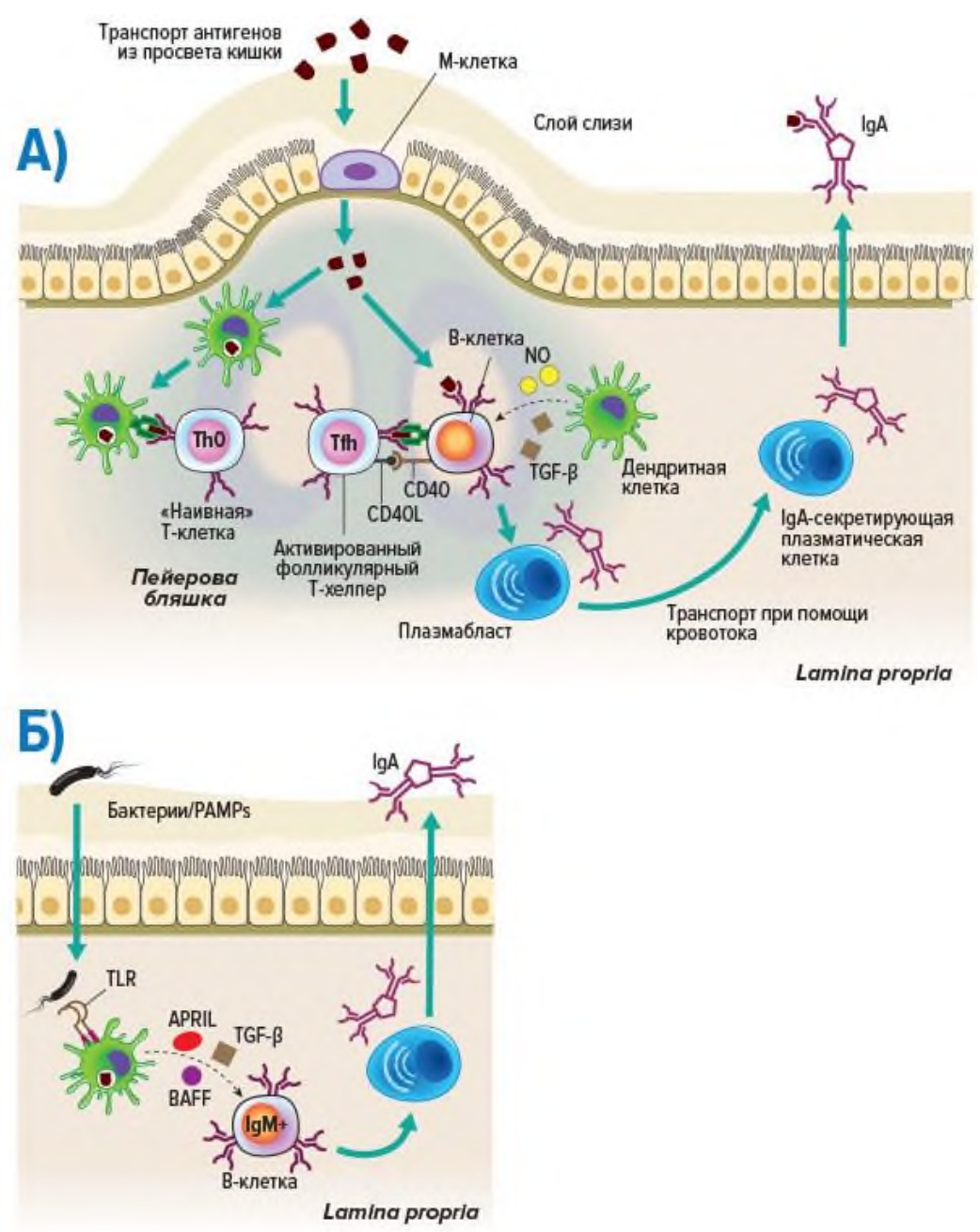

\section{Рис. 94 Переключение} выработки SIgA.

А. Переключение на IgA происходит при связывании APRIL (DCs и эпителий) с TACI -рецептором на В-клетках. Эпителиальные клетки кишечника также продуцируют TSLP, который стимулирует продукцию APRIL дендритными клетками.

Эпителий и DCs продуцируют TGF- $\beta$. TLR лиганды, производимые комменсальными бактериями также индуцируют выработку NO, который тоже способствует выработке IgA. Наконец, выработка IgA зависит от ретиноевой кислоты, которая производится клетками эпителия и DCs, экспрессирующими ретинолдегидрогеназу RALDH.

В. Переключению класса $\operatorname{IgA}$ способствуют сигналы от TLR.

Энтероциты также выделяют TSLP, который усиливает выработку BAFF, APRIL и IL-10. Кроме того, cDC2, которые находятся в куполе Пейеровых бляшек мышей, секретируют высокие уровни IL-10. Презентация DCs антигенов в присутствии IL-10 индуцирует поляризацию «наивных» Т лимфоцитов в Tfh; регуляторные Т-клетки, секретирующие TGF $\beta$ и IL-10; и Th2-эффекторы, синтезирующие IL-4, IL-5 и IL-10. Одновременно поляризация в Th1 и продукция IFNg подавляются. При распознавании TLR5 флагеллина, DCs начинают экспрессировать фермент ретинолдегидрогеназу, который конвертирует витамин А в ретиноевую кислоту. Ретиноевая кислота, TGF $\beta$ и IL10 направляют переключение изотипов иммуноглобулинов в активированных Вклетках в сторону IgA. В-лимфоциты циркулируют через лимфу и кровь в эффекторные сайты слизистой оболочки (напр. мезентериальные лимфоузлы). В этих местах активированные В-клетки завершают свою дифференцировку в зрелые IgA-продуцирующие плазматические клетки.

Плазматические клетки секретируют полимерный $\operatorname{IgA}$ вблизи базолатеральной поверхности эпителиальных клеток, выстилающих кишечник, а также клеток, образующих экзокринные железы. Полимерный IgA связывается 
с поли-иммуноглобулиновым рецептром или pIgR (от англ. «poly-Ig receptor») на базальной поверхности клеток эпителия в эффекторных участках слизистой оболочки и переносится при помощи трансцитоза на апикальную поверхность клеток. При экзоцитозе $\mathrm{pIgR}$ расщепляется таким образом, что секреторный компонент остается прикрепленным к антителу, что приводит к высвобождению комплекса $\operatorname{sg}$ А в слизь (Рис.95)

IgA транспортируются с базальной на апикальную поверхность эпителия. IgA продуцируется в ламина проприа в форме димера, Fcфрагменты мономеров, которого ковалентно связаны с J цепью. Димерный $\operatorname{IgA}$ транспортируется из ламина проприа в просвет кишечника. Этот транспорт осуществляется с помощью poly-Ig рецептора на базальной и апикальной поверхности эпителиальных клеток. Секреторный компонент связывается с бактериями и снижает их подвижность.

Плазматические клетки мыши продуцируют только один подкласс $\operatorname{IgA}$, но у человека продуцируется IgA1 и IgA2, которые отличаются некоторыми своими свойствами. В то время как выработка IgA1 происходит

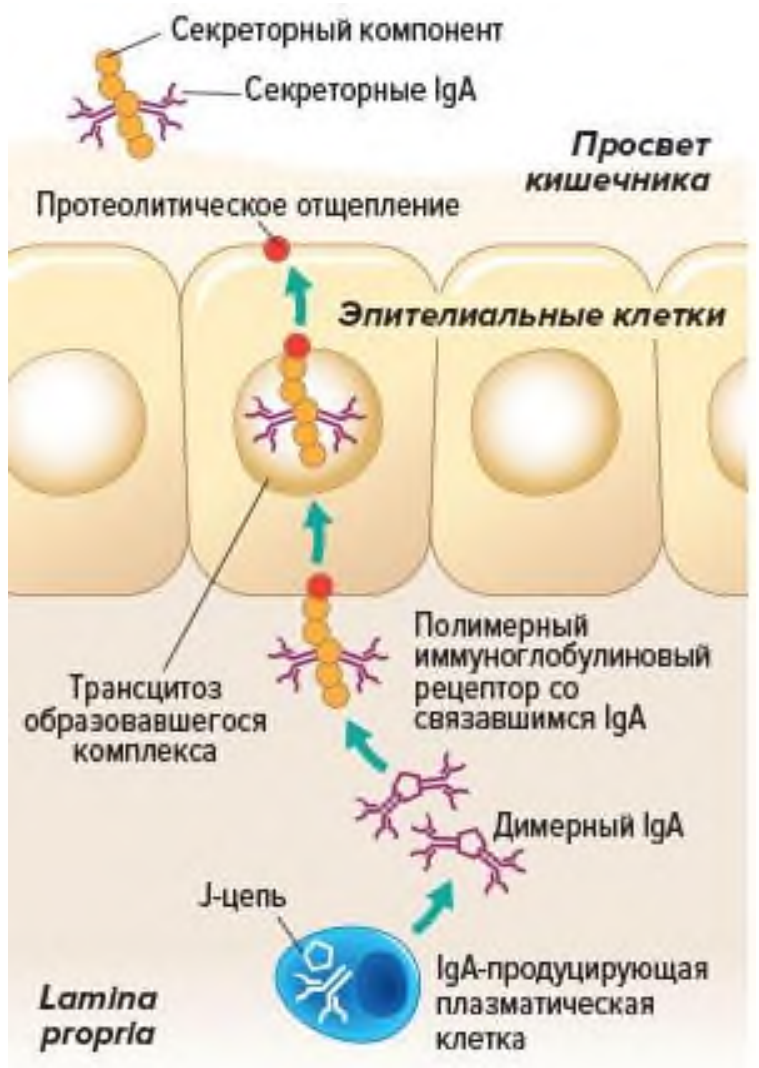
как системно, так и на слизистых, IgA2 присутствует главным образом на слизистых поверхностях (особенно в дистальном отделе кишечника и урогенитальном тракте). Благодаря более короткой области шарнира IgA2 более устойчив, чем IgA1, к деградации протеазами, что позволяет этому антителу обеспечивать устойчивую защиту в суровой биохимической среде.

Th1 тип адаптивного иммунитета имеет решающее значение для защиты от внутриклеточных патогенов

Адаптивный иммунный ответ, опосредованный Th1 и цитотоксические CD8+ T-лимфоцитами, имеет решающее значение для защиты от внутриклеточных патогенов, таких как ротавирусы, норовирусы, Listeria monocytogenes, Citrobacter rodentium, Toxoplasma gondii и Tritrichomonas musculis. Развитие Th1 ответа регулирует популяция $\mathrm{cDC1}$, расположенная в 
межфолликулярных областях Пейеровых бляшек. Эти интерфолликулярные DCs преимущественно продуцируют IL-12, который индуцирует поляризацию Tклетки слизистой оболочки в Th1-эффекторы и активацию CD8+ T-лимфоцитов. Некоторые из межфолликулярных DC также могут мигрировать в дренирующий лимфатический узел и активируют наивные Т-клетки в этом месте, индуцируя системный Th1-ответ против патогена. Локальная продукция IFNg и связывание CD40 могут синергично с сигналами от PRR стимулировать продукцию IL-12. Неконтролируемые Th1-реакции в кишечнике могут приводить к значительным повреждениям собственных тканей и провоцировать развитие Th1опосредованного колита.

Th2 тип адаптивного ответа эффективен в отношении гельминтов и развивается при аллергических заболеваниях

Th2 тип ответа эффективен в отношении гельминтов и развивается при аллергических заболеваниях. Было обнаружено, что преимущественно сDC2 индуцируют Th2-реакции in vivo и in vitro. В ответ на Nippostrongylus brasiliensis, Trichuris muris и Schistosoma mansoni мыши с дефицитом cDC2 демонстрируют снижение IL-4, IL-5 и IL-13-продуцирующих Th2-клеток в мезентериальных ЛУ и lamina propria кишечника. Th2-клетки, которые продуцируют IL-4, IL-5 и IL13, индуцируют рекомбинацию переключение продукции IgE-класса антител и эозинофильно-опосредованное воспаление. Тонкий кишечник является основным резервуаром для эозинофилов, которые контролируют активацию cDC2 и Th2 поляризацию. Недавно было установлено, что CD103+CD11b+cDC2 индуцируют Th2-реакции в тонком кишечнике, тогда как CD103-CD11b+ cDC2 выполняют эту роль в толстой кишке. Кроме того, ILC2, которые продуцируют IL-13, способствуют миграции активированных DCs из легких в ЛУ средостения во время первичной аллергической реакции и индуцируют продукцию хемокина CCL17, привлекающего Th2 и CD103+CD11b+cDC2. Роль ILC2 в регуляции Th2-ответа в кишечнике не исследована. Ретиноевая кислота подавляет аллергические реакции на пероральные АГ, предотвращая поляризацию Th2клеток.

\section{Th17 тип адаптивного ответа обеспечивает защиту от внеклеточных патогенов}

Th17 тип адаптивного ответа обеспечивает защиту от внеклеточных патогенов, например, грибов Candida albicans или бактерий Salmonella typhimurium, C.rodentium и Yersinia enterocolitica. Поддержание Th17 ответа в кишечнике зависит от сигналов микробиоты, в частности, сегментированных нитевидных бактерий. В исследованиях in vitro было показано, что активирован- 


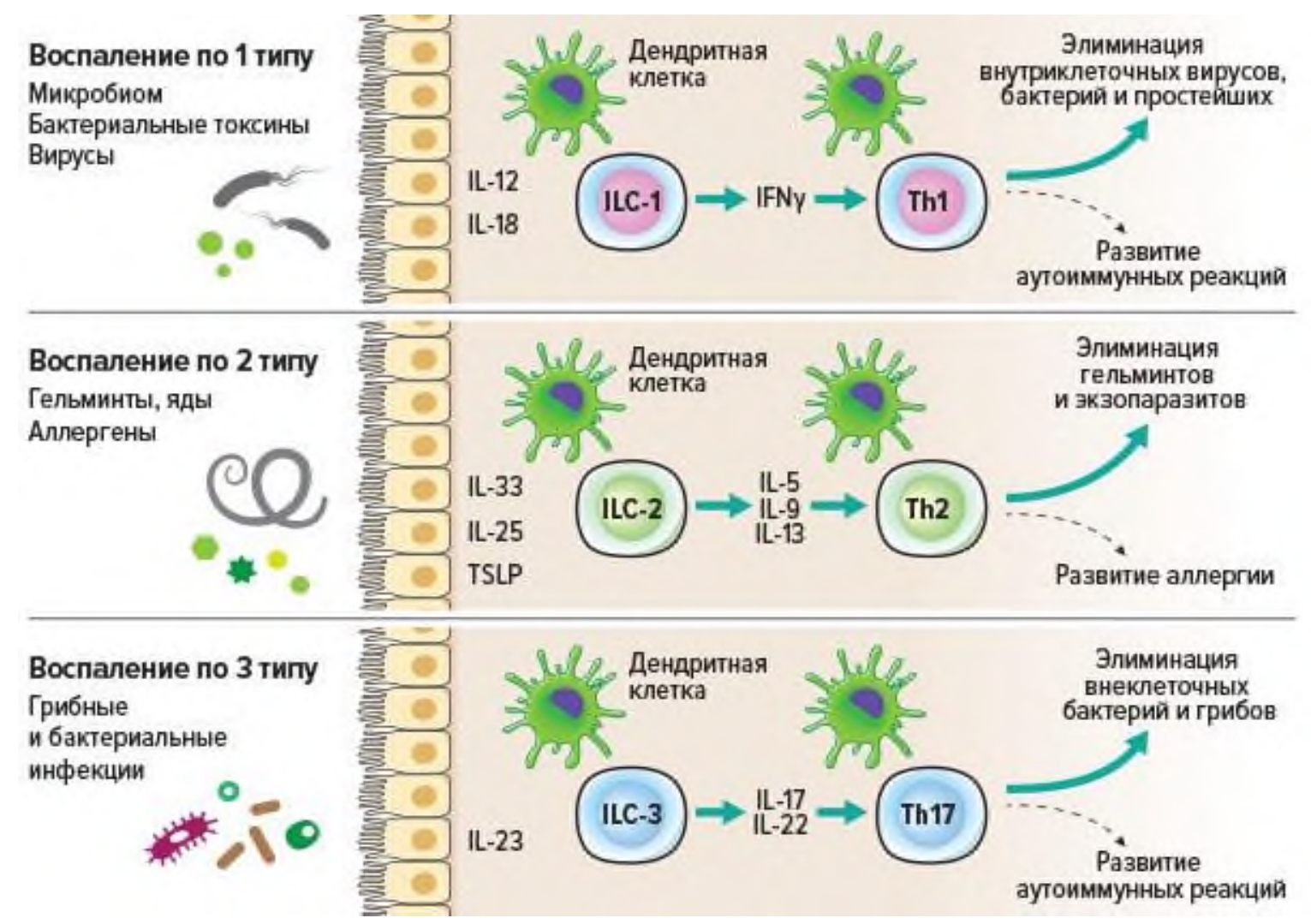

Рис. 96 Типы иммунного ответа, в зависимости от типа патогена.

В зависимости от патогена и цитокинов, которые продуцируют клетки эпителия кишечника происходит активация соответствующей популяции ILCs, которая продуцируют цитокины, активирующие, соответствующие клетки- эффекторы врожденного иммунитета. В зависимости от патогена и цитокинов, которые продуцируют DCs происходит поляризация адаптивного иммунного ответа в сторону Th1, Th2 или Th17. Неконтролируемая активация Th может приводить к развитию патологий (пунктирные стрелочки).

ные зрелые DCs GALT направляют поляризацию «наивных» активированных CD4+ T-клеток преимущественно в сторону Th17. Недавние исследования на мышах показали, что микробиота может оказать влияние на формирование иммунитета в GALT. Например, мыши, выращенные в стерильных условиях, не имеют микробиоты в кишечнике и обладают неразвитой GALT, аномально высоким количество Th2-клеток и аномально низкими уровнями Th1- и Th17клеток. На энтероцитах у этих животных наблюдается снижение экспрессии TLR, и их DCs не могут формировать трансэпителиальные отростки.

Эффеторные клоны Т- и В-лимфоцитов, сформировавшись в одном индукторном сайте слизистых, могут через кровь мигрировать в любые эффекторные сайты слизистых

Для индукции и дифференцировки клеток Th17 требуется сочетание TGFb вместе c IL-6 или IL-21, тогда как для экспансии и поддержания Th17 ответа требуется IL-23. Как CD103+CD11b+, так и CD103-CD11b+ cDC2 могут 
индуцировать поляризацию «наивных» CD4+ Т-клеток в Th17. CD103+CD11b+ cDC2 cDC2 в значительной степени отвечают за дифференцировку и поддержание Тh17-клеток в МЛНС и ЛП тонкого кишечника.

В ответ на распознавание антигена Th17 клетки продуцируют IL-17 и IL22, которые индуцируют секрецию клетками эпителия и нейтрофилами антимикробных субстанций, усиливают барьерные свойства эпителия. Как и в кишечнике, продукция IL-17 очень важна для защиты от бактерий в легких. Преобладающими источниками этого цитокина в NALT/BALT являются легочные Th17-клетки и $\gamma \delta$-Т-клетки, стимулированные IL-23. Th17 в GALT и NALT/BALT также продуцируют IL-22, который в сочетании с IL-17 индуцирует секрецию провоспалительных цитокинов клетками эпителия кишечника и бронхов. Микробиота не только способствует дифференцировке Th17-клеток в GALT, но и может модулировать их активность. Кишечные эпителиальные клетки, в ответ на распознавание определенных компонентов комменсальных микробов, секретируют IL-25, который ингибирует продукцию IL-23 клетками в lamina propria. А без достаточного количества IL-23 пролиферация Th17-клеток блокируется. Эта регуляторная петля обратной отрицательной связи, возможно, эволюционировала, чтобы защитить кишечник от неконтролируемых Th17реакций, которые могут привести к колиту (тяжелому воспалению кишечника).

Было замечено, что инвазия патогена в одном месте в кишечнике может привести к появлению специфических $\operatorname{sgA}$ не только в кишечнике, но и в дыхательных путях, слюнных, слезных железах, глазной ткани, среднем ухе и даже в лактирующих молочных железах. Точно так же интраназальное введение антигена может привести к обнаружению антигенспецифических SIgA в слюне, миндалинах, трахее, легких и кишечнике. Эти наблюдения привели к появлению концепции, называемой общей иммунной системой слизистой оболочки (или CMIS, от англ. «common mucosal immune system»). Суть этой концепции в том, что эффеторные клоны Т- и В-лимфоцитов, сформировавшись в одном индукторном сайте слизистых (например в ЖКТ), могут через кровь мигрировать в любые эффекторные сайты слизистых, как ВНД, так и ЖКТ. В основе этого явления лежит тот факт, что миграция Т- и В-лимфоцитов из индукторного участка слизистой оболочки в эффекторные участки регулируется общими для всех слизистых рецепторами хоуминга. Эти рецепторы экспрессируют только те Т- и В-клетки, которые были «праймированы» (активированы) в индуктивных сайтах слизистых оболочек, и они отличаются от рецепторов «хоуминга», экспрессируемых Т- и В-клетками, «праймированными» в лимфатических узлах. Рецепторы «хоуминга» связываются с белками-адрессинами, экспрессируемыми исключительно в эффекторных участках слизистых оболочек. Например, обычная В-клетка, несущая рецептор «хоуминга» $\alpha 4 \beta 1$-интегрин, циркулирует и связывается с адрессином VCAM-1, который экспрессируется активированными эндотелиальными клетками в очагах воспаления. В отличие от этого, В-клетки

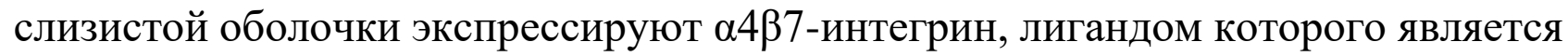
адгезионная молекула с MAdCAM-1, экспрессируемая только эндотелиальными 
клетками в слизистой оболочке. Поэтому В-клетки слизистой оболочки игнорируют участки в периферических тканях и, вместо этого, возвращаются в эффекторные участки слизистой оболочки, где молекулы $\alpha 4 \beta 7$-интегрина могут связываться с MAdCAM-1. CCR9 связывается с хемокином TECK, секретируемым эпителиальными клетками слизистой оболочки в эффекторных участках. На Т-клетках слизистой оболочки экспрессия $\alpha 4 \beta 7$-интегрина, а также хемокинового рецептора CCR9, индуцируются под влиянием DCs в индуктивных участках.

Иммунные реакции, индуцированные в различных участках эффекторов слизистой оболочки, развиваются с разной силой. Наиболее сильные реакции развиваются в тех участках, которые находятся ближе всего к индуктивному участку. Например, если Пейеровы бляшки в GALT являются индуктивным сайтом, сильный антительный ответ будет обнаружен в эффекторных сайтах в близлежащих слизистых оболочках в тонкой кишке (GALT), но в более отдаленных миндалинах (NALT) будет наблюдаться слабый ответ. И, наоборот, иммунный ответ, инициированный в NALT, индуцируют сильные антигенспецифические иммунные реакции в дыхательных путях, но гораздо более слабая реакция будет наблюдаться в кишечнике. Интересно, что появляется все больше доказательств того, что реакция на один патоген в одном индуктивном сайте может влиять на реакцию на совершенно другой патоген в другом индуктивном сайте. Например, у людей, инфицированных Mycobacterium tuberculosis, патогенной бактерией, вызывающей туберкулез, иммунный ответ в BALT зависит от иммунного ответа в GALT против других патогенов.

В одном исследовании пациентов с инфекциями M.tuberculosis исследователи обнаружили, что у человека, который также страдал от инфекции кишечными гельминтами (которые вызывают в преимущественно Th2 тип иммунного ответа), развивался слабый иммунный ответ против M.tuberculosis. Однако у человека, инфицированного M.tuberculosis и коинфицированного кишечной бактерией Helicobacter pylori (которая вызывает в основном Th1 тип ответа), наблюдался гораздо более сильный ответ против M. tuberculosis.

Различия вариантов ко-инфекции и эффективности CMIS у разных людей могут объяснить тот факт, что во всем мире более 2 миллиардов человек инфицированы M.tuberculosis, но только 20 миллионов человек страдают активным туберкулезом. 


\section{Глава 9. Идентификация микроорганизмов}

Идентификация микроорганизмов - определение принадлежности микроорганизмов к определенному виду, роду и т. д., основанное на изучении комплекса их биологических признаков (морфология, биохимическая активность, антигенные свойства, патогенность для человека и др.). Для этого используются различные методы лабораторной диагностики от относительно простой микроскопии до высокотехнологичной хромато-масс-спектрометрии (рис.97.). Каждый из этих методов имеет свои достоинства и недостатки и применяется в зависимости от цели исследования.

\section{Микроскопические}

Световая (светлого
поля, темнопольная,
фазово-контрастная,
люминесцентная
(флюоресцентная)) с
различными
способами
окрашивания и
электронная

морфологическое описание возбудителя

\section{Бактериологические}

Посев материала на питательные среды с последующим выделением чистой культуры возбудителя и определением его вида, оценка чувствительности к антибактериальным/ антимикотическим препаратам

описание культур, определение биохимической и биологической активности
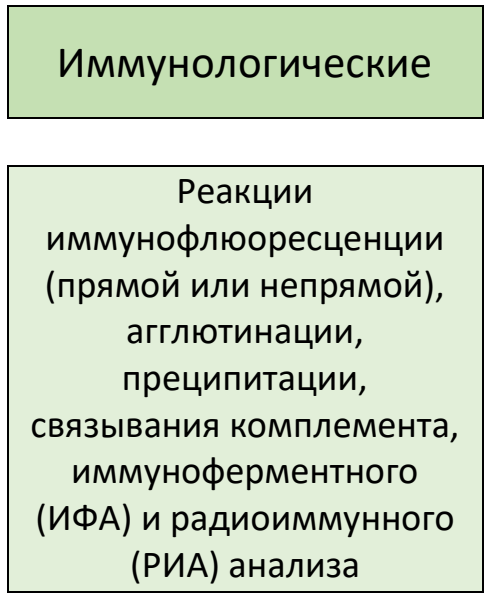

выявлением антигенов возбудителя или антител к возбудителю
Молекулярногенетические

Полимеразная цепная реакция (ПЦР), лигазная цепная реакция (ЛЦР), технология NASBA и др.

обнаружение ДНК/РНК или специфических молекул

Рис. 97. Методы идентификации микроорганизмов.

Микроскопические методы исследования дают возможность быстро обнаружить характерные морфологические особенности возбудителя и имеют важное диагностическое значение при диагностике ряда заболеваний. В основе современных лабораторных методов исследования лежит световая микроскопия с многочисленными еe разновидностями, такими как темнопольная, фазово-контрастная, люминесцентная и др. Электронная микроскопия, используемая для изучения более мелких объектов (вирусов и 
структур микроорганизмов), применяется в основном в крупных научноисследовательских институтах.

Препараты для световой микроскопии (нативные или окрашенные) готовят в момент взятия проб или сразу после поступления их в лабораторию.

Используя различные способы наблюдения и методы окраски, с помощью рутинной микроскопии, возможно идентифицировать большинство простейших, гельминтов, бактерий и грибов.

Нативная (световая, фазовоконтрастная и темнопольная) микроскопия позволяют рассмотреть возбудителей, не прибегая к фиксации

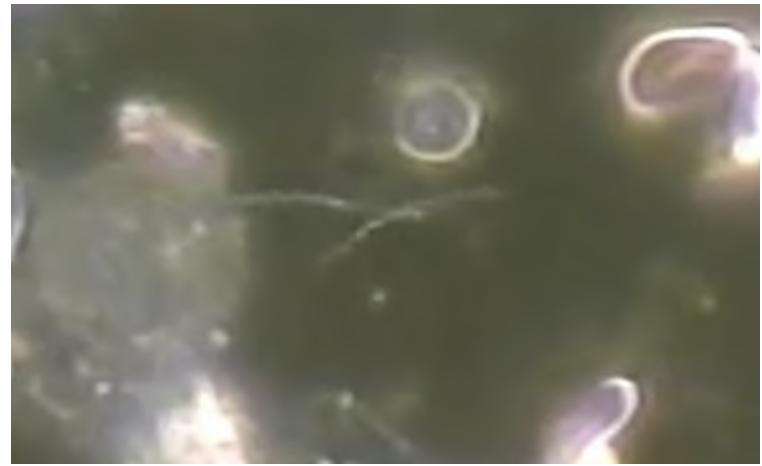

Рис.98. Treponema pallidum. Темнопольная микроскопия. и окраске (рис 98).

Микроскопическое исследование соскобов кожи, ногтевых пластинок, волосяных фолликулов используется для диагностики поверхностных микозов кожи, ее придатков и демодекоза. Выявление спор и мицелия дерматофитов, плесневых грибов (Scopulariopsis brevicaulis, Penicillium spp. и др.) или псевдомицелия дрожжеподобных грибов рода Candida и их сочетаний с очагов поражения ногтевых пластинок, кожи, волос является подтверждением микозов различной этиологии (рис. 99-100).

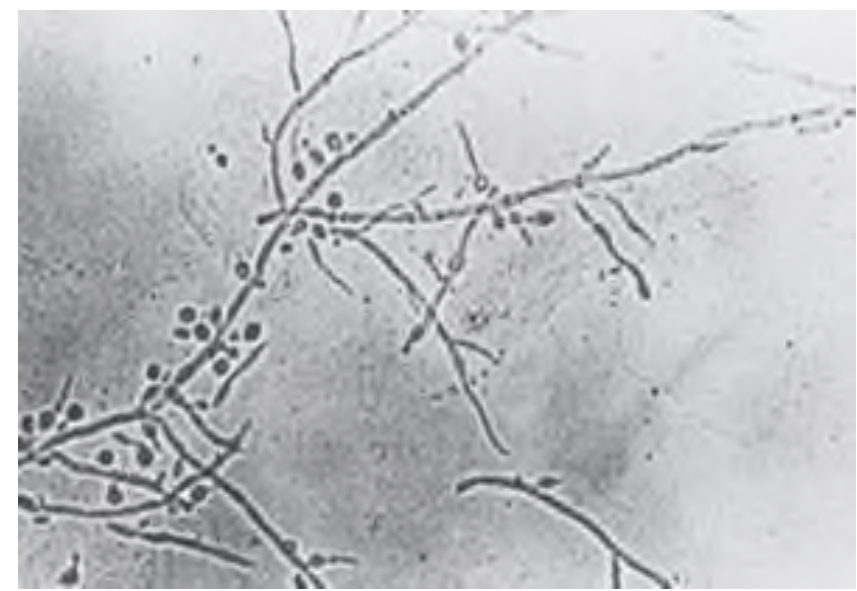

Рис.99. Грибы рода Candida, псевдомицелий, почкующиеся клетки. Нативная микроскопия.

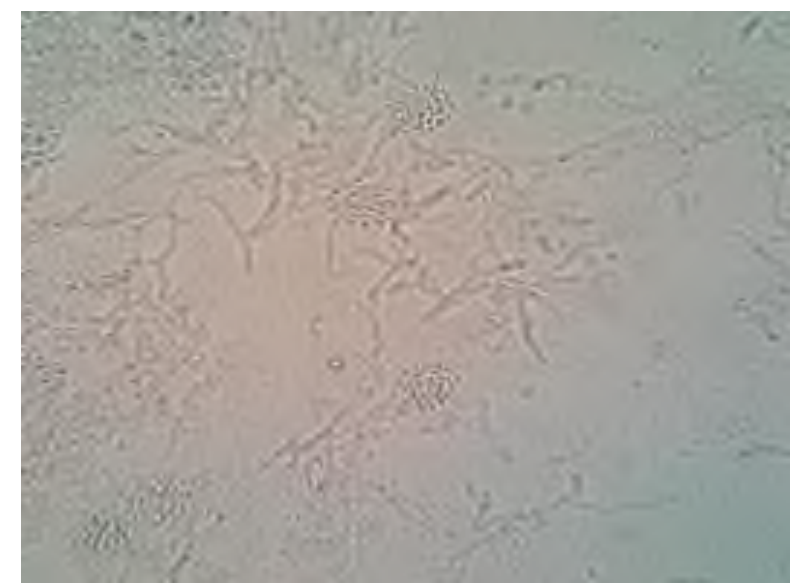

Рис.100 Malassezia furfur, отрубевидный (разноцветный) лишай. Соскоб кожи. Нативная микроскопия с 10\% $\mathrm{KOH}$.

Наличие в препарате клещей, личинок, яиц, пустых яйцевых оболочек клеща рода Demodex и Sarcoptes позволяют определить причину фолликулитов, акне, зудящихся высыпаний на коже (рис.101-102). 


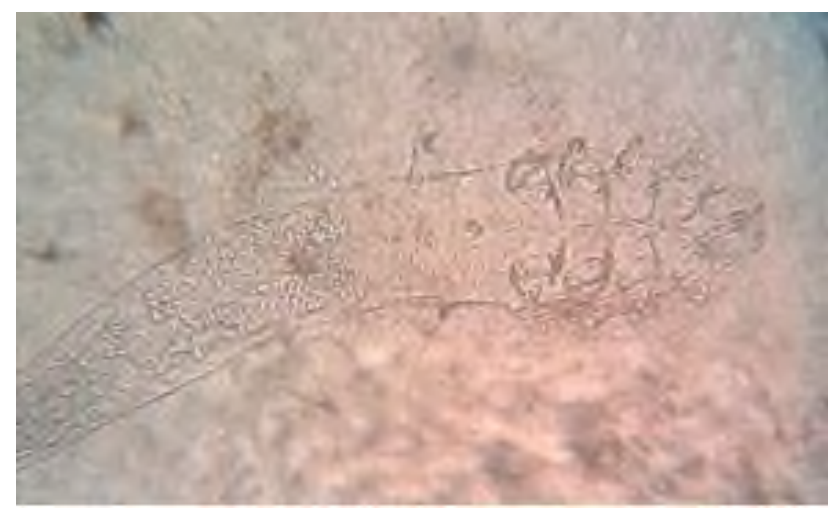

Pис.101. Demodex folliculorum

hominis. Нативная микроскопия.

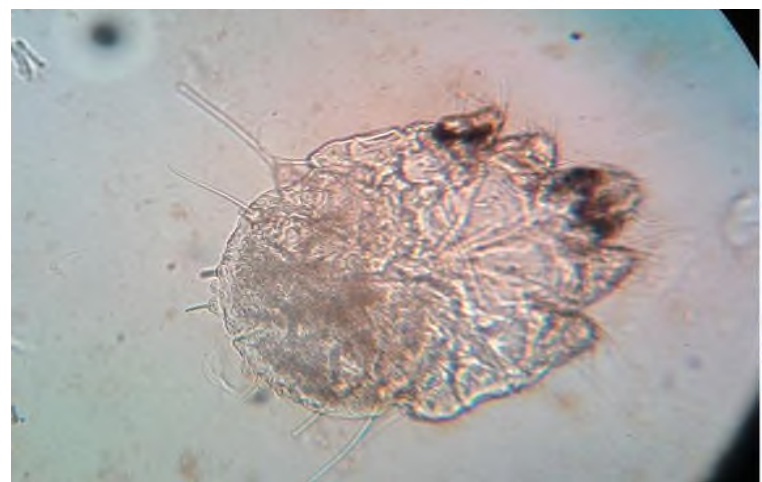

Рис.102. Sarcoptes scabiei

(чесоточный зудень). Нативная

микроскопия.

Морфологию бактерий изучают, как правило, на фиксированных и окрашенных препаратах, т.к. неокрашенные микроорганизмы, плохо различимы в световом микроскопе из-за их малой контрастности. Качественное окрашивание позволяет правильно идентифицировать некоторые бактерии и оценить их особенности. Способность и индивидуальная особенность микроорганизмов окрашиваться теми или иными красителями называются их тинкториальными свойствами. При использовании способа окраски по Граму и его модификаций бактерии подразделяют на две группы: грамположительные, окрашенные в сине-фиолетовый цвет, и грамотрицательные, имеющие розовый или красный цвет (рис.103). При окраске по Цилю-Нильсену возможно идентифицировать микобактерии туберкулеза и другие кислотоустойчивые бактерий (рис.104).

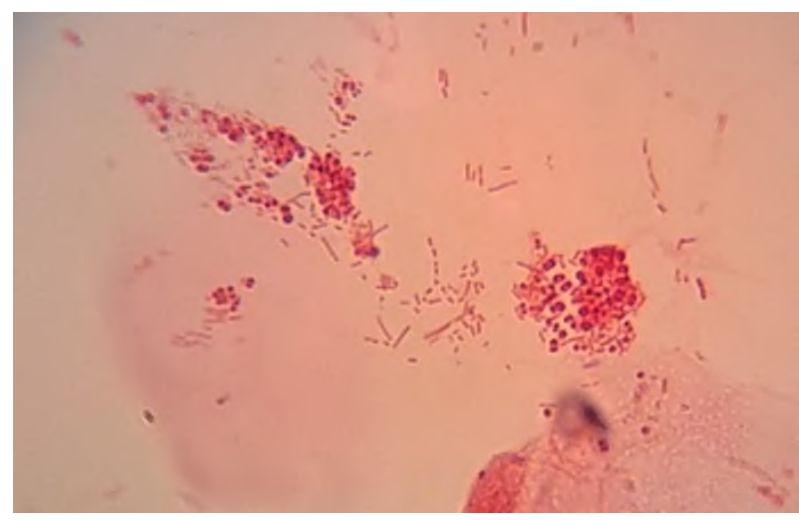

Рис. 103. Окраска по способу Грама. Грамотрицательная флора.

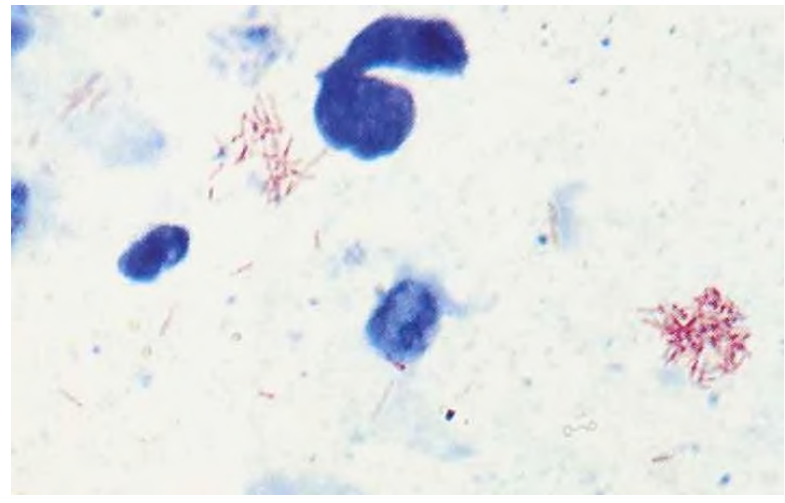

Рис. 104. Окраска по Ziehl-Neelsen. КУМ.

При микроскопии окрашенных препаратов из любого биологического материала всегда оценивается состояние эпителия, лейкоцитарная реакция, количественный и качественный состав микрофлоры. 
Цитологическое исследование позволяет изучить качественный и количественный состав клеток, характерных для данной локализации в норме или появляющихся при аллергических, инфекционных заболеваниях, злокачественных опухолях.

Выраженность лейкоцитарной реакции, проявление фагоцитоза, его завершенность позволяет оценить степень тяжести воспаления (рис.105). Так, например, незавершенный фагоцитоз позволяет определить недостаточность фагоцитарного звена иммунитета (рис. 106).

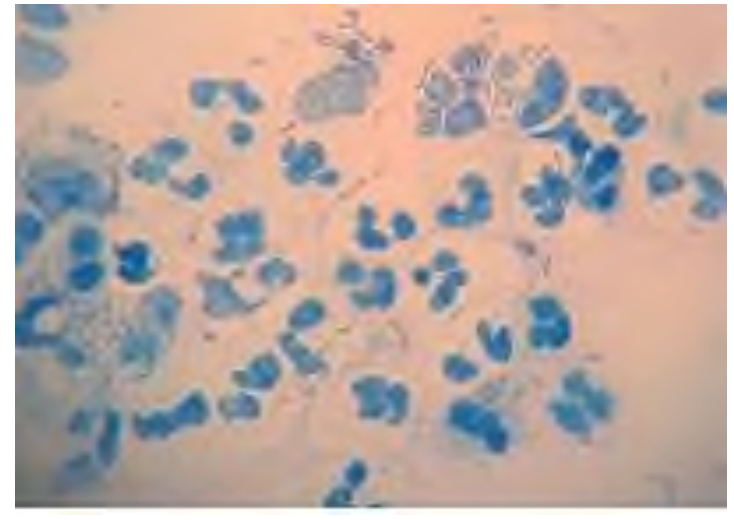

Рис.105. Нейтрофильный лейкоцитоз.

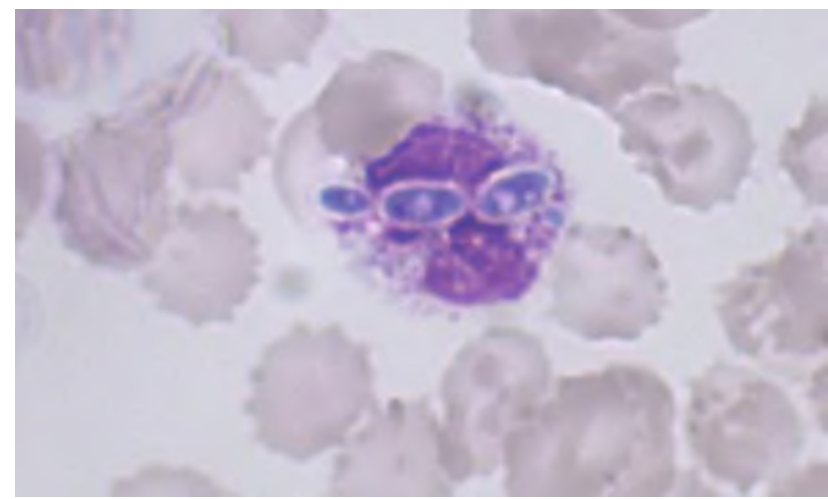

Рис.106. Микроскопия периферической крови. Грибы рода Candida в нейтрофиле.

Спектр бактерий меняется в зависимости от локализации в организме (заселения тех или иных слизистых оболочек и органов), исследование препаратов позволяет дать полуколичественную оценку общей микробной обсемененности, оценить качественный состав микрофлоры (морфотипы), обнаружить элементы грибов (рис. 107-108).

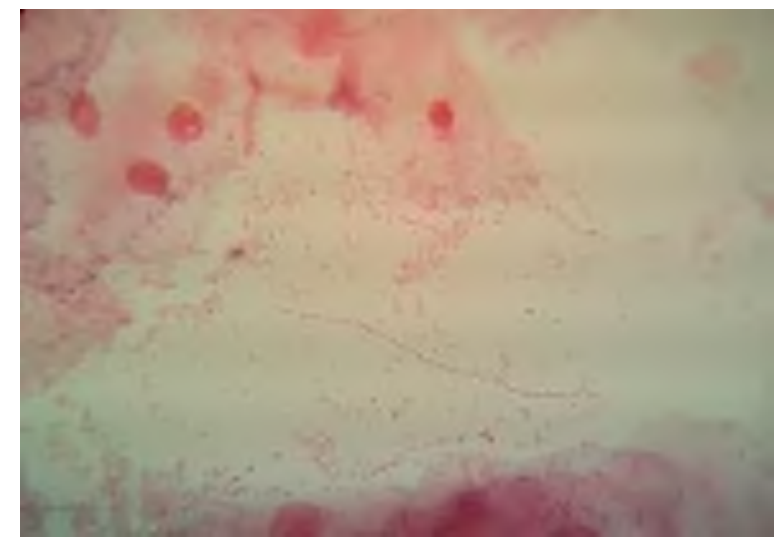

Рис. 107. Флора полиморфная, грамотрицательная. Окраска по способу Грама.

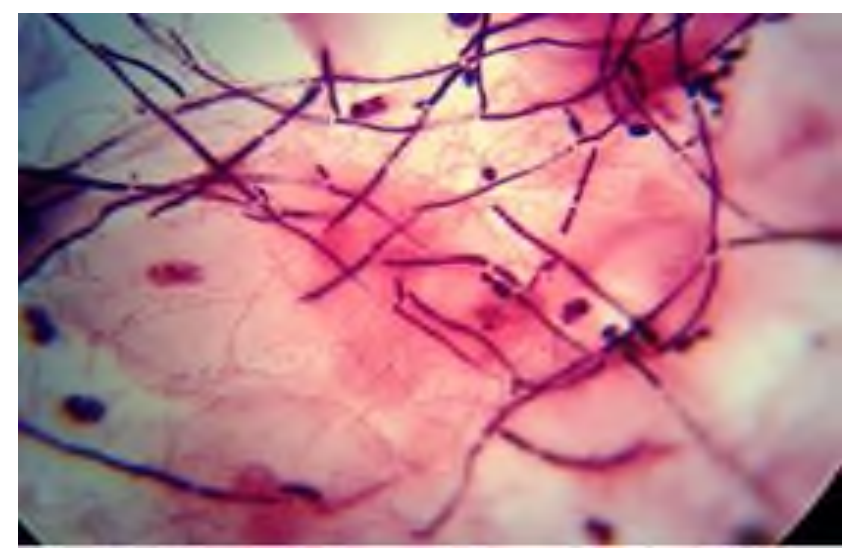

Рис.108. Грибы рода Candida.

Окраска по способу Грама. 
При исследовании отделяемого мочеполовых органов можно поставить диагноз трихомониаза и гонореи (рис.109).
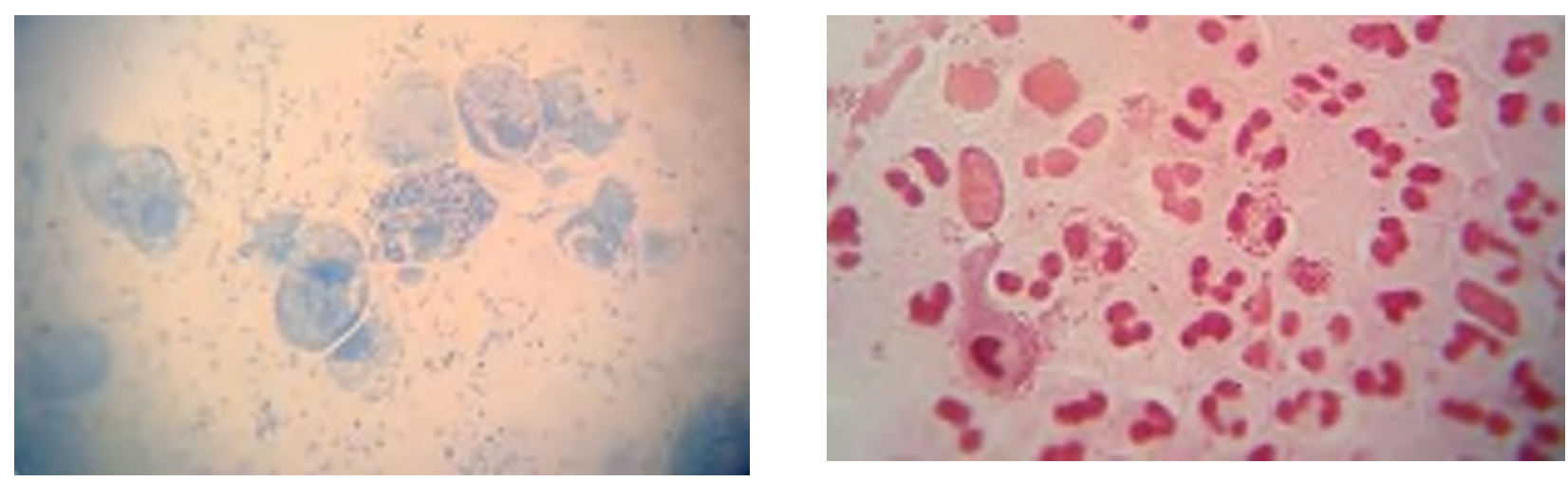

Рис.109. Микроскопия отделяемого мочеполовых органов.

a) T.vaginalis, окраска метиленовым синим; б) Гонококк, окраска по способу Грама.

Микроскопия мазков крови, окрашенных по методу Романовского Гимза позволяет выявить возбудителей малярии (рис.110) в первые дни болезни или поставить диагноз инфекционного мононуклеоза (рис.111).

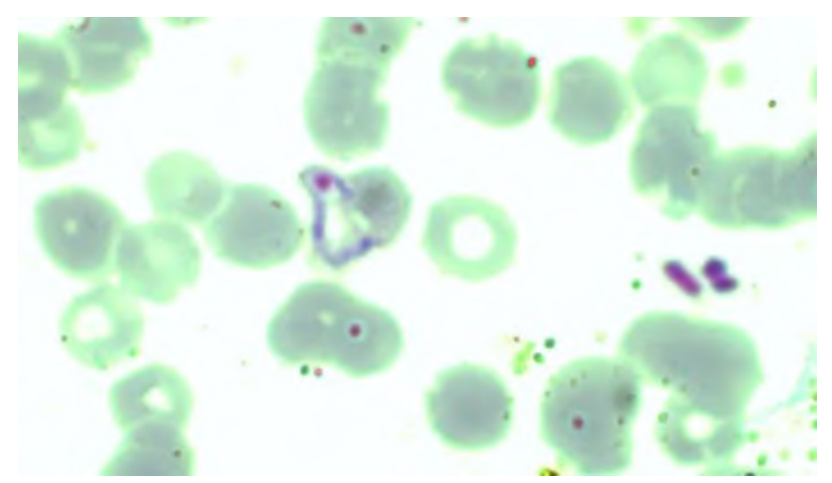

Рис. 110. Трофозоит Plasmodium vivax. Тонкий мазок крови.

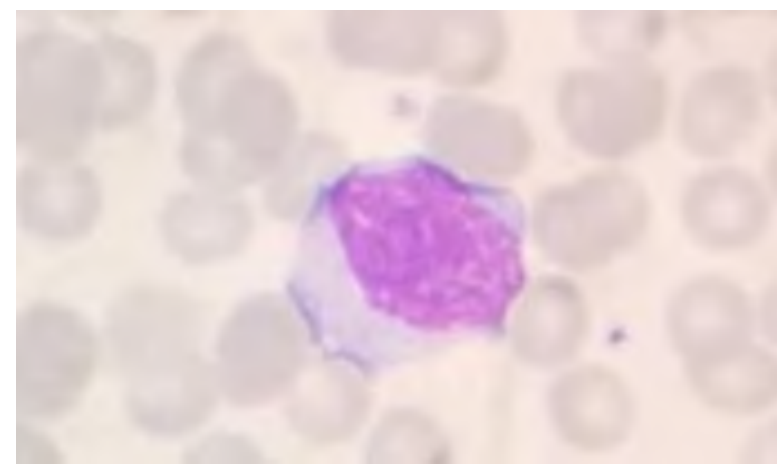

Рис.111. Атипичные мононуклеары при инфекционном мононуклеозе.

Макро- и микроскопические паразитологические методы лабораторной диагностики являются прямыми методами обнаружения гельминтов, их фрагментов, яиц и личинок.

На поверхности кала после дефекации можно увидеть активно ползающих остриц; иногда выделяются с калом аскариды; у больных дифиллоботриозом могут выделяться обрывки стробилы лентеца (в виде "лапши"), а у инвазированных тениидами (свиной или бычий цепень) с калом часто отходят членики гельминтов (в виде "белых обсечек"), членики бычьего цепня могут активно выползать из анального отверстия. В случаях тениаринхоза макроскопический метод диагностики является основным. Для выявления мелких гельминтов применяют ручную лупу. Но выход большинства гельминтов и их фрагментов из организма хозяина наблюдается не всегда. Поэтому для диагностики чаще используют методы гельминтоово- и лавроскопии. Световая микроскопия, по-прежнему используется в качестве 
основного метода диагностики подавляющего большинства паразитарных заболеваний: по морфологическим особенностям обнаруженных яиц, личинок, цист может быть установлен вид паразита.

В практике чаще всего приходится исследовать фекалии, так как именно через кишечный тракт выводятся яйца подавляющего большинства гельминтов и цист простейших. Реже исследуют другие субстраты - желчь, мокроту, мочу и др.

Все пробы фекалий, поступающие в лабораторию, исследуют на наличие гельминтов, их яиц или личинок, а также цист простейших. Биологический материал должен быть доставлен и исследован менее чем через сутки после сбора, так как при длительном хранении яйца и цисты могут деформироваться, личинки гельминтов разрушаются в течение 1-2 часов. Чтобы выявить все возможные паразитарные инвазии у конкретных пациентов, обычно требуется исследовать от 3 до 5 проб с 3-дневным интервалом (рис.112).

Вегетативные простейших можно обнаружить только в дуоденальном содержимом или в жидком кале при поносах или после назначения слабительного. Исследование кала в течение 30-40 мин после дефекации позволяет провести дифференциальную диагностику простейших по типичному движению живых паразитов. Цисты обнаруживаются чаще в оформленном кале, они выделяются периодически поэтому,

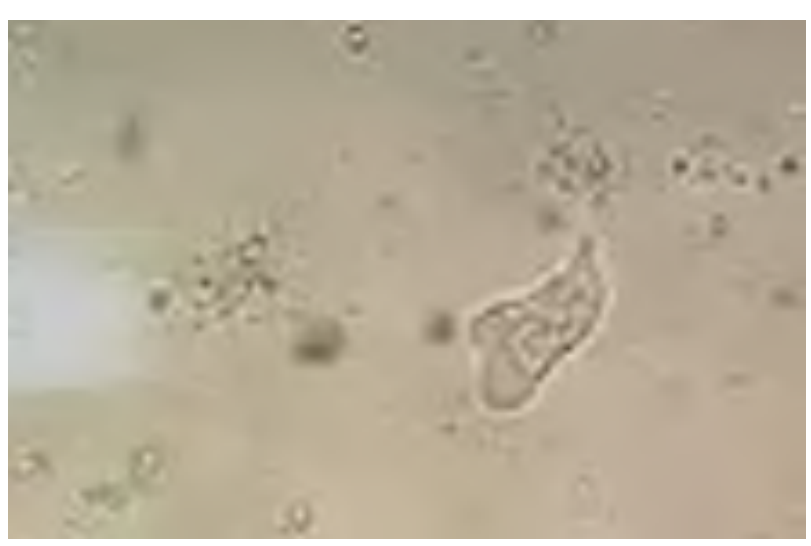

Рис.112 Трофозоит Entamoeba histolytica.

для подтверждения диагноза рекомендуется проводить исследования кала 5 - 6 раз на протяжении $2-4$ нед.

Основной метод обнаружения яиц гельминтов - метод исследования толстого мазка под целлофаном по Като, выявляются яйца кишечных и печеночных гельминтов при высокой и средней интенсивности инвазии (рис. 113-114).

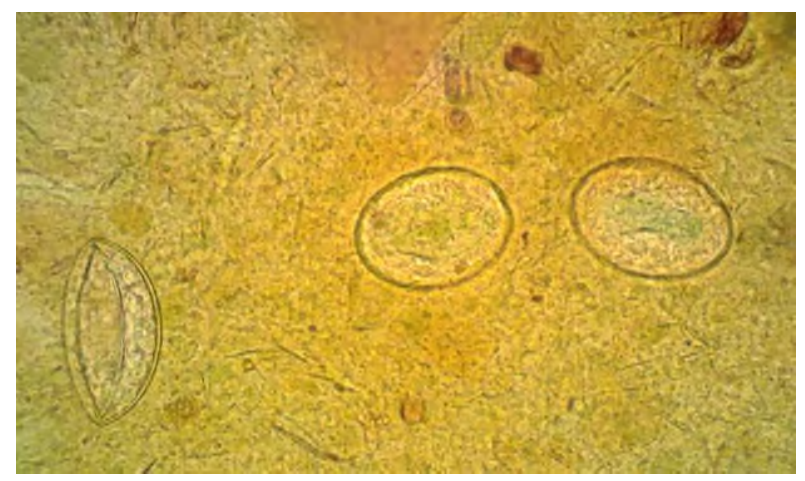

Рис.113. Яйца Diphyllobotrium latum в кале, метод Като.

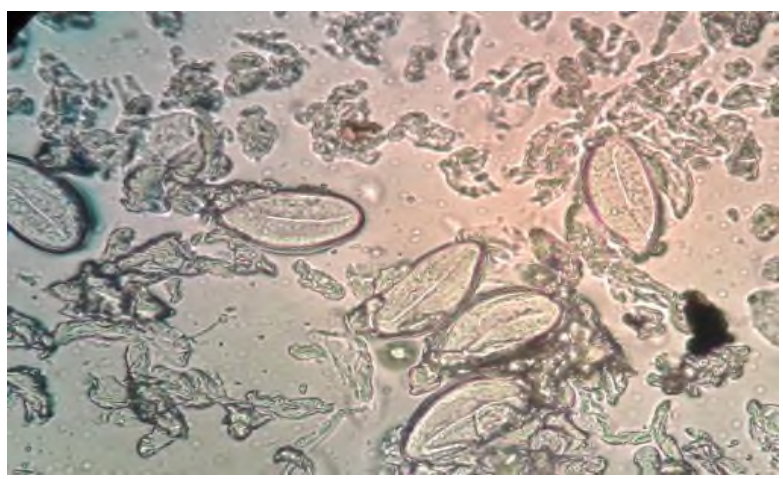

Рис. 114. Яйца Enterobius vermicularis, мазок-отпечаток с перианальных складок. 
Методы исследования перианальных отпечатков применяются для диагностики энтеробиоза и тениаринхоза (рис.114). Морфологически отличить онкосферы бычьего и свинного цепней невозможно. В лабораторном заключении указывают, что обнаружены онкосферы тениид. Диагноз строится на предположении: если онкосферы обнаружены при исследовании фекалий, то это вероятнее всего тениоз, если же в фекалиях онкосфер нет, а обнаруживаются они при исследовании перианального соскоба (отпечатка), скорее всего это тениаринхоз.

Нативный препарат с йодом используют для окрашивания гликогена и ядер у цист, для их видовой идентификации.

Анализ нативных препаратов является наиболее простым и легким методом исследования, но может пропустить низкую степень инвазии. Поэтому обязательно следует использовать методы обогащения, например, модификацию метода седиментации с применением одноразовых концентраторов кала. Комплект концентраторов состоит из разборных пластиковых пробирок, содержащих все необходимые для работы готовые реактивы (рис 115).

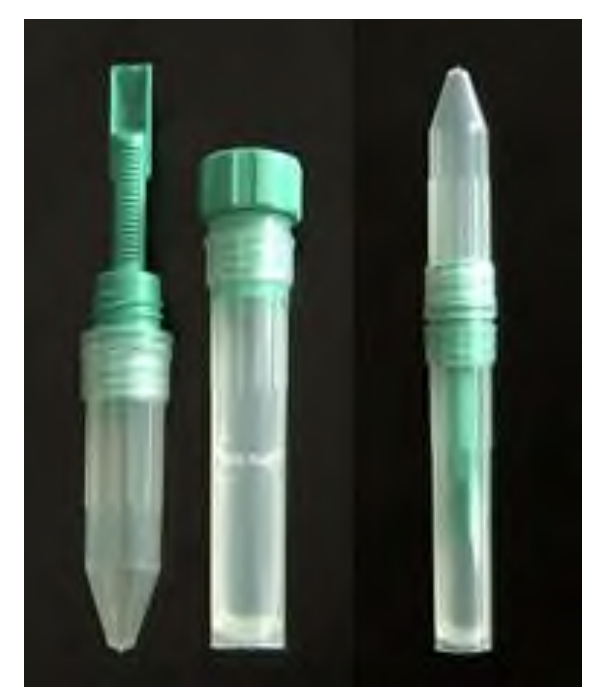

Рис. 115. Концентраторы кала.

Образец, взятый в такую пробирку, может храниться 24 часа при комнатной температуре.

Иммунологические методы (обнаружение антител) применяются только: в острой фазе гельминтозов (миграция личинок), при личиночных гельминтозах, при эктопической локализации гельминтозов, при тканевых протозоозах.

Люминесцентную микроскопию широко применяют для выявления антигенов и антител (метод иммунофлуоресценции). С ее помощью можно увидеть микробы, которые содержат определенные антигены. Для их выявления необходимо иметь специфические люминесцентные сыворотки, которые вызывают флуоресценцию именно данного антигена. Этот метод успешно используют для экспресс-диагностики многих бактериальных и вирусных заболеваний.

Для изучения строения микроорганизмов на субклеточном и молекулярном уровнях, а также для исследования структуры и архитектоники вирусов используют электронный микроскоп. 
Бактериологический метод остается одним из ведущих методов при диагностике большинства современных инфекций. Основным этапом бактериологического метода является посев материала на соответствующие питательные среды, с последующим выделением чистой культуры возбудителя, определением его вида, а, следовательно, и установление окончательного диагноза заболевания. Дополнительно возможно определить чувствительность возбудителя к антибиотикам/антимикотикам, антисептикам и бактериофагам.

В зависимости от цели исследования, а также на основании результатов микроскопии, изучения эпидемической ситуации осуществляют выбор одной или нескольких питательных сред для посева биологического материала. В бактериологии и микологии используются среды разнообразные по своему составу, консистенции и функциональному назначению, с веществами, угнетающими рост посторонней микрофлоры и/или с субстратами для выявления отдельных ферментов. Качество и стандартность питательных сред во многом определяют достоверность результатов бактериологического анализа

Выделению чистых культур возбудителей способствует использование элективных и селективных сред (обеспечивающих избирательный рост определенных видов микроорганизмов). Посев материала на дифференциальнодиагностические среды позволяет получить чистые культуры возбудителей, подсчитать численность колоний каждого типа. Колонии характеризуют по размеру, форме, контуру края, рельефу, поверхности, цвету, прозрачности структуре и консистенции.

Хромогенные питательные среды позволяют выявить специфические ферментативные активности для разных микроорганизмов. Так, дифференцирующим субстратом в средах Эндо, Плоскирева, Мак-Конки является лактоза, по отношению к которой отличают бесцветные колонии бактерий, не ферментирующие этот углевод (шигеллы, сальмонеллы и др.), от окрашенных колоний, обладающих этой способностью (большинство энтеробактерий).

При использовании хромогенных сред можно дифференцировать различные виды бактерий и грибов только по окраске колоний. При использовании хромогенных сред происходит значительное сокращение времени исследования.

В зависимости от клинической и эпидемиологической потребностей уровень проводимой идентификации может быть различным, чаще всего идентифицируют род и вид возбудителя, проводя биохимические тесты для выявления его родо- и/или видоспецифических ферментов. В ряде случаев, бывает, необходима идентификация до уровня отдельных штаммов, т.е. проведение дифференциации и маркировки вариантов одного вида микроорганизма, что особенно важно при выявлении источника заражения и 
путей распространения возбудителей. При этом помимо исследования биохимических особенностей штамма проводят типирование с помощью типовых сывороток, бактериофагов, и бактериоцинов (колицинов, пиоцинов и др.), определяют антибиотикограммы (показатели чувствительности микроорганизмов к антибиотикам) и т.д.

Микробиологическая диагностика при гнойно-воспалительных заболеваниях включает широкий и разнообразный комплекс исследований, что обусловлено необходимостью выделения и идентификации всех культур микроорганизмов, присутствующих в образце материала, в т.ч. представителей нормальной микрофлоры человека. Важным аспектом современной диагностики остается оценка этиологической значимости выделенных из материала условно-патогенных микроорганизмов. Первичная клиническая диагностика таких инфекций осложнена тем, что разнообразные по таксономическому происхождению условно-патогенные микроорганизмы способны вызывать сходные комплексы общих и местных поражений. С другой стороны, один и тот же вид возбудителя может обусловливать многообразные по локализации, тяжести и клиническим проявлениям патологического изменения. Если микроорганизм изолирован из пробы материала, который в норме стерилен (кровь, цереброспинальная жидкость, моча), то он обычно рассматривается как возбудитель заболевания, хотя существует ряд исключений (например, транзиторная бактериемия, контаминация). В этих случаях интерпретация результатов будет зависеть от многих клинических и лабораторных показателей, так на наличие инфекции могут указывать лейкоцитоз, сдвиг лейкоцитарной формулы влево, повышение концентрации Среактивного белка и т.д.

Когда исследуемый материал (фекалии, мокрота, отделяемое кожи и др.) содержит микроорганизмы, характерные для нормального состояния организма, учитывают качественные и количественные изменения, происходящие в составе микрофлоры, появление нетипичной микрофлоры для данной системы органов или на несвойственном анатомическом участке (нарушение естественного биотопа), повторность ее выделения и т.д.

Определение антибиотикограммы является основным этапом исследования, обеспечивающим выбор оптимального препарата для антибактериальной терапии. Ведущим методом определения чувствительности микроорганизмов к антибиотикам является дискодиффузионный метод, отличающийся простотой выполнения и экономичностью. Метод основан на измерении диаметра зон задержки роста колоний исследуемого микроорганизма вокруг диска с антибиотиком. Наиболее точными в количественном отношении являются методы последовательных (серийных) разведений антибиотиков в жидкой или плотной питательной среде. Мерой 
чувствительности микроорганизмов к антибактериальным препаратам при использовании этих методов служит минимальная подавляющая концентрация (МПК) - наименьшая концентрация антибиотика, которая подавляет развитие штамма бактерий при стандартных условиях постановки опыта и выражается в абсолютных единицах действия (мкг/мл). Знание минимальной подавляющей концентрации позволяет на основании сопоставления цифровых значений степени чувствительности клинических штаммов бактерий со средними концентрациями антибактериального препарата в организме выбрать оптимальный препарат.

Одной из задач бактериологического исследования является оценка сочетанного воздействия препаратов на выделенную культуру возбудителя. Для этого диски, пропитанные антибиотиками, наносят на чашки Петри, засеянные исследуемой культурой возбудителя, на расстоянии равном или несколько большем, чем сумма радиусов зон подавления его роста. Эффект может быть разнообразным: индифферентным (независимым), если после инкубации имеются две независимые зоны подавления роста возбудителя вокруг каждого из дисков; синергидным (потенцированным) или аддитивным (суммарным) при слиянии зон подавления роста: антагонистическим, когда зоны подавления роста уменьшаются в части, обращенной друг к другу.

Применяют также диски, пропитанные одновременно двумя препаратами. При этом для сравнения зон подавления роста возбудителя одновременно используют диски, содержащие по одному из данных препаратов. Если зона вокруг двойного диска больше, то говорят об аддитивном или синергидном эффекте, если меньше - об антагонизме.

Определение антимикробной активности биологических жидкостей организма (сыворотки крови, мочи, желчи, цереброспинальной жидкости, различных экссудатов и др.) проводят до и после введения химиотерапевтического препарата, что позволяет получать более надежные данные о его терапевтических возможностях в условиях, приближенных к естественным. Так, задержка развития возбудителя в моче или желчи (при разведении в $4-8$ раз), полученных от больного спустя 2 - 4 ч после начала терапии, указывает на эффективность химиотерапевтического препарата.

При многих инфекционных болезнях лаборатория сообщает окончательный ответ по быстрорастущим микробам через $2-4$ дня, при туберкулезе, бруцеллезе - через 3 - 4 нед, рост микроскопических грибов регистрируется от 5 - 7 дней и до 21 дня. Потребность в сокращении сроков получения окончательных результатов стимулировала разработку экспрессметодов, позволяющих регистрировать результаты через $3-6$ ч, то есть в день проведения исследования, что чрезвычайно важно в экстренных клинических ситуациях. 
Масс-спектрометрия - метод измерения массы молекул или атомов анализируемого вещества, основанный на измерении отношения массы заряженных частиц вещества к их заряду $(\mathrm{m} / \mathrm{z})$. В основе идентификации микроорганизмов с помощью этого метода лежит получение спектра константных белков неизвестного микроорганизма и последующее сравнение полученного спектра с базой данных. Приборы, которые реализуют этот метод, называются масс-спектрометрами (рис.116).

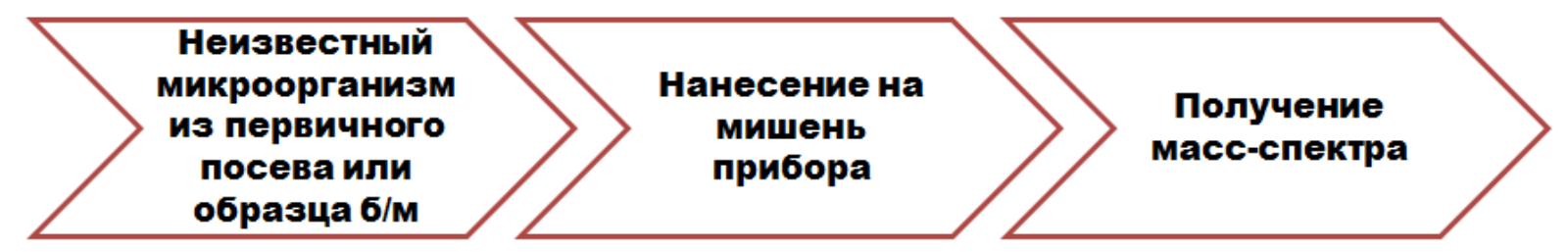

Рис. 116. Общая схема масс-спектрометрии.

Наибольшее распространение получила MALDI TOF-сnектрометрия.

MALDI (матрично-активированная лазерная десорбция/ионизация) способ ионизации вещества, использующийся при масс-спектрометрии. В основе метода лежит использование вспомогательного вещества - «матрицы», свойства которого обуславливают понижение деструктивных свойств лазерного излучения и ионизацию анализируемого вещества. TOF (Time of Flight времяпролетный) - принцип устройства анализатора масс-спектрометра, в котором заряженные частицы разделяются по времени пролета определенного расстояния. При этом время пролета частицы пропорционально отношению массы данной частицы к ее заряду.

Процедура пробоподготовки состоит в перенесении единичной колонии микроорганизмов на мишень прибора и наслоении раствора матрицы поверх анализируемого образца. Мишень прибора с нанесенными образцами помещается в масс-спектрометр. С образца снимается суммарный спектр, состоящий из 240 единичных спектров. Суммарный спектр преобразуется в «основной спектр» (набор пиков разных масс), который сравнивается со спектрами базы данных. При сравнении для каждого спектра из базы данных высчитывается коэффициент совпадения со спектром неизвестного микроорганизма. Микроорганизм, чей масс-спектр имеет наибольшее значение данного коэффициента, вносится в таблицу результатов. При этом достоверными считаются результаты, для которых значение коэффициента совпадения выше определенной величины (рис.117.). Время проведения исследования одного образца менее 1 минуты. 


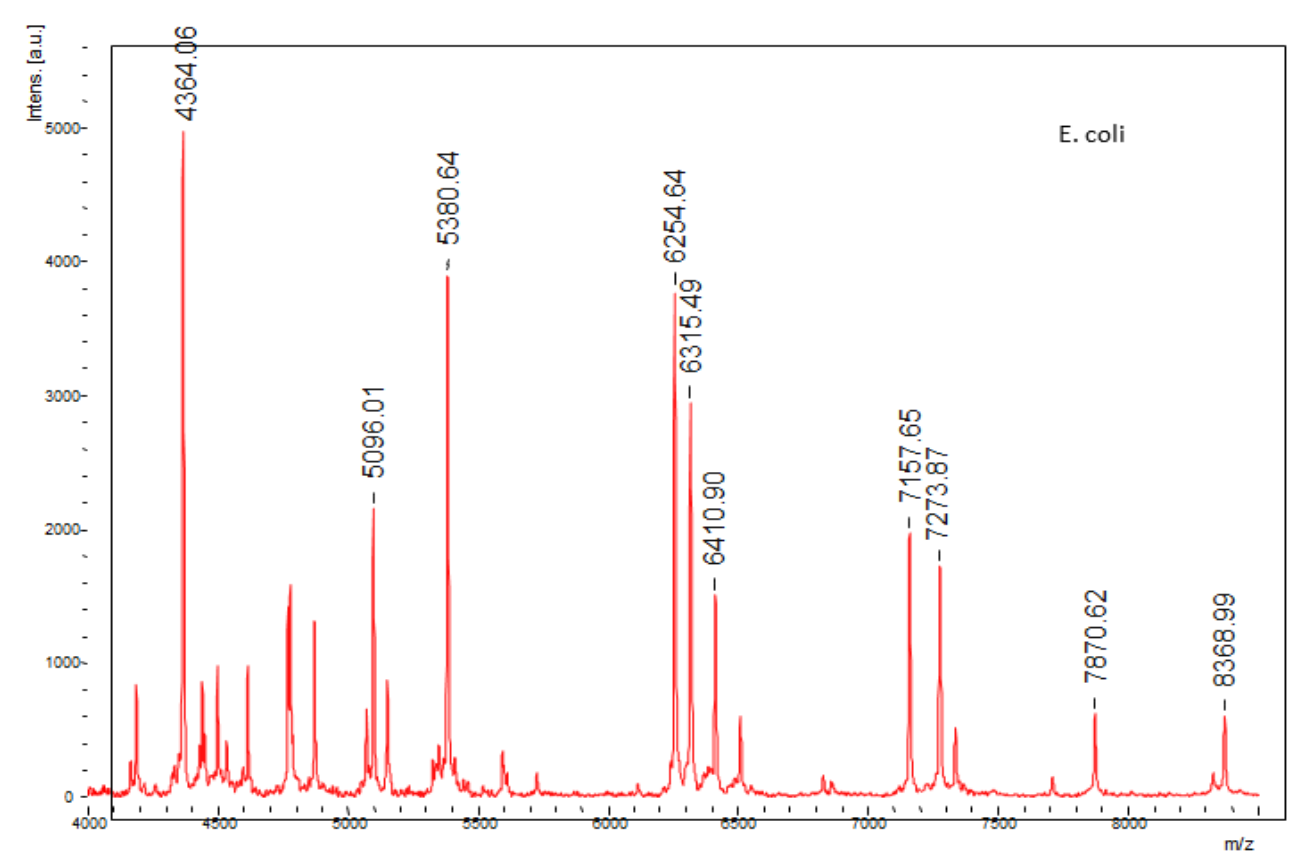

Рис. 117. Визуализация масс-спектров (масс-спектрометр МАЛДИ для идентификации микроорганизмов, BactoSCREEN, Литех).

С помощью данной методики, возможно, не только идентифицировать возбудителя, но и определить его чувствительность к антибактериальным препаратам. Для этого суспензию бактериальной культуры инкубируют с антибиотиками. Если бактерия чувствительна к антибиотику, происходит лизис клетки, и белки оказываются в супернатанте, на спектре присутствуют пики бактериальных белков (рис.118). Если бактерия устойчива к антибиотику, клеточного лизиса не происходит, в спектре пиков нет (рис. 119). В обоих случаях отсутствует деградация бактериальной клетки в контрольном образце, куда не добавляется антибиотик.

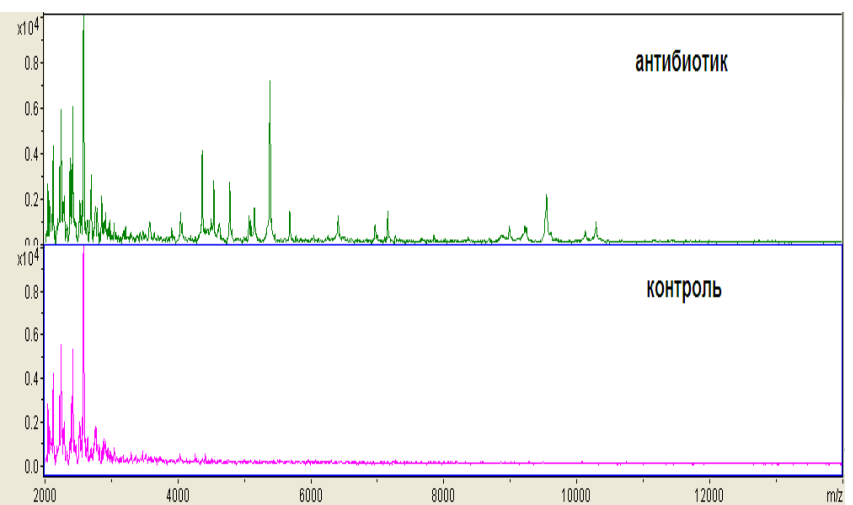

Рис.118. MALDI масс-спектрометрия, бактерия чувствительна к антибиотику.

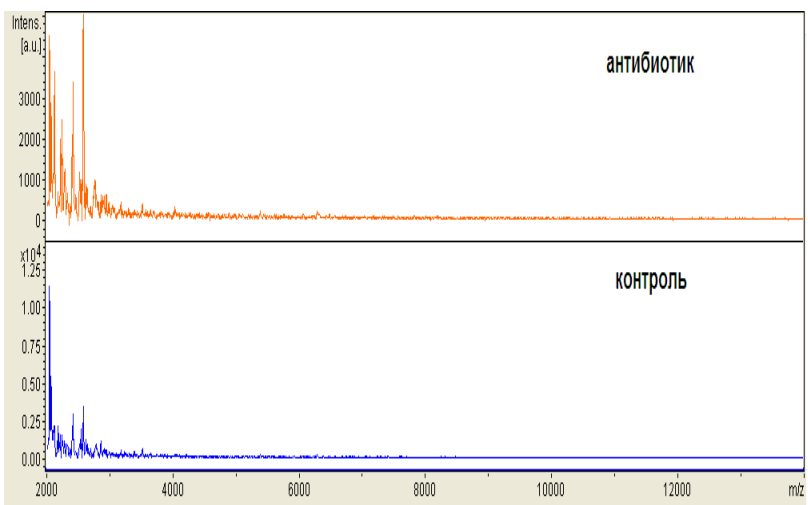

Рис.119. MALDI масс-спектрометрия, бактерия устойчива к антибиотику.

Газовая хромато-масс-спектрометрия - современный метод, используемый для дифференциации и идентификации микроорганизмов (МO). 
Он основан на сочетании двух аналитических методов: капиллярной газовой хроматографии и масс-спектрометрии. Принцип метода - качественное и количественное определение маркерных веществ микроорганизмов (жирных кислот (ЖК), альдегидов, спиртов, стеринов и др.) непосредственно в исследуемом материале. Наличие специфических веществ (маркеров) в исследуемых образцах открывает возможность для направленного поиска и идентификации МО. Для исследования может быть использован любой биологический материал, взятый от пациента. Исследование универсально в отношении разных групп микроорганизмов: бактерий, в том числе анаэробных микроорганизмов, микроскопических грибов, вирусов.

Газовая хромато-масс-спектрометрия микробиома (ГХМС М) - это метод детектирования микрофлоры по видоспецифическим высшим жирным кислотам клеточной стенки микроорганизмов. Разработка метода принадлежит группе Российских ученых под руководством доктора биологических наук, профессора микробиологии Осипова Г.А. Суть исследования состоит в прямом извлечении высших жирных кислот из образца биоматериала, их разделения на хроматографе в капиллярной колонке высокого разрешения и анализе состава на масс-спектрометре. На основании этих измерений расшифровывается состав микробиоты (полученные профили сравнивают с серией библиотек профилей и списком бактерий с наиболее похожими профилями). В ходе исследования в одном анализе определяется более 56 микроорганизмов одновременно. Результат исследования выдается в виде списка исследуемых микроорганизмов, допустимых значений нормы и отклонений от нормы, а также диаграммы в сопоставлении с нормой. Чувствительность составляет $10^{4}-10^{5}$ клеток в пробе; селективность - до вида при наличии маркера.

Биологический метод (метод биологических проб) используется для обнаружения возбудителя в организме больного, выделения культуры возбудителя и определения его патогенности. Биологический метод основан на заражении восприимчивых лабораторных животных исследуемым материалом (кровь, выделения больного) или чистой культурой возбудителя. Его применяют при зоонозных инфекциях (чуме, туляремии и др.). а также для обнаружения токсинов возбудителей. Чаще пробы ставят на белых крысах, мышах, морских свинках и кроликах. Заражение в зависимости от целей постановки биологической пробы производят перорально, интраназально, внутривенно, накожно, внутрикожно, подкожно, внутримышечно, внутрибрюшинно и субдурально. 


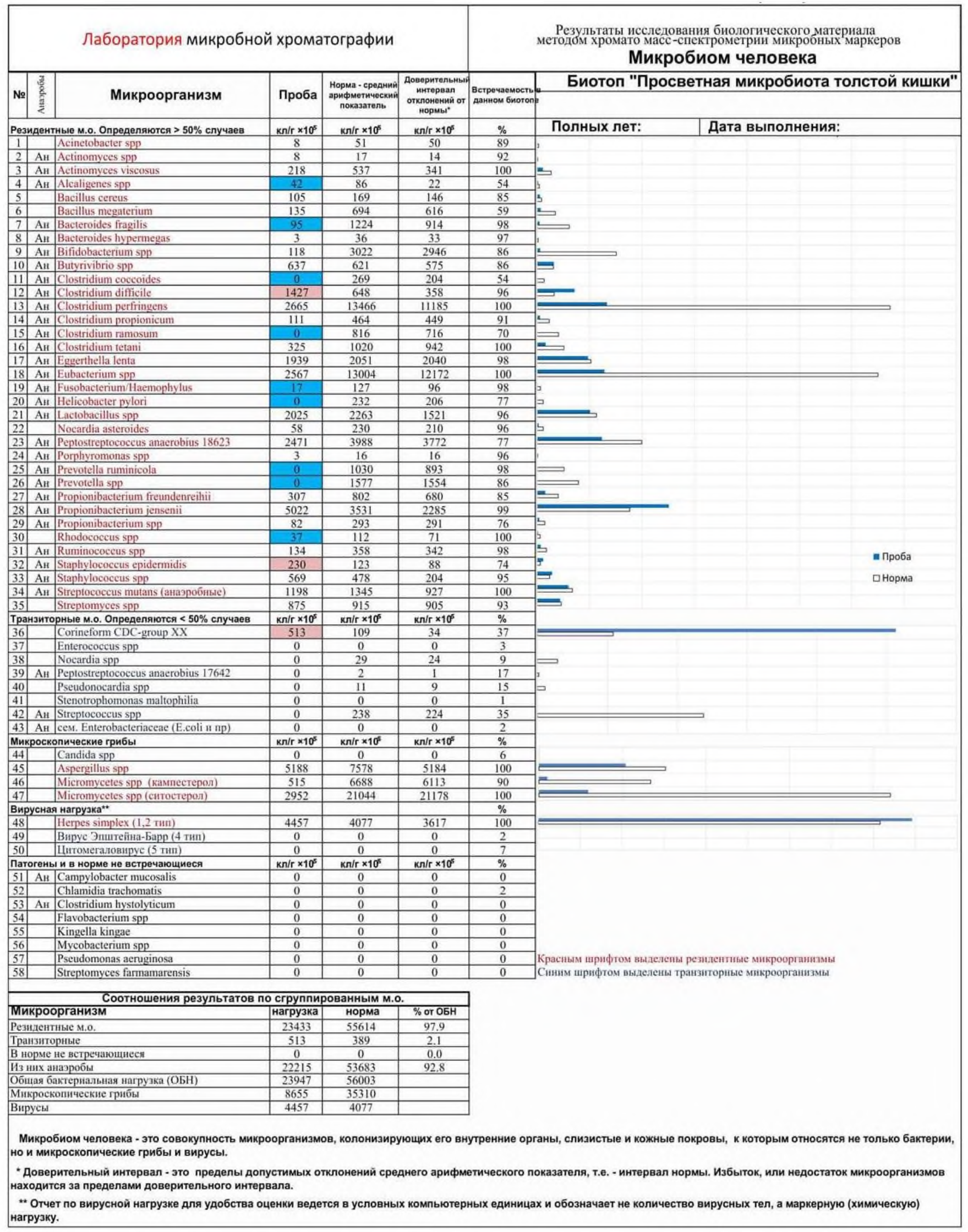

Рис. 120 Пример результата ГХМС М 
Иммунологические методы. В диагностике инфекционных болезней используют реакции иммунитета, которые в зависимости от принципа используемого метода делят на две группы: по известным антителам определяют неизвестный антиген (возбудитель); по известным антигенам выявляют неизвестные антитела. По своей информативности иммунологические методы также подразделяют на две группы: методы, направленные на выявление антигенов возбудителя - являются прямыми, а методы, направленные на выявление антител к возбудителю - непрямыми.

При многих инфекциях соответствующие антитела появляются, как только возбудители начинают размножаться в организме, и сохраняются несколько месяцев или лет, поэтому выявление антител не всегда связано с текущим заболеванием, а может указывать на контакт с возбудителем в прошлом. Определение антител из-за анамнестических, прививочных и перекрестных реакций лишь относительно достоверно и в лабораторной практике имеет вспомогательное значение. Поэтому к более информативным относят методы, основанные на обнаружении в ранней стадии болезни антигенов возбудителя. Определение антигенов или антител можно проводить в любом биологическом материале.

Иммунологические методы применяются для скрининговых исследований (с целью выделения групп высокого риска заболевания) и для диагностических исследований (с целью подтверждения диагноза и установления фазы инфекционного процесса).

Иммунофлюоресцентный метод (реакция иммунофлюоресценции РИФ, метод флюоресцирующих антител - МФА, прямая иммунофлюоресценция - ПИФ, непрямая иммунофлюоресценция - РНИФ) основан на выявлении светящихся иммунных комплексов. В основе метода лежит применение моноклональных или поликлональных антител. Сущность метода заключается в соединении антител/антигенов, меченых флюорохромом, со специфическими детерминантами, находящимися на поверхности клетки, и последующей детекцией с помощью люминесцентного микроскопа на определенной длине волны (рис. 121). Метод позволяет обнаружить антигены/антитела различных возбудителей (токсоплазм, цитомегаловируса ЦМВ, вирусов простого герпеса 1 и 2 типов -

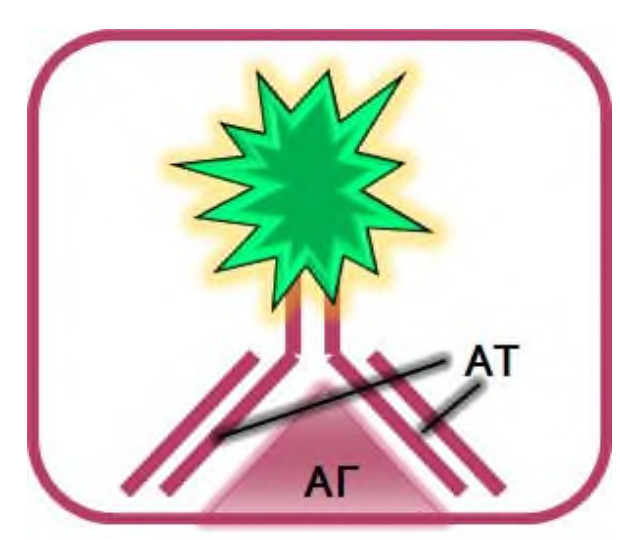

Рис.121. Принцип РИФ. ВПГ-1/2, а также возбудителей урогенитальных инфекций, респираторного микоплазмоза, кандидоза и др.) в различном биоматериале: в крови, спинномозговой жидкости, соскобах из 
предполагаемого очага инфекции, моче, бронхоальвеолярной жидкости, биоптате, патологоанатомическом материале (рис.122).

Использование тест-систем для диагностики респираторных инфекций, позволяет в течение нескольких часов раздельно выявить антитела классов IgM и IgG к вирусам гриппа (серотипам), парагриппа, РCвирусу, легионеллам, возбудителям респираторного хламидиоза и микоплазмоза.

Для определения активности инфекционного процесса (в том числе и реактивации) возможнат детекция антигенов («ранних белков»)

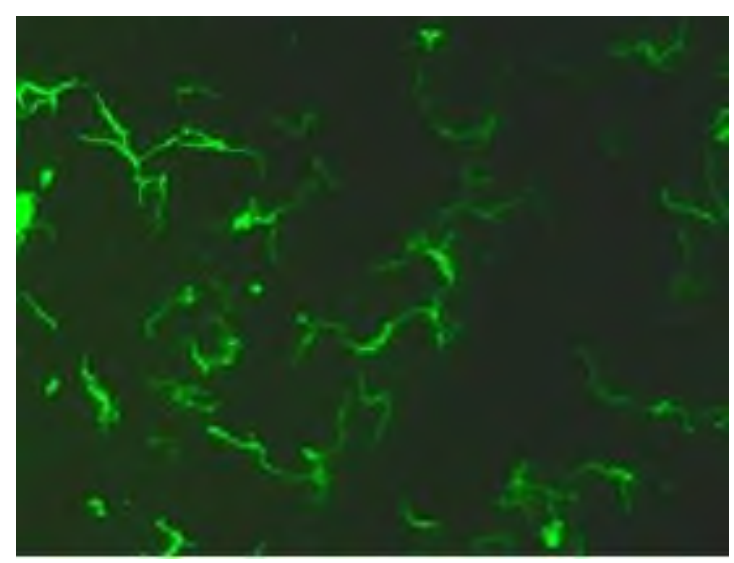

Рис. 122. Положительный результат

РИФ (обнаружение в крови антител к Treponema pallidum). возбудителя в крови (плазме, лейкоцитарной взвеси) и в спинномозговой жидкости. Антигенемия может иметь место в острой фазе инфекционного процесса при цитомегаловирусной инфекции (ЦМВИ), ВПГ-инфекции, токсоплазмозе (паразитемия) с первых дней инфекции; что подтверждает ценность этих исследований для ранней диагностики, а также для установления факта реактивации или суперинфекции.

Для достоверности результата решающее значение имеет использование высококачественных реагентов с довольно высокой чувствительностью и специфичностью, позволяющих избежать перекрестного реагирования антигенов возбудителей и выдать достоверный результат.

Иммуноферментный анализ (ИФА, ELISA - ensim-linked immunosorbent assey) - иммунохимический метод, основанный на образовании комплекса антиген-антитело, который затем выявляется с помощью фермент-субстратной реакции (рис.123).

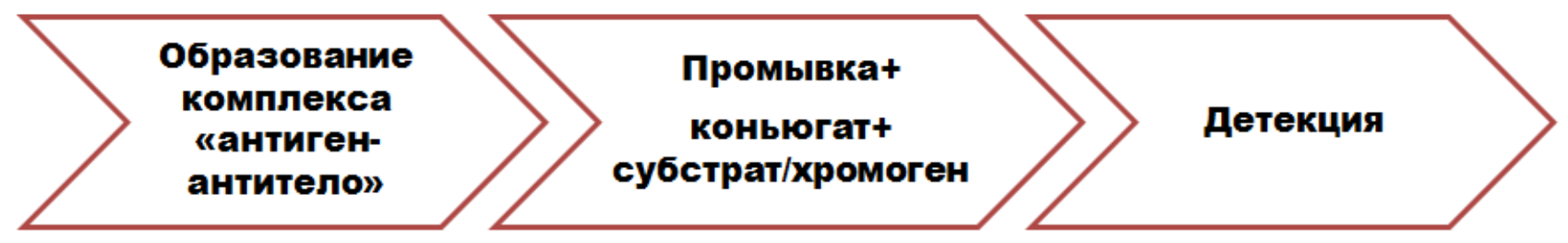

Рис. 123. Общая схема иммуноферментного анализа.

Существует множество модификаций ИФА, но схемы постановки принципиально схожи:

В лунке микропланшета фиксированы очищенные антитела (или антигены), специфически реагирующие с исследуемым антигеном (или 
антителом). В ходе инкубации антиген (или антитело) из образца (при условии его наличия) связывается в комплекс «антиген-антитело». Для выявления образовавшихся иммунных комплексов в реакционную смесь добавляется конъюгат, включающий ферментную метку. При добавлении специального хромогенного субстрата развивается ферментативная реакция (фермент взаимодействует с субстратом), в результате которой меняется цвет реакционной среды - бесцветный хромоген превращается в окрашенный хромофор. Интенсивность окраски раствора можно точно определить с использованием специального фотометра (ридера).

Оптическая плотность является количественной мерой степени окраски, которая пропорциональна концентрации определяемого антигена или антитела (аналита). Для качественной диагностики важно установить наличие или отсутствие антител/антигена при этом за положительное значение принимают сигнал, который в 2-3 раза превышает сигнал контрольного образца, не содержащего аналит.

ИФА позволяет выявлять в биологическом материале специфические антитела различных классов: IgM, IgA, IgG, IgE.

IgM - уровень IgM-антител может повышаться при реактивации, реинфицировании или суперинфицировании.

IgG - наибольшее значение в противоинфекционной защите имеет субкласс $\operatorname{IgG}_{2}$. Можно определять "ранние" специфические $\operatorname{IgG}$ с низкой авидностью, указывающие на первичную инфекцию и высокоавидные антитела, которые являются показателем давнего инфицирования и ранее перенесенной инфекции. Авидность антител в сыворотках оценивают по индексу авидности (ИА), который выражают в \%.

IgA - существует в двух формах: секреторной и сывороточной. Селективное накопление $\operatorname{IgA}$ в секретах говорит о его защитной функции по отношению к возбудителям инфекции. Синтез сывороточных IgA начинается с конца первого месяца заболевания и продолжается до тех пор, пока антиген доступен иммунокомпетентным клеткам. Его обнаружение свидетельствует об остром или подостром процессе, реактивации и суперинфекции. Тест показателен при диагностике врожденных форм инфекций.

IgE - время полужизни - 3 дня в сыворотке крови и 14 дней на мембранах тучных клеток и базофилов. С $\operatorname{IgE}$ (реагинами) тесно связан механизм атопических аллергических реакций. Кроме уровня общего $\operatorname{IgE}$, для поиска причинного аллергена определяют специфический $\operatorname{IgE~(к~кандидам,~}$ аспергиллам, клещу домашней пыли и др. аллергенам).

В ИФА проводится два вида оценки результатов - качественный и количественный. Качественная оценка предполагает выдачу двух вариантов ответа: результат положительный или отрицательный, то есть антиген/антитело 
обнаружено, либо нет. Качественный анализ часто используется при проведении скрининговых исследований в диагностике инфекционных заболеваний. В тест-системах для качественного анализа результат исследования определяется при сравнении его оптической плотности с расчетной величиной критической оптической плотности, для обозначения которой часто используется термин cut-off или «пороговое значение оптической плотности». Если оптическая плотность образца выше, чем cut-off, образец считается положительным, если оптическая плотность образца ниже уровня cut-off, то образец отрицательный.

Иногда образец попадает в так называемую «серую зону». Серая зона это диапазон концентраций специфических антител, в который попадают «сомнительные» результаты с равной вероятностью положительные или отрицательные пробы. Результаты анализов, попавших в серую зону, интерпретируются как «сомнительные», неоднозначные, и должны быть повторены с новой сывороткой, полученной от пациента через 1 - 2 недели.

Образец, давший положительный результат, может быть раститрован $(1: 10,1: 20,1: 40$ и т.д.). При этом за титр антител принимают наибольшее разведение сыворотки крови (ЦСЖ), дающее положительный результат.

Для количественной оценки тест-система содержит ряд стандартных растворов определяемого вещества с известными концентрациями. По результатам анализа стандартных растворов строят калибровочную кривую, отражающую зависимость оптической плотности от концентрации антигена. По калибровочной кривой, зная оптическую плотность опытной пробы, рассчитывают концентрацию определяемого вещества.

Как и при других методах лабораторной диагностики, при ИФА возможен как ложноположительный, так и ложноотрицательный результат.

Наиболее часто ложно-положительный результат встречается при определении специфических антител класса М и может быть обусловлен наличием ревматоидного фактора, гиперпродукцией $\operatorname{IgM}$ при беременности, наличием в пробе антител против неизвестных антигенов или перекрестной реакцией с антигенами других возбудителей, аутоиммунным процессом, нарушением обмена веществ и др.

При детекции IgG-антител также может быть получен ложноположительный результат, связанный, прежде всего, с перекрестным реагированием антигенов (например, между ЦМВ и вирусом простого герпеса; между Chlamydia trachomatis, Chlamydia pneumoniae и Chlamydia psittaci и т.п.) и напрямую зависящий от специфичности используемых тест-систем.

Причины получения ложных результатов в ИФА также могут быть связаны с преаналитическим этапом при заборе биоматериала и его транспортировке. 
Для уточнения лабораторного диагноза и исключения ложно-позитивного результата следует применять метод иммуноблота (Westernblot, Line-blot).

Mетод иммуноблота (Westernblot, Line-blot), позволяет определять антитела к отдельным антигенам возбудителя и относится к подтверждающим тестам.

Антигены в заводских условиях наносятся на нитроцеллюлозную мембрану. Мембрана инкубируется с исследуемой пробой, на нее последовательно наносятся вторичные антитела, проводится ферментативная реакция. В качестве хромогена используют растворимое бесцветное вещество, продукт которого окрашен, становится нерастворимым и преципитирует на нитроцеллюлозе. В результате поэтапно проведенной иммуноферментной реакции при наличии в исследуемой пробе антител к белкам патогена на блоте появляются темные поперченные полоски, расположение которых находится в зоне определенных белков патогена, т.е. в зоне протекания ферментативной реакции.

При вестерн-блоте все антигены, присущие данному микроорганизму расположены на мембране в порядке их молекулярной массы (рис. 124). Этот вид блотинга наиболее актуален для инфекций, при которых необходимо определять антитела ко всем этим антигенам (классическим примером может служить инфекция вызванная ВЭБ). При лайн-блоте на мембрану нанесены только клинически значимые антигены возбудителя или возбудителей, расположенные в произвольном порядке, что позволяет собирать скрининговые блоты, например на TORCH инфекциях (рис. 125).

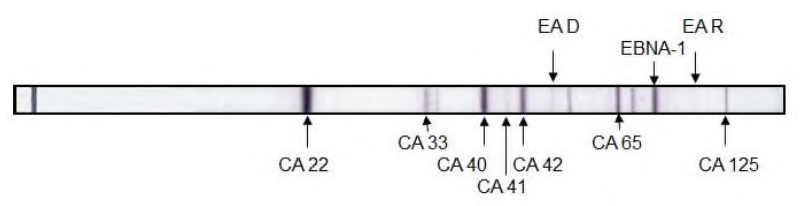

Рис. 124. Westernblot.

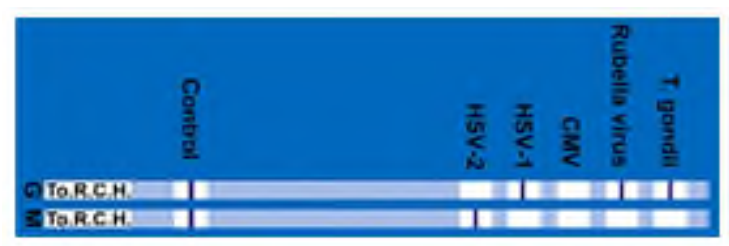

Рис. 125. Line-blot.

При проведении вестерн-блота в одной постановке можно определить спектр антител ко всем антигенам специфичным для данного возбудителя, что позволяет оценить давность и остроту заболевания, исключить перекрестные реакции.

Иммунохроматографический метод (иммунохроматографический анализ, ИХА) - разновидность иммуноферментного анализа, который проводится с помощью специальных тест-полосок или тест-кассет, в течение 10-15 минут. 
Принцип ИХА основан на движении жидкой пробы вдоль мембран (формирующих ИХ-тест-полоску/кассету) под действием капиллярных сил, которое приводит к последовательному взаимодействию антигенов/антител пробы с антителами или антигенами, иммобилизованными на разных участках мембраны и окрашиванию определенных участков тест-полоски (рис.126).

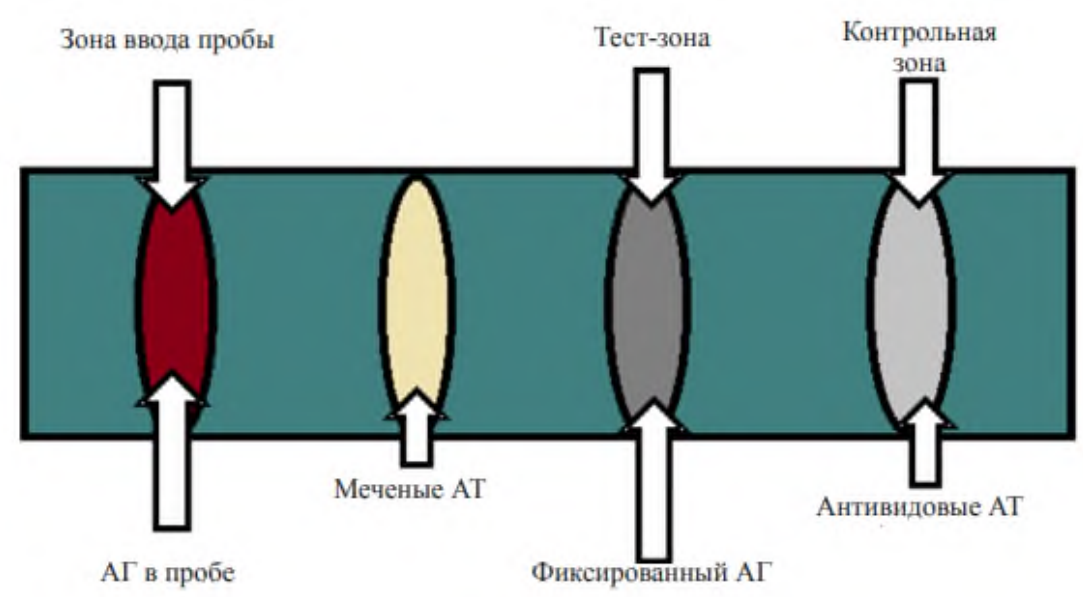

Рис.126. Общая схема (А) и результат (Б) ИХА.

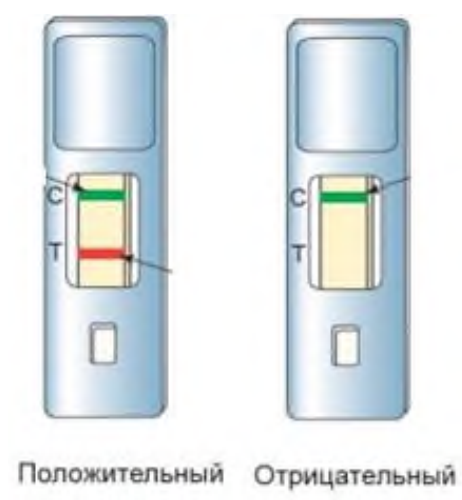

Если в пробе присутствует исследуемый антиген, то происходит его связывание, как с первым типом антител, так и со вторым. При этом происходит накопление антител с красителем, что визуально проявляется в виде окрашивания тест полоски. Свободные антитела с красителем мигрируют далее вдоль полоски и неизбежно взаимодействуют с вторичными антителами в контрольной зоне, где и наблюдается вторая окрашенная (контрольная) полоса (рис.126 Б). Окрашивание контрольной зоны подтверждает правильность проведения тестирования и сохранение конъюгатом реакционной способности.

Таким образом, при наличии в пробе целевого антигена/антитела образуются две окрашенные линии. Если же целевого антигена/антитела в пробе не было, будет видна только одна линия в контрольной зоне (рис.33).

Латекс-агглютинация (РЛА, агглютинация с использованием желатиновых частиц и др. модификации) - позволяет выявлять антитела в любой лаборатории, не имеющей оборудования для ИФА, проводить диагностику ряда инфекций: ВИЧ, вирусных гепатитов, респираторного микоплазмоза. Реакция РЛА можно отнести к экспресс-методам диагностики инфекционных болезней (время проведения - до 10 мин).

Реакция отличается высокой чувствительностью и позволяет выявлять незначительные количества антител в сыворотке, в связи с чем ее возможно использовать для ранней диагностики болезни. Однако надо помнить, что антитела в крови могут присутствовать как в результате активного инфекционного процесса, так и после перенесенной в прошлом инфекции или 
вакцинации. В связи с этим необходима постановка РЛА с парными сыворотками (с интервалом в 5-7 дней) для обнаружения нарастания титра специфических антител, что свидетельствует о течении активного инфекционного процесса. За титр сыворотки принимают максимальное ее разведение, при котором наблюдается агглютинация латекса.

Альтернативой стандартному иммуноферментному анализу, постановка которого осуществляется в 96-лучных плоскодонных планшетах, является иммуноферментный анализ на основе флуоресцентных частиц для проточной цитометрии. Примером такого набора может служить появившийся на рынке в 2021 году набор под названием «Guava® SARS-CoV-2 Multi-Antigen Antibody Kit» (Luminex, USA), предназначенный для исследования уровней SARS-CoV-2-специфичеких антител в биологических жидкостях (рис.127)
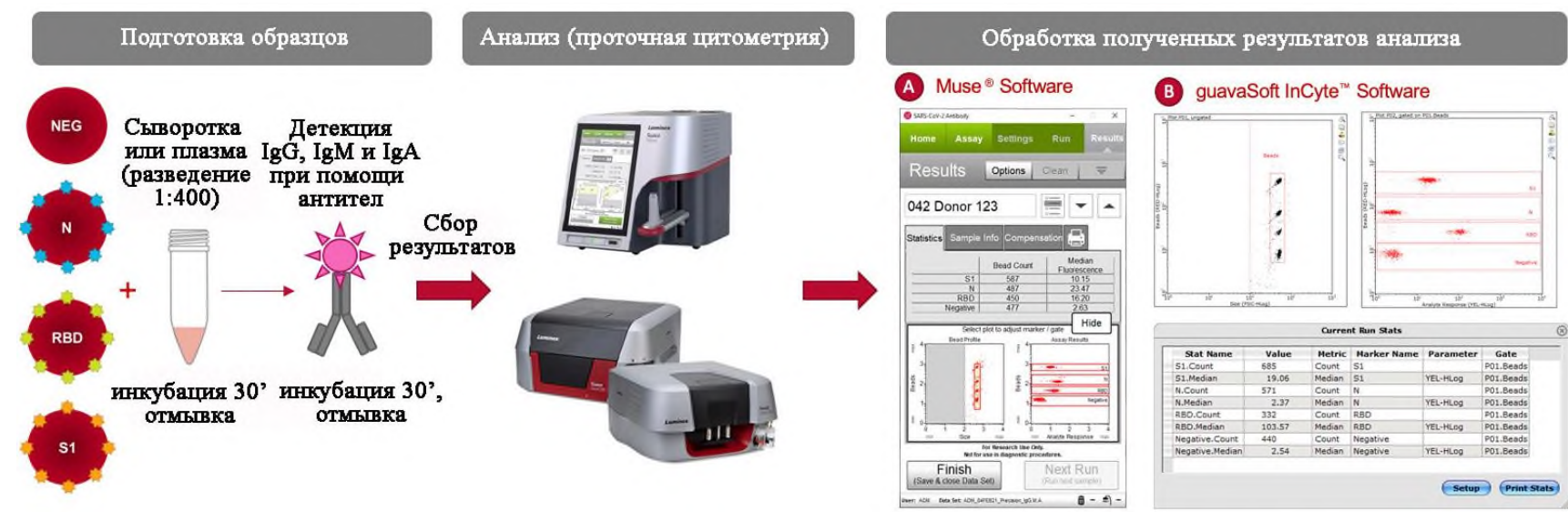

Рис.127. Алгоритм проведения иммуноферментного анализа на основе флуоресцентных частиц для проточной цитометрии.

. Данный набор позволяет выявлять антитела сразу трех классов -IgG, IgM и IgA - одновременно к трем антигенам SARS-CoV-2 - белок нуклеокапсида $(\mathrm{N})$, рецептор-связывающий домен (RBD) S-белка и субъединица S1 S-белка - в образцах сыворотки и плазмы, что позволяет получать сразу 9 параметров для характеристики и комплексной оценки специфического гуморального иммунного ответа. Существенным преимуществом такого подхода (при сравнении со стандартным ИФА) также являются высокие информативность (9 параметров для каждого образца) и скорость проведения исследования (не более 75 минут), а также возможность применения для анализа проточного цитометрии любой фирмы-производителя, который находится в распоряжении иммунологической лаборатории. Образцы

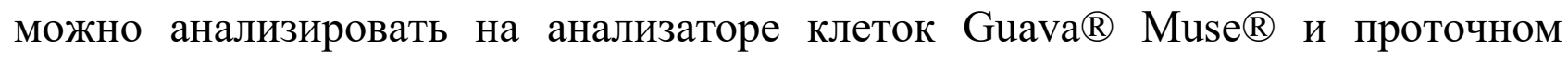
цитометре Guava® easyCyte тм, для которых было разработано специальное программное обеспечения для данного набора (что позволяет автоматизировать 
процесс получения результатов), или любом другом проточном цитометре, оснащенном лазером 488 или 532 нм.

Иммуногистохимический метод. Современный, высокочувствительный метод идентификации и определения локализации в клетке и ткани различных структур, имеющих антигенные свойства, также основан на реакции антигенантитело. Особенность метода заключается в том, что твердой фазой в этом случае служит сам срез ткани, а определяемое вещество иммобилизовано естественным образом на этом подобии иммуносорбента.

Иммунохемилюминесцентный метод хемилюминесцентный иммуноанализ заключается в том, что твердой фазой в нем служит полистирольный шарик, заключенный в тест-единицу (пробирку). На твердой фазе сорбированы моноклональные антитела, специфичные для выбранного исследования (например, для диагностики Hbs-антигена вируса гепатита В шарик покрыт моноклональными антителами против данного антигена). Количество связанных комплексов и, соответственно, выход фотонов, измеренный люминометром, обратно пропорциональны концентрации антигена в пробе.

\section{Молекулярно-генетические методы исследования (методы амплификации нуклеинов кислот (МАНК).}

В основе этих методов лежат манипуляции с ДНК и/или РНК, и молекул формирующиеся в цепочки ген-белок-функция. Это сложные методы диагностики, требуют определённых лабораторных условий и подготовки квалифицированного персонала. Однако в последнее время в связи с внедрением автоматизации и информационных технологий они все шире внедряются в клиническую практику, а некоторые, такие как ПЦР практически вытеснили традиционные лабораторные исследования.

Первый этап всех МАНК - получение образцов ДНК или РНК и их идентификация, затем определение различных полипептидов и определение метаболических реакций, реализуемых определенным пептидом.

Полимеразная цепная реакция (ПЦР). Метод основан на принципе естественной репликации ДНК, включающей расплетение двойной спирали ДНК, расхождение ее нитей и комплементарное достраивание ДНК-матрицы, осуществляемое in vitro c помощью фермента ДНК-полимеразы. При многократном повторении циклов синтеза (амплификация) происходит экспоненциальное накопление практически в любых количествах копий специфического фрагмента ДНК, которая первоначально могла быть представлена всего лишь одной молекулой (рис.128). 


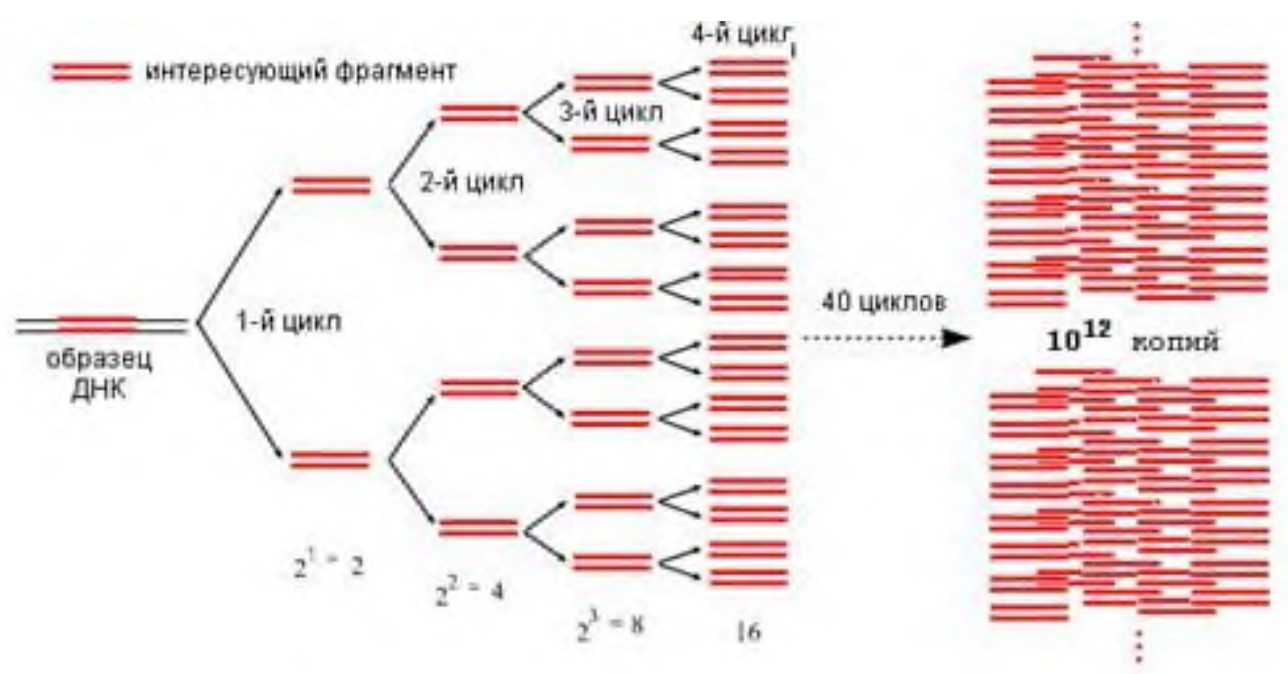

Рис. 128. Амплификация специфического фрагмента ДНК/РНК.

ПЦР состоит из трех основных этапов:

1) подготовка исследуемой пробы материала, которая в большинстве случаев сводится к выделению ДНК или РНК (экстракция нуклеиновых кислот); ПЦР);

2) амплификации (собственно

3) детекция продукта ПЦР (амплифицированной нуклеиновой кислоты).

Современные

технологии позволяют полностью автоматизировать все этапы проведения ПЦР (рис. 129).

В настоящее время существует большое количество различных

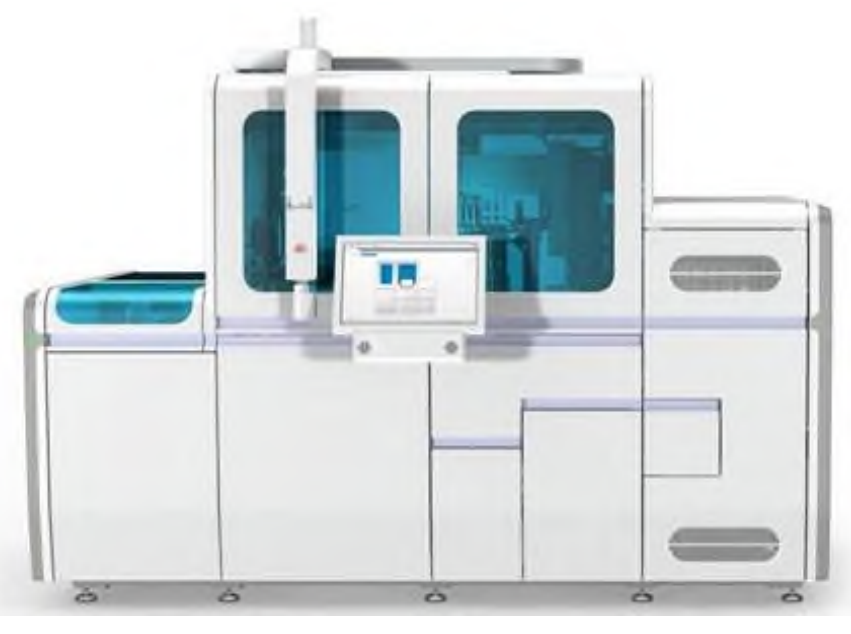

Рис. 129. Полностью

автоматизированная система ПЦР в режиме реального времени. модификаций метода ПЦР:

- $\quad$ ПЦР с горячим стартом (hot-start PCR)

- $\quad$ ПЦР с обратной транскрипцией (ОТ-ПЦР, RT-PCR)

- $\quad$ Мультиплексная (мультипраймерная) ПЦР

- $\quad$ Гнездовая (nested PCR)

- ПЦР инвертированная

- $\quad$ Асимметричная ПЦР

- Метод молекулярных колоний ПЦР длинных фрагментов (long-range, PCR)

- $\quad$ Групп-специфическая ПЦР (group-specific PCR)

- $\quad$ ПЦР с быстрой амплификацией концов кДНК (RACE-PCR)

- $\quad$ Технология NASBA 
ПЦР с обратной транскрипиией (OT-ПЦР, RT-PCR) используют для проведения исследований вируса SARS-CoV-2. Суть этой реакции - синтез ДНК на матрице РНК. Для этого молекулу РНК вируса превращают в реакции обратной транскрипции в комплементарную одноцепочечную ДНК (кДНК), которую используется в качестве матрицы для проведения традиционной ПЦР.

Основу технологии NASBA (Nucleic acid sequence based amplification) составляет амплификация молекул рибосомальной РНК возбудителей заболеваний. Выбор рибосомальной РНК в качестве искомой мишени связан с тем, что данная нуклеиновая кислота выделяется только из живых клеток и быстро разрушается после их гибели. Поэтому данная технология выявляет преимущественно живых возбудителей и является наиболее адекватным методом контроля за лечением. В случае гибели микроорганизмов (эффективное лечение) - результат NASBA будет отрицательный, а результат ПЦР может оставаться положительным (при обнаружении ДНК погибших клеток). Метод NASBA включен в действующие отечественные клинические рекомендации по алгоритму ведения пациентов с урогенитальными инфекциями.

Молекулярно-генетические методы активно развиваются, постоянно создаются новые подходы и тест-системы для диагностики инфекционных, онкологических, генетических заболеваний, идентификации личности, HLAтипирования, оценки действия лекарственных средств.

Последние разработки - модульные системы для проведения ПЦР. Каждый модуль обрабатывает одну пробу пациента, используя отдельный картридж. Все модули универсальны и независимы, поэтому можно проводить разное количество тестов (в пределах числа модулей в системе) в любое время, не накапливая образцы. Модульная система может быть представлена в 1, 2-, 4, 8-, 16- и более канальной конфигурации (рис.130).

Работа осуществляется с использованием одноразового картриджа, полностью изолированного от окружающей среды, что снижает риск контаминации и позволяет использовать прибор в обычных помещениях, без организации полномасштабной ПЦРлаборатории.
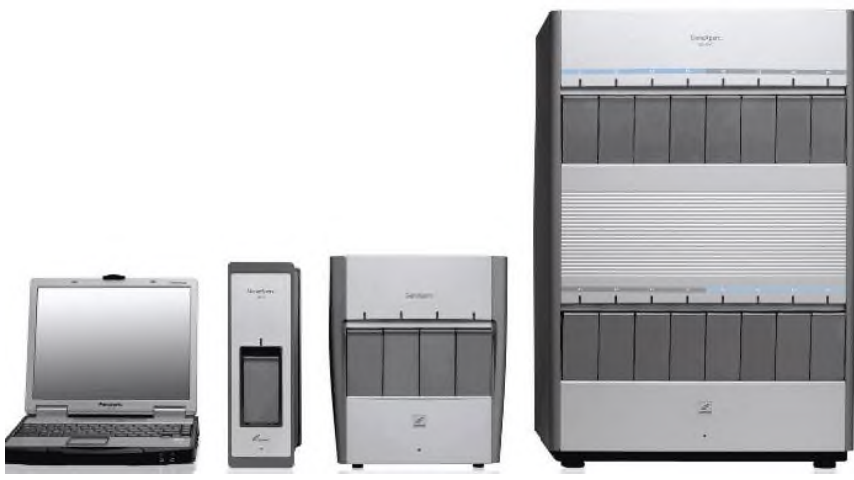

Рис. 130. Модульные системы GeneXpert. 
С 2020 году на территории США начат выпуск портативного устройства GeneXpert Omni, предназначенного для использования непосредственно в кабинете врача-клинициста (рис.131).

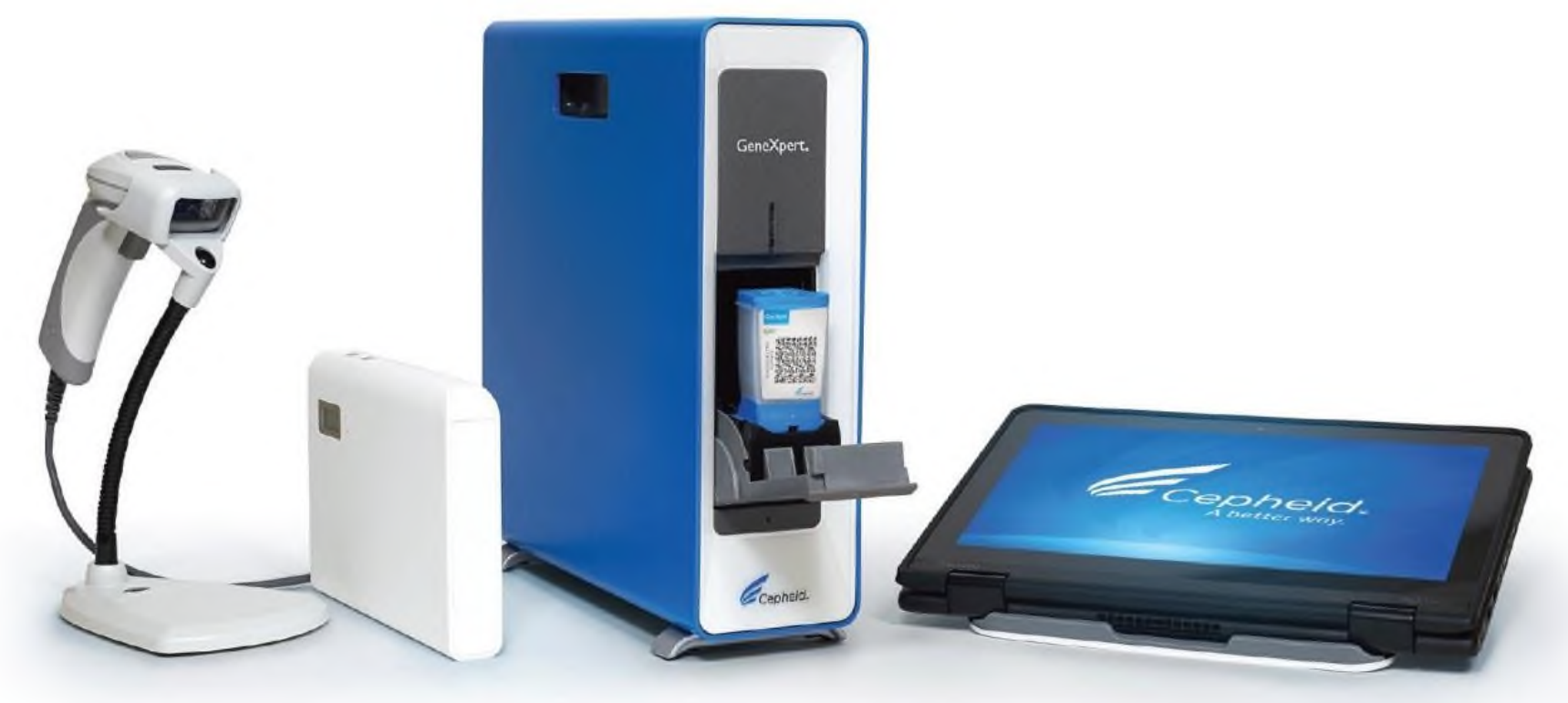

Рис. 131. Оборудование для проведения ПЦР по месту лечения.

При интерпретации результатов МАНК необходимо понимать, что поскольку возбудители инфекционных заболеваний присутствуют в организме человека только в течение определенного временного отрезка, молекулярногенетические методы нельзя использовать для выявления перенесенных инфекций. Для выявления, отслеживания и изучения инфекций, появлявшихся в прошлом, особенно тех, которые могли развиваться и распространяться без симптомов, необходимо использовать другие методы диагностики.

Таким образом, комплексная оценка состояния пациента и результатов специальных анализов, направленных на этиологическую расшифровку, позволяет оперативно установить (или исключить) инфекционное заболевание и наличие микст инфекции, установить смену возбудителя в процессе течения заболевания, выделить ведущий этиологический фактор в формировании патологии на конкретном этапе, определить фазу инфекционного процесса, назначить адекватную терапию и оценить её эффективность. Это проводится при сопоставлении полученных результатов с референсными значениями. Так, например количественное определение основных микроорганизмов при анализе кала на дисбактериоз позволяет нам выделить патогенные микроорганизмы и провести соответствующую терапию (табл.41). 
Таблица 41

Количество основных микроорганизмов при анализе кала на дисбактериоз

\begin{tabular}{|c|c|c|c|}
\hline \multirow[b]{2}{*}{ Виды микроорганизмов } & \multicolumn{3}{|c|}{ Возраст } \\
\hline & До 1 года & $\begin{array}{l}\text { От } 1 \text { года } \\
\text { до } 60 \text { лет }\end{array}$ & $\begin{array}{c}\text { Старше } 60 \\
\text { лет }\end{array}$ \\
\hline Bifidobacterium spp. (бифидобактерии) & от $10^{10}$ до $10^{11}$ & от $10^{9}$ до $10^{10}$ & от $10^{8}$ до $10^{9}$ \\
\hline Lactobacillius spp. (лактобактерии) & от $10^{6}$ до $10^{7}$ & от $10^{7}$ до $10^{8}$ & от $10^{6}$ до $10^{7}$ \\
\hline Бактероиды & от $10^{7}$ до $10^{8}$ & от $10^{9}$ до $10^{10}$ & от $10^{10}$ до $10^{11}$ \\
\hline Энтерококки & от $10^{6}$ до $10^{7}$ & от 105 до $10^{8}$ & от $10^{6}$ до $10^{7}$ \\
\hline Фузобактерии & $<10^{6}$ & от $10^{8}$ до $10^{9}$ & от $10^{8}$ до $10^{9}$ \\
\hline Эубактерии & от $10^{6}$ до $10^{7}$ & от $10^{9}$ до $10^{10}$ & от $10^{9}$ до $10^{10}$ \\
\hline Пептострептококки & $<10^{5}$ & от $10^{9}$ до $10^{10}$ & $10^{10}$ \\
\hline Клостридии & $<10^{3}$ & $<10^{5}$ & $<10^{6}$ \\
\hline E. coli типичные & от $10^{7}$ до $10^{8}$ & от $10^{7}$ до $10^{8}$ & от $10^{7}$ до $10^{8}$ \\
\hline E. Coli лактозонегативные & $<10^{5}$ & $<10^{5}$ & $<10^{5}$ \\
\hline E. Coli гемолитические & 0 & 0 & 0 \\
\hline $\begin{array}{l}\text { Другие условно-патогенные энтеробактерии } \\
\text { в т.ч. Enterobacter spp. Proteus spp. Klebsiella } \\
\text { spp, Hafnia, Serratia, Morganella, Citrobacter }\end{array}$ & $<10^{4}$ & $<10^{4}$ & $<10^{4}$ \\
\hline $\begin{array}{l}\text { Staphylococcus aureus (стафилококк } \\
\text { золотистый) }\end{array}$ & 0 & 0 & 0 \\
\hline $\begin{array}{l}\text { S. epidermis, S. saprophiticus (стафилококк } \\
\text { эпидермальный сапрофитный) }\end{array}$ & $<10^{4}$ & $<10^{4}$ & $<10^{4}$ \\
\hline $\begin{array}{l}\text { Неферментирующие бактерии Pseudomonas } \\
\text { spp. (синегнойная палочка), Acinetobacter }\end{array}$ & 0 & 0 & 0 \\
\hline Clostridium spp. в m.ч. Clostridium difficile & 0 & 0 & 0 \\
\hline $\begin{array}{l}\text { Грибы рода Candid } \\
a\end{array}$ & $<10^{3}$ & $<10^{4}$ & $<10^{4}$ \\
\hline
\end{tabular}

Большое значение для здоровья человека принадлежит нормальной микробиоте (табл.42). Микробиота - устойчивое сообщество микроорганизмов, обитающих на определённом участке организма хозяина. 


\section{Состав биотопов}

\begin{tabular}{|c|c|}
\hline Органы и ткани & Основные микроорганизмы \\
\hline Кожа & $\begin{array}{l}\text { Actinobacteria (51.8 \%), Firmicutes (24.4 \%), Proteobacteria (16.5\%), } \\
\text { Bacteroidetes (6.3\%), грибы. }\end{array}$ \\
\hline $\begin{array}{l}\text { Слизистая оболочка } \\
\text { глаз }\end{array}$ & $\begin{array}{l}\text { Грамположительные кокки (Staphylococcus и Streptococcus), } \\
\text { грамотрицатльные палочки и кокки (Haemophilus and Neisseria) и грибки } \\
\text { (Candida, Aspergillus, and Penicillium). }\end{array}$ \\
\hline $\begin{array}{l}\text { Респираторный } \\
\text { тракт }\end{array}$ & $\begin{array}{l}\text { Hoc - S. aureus, S. epidermidis, непатогенные нейссерии,коринебактерии. } \\
\text { Небные миндалины - S.pyogenes), S.pneumoniae, H.influenzae, } \\
\text { неспорообразующие анаэробы. Легкие - Prevotella, Sphingomonas, } \\
\text { Pseudomonas, Acinetobacter, Fusobacterium, Megasphaera, Staphylococcus, и } \\
\text { Streptococcus. Грибы: Candida, Malassezia, Aspergillus. }\end{array}$ \\
\hline $\begin{array}{l}\text { Урогенетильный } \\
\text { тракт }\end{array}$ & 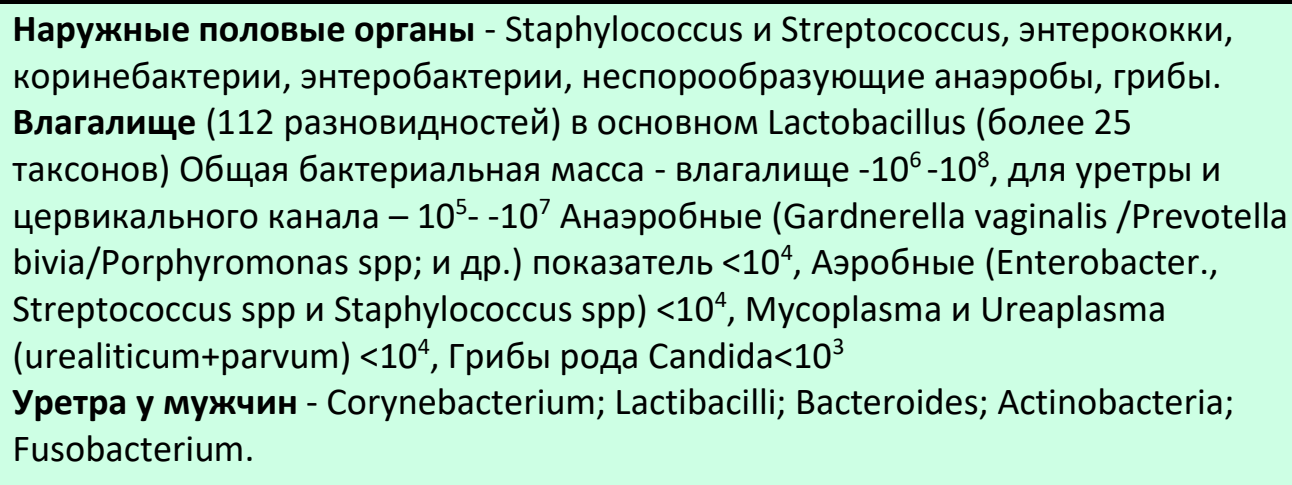 \\
\hline $\begin{array}{l}\text { Пищеварительный } \\
\text { тракт }\end{array}$ & $\begin{array}{l}\text { Полость рта (более } 275 \text { разновидностей) - Анаэробные бактерии } \\
\text { Actinomyces, Arachnia, Bacteroides, Bifidobacterium и др, Lactobacillus, } \\
\text { Leptotrichia, Peptococcus, Peptostreptococcus. Грибы. } \\
\text { Желудок и 12-перстная кишка } 10^{3} \text { KOE /мл. - Firmicutes, Actinobacteria, } \\
\text { Bacteroidetes, Proteobacteria, Fusobacteria. } \\
\text { Тонкий кишечник } 10^{4}-10^{8} \text { KOE/мл - Firmicutes, Actinobacteria, Bacteroidetes } \\
\text { Толстый кишечник } 10^{9}-10^{13} \mathrm{KOE} / \text { мл. - Firmicutes (грам+) (болеe 50\%), } \\
\text { Bacteroidetes (30\%), Proteobacteria (грам-) (3\%), Actinobacteria (грам+) ( } 1 \text { \%). }\end{array}$ \\
\hline
\end{tabular}

Особо важное значение имеют эти исследования при инфекциях, повреждающие иммунную систему - ВИЧ, ВЭБ, герпесвирус человека 8 тип, онкогенных вирусах - вирусы гепатитов B, C, D, папилломовирусов (табл.43).

Выявление различных антигенов важно для ранней диагностики рака, который можно диагностировать уже в стадии равновесия (табл.44) совместно с другими лабораторными и инструментальными исследованиями. 


\section{Папилломовирусная инфекция}

\begin{tabular}{|l|l|l|}
\hline \multicolumn{1}{|c|}{ Группа } & \multicolumn{1}{|c|}{ типы } & \multicolumn{1}{c|}{ Заболевания } \\
\hline $\begin{array}{l}\text { Неонкогенные } \\
\text { папилломавирусы }\end{array}$ & $1,2,3,4,7,10,28,41$ & $\begin{array}{l}\text { подошвенные бородавки, плоские бородавки, } \\
\text { вульгарные бородавки. }\end{array}$ \\
\hline $\begin{array}{l}\text { Онкогенные } \\
\text { папилломавирусы } \\
\text { низкого риска }\end{array}$ & $\begin{array}{l}5,6,8,11,12,14,15, \\
43,44,20,21,22,23,24,25,42,\end{array}$ & $\begin{array}{l}\text { аногенитальные бородавки } \\
\text { ларигеальный папилломатоз } \\
\text { бородавчатую эпидермоплазию. }\end{array}$ \\
\hline $\begin{array}{l}\text { Онкогенные } \\
\text { папилломавирусы } \\
\text { высокого риска }\end{array}$ & $\begin{array}{l}16,18,31,33,35,39,45,51,52, \\
56,58,59 \text { и 68 }\end{array}$ & $\begin{array}{l}\text { бовеноидный папуллез } \\
\text { интраэпителиальная неоплазия шейки матки. }\end{array}$ \\
\hline
\end{tabular}

Таблица 44

\section{Опухолевые маркеры}

\begin{tabular}{|c|c|}
\hline Тип рака & Онкомаркеры \\
\hline Рак яичников & СА 125, остеопонтин, РЭА, SMRP, HЕ4, Ингибин В \\
\hline Рак шейки матки & SCCA, PЭA, цитокератины (CYFRA-21.1, TPS) \\
\hline \multirow{4}{*}{ Рак легкого } & Аденокарцинома - CYFRA-21.1, CEA, CA 125, TPA, TPS, TU M2-PK \\
\hline & Плоскоклеточный - SCCA, CYFRA-21.1, CEA, CA 125, TPA, TPS, TU M2-PK \\
\hline & Крупноклеточная карцинома - CYFRA-21.1, CEA, CA 125, TPA, TPS, TU M2-PK \\
\hline & Мелкоклеточный - NSE и ProGRP, CA 125, TPA, TPS, TU M2-PK \\
\hline Рак молочной железы & UPA, PAI-1, CA15-3, PЭA, TPA, TPS, HER-2 \\
\hline Рак печени & АФП, ферритин, \\
\hline Рак желудка & СА19.9, СА 72,4, СЕА,, РЭА, цитокератины \\
\hline Меланома & S-100, VEGF, bFGF, CD44 \\
\hline Колоректальный рак & TIMP, CA242, PЭA, CA19-9 \\
\hline Рак мочевого пузыря & UPC, NMP22, BTA, TRAP, цитокератины \\
\hline Опухоли яичника & АФП, ХГЧ, ЛДГ, ПщР, NSE \\
\hline Рак простаты & Свободный и связанный ПСА \\
\hline $\begin{array}{l}\text { Рак поджелудочной } \\
\text { железы }\end{array}$ & CA19-9 CA242, PЭA, CA72-4, TPS, OPN, TIMP-1 \\
\hline
\end{tabular}




\section{Глава 10. Лабораторные методы исследования} иммунной системы

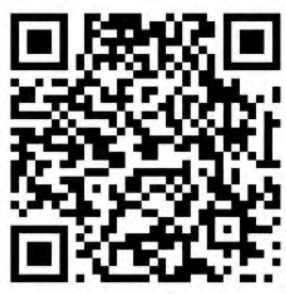

Общепринято считать, что для диагностики иммунных нарушений необходимы специальные иммунологические исследования. Это отчасти верно. Хотя и другие лабораторные исследования дают значимую информацию о работе иммунной системы и причинах ее неадекватной работы.

Прежде всего, основным лабораторным тестом для оценки иммунитета является клинический анализ крови с оценкой количественных и качественных характеристик всех классов форменных элементов и определение скорости оседания эритроцитов.

Повышение количества лейкоцитов (лейкоцитоз) характерно для воспалительных процессов в том числе, связанных с онкологическими заболеваниями, при вирусных и бактериальных инфекциях, интоксикациях, инфаркте внутренних органов, гемобластозах. При инфекциях (брюшной тиф и паратифы, бруцеллёз, туберкулёз, грипп, корь, ветряная оспа, вирусный гепатит, краснуха, малярия, сыпной тиф), приёме лекарственных средств (антибиотики, цитостатики, нестероидные противовоспалительные средства, тиреостатики и др.), аутоиммунных заболеваниях, после воздействия ионизирующего излучения, при истощении и кахексии, анемиях различного генеза, спленомегалии, алейкемических вариантах гемобластозов определяется снижение количества лейкоцитов (лейкопения).

По своему составу лейкоциты не однородны, различные популяции лейкоцитов выполняют разные функции. К клеткам врожденного иммунитета следует отнести нейтрофилы, эозинофилы, базофилы и моноциты. Основная часть лимфоцитов относится к клеткам адаптивного иммунитета.

Наибольшую популяцию лейкоцитов составляют нейтрофилы. Основная их функция - распознавание, захват, уничтожение бактерий и продуктов распада, получаемых в процессе адаптивного иммунитета. Традиционно считаясь индукторами воспалительной реакции, нейтрофилы способны параллельно включать механизмы, влияющие на ограничение и разрешение воспаления.

Средняя продолжительность жизни нейтрофила - 4-5 суток. При выходе из костного мозга в кровеносное русло нейтрофилы, прилипают к эндотелию 
кровеносного сосуда (пристеночный пул), затем в течение 8-10 часов, поступают в периферические ткани.

При контакте с инфекционным агентом, стрессе, физических нагрузках и др. число нейтрофилов в крови может резко увеличится в течение нескольких часов. Это происходит за счёт мобилизации пристеночного пула и ускорения выхода нейтрофилов из костного мозга. Нейтрофилией (нейтрофильным лейкоцитозом) считают повышение количества нейтрофилов более 7,0·109/л. Для правильной интерпретации гемограммы необходимо учитывать региональные нормы, т.к. нормальные диапазоны анализа крови могут варьироваться от лаборатории к лаборатории.

Выделяют шесть видов нейтрофильного лейкоцитоза:

1. без ядерного сдвига - увеличение количества зрелых сегментоядерных нейтрофилов на фоне общего лейкоцитоза;

2. с гипорегенеративным ядерным сдвигом влево - увеличение содержания палочкоядерных форм нейтрофилов (свыше 5 \%) на фоне абсолютной нейтрофилии (характерно для легкого течения инфекций и воспалений). Указывает на незначительное снижение реактивности организма.

3. с регенеративным ядерным сдвигом влево - на фоне нейтрофилии и увеличенного содержания палочкоядерных форм появляются метамиелоциты (более 1\%); (характерно для гнойно-септических процессов, является критерием остроты процесса, указывает на высокий уровень резистентности организма);

4. с гиперрегенеративным ядерным сдвигом влево - появление в гемограмме миелоцитов и промиелоцитов при значительно выраженном лейкоцитозе, эозинофилы часто вообще отсутствуют (анэозинофилия). Подобная картина является тревожным прогностическим признаком, указывающим на неблагоприятное течение инфекционных и гнойносептических заболеваний.

Иногда в крови могут обнаруживаться нормальные (а не опухолевые) миелобласты, а суммарное количество лейкоцитов может быть выше 50·109/л. Такое гиперактивное состояние опасно последующим истощением костного мозга и развитием костномозговой недостаточности.

5. с дегенеративным ядерным сдвигом влево - повышение содержания палочкоядерных нейтрофилов сопровождается появлением значительного числа деструктивно измененных сегментоядерных форм (пикноз ядер, токсогенная зернистость и вакуолизация цитоплазмы и т. д.). Дегенеративный ядерный сдвиг влево является показателем угнетения функциональной активности костного мозга и может иметь место при тяжелом течении инфекционных заболеваний, при эндогенной интоксикации и т. д.; 
6. с дегенеративным ядерным сдвигом вправо - характеризуется появлением в гемограмме гиперсегментированных (свыше 5 сегментов) нейтрофилов, значительным снижением или полным отсутствием палочкоядерных форм, что указывает на первичное подавление миелопоэза (наблюдается при лучевой болезни, некоторых видах анемий). Иногда может обнаруживаться и у практически здоровых людей.

Слишком высокое повышение уровня лейкоцитов может быть следствием онкогематологического заболевания - острого или хронического лейкоза. При этом в мазке крови находят морфологически измененные клетки, а также незрелые формы лейкоцитов (бласты), которые в норме не должны выходить в периферическую кровь.

Нейтропения - характеризуется аномально низким уровнем нейтрофилов (ниже 2,0·10 /л). Снижение количества нейтрофилов менее $0,5 \cdot 10^{9} /$ л ведет к серьезным расстройствам иммунитета. Степень тяжести определяется количеством клеток:

Легкая степень тяжести нейтропении $-1,0-1,5 \cdot 10^{9} /$ л

Умеренная степень тяжести нейтропении - 0,5-1,0·10 $/$ л

Тяжелая степень тяжести нейтропении - менее $0,5 \cdot 10^{9} /$ л

Эозинофилы. Как и нейтрофилы, способны к фагоцитозу бактерий, однако, основная их роль - борьба с паразитами и контроль аллергических реакций. В циркулирующей крови находятся от 30 минут до нескольких часов, после чего поступают в ткани.

Эозинофилией считается повышение их абсолютного количества более $0,5 \cdot 10^{9} /$ л. Эозинофилия подразделяется на легкую $\left(0,5-1,5 \cdot 10^{9} /\right.$ л), умеренную (от 1,5 до $5,0 \cdot 10^{9} /$ л) или тяжелую (более $5,0 \cdot 10^{9} / \pi$ ). В том случае, когда абсолютное количество эозинофилов сохраняется высоким на протяжении длительного времени, возможно возникновение поражения внутренних органов, вызванное эозинофильной инфильтрацией и воздействием токсических продуктов кислорода и гранулярных белков.

Снижение количества эозинофилов (ниже $0,01 \cdot 10^{9} /$ л или менее $0,5 \%$ для относительного содержания вплоть до полного исчезновения) может быть признаком заболеваний различной природы и разной степени тяжести (начала воспалительного процесса, тяжелой гнойной инфекции, шока, отравления тяжёлыми металлами, интоксикаций).

Базофилы. основная их функция - выброс гистамина и других медиаторов в аллергических реакциях различного типа. Базофилией считается увеличение их количества более $0,2 \cdot 10^{9} /$ л. Повышение базофилов в крови может быть физиологическим явлением или сопутствующим признаком некоторых заболеваний. Базофилия наблюдается при аллергиях, в том числе лекарственных, некоторых инфекциях (грипп, ветряная оспа, туберкулёз) 
язвенном колите, при злокачественных новообразованиях, определенных онкогематологических заболеваниях и анемиях. Базопению (уменьшение базофилов) очень трудно заметить, поскольку это самая низкая по количеству популяция циркулирующих лейкоцитов. Отсутствие базофилов может быть связано с тяжелой аллергической реакцией.

Моноциты. Предшественники макрофагов и дендритных клеток. Являются частью врожденного иммунного ответа, выполняют функции, сходные с функциями гранулоцитов, а именно распознавание, захват и уничтожение бактерий и грибов, однако помимо фагоцитарной активности они перерабатывают патогены и презентируют их клеткам адаптивного иммунитета. Из кровотока моноциты в течении суток переходят в ткани. Время жизни этих клеток может достигать нескольких

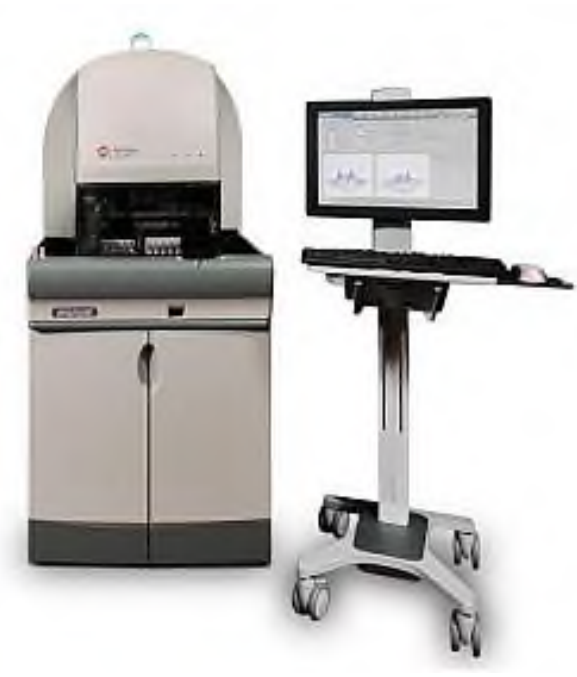

Рис.132. Гематологический анализатор UniCell DxH 800 (Beckman Coulter) использующий систему раннего обнаружения сепсиса. лет.

Моноцитоз - увеличение абсолютного количества моноцитов более $1,0 \cdot 10^{9} /$ л. Моноцитоз отмечается при злокачественных новообразованиях, острых и хронических инфекционно-воспалительных процессах, состоянии после перенесённого инфекционного заболевания, аутоиммунных заболеваниях. Индикатором раннего сепсиса является ширина распределения моноцитов (MDW). Использование Early Sepsis Indicator с показателем MDW более 20,0 U, позволяет эффективно диагностировать сепсис (рис. 132).

Наибольшим разнообразием отличаются лимфоциты. Основные клетки адаптивного иммунитета, которые за счет экспрессии на поверхности уникальных антигенных рецепторов распознают различные антигены. В дальнейшем в зависимости от типа клетки они формируют гуморальный иммунитет (за счет синтеза антител различных классов) или клеточный иммунитет (формирования пула цитотоксических лимфоцитов). Часть лимфоцитов является клетками памяти, которые сохраняют информацию о ранее встречавшемся антигене. Они быстро пролиферируют и продуцируют большие количества антител при повторной встрече с известным антигеном. Лимфоциты обладают способностью синтезировать и секретировать в кровь различные белковые регуляторы - цитокины, посредством которых осуществляют координацию и регуляцию иммунного ответа. Часть лимфоцитов 
(NK- и NKT-клетки) обеспечивают противоопухолевый врожденный иммунитет.

Лимфоцитозом считается повышение абсолютного количества лимфоцитов более $5,0 \cdot 10^{9} /$ л, лимфопенией снижение лимфоцитов менее $1,0 \cdot 10^{9} /$ л.

Единичные морфологически измененные лимфоциты (атипичные мононуклеары), встречающиеся в мазке крови, не имеют диагностического значения. В значительном количестве атипичные мононуклеары появляются в крови пациентов с инфекционным мононуклеозом, ассоциированным с вирусом Эпштейна-Барра (EBV), но могут обнаруживаться и при других вирусных заболеваниях. К патологии можно отнести и появление в переферической крови плазматических клеток (антителообразующие клетки, которые должны находятся в лимфатических узлах и селезёнке).

Анализируя данные клинического анализа крови возможно определить тип и характер иммунного ответа. Тип реакции иммунной системы рассчитывается из соотношения абсолютного количества гранулоцитов и лимфоцитов и характеризует состояние врожденного и адаптивного иммунитета (табл. 45).

Таблица 45

\section{Определение типа реакции иммунитета по развернутому анализу крови}

\begin{tabular}{|c|c|c|c|c|}
\hline \multirow{2}{*}{\multicolumn{2}{|c|}{ Показатели }} & \multicolumn{3}{|c|}{ Лимфоциты, абс. } \\
\hline & & понижены & норма & повышены \\
\hline \multirow{3}{*}{ 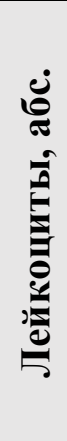 } & повышены & $\begin{array}{c}\text { Активация } \\
\text { врожденного } \\
\text { иммунитета }\end{array}$ & $\begin{array}{c}\text { Активация } \\
\text { врожденного } \\
\text { иммунитета }\end{array}$ & $\begin{array}{c}\text { Активация } \\
\text { адаптивного } \\
\text { иммунитета }\end{array}$ \\
\hline & норма & $\begin{array}{c}\text { Угнетение } \\
\text { иммунитета }\end{array}$ & $\begin{array}{c}\text { Ареактивность } \\
\text { иммунитета }\end{array}$ & $\begin{array}{c}\text { Активация } \\
\text { адаптивного } \\
\text { иммунитета }\end{array}$ \\
\hline & понижены & $\begin{array}{c}\text { Угнетение } \\
\text { иммунитета }\end{array}$ & $\begin{array}{c}\text { Угнетение } \\
\text { иммунитета }\end{array}$ & $\begin{array}{c}\text { Активация } \\
\text { адаптивного } \\
\text { иммунитета }\end{array}$ \\
\hline
\end{tabular}

Определение типа реакции рассчитывается из соотношения процентного и абсолютного количества лимфоцитов в крови пациента и характеризует механизм реакции костного мозга, формирующий соответствующее состояние иммунной системы (табл. 46).

Выделенные иммунотипы позволяют в дальнейшем определить тактику иммунологических исследований, в том числе используя методы проточной цитометрии проводить топическую диагностику нарушений в отдельных звеньях иммунной системы. 
Помимо данных лейкоцитарной формулы важным является определение концентрации гемоглобина, количества эритроцитов, величины гематокрита и эритроцитарных индексов (MCV, RDW, MCH, MCHC).

Таблица 46

\section{Характер реакции иммунитета по развернутому анализу крови}

\begin{tabular}{|c|c|c|c|c|}
\hline \multirow{2}{*}{\multicolumn{2}{|c|}{ Показатели }} & \multicolumn{3}{|c|}{ Лимфоциты, \%. } \\
\hline & & понижены & норма & повышены \\
\hline \multirow{3}{*}{ 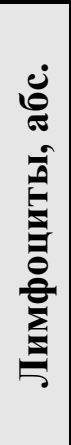 } & повышены & $\begin{array}{c}\text { Ассиметричная } \\
\text { стимуляцией } \\
\text { лейкопоэза }\end{array}$ & $\begin{array}{l}\text { Активация } \\
\text { лимфопоэза }\end{array}$ & Активация лимфопоэза \\
\hline & норма & $\begin{array}{c}\text { Ассиметричная } \\
\text { стимуляцией } \\
\text { лейкопоэза }\end{array}$ & Нормореакция & $\begin{array}{c}\text { Недостаточная } \\
\text { активация лимфопоэза }\end{array}$ \\
\hline & понижены & $\begin{array}{c}\text { Декомпенсированный } \\
\text { лейкопоэз }\end{array}$ & $\begin{array}{c}\text { Недостаточная } \\
\text { активация } \\
\text { лимфопоэза }\end{array}$ & $\begin{array}{c}\text { Недостаточная } \\
\text { активация лимфопоэза }\end{array}$ \\
\hline
\end{tabular}

Снижение количества эритроцитов в единице объёма, гемоглобина и гематокрита свидетельствует об анемии (различной этиологии) или гипергидратации. Повышение - об обезвоживании (при выраженной диарее, рвоте, повышенном потоотделении, диабете, ожоговой болезни, перитоните), недостаточности дыхательной и сердечно-сосудистой системы, поликистозе почек, эритремии.

Понижение значений MCV (средний объём эритроцитов), МCH (среднее количества гемоглобина в 1 эритроците), МСНС (средняя концентрация гемоглобина в эритроцитах) характерно для железодефицитной анемии, анемии хронических заболеваний, некоторых видах гемоглобинопатий. Повышение значений MCV при В12-дефицитной и фолиеводефицитной анемии, апластической анемии, заболеваниях печени, гипотиреозе, аутоиммунной анемии.

Повышение значений RDW (Red cell Distribution Width, распределение эритроцитов по величине) связано с анемиями миелодиспластического, мегалобластного и сидеробластного типов, вследствие успешного лечения анемии, состояний после переливания эритроцитарной массы, холодовых аллергиях, хронических лимфолейкемиях, гипергликемии. При анемии хронических заболеваний, анемия вследствие острой кровопотери, апластической анемии, генетически обусловленных заболеваниях (талассемия, наследственные мембранопатии, наличие гемоглобина Е) не характерно увеличение RDW.

Тромбоциты - фрагменты мегакариоцитов, которые функционируют в системе свертывания крови. Тромбоциты циркулируют от 7 до 12 суток. Около 
одной трети всегда временно удерживаются в селезенке. Количество тромбоцитов, как правило, от $140 \cdot 10^{9} /$ л до 440·10\%/л. Низкая концентрация тромбоцитов (тромбоцитопения) возникает из-за снижения образования (недостаточности синтеза тромбопоэтина) или увеличения разрушения. Повышенная концентрация тромбоцитов (тромбоцитоз) может быть врожденной, реактивной (увеличиваться под воздействием воспалительных цитокинов), либо обусловлена нерегулируемым производством (при некоторых миелопролиферативных новообразованиях).

Традиционно для диагностики воспалительных состояний и мониторинга их течения определяется неспецифический показатель, отражающий изменения белкового состава плазмы крови - скорость оседания эритроцитов (СОЭ). При появлении в плазме крови большого количества белков острой фазы воспаления (фибриноген, С-реактивный белок, орозомукоид, альфа 1антитрипсин, церулоплазмин и гаптоглобин) сила отталкивания между эритроцитами снижается, и эритроциты оседают быстрее. При острых воспалительных и инфекционных процессах ускорение СОЭ наступает через 24 часа или через несколько дней (2-4 дня), в период развертывания клинической картины заболевания, после повышения температуры и увеличения числа лейкоцитов. Нормализация этого показателя после выздоровления происходит медленнее, и может занять от нескольких дней до двух, и более, недель.

При анемии СОЭ повышается в соответствии с уменьшением числа эритроцитов и гематокрита. Некоторые морфологические варианты эритроцитов также могут оказывать влияние на СОЭ: анизоцитоз, сфероцитоз и дрепаноцитоз ингибируют агрегацию эритроцитов; макроциты имеют заряд, соответствующий их массе, и оседают быстрее.

Не маловажными являются биохимические исследования, определяющие различные компоненты иммунной системы.

При количественном определение фракций общего белка крови выделяют 6 стандартных фракций: 1 - альбумины, 2 - альфа1-глобулины, 3 - альфа2глобулины, 4 - бета1 - глобулины, 5 - бета-2 глобулины, 6 - гамма-глобулины.

Альфа1-глобулины - это белки острой фазы воспаления: альфа1антитрипсин - основной компонент этой фракции (ингибитор многих протеолитических ферментов - трипсина, химотрипсина, плазмина и т. д.), а также альфа1-кислый гликопротеин (орозомукоид). Альфа2-глобулины альфа2-макроглобулин, гаптоглобин, церулоплазмин (острофазные белки участвующие в развитии инфекционных и воспалительных реакций). Бетаглобулины состоят из трансферрина, гемопексина, компонентов комплемента.

Гамма-глобулины - это иммуноглобулины (IgG, $\operatorname{IgA,~} \operatorname{Ig}$, IgE), представляющие собой антитела, которые обеспечивающие адаптивное гуморальное звено иммунитета. Изменения отдельных фракций белков 
сыворотки крови зависят от многих причин (наследственных, острых или хронических заболеваний). Например, при миеломной болезни на электрофореграмме выявляются дополнительные фракции парапротеинов (моноклонального или Мбелка), концентрация которого может быть более 15 г/л.

Самым быстрым и чувствительным индикатором повреждения тканей при новообразовании, воспалении, некрозе, травме является белок острой фазы С-реактивный белок (СРБ), который стимулирует фагоцитоз, активирует классическую систему комплемента,

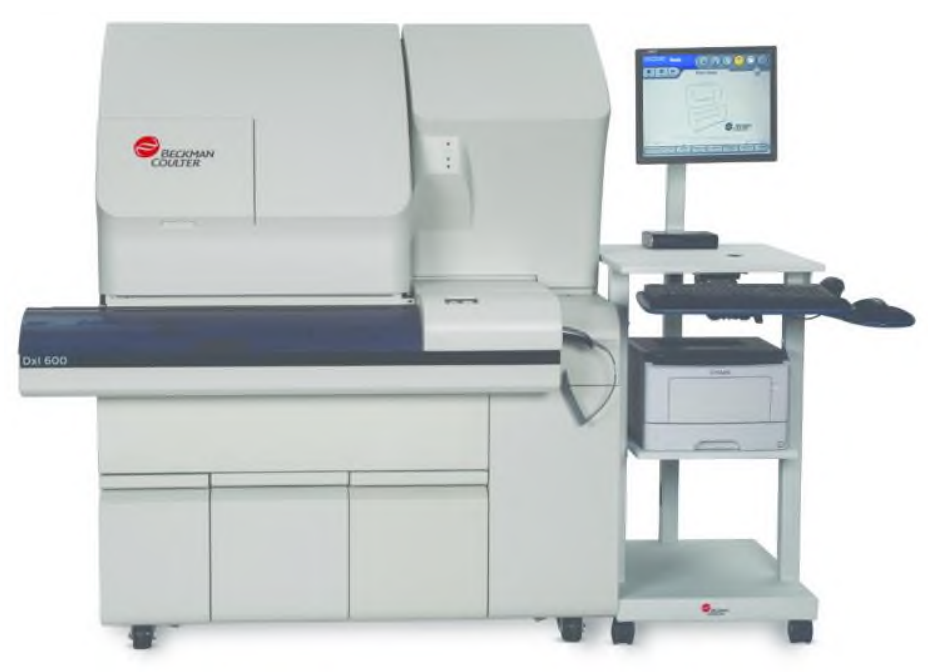
участвует во взаимодействии Т- и В-лимфоцитов.

Синтезируется преимущественно в гепатоцитах, за счет индукции антигенами, иммунными комплексами, бактериями, грибами, при некрозе тканей. При этом концентрация СРБ в плазме возрастает очень быстро (в первые 4-8 часов после повреждения) и весьма значительно (в 20-100 раз, а иногда и в 1000 раз). Величина СРБ (нормальная концентрация в плазме здорового человека - 1,0 мг/л) высоко коррелирует с активностью заболевания и стадией процесса. При бактериальной инфекции наблюдаются самые высокие уровни СРБ (100 мг/л и выше). При эффективной терапии уровень СРБ снижается уже на следующий день, если нет - необходимо более эффективное антибактериальное лечение. Это позволяет использовать мониторинг СРБ для наблюдения за течением болезни и контролем адекватности терапии.

При вирусной инфекции уровень СРБ повышается незначительно (меньше 20 мг/л), что позволяет отличить вирусные инфекции от бактериальных. Но при нейтропении у взрослого пациента уровень СРБ более 10 мг/л может быть единственным объективным указанием на бактериальную инфекцию.

При злокачественных опухолях возможны различные изменения уровней СРБ, так как их интенсивность зависит от присоединения инфекции, некроза тканей, нарушения функций органов из-за непроходимости респираторных путей или желудочно-кишечного тракта, влияния иммуносупрессии и химиотерапии. Некрозы тканей (инфаркт миокарда, опухолевый некроз тканей почки, легких, толстого кишечника) вызывают такой же сильный острофазный 
ответ, как и бактериальная инфекция. Если при высоком уровне СРБ нет явных признаков воспаления, больного следует обследовать на онкозаболевания.

Определение других белков острой фазы количество которых увеличивается (фибриноген, сывороточный амилоид А и Р, эозинофильный катионный белок) или уменьшается (преальбумин, альбумин, трансферин) при воспалении в клинической практике применяется реже.

На состояния иммунной системы большое влияние оказывают нарушения обменных процессов и/или функции отдельных органов и систем.

Важным являются для диагностики белкового обмена общий уровень белка и альбумина. Снижение их количества менее 60 г/л и 30 г/л соответственно свидетельствуют о белковой недостаточности. Это можно расценивать как причину иммунных нарушений.

O нарушении углеводного обмена будет свидетельствовать повышение/понижение уровня глюкозы (гипергликемия более 6 ммоль/л, гипогликемия менее 4 ммоль/л). Глюкоза основной субстрат энергетического обмена человека. В опухолевых клетках идет активное потребление глюкозы за счет гликолиза с последующим образованием лактата. Лактоацидоз (значение лактата более 2,2 ммоль/л) основная причина слабости и утомления.

По рекомендациям ВО3 тестом для выявления нарушений углеводного обмена является определение гликированного гемоглобина. Показатель $\geq 6.5 \%-$ критерий сахарного диабета, $<6 \%$ - отсутствие нарушений углеводного обмена.

На нарушение липидного обмена будет указывать увеличение или снижение уровня холестерина (норма от 3 до 5,2 ммоль/л).

На недостаточность функции печени будет указывать уровень билирубина более 30 ммоль/л, АлАТ - более 35 Ед/л. На недостаточность функция почек - повышенная альбуминурия (стойкое повышение экскреции альбумина с мочой $>30$ мг/сут.) или отношение альбумина к креатинину мочи $>30 \mathrm{Mr} / \mathrm{\Gamma}$.

На нарушение системы регуляции агрегатного состояния крови указывают изменения показателей содержания плазменных факторов и тромбоцитов более чем на $20 \%$ от границ физиологической нормы. Повышение уровня ЛДГ наблюдается при любых заболеваниях, сопровождающихся повреждением тканей и разрушением клеток. В связи с этим она является важным маркером тканевой деструкции. Несмотря на то, что увеличение активности фермента не указывает на какую-то определенную болезнь, определение активности его изоферментов в комплексе с другими лабораторными анализами помогает в диагностике локализации повреждения.

Лактацидоз (повышение значений лактата - продукта анаэробного метаболизма глюкозы (гликолиза) у онкологических больных проявление метаболических нарушениях с развитием ацидоза и эндотоксикоза. 


\section{Исследование клеточного звена иммунитета}

Учитывая многообразие клеток иммунной системы, их идентификация и оценка активности является первоочередным мероприятием по оценки функции иммунитета. В общей практике такие исследования проводятся ежедневно в большом количестве при исследовании клинического анализа крови (см. гл.6). Однако для детального изучения клеток иммунной системы этого исследования недостаточно. В клинической практике и научных исследованиях широкое применение нашли методы основанные на идентификации поверхностных дифференцировочных антигенов на клетках иммунной системы с помощью моноклональных антител. Суть метода заключается в связывании дифференцировочных АГ лимфоцитов с моноклональными АТ и дальнейшим их окрашиванием антиглобулиновыми АТ, меченными флуорохромом (метод непрямой иммунофлуоресценции). В дальнейшем происходит измерение меченых клеток с помощью различных методов где безусловнывм лидером является проточная цитометрия.

Проточная цитофлуориметрия - современная технология быстрого измерения характеристик клеток при помощи моноклональных антител или других зондов, позволяющая судить об их типе (по наличию того или иного набора клеточных маркеров) и их функциональном состоянии (по изменению протекающих в них процессов).

Созданная для ускорения анализа в клинической цитологии и цитодиагностике, эта технология постепенно развилась в эффективный подход к решению многих важных задач биологии клетки, иммунологии, клеточной инженерии и т.Д. Области применения проточной цитометрии весьма разнообразны.

Помимо морфологических характеристик клеток с помощью моноклональных АТ можно: достоверно определять популяционный и субпопуляционный состав лимфоцитов; выявлять стадию дифференцировки и активации клеток; оценивать уровень функциональной активности лимфоцитов; определять внутриклеточные и секретируемые цитокины; проводить исследования фагоцитоза; анализировать клеточный цикл, оценивать апоптоз и пролиферацию. Технология измерения различных характеристик клеток или их органелл следущая (рис. 133):

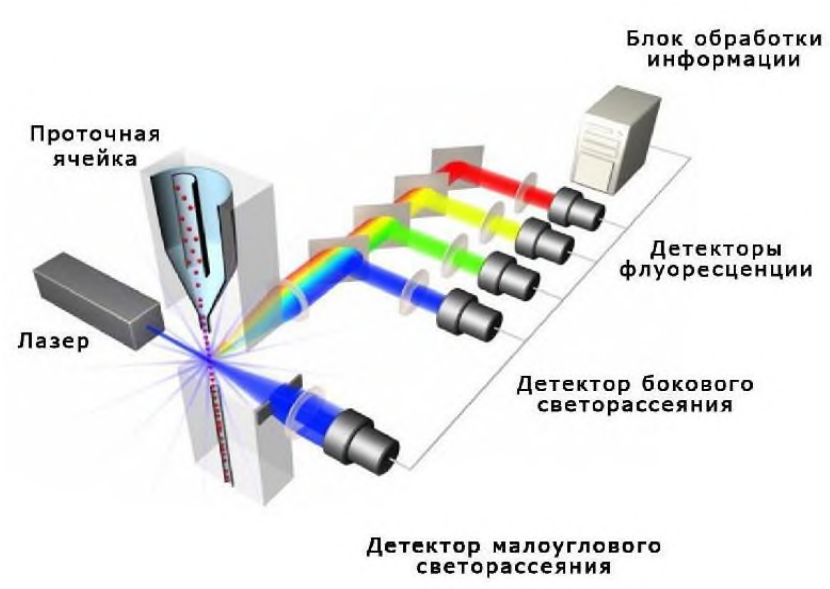

Рис.133. Принцип работы проточного цитометра. 
Клеточная суспензия, предварительно меченная флуоресцирующими моноклональными АТ или флуоресцентными красителями, подается к потоковому элементу. Клетки идут одна за другой, где в проточной ячейке их пересекает лазерный луч, под действием которого окрашенные клетки флуоресцируют. Далее через оптическую систему излучение попадает на регистрирующее устройство, где в дальнейшем обрабатывается. С помощью проточной цитометрии можно определить размеры клетки, соотношение ядра и цитоплазмы, степень асимметричности и интенсивность флуоресценции. Допускаются измерение до 21 флуоресцентного параметра одновременно и с высокой чувствительностью и воспроизводимости при шести длин волн возбуждения (до 6 лазеров). При исследовании допустима оценка свойств от нескольких десятков до нескольких миллионов клеток.

Анализ параметров прямого (FS) и бокового (SS) светорассеяния позволяет получить информацию о таких параметрах клеток как относительный размер и «гранулярность», соответственно. После удаления эритроцитов из образца периферической крови на основании анализа FS и SS можно выявить три основные популяции лейкоцитов (рис. 134).
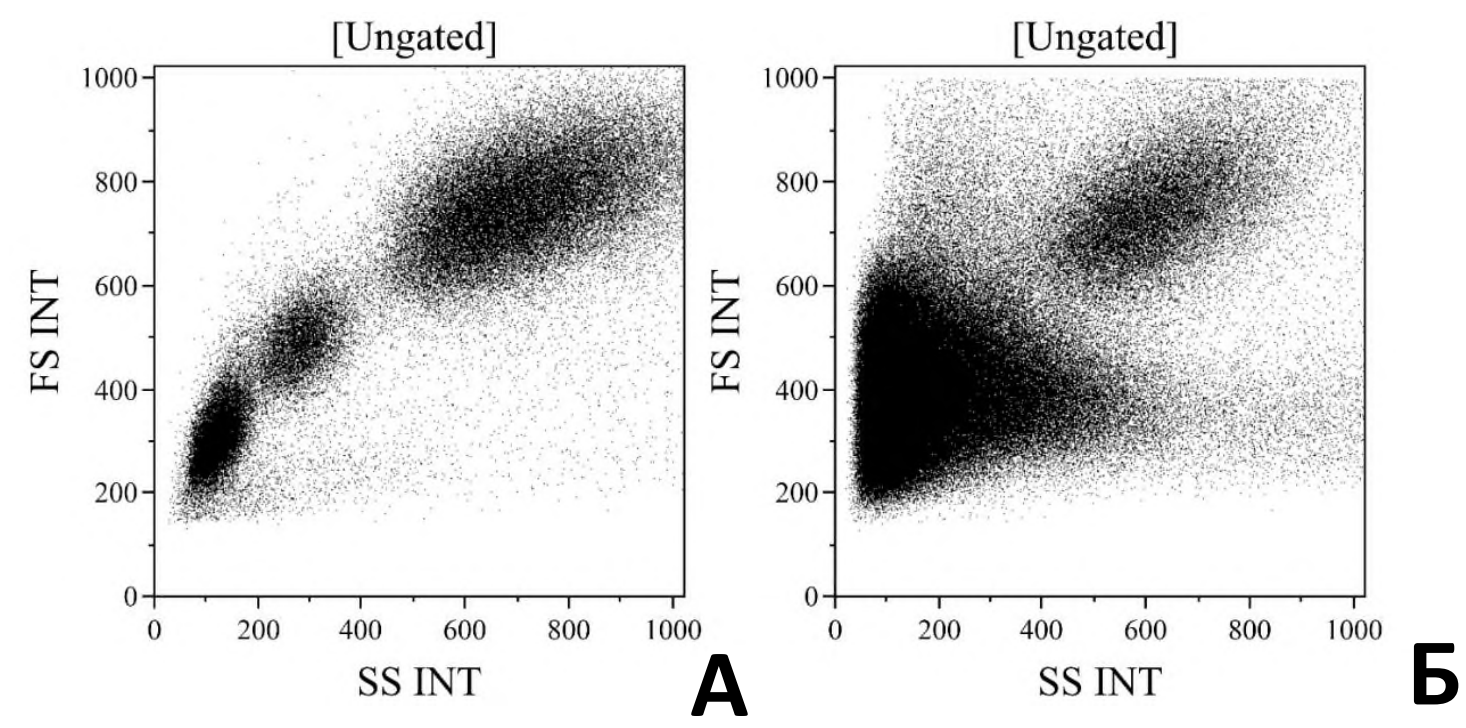

Рис. 134. Анализ морфологических параметров лейкоцитов периферической крови при помощи проточной цитометрии. Комментарии в тексте.

Во-первых, - это лимфоциты, расположенные в левой нижней части гистограммы А.

Во-вторых, - это моноциты, расположенные несколько выше по FS и правее по SS от популяции лимфоцитов.

B-третьих, - это гранулоциты, расположенные выше по оси ординат и правее по оси абсцисс по сравнению с моноцитами. 
Что же касается двух других популяций лейкоцитов - базофилов и эозинофилов, то для их выявления необходимо использовать флуорохромконъюгированные моноклональные антитела, так как по параметрам светорассеяния они «накладываются» на популяции лимфоцитов и гранулоцитов, соответственно. Дендритные клетки, которые могут обнаруживаться в незначительном количестве в периферической крови, по прямому и боковому светорассеянию обычно располагаются между лимфоцитами и моноцитами, не формируя четко оформленных популяций. Для их выявления также необходимо применять моноклональные антитела, конъюгированные с флуорохромами.

Набор клеточных маркеров позволяет судить о типе (табл.47) и функциональном состоянии (табл.48) той или иной клетке.

Таблица 47

\section{CD-антигены, определяющие тип клетки}

\begin{tabular}{|c|c|}
\hline $\begin{array}{c}\text { CD- } \\
\text { антиген }\end{array}$ & Клеточная экспрессии \\
\hline CD3 & $\begin{array}{l}\text { Т-клетки (в комплексе с TCR - передача сигнала при антигенном распознавании Т } \\
\text { клеткой). }\end{array}$ \\
\hline CD4 & $\begin{array}{l}\text { T-хелперы, субпопуляции моноцитов, субпопуляции кортикальных тимоцитов, EBV } \\
\text { трансформированные В-клетки (корецептор МHC II класса, рецептор для ВИЧ). }\end{array}$ \\
\hline CD5 & Зрелые Т-клетки, субпопуляции В-клеток (лиганд CD72 на В-клетках). \\
\hline CD8 & $\begin{array}{l}\text { Т-цитотоксические, субпопуляции NK-клеток, субпопуляции кортикальных тимоцитов, } \\
\text { (корецептор МНС I класса). }\end{array}$ \\
\hline CD14 & Моноциты (LSP рецептор). \\
\hline CD16 & NK-клетки, гранулоциты, макрофаги (Fcg RIII). \\
\hline CD19 & Предшественники В-клеток и В-клетки. \\
\hline CD20 & Субпопуляции предшественников В-клеток, зрелые В-клетки. \\
\hline CD21 & Зрелые В-клетки (рецептор C3d, CD23 и рецептор EBV). \\
\hline CD34 & Стволовая кроветворная клетка. \\
\hline CD45RA & “наивные”, непремированные Т клетки (изоформа CD45). \\
\hline CD45RO & Т - клетки памяти (изоформа CD45). \\
\hline CD56 & NK-клетки, некоторые Т-клетки (молекула адгезии NK клеток N-CAM). \\
\hline CD127 & $\begin{array}{l}\text { Активированные В и Т лимфоциты, макрофаги, NK клетки (ранний маркер } \\
\text { лимфоцитарной активации). }\end{array}$ \\
\hline
\end{tabular}




\section{CD-антигены, используемые для оценки функционального состояния клеток иммунной системы.}

\begin{tabular}{|c|c|}
\hline $\begin{array}{c}\text { CD- } \\
\text { антиген }\end{array}$ & Клеточная экспрессии \\
\hline HLA-DR & $\begin{array}{l}\text { Определяется на всех B-лимфоцитах и моноцитах, на активных T-лимфоцитах } \\
\text { (маркер поздней активации). При наличии HLA-DR на моноцитах менее 50\% является } \\
\text { неблагоприятным патогномоничным признаком развития тяжелой бактериальной } \\
\text { инфекции (сепсис, перитонит). }\end{array}$ \\
\hline CD11b & $\begin{array}{l}\text { Экспрессируется на большинстве лейкоцитов. Относится к наиболее важным для } \\
\text { миграции клеток интегринам, которые определяют активность фагоцитоза, } \\
\text { клеточной цитотоксичности, хемотаксиса и клеточной активации Т-эффекторов, NK- } \\
\text { клеток, макрофагов и гранулоцитов. }\end{array}$ \\
\hline CD14 & $\begin{array}{l}\text { Находится на всех моноцитах периферической крови. Сочетание его с CD16+ } \\
\text { маркером указывает на число провоспалительных моноцитов, который является } \\
\text { критерием тяжести инфекционно-воспалительных заболеваний. }\end{array}$ \\
\hline CD23 & $\begin{array}{l}\text { Экспрессируется на активированных В клетках, макрофагах, клетках тимического } \\
\text { эпителия, эозинофилах, тромбоцитах. Показатель активности В-клеток. }\end{array}$ \\
\hline CD25 & $\begin{array}{l}\alpha \text {-Цепь рецептора ИЛ2. Экспрессируется на различных типах клеток периферической } \\
\text { крови: CD4+, CD8+, NK, NKT-клетках, B-лимфоцитов, моноцитах. Маркер ранней } \\
\text { активации Т-лимфоцитов. может говорить о воспалительном процессе любой } \\
\text { природы (инфекционный, аутоиммунный). }\end{array}$ \\
\hline CD27 & $\begin{array}{l}\text { Дополнительный маркер В2-лимфоцитов. Указывает на переход В-лимфоцитов из } \\
\text { наивных клеток в клетки памяти }\end{array}$ \\
\hline CD28 & $\begin{array}{l}\text { Экспрессируется на большинстве активированных Т-лимфоцитах, NK-клетках и } \\
\text { плазматических клетках. Необходим как костимулирующий фактор для индукции } \\
\text { иммунного ответа (пролиферации и активации клеток). }\end{array}$ \\
\hline CD38 & $\begin{array}{l}\text { Циклическая АДФ-рибозил гидролаза находится на поверхности лимфоцитов, } \\
\text { обеспечивает адгезию, передачу сигнала. CD38 является так же маркером активации } \\
\text { клеток (метаболический маркер). Понижается при ВИч- инфекции, лейкемии, } \\
\text { миеломе, солидных опухолях, диабете II тип. }\end{array}$ \\
\hline CD50 & $\begin{array}{l}\text { Межклеточная молекулы адгезии (ICAM-3) помимо этого является мощной } \\
\text { сигнальной молекулой. Предс тавлена на всех лейкоцитах, эндотелиальных и } \\
\text { дендритных клетках. Обеспечивает костимуляторные сигналы для Т-клеток и } \\
\text { регулирует адгезию клеток путем взаимодействия с интегринами. Показано } \\
\text { снижение количества CD50+ клеток при опухолевых заболеваниях. }\end{array}$ \\
\hline CD57 & $\begin{array}{l}\text { Экспрессируется на субпопуляции 15-20\% мононуклеарных клеток периферической } \\
\text { крови, у 60\% NК клеток и Т-клеток. Повышение показателей определяется у } \\
\text { онкологических больных, больных после трансплантации, у пациентов с ВИЧ, а так же } \\
\text { с ревматоидным артритом и синдромом Фелти. Снижение патогномонично при } \\
\text { хронизации болезни Лайма. }\end{array}$ \\
\hline CD62L & $\begin{array}{l}\text { Представитель семейства молекул клеточной адгезии (L-селектин), находящийся на } \\
\text { клеточной поверхности лейкоцитов (Т и NK клеток, моноцитов, гранулоцитов), } \\
\text { обеспечивает транслокацию лейкоцитов из крови в лимфоидную ткань, где они } \\
\text { взаимодействуют с антигеном. }\end{array}$ \\
\hline
\end{tabular}


Оценка функции фагоцитарных клеток. Процесс фагоцитоза состоит из нескольких этапов: хемотаксис, адгезия, поглощение, дегрануляция, киллинг и разрушение объекта фагоцитоза. Их изучение имеет определенную значимость в оценке фагоцитарного процесса, так как существуют иммунодефициты, связанные с наличием поломок практически на каждом этапе.

Адгезивную способность нейтрофилов можно измерить по прилипанию к волокнам из нейлона.

Миграцию и хемотаксис фагоцитирующих клеток оценивают при использовании агарозных тестов (реакция торможения миграции лейкоцитов). Поглотительную способность лейкоцитов измеряют по захвату ими различных частиц (микроорганизмы, частицы латекса). Метаболическая активность клеток может быть оценена в тесте с нитросиним тетразолием (НСТ-тест) или с помощью хемилюминесцентного метода.

Определяется поглотительная способность нейтрофилов с подсчетом фагоцитарного индекса, т. е. процента (относительного числа) фагоцитирующих нейтрофилов. Оценивается фагоцитарное число, или среднее число частиц, поглощенных одним нейтрофилом. Метод основан в умении полиморфноядерных лейкоцитов (или моноцитов) периферической крови связывать на своей поверхности, поглощать и переваривать чужеродные агенты (микробные агенты, индифферентные частицы, например, используемый в тестах латекс). Бактерицидная активность фагоцитов основана на подсчете жизнеспособных бактерий, оставшихся внутри клеток после инкубации. В норме фагоцитарный показатель составляет: спонтанный - 62-68 \%, стимулированный - 80-88 \%. Фагоцитарное число - спонтанное 3-5, стимулированное 7-11.

Фагоцитарная активность нейтрофилов обычно повышается в начале развития воспалительного процесса. Ее снижение ведет к хронизации заболевания, развитию синдрома ИК за счет того, что нарушается функция разрушения и выведения ИК.

Хемилюминесцентный метод. Уровень хемилюминесценции при фагоцитозе характеризует интенсивность «респираторного взрыва» в клетках с продукцией активных форм кислорода, оказывающих бактерицидное действие. Первичные метаболиты активированного кислорода представляют собой супероксидный анион-радикал $\left(\mathrm{O}^{2-}\right)$, перекись водорода $\left(\mathrm{H}_{2} \mathrm{O}_{2}\right)$, гидроксильный радикал $\left(\mathrm{HO}_{2}\right)$, синглетный кислород $\left(\mathrm{O}_{2}\right)$. В качестве основных вторичных метаболитов необходимо отметить гипохлорную кислоту $(\mathrm{HClO})$, хлорамины и продукты перекисного окисления липидов. Взаимопревращения первичных и вторичных оксидантов с мощным энергетическим потенциалом создают динамический спектр молекул, которые прямо или косвенно вовлекаются в реакции фагоцитов. При этом взаимодействие высокоэнергетических 
оксидантов с люминесцирующими посредниками (люминол, люцигенин и др.) приводит к переходу последних в электронно-возбужденное состояние, выход из которого сопровождается испусканием кванта света. Регистрация светоизлучения хемилюминесцентной реакции производится на хемилюминометрах отечественного или зарубежного производства. Механизм хемилюминесценции лейкоцитов зависит от природы стимулирующего агента, отличаясь своей специфичностью. Доказана высокая степень корреляции между уровнем хемилюминесценции фагоцитов и киллингом, поэтому определение хемилюминесценции лейкоцитов может использоваться как один из критериев их способности к завершенному фагоцитозу, позволяющих оценить функциональную активность лейкоцитов.

НСТ-тест. Восстановление НСТ в фагоцитозе прямо зависит от эффективности метаболических процессов в клетке. Интенсивность восстановления отражает активность генерации супероксидных радикалов. Этот метод является чувствительным индикатором раздражения клеток (спонтанный НСТ) и их функциональных резервов (стимулированный НСТ). В норме число НСТ-положительных нейтрофилов составляет 10 \% (или 50-130 у.е.), после стимуляции - 40-80 \% (80-200 у.е.).

Еще одним методом оценки клеточного звена иммунитета, является ELISPOT (англ. Enzyme-Linked ImmunoSPOT analysis). Метод позволяет идентифицировать конкретные цитокины, выделяемые живыми клетками. Принцип заключается в специфической реакции сенсибилизированных антител c секретируемыми клеткой молекулами. В результате этой реакции формируются окрашенные пятна (споты).

Каждое пятно представляет собой единственную клетку, секретирующую специфический цитокин. Пятна подсчитываются либо вручную (с помощью стереомикроскопа), либо с использованием ELISPOT-ридеров, которые обладают компьютерными возможностями визуализации клеток, активно продуцирующих цитокины.

Благодаря уникально высокой чувствительности ELISPOT-анализа, идентификация малочисленных клеточных популяций (при антигенспецифичных ответах), которая была недоступна ранее, теперь стала относительно простой задачей. Такая уникально высокая чувствительность, во многом, определяется тем, что цитокины связываются буквально рядом с секретирующими их клетками, до растворения в супернатанте и до захвата рецепторами соседних клеток или разрушения. Это делает ELISPOT-анализ значительно более чувствительным, чем ИФА. Пределы его чувствительности ниже 1/100 000, что делает этот метод очень полезным для мониторинга антиген-специфичных ответов в различных областях иммунологических исследований, включая исследования рака, пересадку органов, инфекционные заболевания и разработку вакцин. 


\section{Стадии метода ELISPOT}

\begin{tabular}{|c|c|c|}
\hline 1 & GES & $\begin{array}{l}\text { Моноклональные или поликлональные антитела, } \\
\text { специфические к определенному антигену наносятся } \\
\text { на микропланшет со специальным носителем. }\end{array}$ \\
\hline 2 & 2000 & Блокировка несвязанных сайтов с помощью протеина. \\
\hline 3 & & $\begin{array}{l}\text { К носителю с антителами добавляются анализируемые } \\
\text { клетки и специфический антиген (например, ESAT6 и } \\
\text { CFP10 при диагностике туберкулезной инфекции). }\end{array}$ \\
\hline 4 & \multicolumn{2}{|c|}{$\begin{array}{l}\text { Образец подвергается инкубации в специальных условиях в течение некоторого } \\
\text { времени. Если клетки из исследуемого образца крови уже имели контакт с данным } \\
\text { антигеном, то во время инкубации они активируются и начинают выделять } \\
\text { специфические цитокины. Выделенные цитокины связываются с антителами, } \\
\text { нанесенными на поверхность носителя. }\end{array}$} \\
\hline 5 & & $\begin{array}{l}\text { После окончания периода инкубации клетки, антиген } \\
\text { и субстрат смывают с поверхности носителя. На нем } \\
\text { остаются только антитела и связавшиеся с ними } \\
\text { цитокины }\end{array}$ \\
\hline 6 & & $\begin{array}{l}\text { Добавляются моноклональные вторичные анти- } \\
\text { цитокиновые антитела. }\end{array}$ \\
\hline 7 & & Добавляется стрептавидин-пероксидаза \\
\hline 8 & & $\begin{array}{l}\text { Добавляется хромогенный субстрат и контролируется } \\
\text { формирование окрашенных точек. В результате } \\
\text { окраски на образце образуются специфические пятна, } \\
\text { давшие название анализу (от англ. spot - пятно). }\end{array}$ \\
\hline
\end{tabular}

Метод ELISPOT, благодаря своей высокой чувствительности, воспроизводимости и простоте, остается сегодня эталонной технологией для измерения специфических ответов Т-лимфоцитов с применением в различных областях исследований (разработка вакцин, диагностика инфекционные заболевания, аллергии, опухоли и аутоиммунные заболевания). Так например в AO «Генериум» локализовано производство набора T-SPOT.TB ${ }^{\circledR}$ (компании Oxford Immunotech) для диагностики туберкулеза. Иммунный ответ на инфицирование M. tuberculosis является преимущественно клеточноопосредованным. В процессе этого ответа, Т клетки сенсибилизируются к антигенам M. tuberculosis. Активированные эффекторные Т клетки, CD4 и CD8, выделенные из крови, могут быть подсчитаны благодаря способности стимулироваться этими антигенами in vitro. 
Применение специально подобранных антигенов ESAT6 и CFP10, входящих в состав микобактерий комплекса M. tuberculosis (M tuberculosis, M bovis, $\mathrm{M}$ africanum), повышает эффективность и специфичность теста, так как эти антигены отсутствуют в штамме БЦЖ и во многих других не вирулентных для человека микобактериях, находящихся в окружающей среде. Тесты ELISPOT могут быть использованы для оценки иммунной памяти (иммунного отклика), для определения количества специфичных для вирусных антигенов лимфоцитов, секретирующих цитокины, и для определения Т-хелперного профиля иммунного ответа вакцинированного.

Платформа ELISPOT нашла свое применение и в комплексной оценке иммунного ответа на вирус SARS-CoV-2 (рис. 134). Доказано, что Т-клетки являются более чувствительным индикатором перенесенного COVID-19, чем ответы антител. Так, набор реагентов «Тигра-Тест ${ }^{\circledR}$ SARS-CoV-2» позволяет выявить in vitro в крови Т-лимфоциты, специфически отвечающие на антигены вируса SARS-CoV-2. По количеству SARS-CoV-2-специфичных Т-клеток можно сделать вывод о состоятельности Т-клеточного иммунного ответа. Кроме того, тест-система позволяет отличить иммунный ответ, сформировавшийся в результате естественной встречи с вирусом от ответа Тклеток на вакцину, несущую информацию о S-белке SARS-CoV-2.

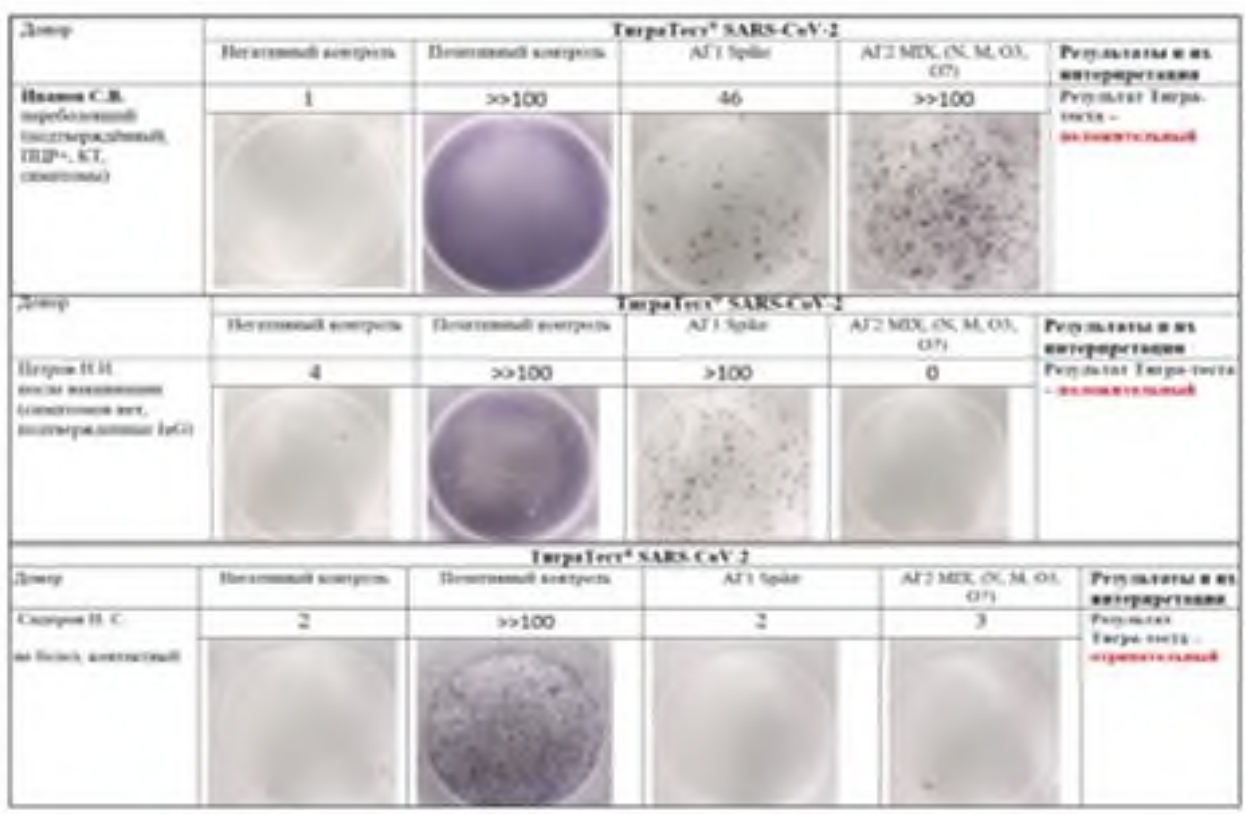

《Положительный» Т-клеточный иммгунитет сформирован в результате естественной встречн с внрусом или прн ятнбрндному нммунитет

жПоложнтельный» Т-клеточный иммунитет сформирован в результате действия вакцины, несущей информацню об S-6елке SARS-CoV-2

«Отрнцательный»

\section{Рис. 134. Пример оценки T-клеточного ответа на SARS-CoV-2 методом ELISPOT.}

Мультиплексной модификацией метода ELISPOT является метод FLUOROSPOT. Основное отличие состоит в том, что анализ FLUOROSPOT позволяет одновременно выявлять наличие нескольких аналитов на одном 
планшете с лунками, за счет использования флуоресценции, а не ферментативной реакции для обнаружения (рис.135).
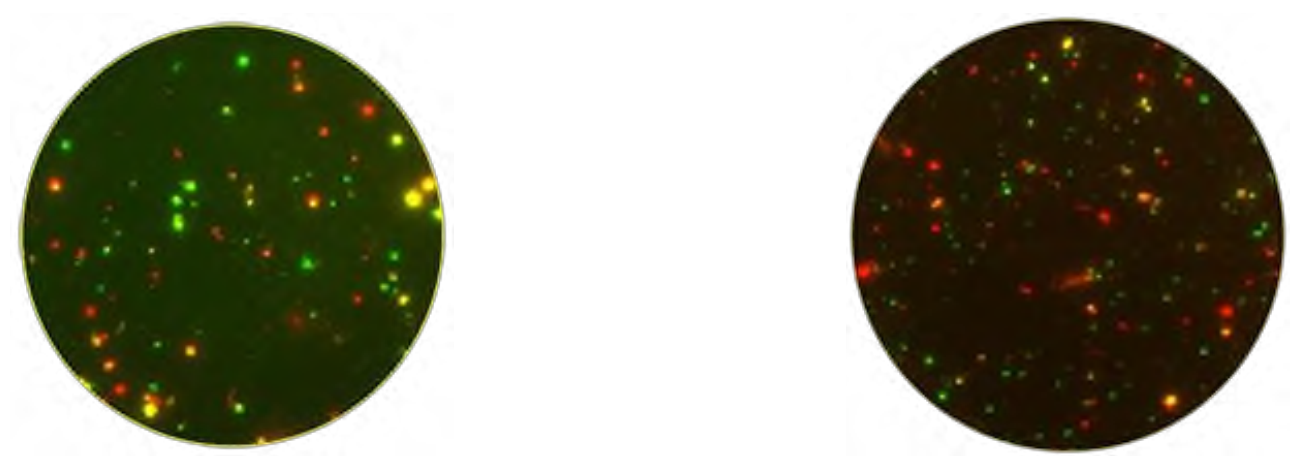

Рис. 135. AID CoV-iSpot обнаруживает реакцию IFN- $\gamma$ и IL-2 специфически активированных Т-клеток против коронавирусов (смесь пептидов PAN-Corona) и / или SARS-CoV-2 (смесь пептидов SARS-CoV-2).

\section{Исследование гуморального звена иммунитета}

Гуморальный иммунитет обеспечивается различными молекулами, которые осуществляют эффекторные и регуляторные функции иммунной системы. Их концентрация в организме обычно стабильно и изменяется при развитии каких-либо патологических процессов.

Наибольшее распространение в определении различных гуморальных показателей иммунитета получил метод иммуноферментного анализа (ИФА), описанный нами выше. С помощью ИФА можно определить уровень специфических AT, общего IgE и специфических IgE- и IgG4-антител, различных цитокинов (IFN, IL и т.д.), аутоиммунные маркеры. В медицинской практике гомогенный ИФА применяют для быстрого выявления низкомолекулярных АГ. Для диагностики противоинфекционной защиты помимо ИФА применяются другие различные методы определения АТ в сыворотке крови больных к инфекционным АГ. Для этого используют серологические методы диагностики пассивной и активной гемагглютинации связывания комплемента и т.д., хотя с активным внедрением ИФА эти методы применяются все реже.

Для определения ЦИК в сыворотке крови человека используют метод нефелометрии, основанный на различной растворимости мономеров иммуноглобулинов в составе ЦИК при наличии в среде полиэтиленгликоля. Установление уровня ЦИК в сыворотке крови - один из диагностических приемов определения степени тяжести и активности иммунопатологических процессов. Этот метод, так же, как и метод радиальной иммунодиффузии в геле, недорогой, прост в постановке, имеет большую диагностическую 
значимость. Обнаружение ЦИК полезно при оценке и мониторинге активности аутоиммунных, аллергических и инфекционных заболеваний. Увеличение его концентрации выше 90 о.е. свидетельствует о наличии иммунокомплексного синдрома.

Более значимо для оценки патологических состояний определение ИК, фиксированных в тканях и сосудах с помощью гистохимических исследований. Но за счет большой сложности и трудоемкости использование таких методов ограничено.

Тесты по выявлению комплемента подразделяются на два типа. Определение общей гемолитической активности - принцип основан на лизисе эритроцитов сенсибилизированными АТ в присутствии комплемента. Инкубируя такие эритроциты с различными разведениями комплемента, можно провести его полуколичественное определение. За единицу количества комплемента принимают активность, необходимую для гемолиза 50\% эритроцитов. И выявление активности комплемента его отдельных компонентов с помощью ИФА.

Оценка функциональных свойств комплемента существенна у больных с подозрением на врожденный дефицит комплемента и полезна при наблюдении больных с различными иммунными расстройствами, мониторинге эффекта лечения.

Преимущество ИФА не обсуждается не даром он занимает ведущее местов идентификации различных молекул, однако в последние годы получил развитие мультиплексный анализ.

За счет точных концентраций данных красителей могут быть созданы 100 различных наборов окрашенных частиц, каждый из которых покрыт специфичными антителами. После того как аналит из тестового образца захватывается частицей, вводятся биотинилированные антитела для детекции.

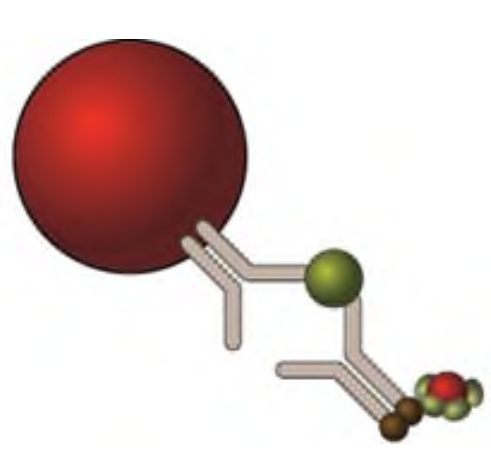

Реакционная смесь затем инкубируется с стрептавидиновым PE (фикоэритрин) конъюгатом, репортной молекулой, для завершения реакции на поверхности каждой микросферы. Микросферы переносятся в магнитную камеру с LED, который возбуждает внутренние красители, маркирующие набор микрочастиц. А также РЕ, флуоресцентный краситель на репортной молекуле. 


\section{Молекулярно-генетические исследования в иммунологии}

Метод ПЦР описан нами выше (глава 9). Однако в иммунологии нашел применение один из видов ПЦР для in vitro диагностике иммунодефицитных состояний.

В процессе созревание Т- и В-лимфоцитов в тимусе и костном мозге происходит формирование клеточных рецепторов посредством рекомбинации генов в цепи эписомальной ДНК, с целью создания уникального участка, распознающего антиген. Во время каждой такой рекомбинации из цепи вырезается небольшой фрагмент, образующий эксцизионное кольцо. Эти кольца получили названия TREC (T-cell Receptor Excision Circle) и KREC (Kappa-deleting Recombination Excision Circle). TREC(и) сопровождают созревание практически всех Т-лимфоцитов, а KREC(и) - всех В-лимфоцитов и, таким образом, служат маркерами их количества (рис.136).

Снижение количества TREC и/или KREC в крови свидетельствует о наличии дефектов иммунной системы.

В настоящий момент в России разработана и зарегистрирована отечественная тест-система («ИММУНО-БИТ») для определения концентрации ДНК TREC и KREC у детей до 18 лет. Параллельно в России и в мире проводятся пилотные исследования по возможному применению данного метода у взрослых. Ожидается, что TREC и KREC смогут быть новыми биомаркерами тяжести течения и исхода таких заболеваний как COVID-19, туберкулез, сепсис и др.

Материалом для исследования

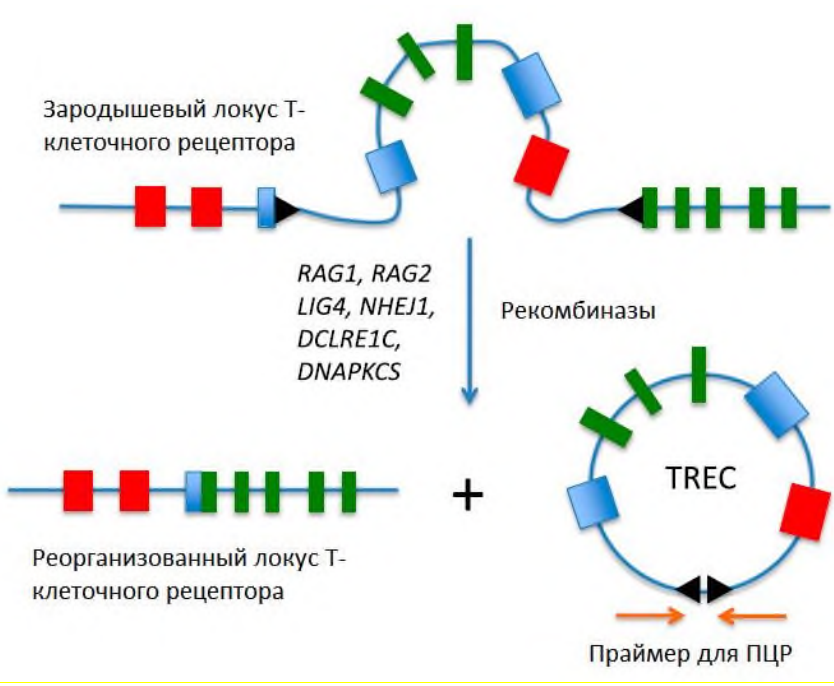

Рис.136. Молекулярные основы диагностики иммунодефицитов используя ПЦР.

может служить как цельная кровь, так и сухое пятно крови (в том числе собираемое в ходе национальной программы скрининга новорожденных).

Секвенирование. Определение линейного порядка следования компонентов макромолекулы (аминокислоты в белке, нуклеотиды в ДНК и РНК, моносахариды в полисахаридах, и т.д.). В генетике, это процесс определения последовательности нуклеиновой кислоты - порядка нуклеотидов в ДНК четырех оснований: аденина, тимина, гуанина и цитозина в различных генах. 
Ген - это последовательность ДНК, содержащий информацию о структуре белков, влияющих на формирование биохимических процессов в организме, является структурной и функциональной единицей наследственности. Непосредственно гены определяют нашу внешность, показатели здоровья, непереносимость продуктов и лекарств и пр.. Всего в геноме человека более 20 тысяч генов. Несмотря на то, что одни и те же гены есть у каждого человека, тем не менее они имеют варианты одного и того же гена (полиморфизм гена).

Отличие между мутациями и полиморфизмом довольно условно: когда один из вариантов нуклеотидных последовательностей участка ДНК выявляется более чем у 1 \% людей в популяции и не приводит к развитию заболевания, это называется полиморфизмом, если же менее 1 \% или с высокой вероятностью приводит к болезни - мутацией.

Полиморфизм в генах могут изменить структуру белков и повлиять на функциональные показатели. Определение первичной нуклеотидной последовательности ДНК является важным этапом молекулярно-генетических исследований, так как различия в нуклеотидном составе могут обуславливать изменения важных функциональных характеристик интересующих нас образцов. Так, отдельные однонуклеотидные полиморфизмы (SNP), вариации копийности генов (CNV), делеции или инсерции (Indel) и структурные перестройки в ДНК могут быть причиной возникновения различных наследственных или аутоиммунных заболеваний. Анализ ДНК опухолевых клеток позволяет выявить степень злокачественности опухоли и подобрать необходимую персонализированную терапию. Важнейшее значение генетическим исследованиям принадлежит в диагностике первичных иммунодефицитов.

Один из ключевых методов определения первичной последовательности ДНК - секвенирование - был изобретен более 50 лет назад. За десятилетия интенсивного развития удалось разработать несколько поколений секвенаторов и сконструировать не один десяток моделей приборов.

В настоящее время выделяют три поколения секвенирования:

1. Секвенирование по Сэнгеру;

2. Массово-параллельное секвенирование нового поколения (Next Generation Sequencing, NGS);

3. Мономолекулярное секвенирование.

Секвенирование по Сэнгеру (или капиллярный электрофорез) является одной из первых разработанных технологий секвенирования, которая и по сей день остаётся золотым стандартом точности.

Данный метод основан на использовании модифицированных флуоресцентно меченных, так называемых «терминирующих» нуклеотидов. 
NGS-секвенирование было разработано в начале XXI века с целью многократно увеличить производительность секвенаторов. Дело в том, что для анализа полного генома человека, как и любых других организмов, необходимо получить данные о миллионах нуклеотидов. Так, например, человеческий геном содержит более 3 млрд пар нуклеотидов, и для его оперативного анализа необходимы существенно более производительные методы, чем секвенирование по Сэнгеру.

Принцип NGS основан на одновременном секвенировании миллионов коротких (до 600 нуклеотидов) фрагментов ДНК, что дало ему название «массово-параллельное» секвенирование. Последующая специальная биоинформатическая обработка позволяет объединить данные последовательностей миллионов коротких фрагментов в длинную исходную цепь ДНК.

Мономолекулярное секвенирование отличается от других платформ исключительно большой длиной прочтений (до 100 тысяч оснований). Определение последовательности ДНК происходит в реальном времени и может быть проанализировано ещё во время работы секвенатора.

Самая широко используемая технология мономолекулярного секвенирования на данный момент - это нанопоровое секвенирование (Oxford Nanopore). При нанопоровом секвенировании молекулы ДНК под воздействием электрического поля проходят через специальные белковые нанопоры, закрепленные на билипидной мембране. При этом изменяется ток ионов через поры. В зависимости от нуклеотидной последовательности, которая в данный момент проходит через пору, ток изменяется на разную величину, и по графику изменения силы тока можно сделать вывод о нуклеотидной последовательности.

Данная технологи позволяет получать прочтения длиной в десятки тысяч нуклеотидов, что делает её незаменимой для de novo сборки геномов. Однако существенным недостатком на данный момент является высокий процент ошибок - до $10 \%$, то есть ошибка встречается в каждом десятом нуклеотиде. Для получения корректных данных рекомендуется комбинировать данные длинных нанопоровых прочтений с высокоточными данными NGSсеквенирования.

\section{Методы исследования метаболизма клеток.}

Развитие иммунного ответа, проявление различных заболеваний, созревание и репрограммирование клеток имеют под собой единую фундаментальную основу, а именно, изменение показателей клеточного метаболизма (см.главу 1). Лабораторные исследования позволяют выявить вклад различных метаболических путей, а именно глюколиза, пентозофосфата, окисления жирных кислот, глутаминолиза, цикла Кребса и окислительного 
фосфорилирования, в модуляции врожденных и адаптивных иммунных клеток на основе их состояния активация/дифференцировка. Используя анализатор Seahorse XF можно, одновременно измеряет показатели двух основных путей получения клеточной энергии: митохондриального дыхания и гликолиза (рис.137).

Измерение гликолиза происходит за счет ECAR (Extracellular Acidification Rate) - измерение скорости внеклеточного закисления. В процессе гликолиза клетки генерируют АТФ без участия кислорода с побочными продуктами в виде лактата и протонов водорода. XFp Analyzer фиксирует показатели внеклеточного закисления протонами, тем самым оценивая интенсивность процессов гликолиза в клетках.

Митохондриальное дыхание оценивается за счет OCR (Oxygen Consumption Rate) - измерение скорости поглощения кислорода. Митохондрии поглощают кислород в процессе синтеза АТФ с помощью митохондриального дыхания. Этот путь является оптимальным для получения максимального количества энергии. XFp Analyzer оценивает интенсивность митохондриального дыхания, фиксируя скорость поглощения клетками кислорода.

A

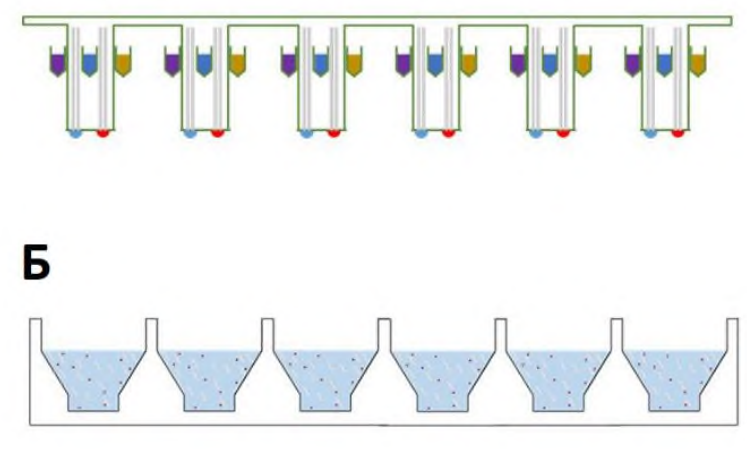

B

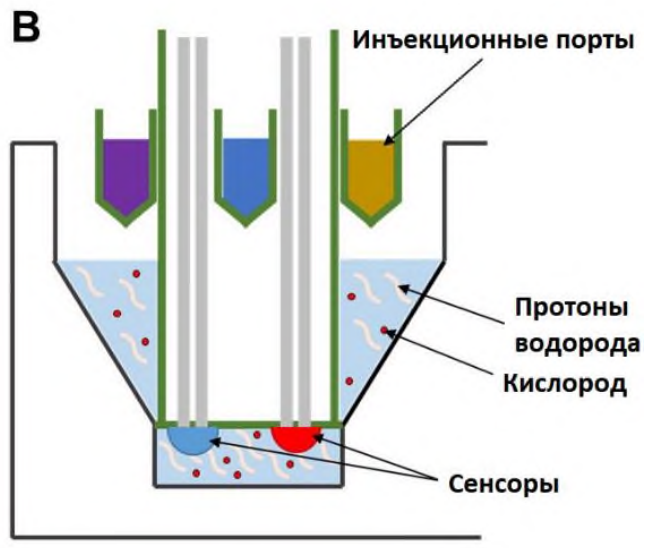

Рис. 137. Схема биоанализатора Seahorse XF.

А. Картридж датчика.

Б. Микропланшет для культивирования клеток.

В. Зонд с 4 портами для добавления любых соединений, и датчиками измерения уровня кислорода и рН раствора.

XFp Analyzer использует специальные транзиентные микрокамеры, позволяющие с высокой точностью и чувствительностью проводить метаболические исследования в считанные минуты. Возможность автоматического добавления до 4-х веществ в реакционную среду делает XFp Analyzer идеальным инструментом для тестирования препаратов, подбора эффективной дозы и цитотоксических исследований в различных научных и медицинских приложениях. 
Биолюминесцентный анализ применим при оценке различных физиологических и патологических состояний человека, связанных с изменением интенсивности и направленности обменных процессов в организме, отдельных его системах. Определение метаболических параметров возможно в цельной крови и в ее составляющих (сыворотке крови или плазме, в эритроцитах, тромбоцитах, лейкоцитах, лимфоцитах), плевральном экссудате, спинномозговой жидкости. Возможна разработка методик для любого биологического материала. Метод основан на использовании биолюминесцентного определения активности ряда ферментов, их кофакторов и субстратов. В настоящее время разработаны методики для определения следующих метаболических параметров: глюкозо-6-фосфатдегидрогеназа; глицерол-3-фосфатдегидрогеназа; лактатдегидрогеназа (прямая и обратная реакция); малатдегидрогеназа (прямая и обратная реакция); малик-фермент (НАДФ-зависимая декарбоксилирующая малатдегидрогеназа); НАДФзависимая глутаматдегидрогеназа (прямая и обратная реакция); НАД-зависимая глутаматдегидрогеназа (прямая и обратная реакция); НАД-зависимая изоцитратдегидрогеназа; глутатионредуктаза;
НАДФ-зависимая пируватдегидрогеназный изоцитратдегидрогеназа; комплекс; 2оксоглутаратдегидрогеназный комплекс; АТФ; малат; пируват; лактат; глюкозо-6-фосфат; НАД и НАДФ.

Для исследований применяется биоферментный комплекс из светящихся бактерий. Для проведения анализа используются микроколичества биологического материала.

Доказана информативность и прогностическая значимость метаболических показателей при оценке влияния экологических (климатических и антропогенных) факторов на организм человека, для выделения групп риска по заболеваниям дыхательных путей и ЛОР-органов, для диагностики метаболической иммунодепрессии при таких заболеваниях как ЧДБ ОРЗ, отиты, бронхиты, пневмонии, гепатиты, герпес-инфекции, грибковые и паразитарные инфекции. Оценка метаболического состояния лимфоцитов крови при вышеперечисленных заболеваниях позволяет более обосновано и корректно назначать медикоментозные средства, контролировать процесс лечения и выздоровления. В случае хронических заболеваний с помощью метаболических параметров возможно осуществлять прогноз время наступления и длительность ремиссии. 


\section{Глава 11. Диагностика}

\section{иммунопатологических}

\section{состояний.}

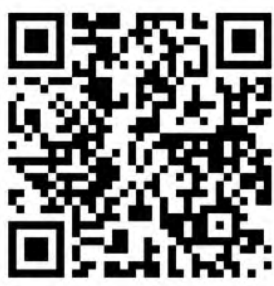

Диагностика патологий иммунной системы основана на выявлении иммунных нарушений, используя классические подходы диагностики заболеваний.

На первом этапе проводится опрос больного, выясняются жалобы на момент осмотра. Устанавливается наличие общепатологических симптомов (лихорадка, слабость, нарушение сознания, снижение веса и др.), а затем активным опросом по органам и системам выявляют основные и второстепенные признаки, уточняя их по времени, интенсивности, продолжительности, локализации и т.д. Уже на данном этапе врач составляет представление о преобладающей патологии.

Для иммунопатологических состояний наибольший интерес представляют следующие проявления.

1. Повышение температуры тела является одним из главных признаков воспалительной реакции, как при инфекциях, так и при аутоиммунных заболеваниях, опухолях, некоторых формах аллергии. Отсутствие температурной реакции при инфекциях свидетельствует о недостаточности макрофагально-фагоцитарного звена иммунитета. Для объективной оценки такой реакции необходимо производить измерения температуры тела через 2 ч. с построением температурной кривой.

2. Боли, их локализация и интенсивность, особенности проявления непосредственно свидетельствуют о поражении определенного органа. При этом выраженность какой-либо органной патологии может доминировать в клинической картине заболевания и служит основанием для определения диагноза. Головная боль - один из признаков интоксикации и т.д.

3. Реакция дыхательных путей (кашель, одышка, чихание, заложенность носа) есть проявление инфекционных или аллергических поражений респираторного тракта человека.

4. Реакция ЖКТ (рвота, диарея, запоры, желтуха). Диарея (понос) учащенное (свыше 2-х раз в сутки) выделение жидких испражнений. Многообразие ее причин - наиболее частое возникновение острых проявлений (до 2-х нед.), связанных с микробными поражениями и аллергическими реакциями. Хронические диареи (продолжающиеся более 2-х нед. или имеющие рецидивирующее течение) могут быть при нарушениях микробного 
соотношения в кишечнике, аутоиммунных заболеваниях и опухолях. По этим же причинам у пациента могут быть и запоры.

5. Желтушное окрашивание кожи (желтуха) - хорошо заметный признак, обращающий на себя внимание не только врача, но и больного. Одна из причин ее - это хроническая вирусная инфекция, другие тяжелые инфекции.

6. Высыпания на коже (экзантемы) имеют большое значение в диагностике иммунопатологий. Это связано с тем, что они встречаются при многих иммунопатологических состояниях и отчетливо заметны. Экзантемы весьма разнообразны, они различаются по характеру отдельных элементов, локализации, этапности высыпания, наличию зуда.

7. Отделяемое из очага воспаления имеет большое значение в дифференциальной диагностике. Гнойные (зеленое, желтое) выделения характерны для бактериальных инфекций, при вирусных инфекциях и аллергических реакциях - бесцветное серозное отделяемое. При грибковых поражениях отделяемое невыраженное с белым оттенком.

8. При всех реакциях иммунитета задействованы лимфатическая система и непосредственно лимфатические узлы, т.к. это основной плацдарм событий адаптивной иммунной системы.

Анализ анамнестических данных - основной этап в постановке диагноза дисфункции иммунной системы. Суммарно для оценки иммунной системы можно предложить ответить на следующие вопросы и, чем больше вопросов, на которые пациент ответит «Да», тем ориентировочно сильнее расстройства функции иммунной системы (табл.49).

Дополнительно достаточно большой объем информации можно получить, анализируя:

- результаты всех ранее проведенных по любому поводу диагностических исследований как нормальных (в них разброс различных параметров в пределах нормы индивидуален), так и патологически измененных;

- ранее сделанные по любому поводу инструментальные исследования;

- развернутое исследование инфекционного статуса, зачастую с дополнительными исследованиями на гепатиты и урогенитальные инфекции;

- $\quad$ клинический анализ крови (определяется общее количество клеток иммунной системы в периферической крови);

- биохимический анализ крови, включающий в различных случаях ли-пидограмму, белковые фракции, коагулограмму, билирубин и другие показатели;

бактериологическое исследование отделяемого из носа и мазка из зева или других органов, исследование на кишечный дисбактериоз.

Анализируя анамнез больного, следует попытаться найти причину возникновения иммунодефицита и составить предварительное заключение о наличии дефекта в том или ином звене иммунной системы. 


\section{Вопросы для выявления иммунопатологии}

\begin{tabular}{|ll|}
\hline \multicolumn{2}{l}{ Основные вопросы } \\
\hline$\checkmark$ & Часто ли бывают простудные заболевания (>4 раз в году у взрослых и 6 раз у ребенка)? \\
$\checkmark$ & Бывает ли без причины температура $37,0-37,5^{\circ}$ С раз в неделю или чаще? \\
$\checkmark$ & Выявляются ли заболевания органов дыхания чаще 2 раз в год? Кашель более 1 мес? \\
& Кашель с отделением мокроты в течение года более 2 мес? Отделение мокроты \\
суммарно в течение года более 1 мес? Возникает ли чувство удушья (при простудных \\
заболеваниях, при цветении растений, на пыль, без видимых причин)? Отмечается ли \\
заложенность и зуд в носу, чихание, обильное выделение из носа?
\end{tabular}

$\checkmark$ Поражения ЖКТ. Диарея, продолжающаяся более 2 нед. или имеющая рецидивирующее течение, желтуха?

$\checkmark$ Имеются ли хронические воспалительные заболевания (хронический бронхит, тонзиллит, отит, простатит, цистит, уретрит, нефрит, гайморит, фронтит, синусит и т.д.)? Носят ли болезни затяжной характер с госпитализацией?

$\checkmark$ Диагностировались ли у пациента хронический вирусный гепатит (B, С, Д и др.), герпес с обострением чаще 2 раз в течение года, цитомегаловирусная инфекция (ЦМВ), инфекция, вызванная вирусом Эпштейна-Барра, ВИЧ-инфекция, дисбактериоз кишечника, аллергические реакции, аутоиммунные заболевания?

$\checkmark$ В течение года были хронических синуситов (гайморит, фронтит, этмоидит), ангина, отит, обострение бронхита с гнойным отделяемым, пиодермия, фурункулез, гидраденит, грибковые инфекции кожи (кандидамикоз, дерматомикоз), ногтей, слизистых оболочек (молочница), внутренних органов?

$\checkmark$ Диагностировались ли у больного в последние три года абсцессы, флегмоны, септические гранулемы, парапроктит, цистит, пиелонефрит, другие инфекции мочеполовой системы, язвенная болезнь, колит, энтероколит, хламидиоз, микоплазмоз, папиломатоз?

$\checkmark$ Диагностировались ли доброкачественные и/или злокачественные опухоли, менингоэнцефалит, сепсис, перитонит, пневмонии более одного раза в течение жизни, туберкулез, сифилис, малярия, стафилококковый эндокардит, паразитарные инвазии (лямблиоз, описторхоз, дифиллоботриоз, токсоплазмоз и пр.)?

$\checkmark$ Болел ли пациент после 16 лет корью, краснухой, эпидемическим паротитом (свинкой), вирусным гепатитом А, ветряной оспой, опоясывающим герпесом, стоматитом?

$\checkmark$ Диагностировались ли заболевания, вызываемые различными инфекциями, у которых затяжное/рецидивирующее течение?

$\checkmark$ Встречались ли заболевания, устойчивые к стандартным методам лечения?

$\checkmark$ Развивались ли осложнения основного заболевания?

$\checkmark$ Медленно ли заживают у пациента раны?

$\checkmark$ Имеются ли врожденные аномалии? Страдает ли пациент или его родственники какимлибо онкологическим, аутоиммунным заболеванием, аллергиями?

Дополнительные вопросы

$\checkmark$ у какого врача находится на диспансерном учете;

$\checkmark$ профессиональные вредности и факторы внешней среды (контакт с химическими веществами, лекарствами, биопрепаратами, воздействие радиации, магнитного поля, высокие или низкие температуры, постоянные стрессовые ситуации);

$\checkmark$ интоксикации, хирургические вмешательства, травмы, нарушения питания;

$\checkmark$ длительная терапия цитостатиками, лучевая и гормональная, антибиотиками;

$\checkmark$ принадлежность к группам риска (наркомания, половые перверсии, хронический алкоголизм, курение);

$\checkmark$ реакции на переливание крови и ее продуктов;

$\checkmark$ патология беременности (бесплодие, выкидыши). 
Зачастую больные с приобретенным иммунодефицитом могут достаточно четко определить сроки его возникновения. В этих случаях они указывают, что нарушения в состоянии здоровья возникли у них после стресса, тяжелого заболевания, облучения, перегрузок и т.д. В качестве причин иммунодефицита могут быть также профессиональные вредности: воздействие химикатов, канцерогенных веществ, облучение, контакт с гербицидами, сверхвысокими частотами и др.; злоупотребление алкоголем, курение, применение наркотиков.

Выяснение причины иммунодефицита очень важно, так как если она продолжает действовать, то рассчитывать на успех проводимой иммунотерапии не приходится.

Тщательный анализ анамнеза позволяет сделать предварительное заключение о поражении определенного звена иммунитета. Наиболее важный момент - это анализ перечня перенесенных заболеваний. В этом смысле важно опираться на знание болезней-«масок» иммунодефицита. Указания в анамнезе на вирусные инфекции, грибковые поражения, наличие аутоиммунной патологии, онкозаболеваний дают основание думать о возможных нарушениях в Т-клеточном звене иммунитета. В то же время, если у больного отмечается целый ряд перенесенных бактериальных инфекций (сепсис, остеомиелит, бактериальные пневмонии, ангины, аднексит и др.), то, скорее всего, можно предположить нарушение гуморального звена иммунитета. В тех случаях, когда у пациента имеются данные о перенесенных им болезнях-«масках» как клеточного, так и гуморального иммунитета, предполагается комбинированный тип поражения иммунной системы. Некоторые инфекции патогномоничны для нарушения того или иного звена иммунитета (табл.50).

Важно отметить, что практически всегда иммунные реакции нарушаются разнонаправлено - когда одни из них неадекватно понижаются, другие неадекватно повышаются, что называется дисбалансом иммунной системы. Поэтому у больных с аллергией почти всегда наблюдаются и признаки недостаточности эффекторного звена (хронические воспалительные процессы или склонность к частым ОРВИ и др.), а у пациентов с иммунодефицитными состояниями присутствует в какой-либо форме и симптоматика аллергии. Следует помнить, что при всяком длительно протекающем воспалительном процессе обязательно происходит местная сенсибилизация. И в этом еще одна опасность осложнений, которую несут хронические воспалительные процессы. В частности, хронические или частые бронхиты могут спровоцировать возникновение бронхоспазмов и бронхиальной астмы. 
Таблица 50

\section{Сочетание инфекции с поражением звена иммунитета}

\begin{tabular}{|c|c|c|}
\hline Звено иммунитета & Основные возбудители инфекций & Основные причины \\
\hline $\begin{array}{l}\text { Недостаточность } \\
\text { гуморального звена } \\
\text { иммунитета }\end{array}$ & $\begin{array}{l}\text { Пневмококк } \\
\text { Hemophilus influenzae } \\
\text { Pneumocystis jirovecii } \\
\text { Giardia intestinalis } \\
\text { Cryptosporidium parvum }\end{array}$ & $\begin{array}{l}\text { Первичный В-клеточный } \\
\text { иммунодефицит } \\
\text { Множественная миелома } \\
\text { Хронический лимфолейкоз } \\
\text { СПИД }\end{array}$ \\
\hline $\begin{array}{l}\text { Недостаточность } \\
\text { клеточного звена } \\
\text { иммунитета }\end{array}$ & $\begin{array}{l}\text { Внутриклеточные возбудители, включая } \\
\text { вирус простого герпеса, микобактерии, } \\
\text { Listeria и внутриклеточных грибковых } \\
\text { инфекции. }\end{array}$ & $\begin{array}{l}\text { Первичный Т-клеточный } \\
\text { иммунодефицит } \\
\text { Трансплантация костного мозга и } \\
\text { другая трансплантация } \\
\text { СПИд } \\
\text { Химиотерапия рака } \\
\text { Лимфома } \\
\text { Глюкокортикоидная терапия }\end{array}$ \\
\hline $\begin{array}{l}\text { Дефицит } \\
\text { гранулоцитов }\end{array}$ & $\begin{array}{l}\text { Enterobacteriaceae } \\
\text { Устные стрептококки } \\
\text { Pseudomonas aeruginosa } \\
\text { Виды энтерококков } \\
\text { Грибы Candida, Aspergillus }\end{array}$ & $\begin{array}{l}\text { Химиотерапия } \\
\text { Трансплантация костного мозга } \\
\text { Дисфункция, такая как хроническая } \\
\text { гранулематозная болезнь }\end{array}$ \\
\hline $\begin{array}{l}\text { Дефицит } \\
\text { комплемента }\end{array}$ & $\begin{array}{l}\text { Виды Neisseria } \\
\text { Пневмококк }\end{array}$ & Врожденные недостатки \\
\hline Аспления & $\begin{array}{l}\text { Бактерии, инкапсулированные в } \\
\text { полисахариды, в частности: Streptococcus } \\
\text { pneumoniae, Haemophilus influenzae, } \\
\text { Neisseria meningitidis, плазмодии. }\end{array}$ & $\begin{array}{l}\text { Спленэктомия } \\
\text { Травма } \\
\text { Серповидноклеточная анемия }\end{array}$ \\
\hline
\end{tabular}

Объективный осмотр: посистемный осмотр пациента поможет определить диагноз заболевания и выявить признаки поражения иммунной системы.

Осмотр кожных покровов позволяет выявить многие патологические состояния. Нередко на коже появляются различные морфологические элементы, отражающие разнообразные заболевания. Различают следующие проявления поражения кожи, связанные с иммунными реакциями (рис. 138149).

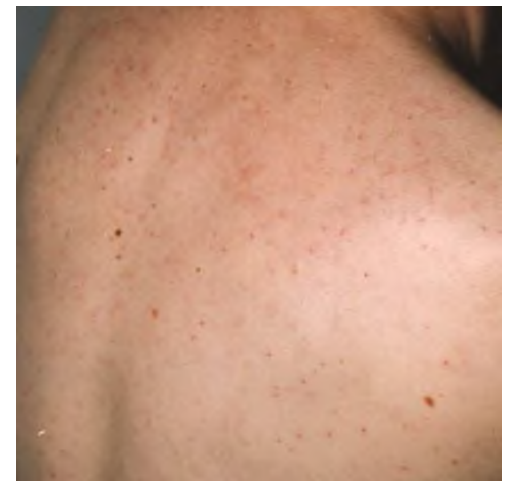

Рис. 138. Розеола небольшое пятнышко (2-5 мм) розового или красного цвета, возникающее за счет расширения

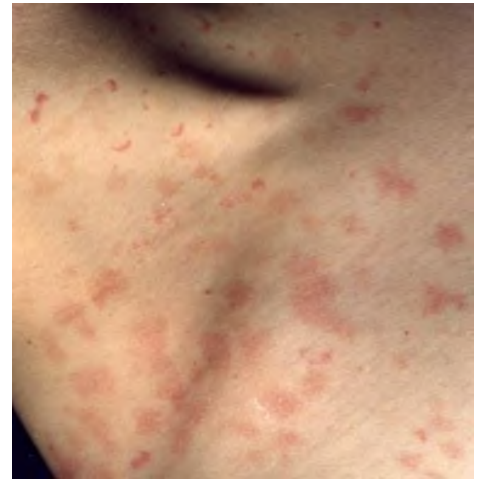

Рис. 139. Пятно аналогичное розеоле образование размером 5-20 мм.

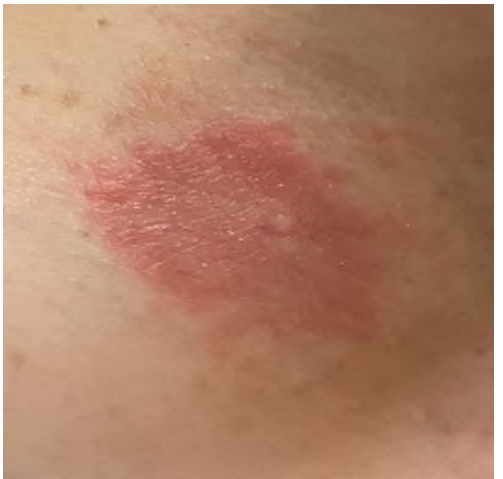

Рис. 140. Эритема - это обширные участки гиперемированной кожи красного цвета, обычно результат слияния 
сосудов.

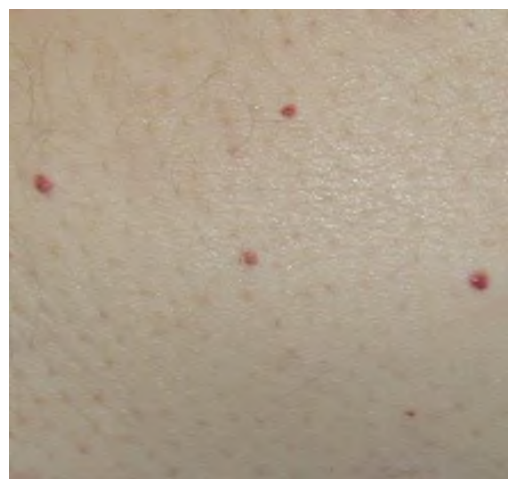

Рис. 141. Папула -

бесполостное поверхностное образование кожи размером $1-20$ мм. Слияние отдельных папул бляшки.

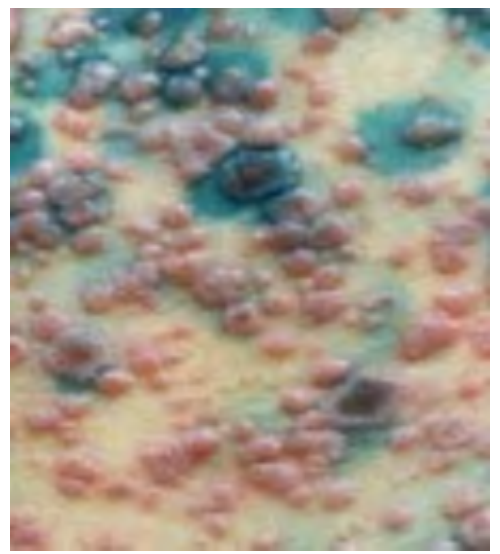

Рис 144. Пузырекполостное образование, содержащее серозную и/или геморрагическую жидкость, размером 1,5-5 мм.

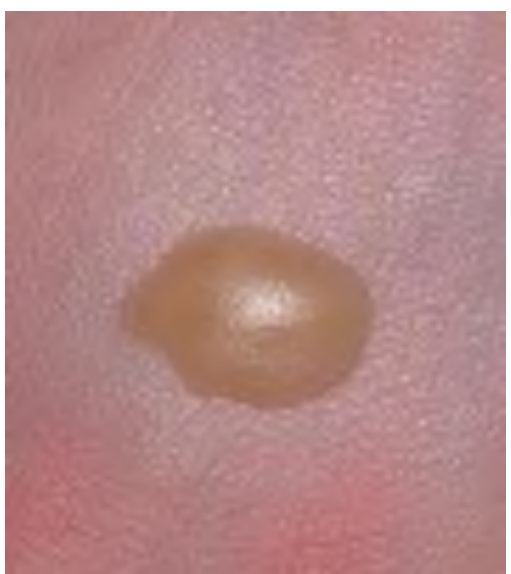

Рис. 147. Волдырь бесполостной элемент островоспалительного характера.

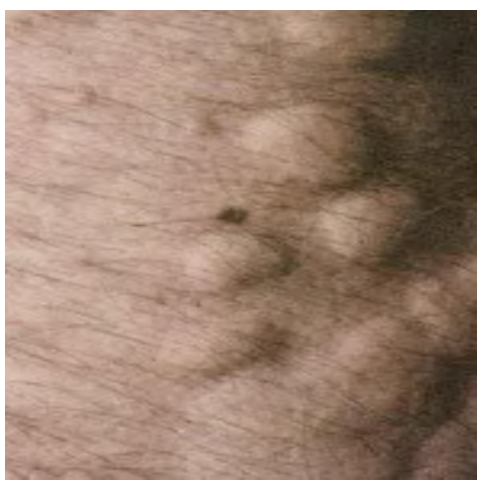

\section{Рис. 142. Бугорок -}

бесполостное образование от 3-5 до 20 мм. В отличие от папулы бугорок залегает глубоко в дерме.

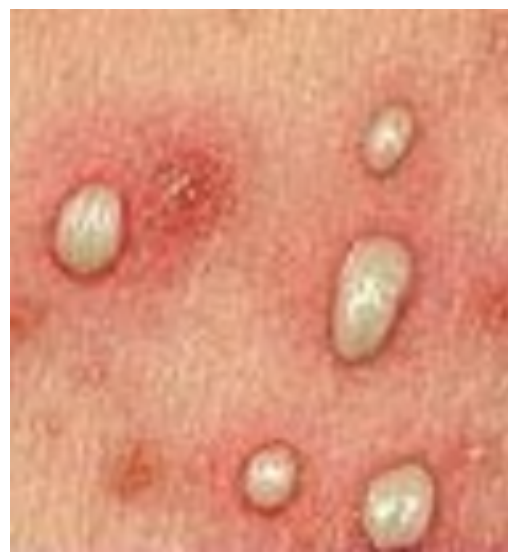

Рис. 145. Пустула или

гнойничок - пузырек с

гнойным содержимым.

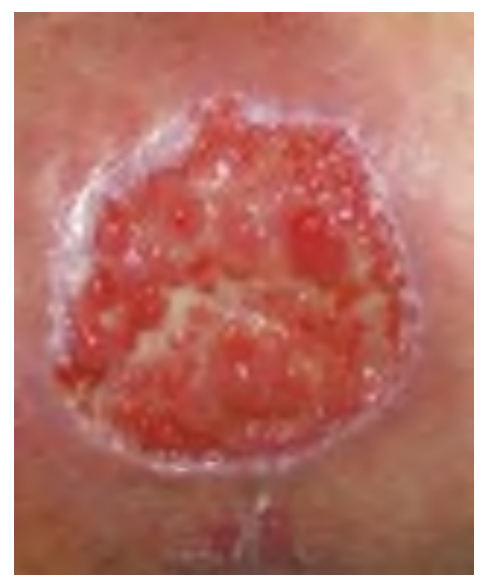

Рис. 148 Эрозия - дефект эпидермиса, обычно появляются после вскрытия пузырей, пустул. крупных пятен.

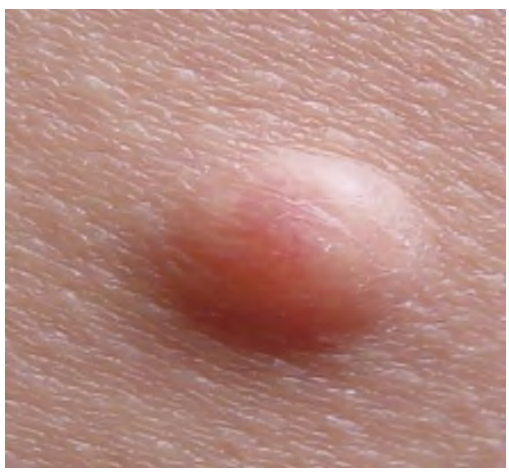

Рис. 143. Узел -

ограниченное плотное образование от 1-5 см и более, расположенное в глубоких отделах дермы

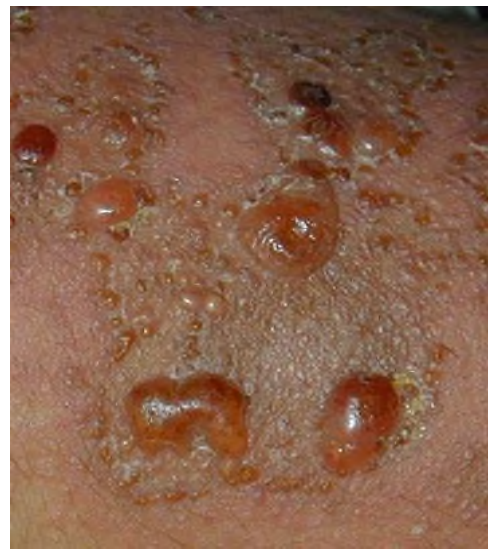

Рис. 146. Пузырьполостное образование более 5 мм с серозным или серозногеморрагическим содержимым.

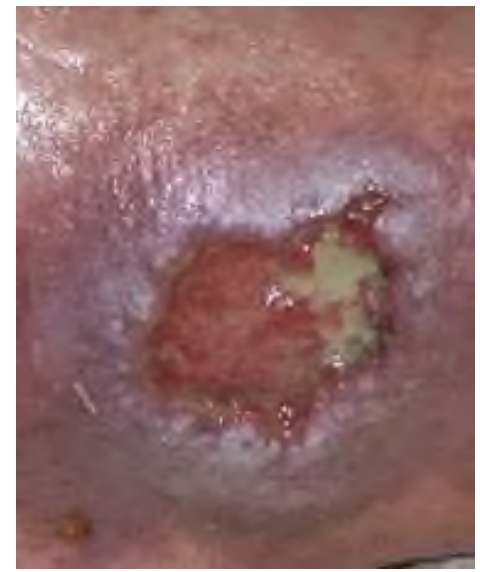

Рис.149. Язва - глубокий дефект кожи, захватывающий эпидермис, дерму, иногда и подлежащие ткани. 
На коже тела и видимых слизистых могут быть и другие морфологические образования: папилломы, фибромы, ангиомы, меланомы, лимфомы и пр..

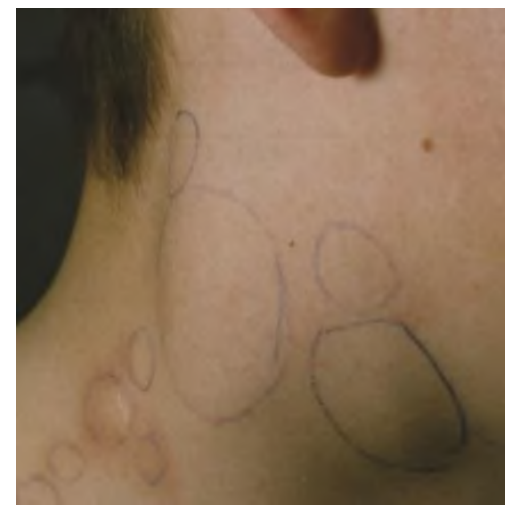

Рис. 150. Лимфатические узлы.

Изучение лимфатических узлов - еще один из важнейших этапов диагностики иммунных нарушений. Лимфатические узлы в норме не видны и практически не прощупываются, они увеличиваются при многих инфекционных заболеваниях (рис. 150). В зависимости от характера патологического процесса их размеры могут достигать до 3-4 см., а также увеличиваться локально только в одной области (подчелюстные, шейные и пр.) или в нескольких группах (генерализованная лимфаденопатия).

Состояние опорно-двигательной системы имеет большое значение для диагностики аутоиммунных заболеваний. Локализация, динамика развития, характер поражения, оценка нарушения функции позволяют достоверно установить диагноз и оценить степень иммунопатологических реакций при этих заболеваниях.

При оценке респираторной системы можно выявить инфекционновоспалительные и аллергические реакции. В зависимости от иммунопатологических реакций могут преобладать поражения того или иного отдела органов дыхания (ринит, ринофарингит, бронхит, пневмония и др.).

Часто при иммунопатологических состояниях встречаются поражения ЖКТ. Проявления инфекции и дисбиотические расстройства (вздутие живота, болезненность и урчание при пальпации, язык с грязно-белыми налетами и пр.) являются признаками гипоэргических реакций больного. Большое значение при осмотре придается печени и селезенки. Увеличение этих «иммунных» органов в большинстве случаев свидетельствует о дисфункции иммунитета. При этом следует обращать внимание на степень увеличения и плотность органов, а также их болезненность (рис. 151). Также для поражения печени характерна желтушность кожных покровов и иктеричность склер (рис.152).

Нарушения деятельности сердечно-сосудистой системы, найденные при осмотре, обычно характеризуют тяжесть состояния больного (тахикардия, гипотония). Выявленные признаки миокардита или перикардита сопровождают антителозависимый цитотоксический синдром.

Уровень интоксикации обычно характеризуют признаками поражения ЦНС (заторможенность, эйфория, сопор, кома). 
Для объективной диагностики иммунопатологических состояний больного необходимо наблюдать в динамике.

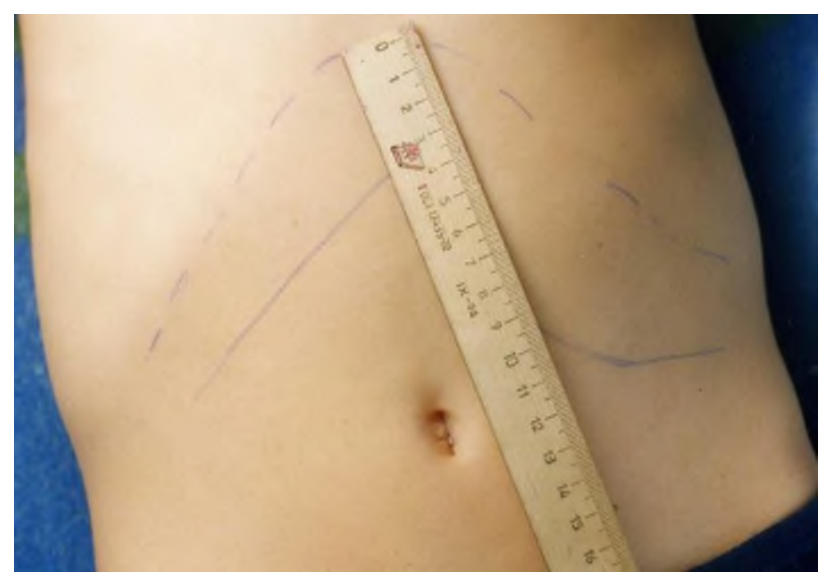

Рис. 151. Увеличение печени и селезенки.

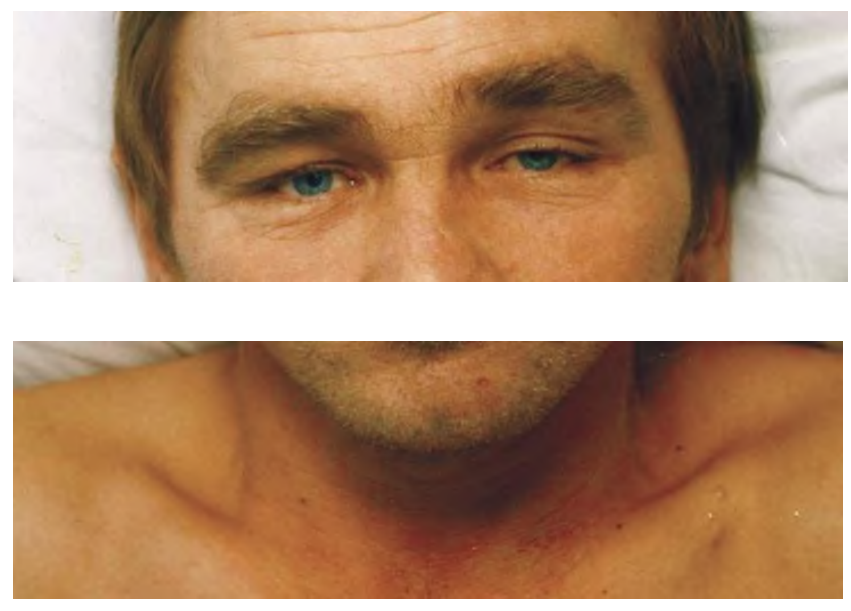

Рис. 152. Иктеричность склер, желтуха кожи.

\section{Кожные пробы}

К клиническим методам диагностики прежде всего туберкулезной инфекции следует отнести и кожные пробы. Скарификационная кожная проба в настоящее время не рекомендуется. Обычно делается туберкулиновая кожная проба (реакция Манту или тест PPD - с очищенным белковым дериватом). Она позитивна как при латентной, так и при активной инфекции и, следовательно, не может различать их. Стандартная доза в мире 5 единиц туберкулина (TU) PPD в 0,1 мл раствора вводится на тыльной поверхности предплечья. В России используется проба Манту с 2 туберкулиновыми единицами (2TE) PPD-L (PPD-L - с очищенным белковым дериватом в модификации Линниковой). Важно ввести раствор внутрикожно, но не подкожно. Волдырь или пузырек с четкими границами должен появиться немедленно. Диаметр уплотнения/индурации (не эритема) поперек к продольной оси руки измеряется через 48-72 ч после инъекции.

Согласно международным подходам, рекомендуемые точки границ положительной реакции зависят от клинической ситуации:

5 мм: пациенты с высоким риском развития активного туберкулеза, с указанием на заражение в анамнезе, таким как признаки перенесенного в прошлом туберкулеза на рентгенографии, с пониженным иммунитетом вследствие ВИЧ-инфекции или применения препаратов (например, ингибиторы ФНО-alpha использование кортикостероидов, эквивалентное преднизону 15 мг/день в течение $>1$ месяца) или с указаниями на тесный контакт с больными с острозаразными формами туберкулеза 
10 мм: пациенты с некоторыми факторами риска, такие как инъекционные наркоманы; иммигранты, недавно прибывшие из областей с высоким уровнем заболеваемости; лица, проживающие в условиях с высоким риском заражения (например, тюрьмы, убежища для бездомных); пациенты с определенными заболеваниями (например, силикоз, почечная недостаточность, диабет, рак головы или шеи) и перенесшие гастрэктомию или шунтирование тощей кишки

15 мм: у пациентов нет факторов риска (как правило, их не нужно дополнительно обследовать).

Учитывая, что в России существует массовая вакцинация БЦЖ при применении пробы Манту с 2 TE PPD-L рекомендауемые точки границы положительного результата 5 мм.

Результаты могут быть ложноотрицательными, чаще всего у пациентов с лихорадкой, в преклонном возрасте, зараженных ВИЧ (особенно, если количество CD4 < 200 клеток/мкл) или с серьезным сопутствующим заболеванием, при котором отмечается отрицательная реакция на любой кожный тест (анергия). Анергия, вероятно, является следствием наличия ингибирующих антител или того, что слишком большое количество Т-клеток было мобилизовано к очагу инфекции и, соответственно, количества оставшихся свободных клеток недостаточно для реализации значительной кожной реакции.

Ложноположительные результаты могут возникать, если пациенты имеют микобактериальную инфекцию нетуберкулезного типа или получили вакцинацию БЦЖ. Тем не менее, эффект вакцинации БЦЖ на туберкулиновую кожную пробу ослабевает через несколько лет; после этого времени положительный тест, вероятно, будет связан с инфекцией туберкулеза.

С цель раннего выявления инфекционной аллергии на наличие инфекционного возбудителя туберкулеза в организме используется внутрикожная проба с аллергеном туберкулезным рекомбинантным (Диаскинтест, АО Генериум, Россия). Диаскинтест содержит два антигена (ESAT6/CFP10), присутствующие в вирулентных штаммах микобактерий туберкулеза и отсутствующие в вакцинном штамме БЦЖ и нетуберкулезных микобактериях. При внутрикожном введении Диаскинтест® вызывает у лиц с туберкулезной инфекцией специфическую кожную реакцию, являющуюся проявлением гиперчувствительности замедленного типа (ГЧЗТ). Техника постановки пробы и сроки учета результатов аналогичны туберкулиновой пробе. Рекомендуемые границы положительного результата - папула любого размера. Проба обладает высокой специфичностью и чувствительностью, не вызывает реакцию на вакцинный штамм БЦЖ и поэтому может использоваться для раннего выявления как активного туберкулеза, так и латентной туберкулезной инфекции, исключая ложноположительные результаты. 


\section{Иммунологический диагноз}

Диагностика иммунных нарушений сопряжена с рядом проблем. Это связано со сложной многоуровневой организацией иммунной системы, высокой надежностью иммунитета с многочисленными компенсаторными механизмами, многочисленными регуляторными связями между компонентами иммунной системы и нервной и эндокринной системой. На эффективность иммунитета влияют многочисленные факторы как внутри, так и вне организма. Поэтому после проведения клинического осмотра и получения лабораторных исследований необходимо классифицировать имеющиеся иммунные нарушения для разработки стратегии и тактики эффективной терапии. Традиционно все нарушения функции иммунной системы классифицируют, исходя из проявления различных заболеваний. Во всем мире принято выделять:

1. 1 первичные иммунодефициты;

2. 2 вторичные иммунодефициты (ВИД);

3. 3 аутоиммунные заболевания;

4. 4 аллергии;

5. 5 опухоли иммунной системы.

Но во всех этих случаях мы диагностируем не нарушения функции иммунной системы, а непосредственно определенные заболевания. Однако в патогенезе развития иммунопатологического состояния принимает участие, как правило, не один, а несколько типов реакций, при этом, учитывая клональноселекционный тип реагирования иммунной системы, могут даже сочетаться гипоэргические и гиперергические типы реакций при одной и той же патологии. Исходя из этого в клинической работе необходимо определить наличие и охарактеризовать тот или иной иммунопатологический синдром, оценить степень его тяжести, выявить причины его возникновения, провести дополнительные лабораторные и инструментальные исследования, сформировать именно иммунологический диагноз, аналогичный диагноза сердечной или печеночной недостаточности.

Схематично это можно описать как трехуровневый алгоритм диагностики нарушений функции иммунной системы. На первом этапе проводятся клинические исследования, на втором этапе анализируются лабораторные исследования, на третьем этапе проводятся иммунологические исследования с элементами топической диагностикой. На любом этапе как итог диагностики формируется иммунологический диагноз (предварительный, клинический, топический). В зависимости от диагноза определяется необходимая терапия и дальнейшая тактика ведения пациента (рис.153).

Предварительный диагноз нарушений функции иммунной системы не требует дополнительно специальных лабораторных исследований и базируется только на основании анализа клинических данных, что мы отмечали выше. 
Традиционно при иммунопатологии принято выделять ряд синдромов: инфекционный, аутоиммунный, аллергический, пролиферативный. Но все они, как и большинство заболеваний сопровождаются реакцией иммунитета воспалением.

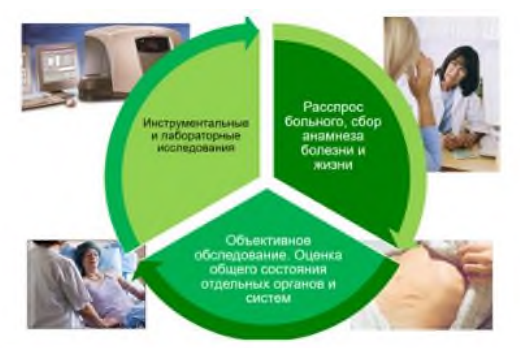

Предварительный иммунологический диагноз

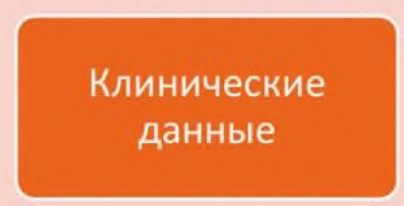

Решение вопроса о иммуноактивной терапии симптомы

синдромы

\section{диагноз}

Клинический иммунологический диагноз

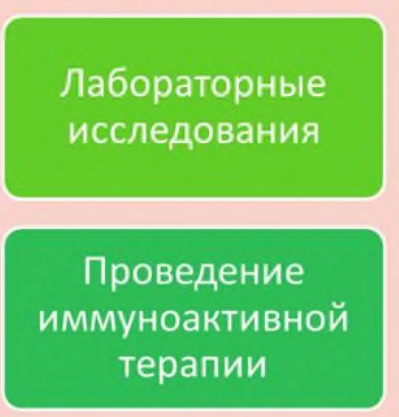

Топический иммунологический диагноз

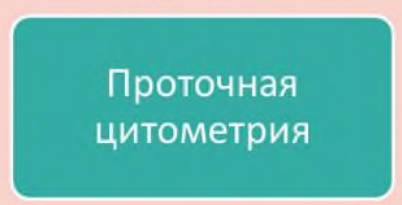

Таргентная

иммунотропная

терапия

\section{Рис.153. Принципы формирования иммунологического диагноза.}

Наиважнейшим диагностическим шагом в диагностике иммунопатологии является выявление локальных (местных) и системных признаков воспаления. Основной клинический синдром местного воспаления описанием которого в практике занимаются большинство врачей. Классически основными местными признаками воспаления описанные со времен Гиппократа являются припухание, боль, краснота, локальное повышение температуры и нарушение функции органа (рис.154). Однако в клинике гораздо важнее определить проявление системного воспалительного ответа.
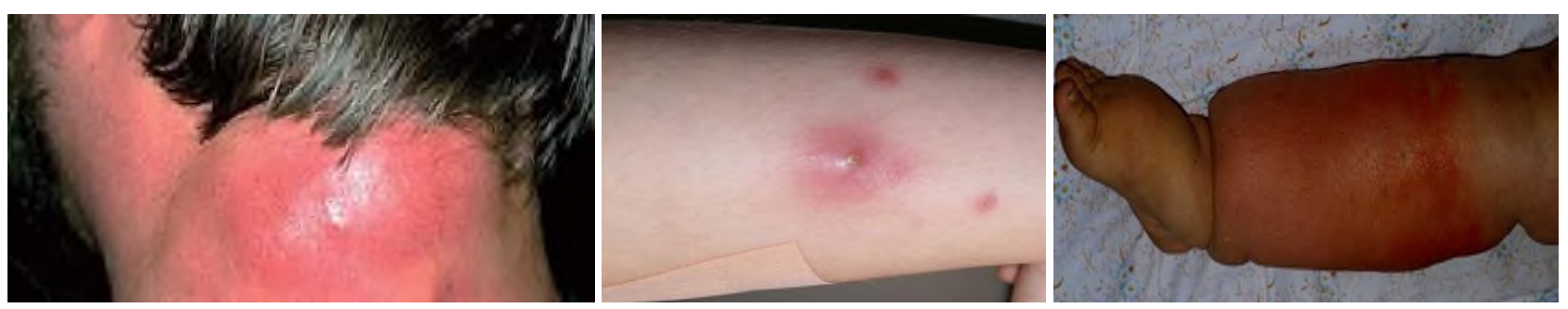

Рис. 154. Местные признаки воспаления. 
Диагноз синдрома системного воспалительного ответа (CCBO или SIRS systemic inflammatory response syndrome) появился в связи с необходимостью повышения эффективности лечения сепсиса. Согласно принятой конвенции Американской коллегии торакальных хирургов и Общества специалистов интенсивной терапии, принятой на конференции в Чикаго в 1992 г. диагноз правомочен при наличии двух или более критериев указанных в таблице (табл. 51). Исходя из этого в мировых критериях ССВО (табл.51) на основании клинических данных можно выделить две его разновидности I- преобладание провоспалительной реакции (фебрильная температура, лейкоцитоз и/или смещение лейкоцитарной формулы влево), II - преобладание провоспалительной реакции (гипотермия, лейкопения и/или лимфопения).

Таблица 51

Критерии синдрома системного воспалительного ответа

\begin{tabular}{|l|l|l|}
\hline \multicolumn{1}{|c|}{ Показатель } & \multicolumn{2}{c|}{ Значение } \\
\hline Температура тела & $\begin{array}{l}\geq 38{ }^{\circ} \mathrm{C} \text { (фебрильная } \\
\text { температура) }\end{array}$ & $\begin{array}{l}\text { или } \leq 36{ }^{\circ} \mathrm{C} \\
\text { (гипотермия) }\end{array}$ \\
\hline $\begin{array}{l}\text { Частота сердечных } \\
\text { сокращений }\end{array}$ & $\geq 90 /$ мин (тахикардия) \\
\hline Частота дыхания & $\begin{array}{l}\geq 20 / \text { мин или содержание диоксида углерода в крови } \leq 32 \\
\mathrm{mmHg}\end{array}$ \\
\hline $\begin{array}{l}\text { Клинический анализ } \\
\text { крови }\end{array}$ & $\begin{array}{l}\text { Лейкоцитоз }>12 \cdot 10^{9} / \text { л или } \\
\text { содержание молодых форм } \\
\text { гранулоцитов более } 10 \% .\end{array}$ & или лейкопения $<4 \cdot 10^{9} / л$ \\
\hline
\end{tabular}

В последнее время помимо понятия системный воспалительный ответ выделяют другие определения и синдромы. Это и «цитокиновый шторм» или «цитокиновая буря», синдром вторичного гемофагоцитарного лимфогистиоцитоза (HLH), синдром активации макрофагов (MAS). В основе всех их лежат врожденные и/или приобретенные нарушения регуляции иммунного ответа, приводящие к аномальной активации клеток иммунной системы, за счет цитокиновой дисрегуляции, развития системного воспалительного ответа и поражения органов. Это все проявление системной воспалительной реакции, а возникшая путаница с их наименованием связана с тем, что в мире до настоящего времени нет единых подходов к терминологии, диагностики и лечению подобных состояний.

Клиническими проявлениями синдрома активации макрофагов, точнее клинические проявления цитокиновой дисрегуляции, суммированные нами из различных источников и руководствующими собственным опытом указаны в таблицы (табл.52). Синдром определяется при наличии по крайней мере 5 диагностических критериев и/или при наличии мутации в гене, обуславливающем данное заболевание. 


\section{Клинические проявления цитокинового шторма}

\begin{tabular}{|c|c|}
\hline Симптом & Показатель \\
\hline Лихорадка & $\begin{array}{l}\text { Максимальный подъем температуры тела }>38,5^{\circ} \mathrm{C} \text { или } \\
\leq 36^{\circ} \mathrm{C} \text { (гипотермия) }\end{array}$ \\
\hline Тахикардия & $\geq 90 /$ мин \\
\hline Дыхательная недостаточность & $\begin{array}{l}\text { Одышка } \geq 20 / \text { мин или содержание диоксида углерода } \\
\text { в крови } \leq 32 \mathrm{mmHg} \text { или сатурация менее 95\%. }\end{array}$ \\
\hline Гепатомегалия & Печень пальпируется ниже края рёберной дуги \\
\hline Спленомегалия & $\begin{array}{l}\text { Селезёнка пальпируется >3 см ниже края рёберной } \\
\text { дуги }\end{array}$ \\
\hline Лейкоцитоз & $>12 \times 10^{9} / \pi$ \\
\hline $\begin{array}{l}\text { Цитопения с вовлечением } \\
\text { более } 2 \text { клеточных ростков }\end{array}$ & $\begin{array}{l}\mathrm{Hb}<90 \text { г/л, } \\
\text { нейтрофилы }<1 \times 10^{9} / л, \\
\text { тромбоциты }<100 \times 10^{9} / \text {, }\end{array}$ \\
\hline Лимфоцитопения & Менее $1,0 \times 10^{9} / л$ \\
\hline NК-клетки, Цтл & Снижение или отсутствие активности \\
\hline 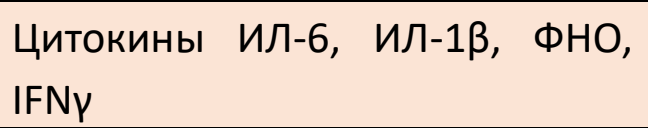 & Повышены \\
\hline $\begin{array}{l}\text { Уровень растворимого IL-2 } \\
\text { (CD25) }\end{array}$ & $>2400$ Ед/мл или очень высокие для своего возраста. \\
\hline $\begin{array}{l}\text { Хемокин, } \\
\text { IFNY, CXCL9 }\end{array}$ & Повышен \\
\hline С-реактивный белок & Более 5 мг/л \\
\hline Ферритин в сыворотке & $>500$ мкг/л \\
\hline ЛДГ, АСТ, АЛТ & Повышены, связаны с поражением ткани. \\
\hline Гемостаз & Фибриноген <1,5 г/л, D-димер более 243 нг/мл \\
\hline Гипертриглицеридемия & $\begin{array}{l}\text { Триглицериды натощак >3,0 ммоль/л или превышение } \\
\text { возрастной нормы на >3 стандартных отклонений. }\end{array}$ \\
\hline Прокальцитонин & Выше 2,0 нг/мл \\
\hline Гемофагоцитоз & $\begin{array}{l}\text { В биоптатах костного мозга, селезенки или } \\
\text { лимфатических узлов. }\end{array}$ \\
\hline
\end{tabular}

Как одно из тяжелых осложнений иммунной дисрегуляции является синдром вторичного гемофагоцитарного лимфогистиоцитоза (HLH) - это термин, был впервые описан в ревматологии при потенциально опасном для жизни осложнения системных воспалительных заболеваний (системный ювенильный идиопатический артрит, системная красная волчанка (СКВ), болезнь Кавасаки, и периодические лихорадки). Гемофагоцитоз определяется 
как поглощение клеток крови, включая эритроциты (повышение ферритина), лейкоциты и тромбоциты, фагоцитарными клетками. Помимо этого, острая фаза HLH связана с заметно повышенным уровнем провоспалительных цитокинов. Этот цитокиновый шторм запускает каскад воспалительных процессов, которые, если их не лечить, приводят к повреждению тканей и смерти.

C позиций иммунных про- и противовоспалительных реакций на инфекцию (см. главу 6.) формируется еще ряд синдромов: CARS - синдром компенсаторного противовоспалительного ответа, MARS- синдром смешанного антагониста ответа, PICS - стойкое воспаление, иммуносупрессия и синдром катаболизма (табл.53).

Таблица 53

\section{Реакций иммунитета при формировании синдромов системного ответа}

\begin{tabular}{|l|c|c|c|c|}
\hline Реакция иммунитета & SIRS & CARS & MARS & PICS \\
\hline Провоспалительная & +++ & + & +++ & ++ \\
\hline Противовоспалительная & + & +++ & +++ & + \\
\hline
\end{tabular}

Таким образом, выделение и характеристика системного воспалительного ответа обязательна для врача любой специальности его своевременное распознавание является основой эффективного и точного лечение.

В последующем по механизму развития воспаления следует выделять синдромы связанные с гипореактивным и гиперреактивным состоянием иммунной системы (рис. 155).

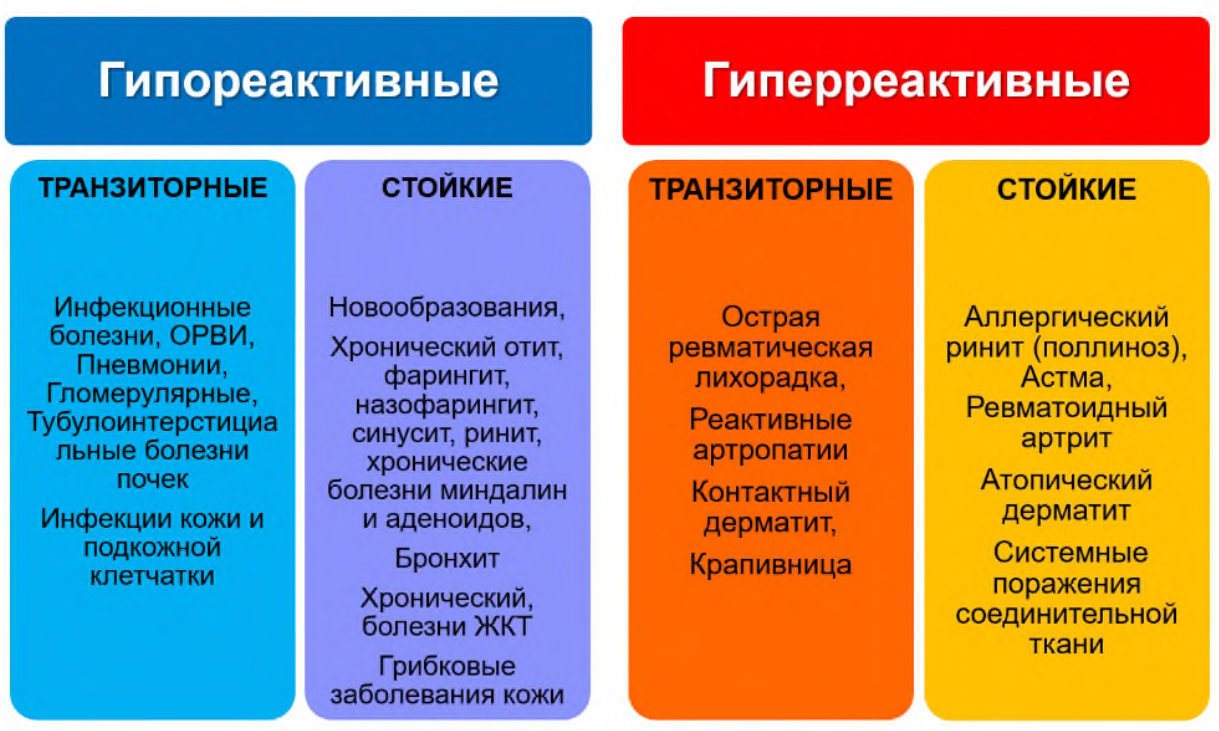

Рис.155. Синдромы и заболевания связанные с нарушением функции иммунной системы. 


\section{Синдромы гипореактивных (гипоэргических) состояний:}

\section{1. Недостаточность (иммунодефицит) клеточно-эффекторного звена}

иммунитета, этот синдром проявляется одним или несколькими следующими признаками, а именно:

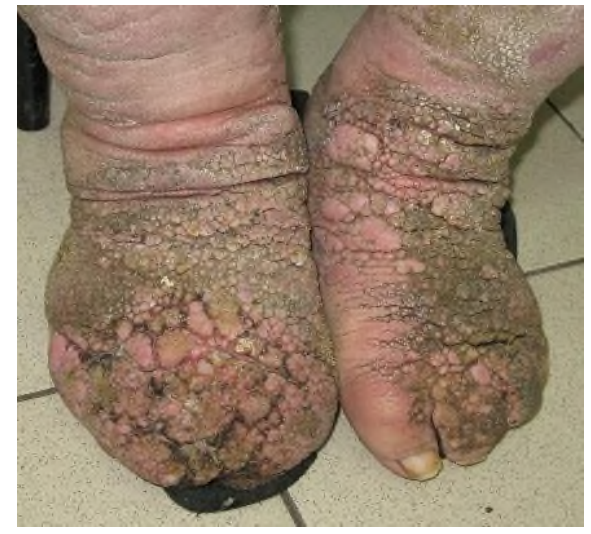

Рис.156. ВПЧ стоп.

- частые ОРВИ (более 4 раз в год);

- клинически выраженные инфекции, вызванные группой вирусов герпеса (рецидивирующее течение герпеса 1 и 2 типа, 3 типа (герпес зостера), цитомегаловирусная инфекция, заболевания, вызванные вирусом Эпштена-Барр;

- все виды бородавок, остроконечные кондиломы, опосредованные папилломавирусом человека и контагиозным моллюском (рис.156);

- вирусные гепатиты (B, C, D, F, G);

- вирусные энтериты;

- повторные детские инфекции и/или инфекции, развивающиеся после проведения вакцинации (у детей в возрасте старше 7 лет и взрослых);

- грибковые инфекции (кандидамикоз, дерматомикоз) кожи, ногтей, слизистых оболочек (молочница), внутренних органов, трихофития;

- все виды опухолевых процессов.

2. Гуморально-эффекторный иммунодефицит (недостаточность) диагностирован при наличии у больного:

- бактериальных инфекций верхних дыхательных путей и ЛОР-органов (более 3-4 раз в год с затяжным течением, с остаточными явлениями в виде субфебрилитета, астении, ангина (рис.157);

- бактериальных инфекций легких (хронические бронхиты с бронхоспазмом или без него, пневмонии различной этиологии);

- бактериальных инфекций кожи и подкожной клетчатки (фурункулез, абсцессы, флегмоны, рецидивирующий парапроктит);

- инфекционно-воспалительных заболеваний органов мочеполовой системы (цистит, пиелонефрит и др.); - других бактериальных инфекций: менингоэнцефалита, артрита, сепсиса и пр.;

- заболеваний пищеварительного тракта, вызванные бактериями (стоматит, пародонтит, гастрит, гастродуоденит, язвенная болезнь, колит, энтероколит, холецистит, перитонит), дисбактериоз, в том числе кишечный. 


\section{3. Синдром недостаточности макрофагально-фагоцитарного звена}

Диагностические признаки нередко идентичны признакам синдрома недостаточности гуморального звена иммунитета. Однако обычно при этом синдроме бактериальные инфекции протекают вяло, без высокой температуры и других признаков воспаления. Характерными признаками недостаточности макрофагальнофагоцитарного звена считаются рецидивирующие абсцессы разных локализаций и локальные бактериальные инфекции (рис.158).

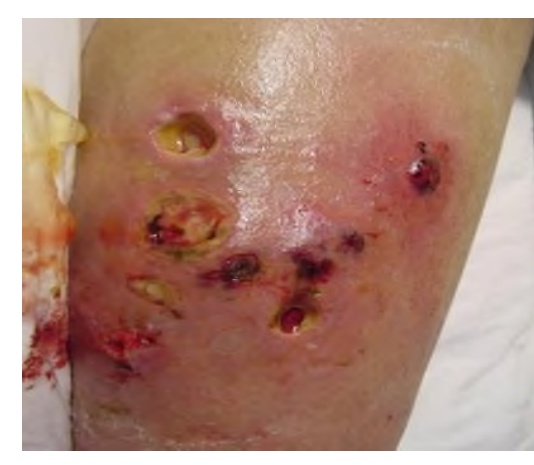

\section{Рис.158. Абсцесс голени.}

\section{4. Гипорегенеративный синдром.}

Определяется тогда, когда после повреждения не происходит возмещение дефекта ткани, идентично погибшей, с восстановлением структуры и способности органа к выполнению специализированной функции (рис.159).

\section{5. Синдром недостаточности регуляторного звена иммунитета.}

Диагностируется при сочетании вышеописанных синдромов. При этом необходимо выделить некоторые особенности течения этих заболеваний, а

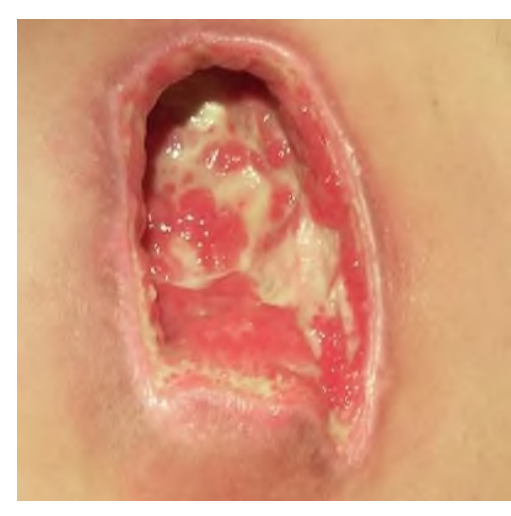

Рис. 159. Пролежень. именно: устойчивость к стандартной специфической терапии или быстрое развитие рецидива после лечения; затяжное или хроническое течение с частыми рецидивами; активация условнопатогенной флоры, микст-инфекция, смена возбудителя в динамике болезни.

\section{Синдромы гиперреактивных (гиперэргических) состояний:}

1. Реагиновый (анафилактический, атопический) синдром.

Его развитие связано с действием $\operatorname{IgE}$ и частично с $\operatorname{IgG}$ на тучные клетки. Синдром проявляется реакциями, возникающими обычно через 5-30 мин. после контакта сенсибилизированного организма со специфическим аллергеном. Они бывают общие (анафилактический шок) и местные (крапивница (рис.160), отек Квинке, бронхиальная астма, поллиноз, атопический дерматит, аллергический ринит).

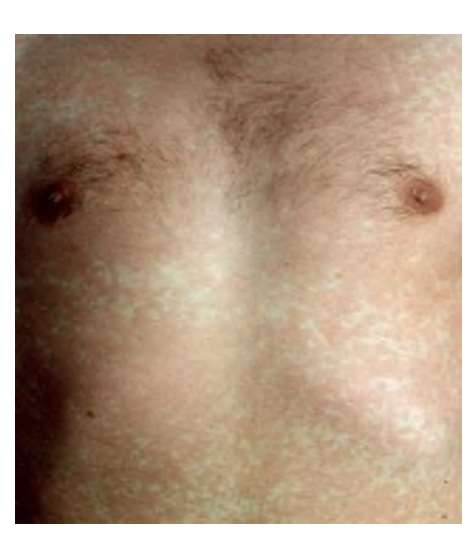

Рис.160. Крапивница. 
2. Антителозависимый цитотоксический синдром (цитолитический или антителозависимая цитотоксическая гиперчувствительность).

Он наблюдается при попадании в организм гомологичных антигенов, при лекарственной аллергии. Это один из механизмов развития аутоиммунных заболеваний, где в качестве антигена выступают собственные аутоантигены (рис.161).

3. Синдром патогенного воздействия иммунных комплексов.

Проявления, обусловленные образованием иммунных комплексов, обычно связаны с хроническими персистирующими инфекциями, аутоиммунными заболеваниями, поступлениями большого количества антигена

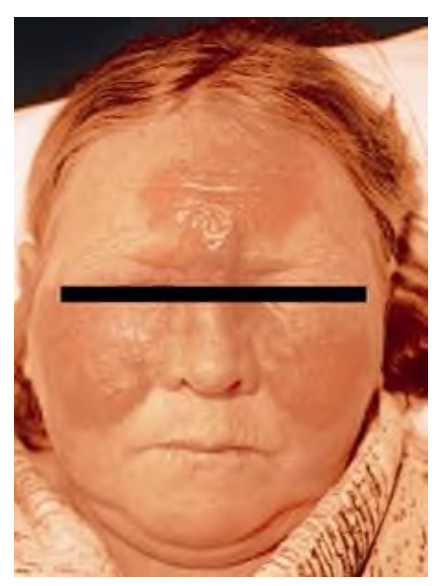

Рис. 161. Системная красная волчанка. в сенсибилизированный или интактный организм (сывороточная болезнь). При менингококковой инфекции это патогномоничный признак (рис.162)

4. Клеточно-опосредованная цитотоксичность (гиперчувствительность замедленного типа). Клинически это проявляется через 21-28 суток с развитием гранулемы (рис.163), способствующей ограничению инфекции. К основным заболеваниям с реакциями гиперчувствительности замедленного типа относятся проказа, туберкулез, шистосомоз, саркоидоз, болезнь Крона, бруцеллез, сифилис.

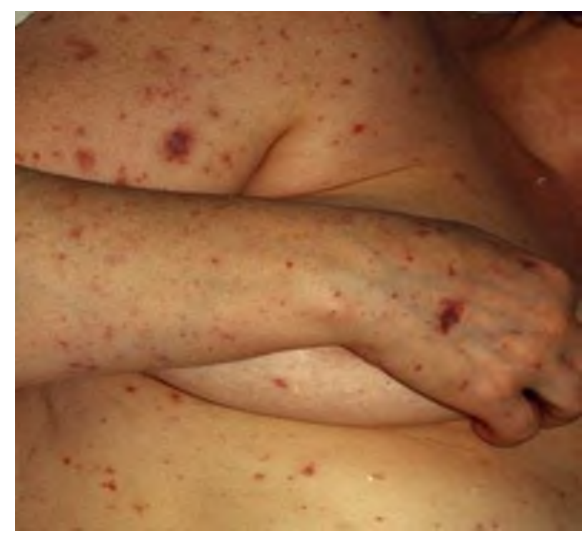

Рис.162. Менингококцемия.

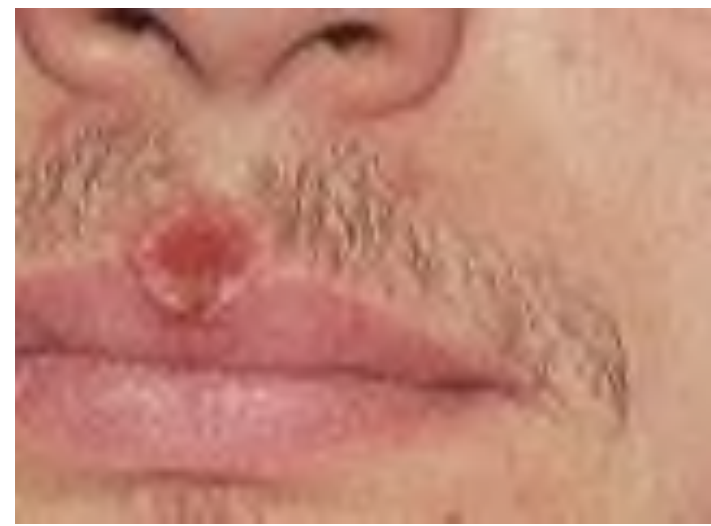

Рис.163. Гранулема.

5. Реакции врожденного иммунитета (аутовоспалительные реакции). патогенетически связанны с аномальной активацией врожденного иммунитета, 
клинически проявляются повторяющимися эпизодами лихорадки с системным воспалением, различными типами поражения кожи и/или слизистых и/или суставов. Это основной механизм развития подагры, болезни Крона, псориаза, саркоидоза (рис.164).

Так же этот синдром встречается при злокачественных новообразованиях, инфекциях (например, COVID-19, ВЭБ, сепсис) и первичные иммунодефицитах.

Принимая во внимание клонально-селекционный тип реагирования иммунной системы и то, что в развитии иммунных нарушений принимает участие, как правило, не один, а несколько типов реакций, по механизму действия выделяют смешанные, а по уровню нарушения - комбинированные иммунные нарушения.

В дальнейшем при положительном ответе на наличие иммунопатологического состояния и определения иммунопатологических синдромов очень важно определить длительность его течения. Поэтому выделяют транзиторные и стойкие проявления дисфункции иммунной системы (табл.54).

Таблица 54

Классификация иммунных нарушений по длительности Транзиторные Стойкие

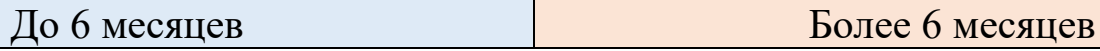

1. Транзиторные (острые) иммунопатологические состояния развиваются за счет острых патологических процессов и воздействий (инфекции, травмы, интоксикации и т.д.) и по длительности протекают не более 6 мес., как правило, изменения со стороны иммунной системы спонтанно исчезают при устранении их причины.

2. Стойкие, хронические дисфункции иммунной системы возникают вследствие длительно действующих патологических процессов (хронические гнойно-воспалительные заболевания, аутоиммунные нарушения, опухоли, персистирующие инфекции и т.д.), диагностируемых более 6 мес.

По распространенности и по степени тяжести следует выделить иммунные нарушения легкой, среднетяжелой и тяжелой степени (табл.55). 
Таблица 55

\section{Определение степени тяжести иммунных нарушений}

\begin{tabular}{|c|c|c|c|}
\hline \multirow{2}{*}{ Признак } & \multicolumn{3}{|c|}{ Степень тяжести } \\
\hline & Легкая & Среднетяжелая & Тяжелая \\
\hline $\begin{array}{l}\text { Локализация } \\
\text { процесса }\end{array}$ & $\begin{array}{c}\text { Локальная не более } \\
\text { одного органа }\end{array}$ & $\begin{array}{c}\text { Вовлечены другие } \\
\text { органы }\end{array}$ & $\begin{array}{c}\text { Генерализованный } \\
\text { процесс }\end{array}$ \\
\hline $\begin{array}{l}\text { Нарушение функции } \\
\text { пораженного органа }\end{array}$ & Нет & Имеются & Выражены \\
\hline $\begin{array}{l}\text { Периферические } \\
\text { лимфатические } \\
\text { органы }\end{array}$ & Не задействованы & Задействованы & Задействованы \\
\hline $\begin{array}{l}\text { Воздействие на } \\
\text { организм в целом }\end{array}$ & Нет & Не выражено & Выражено \\
\hline Угроза для жизни & Нет & Нет & Имеется \\
\hline
\end{tabular}

1. «Локальные (местные)» иммунные нарушения возникают на фоне патологии барьерных тканей (кожа, слизистые) чаще всего вследствие воспалительного процесса. Во внутренних органах повреждение местных клеток иммунной системы и затруднение поступления лимфоцитов, фагоцитов и АТ из крови могут происходить из-за нарушения микроциркуляции, ацидоза и т.п. Такие иммунодефициты имеют место у больных с хроническими неспецифическими заболеваниями верхних дыхательных путей, ЛОР-органов, ареактивно текущими ранами и ожогами, а также при состояниях тканей, описываемых онкологами как предраковые: хронический воспалительный процесс, рубцы, длительно незаживающие трофические язвы и т.д. Обычно такие иммунные нарушения бывают легкой степени.

2. Системные иммунные нарушения - это нарушения средней и тяжелой степени, когда в процесс вовлечены органы и системы всего организма. Предлагается выделять три степени тяжести: легкую, среднетяжелую и тяжелую. Иммунные нарушения легкой степени характеризуются локальным поражением с вовлечением в процесс одного органа без повреждений функций всего организма. При тяжелой степени - это генерализованные процессы с нарушением функций организма с угрозой для жизни больного. Все оставшиеся клинические случаи следует квалифицировать как среднетяжелые.

Следующим этапом необходимо попытаться определить причину возникновения (этиологию) иммунопатологического состояния (подробнее см. главы 12-13).

Суммируя этиологические и патогенетические факторы развития иммунопатологий, в том числе с учетом данных ВОЗ, можно выделить следующие причины их возникновения: 
Генетические, врожденные, первичные иммунодефициты представляет собой врожденные нарушения иммунной системы, обусловленные генетическими нарушениями.

Инфекции: острые и хронические вирусные, бактериальные, микстинфекции, имеющие многофакторное повреждающее действие на иммунную систему (воздействие токсинов, других иммуносупрессирующих факторов, микробов и вирусов, истощение антиоксидантной системы и повреждающее действие свободных форм кислорода) и др. Как причины могут служить: протозойные и глистные инвазии (малярия, токсоплазмоз, лейшманиоз, трихинеллез, аскаридоз и т.д.); бактериальные инфекции (туберкулез, стафилококковая, пневмококковая, менингококковая инфекции, сифилис и др.); вирусные инфекции: а) острые - корь, краснуха, грипп, паротит, ветряная оспа, гепатит, герпес и др.; б) персистирующие - хронический гепатит В, подострый склерозирующий панэнцефалит, СПИД, и др.; в) врожденные - цитомегалия, краснуха.

3. Повреждающие факторы внешней среды физического и химического характера (температурные, лучевые, антропогенные загрязнения окружающей среды химическими токсическими веществами - тяжелыми металлами, пестицидами, хлорсодержащими веществами, радионуклидами и т.п., формирование разнообразных физических полей, широкое использование источников неионизирующих излучений), в том числе экологические (включая экологические катастрофы планетарного масштаба, типа аварии на ЧАЭС и др.).

4. Интоксикации различного генеза как экзогенные (отравления), так и эндогенные (тиреотоксикоз, декомпенсированный сахарный диабет).

5. Ятрогенные факторы: длительный прием иммуносупрессантов.

6. Метаболические факторы:

Алиментарные - дефицит белков, макро- и микроэлементов, витаминов и других жизненно важных веществ вследствие недостаточного поступления их с пищей (социальные причины, «модные» диеты, самостоятельное голодание с целью снижения веса, омоложения, лечения и т.д.) или повышенного расхода из-за нарушения расщепления, всасывания и/или транспорта необходимых веществ.

Гипоксические - вследствие гипоксии различного генеза.

Эндокринные - нарушения обмена веществ вследствие заболеваний органов эндокринной системы (гипотиреоз, тиреотоксикоз, недостаточность половых гормонов, сахарный диабет и др.).

Стрессовые - вследствие нарушения нейрогормональной регуляции. Истощение антиоксидантной системы в результате хронической инфекции, радиационных поражений, заболеваний внутренних органов. «Истощающие заболевания» - цирроз печени, обширные ожоги, анемия, алкоголизм, наркомания и др. 
7. Оперативные вмешательства, травмы.

8. Злокачественные новообразования, в том числе лимфопролиферативные.

9. Аутоиммунные заболевания.

10. Состояния, приводящие к потере клеток иммунной системы и иммуноглобулинов (кровотечения, лимфорея, нефриты).

11. «Физиологические» иммунодефициты, возникающие в периоды физиологических изменений в иммунной системе: ранний детский и старческий возраст, беременность. Возрастная инволюция тимуса начинается после полового созревания. Фактически все люди более или менее рано становятся иммунными больными, причем само развитие процесса старения и сопутствующих ему болезней (хроническое воспаление, аутоиммунные болезни, аллергия, опухоли) в значительной степени связывают с нарушением функции иммунной системы.

В некоторых случаях дисфункции иммунной системы развивается без видимых причин такое состояние определяется как спонтанная форма иммунных нарушений.

При таком многообразии причин развития иммунных нарушений врачу тем не менее необходимо выявить причину иммунопатологии, т. к. простое исключение фактора, неблагоприятно влияющего на иммунитет, уже приведет к клиническому эффекту. Чтобы рассмотреть причины иммунодефицитов, уместно еще раз вспомнить, что иммунитет человека есть сложная многокомпонентная система, и в защите организма от инфекции участвуют факторы как врожденного, так и адаптивного иммунитета. Возможно, что дефект в этой системе может какое-то время не проявляться клинически в виде повышенной инфекционной заболеваемости, потому как все другие компоненты иммунитета находятся в нормальном функциональном состоянии и компенсируют этот дефект. Однако происходящие со временем и под влиянием различных неблагоприятных факторов изменения в этих компенсаторных компонентах могут давать суммарный эффект, ведущий к возникновению первичного дефекта и развитию повышенной заболеваемости.

Суммируя полученные данные на первом этапе на основании клинических данных, формируется иммунологический клинический диагноз (табл.41).

В качестве построения диагноза иммунных нарушений можно привести следующие примеры:

Транзиторные, индуцированные (экзогенные), гиперреактивные нарушения гуморально-эффекторного звена иммунитета средней степени тяжести.

Стойкие, спонтанные, гипореактивные нарушения макрофагальнофагоцитарного звена иммунитета легкой степени тяжести. 
Таблица 56

Клиническая классификация нарушений функции иммунной системы

\begin{tabular}{|c|c|c|c|c|}
\hline \multirow{2}{*}{$\begin{array}{c}\text { По } \\
\text { длительности }\end{array}$} & \multirow[b]{2}{*}{ По этиологии } & \multicolumn{2}{|c|}{ По патогенезу } & \multirow{2}{*}{$\begin{array}{c}\text { По степени } \\
\text { тяжести }\end{array}$} \\
\hline & & Механизм & $\begin{array}{c}\text { Уровень } \\
\text { нарушения }\end{array}$ & \\
\hline \multirow[t]{2}{*}{ Транзиторные } & \multirow{2}{*}{ Врожденные } & \multirow{2}{*}{ Гипореактивные } & $\begin{array}{c}\text { Клеточно- } \\
\text { эффекторное }\end{array}$ & \multirow{2}{*}{ Легкой степени } \\
\hline & & & $\begin{array}{c}\text { Гуморально- } \\
\text { эффекторное звено }\end{array}$ & \\
\hline \multirow[t]{3}{*}{ Стойкие } & \multirow[t]{2}{*}{ Индуцированные } & \multirow[t]{2}{*}{ Гиперреактивные } & $\begin{array}{c}\text { Макрофагально- } \\
\text { фагоцитарное звено }\end{array}$ & \multirow[t]{2}{*}{ Средней степени } \\
\hline & & & Регуляторное звено & \\
\hline & Спонтанные & Смешанные & Комбинированные & Тяжелой степени \\
\hline
\end{tabular}

Определяя клинический иммунологический диагноз, мы тем самым выделяем определенный иммунотип в формировании заболевания. Иммунотипы (эндотипы иммунного ответа) - это кластеры клинических компонентов заболевания (физиологические, иммунологические, патологические, генетические признаков, ответ на лечение и другие), которые в совокупности формируют фенотип заболевания. Однако наиболее важно ответить на вопрос какие конкретно нарушения имеются у иммунной системы. Учитывая сложность и многокомпонентность организации иммунной системы (клеточный/гуморальный, мукозальный/врожденный/ адаптивный иммунитет) необходимо точечная, топическая диагностика. 


\section{Глава 12. Топическая}

\section{диагностика иммунных} нарушений

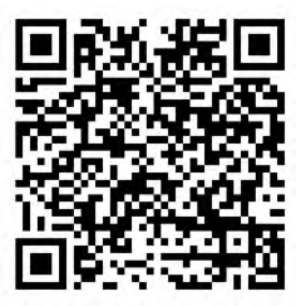

Топическая диагностика (по аналогу определения в неврологии) определение локализации и распространенности нарушений иммунной системы на основании выявленных при комплексном обследовании нарушений иммунной системы. Учитывая, что основная структурная и функциональная единица иммунной системы клетка, основной акцент на выявление нарушений функции иммунитета стоит сфокусировать на исследовании клеток иммунной системы и эффекторных и регуляторных молекулах. В настоящее время с помощью проточной цитометрии возможно дифференцировать практически любые виды клеток определить их функциональную активность. Однако в связи с тем, что основная масса клеток иммунной системы находится в ткани и их исследования в отличии от периферической крови имеют технические сложности требуется дополнительные разработки по клинической оценки топической диагностики иммунных нарушений. Тем не менее существующие методы исследования позволяют выявить нарушения в том или ином звене иммунитета. Не менее важным является оценка и гуморальных факиров иммунитета. Суммарно с позиций физиологии иммунный ответ возможно разделить на 3 этапа (рис.165). Именно с этих позиций необходимо проводить и топическую диагностику.

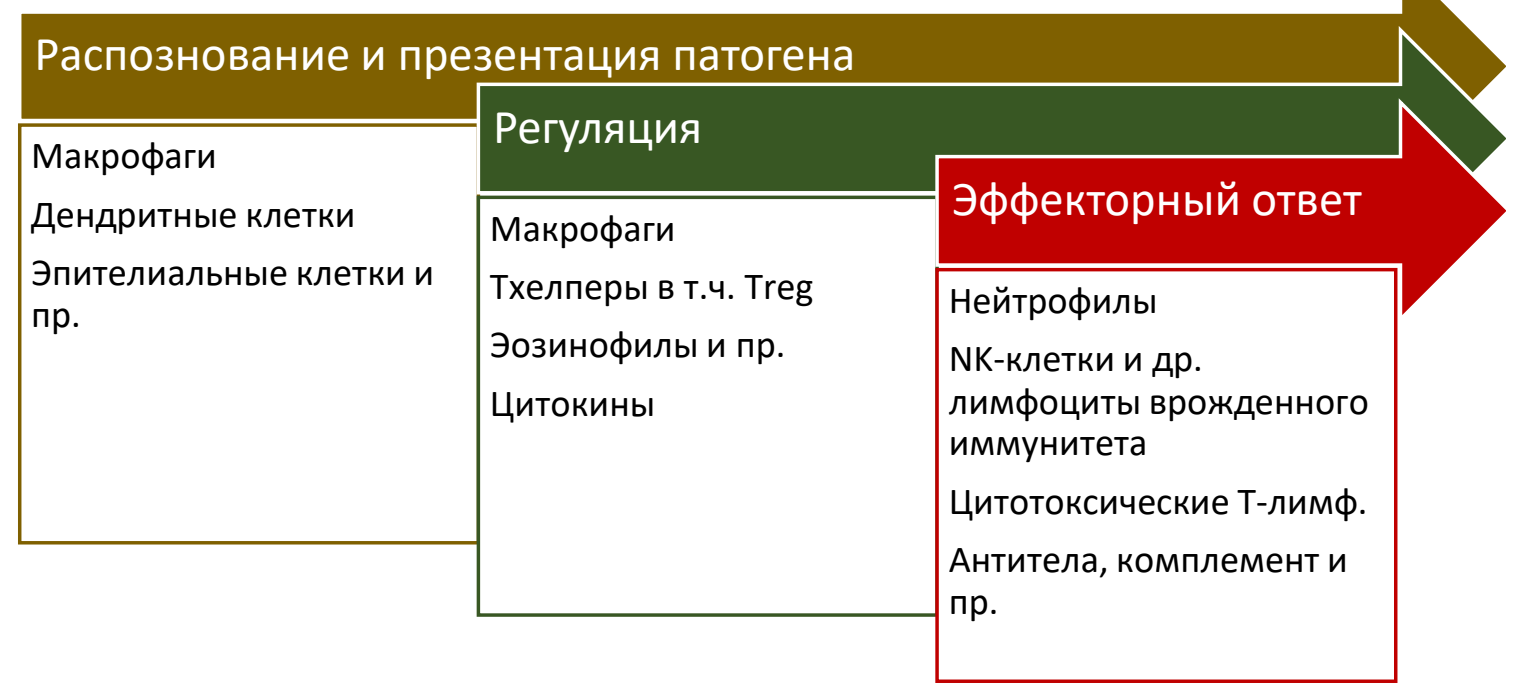

Рис. 165. Этапы развития иммунного ответа. 


\section{Эффекторный ответ}

Основной функциональный продукт иммунной системы. Наиболее простые и достаточно информативные методы заключаются в определении концентрации иммуноглобулинов, специфических АТ и других показателей, характеризующих состояние гуморального звена иммунной системы. Наибольшее распространение в определении различных гуморальных показателей иммунитета получил метод иммуноферментного анализа (ИФА).

Определение уровня иммуноглобулинов - это по-прежнему важный и надежный метод оценки иммунитета. Его можно считать главным методом диагностики всех форм иммунодефицитов, связанных с биосинтезом АТ. Лабораторным методом можно определить не только уровни концентрации иммуноглобулинов $\mathrm{G}, \mathrm{A}, \mathrm{E}$ и $\mathrm{M}$ в сыворотке крови, но и субклассы иммуноглобулинов, особенно $\operatorname{IgG}$, секреторного $\operatorname{IgA}$, соотношения каппа (x)- и лямбда $(\lambda)$-цепей. Нормативные показатели зависят от возраста исследуемого (табл.57).

Таблица 57

Нормативные показатели уровня иммуноглобулина

\begin{tabular}{|l|c|c|c|c|}
\hline \multirow{2}{*}{ Возраст } & \multicolumn{4}{|c|}{ Показатель } \\
\cline { 2 - 5 } & $\operatorname{Ig~E~(мг/дл~)~}$ & $\operatorname{lg~G~(мг/дл)~}$ & $\operatorname{lg~A~(мг/дл)~}$ & $\operatorname{Ig~M~(мг/дл)~}$ \\
\hline $1-3$ мес. & $0-30$ & $3.3-9.1$ & $0.1-0.2$ & $0.4-1.2$ \\
\hline 4-12 мес. & $0-30$ & $3.2-12.8$ & $0.1-0.4$ & $0.4-0.8$ \\
\hline 12-24 мес. & $0-45$ & $4.6-14.6$ & $0.1-1.0$ & $0.6-1.8$ \\
\hline 2-5 лет & $0-100$ & $8.8-15.4$ & $0.3-1.5$ & $0.8-1.6$ \\
\hline 6-8 лет & $0-100$ & $9.7-11.7$ & $0.9-1.9$ & $0.8-1.9$ \\
\hline 9-11 лет & $0-100$ & $9.4-16.6$ & $0.9-2.9$ & $0.6-2.0$ \\
\hline
\end{tabular}

Изменения концентрации иммуноглобулинов служат подтверждением гуморально-ассоциированной иммунопатологии. Снижение такой концентрации в сыворотке крови больных может свидетельствовать о различных патологиях- от генетических дефектов синтеза иммуноглобулинов до транзиторных состояний, связанных с потерей белка организмом (гуморально-эффекторный иммунодефицит). Повышение концентраций относительно нормативных значений говорит о наличии аллергических, аутоиммунных процессов (АТ-зависимая цитотоксичность), оно характерно для инфекционных заболеваний на определенных этапах их развития (увеличение $\operatorname{IgM}$ в острый период заболевания и/или обострения хронической инфекции, $\operatorname{IgG}$ в стадии разрешения и/или формирования хронической инфекции). Кроме того, указанный метод является критерием эффективности проводимого лечения, в том числе заместительной терапии иммуноглобулинсодержащими препаратами. 
Определение субклассов $\operatorname{IgG}$ представляет диагностическую ценность, так как при нормальном его уровне могут быть дефициты по субклассам иммуноглобулинов. У таких людей в ряде случаев наблюдаются иммунодефицитные состояния, проявляющиеся в повышенной частоте инфекционной заболеваемости. Так, IgG2 - субкласс иммуноглобулина G, который преимущественно содержит АТ против полисахаридов инкапсулированных бактерий (Haemophiluls influlenzae, Steptococculs pneumoniae). Поэтому дефицит, связанный с $\operatorname{IgG} 2$, а также с $\operatorname{IgA}$, ведет к повышенной заболеваемости респираторными инфекциями. Нарушения в соотношении субклассов IgA и в соотношении каппа $(x)$ - и лямбда $(\lambda)$-цепей также могут быть причиной иммунодефицитных состояний.

Уровни сывороточных иммуноглобулинов, характерные для взрослых (IgM, IgG1, IgG3), достигают нормальных значений уже в раннем постнатальном периоде. Концентрации IgG2, IgG4, IgA не достигают нормы даже в период полового созревания. Распределение субклассов IgG в сыворотке крови взрослого человека следующее: $\operatorname{IgG1}$ - 60-65 \%; IgG2 - 20-25 \%; IgG3 10-20\%; IgG4 - 10-20\%. Наиболее часто у больных имеется ассоциация дефицитов IgG2, IgG4, IgA, IgE. Определение уровня субклассов $\operatorname{IgG}$ существенно при повышенной чувствительности к бактериальным инфекциям.

Определение специфических антител. Важную информацию о состоянии гуморального иммунитета дает определение АТ к различным АГ, так как степень защиты организма от данной конкретной инфекции зависит не от общего уровня иммуноглобулинов, а от количества специфических АТ к ее возбудителю. В настоящее время существует большое количество тест-систем по распознаванию уровня АТ к бактериальным, вирусным, грибковым инфекциям и инвазиям.

Особо важное значение имеют эти исследования при инфекциях с эритемами (табл.58), инфекции повреждающие иммунную систему - вирус иммунодефицита человека, вирус Эпштейна-Барр, герпесвирус человека (табл.59).

Таблица 58

\section{Диагностика эритем}

\begin{tabular}{|c|c|}
\hline Заболевания & Лабораторная диагностика \\
\hline Kopb & ИФА специфические IgG (с 10 дня) и IgМ (с 10 по 90 день). ДНК (ПЦР) \\
\hline Краснуха & ИФА специфические IgG (с 14 дня) и І IgМ (с 5 по 35 день). \\
\hline Парвовирус В19 & ИФА специфические IgG (с 21 дня) и IgМ (с 5 по 120 день). ДНК (ПЦР) \\
\hline $\begin{array}{l}\text { Вирус Эпштейна - } \\
\text { Барр }\end{array}$ & $\begin{array}{l}\text { ИФА AT Ig M, Ig G к ЕА- ранний антиген, VCA-капсидный антиген, ЕBNA-нуклеарный } \\
\text { антиген. ДНК (ПЦР) }\end{array}$ \\
\hline Скарлатина & Бактериологический, ИФ, ИФА, латексная агглютинация, АСЛО \\
\hline Иерсиниозы & Бактериологическая, ИФА и РСК или ИФА АТ Іg М, Ig G ДНК (ПЦР) \\
\hline Боррелиоз & ИФА АТ Ig М, Ig G к боррелиям. ДНК (ПЦР) \\
\hline Эрлихиоз & ИФА АТ Ig М, Ig G к риккетсиям. ДНК (ПЦР) \\
\hline
\end{tabular}




\section{Герпесвирусные инфекции}

\begin{tabular}{|c|c|c|}
\hline $\begin{array}{c}\text { Обозначен } \\
\text { ие }\end{array}$ & $\begin{array}{c}\text { Общепринятое } \\
\text { название }\end{array}$ & Клинический диагноз \\
\hline $\begin{array}{l}\text { HSV-1 } \\
(\mathrm{HHV}-1)\end{array}$ & Вирус простого герпеса 1 типа & $\begin{array}{l}\text { Герпес кожи и слизистых, нейрогерпес, офтальмогерпес, } \\
\text { генитальный герпес, интерстициальная пневмония, } \\
\text { герпетиформная экзема Капоши. }\end{array}$ \\
\hline $\begin{array}{l}\mathrm{HSV}-2 \\
(\mathrm{HHV}-2)\end{array}$ & Вирус простого герпеса 2 типа & То же \\
\hline $\begin{array}{l}\text { VZV } \\
\text { (HHV-3) }\end{array}$ & $\begin{array}{l}\text { Вирус варицелла-зостер } \\
\text { (ветряной оспы) }\end{array}$ & $\begin{array}{l}\text { Ветряная оспа, офтальмогерпес, опоясывающий лишай, } \\
\text { постгерпетическая невралгия. }\end{array}$ \\
\hline $\begin{array}{l}\text { EBN } \\
\text { (HHV-4) }\end{array}$ & Вирус Эпштейна-Барр & $\begin{array}{l}\text { Инфекционный мононуклеоз, лимфаденопатия, } \\
\text { лимфома Беркита, волосатоклеточный лимфолейкоз. }\end{array}$ \\
\hline $\begin{array}{l}\mathrm{CMV} \\
(\mathrm{HHV}-5)\end{array}$ & Цитомегаловирус & $\begin{array}{l}\text { Цитомегалия, гепатит, доброкачественная лимфома, } \\
\text { интерстициальная пневмония. }\end{array}$ \\
\hline HSV-6 & Вирус внезапной экзантемы & $\begin{array}{l}\text { Вариант А синдром хронической усталости } \\
\text { Вариант В розеола новорожденных, мононуклеоз, } \\
\text { лимфоаденопатия, энцефалит. }\end{array}$ \\
\hline HSV-7 & Вирус герпеса 7 типа & Розовый лишай, синдром хронической усталости. \\
\hline $\begin{array}{l}\text { KSHV } \\
\text { (HHV-8) }\end{array}$ & $\begin{array}{l}\text { Герпесвирус ассоциированный с } \\
\text { саркомой Капоши }\end{array}$ & Саркома Капоши \\
\hline
\end{tabular}

Большое значение определение АТ имеет диагностика хронических инфекций и инвазий в т.ч. сифилиса, туберкулеза, токсоплазмоза, бруцеллёза и пр.

Одни из важнейших эффекторных молекул гуморального иммунитета белки системы комплемента. Центральными компонентами которого является компоненты С3 и С4. (табл.60).

Таблица 60

Нормативные показатели в диагностики патологии системы комплемента

\begin{tabular}{|c|c|c|c|c|c|c|c|}
\hline & \multicolumn{7}{|c|}{ Показатель } \\
\cline { 2 - 8 } Возраст & С3 (г/л) & C4 (г/л) & $\begin{array}{c}\text { ЦИК с } \\
\text { IgG (ед. } \\
\text { опт. пл.) }\end{array}$ & $\begin{array}{c}\text { ЦИК с } \\
\text { IgA (ед. } \\
\text { опт. пл.) }\end{array}$ & CH 50 & $\begin{array}{c}\text { С1- } \\
\text { ингбитор } \\
\text { (г/л) }\end{array}$ & $\begin{array}{c}\text { С3- } \\
\text { активатор } \\
\text { (г/л) }\end{array}$ \\
\hline $1-3$ мес. & $0.5-1.0$ & $0.12-0.36$ & $0,020-0,14$ & $0,3-0,7$ & $3.5-6.7$ & $0.36-0.38$ & $0.08-0.18$ \\
\hline $4-12$ мес. & $0.7-1.2$ & $0.15-0.44$ & $0,020-0,14$ & $0,3-0,7$ & $3,5-6,7$ & $0.26-0.5$ & $0.16-0.24$ \\
\hline $12-24$ мес. & $0.6-1.4$ & $0.13-0.37$ & $0,020-0,14$ & $0,3-0,7$ & $3,5-6,7$ & $0.24-0.48$ & $0.11-0.26$ \\
\hline $2-5$ лет & $0,7-1,1$ & $0,19-0,31$ & $0.020-0.14$ & $0,3-0,7$ & $3,5-6,7$ & $0.28-0.4$ & $0.14-0.25$ \\
\hline $6-8$ лет & $0.6-1.1$ & $0.14-0.27$ & $0.020-0.14$ & $0,3-0,7$ & $3,5-6,7$ & $0.21-0.43$ & $0.09-0.19$ \\
\hline $9-11$ лет & $0.6-1.1$ & $0.14-0.27$ & $0.020-0.14$ & $0,3-0,7$ & $3,5-6,7$ & $0.21-0.43$ & $0.09-0.19$ \\
\hline Старше 12 лет & $0.6-1.1$ & $0.14-0.27$ & $0.02-0.14$ & $0.3-0.7$ & $3.5-6.7$ & $0.21-0.43$ & $0.09-0.19$ \\
\hline
\end{tabular}

Определение общей гемолитической способности комплемента (СН-

50) позволяет выявить большинство нарушений этой системы. При наследственной недостаточности компонентов от С1 до С8 показатель СH50 
приближен к нулю, а при недостаточности С9 он составляет примерно половину от нормы. При приобретенной недостаточности комплемента показатели СН50 зависят от характера и тяжести основного заболевания. Анализ не выявляет недостаточности факторов альтернативного пути и лектинового пути активации комплемента.

Компонент комплемента С3 - белок острой фазы воспаления, важнейшая часть защиты от инфекций. Он образуется в макрофагах и фибробластах, печени лимфоидной ткани и коже, составляет около 70\% всех белков системы комплемента.

Компонент комплемента C4 участвует только в классическом пути активации системы комплемента, имеет важное значение в развитии аутоиммунных заболеваний.

С1-ингибитор, связанный с количественной недостаточностью или сниженной активностью - один из наиболее частых врожденных дефектов системы комплемента. Он служит причиной наследственного ангионевротического отека, который проявляется повторными эпизодами сосудистого отека, захватывающего подслизистый слой дыхательных путей, пищеварительного тракта и подкожную клетчатку. Наиболее опасным является отек гортани. В большинстве случаев заболевание манифестирует в детстве, реже - во взрослом состоянии.

Циркулирующие иммунные комплексы (ЦИК) образуются при взаимодействии АГ и АТ в крови. В норме они выводятся системой мононуклеарных фагоцитов. При избыточном формировании иммунных комплексов и их неэффективной элиминации может возникнуть болезнь иммунных комплексов (гиперчувствительность III типа).

Антитела к C1q-фактору приводят к снижению уровня C1q в крови, способствуют образованию иммунных комплексов, которые, в свою очередь, откладываются в тканях и нарушают их функцию. Наличие антител к C1q напрямую связано с болезнью иммунных комплексов (васкулиты, аутоиммунные болезни, заболевания почек).

Нарушение функции комплемента подозревают во всех случаях рецидивирующего отека Квинке, аутоиммунных заболеваний, хронического нефрита или сегментарной липодистрофии, а также при частых гнойных инфекциях, диссеминации менингококковой или гонококковой инфекции и повторной бактериемии у больных любого возраста.

\section{Клеточный компонент эффекторного ответа.}

Не менее важным является оценка клеточного компонента эффекторного ответа. Однако в отличии от гуморального звена иммунитета сделать это достаточно сложно т.к. основное количество клеток иммунной системы 
находятся в тканях и прежде всего в слизистых и коже (барьерные органы). Тем не менее с помощью проточной цитометрии возможно определить даже малые популяции клеток, которые свидетельствуют об активности или недостаточности той или иной популяции клеток.

Для первого этапа топической диагностики возможно использовать

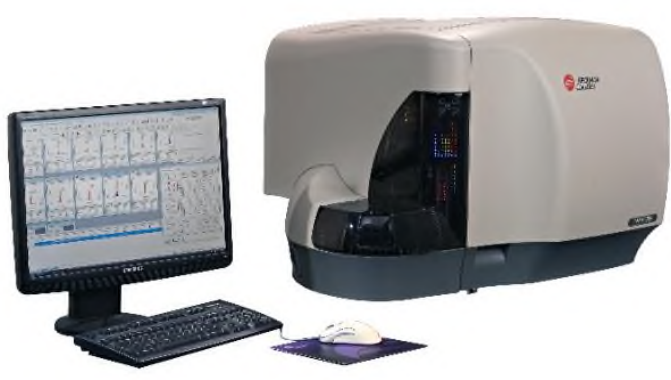

Проточный цитометр Navios (Beckman Coulter, США) стандартизованную технологию

«Исследование субпопуляционного состава лимфоцитов периферической крови с применением проточных цитофлюориметров-анализаторов». (табл. 61).

Таблица 61

Относительное и абсолютное содержание основный популяций лимфоцитов в периферической крови

\begin{tabular}{|c|c|c|}
\hline Популяции и субпопуляции & $\begin{array}{l}\text { Относительное кол-во } \\
\text { позитивных клеток (\%) }\end{array}$ & $\begin{array}{c}\text { Абсолютное кол-во кл/л } \\
\text { (х109) }\end{array}$ \\
\hline Лимфоциты (CD45bright) & $28-36$ & $1,363-2,808$ \\
\hline В-клетки общие (CD3-CD19+) & $7-17$ & $0,111-0,376$ \\
\hline NK-клетки (CD3-CD16+CD56+) & $8-17$ & $0,123-0,369$ \\
\hline Т-клетки общие (CD3+CD19-) & $61-85$ & $0,946-2,079$ \\
\hline Т хелперы (CD3+CD4+) & $35-55$ & $0,576-1,336$ \\
\hline Т цитотоксические (CD3+CD8+) & $19-35$ & $0,372-0,974$ \\
\hline NKT клетки (CD16+CD56+CD3+) & $0,5-6$ & $0,007-0,165$ \\
\hline \multicolumn{3}{|c|}{ Расчетные показатели } \\
\hline Показатель & \multicolumn{2}{|c|}{ Нормативные показатели } \\
\hline Индекс соотношения (Тx/Тц) & \multicolumn{2}{|c|}{$1,5-2,6$} \\
\hline Контрольная сумма (T+B+NK) & \multicolumn{2}{|c|}{$100 \pm 5 \%$} \\
\hline
\end{tabular}

Большое значение при этом принадлежит определению абсолютного числа клеток т.к. именно их снижение или увеличение имеют клиническую значимость. Изменение относительного числа популяций клеток в большей степени свидетельствует о дисбалансе и требует обязательного перерасчета на абсолютное количество.

Особое внимание при проведении иммунофенотипирования следует уделить подсчету контрольных сумм, характеризующих качество и достоверность проведенного исследования. Пожалуй, главной из них является 
сумма Т-, В- и НК-клеток, которая должна находиться в пределах 100\% (100\% $\pm 5 \%)$.

Однако для топической диагностики клеточного звена иммунитета стандартного исследования недостаточно. Используя проточную цитометрию возможно более детально охарактеризовать патологию клеток.

\section{Эффекторные клетки}

Гранулоциты составляют большинство лейкоцитов в периферической крови и преобладают в областях воспаления. Ключевыми клетками в развитии воспаления являются нейтрофилы, которые являются высоко реактивными клетками врожденного иммунитета, способными быстро мобилизоваться в очаг воспаления. За счет широкого спектра рецепторов нейтрофильные гранулоциты являются очень чувствительными клетками к изменению гомеостаза организма.

В клинической практике возможно оценивать эти клетки морфологически (юные, палочко-, сегментоядерные нейтрофилы). Однако используя проточную цитометрию по набору клеточных маркеров возможно оценить функциональную активность и степень зрелости нейтрофилов. Так наличие большого количества нейтрофилов с экспрессией на поверхности $\mathrm{CD} 15$ и $\mathrm{CD} 11 \mathrm{~b}$ свидетельствует о нарушении дифференцировки нейтрофилов, наоборот - CD16, CD64 свидетельствуют об активации нейтрофилов. (рис.166). Снижение
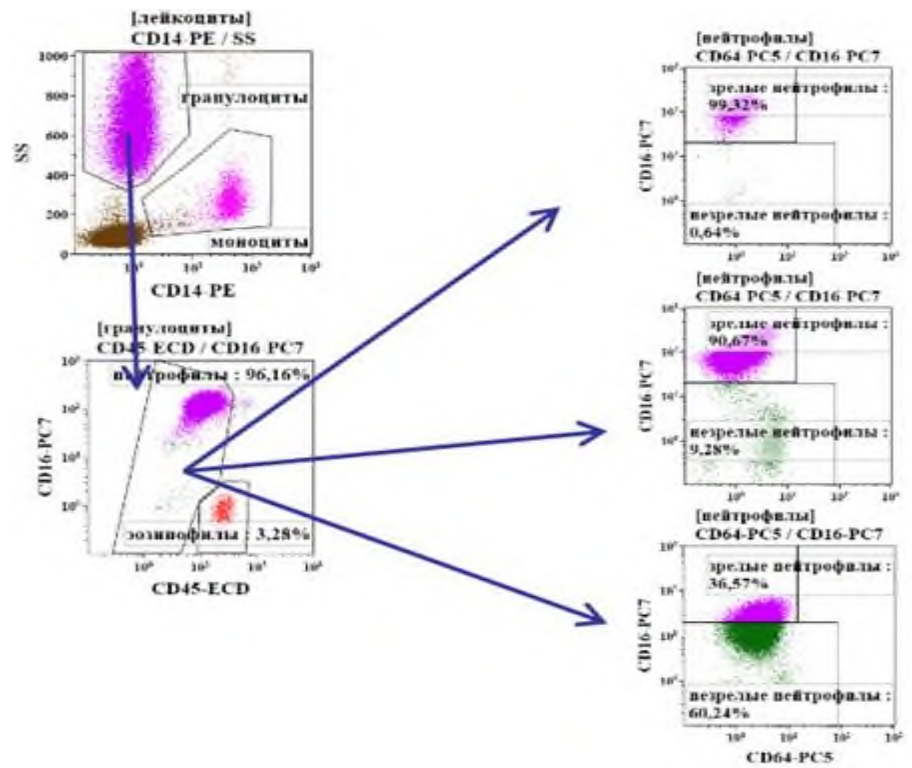

Рис.166. Гранулоциты.

Анализ образов периферической крови проведен на проточном цитометре Navios 3/10 (Beckman Coulter Inc., USA), полученные результаты обработаны при помощи Kaluza Softvare 2.1 (Beckman Coulter Inc., USA). экспрессии CD62L, CD50 позволяют выявить, дефекты миграции. Наличие на нейтрофилах HLA-DR свидетельствует о способности нейтрофилов к презентации АГ.

Количественный анализ базофилов и эозинофилов их клиническое значение описано выше (глава 3). Однако при топической диагностике заболеваний связанных с дегрануляцией базофилов хотелось бы выделить базофильный тест.

Базофильный тест основан на выявлении маркера активации базофилов (CD203) под действием исследуемого аллергена in vitro методом проточной цитофлуориметрии. Исследование проводится в короткие сроки, абсолютно 
безопасен для пациента. В качестве аллергена можно использовать любые вещества в том числе лекарственные средства (наибольшее применение нашли препараты для местной анестезии и контрастные вещества). На настоящий момент базофильный тест является основным тестом клеточной диагностики, используемым для обследования пациентов с аллергическими заболеваниями за рубежом.

\section{Хемилюминесцентный анализ}

Одним из проявлений функциональной активности нейтрофилов является спонтанная и индуцированная люминол- и люцигенин-зависимая хемилюминесценция. Основные нормативные показатели которой представлены в таблице 62 .

Таблица 62

\section{Хемилюминесцентный анализ}

\begin{tabular}{|c|c|c|c|}
\hline Показатель & Ед.изм. & \multicolumn{2}{|c|}{ Нормативный показатель } \\
\hline \multicolumn{4}{|c|}{ Люминол-зависимая хемилюминесценция } \\
\hline & & Спонтанная & Индуцированная \\
\hline Tmax -, & время, сек & $636-1545$ & $814-1526$ \\
\hline Imax - интенсивность & o.e. & $3110-14990$ & $6220-26550$ \\
\hline S - площадь & o.e. & $20857435-160627588$ & $3772475-439100000$ \\
\hline \multicolumn{2}{|l|}{ Индекс активации } & \multicolumn{2}{|c|}{$1,27-2,37$} \\
\hline \multicolumn{4}{|c|}{ Люцигенин-зависимая хемилюминесценция } \\
\hline Tmax -, & время, сек & $941-2881$ & $1389-2331$ \\
\hline Imax - интенсивность & o.e. & $2611-16536$ & $7586-28960$ \\
\hline S - площадь & o.e. & $3950000-41114989$ & $10700771-64610000$ \\
\hline \multicolumn{2}{|l|}{ Индекс активации } & \multicolumn{2}{|c|}{$1,17-3,10$} \\
\hline
\end{tabular}

Натуральные киллеры (NK-клетки). В настоящее время для локализации NK-клеток в периферической крови наиболее широко используют анализ экспрессии CD16 и CD56, конъюгированных с одним и тем же флуорохромом, на CD3-негативных клетках.

Нормативные показатели представлены в таблице 63. Данная комбинация моноклональных антител позволяет локализовать общую популяцию NKклеток количественно, но не охарактеризовать их отдельные субпопуляции. Кроме того, у такого подхода есть чисто практическое значение, позволяющее упростить процедуру идентификации NK-клеток в клинической практике. Как известно, НК-клетки способны индуцировать апоптоз в клетках-мишенях, которые инфицированы вирусами и другими внутриклеточными антигенами, или же являются собственными «перерожденными» опухолевыми клетками, а также другие клетки аллогенного и ксеногенного происхождения (реакции отторжения трансплантата, например). Именно поэтому клиническая 
значимость определения NK-клеток при реакциях врожденного иммунитета, направленных на элиминацию внутриклеточных патогенов, не вызывает сомнений. Так,

увеличение количества NK-

клеток в периферической крови встречается при вирусных заболеваниях, повышается при злокачественных

новообразованиях и лейкозах, в периоде реконвалесценции, в некоторых случаях увеличение фиксируется при бронхиальной астме, может быть связано с Таблица 63

Показатели числа NK-клеток

\begin{tabular}{|c|c|c|}
\hline \multirow{2}{*}{ Возраст } & \multicolumn{2}{|c|}{ Показатель } \\
\cline { 2 - 3 } & CD16/56, \% & CD16/56, абс. \\
\hline 1-3 мес. & $5,2-17,3$ & $319-1142$ \\
\hline 4-12 мес. & $6.2-18.2$ & $381-971$ \\
\hline 1-5 лет & $7,5-19,5$ & $276-896$ \\
\hline 6-8 лет & $10.6-22.4$ & $257-619$ \\
\hline 9-11 лет & $10.6-22.4$ & $257-619$ \\
\hline Старше 12 лет & $9.9-22.9$ & $129-557$ \\
\hline
\end{tabular}
активацией иммунитета после

трансплантаций. Снижение данного показателя наблюдается при различных врожденных иммунодефицитах, паразитарных инфекциях, аутоиммунных заболеваниях, облучении, лечении цитостатиками и кортикостероидами, стрессе, дефиците цинка.

Необходимо отметить, что NK-лимфоциты представляют собой гетерогенную популяцию клеток, и уже при иммунофенотипировании общей фракции NK-клеток по маркерам CD16 и CD56 можно выделить их основных субпопуляций (рис. 167).

CD16 является низкоаффинным рецептором иммуноглобулинов G III типа (FcyRIII), с помощью которого осуществляется механизм клеточной цитотоксичности. Маркер CD56 (NCAM, Leu-19, NKH-1) является гликопротеином, принадлежащим к суперсемейству иммуноглобулинов, и принимает участие в реализации межклеточных контактов. При этом NK-клетки, активно экспрессирующие CD16 и CD56, определяются как зрелые. NK-клетки с фенотипом CD16-CD56+ проявляют цитотоксическую активность. NKклетки с фенотипом

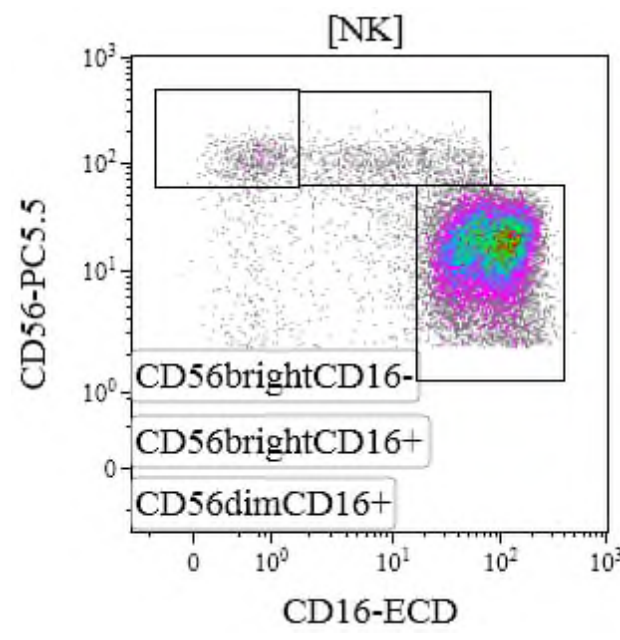

Рис. 167. NK-клетки.

Анализ образов периферической крови проведен на проточном цитометре Cytomics FC500 (Beckman Coulter Inc., USA), полученные результаты обработаны при помощи Kaluza Softvare 2.1 (Beckman Coulter Inc., USA) 
CD16+CD56- в ответ на стимуляцию IL-2 начинают секретировать широкий спектр цитокинов, но проявляют слабую цитолитическую активность (цитокинпродуцирующие клетки).

Важным является определение на этих клетках различных маркеров активации, характеризующие их функциональную активность и/или недостаточность. Среди них важнейшим является выделение субпопуляции цитолитических NK-клеток (обладают цитолитической активностью, но секретируют относительно немного цитокинов) и цитокин-продуцирующих натуральных киллеров (выделяют IFN- $\gamma$ для активации других клеток, но обладают меньшей цитолитической активностью) и NKT-клетки, обладающие большей цитотоксичностью.

Экспрессия различных рецепторов позволяет судить о той или иной функции NK-лимфоцитов (табл.64).

Таблица 64

\section{Основные популяции NK-клеток}

\begin{tabular}{|c|c|c|}
\hline Популяции NK клеток & Маркеры & $\begin{array}{c}\text { Показатель у } \\
\text { здорового человека } \\
\text { (\%) }\end{array}$ \\
\hline Общая популяция & $\begin{array}{l}\text { CD3-CD16/CD56+CD19- } \\
\text { CD3-CD16+CD56+CD19- }\end{array}$ & $9.9-22.9$ \\
\hline Цитотолитические & $\mathrm{CD}^{\mathrm{h}}{ }^{\text {hi }} \mathrm{CD} 56^{\mathrm{dim}}$ & $0,20-0,56$ \\
\hline Цитокинпродуцирующие & CD3-CD16-CD56 ${ }^{\text {bright }}$ CD19- & $0,17-0,53$ \\
\hline NKT клетки & CD3+CD16+CD56+CD19- & $0,5-6,0$ \\
\hline Активированные & CD16/56+CD38+ & $1,52-4,18$ \\
\hline \multirow{2}{*}{ Активно мигрирующие } & CD16/CD56+CD11b+ & \multirow{2}{*}{$0,16-0,47$} \\
\hline & CD16/56+CD62L+ & \\
\hline $\begin{array}{l}\text { Конечно-дифференцированные } \\
\text { NK-клетки }\end{array}$ & CD16/56+CD57+ & $0,21-1,82$ \\
\hline
\end{tabular}

В норме увеличение той или иной субпопуляции клеток свидетельствует о наличии острого воспалительного процесса. При разрешении процесса происходит постепенно снижение показателя до нормального значения. Если количество активированных клеток находится на стабильно повышенном уровне, это может быть признаком хронического воспалительного процесса.

\section{Т-лимфоциты}

Оценка абсолютного и относительного содержания CD3+ Т-лимфоцитов и их субпопуляций в периферической крови осуществляется в диагностике широкого спектра патологических состояний (рис.168). К числу которых, в 
первую очередь, относятся первичные и вторичные иммунодефициты. Патологии связанные с нарушением дифференцировки и созревании Т-клеток (прежде всего лейкозы). Большое значение принадлежит оценке количества Т-лимфоцитов при острых и хронических вирусных инфекциях, включая ВИЧинфекцию и хронические вирусные гепатиты.Более того, определение уровня Тлимфоцитов в периферической крови показало свою значимость при анализе образцов, полученных от пациентов с различными внутриклеточными инфекционными заболеваниями (например, при и нфицировании M.tuberculosis, M.lepra или

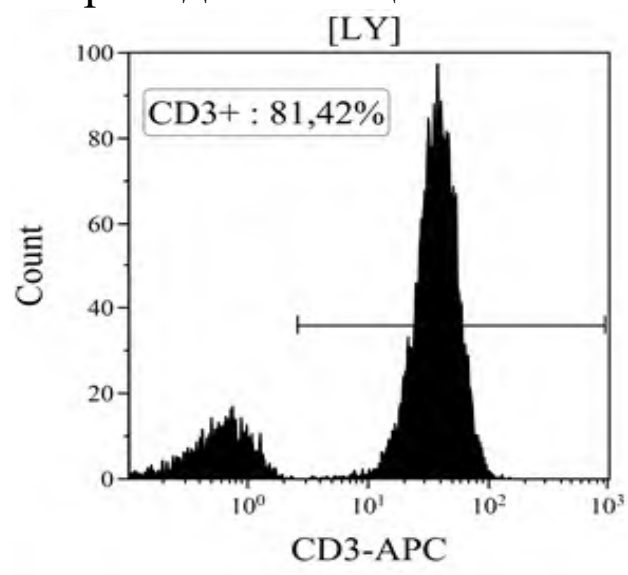

Рис.168 Определение общего количества Т-лимфоцитов.

Анализ образов периферической крови проведен на проточном цитометре Navios 3/10 (Beckman Coulter Inc., USA), полученные результаты обработаны при помощи Kaluza Softvare 2.1 (Beckman Coulter Inc., USA).

Leishmania spp.), при септических состояниях, диагностике отторжения пересаженного трансплантата, реакции "трансплантат-против-хозяина" и при другой патологии.

Традиционно, абсолютное число Т-лимфоцитов в периферической крови (табл.65) трактуется как свидетельство «гиперактивности» иммунной системы пациента, которое может быть тесно связано с различными Т-клеточными

Таблица 65

Показатели числа Т-лимфоцитов

\begin{tabular}{|c|c|c|}
\hline \multirow{2}{*}{ Возраст } & \multicolumn{2}{|c|}{ Показатель } \\
\cline { 2 - 3 } & CD3, \% & CD3, абс. \\
\hline 1-3 мес. & $55-78$ & $2070-6540$ \\
\hline 4-12 мес. & $45-79$ & $2280-6450$ \\
\hline 12-24 мес. & $53-81$ & $1460-5440$ \\
\hline 2-5 лет & $62-80$ & $1610-4230$ \\
\hline старше 6 лет & $66-76$ & $1400-2000$ \\
\hline
\end{tabular}

лимфомами или лейкозами. Тогда как увеличение относительного содержания этих клеток имеет место при некоторых вирусных и бактериальных инфекциях в дебюте заболевания, а также при обострениях хронических заболеваний. Снижение количества Т-лимфоцитов рассматривается как «недостаточность» реакций

специфического клеточного иммунитета и обнаруживается при воспалительных процессах разнообразной этиологии, злокачественных новообразованиях, после травмы, операций, инфаркта, приеме цитостатиков. Повышение их числа в динамике заболевания или на фоне проведения соответствующей терапии принято рассматривать в качестве клинически благоприятного признака.

Важным и одним из основных методов исследования Т-лимфоцитов является диагностика при исследовании первичных иммунодефицитов. При 
ТКИД, синдром Ди-Джорджи, синдром «голых лимфоцитов», X-сцепленный лимфопролиферативный синдром, синдром Вискотта-Олдрича происходит значительное снижение Т-лимфоцитов.

Популяции Т-лимфоцитов состоит из различных субпопуляций. С клинической точки зрения важным является выделение эффекторных (цитотоксические и Түб- лимфоциты) и регуляторных (Т-хелперы и Treg) клетки.

Цитотоксические Т-лимфоциты основные клетки адаптивного иммунитета (табл.66). Определение уровня Т-цитотоксических лимфоцитов с фенотипом $\mathrm{CD} 3+\mathrm{CD} 8+$ в периферической крови показало свою клиническую значимость при выявлении первичных иммунодефицитных состояниях, диагностике пациентов с различными вирусными инфекциями, при опухолевом росте и метастазировании, а также имеет важнейшее значение при исследовании специфической иммунологической памяти (оценка эффективности вакцинации). Так, повышение выявляется практически при всех хронических инфекциях, вирусных, бактериальных, протозойных инфекциях. Является характерным для начале ВИЧТаблица 66 Показатели числа ЦТЛ

\begin{tabular}{|c|c|c|}
\hline \multirow{2}{*}{ Возраст } & \multicolumn{2}{|c|}{ Показатель } \\
\cline { 2 - 3 } & CD3+CD8+, \% & CD3+CD8+, абс. \\
\hline $1-3$ мес. & $16-35$ & $650-2450$ \\
\hline $4-12$ мес. & $16-34$ & $720-2490$ \\
\hline $12-24$ мес. & $16-38$ & $570-2230$ \\
\hline $2-5$ лет & $22-38$ & $630-1910$ \\
\hline Старше 6 лет & $27-35$ & $600-900$ \\
\hline
\end{tabular}
инфекции. Снижение же уровня

CD3+CD8+ клеток в периферической крови может свидетельствовать о вирусных гепатитах, хронической герпес-вирусной инфекции, некоторых типах аутоиммунных заболеваниях.

Увеличение CD3+CD8+ обычно связано с ВИЧ-инфекцией, острыми вирусными инфекциями, парапротеинемиями, малярией, при дебюте аутоиммунных заболеваний, множественной миеломе, хроническом вирусном гепатите, сепсисе, перитоните, гемофилии, шистосомозе, инфекционном мононуклеоз, абсцесс легкого, почки. Уменьшение при первичные иммунодефицитах (ТКИД, синдром Ди-Джорджи, синдром «голых лимфоцитов», Х-сцепленный лимфопролиферативный синдром, синдром Вискотта-Олдрича) вирусных инфекциях (герпес-вирусные инфекци (ВГ 1-2, 3 тип, ЦМВ, ВЭБ-инфекции), облучении, отравление диоксинами. Для Тхелперов, находящихся на терминальных стадиях дифференцировки, также характерно появление CD8 (обычно $\alpha \alpha$ гомодимера) на поверхностной мембране. CD8 может обнаруживаться на поверхности Т-клеток, несущих $\gamma \delta$-Tклеточный рецептор, а также на «инвариантных» НКТ-клетках. Способностью к экспрессии $\alpha \alpha \mathrm{CD} 8$ обладают некоторые популяции НК-клеток. 
Важное значение принадлежит в определении стадии дифференцировки цитотоксических Тлимфоцитов и определении на их поверхности активационных маркеров. В стадии дифференцировки CTL можно выделит: наивные CTL (Naïve), CTL центральной памяти (CM), CTL эффекторной памяти (EM) и дифференцированные клетки памяти CTL (TEMRA) (рис.169). Определение клеток с этими маркерами позволяют определить нарушение дифференцировки и могут быть единственным подтверждением причины развития того или иного патологического процесса.

По наличию тех или иных маркеров можно охарактеризовать функциональную активность клеток. Так CD3+CD4CD8+CD25 CTL клетки с ранним маркером активации, CD3+CD4-CD8+CD38 с метаболическим маркером активации, CD3+CD4-CD8+CD11b и CD3+CD4CD8+CD62L - активно мигрирующие CTL, CD3+CD4-CD8+CD297(PD1) конечно дифференцированные CTL. B недалёком бедующем появятся нормативные показатели и для этих субпопуляций клеток, но уже в настоящее время при отсутствии данных параметров можно определить причину развития той или иной иммунопатологии. Итоговые основные популяции ЦТЛ их активационных маркеров и нормативные показатели представлены в таблице (табл.67).

Таблица 67

Основные популяции цитотоксических Т-лимфоцитов (\% от CD3+CD8+ клеток)

\begin{tabular}{|c|c|c|c|}
\hline \multirow[t]{2}{*}{ Популяция } & \multirow[t]{2}{*}{ Маркеры } & \multicolumn{2}{|c|}{$\begin{array}{c}\text { Показатель у здорового } \\
\text { человека }\end{array}$} \\
\hline & & $\%$ & абс. \\
\hline Наивные CTL & $\mathrm{CD} 3+\mathrm{CD} 8+\mathrm{CD} 45 \mathrm{RA}+\mathrm{CD} 62 \mathrm{~L}+$ & $2.0-18,0$ & $40-350$ \\
\hline CTL центральной памяти & CD3+CD8+CD45RA-CD62L+ & $1,0-8,0$ & $25-150$ \\
\hline CTL эффекторной памяти & CD3+CD8+CD45RA-CD62L- & $3,0-12,0$ & $50-220$ \\
\hline $\begin{array}{l}\text { Терминально дифференцир- } \\
\text { ованные клетки памяти CTL }\end{array}$ & CD3+CD8+CD45RA+CD62L- & $2,0-20,0$ & $40-300$ \\
\hline Активированные & CD8/HLA-DR & $5,0-25,0$ & $30-180$ \\
\hline $\begin{array}{l}\text { Имеющие костимулиру-ющий } \\
\text { фактор }\end{array}$ & $\mathrm{CD} 3+\mathrm{CD} 4-\mathrm{CD} 8+\mathrm{CD} 28$ & $9,5-26,0$ & $120-600$ \\
\hline $\begin{array}{l}\text { Конечно- } \\
\text { дифференцированные }\end{array}$ & $\mathrm{CD} 3+\mathrm{CD} 4-\mathrm{CD} 8+\mathrm{CD} 57$ & менее 30 & менее 520 \\
\hline
\end{tabular}




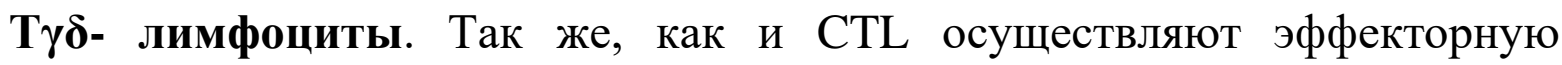
функцию, напрямую используя рецепторный аппарат так и с использованием АТ. Они выделяют большое количество провоспалительных цитокинов. Некоторые клетки выполняют функции АПК.

В отличии от основной Т-клеточной популяции экспрессирующей $\alpha \beta \mathrm{CD} 3$ рецепторов на них представлен $\gamma \delta$-рецептор. Отличительной чертой этих клеток является отсутствие на поверхности CD4 и CD8, что позволяет предварительно оценить количество Т $\gamma \delta$ - лимфоцитов в крови. Помимо лейкоцитарного маркера CD45, как функциональные маркеры T $\gamma \delta$ - лимфоциты имеют рецепторы CD16 (к Fc-фрагменту антител), CD92L (запускает апоптоз клетки мишени), CD282 (TLR2), CD204 (скавенджер-рецепторы). На части клеток помимо МНC I продуцируются и МНC II класса.

Увеличение циркуляции субпопуляции Т $\gamma \delta$-клеток позволяет предположить наличие стимуляции иммунной системы, особенно на слизистых оболочках и коже. В острую фазу воспаления их количество в периферической крови может увеличится в разы. При медленно прогрессирующих инфекционных заболеваниях увеличение Т $\gamma \delta$ - лимфоцитов может служить дополнительным критерием активности процесса.

В настоящее время нормативных показателей для этих субпопуляций клеток нет, но по количеству клеток с той или иной функцией можно охарактеризовать функциональную активность Т $\gamma \delta$ - лимфоцитов, определить роль этих клеток, например в процессах антигенпрезентации, эффекторных функций и/или процессах регенерации.

\section{В-лимфоциты.}

Выявление В-лимфоцитов производится на основании экспрессии CD19. CD19 является важнейшим компонентом рецепторного аппарата В-клеток, без которого функционирование данной популяции лимфоцитов невозможно (рис.170).

Экспрессия CD19 обнаруживается со стадии про-В-клетки и сохраняется на протяжении всей жизни Влимфоцита, несколько снижаясь лишь на плазматических клетках. Более того, этот антиген рассматривается в качестве «линейного» маркера всех Влимфоцитов. Его экспрессия может быть обнаружена в некотором количестве на фолликулярных дендритных клетках, относительное содержание которых в периферической крови крайне низко. В-лимфоциты

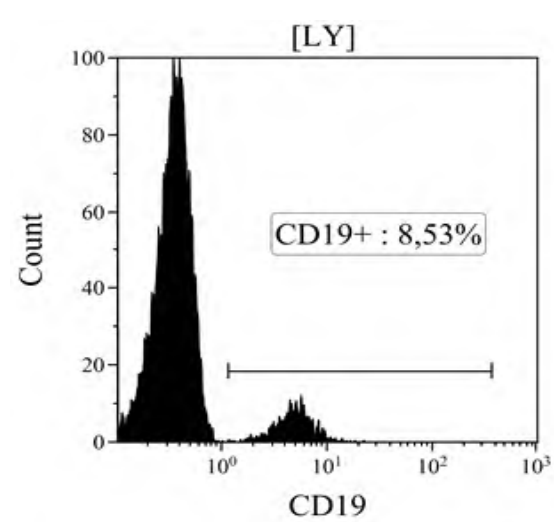

Рис. 170. Определение общего количества В-лимфоцитов. Анализ образов периферической крови проведен на проточном цитометре Navios 3/10 (Beckman Coulter Inc., USA), полученные результаты обработаны при помощи Kaluza Softvare 2.1 (Beckman Coulter Inc., USA 
играют ведущую роль в формировании эффективно функционирующего специфического гуморального иммунитета, благодаря своей способности дифференцироваться в плазматические клетки и формированию долгоживущих клеток иммунологической памяти. Поэтому клиническая значимость определения уровня CD19+ лимфоцитов в циркулирующей крови показано при широком круге патологических состояний (табл.68).

Таблица 68

\section{Показатели числа В-клеток}

\begin{tabular}{|c|c|c|}
\hline \multirow{2}{*}{ Возраст } & \multicolumn{2}{|c|}{ Показатель } \\
\cline { 2 - 3 } & $\mathrm{CD} 19, \%$ & СD19+, абс. \\
\hline $\mathbf{1 - 3}$ мес. & $6-31$ & $300-2000$ \\
\hline $\mathbf{4 - 1 2}$ мес. & $11-41$ & $430-3000$ \\
\hline $\mathbf{1 2 - 2 4}$ мес. & $16-35$ & $720-2600$ \\
\hline $\mathbf{2 - 5}$ лет. & $14-33$ & $390-1400$ \\
\hline $\mathbf{6 - 1 2}$ лет. & $13-27$ & $270-860$ \\
\hline Старше 12 лет. & $10-22$ & $300-570$ \\
\hline
\end{tabular}

В первую очередь, определение В-клеток важно при диагностике первичных иммунодефицитов, связанных с наличием агаммаглобулинемии и дисгаммаглобулинемии. Данный показатель необходим при скрининге и выявлении системных патологических аутоиммунных связанных с наличием высокого титра аутореактивных

антител в сыворотке крови. Кроме того, анализ содержания В-лимфоцитов в периферической крови значим при инфекционных бактериальных заболеваниях и паразитарных инвазиях; злокачественных новообразования, связанных с неконтролируемым делением клонов В-лимфоцитов (лимфолейкозы, лимфомы, миеломная болезнь и т.д.). Увеличение доли этих клеток в рамках лимфоцитарного пула отмечается при некоторых аутоиммунных заболеваниях, хронических заболеваниях печени, паразитарных и грибковых инфекциях.

Важными показателями являются стадия дифференцировки и активационные маркеры В-лимфоцитов, а также идентификация в периферической крови В1-клеток (табл.69).

Окраска антителами против $\operatorname{IgD}$ и $\mathrm{CD} 38$ позволяет идентифицировать следующие популяции В-клеток: “наивные" Bm1 клетки с фенотипом IgD+CD38-, “активированные наивные” Bm2 клетки (IgD+CD38+), Bm2' клетки-предшественники В-клеток герминального центра ( $\operatorname{lgD}+\mathrm{CD} 38++)$, общая субпопуляция, включающая в себя центробласты и центроциты - так называемые "Bm3+Bm4" клетки (IgD-CD38++), клетки ранней памяти eBm5 (IgD-CD38+) и покоящиеся клетки памяти $\mathrm{Bm} 5$ (IgD-CD38-). Окраска антителами против поверхностных молекул IgD и $\mathrm{CD} 27$ позволяет отделить группу «наивных» клеток с фенотипом IgD+CD27- от трех разновидностей клеток памяти - клетки памяти с непереключенным классом синтезируемых антител ("unswitched" IgD+CD27+), клетки памяти с переключенным классом синтезируемых антител ("class-switched" memory cells, IgD-CD27+) и так называемые «дважды-негативные» клетки памяти (IgD-CD27-). 
Таблица 69

Основные субпопуляции В-клеток (\% от В-клеток)

\begin{tabular}{|c|c|c|}
\hline Популяция & Маркеры & $\begin{array}{c}\text { Показатель у здорового } \\
\text { человека }\end{array}$ \\
\hline В1 - лимфоциты & CD19+CD5+ & $8,0-16,0$ \\
\hline В2 лимфоциты & CD19+CD5- & $78,0-90,0$ \\
\hline В-клетки памяти & CD19+CD27+CD5- & $20,0-40,0$ \\
\hline Наивные В-лимфоциты & CD19+CD27-CD5- & $40,0-65,0$ \\
\hline «naïve» & CD19+ (CD27-lgD+) & $50,0-75,0$ \\
\hline «unsw memory» & CD19+ (CD27+lgD+) & $8,0-20,0$ \\
\hline «sw memory» & CD19+ (CD27+lgD-) & $11,0-22,0$ \\
\hline «DN» & CD19+ (CD27-IgD-) & $2,0-6,0$ \\
\hline “наивные” Bm1 клетки & CD19+ IgD+CD38- & $7,0-16,0$ \\
\hline Bm2 клетки & CD19+ IgD+CD38+ & $45,0-70,0$ \\
\hline Bm2' клетки & CD19+ IgD+CD38++ & $4,0-10,0$ \\
\hline “Bm3+Bm4” клетки & CD19+ IgD-CD38++ & $0,5-1,5$ \\
\hline eBm5 клетки & CD19+ IgD-CD38+ & $8,0-17,0$ \\
\hline Bm5 клетки & CD19+ IgD-CD38- & $5,0-12,0$ \\
\hline
\end{tabular}

\section{Антиген презентующие клетки.}

Функция АПК клеток описана нами выше (см. главы 3). В периферической крови их достаточно мало и основным представителем здесь являются моноциты (рис.171).

Среди моноцитов (линейным маркером которых долгое время считался CD14) по экспрессии CD16 можно выявить ряд популяций. Популяция «классических» моноцитов CD16 не несет (на них обнаруживается только $\mathrm{CD} 14$, их фенотип описывается как $\mathrm{CD} 14^{++} \mathrm{CD} 16^{-}$), в то время как моноциты «неклассической» и «переходной» популяций $\mathrm{CD} 16 \quad$ экспрессируют (фенотипы $\mathrm{CD} 14^{+} \mathrm{CD} 16^{++}$и $\mathrm{CD} 14^{++} \mathrm{CD} 16^{+}$, соответственно). Основная функция классических моноцитов, как и макрофагов, фагоцитоз апоптотических телец. За счет низкой экспрессией HLA-DR, они слабо

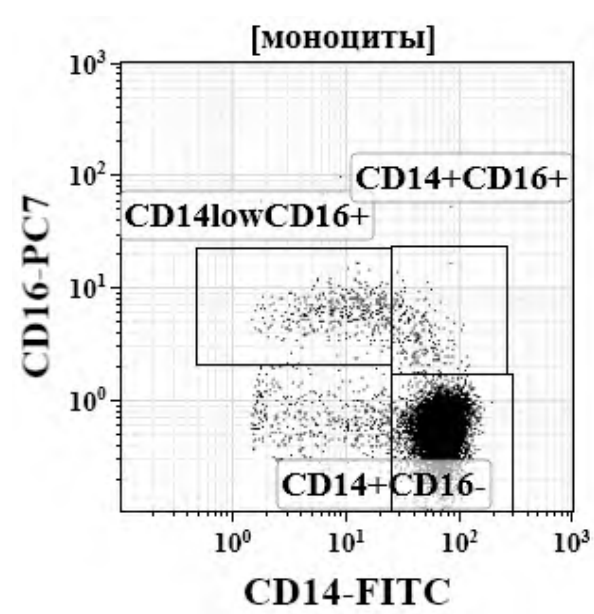

Рис. 171. Основные популяции моноцитов

Анализ образов периферической крови проведен на проточном цитометре Navios 3/10 (Beckman Coulter Inc., USA), полученные результаты обработаны при помощи Kaluza Softvare 2.1 (Beckman Coulter Inc., USA). 
выполняют функцию антигенпрезентации. Наоборот, неклассические моноциты слабо фагоцитируют апоптотические клетки, но за счет экспрессии большого количества HLA-DR и костимуляторных молекул они активно выполняют функцию антигенпрезентации и продукции провоспалительных цитокинов. Переходные моноциты образуются в результате активации и дифференцировки классических моноцитов. Их основные функции: распознавание РАМР и синтез цитокинов (как провоспалительных-TNF $\alpha$, IL- $1 \beta$, так и противовоспалительных IL-10), IgG-опосредованный фагоцитоз, антигенпрезентация.

Одним из важнейших клинических критериев в диагностике прежде всего критических состояний принадлежит определению HLA-DR на моноцитах. Значительное снижение экспрессии HLA-DR может служить тестом для идентификации временной иммунодепрессии и коррелирует с неблагоприятным исходом при сепсисе, травме, панкреатите, при осложнениях в сердечно-легочной хирургии, после трансплантации у пациентов после удаления опухоли. Резкое снижение HLA-DR на моноцитах может служить показателем для применения более раннего терапевтического вмешательства с использованием IFN $\gamma$, растворов, обогащенных глютамином и мурамилсодержащие гликопептиды, чтобы стимулировать иммунную систему и в первую очередь антигенпрезентирующую функцию моноцитов.

Нормативные показатели моноцитов представлены в таблице (табл.70). В настоящее время используя проточную цитометрию возможно оценить и другие функции моноцитов такие как миграционная активность $(\mathrm{CD} 11 \mathrm{~b}+$, $\mathrm{CD} 62 \mathrm{~L}+)$, метаболические свойства (CD38+, CD184+), костимуляторные возможности ( $\mathrm{CD} 80+, \mathrm{CD} 86+$ ), однако нормативные показатели и их клиническая интерпретация пока не описаны.

Таблица 70

Основные показатели моноцитов (\% от моноцитов)

\begin{tabular}{|l|l|c|}
\hline \multicolumn{1}{|c|}{ Популяция } & \multicolumn{1}{|c|}{ Маркеры } & $\begin{array}{c}\text { Показатель у здорового } \\
\text { человека }\end{array}$ \\
\hline $\begin{array}{l}\text { Общий пул моноцитов } \\
\text { (абс.) }\end{array}$ & CD14+ & $0.18-0.51$ \\
\hline Классические & CD14+CD16- & $42.3-72.3$ \\
\hline Переходные & CD14++CD16+ & $16.2-52.2$ \\
\hline Неклассические & CD14/ ${ }^{\text {क्w CD16+ }}$ & $4.1-11.1$ \\
\hline Дендритные клетки & CD3-/CD19-/CD16/56-/CD45+ & $0-2,0$ \\
\hline $\begin{array}{l}\text { Антиген-презентующие } \\
\text { моноциты }\end{array}$ & CD14+HLA-DR+ & $84.5-95.8$ \\
\hline
\end{tabular}




\section{Регуляторные клетки.}

Большая популяция клеток врожденного и адаптивного иммунитета. Некоторые клетки (цитокинпродуцирующие NK-клетки, миелоидные супрессорные клетки) описаны нами выше. Некоторые клетки в практике идентифицировать практически невозможно. Основной популяцией регулирующие большинство этапов иммунного ответа являются Т-хелперы и Трегуляторные лимфоциты.

T-хелперы. CD4 представлен на поверхности отдельной субпопуляции Тлимфоцитов, получивших название Т-хелперов и обладающих фенотипом CD3+CD4+, то есть клетки, экспрессирующие эти две молекулы одновременно. В ходе развития Т-лимфоцитов CD4 обнаруживается в тимусе, начиная со стадии DP, после чего сохраняется на T-хелперах до терминальных стадий дифференцировки. CD4 обнаружен на мембране моноцитов, макрофагов и некоторых популяций дендритных клеток. Именно поэтому для корректного выделения Т-хелперных клеток в рамках проведения иммунофенотипирования необходимо оценивать ко-экспрессию CD3 и CD4, чтобы избежать контаминации данной популяции Т-лимфоцитов другими клетками периферической крови. Клинические нормативы числа Т-хелперов представлены в таблице (табл.71).

Определение содержания Таблица 71

CD4+ Т-клеток отводится решающая роль при прогнозе течения ВИЧ-инфекции и эффективности проведения антиретровирусной терапии. Кроме того, изменения уровня Т-хелперов значимо при выявлении врожденных и приобретенных

иммунодефицитных состояниях, связанных с нарушениями реакций клеточного иммунитета и дефектами продукции антител при специфическом гуморальном ответе, опосредованном В-лимфоцитами. Так, увеличение абсолютного и относительного содержания CD3+CD4+ периферической крови тесно связано с наличием аутоиммунных заболеваний, может быть иметь место при некоторых типах аллергических реакциях и инфекционных процессах. Тогда как снижение абсолютного и относительного уровня Т-хелперов в циркуляции указывает на «гипореактивный» синдром с нарушением регуляторного звена иммунитета, а также встречается при различных хронических заболеваниях (бронхитах, пневмониях и т.д.), опухолевом росте (в первую очередь, при солидных опухолях различной локализации). 
По наличию на Т-хелперов различных хемокинов рецепторов можно определить их субпопуляцию (табл. 72). Более подробно популяции этих клеток мы описывали выше (глава 7). Сопоставляя клинические проявления с нормативными показателями различных популяций клеток возможно оценить течение инфекций.

Большое значение принадлежит определению стадии дифференцировки Т-хелперов (табл.73).

Таблица 72

\section{Основные популяции Т-хелперов (\% от CD3+CD4+ клеток)}

\begin{tabular}{|l|l|c|}
\hline \multicolumn{1}{|c|}{ Популяция } & \multicolumn{1}{|c|}{ Маркеры, фенотип } & $\begin{array}{c}\text { Показатель у здорового } \\
\text { человека }\end{array}$ \\
\hline Th0 & CXCR5-CXCR3-CCR6-CCR4- & $34-49$ \\
\hline Th1 & CXCR5-CXCR3+CCR6-CCR4+ & $10-15$ \\
\hline Th2 & CXCR5-CXCR3-CCR6-CCR4+ & $4-7$ \\
\hline 06щий пул Th17: & CXCR5-CCR6+ & $19-29$ \\
\hline - классические Th17 & CXCR5-CXCR3-CCR6+CCR4+ & $6-9$ \\
\hline - DN Th17 & CXCR5-CXCR3-CCR6+CCR4- & $1-2$ \\
\hline - DP Th17 & CXCR5-CXCR3+CCR6+CCR4+ & $4-7$ \\
\hline - Th17.1 & CXCR5-CXCR3+CCR6+CCR4- & $6-10$ \\
\hline O6щий пул Tfh: & CXCR5+ & $7-12$ \\
\hline - Tfh1 & CXCR5+CXCR3+CCR6- & $2-4$ \\
\hline - Tfh2 & CXCR5+CXCR3-CCR6- & $1-3$ \\
\hline - Tfh17 & CXCR5+CXCR3-CCR6+ & $2-4$ \\
\hline - DP Tfh & CXCR5+CXCR3+CCR6+ & $1-2$ \\
\hline
\end{tabular}

Таблица 73

Основные показатели Т-хелперов

\begin{tabular}{|l|l|c|c|}
\hline \multicolumn{1}{|c|}{ Популяция } & \multicolumn{1}{c|}{ Маркеры } & $\begin{array}{c}\text { Показатель у здорового } \\
\text { человека }\end{array}$ \\
\hline & & $44-53$ & $670-1050$ \\
\hline Общее количество Th & CD3+CD4+CD8- & $12-19$ & $190-325$ \\
\hline Наивные Th & CD3+CD4+CD45RA+CD62L+ & $16-23$ & $260-470$ \\
\hline Th центральной памяти & CD3+CD4+CD45RA-CD62L+ & $9-13$ & $130-240$ \\
\hline Th эффекторной памяти & CD3+CD4+CD45RA-CD62L- & $1-2$ & $3-15$ \\
\hline $\begin{array}{l}\text { Терминально } \\
\text { дифференцированные Th }\end{array}$ & CD3+CD4+CD45RA+CD62L- & \\
\hline
\end{tabular}

Не потеряло свое значение анализ соотношения CD4/CD8. Соотношение субпопуляций Т-хелперов и цитотоксических Т-клеток (также известное под устаревшим названием «иммунорегуляторный» индекс) является расчетным показателем, получаемым в результате деления величины относительного (или 
абсолютного) содержания $\mathrm{CD} 3+\mathrm{CD} 4+$ клеток на аналогичное значение CD3+CD8+ клеток (рис.172).

В норме это значение находится в пределах 1,5-2,6, тогда как при ряде патологических состояний, связанных с нарушениями в функционировании клеточных механизмов приобретенного иммунитета, эта величина существенно изменяется. Классическим примером является сниженное соотношение CD4/CD8

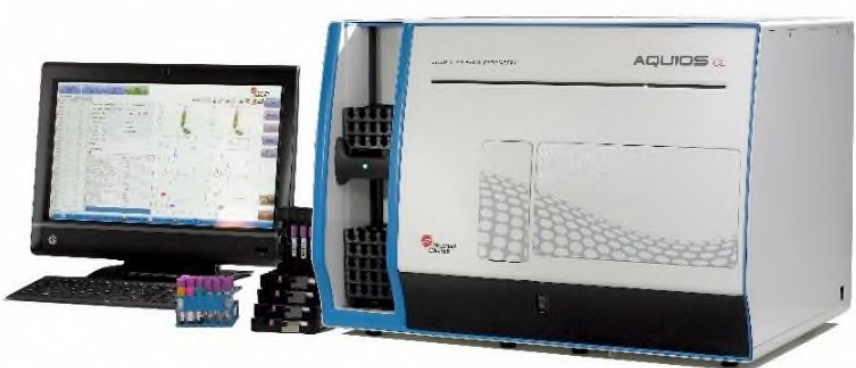

Полностью автоматический проточный цитометр AQUIOS CL (Beckman Coulter, США) при ВИЧ-инфекции (см. рис.172. На гистограммах приведены результаты анализа распределения клеток по экспрессии CD4 (ось абсцисс) и CD8 (ось ординат) в рамках популяции Т-лимфоцитов. У условно здорового донора CD4/CD8 составляет 2,09 $(62,17 / 29,68=2,09)$, тогда как у пациента с ВИЧ инфекцией $-0,55(31,87 / 58,29=0,55)$. В целом, устойчиво низкое соотношение CD4/CD8 в течение длительного применения антиретровирусной терапии является маркером нарушений в функционировании иммунной системы, наличия хронического воспалительного процесса, а также высокого риска заболеваемости «сопутствующими» инфекциями, и, как следствие, повышенной вероятности летального исхода.
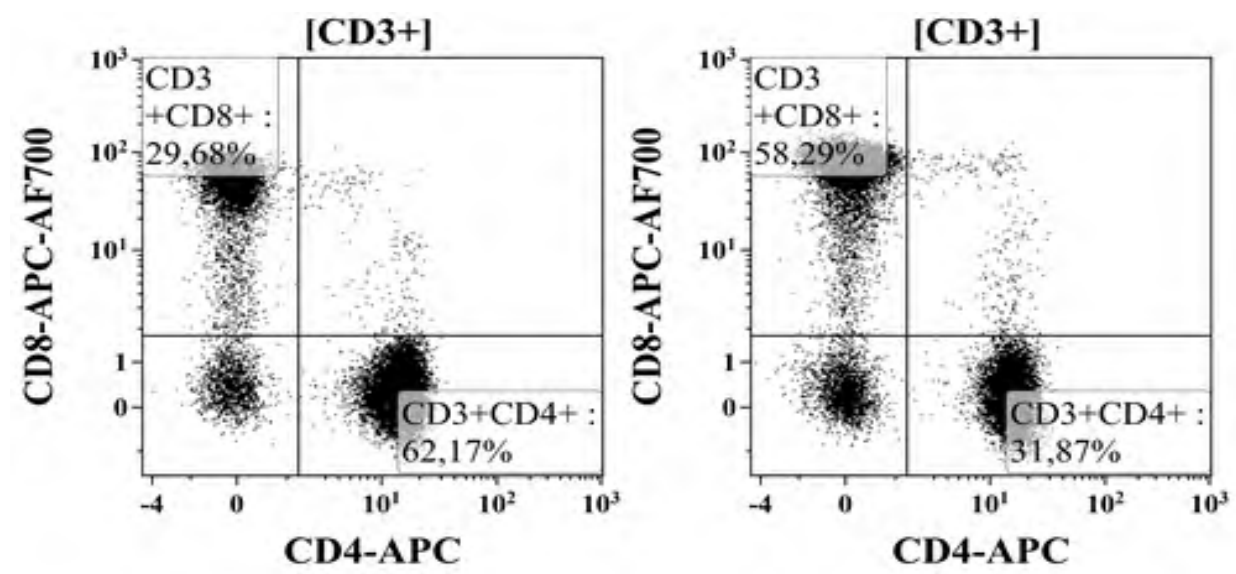

Рис. 172. Анализ соотношения CD4/CD8 в норме (гистограмма слева) и при ВИЧ-инфекции (гистограмма справа).

Анализ образов периферической крови проведен на проточном цитометре Navios 3/10 (Beckman Coulter Inc., USA), полученные результаты обработаны при помощи Kaluza Softvare 2.1 (Beckman Coulter Inc., USA 
Однако, снижение соотношения $\mathrm{CD} 4 / \mathrm{CD} 8$ наблюдается и при врожденных иммунодефицитах (синдром Ди-Джоржи, Незелофа, ВискоттаОлдрича), при других вирусных и бактериальных инфекциях, хронических процессах, воздействии радиации и токсических химических веществ, множественной миеломе, стрессе, снижается с возрастом, при эндокринных заболеваниях, солидных опухолях. Увеличение соотношения CD4/CD8 более трех - отмечается при широком круге аутоиммунных заболеваний, остром Тлимфобластном лейкозе, тимоме, хроническом Т-клеточном лейкозе.

T-регуляторные лимфоциты (Treg) - это отдельная популяция Tхелперов способная подавлять развитие иммунного ответа. В настоящее время используя тактику «гейтирования», основанная на оценке CD25 и CD 127, возможно эффективно выделять Treg в периферической крови (рис.173).

Увеличение содержания Treg определяется у больных с различными видами опухолей и связан с прогрессированием опухолевого роста. Более того, уровень этих клеток в циркуляции и в окружающих опухоль тканях оказался значимым для прогноза течения заболевания и эффективности применяемой терапии. Существенную роль Treg играют в подавлении иммунного ответа при инфекциях число которых значительно повышается. При сепсисе увеличение уровня этих клеток напрямую связано с неблагоприятным течением данного заболевания. С другой стороны, у больных с различными аутоиммунными патологическими состояниями изменялась функциональная активность Treg, что вызывало нарушение толерантности к собственным антигенам организма.

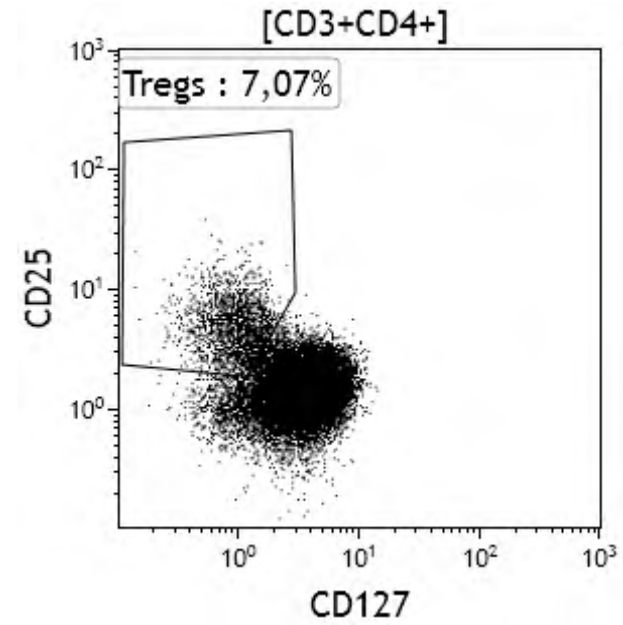

Рис. 173. Идентификация Т-регуляторных клеток.

Анализ образов периферической крови проведен на проточном цитометре Navios 3/10 (Beckman Coulter Inc., USA), полученные результаты обработаны при помощи Kaluza Softvare 2.1 (Beckman Coulter Inc., USA).

Однако подобные закономерности не всегда выполняются, что указывает на то, что в развитии патологических процессов Treg имеют важное, но не единственное значение. Этим и обусловлена важность проведения топической диагностики. В этой связи интересно определение других показателей Трегуляторных клеток (табл.74). 
Основные показатели Т-регуляторных клеток

\begin{tabular}{|l|l|c|c|}
\hline \multicolumn{1}{|c|}{ Популяция } & \multicolumn{1}{c|}{ Маркеры } & \multicolumn{2}{c|}{ Показатель у здорового } \\
человека
\end{tabular}

\section{Цитокины}

Основными регуляторными молекулами иммунной системы являются цитокины. Как мы отмечали выше у здоровых людей концентрация цитокинов в периферической крови ничтожно мала и обычно не определяются т.к. их выработка и действие осуществляется местно, локально. Однако при развитии патологического процесса при несостоятельности местных защитных реакций синтез прежде всего провоспалительных цитокинов возрастает в разы, что может служить эффективным биомаркером (табл.75).

Таблица 75

Нормативные значение цитокинов в клинических ситуациях

\begin{tabular}{|c|c|c|}
\hline Показатель & $\begin{array}{c}\text { Референсные } \\
\text { значения }\end{array}$ & Клинические ситуации, связанные с повышением \\
\hline $\begin{array}{l}\text { Интерлейкин } 1 \\
\text { бета }\end{array}$ & < 5 пг/мл & $\begin{array}{l}\text { Воспалительные заболевания и бактериальные инфекции: } \\
\text { пневмокониоз, туберкулёз, саркоидоз; септический шок, } \\
\text { аутоиммунные заболевания, множественная травма; отторжение } \\
\text { почечного трансплантата; угроза прерывания беременности; спИД; } \\
\text { острый и хронический миелолейкоз, ДВС-синдром. }\end{array}$ \\
\hline Интерлейкин 6 & $<7,0$ пг/мл & $\begin{array}{l}\text { Тяжёлые воспалительные процессы, инфекции и травмы; } \\
\text { аутоиммунные заболевания; саркома Капоши; алкогольный цирроз; } \\
\text { лимфома, миелома и карцинома почек; обострение язвенной } \\
\text { болезни желудка и 12-перстной кишки; панкреатит; глютеновая } \\
\text { энтеропатия. }\end{array}$ \\
\hline Интерлейкин 8 & < 62 пг/мл & $\begin{array}{l}\text { Воспалительные заболевания лёгких; бактериальные инфекции (в } \\
\text { том числе менингококковая); септический шок; аутоиммунные } \\
\text { болезни; опухоли; алкогольный гепатит; хроническое воспаление; } \\
\text { псориаз; инфаркт миокарда (острая фаза). }\end{array}$ \\
\hline Интерлейкин 10 & $<$ 9,1 пг/мл & $\begin{array}{l}\text { Неходжкинская лимфома; хроническая почечная недостаточность; } \\
\text { злокачественные опухоли. } \\
\text { Снижается при отторжение почечного трансплантата; инсульт } \\
\text { (неблагоприятное течение). }\end{array}$ \\
\hline $\begin{array}{l}\text { Фактор некроза } \\
\text { опухоли }\end{array}$ & $<-8,1$ пг/мл & $\begin{array}{l}\text { ДВС-синдром; сепсис; инфекционные заболевания (особенно, } \\
\text { инфекционный эндокардит, рецидивирующий герпес, хронический } \\
\text { гепатит С); травматический и ожоговый шок; аллергические и } \\
\text { аутоиммунные заболевания; онкологические заболевания; } \\
\text { отторжение трансплантанта; атеросклеротическое слабоумие; } \\
\text { коронарный атеросклероз; ревматоидный артрит; хронический } \\
\text { бронхит; грибовидный микоз; псориаз; коллагенозы. }\end{array}$ \\
\hline
\end{tabular}




\section{Глава 13. Принципы терапии инфекционных болезней}

Лечение инфекционных больных - старая и новая проблема. Основные положения лечения больных инфекционными заболеваниями, с позиции клинициста, были сформулированы еще А.Ф. Билибиным (1958г). Наибольшее внимание надо уделять не только выбору антибиотика, методу его введения, но и, что особенно важно, инфекционному процессу, подчиненному трем факторам: возбудителю, макроорганизму и окружающей среде.

Общими принципами лечения инфекционных больных является раннее начало лечения, его индивидуальность и комплексность. Следует отметить, что даже при отсутствии точного диагноза, лечение должно начинаться немедленно, исходя из наиболее вероятного диагноза, беря во внимание данные эпидемиологического анамнеза и наличие патогномоничных симптомов. При ряде инфекций (дифтерия, ботулизм, менингококковая инфекция) это определяет прогноз жизни и смерти больного, а также вероятность развития затяжных и хронических форм болезни.

Принцип индивидуализированности терапии предполагает необходимость к назначению соответствующего лечения, возможно, более полному индивидуальному диагнозу, а именно, должны быть учтены этиологический фактор, клиническая форма, механизм развития болезни (патогенез) и тяжесть состояния. Однако, не всегда из-за несовершенства лабораторных данных и схожести основных синдромов болезни, можно применить принцип индивидуализированности терапии. Например, приблизительно половине больных острыми кишечными инфекциями выставляется диагноз «ОКИ неуточненной этиологии» и назначается ципрофлоксацин.

Слишком большая или длительная агрессия возбудителя болезни или неадекватный сильный ответ на нее организма больного делают патологические проявления болезни чрезмерными - развиваются критические состояния, как крайняя степень патологии. Особенностью инфекционных заболеваний является стереотипность патофизиологических сдвигов при различных инфекциях, определяющих клинико-патогенетические синдромы критических состояний (ИШ, дегидратационный синдром, острая печеночная недостаточность, острая дыхательная недостаточность). Поэтому интенсивная терапия является составной частью и важным звеном специализированной медицинской помощи инфекционным больным. 
Принцип комплексности терапии при инфекционных заболеваниях является ведущим, так как конкретными направлениями терапии должны быть одновременные воздействия на возбудителя болезни и его токсины этиотропная терапия, на реактивность организма больного (повышение защитных сил) - иммунотерапия и на отдельные звенья развития инфекционного процесса - патогенетическая терапия.

В практике лечения инфекционных больных применяется различные этиотропные средства. Это связано с тем, что появляются высокопатогенные штаммы возбудителей и возникает лекарственная устойчивость их к противобактериальным или противовирусным препаратам, а также с изменением резистентности макроорганизма и вторичным иммунодефицитом.

Вирусные заболевания человека становятся все более актуальными год от года. Противовирусная терапия, в отличие от антибактериальной, обладает меньшим арсеналом лечебных препаратов. А если еще учесть появление «новых» вирусных инфекций (COVID-19, свиной грипп) с постоянной мутацией вирусов и применение для лечения противовирусных средств с недостаточными знаниями их фармакокинетики. Поэтому подходы к противовирусной терапии определяются рядом особенностей течения вирусных инфекций: препараты должны отличаться надежностью противовирусного действия при минимальном повреждающем воздействии на клетки макроорганизма. Эффективность противовирусных химиопрепаратов во многом зависит от защитных сил организма и напряженности иммунитета.

Сейчас уже четко определены роли и место этиотропной терапии при инфекционных заболеваниях, которая должна использоваться строго по показаниям и обязательно в комплексе с рациональной патогенетической терапией и иммунотерапией. Чаще всего инфекционные больные нуждаются в иммунотерапии в остром периоде инфекционного процесса, так как проводимые лечебные мероприятия будут направлены на подавление инфекционного процесса или на обеспечение благоприятного его течения с помощью целенаправленного повышения (в отдельных случаях - понижения) иммунитета.

Нельзя забывать о немедикаментозных методах воздействия на реактивность организма и также новые возможности, связанные с успехом в области реабилитации (иммунореабилитации) инфекционных больных. 


\section{Глава 14. Этиотропная терапия}

Устранение патогенного агента - основной метод в лечении больных с инфекционной патологией. Сложно получить положительный результат лечения без санационных мероприятий, этиотропной терапии и нормализации микрофлоры.

Санационные мероприятия. Основным мероприятием при лечении больного с иммунными нарушениями является санация патогенного очага. Обычно это хирургические вмешательства. Данная операция приводит к уменьшению интоксикации, подавлению инфекции, как в очаге, так и в организме больного в целом.

Однако санация подразумевает не только хирургические мероприятия. При лечении заболеваний верхних дыхательных путей (ангина, ОРВИ, острые и хронические синуситы и т.д.) это полоскание горла и промывание носа с применением гипертонического раствора и/или противовоспалительными и антибактериальными средствами. При бронхитах и пневмониях - ингаляции и вибромассаж, применение муколитиков, при заболеваниях мочеполовой системы - гигиенические процедуры, с использованием антибактериальных средств. Важным является местное применения антисептиков (табл.76).

Таблица 76

\section{Антисептики}

\begin{tabular}{|l|l|}
\hline \multicolumn{1}{|c|}{ Группа антисептиков } & \multicolumn{1}{|c|}{ Наименование препарата } \\
\hline $\begin{array}{l}\text { Галогенсодержащие } \\
\text { соединения }\end{array}$ & $\begin{array}{l}\text { Хлорамин Б, хлоргексидин, натрия гипохлорид, } \\
\text { раствор йода спиртовой, Повидон-йод (Бетадин), Йодоформ, Йодинол }\end{array}$ \\
\hline $\begin{array}{l}\text { Соединения } \\
\text { ароматического ряда } \\
\text { (группа фенола) }\end{array}$ & Карболовая кислота (фенол), Резорцин, деготь березовый (мазь Вишневского) \\
\hline $\begin{array}{l}\text { Соединения } \\
\text { алифатического ряда } \\
\text { (альдегиды и спирты) }\end{array}$ & Спирт этиловый 70-95\%, формальдегид (Формалин), Метенамин (Уротропин) \\
\hline $\begin{array}{l}\text { Красители } \\
\text { Окислители }\end{array}$ & $\begin{array}{l}\text { Бриллиантовый зеленый, метилтиония хлорид (метиленовый синий), } \\
\text { такридина лактат (риванол) }\end{array}$ \\
\hline $\begin{array}{l}\text { Производные } \\
\text { нитрофурана }\end{array}$ & Калия перманганат, раствор перекиси водорода (3\%) \\
\hline Кислоты и щелочи & Борная кислота, раствор аммиака (нашатырный спирт) \\
\hline Соли металлов & $\begin{array}{l}\text { Растворы ртути дихлорида (сулема), ртути окись желтая, ртути амидохлорид, } \\
\text { серебра нитрат (ляпис), серебра протеинат (Протаргол), серебро коллоидное } \\
\text { (Колларгол), цинка сульфат }\end{array}$ \\
\hline Детергенты & Бензалкония хлорид, метилпиридиния хлорид, Мирамистин \\
\hline
\end{tabular}




\section{Этиотропная терапия}

Этиотропная терапия выполняет защитную функцию, аналогичную функции иммунной системы. Разделение таких препаратов на группы по преимущественной активности базируется на классификации возбудителей инфекционных заболеваний человека. Выделяют антибактериальные (антибиотики, сульфаниламиды и ко-тримоксазол, нитроимидазолы, нитрофураны); противогрибковые; противовирусные; противопротозойные; противогельминтные препараты.

Противовирусные препараты. Спектр противовирусных препаратов в последнее время значительно увеличился. Благодаря чему стало возможно практически полностью излечить хронические инфекции (ВГС) и/или добиться стойкой ремиссии (ВИЧ, ХГВ). Противовирусные препараты предназначены для лечения конкретной вирусной инфекции, реже используются в профилактических целях. В последнее время производятся попытки классифицировать противовирусные препараты по механизму действия с учетом жизненного цикла вируса (табл. 83), однако к клинической практике удобнее рассматривать препараты к конкретному вирусу (грипп, герпесы, гепатиты, ВИЧ-инфекции и др.)

\section{Противогерпетические препараты.}

Основным противогерпетическим препаратом является аналог нуклеозидов - Ацикловир и его версии Валацикловир, Пенцикловир и Фамцикловир. Все эти лекарственные средства блокируют синтез ДНК у размножающихся вирусов герпеса человека, в том числе Herpes simplex типы

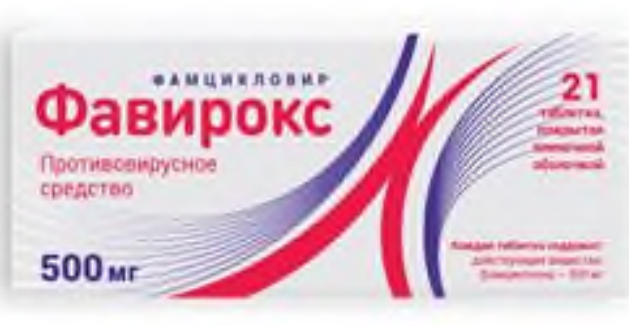
1 и 2, Varicella zoster, Epstein-Barr и цитомегаловируса.

Ганцикловир по структуре, метаболизму и механизму действия очень близок к ацикловиру, но значительно более токсичен. Ганцикловир, как правило, вводится только внутривенно, реже применяется внутрь. Применение противогерпетических препаратов не ведет к полному излечению, так как вирус герпеса сохраняется в организме в неактивном (латентном) состоянии. Резистентность к противогерпетическим препаратам редкое явление, особенно у пациентов с нормальным иммунитетом.

Препараты против вирусов респираторного тракта. При лечении ОРВИ учитывают большое количество разновидностей патогенных вирусов (более 2000), этиотропная терапия отсутствует. Исключения составляют грипп и коронавирус (см. ниже). В тяжелых случаях при ОРВИ, особенно вызванное РСвирусом, рекомендовано применять Рибавирин. Аналогичным действием 
Таблица 83

\section{Классификация противовирусных препаратов}

\begin{tabular}{|c|c|c|}
\hline Этап & Группа & Препараты \\
\hline \multirow{3}{*}{$\begin{array}{l}\text { Адсорбция на } \\
\text { клетки-мишени }\end{array}$} & Ингибиторы рецепторов & Маравирок (ВИЧ) \\
\hline & Ингибиторы слияния (фузии) & $\begin{array}{l}\text { Энфувиртид (ВИЧ), Нобазит, Умифеновир (ОРВИ), } \\
\text { Йодантипирин (КЭ) }\end{array}$ \\
\hline & Антитела & Внутривенные иммуноглобулины \\
\hline $\begin{array}{l}\text { Проникновение в } \\
\text { цитоплазму }\end{array}$ & $\begin{array}{l}\text { Блокируют проникновение } \\
\text { вирусов в клетку }\end{array}$ & $\begin{array}{l}\text { Производные адамантана (Ремантадин, Амантадин), } \\
\text { Булевиртид (ВГВ и HDV). }\end{array}$ \\
\hline $\begin{array}{l}\text { Транспорт внутри } \\
\text { клетки }\end{array}$ & $\begin{array}{l}\text { Препараты, ингибирующие } \\
\text { интегразы }\end{array}$ & $\begin{array}{l}\text { Долутегравир, Элвитегравир, Ралтегравир, } \\
\text { Биктегравир (ВИЧ) }\end{array}$ \\
\hline \multirow[t]{10}{*}{$\begin{array}{l}\text { Внутриклеточная } \\
\text { репродукция }\end{array}$} & $\begin{array}{l}\text { Средства, блокирующие синтез } \\
\text { вирусной ДНК }\end{array}$ & $\begin{array}{l}\text { Ацикловир, Валацикловир, Пенцикловир, } \\
\text { Фамцикловир, Ганцикловир (группа герпесвирусов) }\end{array}$ \\
\hline & $\begin{array}{l}\text { Ингибиторы обратной } \\
\text { транскриптазы. Нуклеотиды }\end{array}$ & $\begin{array}{l}\text { Тенофовир (ВИЧ, ВГВ), Адефовир (ВГВ, герпесы), } \\
\text { фосфазид (ВИЧ) }\end{array}$ \\
\hline & Нуклеозиды & $\begin{array}{l}\text { Абакавир, Диданозин, Зальцитабин, Зидовудин, } \\
\text { Ставудин, Эмтрицитабин, (ВИЧ) Ламивудин, (ВИЧ, ВГВ) } \\
\text { Энтекавир (ВГВ) }\end{array}$ \\
\hline & Ненуклеозиды & $\begin{array}{l}\text { Делавирдин, Невирапин, Эфавиренз, Этравирин, } \\
\text { Рилпивирин (ВИЧ) }\end{array}$ \\
\hline & $\begin{array}{l}\text { Средства, блокирующие синтез } \\
\text { вирусной РНК: }\end{array}$ & $\begin{array}{l}\text { Рибавирин (ОРВИ, ВГС, Вирус Эбола), Триазавирин } \\
\text { (ОРВИ, КЭ), Рибонуклеаза (КЭ), Фавипиравир } \\
\text { (короновирусная инфекция) }\end{array}$ \\
\hline & Нуклеотидные ингибиторы & Софосбувир (ВГС), Балоксавира марбоксил (грипп) \\
\hline & Ненуклеозидные ингибиторы & Беклабувир, Дасабувир (ВГС) \\
\hline & Ингибитор вирусных протеаз & $\begin{array}{l}\text { Ампренавир, Атазанавир, Индинавир, Нелфинавир, } \\
\text { Ритонавир, Саквинавир, Типранавир, Фосампренавир, } \\
\text { Дарунавир (ВИЧ), Воксилапревир, глекапревир, } \\
\text { гразопревир. Асунапревир, } \\
\text { Нарлапревир/Паритапревир (с ритонавиром), } \\
\text { Боцепревир, Телапревир (ВГС) }\end{array}$ \\
\hline & $\begin{array}{l}\text { Ингибитор вирусных } \\
\text { регуляторных белков }\end{array}$ & $\begin{array}{l}\text { Велпатасвир, Пибрентасвир, Даклатасвир, } \\
\text { Ледипасвир, Омбитасвир, Элбасвир (ВГС) }\end{array}$ \\
\hline & Интерфероны-альфа (ИФ-альфа) & ИФ-альфа 1а, 1в, 2а,2в, ПЭГ, ЦеПЭГ \\
\hline Сборка вириона & $\begin{array}{l}\text { Ингибитор сборки вирусных } \\
\text { частиц }\end{array}$ & Ледипасвир (ВГС), Метисазон (оспа) \\
\hline Выход вируса & Ингибиторы нейраминидазы & $\begin{array}{l}\text { Озельтамивир, Занамивир, Перамивир, Ланинамивир } \\
\text { (грипп) }\end{array}$ \\
\hline $\begin{array}{l}\text { Вирус вне } \\
\text { клетки }\end{array}$ & Антисептики, «Оксолин» & $\begin{array}{l}\text { Этанол, гипохлорит, перекись водорода, нитрат } \\
\text { серебра, хлоргексидин, оксолиновая мазь } \\
\text { (риновирусная инфекция, профилактика гриппа) }\end{array}$ \\
\hline
\end{tabular}

\section{обладает Риамиловир (Триазавирин). Активное вещество препарата} «Триазавирин» - синтетический аналог оснований пуриновых нуклеозидов (гуанина) с выраженным противовирусным действием широкого спектра. Основной механизм действия Триазавирина: ингибирование синтеза вирусных РНК и репликации геномных фрагментов. Они действуют против широкого спектра РНК- содержащих вирусов в том числе вирусов ОРВИ и гриппа, ротавирусной инфекции, серозных менингитах, клещевом энцефалите, лихорадке Денге и других геморрагических лихорадках. 
Метаанализ рандомизированных контролируемых клинических исследований эффективности препарата Риамиловир в этиотропной терапии ОРВИ показал, что терапия препаратом «Триазавирин» статистически достоверно влияет на выраженность клинических симптомов у пациентов с ОРВИ, эффективно как на начальных, так и на поздних стадиях заболевания, в связи с чем «Триазавирин» может быть использован при стартовой терапии взрослых больных с респираторными заболеваниями вирусной этиологии.

Во время пандемии COVID-19 накоплен большой опыт применения препарата «off label» в отношении новой коронавирусной инфекции. Установлены высокая эффективность и безопасность применения препарата «Триазавирин» в терапии COVID-19. При ретроспективном сравнительном исследование клинической эффективности и безопасности применения нуклеозидных аналогов в лечении пациентов с COVID-19 средней тяжести с использованием препаратов прямого противовирусного действия в условиях инфекционного стационара при применении триазаверина установлено статистически значимое: снижение длительности лихорадки, кашля, аносмии и более быстрая элиминация вируса из организма; снижение уровня неспецифических маркеров воспаления в сыворотке крови и нормальные показатели активности печеночных ферментов на протяжении лечения. при сравнении с другими методами лечения.

Препараты против коронавируса. В связи с продолжающейся глобальной пандемией 2020 года активно ведется поиск препаратов против коронавируса. В настоящее время в России применяется несколько препаратов, которые используются как этиотропные препараты при лечении COVID-19. Это фавипиравир (авифавир, арепливир, коронавир), ремдесивир (веклури, ремдеформ), умифеновир (арбидол, арпефлю, афлюдол). Фавипиравир ингибируют РНК-зависимую РНК-полимеразу, участвующую в репликации не только вируса гриппа, но и других РНК-овых вирусов. Ремдесивир является ингибитором РНК-зависимой РНК-полимеразы SARS-CoV-2 (RdRp), которая необходима для репликации вируса. Умифеновир по механизму противовирусного действия относится к ингибиторам слияния (фузии). Этим же механизмом обладают нобазит и йодантипирин.

Противовирусными препаратами, одобренный FDA для лечения COVID19 является ремдесивир и противовирусный препарат нирматрелвир (паксловид) активный ингибитор протеазы 3CLpro. B настоящее время некоторые лекарства 
проходят клинические испытания. Так препарат плитидепсин (аплидин) который взаимодействует с факторами трансляции eEF1A SARS-CoV-2 и подавляет процесс репликации вируса является более эффективным средством против коронавируса in vitro, чем ремдесивир. Молнупиравир подавляет репродукцию вируса, способствуя распространению мутаций при репликации вирусной РНК с помощью РНК-направленной РНК-полимеразы. Одобрен для лечения COVID-19 в Великобритании. В России зарегистрировал препарат для лечения новой коронавирусной инфекции «МИР 19». Основной компонент препарата малые интерферирующие РНК (миРНК), которые внутри инфицированной клетки организма нацеливаются на геном патогена и способствуют его деградации, не затрагивая ДНК клетки.

Противогриппозные npenapambl. В мире для лечения гриппа рекомендуется три группы препаратов: препараты, блокирующие депротеинизацию вирусов за счет блокирования М2-каналов вируса гриппа А (Амантадин, Ремантадин); ингибиторы нейроаминидазы, препятствующие откреплению вирионов от поверхности инфицированной клетки (Осельтамивир (Тамифлю), Занамивир (Реленза), Перамивир (Рапиваб), Ланинамивир (Инавир)); ингибиторы инициации синтеза мРНК Балоксавира марбоксил (Ксофлюза), Риамиловир (Триазавирин).

В России также рекомендуются к применению ингибиторы слияния (фузии) - Нобазит и Умифеновир. Несмотря на частичную или полную устойчивость к препаратам, в том числе последнего поколения, их применение оправдано, так как непонятно есть ли у данного конкретного возбудителя устойчивость к препарату. Так же доказано, что при применении противогриппозных препаратов снижается тяжесть симптомов, сокращается продолжительность заболевания, уменьшается частота вторичных осложнений. Препараты для лечения гриппа и ОРВИ целесообразно использовать в первые три дня заболевания т.к. от этого зависит эффективность лечения.

Препараты для лечения клещевого энцефалита и геморрагических лихорадок. Растущий уровень заболеваемости, развитие тяжелых форм болезни, хронизация процесса не оставляет сомнения для поиска новых методов терапии. К сожалению, до настоящего времени с позиций доказательной терапии этиотропные препараты для лечения этих заболеваний отсутствуют. С позиций патогенетической терапии обосновано применение альфа интерферонов, 
которые блокируют сборку вируса. Специфические иммуноглобулины в высоких титрах к этим инфекциям блокируют адсорбцию вируса на клеткимишени.

При клещевом энцефалите в России активно применяется Йотантипирин (как ингибиторы слияния (фузии), Триазавирин и Рибонуклеаза (как средство, блокирующее синтез вирусной РНК). Хороший эффект от применения рибаверина, блокирующего синтез вирусной РНК. В некоторых случаях при хроническом клещевом энцефалите удается добиться стабилизирующего эффекта, усиливая специфический иммунитет вакциной. Вакцину для профилактики клещевого энцефалита вводят подкожно тремя курсами: первый курс по 0,5-1,0 мл трехкратно с интервалами в 5 дней; второй курс через 4-5 недель по 0,5-1,0 мл трехкратно с интервалами в 3 дня; третий курс через 5-6 месяцев трехкратно по 1,0 мл через 1 день.

Aнтиретровирусные npenapambl. Основная задача проведения антиретровирусной терапии, используя несколько препаратов, достигнуть нулевой вирусной нагрузки. Комбинация препаратов собирается из двух, трёх или четырёх компонентов. Все компоненты относятся к различным группам (табл.96). Это нуклеозидные, нуклеотидные и ненуклеозидные ингибиторы обратной транскриптазы, ингибиторы протеазы, ингибиторы интегразы, ингибиторы слияния (ингибиторы фузии), ингибиторы рецепторов.

Применение АРВП проводится под контролем врачей-инфекционистов в специализированных медицинских учреждениях (центрах по профилактике и борьбе со СПИД, инфекционных больницах). В последнее время выпускаются уже готовые комбинации препаратов с однократным приёмом препаратов в сутки, что повышает эффективность проводимой терапии. Современные варианты лечения практически не имеют побочных эффектов, безопасны для человека и состоят в приёме одной таблетки в сутки либо одной инъекции в один или два месяца.

Антиретровирусные препараты не излечивают от СПИДа и не предупреждают заражение ВИЧ, однако снижение вирусной нагрузки до менее $20-50$ копий/мл способствуют восстановлению количества CD4-лимфоцитов и, формированию адекватного иммунного ответа. Благодаря этому не развивается СПИД, не формируются заболевания, ухудшающие качество жизни больного. Увеличивается продолжительность и качество жизни. ВИЧ-положительный человек с нулевой вирусной нагрузкой ничем не отличается от ВИЧотрицательных людей.

Препараты для лечения вирусного гепатита С. В терапии хронического гепатита С (ХГС) произошел существенный прорыв в последние годы. Внедрение высокоэффективных режимов на основе ПППД позволило достигать излечения у более $95 \%$ пациентов независимо от генотипа вируса. 
В 2020 году были обновлены рекомендации Европейской ассоциации по изучению печени (EASL), где также описаны и подходы по упрощенному подходу к диагностике и лечению ХГС (табл.97).

Таблица 97

Рекомендации EASL 2020 по лечению ХГС (включая ко-инфекцию с ВИЧ)

у пациентов старше 18 лет (EASLiver, EASL recommendations on treatment of hepatitis C - Final update of the series, Journal of Hepatology (2020), https://doi.org/10.1016/j.jhep.2020.08.018.)

\begin{tabular}{|c|c|c|c|c|c|c|}
\hline \multicolumn{3}{|c|}{ Варианты инфекции } & \multicolumn{4}{|c|}{ Препараты } \\
\hline Генотип & Цирроз & $\begin{array}{c}\text { Предшес } \\
\text { твующая } \\
\text { терапия }\end{array}$ & SOF/VEL & GLE/PIB & $\begin{array}{l}\text { SOF/VEL } \\
\text { /VOX }\end{array}$ & EBR/GZR \\
\hline \multicolumn{7}{|c|}{ Упрощенный подход без определения генотипа/субтипа } \\
\hline \multirow{4}{*}{ Bce } & \multirow{2}{*}{ HET } & HET & \multirow{4}{*}{12 недель } & \multirow{3}{*}{8 недель } & \multirow{4}{*}{ HET } & \multirow{4}{*}{ HET } \\
\hline & & ДА & & & & \\
\hline & \multirow{2}{*}{ ДА } & HET & & & & \\
\hline & & ДА & & 12 недель & & \\
\hline \multicolumn{7}{|c|}{ Терапия в зависимости от генотипа/субтипа } \\
\hline \multirow{4}{*}{$\begin{array}{c}1 a, 1 b, 2, \\
4,5 \text { и } 6\end{array}$} & \multirow{2}{*}{ HET } & HET & \multirow{4}{*}{12 недель } & \multirow{3}{*}{8 недель } & \multirow{4}{*}{ HET } & \multirow{4}{*}{$\begin{array}{c}12 \text { недель } \\
\text { (генотип } \\
\text { 1b) }\end{array}$} \\
\hline & & ДА & & & & \\
\hline & \multirow{2}{*}{ ДА } & HET & & & & \\
\hline & & ДА & & 12 недель & & \\
\hline \multirow{4}{*}{3} & \multirow{2}{*}{ HET } & HET & \multirow{2}{*}{12 недель } & 8 недель & \multirow{2}{*}{ HET } & HET \\
\hline & & ДА & & 12 недель & & HET \\
\hline & \multirow{2}{*}{ ДА } & HET & \multirow{2}{*}{$\begin{array}{c}12 \text { недель с } \\
\text { рибавирином }\end{array}$} & 8-12 недель & \multirow{2}{*}{$\begin{array}{c}12 \\
\text { недель }\end{array}$} & HET \\
\hline & & ДА & & 16 недель & & HET \\
\hline \multirow{4}{*}{$\begin{array}{c}\text { Субтипы } \\
\text { 1l, 4r, 3b, } \\
3 g, 6 u, 6 v \\
\text { Мутации } \\
\text { в регионе } \\
\text { NS5A }\end{array}$} & \multirow{2}{*}{ HET } & HET & \multirow{4}{*}{ Неизвестно } & \multirow{4}{*}{ Неизвестно } & \multirow{4}{*}{$\begin{array}{c}12 \\
\text { недель }\end{array}$} & \multirow{4}{*}{ HET } \\
\hline & & ДА & & & & \\
\hline & \multirow{2}{*}{ ДА } & HET & & & & \\
\hline & & ДА & & & & \\
\hline
\end{tabular}

SOF/VEL - софосбувир/велпатасвир (Epclusa)

GLE/PIB - глекапревир/пибрентасвир (Mavyret)

SOF/VEL/VOX - софосбувир/велпатасвир/воксилапревир (Vosevi) - не зарегистрирован в РФ EBR/GZR - гразопревир/элбасвир (Zepatier)

цирроз - компенсированный цирроз печени (класс А по Child-Turcotte-Pugh)

Согласно глобальной стратегии ВОЗ главной целью является элиминация вирусного гепатита как проблемы общественного здравоохранения со снижением к 2030 г. числа новых случаев инфицирования вирусным гепатитом на $90 \%$ и смертности от вирусного гепатита на $65 \%$.

Препараты для лечения вирусного гепатита В.

Для лечения хронического гепатита В (ХГВ) в настоящее время используется долгосрочная терапия аналогами нуклеоз(т)идов, которые 
принимаются внутрь 1 раз в день. У пациентов с нетяжелыми формами заболевания также возможно проведение монотерапии пегилированным интерфероном альфа в течение 48 недель с возможным увеличением длительности у отдельных пациентов с HBeAg-негативным ХГВ. Острый гепатит В не требует назначения противовирусной терапии. Однако, больным с молниеносными формами и/или сопутствующей дельта-инфекцией и/или с проявлениями иммунных нарушений лечение показано.

Согласно действующим в настоящий момент рекомендациям EASL 2017 года, при ХГВ начало терапии может быть рассмотрено по результатам оценки сочетания трех критериев:

- $\quad$ уровень ДНК вируса гепатита В (ВГВ);

- уровень АЛТ в сыворотке крови;

- $\quad$ тяжесть заболевания печени.

Лечение должно быть обязательно назначено пациентам c $\mathrm{HBeAg}$ позитивным или негативным ХГВ; пациентам с циррозом печени и любым определяемым уровнем ДНК ВГВ (независимо от уровня АЛТ); пациентам с ДНК ВГВ $>20000$ МЕ/мЛ и АЛТ $>2$ ВГН (независимо от тяжести поражения печени по гистологическому исследованию).

Долгосрочное применение высокоактивных аналогов нуклеоз(т)идов с высоким барьером резистентности является терапией выбора вне зависимости от тяжести поражения печени. Предпочтительными в качестве монотерапии являются препараты ETV (Энтекавир), TDF (Тенофовира дизопроксила фумарат) и TAF (Тенофовира алафенамид). Не рекомендуются к применению препараты Ламивудин и Телбивудин.

Кроме того, учитывая профиль безопасности TDF при долгосрочном применении, в некоторых случаях следует отдавать предпочтение назначению ETV и TAF. TAF по сравнению с TDF обеспечивает сходные показатели вирусологической супрессии, более высокую частоту нормализации АЛТ и лучшую переносимость

Показания к предпочтительному применению ETV или TAF вместо TDF (У пациентов, ранее получавших аналоги нуклеоз(т)идов, применение TAF более предпочтительно, чем ЕTV):

В случае развития резистентности к ламивудину, телбивудину или энтекавиру, рекомендуется переключение на TDF или TAF. В случае резистентности к TDF или TAF - переключение на ETV (при отсутствии опыта терапии ламивудином) или добавление к режиму ETV (в случае, если есть резистентность к ламивудину). При множественной резистентности рекомендуется переключение на ETV в комбинации с TDF или TAF.

Представителем нового класса противовирусных средств для лечения ХГВ с дельта-агентом является Булевиртид. Механизм противовирусного действия объясняется высокоспецифичным и стабильным связыванием с расположенным на поверхности гепатоцитов транспортным белком, отвечающем за реабсорбцию 
желчных кислот в печени и используемым HBV и HDV в качестве рецептора для проникновения в клетку. Булевиртид препятствует присоединению к нему вирусов, блокирует проникновение вирусов в клетку и последующие этапы их репликации. Не происходит образование новых вирусных частиц и поражение здоровых гепатоцитов. Наряду со снижением вирусной нагрузки происходит уменьшение воспалительного и цитолитического процессов в печени. Замедляется прогрессирование фиброза и цирроза печени и уменьшается риск связанных с ними осложнений.

\section{Антибактериальные препараты представляют собой самую} многочисленную группу лекарственных средств. Их можно классифицировать по механизму действия, химической структуре, типу действия на микробную клетку (табл. 77).

Таблица 77

\section{Классификация антибактериальных препаратов}

\begin{tabular}{|c|c|c|c|c|}
\hline \multicolumn{3}{|r|}{ Химическое строение } & $\begin{array}{l}\text { Характер } \\
\text { действия }\end{array}$ & $\begin{array}{l}\text { Механизм } \\
\text { действия }\end{array}$ \\
\hline \multirow{10}{*}{ 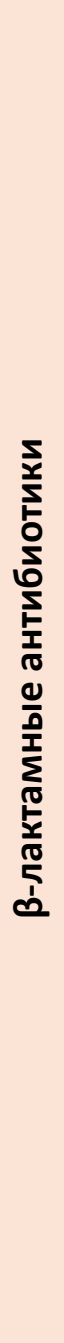 } & \multirow{3}{*}{ 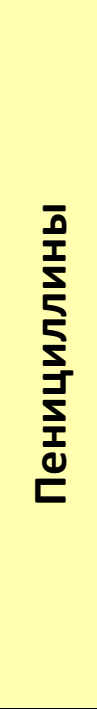 } & $\begin{array}{l}\text { Природные: Бициллин } 1 \text { и 5, } \\
\text { Бензилпенициллин Na-вая, К-вая, } \\
\text { новокаиновая соль, } \\
\text { Феноксиметилпенициллин, экстенциллин }\end{array}$ & \multirow{3}{*}{ бактерицидный } & \multirow{3}{*}{$\begin{array}{l}\text { Блокируют синтез } \\
\text { пептидогликана - } \\
\text { биополимера, } \\
\text { являющегося } \\
\text { основным } \\
\text { компонентом } \\
\text { клеточной стенки } \\
\text { бактерий, за счет } \\
\text { чего происходит } \\
\text { гибель бактерий. }\end{array}$} \\
\hline & & $\begin{array}{l}\text { Полусинтетические: Оксациллин, } \\
\text { Клоксациллин, Диклоксациллин, } \\
\text { Флуклоксациллин, Метициллин, } \\
\text { Амоксициллин, Ампициллин, Карбенициллин, } \\
\text { Тикарциллин, } \\
\text { Азлоциллин, Мезлоциллин, Пипероциллин } \\
\end{array}$ & & \\
\hline & & $\begin{array}{l}\text { Ингибиторозащищенные: } \\
\text { Амоксициллин /клавуланат, } \\
\text { Ампициллин /сульбактам, } \\
\text { Тикарциллин /клавуланат, } \\
\text { Пиперациллин /тазобактам }\end{array}$ & & \\
\hline & \multirow{5}{*}{ 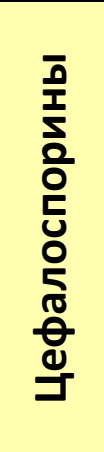 } & $\begin{array}{l}1 \text { поколение: Цефазолин, Цефалотин, } \\
\text { Цефалексин, Цефадроксил }\end{array}$ & \multirow{5}{*}{ бактерицидный } & \multirow{7}{*}{$\begin{array}{l}\text { Связываются с } \\
\text { мембранными } \\
\text { пенициллин- } \\
\text { связывающими } \\
\text { белками, вызывает } \\
\text { выброс } \\
\text { лизосомальных } \\
\text { ферментов и } \\
\text { гибель бактерии }\end{array}$} \\
\hline & & $\begin{array}{l}2 \text { поколение: Цефоранид, Цефотетан, } \\
\text { Цефаклор, Цефуроксим, Цефамандол }\end{array}$ & & \\
\hline & & $\begin{array}{l}3 \text { поколение: Цефтриаксон, Цефаперазон, } \\
\text { Цефтазидин, Цефиксим }\end{array}$ & & \\
\hline & & 4 поколение: Цефпиром, Цефепим & & \\
\hline & & $\begin{array}{l}\text { Ингибиторозащищенные: Цефоперазон } \\
\text { /сульбактам }\end{array}$ & & \\
\hline & \multirow{2}{*}{ 尊 } & Азтреонем & \multirow[b]{2}{*}{ бактерицидный } & \\
\hline & & $\begin{array}{l}\text { Имипенем (Тиенам), Меропенем, } \\
\text { Эртапенем }\end{array}$ & & \\
\hline
\end{tabular}




\section{Классификация антибактериальных препаратов}

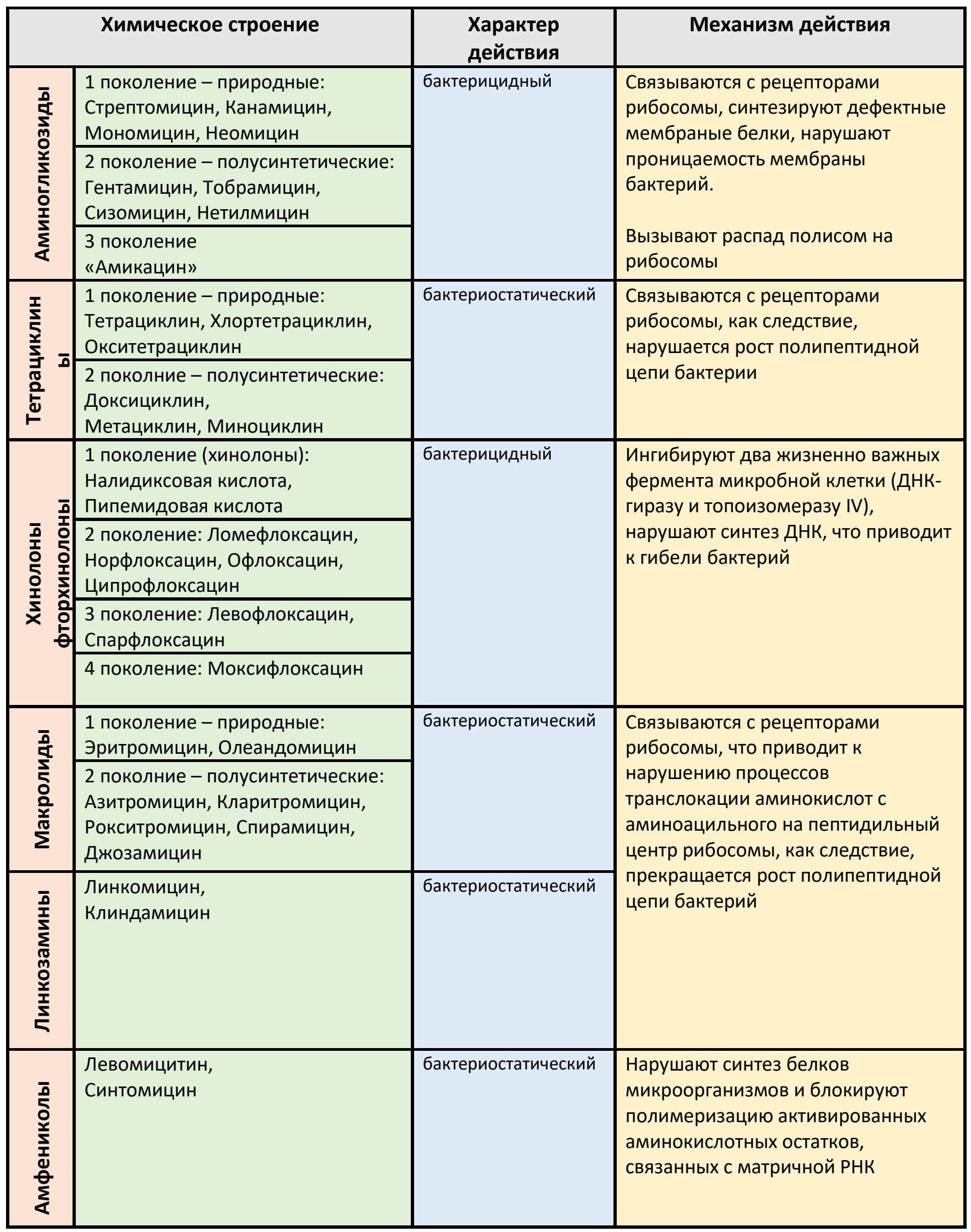


Таблица 77 (продолжение)

\section{Классификация антибактериальных препаратов}

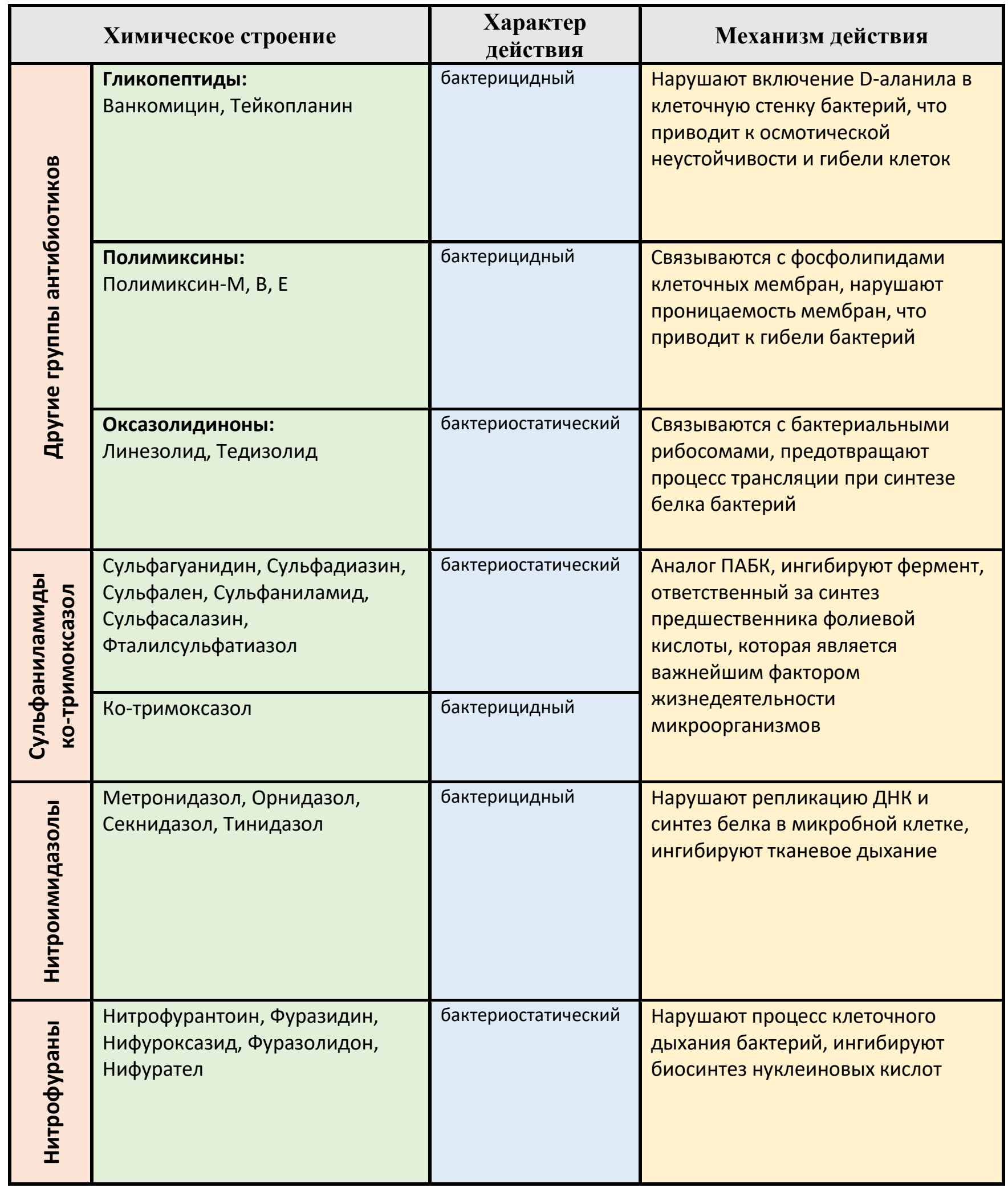

Основным показанием к антибактериальной терапии является наличие бактериальной инфекции (в некоторых случаях допускается применение антибиотиков в качестве профилактики). При этом главное и решающее в выборе 
антибактериального средства - это возбудитель и его чувствительность к избранному препарату.

Для установления возбудителя традиционно проводят бактериологическое исследование. Определение чувствительности микроорганизмов к антибиотикам позволяет выявить резистентные штаммы, а полученная антибиотикограмма служит хорошим подспорьем клиницисту для выбора препарата. При этом забор материала для микробиологических исследований необходимо брать до начала антибактериальной терапии, срок транспортировки материала от забора до посева на среду не должен превышать 2 ч. Для предварительной диагностики необходимо прибегать к экспресс-методам по этиологической диагностике, к которым относятся микроскопия мазка, окрашенного по Граму, методы прямой иммунофлюоресценции, определение АГ в мокроте или мазке со слизистых. После получения бактериологического заключения о характере микрофлоры и ее чувствительности к антибиотикам при необходимости следует произвести смену антибиотика.

Нередко при микроскопии мокроты дифференцировать микроорганизмы не удается и необходимо ориентироваться лишь на преобладание грамположительной или грамотрицательной флоры, а также на наличие смешанной флоры. Необходимо знать региональную ситуацию с антибиотикорезистентностью наиболее актуальных возбудителей и учитывать наличие у больного риска инфицирования данными устойчивыми возбудителями. Многие инфекционные поражения - полимикробные, и в силу этого для их лечения может понадобиться комбинация антибиотиков.

Выбор антибактериальных средств при установленной этиологии определяется с учетом наиболее эффективных в отношении той или иной флоры антибиотиков (табл. 78). Больным с иммунными нарушениями предпочтительнее назначать препараты бактерицидного действия: $\beta$-лактамы, аминогликозиды, ванкомицин, фосфомицин, фторхинолоны.

Однако в реальной жизни врач крайне редко располагает достоверными данными о возбудителе и обычно ориентируется на спектр действия имеющихся антибиотиков, региональных особенностях приобретенной резистентности бактерий к антибиотикам, клиническим свойствам течения болезни и на свой опыт (табл.79). Нередко в клинической практике используется комбинированная антибиотикотерапия. Она показана при смешанных инфекциях, необходимости предупреждения развития устойчивости микроорганизмов к антибиотику, усилении антибактериального эффекта, недостаточной чувствительности возбудителей к моноантибиотикам. 
Таблица 78

\section{Спектр действия антибактериальных средств при заболеваниях человека}

\begin{tabular}{|c|c|c|c|c|c|c|c|c|c|c|c|c|c|c|c|c|c|c|c|c|c|c|c|c|}
\hline \multirow{2}{*}{ 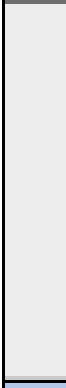 } & 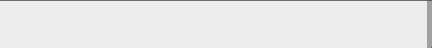 & \multicolumn{23}{|c|}{ Антибактериальные средства } \\
\hline & $\begin{array}{c}\text { Группы } \\
\text { микроорганизмов }\end{array}$ & $\begin{array}{ll}\frac{1}{2} \\
\frac{1}{2} \\
\end{array}$ & 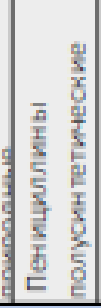 & 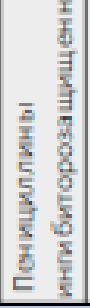 & 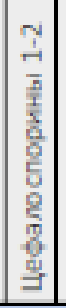 & 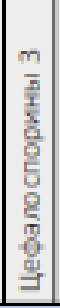 & 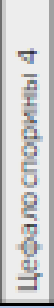 & 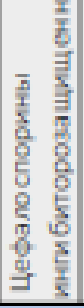 & 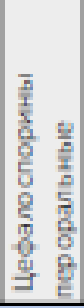 & 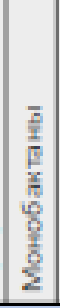 & 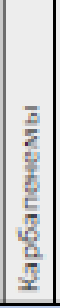 & 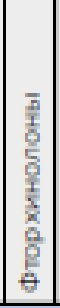 & 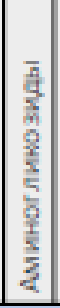 & \begin{tabular}{|l} 
\\
吾 \\
$\frac{5}{5}$ \\
$\frac{5}{8}$ \\
$\frac{8}{5}$ \\
$\frac{9}{2}$ \\
\end{tabular} & 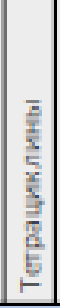 & 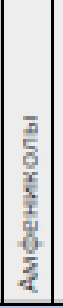 & 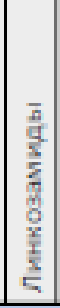 & 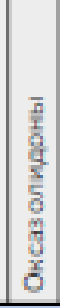 & 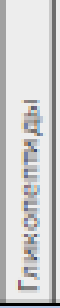 & 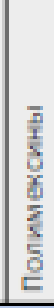 & 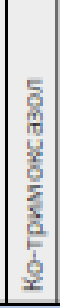 & 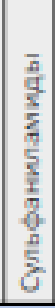 & 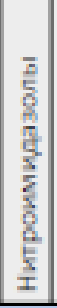 & 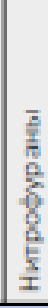 \\
\hline \multicolumn{25}{|c|}{ Грамм-положительные кокки } \\
\hline \multirow{2}{*}{ 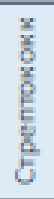 } & $\begin{array}{l}\text { Str.pneumoniae/pyogenes } \\
\text { /viridans }\end{array}$ & & & & & & & & & & & & & & & & & & & & & & & \\
\hline & $\begin{array}{l}\text { Энтерококки (группа D } \\
\text { стрептококк) }\end{array}$ & & & & & & & & & & & & & & & & & & & & & & & \\
\hline \multirow{4}{*}{$\begin{array}{l}\frac{2}{2} \\
\frac{9}{9} \\
\frac{5}{5} \\
\frac{5}{6} \\
\frac{5}{5}\end{array}$} & $\begin{array}{l}\text { Staph.epidermidis } \\
\text { (Коагулазонегативный (CONS) }\end{array}$ & & & & & & & & & & & & & & & & & & & & & & & \\
\hline & $\begin{array}{l}\text { Staph.aureus чувствителен K } \\
\text { метициллину }\end{array}$ & & & & & & & & & & & & & & & & & & & & & & & \\
\hline & $\begin{array}{l}\text { Устойчивый к метициллину } \\
\text { золотистый стафилококк (MRSA) }\end{array}$ & & & & & & & & & & & & & & & & & & & & & & & \\
\hline & $\begin{array}{l}\text { Внутриболоничный метициллин- } \\
\text { резистентный стафилококк (HА- } \\
\text { MRSA) }\end{array}$ & & & & & & & & & & & & & & & & & & & & & & & \\
\hline \multicolumn{25}{|c|}{ Грамм-негативные коккобациллы } \\
\hline \multicolumn{25}{|c|}{ Neisseria meningitdis } \\
\hline \multicolumn{25}{|c|}{ Neisseria gonorrhea } \\
\hline \multicolumn{25}{|c|}{ Грамм-негативные бациллы } \\
\hline \multicolumn{25}{|c|}{$\begin{array}{l}\text { Escherichia coli, Klebsiella } \\
\text { pneumoniae, Haemophilus influenzae }\end{array}$} \\
\hline \multicolumn{25}{|c|}{ не производящие бета-лактамазу } \\
\hline \multicolumn{25}{|c|}{ Продуцируюцие бета-лактамазы } \\
\hline \multicolumn{25}{|c|}{$\begin{array}{l}\text { SPACE Serratia marcescens, Proteus } \\
\text { mirabilis, Acinetobacter sp., } \\
\text { Citrobacter sp., Enterobacter sp. }\end{array}$} \\
\hline \multicolumn{25}{|c|}{$\begin{array}{l}\text { ESBL ( Выра6атывающие 6ета- } \\
\text { лактамазы с расширенным спектром } \\
\text { ) Escherichia coli, Klebsiella } \\
\text { pneumoniae }\end{array}$} \\
\hline \multicolumn{25}{|c|}{ Shigella spp. } \\
\hline \multicolumn{25}{|c|}{ Salmonella spp. } \\
\hline \multicolumn{25}{|c|}{ Pseudomonas aeruginosa } \\
\hline \multirow{2}{*}{\multicolumn{25}{|c|}{ Спирохеты }} \\
\hline & & & & & & & & & & & & & & & & & & & & & & & & \\
\hline \multicolumn{25}{|c|}{ Peptostreptococcus } \\
\hline \multicolumn{25}{|c|}{ Bacteroides sp } \\
\hline \multicolumn{25}{|c|}{ Clostridium difficile } \\
\hline \multicolumn{25}{|c|}{ 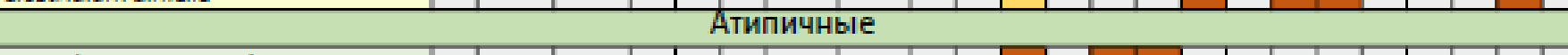 } \\
\hline $\begin{array}{l}\text { Myco } \\
\text { Chlar }\end{array}$ & $\begin{array}{l}\text { roplasma pneumoniae, } \\
\text { amwdophilia spp }\end{array}$ & & & & & & & & & & & & & & & & & & & & & & & \\
\hline Legio & onella pneumophilia & & & & & & & & & & & & & & & & & & & & & & & \\
\hline Chlar & mydia trachomtis & & & & & & & & & & & & & & & & & & & & & & & \\
\hline
\end{tabular}


Таблица 79

Применение антибактериальных средств при заболеваниях человека

\begin{tabular}{|c|c|c|c|}
\hline Заболевание & $\begin{array}{c}\text { Основной } \\
\text { возбудитель }\end{array}$ & $\begin{array}{c}\text { Первоочередной } \\
\text { антибиотик }\end{array}$ & Антибиотики резерва \\
\hline $\begin{array}{l}\text { Стафилококковые } \\
\text { инфекции }\end{array}$ & $\begin{array}{l}\text { Staphylococcus } \\
\text { aureus }\end{array}$ & $\begin{array}{l}\text { Оксацилин, } \\
\text { Ампицилин, } \\
\text { цефалоспорины }\end{array}$ & $\begin{array}{l}\text { Ингибиторозащищенные } \\
\text { пенициллины (ИП), } \\
\text { макролиды, линкозамиды }\end{array}$ \\
\hline Импетиго & $\begin{array}{l}\text { Staphylococcus } \\
\text { pyogenes }\end{array}$ & Цефалоспорины & $\begin{array}{l}\text { ИП, макролиды, } \\
\text { линкозамиды }\end{array}$ \\
\hline Рожа & $\begin{array}{l}\text { Стрептококки } \\
\text { группы A, }\end{array}$ & $\begin{array}{l}\text { Природные } \\
\text { пенициллины }\end{array}$ & ИП, линкозамиды \\
\hline $\begin{array}{l}\text { Сибирская язва } \\
\text { (кожная форма) }\end{array}$ & $\begin{array}{l}\text { Bacillus } \\
\text { anthracis }\end{array}$ & $\begin{array}{l}\text { Ципрофоксацин, } \\
\text { Амоксициллин или } \\
\text { Доксициллин }\end{array}$ & бензилпенициллин \\
\hline Чума & Yersinia pestis & $\begin{array}{l}\text { Гентамицин + } \\
\text { Ампициллин, } \\
\text { Цефтриаксон, } \\
\text { Рифампицин }\end{array}$ & $\begin{array}{l}\text { Тетрациклины, } \\
\text { Ципрофлоксацин }\end{array}$ \\
\hline Туляремия & $\begin{array}{l}\text { Francisela } \\
\text { tularensis }\end{array}$ & $\begin{array}{l}\text { Гентамицин, } \\
\text { Цефалоспорины, } \\
\text { Амикацин }\end{array}$ & $\begin{array}{l}\text { Хлорамфеникол, } \\
\text { тетрациклины }\end{array}$ \\
\hline Бруцеллез & $\begin{array}{l}\text { Бактерии рода } \\
\text { Brucella }\end{array}$ & $\begin{array}{l}\text { Тетрациклины, } \\
\text { Рифампицин }\end{array}$ & $\begin{array}{l}\text { Аминогликозиды, } \\
\text { фторхинолоны }\end{array}$ \\
\hline Лептоспироз & $\begin{array}{l}\text { Анаэробы рода } \\
\text { Leptospirae }\end{array}$ & $\begin{array}{l}\text { Бензилпенициллины, } \\
\text { Цефалоспорины }\end{array}$ & $\begin{array}{l}\text { Тетрациклины, } \\
\text { Хлорамфеникол }\end{array}$ \\
\hline Скарлатина & S. pyogenes & Пенициллины & Макролиды \\
\hline $\begin{array}{l}\text { Менингококковая } \\
\text { инфекция }\end{array}$ & $\begin{array}{l}\text { Neisseria } \\
\text { meningitidis }\end{array}$ & $\begin{array}{l}\text { Цефалоспорины, } \\
\text { Ампицилин, } \\
\text { Хлорамфеникол }\end{array}$ & $\begin{array}{l}\text { Ципрофлоксацин, } \\
\text { карбопенемы }\end{array}$ \\
\hline Дифтерия & $\begin{array}{l}\text { Corynebacteriu } \\
\mathrm{m} \\
\text { diphtheriae } \\
\end{array}$ & Бензилпенициллин & $\begin{array}{l}\text { Рифампицин, } \\
\text { Эритромицин }\end{array}$ \\
\hline $\begin{array}{l}\text { Коклюш и } \\
\text { паракоклюш }\end{array}$ & $\begin{array}{l}\text { Bordetella } \\
\text { pertussis }\end{array}$ & $\begin{array}{l}\text { Макролиды, } \\
\text { Цефтриаксон }\end{array}$ & \\
\hline Легионеллез & $\begin{array}{l}\text { Legionella } \\
\text { pneumophila }\end{array}$ & $\begin{array}{l}\text { Ампициллин, } \\
\text { Рифампицин, } \\
\text { Эритромицин }\end{array}$ & Фторхинолоны \\
\hline Тонзилит & $\begin{array}{l}\text { Streptococcus } \\
\text { pyogenes }\end{array}$ & $\begin{array}{l}\text { Пенициллины, } \\
\text { аминопенециллины }\end{array}$ & ИП, макролиды \\
\hline
\end{tabular}


Таблица 79 (продолжение)

Применение антибактериальных средств при заболеваниях человека

\begin{tabular}{|c|c|c|c|}
\hline Заболевание & $\begin{array}{c}\text { Основной } \\
\text { возбудитель }\end{array}$ & $\begin{array}{c}\text { Первоочередной } \\
\text { антибиотик }\end{array}$ & Антибиотики резерва \\
\hline Клещевой боррелиоз & $\begin{array}{l}\text { Бактерии рода } \\
\text { Borrelia }\end{array}$ & $\begin{array}{l}\text { Тетрациклины, } \\
\text { цефалоспорины }\end{array}$ & Пенициллины \\
\hline $\begin{array}{l}\text { Эпидемический } \\
\text { сыпной тиф }\end{array}$ & Rickettsia prowazekii & Тетрациклины & $\begin{array}{l}\text { Рифампицин, } \\
\text { макролиды }\end{array}$ \\
\hline $\begin{array}{l}\text { Клещевой } \\
\text { риккетсиоз }\end{array}$ & Rickettsia sibirica & Тетрациклины & $\begin{array}{l}\text { Рифампицин, } \\
\text { макролиды }\end{array}$ \\
\hline $\begin{array}{l}\text { Брюшной тиф, } \\
\text { паратифы }\end{array}$ & Salmonella typhi & $\begin{array}{l}\text { Хинолоны: } \\
\text { Ципрофлоксацин, } \\
\text { Офлоксацин }\end{array}$ & $\begin{array}{l}\text { Цефалоспорины III } \\
\text { поколения+аминоглик } \\
\text { озиды: } \\
\text { Цефтриаксон + } \\
\text { Амикацин }\end{array}$ \\
\hline Шигеллезы & Shigella & $\begin{array}{l}\text { Ципрофлоксацин, } \\
\text { Норбактин, } \\
\text { Рифаксимин }\end{array}$ & $\begin{array}{l}\text { Цефалоспорины III } \\
\text { поколения }\end{array}$ \\
\hline $\begin{array}{l}\text { Сальмонеллезы } \\
\text { (тяжелая степень, } \\
\text { генерализованные } \\
\text { формы) }\end{array}$ & $\begin{array}{l}\text { Бактерии рода } \\
\text { Salmonella }\end{array}$ & $\begin{array}{l}\text { Ципрофлоксацин, } \\
\text { Рифаксимин }\end{array}$ & Фторхинолоны \\
\hline Иерсиниозы & $\begin{array}{l}\text { Yersinia } \\
\text { enterocolitica }\end{array}$ & $\begin{array}{l}\text { Тетрациклины, } \\
\text { фторхинолоны, } \\
\text { Рифампицин }\end{array}$ & $\begin{array}{l}\text { Цефалоспорины III } \\
\text { поколения }\end{array}$ \\
\hline эшерихиозы & $\begin{array}{l}\text { Бактерии рода } \\
\text { Escherichia }\end{array}$ & $\begin{array}{l}\text { Нифуроксазид, } \\
\text { Рифаксимин }\end{array}$ & $\begin{array}{l}\text { Цефалоспорины II-III } \\
\text { поколения }\end{array}$ \\
\hline Кампилобактериозы & Campylobacter & $\begin{array}{l}\text { Тетрациклины, } \\
\text { Рифаксимин }\end{array}$ & Фторхинолоны \\
\hline Ботулизм & $\begin{array}{l}\text { Clostridium } \\
\text { botulinum }\end{array}$ & Тетрациклины & Хлорамфеникол \\
\hline Холера & Vibrio cholerae & Тетрациклины & Рифаксимин \\
\hline
\end{tabular}

Оптимальной является комбинация двух бактерицидных, антибактериальных средств. 
При лечении бактериальных инфекций с внутриклеточной локализацией возбудителя следует учитывать разную степень проникновения антибактериальных препаратов в клетку. Наиболее активны макролиды и фторхинолоны, которые хорошо проходят в клетку и оказывают антибактериальный эффект на внутриклеточные бактерии. При инфекциях центральной нервной системы важно, чтобы антибактериальный препарат хорошо проникал через гематоэнцефалический барьер, это Хлорамфеникол, сульфаниламиды, Ко-тримоксазол, нитроимидазолы, Флуконазол. Только при воспалении проникают - пенициллины, цефалоспарины и тетрациклины.

Продолжительность антибактериальной терапии зависит от клинического течения нозологической формы. Обычно продолжительность антибиотикотерапии 7 - 10 дней. При острых кишечных инфекциях (шигеллез, эшерихиозы, кампилобактериозы) антибиотики применяются до 5-7 суток, а при брюшном тифе, иерсиниозе - до 10 дня нормальной температуры. Оценка эффективности проводимой терапии проводится через 48 - 72 ч. после ее начала. При правильном выборе антибиотика температура тела и лейкоцитарная формула нормализуются в течение $2-4$ суток. Если через 48 ч (реже 72) делается вывод о неэффективности проводимой терапии, необходима коррекция лечения.

Выбор антибиотика второго ряда является не менее ответственным и чаще всего осуществляется по клиническим данным, так как в эти сроки возбудитель обычно культурально не установлен. Если он установлен, и антибиотик первого ряда не соответствовал биологической чувствительности микроорганизма, самое простое решение - назначение антибиотика соответствующего спектра действия. Сложнее решается вопрос, если установленный возбудитель входил в спектр действия антибиотика, но терапевтический эффект не получен. Вариантами решений могут быть: увеличение дозы применявшегося антибиотика; назначение препарата другой группы, но сходного спектра действия; использование антибиотиков с ингибиторами $\beta$-лактамаз.

В большинстве случаев антибиотики используются в среднетерапевтических дозах. Уменьшение дозировок препаратов допустимо только при почечной недостаточности и в зависимости от степени, которой редуцируется доза. При лечении септической или осложненной инфекции нередко используются высшие дозы антибактериальных средств, введение которых начинается, как правило, парентерально. Пероральная терапия возможна, если она обеспечивает необходимые концентрации в сыворотке крови и тканях или когда высокие концентрации антибиотика уже не требуются. При циклических, но не рецидивирующих инфекциях антибактериальный препарат можно отменить через 1 - 2 дня после получения клинического эффекта. При циклических, но рецидивирующих болезнях антибактериальное лечение продолжают столько времени, сколько болезнь протекала бы без этиотропной 
терапии. При ациклических инфекциях, к числу которых относится сепсис, а также большинство заболеваний, вызванных условно-патогенной флорой, антибактериальные препараты назначают в эмпирически установленные оптимальные сроки с учетом клинического выздоровления.

При лечении антибактериальными препаратами необходимо иметь в виду вторичную резистентность микроорганизмов. К $\beta$-лактамам, тетрациклинам, линкозамидам, левомицетину, ванкомицину, фосфомицину, фторхинолонам, нитрофуранам, нитроимидазолам вторичная устойчивость развивается медленно («пенициллиновый» вид резистентности), а к аминогликозидам, макролидам, рифамицинам, фузидину, производным 8-оксихинолина, хинолонам I и II поколения - быстро («стрептомициновый» вид резистентности). Поэтому эти препараты следует назначать курсом не более $5-7$ дней или комбинировать с другими антибактериальными препаратами.

При планировании комплексной этиопатогенетической терапии необходимо учитывать взаимное усиление возможных побочных (нежелательных) эффектов антибиотиков, патогенетических препаратов и алкоголя. Данные о несовместимости лекарственных веществ с антибиотиками указаны в инструкциях к этим препаратам и комбинации указанных препаратов не рекомендуют для применения на практике, поскольку они в той или иной степени неблагоприятны для пациентов.

Иногда коррекция антибактериальной терапии требуется не из-за неэффективности препарата, а в связи с развитием побочных эффектов. Отмена применяемого антибиотика нужна во всех случаях развития аллергических реакций (нередко аллергические реакции возникают на 6 - 7-й день лечения). Если в этот период продолжение химиотерапии необходимо по жизненным показаниям, то следует продлить лечение препаратами других групп (препараты «резерва»). В частности, если проявилась реакция на пенициллины, то рискованно лечить любым $\beta$-лактамным антибиотиком (цефалоспорины, карбапенемы). При токсических побочных эффектах производится замена препарата на антибиотики, которым не свойственны отмеченные нежелательные явления. Наиболее часто при антибактериальной терапии развивается дисбактериоз. Если проводимая терапия эффективна и есть необходимость ее продолжать, то отменять антибиотик не следует. Обычно, в зависимости от конкретных обстоятельств, назначаются противогрибковые препараты или средства, нормализующие флору кишечника.

Одним из рациональных подходов к применению антимикробной терапии является ступенчатая терапия (двухэтапное применение антиинфекционных препаратов) - переход c парентерального на не парентеральный (чаще пероральный) путь введения в возможно более короткие сроки с учетом клинического состояния больного. Следует иметь в виду, что угрожающие 
жизни инфекции (бактериальный эндокардит, менингит и др.), на протяжении почти всего курса антибактериальной терапии требуют парентерального назначения антибиотиков, тогда как при кишечных инфекциях могут быть с самого начала препараты прописаны перорально.

Важным фактором при ступенчатой терапии является срок перевода больного на пероральный путь введения антибиотика; ориентиром могут служить стадии инфекции. Выделяют три стадии инфекционного процесса у больных, находящихся на стационарном лечении:

I стадия продолжается 2-3 дня и сопровождается нестабильной клинической картиной: возбудитель и его чувствительность к антибиотику, как правило, не известны, антибактериальная терапия носит эмпирический характер, поэтому чаще всего назначают препарат широкого спектра действия;

На II стадии клиническая картина стабилизируется или улучшается, возбудитель и его чувствительность могут быть установлены, что позволяет провести коррекцию терапии;

На III стадии (примерно через 7 дней от начала заболевания) наступает выздоровление, и антибактериальная терапия завершается.

Оптимальным временем для перевода больного на пероральную терапию является II стадия инфекционного процесса. Выделяют клинические, микробиологические и фармакологические критерии перевода на второй этап ступенчатой терапии при следующих клинических критериях - отсутствие лихорадки (температура тела $<38^{\circ} \mathrm{C}$ в течение 24-48 ч) и нарушения всасывания в ЖКТ, тенденция к нормализации клинического анализа крови, СРБ отрицательный, улучшение/стабилизация клинической картины, возможность перорального приема пищи и жидкости. Хорошо если к этому времени выделен возбудитель и определена его чувствительность к антибиотику.

Побочное действие антибиотиков. Клинические проявления аллергических реакций выражаются в виде анафилактического шока, поражения кожи, слизистых оболочек, отека Квинке, астматического бронхита.

Проявления токсических реакций характеризуются четкой симптоматикой и возникают чаще аллергических. При приеме аминогликозидов могут развиваться: неврит слухового нерва, поражение зрительного нерва, вестибулярные расстройства, полиневрит, токсическое поражение почек. Тетрациклины, Рифампицин, Эритромицин, сульфаниламиды обладают гепатотоксичным действием. Патологическое влияние на кроветворную систему могут оказывать Хлорамфеникол, Рифампицин, Стрептомицин. Токсически действуют на ЖКТ Тетрациклин, Эритромицин, Амфотерицин и др.

Противомикробные препараты могут вызвать дисбактериоз, снижение напряженности иммунного ответа организма. Вследствие подавления нормальной микрофлоры кишечника может развиться гиповитаминоз. 


\section{Фаготерапия}

Бактериофаги представляют собой вирусы, избирательно поражающие бактериальные клетки. Их жизнедеятельность и репродукция возможна только внутри бактериальных клеток. Размножаясь внутри клетки, они вызывают разрушение и гибель самой бактерии. В отличие от антибиотиков, бактериофаги не уничтожают полезную микрофлору и не вызывают развитие дисбактериоза. Препараты можно принимать на длительной основе и не бояться появления резистентности патогенных микроорганизмов к действующим компонентам (табл. 80).

Таблица 80

\section{Виды бактериофагов и их использование}

\begin{tabular}{|c|c|c|}
\hline Бактериофаг & Возбудитель & Заболевание \\
\hline Брюшнотифозный & Сальмонеллы & Брюшной тиф \\
\hline Дизфаг & Шигеллы & Дизентерия \\
\hline $\begin{array}{l}\text { Клебсифаг } \\
\text { клебсиеллезный, } \\
\text { поливалентный }\end{array}$ & Клебсиелл & $\begin{array}{lc}\text { Урогенитальной, } & \text { пищеварительной, } \\
\text { дыхательной системы, генерализованных } \\
\text { септических патологий, хирургических } \\
\text { инфекций, cпровоцированных } \\
\text { клебсиеллами пневмонии }\end{array}$ \\
\hline Колифаг & E. Coli & $\begin{array}{l}\text { Любых инфекций внутренних органов и } \\
\text { кожи, вызванных энтеропатогенной } \\
\text { кишечной палочкой }\end{array}$ \\
\hline Колипротеофаг & $\begin{array}{l}\text { Бактерии протея и } \\
\text { эшерихий }\end{array}$ & 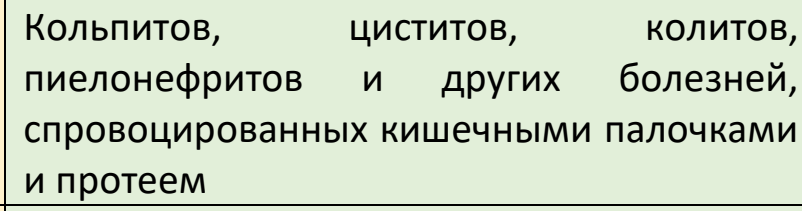 \\
\hline Протеофаг & $\begin{array}{l}\text { Протеи мирабилис } \\
\text { и вульгарис }\end{array}$ & $\begin{array}{l}\text { Гнойных } \\
\text { кишечника }\end{array}$ \\
\hline Синегнойный & $\begin{array}{l}\text { Псевдомонас } \\
\text { аэругиноза }\end{array}$ & $\begin{array}{l}\text { Дисбактериоз, инфекции, } \\
\text { спровоцированные синегнойной палочкой }\end{array}$ \\
\hline Стафилофаг & Стафилококки & Любые гнойные инфекции \\
\hline Стрептофаг & Стрептококк & Активен в отношении стрептококков \\
\hline \multicolumn{3}{|c|}{ Комбинированные } \\
\hline Интести & \multicolumn{2}{|c|}{$\begin{array}{l}\text { Сальмонеллы, шигеллы, кишечные палочки, стафилококки, } \\
\text { энтерококки, псевдомонас аэругиноза и протей }\end{array}$} \\
\hline Пиополифаг & \multicolumn{2}{|c|}{ От стрептококков } \\
\hline Секстафаг & \multicolumn{2}{|c|}{$\begin{array}{l}\text { Пиобактериофаг поливалентный (дополнительно убивает } \\
\text { эшерихии коли) }\end{array}$} \\
\hline $\begin{array}{l}\text { Комплексный } \\
\text { пиобактериофаг }\end{array}$ & \multicolumn{2}{|c|}{ 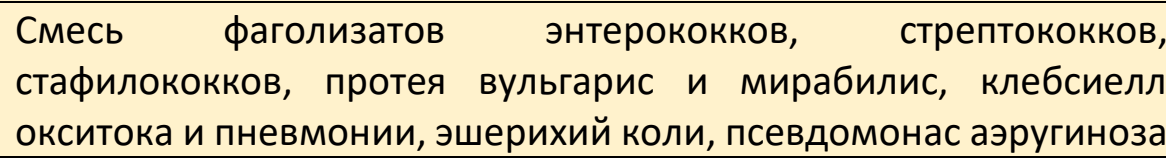 } \\
\hline
\end{tabular}


При повторном выделении возбудителя и отсутствии клинических проявлений болезни лечение антибиотиками или химиопрепаратами не показано, в таких случаях используют фаготерапию в возрастных дозировках, стимулирующую терапию, биологические препараты.

При получении результатов бактериологического обследования в качестве этиотропной терапии ОКИ могут применяться специфические бактериофаги (сальмонеллезный, дизентерийный, стафилококковый, коли-протейный и др.).

Фаги назначают за 1-1,5 часа до еды 2 раза в день в сочетании с ректальным введением 1 раз в сутки после опорожнения кишечника, курс лечения 5 - 7 дней.

Противогрибковые химиопрепараты. Это достаточно обширный класс разнообразных химических соединений как природного происхождения, так и полученных путем химического синтеза, обладающих специфической активностью в отношении патогенных грибов. В зависимости от химической структуры они разделяются на несколько групп, отличающихся по особенностям спектра активности, фармакокинетике и клиническому применению при различных грибковых инфекциях (табл.81).

Таблица 81

\section{Классификация противогрибковых препаратов}

\begin{tabular}{|c|c|c|}
\hline Группы препаратов & Локального действия & Системные \\
\hline $\begin{array}{l}\text { Полиены. } \\
\text { Природные антимикотины } \\
\text { используемые преимущественно для } \\
\text { лечения тяжелых системных микозов }\end{array}$ & \multicolumn{2}{|l|}{$\begin{array}{l}\text { Нистатин, } \\
\text { Леворин, } \\
\text { Натамицин, } \\
\text { Амфотерицин В, } \\
\text { Амфотерицин В липосомальный }\end{array}$} \\
\hline $\begin{array}{l}\text { Азолы. } \\
\text { Синтетические антимикотики с широким } \\
\text { спектром лечения грибковых инфекций }\end{array}$ & $\begin{array}{l}\text { Клотримазол, } \\
\text { Миконазол, } \\
\text { Бифоназол, } \\
\text { Эконазол, } \\
\text { Изоконазол, } \\
\text { Оксиконазол }\end{array}$ & $\begin{array}{l}\text { Кетоконазол, } \\
\text { Флуконазол, Итраконазол, } \\
\text { Вориконазол }\end{array}$ \\
\hline $\begin{array}{l}\text { Аллиламины. } \\
\text { Синтетические антимикотики для } \\
\text { лечения дерматомикозов }\end{array}$ & Нафтифин & Тербинафин \\
\hline $\begin{array}{l}\text { Эхинокандины. } \\
\text { Как препараты выбора при большинстве } \\
\text { клинических форм инвазивных микозов }\end{array}$ & & $\begin{array}{l}\text { Каспофунгин, } \\
\text { Микафунгин, } \\
\text { Анидулафунгин }\end{array}$ \\
\hline Препараты разных групп & $\begin{array}{l}\text { Аморолфин, } \\
\text { Циклопирокс, } \\
\text { Ундецин (Нитрофунгин), } \\
\text { антисептики }\end{array}$ & $\begin{array}{l}\text { Гризеофульвин, } \\
\text { калия йодид, } \\
\text { Флуцитозин }\end{array}$ \\
\hline
\end{tabular}

С клинической точки зрения препараты необходимо применять в зависимости от формы грибковых заболеваний (микозов) (табл.82). 
Таблица 82

\section{Спектр действия противогрибковых препаратов}

\begin{tabular}{|l|l|l|}
\hline $\begin{array}{c}\text { Системные (глубокие) } \\
\text { микозы }\end{array}$ & $\begin{array}{l}\text { Поверхностные микозы } \\
\text { (дерматомикозы) }\end{array}$ & \multicolumn{1}{|c|}{ Кандидамикозы } \\
\hline $\begin{array}{l}\text { Кокцидиомикоз, криптококкоз, } \\
\text { гистоплазмоз, бластомикоз }\end{array}$ & $\begin{array}{l}\text { Грибковые поражения кожи, } \\
\text { ногтей, волос, вызванные } \\
\text { дерматофитами в т.ч. } \\
\text { стригущий лишай (трихофития, } \\
\text { микроспория), парша и } \\
\text { грибковые заболевания стоп } \\
\text { (эпидермофития) }\end{array}$ & $\begin{array}{l}\text { Инфекции, вызванные Саndida } \\
\text { albicans поражающие слизистые } \\
\text { оболочек рта, глотки, кишечника, } \\
\text { бронхов, наружных половых } \\
\text { органов, может быть } \\
\text { кандидамикозный сепсис }\end{array}$ \\
\hline $\begin{array}{l}\text { Амфотерицин В, Микогептин, } \\
\text { Миконазол, Кетоконазол, } \\
\text { Флуконазол, Итраконазол }\end{array}$ & $\begin{array}{l}\text { Гризеофульвин, Тербинафин, } \\
\text { Клотримазол, Миконазол, } \\
\text { Эконазол, Кетоконазол, } \\
\text { Тербинафин, Нитрофунгин }\end{array}$ & $\begin{array}{l}\text { Амфотерицин В, Нистатин, } \\
\text { Леворин, Флуконазол, } \\
\text { Клотримазол, Миконазол, } \\
\text { Тербиафин }\end{array}$ \\
\hline
\end{tabular}

Противопротозойные препараты. Класс препаратов предназначенных для лечения инфекций, вызванных одноклеточными простейшими. В России наиболее распространенными из них являются ляблиоз, токсоплазмоз, трихомониаз, в мире - малярия, лейшманиоз, амёбиаз, трипаносомозы. В связи с большим распространением ВИЧ-инфекции актуальность приобретают криптоспоридиоз, изоспороз, пневмоцистоз. Основные группы препаратов и спектр их действия представлен в таблице (табл.98).

Таблица 98

\section{Спектр действия противопротозойных препаратов}

\begin{tabular}{|c|c|c|c|c|c|c|c|c|c|c|}
\hline Препараты & 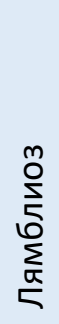 & 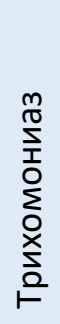 & 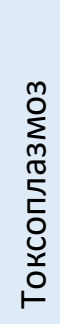 & 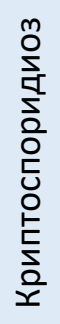 & 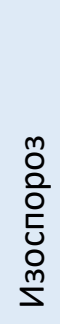 & 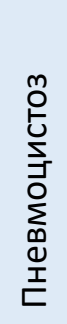 & 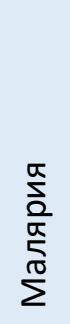 & 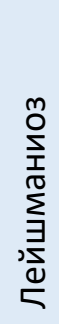 & 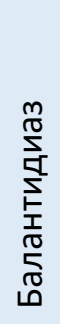 & 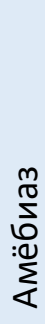 \\
\hline Хинолины & + & & & & & & + & & & + \\
\hline Бигуаниды & & & 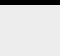 & & & & + & & & \\
\hline Диаминопиримидины & & & + & & & & + & & & \\
\hline Фенантренметанолы & & & & & & & + & & & \\
\hline Терпенлактоны & & & 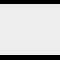 & & & & + & & & \\
\hline Сульфаниламиды & & & + & & + & + & + & & & \\
\hline Тетрациклины & & & & & & & + & & + & \\
\hline Линкозамиды & & & + & & & + & + & & & \\
\hline Аминогликозиды & & & & + & & & & + & & + \\
\hline Нитроимидазолы & + & + & & & + & & & & + & + \\
\hline Макролиды & & & + & + & & & & & & \\
\hline Милтефозин & & & & & & & & + & & \\
\hline
\end{tabular}


К хинолинам относятся - Хлорохин, Хинин, Мефлохин, Примахин, Тафенохин, к бигуанидинам - Прогуанил к диаминопиримидинам Пириметамин, фенантренметанолам - Галофантрин, к терпенлактонам Артемизинин и его производные, к сульфаниламидам - Сульфадоксин, Котримоксазол, к тетрациклинам - Тетрациклин, Доксициклин, к линкозамидам Клиндамицин, к аминогликозидам - Паромомицин, к нитроимидазолам Метронидазол, Тинидазол, Орнидазол, Секнидазол, к макролидам - Спирамицин, Азитромицин, Кларитромицин

Противоглистные средства. Арсенал препаратов, используемых при гельминтозах достаточно небольшой. Можно выделить производные бензимидазола (Мебендазол, Албендазол) и препараты других химических групп (Пирантела памоат, Диэтилкарбамазин, Никлозамид, Празиквантел) (табл.99).

Схемы применения этих препаратов приведены в таблице (табл.100).

Противогельминтный эффект производных бензимидазола обусловлен нарушением синтеза клеточного тубулина, нарушением биоэнергетики гельминтов и, как следствие, парализующим действием. И если Мебендазол (Вермокс) всасывается плохо (не более 10\%), то Альбендазол (Немозол) обладает более высокой биодоступностью в тканях и способен проникать через ГЭБ и внутрь личиночных кист (при эхинококкозе, цистицеркозе). Производное пиримидина Пирантел на гельминтов действует как деполяризующий миорелаксант.

Выраженным антигельминтным действием при многих гельминтозах обладает производное изохинолина Празиквантель (Бильтрицид). Его действие обусловлен генерализованным сокращением мускулатуры паразитов с последующим развитием стойкого паралича. Альтернативой при лечении ленточных гельминтов является Никлозамид (Фенасал), производное салициланилида. Действие препарата связано с развитием паралича у гельминтов и уменьшением их устойчивости к протеолитическим ферментам ЖКТ.

\section{Коррекция дисбактериоза}

Как описывалось выше нарушение состава микробной флоры связано с нарушениями функции иммунной системы организма человека. Поэтому нормализация кишечного дисбактериоза, может быть, одним из основных мероприятий по коррекции иммунных нарушений. При этом необходимо решить следующие задачи:

1. Нормализовать работу кишечника (избавить больного от поносов и/или запоров); 
Таблица 99

\section{Антигельминтные препараты}

\begin{tabular}{|c|c|c|c|c|c|c|c|}
\hline \multicolumn{2}{|c|}{ Гельминтоз } & \multicolumn{2}{|c|}{$\begin{array}{c}\text { Производные } \\
\text { бензимидазола }\end{array}$} & \multirow[b]{2}{*}{ 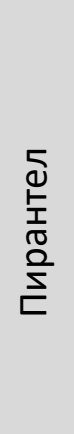 } & \multirow[b]{2}{*}{ 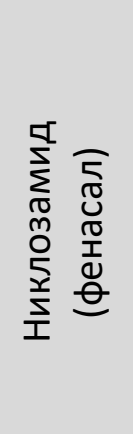 } & \multirow{2}{*}{ 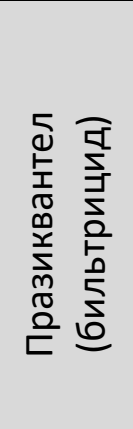 } & \multirow[b]{2}{*}{ 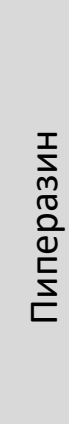 } \\
\hline Заболевание & Гельминт & 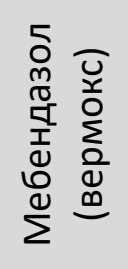 & 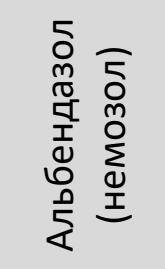 & & & & \\
\hline \multicolumn{8}{|c|}{ Круглые черви } \\
\hline Аскаридоз & Аскарида & + & + & + & & & + \\
\hline Энтеробиоз & Острица & + & + & + & & & + \\
\hline Анкилостомоз & Анкилостома & + & + & & & & \\
\hline Трихоцефалёз & Власоглав & + & + & & & & \\
\hline Трихинеллез & Трихинелла & + & 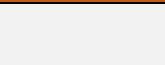 & & & & \\
\hline Дирофиляриоз & Дирофилярии & 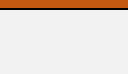 & + & & & & \\
\hline \multirow[t]{2}{*}{ Токсокароз } & Личинка & + & + & & & & \\
\hline & Кишечная форма & & & + & & & \\
\hline Стронгилоидоз & Угрица кишечная & + & + & & & & \\
\hline \multicolumn{8}{|c|}{ Плоские ленточные черви } \\
\hline Дифиллоботриоз & Широкий лентец & & & & + & + & \\
\hline Тениаринхоз & Бычий цепень & & & & + & + & \\
\hline Тениоз & Свиной цепень & & & & & + & \\
\hline Цистицеркоз & & & + & & & + & \\
\hline Гименолепидоз & Карликовый цепень & & & & & + & \\
\hline Эхинококкоз & Эхинококк & & + & & & & \\
\hline \multicolumn{8}{|c|}{ Плоские черви сосальщики } \\
\hline Описторхоз & Кошачья двуустка & & + & & & + & \\
\hline Клонорхоз & Двуустка китайская & & & & & + & \\
\hline Фасциолёз & Печеночная двуустка & & + & & & + & \\
\hline Шистосомоз & Шистосома & & & & & + & \\
\hline
\end{tabular}


Таблица 100

\section{Схемы применения основных антигельминтных препаратов}

\begin{tabular}{|c|c|c|}
\hline Препарат & Заболевание & Схема применения \\
\hline \multirow{4}{*}{ 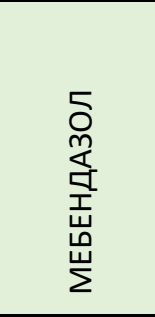 } & $\begin{array}{l}\text { Аскаридоз, } \\
\text { трихоцефалез }\end{array}$ & От 2 лет в дозе 100 мг два раза в день в течение 3-х дней \\
\hline & Энтеробиоз & В дозе 100 мг однократно в один прием, через 2 нед. повторить \\
\hline & Токсокароз & $\begin{array}{l}\text { Взрослым по } 100 \text { мг два раза в день, детям - } 5 \text { мг/кг/сут. курс 7-10 дней; при } \\
\text { необходимости повторить }\end{array}$ \\
\hline & Трихинеллез & $\begin{array}{l}\text { Взрослым по } 100 \text { мг три раза в день, детям - } 5 \text { мг/кг/сут. в два приема } \\
\text { курсом 7-14 дней }\end{array}$ \\
\hline \multirow{4}{*}{ 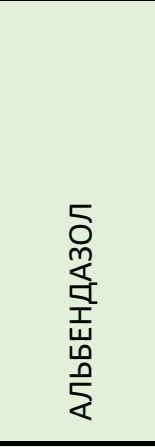 } & $\begin{array}{l}\text { Аскаридоз, } \\
\text { энтеробиоз }\end{array}$ & $\begin{array}{l}\text { От } 2 \text { лет и старше в дозе } 5 \text { мг/кг массы или } 400 \text { мг для взрослых однократно } \\
\text { в один прием или в два приема после еды }\end{array}$ \\
\hline & $\begin{array}{l}\text { Трихоцефалез, } \\
\text { стронгилоидоз }\end{array}$ & $\begin{array}{l}\text { От } 2 \text { лет и старше в дозе } 10 \text { мг/кг массы или } 400 \text { мг для взрослых } \\
\text { однократно в один прием } 3 \text { дня. Через неделю повторить }\end{array}$ \\
\hline & $\begin{array}{l}\text { Токсокароз, } \\
\text { трихинеллез }\end{array}$ & $\begin{array}{l}\text { От } 14 \text { лет с массой тела более } 60 \text { кг по } 400 \text { мг } 2 \text { раза в день, менее } 60 \text { кг - по } \\
200 \text { мг } 2 \text { раза в день. Дети } 10 \text { мг/кг /сут. в } 2 \text { приема. Курс от } 7 \text { до } 14 \text { дней. } \\
\text { Повторно с интервалом в 2-4 нед. }\end{array}$ \\
\hline & $\begin{array}{l}\text { Эхинококкоз, } \\
\text { цистицеркоз }\end{array}$ & $\begin{array}{l}\text { От } 14 \text { лет с массой тела более } 60 \text { кг по } 400 \text { мг } 2 \text { раза в день, менее } 60 \text { мг - из } \\
\text { расчета } 15 \text { мг/кг/сут. } 2 \text { раза в день. Курс терапии } 28 \text { дней. } 3 \text { курса терапии с } \\
\text { интервалом в } 14 \text { дней. }\end{array}$ \\
\hline 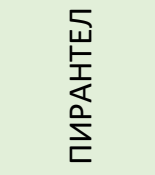 & $\begin{array}{l}\text { Аскаридоз, } \\
\text { энтеробиоз, } \\
\text { стронгилоидоз }\end{array}$ & $\begin{array}{l}\text { В дозе } 10 \text { мг/кг однократно в один прием, при стронгилоидозе - в течение } 3 \\
\text { дней }\end{array}$ \\
\hline \multirow{3}{*}{ 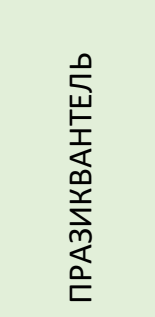 } & Описторхоз & $\begin{array}{l}\text { Из расчета } 40 \text { - } 75 \text { мг/кг массы при однодневном курсе в три приема с } \\
\text { интервалом четыре часа, после еды }\end{array}$ \\
\hline & $\begin{array}{l}\text { Тениоз, } \\
\text { тениаринхоз, } \\
\text { дифиллоботриоз }\end{array}$ & В дозе 25 мг/кг массы однократно \\
\hline & Гименолепидоз & 25 мг/кг в три приема через 6 ч в течение суток, через 2 недели повторить \\
\hline \multirow{2}{*}{ 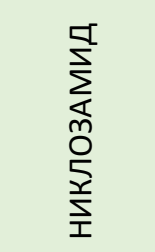 } & Тениоз & $\begin{array}{l}\text { Суточная доза для взрослых - 2-3 г принимают натощак с сахарным } \\
\text { сиропом, через } 2 \text { часа - солевое слабительное, через } 1 \text { месяц - прием } \\
\text { препарата повторить }\end{array}$ \\
\hline & $\begin{array}{l}\text { Тениаринхоз, } \\
\text { дифиллоботриоз }\end{array}$ & $\begin{array}{l}\text { Утром натощак или вечером через 3-4 часа после легкого ужина, через } 2 \\
\text { часа - солевое слабительное }\end{array}$ \\
\hline
\end{tabular}

2. Санировать кишечника от патогенной и условно-патогенной флоры (бактериофаги, кишечные антисептики, фитонциды и антибактериальные препараты);

3. Создать условия, способствующие более благоприятному развитию собственной флоры (аутофлоры) организма - коррекция нормальной микрофлоры кишечника с помощью различных пробиотиков, проведение энтеросорбции и энтеропротекции (карболен, полифепан, смекта и др.);

4. Обеспечить функциональное питание;

5. Сохранять и поддерживать микробную экологию кишечника. 
Санации кишечника от патогенной и условно-патогенной микрофлоры обязательна у пациентов с III и IV степенями тяжести дисбиотического процесса, с признаками микробной контаминация кишечника. Препараты назначают с учетом вида и чувствительности возбудителя. При острых диареях бактериальной этиологии применяются антибиотики, противомикробные средства из группы хинолонов (Нитроксолин), фторхинолонов (Офлоксацин, Ципрофлоксацин и др.), производные нитрофурана (Фурадонин, Фуразолидон). При хронических инфекциях предпочтение отдается кишечным антисептикам Интетрикс, Энтероседива нифуроксазид. Целесообразно одновременно с ними или отдельно назначать и лечебные бактериофаги. Решение о назначении того или иного антибиотика применяется с учетом лабораторных исследований в идеале с проведением антибиотикограммы. Как альтернатива предлагается при выявлении аэробных микроорганизмов пользоваться антибиотиками, при анаэробной - нитроимидозольными препаратами, при бактериальнокандидозном дисбалансе обязательно дополнительно антимикотики.

В комплексном лечении и как монотерапию при I II степени дисбиоза для санации кишечника предлагаются сборы трав: на 1 этапе - шалфей, календула, крапива, зверобой, тысячелистник, донник, ольха и бадан; затем на 2 этапе шиповник, крапива, смородина, клевер, элеутерококк, календул, рябина, анис и душиц.

Для восстановления нормальной микрофлоры кишечника применяют три группы препаратов: пробиотики, пребиотики, синбиотики (табл.101).

Пробиотики - живые микроорганизмы, которые, при назначении в адекватных количествах приносят пользу здоровью хозяина. C позиций QPS (Qualified Presumption of Safety - квалифицированная презумпция безопасности) пробиотики могут содержать либо один штамм, либо смесь двух или более штаммов бактерий. Это 5 видов бифидобактерий (Bifidobacterium spp.), 33 вида лактобактерий (Lactobacillus spp.), а также Lactoccocus lactis, Leuconostoc spp., Pediococcus spp., Propionibacterium freudenreichii u Streptococcus thermophilus.

Механизм действия пробиотиков связан с производством антимикробных веществ, ингибирование выработки бактериальных токсинов, иммуноактивное действие (по типу вакцины).

Пребиотики - субстрат, который избирательно используется микроорганизмами-хозяевами, приносящими пользу для здоровья. Это пищевые вещества, в основном состоящие из некрахмальных полисахаридов и олигосахаридов, плохо перевариваемых человеческими ферментами.

Синбиотики представляют собой комбинацию пробиотика и пребиотика, обладающих синергическим эффектом на физиологические функции и метаболизм человека в целом. 


\section{Препараты для восстановления нормальной микрофлоры кишечника}

\begin{tabular}{|c|c|}
\hline Препарат & Состав \\
\hline \multicolumn{2}{|r|}{ Пробиотики } \\
\hline Бифидумбактерин & Лиофильно высушенные Bifidobacterium bifidum $5 \times 10^{8} \mathrm{KOE}$ \\
\hline Лактобактерин & Лактобактерии ацидофильные менее 2 млрд KОЕ \\
\hline Колибактерин & Живые бактерий кишечной палочки не менее 1 млрд КОЕ \\
\hline Бактиспорин & Лиофилизированные живые бактерий Bacillus subtilis 1-5 млрд КОЕ \\
\hline Энтерол & Лиофилизированных Saccharomyces boulardii 250 мг \\
\hline Ацилакт сухой & L.acidophilus - 3 разных штамма \\
\hline Бификол & Кишечная палочка и бифидобактерий В. bifidum \\
\hline Биоспорин & Лиофильно высушенные живые B.subtilis и B.licheniformis \\
\hline Линекс & B.infantis, L.acidophilus, E. faecium \\
\hline Бифиформ & B. longum и E. faecium \\
\hline Пробифор & В. bifidum, адсорбированные на активированном угле \\
\hline Бифилиз сухой & B.bifidum и лизоцим (комбинированный пробиотик) \\
\hline \multicolumn{2}{|r|}{ Пребиотики } \\
\hline Инулин & Олигофруктоза \\
\hline Лактулоза & Олигосахариды \\
\hline Хилак форте & $\begin{array}{l}\text { Биосинтетическая молочная кислота и ее буферные соли и другие } \\
\text { короткоцепочечные летучие жирные кислоты }\end{array}$ \\
\hline Лактофильтрум & Двухкомпонентный препарат, состоящий из лактулозы и лигнина \\
\hline \multicolumn{2}{|r|}{ Синбиотики } \\
\hline Нормоспектрум & $\begin{array}{l}\text { Инулин, бифидобактерии и лактобациллы (9 штаммов), витамины (Е, С, В1, } \\
\text { В2, В6, В12 и пр.), минеральные вещества (цинк, селен) }\end{array}$ \\
\hline Бион-3 & $\begin{array}{l}\text { Пробиотические культуры (Lactobacillus gasseri Bifidobacterium bifidum } \\
\text { Bifidobacterium longum); витамины A, B1, B2, B6, B12, C, D3, Е, никотинамид, } \\
\text { пантотеновая кислота, фолиевая кислота, биотин; минеральные вещества } \\
\text { (фосфат, магний, железо, цинк, марганец, йод, селен, хром, молибден) }\end{array}$ \\
\hline Бифидум-Мульти & Бифидобактерии (6 штаммов), пектин яблочный; инулин \\
\hline Биовестин-лакто & $\begin{array}{l}\text { Bifidobacterium adolescentis (1 млрд KOЕ/мл); Lactobacillus plantarum (100 млн. } \\
\text { КОЕ/мл); продукты метаболизма бифидо- и лактобактерий }\end{array}$ \\
\hline ВитаФлор & $\begin{array}{l}\text { Лиофилизированные Lactobacillus acidophilus, аскорбиновая кислота (витамин } \\
\text { C) - 12,5 мг; молоко сухое обезжиренное; сахароза; желатин пищевой; } \\
\text { автолизат пекарских дрожжей; лукаротин ( } \beta \text {-каротин). }\end{array}$ \\
\hline Аципол & L.acidophilus и полисахариды кефирных грибков \\
\hline
\end{tabular}

В качестве одного из эффективных способов лечения, позволяющий полностью восстанавливать микробиоту кишечника, является фекальные трансплантация. Она показала высокую эффективность при терапии псевдомембранозного колита (CDI). В настоящее время рассматривается возможность его применения при других патологических состояниях (воспалительные заболевания кишечника, атеросклероз, неалкогольные жировые заболевания печени, ожирение, нервно-психические заболевания, микроорганизмы с множественной лекарственной устойчивостью). 
Задача поддержания нормального микробиоценоза толстой кишки осуществляется принципами функционального питания, включающего в себя прием пищевых волокон в различных формах, лечебных молочнокислых продуктов, содержащих ацидофильные бактерии и бифидобактерии (Бифидок, бифидумкефир, биойогурты). Кроме того, рекомендуется периодический, короткими курсами, прием Хилак форте, травяных чаев и сборов.

Для стабилизации микробиоценоза толстой кишки необходимо постоянное его поддерживание, так как после прекращения приема биологически активных препаратов бактериологическое обследование через $2-4$ нед. вновь выявляет состояние дисбактериоза в той или иной степени выраженности. С этой целью предложена методика пульстерапии: каждый последующий месяц на протяжении полугода пациенту проводят укороченные курсы лечения препаратами, которые использовались для первоначальной санации - кишечные антисептики $1-2$ дня, а затем бактериальные препараты $7-10$ дней. Одновременно продолжается постоянный прием витаминно-минеральных комплексов, травяных сборов, по показаниям применяются ферментные препараты. 


\section{Глава 15. Детоксикационная терапия и средства,}

\section{направленные на улучшение}

\section{реологии}

Первым и очень важным звеном «подготовки» к лечению пациентов с нарушениями функции иммунной системы является улучшить состояние межклеточного взаимодействия. Во многих случаях без этого этапа в лечении реакция на иммуномодулирующую терапию может быть неадекватной или даже парадоксальной. Под действием токсинов, микробных супрессивных белков, длительного избыточного воздействия АГ, оксидантов, провоспалительных цитокинов и других факторов меняются свойства мембран клеток иммунной и сопряженной с ними систем, блокируются рецепторы мембран. После длительной активации тех или иных клеток наступает фаза их супрессии.

Крайняя степень интоксикация проявляется в виде инфекционнотоксического шока (табл. 102).

Таблица 102

\section{Клиническое определение степеней инфекционно-токсического шока}

\begin{tabular}{|c|c|c|c|}
\hline $\begin{array}{l}\text { Критерии } \\
\text { тяжести }\end{array}$ & І степень & II степень & III степень \\
\hline Сознание & Возбуждение & Заторможенность & $\begin{array}{l}\text { Спутанное, } \\
\text { отсутствует }\end{array}$ \\
\hline Реакция зрачков & Сужены & \multicolumn{2}{|c|}{ Расширены, реакция вялая } \\
\hline Температура & Гипертермия & \multicolumn{2}{|c|}{ Критическое падение } \\
\hline Кожные покровы & $\begin{array}{c}\text { Цианоз губ и } \\
\text { ногтевых фаланг }\end{array}$ & $\begin{array}{l}\text { Акроцианоз, } \\
\text { холодный пот }\end{array}$ & $\begin{array}{l}\text { Тотальный } \\
\text { цианоз }\end{array}$ \\
\hline Дыхание & Не нарушено & Легкая одышка & Поверхностная \\
\hline АД & Норма & до 80 мм рт.ст. & менее 80 мм рт.ст. \\
\hline Пульс & $\begin{array}{l}\text { Умеренная } \\
\text { тахикардия }\end{array}$ & $\begin{array}{c}\text { Тахикардия } \\
\text { более } 100 \text { в минуту }\end{array}$ & $\begin{array}{l}\text { Нитевидный, } \\
\text { не определяется }\end{array}$ \\
\hline $\begin{array}{l}\text { Индекс Аллговера } \\
\text { (САД/пульс) }\end{array}$ & До 1,0 & $1-1,5$ & Более 1,5 \\
\hline Диурез & $\begin{array}{l}\text { Несколько } \\
\text { снижен }\end{array}$ & Олигоурия & Анурия \\
\hline $\begin{array}{l}\text { Геморрагический } \\
\text { синдром }\end{array}$ & Не характерен & \multicolumn{2}{|c|}{$\begin{array}{c}\text { Рвота «кофейной гущей», гематурия, } \\
\text { мелена, ДВС-синдром }\end{array}$} \\
\hline
\end{tabular}


Медикаментозные стимулирующие или модулирующие воздействия на таком фоне могут быть малоэффективны или даже вредны. Для предотвращения этих процессов используется детоксикационная терапия, средства для улучшения реологии крови.

Детоксикационная (эфферентная) терапия (от лат. efferens - выводить) метод лечения, направленный на выведение из организма токсических и балластных веществ, метаболитов.

Эндогенная интоксикация, свойственная большинству заболеваний, представляет собой основную точку приложения эфферентных методов. Влияние эфферентной терапии на патологические процессы не исчерпывается прямой детоксикацией. При некоторых состояниях целью применения таких методов лечения является необходимость коррекции иммунологических нарушений (путем выведения избытка ЦИК, иммунокомпетентных клеток, аутоантител). Практическое значение имеет также возможность направленной коррекции белкового и водно-электролитного состава крови.

Детоксикация - это комплекс лечебных мероприятий, проводимых с целью прекращения воздействия токсичных веществ и их удаления из организма. Достижению этой цели служит большое число методов, направленных на стимуляцию естественной детоксикации, а также проведение искусственной и антидотной дезинтоксикационной терапии.

Эфферентную терапию следует с полным основанием относить к этиопатогенетическим методам лечения, поскольку возможно связывание и удаление не только микробных токсинов, но и самих бактерий и вирусов. Вместе с тем такая терапия эффективна только в комплексе с обычным этиотропным и поддерживающим лечением соответственно нозологической форме заболевания.

В клинической практике методы детоксикации проводятся либо путем стимуляции естественной детоксикации, либо путем активной искусственной (эфферентная терапия).

Можно выделить следующие виды детоксикации: 1) стимуляция естественных процессов выведения - очищение ЖКТ, форсированный диурез; 2) неинвазивные методы эфферентной терапии; 3) инвазивные методы эфферентной терапии.

Как способ дезинтоксикации возможно также рассматривать описанные выше методы стимуляция биотрансформации - регуляция ферментативной функции гепатоцитов за счет фармакологической или физико-химической индукции или ингибиции, и стимуляция активности иммунной системы фармакологическая коррекция - физиогемотерапия.

К методам, направленным на усиление физиологической детоксикации, относятся очищение ЖКТ, форсированный диурез, регуляция активности ферментов, создание гипер- или гипотермии и др. При их проведении 
используются рвотные и слабительные средства, препараты, обеспечивающие водно-электролитную нагрузку, осмотические диуретики и салуретики. Следует отметить, что стимуляция естественных механизмов детоксикации возможна только при условии сохранения функции элиминирующих систем организма.

Стимуляция выведения токсинов.

Очищение желудочно-кишечного тракта - пищеварительная система поставляет питательные вещества и удаляет отработанные элементы, если в работе органов пищеварения происходят какие-то нарушения, происходят сбои в работе и других органов и систем. Одна из причин дисфункции пищеварительной системы связана с нарушением вывода продуктов обмена веществ и накоплением их в организме, что приводит к хронической эндогенной интоксикации. Прежде всего, при очищении кишечника большое значение имеет диета. Список запрещенных продуктов включает жирное мясо и мясопродукты, копчености, белый хлеб и кондитерские изделия, макаронные изделия и крупы (кроме, овсяной), жирное цельное молоко, творог, сахар, алкоголь. Обязательное условие: принимать не менее 2 - 3 л жидкости в день, а на ночь выпивать стакан любого кисломолочного продукта (кефир, йогурт, ряженка).

Большое значение имеет очищение кишечника и печени. Промывание кишечника через задний проход - постановка клизмы, один из древнейших способов очищения. В настоящее время арсенал промывания через задний проход весьма широк - от проведения микроклизм с введением небольших объемов, обычно лекарственных веществ, до сифонных клизм и промывания желудка с помощью специальной аппаратуры (гидроколонотерапия).

Достаточно эффективное средство для очищения и промывания желчных протоков - слепой тюбаж. Процедура помогает избавиться от застоя желчи и, как следствие, способствует выделению продуктов обмена веществ. Наиболее простой вид слепого тюбажа - с помощью минеральной воды. Процедуру лучше проводить рано утром, перед этим натощак (не едят минимум 6 ч) выпивают 250 - 300 мл минеральной воды, обладающей желчегонным действием (Ессентуки № 4). Предварительно из воды нужно выпустить все газы и подогреть до $36-38^{\circ}$ C, затем положить на область печени теплую грелку и лечь на правый бок. Воду в грелке нужно также обновлять. Необходимо допить минеральную воду (200 250 мл). Общая продолжительность процедуры 1,5 ч, эффектом будет являться разжиженный стул с зеленоватым оттенком. Помимо минеральной воды можно использовать раствор сернокислой магнезии (1 чайная ложка на стакан воды), мед (1 столовая ложка на стакан воды), яблочный сок, овсяный отвар, растительное масло с лимонным соком.

При детоксикации достаточно широко применяются внутривенные введения растворов. Однако, при этом необходимо учитывать распределение воды в организме, изменения других жидкостей и электролитов. 
Удельная масса воды в организме колеблется от 50 до $70 \%$. Она состоит из внутриклеточной жидкости, которая составляет примерно 40 \% от массы тела, и внеклеточной воды: внутрисосудистой, составляющей $5 \%$, и интерстициальной, составляющей $15 \%$ от массы тела. Водный баланс за сутки 2000 мл. Поступает в организм 1500 мл воды за счет питья и 500 мл-за счет еды. Выделяется 250 мл с испражнениями, $800-1500$ мл - с мочой и 600 мл неощутимые потери влаги. Изменения жидкостей в организме может осуществляться за счет трех причин: изменения объема, изменения концентрации ионов и изменения состава ионов. Дефицит объема жидкости наиболее частая проблема у хирургических больных и больных с инфекционной патологией (рис.174).

Причиной является потеря жидкости при рвоте, через свищи, при кровотечениях и перемещение жидкости в интерстициальное пространство при травмах и инфекционных процессах. Клинически при этом наблюдаются ортостатическая гипотензия, снижение диуреза и небольшое понижение температуры тела (табл. 103). Лечение заключается в восполнении циркулирующего объема плазмы изотоническими солевыми растворами. Важное значение при проведении регидратационной терапии принадлежит сохранению или восстановлению нормального состава ионов в плазме (натрий, калий, кальций). Прежде всего необходимо решить вопрос, требуется ли возмещение этих веществ в ходе инфузионной терапии.

Совместно с инфузионной терапией для проведения дезинтоксикационных мероприятий применяется форсированный диурез. Этот метод детоксикации основан на применении препаратов, способствующих возрастанию диуреза, и является наиболее распространенным методом удаления из организма токсических веществ.

Форсированный диурез всегда проводится в три этапа: предварительная водная нагрузка, быстрое введение диуретика и заместительная инфузия раствором электролитов. Обычно этот метод проводится на фоне интенсивно 


\section{Клинические проявления дегидратации}

\begin{tabular}{|c|c|c|c|c|}
\hline \multirow{2}{*}{$\begin{array}{l}\text { Клинические } \\
\text { проявления }\end{array}$} & \multicolumn{4}{|c|}{ Дегидратация: степень (потеря жижкости в \% от массы тела) } \\
\hline & I (до 3\%) & II (4-6\%) & III (7-9\%) & IV (более 9\%) \\
\hline $\begin{array}{l}\text { Общее } \\
\text { состояние }\end{array}$ & Не нарушено & $\begin{array}{l}\text { Слабость, } \\
\text { головокружение и } \\
\text { обмороки. } \\
\text { Температура тела } \\
\text { нормальная или } \\
\text { субфебрильная. } \\
\text { Кратковременные } \\
\text { судороги мышц }\end{array}$ & $\begin{array}{l}\text { Сознание сохранено, } \\
\text { жажда. За счет } \\
\text { развития ацидоза } \\
\text { (рН 7,3-7,36) } \\
\text { учащенное шумное } \\
\text { дыхание. Но } \\
\text { отсутствуют } \\
\text { вторичные } \\
\text { нарушения гемостаза } \\
\text { и органная патология }\end{array}$ & $\begin{array}{l}\text { Генерализованные } \\
\text { продолжительные } \\
\text { судороги, «рука } \\
\text { акушера», «конская } \\
\text { стопа»; судорожные } \\
\text { сокращения мышц } \\
\text { живота, икота. } \\
\text { Дыхание учащено, до } \\
60 \text { в мин. } \\
\text { поверхностное }\end{array}$ \\
\hline $\begin{array}{l}\text { Проявление со } \\
\text { стороны } \\
\text { желудочно- } \\
\text { кишечного } \\
\text { тракта }\end{array}$ & $\begin{array}{l}\text { Жидкий } \\
\text { кашицеобразный } \\
\text { до } 10 \text { раз в сутки, } \\
\text { не более } 3 \text { суток. } \\
\text { Рвоты нет }\end{array}$ & $\begin{array}{l}\text { Жидкий стул } \\
\text { обильный до 10-15 } \\
\text { раз в сутки. } \\
\text { Возможна рвота до } \\
10 \text { раз в сутки без } \\
\text { предшествующей } \\
\text { тошноты }\end{array}$ & $\begin{array}{l}\text { Обильный } \\
\text { водянистый стул 10- } \\
20 \text { раз в сутки, рвота } \\
\text { более } 20 \text { раз в сутки } \\
\text { при обезвоживании } \\
\text { рвота болезненная, } \\
\text { затруднена }\end{array}$ & $\begin{array}{l}\text { Непрерывная } \\
\text { дефекация («дорожка } \\
\text { фекальных масс»). } \\
\text { Обильная } \\
\text { мучительная рвота }\end{array}$ \\
\hline $\begin{array}{l}\text { Проявление со } \\
\text { стороны } \\
\text { сердечно- } \\
\text { сосудистой } \\
\text { системы }\end{array}$ & $\begin{array}{l}\text { АД в пределах } \\
\text { возрастной } \\
\text { нормы, } \\
\text { лабильность } \\
\text { пульса }\end{array}$ & $\begin{array}{l}\text { Тахикардия, } \\
\text { гипотония }\end{array}$ & $\begin{array}{l}\text { АД значительно } \\
\text { снижено. Пульс } \\
\text { частый, слабый }\end{array}$ & $\begin{array}{l}\text { АД резко снижено, } \\
\text { пульс не } \\
\text { определяется, на } \\
\text { периферических } \\
\text { сосудах. ЭКг - } \\
\text { диастолическая } \\
\text { перегрузка правых } \\
\text { отделов сердца }\end{array}$ \\
\hline Мочеиспускание & $\begin{array}{l}\text { Диурез не } \\
\text { изменен }\end{array}$ & Диурез не изменен & Олиго- или анурия & Анурия \\
\hline $\begin{array}{l}\text { Кожа и } \\
\text { слизистые }\end{array}$ & $\begin{array}{l}\text { Сухость слизистых } \\
\text { рта Кожа влажная, } \\
\text { тургор не } \\
\text { изменен, цианоза, } \\
\text { судорог нет }\end{array}$ & $\begin{array}{l}\text { Язык сухой, } \\
\text { обложен бурым } \\
\text { налетом, сухость во } \\
\text { рту, охриплый } \\
\text { голос. Бледность и } \\
\text { сухость кожных } \\
\text { покровов }\end{array}$ & $\begin{array}{l}\text { Кожа и слизистые } \\
\text { сухие, тургор кожи } \\
\text { снижен, кожная } \\
\text { складка медленно, } \\
\text { расправляется, кожа } \\
\text { рук морщинистая } \\
\text { («руки прачки»), } \\
\text { акроцианоз }\end{array}$ & $\begin{array}{l}\text { Кожные покровы } \\
\text { холодные, покрыты } \\
\text { липким потом, } \\
\text { тотальный цианоз, } \\
\text { «руки прачки», } \\
\text { кожная складка не } \\
\text { расправляется в } \\
\text { течение часа }\end{array}$ \\
\hline $\begin{array}{l}\text { Лабораторные } \\
\text { данные }\end{array}$ & $\begin{array}{l}\text { Показатели крови } \\
\text { (вязкость, } \\
\text { гематокрит, } \\
\text { электролиты) не } \\
\text { отклоняются от } \\
\text { нормы }\end{array}$ & $\begin{array}{l}\text { Нарушения } \\
\text { электролитного } \\
\text { состава крови } \\
\text { непостоянны, } \\
\text { наблюдается } \\
\text { гипокалиемия и } \\
\text { гипохлоремия }\end{array}$ & $\begin{array}{l}\text { Сгущение крови } \\
\text { умеренное, } \\
\text { гипокалиемия, } \\
\text { гипохлоремия, } \\
\text { компенсаторная } \\
\text { гипернатриемия }\end{array}$ & $\begin{array}{l}\text { Эритроцитоз, } \\
\text { лейкоцитоз, } \\
\text { гипокалиемия (до 2,5 } \\
\text { ммоль/л), } \\
\text { гипохлоремия, } \\
\text { гипонатриемия, } \\
\text { декомпенсированный } \\
\text { метаболический } \\
\text { ацидоз (рН < 7,3), } \\
\text { одновременно } \\
\text { респираторный } \\
\text { алкалоз малого круга } \\
\text { кровообращения }\end{array}$ \\
\hline
\end{tabular}


проводимой инфузионной терапии $1,0-1,5$ л 5 \%-й глюкозы, солевых и плазмозаменяющих растворов. Как мочегонное средство применяют мочевину или маннитол (15 - $20 \%$-й раствор). Их вводят внутривенно струйно в количестве 1,0 - 1,5 г на 1 кг массы тела больного. Возможно также применение фуросемида. В последующем вводится раствор электролитов со скоростью, равной скорости диуреза. При форсированном диурезе необходимо проводить строгий учет введенной и выделенной жидкости, определение гематокрина и электролитов крови. Метод противопоказан при тяжелых сердечно-сосудистых заболеваниях, а также при нарушении функции почек.

\section{Неинвазивные сорбционные методы детоксикации.}

К неинвазивным сорбционным методам детоксикации относят методы детоксикации, метаболической и иммунологической коррекции, в процессе проведения которых не осуществляется прямой контакт сорбента с кровью. У больных практическое применение нашла гастроинтестинальная энтеросорбция.

Сорбенты. В качестве энтеросорбентов используют углеродные сорбенты на основе активированного угля (Карболен, Карбактин, уголь активированный и др.), кремний-содержащие энтеросорбенты (Полисорб МП и др.), пористые полимеры природного происхождения (пектины, Полифепан, Лигносорб и др.), ионообменные материалы (Холестирамин, Вазозан), синтетические полимеры (Энтеродез, Энтеросорб). Выбор сорбентов зависит от конкретных задач терапии, сорбционной емкости и удобства приема препарата, возможности применения у детей с рождения, беременных и кормящих женщин, у пациентов с отягощенным аллергоанамнезом и наличием сопутствующих заболеваний и других условий. При инфекционной патологии и аллергических заболеваниях наиболее эффективны современные сорбенты, способные связывать молекулы разного размера и массы, а также бактерии, вирусы, токсины, аллергены и биологически активные вещества (Полисорб МП, препараты на основе лигнина). Накопленный к настоящему времени опыт этого вида лечения показал целесообразность его применения как в остром периоде заболевания, так и с целью профилактики рецидивов. 
Энтеросорбция может назначаться по синдромальному принципу до установления этиологического диагноза. При острых инфекционных заболеваниях и токсических отравлениях эффективность энтеросорбции существенно повышается в случае применения ее в первые часы (дни) болезни. По степени детоксикации энтеросорбция в течение 1-2 дней сопоставима с однократной экстракорпоральной процедурой. Так же, как и другие методы эфферентной терапии, энтеросорбция не заменяет, а дополняет обычное этиотропное и патогенетическое лечение.

Как отдельное направление инвазивной эфферентной терапии возможно рассматривать методы с использованием межклеточных детоксикантов. В настоящее время единственным таким препаратом является Азоксимера бромид (Полиоксидоний). Он сорбирует на себе растворимые токсические вещества, микрочастицы и другие алармины, которые в дальнейшем захватываются макрофагами. За счет этого снижается концентрация РАMP и DAMP чем и обусловлено в какой-то мере его противовоспалительный эффект.

Проведение дезинтоксикации (очищения организма) - одно из самых важных мероприятий при лечении больного с иммунными нарушениями. Клеткам постоянно угрожает загрязнение: вредные вещества поступают как из внешней среды, так и образуются внутри организма в процессе жизнедеятельности. Если внутреннюю среду не очищать, клетки погибнут. Это дает нам основания назвать дезинтоксикационную терапию одним из важнейших блоков в лечении пациента.

\section{Средства, влияющие на реологию крови}

К этой группе можно отнести антикоагулянты и антиагреганты. Антикоагулянты предотвращают образование сгустков (тромбов), влияя на активность белков, участвующих в свертывании крови (факторов свертывания), в то время как антиагреганты, предотвращают агрегацию тромбоцитов и препятствуют образованию тромбов. Наиболее распространенным побочным эффектом применения антикоагулянтнов и/или антиагрегантнов является склонность к кровотечению. Данные препараты нашли широкое применение в кардиологии для предотвращения инсультов и инфарктов. Однако с целью улучшение микроциркуляции и трофики ткани, для предотвращения 
хронического системного воспаления целесообразен прием данной группы препаратов.

Антиагреганты ингибируют агрегацию тромбоцитов и эритроцитов, уменьшают их способность к склеиванию и прилипанию (адгезии) к эндотелию кровеносных сосудов. Снижая поверхностное натяжение мембран эритроцитов, они облегчают их деформирование при прохождении через капилляры и улучшают текучесть крови. Антиагреганты способны не только предупреждать агрегацию, но и вызывать дезагрегацию уже агрегированных кровяных пластинок.

Ингибирующее влияние на склеивание (агрегацию) тромбоцитов (и эритроцитов) оказывают в той или иной степени лекарственные средства разных фармакологических групп (органические нитраты, блокаторы кальциевых каналов, производные пурина, антигистаминные препараты и др.). Выраженное антиагрегантное действие оказывает ацетилсалициловая кислота, которая широко применяется в целях профилактики тромбообразования.

Ацетилсалициловая кислота (АСК) является в настоящее время основным представителем антиагрегантов. Она оказывает тормозящее влияние на спонтанную и индуцированную агрегацию и адгезию тромбоцитов, на высвобождение и активацию тромбоцитарных факторов 3 и 4. Показано, что ее антиагрегационная активность тесно связана с влиянием на биосинтез, либерацию и метаболизм простагландинов. Она способствует высвобождению эндотелием сосудов простагландинов, в том числе простагландина-I2 (простациклина). Последний активирует аденилатциклазу, снижает в тромбоцитах содержание ионизированного кальция - одного из трех главных посредников агрегации, а также обладает дезагрегационной активностью. Кроме того, АСК, подавляя активность циклооксигеназы, уменьшает образование в тромбоцитах тромбоксана А2-простагландина с противоположным типом активности (проагрегационный фактор). В больших дозах АСК тормозит биосинтез простациклина и других антитромботических простагландинов (D2, E1 и др.). В связи с этим в качестве антиагреганта АCК назначают в относительно небольших дозах (75 - 325 мг в сут).

Другая группа препаратов - антагонисты рецепторов к аденозиндифосфату: тиенопиридины. Производные тиенопиридина Тиклопидин (Тиклид) и Клопидогрель (Плавикс) угнетают АДФ-зависимый путь агрегации тромбоцитов. Их действие наступает медленнее, чем действие аспирина, поэтому в начале лечения используются нагрузочные дозы препаратов. Иногда отмечаются нейтропения и тромбоцитопения, поэтому необходимо выполнение клинического анализа крови с подсчетом тромбоцитов через каждые 2 нед. на протяжении первых 3 мес лечения. Считается, что меньшими побочными эффектами обладает Плавикс. 
Также к антиагрегантам относится Курантил. Механизм дипиридамола (Курантила) заключается в действии на метаболизм арахидоновой кислоты, увеличении продукции простациклина и торможении синтеза тромбоксана А2. По антиагрегационной активности Дипиридамол уступает Тиклопидину, но близок к АСК. Применяется перорально и внутривенно.

Некоторой антиагрегационной активностью обладает и Пентоксифиллин (Трентал). Он блокирует аденозиновые рецепторы тромбоцитов, способствует накоплению в тромбоцитах цАМФ, дезагрегации, уменьшает их агрегацию. Реологическое воздействие осуществляется за счет увеличения деформируемости эритроцитов.

Антикоагулянты - лекарственные средства, оказывающие влияние на различные звенья процесса коагуляционного гемостаза (свёртывающей системы крови), препятствуют образованию тромбов, продлевая время свертывания. По механизму действия различают антикоагулянты прямого и непрямого действия (табл.104). Препараты, влияют не только на агрегацию тромбоцитов и свертывание крови, но и улучшающие реологические свойства крови улучшая микроциркуляцию.

Таблица 104

\section{Антикоагулянты}

\begin{tabular}{|c|c|}
\hline Группа препаратов & Наименование препаратов \\
\hline \multicolumn{2}{|r|}{ Прямого действия } \\
\hline $\begin{array}{l}\text { Гепарины } \\
\text { (антитромбин III) }\end{array}$ & Гепарин, Сулодексид, Эноксипарин. \\
\hline Тромболитики & $\begin{array}{l}\text { Стрептокиназа, Фибринолизин, Тенектеплаза, Альтеплаза, } \\
\text { Урокиназа, Протеин С, Анкорд. }\end{array}$ \\
\hline \multicolumn{2}{|r|}{ Непрямого действия } \\
\hline Антагонисты витамина К & Варфарин, Аценокумарол, Фениндион. \\
\hline $\begin{array}{lll}\text { Прямые } & \text { ингибиоторы Ха } \\
\text { фактора } & & \end{array}$ & Ривароксабан (Ксарелто), Апиксабан (Эликвис), Эндоксабан. \\
\hline $\begin{array}{ll}\text { Прямые } \quad \text { ингибиторы } \\
\text { тромбина }\end{array}$ & $\begin{array}{l}\text { Бивалирудин (Ангиокс), Лепирудин, Дабигатран, } \\
\text { Ксимеланатран, Десирудин, Меланатран, Аргатробан. }\end{array}$ \\
\hline $\begin{array}{l}\text { Другие антитромботические } \\
\text { средства }\end{array}$ & Фондапаринукс, Дефибротид, Сульфат дерматана. \\
\hline
\end{tabular}




\section{Глава 16. Метаболическая терапия}

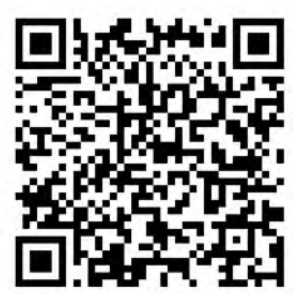

Большое значение в лечении больного с наличием иммунных нарушений имеет нормализация и/или стимуляция работы клетки. К препаратам этой группы относится множество лекарственных средств, прямо или опосредованно влияющих на различные клетки человека, поэтому такой подход рекомендован в комплексной терапии и иммунных нарушениях. В настоящее время в современной фармакопии это следующие препараты - витамины, (водо- и жирорастворимые), антиоксиданты, анаболики, естественные метаболиты, средства, стимулирующие процессы регенерации и т.д. Однако уже сегодня необходимо выделять лекарственные средства, непосредственно влияющие на различные звенья метаболизма клетки (рис.175).

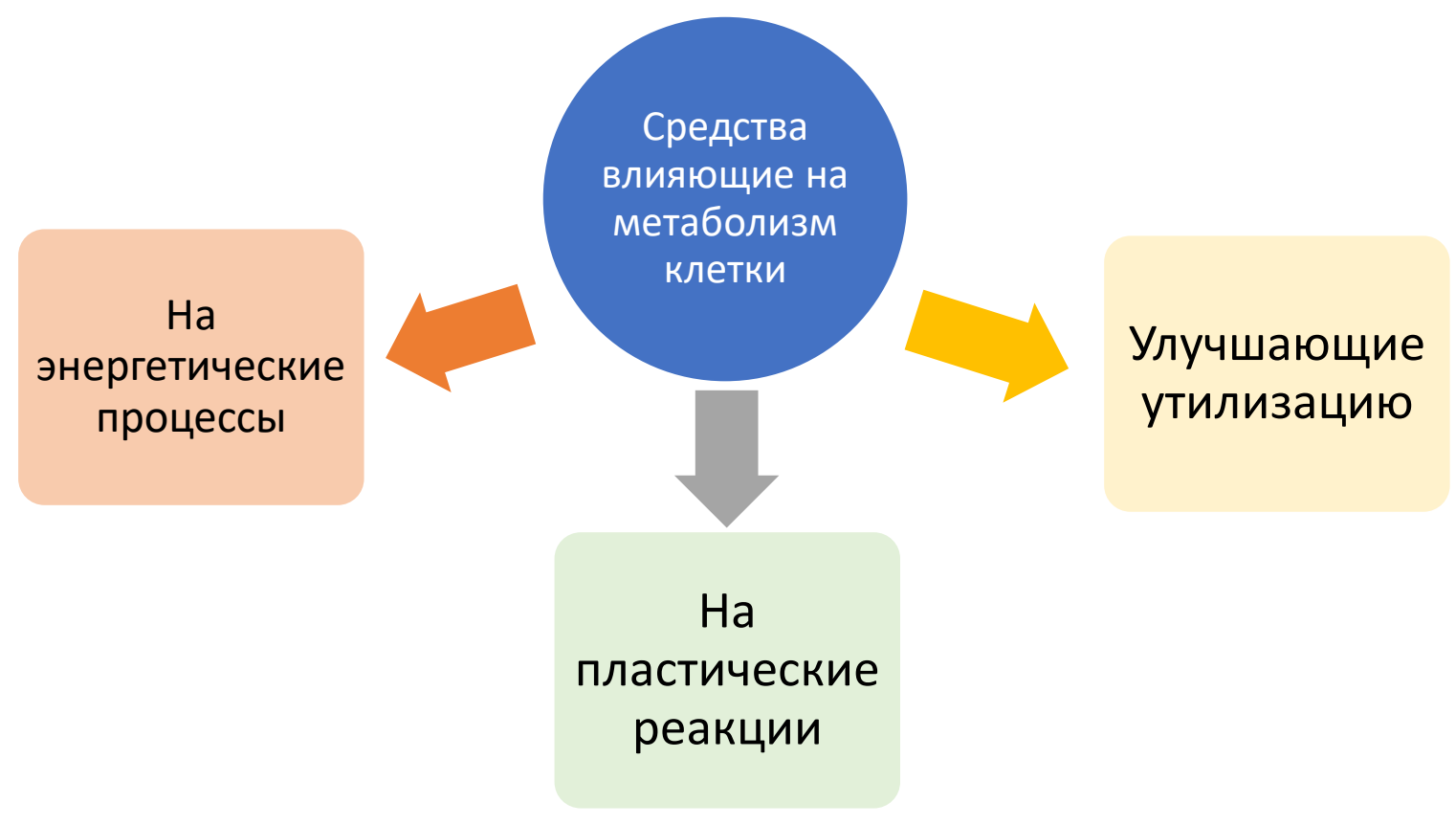

\section{Рис.175. Метаболические препараты.}

К этой группе необходимо отнести и большое количество иммуномодуляторов, применяемых в России, т.к. они в основном не обладают избирательным действием на иммунную систему, а действуют через метаболизм клеток иммунной системы.

С позиций биохимических реакций в каждой группе необходимо выделить препараты, действующие на регуляцию какой-либо реакции (гормоны, ферменты и коферменты) и субстраты этой реакции (естественные метаболиты). 


\section{Препараты, преимущественно влияющие на энергетические} процессы клетки.

В эту группу входит большое количество водорастворимых витаминов и естественных метаболитов.

Витамин В1 (тиамин) содержится в дрожжах, зародышах и оболочках пшеницы, овса, гречихи, а также в хлебе, изготовленном из муки простого помола. Суточная потребность взрослого человека в витамине В1 составляет 1,5 -2 мг.

Препараты группы витамина В1 активно влияют на различные функции организма, вмешиваясь в обмен веществ и нервно-рефлекторную регуляцию. С помощью фермента тиаминпирофосфаткиназы тиамин в организме превращается в тиаминпирофосфат, который является кофактором окислительного дезаминирования $\alpha$-кетокислот. При гиповитаминозе В1 наблюдается снижение иммуногенеза по отношению к корпускулярным АГ, устойчивости к некоторым инфекциям. Влияние на фагоцитоз происходит путем вмешательства в углеводно-фосфорный обмен фагоцитов.

Витамин В2 (рибофлавин) в организм человека поступает, главным образом, с мясными и молочными продуктами. Он широко распространен в растительном и животном мире и содержится в дрожжах, молочной сыворотке, яичном белке, мясе, рыбе, печени, горохе, зародышах и оболочках зерновых культур. Получен синтетически. Суточная потребность в витамине В2 для взрослого человека составляет 1,5-2 мг.

При поступлении в организм рибофлавин с помощью фермента рибофлавинкиназы превращается во флавинмононуклеотид, реакция которого с АТФ, катализируемая ФМН-аденилилтрансферазой, приводит к образованию флавинадениндинуклеотиду. Оба продукта являются коферментами оксидоредуктаз и участвуют в переносе протонов и регулировании окислительно-восстановительных процессов, этим обусловлена их роль в углеводном, белковом и жировом обмене.

Витамин РP (никотиновая кислота). Продукты богатые витамином РP говяжья печень, дрожжи, брокколи, морковь, сыр, кукурузная мука, финики, яйца, рыба, молоко, арахис, свинина, картофель, помидоры, проростки пшеницы, продукты из цельных злаков. Травы - люцерна, корень лопуха, листья одуванчика, котовник кошачий, кайенский перец, ромашка, песчанка, очанка, семя фенхеля, пажитник сенной, женьшень, хмель, хвощ, коровяк, крапива, овес, петрушка, мята перечная, листья малины, красный клевер, плоды шиповника, шалфей, щавель. Суточная потребность в никотиновой кислоте и никотинамиде составляет для взрослого человека около 20 мг, при тяжелом физическом труде - около 25, для детей в зависимости от возраста - от 6 до 18 мг. 
Витамин существует в двух формах - никотиновой кислоты и никотиномида. Включается в простетическую группу ферментов, являющихся переносчиками водорода: никотинамидадениндинуклеотида (НАД) и никотинамидадениндинуклеотидфосфата (НАДФ), регулирует окислительновосстановительные процессы, тканевое дыхание, синтез белков и жиров, распад гликогена. Угнетает липолиз в жировой ткани, уменьшает скорость синтеза липопротеидов низкой плотности. Нормализует липидный состав крови: снижает уровень общего холестерина, липопротеидов низкой плотности, триглицеридов и повышает уровень липопротеидов высокой плотности, обладает антиатерогенными свойствами.

Витамин С (аскорбиновая кислота) содержится в значительных количествах в плодах шиповника, капусте, лимонах, апельсинах, хрене, ягодах, хвое и др. Небольшое содержание - в печени, мозге, мышцах животных. Для медицинских целей витамин С получают синтетическим путем. В обычных условиях суточная потребность взрослого человека в аскорбиновой кислоте составляет $70-100$ мг.

Основные эффекты обусловлены участием в регуляции окислительновосстановительных процессов, поскольку аскорбиновая кислота легко переходит в дегидроаскорбиновую и обратно, донируя или акцептируя два протона (окисляя или восстанавливая соответствующие субстраты). Витамин С активирует деятельность желез внутренней секреции, регулирует все виды обмена, свертываемость крови, регенерацию тканей, образование стероидных гормонов, синтез коллагена, проницаемость капилляров и др. Аскорбиновая кислота, оказывая стимулирующее влияние на организм в целом, повышает его адаптационные возможности, резистентность к инфекциям. Дефицит витамина С приводит к отчетливому нарушению Т-системы иммунитета.

Система гуморального иммунитета более устойчива к С-витаминной недостаточности. Кроме величины дозы большое значение имеет характер сочетания витамина C с другими препаратами, например с витаминами группы В (B9 и В12). Стимуляция фагоцитоза связана с непосредственным влиянием витамина на фагоциты и зависит от дозы препарата. Полагают, что витамин $\mathrm{C}$ увеличивает чувствительность бактерий к лизоциму.

Декстроза (глюкоза, глюкостерил) субстратно обеспечивает энергетический обмен, поддерживает объем циркулирующей плазмы. Изотонический раствор восполняет объем потерянной жидкости, повышенная осмотическая активность гипертонических растворов увеличивает выход тканевой жидкости в сосудистое русло и удерживает ее в нем, повышает диурез и выведение токсических веществ. Молекулы декстрозы утилизируются в процессе энергетического обеспечения. 
Янтарная кислота за счет стимуляции окислительно-восстановительных реакций, процессов дыхания и синтеза АТФ способна активировать физиологические функции органов и тканей, тем самым улучшая адаптационные и компенсаторно-защитные возможности организма.

Гамма-аминомасляная кислота (аминалон, нооклерин) активирует энергетические процессы, повышает дыхательную активность тканей, улучшает утилизацию глюкозы и удаление токсических продуктов обмена. Взаимодействует со специфическими ГАМК-эргическими рецепторами А и Б типов. Улучшает динамику нервных процессов в головном мозге, увеличивает продуктивность мышления, обладает антигипоксическим действием.

Предуктал обусловливает эффект действия повышением энергетического потенциала, активацией окислительного декарбоксилирования и рационализацией потребления кислорода (усиление аэробного гликолиза и блокада окисления жирных кислот). Предотвращает внутриклеточное истощение АТФ и фосфокреатинина. В условиях ацидоза нормализует функционирование ионных каналов мембран, нормализует внутриклеточную концентрацию $\mathrm{K}+$, препятствует накоплению $\mathrm{Ca} 2+$ и $\mathrm{Na}+$ в кардиомиоцитах. Уменьшает внутриклеточный ацидоз и концентрацию фосфатов, обусловленных ишемией, ишемических повреждений миокарда выход креатинфосфокиназы из клеток. Останавливает повреждающее действие свободных радикалов, сохраняет целостность клеточных мембран, предотвращает активацию нейтрофилов в зоне ишемии, увеличивает продолжительность электрического потенциала.

Энерион представляет собой средство, регулирующее метаболические процессы клетки. Синтетическое соединение, близкое по строению к тиамину (имеет открытый тиазольный цикл, дополнительную дисульфидную связь и липофильный эфир). Обладает высокой эффективностью при симптоматическом лечении больных с функциональными астеническими состояниями.

Цитохром С является катализатором клеточного дыхания, стимулирует окислительные реакции и активизирует тем самым обменные процессы в тканях, уменьшает гипоксию тканей при различных патологических состояниях.

\section{Средства, направленные на пластические реакции клетки}

В основе фармакологической регуляции пластических реакций клетки лежит стимуляция белкового синтеза, пролифирации и дифференцировки клеток. Для стимуляции этих процессов могут быть использованы различные группы лекарственных препаратов: 1) регуляторы - витамины, анаболические гормоны и другие синтетические средства в т.ч. индукторы ИФН и синтетические иммуномодуляторы; 2) естественные метаболиты в т.ч. препараты дезоксирибонуклеиновой кислоты. 
Витамин В3 (пантотеновая кислота). Наиболее богаты витамином В3 мясо и субпродукты, пивные дрожжи, отруби, зародыши пшеницы, зеленые овощи, орехи, маточное молочко пчел.

Витамин может синтезироваться кишечными бактериями, но в недостаточном количестве, учитывая суточную потребность организма для детей и подростков $5-7$ мг, для взрослых - $10-12$ мг, хотя при лечении доза может быть увеличена в несколько раз. В организме является субстратным (единственный незаменимый компонент) стимулятором синтеза кофермента А. Последний катализирует в организме ацилирование, участвует практически во всех метаболических процессах (цикл трикарбоновых кислот, обмен углеводов, жиров и жирных кислот, фосфолипидов, белков и др.), обеспечивает образование кортикостероидов, ацетилирование холина. Обладает противовоспалительным действием, стимулирует процессы репарации и регенерации.

Витамин В6. (Пиридоксин). Это групповое название трех производных пиридина: пиридоксаля, пиридоксина и пиридоксамина. Витамин В6 содержится в растениях и органах животных, особенно в неочищенных зернах злаковых культур, в овощах, мясе, рыбе, молоке, печени трески и крупного рогатого скота, яичном желтке, дрожжах. Суточная потребность взрослого человека составляет 2 мг и удовлетворяется частично продуктами питания, частично синтезом микрофлоры кишечника. Пиридоксин, поступая в организм, фосфорилируется и в этой форме катализирует декарбоксилирование и переаминирование аминокислот.

Витамин В9 (фолиевая кислота). Содержится в свежих овощах (бобах, шпинате, томатах и др.), а также в печени и почках животных. В организме человека, кроме того, синтезируется микрофлорой кишечника. Суточная потребность взрослых людей в фолиевой кислоте равна 200 мкг, беременных и кормящих женщин - 400 - 600 мкг, детей первого года жизни - $40-60$ мкг. Для медицинских целей (в том числе, при интоксикации, вызванной противоопухолевыми препаратами) используют синтетическую фолиевую кислоту, хотя сама она неактивна и в организме восстанавливается до тетрагидрофолиевой, являющейся коферментом многих метаболических процессов. В первую очередь катализирует перенос одноуглеродистых фрагментов в синтезе пуринов и пиримидинов, а значит, необходима для образования РНК и ДНК. Ее дефицит нарушает митотическое деление клеток, их созревание и функционирование.

Витамин В12 (цианокобаламин). Комплексное соединение, имеющее в основе цикл коррина и содержащее координационно связанный ион кобальта. В тканях животных не синтезируется. Источниками витамина В12 служат различные виды мяса, рыба, яйца, молоко, сыр, но он полностью отсутствует в растительной пище. Витамин всасывается слизистой желудка только в 
присутствии секретируемого (эндогенного) гликопротеина, так называемого внутреннего фактора. Назначение этого мукопротеида заключается в связывании цианокобаламина и тем самым в защите от деградации. В крови В12 также связывается специальным белком - транскобаламином. Его синтез в природе осуществляется только микроорганизмами. Потребности человека и животных в нем обеспечиваются микрофлорой кишечника, откуда цианокобаламин поступает в органы, накапливаясь в наибольших количествах в почках, печени, стенке кишечника. Суточная потребность в этом витамине составляет 0,003 мг. Витамин В12 в организме превращается в коферментные формы метилкобаламин и дезоксиаденозилкобаламин. Как кофермент участвует в различных метаболических процессах, включая метаболизм жиров и углеводов и синтез белка. Является фактором роста и стимулятором гемопоэза, оказывает благоприятное влияние на функции печени и нервной системы, активирует процессы свертывания крови. Очевидна эффективность витамина В12 в нормальных дозах при крайне расстроенных гемопоэтических и имунологических функциях (нарушение дифференцировки В-клеток, снижение числа плазмоцитов, АТ, лейкопения, мегалобластная анемия, рецидивирующая инфекция). Однако отмечается стимулирующее влияние витамина В12 на рост опухоли (в отличие от В1, В2, В6). Одно из основных иммуномоделирующих действий витамина В12 - влияние на обмен нуклеиновых кислот и белков.

Витамин U (S-метилметионин). Содержится в соке капусты, картофеля и других сырых овощах. Суточная доза не определена. Препарат рассматривается как активированная форма метионина. Полагают, что механизм действия связан со стимуляцией заживления повреждений слизистой оболочки ЖКТ. Это объясняется способностью препарата отдавать свои метильные группы, необходимые для процессов синтеза в организме. Метилируя гистамин, витамин $\mathrm{U}$ превращает его в неактивную форму, а это способствует уменьшению желудочной секреции и обусловливает обезболивающий эффект.

Витамин А. Его синтетические аналоги и гомологи относят к ретиноидам - производным ретиноевой кислоты. Биологически активными формами витамина А являются ретинол, ретиналь и сама ретиноевая кислота. Этот витамин содержится в продуктах животного происхождения - рыбьем жире, сливочном масле, яичном желтке, печени некоторых рыб (треска, морской окунь и др.) и морских животных (кит, морж, тюлень). В растительных пищевых продуктах ретинол не встречается. Однако многие из них (морковь, шпинат, салат, петрушка, зеленый лук, щавель, красный перец, черная смородина, черника, крыжовник, персики, абрикосы и др.) содержат каротин, представляющий собой провитамин А, из которого в организме образуется ретинол. Витамин А регулирует процессы ороговения, образование и выделение 
сала в коже (секрет сальных желез), необходим для нормального роста волос, поддержания иммунитета, участвует в противоопухолевой защите организма.

Витамин D. В настоящее время называют два жирорастворимых, близких по химическому строению и действию вещества - «Эргокальциферол» (витамин D2) и «Колекальциферол» (витамин D3). Основное свойство этих соединений способность предупреждать и лечить рахит, в связи с чем их иногда называют противорахитическими витаминами. Витамин D2 в небольшом количестве содержится в пищевых продуктах: яичном желтке, сливочном масле, сыре, молоке, икре, жирных сортах рыбы (угорь, лосось, макрель, сардины), устрицах, печени трески, говяжей печени, хлебе из зерен крупного помола. Витамин D3 образуется в коже человека под воздействием солнечных лучей. За 25 мин. пребывания на солнце организм синтезирует до $2000 \mathrm{ME}$ витамина D. Более того, в этом случае невозможно «превысить дозу». По биологической активности витамины D2 и D3 практически не различаются, поскольку в организме оба, вероятно, превращаются в кальцитриол - активный метаболит витамина D. Считается что нужно потреблять ежедневно 50 - 200 мг витамина D, а после 50ти лет дозу необходимо удвоить (1 мг витамина D равен $40 \mathrm{ME}$ ).

Основным свойством витамина D является его участие в метаболизме кальция. В настоящее время витамин рассматривают не только как витамин, но и как гормон, регулирующий вместе с гормоном паращитовидной железы концентрацию ионов кальция в плазме крови, в том числе всасывание кальция в пищеварительном тракте, отложение его в костях, препятствуя резорбции из костной ткани. Витамин D регулирует также содержание фосфора в организме. Применяют его для профилактики и лечения рахита и заболеваний костей, вызванных нарушениями обмена кальция (остеомаляция и некоторые формы остеопороза). В последнее время доказано иммунотропное действие витамина D. Терапия высокими дозами витамина D эффективна в предотвращении активации латентных форм туберкулеза и для профилактики рака.

Анаболические гормоны. Эта группа препаратов активно действует на клетку (в том числе и на клетки иммунной системы), так как активно способствует биосинтезу продуктов обмена (белков, жиров, углеводов). Анаболическое действие оказывают некоторые стероидные и нестероидные соединения.

Из стероидных веществ анаболической активностью обладают препараты мужских половых гормонов. Специально синтезированные препараты на основе мужских половых гормонов - Метандиенон (Метандростенолон) и Нандролон (Феноболин, Ретаболил) - практически не обладают андрогенной активностью. Наиболее характерное свойство веществ этой группы - их способность стимулировать синтез белка в организме и вызывать уменьшение выведения азота (положительный азотистый баланс). Снижается также выделение 
необходимых для синтеза белков калия, серы и фосфора. Клинически действие стероидных анаболиков проявляется в повышении аппетита, улучшении работоспособности, общего состояния больных, увеличении массы тела. Для достижения выраженного эффекта одновременно с анаболическими препаратами больные должны получать с пищей адекватные количества белков, жиров, углеводов, витаминов и минеральных веществ.

Левокарнитин (Элькар, Карнитен, Карнифит) - является кофактором метаболических процессов, обеспечивающих поддержание активности КоА. Оказывает анаболическое действие, снижает основной обмен, замедляет распад белковых и углеводных молекул. Способствует проникновению через мембраны митохондрий и расщеплению длинноцепочечных жирных кислот (пальмитиновой и др.) с образованием ацетил-КоА (необходим для обеспечения активности пируваткарбоксилазы в процессе глюконеогенеза, образования кетоновых тел, синтеза холина и его эфиров, окислительного фосфорилирования и образования АТФ). Оказывает жиромобилизующее действие, обусловленное наличием трех лабильных метильных групп. Конкурентно вытесняя глюкозу, включает жирнокислотный метаболический шунт, активность которого не лимитирована кислородом (в отличие от аэробного гликолиза), поэтому эффективен при острой гипоксии мозга и других критических состояниях. Вызывает незначительное угнетение ЦНС, повышает секрецию и ферментативную активность пищеварительных соков (желудочного и кишечного), улучшает усвоение пищи. Снижает избыточную массу тела и уменьшает содержание жира в мускулатуре. Увеличивает запасы гликогена в печени и мышцах, способствует более экономному его использованию.

\section{Естественные метаболиты.}

К этой группе относят препараты предшественников пуриновых или пиримидиновых оснований, либо продукты частичного гидролиза нуклеиновых кислот.

Инозин (Рибоксин, Рибонозин). Нуклеозид - предшественник АТФ. Субстратно стимулирует синтез адениновых нуклеотидов, повышает активность некоторых ферментов цикла Кребса. Принимает непосредственное участие в обмене глюкозы и способствует активизации обмена при гипоксии и при отсутствии АТФ. Стимулирует окислительно-восстановительные процессы. Интенсифицирует метаболизм пировиноградной кислоты, нормализует процесс тканевого дыхания, способствует повышению активности ксантиндегидрогеназы. Оказывает положительное влияние на обменные процессы в миокарде, повышает его энергетический баланс, улучшает коронарное кровообращение, снижает агрегацию тромбоцитов, активирует регенерацию тканей. 
Калия оротат (1,2,3,6-Тетрагидро-2,6-диоксо-4-пиримидинкарбоновая кислота) обеспечивает синтез пиримидиновых нуклеотидов, входящих в состав нуклеиновых кислот, участвующих в образовании белковых молекул.

Кальция глицерофосфат восстанавливает уровень кальция в организме, стимулирует анаболические процессы.

Метионин - незаменимая аминокислота, регулирующая азотистый баланс. Содержит подвижную метильную группу и участвует в процессах метилирования, обеспечивающих синтез холина, адреналина, креатина и других биологически важных соединений, обезвреживание токсичных продуктов, образование фосфолипидов. Тормозит отложение в печени нейтрального жира, оказывает липотропный эффект (удаление из печени избытка жира). Модулирует эффект гормонов и витаминов (В12, аскорбиновой и фолиевой кислот).

Глутаминовая кислота - заменимая аминокислота поступает в организм с пищей, а также синтезируется в организме при переаминировании в процессе катаболизма белков. Участвует в белковом и углеводном обмене, стимулирует окислительные процессы, препятствует снижению окислительновосстановительного потенциала, повышает устойчивость организма к гипоксии. Принимает в норму обмен веществ, изменяя функциональное состояние нервной и эндокринной систем. Принимает участие в синтезе других аминокислот, ацетилхолина, АТФ, способствует переносу ионов калия, улучшает деятельность скелетной мускулатуры (является одним из компонентов миофибрилл). Оказывает дезинтоксикационное действие, способствует обезвреживанию и выведению из организма аммиака. Нормализует процессы гликолиза в тканях, оказывает гепатопротекторное действие, угнетает секреторную функцию желудка.

Гептрал (Адеметионин) - биологическое вещество, входящее в состав всех тканей и жидких сред организма. Его молекула включена в большинство биологических реакций, в том числе как донор метиловой группы - в процесс метилирования в составе липидного слоя клеточной мембраны (трансметилирование); как предшественник эндогенных тиоловых соединений цистеина, таурина, глютатиона, коэнзима А (транссульфурирование); как предшественник полиаминов - путресцина, стимулирующего регенерацию клеток, пролиферацию гепатоцитов, спермидина, спермина, входящих в структуру рибосом (аминопропилирование). Гептрал включается в биохимические процессы организма, одновременно активизируя действие выработки эндогенного адеметионина. Восполняет дефицит адеметионина и стимулирует его выработку в организме, в первую очередь в печени и мозге. Повышает содержание глутамина в печени, цистеина и таурина в плазме, снижает содержание метионина в сыворотке крови, нормализуя метаболические реакции в печени. После декарбоксилирования участвует в процессах аминопропилирования как предшественник полиаминов - путресцина 
(стимулятор регенерации клеток и пролиферации гепатоцитов), спермидина и спермина, входящих в структуру рибосом.

Таурин (Дибикор, Тауфон) - аминокислота, образующаяся в организме в процессе превращения цистеина. Играет большую роль в липидном обмене, способствует нормализации функции клеточных мембран, оптимизации энергетических и обменных процессов, сохранению электролитного состава цитоплазмы (за счет накопления ионов калия и кальция), входит в состав парных желчных кислот (таурохолиевой, тауродезоксихолевой), способствующих эмульгированию жиров в кишечнике. В головном мозге выполняет функцию нейромедиатора, тормозящего синаптическую передачу, обладает противосудорожной и кардиотонической активностью. Вызывает нормализацию метаболизма глазных тканей при заболеваниях дистрофического характера.

Глутоксим играет важную роль в регуляции метаболических процессов в клетках и тканях. Он оказывает селективное воздействие на сульфгидрильные группы поверхностно-клеточных и растворимых рецепторов, что приводит к восстановлению их функционально активной конформации, чувствительности к регуляторным и транспортным молекулам пептидной природы, определяет иммуномодулирующий и цитотропные эффекты препарата. Глутоксим способствует реализации действия регуляторных молекул пептидной природы на нормальные (регуляция метаболических процессов) и трансформированные (индукция апоптоза) клетки, стимулирует на каскадные механизмы фосфатной модификации ключевых белков сигналпередающих систем; инициацию действия системы цитокинов, в том числе ИЛ-1, ИЛ-2, ИЛ-6, TNF, ИФН, эритропоэтина.

\section{Средства, устраняющие продукты метаболизма в клетке}

В эту группу препаратов входят средства способствующие утилизации продуктов метаболизма клетки, антиоксиданты и стабилизаторы мембран.

Средства, способствующие утилизации продуктов метаболизма клетки.

Витамин В15 (пангамовая кислота). Так как витамин В15 широко представлен в семенах растений, в связи с этим и получил свое название пангамовая кислота (от греч. pan - всюду и gamy - семя). Наибольшее содержание пангамовой кислоты обнаружено в семенах злаковых растений и в ядрах косточковых плодов, а также в большом количестве содержится в печени, почках, яичном желтке, икре рыб, горохе, рисе, дрожжах, отрубях. Суточная потребность 2 мг в сутки. Пангамовая кислота активирует окислительные процессы, уменьшает явления гипоксии, оказывает детоксицирующее действие, улучшает липидный обмен, участвует в образовании холина, увеличивает содержание гликогена и креатинфосфата в мышцах, является донором метильных групп. 
Глицин (аминоуксусная кислота) обладает глицин- и ГАМКэргическим, $\alpha 1$-адреноблокирующим, антиоксидантным, антитоксическим действием; регулирует деятельность глутаматных (NMDA) рецепторов, за счет чего препарат является регулятором обмена веществ.

Милдронат - аналог $\gamma$-бутиробетаина, подавляет $\gamma$ бутиробетаингидроксиназу, снижает синтез карнитина и транспорт длинноцепочечных жирных кислот через оболочки клеток, препятствует накоплению в клетках активированных форм неокисленных жирных кислот производных ацилкарнитина и ацилкоэнзима А. В условиях ишемии восстанавливает равновесие процессов доставки кислорода и его потребления в клетках, предупреждает нарушение транспорта АТФ, одновременно с этим активирует гликолиз, который протекает без дополнительного потребления кислорода. В результате снижения концентрации карнитина усиленно синтезируется $\gamma$-бутиробетаин, обладающий вазодилатирующими свойствами.

Натрия тиосульфат оказывает дезинтоксикационное, противовоспалительное, десенсибилизирующее действие.

«Унитиол» способствует дезинтоксикационному действию. Увеличивает выведение некоторых катионов (особенно $\mathrm{Cu} 2+$ и $\mathrm{Zn} 2+$ ) из металлосодержащих ферментов клеток. Активные сульфгидрильные группы восстанавливают функции ферментных систем организма.

Аллопуринол-Эгис - средство, нарушающее синтез мочевой кислоты. Является структурным аналогом гипоксантина. Ингибирует фермент ксантиноксидазу, который участвует в превращении гипоксантина в ксантин и ксантина в мочевую кислоту. Этим обусловлено уменьшение концентрации мочевой кислоты и ее солей в жидких средах организма и моче, что способствует растворению имеющихся уратных отложений и предотвращает их образование в тканях и почках. При приеме аллопуринола повышается выделение с мочой гипоксантина и ксантина.

Как способ утилизации продуктов метаболизма, особенно хронических ее форм, можно стимулировать биотрансформации. Биотрансформация токсических веществ - один из важнейших путей естественной детоксикации организма. При этом может произойти повышение активности индукции ферментов, главным образом в микросомах печени, ответственных за метаболизм токсичных соединений, или снижение активности этих метаболитов (ингибиция), влекущее за собой замедление метаболизма. В клинической практике используются препараты - индукторы или ингибиторы ферментов, влияющие на биотрансформацию ксенобиотиков с целью снижения их токсического действия. В настоящее время известно более двухсот веществ, способных влиять на активность микросомальных ферментов (цитохром Р-450). Наиболее изученными индукторами являются барбитураты, в частности 
фенобарбитал или бензонал и специальный препарат - Зиксорин. Под влиянием этих препаратов в митохондриях печени увеличиваются уровень и активность цитохрома Р-450, что обусловлено стимуляцией процессов их синтеза. Лечебное действие проявляется не сразу, а спустя 1,5 - 2 сут.

\section{Антиоксиданты.}

Протекающие в организме процессы биологического окисления состоят из последовательных реакций дегидрирования, при которых атомы водорода переходят от субстрата (жирные кислоты, углеводы) к акцептору. Кислород вовлекается в тканевое дыхание в завершающей цитохромоксидной реакции, соединяясь с акцептированными атомами водорода. Биологическое окисление структурно организовано в клетке, строго регулируется, ступенчато освобождает макроэрги и в конечной стадии образует нетоксичные продукты (H2O и $\mathrm{CO} 2)$. Наряду с биологическим окислением в организме могут происходить реакции прямого присоединения кислорода к субстрату - аутоокисление. Обычно они начинаются с образования частиц с неспаренным электроном - свободными радикалами, образуя промежуточные соединения - перекиси. Соответственно эти процессы называют свободнорадикальным или перекисным окислением. Свободнорадикальное окисление развивается как цепной лавинообразный процесс, вовлекающий все новые молекулы субстрата. Усиление свободнорадикального окисления в организме наблюдается при многих заболеваниях.

Общими признаками являются: повышение гидрофильности мембран и как следствие увеличение их проницаемости; разобщение дыхания и фосфорилирования; нарушение связи фосфолипидов со структурными и рецепторными белками клеточных мембран; повреждение нуклеиновых кислот и инактивация ферментов; лизис мембран лизосом, сопровождающийся выходом из них фосфолипаз и других гидролитических ферментов, способных вызвать аутолиз клетки.

Свободнорадикальные механизмы угнетают клеточный и гуморальный иммунитет. Развитие этого окисления может быть прекращено ингибиторами, восстанавливающими свободные радикалы в стабильную молекулярную форму, не способную продолжать цепь аутоокисления.

Лекарственное влияние реализуется либо непосредственным связыванием свободных радикалов - так действуют прямые антиоксиданты, либо через активацию антиоксидантной системы организма - группа непрямых антиоксидантов. Можно выделить основные принципы их применения.

Приоритетное использование природных биоантиоксидантов, полностью лишенных побочных эффектов. 
Учет алиментарного фактора. В зимне-весенний период обязательно назначение прямых антиоксидантов, летом и осенью при высоком содержании в рационе овощей и фруктов предпочтительны антиоксиданты непрямого действия.

Комбинированное применение. Процессы свободнорадикального окисления могут развиваться как в липидной, так и в водной фазе клеточных и неклеточных структур. Соответственно необходимо одновременное введение липидорастворимых и гидрофильных антиоксидантов.

Адекватный выбор дозировки препаратов. Дозирование антиоксидантов должно базироваться на учете не только массы тела, но и возраста человека, характера его питания.

Достаточно продолжительный курс фармакопрофилактики или фармакотерапии, который определяется длительностью воздействия фактора или ситуации, способствующих усилению свободнорадикального окисления (от $1-2$ нед до $2-3$ мес).

Классическим антиоксидантом является витамин Е. Под этим названием известен ряд соединений (токоферолов), близких по химической природе и биологическому действию. Наиболее активен из них $\alpha$-токоферол. Токоферолы содержатся в зеленых частях растений, особенно в молодых ростках злаков, также богаты ими растительные масла (подсолнечное, хлопковое, кукурузное, арахисовое, соевое, облепиховое). Некоторое количество их содержится в мясе, жире, яйцах, молоке. Потребность в витамине Е составляет 8 - 10 МЕ для взрослых и от $3-7 \mathrm{ME}$ для детей (в зависимости от возраста). Витамин Е является эндогенным противоокислительным фактором (антиоксидантом), тормозящим перекисное окисление липидов клеточных мембран. Участвует в биосинтезе белков, в тканевом дыхании, пролиферации клеток и других важнейших процессах.

Высокой антиоксидантной активностью обладают дибунол и пробукол препараты с широким спектром биологических свойств. В зависимости от дозы они способны подавлять биосинтез белка за счет включения торможения аминокислот и ингибирования синтеза РНК, повышать активность оксигеназ печени, стимулируя биотрансформации многих соединений, ускорять регенерацию тканей, интенсифицируя вступление клеток в фазу синтеза ДНК и повышая активность РНК-полимераз.

Многие биофлавоноиды (витамин $\mathbf{P})$ имеют выраженные антиоксидантные свойства за счет прямого антирадикального действия. Это растительные биофлавоноиды, представляющие собой группу биологически активных веществ (рутин, катехины, кверцетин, цитрин, гесперидин, эриодиктиол, цианидин). Всего известно около 150 биофлавоноидов, обладающих сходными биологическими действиями. Витамин Р находится 
обычно в тех же растительных продуктах, в которых встречается и аскорбиновая кислота. Особенно много его содержится в цитрусовых, черной смородине, плодах шиповника, щавеле, зеленом чае, салате. В гречихе, белой оболочке под кожурой цитрусовых немного меньше его присутствие в помидорах, винограде, капусте, петрушке, сливах, яблоках, ягодах. Данный витамин не вырабатывается нашим организмом и поэтому должен быть включен в ежедневный рацион питания. Суточная потребность взрослого человека в рутине - 30 мг, кверцетине - 15, геспередине - 100 мг. Витамин Р - эффективный антиоксидант, способный восстанавливать клеточную структуру, в основе действия которого лежит свойство перехватывать свободные радикалы кислорода и обезвреживать их. Являясь мощными природными антиоксидантами, биофлавоноиды предохраняют клетки нашего организма от разрушительного воздействия свободных радикалов, предотвращая старение организма, нарушения иммунитета, возникновение различных заболеваний. Традиционно считается, что биофлавоноиды обладают капилляроукрепляющим свойством: нормализуют и поддерживают структуру, эластичность, функцию и проницаемость кровеносных сосудов, предупреждают их склеротическое поражение, снижают проницаемость стенок сосудов, препятствуют выработке гистамина и серотонина.

Существенный интерес вызывает и их способность оказывать сберегающий эффект в отношении аскорбиновой кислоты.

Глутатион - глутамилцистеинглицин как трипептид при приеме внутрь гидролизуется на составляющие аминокислоты. Предшественниками глутатиона являются метионин и глутаминовая кислота. В последние годы вместо метионина используется его более активная форма - метилметионинсульфоний. Все указанные соединения проявляют актиоксидантное действие и оказывают нормализующий эффект в отношении показателей липидного обмена.

\section{Стабилизаторы мембран.}

Тиоктовая кислота (берлитион, липоевая кислота, $\alpha$-липоевая кислота, октолипен, тиоктацид, тиогамма) - эндогенный антиоксидант (связывает свободные радикалы), в организме образуется при окислительном декарбоксилировании $\alpha$-кетокислот. В качестве коэнзима митохондриальных мультиферментных комплексов участвует в окислительном декарбоксилировании пировиноградной кислоты и $\alpha$-кетокислот. Способствует снижению концентрации глюкозы в крови и увеличению гликогена в печени, а также преодолению инсулинорезистентности. По характеру биохимического действия препарат близок к витаминам группы В. Участвует в регулировании липидного и углеводного обмена, стимулирует обмен холестерина, улучшает функцию печени. Оказывает гепатопротекторное, гиполипидемическое, 
гипохолестеринемическое, гипогликемическое действие. Улучшает трофику нейронов. Использование трометамоловой соли тиоктовой кислоты в растворах для в/в введения (имеющей нейтральную реакцию) позволяет уменьшить выраженность побочных реакций.

Эссенциале - эссенциальные фосфолипиды, которые представляют собой высокоочищенную фракцию фосфатидилхолина. По своей химической структуре подобны эндогенным мембранным фосфолипидам, превосходя их по своим функциональным свойствам за счет высокого содержания в них полиненасыщенных жирных кислот, особенно липоевой кислоты. Фосфолипиды являются основными структурными элементами клеточных мембран и органел. Они принимают участие в дифференциации, размножении и регенерации клеток. Функциональное значение основывается на их амфифильных свойствах, которые позволяют регулировать проницаемость клеточной оболочки. Улучшают функцию мембран, в частности ионный обмен, процесс внутриклеточного дыхания, биологического окисления, влияют на связывание ферментов внутриклеточного дыхания в митохондриях, а также на процесс окислительного фосфорилирования в энергетическом обмене клеток. В физиологических условиях синтез фосфолипидов удовлетворяет нормальные потребности гепатоцитов, которые содержат достаточное количество фосфолипидов. Эссенциале является универсальным стабилизатором мембран. Известно, что структура клеточных мембран, функция ферментных систем при заболеваниях печени и биосинтез фосфолипидов, дефицит которых приводит к изменению функции клеточной мембраны, нарушаются. Эссенциале Форте устраняет указанные нарушения, способствует регенерации клеточных мембран, реактивирует мембраносвязанные ферментные системы и рецепторы, повышает детоксикационную способность печени и таким образом нормализует ее функцию. Кроме того, эссенциале представляют как индуктор иммуномодулирующих свойств эритроцитов, так как эритроциты, обработанные эссенциале стимулируют развитие иммунного ответа на Т-зависимые АГ, но не влияют на выраженность иммунного ответа, индуцированного Т-независимыми $\mathrm{A} \Gamma$.

Целесообразно применение и других стабилизаторов мембран Ксидифона, Димефосфона. Ксидифон - мембраностабилизирующий препарат, обладающий способностью “включаться” в структуры липидного слоя мембран, способствуя образованию фосфолипидов, менее проницаемых для биологически активных веществ (75 - 100 мг/кг веса в сут, в зависимости от возраста - в виде $2 \%$ раствора 3 раза в день, в течение месяца). Полиненасыщенные фосфолипиды, внедряясь в наружный слой мембраны, оказывает влияние на содержание ненасыщенных жирнокислотных радикалов, обладают антиоксидантными свойствами и могут оказывать влияние на структуру мембраны за счёт снижения интенсивности постоянно протекающих процессов перекисного окисления липидов мембраны. 


\section{Глава 17. Принципы, коррекции иммунных нарушений при инфекционных болезнях}

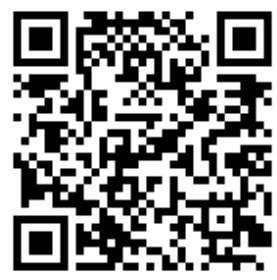

В настоящее время не определены единые подходы к коррекции иммунных нарушений. Это связано с большим разнообразием иммунопатологических реакций и разными «сценариями» развития иммунных нарушений у одного и того же заболевания. При этом лечение больного с нарушением функции иммунитета не может ограничиваться только иммуноактивной терапией. Каждое заболевание процесс мультифакторный и исходя из этого лечение любого больного должно быть комплексным и индивидуальным, тем не менее необходимо соблюдать пять основных принципов лечения больных с нарушениями функции иммунной системы к которым и относятся больные инфекционного профиля (рис.176).

Устранение патогенного агента
(санационные мероприятия, этиотропная терапия,
коррекция дисбиоза)

Рис.176. Принципы коррекции иммунных нарушений у больных с инфекционной патологией. 
В предыдущих главах мы уже подробно описали разделы, касающиеся устранения патогенного агента (санационные мероприятия, этиотропная терапия и коррекция дисбиоза (глава 14), мероприятий, влияющих на клеточное окружение (глава 15) и метаболическую терапию (глава 16). Нередко причиной иммунных нарушений являются инфекции и инвазии. Устранение их также описаны выше (глава 14). Однако немаловажное значение в лечении инфекционных больных принадлежит иммуноактивной терапии.

Иммунотерапия - это способы лечения заболеваний человека с помощью методов и/или фармакологических средств, направленных на активацию и/или подавление иммунной системы.

Актуальность проблемы восстановления иммунологических нарушений с помощью иммунокорригирующих препаратов в настоящее время несомненна и не требует обоснования. Однако при всей очевидности использование иммунотропных средств в комплексном лечении больных, их применение представляет собой сложную задачу и в настоящее время разработано недостаточно. Даже нет единого названия данного раздела терапии. В разное время этот вид терапии назывался по-разному: иммуномодулирующая, иммунокорригирующая, иммуноактивная, иммунотропная, более конкретно иммуностимулирующая или иммунодепрессивная. Действительно, не всегда понятно каким образом иммуномодулирующие препараты вызывают эффект возвращения из любого положения (угнетения, стимуляция) к нормальному уровню функционирования, при котором звенья иммунной системы не меняются или колеблются в нормальных пределах. Иммунная система - это мощная эшелонированная многокомпонентная система, которую сложно вывести из равновесия и поэтому при незначительных сбоях работы иммунитета самое главное иммунной системе «не мешать» она сама восстановится.

В последние годы, в связи с бурным развитием биотехнологий, сформирована группа препаратов, точечно действующих на определенные молекулы, так называемая молекулярно-прицельная или молекулярно-таргетная (англ. target «цель, мишень») или просто таргетная терапия. Учитывая, что основой для производства таких препаратов являются биофармацевтические технологии такую иммунотерапию называют таргетной или биологической терапией. Отдельно выделяют заместительную терапию у больных с первичными иммунодефицитами. Клеточные технологии, которые в большинстве случаев направлены на коррекцию иммунной системы, нередко выделяются как отдельное направление не только в иммунологии, но и в медицине вообще.

Важным акцентом в назначении иммунотропных препаратов является метод и место применения препарата: направленно на конкретный очаг или системно. Этот принципиальный аспект вообще не учитывается при классификации иммунотропных препаратов. Учитывая все это, варианты иммунотерапии представлена на рисунке (рис. 177). 


\section{ПО ЛОКАЛИЗАЦИИ}

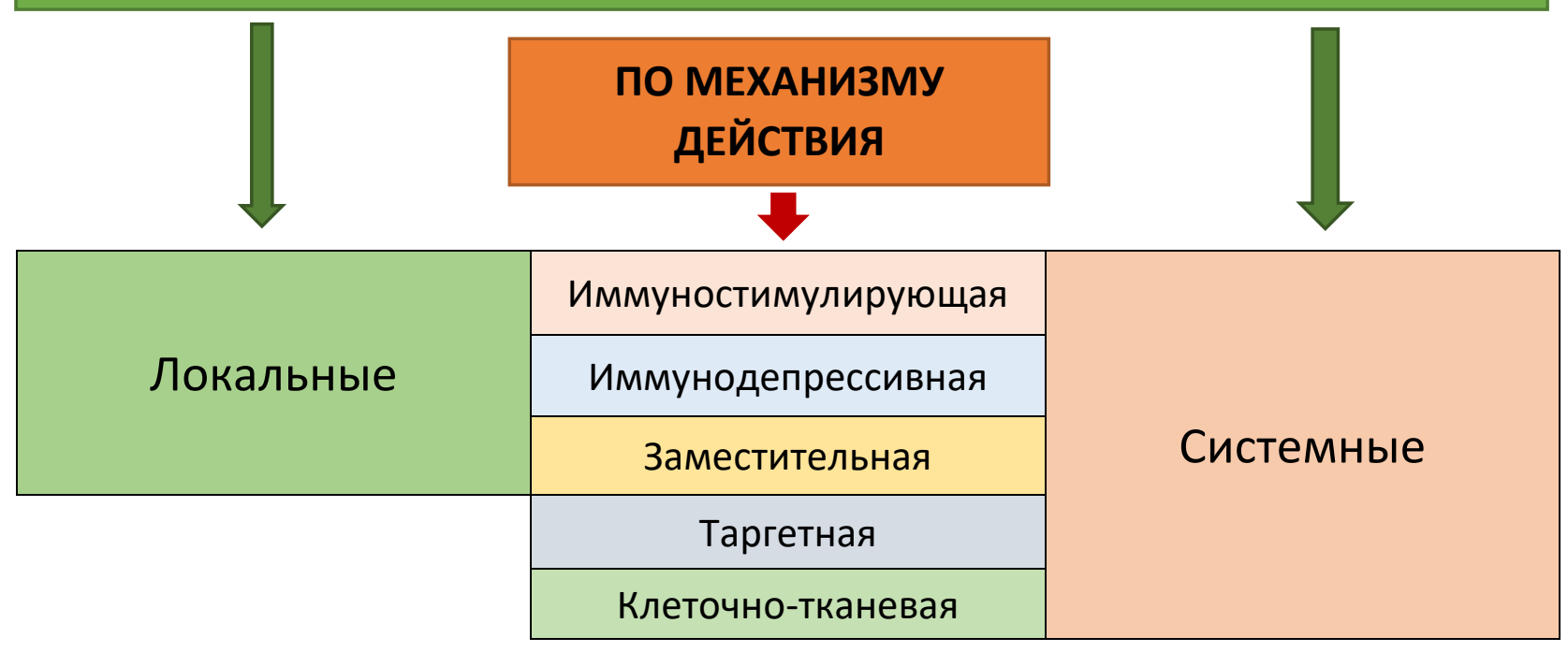

\section{Рис.177. Варианты иммунотерапии.}

Обычно считается, что именно назначение иммуноактивных препаратов это и есть работа клинического иммунолога. Действительно, иммунотерапия в клинической иммунологии - сложный лечебный процесс, направленный на восстановление нормального функционирования иммунной системы и достижение полноценной клинико-иммунологической ремиссии, вплоть до полного выздоровления. При применении иммуноактивных препаратов следует соблюдать следующие правила:

1. Опираться на достоверный клинический диагноз и определять степень иммунной патологии на основании клинических признаков иммунной недостаточности, данных лабораторных иммунологических обследований с обязательным учетом сопутствующих соматических заболеваний. Обязательно оценивать характер иммунных нарушений у больных, определять степень выраженности иммунных расстройств. Определить иммунологический диагноз.

2. Индивидуально подбирать иммунотропные препараты в зависимости от степени иммунных нарушений и их длительности. При возможности использовать индивидуальный подбор с учетом лабораторных тестов. Для больных с длительно протекающими и часто рецидивирующими иммунопатологическими процессами использовать несколько иммуноактивных препаратов, имеющих различные точки приложения в иммунной системе, но необходимо учитывать, что иммуноактивные препараты способны нанести непоправимый вред больному, например, запустить тяжелый аутоиммунный процесс или приостановить продукцию собственных IFN. T.е. индивидуальный подход к назначаемой терапии. 
3. Назначать иммуноактивную терапию с первых дней заболевания (вместе с этиотропными средствами). При этом антибактериальный препарат снижает функциональную активность микроба, а иммуноактивный препарат повышает функциональную активность клеток иммунной системы, что позволяет добиться достаточного клинического эффекта при заболеваниях, торпидных к проводимой стандартной терапии, в комплексной терапии рецидивирующих инфекционно-воспалительных процессов, аллергических, онкологических и др. заболеваний, протекающих в сочетании с иммунными нарушениями, а также для стимуляции лейкопоэза, улучшения качества жизни при проведении химио- и радиотерапии. Т.е. раннее назначение препаратов.

4. Назначать в некоторых случаях (например, при нарушении фагоцитарного звена иммунитета) иммуноактивные препараты больным как с выявленными, так и с невыявленными нарушениями иммунного статуса основанием для назначения препарата является клиническая картина. В тех случаях, когда обнаружены лишь изменения отдельных лабораторных показателей, но нет клинических признаков иммунной недостаточности, от введения иммуноактивных препаратов следует воздержаться. Применение только при болезни.

5. Применять иммуноактивные препараты целесообразно на фоне иммунологического мониторинга, который следует проводить вне зависимости от выявленных или исходных изменений в иммунной системе.

6. Помнить, что многие традиционные лекарственные вещества обладают иммунотропным эффектом, а также учитывать побочные реакции как различных препаратов на иммунную систему, так и иммуноактивных препаратов на другие органы и системы. Т.е. необходимо прогнозировать взаимодействие препаратов.

7. Учитывать возраст, биоритмы больного и другие особенности. Препарат полностью реализует свои эффекты только в оптимальной дозе в определенное время.

8. Обязательное использование иммунотерапии при проведении реабилитационных мероприятий.

9. Осуществить коррекцию иммунитета совместно с общеукрепляющими мероприятиями: сбалансированное питание, полноценный сон и режим отдыха, двигательная активность, ограничение стресса, санация хронических инфекций, в том числе, с удалением любых образований на коже и слизистых. 


\section{Глава 18. Иммунотерапия при инфекционных болезнях}

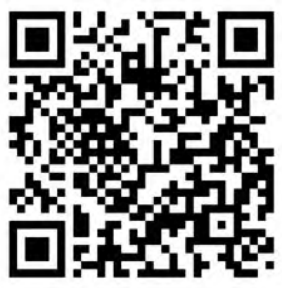

\section{Заместительная терапия}

Заместительная терапия длительное время успешно применяется в клинической практике в виде введения специфических АТ и сывороток, иммуноглобулинов и свежезамороженной плазмы. В последние годы, в связи с развитием биотехнологий и получением большого количества цитокинов к заместительной терапии можно отнести и коррекцию нарушений иммунной системы с помощью этих агентов.

Иммуноглобулиновые препараты. Опыт использования антител для профилактики и лечения инфекционных заболеваний имеет вековую историю. В период с 1891 по 1894 г.г. Эмиль Адольф фон Беринг совместно с Робертом Кохом разработали и впервые применили противодифтерийную сыворотку. В 1901 году Э. Берингу «...за работу по сывороточной терапии, главным образом за её применение при лечении дифтерии, что открыло новые пути в медицинской науке и дало в руки врачей победоносное оружие против болезни и смерти...», была присуждена первая Нобелевская премия по физиологии и медицине.

Специфические методы пассивной иммунотерапии основаны на использовании в лечебных целях иммунной плазмы, иммунных сывороток или иммуноглобулинов. Один из активных иммуноглобулин-содержащих препаратов в виде свежезамороженной плазмы достаточно давно и с хорошим клиническим эффектом применяется в клинической практике. Методы спиртового фракционирования плазмы крови и деактивации $\mathrm{Fc}$ фрагмента антител позволили с 80-х годов $\mathrm{XX}$-столетия наладить производство внутривенных иммуноглобулинов (ВВИГ), которые полностью заменили свежезамороженную плазму крови. Специфические АТ, используемые с лечебной целью, выпускаются промышленностью в виде иммунных сывороток или активных в иммунном отношении фракций - иммуноглобулинов. Их готовят из крови переболевших людей (гомологичные) или животных (гетерологичные). Гомологичные иммунные препараты обладают определенным преимуществом перед гетерологичными в связи с большой продолжительностью (до 1-2 мес.) их циркуляции в организме и отсутствием у них побочных эффектов. Сыворотки и иммуноглобулины, изготовленные из крови животных, действуют сравнительно недолго (1 - 2 нед) и способны вызывать побочные реакции, поэтому их 
применение оправдано только в случаях тяжелых заболеваний (дифтерия, ботулизм, столбняк, бешенство и пр.). В целях выявления повышенной чувствительности больного к чужеродному белку необходимо проводить внутрикожную пробу с разведенными препаратами (метод Безредко). При положительной пробе на чувствительность к чужеродному белку гетерогенные сыворотки вводятся под прикрытием глюкокортикоидов.

Чаще всего инфекционные больные нуждаются в иммунотерапии в остром периоде инфекционного процесса. Эффективность иммунных сывороток (иммуноглобулинов), в значительной мере, определяется оптимальной их дозой и своевременностью применения. Доза препарата должна соответствовать клинической форме заболевания и быть способной нейтрализовать не только циркулирующие в данный момент в организме АГ возбудителей заболевания, но и те, которые могут появиться в нем в промежуток времени между введениями препарата. Антимикробный и клинический эффект иммунных сывороток (иммуноглобулинов) тем выше, чем раньше они применяются. Назначение их после 4-5-го дня болезни редко дает выраженный положительный результат.

В настоящее время микробиологическая промышленность России и других стран производит иммунные сыворотки и иммуноглобулины для лечения больных различными инфекционными заболеваниями. Это предусмотрено в отношении возбудителей тех болезней, в патогенезе которых первостепенную роль играют экзотоксины (дифтерия, ботулизм, столбняк и др.), а также ряд опасных для здоровья людей болезней - сибирская язва, лептоспироз, бешенство, клещевой энцефалит и т.Д.. Начали выпускаться препараты этой группы и против COVID-19.

Дифтерия

Основным специфическим средством в лечении больных дифтерией является антитоксическая противодифтерийная сыворотка (АПДС), которая нейтрализует циркулирующий дифтерийный экзотоксин. При установлении диагноза «дифтерия» АПДС следует вводить немедленно, не ожидая результатов бактериологического исследования. Ниже в таблице приведены необходимые дозы для лечения дифтерии (табл. 105).

\section{Ботулизм}

Введение антитоксических сывороток является обязательным и главным компонентом неотложной терапии больных ботулизмом. Оно должно осуществляться в каждом случае клинического, не ожидая его лабораторного подтверждения. Для специфической антитоксической терапии применяют противоботулиновые лечебно-профилактические антитоксические сыворотки, выпускаемые в виде комплекта моновалентных или поливалентных сывороток. 


\section{ИММУНОТЕРАПИЯ}

Таблица 105

Дозы противодифтерийной сыворотки применяемые при лечении дифтерии

\begin{tabular}{|l|c|}
\hline \multicolumn{1}{|c|}{ Форма дифтерии } & Доза сыворотки, тыс. МЕ \\
\hline $\begin{array}{l}\text { Локализованная форма дифтерии } \\
\text { ротоглотки, носа, половых органов, } \\
\text { глаз, кожи и др. }\end{array}$ & $15-30$ внутримышечно \\
\hline $\begin{array}{l}\text { Распространенная дифтерия } \\
\text { ротоглотки }\end{array}$ & $30-40$ внутримышечно \\
\hline $\begin{array}{l}\text { Субтоксическая дифтерия ротоглотки } \\
\text { Токсическая дифтерия ротоглотки: } \\
\text { І ст. тяжести }\end{array}$ & $50-60$ внутримышечно \\
ІІ ст. тяжести & 80-100 внутримышечно и внутривенно \\
\hline ІІІ ст. тяжести & $100-120$ внутримышечно и внутривенно \\
Гипертоксическая & $120-150$ внутримышечно и внутривенно \\
\hline Круп локализованный & внумышечно \\
\hline Круп распространенный и нисходящий & 15-20 внутримышечно \\
\hline
\end{tabular}

До установления типа токсина вводят смесь моновалентных сывороток (А, В и Е) по 1 лечебной дозе в случаях легкого или среднетяжелого течения и по 2 -4 лечебные дозы больным с тяжелой клинической картиной заболевания. Сыворотку подогревают до температуры $37^{\circ} \mathrm{C}$ и вводят внутривенно (при затруднении внутривенного введения, ее вводят внутримышечно) в зависимости от степени тяжести заболевания. Если тип токсина известен, назначают моновалентную антитоксическую сыворотку.

Одна лечебная доза для антитоксинов типа А, С, Е составляет по 10000 ME, типа В по 5000 ME, типа F -300 ME.

\section{Столбняк}

Противостолбнячную сыворотку вводят внутримышечно однократно по 50-100 тыс. МЕ. Одновременно с этим 3-10 тыс. МЕ препарата вводят в ткани, окружающие рану. При аллергии организма больного к чужеродному белку целесообразно вместо сыворотки применять специфический 
противостолбнячный человеческий иммуноглобулин, который вводят внутримышечно в дозе 900-1800 МЕ (6-12 мл).

\section{Бешенство.}

Человеческий иммуноглобулин для профилактики бешенства. Для лечебно-профилактических мероприятиях при подозрении на бешенство рекомендуется немедленно применять иммунизацию, при любых повреждениях кожных покровов - укусах, любых ранах и глубоких царапинах на лице, голове, шее, кистях рук, стопах, на туловище, нанесенных животными, больными бешенством, с подозрением на бешенство, находящимися под ветеринарным наблюдением и вне его, дикими.

\section{Сибирская язва.}

Иммуноглобулин противосибиреязвенный лошадиный. $\mathrm{C}$ целью экстренной профилактики препарат назначают в случаях: прямого контакта с материалом, содержащим возбудитель сибирской язвы; при уходе за больными сибирской язвой животными; при убое и разделке туш больных животных; при приготовлении и употреблении в пищу мяса больных животных. Экстренно профилактическое введение препарата производится лицам, не привитым против сибирской язвы. С лечебной целью препарат назначают при среднетяжелом и тяжелом течении сибирской язвы.

\section{Клещзевой энцеефалит.}

Применяют иммуноглобулин человека против клещевого энцефалита при экстренной профилактике (после укуса энцефалитного клеща) и лечении. Для профилактики (0,05 мл/кг, однократно): в возрасте до 12 лет - 1 мл, от 12 до 16 лет -2 мл, от 16 лет и старше -3 мл. Для лечения (0,2 мл/кг) - в первые дни по 3 мл с интервалом 10-12 ч. (до падения температуры). После введения необходимо наблюдение за пациентами в течение 30 мин. (возможность развития аллергических реакций).

\section{COVID-19.}

Пассивная иммунизация плазмой выздоровевших от вируса COVID - 19 или гипериммунным иммуноглобулином была предложена в качестве потенциального лечения COVID-19, уже в начале пандемии. Однако проведенные рандомизированные исследования без учета особенностей функции иммунной системы позволили сделать вывод, что плазма выздоравливающих для лечения людей с умеренным и тяжелым заболеванием не снижает смертность и практически не влияет на показатели клинического улучшения. Тем не менее в России зарегистрирован отечественный препарат "КОВИД-глобулин" (разработчик - компания "Нацимбио") представляющий собой высококонцентрированный препарат на основе плазмы переболевших доноров, который можно рекомендовать больным COVID-19 с недостаточностью гуморально-эффекторного звена иммунитета. 
Отдельная группа препаратов обладающие вируснейтрализующим действием в отношении SARS-CoV-2 рекомбинантные мAT человека. Они связываются с эпитопами рецептор-связывающего домена S-белка, блокируют взаимодействие S-белка SARS-CoV-2 с AПФ2 (ангиотензин-превращающий фермент 2), это приводит к подавлению инфицирования клеток хозяина и останавливает репликацию вируса. Разработаны и применяются казиривимаб / имдевимаб (мAT к белку шипа SARS-CoV-2) бамланивимаб / этесевимаб (мАТ к поверхности шипа белка из SARS-COV-2), тиксагевимаб / цилгавимаб (мAT против поверхностного шипового белка SARS-CoV-2), сотровимаб (мAТ к шипу белка SARS-CoV-2), регданвимаб (мAT против спайка белка SARS-COV-2).

Данные препараты не зарегистрированы в Российской Федерации, и их назначение возможно только при наличии решения врачебной комиссии и разрешения на временное обращение (постановление Правительства Российской Федерации от 3 апреля 2020 г. № 441 «Об особенностях обращения лекарственных препаратов для медицинского применения, которые предназначены для применения в условиях угрозы возникновения, возникновения и ликвидации чрезвычайной ситуации и для организации оказания медицинской помощи лицам, пострадавшим в результате чрезвычайных ситуаций, предупреждения чрезвычайных ситуаций, профилактики и лечения заболеваний, представляющих

Внутривенные иммуноглобулины (ВВИГ) содержат в своем составе широкий спектр антител, направленных против наиболее часто встречающихся патогенов, а также блокирующих антител. В настоящий момент в РФ зарегистрировано 13 лекарственных препаратов ВВИГ: все они представляют собой готовые растворы для внутривенного введения. Десять препаратов 5\% (предыдущее поколение) и только три (Привиджен, Гамунекс-С, Октагам) содержат 10\% раствор нормального иммуноглобулина (Ig) человека. При таком разнообразии естественно возникают трудности с выбором препарата. Ситуация усугубляется еще тем, что в типовом формуляре ВО3 (2009 г.) содержится основополагающая фраза «препараты иммуноглобулинов различных производителей различаются и не могут рассматриваться как эквивалентные». Поэтому к подбору препарата ВВИГ следует относиться с повышенным вниманием, учитывая все особенности его способа производства и состава.

Подавляющее большинство антител в составе ВВИГ относится к классу $\operatorname{IgG}(>95 \%)$, при этом с точки зрения терапевтического действия важно, чтобы в препарате сохранялось естественное соотношение всех 4 субклассов IgG (IgG1 IgG4) как, например, в препарате «Привиджен».

У ВВИГ достаточно много механизмов действия (табл.106). По направленности их можно разделить на 2 группы: заместительные (в физиологических дозах) и иммуномодулирующие (в высоких дозах). Из этих механизмов вытекают показания к назначению этих препаратов. 


\section{Механизмы и действия ВВИГ}

\begin{tabular}{|c|c|}
\hline Характер эффектов & Механизмы \\
\hline Заместительные & $\begin{array}{ll}\text { - } & \text { нейтрализация антигена } \\
\text { - } & \text { блокада Fс рецепторов на макрофагах } \\
\text { - } & \text { блокада классического пути активации комплемента } \\
\text { (ингибиция C1q, С3 и С4 компонентов) } \\
\text { - } \quad \text { модуляция продукции провоспалительных цитокинов }\end{array}$ \\
\hline Иммуномодулирующие & $\begin{array}{ll}\text { - } & \text { ингибирование синтеза аутоантител (по механизму обратной } \\
\text { связи) } & \\
\text { - } & \text { нейтрализация циркулирующих аутоантител по механизму } \\
\text { идиотип-антиидиотипического взаимодействия } \\
\text { - } \quad \text { элиминация циркулирующих иммунных комплексов, } \\
\text { диссоциация их отложений в тканях } \\
\text { - } \quad \text { изменение Th1-Th2 баланса в сторону Th1 }\end{array}$ \\
\hline
\end{tabular}

Заместительная терапия показана при заболеваниях, вызываемых недостаточной продукцией Ig. Это прежде всего первичные иммунодефициты (ПИД) с нарушением гуморального звена. В большинстве инструкций к препаратам ВВИГ указаны лишь 4 заболевания: врожденная агаммаглобулинемия и гипогаммаглобулинемия, общая вариабельная иммунная недостаточность, тяжелая комбинированная иммунная недостаточность, синдром Вискотта-Олдрича. Вместе с тем, накопленный клинический опыт в отечественных и зарубежных иммунологических центрах свидетельствует об эффективности ВВИГ при множестве других ПИД. Другим направлением заместительной терапии ВВИГ являются вторичные иммунодефициты (ВИД). Здесь также как и в случае с ПИД спектр нозологий по инструкции сильно ограничен. Это множественная миелома, хронический лимфоидный лейкоз, врожденный СПИД у детей при наличии рецидивирующих инфекций. До последнего времени предполагалось, что назначение ВВИГ при других ВИД (например, тяжелые инфекции, ожоги, акушерско-гинекологическая патология) должно проходить в формате off-label. В прошлом году эту проблему решила компания CSL Behring, внеся в инструкцию препарата «Привиджен» новое показание «симптоматическая гипогаммаглобулинемия, вторичная по отношению к основному заболеванию или лечению». Это позволяет назначать препарат практически при любых ПИД и ВИД.

Иммуномодулирующая (высокодозная) терапия ВВИГ направлена на лечение аутоиммунных и аутовоспалительных заболеваний. Наиболее частыми показаниями в инструкциях ВВИГ являются идиопатическая тромбоцитопеническая пурпура, синдром Гийена-Барре, болезнь Кавасаки и 
хронические воспалительные демиелинизирующие полинейропатии. Но, как и в случае с иммунодефицитами, в литературе можно обнаружить десятки аутоиммунных нозологий, при которых в клинических исследованиях доказана эффективность ВВИГ.

Учитывая естественное происхождение ВВИГ, они являются достаточно безопасными с точки зрения применения. Побочные эффекты достаточно редкие и, как правило, легкой степени тяжести. Однако частота и выраженность нежелательных явлений напрямую связана с используемым препаратом. На сегодняшний день уже хорошо описаны параметры производственного процесса и характеристики конечного препарата ВВИГ, которые сводят риски побочных эффектов от их применения к минимуму:

1. Вирусинактивация. В связи с тем, что ВВИГ являются препаратами крови человека, существует риск переноса трансмиссивных вирусов. В Европе не регистрируют ВВИГ, не имеющих минимум 2 стадий вирусинактивации. Некоторые производители препаратов из крови считают это требование недостаточным и увеличивают количество процедур очистки от вирусов. Например, в производственном процессе препарата «Привиджен» предусмотрены 4 цикла вирусинактивации.

2. Агрегация Ig. Количество комплексов из Ig напрямую коррелирует с частотой побочных эффектов. Поэтому производитель должен представить эту информацию либо в инструкции, либо по запросу.

3. Изогемагглютинины. Анти-А и анти-В агглютинины содержатся в плазме крови здоровых людей (фракции $\operatorname{IgM}$ и $\operatorname{IgG}$ ) и могут стать причиной гемолиза. В связи с этим производитель должен не только контролировать их содержание в конечном препарате, но и включить в производственный цикл технологические процедуры по снижению (в идеале полному отсутствию) изогемагглютининов в препарате. Например, компания CSL Behring при производстве препарата «Привиджен» использует иммуноаффинную хроматографию для специфического удаления антител к группе крови А и В.

4. Содержание IgA. У пациентов с селективным дефицитом IgA переливание препаратов ВВИГ содержащих данный Ig несет потенциальный риск развития анафилактических реакций. Поэтому при производстве препаратов ВВИГ необходимо не только контролировать количество $\operatorname{IgA,~но~и~}$ свести его содержание к минимуму.

Существенными факторами, осложняющими применение ВВИГ в практике, являются низкая температура, при которой они транспортируются и хранятся, а также скорость введения пациенту. Большинство препаратов ВВИГ в силу своего белкового происхождения должны храниться при температурах +4 $+8^{\circ} \mathrm{C}$. Использование специального стабилизатора - пролина позволяет хранить препарат «Привиджен» при комнатной температуре 3 года, что исключает его инактивацию при нарушении холодовой цепи. Время инфузии 5\% ВВИГ, в среднем, составляет 6 часов 12 минут (расчет на пациента массой тела 50 кг). 
Использование «высокоскоростных» $10 \%$ препаратов («Привиджен», «Октагам») снижает это время до 46 минут, что безусловно сказывается на качестве жизни пациента и его согласии на проводимую терапию.

Обогащенные иммуноглобулины - ВВИГ содержащие антитела класса IgG и обогащенные антителами классов IgM и IgA (Пентаглобин). Пентаглобин был разработан для лечения распространенных тяжелых бактериальных инфекций за счет специфических функций, которыми обладают иммуноглобулины классов А и М. Однако мультицентровые исследования применения стандартных иммуноглобулинов при лечении сепсиса не показали свою эффективность, поэтому препарат ушел с рынка как у нас в России, так и в Европе. При этом необходимо отметить, что применение препарата было проведено без учета вариантов течения сепсиса (преобладание SIRS, CARS, MARS, PICS (см. главу 10), что не позволяет отвергать применение данного препарата в связи с его «физиологической целесообразностью» (содержит широкий спектр антител против микроорганизмов, для комплемент-опосредованного уничтожения микроорганизмов и повышения фагоцитарной активности моноцитов/макрофагов и гранулоцитов).

Гипериммунные специфические иммуноглобулины - ВВИГ, содержащие антитела класса IgG с повышенной концентрацией против определенных возбудителей (Неоцитотект, Неогепатект и др.).

Неоцитотект является препаратом Ig, который изготовлен из плазмы доноров с высоким титром антител против возбудителя цитомегалии. Распределение подклассов IgG соответствует распределению в плазме здоровых доноров. Препарат применяется при профилактике ЦМВ-инфекции у пациентов с подавленной медикаментами иммунной системой, в частности, после трансплантации органов, предотвращение манифестации заболевания после инфицирования ЦМВ, терапия ЦМВ-инфекции у пациентов с ослабленным иммунитетом, например, недоношенных детей, новорожденных, а также у пациентов с подавленным медикаментами иммунитетом или иммунодефицитом, вызванным другими причинами (например, СПИД). Препарат вводят в разовой дозе 1 мл на кг массы тела.

Показаниями к применению препарата «Неогепатект» являются: профилактика гепатита В у новорожденных, родившихся от матерей носительниц поверхностного антигена вируса гепатита В; использование у лиц с повышенным риском заражения вирусом гепатита В до или одновременно с вакцинацией против гепатита В (в т.ч. перед операциями, повторной гемотрансфузией, гемодиализом), профилактика инфицирования трансплантата печени у пациентов, имеющих поверхностный антиген вируса гепатита В, профилактика гепатита В у взрослых и детей, подвергшихся опасности заражения гепатитом В (например, в случае нарушения целостности кожного покрова при уколе инъекционной иглой или непосредственного контакта со слизистой оболочкой). 


\section{Цитокинотерапия.}

В настоящее время, используя последние достижения молекулярной биологии, биохимии, иммунологии, генной инженерии, были созданы новые эффективные лекарственные средства - рекомбинантные препараты. Принципы создания таких препаратов заключается в следующем: 1) распознается участок ДНК человека, ответственный за синтез нужного белка; 2) этот участок вырезается и встраивается в ДНК живой бактерии (например, кишечной палочки или дрожжевой клетки); 3) пересаженный участок начинает работать и синтезировать нужные белковые молекулы. Далее эти биологически активные вещества выделяются и очищаются. Препараты, полученные таким способом, называют рекомбинантными. Они, являясь чистыми от посторонних биологически активных веществ, оказывают меньше побочных действий, их специфическая фармакологическая активность выше, чем у аналогичных природных препаратов.

Основные рекомбинантные препараты вместе с ферментами, гормонами, вакцинами и факторами свертывания крови являются цитокины, наиболее часто применяющиеся в медицине.

В клинической практике существуют три основных направления использования цитокинов:

1. цитокиновая иммунотерапия, при которой цитокины выступают в роли лекарственных средств - заместительная терапия;

2. антицитокиновая терапия, направленная на блокирование биологического действия или удаление избытка цитокинов из организма - таргетная терапия (см. ниже);

3. цитокиновая генотерапия, применяемая с целью усиления противоопухолевого иммунитета, коррекции дефектов в системе цитокинов и их рецепторов - клеточно-тканевая терапия (см. ниже).

Разработка доступных методов оценки многих цитокинов позволила сформулировать понятие об иммуноцитокиновом статусе и определить круг иммунопатологии, при которой существенно нарушена их продукция и рецепция.

Интерфероны. Основная группа активно применяемых цитокинов (табл.107). Это биологически активные белки, которые синтезируются клеткой в процессе защитной реакции. Они секретируются во внеклеточную жидкость и через рецепторы действуют на другие клетки, повышая устойчивость к внутриклеточным микроорганизмам, в первую очередь, - вирусам. По структуре и биологическим свойствам ИФН подразделяются на три вида: ИФН- $\alpha$, ИФН- $\beta$ и ИФН- $\gamma$. 


\section{Интерфероны и их препараты}

\begin{tabular}{|c|c|}
\hline $\begin{array}{c}\text { Препараты (торговые } \\
\text { названия) }\end{array}$ & Фармакологическое действие \\
\hline & Альфа-интерфероны \\
\hline $\begin{array}{l}\text { Альтевир, Альфарона, } \\
\text { Виферон, Роферон-А, } \\
\text { Интрон-А, Реальдирон, } \\
\text { Реаферон-ЕС, Интераль, } \\
\text { Альтевир, Виферон, } \\
\text { Гриппферон и др. }\end{array}$ & $\begin{array}{l}\text { Препятствует вирусному инфицированию клеток, изменяет свойства клеточной } \\
\text { мембраны, предотвращает адгезию и проникновение вируса внутрь клетки. } \\
\text { Инициирует синтез ряда специфических ферментов, нарушает синтез вирусной } \\
\text { РНК и белков вируса в клетке. Изменяет цитоскелет мембраны клетки, } \\
\text { метаболизм, предотвращая пролиферацию опухолевых (особенно) клеток. } \\
\text { Оказывает модулирующее влияние на синтез некоторых онкогенов, } \\
\text { приводящее к нормализации неопластической трансформации клеток и } \\
\text { ингибированию опухолевого роста. Стимулирует процесс презентации антигена } \\
\text { иммунокомпетентным клеткам, модулируетактивность киллеров, участвующих } \\
\text { в противовирусном иммунитете. }\end{array}$ \\
\hline \multicolumn{2}{|r|}{ Альфа-интерфероны пролонгированного действия } \\
\hline $\begin{array}{l}\text { Пегасис, ПегИитрон } \\
\text { Альгерон }\end{array}$ & $\begin{array}{l}\text { Препараты образуется путем присоединения к молекуле интерферона альфа } \\
\text { полимерной структуры - полиэтиленгликоля (ПЭГ), за счет чего обеспечивается } \\
\text { пролонгированное действие препарата аналогичное альфа-интерферонам. }\end{array}$ \\
\hline \multicolumn{2}{|r|}{ Бета-интерфероны } \\
\hline $\begin{array}{l}\text { Аванекс, Ребиф, } \\
\text { Тебериф, Бетаферон, } \\
\text { Ронбетал, Инфибета }\end{array}$ & $\begin{array}{l}\text { Обладают противовирусным, антипролиферативным ипротивовоспалительным } \\
\text { действием. При рассеянном склерозе стимулирует противовоспалительные } \\
\text { цитокины, тормозит пролиферацию лейкоцитов с нарушением презентации } \\
\text { аутоантигенов, снижает темпы миграции лейкоцитов через ГЭБ. Является } \\
\text { антагонистом интерферона-гамма, повышает супрессорную активность } \\
\text { мононуклеарных клеток и снижает устойчивость Т-лимфоцитов к апоптозу, } \\
\text { вызывая гибель аутореактивных клонов. }\end{array}$ \\
\hline \multicolumn{2}{|r|}{ Гамма-интерферон } \\
\hline Ингарон & 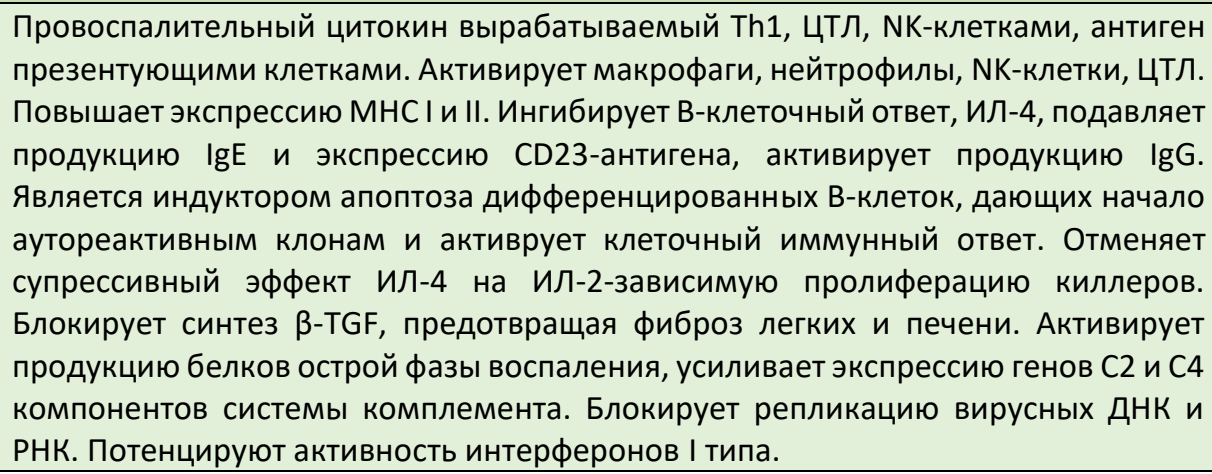 \\
\hline
\end{tabular}

Препараты ИФН- $\boldsymbol{\alpha}$ применяются в первую очередь при вирусных инфекциях, среди которых наиболее изучены острые и хронические вирусные гепатиты, герпетические поражения, грипп, COVID-19, ОРВИ и др. Показана эффективность ИФН при лечении ЦМВИ, различных бактериальных заболеваниях (гнойно-септической инфекции у новорожденных и хирургических больных, хламидиозе и др.). ИФН используются также при многих онкологических заболеваниях.

В России выпускается целая гамма разнообразных препаратов на основе рекомбинантного ИФН- $\alpha$. Прежде всего, необходимо выделить препараты для локального (местного) применения в виде капель и спрея - Гриппферон, 
Альфарона, мазей и геля - Виферон, вагинальных и ректальных свечей Генферон, Гиаферон и Виферон, для перорального применения - Реаферонлипинт, глазные капли - Офтальмоферон, Интерфераль.

При любой вирусной инфекции необходимо местное применение ИФН- $\alpha$, это определяется «физиологической целесообразностью» и идентичностью данных препаратов. Однако срок применения должен быть ограничен 3 днями от начала заболевания в связи с дальнейшим иммуносупрессивным действием интерферонов (эффект истощения).

В некоторых случаях так, например, при ВПЧ инфекции эти препараты являются единственными патогенетическими препаратами для лечения с обоснованными доказательствами.

Гораздо больше препаратов ИФН- $\alpha$ для системного применения. Это Роферон-А (3-4,5-6-9 млн. МЕ), Альтевир флаконы (1, 3, 5, 10, 15 млн. МЕ) или шприцы (3, 5, 10, 15 млн. МЕ), Альфарона (500 тыс.-1-3-5 млн. МЕ), Интрон А во флаконах объемом по 1 мл/10 млн. ME (1 доза), 3 мл/18 млн. ME (6 доз по 3 млн. ME), 2,5 мл/25 млн. ME (5 доз по 5 млн. МЕ) или в шприц-ручках по 1,2 мл (6 доз по 3 млн. МЕ - 18 млн. МЕ; 6 доз по 5 млн. МЕ - 30 млн. МЕ; 6 доз по 10 млн. МЕ - 60 млн. МЕ), Реальдирон (1-3-6-9-18 млн. МЕ), Реаферон-ЕС (ампулы 0,5-1-3-5 млн. МЕ). Отдельно необходимо отметить препараты ИФН- $\alpha$ пролонгированного действия - Пегасис шприцы (135 или 180 мкг/0,5 мл), пегИнтрон во флаконах (50-80-100-120 мкг) или шприцах (50-80-100-120-150 мкг), Альгерон (200 мкг/мл шприцы с градуировкой по 0,4, 0,5, 0,6, 0,8 или 1,0 мл).

Принципы применения препаратов ИФН, несмотря на активное и длительное использование в клинической практике, все еще можно сформулировать в самом общем виде. Это связано с тем, что ИФН влияют на многие реакции инфекционного, в частности, противовирусного, и противоопухолевого иммунитета, но их направленность зависит от состояния иммунной и интерфероновой систем организма, а также дозы, кратности, способа введения препарата. Важным фактором являются индивидуальные особенности препарата, в частности, тип ИФН, его лекарственная форма. Все это крайне усложняет разработку обоснованной тактики использования ИФН при каждом конкретном заболевании. Возможны лишь общие рекомендации, к которым всегда следует относиться критически.

Основные принципы применения препаратов ИФН.

- Адекватная оценка показаний и противопоказаний к назначению ИФН с учетом иммунного и интерферонового статуса больного.

- Выбор оптимального режима дозирования (часто подбирается индивидуально с учетом переносимости). 
- Правильный выбор препарата (учитывая тип ИФН и способ его получения, в некоторых случаях необходимо предварительное индивидуальное лабораторное тестирование).

- Прогнозирование и контроль возникновения побочных эффектов с учетом дозировки, основной патологии, особенностей препарата. Снижение выраженности побочных эффектов за счет изменения режима дозирования, применения нестероидных противовоспалительных средств и т.д. При возможности типирование препарата или линейки препаратов in vitro.

- Адекватный контроль эффективности лечения (критерии и сроки значительно отличаются при разных заболеваниях и для различных препаратов).

- Обязательный иммунологический и интерфероновый мониторинг при проведении интерферонотерапии.

- У Учет возможных лекарственных взаимодействий препаратов ИФН с другими лекарственными средствами.

Интерфероны - препараты крайне трудные для врача. Рациональное применение этих препаратов должно основываться на том понимании, что ИФН с иммунобиологической точки зрения - это активный иммуномодулятор, влияющий на процессы дифференцировки, рекрутирования, а также функциональную активность эффекторных клеток иммунной системы и, прежде всего, Т-лимфоцитов и моноцитов/макрофагов. Под действием ИФН повышается эффективность иммунного распознавания антигенами, усиливаются фагоцитарная и цитолитическая функции, направленные на элиминацию возбудителя или антигенно измененных клеток. Следовательно, ИФН относятся к группе лекарственных средств с четко охарактеризованным направленным действием на иммунную систему. Клиническое применение этих препаратов требует обязательного иммунологического контроля, поэтому выбор препарата должен осуществляться с учетом индивидуальных иммуномодулирующих эффектов и состояния иммунной системы (клинические данные, показатели иммунного и интерферонового статуса) больного. Большое значение при этом имеет типирование препаратов в лаборатории in vitro.

При инфекционных заболеваниях разовые дозы ИФН определяются спецификой патологического процесса и должны быть достаточными для проявления иммуностимулирующего и корригирующего его влияния. В качестве лабораторной оценки можно рекомендовать такие тесты, как активация макрофагального или нейтрофильного фагоцитоза, цитолитических NK-клеток, методы хемилюминесцентного анализа.

Чтобы исключить явление рефрактерности эффекторных клеток к действию ИФН, системное введение препарата должно быть прерывистым с интервалом в $1-3$ дня. Следует избегать ежедневного введения более 3-х дней подряд. 
При онкологических заболеваниях тактика медицинского применения препаратов ИФН зависит от характера опухоли, клинического состояния больного и должна учитывать схему использования других методов терапии. Важное значение имеет хирургическое удаление опухоли. Курс интерферонотерапии может сочетаться с другими средствами химиотерапии, а также с радиотерапией. Необходимо учитывать, что наряду с чувствительными к интерферонотерапии опухолями (аденокарцинома почки, саркома легкого, злокачественная меланома, нейробластомы, опухоли лимфоидных эндокринных и генеративных органов) имеются и более устойчивые опухоли (желудка, прямой кишки, печени). Как правило, высокой чувствительностью обладают вирусиндуцированные опухоли - папилломы гортани, мочевого пузыря, назофарингеальная карцинома, базально-клеточный рак кожи.

Заслуживает внимания тактика использования препаратов ИФН с целью реабилитации иммунной системы после жестких курсов цитостатической и радиотерапии. Наиболее рационально с этой целью применять комплексные препарататы, например лейкинферон для инъекций.

Побочное действие препаратов ИФН. Нежелательные реакции на ИФН являются дозозависимыми. Условно подразделяются на ранние, возникающие чаще на первой неделе лечения, и поздние, развивающиеся на 2-6-й неделе терапии.

Ранние реакции: гриппоподобный синдром: лихорадка, миалгия, болезненность глазных яблок. Встречаются практически у всех пациентов и обычно не требуют отмены препарата. Меры профилактики - прием парацетамола перед введением ИФН- $\alpha$.

Поздние реакции (нередко бывают причиной отмены препарата): гематологические: анемия, тромбоцитопения, агранулоцитоз. Меры профилактики - систематический контроль гемограммы.

Можно выделить побочные эффекты препаратов ИФН со стороны различных органов и систем. Центральная нервная система: сонливость, заторможенность, депрессия, судороги, головокружение, нарушение зрения, ухудшение психического состояния, спутанность сознания, нарушение памяти и поведения (тревога, нервозность), бессонница. Редко - выраженная сонливость, судороги, кома, нарушение мозгового кровообращения, временная импотенция и ишемическая ретинопатия, суицидальное поведение. Периферическая нервная система: парестезия, онемение кожи конечностей, зуд, тремор. Сердечнососудистая система: аритмия, транзиторная кардиомиопатия, артериальная гипотензия, инфаркт миокарда. Легкие (редко): кашель, одышка, отек легких, пневмония, остановка дыхания. Эндокринная система: аутоиммунный тиреоидит. Кожа: сыпь различного характера. ЖКТ: потеря аппетита, тошнота, рвота, изменение вкуса, сухость во рту, похудение, диарея, боль в животе. Редко 
- запор, метеоризм, усиление перистальтики, изжога, обострение язвенной болезни желудка и двенадцатиперстной кишки, кровотечение. Повышение активности аланинаминотрансферазы, щелочной фосфатазы, ЛДГ, гипербилирубемия. Другие побочные эффекты: гиперлипидемия, алопеция.

Противопоказания к применению препаратов ИФН. Абсолютные гиперчувствительность к препаратам ИФН, психоз (на момент лечения или в анамнезе), тяжелая депрессия, нейтропения или тромбоцитопения, декомпенсированные заболевания сердечно-сосудистой системы, декомпенсированный цирроз печени, неконтролируемые судороги, трансплантация органов (кроме печени), беременность, цирроз печени (кроме пегелированного ИФН). Относительные - аутоиммунные заболевания, неконтролируемый диабет.

Препараты ИФН-ק представлены зарубежными препаратами «Авонекс», «Бетаферон», «Ребиф», «Инфибета», «Ронбетал» и отечественным препаратом «Тебериф». Имеется пролонгированная форма ИФН- $\beta$ - Плегриди. Все они в настоящее время применяются по одному показанию - лечение рассеянного склероза.

Единственным препаратом ИФН- $\boldsymbol{\gamma}$ в России с 2006 г. является «Ингарон». Он выпускается в двух лекарственных формах - лиофилизат для приготовления раствора для внутримышечного и подкожного введения флаконы (100000 и $500000 \mathrm{ME})$ и лиофилизат для приготовления раствора для интраназального введения (100000 ME). Этот препарат может быть использован для лечения недостаточности клеточно-эффекторного звена иммунитета.

Интраназальная форма применяется для лечения и профилактики вирусных инфекций прежде всего ОРВИ. Ингарон эффективно стимулирует клетки мукозального иммунитета обладает иммуностимулирующим и противовирусным действием. Для лечения респираторных вирусных инфекций в том числе гриппа и COVID-19 по 2-3 капли в каждый носовой ход, 5 раз в день, в течение 5-7 дней. Ингарон можно использовать и для сезонной профилактики ОРВИ. Данная профилактика способна предотвратить все вирусные простудные заболевания в том числе COVID-19.

При недостаточности клеточно-эффекторного звена иммунитета средней и тяжелой степени применяется инъекционная форма ингарона (табл.108).

Другие цитокины начали массово внедряться в медицинскую практику с 90-х годов прошлого столетия. Для получения цитокинов использовали методы естественного активирования клеток-продуцентов с последующим фракционированием материала и очистки или метод генной инженерии (рекомбинантные цитокины). В последнее время первый метод производства практически не применяется. 


\section{Рекомендуемые схемы применения ингарона}

\begin{tabular}{|c|c|c|c|}
\hline Нозология & Суточная доза & Кратность введения & Курс терапии \\
\hline $\begin{array}{l}\text { Хронический вирусный } \\
\text { гепатит В, в/м или п/к }\end{array}$ & $500000 \mathrm{ME}$ & $\begin{array}{l}\text { В комплексной терапии } \\
\text { совместно с интерфероном } \\
\text { альфа, монотерапия }\end{array}$ & $\begin{array}{c}6 \text { мес. } \\
\text { курсами 1-3 мес. с } \\
\text { перерывами 1-2 } \\
\text { мес } \\
\end{array}$ \\
\hline Герпесвирусная инфекция п/к & $500000 \mathrm{ME}$ & Через день & 5 инъекций \\
\hline $\begin{array}{l}\text { Опоясывающий лишай } \\
\text { п/к }\end{array}$ & $500000 \mathrm{ME}$ & Через день & 5 инъекций \\
\hline $\begin{array}{l}\text { Папилломавирусная } \\
\text { инфекция, }\end{array}$ & $100000 \mathrm{ME}$ & $\begin{array}{l}\text { После криодеструкции, через } \\
\text { день }\end{array}$ & 5 инъекций \\
\hline $\begin{array}{l}\text { Профилактика инфекционных } \\
\text { осложнений при хронической } \\
\text { гранулематозной болезни в/м } \\
\text { или п/к }\end{array}$ & $500000 \mathrm{ME}$ & Ежедневно или через день & $\begin{array}{c}\text { 5-15 инъекций } \\
\text { при необходимости } \\
\text { повторить через } \\
\text { 10-14 дней }\end{array}$ \\
\hline Туберкулез легких в/м или п/к & $500000 \mathrm{ME}$ & $\begin{array}{l}\text { В комплексной терапии } \\
\text { ежедневно или через день }\end{array}$ & $\begin{array}{c}\text { Устанавливается } \\
\text { индивидуально, - } \\
\text { не более } 3 \text { мес. } \\
\end{array}$ \\
\hline $\begin{array}{l}\text { Урогенитальный хламидиоз } \\
\text { п/к }\end{array}$ & $500000 \mathrm{ME}$ & Через день & 5 инъекций \\
\hline Хронический простатит п/к & $100000 \mathrm{ME}$ & Через день & 10 инъекций \\
\hline $\begin{array}{l}\text { Онкологические заболевания } \\
\text { в/м или п/к }\end{array}$ & $500000 \mathrm{ME}$ & $\begin{array}{l}\text { Через день, зависит от режима } \\
\text { химиотерапии }\end{array}$ & $\begin{array}{l}\text { Устанавливается } \\
\text { индивидуально, } \\
\text { Курсами по 5-10 } \\
\text { инъекций (3-6 } \\
\text { күрсов) }\end{array}$ \\
\hline
\end{tabular}

Препараты, приготовленные на основе цитокинов, являются основными препаратами для коррекции иммунных нарушений, развивающихся при инфекционных и онкологических заболеваниях, профилактики осложнений при радио- и химиотерапии онкологических больных (табл.109).

Так же к этой группе относятся цитокины тромбопоэза и эритропоэза. Первые активно участвуют в формировании мукозального иммунитета, вторые в предотвращении формирования нарушении функций органов и систем и развития полиорганной недостаточности.

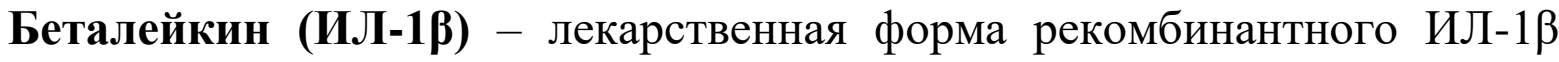
человека. Препарат стимулирует кроветворение, иммунитет и раннее постлучевое восстановление. Кроме того, препарат ускоряет восстановление стволового потенциала и костномозгового кроветворения, особенно гранулопоэза, после поражающего действия цитостатиков и ионизирующей радиации. Это обусловлено его способностью инициировать вступление СК в митотический цикл и их мобилизацию в кровь, усиливать выработку гемопоэтических ростовых факторов, включать механизмы мукозального иммунитета. Иммуностимулирующее действие препарата реализуется путем 


\section{Цитокины и их препараты}

\begin{tabular}{|c|c|}
\hline $\begin{array}{l}\text { Препараты (торговые } \\
\text { названия) }\end{array}$ & Фармакологическое действие \\
\hline \multicolumn{2}{|r|}{ Интерлейкин-1 бета } \\
\hline Беталейкин & $\begin{array}{l}\text { Стимулирует лейкопоэз, обусловленной применением цитостатиков или } \\
\text { воздействием ионизирующего излучения. Индуцирует выработку } \\
\text { колониестимулирующих факторов, усиливает пролиферацию и дифференцировку } \\
\text { клеток различных ростков кроветворения. Оказывает также } \\
\text { иммуностимулирующее действие (увеличивает функциональную активность } \\
\text { нейтрофильных гранулоцитов илимфоцитов). }\end{array}$ \\
\hline \multicolumn{2}{|r|}{ Интерлейкин-2 } \\
\hline $\begin{array}{l}\text { Ронколейкин, } \\
\text { Пролейкин }\end{array}$ & $\begin{array}{l}\text { Воздействует на Т-лимфоциты, усиливая их пролиферацию и последующий синтез } \\
\text { ИЛ-2. Направленно влияет на рост, дифференцировку и активацию Т-и В- } \\
\text { лимфоцитов, моноцитов, макрофагов, дендритных клеток. Усиливает активность } \\
\text { NК-клеток и цитотоксических Т-лимфоцитов; вызывает образование LAК-клеток и } \\
\text { активирует опухоль-инфильтрирующие клетки. }\end{array}$ \\
\hline \multicolumn{2}{|r|}{ Фактор некроза опухоли альфа 1} \\
\hline Рефнот & $\begin{array}{l}\text { Прямое противоопухолевое действие: цитотоксическое или цитостатическое } \\
\text { действие. }\end{array}$ \\
\hline \multicolumn{2}{|c|}{ Гранулоцитарно-макрофагальный колониестимулирующий фактор (ГМ-КСФ) } \\
\hline $\begin{array}{l}\text { Лейкомакс } \\
\text { Неостим }\end{array}$ & $\begin{array}{l}\text { Регулирует гемопоэз и активирует созревание (пролиферацию и дифференцировку } \\
\text { клеток-предшественников) миелоидных и лимфоидных клеток (гранулоцитов, } \\
\text { моноцитов/макрофагов, Т-лимфоцитов). }\end{array}$ \\
\hline \multicolumn{2}{|r|}{ Гранулоцитарный колониестимулирующий фактор (Г-КСФ) } \\
\hline $\begin{array}{l}\text { Лейкостим } \\
\text { Граноцит } \\
\text { Лонквекс }\end{array}$ & $\begin{array}{l}\text { Стимулирует клетки-предшественники нейтрофильного ростка костного мозга, } \\
\text { вызывает заметное увеличение количества нейтрофилов в периферической крови. } \\
\text { Способен стимулировать пролиферацию эндотелиальных клеток человека. }\end{array}$ \\
\hline Неуластим, Экстимия & Пэгелированный гранулоцитарный колониестимулирующий фактор \\
\hline \multicolumn{2}{|r|}{ Эритропоэтины } \\
\hline 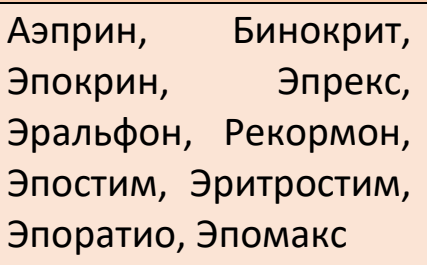 & $\begin{array}{l}\text { Стимулирует митоз и дифференциацию эритроидных клеток-предшественников. } \\
\text { Увеличивает число эритроцитов, ретикулоцитов, содержание гемоглобина, } \\
\text { улучшает кровоснабжение тканей. }\end{array}$ \\
\hline \multicolumn{2}{|r|}{ Тромбопоэтин } \\
\hline Револейд & $\begin{array}{l}\text { Принимает участие в регуляции мегакариопоэза и выработке } \\
\text { тромбоцитов. }\end{array}$ \\
\hline
\end{tabular}

повышения функциональной активности нейтрофильных гранулоцитов, индукции дифференцировки предшественников иммунокомпетентных клеток, усиления пролиферации лимфоцитов, активации продукции цитокинов и увеличения антителообразования. Препарат вводят подкожно или внутривенно капельно. В качестве стимулятора лейкопоэза препарат применяют в дозе 15-20 
нг/кг массы тела, для иммуносгимуляции - 5-8 нг/кг. Курс лечения состоит из 5 ежедневных инъекций или внутривенных инфузий. Продолжительность внутривенного введения составляет 120-180 мин. При необходимости проводят повторные курсы с интервалом 2 нед.

У отдельных больных могут наблюдаться озноб, головная боль, повышение температуры тела. Эти реакции продолжаются в течение 2-3 ч. и не являются противопоказанием к продолжению курса лечения. При возникновении особо тяжелых побочных явлений их следует купировать введением парацетамола, анальгина, димедрола или их сочетаний. При крайне редко наблюдаемых выраженных общих, в том числе аллергических, реакциях допустимо применение кортикостероидов. Противопоказанием является индивидуальная непереносимость. Препарат не рекомендуется применять у больных в стадии септического шока и при выраженной лихорадке. Выпускается в ампулах по 50, 500 и 1000 нг.

\section{Ронколейкин рекомбинантный}

интерлейкин-2 человека (rIL-2), который широко используется в комплексных схемах лечения

гнойно-воспалительных заболеваний, при бактериальных и вирусных инфекционных болезнях и в онкологии.

Ронколейкин - аналог эндогенного интерлейкина-2. Его получают методами генной инженерии из клеток непатогенных дрожжей Saccharomyces cerevisiae, в генетический аппарат которых встроен ген человеческого IL-2.

Препарат направленно влияет на рост, дифференцировку и активацию T- и В-лимфоцитов, моноцитов, макрофагов, дендритных клеток. От его присутствия зависит развитие цитолитической активности натуральных киллеров и цитотоксических Т-лимфоцитов, снижается апоптоз, повышается синтез иммуноглобулинов плазмацитами. rIL-2 увеличивает способность иммунных клеток к синтезу цитокинов.

Расширение спектра лизирующего действия эффекторных клеток обусловливает элиминацию разнообразных патогенных микроорганизмов, инфицированных и малигнизированных клеток, что обеспечивает иммунную защиту, направленную против опухолевых клеток, а также возбудителей вирусной, бактериальной и грибковой инфекции.

Ронколейкин применяют в комплексной терапии иммунодефицитов при острых и хронических инфекционных процессах: для лечения септических состояний различной этиологии, при острых панкреатитах и перитонитах, 
эндометрите и послеродовом сепсисе, тяжелой пневмонии, других генерализованных и тяжелых локализованных инфекциях; при туберкулёзе легких; а также при диссеминированных и местнораспространенных формах почечноклеточного рака.

Препарат выпускается в ампулах, 1 мл раствора 1; 0,5 или 0,25 мг rIL- 2. Степень очистки от примесных дрожжевых белков - 95\%.

Существуют разные способы введения Ронколейкина. Фармакопейным является подкожное и внутривенное капельное введение. Имеется опыт применения ингаляционного, перорального, внутриполостного и эндолимфатического способов. Внутривенно капельно препарат вводят на 0,9\% растворе $\mathrm{NaCl}$ (от 250 до 400 мл). На курс назначаются 2-3 инфузии с интервалом в 48-72 ч. Больным с явными признаками иммунодепрессии (абсолютная лимфопения на фоне тяжелого эндотоксикоза) препарат назначается в дозе до 1,0-2,0 мг, а количество инфузий на курс увеличивается до 4-5. Подкожно Ронколейкин следует вводить 1раз в сутки, для усиления эффекта можно разделить одну дозу препарата для введения в несколько точек.

Ронколейкин разрешен к применению у детей с первого дня жизни, в том числе у недоношенных.

Рефнот - лекарственный препарат рекомбенантного фактора некроза опухолей и тимозина. По спектру цитотоксического и цитостатического действия на опухолевые клетки препарат соответствует фактору некроза опухоли $\alpha$ (ФНО) человека, однако препарат более чем в 100 раз имеет меньшую общую токсичность. Включает несколько путей уничтожение опухоли:

- $\quad$ непосредственное воздействие фактора некроза опухолей-тимозин альфа1 (ФНО) на опухолевую клетку-мишень через соответствующие рецепторы на ее поверхности, в результате чего происходит апоптоз клетки (цитотоксическое действие) или остановка клеточного цикла (цитостатическое действие);

- каскад химических реакций, включающий активацию коагуляционной системы крови и местных воспалительных реакций, обусловленных РЕФНОТ®-активированными клетками эндотелия и лимфоцитами и ведущий к геморрагическому некрозу опухолей

- блокирование ангиогенеза, приводящее к уменьшению прорастания новыми сосудами быстрорастущей опухоли и, как следствие, к снижению кровоснабжения вплоть до некроза центра опухоли;

- воздействие клеток иммунной системы, цитотоксичность которых оказалась тесно связана с наличием молекул ФНО на их поверхности или процесс созревания/активации этих клеток связан с ответом на ФНО.

Комбинации Рефнота с $\gamma$-интерфероном обладают синергическим цитотоксическим эффектом. Происходит усиление противирусной активности 
рекомбинантного интерферона гамма в 100-1000 раз (на примере эксперимента против вируса везикулярного стоматита).

Рефнот увеличивает эффективность химиопрепаратов: актиномицина Д, цитарабина, доксорубицина против опухолевых клеток слабо чувствительных к ним, ликвидируя эту резистентность. Это позволяет рассматривать препарат как модификатор противоопухолевого действия химических цитостатиков в случаях множественной лекарственной устойчивости опухолевых клеток.

Рефнот не оказывает цитотоксического действия на нормальные клетки и в высоких концентрациях in vitro стимулирует пролиферацию клеток селезенки и лимфатических узлов. Усиливает продукцию антител на Т-зависимые антигены, оказывает стимулирующее влияние на цитотоксическое действие естественных киллерных клеток по отношению к опухолевым клеткам, оказывает стимулирующее влияние на фагоцитоз, усиливает экспрессию антигенов MHC I класса H-2K, CD-4 и CD-8, являясь фактором дифференцировки Т-хелперов и Т-киллеров.

Факторы роста клеток костного мозга. Факторы роста миелоидных клеток костного мозга в организме продуцируются различными типами клеток: фибробластами, эндотелиальными клетками, макрофагами, Т-лимфоцитами. В настоящее время производятся генно-инженерными методами:

1) гранулоцитарный колониестимулирующий фактор (Г-КСФ) филграстрим и ленограстим;

2) гранулоцитарно-макрофагальный колониестимулирующий фактор (ГМКСФ) - молграмостим.

Человеческий гранулочитарный колониестимулирующий фактор (Г-КСФ) - гликопротеин, регулирующий образование функционально активных нейтрофилов и их выход в кровь из костного мозга. Филграстим, содержащий рекомбинантный Г-КСФ, заметно увеличивает число нейтрофилов в периферической крови уже в пределах первых 24 ч после введения, с небольшим увеличением числа моноцитов. У некоторых больных тяжелой хронической нейтропенией он может также вызывать незначительное повышение числа циркулирующих эозинофилов и базофилов по сравнению с исходным уровнем, но у части этих больных эозинофилия и базофилия могут наблюдаться еще до назначения препарата. Рост числа нейтрофилов зависит от дозы препарата. Функция нейтрофилов, образующихся в организме человека при введении филграстима, нормальна или усилена. После окончания лечения число нейтрофилов в периферической крови снижается на $50 \%$ в течение $1-2$ дней и до нормального уровня - в течение $1-7$ дней.

Торговые названия препаратов с действующим веществом филграстим Нейпоген, Грастим, Граностим, Грасальва, Лейкостим. Чаще всего в клинической практике применяют нейпоген и лейкостим. 
Ленограстим также является генно-инженерным Г-КСФ. По фармакологическому действию мало чем отличается от филграстима, хотя спектр применения первого шире.

Торговые названия препаратов с действующим веществом ленограстим Граноцит.

Гранулоцитарно-макрофагальный колониестимулирующий фактор рекомбинантный человеческий ГМ-КСФ (молграмостим) стимулирует пролиферацию и дифференцировку предшественников, содержание зрелых клеток в периферической крови, рост гранулоцитов, моноцитов и макрофагов. Повышает функциональную активность зрелых нейтрофилов - усиливает фагоцитоз и степень выраженности «респираторного взрыва», повышает цитотоксичность в отношении злокачественных клеток. Обладает иммунотропной активностью, ускоряет созревание Т-лимфоцитов. Способен усиливать экспрессию антигенов II класса HLA на моноцитах и увеличивать продукцию АТ. Терапевтический эффект наступает через 2 - 4 дня после введения. При миелодиспластических синдромах эффективно нормализует миелопоэз. Уменьшает время восстановления миелоидного кроветворения после трансплантации костного мозга у пациентов с острой лейкемией, не влияя при этом на общую выживаемость и время до развития рецидива. Устраняет лейкопению после химиотерапии, достоверно понижая частоту глубокой нейтропении и инфекционных осложнений, снижает потребность в антибиотикотерапии и обеспечивает возможность интенсификации химиотерапии. Повышает безрецидивную выживаемость больных с резистентными лимфомами.

Показания к применению: лейкопения при патологических состояниях, сопровождающихся нарушением миелоидного кроветворения (в том числе при СПИДе и других инфекционных заболеваниях, миелодиспластическом синдроме), или на фоне противоопухолевой химиотерапии; первичная профилактика нейтропении и нейтропенической инфекции при высоком риске ее развития после химиотерапии (например, указания на развитие фебрильной нейтропении при проведении первого курса химиотерапии); для уменьшения миелотоксического действия противовирусных препаратов при лечении ЦМВИ у больных СПИДом, восстановления миелоидного кроветворения при трансплантации костного мозга; стимуляция высвобождения клеток предшественников гемопоэза из костного мозга в периферическую кровь для последующего их выделения методом лейкофереза и трансплантации (подготовка к противоопухолевой химиотерапии сверхвысокими дозами).

Торговое название препарата с действующим веществом молграмостим зарегистрированного в России - Лейкомакс.

Как уже и отмечалось выше цитокины тромбопоэза и эритропоэза (табл.105) так же опосредованно оказывают влияние на иммунную систему. 


\section{Иммуностимулирующие препараты}

Актуальность проблемы восстановления иммунологических нарушений с помощью препаратов не подвергается сомнению. В настоящее время фармацевтический рынок предлагает огромное количество препаратов, относящихся к иммуномодуляторам - лекарственным препаратам, которые в терапевтических дозах восстанавливают нарушенные функции иммунной системы. Существует большое количество классификаций иммуноактивных препаратов. Их подразделяют на подгруппы по происхождению, способам получения, химической структуре, влиянию на звенья иммунной системы и т.д. Чаще всего выделяют биологические препараты (микробного, вирусного, грибкового, растительного, животного происхождения, клетки культуры тканей) и химические вещества природного происхождения или химически синтезированные. По происхождению иммунотропные лекарственные средства можно разделить на три группы: полимерные, экзогенные и эндогенные. В некоторых классификациях используется патогенетический подход, предусматривающий действие различных иммуностимуляторов на основные звенья иммунной системы. Необходимость такой классификации диктуется практикой, поскольку клинико-иммунологическая разнородность иммунопатологических состояний определяет дифференцированный подход к терапии. Однако попытка разделения иммуностимуляторов по избирательности действия осложняется отсутствием селективности у большинства препаратов. Многие средства, отнесенные к иммуноактивным, воздействуют не только на иммунокомпетентные клетки, но, прежде всего, - на внутриклеточный метаболизм клеток (см. выше). Поэтому с позиций воздействия на различные звенья иммунной системы целесообразно разделить иммуностимулирующие препараты согласно групп, представленных на рисунке (рис.178).

\section{Иммуностимулирующая терапия}

\begin{tabular}{|c|c|}
\hline$\gamma$ & 7 \\
\hline С воздействием на адаптивный & С воздействием на врожденный \\
\hline иммунитет & иммунитет \\
\hline$\checkmark$ & $V$ \\
\hline Вакцины & $\begin{array}{c}\text { Препараты бактериального } \\
\text { происхождения }\end{array}$ \\
\hline \multirow{2}{*}{$\begin{array}{c}\text { Аллергенспецифическая } \\
\text { иммунотерапия }\end{array}$} & Иммунорегуляторные пептиды \\
\hline & Индукторы интерферона \\
\hline
\end{tabular}

Рис.178. Классификация иммуностимулирующих препаратов. 


\section{Иммуностимуляторы бактериального происхождения и их синтетические аналоги.}

Это разновидность бактериальных вакцин, обладающих неспецифическим действием в основном, на врожденный иммунитет и гуморальное звено адаптивного иммунитета. По способу получения различают следующие группы препаратов:

Лизаты и антигенные экстракты бактерий. Бактериальные иммуномодуляторы создавались как низкоиммуногенные «вакцины» с целью выработки временного стойкого иммунитета против бактерий. Большое значение в этой связи имеет система местного иммунитета слизистых, особенно синтеза секреторного иммуноглобулина A (sIgA) против компонентов лизата. Антиген-стимулированные клетки с поверхностным IgA попадают с циркулирующей кровью в лимфоидные органы, например, Пейеровы бляшки. Развитие специфического иммунного ответа происходит при кооперации Т- и Влимфоцитов, макрофагов или ДК. В дальнейшем специфический sIgA вновь транспортируется на поверхность слизистых, препятствуя инвазии инфекционных агентов, их адсорбции, фагоцитозу и формированию ИК. Кроме того, активация цитотоксических Т-лимфоцитов приводит к уничтожению инфицированных клеток.

Препараты, содержащие лизаты бактерий, способствуют профилактике инфекций носоглотки и респираторного тракта, не вызывают формирования длительного иммунитета, поэтому правильнее называть их бактериальными иммуномодуляторами, которые можно разделить на две группы: системного и локального действия

Иммуномодуляторы бактериального происхождения системного действия.

Бронхо-Ваксом и отечественный аналог Бронхомунал содержит лиофилизированные экстракты восьми возбудителей: Haemophilus influenzae, Diplococcus pneumonia, Streptococcus viridans, Streptococcus pyogens, Klebsiella pneumoniae, Klebsiella ozenae, Staphylococcus aureus, Neisseria (Branhamella) catarrhalis. Он стимулирует В-клетки, повышает уровень SIgA, на слизистых и в слюне, бронхоальвеолярной лаважной жидкости, функциональную и метаболическую активность макрофагов (в том числе альвеолярных).

Бронхомунал активизирует деятельность секреции простагландина Е2 и IL-1 альвеолярными макрофагами, усиливает активность макрофагов против инфекционных агентов и клеток опухоли, секрецию IL-2, IL-8, TNF- $\alpha$, нейтрофил-активирующего фактора, повышает реактивность естественных киллеров.

При назначении Бронхомунала у больных с заболеваниями респираторного тракта и носоглотки повышается уровень сывороточных IgM, G, 
А и сохраняется до 100 - 150 дней, увеличивается иммунорегуляторный индекс (CD4+/CD8+), функциональная активность Т-клеток.

Уро-Ваксом. Активный компонент: лиофилизированный бактериальный лизат 18 штаммов Escherichia coli. Капсула уро-ваксома содержит 6 мг этого активного вещества. При приеме внутрь препарат стимулирует иммунную защиту организма и увеличивает сопротивляемость к инфекциям дыхательной системы. Иммунофармакологические исследования показали, что бронховаксом увеличивает образование IgA, секретируемого слизистой дыхательных путей и слюной, количество циркулирующих Т-лимфоцитов, индуцирует образование эндогенного ИФН. Клинически понижает частоту острых инфекций мочевого тракта, в особенности циститов, сокращает продолжительность их течения, уменьшает тяжесть симптомов, и вероятность обострений хронических заболеваний. При этом меньше потребность применения других лекарственных препаратов, в особенности антибиотиков.

Исмиген. Лизаты бактерий Staphylococcus aureus, Streptococcus pyogenes, Streptococcus viridans, Streptococcus pneumoniae, Klebsiella pneumoniae, Klebsiella ozaenae, Haemophilus influenzae b, Neisseria catarrhalis. Комбинированный иммуностимулирующий препарат бактериального происхождения для сублингвального применения. Представляет собой поливалентный антигенный комплекс, включающий лизаты бактерий - наиболее часто встречающихся возбудителей респираторных инфекций. Лизаты, входящие в состав препарата, получены путем механического разрушения бактериальных клеток. Применяется при острых и рецидивирующих инфекции верхних и нижних дыхательных путей. По 1 табл./сут, в течение 10 дней. Профилактический курс включает 3 цикла по 10 дней с 20-дневными интервалами между ними.

Иммуномодуляторы бактериального происхождения топического действия.

ИРС-19 выпускается в виде спрея для интраназального применения и содержит лизаты 19 наиболее часто встречающихся возбудителей заболеваний верхних дыхательных путей: Streptococcus, Staphylococcus aureus, Gafkya tetragena, Neisseria, Klebsiella pneuminiae, Moraxella, Haemophilus influenzae и др.. Препарат повышает содержание лизоцима, стимулирует фагоцитоз. Его специфическое действие связывают с увеличением синтеза секреторного IgA. Он действует преимущественно на систему местного иммунитета верхних отделов респираторного тракта и носоглотки.

Назначение препарата не приводит к усилению синтеза IgE. По нашим данным, его воздействия не наблюдаются на показатели системного иммунитета, отмечается повышение IgA в слюне. ИРС-19 применяется с профилактической целью и в остром периоде заболеваний носоглотки и верхних отделов 
респираторного тракта на фоне базисной терапии, сокращая сроки заболевания и потребность в других вмешательствах.

Имудон. В состав препарата входят лизаты: Lactobacillus acidophylus, L.fermentum, L.helveticus, L.lactis, Strept. pyogenes, Enterococcus faecalis, Streptococcus sanglus, Staph.aureus, Klebsiella pneumoniae, Corynebacterium pseudodiphtheriae, Fusiformis fusiformis, Candida albicans.

Препарат представляет собой поливалентный антигенный комплекс, включающий наиболее распространенных возбудителей рецидивирующих инфекций носоглотки. Имудон активирует фагоцитоз, повышает уровень лизоцима и IgA в слюне.

Липополисахариды бактерий. Препараты, на основе выделенных липополисахаридов, которые образуются в процессе жизнедеятельности микроорганизмов.

Пирогенал. Препарат, который давно вошел в арсенал средств неспецифической иммуностимулирующей терапии. Он вызывает кратковременную (несколько часов) лейкопению, сменяющуюся лейкоцитозом, и повышает фагоцитарную функцию лейкоцитов. В организации неспецифической защиты против инфекции основное значение пирогенала связано с активацией фагоцитоза.

Как и другие ЛПС, пирогенал проявляет адъювантные свойства, повышая иммунный ответ к различным АГ. Мобилизация фагоцитарных механизмов, стимуляция образования АТ, гуморальных неспецифических факторов защиты могут быть причиной повышения антиинфекционной резистентности под влиянием данного препарата. Но это зависит от времени воздействия пирогенала по отношению к моменту заражения, дозы, частоты введения. Его способность стимулировать антибиотикотерапию, по-видимому, связана с противовоспалительным, фибринолитическим эффектами, с усилением регенеративных процессов в тканях.

Основная клиническая область использования пирогенала как средства неспецифической иммуностимулирующей терапии - хронические инфекционновоспалительные заболевания. Препарат оказывает пирогенное действие. Маленьким детям и лицам старше 60 лет его необходимо вводить с осторожностью, начиная с уменьшенных доз и постепенно повышая их только в случае хорошей переносимости препарата больными.

Применяется в/м, 1 раз в сутки. Инъекции производят через день. При необходимости разводят 0,9 \% раствором натрия хлорида для инъекций. Препарат во вскрытой ампуле хранению не подлежит. Начальная разовая доза 2,5 мкг. В последующие дни дозу постепенно увеличивают на 2,5-5 мкг. Максимальная разовая доза - 100 мкг. Полный курс - от 10 до 30 инъекций. В случае необходимости курсы инъекций повторяют не менее чем через 2-3 мес. 
Продигиозан. Высокополимерный липополисахаридный комплекс, выделенный из микроорганизма $B$. prodigiosum. Относится к группе бактериальных полисахаридов, является средством, стимулирующим факторы неспецифической и специфической резистентности организма. Активирует Тсистему иммунитета. Влияние продигиозана, в значительной степени, связано со стимуляцией эндогенных иммунных систем организма, активацией образования ИФН, т.е. с интерфероногенной активностью. Кроме высокой эффективности при генерализованных инфекциях, комплекс показан и при локальных гнойновоспалительных процессах, ускоряет ликвидацию инфекции, продуктов некротического распада, рассасывание воспалительного экссудата, заживление поврежденных тканей, способствует восстановлению функций органов.

Весьма важно то, что Продигиозан усиливает эффект антибиотиков при использовании их в субэффективных дозах и при инфекциях, вызванных антибиотикоустойчивыми штаммами.

Как и другие ЛПС, Продигиозан, не оказывает прямого воздействия на микроорганизмы. Повышение устойчивости к инфекциям целиком обусловлено антиинфекционными механизмами макроорганизма. Эффект продигиозана основан на энергичной мобилизации фагоцитарной активности макрофагов и лейкоцитов и увеличении их числа, на усилении поглотительной и переваривающей функций за счет повышения активности лизосомальных ферментов, опсонизирующего действия сыворотки крови. Путь данного комплекса: стимуляция макрофагов продигиозаном - монокины - лимфоциты лимфокины - активация макрофагов.

Фрагменты пептидогликана клеточной стенки и РНК. Действующее начало этих препаратов - фрагменты клеточной стенки бактерий.

Ликопид - действующее вещество глюкозаминилмурамилдипептид (ГМДП) синтетический аналог структурного фрагмента оболочки (пептидогликана) бактериальных клеток. ГМДП является активатором врожденного и приобретенного иммунитета, усиливает защиту организма от вирусных, бактериальных и грибковых инфекций; оказывает адъювантный эффект в развитии иммунологических реакций.

Биологическая активность препарата реализуется посредством связывания ГМДП с внутриклеточным рецепторным белком NOD2, локализованным в цитоплазме фагоцитов (нейтрофилы, макрофаги, дендритные клетки). Препарат 
стимулирует функциональную (бактерицидную, цитотоксическую) активность фагоцитов, усиливает презентацию ими антигенов, пролиферацию Т-и Влимфоцитов, повышает синтез специфических антител, способствует нормализации баланса Thl/Th2-лимфоцитов в сторону преобладания Thl. Фармакологическое действие осуществляется посредством усиления выработки ключевых ИЛ (IL-1, IL-6, IL-12), ФНО- $\alpha, \quad \gamma$-интерферона, колониестимулирующих факторов. Препарат повышает активность естественных киллерных клеток. Его применение в комплексной терапии позволяет значительно повысить эффективность антибактериальной, противогрибковой и противовирусной терапии, сократить продолжительность лечения и существенно снизить дозу химиотерапевтических средств.

Провоспалительные цитокины, чей синтез повышает Ликопид, являются необходимыми медиаторами эффекторного противовоспалительного ответа. Между провоспалительными и противоспалительными медиаторами воспаления существует прямая корреляционная зависимость. Таким образом, Ликопид, запуская быструю инициацию воспалительного процесса, активирует естественные механизмы реализации иммунитета. Эти особенности ликопида позволяют эффективно применять его при различных патологиях. Препарат не оказывает токсического действия на центральную нервную и сердечнососудистую системы, не вызывает патологических изменений со стороны внутренних органов.

\section{Иммунорегуляторные пептиды}

Тимические иммунорегуляторные пептиды (Тактивин, Тималин, Вилозен) - препараты, представляющий собой комплекс полипептидных фракций, выделенных из вилочковой железы (тимуса) крупного рогатого скота.

Обладают способностью стимулировать иммунологическую реактивность организма: регулируют количество Т- и В-лимфоцитов, активируют деятельность реакции клеточного иммунитета и процессов регенерации и кроветворения в случаях их угнетения, усиливает фагоцитоз. За счет основного эффекта происходит индукция созревания, ускорение пролиферации и дифференцировки пре-Т-лимфоцитов, активация фагоцитоза. При иммунодефицитных состояния нормализует количественные и функциональные показатели Т-системы и ИФН, другие показатели клеточного иммунитета, активирует деятельность продукции лимфокинов, в том числе. Обладая иммуномодулирующей активностью, стимулирует пролиферацию и дифференциацию Т-лимфоцитов, подавляет развитие гиперчувствительности немедленного типа. Данные о влиянии на гуморальный иммунитет противоречивы. Существует мнение, что, усиливая проявление иммунных реакций, тимические пептиды снижают образование аутоантител. 
Желательно перед назначением препаратов провести подготовку с целью повышения выброса из костного мозга предшедственников Т-клеток. Для этого можно рекомендовать стимуляторы лейкопоэза: метилурацил, изопринозин, натрия нуклеинат в течение 10 - 14 дней.

Аналоги гормонов тимуса. Тимоген - синтетически полученный дипептид, состоящий из остатков аминокислот - глутамина и триптофана. Механизм действия: иммуномодулятор, нормализует содержание Т-хелперов, индуцирует дифференцировку Т-лимфоцитов, увеличивает концентрацию цАМФ в предшедственниках Т-лимфоцитов, модулирует показатели Т- и Влимфоцитов, усиливает неспецифическую резистентность. По показаниям к применению он, в основном, сходен с другими иммуностимуляторами и используется в комплексной терапии взрослых и детей при острых и хронических инфекционных заболеваниях, сопровождающихся снижением показателей клеточного иммунитета, при угнетении репаративных процессов после тяжелых травм (переломы костей), некротических процессов, а также при других состояниях иммунодефицита. С профилактической целью используется для предупреждения осложнений при инфекционных заболеваниях, оперативных вмешательствах, лучевой терапии и химиотерапии опухолей и т.п. Имунофан - препарат, обладающий иммунорегулирующим, детоксикационным, гепатопротективным действием и вызывает инактивацию свободнорадикальных и перекисных соединений. Фармакологические свойства пептидного иммуноксидредуктанта основаны на достижении коррекции иммунной и окислительно-антиокислительной систем организма. Действие препарата развивается в течение 2 - 3 ч (быстрая фаза) и продолжается до 4 мес. (средняя и медленная фазы). В течение быстрой фазы (продолжительность до 2 - 3 сут) проявляется прежде всего, детоксикационный эффект - усиливается антиоксидантная защита организма путем стимуляции продукции церулоплазмина, лактоферрина, активности каталазы; препарат нормализует перекисное окисление липидов, ингибирует распад фосфолипидов клеточной мембраны и синтез арахидоновой кислоты с последующим снижением уровня холестерина крови и продукции медиаторов воспаления.

В течение средней фазы (начинается через $2-3$ сут., продолжительность до 7 - 10) происходят усиление реакций фагоцитоза и гибели внутриклеточных бактерий и вирусов. В результате активации фагоцитоза возможно незначительное обострение очагов хронического воспаления, поддерживаемых за счет персистенции вирусных или бактериальных АГ.

В течение медленной фазы (развивается на 7-10-е сутки, длится до 4 мес.) проявляется иммунорегуляторное действие препарата - восстановление нарушенных показателей клеточного и гуморального иммунитета. В этот период наблюдается увеличение продукции специфических АТ. Влияние препарата на 
продукцию специфических противовирусных и антибактериальных AT эквивалентно действию некоторых лечебных вакцин. В отличие от последних препарат не оказывает существенного воздействия на продукцию реагиновых АТ класса IgE и не усиливает реакцию гиперчувствительности немедленного типа. Он стимулирует образование $\operatorname{IgA}$ при его врожденной недостаточности. Действие имунофана не зависит от продукции ПГЕ2 и его назначение возможно в комбинации с противовоспалительными препаратами стероидного и нестероидного ряда.

Гепон, иммунофармакологические и противовирусные механизмы действия препарата, заключащиеся в стимуляции продукции ИФН- $\alpha$ и - $\beta$. Он мобилизирует и активирует макрофаги, ограничивает выработку цитокинов воспаления (ИЛ-1, -6, -8 и TNF), стимулирует продукцию АТ к различным АГ инфекционной природы, подавляет репликацию вирусов, повышает резистентность организма в отношении инфекций, вызванных вирусами, бактериями или грибами.

Клинический эффект курса лечения гепоном состоит в предупреждении рецидивов оппортунистических инфекций в течение 3 - 6 мес. Короткий курс местного применения препарата позволяет лечить рецидивирующие инфекции слизистых и кожи, вызванные грибами Candida. Его применение оказывает противовоспалительное действие.

Бестим Гамма-D-глутамил-триптофан натрия - дипептид, обладающий иммуностимулирующим действием. Стимулирует клеточный и гуморальный иммунитет. Повышает антибактериальную и противовирусную резистентность. Фармакологическое действие определяется усилением дифференцировки и пролиферации предшественников Т-лимфоцитов, стимуляцией продукции ИЛ2, увеличением экспрессии рецепторов ИЛ-2 и маркеров дифференцировки Тклеток, восстановлением иммунорегуляторного индекса. Применение препарата в комплексной терапии заболеваний, сопровождающихся вторичными иммунодефицитами, значительно повышает ее эффективность. Препарат эффективен при включении в комплексную терапию вирусных заболеваний, сопровождающихся недостаточностью клеточного звена иммунитета.

Производные имидазола. Левамизол - препарат, являющийся эффективным противоглистным средством. Его влияние на иммунологические процессы обнаружено позднее. Левамизол стимулирует, в основном, клеточный иммунитет. Это первый препарат, имитирующий гормональную регуляцию иммунной системы, т.е. модулирование регуляторных Т-клеток. Способность левамизола имитировать тимусный гормон обеспечивается его имидозолоподобным воздействием на уровень циклических нуклеотидов в лимфоцитах. Возможно, что препарат стимулирует тимопоэтинрецепторы, благоприятно влияет на иммунологический статус путем восстановления 
эффекторных функций периферических Т-лимфоцитов и фагоцитов, стимуляции созревания предшественников Т-лимфоцитов аналогично действию тимусных гормонов.

Левамизол представляет собой мощный индуктор дифференцировки, который вызывает быстрый эффект (через 2 ч. при пероральном приеме). Повышение активности макрофагов с помощью левамизола играет большую роль в способности препарата усиливать иммунологические свойства организма.

Имиквимод (алдара, кераворт, вартоцид и пр.) в виде крема показан для местного лечения: наружных генитальных и перианальных бородавок, небольших поверхностные базальноклеточные карциномы, клинически типичных негиперкератотических, негипертрофических актинических кератозах на лице или волосистой части головы, когда другие варианты местного лечения противопоказаны или менее целесообразны.

Имиквимод проявляет свое действие за счет увеличения уровня рецептора опиоидного фактора роста (OGFr) и стимуляции врожденную иммунную систему,через Толл-подобные рецепторы 7 (TLR7), за счет чего, секретируются IFN- $\alpha$, IL-6 и TNF- $\alpha$. Активируются клетки Лангерганса, клетки-киллеры (NK- и ЦТЛ), макрофаги и В-лимфоциты.

Препарат применяют наружно, предпочтительно на ночь перед сном и оставляют на коже в течение 6-10 ч. Крем наносят только на пораженные предварительно очищенные участки кожи тонким слоем и аккуратно втирают до полного впитывания. Обработанный участок кожи не следует закрывать повязками. Не допускается использование избыточного количества крема. По истечении указанного времени крем должен быть смыт теплой водой с применением мыла с нейтральным значением $\mathrm{pH}$. Разовая (суточная) доза препарата - 10 мг крема на 1 см2 (полоса крема диаметром 2 мм и длиной 0,5 см). Максимальная площадь нанесения - 25 см2, что соответствует максимальной дозе препарата - 250 мг. Препарат применяют 1 раз в сутки, 3 раза в неделю (например, понедельник, среда, пятница или вторник, четверг, суббота), до полного исчезновения генитальных или перианальных остроконечных кондилом, но не более 16 нед.

\section{Индукторы синтеза интерферонов.}

Среди иммуномодуляторов особое место занимают индукторы выработки эндогенного ИФН, группа которых разнородна по составу. Выделяют синтетические препараты (Амиксин, Циклоферон, Полудан, Неовир, Амплиген) и природные соединения (Кагоцел, Панавир, Рогасин, Саврац). Клинические испытания показали широкий диапазон их иммуномодулирующей и противовирусной активности. Многие авторы эти препараты рассматривают как противовирусные средства. Индукторы ИФН являются препаратами с 
комбинированным эффектом: этиотропным, направленным непосредственно на вирус, и иммуномодулирующим, т.е. корригирующим нарушения системы иммунитета. Эти индукторы индуцируют синтез всех иммунологических классов ИФН: $\alpha, \beta$ и $\gamma$ в разных пропорциях. Все они хорошо сочетаются друг с другом - рекомбинантными ИФН, иммуномодуляторами и химиотерапевтическими средствами. Комбинированное применение с другими препаратами часто приводит к потенцированию эффектов индукторов ИФН.

Индукторы ИФН имеют ряд преимуществ перед рекомбинантными ИФН.

- Индукторы ИФН не обладают антигенностью.

- Естественный, но стимулированный синтез эндогенного ИФН не вызывает гиперинтерферонэмии, которая нередко возникает при использовании рекомбинантных ИФН, что в свою очередь, приводит к побочным эффектам, т.е. отсутствуют симптомы передозировки.

- Однократное введение индукторов ИФН обеспечивает их длительную циркуляцию на терапевтическом уровне. Для достижения такого уровня экзогенных ИФН требуется многократное введение высоких доз рекомбинантных ИФН.

- Рекомбинантные ИФН, принимая участие в иммунных реакциях организма, стимулируют неспецифическую цитотоксичность иммуноцитов и вызывают экспрессию молекул HLA в тех популяциях клеток, которые обычно не экспрессируют эти АГ. Это может быть причиной усугубления аутоиммунного ответа организма человека.

- Некоторые индукторы ИФН (Амиксин) обладают уникальной способностью запускать синтез ИФН в определенных популяциях клеток, что предпочтительнее, чем поликлональная стимуляция иммуноцитов рекомбинантными ИФН.

- Широко применяемые рекомбинантные ИФН являются препаратами ИФН- $\alpha$, что существенно ограничивает их противовирусные свойства, так как для эффективной противовирусной защиты необходимо наличие всех трех классов ИФН, синтез которых вызывается индукторами интерфероногенеза.

- И Ито немаловажно, индукторы ИФН дешевле препаратов ИФН.

Эффективность индукторов выработки ИФН показана при ряде вирусных заболеваний: Амиксин - при герпетической инфекции, гриппе, ОРВИ, гепатитах, энцефалите; Кагоцел - при гриппе, ОРВИ, герпесе; Неовир - при герпетической инфекции, ОРВИ; Полудан - при герпетической инфекции; Ридостин - при гриппе, ОРВИ, бешенстве; Рогасин - при гепатите А, В; Соврац - при ОРВИ, гепатите А, энтеровирусных инфекциях.

Амиксин (Лавомакс, Тилорон) - известный отечественный препарат, является первым пероральным индуктором эндогенных ИФН- $\alpha, \beta, \gamma$. Он наиболее полно сочетает в себе все преимущества индукторов ИФН. 
Представляя собой поликлональный стимулятор, Амиксин вызывает синтез ИФН в Т-лимфоцитах, энтероцитах кишечника, гепатоцитах, проникает через гематоэнцефалический барьер и индуцирует ИФН в клетках мозга. Стимулирует СК костного мозга, в зависимости от дозы усиливает антителообразование, уменьшает степень иммунодепрессии, восстанавливает соотношение CD4+/CD8+. Эффективен против различных вирусных инфекций, в том числе против вирусов гриппа, других острых респираторных вирусных инфекций, вирусов гепатита и герпеса. У него отсутствуют мутагенный, тератогенный, эмбриотоксический, канцерогенный и другие токсические эффекты. Препарат не обладает антигенностью. Важная особенность Амиксина - вызываемая им длительная циркуляция в организме терапевтической концентрации ИФН (50 100 ЕД/мл в сыворотке крови).

Неовир - низкомолекулярный синтетический супериндуктор ИФН. Представляет собой производное карбоксиметилакридона с молекулярной массой менее 300. Повышает способность клеток-интерферонопродуцентов вырабатывать ИФН при индукции патологическим агентом (свойство сохраняется длительное время после отмены препарата) и создает в организме высокие титры эндогенных ИФН, идентифицированных как ранний ИФН- $\alpha$ и $\gamma$. Активирует СК костного мозга, устраняет дисбаланс в субпопуляциях Тлимфоцитов с активацией эффекторных звеньев Т-клеточного иммунитета и макрофагов. На фоне опухолевых заболеваний усиливает активность естественных киллерных клеток (обусловлена продукцией IL-2) и нормализует синтез TNF. Стимулирует активность полиморфноядерных лейкоцитов (миграция, цитотоксичность, фагоцитоз). Оказывает противовирусное (в отношении РНК- и ДНК-геномных вирусов) и антихламидийное действие.

Циклоферон - метилглюкаминовая соль карбоксиметилакридона, представляющая собой синтетический аналог природного алкалоида Citrus Grandis, обладает пролонгированным противовирусным, противовоспалительным и иммуномодулирующим действием. Циклоферон стимулирует продукцию IFN- $\alpha, \beta, \gamma$ (до 60 - 80 ЕД/мл и выше) лейкоцитами, макрофагами, Т- и В-лимфоцитами, эпителиальными клетками, а также тканями селезенки, печени, легких, мозга. Проникает в цитоплазму и ядерные структуры, индуцирует синтез «ранних» ИФН. Активирует Т-лимфоциты и естественные киллерные клетки. Способствует коррекции иммунного статуса при иммунодефицитных состояниях различного генеза, в том числе ВИЧ. Активен в отношении вирусов клещевого энцефалита, гриппа, гепатита, герпеса, ЦМВ, ВИЧ, различных энтеровирусов, хламидий. Проявляет высокую эффективность при ревматических и других системных заболеваниях соединительной ткани, подавляя аутоиммунные реакции и оказывая противовоспалительное и обезболивающее действие. Отличается низкой токсичностью и отсутствием 
мутагенных, тератогенных, эмбриотоксических и канцерогенных эффектов, обладает пролонгированным иммуномодулирующим действием. Препарат хорошо сочетается с традиционными средствами терапии.

Полудан (Полиаденур) - синтетический индуктор ИФН, состоящий из двухнитевого комплекса полиадениловой и полиуридиновой кислот. Он обладает иммуномодулирующим действием, индуцируя образование эндогенного ИФН- $\alpha$ и - $\gamma$. Показано применение полудана при гепатите В, герпетических кератитах и кератоконъюнктивитах.

\section{Иммунометаболические препараты}

\section{Препараты дезоксирибонуклеиновой кислоты.}

Различают препараты нуклеиновых кислот животного (Деринат, Ферровир и пр.) и грибкового происхождения (нуклеинат натрия). К этой же группе следует отнести производные пиримидина и пурина.

Одним из старейших иммуноактивных препаратов, проверенных временем, является натрия нуклеинат, обладающий широким спектром биологической активности. Он способствует ускорению процессов регенерации, активизирует деятельность костного мозга и лейкопоэз, вызывает лейкоцитарную реакцию, увеличивает количество Т-лимфоцитов. Стимулирует миграцию и кооперацию Т- и В-лимфоцитов, фагоцитарную активность макрофагов и факторов неспецифической резистентности, процессы клеточного деления и дифференцировки. Усиливает синтез нуклеиновых кислот в лимфоцитах, повышает накопление цАМФ в лимфоцитах и функциональную активность неспецифических факторов защиты. Нуклеинат натрия увеличивает содержание РНК и белка в макрофагах в 1,5 раза и гликогена в 1,6 раза активность лизосомальных ферментов, следовательно, завершает фагоцитоз макрофагами. Препарат повышает содержание у человека лизоцима и нормальных АТ, если их уровень был снижен.

Деринат - препарат, в качестве биологически активного вещества которого выступает дезоксирибонуклеат натрия, полученный из вытяжки молок осетровых рыб. Активирует процессы клеточного и гуморального иммунитета, оптимизирует воспалительную реакцию и специфический иммунный ответ на бактериальные, грибковые, вирусные АГ, активизирует В-лимфоциты, Тхелперы, повышает фагоцитоз. Снижает чувствительность клеток к повреждению 
химиотерапевтическими препаратами и радиотерапией, что сопровождается понижением кардио- и миелотоксического действия у онкологических больных и приводит к повышению стабильности и результативности терапевтического эффекта повторных курсов лечения. Деринат обладает высокими репаративными и регенеративными свойствами, стимулирует дренажно-детоксикационную функцию лимфатической системы в первую очередь в очаге воспалительной реакции, нормализует состояние органов и тканей при дистрофиях сосудистого происхождения. Увеличивает толерантность к физической нагрузке, снимает боль в икроножных мышцах, способствует заживлению различного типа гангренозных трофических инфицированных ран и глубоких ожогов и эрадикации Helicobacter pylori при язвенной болезни двенадцатиперстной кишки, улучшает сократимость миокарда, микроциркуляцию в сердечной мышце, восстанавливает функцию миоцитов, стимулирует заживление язв ЖКТ.

Ферровир - комплекс дезоксирибуноклеат натрия с железом. Представляет собой биологически активное вещество из вытяжки молок осетровых рыб (очищенная и стандартизованная комплексная соль дезоксирибуноклеат натрия с железом). Препарат оказывает иммуномодулирующее и противовирусное действие, активизирует противовирусный, противогрибковый и противомикробный иммунитет, проявляет противовирусное действие и к РНК-, и к ДНК-содержащим вирусам. Курсовое применение Ферровира при комплексной терапии ВИЧ-инфекции повышает уровень CD4+-лимфоцитов в крови на 1 - 1,5 мес. При рецидивирующей герпетической инфекции сокращается продолжительность рецидива и наступает длительная ремиссия. Применение этого препарата больными хроническим гепатитом С способствует снижению репликативной активности $\mathrm{HCV}$ и переводит процесс в латентную фазу.

\section{Производные пиримидина и пурина.}

В качестве средств, повышающих резистентность организма к инфекциям, с каждым годом все шире применяются производные пиримидина и пурина. Производные пиримидина интересны тем, что они обладают низкой токсичностью, активизируют деятельность белкового и нуклеинового обмена, ускоряют клеточный рост и размножение, вызывают противоспалительные действия. Наибольшее распространение в качестве стимулятора антиинфекционной резистентности получил метилурацил, который стимулирует лейкопоэз, эритропоэз. Производные пиримидина способны предупреждать снижение фагоцитарной активности лейкоцитов, которое наступает под влиянием антибиотиков, вызывать индукцию синтеза ИФН, увеличивать уровень иммунизации и уровень нормальных АТ. Механизм действия как стимуляторов иммуногенеза, по-видимому, связан с включением их в белковый и нуклеиновый обмен, вызывающий поливалентное влияние на иммуногенез и 
процессы регенерации. Аналогичным механизмом действия обладает производный пурина инозин пранобекс (изопринозин, гроприносин, нормомед)

Метилурацил. Как стимулятор лейкопоэза метилурацил назначают при агранулоцитарной ангине, алиментарно-токсической алейкии, хроническом бензольном отравлении, лейкопении в результате химиотерапии злокачественных новообразований, при рентгено- и радиотерапии и других состояниях, сопровождающихся лейкопенией. Необходимо учитывать, что метилурацил, как и другие стимуляторы лейкопоэза, целесообразно назначать при легких формах лейкопении. При поражениях средней тяжести применение стимуляторов кроветворения показано лишь в случае возобновлений нарушенной регенерации кровяных клеток.

Инозин пранобекс. Активное вещество инозин пранобекса увеличивает суммарное число Т-лимфоцитов и выработку ими ИЛ-2, активирует функцию NK-клеток и Т-хелперов, стимулирует хемотаксическую и фагоцитарную активность моноцитов, макрофагов (повышает в них синтез ИЛ-1) и полиморфноядерных клеток. Усиливает синтез РНК и рибосомального белка,

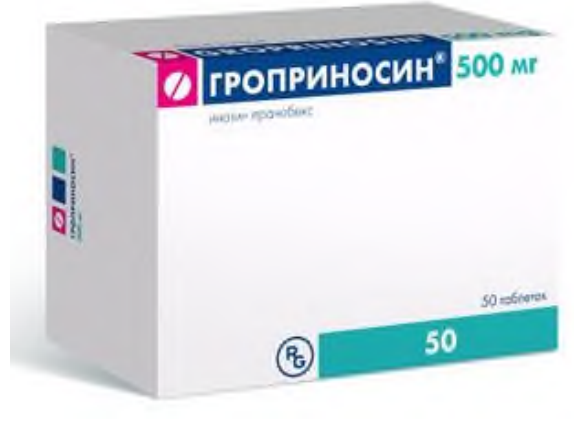
одновременно препятствуя использованию рибосомальной РНК для размножения вируса.

Активными пластическими препаратами и, как следствие, стимуляторами пролиферации клеток являются стимуляторы регенерации и репарации. В соответствии с локализацией действия (и задачами фармакотерапии) стимуляторы регенерации и репарации условно подразделяются на общеклеточные (универсальные) и тканеспецифические.

Тканеспецифические стимуляторы процесса регенерации представляют собой препараты с разным механизмом работы, объединенные в подгруппы по избирательному действию на ту или другую ткань или систему органов. Средства, восстанавливающие образование форменных элементов крови в костном мозге, относятся к стимуляторам кроветворения. Витамин D и препараты кальция, фосфора и фтора, хондроитин-сульфат (структум), остеогенон и др. обладают способностью усиливать регенеративные процессы в костной ткани.

Восстановительные процессы в хрящевой ткани стимулируют и обеспечивают витамины $\mathrm{C}$, E, хондроитин-фосфат и др. Одной из самых представительных является группа препаратов - стимуляторов регенерации и репарации слизистой оболочки ЖКТ. Эти средства способствуют ускорению процесса заживления эрозивно-язвенных дефектов слизистой оболочки ЖКТ. Механизм репаративного действия препаратов этой группы помимо стимуляции 
биосинтеза белка и клеточного деления включает торможение свободнорадикальных реакций и либерации лизосомальных ферментов. Дополнительный фактор, играющий важную роль в проявлении репаративного эффекта, представляет собой усиление местного синтеза простагландинов, способных улучшать микроциркуляцию в слизистой оболочке ЖКТ. К средствам, стимулирующим регенерацию и репарацию слизистой оболочки ЖКТ, относятся висмута трикалия дицитрат (де-нол), даларгин, натрия альгинат, вентрамин, поливинокс и др. В гастроэнтерологической практике репаранты назначают после достижения ремиссии, при резистентности к обычным методам, в том числе в случае длительно нерубцующихся язв и чаще пациентам пожилого возраста. В эту группу можно отнести и лонгидазу.

Лонгидаза (бовгиалуронидаза азоксимер) - представляет собой конъюгат протеолитического фермента гиалуронидаза с высокомолекулярным носителем из группы производных $\mathrm{N}$-оксида поли-1,4-этиленпиперазина обладает всем спектром фармакологических свойств препаратов с гиалуронидазной активностью.

Специфическим субстратом гиалуронидазы являются мукополисахариды - гликозаминогликаны (гиалуроновая кислота, хондроитин, хондроитин-4сульфат, хондроитин-6-сульфат, дерматансульфат) которые составляют основу межклеточного матрикса соединительной ткани. Благодаря своей ферментативной активности гиалуронидаза способна расщеплять такие

гликозаминогликаны, а также их олигосахаридные производные. Разрушение данных молекул препятствует образованию коллагеновых волокон. В результате гидролиза (деполимеризации) уменьшается вязкость гликозаминогликанов, способность связывать воду и ионы металлов. Как следствие, увеличивается проницаемость тканей, улучшается их трофика, уменьшаются отеки, рассасываются гематомы, повышается эластичность рубцовоизмененных участков, устраняются контрактуры и спайки, увеличивается подвижность суставов.

Конъюгация фермента с азоксимером бромидом позволяет усилить активность фермента, но и привносит новые свойства, направленные на модуляцию выработки цитокинов и медиаторов воспаления. Данный носитель подавляет свободнорадикальные реакции, проявляет антиоксидантные и детоксикационные свойства. Помимо этого, ковалентная связь фермента с 
азоксимером бромида предотвращает от разрушения собственными протеазами, пролонгируя период пребывания в организме.

Традиционно Лонгидаза используется для лечения и профилактики заболеваний, сопровождающихся образованием спаек и различных видов фиброза (пневмофиброза, фиброза простаты и др.). Эффект наиболее выражен на начальных стадиях патологического процесса.

\section{Синтетические стимуляторы клеток иммунной системы.}

\section{Производные полиэтиленперазина.}

Полиоксидоний ранее нами был описан как тканевой детоксикант, однако он является препаратом, прямо воздействующий на фагоцитирующие клетки и естественные киллеры, а также стимулирующий антителообразования. Восстанавливает иммунные реакции при вторичных иммунодефицитных состояниях, вызванных инфекциями, травмами, ожогами, злокачественными новообразованиями, осложнениями после хирургических операций, употреблением химиотерапевтических средств, в том числе цитостатиками и стероидными гормонами. При сублингвальном применении полиоксидоний активирует лимфоидные клетки, находящиеся в бронхах, носовой полости, евстахиевых трубах, тем самым повышая устойчивость этих органов к инфекционным агентам, а при пероральном - лимфоидные клетки, присутствующие в кишечнике, а именно В-клетки, продуцирующие секреторные IgA. Следствием этого является повышение устойчивости ЖКТ и дыхательного тракта к инфекционным агентам. Кроме того, при пероральном применении полиоксидоний активирует тканевые макрофаги, что способствует более быстрой элиминации возбудителя из организма при наличии очага инфекции.

Наряду с иммуномодулирующим действием полиоксидоний обладает выраженной детоксицирующей и антиоксидантной активностью, которая определяется структурой и высокомолекулярной природой препарата. Повышает устойчивость мембран клеток к цитотоксическому действию лекарственных препаратов и химических веществ, снижает их токсичность.

Полиоксидоний в комплексной терапии позволяет повысить эффективность и сократить продолжительность лечения, значительно уменьшить использование антибиотиков, бронхолитиков, ГКС, удлинить срок ремиссии.

\section{Производные аминофтальгидразита.}

Галавит - препарат, активным компонентом которого является производное фталгидразида. Он действует на моноцитарно-макрофагальное звено иммунитета: регулирует синтез цитокинов макрофагами (ИЛ-1, ИЛ-6, 
TNF- $\alpha$ и др.) и лимфоцитами (ИЛ-2), стимулирует бактерицидную активность нейтрофилов, усиливает фагоцитоз и повышает бактерицидную активность нейтрофильных гранулоцитов и неспецифическую резистентность организма к инфекционным заболеваниям, регулирует

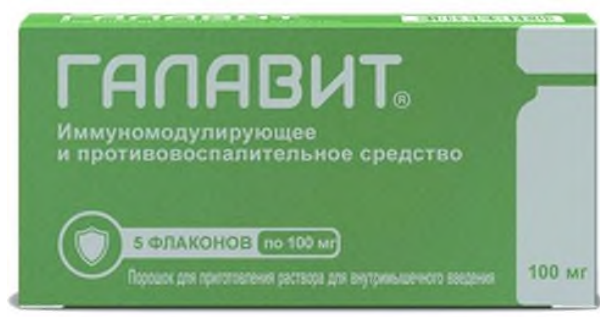
пролиферативную функцию Т-лимфоцитов,

пролиферативную активность естественных киллеров (NК-клеток) и синтез АТ;обладает антиоксидантным и антидиарейным действием; регулирует репарацию тканей, уменьшает образование рубцов при заживлении, стимулирует синтез ИФН. Описана роль галавита в метаболизме клеток иммунной системе. Он повышает интенсивность субстратного потока по гликолизу и активация реакций пентозофосфатного цикла, активирует глутатион-зависимые антиоксидантные системы и липидный анаболизма, снижает хемилюминесцентную активность клеток смещение с внешнего киллинга (стимуляция провоспалительных процессов) к фагоцитозу (завершение воспаления).

К иммуностимулирующим препаратам пытаются отнести и так называемые иммуномодуляторы растительного происхождения. Это достаточно большая группа препаратов, в которую ранее входило большое количество неспецифических стимуляторов растительного происхождения как фармакокопийных (экстракт алоэ, элеутерококка, сок каланхое, препараты женьшеня), так и различных сборов трав. Именно эта группа чаще всего «радует» нас новыми иммуноактивными препаратами, в дальнейшем не оправдывающими ожидания, хотя в нее входят и препараты достаточно активные.

Иммуномакс. Кислый пептидогликан с молекулярной массой 1000-40000 кД, усиливает иммунную защиту от вирусных и бактериальных инфекций.

Кагоиел. Гетероцепный полимер молекулярной массой 120 - 130 кД, получаемый путем химического синтеза из растительного сырья водорастворимой карбоксиметилцеллюлозы и госсипола. Последний представляет собой природный полифенол специфический пигмент хлопчатника.

Иммунал и другие препараты эхинации пурпурной.

Стимулирующее влияние на процессы регенерации оказывает - мумие, использующееся в народной медицине более 3000 лет. В зависимости от места сбора химический состав его может меняться, но в любом мумие содержится большое количество макро- и микроэлементов, окиси металлов, ряд витаминов, эфирные масла, пчелиный яд, смолоподобные вещества. Входящие в его состав компоненты активируют заживление ран и переломов, оказывают 
противовоспалительное, антитоксическое действие, улучшают адаптацию организма к неблагоприятным условиям. Однако создание на основе мумие лекарственного препарата затруднено, поскольку оно с трудом поддается стандартизации.

Мед и производные пчеловодства (прополис, заборус, маточное молочко и пр.) так же давно и успешно находит применение в лечении различных заболеваний.

Однако все эти препараты не имеют доказательной базы с позиций современной медицины.

\section{Иммунодепрессивная терапия}

В определенных условиях иммунные механизмы, играющие важную роль в защите организма от различных вредных воздействий, могут быть причиной нежелательных реакций, о чем отмечалось выше. В связи с указанными причинами получило развитие направление поиска лекарств, тормозящих иммуногенез, подавляющих продукцию АТ, пролиферативные процессы в лимфоидных (иммунокомпетентных) тканях и угнетающие биосинтез нуклеиновых кислот и/или устраняющие реакции, сопровождающиеся иммунными процессами. Иммуносупрессивные препараты, или иммуносупрессоры (иммунодепрессанты) - это класс лекарственных препаратов, применяемых для обеспечения искусственного угнетения иммунитета. Искусственная иммуносупрессия применяется, прежде всего, при трансплантации органов и тканей и лечении аутоиммунных заболеваний и заболеваний, предположительно (но пока не доказано) имеющих аутоиммунную природу. Класс иммуносупрессивных препаратов неоднороден и содержит препараты с различными механизмами действия и профилем побочных эффектов. Различается и профиль иммуносупрессивного эффекта: некоторые препараты более или менее равномерно подавляют все виды иммунитета, другие имеют особую избирательность по отношению к трансплантационному иммунитету и аутоиммунитету при сравнительно меньшем влиянии на антибактериальный, противовирусный и противоопухолевый иммунитет. Неодинаковы иммуносупрессивные препараты и по преимущественному влиянию на клеточный либо гуморальный иммунитет. Как оказалось, иммуносупрессивное воздействие оказывают многие вещества, однако с клинической точки зрения их можно разделить на препараты подавляющие иммунный ответ в целом и препараты устраняющие реакции, сопровождающие иммунные процессы, обладающие противовоспалительным и частично иммунодепрессивным действием (рис.179). 


\section{Иммунодепрессивная терапия}

\begin{tabular}{|c|}
\hline $\begin{array}{c}\text { Подавляющие иммунный ответ } \\
\text { в целом }\end{array}$ \\
\hline Цитостатики \\
\hline Глюкокортикоиды \\
\hline Другие иммунодепрессанты \\
\hline
\end{tabular}

\begin{tabular}{c}
$\begin{array}{c}\text { Устраняющие реакции, сопровождающие } \\
\text { иммунные процессы }\end{array}$ \\
\hline Нестероидные противовоспалительные \\
средства \\
\hline Антигистаминные препараты \\
\hline
\end{tabular}

\section{Рис.179. Классификация иммунодепрессивных препаратов.}

\section{Препараты, подавляющие иммунный ответ в целом.}

Цитостатики. Особенно выраженная иммунодепрессивная активность присуща цитостатикам - алкилирующим средствам (Циклофосфамид, Хлорамбуцил, Тиофосфамид, Проспидия Хлорид и др.), антиметаболитам (Меркаптопурин, Фторурацил и др.), некоторым антибиотикам (Дактиномицин и др.). Представители этих групп назначаются в настоящее время как иммунодепрессанты. Иммунодепрессивные препараты могут снизить тканевую несовместимость и быть весьма эффективными при лечении аутоиммунных заболеваний. Однако ныне существующие препараты не обладают достаточной избирательностью действия, и их использование может сопровождаться побочными явлениями. Они подавляют продукцию ИФН, угнетают кроветворение (приводя к лейкопении, тромбоцитопении, анемии и даже панцитопении), возможно, понижают общие защитные функции организма, активизируют вторичную инфекцию, развивают септицемии, при длительном употреблении они могут способствовать развитию злокачественных новообразований. Иммунодепрессанты должны применяться по строгим показаниям с соблюдением необходимых мер предосторожности.

Алкилирующие средства. Поводом к использованию этих соединений послужило влияние на организм отравляющего вещества - иприта. Было установлено, что иприт оказывает специфическое цитотоксическое действие на лимфоидные ткани и обладает противоопухолевой активностью. В настоящее время в медицинской практике используются менее токсичные соединения других химических групп.

Цитотоксическое действие алкилирующих соединений обусловлено, в первую очередь, алкилированием структурных элементов ДНК (пуринов, 
пиримидинов) и РНК (в меньшей степени), в результате чего нарушается стабильность, вязкость, целостность нитей ДНК и РНК, жизнедеятельность клеток, блокируется участие различных групп в метаболических реакциях, нарушаются митотическое деление и репликация клеток. Клетки при воздействии алкилирующих соединений останавливаются в G1-фазе и не входят в S-фазу. Высокой чувствительностью к этим веществам обладают ядра клеток гиперплазированных (опухолевых) тканей и лимфоидной ткани.В настоящее время из этой группы наиболее широко применяются Циклофосфамид $u$ Ифосфамид.

Антиметаболиты. Это вещества, близкие по химической структуре к эндогенным продуктам метаболизма и ингибирующие в результате конкурентных отношений определенные биохимические процессы, что сопровождается нарушением функции клеток и торможением клеточного роста. К антиметаболитам, употребляемым в качестве цитотоксических средств, относят структурные аналоги фолиевой кислоты (Метотрексат), пуринов (Меркаптопурин, Тиогуанин и др.), пиримидинов (Фторуращчил, Тегафур, Цитарабин и др.). Цитостатическое действие всех этих соединений связано с нарушением синтеза нуклеиновых кислот (ДНК и РНК). Антиметаболиты являются фазоспецифичными средствами, преимущественно действующими в Sфазе клеточного цикла.

В целом антиметаболиты обладают выраженным противоопухолевым действием и эффективны при ряде злокачественных новообразований. Преимущественно иммуносупрессивным действием характеризуются следующие цитостатики.

Азатиоприн (Имуран). Синтетическое имидозольное производное 6меркаптопурина, обладающее большим иммунодепрессивным действием и меньшим цитотоксическим.

6-Меркаптопурин. Применение (Леупурин, Меркалейкин, Микаптин) резко снизилось после введения в клиническую практику азатиоприна. Первичная фармакологическая реакция меркаптопурина почти идентична азатиоприну.

Используют этот препарат только при лечении аутоиммунных заболеваний: гемолитической анемии, ревматоидного артрита, хронического гепатита, идиопатической тромбоцитопенической пурпуры, волчаночного нефрита, для лечения псориаза.

Циклофосфан (Циклофосфамид, Митоксан, Цитоксан, Эндоксан). Относится к синтетическим хлорэтиламинам. Препарат - иммунодепрессант, проявляющий супрессорную активность как в отношении профилирующих, так и в отношении «покоящихся» иммунокомпетентных клеток. Клеткамимишенями для него являются Т-хелперы, предшественники и зрелые эффекторные клетки. В дозах 2-5 мг/кг сут препарат цитотоксичен для В- 
лимфоцитов и угнетает их стимулированную пролиферацию, истощаются Взависимые пулы в селезенке и лимфоузлах без нарушения Т-зависимых регионов. Нормализация функции В-клеток в ходе иммунного ответа после отмены циклофосфана происходит более медленно, чем восстановление Тклеточных функций.

Метотрексат (Аметоптерин, Метиламиноптерин). Это синтетический антагонист фолиевой кислоты, влияющий на гуморальный и клеточный иммунитет, но более выражен первый из эффектов. Употребляется метотрексат как иммунодепрессант для профилактики отторжения костномозгового трансплантата при хронической реакции «трансплантант против хозяина». Обычно используют его в виде курсов в течение 100 дней после инфузии костного мозга, с последующим переводом на комбинацию азатиоприна с преднизолоном.

Винбластин. В отличие от вышеперечисленных акилирующих веществ и антиметаболитов по механизму действия является метафазным «ядом», так как электронно-микроскопически показано, что сконденсированные и расположенные по экватору клетки хромосомы не могут расходиться к полюсам. Причина этого явления - отсутствие микротрубочек веретена давления. Винбластин, попав в цитоплазму иммунокомпетентной клетки, нарушает сборку веретена деления.

Арава (Лефлуномид). Иммуномодулирующий препарат изоксазолового ряда, блокирующий синтез пиримидина. Применяется в активной фазе ревматоидного и псориатического артрита у взрослых пациентов. Как правило, препарат следует принимать продолжительное время.

\section{Агонисты иммунофилинов.}

Циклоспорин $A$. Циклический олигопептид проникает в антигенчувствительные клетки на стадиях G0 и G1 и блокирует синтез мРНК лимфокинов. Клетками-мишенями для циклоспорина являются $\mathrm{CD}^{+}{ }^{-}$ лимфоциты, которые участвуют в развитии аутоиммунных болезней. Связываясь со специфическими внутриклеточными рецепторами (циклофилинами), он селективно ингибирует экспрессию генов, участвующих на ранних этапах активации Т-лимфоцитов. К эффектам циклоспорина относят подавление транскрипции тРНК Т-клеточных цитокинов: ИЛ-2, ИЛ-3, ИЛ-4, ИФН, экспрессии мембранных ИЛ-2 рецепторов на Т-лимфоцитах, хемотаксиса мононуклеарных фагоцитов, синтеза TNF и в меньшей степени ИЛ-1 и экспресссии АГ II класса МНС на мембранах АПК.

\section{Природные макролиды.}

К ним относится Такролимус (Програф, Фуджимицин, Такропик, Протопик (мазь для наружного применения), Адваграф (капсулы пролонгированного действия) продуцирующийся актиномицетом Streptomyces tsukubaensis. Подобно 
циклоспорину он является агонистом иммунофилина. Он подавляет формирование цитотоксических лимфоцитов, снижает активацию Т-клеток, зависимую от Т-хелперов пролиферацию В-клеток, а также формирование цитокинов (IL-2, IL-3, $\gamma \mathrm{IFN}$ ). Такролимус более активен, чем циклоспорин, и более эффективен в меньших дозах.

Другим препаратом этой группы является Рапамицин (Сиролимус) макролид, выделенный из Stephomyces higroscopicus. За счет ингибирование mTOR происходит блокада нескольких специфических путей преобразования сигнала, нарушается регуляция аутофагии, трансляции и транскрипции. Снижается активность Т- и В-лимфоцитов и как следствие угнетается иммунный ответ. Рапамицин активно используется для того что бы избежать отторжений органов при трансплантации. При обработке стентов для предотвращения рестеноза сосудов. Он подавляет развитие аутоиммунного процесса, что делает целесообразным испытания препарата при аутоиммунных заболеваниях.

\section{Глюкокортикоиды, или глюкокортикостерооиды}

Общее собирательное название подкласса гормонов коры надпочечников и их синтетических аналогов, по строению все являются стероидами. Они обладают разносторонним действием на организм. ГКС активно влияют на:

$\checkmark$ Белковый обмен - ограничения на уровне микросом включения аминокислот во вновь синтезируемые белки. Одновременно осуществляется катаболическое воздействие путем стимуляции расщепления аминокислот с превращением их углеродной цепи в глюкозу.

$\checkmark$ Углеводный обмен - индуцирует синтез ферментов глюконеогенеза, способствуя образованию глюкозы из аминокислот, уменьшает чувствительность к инсулину при одновременном повышении активности инсулиназы. В результате растет уровень сахара в крови, необходимый для высоких энергозатрат. Однако при длительном стимулирующем воздействии на инсулярный аппарат поджелудочной железы может произойти его истощение с развитием так называемого стероидного диабета. Обычно он протекает достаточно легко, купируется диетой, снижением и постепенной отменой ГКС.

$\checkmark$ Обмен жиров - мобилизация их периферических запасов. В результате расщепления жирных кислот происходит накопление в крови кетоновых тел, возникает гипергликемия. При продолжительном применении ГКС катаболизирующий эффект сочетается с отложением жировой ткани на спине, животе, щеках.

$\checkmark$ Минеральный обмен при введении ГКС усиливает реабсорбции натрия почечными канальцами при одновременном выведении с мочой калия и 
кальция. В случаях продолжительного применения могут развиться гипокалиемия, метаболический алкалоз, гипокальциемия с остеопорозом.

ГКС обладают мощным иммунорегулирующим, противовоспалительным и противоаллергическим действием. Они угнетают активность клеток лимфоидного ряда, тормозят созревание и дифференцировку как Т-, так и Всубпопуляций лимфоцитов, вызывают апоптоз лимфоидных клеток и тем самым снижают количество лимфоцитов в крови. Глюкокортикоиды также тормозят продукцию антител В-лимфоцитами и плазматическими клетками, уменьшают продукцию лимфокинов и цитокинов разными иммунокомпетентными клетками, угнетают фагоцитарную активность лейкоцитов.

Глюкокортикоиды усиливают нейтрофилопоэз и ответ нейтрофильного ростка костного мозга на ростовые факторы Г-КСФ и ГМ-КСФ и на ИЛ, повышают содержание нейтрофильных гранулоцитов в крови, уменьшают повреждающее действие лучевой и химиотерапии злокачественных опухолей на костный мозг и степень вызываемой этими воздействиями нейтропении. Благодаря этому эффекту глюкокортикоиды широко применяются в медицине при нейтропениях, вызванных химиотерапией и радиотерапией, и при лейкозах и лимфопролиферативных заболеваниях.

ГКС угнетают эозинофилопоэз и вызывают апоптоз зрелых эозинофилов крови и тем самым снижают содержание эозинофилов в крови вплоть до полной анэозинофилии. Они оказывают мощное противовоспалительное действие, тормозят активность различных разрушающих ткани ферментов - протеаз и нуклеаз, матриксных металлопротеиназ, гиалуронидазы и т. п., синтез простагландинов, кининов и других медиаторов воспаления, тормозят экссудацию в очаг воспаления жидкости и белка, миграцию лейкоцитов (хемотаксис) и пролиферацию соединительной ткани. Понижают проницаемость тканевых барьеров и стенок сосудов, стабилизируют клеточные мембраны, приостанавливают перекисное окисление липидов, образование в очаге воспаления свободных радикалов и многие другие процессы, играющие роль в осуществлении воспаления.

ГКС свойственно сильное противоаллергическое действие, которое осуществляется различными механизмами: понижением продукции IgEиммуноглобулинов, стабилизацией мембран тучных клеток и уменьшением высвобождения из них медиаторов аллергии, падением чувствительности периферических тканей к гистамину и серотонину с одновременным повышением чувствительности к адреналину и др.

Спектр использования ГКС достаточно широк и вытекает из механизмов действия, описанных выше. Сегодня практически нет ни одной области медицины, где бы не нашли применения ГКС. В настоящее время в арсенале врача имеется значительное количество гормональных препаратов, относящихся 
к этому классу. Чаще всего назначают Преднизолон, который по противовоспалительному эффекту в 5 раз сильнее естественного гормона коры надпочечников кортизола и при этом в меньшей степени задерживает в организме натрий. Этого нежелательного действия практически лишен Метилпреднизолон, что делает его предпочтительным при лечении больных, склонных к отекам. Кроме того, он в минимальной степени обладает ульцерогенными свойствами. Метилпреднизолон при внутримышечном введении медленнее всасывается, что обеспечивает более продолжительный и равномерный терапевтический эффект. Из других ГКС особого внимания заслуживают Триамцинолон и Дексаметазон, которые выгодно отличаются от гидрокортизона (кортизола) и преднизолона еще более выраженной противовоспалительной активностью. Триамцинолон при высоком противовоспалительном потенциале и катаболическом эффекте в меньшей степени оказывает гипергликемическое и гипертензивное действие. Следовательно, его лучше назначать больным со склонностью к гипергликемии или артериальной гипертензии. В связи с достаточно сильно выраженным иммуносупрессивным эффектом Триамцинолон может применяться при лечении больных с преобладающим аутоиммунным компонентом в патогенезе заболевания (хронический вирусный гепатит) или в случаях осложнений иммуноаллергического характера (полиартриты, миокардиты, нефропатии и др.).

Дексаметазон при более выраженных, чем Преднизолон, противовоспалительном и противоаллергическом эффектах оказывает противошоковое действие, практически не влияя на водно-электролитный баланс.

Определение доз ГКС зависит от характера патологического процесса и целей их применения. При назначении глюкокортикоидов необходимо учитывать их эквивалентные дозы: по противовоспалительному эффекту 5 мг преднизолона соответствуют 25 мг кортизона, 20 мг гидрокортизона, 4 мг метилпреднизолона, 4 мг триамцинолона, 0,75 мг дексаметазона, 0,75 мг бетаметазона.

$$
\begin{gathered}
5 \text { мг преднизолона = } 25 \text { мг кортизона = } 20 \text { мг гидрокортизона = } \\
=4 \text { мг метилпреднизолона = 4 мг триамцинолона = } \\
=0,75 \text { мг дексаметазона = 0,75 мг бетаметазона }
\end{gathered}
$$

Важной проблемой лечения ГКС являются порядок и темп их отмены. Известно, что при поступлении в кровь ГКС срабатывает система отрицательной обратной связи, в результате чего угнетаются функции гипоталамуса-гипофизакоры надпочечников, особенно при продолжительных курсах лечения. Может возникнуть ситуация, когда после отмены ГКС кора надпочечников не 
вырабатывает нужного количества эндогенных гормонов, необходимых для нормального функционирования организма. Возникает состояние, которое определяется как синдром отмены, характеризующийся нарастающей общей слабостью, вялостью, снижением аппетита, артериальной гипотензией. Депрессия системы гипоталамус-гипофиз-кора надпочечников обычно наступает через 10 - 12 дней лечения. Следовательно, при коротких курсах она не успевает развиться, поэтому отмена ГКС может осуществляться сразу или в течение 2 - 3 дней. При более продолжительных курсах лечения целесообразно придерживаться формулы: время применения оптимальных доз равно времени постепенной их отмены. Следует иметь в виду, что в случаях преждевременной отмены ГКС или преждевременного снижения их суточных доз может наступить обострение заболевания, которое часто неправильно трактуется как рецидив болезни. В случаях появления синдрома отмены или обострения патологического процесса следует возвратиться к предыдущей дозе. Снижение суточной дозы начинают со второй половины дня (с учетом биоритма естественной продукции ГКС). Если период отмены продолжительный, то суточные дозы уменьшаются через каждые 2 - 3 дня и более. Побочные действия или осложнения ГКС терапии представляют собой результат усиления их физиологического действия и наблюдаются преимущественно при продолжительном употреблении.

Интраназальные глюкокортикостероиды (НГКС). Это неоднородная группа препаратов, обладая схожими лечебными свойствами, различаются по фармакокинетическим показателям, прежде всего по системе биодоступности. НГКС на основе беклометазона, будесонида или триамцинолона, имеющие биодоступность до 50\%, при длительном применении подавляли функцию коры надпочечников, с развитием надпочечниковой недостаточности при резкой отмене препарата. Препараты нового поколения мометазона фуроат, флутиказона фуроат и флутиказона пропионат этих нежелательных эффектов лишены. Т.е. их действие ограничивается на уровне мукозального иммунитета воздействуют на воспаление, эффективно уменьшая выраженность таких симптомов, как зуд, чихание, ринорея и заложенность носа, а также слезотечение. Эффективно применяется при аллергическом ринит у взрослых, подростков и детей с 2 лет, остром синусите или обострение хронического синусита у взрослых (в т.ч. пожилого возраста) и подростков с 12 лет в составе комплексной терапии; остром риносинусите без признаков тяжелой бактериальной инфекции у пациентов 12 лет и старше (когда антибиотики не рекомендуются), полипозе носа, сопровождаемый нарушением носового дыхания и обоняния, у взрослых (от 18 лет). 
При наличии соответствующих показаний, соблюдении схем приема такие препараты могут применяться на протяжении длительного времени.

К ингаляционным глюкокортикоидам относятся Беклометазон, Будесонид, Флутиказон, Мометазон, Триамцинолон. Ингаляционные глюкокортикоиды отличаются от системных по фармакологическим свойствам: действуют в минимальных дозах, сильное местное противовоспалительное действие, низкая системная биодоступность, быстрая инактивация. Ингаляционные глюкокортикоиды угнетают все фазы воспаления в бронхах и снижают их повышенную реактивность. Очень важное значение имеет их способность понижать бронхиальную секрецию (уменьшать объем трахеобронхиального секрета) и потенцировать действие бета2адреномиметиков. Применение ингаляционных форм глюкокортикоидов позволяет уменьшить потребность в таблетированных глюкокортикоидах. Важной характеристикой ингаляционных глюкокортикоидов является терапевтический индекс - соотношение местной противовоспалительной активности и системного действия. Из ингаляционных глюкокортикоидов наиболее благоприятный терапевтический индекс имеет будесонид.

Одним из факторов, определяющих эффективность и безопасность ингаляционных глюкокортикоидов, являются системы для их доставки в дыхательные пути. В настоящее время для этой цели используются дозированные и порошковые ингаляторы (турбухалер и др.), небулайзеры.

Показано, что ингаляционные глюкокортикоиды и бета-адреномиметики длительного действия (Салметерол, Формотерол) обладают синергическим эффектом. Это обусловлено стимуляцией биосинтеза бета2-адренорецепторов и повышением их чувствительности к агонистам под влиянием глюкокортикоидов. В связи с этим при лечении бронхиальной астмы эффективными являются комбинированные препараты, предназначенные для длительной терапии, но не для купирования приступов - например фиксированная комбинация Салметерол / Флутиказон или Формотерол / Будесонид.

Ингаляции глюкокортикоидами противопоказаны при грибковых поражениях дыхательных путей, туберкулезе, беременности.

Глюкокортикоиды нашли широкое применение в дерматологии для лечения различных заболеваний кожи неинфекционной природы: атопический дерматит, псориаз, экзема, красный плоский лишай и другие дерматозы. Они оказывают местное противовоспалительное, противоаллергическое действие, устраняют зуд (применение при зуде обосновано только в случае, если он вызван воспалительным процессом).

Наиболее низкой всасываемостью при аппликации на кожу отличаются галогенированные соединения (Флуметазон, Флуоцинолона Ацетонид и др.), однако при нанесении их на обширные поверхности и длительном применении, 
развиваются побочные явления (атрофия кожи, телеангиэктазии, стероидные акне, стрии, инфекции). Этих недостатков лишены мометазона фуроата и метилпреднизолона ацепонат

Топические глюкокортикоиды отличаются друг от друга по химической структуре, а также по силе местного противовоспалительного действия. Согласно классификации по потенциальной активности местных стероидов выделяют 4 класса (табл.109).

Таблица 109

\section{Классификация местных стероидов по активности}

\begin{tabular}{|l|l|}
\hline \multicolumn{1}{|c|}{ Степень активности } & \multicolumn{1}{|c|}{ Действующие вещества } \\
\hline Класс I - слабые & $\begin{array}{l}\text { Гидрокортизон (гидрокортизона ацетат) 0,5 и 1\% мазь } \\
\text { Преднизолон 0,5\% мазь }\end{array}$ \\
\hline Класс II - средней силы & Алклометазон (алклометазона дипропионат) 0,05\% мазь и крем \\
\hline Класс III - сильные & Бетаметазон (бетаметазона валерат, бетаметазона дипропионат, \\
& 0,05 и 0,1\% крем и мазь Гидрокортизон (гидрокортизона бутират) \\
& 0,1\% мазь, крем, эмульсия, раствор Метилпреднизолона ацепонат \\
& $0,1 \%$ жирная мазь, мазь, крем, эмульсия Мометазон (мометазона \\
& фуроат) 0,1\% мазь, крем, раствор. Триамцинолона ацетонид 0,1\% \\
& мазь Флуоцинолона ацетонид 0,025\% мазь, крем, гель, линимент \\
Флутиказон (флутиказона пропионат) 0,005\% мазь, 0,05\% крем
\end{tabular}

Терапевтический эффект топических глюкокортикоидов зависит также от применяемой лекарственной формы. Способность к проникновению в кожу убывает в следующем порядке: жирная мазь $\Rightarrow$ мазь $\Rightarrow$ крем $=>$ лосьон (эмульсия)

При хронической сухости кожи проникновение глюкокортикоидов в эпидермис и дерму затруднено, поэтому при дерматозах, сопровождающихся повышенной сухостью и шелушением кожи, лихенизацией целесообразнее применять мази, т.к. увлажнение рогового слоя эпидермиса мазевой основой в несколько раз увеличивает проникновение ЛС в кожу. При острых процессах с выраженным мокнутием целесообразнее назначать лосьоны, эмульсии.

Поскольку глюкокортикоиды для местного применения снижают сопротивляемость кожи и слизистых оболочек, что может привести к развитию суперинфекции, при вторичном инфицировании целесообразно сочетание в одной лекарственной форме глюкокортикоида с антибиотиком, например, крем и мазь Белогент (бетаметазон + гентамицин), аэрозоли Оксикорт (гидрокортизон + окситетрациклин) и Полькортолон ТС (триамцинолон + тетрациклин) и др., или с антибактериальным и противогрибковым средством, например Акридерм ГК (бетаметазон + клотримазол + гентамицин). 


\section{Другие иммунодепресанты.}

Препараты золота. Обладают противовоспалительным, иммунодепрессивным, антипролиферативным действием (Тауредон, Ауранофин, Ауротиомалат натрия, Ауротиопрол)

Пеницилламин (Купренил, Троловол, Дистамин и т.д.).

Производные хинолина. (Хлорохин, Гидроксихлорохин, Делагил) В последние годы наиболее активным производным хинолина является Лаквинимод.

\section{Средства, устраняющие реакции, которые сопровождают иммунные процессы}

Нестероидные противовоспалительные средства (НПВС) Данная группа препаратов нашла широкое применение при ревматических, неврологических, травматологических заболеваниях и инфекциях.

Противовоспалительный эффект препаратов в основном, связан с подавлением экссудативной и пролиферативной фазой воспаления за счет прерывания циклооксигеназного пути метаболизма арахидоновой кислоты участвующих в синтезе простагландинов (ПГ), простациклинов и тромбоксанов. В настоящее время описано 3 различных изофермента ЦОГ. ЦОГ-1 нужен постоянно для регуляции синтеза гомеостатических и цитопротективных ПГ в слизистой оболочке желудочно-кишечного тракта (ЖКТ), эндотелия, тромбоцитах и канальцах почек. ЦОГ-2 вырабатывается макрофагами, эндотелиальными клетками, синовиоцитами, фибробластами, гладкой сосудистой мускулатурой и хондроцитами под воздействием их цитокинами или факторами роста под действием бактериальных токсинов. ПГ так же стимулируют выработку ЦОГ по механизму положительной обратной связи. ЦОГ-3 (или ЦОГ-1b) является ферментом нервной системы и, по-видимому, участвует в процессах регуляции температуры тела, влияя на синтез ПГ в гипоталамусе. Торможение синтеза простагландинов (ПГЕ $2, \Pi \mathrm{I}_{2}, \Pi_{\Gamma} \mathrm{F}_{2 \mathrm{a}}$ ), тромбоксана $\mathrm{A}_{2}$, что приводит к уменьшению гиперемии, отека, боли. Одновременно снижается выброс других тканевых медиаторов воспаления (гистамина, серотонина, брадикинина, норадреналина). Угнетение образования тромбоксана $\mathrm{A}_{2}$ и активности гиалуронидазы способствует нормализации микроциркуляции. Препараты так же снижают энергетический обмен клетки, уменьшая АТФ в тканях очага воспаления. Блокируя синтез ПГ, препараты уменьшают проницаемость сосудистой стенки и проникновение в ткани плазменных факторов. При этом снижается активность гуанилатциклазы и уровень цГМФ, угнетается деление фибробластов, синтез коллагена, мукополисахаридов, образование ревматических гранулем и соединительной ткани. За счет редукции синтеза ПГЕ2, под воздействием НПВС, снижается 
хемотаксис моноцитов, Т-лимфоцитов, эозинофилов, полиморфноядерных лейкоцитов в очаге воспаления и тормозится деление лимфоцитов. Этим объясняется десенсибилизирующее действие НПВС.

Торможение синтеза ПГ, имеющих важное значение для течения физиологических процессов в тканях, может привести к возникновению ряда общих осложнений. Наиболее частым и опасным побочным эффектом являются эрозивно-

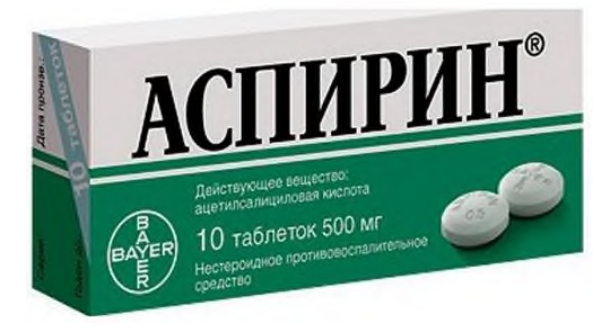
язвенные изменения слизистой оболочки желудка. Высокий риск побочных эффектов со стороны желудочно-кишечного тракта характерен для бутадиона, индометацина, пироксикама, АСК. Частота этих осложнений снижается, если препараты принимают после еды, запивая большим количество воды, или в сочетании с антацидами.

Опасным осложнением НПВС является бронхоспазм. Блокада ПГ может вызвать сдвиг метаболизма арахидоновой кислоты в сторону образования лейкотриенов и возникновению реагинового (анафилактического, атопического) синдрома. Наиболее часто это осложнение развивается при назначении АСК.

НПВС снижают диурез и вызывают отеки, так как подавляют образование почечных ПГ, участвующих в регуляции почечного кровотока, клубочковой фильтрации, секреции ренина и водно-солевого баланса. Падение уровня ПГ способствует задержке натрия и возникновению отеков (особенно характерно для Бутадиона, Диклофенака натрия, Кетопрофена, кислоты мефенамовой).

Наряду с перечисленными, НПВС дают ряд других (не связанных с ПГ) побочных эффектов: изменения со стороны крови, печени, ЦНС, кожи. Тяжелые гематологические нарушения (лейкопения и даже агранулоцитоз, апластическая анемия) характерны для пиразолоновых производных (Бутадион, Амидопирин, Анальгин); нарушения кроветворения могут вызвать Индометацин, кислота мефенамовая. Различные формы поражения печени вплоть до токсического гепатита (длительное назначение) развиваются при применении бутадиона, индометацина, сулиндака, диклофенака натрия (ортофен). Побочные эффекты со стороны центральной нервной системы наблюдаются при лечении ацетилсалициловой кислотой (шум в ушах, снижение остроты слуха, головокружение, гипервентиляция), индометацином (головокружение, сильные головные боли, депрессия, иногда галлюцинации, судороги); со стороны кожных покровов (кожный зуд, ограниченная или генерализованная крапивница, эритродермия) - особенно при применении бутадиона, индометацина, оксикамов.

НПВС нельзя назначать в первый триместр беременности, так как они обладают тератогенными свойствами, Лечение НПВС во второй половине 
беременности также рискованно, поскольку иногда способствует сужению (и даже закрытию) артериального протока и нарушению гемодинамики плода. Опасно назначение этих препаратов (особенно индометацина) в предродовом периоде - снижая уровень ПГ, они ослабляют сократимость матки и тормозят родовую деятельность.

Классификация НПВС базируется на данных о способности блокировать различные форм ЦОГ (табл. 110).

Таблица 110

\section{Классификация НПВП по химической структуре}

\begin{tabular}{|c|c|}
\hline Вещество & Препарат \\
\hline \multicolumn{2}{|c|}{ Селективные ингибиторы циклооксигеназы-1 } \\
\hline Ацетилсалициловая кислота & Ацетилсалициловая кислота низкие дозы \\
\hline \multicolumn{2}{|r|}{ Ингибиторы циклооксигеназы-1 и -2 } \\
\hline Салицилаты & Ацетилсалициловая кислота (аспирин), дифлунисал (долобид) \\
\hline $\begin{array}{l}\text { Производные уксусной } \\
\text { кислоты }\end{array}$ & $\begin{array}{l}\text { Индометацин, ацеклофенак, диклофенак, кеторолак, } \\
\text { триметиамин }\end{array}$ \\
\hline $\begin{array}{l}\text { Производные пропионовой } \\
\text { кислоты }\end{array}$ & Ибупрофен (нурофен), кетопрофен, напроксен \\
\hline Производные пиразолона & Фенилбутазон (бутадион), метамизол (баралгин, анальгин) \\
\hline Оксикамы & Пироксикам, теноксикам (артоксан) \\
\hline \multicolumn{2}{|c|}{ Селективные ингибиторы циклооксигеназы-2 } \\
\hline Производные сульфонамида & Нимесулид (найз) \\
\hline Оксикамы & Мелоксикам (мовалис, амелотекс) \\
\hline $\begin{array}{l}\text { Производное индолуксусной } \\
\text { кислоты }\end{array}$ & Этодолак (нобедолак) \\
\hline \multicolumn{2}{|c|}{ Высокоселективные ингибиторы циклооксигеназы-2 } \\
\hline Коксибы & $\begin{array}{l}\text { Целекоксиб (дилакса, целебрекс), рофекоксиб (виокс), парекоксиб } \\
\text { (династат), эторикоксиб (аркоксиа, бикситор) }\end{array}$ \\
\hline Алканоны & Набуметон \\
\hline \multicolumn{2}{|r|}{ Ингибиторы ЦОГ-3 } \\
\hline Анилиды & Парацетамол \\
\hline
\end{tabular}

С клинической точки зрения необходимо отметить, что эффективность НПВП, в целом, зависит от дозы. Использование более высоких доз позволяет обеспечить более выраженное обезболивающее и противовоспалительное действие, при этом все НПВП в адекватных противовоспалительных дозах (средних и максимальных терапевтических) при длительном применении имеют равный обезболивающий потенциал. Противовоспалительный препарат выбирается на основании оценки безопасности его действия и возможных рисков осложнений со стороны ЖКТ и сердечно-сосудистой системы (табл. 111, 112). Однако до настоящего времени остается градация эффективности средних доз НПВС по силе противовоспалительного и анальгезирующего действия (рис. $180)$. 


\section{ИММУНОТЕРАПИЯ}

Таблица 111

Алгоритм назначения НПВП согласно рекомендациям российских

экспертов (doi: 10.14412/1995-4484-2018-1-29)

\begin{tabular}{|c|c|c|c|c|}
\hline \multirow{2}{*}{\multicolumn{2}{|c|}{$\begin{array}{c}\text { Риски } \\
\text { осложнений }\end{array}$}} & \multicolumn{3}{|c|}{ со стороны сердечно-сосудистой системы } \\
\hline & & низкий & умеренный и высокий & очень высокий \\
\hline \multirow{3}{*}{ 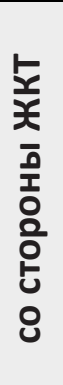 } & низкий & Любые НПВС & $\begin{array}{l}\text { целекоксиб, напроксен, } \\
\text { кетопрофен, низкие дозы } \\
\text { ибупрофена (<1200 мг/сут) }\end{array}$ & \multirow{3}{*}{$\begin{array}{l}\text { Избегать } \\
\text { назначение } \\
\text { любых НПВС }\end{array}$} \\
\hline & умеренный & НПВС + ИПП, с-НПВС & Напроксен + ИПП или целекоксиб & \\
\hline & $\begin{array}{l}\text { высокий и } \\
\text { очень } \\
\text { высокий }\end{array}$ & $\begin{array}{l}\text { Целекоксиб или } \\
\text { эторикоксиб + ИПП }\end{array}$ & Целекоксиб + ИПП & \\
\hline
\end{tabular}

ИПП-ингибитор протонной помпы

Таблица 112

Оценка факторов риска при назначении НПВП

(doi: 10.14412/1995-4484-2017-485-492)

\begin{tabular}{|c|l|l|}
\hline $\begin{array}{c}\text { Уровень } \\
\text { риска }\end{array}$ & \multicolumn{1}{|c|}{ ЖКТ } & \multicolumn{1}{|c|}{ сердечно-сосудистая система } \\
\hline низкий & $\begin{array}{l}\text { Отсутствие каких-либо факторов } \\
\text { риска }\end{array}$ & $\begin{array}{l}\text { Отсутствие заболевания, } \\
\text { SCORE <1\% }\end{array}$ \\
\hline умеренный & $\begin{array}{l}\text { Диспепсия, прием } \\
\text { глюкокортикоидов, } \\
\text { курение, возраст >65 лет }\end{array}$ & SCORE 1-4\% \\
\hline высокий & $\begin{array}{l}\text { Язвенный анамнез, прием низких } \\
\text { доз аспирина и/или иных } \\
\text { антитромботических средств }\end{array}$ & SCORE >5\% \\
\hline $\begin{array}{c}\text { очень } \\
\text { высокий }\end{array}$ & $\begin{array}{l}\text { Кровотечение, перфорация в } \\
\text { анамнезе }\end{array}$ & $\begin{array}{l}\text { Клинически выраженная ИБС, инфаркт } \\
\text { ииокарда, инсульт или транзиторная } \\
\text { ишемическая } \\
\text { атака в анамнезе, ХСН II ФК и выше, СД 2-го } \\
\text { типа с поражением органов-мишеней, } \\
\text { хроническая болезнь почек 3-й степени и } \\
\text { выше }\end{array}$ \\
\hline
\end{tabular}

По эффективности НПВС в средних и максимальных терапевтических дозах при лечении хронической боли не уступают по эффективности «мягким» опиоидным препаратам, таким как трамадол, и более эффективны чем парацетамол. Использование НПВП в операционном периоде и в качестве дополнительного средства для контроля боли у онкологических больных позволяет повысить эффективность обезболивания, снизить потребность в наркотических анальгетиках.

Использование инъекционных форм НПВС (в/в и в/м введение), а также быстрорастворимых препаратов для приема внутрь может иметь преимущество в скорости наступления обезболивающего эффекта в сравнении с пероральным приемом стандартных препаратов. В то же время нет однозначных данных о том, 


\section{ПРОТИВОВОСПАЛИТЕЛЬНОЕ ДЕЙСТВИЕ}

MAX

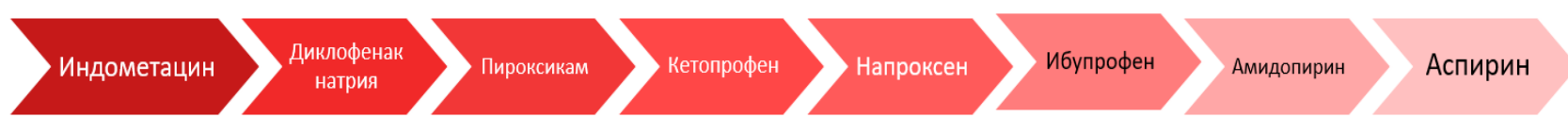

АНАЛЬГЕЗИРУЮЩЕЕ ДЕЙСТВИЕ

MAX

MIN

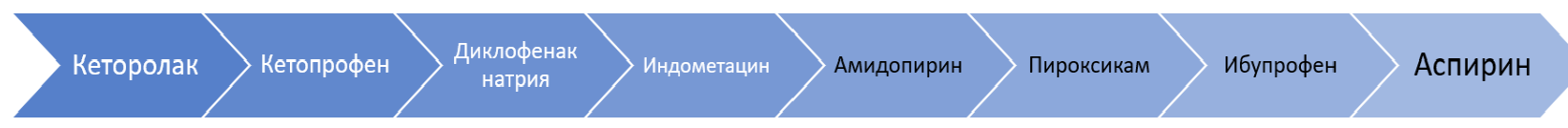

Рис. 180. Эффективность НПВС.

что применение НПВС в виде инъекций или быстрорастворимых форм для приема внутрь имеет преимущество перед пероральными формами по выраженности обезболивающего и противовоспалительного действия при проведении лечения более 1 дня. Так же, как и локальные формы НПВС обладают доказанной обезболивающей и противовоспалительной эффективностью при лечении.

Длительное непрерывное использование НПВС обеспечивает лучший контроль симптомов, чем прием НПВС в режиме «по требованию». При этом длительное применение НПВС способно уменьшить частоту рецидивов и замедлить прогрессирование хронических воспалительных заболеваний и должно рассматриваться как патогенетическая терапия этой группы болезней.

\section{Антигистаминные средства.}

Гистамин - это органическое соединение, биогенный амин, вырабатывается тучными клетками, базофилами, нейронами и клетками ECL (энтерохромаффиноподобные клетки желудка - особый тип нейроэндокринных клеток). Он является одним из эндогенных факторов медиаторов, участвующих в регуляции жизненно важных функций организма и играющих важную роль в развитии ряда заболеваний. В физиологических концентрациях гистамин необходим для поддержания нормальной жизнедеятельности, в более высоких вызывает ряд патологических эффектов. Он участвует в развитии воспалительного процесса любой природы. Эффектами гистамина являются стимуляция секреции слизистой носа (ринорея), зуд, чихание, сокращение гладких мышц бронхов и кишечника, гиперемию тканей, дилатацию мелких кровеносных сосудов, повышение сосудистой проницаемости для воды, белков, нейтрофилов, образование воспалительного отека (заложенность носа). 
Гистамин вызывает усиление секреции желудочного сока, играет роль нейромедиатора. (см. главу 2). Повышают его выход так называемые либераторы гистамина (тубокурарин, морфин, яд крапивы, пчелиный и змеиный яды и др.). Либераторы могут также образовываться в организме при химических превращениях пищевых веществ (земляника, устрицы, желтки куриных яиц и пр.). Инактивация гистамина осуществляется несколькими путями: окислительное дезаминирование (гистаминаза), ацетилирование или метилирование, связывание гепарином или тканевыми белками.

Различные действия гистамина опосредованы разными гистаминовыми рецепторами (табл.113).

Таблица 113

\section{Биологические мишени гистамина в организме человека}

\begin{tabular}{|c|c|c|}
\hline Рецептор & Экспрессия на клетках & Эффекты \\
\hline $\begin{array}{l}\text { Гистаминовый } \\
\text { рецептор Н1 }\end{array}$ & $\begin{array}{lr}\text { Гладкие } & \text { мышцы, } \\
\text { эндотелиальные } & \text { клетки } \\
\text { сосудов, сердце, цнС }\end{array}$ & 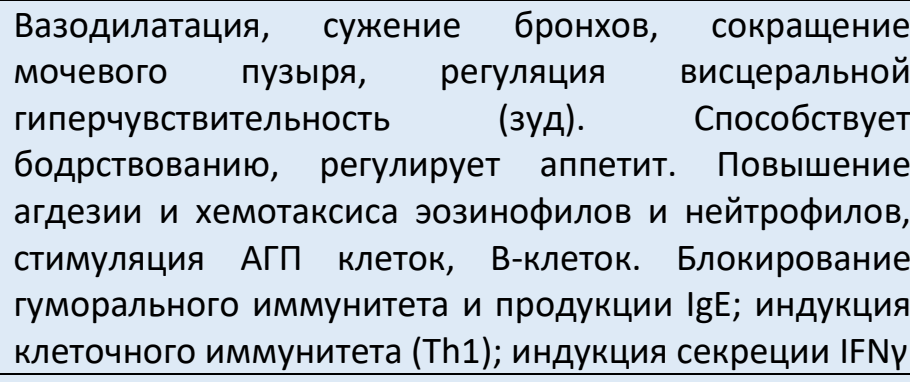 \\
\hline $\begin{array}{l}\text { Гистаминовый } \\
\text { рецептор Н2 }\end{array}$ & $\begin{array}{lr}\text { Париетальные } & \text { клетки, } \\
\text { гладкомышечные } & \text { клетки, } \\
\text { эпителиальные } & \text { клетки, } \\
\text { эндотелиальные } & \text { клетки, } \\
\text { кардиомиоциты, } & \text { клетки } \\
\text { молочных желёз, } & \text { матки, } \\
\text { клетки ЦНС, миелоидные и } \\
\text { лимфоидные } \\
\text { дендритные клетки }\end{array}$ & $\begin{array}{l}\text { Вазодилатации, стимуляции секреции желудочного } \\
\text { сока. Расслабление мочевого пузыря. Регулирует } \\
\text { работу желудочно-кишечного тракта. } \\
\text { Подавление активации и хемотаксиса нейтрофилов и } \\
\text { эозинофилов, индукция синтеза IL-10, подавление } \\
\text { синтеза AT, пролиферации Т-клеток и производство } \\
\text { цитокинов }\end{array}$ \\
\hline $\begin{array}{l}\text { Гистаминовый } \\
\text { рецептор Н3 }\end{array}$ & $\begin{array}{l}\text { ЦНС, периферическая } \\
\text { нервная система, ЖкТ, } \\
\text { эндотелиальные клетки } \\
\text { сердце, легкие. }\end{array}$ & $\begin{array}{l}\text { Регуляция по типу отрицательной обратной связи } \\
\text { высвобождения нейромедиаторов (дофамина, гАМК, } \\
\text { ацетилхолина, серотонина, норадреналина, } \\
\text { гистамина). Регуляция чувствительности (боль), } \\
\text { секрецию желудочного сока и прием пищи. }\end{array}$ \\
\hline $\begin{array}{l}\text { Гистаминовый } \\
\text { рецептор Н4 }\end{array}$ & $\begin{array}{l}\text { Костный мозг, базофилы, } \\
\text { тучные клетки, внутренние } \\
\text { органы (тонкий и толстый } \\
\text { кишечник, лёгкие, печень, } \\
\text { селезёнка, семенники, } \\
\text { тимус, трахея, миндалины). }\end{array}$ & $\begin{array}{l}\text { Полностью не охарактеризованы. Участвует в } \\
\text { восприятии зуда, воспалении, аллергии, когнитивных } \\
\text { функциях висцеральной гиперчувствительности. } \\
\text { Играет роль в секреции цитокинов, хемотаксисе } \\
\text { тучных клеток и эозинофилов. Сигнал к дегрануляции } \\
\text { эозинофилов }\end{array}$ \\
\hline $\begin{array}{l}\text { Хлоридный } \\
\text { канал, } \\
\text { управляемый } \\
\text { гистамином }\end{array}$ & $\begin{array}{l}\text { ЦНС (гипоталамус, таламус) } \\
\text { и эпителий кишечника. }\end{array}$ & $\begin{array}{l}\text { Быстрая выработка тормозящиго постсинаптические } \\
\text { потенциалы. } \\
\text { Секреция хлоридов связанная с секреторной диареей. }\end{array}$ \\
\hline
\end{tabular}

Учитывая, что при любых патологических процессах с выраженным воспалительным компонентом всегда повышен уровень гистамина в организме, 
патогенетически целесообразным и клинически обоснованным является снижение активности гистаминовой системы в условиях еe повышенной активности. Подавить действие гистамина возможно либо через уменьшение количества свободного гистамина (торможение синтеза, активация метаболизма, торможение высвобождения из депо), либо через блокаду гистаминовых рецепторов. Антагонисты H1 рецепторов, (блокаторы H1), препараты, блокирующие действие гистамина на рецептор Н1 помогают облегчить аллергические реакции. Основной терапевтический эффект опосредован отрицательной модуляцией гистаминовых рецепторов, называются антигистаминными. Блокаторы Н2-гистаминовых рецепторов париетальных клеток слизистой оболочки желудка снижают продукцию соляной кислоты. Относятся к антисекреторным препаратам.

Bсе антигистаминные препараты подразделяются на 2 поколения в зависимости от их влияния на ЦНС (рис.181).

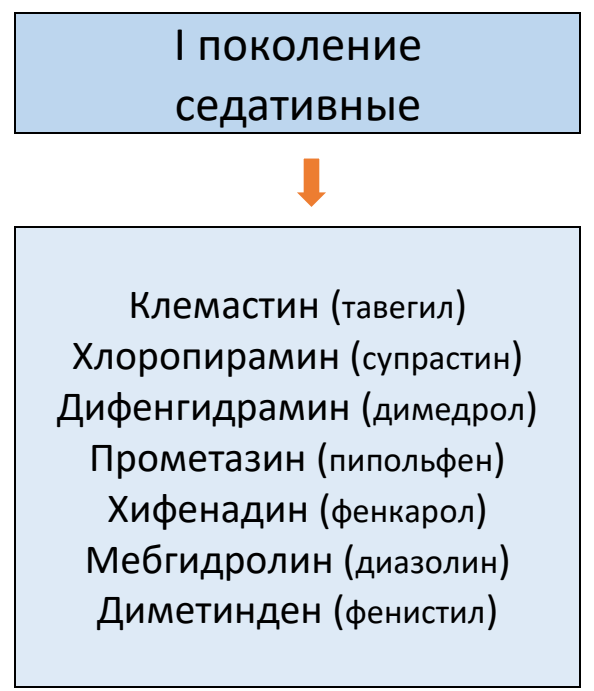

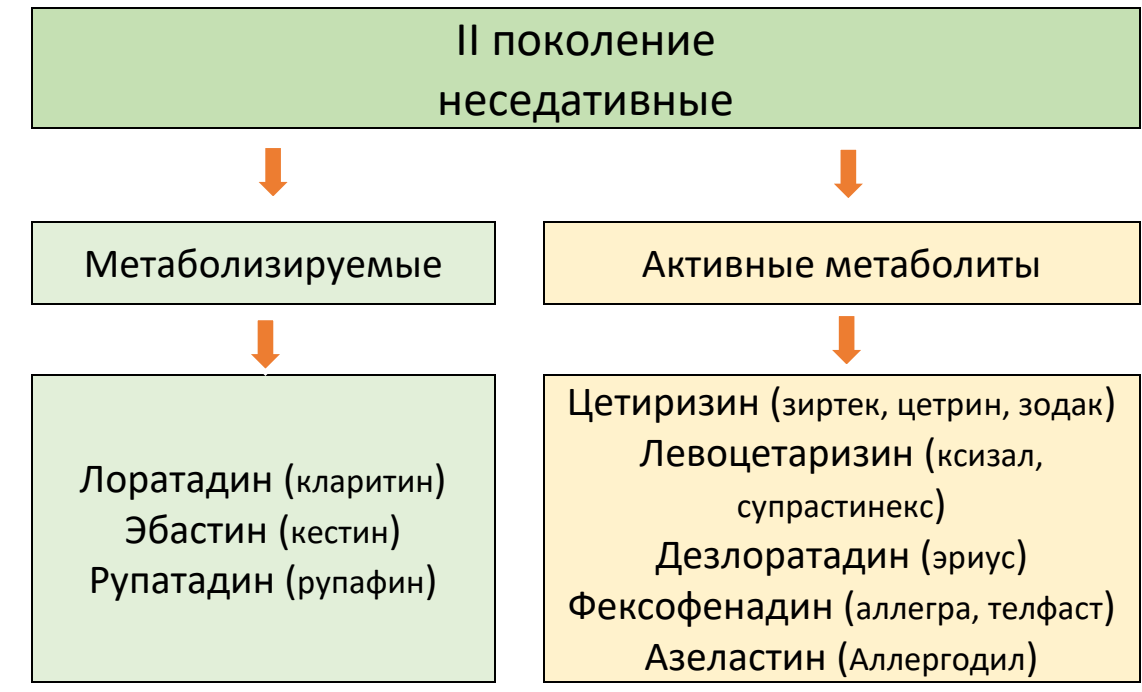

II поколение

неседативные

\section{Рис. 181. Классификация антигистаминных препаратов.}

\section{Антигистаминные препараты І поколения}

Н1-антагонисты первого поколения назначают при различных аллергических процессах: анафилактический шок, сенная лихорадка, аллергический дерматит, отек Квинке, крапивница, лекарственные аллергии и др. Антигистаминные средства вызывают и другие фармакологические эффекты. Они проникают через гематоэнцефалический барьер и как правило подавляют работу ЦНС. Нарушение функции ЦНС наблюдается даже при использовании минимальных доз этих средств. Н1-антагонисты первого поколения оказывают местноанестезирующее и болеутоляющее действие, потенцируют эффект анальгетиков, местных анестетиков, снотворных, барбитуратов, транквилизаторов, наркотиков (особенно Дипразин). Все они (больше Дипразин, меньше Димедрол) тормозят тошноту, рвоту. Димедрол, Дипразин, Супрастин 
обладают адренолитическими, ганглиоблокирующими и центральными холинолитическими свойствами.

При длительном применении противогистаминных средств лечебный эффект постепенно ослабевает, что обусловливает целесообразность периодической замены одного препарата другим.

При приеме антигистаминных препаратов I поколения необходимо отметить их кратковременный эффект (вынужденный прием 3-4 раза в сутки), низкую избирательность действия (они так же блокируют рецепторы ацетилхолина, адреналина, серотонина, дофамина и ионные каналы, вызывая множество побочных эффектов: тахикардию, сухость слизистых оболочек, повышение вязкости мокроты). Они могут способствовать повышению внутриглазного давления, нарушать мочеиспускание, вызывать боли в желудке, запоры, тошноту, рвоту, увеличивать массу тела. Поэтому указанные препараты ограничены к применению среди пациентов с глаукомой, доброкачественной гиперплазией предстательной железы, сердечно-сосудистой патологией и т. д.. Специалисты во многих странах призывают отказаться в лечении детей от этой группы препаратов или применять их под строгим контролем.

Однако у антигистаминных препаратов I поколения имеется очень важное преимущество - наличие инъекционных форм, незаменимых при оказании экстренной помощи, премедикации перед проведением некоторых видов диагностического обследования, хирургических вмешательствах и т.д. Кроме того, некоторые препараты обладают противорвотным действием, снижают состояние повышенной тревожности, эффективны при укачивании. Дополнительный антихолинергический эффект ряда препаратов указанной группы проявляется в значительном снижении зуда и кожных высыпаний при зудящих дерматозах, острых аллергических и токсических реакциях на пищевые продукты, лекарственные препараты, укусы и ужаления насекомых.

\section{Антигистаминные препараты II поколения}

Как и препараты первого поколения назначают при различных аллергических процессах. Они отличаются высокой избирательностью действия на $\mathrm{H}_{1-}$ рецепторы, незначительно влияют на другие медиаторные системы (холинергические и др.), не проходят через гемоэнцефалический барьер (ГЭБ) (не влияют на ЦНС), не теряют активность при длительном применении. Многие препараты II поколения неконкурентно связываются с $\mathrm{H}_{1}$-рецепторами, а образовавшийся лиганд-рецепторный комплекс характеризуется сравнительно медленной диссоциацией, обусловливающей увеличение продолжительности терапевтического действия (назначаются 1 раз в сутки), как правило, не вызывают привыкания. В связи с их более высоким профилем безопасности они предпочтительны для пожилых пациентов (старше 65 лет). 
При сравнении различных препаратов необходимо отметить, что антигистаминное действие начинает развиваться значительно раньше у активных метаболитов. Они же обладают и большей безопасностью, не зависят от взаимодействия с другими лекарственными веществами и продуктами. Так метаболизируемые антигистаминные препараты второго поколения необходимо с осторожностью принимать с антибиотиками макролидами, некоторые антимикотическими и противовирусными препаратами, антидепрессантами и др.. Необходимо при приеме этих препаратов исключить грейпфрукты и алкоголь.

Важнейшим свойством антигистаминных препаратов является их способность снижать экспрессию гистаминовых Н1-рецепторов, тем самым уменьшать чувствительность тканей к гистамину. По силе антигистаминного действия препараты II поколения можно расположить в следующем порядке: Цетиризин $>>$ Эбастин $>$ Фексофенадин $>>$ Лоратадин.

K антигистаминным препаратам относится и теоритин. Однако он обладает не только выраженным антигистаминным эффектом, но оказывает и выраженный противовоспалительный эффект, который достигается за счет биогенной структуры ксантина в единой молекуле теоритина.

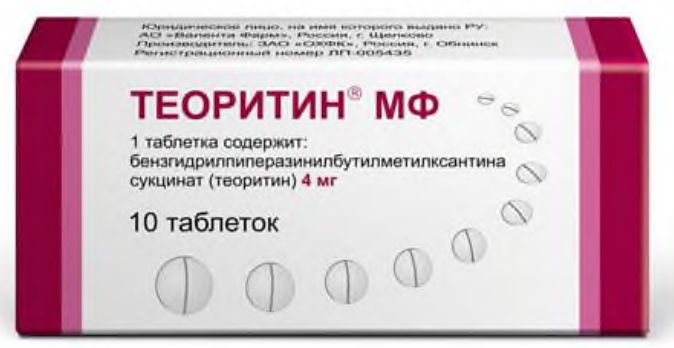

В клинической практике нашли применение препараты, стабилизирующие мембраны тучных клеток, тем самым предотвращающие выделение гистамина. Однако наступления желаемого действия при их использовании приходится долго ждать, и терапевтическая эффективность данной группы лекарств весьма умеренная, поэтому они применяются исключительно с профилактической целью.

Стабилизаторы мембран тучных клеток (Кетотифен, Кромолин Натрия, Интал, Тайлед и др.) - средства, влияющие на клетку и прежде всего на мембраны тучных клеток, представляют собой препараты, препятствующие открытию кальциевых каналов и входу кальция в клетки. Они угнетают кальцийзависимую дегрануляцию клеток и выход из них гистамина (в тучных клетках депонировано 90 \% этого медиатора), фактора, активирующего тромбоциты, лейкотриенов, в том числе медленно реагирующей субстанции анафилаксии, лимфокинов и других биологически активных веществ, индуцирующих аллергические и воспалительные реакции. Стабилизация мембран тучных клеток обусловлена блокадой фосфодиэстеразы и накоплением в них цАМФ. 
Важным аспектом противоаллергического влияния стабилизаторов мембран тучных клеток является повышение чувствительности адренорецепторов к катехоламинам. Кроме того, препараты способны блокировать хлорные каналы и предупреждать таким образом деполяризацию парасимпатических окончаний в бронхах. Они препятствуют клеточной инфильтрации слизистой оболочки бронхов и тормозят развитие замедленной реакции гиперчувствительности. Некоторые из лекарственных средств этой группы (Кетотифен и др.) блокируют $\mathrm{H}_{1}$-рецепторы (антигистаминное действие). Стабилизаторы мембран тучных клеток устраняют отек слизистой оболочки бронхов и предупреждают (но не купируют) повышение тонуса гладких мышц. Основное показание к их назначению - предупреждение бронхообструкции. Профилактический эффект развивается постепенно, в течение 2 - 12 нед. Стабилизаторы мембран тучных клеток хорошо сочетаются с другими средствами для профилактики бронхообструктивного синдрома. В ряде случаев их использование позволяет уменьшить дозу или прекратить прием кортикостероидов и бронходилататоров.

Часто назначают также средства, направленность действия которых противоположна медиаторам аллергии (функциональные антагонисты). К этим препаратам относят Адреналин, Эфедрин, Мезатон (адреномиметики), Эуфиллин, Папаверин (спазмолитики) и др.

\section{Таргетная иммунотерапия}

Таргетная терапия или молекулярно-таргетная терапия является одним из основных методов лечения рака и аутоиммунных заболеваний. Как форма молекулярной медицины, таргетная терапия блокирует рост раковых или гиперсенсибилизированных клеток, вмешиваясь в конкретные целевые молекулы. Большинством агентов для таргетной терапии являются клетки и молекулы иммунной системы, поэтому имеет смысл выделить иммунотерапию с применением биофармацевтических препаратов, направленных на конкретные мишени иммунной системы. В идеале при диагностике, иммунных нарушений используя принципы топической диагностики у больного определяются те или иные мишени и в дальнейшем, используя таргетную терапию, проводится лечение.

По точке приложения таргентные препараты имеет смысл разделить на препараты, блокирующие цитокины и другие молекулы иммунной системы, направленные на рецепторы клеток иммунной системы, и препараты, действующие на различные сигнальные пути клеток иммунной системы (рис. 180). Для этих целей используют малые молекулы или моноклональные антитела. 
В фармакологии к малым молекулам относятся практически все лекарственные вещества, тем не менее, с позиций таргетной терапии значение термина «малые молекулы» определяется как низкомолекулярные вещества, которые способны связываться с определёнными, чётко установленными, биологическими молекулярными мишенями - теми или иными специфическими биополимерами, такими, как тот или иной рецепторный, ферментный или регуляторный белок или нуклеиновая кислота, и действовать как эффектор, изменяя химическую структуру, пространственную конформацию, активность или функцию данного биополимера. Малые молекулы могут выполнять различные биологические функции, в частности служить передатчиками или блокаторами сигнала.

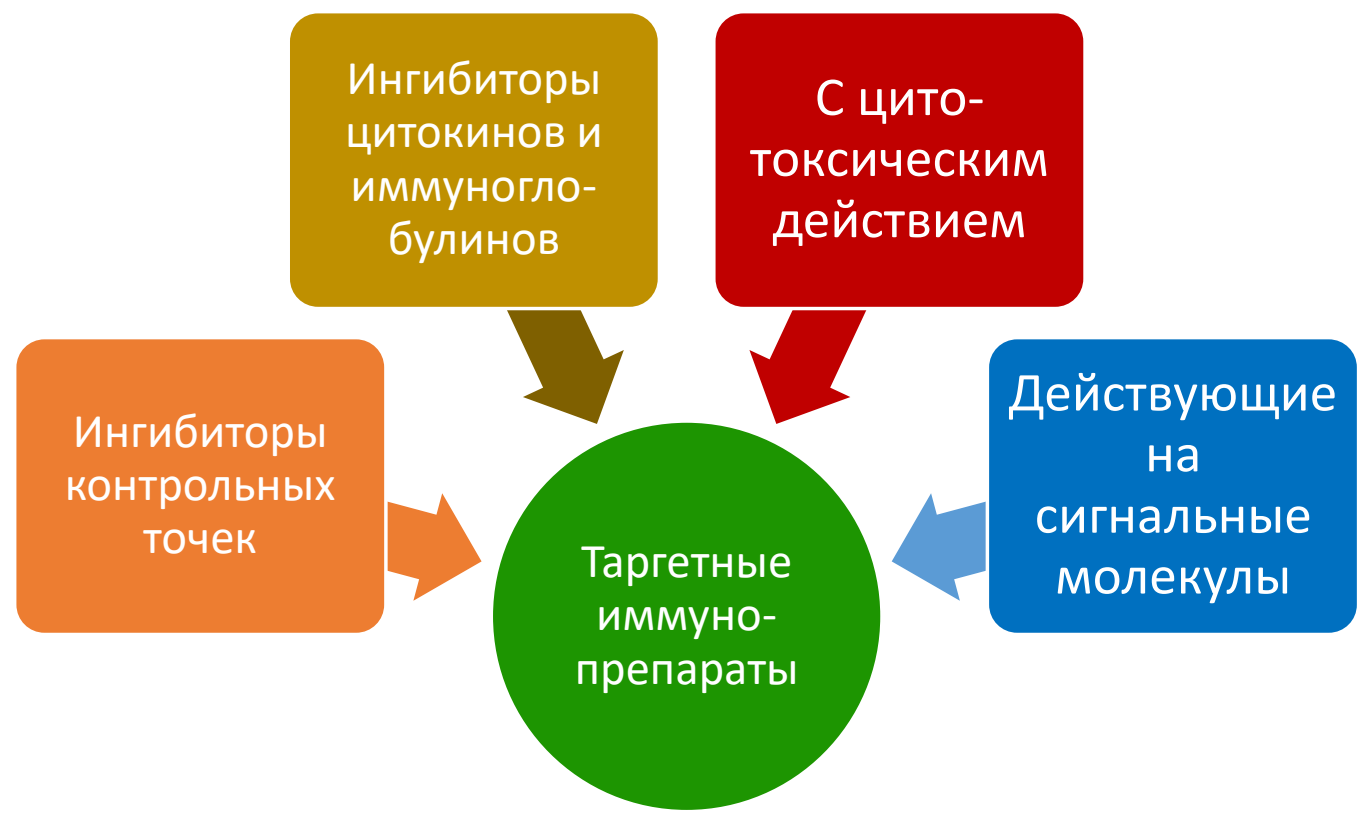

Рис. 180. Классификация таргетных иммунопрепаратов.

Моноклональных АТ - это антитела строго заданной специфичности, которые синтезируются одним клоном, т.е. отдельной линией лимфоидных клеток. Моноклональные АТ получают путем слияния В-лимфоцита, вырабатывающего антитела заданной специфичности и опухолевой клетки, лимфоидной ткани - плазмоцитомы, обеспечивающей непрерывный рост образующегося гибрида. Слившиеся гибридомные клетки могут бесконечно размножаться и синтезируемые ими моноклональные АТ могут быть получены в неограниченном количестве. Таким образом, получают моноклональные АТ к определенным АГ бактерий или вирусов, опухолевых клеток, лимфоцитов, гормонов, ферментов, медиаторов и т.д. С появлением моноклональных АТ в биологии и медицине связана современная эпоха исследований высокой 
точности. Их использование в повседневных исследованиях в клинической и лабораторной диагностиках сегодня стало уже рутинным методом. Первоначально для лечения использовались мышиные антитела, однако это приводило к реакциям гиперчувствительности, и как следствие, снижению эффективности. Для уменьшения чужеродности были разработаны химерные, гуманизированные («очеловеченные») и полностью человеческие антитела. Все названия моноклональных антител оканчиваются на корень -mab. Для обозначения источника мАТ к корню присоединяется субкорень: -отаb - мышь, ximab - химерные, zumab - гуманизировнные, -xizu- частично химерные и частично гуманизированные антитела, umab - полностью человеческие. Для определения цели лекарства определен субэлемент, предшествующий источнику антитела: - сі- для системы кровообращения, -li- для иммунной системы, -ne - для нервной системы и т.д. Если мАТ ПЭГилировано (присоединено к молекулам полиэтиленгликоля) для замедления его расщепления и снижения иммуногенности, добавляется слово пегол.

\section{Ингибиторы цитокинов (табл.114).}

Группа препаратов ингибиторов ФНО (Этанери̧епт, Инфликсимаб, Адалимумаб, Цертолизумаб, Голимумаб) образует устойчивый комплекс, как с растворимой, так и с мембранассоциированной формами человеческого ФНОальфа, снижая его функциональную активность. Понижает концентрацию (связывает и ингибирует синтез) ИЛ-1, ИЛ-6, ИЛ-8, моноцитарного хемоатрактантного белка-1, оксида азота, металлопротеиназ (коллагеназа, стромелизин), и других индукторов воспаления и тканевой деструкции, а также уровень растворимых форм молекул адгезии - ICAM-1 и Е-селектина, отражающих активацию сосудистого эндотелия.

Канакинумаб - человеческое моноклональное антитело интерлейкину- $1 \beta$. Канакинумаб связывается с человеческим ИЛ-1 $\beta$, конкурентно ингибируя активацию генов под действием интерлейкина- $1 \beta$ и продукцию медиаторов воспаления - интерлейкина-6 и ЦОГ-2.

Дупилумаб рекомбинантное человеческое моноклональное антитело (IgG4), которое блокирует передачу сигналов ИЛ-4 и ИЛ-13. Эти интерлейкины выступают в качестве основных факторов воспаления 2-го типа, активируя множественные типы клеток (тучные клетки, лимфоциты, эозинофилы, нейтрофилы, макрофаги) и индуцируя множественные медиаторы (иммуноглобулин Е, гистамин, лейкотриены, хемокины и цитокины, включая эотаксин/CCL11, TARC/CCL17 и ИЛ-5), участвующие в воспалении 2-го типа. Блокирование пути передачи сигналов ИЛ-4/ИЛ-13 у пациентов снижает концентрации многих из этих маркеров воспаления 2-го типа, включая иммуноглобулин Е, периостин и множественные провоспалительные цитокины 
и хемокины (например, эотаксин, TARC), предотвращает последующие действия этих цитокинов и хемокинов, в т.ч. гиперплазию бокаловидных клеток, гиперреактивность гладкомышечных клеток дыхательных путей, эозинофильное воспаление в легких, другие воспалительные процессы в легких.

Таблица 114.

\section{Ингибиторы цитокинов}

\begin{tabular}{|c|c|}
\hline Препарат & Мишень \\
\hline Этанерцепт & $\begin{array}{l}\text { Ингибирует биологическую активность ФНО, являясь конкурентным ингибитором } \\
\text { связывания ФНО с его рецепторами на поверхности клетки }\end{array}$ \\
\hline Инфликсимаб & 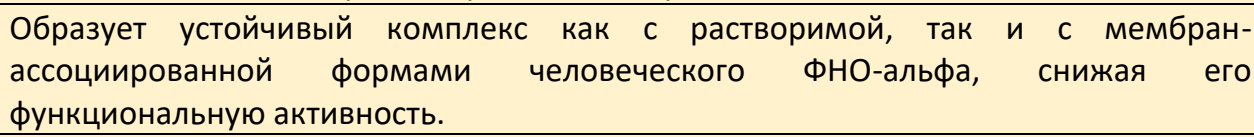 \\
\hline Адалимумаб & $\begin{array}{l}\text { Связываясь с ФНО, блокирует его взаимодействие с поверхностными клеточными } \\
\text { р55 и р75 рецепторами, и нейтрализует функции ФНО }\end{array}$ \\
\hline $\begin{array}{l}\text { Цертолизумаба } \\
\text { пэгол }\end{array}$ & $\begin{array}{l}\text { Нейтрализует связанный с мембраной и растворимый человеческий ФНО } \\
\text { дозозависимым способом. }\end{array}$ \\
\hline Голимумаб & $\begin{array}{l}\text { Образуют высокоаффинные стабильные комплексы антиген-антитело как с } \\
\text { растворимыми, так и с трансмембранными биоактивными формами ФНО- } \alpha \\
\text { человека, предотвращая связывание ФНО- } \alpha \text { с его рецепторами. }\end{array}$ \\
\hline Анакинра & Антагонист рецептора интерлейкина 1 \\
\hline Канакинумаб & $\begin{array}{l}\text { Связывается с человеческим ИЛ-Іß, нейтрализуя таким образом его биологическое } \\
\text { действие }\end{array}$ \\
\hline Даклизумаб & Антагонист рецепторов интерлейкина-2 (ИЛ-2). \\
\hline Базиликсимаб & $\begin{array}{l}\text { Специфически связывается и блокирует } \alpha \text {-субъединицу интерлейкин-2 (CD25) на } \\
\text { поверхности активированных Т-лимфоцитов. }\end{array}$ \\
\hline Дупилумаб & Блокирует передачу сигналов ИЛ-4 и ИЛ-13 \\
\hline Тоцилизумаб & Связывается и подавляет как растворимые, так и мембранные рецепторы ИЛ-6 \\
\hline Сарилумаб & $\begin{array}{l}\text { Специфически связывается как с растворимыми, так и с мембранными } \\
\text { рецепторами ИЛ-6(IL-6R } \alpha)\end{array}$ \\
\hline Левилимаб & Рекомбинантное человеческое моноклональное антитело к рецептору ИЛ-6 \\
\hline Олокизумаб & $\begin{array}{l}\text { Селективно связывается с человеческим ИЛ-6 не связывается в значительной } \\
\text { степени с другими молекулами семейства ИЛ-6 }\end{array}$ \\
\hline Устекинумаб & $\begin{array}{l}\text { Блокирует биологическую активность ИЛ-12 и ИЛ-23, предотвращая связывание р40 } \\
\text { с рецептором ИЛ-12R- } 31 \text {, экспрессируемым на поверхности иммунных клеток. }\end{array}$ \\
\hline Секукинумаб & Связывается и нейтрализует провоспалительный цитокин - ИЛ-17А. \\
\hline Иксекизумаб & Связывается с ИЛ-17А и подавляет его действие за счет нейтрализации активности. \\
\hline Гуселькумаб & Селективно связывается с белком ИЛ-23 \\
\hline Омализумаб & $\begin{array}{l}\text { Ингибирует связывание IgE с высокоаффинными рецепторами IgE (FcعRI), } \\
\text { расположенными на поверхности тучных клеток и базофилов. }\end{array}$ \\
\hline Экулизумаб & $\begin{array}{l}\text { Ингибирует расщепления компонента комплемента С5 до С5a и C5b, предотвращая } \\
\text { образование комплекса терминального комплемента C5b-9, что приводит к } \\
\text { блокированию комплемент-зависимого клеточного лизиса }\end{array}$ \\
\hline
\end{tabular}

Даклизумаб (гуманизированные моноклональные мышиные антитела) и Базиликсимаб (химерное моноклональное антитело против рецептора интерлейкина-2). Действуют как антагонисты рецепторов интерлейкина-2 путем связывания с альфа-цепочкой рецептора интерлейкина-2, который экспрессируется на поверхности активированных Т-лимфоцитов. В результате 
специфического связывания антитела с антигеном происходит угнетение активности Т-лимфоцитов, и вследствие этого угнетается иммунный ответ.

Тоцилизумаб и Олокизумаб (рекомбинантное гуманизированное моноклональное антитело к человеческому рецептору ИЛ-6), Сарилумаб $и$ Левилимаб (человеческое моноклональное антитело (IgG1) к рецептору ИЛ-6), связывают и подавляют как растворимые, так и мембранные рецепторы ИЛ-6 (sIL-6R и mIL-6R). ИЛ-6 является многофункциональным цитокином, вырабатываемым различными типами клеток, участвующих в паракринной регуляции, системных физиологических и патологических процессах, таких как стимуляция секреции Ig, активация Т-клеток, стимуляция выработки белков острой фазы в печени и стимуляция гемопоэза. ИЛ-6 вовлечен в патогенез различных заболеваний, в т.ч. воспалительных, остеопороза и новообразований. Показалали свою эффективность при COVID-19.

Устекинумаб полностью человеческое моноклональное антитело, которое блокирует биологическую активность ИЛ-12 и ИЛ-23, предотвращая связывание p40 с рецептором ИЛ-12R- $\beta 1$, экспрессируемым на поверхности иммунных клеток. ИЛ-12 и ИЛ-23 являются гетеродимерными цитокинами, которые секретируются активированными антигенпрезентирующими клетками, в частности макрофагами и дендритными клетками. ИЛ-12 активирует NK-клетки, стимулирует дифференциацию CD4+ Т-клеток до Т-хелперов 1 (Th1), а также усиливает выработку интерферона гамма. ИЛ-23 стимулирует образование Тхелперов 17 (Тh17) и увеличивает секрецию ИЛ-17А, ИЛ-21 и ИЛ-22.

Секукинумаб (полностью человеческое антитело) и иксекизумаб (гуманизированное моноклональное антитело к цитокину интерлейкин 17А. Связывают и нейтрализует провоспалительный цитокин - ИЛ-17А. Оказывает направленное действие на ИЛ-17 и ингибирование его взаимодействия с рецептором ИЛ-17, который экспрессируется разными типами клеток, включая кератиноциты и синовиоциты. В результате этого блоктруется высвобождение провоспалительных цитокинов, хемокинов и медиаторов повреждения тканей и снижает вклад ИЛ-17А в аутоиммунные и воспалительные заболевания. В клинически значимых концентрациях препаратов достигает кожи и снижает концентрацию местных воспалительных маркеров.

Гуселькумаб селективно связывается с белком ИЛ-23 с высокой специфичностью и аффинностью. ИЛ-23 - регуляторный цитокин, который влияет на дифференцировку, распространение и жизнеспособность субпопуляций Т-клеток (например, Th17 и Тс17) и незрелых субпопуляций иммунных клеток, являющихся источником эффекторных цитокинов, включая ИЛ-17А, ИЛ-17Е и ИЛ-22, способствующих развитию воспалительных заболеваний. В исследованиях у людей было показано, что селективная блокада ИЛ-23 нормализует выработку этих цитокинов. 


\section{Омализумаб (ксолар, генолар) является \\ гуманизированным} моноклональным антителом, полученным на основе рекомбинантной ДНК; селективно связывается с иммуноглобулином (IgE). Омализумаб представляет собой IgG1 каппа антитело, содержащее человеческую структурную основу с определяющими комплементарность участками мышиного антитела, связывающими IgE.

Омализумаб применяется при лечении персистирующей атопической бронхиальной астмы среднетяжелого и тяжелого течения, симптомы которой недостаточно контролируются применением ГКС, у пациентов 6 лет и старше; лечение хронической идиопатической крапивницы, резистентной к терапии блокаторами Н1-гистаминовых рецепторов, у пациентов 12 лет и старше. Имеются исследования по применению омализумаба при атопическом дерматите.

\section{Ингибиторы контрольных точек}

Вторая группа таргетных иммуноактивных препаратов направлена на рецепторы клеток иммунной системы. Некоторые из них описаны выше т.к. рецепторы к цитокинам блокируются за счет применения мАТ, селективно связывающиеся с рецепторами клеток иммунной системы, блокируя его действия. Особенно это важно при иммунотерапии рака (табл.115).

Таблица 115

\section{Ингибиторы контрольных точек}

\begin{tabular}{|l|l|}
\hline \multicolumn{1}{|c|}{ Препарат } & \multicolumn{1}{|c|}{ Мишень } \\
\hline Ипилимумаб & Связывается с CTLA-4 \\
\hline Ниволумаб & $\begin{array}{l}\text { Блокирует взаимодействие между рецептором PD-1 и его лигандами PD-L1 и PD- } \\
\text { L2 }\end{array}$ \\
\hline Пембролизумаб & Высокоаффинное антитело к PD-1 рецептору \\
\hline Дурвалумаб & Селективно блокирует взаимодействие PD-L1 с PD-1 или CD80 \\
\hline Авелумаб & $\begin{array}{l}\text { Авелумаб непосредственно связывается с PD-L1 и блокирует его } \\
\text { взаимодействие с рецепторами PD-1 и CD80 }\end{array}$ \\
\hline Атезолизумаб & $\begin{array}{l}\text { Непосредственно связывается c PD-L1 и блокирует его взаимодействие с } \\
\text { рецепторами PD-1 и CD80 }\end{array}$ \\
\hline
\end{tabular}

Терапия ингибиторами контрольных точек произвела революцию в онкологии. Терапия нацелена на иммунные контрольные точки, ключевые регуляторы иммунной системы, которые при стимуляции могут ослабить иммунный ответ на иммунологический стимул. Некоторые виды рака могут 
защитить себя от нападения, стимулируя иммунные контрольные точки. Терапия может блокировать тормозящие контрольные точки, восстанавливая функцию иммунной системы.

В настоящее время одобренные ингибиторы контрольных точек CTLA4, PD-1 и PD-L1. PD-1 является трансмембранным белком запрограммированной гибели клеток 1 (также называемым PDCD1 и CD279), который взаимодействует c PD-L1 (лиганд 1 PD-1 или CD274). PD-L1 на поверхности клетки связывается с PD1 на поверхности иммунных клеток, что подавляет активность иммунных клеток. Среди функций PD-L1 ключевая регулирующая роль в активности Tклеток. Опосредованная раком активация PD-L1 на поверхности клетки может ингибировать Т-клетки, которые в противном случае могли бы атаковать. Антитела, которые связываются либо с PD-1, либо с PD-L1 блокируют это взаимодействие, и позволяет Т-клеткам атаковать опухоль.

Ипилимумаб (Ервой). Рекомбинантное человеческое моноклональное антитело, связывается с цитотоксическим Т-лимфоцитассоциированным антигеном 4 (CTLA- 4). CTLA-4 является ключевым регулятором активации Tлимфоцитов. Ипилимумаб является ингибитором CTLA-4, блокирует тормозные сигналы каскада CTLA-4, увеличивая количество противоопухолевых Tхелперов, которые в свою очередь вызывают рост числа прямых Т-киллеров. Показано, что блокада CTLA-4 также уменьшает регуляторную функцию Тклеток, что может приводить к усилению иммунного противоопухолевого ответа. Ипилимумаб может селективно уменьшать количество Т-регуляторных клеток в области опухоли, приводя к росту отношения противоопухолевых Тхелперов к Т-регуляторам, что способствует гибели опухолевых клеток.

Ниволумаб (человеческое мАТ) и Пембролизумаб (гуманизированное мАТ) представляет собой высокоаффинное AT к PD-1 рецептору, при ингибировании которого осуществляется двойная блокада сигнального пути PD-1, включающего лиганды PD-L1 и PD-L2 на опухолевых или антигенпрезентирующих клетках. B результате ингибирования связывания рецептора $\mathrm{PD}-1$ с его лигандами пембролизумаб реактивирует опухоль-специфичные цитотоксические Тлимфоциты в микроокружении опухоли и, таким образом, реактивирует противоопухолевый иммунитет.

Дурвалумаб полностью человеческое, высокоаффиное мАТ (IgGlK), которое селективно блокирует взаимодействие PD-L1 с PD-1 или CD80 (B7.1), при этом не затрагивая взаимодействие между PD-1 и PD-L2. Селективная блокада взаимодействий между PD-L1 и

PD-1 и PD-L1 и CD80 приводит к усилению противоопухолевого иммунного ответа, который может привести к элиминации опухоли за счет восстановления цитотоксической активности Т-клеток, их пролиферации и выработки цитокинов. Такими же эффектами обладают Авелумаб (человеческий 
иммуноглобулин IgG1 мАТ против PDL1) и Атезолизумаб (гуманизированное мАТ против PD-L1).

K сожалению, ингибиторами контрольных точек могут быть вызваны иммунологические побочные эффекты для большинства систем и органов организма. Чаще всего возникают осложнения в желудочно-кишечном тракте, эндокринных железах, легких на коже, и в печени, реже поражаются ЦНС, костно-мышечная и сердечно-сосудистая системы органы кроветворения.

\section{Препараты с цитотоксическим действием}

В отличие от ингибиторов контрольных точек, группа мАТ к различным клеточным рецепторам вызывают гибель этих клеток, что позволило их рассматривать как противоопухолевые средства. В некоторых случаях эти препараты применяются при тяжелых аутоиммунных и аутовоспалительных заболеваниях и аллергиях (табл.116).

Таблица 116

\section{Таргетные препараты с цитотоксическим действием}

\begin{tabular}{|c|c|}
\hline Препарат & Мишень \\
\hline Катумаксомаб & Против молекул адгезии клеток эпителия (ЕрСАМ) и CD3-антигена \\
\hline Ритуксимаб & $\begin{array}{l}\text { Обладающие специфичностью к CD20 антигену, обнаруживаемому на } \\
\text { поверхности нормальных и малигнизированных В-лимфоцитов }\end{array}$ \\
\hline Офатумумаб & $\begin{array}{l}\text { Связывается с эпитопом, включающим малую и большую внеклеточные петли } \\
\text { молекулы CD20 }\end{array}$ \\
\hline Обинутузумаб & $\begin{array}{l}\text { Избирательно взаимодействует с внеклеточным участком трансмембранного } \\
\text { антигена CD20 }\end{array}$ \\
\hline $\begin{array}{l}\text { Инотузумаб } \\
\text { озогамицин }\end{array}$ & Обладает специфичностью к CD22 \\
\hline Абатацепт & $\begin{array}{l}\text { Модулирует ключевой ко-стимулирующий сигнал, необходимый для полной } \\
\text { активации Т-лимфоцитов, CD28 }\end{array}$ \\
\hline $\begin{array}{l}\text { Брентуксимаб } \\
\text { ведотин }\end{array}$ & Экспрессирующим антиген CD30 клетки \\
\hline Изатуксимаб & Связывается с внеклеточным эпитопом CD 38 \\
\hline Даратумумаб & Связывается с белком CD38 \\
\hline Алемтузумаб & $\begin{array}{l}\text { Вызывает лизис лимфоцитов за счет взаимодействия с антигеном CD52, который } \\
\text { не подвержен модуляции и экспрессируется на поверхности всех В- и Т- } \\
\text { лимфоцитов, а также моноцитов, тимоцитов и макрофагов. }\end{array}$ \\
\hline Белимумаб & $\begin{array}{l}\text { Специфически связывается с растворимым BLyS Стимулятор В-лимфоцитов } \\
\text { (BLyS, также известен как BAFF и TNFSF13) }\end{array}$ \\
\hline Цетуксимаб & Связывается с рецепторами эпидермального фактора роста \\
\hline Натализумаб & $\begin{array}{l}\text { Селективный ингибитор молекул адгезии ( } \alpha 4 \text {-субъединица человеческого } \\
\text { интегрина), экспрессирующих на поверхности всех лейкоцитов, за исключением } \\
\text { нейтрофилов }\end{array}$ \\
\hline Ведолизумаб & 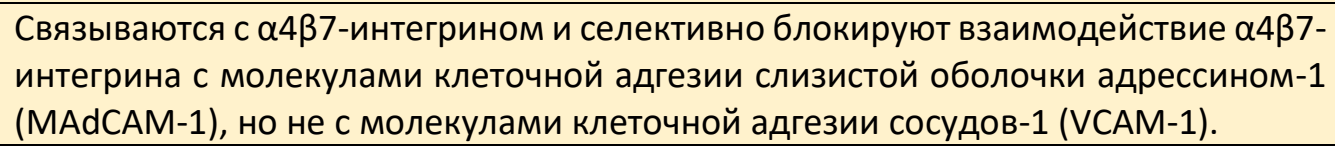 \\
\hline
\end{tabular}


Механизм действия этих препаратов связан со специфической связью моноклонального антитела с определенным эпитопом и запуском механизмов ведущие к гибели «помеченных» клеток. Это может быть антителозависимая клеточно-опосредованная цитотоксичность, антителозависимый клеточный фагоцитоз, комплементзависимая цитотоксичность. Кроме этого, гибель клетки может быть за счет индукции программируемой клеточной гибели посредством Fc-независимого механизма. Так же моноклональное антитело может блокировать определенный рецептор на клетке, что приводит к прерыванию внутриклеточных сигнальных цепей, блокаде биоактивных молекул, важных для реализации злокачественного фенотипа, индукции идиотипантиидиотипического ответа.

В настоящее время эти препараты широко используются в клинической практике. Сегодня трудно назвать в онкологии область, в которой не применялись бы моноклональные антитела с цитотоксическим действием. За счет их применения достигнуты успехи при лечении рака молочной железы, легких и лимфомах.

В иммунологии эта группа препаратов представлена моноклональными антитела против клеток иммунной системы, непосредственно участвующих в формирования того или иного заболевания, прежде всего, аутоиммунной патологии.

Ритуксимаб химерные моноклональные антитела мыши/человека. Разрушает как нормальные, так и злокачественные В-клетки, имеющие на своей поверхности CD20, и поэтому используется для лечения заболеваний, которые характеризуются наличием слишком большого количества В-клеток, сверхактивных В-клеток или дисфункциональных В-клеток. Используется для лечения лейкемии и лимфомы, включая неходжкинскую лимфому, хронический лимфолейкоз и лимфому с преобладанием лимфоцитов подтипа лимфомы Ходжкина в т.ч. макроглобулинемию Вальденстрема. Является эффективным средством лечения ревматоидного артрита. Применение ритуксимаба (2x1000 мг) в сочетании с метотрексатом является эффективным методом лечения пациентов с РА, приводящее к устойчивому улучшению рентгенографических, клинических и функциональных результатов в течение 2- х лет

Офатумумаб - представляет собой человеческое моноклональное антитело, специфически связывающееся с эпитопом, включаещий и малую, и большую внеклеточные петли молекулы CD20 и приводит к В-клеточному лизису. Применяется для лечения пациентов с хроническим лимфоцитарным лейкозом при неэффективности ранее проводимой терапии. Не вызывает иммуногенности. Один курс двух инфузий по 700 мг является эффективным и безопасным у пациентов с активным рематоидным артритом на фоне метотрексата. 
Окрелизумаб - рекомбинантное гуманизированное анти-CD20 моноклональное антитело. Применяется при первично-прогрессирующем и рецидивирующем рассеянном склерозе, однако точный механизм действия, за счет которого достигается клинический эффект полностью не установлен. При ревматоидном артрите и системной красной волчанке исследования на III фазы показали повышенную смертности от оппортунистических инфекций. При рассеянном склерозе такие результаты не наблюдались.

Белимумаб человеческие рекомбинантные моноклональные антитела, направленные против фактора В-клеточной активации (BAFF). За счет блокады BAFF угнетается жизнеспособность В-лимфоцитов, в т.ч. аутореактивных, снижается дифференцировка В-лимфоцитов в плазматические клетки, вырабатывающие Ig. Белимумаб значительно снижал количество циркулирующих В-лимфоцитов, наивных и активных форм, плазматических клеток и субпопуляции волчаночных В-лимфоцитов. Белирумаб может блокировать секрецию INFy и IL-2, это приводит к снижению патологии, связанной с СКВ

Aбатаџ̧еnт представляет собой генетический рекомбинантный растворимый белок, CTLA4 специфически связываясь с CD80 и CD86, ингибируя активацию Т-лимфоцитов (см. главу 4).

\section{Таргетные препараты, действующие на сигнальные молекулы}

На различные сигнальные пути клеток иммунной системы избирательно действуют малые молекулы, которые оказывают иммунодепрессивное и противовоспалительное действие (табл.117).

Таблица 117

Таргетные препараты действующие на сигнальные молекулы

\begin{tabular}{|l|l|}
\hline \multicolumn{1}{|c|}{ Препарат } & \multicolumn{1}{|c|}{ Мишень } \\
\hline Апремиласт & Ингибитор фосфодиэстеразы-4 \\
\hline Элотузумаб & $\begin{array}{l}\text { Связывается с белком SLAMF7 (представитель в семействе сигнальных молекул } \\
\text { активации лимфоцитов). }\end{array}$ \\
\hline Руксолитиниб & Селективный ингибитором Янус-киназ (JAK1 и JAK2). \\
\hline Тофацитиниб & Селективный ингибитор семейства янус киназ \\
\hline Барицитиниб & Селективным и обратимым ингибитором Янус-киназы 1 и 2 (JAK1, 2) \\
\hline Упадацитиниб & Селективный обратимый ингибитор JAK1 \\
\hline Эверолимус & Ингибитор пролиферативного сигнала \\
\hline
\end{tabular}

Aпремиласт - Ингибитор фосфодиэстеразы-4. При угнетении этого фермента возрастает количество цАМФ, что, в свою очередь, ведет к подавлению воспалительной реакции за счет модуляции экспрессии ФНО- $\alpha$, ИЛ23, ИЛ-17 и других воспалительных цитокинов (угнетение) со стимуляцией синтеза некоторых противовоспалительных цитокинов, в т.ч. ИЛ-10. Это нашло 
применение при лечении бляшечного псориаза средней и тяжелой степени, при псориатическом артрите, у пациентов, которым показана фототерапия или системная терапия.

Элотузумаб - блокирует SLAMF7 (член семейства рецепторов SLAM активирующие клеточный иммунный ответов, регулятор функции NK-клеток, фактор опосредованного макрофагами фагоцитоза опухолевых клеток) который в большом количестве экспрессируется на миеломных клетках (CD319) независимо от типа цитогенетических аномалий также экспрессируется на натуральных киллерах, нормальных плазматических клетках, на некоторых Тклетках, моноцитах, B-клетках и дендритных клетках. SLAMF7 не обнаруживается на клетках здоровых тканей и гемопоэтических стволовых клетках. Элотузумаб в комбинации с леналидомидом и дексаметазоном показан для лечения пациентов с множественной миеломой, получивших один или несколько предшествующих циклов терапии.

Ингибиторы Янус-киназы (якинибы). Группа лекарств, которые действуют путем ингибирования активности одного или нескольких ферментов семейства Янус-киназ (JAK1, JAK2, JAK3, TYK2), тем самым препятствуя JAK-STAT сигнального пути. Большинство цитокинов включая интерлейкины, интерфероны и колониестимулирующий фактор, и гормонов (эритропоэтин, пролактин и гормон роста) используют этот путь для передачи сигнала. Препараты, которые ингибируют активность этих киназ, блокируют передачу сигналов цитокинов.

Руксолитиниб ингибитор JAK1/JAK2, для лечения миелофиброза (среднего или высокого риска) и истинной полицитемии у пациентов с неадекватным ответом или непереносимость гидроксимочевины.

Тофаџитиниб блокирует ЈАК 3, применяется при псориазе и ревматоидном артрите (умеренно или очень активным) у пациентов с неадекватным ответом или непереносимостью метотрексата.

Барицитиниб блокирует JAK1/JAK2 применяется при ревматоидном артрите.

Упадацитиниб ингибирует ЈАК1 применяется при ревматоидном артрите.

\section{Клеточно-тканевая терапия}

Клеточно-тканевая терапия - профилактика или лечение болезней

человека путем введения живых клеток и/или ткани, которые были отобраны, размножены и обработаны или изменены вне организма. Цель такой терапии - заместить, восстановить или улучшить функцию поврежденной ткани или органа.

В настоящее время в медицине необходимо выделить несколько направлений по развитию клеточно-тканевой терапии (рис. 181). 


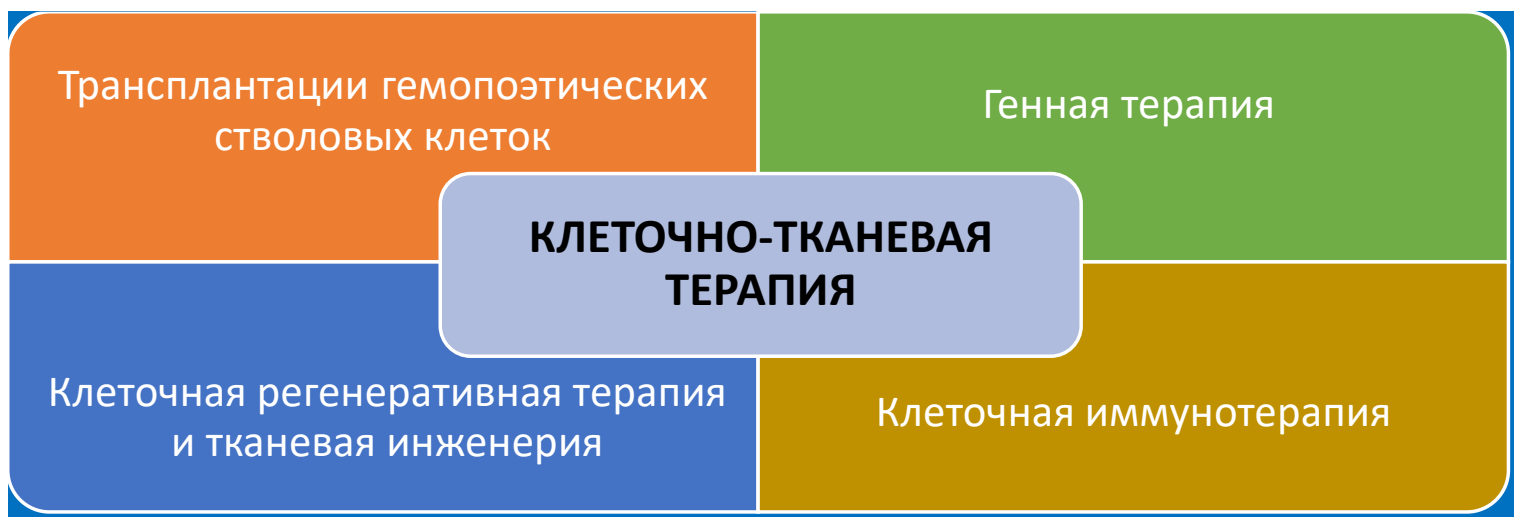

Рис. 181. Разновидности клеточно-тканевой терапии.

Трансплантация гемопоэтических стволовых клеток.

Первыми трансплантировать клетки человеку, не осознавая этого, уже давно начали трансфузиологи. При переливании крови в организм реципиента попадает небольшое количество содержащихся в крови донора стволовых клеток (CK). Недавно было показано, что эти клетки внедряются в ткани реципиента и дифференцируются. Как кровь, так и костный мозг содержат СК, дающие начало всем клеткам крови. Из донорских СК образуются нормальные, не пораженные раком лейкоциты и лимфоциты, что улучшает состояние пациента. Но наиболее эффективным является трансплантация гемопоэтических стволовых клеток (ранее называющееся пересадкой костного мозга).

Трансплантация гемопоэтических стволовых клеток - это медицинская технология, при которой производится перенос здоровых мультипотентных кроветворных стволовых клеток, полученных из костного мозга, периферической крови или пуповинной крови донора реципиенту. Донор и реципиент могут быть одним и тем же человеком (аутологичный трансплантат) или двумя разными людьми (аллогенный трансплантат).

\section{Клеточная регенеративная терапия}

Этот раздел медицины занимается лечением различных заболеваний путем восстановления пораженных органов и тканей с помощью трансплантации клеток (клеточная терапии) и/или путем стимуляции эндогенных стволовых клеток.

Фундаментальные основы развития данного направления положили наши отечественные ученые А.А. Максимов и А.Я. Фриденштейн (рис.182).

В настоящее время к клеточным технологиям относят всю совокупность методов и практик всех этапов работы с клетками: технологии получения исходного биоматериала, всей работы in vitro и собственно клеточной терапии: заместительной и восстановительной, прямой и непрямой. Стволовые клетки являются самым важным объектом исследований и ключевым субстратом клеточных технологий - и клеточной терапии в первую очередь. Однако существует и другие подходы лечения разных заболеваний, основанных на применении иных типов клеток, не являющихся стволовыми. Описано 


\section{ИММУНОТЕРАПИЯ}

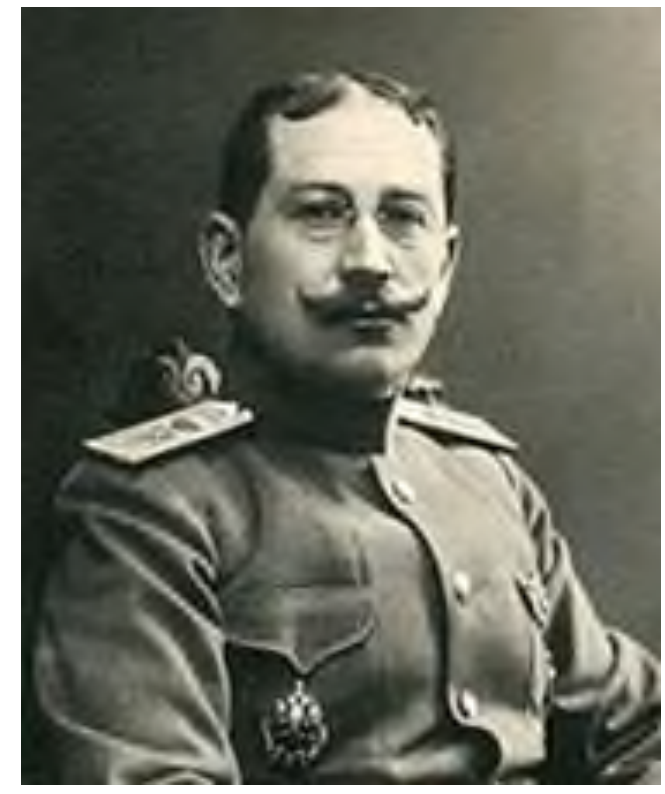

Александр Александрович Максимов (3 февраля 1874 - 4 декабря 1928) обосновал теории кроветворения, ввёл понятие стволовые клетки.

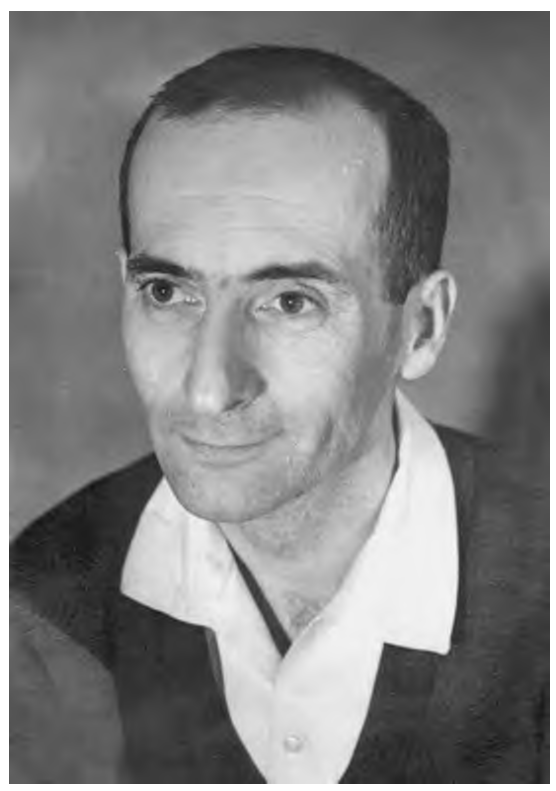

Александр Яковлевич Фриденштейн (24 июня 1924 - 31 августа 1997) впервые описал мультипотентные мезенхимальные стволовые клетки

\section{Рис. 182. Основатели регенеративной медицины}

применение клеточной терапии для регенерации практически всех типов тканей. В зависимости от типа ткани и патологии значительно отличаются уровни разработки клеточных продуктов. Это связано, с одной стороны, с методологическими особенностями производства и применения клеточных продуктов, с другой - с особенностями дифференцировки типов клеток, использующихся в регенеративной медицине, прежде всего мезенхимальных стволовых клеток (МСК).

\section{Генная терапия}

Под генной терапией подразумевается совокупность молекулярногенетических и медицинских методов, направленных на внесение изменений в генетический аппарат клеток человека в целях лечения заболеваний.

Концепция генной терапии заключается в устранении генетической проблемы в ее источнике. Если, например, при наследственном заболевании (обычно рецессивном) мутация в определенном гене приводит к выработке дисфункционального белка, можно использовать генную терапию для доставки копии этого гена, не содержащей вредной мутации, и тем самым производит функциональный белок. Эта стратегия называется генной заместительной терапией.

В настоящее время наиболее распространёнными методами геномного редактирования являются нуклеазы цинковых пальцев (ZFNs), эффекторные 
нуклеазы, подобные активаторам транскрипции (TALENs), и система CRISPR/Cas9.

К сожалению, в клинической практике эти методы лечения недоступны.

\section{Клеточная иммунотерапия}

Использование живых клеток в качестве «лекарства» представляет собой отход от традиционного взгляда на «лекарство» как на небольшую молекулу или антитело, выполняющее единственную функцию. Клетки - это динамические живые агенты, которые в отличие от обычных лекарств могут интегрировать ряд входных сигналов, реагировать на изменения в окружающей среде, взаимодействовать с другими клетками и посредством сложных сигнальных путей вызывают спектр ответов. В дополнение к этому клеточные препараты могут сохраняться в организме от месяцев до лет, тогда как большинство обычных лекарств метаболизируются и выводятся из организма вскоре после приема, добавляя еще одну проблему к сложности взаимодействия между пациентом и лекарством. 


\section{Глава 19. \\ Иммунореабилитация больных, перенесших инфекции}

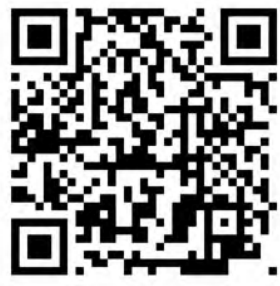

Иммунореабилитация - комплекс медицинских, мероприятий, направленных на максимально возможное восстановление или компенсацию нарушенных или полностью утраченных, в результате болезни нормальных физиологических функций иммунной системы.

Современные достижения иммунологии и других смежных специальностей позволяют врачу оказать реальную и долговременную помощь больным с иммунными нарушениями. Однако назначение только иммуноактивных средств не всегда приводит к положительным результатам, так как стандартное лечение проводится без учета всех патогенетических факторов развития болезни. Поэтому при коррекции иммунных нарушений в период иммунореабилитации необходимо проводить комплексную терапию и решать следующие задачи, а именно:

- удалить, если это возможно, причины иммунных нарушений всеми возможными способами (протозойные и глистные инвазии, хронические и бактериальные и вирусные инфекции), избегать неблагоприятные факторы внешней среды (переохлаждение, перегревание, тяжелые физические нагрузки), интоксикации (ограничить прием алкоголя), обеспечить полноценное питание, скорректировать имеющиеся гормональные нарушения и стресс.

- применить средства, влияющие на метаболизм клетки и клеточное окружение, в том числе все необходимые виды детоксикации.

- провести иммуноактивную терапию, в том числе в особо тяжелых случаях необходимо рассматривать вопрос о заместительной терапии.

\section{Устранение причины иммунных нарушений}

Выявив и устранив причину иммунных нарушений, возможно практически полностью решить проблемы, связанные с иммуноопосредованной патологией. Общепризнанными мероприятиями по улучшению функции иммунитета является сбалансированное питание, полноценный сон и режим отдыха, двигательная активность, ограничение стресса. Неотъемлемой частью этих мероприятий является санация хронических инфекции, в том числе с удалением любых образований на коже и слизистых. 


\section{Сбалансированное полноценное здоровое питание}

Для иммунитета важно поступление пища, которое поддерживает функции иммунных клеток, позволяя им инициировать эффективные ответы против патогенов, а также быстро разрешать ответ при необходимости и избегать какого-либо хронического воспаления. Потребности иммунной системы в энергии и питательных веществах могут быть удовлетворены из внешних источников, например, из рациона или, если пищевые источники неадекватны, из эндогенных источников, таких как запасы глюкозы и жира. Точный состав разнообразного, сбалансированного и здорового питания зависит от индивидуальных особенностей (таких как возраст, пол, образ жизни и степень физической активности), культурного контекста, имеющихся местных продуктов и обычаев в области питания. Однако основные принципы здорового питания остаются одинаковыми.

Диета, положительно влияющая на функцию иммунитета должна, содержать достаточное количество белка, в частности, глютамина, аргинина и аминокислот с разветвленной цепью, высокое содержание омега-3 жирных кислот и низкое содержание насыщенных, трансжиров и омега-6 жирных кислот, низкое содержание рафинированного сахара, высокое содержание клетчатки, например, цельного зерна, и микроэлементов, включая витамин $\mathrm{A}$, витамин $\mathrm{D}$, витамин С, витамин Е, витамины группы В, цинк, селен и железо, а также полифенолы и каротинойды. С позиций влияния на функцию иммунитета пищевые продукты и компоненты получили так называемый - диетический воспалительный индекс (DII). Основные противовоспалительные продукты необходимые для ежедневного применения представлены на рисунке (рис.122).

Пищу готовят, в основном, в измельченном и протертом виде, варят в воде, на пару, запекают. Очень горячие и холодные блюда исключаются. Использование интервального голодание (в течение суток: прием пищи - 6 часов, полный отказ от пищи - 18 часов) позволяет активировать процессы аутофагии и тем самым предотвращать хроническое системное воспаление.

Некоторые микроэлементы играют ключевую роль в иммунной системе. Это некоторые аминокислоты (глютамин, аргенин, лизин), витамины C, D, A, E, В6, В12, фолиевая кислота, цинк, железо, медь, селен, магний. Они поддерживают структурную и функциональную целостность клеток слизистой оболочки врожденных барьеров, обеспечивают синтез антимикробных факторов и антител, участвуют в дифференциации, пролиферации, функционировании и миграции клеток врожденного и адаптивного иммунитета, распознавании антигена, играют важную роль в воспалении, антиоксидантных эффектах и эффектах окислительного взрыва. 
Например, глютамин является незаменимой аминокислотой, которая обеспечивает важный источник энергии для многих типов клеток, включая клетки, участвующие в иммунных реакциях. Он также служит предшественником синтеза нуклеотидов, особенно актуален для быстро делящихся клеток, таких как иммунные клетки, во время иммунного ответа. Аминокислота аргинин необходима для генерации оксида азота макрофагами, а микроэлементы, витамин А и цинк регулируют деление клеток и поэтому необходимы для успешного пролиферативного ответа в иммунной системе. С другой стороны, аргинин стимулирует рост опухолевых клеток и репликацию вируса. В противовес ему лизин блокирует репликацию вируса и рост опухолевых клеток. Используя соотношения лизин/аргенин необходимо потребление продуктов с повышенным содержанием лизина.

Селен является микроэлементом, который, как и цинк, играет важную роль в ряде белков. Витамина Е играет роль антиоксиданта, ингибитора активности протеинкиназы $\mathrm{C}$ и потенциально взаимодействует с ферментами и транспортными белками.

Важным является пища для питания и формирования микробиоты. Пребиотики, неперевариваемые олигосахариды (фруктоолигосахариды и галактоолигосахариды) избирательно используются микроорганизмами человека, поддерживают нормальную микрофлору.

При лечении аллергических заболеваний высокоэффективна и обязательна элиминация или ограничение воздействия аллергена, вплоть до переезда больного в другую местность. Соблюдение гипоаллергенной диеты с исключением продуктов, вызывающих аллергию.

Применять гипоаллергенную диету необходимо при всех видах аллергии. На первом этапе надо исключить из своего рациона высокоаллергенные и средеаллергенные продукты. Такую диету надо соблюдать взрослым 2-3 недели, детям младшего возраста обычно бывает достаточно 7-10 дней. Если в течение этого времени наступает улучшение, то исключенные продукты вновь вводят в рацион: по одному, начиная с небольших количеств, не чаще чем через 3 дня, и внимательно наблюдают, не возобновились ли аллергические реакции. Если в течение 3 дней после введения нового продукта симптомы аллергии возобновились, значит, этот продукт и является вашим аллергеном.

На основании проведенного анализа литературных данных предлагается нами диета, обладающая в основном противовоспалительным действием (табл. 118). 


\section{Таблица 118}

\section{Противовоспалительная диета}

\begin{tabular}{|c|c|}
\hline Исключить: & Рекомендовано: \\
\hline $\begin{array}{l}\text { Сахар, маргарины, кондитерский жир. Соль } \\
\text { Кондитерские изделия. Торты с масляным } \\
\text { кремом, чипсы, картофель-фри. } \\
\text { Любые жареные блюда. } \\
\text { Хлебобулочные изделия, вафли, печенье. } \\
\text { Шоколад и шоколадные конфеты на основе } \\
\text { масло-какао. }\end{array}$ & $\begin{array}{l}\text { Продукты, богатые хролофиллом (все, что имеет зеленый } \\
\text { цвет) с высоким уровнем пищевых волокон } \\
\text { Капуста. Гречка, семена чиа. Овес, чечевица, фасоль, горох, } \\
\text { нут (одна чашка, два раза в неделю). Миндаль, кедровые и } \\
\text { другие орехи. Лук, чеснок. } \\
\text { Чистый темный шоколад без сахара (какао 70-95\% и выше). }\end{array}$ \\
\hline $\begin{array}{l}\text { Любой хлеб, ржаной хлеб, слоеное и сдобное } \\
\text { тесто, пирожки, торты, бисквит, печенье } \\
\text { вчерашний выпечки, сухари, сухой бисквит. }\end{array}$ & Хлеб и сахар исключен. \\
\hline $\begin{array}{l}\text { Жирные сорта мяса (свинина, баранина, утка, } \\
\text { гусь), печень, почки, мозги, свиной, бараний, } \\
\text { говяжий жир, рыба соленая. } \\
\text { Жирные мясные бульоны. } \\
\text { Копчености в любом виде, колбасы, ветчина, } \\
\text { бекон, мясные консервы и соусы на мясной } \\
\text { основе и пр. }\end{array}$ & $\begin{array}{l}\text { Нежирные сорта мяса - говядина, кролик, язык говяжий. } \\
\text { Свиное сало соленое (20-30 грамм в день). } \\
\text { Птица - курица, индейка. } \\
\text { Рыба - жирные сорта рыбы (лосось, скумбрия муксун, чир, } \\
\text { белуга, кета, осетрина, севрюга, нельма). } \\
\text { Куриный бульон рыбные и грибные бульоны. }\end{array}$ \\
\hline $\begin{array}{l}\text { Рафинированное растительное масло } \\
\text { (пальмовое, подсолнечное, кукурузное, соевое, } \\
\text { масло из косточек винограда). }\end{array}$ & $\begin{array}{l}\text { Льняное, рапсовое, оливковое масло одна-две столовые } \\
\text { ложки в день (Extra Virgin нерафинированное в темной } \\
\text { бутылки с печатью DOP, срок годности не прошел половины). }\end{array}$ \\
\hline $\begin{array}{l}\text { Жирный творог, соленый и острый сыр, } \\
\text { мороженое, сливочное масло. }\end{array}$ & Кефир. \\
\hline $\begin{array}{l}\text { Очищенные злаки (пшеница, овес, ячмень, } \\
\text { рожь, пшено, кукуруза, рис (включая дикий), } \\
\text { гречневая крупа. }\end{array}$ & $\begin{array}{l}\text { Семена чиа. Цельнозерновые продукты овес, рис (бурый или } \\
\text { коричневый рис), полба, ячмень (перловая крупа), просо, } \\
\text { гречиха. Цельнозерновые макаронные изделия, овсяные, } \\
\text { ячменные хлопья, каши и прочие блюда из неочищенных } \\
\text { круп. }\end{array}$ \\
\hline Баклажаны, помидоры, перец, картофель. & $\begin{array}{l}\text { Капуста в т.ч. квашеная, брокколи, брюссельская капуста, } \\
\text { морковь, тыква, кабачки, свекла, артишок, шпинат, огурцы, } \\
\text { лук, чеснок, листовая зелень, горчица. }\end{array}$ \\
\hline \multirow[t]{3}{*}{$\begin{array}{l}\text { Сахара, мед, варенье, джемы из спелых и } \\
\text { сладких фруктов и ягод, мармелад, пастила, } \\
\text { зефир, фруктовые и ягодные соусы. }\end{array}$} & $\begin{array}{l}\text { Груши, яблоки, авокадо, мандарин, апельсин, гранат, } \\
\text { грейпфрут. } \\
\text { Косточковые (абрикосы, персики, слива, вишня). Сухофрукты } \\
\text { - чернослив, курага, инжир, изюм. }\end{array}$ \\
\hline & $\begin{array}{l}\text { Черника, брусника, клюква, малина, смородина, клубника, } \\
\text { ежевика. }\end{array}$ \\
\hline & Миндаль, грецкие, кедровые орехи, фисташки \\
\hline Газированные напитки, сладкие напитки, соки & Зеленый, черный чай. Кофе (не более 2 чашек в день) \\
\hline $\begin{array}{l}\text { Алкогольные напитки более } 20 \text { доз (пива не } \\
\text { более } 13 \text { доз) в неделю, не более } 5 \text { доз за } 1 \text { раз. }\end{array}$ & $\begin{array}{l}1 \text { доза: вино - 150мл, } \\
\text { крепкие напитки - } 45 \mathrm{мл,} \\
\text { пиво - } 355 \text { мл. }\end{array}$ \\
\hline
\end{tabular}

\section{Полноценный сон вторая составляющая формирования «хорошего»} иммунитета. Сон - это естественное повторяющееся состояние организма, характеризующееся измененным сознанием, с подавлением сенсорной и мышечной активности. Внутренние циркадные часы способствуют ежедневному сну ночью. Во время сна большинство систем организма находятся в анаболическом состоянии, способствующем восстановлению иммунной, нервной, скелетной и мышечной систем. 
Сон регулируется гомеостатически, что означает, что продолжительность и интенсивность сна увеличивается после длительного периода без сна. В дополнение к этому гомеостатическому компоненту, второй процесс, который не зависит от предшествующего бодрствования, модулирует время сна, а именно циркадную систему. Эта система отвечает за наложение и синхронизацию ритма, близкого к 24-часовому, для некоторых типов поведения и функций организма, включая склонность ко сну или бодрствованию в течение 24-часового цикла сна и бодрствования.

Учитывая циркадные ритмы организма лучше всего ложиться спать до 23 часов. Для быстрого засыпания поможет прогулка перед сном на свежем воздухе, расслабление, теплая ванна или душ, негромкая спокойная музыка, звуки природы, колыбельные и т.п.. В спальном помещении должно быть темно. Спать лучше в минимальном количестве одежды идеально обнаженным, при необходимости используя дополнительное одеяло. Спальное место должно быть ровным, не слишком мягким и не слишком жестким. После пробуждения нужно не спеша потянуться и встать.

Помимо сна необходимо чередовать пассивный отдых и физические нагрузки. Любые аэробные упражнения (физического упражнения низкой или умеренной интенсивности выполняемые длительное время - ходьба или походы (10000 шагов), бег трусцой, плавание, коньки, лыжи, танцы, баскетбол, теннис и пр.) способствуют выработки эндорфинов так же как и смех, секс, прослушивание музыки и употребление «вкусной» пищи. Эндорфины способствуют ликвидации тревожности и депрессии. Таким же действием обладает дофамин, который в больших количествах вырабатывается во время положительного, по представлению человека, действию (например: секс, приём вкусной пищи, приятные телесные ощущения) и противостоит стрессу.

Первым и очень важным звеном «подготовки» к лечению пациентов с нарушениями функции иммунной системы является улучшение состояния межклеточного взаимодействия. Во многих случаях без этого этапа в лечении реакция на иммуномодулирующую терапию может быть неадекватной или даже парадоксальной. Под действием токсинов, микробных супрессорных белков, длительного избыточного воздействия АГ, оксидантов, провоспалительных цитокинов и других факторов меняются свойства мембран клеток иммунной и сопряженной с ними систем, блокируются рецепторы мембран. После длительной активации тех или иных клеток наступает фаза их супрессии или гипореактивности. Для предотвращения этих процессов используется детоксикационная терапия, средства для улучшения реологии крови.

Детоксикация - это комплекс лечебных мероприятий, проводимых с целью прекращения воздействия токсичных веществ и их последующего удаления из 
организма. Достижению этой цели служит большое число методов, направленных на стимуляцию естественной детоксикации, а также проведение искусственной и антидотной дезинтоксикационной терапии. В клинике нашло широкое применение внутривенные введения растворов, в том числе с использованием межклеточных детоксикантов и гастроинтестинальная энтеросорбция (см. выше).

Большое значение в реабилитации больного с наличием иммунных нарушений имеет нормализация и/или стимуляция работы клетки. Широкое применение имеют комплексные препараты, влияющие на энергетический обмен, пластические процессы, улучшающие утилизацию.

Актуальность проблемы восстановления иммунологических нарушений с помощью иммунокорригирующих препаратов в настоящее время несомненна и не требует обоснования. Однако при всей очевидности использование иммунотропных средств в комплексном лечении больных представляет собой сложную задачу и в настоящее время разработано недостаточно. При иммунореабилитации больных, перенесших тяжелые инфекции, назначение того или иного препарата обосновано в зависимости от наличия иммунных нарушений и имеющиейся клинической целесообразности. С этой целью применяется система этапной иммунореабилитации больных, перенесших инфекционные болезни. Он подразумевает несколько этапов.

1 этап, отбор пациентов для иммунореабилитации с проведением при необходимости противовоспалительной терапии.

2 этап. Проведение диагностики иммунных нарушений с последующей иммунотерапией.

3 этап. Проведение таргетной иммунотерапии с учетом топической диагностики иммунных нарушений.

\section{1 этап. Система отбора для иммунореабилитации с проведением при} необходимости противовоспалительной терапии.

На первом этапе проводится отбор пациентов, с признаками иммунных нарушений. Для диагностики иммунных нарушений используются все методы и приемы, применяемые в клинике внутренних болезней (опрос больного, анализ анамнестических данных, объективный осмотр, лабораторные и инструментальные методы исследования). Как итог диагностики, формируется иммунологический диагноз. В зависимости от диагноза определяется необходимая терапия.

Ведущими признаками для иммунореабилитации пациентов будут: усталость, потеря трудоспособности, лихорадка, одышка или затрудненное дыхание, кашель, боли в суставах мышцах или головная боль, учащенное сердцебиение, когнитивные нарушения, в т.ч. потеря обоняния и/или вкуса, проблемы с памятью, концентрацией или сном, депрессия или тревога. При 


\section{ИММУНОТЕРАПИЯ}

осмотре выявлена: гепато- и/или спленомегалия, увеличение лимфатических узлов, тахикардия, одышка, повышение температуры. При анализе лабораторных данных ведущим является развернутый анализ крови (см. выше). Определение типа реакции иммунитета в виде активации врожденного иммунитета, угнетения иммунитета или характера реакции в виде недостаточной активации лимфопоэза, ассиметричной стимуляции лейкопоэза, декомпенсированного лейкопоэза требуют проведения иммунореабилитационных мероприятий.

Суммарно система отбора для проведения иммунореабилитации представлена на рисунке (рис. 183).

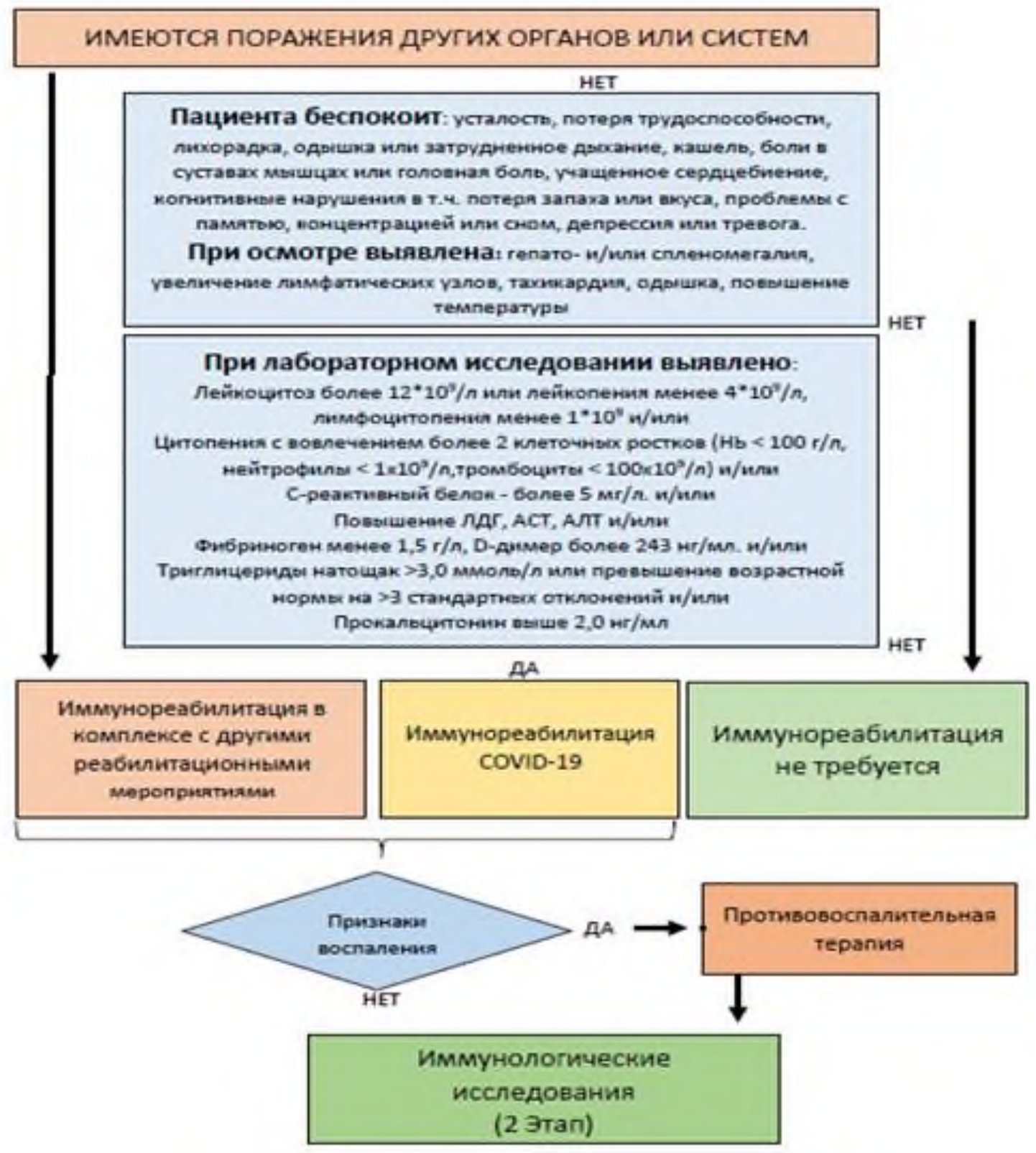

Рис. 183. Отбор пациентов, переболевших COVID-19, для последующей иммунореабилитации (1 этап). 


\section{Проведение противовоспалительной терапии.}

При наличии остаточных явлений системного воспаления проводится детоксикационная и противовоспалительная терапия.

В качестве детоксикационной терапии рекомендуется внутривенные инфузии (см.выше).

Противовоспалительная терапия подразумевает применения нестероидных противоспалительных средств, антигистаминных препаратов, средств, угнетающих активность нейтрофилов - колхицин, галавит, как препарат, нормализующий работу макрофагов (см. выше).

Bce препараты применяются согласно инструкциям. Обычный курс лечения составляет до 10 дней. После чего необходимо оценить эффект лечения. При отсутствии эффекта рекомендуется применение глюкокортикостероидов коротким курсом.

Как следствие, увеличивается проницаемость тканей, устраняются контрактуры и спайки, увеличивается подвижность суставов рекомендуется применение лонгидазы. Особенно эффективно ее применение в начальных стадиях патологического процесса.

При купировании воспаления проводятся иммунологические исследования с решением вопроса о применении иммунотерапии (этап 2 и 3 ).

\section{2 этап. Проведение диагностики иммунных нарушений с последующей} иммунотерапией.

До проведения иммунотерапии с целью решения вопроса о методах и объеме иммунотерапии проводятся иммунологические исследования.

Иммунологические исследования проходят в две стадии. Первая стадия подразумевает оценку состояния иммунной системы с выделением определенных иммунотипов с последующим применением системных иммуностимулирующих и иммунометаболических препаратов (2 этап). При недостаточности данных или при отсутствии эффекта от проводимой иммунотерапии, проводится вторая стадия исследований, а именно топическая диагностика иммунных нарушений с решением вопросов о применении таргентных препаратов (3 этап).

На втором этапе проводится исследование количества основных популяций клеток иммунной системы. Наряду с определением иммуноглобулинов A, M, G, Е мы имеем полную информацию для проведения иммунотерапии. В зависимости от количества нейтрофилов, моноцитов, В- Т- и NK лимфоцитов и концентрации иммуноглобулинов необходимо определить пациентов к одному из шести иммунотипов (табл. 119). 


\section{ИММУНОТЕРАПИЯ}

Таблица 119

Характеристика иммунологических иммунотипов

\begin{tabular}{|c|c|c|c|c|c|c|c|c|c|}
\hline \multirow[b]{2}{*}{$\begin{array}{c}\text { Характеристика } \\
\text { иммунотипа }\end{array}$} & \multicolumn{9}{|c|}{ Показатели } \\
\hline & $\begin{array}{l}\overline{0} \\
5 \\
5 \\
0 \\
0 \\
0 \\
\frac{0}{5} \\
\frac{1}{1} \\
\frac{1}{1}\end{array}$ & 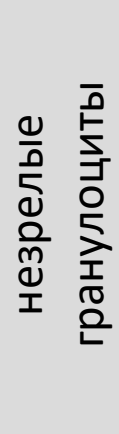 & 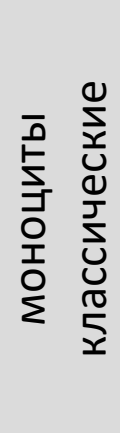 & 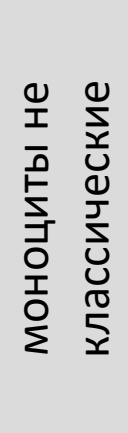 & $\begin{array}{l}\stackrel{1}{1} \\
+ \\
+ \\
\stackrel{0}{0} \\
\stackrel{1}{0} \\
\dot{0}\end{array}$ & 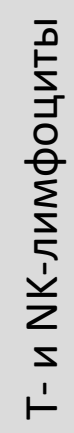 & 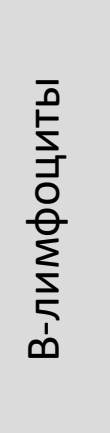 & 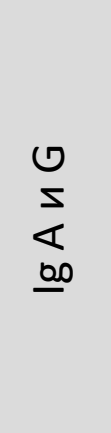 & $\underset{\underline{\infty}}{\stackrel{w}{\Sigma}}$ \\
\hline $\begin{array}{l}\text { Кластер } 1 \text { - иммунотип с } \\
\text { активацией врожденного } \\
\text { иммунитета }\end{array}$ & ++ & ++ & ++ & ++ & $\begin{array}{c}++/ \\
0\end{array}$ & $0 /-$ & 0/- & 0 & + \\
\hline $\begin{array}{l}\text { Кластер } 2 \text { - иммунотип с } \\
\text { активацией адаптивного } \\
\text { иммунитета }\end{array}$ & 0/- & 0 & 0 & 0 & 0 & ++ & ++ & ++ & 0 \\
\hline $\begin{array}{l}\text { Кластер } 3 \text { - иммунотип, с } \\
\text { гиперреакцией } \\
\text { адаптивного иммунитета }\end{array}$ & 0 & 0 & 0 & 0 & 0 & ++ & ++ & ++ & ++ \\
\hline $\begin{array}{l}\text { Кластер 4- } \\
\text { дизрегуляторный } \\
\text { иммунотип }\end{array}$ & ++ & ++ & ++ & 0 & 0 & -- & $++/-$ & 0/-- & ++ \\
\hline $\begin{array}{l}\text { Кластер } 5 \text { - } \\
\text { иммунодефицитный } \\
\text { иммунотип }\end{array}$ & 0/- & 0/- & 0/- & 0/- & -- & -- & $0 /-$ & 0/- & 0/- \\
\hline $\begin{array}{l}\text { Кластер } 6 \text { - ареактивный } \\
\text { иммунотип }\end{array}$ & 0 & 0 & 0 & 0 & 0 & 0 & 0 & 0 & 0 \\
\hline
\end{tabular}

Примечание: Показатель ++ - повышен; 0 - нет изменений; -- - понижен

Как предварительную оценку определения нарушения дифференцировки Т и В-лимфоцитов при отсутствии необходимого оборудования (проточного цитометра), вместе с развернутым анализом крови возможно проводить определения TREC и KREC. Снижение количества TREC и/или KREC (табл.120) свидетельствует о нарушениях клеточного и/или гуморального звена иммунитета. Особого внимания заслуживают взрослые с отсутствием TREC и KREC т.к. согласно нашим исследованиям в этой группе, очень высокий риск развития смертельных исходов в острый период COVID-19.

Для иммунотипов с активацией врожденного и гиперреакцией адаптивного иммунитета показана терапия 1 этапа. 
Таблица 120

Нормативные показатели TREC и KREC у взрослых

\begin{tabular}{|c|c|c|c|c|c|}
\hline \multirow{2}{*}{\multicolumn{2}{|c|}{ Показатель }} & \multicolumn{4}{|c|}{ Возраст (лет) } \\
\hline & & $18-24$ & $25-45$ & $45-60$ & старше 60 \\
\hline \multirow[t]{2}{*}{ TREC } & кровь & 35,35 & 11,21 & 0,18 & 0,21 \\
\hline & сухие пятна & 15,6 & 3,8 & 0,26 & 0,18 \\
\hline \multirow[t]{2}{*}{ KREC } & кровь & 16,77 & \multicolumn{2}{|c|}{12,57} & 5,67 \\
\hline & сухие пятна & \multicolumn{4}{|c|}{2,25} \\
\hline
\end{tabular}

При активации адаптивного иммунитета необходимо проведение метаболической терапии и мероприятий, направленных на нормализацию микробиоты кишечника.

Метаболическая терапия подразумевает применение селективных иммунометаболических препаратов (инозин пранобекс, деринат, ферровир) и комплекса препаратов, обеспечивающих пластические и энергетические процессы в клетках.

Энергетические процессы в клетки наиболее эффективно активирует цитофлавин. Пластические процессы оптимально поддерживают витаминные комплексы с большим содержанием витаминов, например Берокка Плюс 1 таблетка в день продолжительность курса составляет 30 дней.

Для нормализации микробиоты кишечника помимо противовоспалительной диеты (см. выше) в курс реабилитации необходимо включить малые дозы лактулозы и/или пребиотик хилак форте. Применение пробиотиков при иммунореабелитации ограничено.

При ареактивном и иммунодефицитном иммунотипе, наряду с метаболической терапией и нормализацией микробиоты, применяются иммуностимуляторы. Оптимальным является применение синтетического препарата широкого спектра действия, с точно известным механизмом действия - глюкозаминилмурамилдипептид (ликопид).

Помимо иммуностимуляторов, при нарушениях Т-клеточного иммунитета необходимо применять гормоны тимуса или их аналоги.

При выявлении грубых количественных (относительных и/или абсолютных) нарушений отдельных популяций клеток, или при несоответствии иммунологических проявлений с патофизиологическим развитием патологического процесса, или при отсутствии эффекта от иммунотерапии у пациентов с дисзрегуляторным иммунотипом проводится топическая диагностика иммунных нарушений.

Алгоритм ведения пациентов представлен на рисунке (рис.184). 


\section{ИММУНОТЕРАПИЯ}

\section{ИММУНОЛОГИЧЕСКИЕ ИССЛЕДОВАНИЯ ОПРЕДЕЛЕНИЯ ИММУНОТИПА}

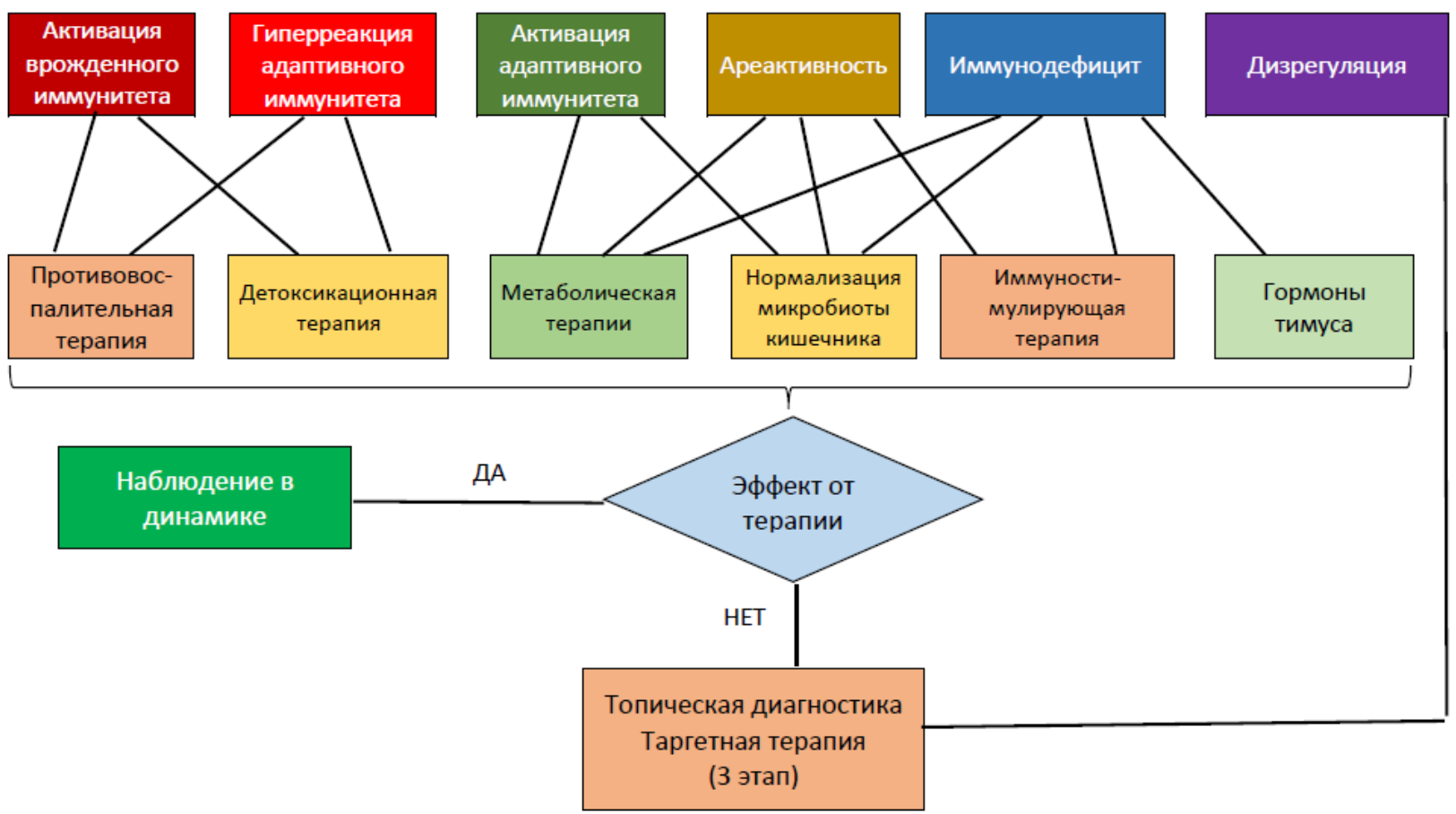

Рис. 184. Алгоритм ведения иммунореабилитации на 2 этапе.

\section{3 этап. Проведение таргетной иммунотерапии с учетом топической} диагностики иммунных нарушений. Топическая диагностика позволяет определить локализации и распространенности нарушений иммунной системы. В настоящее время с помощью проточной цитометрии возможно дифференцировать практически любые виды клеток, определить их функциональную активность. Характеристика популяционных нарушений проводится методом проточной цитометрии (см. выше).

Лабораторные исследования позволяют получить информацию о количестве различных субпопуляций клеток иммунной системы и определить их функциональную активность с определением различных активационных маркеров и в соответствии с этим провести таргентную иммунотропную терапию.

В качестве препаратов для иммунореабилитации применяется группа цитокинов (альфа- и гамма-интерфероны, колониестимулирующие факторы, интерлейкин-2 и фактор некроза опухоли) и внутривенные иммуноглобулины (рис.185). 


\section{Топическая диагностика}

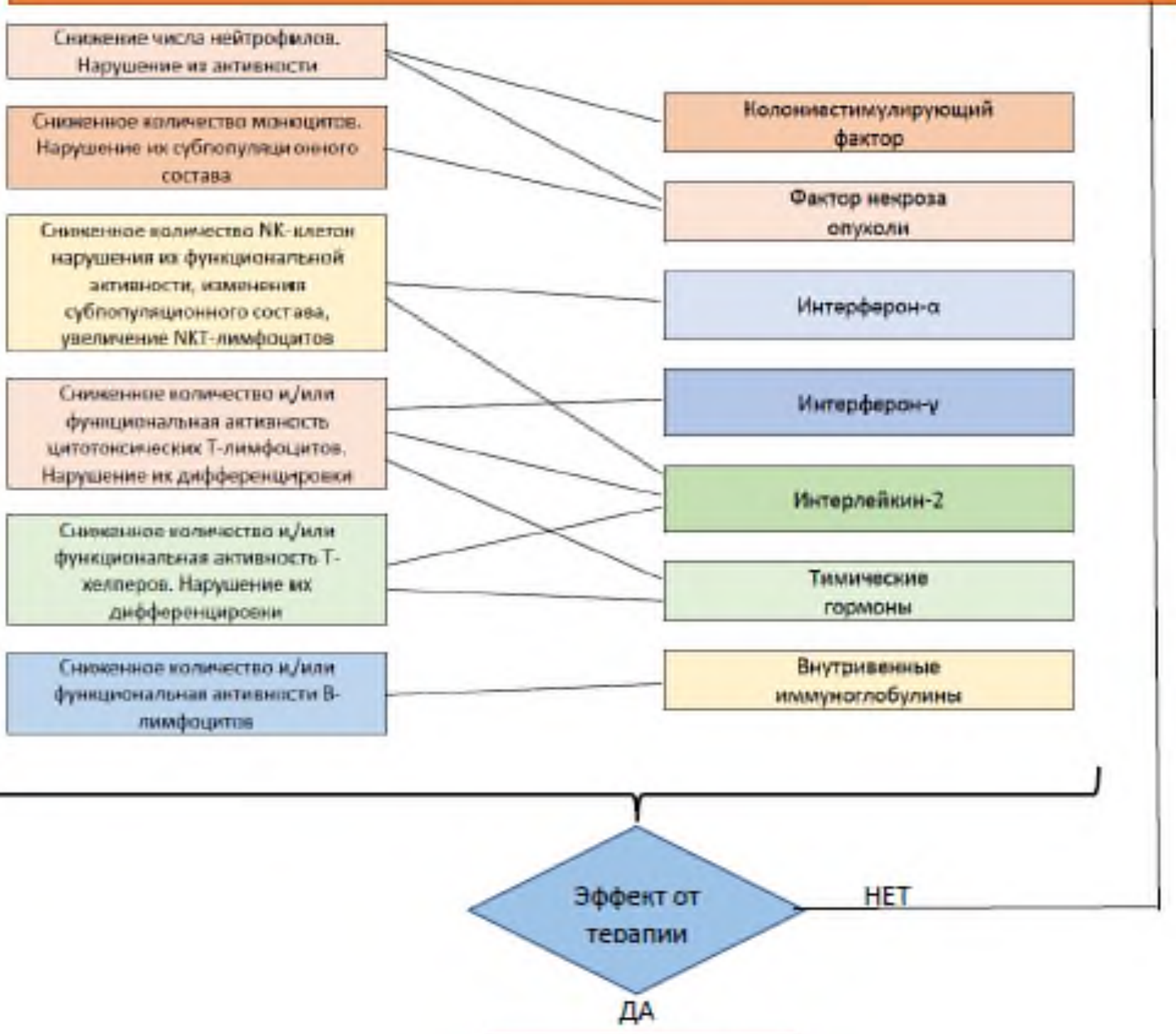

Наблюдение в

динамике

Рис. 185. Алгоритм ведения иммунореабилитации на 3 этапе. 


\section{Глава 20. Иммунопрофилактика инфекций}

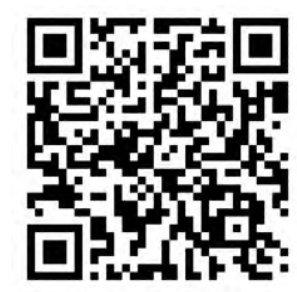

Иммунопрофилактика инфекционных болезней - это система индивидуальных или массовых мероприятий, осуществляемых в целях предупреждения, ограничения распространения и ликвидации инфекционных болезней путем создания или усиления иммунитета к определенному заболеванию. Если индивидуальную иммунопрофилактику можно рассматривать как лечебное мероприятие (частично описано выше), то массовая иммунопрофилактика проводится по эпидемическим показаниям при угрозе возникновения массовых инфекционных болезней. Иммунопрофилактика - это самое эффективное и экономически выгодное средство защиты против инфекционных болезней, известное современной медицине со времен Э.Дженнера. Применение вакцин позволило снизить, а в некоторых случаях полностью ликвидировать ряд болезней, от которых ранее страдали и умирали десятки тысяч детей и взрослых.

При вакцинации в организм человека вводится ослабленный или убитый болезнетворный агент (или искусственно синтезированный белок, который идентичен белку агента) для того, чтобы стимулировать иммунитет в борьбе с возбудителем заболевания.

В настоящее время успешно борются при помощи прививок против вирусных (оспа, корь, краснуха, паротит, полиомиелит, гепатит А и т.д.) и бактериальных (туберкулез, дифтерия, коклюш, столбняк, клещевой энцефалит и т.д.) инфекций. Чем больше людей имеют иммунитет к той или иной болезни, тем меньше вероятность у остальных (неиммунизированных) заболеть.

Выработка специфического иммунитета до протективного (защитного) уровня может быть достигнута при однократной вакциннации (корь, паротит, туберкулез) или при многократной (полиомиелит, АКДС). Ревакцинация (повторное введение вакцины) направлена на поддержание иммунитета, выработанного предыдущими вакцинациями.

Необходимо иметь в виду, что вакцинация не всегда бывает эффективной. На развитие поствакцинального иммунитета влияют факторы, связанные с:

a) самой вакциной (чистота препарата, время жизни АГ, доза, наличие протективных АГ, кратность введения, правильное хранение);

б) состоянием организма, прививаемого в целом (иммунная реактивность, возраст, наличие иммунных нарушений, наследственность);

в) факторами внешней среды (качество питания, условия труда и быта, климат, физико-химические факторы). Нами, было показано, что специфические 
АТ после введения живой паротитной вакцины практически не вырабатываются у детей, у которых накануне вакцинации определялись клинические признаки иммунных нарушений и/или происходили события, связанные с «воздействием» на иммунную систему (перенесли ОРВИ, переехали из другой климатической зоны и т.д.). Поэтому очевиден индивидуальный подход для каждого случая вакцинации, для конкретного коллектива, для конкретного региона нашей страны и мира в целом при максимальном охвате вакцинацией.

Различают следующие виды вакцин.

1. Живые вакцины, содержащие ослабленный живой микроорганизм. Примером могут служить вакцины против полиомиелита, кори, свинки, краснухи или туберкулеза. Они способны размножаться в организме и вызывать выработку защитных факторов, которые обеспечивают невосприимчивость человека к патогену. Утрата вирулентности у таких штаммов закреплена генетически, однако у лиц с иммунодефицитами могут возникнуть серьезные проблемы.

2. Инактивированные (убитые) вакцины (например, цельноклеточная вакцина против коклюша, инактивированная вакцина против бешенства), представляющие собой патогенные микроорганизмы, инактивированные высокой температурой, радиацией, ультрафиолетовым излучением, спиртом, формальдегидом и т.д. Такие вакцины реактогенны и в настоящее время применяются редко (коклюшная, против гепатита $A$ ).

3. Анатоксинь - это вакцины, состоящие из инактивированного токсина, продуцируемого бактериями. В результате специальной обработки токсические свойства его утрачиваются, но остаются иммуногенные. Примером анатоксинов могут служить вакцины против дифтерии и столбняка.

4. Субъединичная вакцина содержит части патогена (белки, полисахариды, пептиды), которые являются антигенными. В том числе рекомбинантные вакцины, получающие методами генной инженерии, примером могут служить рекомбинантная вакцина против вирусного гепатита $B$, вакцина против ротавирусной инфекиии, синтетические вакиины, представляющие собой искусственно созданные антигенные детерминанты (белки) микроорганизмов, векторные вакцины (реплицирующиеся, нереплицирующиеся) создают из вирусов, внутри которых помещают ген вакцинного белка. Реплицирующие векторы делают на основе вирусов кори или везикулярного стоматита, и они сохраняют способность размножаться в клетке. В качестве платформы для нереплицирующихся векторов используют аденовирусы или герпесвирусы и удаляют у них участки генома, ответственные за размножение вирусов. $\mathrm{PHK}$ вакцина это молекулы РНК вируса в липидной оболочке. Липидная оболочка сливается с клеточной мембраной, РНК проникает внутрь клетки синтезирует вакцинный белок, на который формируется иммунитет.

5. Ассоциированные вакцины - вакцины различных типов, содержащие

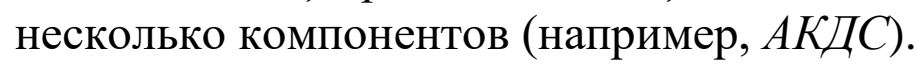




\section{ИММУНОТЕРАПИЯ}

Помимо создания путем вакцинации в организме здорового человека определенного иммунитета с целью защиты (профилактическая вакиинация) от возможного заболевания существует еще и специфическая активная иммунотерапия (вакцинотерапия), применяемая для лечения вялотекущих, хронических инфекций.

Вакцинация необходима, но перед этим обязательно следует пройти достаточно полное обследование и правильно оценить состояние прививаемого (с учетом выводов грамотного специалиста, основанных на результатах объективных исследований). Общеизвестно: любая вакцина - чужеродный белок, а потому «неизбежно небезопасна», поэтому при вакцинации следует провести максимально возможную иммунодиагностику, чтобы предотвратить осложнения не только ранние, но и поздние.

В России рекомендованы следующие виды вакцинации (табл.121).

Таблица 121

\section{Национальный календарь профилактических прививок}

\begin{tabular}{|c|c|c|c|c|c|c|c|c|c|c|c|c|c|c|c|c|c|}
\hline $\begin{array}{l}\text {. } \\
\mathbb{0} \\
0 \\
0 \\
0 \\
0\end{array}$ & 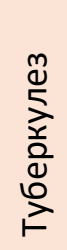 & $\begin{array}{l}\infty \\
\stackrel{5}{5} \\
\stackrel{5}{\sigma} \\
\stackrel{\leftarrow}{U}\end{array}$ & 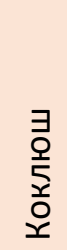 & 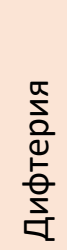 & 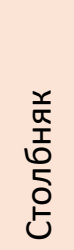 & 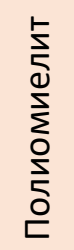 & $\begin{array}{l}0 \\
\stackrel{0}{0}\end{array}$ & 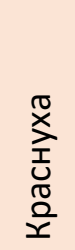 & $\begin{array}{l}\stackrel{5}{5} \\
\stackrel{5}{\circ} \\
\stackrel{2}{0} \\
\text { ㅇ }\end{array}$ & 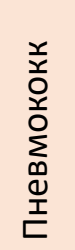 & $\Sigma$ & 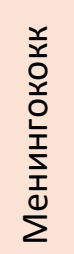 & 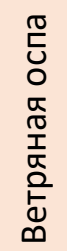 & 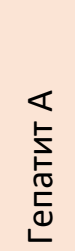 & 돔 & 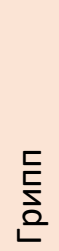 & 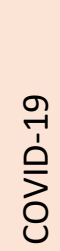 \\
\hline Рождение & & B1 & & & & & & & & & & & & & & & \\
\hline 3-7 день & B1 & & & & & & & & & & & & & & & & \\
\hline 1 месяц & & B2 & & & & & & & & & & & & & & & \\
\hline 2 месяц & & B3 & & & & & & & & B1 & & & & & & & \\
\hline 3 месяц & & & B1 & B1 & B1 & B1 & & & & & B1 & & & & & & \\
\hline 4-5 месяц & & & B2 & B2 & B2 & B2 & & & & & B2 & & & & & & \\
\hline 6 месяц & & B3 & B3 & B3 & B3 & B3 & & & & & B3 & & & & & \multirow{15}{*}{ 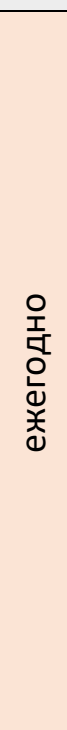 } & \\
\hline 9 месяц & & & & & & & & & & & & B1 & & & & & \\
\hline 12 месяц & & B4 & & & & & B1 & B1 & B1 & & & B2 & \multirow{2}{*}{ B1 } & & & & \\
\hline 15 месяц & & & & & & & & & & P1 & & \multirow{12}{*}{ 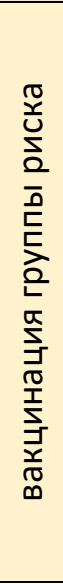 } & & & & & \\
\hline 18 месяц & & & P1 & P1 & P1 & P1 & & & & & P1 & & & & & & \\
\hline 20 месяц & & & & & & $\mathrm{P} 2$ & & & & & & & & B1 & & & \\
\hline 23 месяц & & & & & & & & & & & & & & & & & \\
\hline 2-3 года & & & & & & & & & & & & & & B2 & & & \\
\hline 4-5 лет & & & & & & & & & & & & & & & & & \\
\hline 6 лет & \multirow[t]{2}{*}{ P1 } & & \multirow[t]{2}{*}{ P2 } & \multirow[t]{2}{*}{ P2 } & \multirow[t]{2}{*}{ P2 } & & & & & & & & & & & & \\
\hline 7 лет & & & & & & & & & & & & & & & & & \\
\hline 9-11 лет & & & & & & & & & & & & & & & & & \\
\hline 12-13 лет & & & & & & & & & & & & & & & B & & \\
\hline 14-17 лет & & & P3 & P3 & P3 & P3 & B2 & B2 & B2 & & & & B2 & & & & \\
\hline старше 18 & & B1 & & & & & & & & & & & & & & & B1 \\
\hline
\end{tabular}

ГИ - Гемофильная инфекция, ВПЧ - Вирус папилломы человека инфекция, В1 В2 В3 В4 - вакцинация 123 4, P1 P2 P3 - ревакцинация 123 


\section{І. Плановые профилактические прививки.}

1. Вакцинация против дифтерии, столбняка и коклюша. Вакцинация

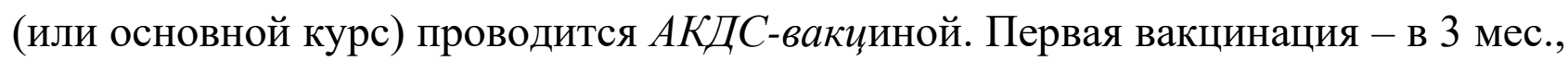
вторая - в 4, третья - в 5 мес. от рождения. Ревакцинации: первая - в 18 мес. (АКДС-вакииной), вторая - в 6 лет (АДС-м анатоксином), третья - в 11 лет (АДм анатоксином), четвертая - в $16-17$ лет (АДС-м анатоксином), далее взрослым - однократно, через каждые 10 лет (АДС-м или АД-м анатоксином).

2. Вакцинация против полиомиелита. Курс вакцинации происходит в возрасте 3, 4 и 5 мес. от рождения. Ревакцинации: в 18 мес, в 2 года и в 6 лет. Существует два типа полиовакцин: инактивированная (ИПВ) - содержит убитые вирусы полиомиелита и вводится инъекцией, известна как вакиина Солка; живая полиовакцина (ЖПВ) или вакцина Сэбина. содержит безопасные ослабленные живые полиовирусы трех типов, которые вводятся через рот. Это наиболее часто используемая вакцина против полиомиелита.

3. Вакцинация против туберкулеза. Вакцинация на 4-7-й день жизни (как правило, в родильном доме). Ревакцинации: первая - в 7 лет. Для профилактики туберкулеза применяют БЦЖ вакизину (BCG - Bacillus Calmette Guerin vaccine). Она представляет собой живые, ослабленные микобактерии туберкулеза (тип bovis). Вакцинацию проводят обычно в родильном доме.

4. Вакцинация против кори, паротита (свинки) и краснухи трехвалентной вакциной или моновалентными вакцинами. Вакцинацию проводят в 1 год, ревакцинацию в 6 лет. Вакцина против кори готовится из ее живых ослабленных вирусов. Во многих странах применяют тривакцины, содержащие помимо коревого - краснушный и паротитный компоненты.

5. Вакцинация против вирусного гепатита B. Вакцинация детей проводится по одной из двух схем. Первая схема рекомендуется в том случае, если мать новорожденного является носительницей HBsAg. У таких детей повышен риск заражения гепатитом, поэтому вакцинация должна начаться в 1-е сут после рождения перед прививкой против туберкулеза вакциной БЦЖ.

Вакцина против гепатита В может вводиться одновременно с любыми другими детскими вакцинами, поэтому для детей, не входящих в группу риска, более удобна вторая схема вакцинации, при которой вакцину вводят вместе с АКДС. Первая доза - на 4-5 мес жизни, вторая - через месяц (5-6 мес жизни). Ревакцинация проводится через 6 мес. (на 12-13 мес жизни).

Вакцина против гепатита $B$ готовится генно-инженерными методами. Все они содержат рекомбинантный поверхностный АГ вируса гепатита B - HBsAg. Применяют следующие вакцины: Энджерикс B (GlaxoSmithKline) - первая в мире рекомбинантная вакцина, производство которой было освоено в 1987 г., Эувакс (Aventis Paster), НВ Вакс II (Merck Sharp \& Dohme), Биовак-B, Wokhard Ltd, (Индия), Шанвак, Shanta, (Индия), Рекомбинантная дрожжевая вакиина 


\section{ИММУНОТЕРАПИЯ}

против гепатита B (НПК «Комбиотех», Россия), вакцина против гепатита $B$ ДНК-рекомбинантная (ФГУП НПО «Микроген», филиал «Вирион» г. Томск), Регевак В (Медико-технологический холдинг МТХ, Россия).

6. Вакцинация против COVID-19. По данным ВОЗ, различными научными коллективами в мире в клинических испытаниях исследуется более 80 кандидатных вакцин, основанных на различных технологиях и платформах. Более 180 кандидатных вакцин находятся на этапе доклинической оценки. По состоянию на июнь 2021 г. зарегистрированные вакцины против COVID-19 представлены в таблице (табл.122)

Таблица 122

\section{Вакцины против COVID-19}

\begin{tabular}{|c|c|c|}
\hline Тип вакцины & Название & Разработчик/страна \\
\hline \multirow{4}{*}{$\begin{array}{l}\text { Вакцины на основе } \\
\text { инактивированного } \\
\text { вируса }\end{array}$} & КовиВак & $\begin{array}{l}\text { ФНЦИРИП им. М.П.Чумакова/ } \\
\text { Россия }\end{array}$ \\
\hline & BBIBP-CorV & Sinophann/ Китай \\
\hline & Covaxin (BBV152) & Bharat Biotech/ Индия \\
\hline & Corona Vac. & Sinovac Biotech/ Китай \\
\hline $\begin{array}{l}\text { Рекомбинантные } \\
\text { вакцины }\end{array}$ & ЭпиВакКорона & ГНЦВБ «Вектор»/ Россия \\
\hline \multirow[t]{4}{*}{ Векторные вакцины } & $\begin{array}{l}\text { Спутник V (Гам-КОВИД- } \\
\text { Вак) }\end{array}$ & \multirow[t]{2}{*}{ НИЦЭМ нм. Н.Ф. Гамалеи/ Россия } \\
\hline & Спутник Лайт & \\
\hline & $\begin{array}{l}\text { AZD1222 } \\
\text { (ChAdOxI nCoV-19). }\end{array}$ & $\begin{array}{l}\text { AstraZeneca/ Швеция. } \\
\text { Великобритания }\end{array}$ \\
\hline & Ad26.COV2.S & $\begin{array}{l}\text { Joluison \& Jonhson/ Janssen-Cilag } \\
\text { International N.Y./ США. Бельгия }\end{array}$ \\
\hline \multirow[t]{2}{*}{ РНК-вакцина } & BNT162b2 & BioNTech/Pfizer/ Германия. США \\
\hline & mRNA-1273 & Moderna NIAI/ США \\
\hline
\end{tabular}

Кроме того, в НИИ гриппа им. А.А. Смородинцева Минздрава России (Санкт-Петербург) разработана назальная форма вакцины "Спутник-V". На базе ФГБНУ «Институт экспериментальной медицины» (Санкт-Петербург) идут испытания вакцины против коронавирусной инфекции на основе кисломолочного персонализированного продукта. Идут работы по профилактике с применением моноклональных антител, гипериммунных иммуноглобулинов и реконвалесцентной плазмы с высоким титром нейтрализующих антител. 


\section{Профилактические прививки по эпидемическим показаниям.}

По эпидемическим показаниям прививается население, проживающее на энзоотичных территориях, а также прибывшие на эти территории лица и/или лица, подверженные риску заражения при работе над заготовками, хранением, обработкой сырья и продуктов животноводства. Лица, работающие с живыми культурами возбудителя, прививаются против туляремии, чумы бруцеллеза, сибирской язвы, бешенства, лептоспироза, клещевого энщефалита. По экстренным показаниям в очаге инфекции всем здоровым, ранее не привитым, рекомендуется вакцинация против брюшного тифа, менингококковой инфекиии, вирусного гепатита $A$ и $B$, кори, паротита, дифтерии. По эпидемическим показаниям проводятся и прививки против лихорадки Ку, желтой лихорадки, холеры. Все эти виды иммунопрофилактики регламентированы законами РФ.

Специфическая активная иммунотерапия основана на применении препаратов из АГ возбудителей заболевания (вакцин). В острый период инфекционного заболевания противопоказана, так как она способна увеличить иммунодепрессивный эффект, обусловленный инфекционным процессом, и способствовать неблагоприятному его течению.

Вакцины, как правило, следует назначать в период ремиссии болезней с целью обеспечить формирование полноценного иммунитета, способного предупредить развитие их рецидивов, или при затяжном и хроническом течении с незначительно выраженными клиническими проявлениями инфекционного процесса. Лечебные вакцины применяют внутривенно, внутримышечно, подкожно и внутрикожно. Наиболее эффективен внутрикожный способ.

Весьма важным требованием специфической активной иммунотерапии является правильный выбор рабочей дозы вакцины для каждого больного. Большие дозы препарата могут оказать иммунодепрессивное действие и вызвать рецидив заболевания, а малые - вообще не дадут необходимого эффекта.

В период применения вакцин с лечебной целью противопоказано использование глюкокортикоидов, антибиотиков, цитостатиков и других веществ, угнетающих формирование иммунитета.

Важным условием эффективности специфической активной иммунотерапии считается использование в этот период препаратов, обеспечивающих активность метаболических процессов иммунокомпетентных клеток (метилурачил, нуклеинат натрия, пентоксил, витамины).

Бруцеллез. Многообразие клинических форм заболевания и механизмов поражения макроорганизма определяют разные подходы к методам специфической активной иммунотерапии больных. При остросептическом бруцеллезе она противопоказана в остром периоде заболевания и осуществляется только во время ремиссии с целью формирования иммунитета, 
способного предупредить развитие рецидива. В этих случаях в основном используют внутрикожный способ введения бруцеллезной вакцины.

туляремия. Для лечения больных с затяжным течением этого заболевания применяется туляремийная вакцина.

токсоплазмоз. Одним из важнейших лечебных мероприятий при хроническом токсоплазмозе является вакцинотерапия токсоплазмином. Ее осуществляют внутрикожно по общепринятой методике.

Бактериальные инфекции и трихомониаз. Новый иммунологический метод лечения неспецифических бактериальных вагинозов, цистита, уретрита, пиелонефрита, простатита и др. (особенно при хроническом рецидивирующем течении). Вакцинация солкоТриховаком или солкоУроваком приводит к образованию неспецифических секреторных АТ, принадлежащих классу $\operatorname{IgA,}$ которые способствуют элиминации атипичных форм лактобацилл, трихомонад и других патогенных возбудителей. В результате этого восстанавливается нормальная микрофлора влагалища. Вакцинация обеспечивает длительную защиту от реинфекции.

Гонококковая инфекция. Гонококковая инактивированная жидкая вакцина (гоновакцина) позволяет проводить диагностику (установление излеченности гонореи), служит вспомогательным методом лечения гонорейной инфекции с 3-летнего возраста. Применяется после безуспешной антибиотикотерапии при вяло протекающих рецидивах, при свежих торпидных и хронических формах заболевания, для мужчин с осложненной и женщин с восходящей гонореей (после стихания острых воспалительных явлений), в гинекологической практике при лечении воспалительных процессов.

Герпес. Для профилактики рецидивов герпетической инфекции применяется вакичина герпетическая, культуральная, инактивированная, сухая, которая представляет собой инактивированный ВПГ I и II антигенных типов, полученный путем репродукции в культуре клеток (витагерпавак) или на культуре клеток ткани фибробластов куриных эмбрионов (герповакс). Вакцина стимулирует клеточные механизмы резистентности организма человека к ВПГ I и II типов. Вакцинацию проводят в лечебных учреждениях под контролем врача и применяют в стадии ремиссии не ранее, чем через 5 дней после полного исчезновения клинических проявлений герпетической инфекции.

Как способ активного воздействия на иммунную систему, особенно при хронических инфекциях, следует рассматривать и производства аутовакцин.

Реакции и осложнения после прививок. Различают общзие и местные послепрививочные реакции. Общие реакции проявляются умеренным повышением температуры тела, легким недомоганием. При введении вакцины подкожно появляется болезненность, реже припухлость в месте инъекции (местная реакция). После введения БЦЖ-вакцины могут быть подкожные 
«холодные» абсцессы (гнойники), воспаление местных лимфатических узлов. Как общая, так и местная реакции после прививок переносятся легко и продолжаются не более 3 дней.

Тяжелая общая интоксикация, припухлость, нагноение в месте введения вакцины расцениваются как поствакцинальное осложнение. Необходимо учитывать сроки и характер возможных осложнений после прививок:

1) общие тяжелые реакции с повышением температуры, иногда судорожные подергивания мышц, возникающие не позже 48 ч после прививок АКДС, АДС и АДС-м и не раньше 4-5 дней на вакцины против кори и эпидемического паротита (свинки);

2) появление признаков менингита возможно на 3 - 4-й неделе после введения вакцины против эпидемического паротита;

3) возникновение аллергических реакций на коже не позже 24 ч после введения любой вакцины;

4) катар дыхательных путей после введения вакцины против кори на 2-й неделе после прививки.

Медицинские отводы от прививок. В последнее время перечень заболеваний, считавшихся противопоказаниями для вакцинации, существенно сужен (табл.123).

Таблица 123

\section{Перечень медицинских противопоказаний к проведению профилактических прививок}

\begin{tabular}{|l|l|}
\hline \multicolumn{1}{|c|}{ Вакцина } & \multicolumn{1}{|c|}{ Противопоказания } \\
\hline Все вакцины & Сильная реакция или осложнение на предыдущую дозу \\
\hline Все живые вакцины & $\begin{array}{l}\text { Иммунодефицитное состояние (первичное), иммуносупрессия, } \\
\text { злокачественные новообразования, беременность }\end{array}$ \\
\hline БЦЖ вакцина & $\begin{array}{l}\text { Вес ребенка менее 2000 г, коллоидный рубец после предудущей } \\
\text { дозы }\end{array}$ \\
\hline $\begin{array}{l}\text { ОПВ (оральная полиомиелитная } \\
\text { вакцина) }\end{array}$ & Абсолютных противопоказаний нет \\
\hline АКДС & $\begin{array}{l}\text { Прогрессирующие заболевания нервной системы, афебрильные } \\
\text { судороги в анамнезе (вместо АКдС вводят АДС) }\end{array}$ \\
\hline АДС, АДСМ & Абсолютных противопоказаний нет \\
\hline ЖКВ (живая коревая вакцина), & Тяжелые реакции на аминогликозиды \\
\hline ЖПВ (живая паротитная вакцина) & Анафилактические реакции на яичный белок \\
\hline & \\
\hline
\end{tabular}

Примечания: Плановая вакцинация откладывается до окончания острых проявлений заболевания и обострения хронических заболеваний. При нетяжелых ОРЗ, острых кишечных заболеваниях и др. прививки проводятся сразу же после нормализации температуры тела. 


\section{Список литературы}

1. Аксенова В.А., Барышникова Л.А., Клевно Н.И., Кудлай Д.А. Скрининг детей и подростков на туберкулезную инфекцию в России прошлое, настоящее, будущее. Туберкулез и болезни легких. 2019. Т. 97. № 9. C. $59-67$.

2. Аксенова В.А., Барышникова Л.А., Клевно Н.И., Сокольская Е.А., Долженко Е.Н., Шустер А.М., Мартьянов В.А., Кудлай Д.А., Николенко Н.Ю., Курилла А.А. Новые возможности скрининга и диагностики различных проявлений туберкулезной инфекции у детей и подростков в России. Вопросы современной педиатрии. 2011. Т. 10. № 4. С. 16-22.

3. Аксенова В.А., Леви Д.Т., Александрова Н.В., Кудлай Д.А. Современное состояние вопроса заболеваемости детей туберкулезом, препараты для профилактики и диагностики инфекции. Биопрепараты. Профилактика, диагностика, лечение. 2017. Т. 17. № 3 (63). С. 145-151.

4. Аксёнова В.А., Леви Д.Т., Александрова Н.В., Кудлай Д.А., Барышникова Л.А., Клевно Н.И. Туберкулез у детей: современные методы профилактики и ранней диагностики. Доктор.Ру. 2017. № 15 (144). С. 9-15.

5. Аллергология и иммунология (Практические рекомендации для педиатров) / под ред. Л.С. Намазовой-Барановой, А.А. Баранова, Р.М. Хаитова: Союз педиатров России [и др.]. - М.: Изд-во «ПедиатрЪ», 2020. - 512 с.

6. Арсентьева Н.А., Любимова Н.Е., Бацунов О.К., Коробова 3.Р., Станевич О.В., Лебедева А.А., Воробьев Е.А., Воробьева С.В., Куликов А.Н., Лиознов Д.А., Шарапова М.А., Певцов Д.Э., Тотолян А.А. Цитокины в плазме крови больных COVID-19 в острой фазе заболевания и фазе полного выздоровления. Медицинская иммунология. 2021;23(2):311-326. https://doi.org/10.15789/1563-0625-PCI-2312.

7. Бармина Н.А., Барышникова Л.А., Рейхардт В.В., Ждакаев М.С., Кудлай Д.А. Критерии эффективности лечения туберкулеза у детей в современных условиях. Туберкулез и болезни легких. 2017. Т. 95. № 10. С. 6975.

8. Беленюк В.Д., Савченко А.А., Борисов А.Г., Кудрявцев И.В. Особенности фенотипа В-лимфоцитов крови в зависимости от исхода распространенного гнойного перитонита // Инфекция и иммунитет. $\square 2021 . \square \mathrm{T}$. 11, № 3.- С. 454-462.

9. Бозрова С.В., Друцкая М.С., Недоспасов С.А. Лекарства против COVID-19: от мифов к реалиям и надеждам. Медицинская иммунология. 2020;22(5):827-836.

10. Борисов, А.Г. Заболеваемость, связанная с нарушениями функции иммунной системы (на примере Красноярского края) / А.Г. Борисов, А.А. Савченко, В.К. Соколовская // Здравоохранение Российской Федерации. -2014. - Т. 58, № 6. - С. 38-41. 
11. Борисов, А.Г. Клиническая характеристика нарушения функции иммунной системы / А.Г. Борисов // Медицинская иммунология. - 2013. - Т. 15, № 1. - С.45-50.

12. Борисов А.Г. Кластерный анализ типов иммунных нарушений при инфекционно-воспалительных заболеваниях / А.Г. Борисов // Российский иммунологический журнал. - 2014. - Т. 8(17), № 4. - С. 1002-1011.

13. Борисов, А.Г. Особенности иммунного реагирования при вирусных инфекциях / А.Г. Борисов, А.А. Савченко, И.В. Кудрявцев // Инфекция и иммунитет. - 2015. - Т. 5, № 2. - С. 148-156.

14. Борисов, А.Г. Особенности состояния клеточного и гуморального иммунитета при остром и хроническом вирусном гепатите В / А.Г. Борисов, А.А. Савченко // Acta Biomedica Scientifica. - 2012. - № 3-2 (85). - С. 53-57.

15. Борисов, А.Г. Скрининг-тестирование с использованием программы «МедТест» для оценки состояния здоровья при проведении диспансеризации / А.Г. Борисов, А.А. Савченко // Врач и информационные технологии. - 2013. - № 1. - С. 42-48.

16. Борисов, А.Г. К вопросу о классификации нарушений функционального состояния иммунной системы / А.Г. Борисов, А.А.Савченко, С.В Смирнова. // Сибирский медицинский журнал. - 2008. - Том 23, №3 (выпуск 1). - С.13-18.

17. Борисов, А.Г. Типы иммунного реагирования при распространенном гнойном перитоните (с комментарием) / А.Г. Борисов, А.А. Савченко, Д.В. Черданцев, Д.Э. Здзитовецкий, О.В. Первова, И.В. Кудрявцев, В.Д Беленюк., В.А. Шапкина // Хирургия. Журнал им. Н.И. Пирогова. - 2016. - № 9. - С. 28-34.

18. Борисов, А.Г. Особенности иммунного реагирования при вирусных инфекциях / А.Г. Борисов, А.А. Савченко, И.В. Кудрявцев // Инфекция и иммунитет. - 2015. - Т. 5, № 2. - С. 148-156.

19. Борисов, А.Г. Анализ экспрессии CD57 и $\mathrm{CD} 279$ цитотоксическими Т-лимфоцитами различного уровня дифференцировки у больных ветряной оспой / А.Г. Борисов, А.А. Савченко, Е.П. Тихонова, И.В. Кудрявцев, Ю.С. Калинина // Инфекционные болезни. - 2017. - Т. 15, № 4. - С. 26-32.

20. Борисов, А.Г. Варианты иммунного реагирования при раке почки / А.Г. Борисов, А.А. Савченко, И.В. Кудрявцев, А.А. Модестов, О.Г. Тоначева, А.В. Мошев // Медицинская иммунология. - 2017. - Т. 19, № S. - С. 227.

21. Бородулина Е.А., Широбоков Я.Е., Гладунова Е.П., Кудлай Д.А. Диагностика и фармакотерапия вирус-ассоциированных поражений легких. Клиническая фармакология и терапия. 2020. Т. 29. № 3. С. 61-66.

22. Бородулина Е.А., Санталова Г.В., Кудлай Д.А., Амосова Е.А., Бородулин Б.Е., Ураксина М.В. Мониторинг туберкулезной инфекции у детей с ювенильным идиопатическим артритом, получающих генно-инженерные препараты. Педиатрия. Журнал им. Г.Н. Сперанского. 2019. Т. 98. № 2. С. 209213. 
23. Валутите Д.Э., Семенов А.В., Останкова Ю.В., Козлов К.В., Борисов А.Г., Назаров В.Д., Тотолян А.А. Выявление мутаций лекарственной устойчивости вируса гепатита $\mathrm{C}$ у пациентов с неэффективной терапией препаратами прямого противовирусного действия // Журнал микробиологии, эпидемиологии и иммунобиологии. $\square 2021 . \square$ Т. 98, № 1. $\square$ С. 18-27.

24. Васильева, Е.В. Влияние ВИЧ-инфекции и туберкулеза на степень дифференцировки Т-лимфоцитов периферической крови / Е.В. Васильева, И.В. Кудрявцев, Г.В. Максимов, В.Н. Вербов, М.К. Серебрякова, А.П. Ткачук, Арег А. Тотолян // Инфекция и иммунитет. - 2017. - Т. 7, № 2. - С. 151-161.

25. Воробьёв, С.В. Роль иммунной реакции в патогенезе болезни Альцгеймера и возможности противовоспалительной терапии / С.В. Воробьёв, А.Ю. Емелин, Р.Н. Кузнецова, И.В. Кудрявцев // Неврологический вестник. 2020. - T. LII (3). - C. 55-62.

26. Воробьева О.В., Ласточкин А.В. Патоморфологические изменения в органах при COVID-19. Инфекция и иммунитет. 2020. 10(3). С. 587-590.

27. Головкин А.С., Асадуллина И.А., Кудрявцев И.В. Пуринергическая регуляция основных физиологических и патологических процессов. Медицинская иммунология. 2018. Т. 20. № 4. С. 463-477.

28. Головкин А.С., Зурочка А.В., Хайдуков С.В., Кудрявцев И.В. Современные методы и подходы к изучению апоптоза в экспериментальной биологии. Медицинская иммунология. 2012. Т. 14. № 6. С. 461-482.

29. Головкин А.С., Кудрявцев И.В., Дмитриев А.В., Калинина О.В. Фиброзные изменения сердечно-сосудистой и дыхательной систем после перенесенной COVID-19: вклад факторов иммунной системы и генетическая предрасположенность. Российский кардиологический журнал 2020; 25 (10). doi:10.15829/1560-4071-2020-4087.

30. Головкин А.С., Кудрявцев И.В., Дмитриев А.В., Калинина О.В. Фиброзные изменения сердечно-сосудистой и дыхательной систем после перенесенной COVID-19: вклад факторов иммунной системы и генетическая предрасположенность. Российский кардиологический журнал. 2020. Т. 25. № 10. C. $214-220$.

31. Головкин А.С., Матвеева В.Г., Кудрявцев И.В., Григорьев Е.В., Великанова Е.А., Байракова Ю.В. Субпопуляции моноцитов крови при неосложненном течении периоперационного периода коронарного шунтирования. Медицинская иммунология. 2012. Т. 14. № 4-5. С. 305-312.

32. Головкин А.С., Серебрякова М.К., Жидулева Е.В., Муртазалиева П.М., Титов В.А., Иртюга О.Б., Моисеева О.М., Кробинец И.И., Кудрявцев И.В. Экспрессия рецепторов пуринергического сигналинга на Т-лимфоцитах периферической крови здоровых доноров. Трансляционная медицина. 2017. Т. 4. № 5. С. 46-60.

33. Гоми Р., Асгари Н., Хаджихейдари А., Эстеки Р., Бйабанаки Ф., Насиринасаб Ф. Пандемия COVID-19: систематический обзор современных данных. Инфекция и иммунитет. 2020;10(4):655-663. 
34. Гончаров Н.В., Попова П.И., Авдонин П.П., Кудрявцев И.В., Серебрякова М.К., Корф Е.А., Авдонин П.В. Маркеры эндотелиальных клеток в норме и при патологии. Биологические мембраны. 2020. Т. 37. № 1. С. 3-21.

35. Грицинская В.Л., Гордиец А.В., Галактионова М.Ю., Савченко А.А., Манчук В.Т., Кадричева С.Г. Клинико-метаболические показатели детей в период адаптации к школе // Педиатрия. Журнал им. Г.Н. Сперанского. 2001.-T. 80, № 5. - С. 57-59

36. Гудима Г.О., Хаитов Р.М., Кудлай Д.А., Хаитов М.Р. Молекулярно-иммунологические аспекты диагностики, профилактики и лечения коронавирусной инфекции. Иммунология. 2021. Т. 42. № 3. С. 198210.

37. Гусев Е.Ю., Зотова Н.В., Журавлева Ю.А., Черешнев В.А. Физиологическая и патогенетическая роль рецепторов-мусорщиков у человека. Медицинская иммунология. 2020. Т. 22. № 1. С. 7-48.

38. Гусев Е.Ю., Зотова Н.В., Черешнев В.А. "СЕПСИС-3": новая редакция - старые проблемы. Анализ с позиции общей патологии. Инфекция и иммунитет. 2021. Т. 11. № 4. С. 649-662.

39. Давыдова Н.В., Продеус А.П., Образцов И.В., Кудлай Д.А., Корсунский И.А. Референсные значения концентрации TREC и KREC у взрослых. Врач. 2021. Т. 32. № 6. С. 21-28.

40. Добин В.Л., Панин И.В. Саркоидоз и COVID-19. Туберкулез и болезни легких. 2021. Т. 99. № 8. С. 7-12.

41. Екатеринчева О.Л., Малкова А.М., Карев В.Е., Кудрявцев И.В., Зинченко Ю.С., Потепун Т.Б., Кудлай Д.А., Старшинова А.А. Особенности диагностики туберкулеза на фоне COVID-19. Журнал инфектологии. 2021. T. 13. № 1. C. 117-123.

42. Екатеринчева О.Л., Малкова А.М., Карев В.Е., Кудрявцев И.В., Зинченко Ю.С., Потепун Т.Б., Кудлай Д.А., Старшинова А.А. Особенности диагностики туберкулеза на фоне COVID-19. Журнал инфектологии. 2021. T. 13. № 1. С. 117-123.

43. Елезов Д.С., Кудрявцев И.В., Арсентьева Н.А., Семенов А.В., Эсауленко Е.В., Басина В.В., Тотолян Арег А. Анализ субпопуляций Тхелперов периферической крови больных хроническим вирусным гепатитом C, экспрессирующих хемокиновые рецепторы CXCR3 и CCR6 и активационные маркеры CD38 и HLA-DR. Инфекция и иммунитет. 2013. T. 3. № 4. C. 327-334.

44. Зурочка, А.В. Проточная цитометрия в биомедицинских исследованиях / А.В. Зурочка, С.В. Хайдуков, И.В. Кудрявцев, В.А. Черешнев. Екатеринбург: РИО УрО РАН, 2018. - 720 с.

45. Иммунология: структура и функции иммунной системы / Под ред. Р.М. Хаитова. - М.,2013. - 280 с.

46. Исихак Ф.А., Хамад М.А., Мустафа Н.Г. COVID-19: обновленный взгляд. Инфекция и иммунитет. 2020;10(2):247-258. 
47. Кетлинский С.А., Симбирцев А.С. Цитокины. СПб.: Фолиант, 2008. 552c.

48. Клеменков А.С., Фурсова Я.Е., Клеменков С.В., Каспаров Э.В., Кубушко И.В. Влияние общих пресных ванн и физических тренировок при разной длительности назначения на физическую работоспособность больных стабильной стенокардией с нарушением ритма// Фундаментальные исследования. 2006. № 3. С. 13-17

49. Козлов, В.А. Практические аспекты диагностики и лечения иммунных нарушений: Руководство для врачей. / В.А. Козлов, А.Г. Борисов, С.В. Смирнова, А.А. Савченко. Новосибирск: Наука, 2009. - 274c.

50. Козлов В.А., Черных Е.Р. Современные проблемы иммунотерапии в онкологии // Бюллетень Сибирского отделения Российской академии медицинских наук. 2004. № 2. - С. 13-19.

51. Козлов В. А., Савченко А. А., Кудрявцев И. В., Козлов И. Г., Кудлай Д. А., Продеус А. П., Борисов А. Г. Клиническая иммунология. Красноярск: Поликор, 2020. - 386 с.

52. Корсунский И.А., Гордукова М.А., Мунблит Д.Б., Козлов И.Г., Продеус А.П., Корсунский А.А. Клинические и эпидемиологические аспекты первичных иммунодефицитных состояний и их раннего обнаружения. Медицинская иммунология. 2017. 19(5). С. 505-512.

53. Корсунский И.А., Продеус А.П., Румянцев А.Г., Гордукова М.А., Корсунский А.А., Кудлай Д.А., Филипенко М.Л., Шустер А.М. Скрининг новорожденных на первичные иммунодефициты и группу риска иммунорегуляторных расстройств, требующих диспансерного наблюдения. Педиатрия. Журнал им. Г.Н. Сперанского. 2019. Т. 98. № 3. С. 49-53.

54. Крюкова Е.В., Савченко А.А., Манчук В.Т., Осокина И.В. Особенности иммунитета у детей и подростков с разной продолжительностью сахарного диабета типа $1 / /$ Проблемы эндокринологии. $\square 2000$. $\square$ Т. 46, № 3. $\square$ С. 7-10.

55. Кудлай Д.А. Биомаркеры и иммунологические тесты. Экспериментально-клинические параллели латентной туберкулезной инфекции. Туберкулез и болезни легких. 2020. Т. 98. № 8. С. 63-74.

56. Кудлай Д.А., Старшинова А.А., Довгалюк И.Ф. Аллерген туберкулезный рекомбинантный: 10 -летний опыт применения теста у детей и подростков в Российской Федерации (данные метаанализа). Педиатрия. Журнал им. Г.Н. Сперанского. 2020. Т. 99. № 3. С. 121-129.

57. Кудлай Д.А., Широбоков Я.Е., Гладунова Е.П., Бородулина Е.А. Диагностика COVID-19. Способы и проблемы обнаружения вируса SARSCoV-2 в условиях пандемии. Врач. 2020. Т. 31. № 8. С. 5-10.

58. Кудрявцев, И.В. Анализ основных популяций цитотоксических Т-лимфоцитов периферической крови на основании уровня экспрессии CD27, CD28, CD45R0 и CD62L / И.В. Кудрявцев, Д.С. Елезов // Российский иммунологический журнал. - 2013. - Т. 7, № 2-3 (1) (16). - С. 57-61. 
59. Кудрявцев И.В. Т-клетки памяти: основные популяции и стадии дифференцировки / И.В. Кудрявцев // Российский иммунологический журнал. - 2014. - Т. 8, № 4 (17). - С. 947-964.

60. Кудрявцев И.В. Т-клетки памяти: основные популяции и стадии дифференцировки / И.В. Кудрявцев // Российский иммунологический журнал. - 2014. - Т. 8. № 4 (17). - С. 947-964.

61. Кудрявцев, И.В. Определение основных субпопуляций цитотоксических Т-лимфоцитов методом многоцветной проточной цитометрии / И.В. Кудрявцев, А.Г. Борисов, И.И. Кробинец, А.А. Савченко, М.К. Серебрякова // Медицинская иммунология. - 2015. - Т. 17, № 6. - С. 525538.

62. Кудрявцев, И.В. Анализ уровня экспрессии CD56 и CD57 цитотоксическими Т-лимфоцитами различного уровня дифференцировки / И.В. Кудрявцев, А.Г. Борисов, А.Е. Волков, А.А. Савченко, М.К. Серебрякова, А.В. Полевщиков // Тихоокеанский медицинский журнал. - 2015. - № 2. - С. 30-35.

63. Кудрявцев, И.В. Опыт измерения параметров иммунного статуса с использованием шестицветного цитофлуориметрического анализа / И.В. Кудрявцев, А.И. Субботовская // Медицинская иммунология. - 2015. - Т. 17, № 1. - С. 19-26.

64. Кудрявцев, И.В. Особенности экспрессии поверхностных рецепторов семейства KLR цитотоксическими T-клетками различного уровня дифференцировки / И.В. Кудрявцев, А.Г. Борисов, И.И. Кробинец, А.Я. Рак, А.А. Савченко, М.К. Серебрякова // Российский иммунологический журнал. 2016. - T. 10, № 3 (19). - С. 297-302.

65. Кудрявцев, И.В. Хемокиновые рецепторы на Т-хелперах различного уровня дифференцировки: основные субпопуляции / И.В. Кудрявцев, А.Г. Борисов, И.И. Кробинец, А.А. Савченко, М.К. Серебрякова, А.А. Тотолян // Медицинская иммунология. - 2016. - Т. 18, № 3. - С. 239-250.

66. Кудрявцев, И.В. Фенотипическая характеристика цитотоксических Т-лимфоцитов: регуляторные и эффекторные молекулы / И.В. Кудрявцев, А.Г. Борисов, Е.В. Васильева, И.И. Кробинец, А.А. Савченко, М.К. Серебрякова, А.А. Тотолян // Медицинская иммунология. - 2018. - Т. 20, № 2. - C. 227-240.

67. Кудрявцев, И.В. Фенотипическая характеристика цитотоксических Т-лимфоцитов: регуляторные и эффекторные молекулы / И.В. Кудрявцев, А.Г. Борисов, Е.В. Васильева, И.И. Кробинец, А.А. Савченко, М.К. Серебрякова, А.А. Тотолян // Медицинская иммунология. - 2018. - Т. 20, № 2. - C. 227-240.

68. Куртасова Л.М., Манчук В.Т., Савченко А.А. Основы метаболической иммунореабилитации детей с атопическим дерматитом.Красноярск, 2002.-153 с. 
69. Куртасова Л.М., Савченко А.А., Манчук В.Т. Метаболические аспекты иммунореабилитации детей с атопическими заболеваниями. $\square$ Новосибирск: Наука, 2006.-222 с.

70. Куртасова Л.М., Савченко А.А., Рузаева Л.А., Шмидт А.Р. Особенности метаболизма иммунокомпетентных клеток у детей с рецидивирующей герпетической инфекцией // Вопросы вирусологии.-2002.-T. 47, № 3.-С. 45-48.

71. Лагерева Ю.Г., Черешнев В.А., Еременко А.Ю., Бейкин Я.Б. Содержание CD4+ и CD8+ T-клеток памяти, наивных и терминальнодифференцированных Т-эффекторов в цереброспинальной жидкости при менингеальной форме энтеровирусной инфекции у детей. Российский иммунологический журнал. 2014. Т. 8 (17). № 3. С. 823-825.

72. Ладожская-Гапеенко Е.Е., Храпов К.Н., Полушин Ю.С., Шлык И.В., Вартанова И.В., Фионик А.М., Данилова Д.М. Оценка состояния микроциркуляции у больных с тяжелым течением COVID-19 методом капилляроскопии ногтевого ложа. Вестник анестезиологии и реаниматологии. 2021. T. 18. № 1. C. 27-36. DOI: 10.21292/2078-5658-2021-18-1-27-36.

73. Лазанович, B.A. Анализ экспресии C3aR, C5aR1 (CD88) на миелоидных клетках у пациентов с сепсисом / B.А. Лазанович, Е.В. Маркелова, Е.В. Просекова, И.В. Кудрявцев, Т.П. Смолина, В.А. Павлов // Патологическая физиология и экспериментальная терапия. - 2017. - Т. 61, № 1. - C. $72-77$.

74. Лазанович, B.A. TOLL-рецепторы на моноцитах и их клиническая значимость у пациентов с сепсисом / В.А. Лазанович, Е.В. Маркелова, Г.А. Смирнов, В.А. Павлов // Российский иммунологический журнал. - 2014. - Т. 8, № 3 (17). - С. 825-828.

75. Лазанович, В.А. Клиническая значимость экспрессии TLR2, TLR4 на клетках миелоидного ряда и сывороточного уровня цитокинов у пациентов с сепсисом / В.А. Лазанович, Е.В. Маркелова, А.В. Караулов // Иммунопатология, аллергология, инфектология. - 2015. - № 2. - С. 71-76.

76. Литвинова Л.С., Гуцол А.А., Сохоневич Н.А., Кофанова К.А., Хазиахматова О.Г., Шуплецова В.В., Кайгородова Е.В., Гончаров А.Г. основные поверхностные маркеры функциональной активности Тлимфоцитов // Медицинская иммунология. -2014.-Т. 16, № 1.-С. 7-26.

77. Лядова И.В., Стариков А.A. COVID-19 и вакцинация БЦЖ: есть ли связь? Инфекция и иммунитет. 2020. 10(3). С. 459-468.

78. Маев И.В., Цуканов В.В., Третьякова О.В., Каспаров Э.В., Кучерявый Ю.А., Андреев Н.Г., Васютин А.В. Терапевтические аспекты лечения язвенных кровотечений// Фарматека. 2012. № 2 (235). С. 56-59.

79. Малкова А.М., Старшинова А.А., Кудрявцев И.В., Довгалюк И.Ф., Зинченко Ю.С., Кудлай Д.А. Возможности иммунотерапии в лечении COVID19. Вопросы гематологии/онкологии и иммунопатологии в педиатрии. 2021. T. 20. № 3. C. 158-168. 
80. Матвеева В.Г., Головкин А.С., Григорьев Е.В. Субпопуляционный состав моноцитов - прогностический маркер тяжелых осложнений системного воспалительного ответа после операции коронарного шунтирования // Комплексные проблемы сердечно-сосудистых заболеваний.-2014.-№ 4.-С. 512.

81. Матвеева В.Г., Головкин А.С., Кудрявцев И.В., Григорьев Е.В., Чернова М.Н. Динамика CD14+CD16+ субпопуляций моноцитов при неосложненном системном воспалительном ответе в периоперационном периоде коронарного шунтирования // Медицинская иммунология.-2012. Т. 14, № 4-5.- С. 391-398.Медицинская микробиология и иммунология/ У. Левинсон ; пер. с англ. под ред. д-ра мед. наук, проф. В. Б. Белобородова. - М. : БИНОМ. Лаборатория знаний, 2015.

82. Новик А.В. Анемия и метаболические расстройства у онкологических больных / А.В. Новик // Практическая онкология. - 2009. - Т. 10, № 3. - С. 131-140.

83. Новик А.В. Принципы современной иммунотерапии / А.В. Новик // Фарматека. - 2018. - № 7. - С.10-18.

84. Новиков Д. К. Клиническая иммунология : учебное пособие / Д. К. Новиков, П. Д. Новиков. // Витебск : ВГМУ, 2006. - 392 с.

85. Новиков Д. К. Клиническая иммунология и аллергология: учебник /Д. К. Новиков, П. Д. Новиков, Н. Д. Титова. - Минск: Вышэйшая школа, 2019. $-495 \mathrm{c}$.

86. Олейник Е.А., Леплина О.Ю., Останин А.А., Старостина Н.М., Черных Е.Р. Адаптивный Т-клеточный ответ в патогенезе вирусной инфекции, обусловленной вирусом гепатита С. Медицинская иммунология. 2016. Т. 18. № 4. С. 309-316.

87. Основы клинической иммунологии и аллергологии: уч. пособие / под ред. Л.С. Намазовой-Барановой, Л.В. Ганковской, Н.Г. Астафьевой - М.: Педиатръ, 2016. - 152 с.

88. Полушин Ю.С., Гаврилова Е.Г., Шлык И.В., Лапин С.В., Ткаченко O.Ю. Катастрофический антифосфолипидный синдром при COVID-19. Вестник анестезиологии и реаниматологии. 2021. Т. 18. № 1. С. 17-26.DOI: 10.21292/2078-5658-2021-18-1-17-26.

89. Попов С.В., Шмельков И.Ю., Хайдуков С.В. Анализ регуляторных Т-лимфоцитов при грибковых инфекциях. Медицинская иммунология. 2020. Т. 22. № 6. С. 1055-1064.

90. Попова А.Ю., Андреева Е.Е., Бабура Е.А., Балахонов С.В., Башкетова Н.С., Буланов М.В., Валеуллина Н.Н., Горяев Д.В., Детковская Н.Н., Ежлова Е.Б., Зайцева Н.Н., Историк О.А., Ковальчук И.В., Козловских Д.Н., Комбарова С.В., Курганова О.П., Кутырев В.В., Ломовцев А.Э., Лукичева Л.А., Лялина Л.В., Мельникова А.А., Микаилова О.М., Носков А.К., Носкова Л.Н., Оглезнева Е.Е., Осмоловская Т.П., Патяшина М.А., Пеньковская Н.А., Самойлова Л.В., Смирнов В.С., Степанова Т.Ф., Троценко О.Е., Тотолян А.А. Особенности формирования серопревалентности населения Российской 
Федерации к нуклеокапсиду SARS-CoV-2 в первую волну эпидемии COVID19. Инфекция и иммунитет. 2021. 11(2). С 297-323.

91. Радкевич А.А., Каспарова И.Э., Винник Ю.С., Горбунов Н.А., Каспаров Э.В., Усольцев Д.М., Иванов В.А., Галонский В.Г. Репаративный десмогенез после замещения соединительно-тканных дефектов тканевыми имплантатами из никелида титана// Сибирский медицинский журнал (Иркутск). 2009. Т. 91. № 8. С. 151-153.

92. Савченко А.А., Смирнова С.В. Особенности уровней активности НАД(Ф)-зависимых дегидрогеназ в лимфоцитах крови у больных истинной аллергией и псевдоаллергией // Вестник новых медицинских технологий.-2001.-Т. 8, № 2.-С. 64-67.

93. Савченко А.А., Борисов А.Г. Основы клинической иммунометаболомики. Новосибирск: Наука, 2013.- 263 с.

94. Савченко, А.А. Иммунометаболические нарушения при распространенном гнойном перитоните / А.А. Савченко, Д.Э. Здзитовецкий, А.Г. Борисов. Новосибирск: Наука, 2013.-142 с.

95. Савченко, А.А. Хемилюминесцентная активность нейтрофильных гранулоцитов и уровни концентрации цитокинов у больных распространенным гнойным перитонитом / А.А. Савченко, Д.Э. Здзитовецкий, А.Г. Борисов, Н.А. Лузан // Цитокины и воспаление. - 2013. - Т. 12, № 1-2. - С. 115-119.

96. Савченко А.А., Здзитовецкий Д.Э., Борисов А.Г., Лузан Н.А. Хемилюминесцентная и энзиматическая активность нейтрофильных гранулоцитов у больных распространенным гнойным перитонитом в зависимости от исхода заболевания // Вестник Российской академии медицинских наук.-2014.-Т. 69, № 5-6.-С. 23-28.

97. Савченко А.А., Борисов А.Г., Анисимова Е.Н., Беленюк В.Д., Кудрявцев И.В., Решетников И.В., Квятковская С.В., Цейликман В.Э., Зорин А.Н. Исследование фенотипа лейкоцитов крови у больных онихомикозами с помощью метода Hematoflow // Инфекция и иммунитет.-2015.-Т. 5, № 4.-С. 339-348.

98. Савченко А.А. Определение активности NAD(P)-зависимых дегидрогеназ в нейтрофильных гранулоцитах биолюминесцентным методом / А.А. Савченко // Бюллетень экспериментальной биологии и медицины. - 2015.- T. 159, № 5. - C. 656-660.

99. Савченко, А.А. Исследование фенотипа лейкоцитов крови у больных онихомикозами с помощью метода Hematoflow / А.А. Савченко, А.Г. Борисов, Е.Н. Анисимова, В.Д.Беленюк, И.В. Кудрявцев // Инфекция и иммунитет. - 2015. - Т. 5, № 4. - С. 339-348.

100. Савченко, А.А. Роль Т- и В-клеточного иммунитета в патогенезе онкологических заболеваний / А.А. Савченко, А.Г. Борисов, И.В. Кудрявцев, А.В. Мошев // Вопросы онкологии. - 2015. - № 6. - С. 867-875.

101. Савченко, А.А. Методы оценки и роль респираторного взрыва в патогенезе инфекционно-воспалительных заболеваний / А.А. Савченко, И.В. 
Кудрявцев, А.Г. Борисов // Инфекция и иммунитет. - 2017. - Т. 7, № 4. - С. 327 340.

102. Савченко А.А., Каспаров Э.В., Тихонова Е.П., Гоголашвили Н.Г., Головкин А.С., Иванова Е.Б., Кудрявцев И.В., Гребенников С.В., Кузьмина Т.В., Калинина Ю.С., Федюкович Н.В., Мастерова А.А., Борисов С.А., Беленюк В.Д., Перетятько О.В., Борисов А.Г. Иммунореабилитация больных, перенесших COVID-19.-Красноярск, 2021.-58 c.

103. Самойлова Ю.Г., Олейник О.А., Саган Е.В., Денисов Н.С., Ворожцова И.Н., Кудлай Д.А., Канская Н.В. Микробиота и метаболическое программирование ожирения у детей. Педиатрия. Журнал им. Г.Н. Сперанского. 2020. Т. 99. № 1. С. 209-216.

104. Санталова Г.В., Бородулина Е.А., Кудлай Д.А., Бадаева Д.С., Бородулин Б.Е., Гасилина Е.С. Ревматические заболевания и туберкулезная инфекция у детей и взрослых. Туберкулез и болезни легких. 2019. Т. 97. № 2. C. 50-55.

105. Семенов А.В., Пшеничная Н.Ю. Рожденная в Ухане: уроки эпидемии COVID-19 в Китае. Инфекция и иммунитет. 2020;10(2):210-220.

106. Семенов А.В., Пшеничная Н.Ю. Уроки эпидемии COVID-19 в Италии. Инфекция и иммунитет. $2020.210(3)$. С. 410-420. https://doi.org/10.15789/2220-7619-LTL-1468.

107. Семикина, Е.Л. Возрастные особенности формирования гуморального звена иммунного ответа у детей / Е.Л. Семикина, Е.А. Копыльцова, В.А. Алешкин, А.П. Топтыгина // Медицинская иммунология. 2012. - T. 14, № 4-5. - C. 289-294.

108. Серебряная, Н.Б. Нуклеотиды как регуляторы иммунного ответа / Н.Б. Серебряная // Иммунология. - 2010. - Т. 31, № 5. - С. 273-280.

109. Симбирцев. А. С. Цитокины в патогенезе и лечении заболеваний человека / А.С. Симбирцев. - С-Петербург: Фолиант, 2018. - 512 с.

110. Симбирцев, А. С. Иммунофармакологические аспекты системы цитокинов / А.С. Симбирцев // Бюллетень сибирской медицины. - 2019. - Т. 8, № 1. - С. 84-95

111. Слогоцкая Л.В., Богородская Е.М., Сенчихина О.Ю., Никитина Г.В., Кудлай Д.А. Формирование групп риска заболевания туберкулёзом при различных иммунологических методах обследования детского населения. Российский педиатрический журнал. 2017. Т. 20. №4. С. 207-213.

112. Слогоцкая Л.В., Синицын М.В., Кудлай Д.А. Возможности иммунологических тестов в диагностике латентной туберкулезной инфекции и туберкулеза. Туберкулез и болезни легких. 2019. Т. 97. № 11. С. 46-58.

113. Смирнов В.С., Тотолян А.А. Врожденный иммунитет при коронавирусной инфекции. Инфекция и иммунитет. 2020. 10(2). С.259-268.

114. Смирнов В.С., Тотолян А.А. Некоторые возможности иммунотерапии при коронавирусной инфекции. Инфекция и иммунитет. 2020. 10(3). C. 446-458. 
115. Смирнова О.В., Титова Н.М., Каспаров Э.В., Елманова Н.Г. Хемилюминесцентная активность нейтрофильных гранулоцитов в прогрессировании механической желтухи в зависимости от уровня билирубина и генеза желтухи // Медицинская иммунология. 2016. Т. 18. № 3. C. 269-278.

116. Сохоневич Н.А., Хазиахматова О.Г., Юрова К.А., Шуплетова В.В., Литвинова Л.С. Фенотипическая характеристика и функциональные особенности Т- и В-клеток иммунной памяти. Цитология. 2015. Т. 57. № 5. С. 311-318.

117. Старшинова А.А., Кудлай Д.А., Довгалюк И.Ф., Басанцова Н.Ю., Зинченко Ю.С., Яблонский П.К. Эффективность применения новых методов иммунодиагностики туберкулезной инфекции в Российской Федерации. Педиатрия. Журнал им. Г.Н. Сперанского. 2019. Т. 98. № 4. С. 229-235.

118. Старшинова А.А., Кушнарева Е.А., Кудлай Д.А., Довгалюк И.Ф. Возможности лечения больных с COVID-19: анализ данных литературы. Трансляционная медицина. 2020. Т. 7. № 3. С. 30-37.

119. Старшинова А.А., Кушнарева Е.А., Малкова А.М., Довгалюк И.Ф., Кудлай Д.А. Новая коронавирусная инфекция: особенности клинического течения, возможности диагностики, лечения и профилактики инфекции у взрослых и детей. Вопросы современной педиатрии. 2020. Т. 19. № 2. С. 123131.

120. Топтыгина, А.П. Лимфоидный фолликул - территория иммунного ответа / А.П. Топтыгина // Иммунология. - 2012. - Т. 33, № 3. - С. 162-168.

121. Топтыгина, А.П. Т-клетки памяти / А.П. Топтыгина // Иммунология. - 2008. - Т. 29, № 5. - С. 311-316.

122. Топтыгина, А.П. Изменение уровня субпопуляций Трегуляторных клеток и Т-хелперов 17 в периферической крови здоровых людей в зависимости от возраста / А.П. Топтыгина, Е.Л. Семикина, С.В. Петричук // Медицинская иммунология. - 2017. - Т. 19, № 4. - С. 409-420.

123. Тотолян, А.А. Роль хемокинов и их рецепторов в иммунорегуляции / А.А. Тотолян // Иммунология. - 2001. - № 5. - С. 7-15.

124. Тотолян, А.А. Стандартизация методов иммунофенотипирования клеток крови и костного мозга человека / А.А. Тотолян, И.А. Балдуева, Л.Н. Бубнова, А.В. Закревская // Клиническая лабораторная диагностика. - 2002. № 1. - C. 44-50.

125. Трунин А.О., Чудинов И.К., Лебедева В.О., Алешина Д.А., Ильина А.А., Широбоков Я.Е., Мелерзанов А.В. Организационно-управленческие решения по борьбе с распространением COVID-19. Врач. 2021. Т. 32. № 7. С. 5-11. DOI: 10.29296/25877305-2021-07-01.

126. Хаитов Р.М.. Иммунология. Учебник. ГЭОТАР-Медиа, 2018 г. $496 \mathrm{c}$.

127. Хаитов Р.М., Елисютина О.Г., Данилычева И. В. Аллергология и клиническая иммунология. Клинические рекомендации. ГЭОТАР-Медиа, 2019 г. 352 c. 
128. Хаитов, Р.М. Аллергология и клиническая иммунология. Клинические рекомендации / Р.М. Хаитов, О.Г. Елисютина, И.В. Данилычева - ГЭОТАР-Медиа, 2019. - 352 с.

129. Хаитов, Р.М.. Иммунология. Структура и функции иммунной системы. Учебное пособие. ГЭОТАР-Медиа, 2019. - 328 с.

130. Хаитов, Р.М. Иммунотерапия. Руководство для врачей. / Р.М. Хаитов, И. И. Балаболкин, А. Е. Шульженко, С. Н. Алленов, Р.И. Атауллаханов. - ГЭОТАР-Медиа, 2020. - 768 с.

131. Хаитов, Р.М., Гариб, Ф. Ю. Иммунология. Атлас. ГЭОТАР-Медиа, 2020 г. - 416 с.

132. Хайдуков, С.В. Подходы к стандартизации метода проточной цитометрии для иммунофенотипирования. Настройка цитометров и подготовка протоколов для анализа / С.В. Хайдуков // Медицинская иммунология. - 2007. - Т. 9, № 6. - С. 569-574.

133. Хайдуков, С.В. Стандартизованная технология «Исследование субпопуляционного состава лимфоцитов периферической крови с применением проточных цитофлюориметров-анализаторов» / С.В. Хайдуков, Л.В. Байдун, А.В. Зурочка, А.А. Арег // Российский иммунологический журнал. - 2014. - Т. 8, № 4 (17). - С. 974-992.

134. Хайдуков, С.В. Возможности проточной цитофлюориметрии в диагностике инфекционных заболеваний. Часть 1 / С.В. Хайдуков, А.В. Зурочка // Инфекция и иммунитет. - 2011. - № 1. - С. 59-66.

135. Хайдуков, С.В. Возможности проточной цитофлюориметрии в диагностике инфекционных заболеваний. Часть 2 / С.В. Хайдуков, А.В. Зурочка //Инфекция и иммунитет. - 2011. - № 2. - С. 113-120.

136. Хайдуков, С.В. Возможности проточной цитофлюориметрии в диагностике инфекционных заболеваний. Часть 3 / С.В. Хайдуков, А.В. Зурочка // Инфекция и иммунитет. - 2011. - № 3. - С. 221-230.

137. Хайдуков, С.В. Цитометрический анализ субпопуляций Тхелперов (Th1, Th2, Treg, Th17, Т-хелперы активированные) / С.В. Хайдуков, А.В. Зурочка // Медицинская иммунология. - 2011. - № 1. - С. 7-16.

138. Хайдуков, С.В. Основные и малые популяции лимфоцитов периферической крови человека и их нормативные значения (методом многоцветного цитометрического анализа) / С.В. Хайдуков, А.В. Зурочка, Арег А. Тотолян, В.А. Черешнев // Медицинская иммунология. - 2009. - № 23. - C. 227-238.

139. Хайдуков С.В., Цитометрический анализ в клинической иммунологии / С.В. Хайдуков, А.В. Зурочка, В.А. Черешнев - УрО РАН, Екатеринбург, 2011. - 220 с.

140. Цуканов, В.В. Взаимосвязь иммунологических показателей и степени вирусной нагрузки при остром вирусном гепатите В /В.В. Цуканов, Д.В. Родина, А.Г. Борисов, А.А. Савченко // Медицинская иммунология. 2011. - Т. 13, № 2-3. - С. 181-188. 
141. Цхай, В.Б. Некоторые иммунологические показатели при патологии шейки матки, ассоциированной с папилломавирусной инфекцией / В.Б. Цхай, Д.Ю. Круглова, А.Г. Борисов, А.А. Савченко // Медицинская иммунология. - 2012. - Т. 14, № 3. - С. 207-212.

142. Черданцев, Д.В. Современный подход к лечению пациентов с распространенным гнойным перитонитом / Д.В. Черданцев, О.В. Первова, В.А. Шапкина, В.Ю. Дятлов, Ю.Г. Трофимович // Сибирское медицинское обозрение. - 2016. - № 6 (102). - С. 24-35.

143. Черешнев, В.А., Шмагель, К.В. Иммунология. М.: Изд-во «МАГИСТР». 2013. - 448 с.

144. Ярилин, А.А. Иммунология. М.: ГЭОТАР-Медиа, 2010. - 752 с.

145. Abbas A., Lichtman A., Pillai S. Basic Immunology 6-ed.-Elsevier, 2019. $-336 \mathrm{p}$.

146. Actor J.. Introductory immunology. Basic Concepts for Interdisciplinary Applications.-Academic Press, 2019.-196 p.

147. Bogitsh B., Carter C., Oeltmann T. Human Parasitology.-Academic Press, 2018.-422 p.

148. Clinical Immunology: Principles and Practice.-Elsevier, 2019.-1318 p.

149. de Candia P., Prattichizzo F., Garavelli S., Matarese G. T Cells: Warriors of SARS-CoV-2 Infection // Trends Immunol.-2021.-Vol. 42, no. 1.-P. $18-30$.

150. Golovkin A., Kalinina O., Bezrukikh V., Aquino A., Zaikova E., Karonova T., Melnik O., Vasilieva E., Kudryavtsev I. Imbalanced Immune Response of T-Cell and B-Cell Subsets in Patients with Moderate and Severe COVID-19 // Viruses.-2021.-Vol. 13, no. 10.-P. 1966.

151. Hematology, Basic Principles and Practice.-Elsevier, 2018.-2650 p.

152. Immuno-Oncology Cellular and Translational Approaches. Tan S.-Elsevier, 2020.-259 p.

153. Jawetz, Melnick, \& Adelberg's Medical Microbiology.-McGraw-Hill, 2019. $-897 \mathrm{p}$.

154. Jung M.K., Shin E.C. Phenotypes and Functions of SARS-CoV-2Reactive T Cells // Mol. Cells.-2021.-Vol. 44, no. 6.-P. 401-407.

155. Kalathil S.G., Thanavala Y. Natural Killer Cells and T Cells in Hepatocellular Carcinoma and Viral Hepatitis: Current Status and Perspectives for Future Immunotherapeutic Approaches // Cells.-2021.-Vol. 10, no. 6.-P. 1332.

156. Keogan M.T., Wallace E.M., O'Leary P. Concise Clinical Immunology for Healthcare Professionals.-New York, 2006.-426 p

157. Kudryavtsev I., Kalinina O., Bezrukikh V., Melnik O., Golovkin A. The significance of phenotyping and quantification of plasma extracellular vesicles levels using high-sensitivity flow cytometry during COVID-19 treatment // Viruses.-2021.-Vol. 13, no. 5.-P. 767.

158. Lagadinou M., Zareifopoulos N., Gkentzi D., Sampsonas F., Kostopoulou E., Marangos M., Solomou E. Alterations in lymphocyte subsets and 
monocytes in patients diagnosed with SARS-CoV-2 pneumonia: a mini review of the literature // Eur. Rev. Med. Pharmacol. Sci.-2021.-Vol. 25, no. 15.-P. 50575062 .

159. Lipsitch M., Grad Y.H., Sette A., Crotty S. Cross-reactive memory T cells and herd immunity to SARS-CoV-2 // Nat. Rev. Immunol.-2020.-Vol. 20, no. 11.-P. 709-713.

160. Longhi M.S., Mieli-Vergani G., Vergani D. Regulatory T cells in autoimmune hepatitis: an updated overview // J. Autoimmun.-2021.-Vol. 119.-P. 102619.

161. Male D., Male V., Peebles, Jr. R. S. Immunology.-Elsevier Health Sciences, 2020.-482 p.

162. Malkova A., Kudryavtsev I., Starshinova A., Kudlay, D., Zinchenko Y., Glushkova A., Yablonskiy P., Shoenfeld Y. Post COVID-19 Syndrome in Patients with Asymptomatic // Mild. Form. Pathogens.-2021.-Vol. 10.-P. 1408.

163. Malkova A.M., Kudlai D.A., Kudryavtsev I.V., Starshinova A.A., Yablonsky P.K. Immunogenetic predictors of severe COVID-19 // Vaccines.-2021.-Vol. 9, no. 3.-P. 1-13.

164. Mattner J. Natural killer T (NKT) cells in autoimmune hepatitis // Curr. Opin. Immunol.-2013.-Vol. 25, no. 6.-P. 697-703.

165. Matyushenko V., Isakova-Sivak I., Kudryavtsev I., Goshina A., Chistyakova A., Stepanova E., Prokopenko P., Sychev I., Rudenko L. Detection of IFN $\gamma$-Secreting CD4+ and CD8+ Memory T Cells in COVID-19 Convalescents after Stimulation of Peripheral Blood Mononuclear Cells with Live SARS-CoV-2 // Viruses.-2021.-Vol. 13, no. 8.-P. 1490.

166. Niedźwiedzka-Rystwej P., Grywalska E., Hrynkiewicz R., Bębnowska D., Wołącewicz M., Majchrzak A., Parczewski M. Interplay between Neutrophils, NETs and T-Cells in SARS-CoV-2 Infection-A Missing Piece of the Puzzle in the COVID-19 Pathogenesis? // Cells.-2021.-Vol. 10, no. 7.-P. 1817.

167. Peng H., Tian Z. NK cells in liver homeostasis and viral hepatitis // Sci. China Life Sci.-2018.-Vol. 61, no. 12.-P. 1477-1485.

168. Perricone C., Shoenfeld Y. Mosaic of Autoimmunity: The Novel Factors of Autoimmune Diseases.-Elsevier, 2019.-1136 p.

169. Punt J., Stranford S., Jones P., Owen J. Kuby Immunology.-W. H. Freeman and Company, 2019.-1905 p.

170. Roitt's Essential Immunology Peter J. Delves, Seamus J. Martin, Dennis R. Burton, Ivan M. Roitt.-Wiley-Blackwell, 2017.-576 p.

171. Smirnova O.V., Manchouk V.T., Savchenko A.A. Immune status \& enzymes activity in blood lymphocytes in adult patients at different stages of acute lymphoblastic leukaemia // Indian Journal of Medical Research.-2011.-Vol. 133, no. 3.-P. 280-286.

172. Sompayrac L., How the Immune System Works.-Wiley, 2019.-169 p.

173. The Autoimmune Diseases ed N. Rose, I. Mackay.-Academic Press, 2020.-1450 p. 
174. Tsukanov V.V., Kasparov E.V., Tonkikh J.L., Amelchugova O.S., Vasyutin A.V., Bronnikova E.P., Shtygasheva O.V., Butorin N.N., Fassan M., Rugge M. Peptic ulcer disease and Helicobacter pylori infection in different siberian ethnicities // Helicobacter.-2017.-Vol. 22, no. 1.-e12322.

175. Wang H., Feng X., Yan W., Tian D. Regulatory T Cells in Autoimmune Hepatitis: Unveiling Their Roles in Mouse Models and Patients // Front. Immunol.-2020.-Vol. 11.-P. 575572.

176. White G.R., Vanbergen O. Crash Course Haematology and Immunology.- Elsevier Health Sciences, 2018.-200 p. 
Научное издание

Козлов Владимир Александрович

Тихонова Елена Петровна

Савченко Андрей Анатольевич

Кудрявцев Игорь Владимирович

Андронова Наталья Владимировна

Анисимова Елена Николаевна,

Головкин Алексей Сергеевич

Демина Дарья Владимировна

Здзитовецкий Дмитрий Эдуардович

Калинина Юлия Сергеевна

Каспаров Эдуард Вильямович

Козлов Иван Генрихович

Корсунский Илья Анатольевич

Кудлай Дмитрий Анатольевич

Кузьмина Татьяна Юрьевна

Миноранская Наталья Сергеевна

Продеус Андрей Петрович

Старикова Элеонора Александровна

Черданцев Дмитрий Владимирович

Чесноков Андрей Борисович

Шестерня Павел Анатольевич

Борисов Александр Геннадьевич

\title{
КЛИНИЧЕСКАЯ ИММУНОЛОГИЯ. ПРАКТИЧЕСКОЕ ПОСОБИЕ ДЛЯ ИНФЕКЦИОНИСТОВ
}

\author{
Редактор В.А. Козлов \\ Художник О.В.Цай \\ Оператор компьютерной верстки В.Д.Беленюк
}

Подписано в печать 29.12.2021

Формат 80×1201/16 Бумага офсетная

Гарнитура Times

Печать офсетная. Усл.печ.л. 35,19

Тираж 3000 экз. Заказ № 1405

Отпечатано в Типография Поликор

660017, Красноярск, ул. Дубровинского, 58

Тел. 8 (391) 227-44-05. E-mail: polikor@ polikor.ru 